\title{
ICE INDUCED SEA LEVEL CHANGE IN THE LATE NEOGENE
}

\author{
By \\ Gary Steven Wilson
}
A thesis
submitted to the Victoria University of Wellington
in fulfilment of the
requirements for the degree of
Doctor of Philosophy
in
Geology

Victoria University of Wellington

Wellington

New Zealand

1993 


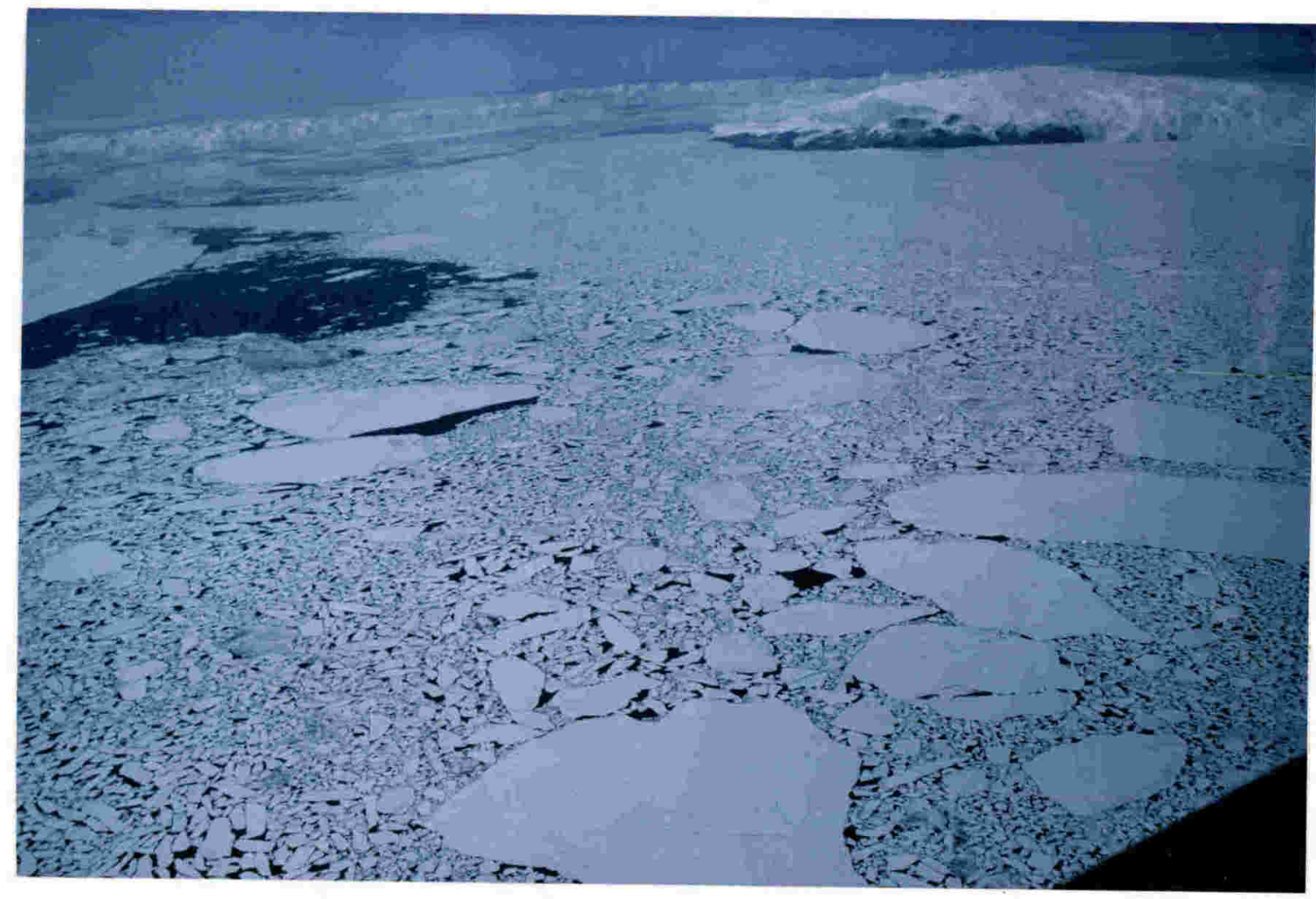

Aerial view of the Ross Sea from the south. In the foreground is the pack ice (Ice sheets are up to $10 \mathrm{~km}$ across) breaking northward Mount. Bird, Ross Island is in the top right of the view. 
"It is the nature of the history of the earth that a geologist has available to him only partial information. Occasional lines from disconnected paragraphs in obscurantist chapters are what can be read. Violence in the handling of the book through time has caused many of these chapters to be ripped and reassembled out of context. That the gist of the early chapters can be deciphered at all is a credit to perseverance and imagination not always associated with other sciences. The geologist operates at all times in an environment characterised by a high degree of uncertainty and omamented with end-products which are the outcomes of the interactions of many complex variables. He sees only the end, and has to induce the processes and the responses that filled the time since the beginning."

D.A. Pretorius (1973); The role of E.G.R.U. in mineral exploration in South Africa: Economic Geology Research Unit. Witwatersrand Informal Circular, no. 77, 16p. 


\section{To Suzanne Rose,}

My Wife, whose support and loyal friendship is the only reason this thesis was ever possible, thankyou. 
Two independent records of latest Neogene (2.0 - 6.0 Ma.) glacioeustasy are presented, one of Antarctic ice volume from East Antarctica and the other of eustatic sea level from the South Wanganui Basin, New Zealand.

Glacial deposits in the Transantarctic Mountains (Sirius Group) and sediment at the Antarctic continental margin provide direct evidence of Antarctic ice sheet fluctuation. Evidence for deglaciation includes the occurrence of Pliocene marine diatoms in Sirius Group deposits, which are sourced from the East Antarctic interior. $\mathrm{K} / \mathrm{Ar}$ and ${ }^{39} \mathrm{Ar} /{ }^{40} \mathrm{Ar}$ dating of a tuff in the CIROS-2 drill-core confirms their Pliocene age at high latitudes $\left(78^{\circ}\right.$ $S$ ) in Antarctica. Further evidence for Antarctic ice volume fluctuation is recorded by glaciomarine strata from the Ross Sea Sector cored by the CIROS-2 and DVDP-11 drillholes. Magnetostratigraphy integrated with Beryllium-10, $\mathrm{K} / \mathrm{Ar}$ and ${ }^{39} \mathrm{Ar} /{ }^{40} \mathrm{Ar}$ dating provides a high resolution ( \pm 50 k.y.) chronology of events in these strata.

In the Wanganui Basin, New Zealand, a $5 \mathrm{~km}$ thick succession of continental shelf sediments, now uplifted, records Late Neogene eustatic sea level fluctuation. In the Late Neogene, basin subsidence equalled sediment input allowing eustatic sea level fluctuation to produce a dynamic alternation of highstand, transgressive, and lowstand sediment wedges. This record of Late Neogene sea level variation is unequalled in its resolution and detail. Magnetostratigraphy provides a high resolution chronology for these sedimentary cycles as well as magnetic tie lines with the Antarctic margin record in McMurdo Sound.

These two independent records of Late Neogene glacioeustasy are in good agreement and record the following history: The Late Miocene and Late Pliocene are times of low 'base level' glacioeustasy (here termed glacialism, rather than glacial), with growth of continental-scale ice sheets on the Antarctic continent causing a lowering of global sea level. The Early Pliocene was a time of high 'base level' glacioeustasy (here termed interglacialism, rather than interglacial), driven by collapsing of continental-scale ice sheets to local and subcontinental ice caps. The middle Pliocene is marked by a move into glacialism with an increasing 'base level' of glacioeustatic fluctuation. Higher-order glacial advances and associated eustatic sea-level lowering occurred at approximately 3.5 and 4.3 Ma., separating the Early Pliocene into 3 sea-level stages. Still higher-order glacioeustatic fluctuations are recognised in this study, with durations of $50 \mathrm{Ka}$. and $100-300 \mathrm{Ka}$. The $100-300 \mathrm{Ka}$. duration cycles are prominent during interglacialisms, and the $50 \mathrm{Ka}$. duration cycles are prominent during glacialisms. These shorter duration fluctuations in glacioeustasy have already been recognised as glacial/deglacial cycles from detailed studies of the Quaternary.

Four orders of sea-level fluctuation are recognised within the Late Neogene, these are of approximately 0.05 Ma., 0.1-0.3 Ma., $2 \mathrm{Ma}$., and $4 \mathrm{Ma}$. in duration. The $2 \mathrm{Ma}$. and $4 \mathrm{Ma}$. duration cycles are subdivisions of the third order cyclicity recognised by Vail et al. (1991) (referred to here as cyclicity orders $3 \mathrm{a}$ and $3 \mathrm{~b}$ ). The $0.1-0.3 \mathrm{Ma}$. duration cycles are a subset of the fourth order cyclicity recognised Vail et al. (1991), and the $0.05 \mathrm{Ma}$. duration cycles are a subset of the 5 th order cyclicity recognised by Vail et al. (1991). 3a, 3b and 4 th order sea level fluctuations are driven by fluctuations in the volume of the Antarctic Ice Sheet. Fifth order sea level fluctuations are also suggested to be at least partially driven by fluctuations in the volume of the Antarctic Ice Sheet. Milankovitch cyclicities in glacioeustasy $(<100 \mathrm{Ka}$., fifth order cyclicity) are prominent in the geologic record at times when there is large scale glaciation (glacialism) of the Antarctic Continent (e.g. for the Pleistocene). Conversely, at times when the Antarctic continent is in a deglaciated state (deglacialism) fourth order cyclicity is more prominent, with Milankovitch cyclicities present at a parasequence level. 
Contents

Figures $\quad x i$

Plates $\quad$ xxiii

Tables $\quad$ xxvii

Acknowledgments $\quad$ xxix

1 Introduction 1

1.1 The Nature of the problem 1

1.2 Aims of the present study 3

1.3 The present physiography of the Antarctic Ice Sheets 4

1.4 Methodology of the present study 4

$\begin{array}{ll}1.5 \text { Approach } & 6\end{array}$

SECTION 1 - THE RECORD OF LATE NEOGENE ANTARCTIC 11 ICE VOLUME VARIATION

2 Introduction $\quad 13$

2.1 Introduction 13

2.2 Aims 15

2.3 Fieldwork methods $\quad 16$

2.4 Setting 17

3 Synthesis of existing knowledge of the Antarctic Ice Sheet 19

3.1 Introduction 19

3.2 Oceanic evidence for ice sheet development 19

3.2.1 The Southern Ocean 19

3.2.2 Palaeoceanographic development of the Southern
Ocean

3.2.3 The deep sea $\delta^{18} \mathrm{O}$ record $\quad 21$

3.2.4 The Ross Sea 23

3.2.5 Prydz Bay 23

3.3 Continental evidence for East Antarctic Ice Sheet development 24

3.3.1 The Sirius Group 24

3.3.2 Southern Victoria Land and McMurdo Sound $\quad 30$

3.3.3 The Lambert Glacier Region 33

3.3.4 Drill-hole evidence from the Antarctic Margin $\quad 34$

4 Stratigraphy of Antarctic Margin sediments in McMurdo 35

Sound

4.1 Stratigraphic nomenclature of the CIROS-2 and DVDP-11 35 drillholes

4.2 CIROS-2 stratigraphy 37

Group C 38

Group D $\quad 39$

Undifferentiated group $\quad 40$

$\begin{array}{ll}4.3 \text { DVDP-11 stratigraphy } & 40\end{array}$ 
Group A $\quad 40$

Group B $\quad 42$

Group C 43

Group D 44

5 Facies analysis and interpretation of the CIROS-2 and 45 DVDP-11 cores

5.1 Introduction 45

5.2 Facies associations $\quad 46$

5.2.1 Massive diamictite $\quad 46$

5.2.2 Stratified diamictite $\quad 46$

5.2.3 Stratified sandstone $\quad 46$

5.2.4 Massive mudstone 46

5.2.5 Stratified mudstone $\quad 47$

5.2.6 Breccia/Conglomerate 47

5.3 Stratal unconformities $\quad 47$

5.4 Facies successions $\quad 48$

5.5 Interpretation of successions 51

5.6 History of sedimentation in McMurdo Sound as recorded by $\quad 53$ the CIROS-2 and DVDP-11 cored sequences

6 Late Neogene Ice Volume History 61

6.1 Introduction 61

6.2 Deglaciation and reglaciation? 61

6.3 Continued glaciation 63

6.4 Evidence from Antarctic margin strata in McMurdo Sound 64

6.5 The record of ice volume variation on the East Antarctic $\quad 65$ Craton

\section{SECTION 2 - NEW CHRONOLOGY OF ANTARCTIC LATE NEOGENE STRATA}

7 Dating of the CIROS-2 ash 71

7.1 Introduction 71

7.2 Reprint of the paper: Barrett et al. (1992); Geochronological 72 evidence supporting Antarctic deglaciation three million years ago. Nature, vol. 359, 816-818.

7.3 Sample processing

7.4 Theory of simultaneous equation $\mathrm{K} / \mathrm{Ar}$ dating - of a mixed $\quad 79$ age population.

7.5 Grain recognition criteria $\quad 80$

7.6 Simultaneous equation analysis of $\mathrm{K} / \mathrm{Ar}$ age of the CIROS-2 $\quad 81$ tuff

8 Beryllium-10 Dating $\quad 83$

8.1 - Introduction 83

8.2 - Theory 84

8.2.1 Beryllium systematics and definitions $\quad 84$

8.2.2 The Beryllium-10 cycle 86

8.2.3 Dating methods using Beryllium-10 87

Discussion of the necessary parameters and $\quad 88$ assumptions

8.2.4 Applicability of the ${ }^{10} \mathrm{Be}$ method to the Antarctic $\quad 89$ Margin

Clay mineralogy 
The ice sheet effect

8.3 Measurement procedure 93

8.3.1 Sample preparation 93

8.3.2 Accelerator Mass Spectrometry 95

8.4 Results

8.4.1 Discussion of Standards 99

8.4.2 CNRS measurements 102

8.4.3 IGNS measurements 104

8.4.4 Dating CIROS-2 and DVDP-11 with ${ }^{10} \mathrm{Be} \quad 107$ CIROS-2 107

8.5 Conclusions

DVDP-11 109

9 Palaeomagnetism 113

9.1 Introduction 113

9.2 Palaeomagnetism 113

9.3 Age and definition of biostratigraphic datums $\quad 114$

9.3.1 CIROS-2 114

9.3.2 DVDP-11 114

9.4 Ages from radiometric methods $\quad 115$

9.5 Magnetostratigraphy 116

9.5.1 The CIROS-2 record $\quad 116$

Magnetozones 116

Correlation to the magnetic polarity timescale $\quad 116$

9.5.2 The DVDP-11 record $\quad 119$

Magnetozones 119

Correlation to the magnetic polarity timescale $\quad 120$

$\begin{array}{ll}\text { 9.6 Discussion and correlation } & 120 \\ & 120\end{array}$

SECTION 3 - THE RECORD IN THE WANGANUI BASIN 125

$\begin{array}{ll}10 \text { Introduction } & 127\end{array}$

10.1 Introduction and aims $\quad 127$

10.2 Fieldwork methods 128

10.2.1 Tectonic setting $\quad 129$

10.2.2 The South Wanganui Basin 131

10.2.3 Structure 132

11 Stratigraphy $\quad 135$

11.1 Stratigraphic Nomenclature of the South Wanganui Basin $\quad 135$ sequences

11.2 Wanganui River Stratigraphy 143

Matemateaonga Group $\quad 143$

Tangahoe Group 146

Whenuakura Group $\quad 146$

Paparangi Group 148

Okiwa Group 149

11.2.1 Hautawa Road Stratigraphy $\quad 149$

11.3 Rangitikei River Stratigraphy 149

Matemateaonga Group $\quad 150$

Tangahoe Group 151

Whenuakura Group 151

Paparangi Group 151

Okiwa Group $\quad 152$ 
12.1 Introduction

12.2 New Zealand Stages

12.2.1 The Kapitean Stage

12.2.2 The Opoitian Stage

12.2.3 The Waipipian Stage

12.2.4 The Mangapanian Stage $\quad 156$

12.3 The Hautawa Shell bed

$\begin{array}{ll}13.1 \text { Introduction } & 163\end{array}$

13.2 Sedimentary facies associations

13.2.1 Coarsening upward interbedded mudstone and $\quad 164$ sandstone

13.2.2 Fining upward interbedded mudstone and sandstone

13.2.3 Mudstone

13.2.4 Rhythmically bedded mudstone

13.2.5 Massive well-sorted sandstone

169

13.2.6 Muddy shellbed

171

13.2.7 Sandy shellbed/ reefs

171

13.2.8 Siltstone

13.3 Facies Successions

13.3.1 Coarsening

13.3.2 Fining

173

13.3.3 Interpretation

173

175

13.4 Stratal unconformities

\section{Sequence Stratigraphy}

14.1 Introduction

14.1.1 Terminology

14.2 Sequences and their boundaries

14.2.1 Marine Flooding Surfaces 14.2.2 Parasequences

14.3 Systems Tracts

14.3.1 Lowstand Systems Tract

14.3.2 Transgressive Systems Tract

14.3.3 Highstand Systems Tract

14.4 Discussion of variables

14.4.1 Accommodation Space 194

14.4.2 Sediment Supply 195

14.4.3 Eustatic Sea Level 196

14.5 Assumptions of the sequence stratigraphic model 196

14.6 The South Wanganui Basin sequence architecture 197

$\begin{array}{ll}\text { 14.6.1 Sequence } 1 & 197\end{array}$

14.6.2 Sequence $2 \quad 200$

14.7 Model for formation of the Late Neogene South Wanganui $\quad 200$ Basin Sequences

14.8 The South Wanganui Basin Late Neogene Sequence 205 lithostratigraphic framework.

15.1 Introduction 
15.2.1 The Wanganui River Section 210

15.2.2 The Rangitikei River Section 213

15.3 Origin of the Successions 216

15.4 Onlap, Downlap, Toplap and the eustatic curve 217

15.5 The Eustatic Sea Level record 223

15.5.1 Comparison with the EXXON global sea level 224 curve

$\begin{array}{ll}\text { 15.5.2 Amplitude of Eustatic Sea Level variation. } & 224 \\ \text { model for Eustatic Cyclicity in the Late Neogene } & 226\end{array}$

15.6 A model for Eustatic Cyclicity in the Late Neogene
$(2.4-6.0$ m.y.)

\section{SECTION 4 - PALAEOMAGNETISM OF SOUTH WANGANUI BASIN STRATA}

16 Palaeomagnetism

16.1 Introduction

16.2 Field and laboratory work $\quad 231$

16.2.1 Sampling 232

16.2.2 Laboratory measurements $\quad 234$

16.2.3 Data Processing 236

$\begin{array}{ll}\text { 16.3 Palaeomagnetism } & 236\end{array}$

16.3.1 Introduction $\quad 236$

Palaeomagnetism of N.Z. Tertiary sediments $\quad 236$

Palaeomagnetic analysis techniques 238

16.3.2 Palaeomagnetic behaviour of South Wanganui $\quad 242$ Basin sediments

16.3.3 Palaeomagnetism of theWanganui River section 255

Palaeomagnetism of the Hautawa Road section $\quad 259$

16.3.4 Palaeomagnetism of the Rangitikei River section $\quad 260$

16.4 Tectonic considerations

17 Sedimentary Petrography and Mineralogy 271

$\begin{array}{ll}17.1 \text { Introduction } & 271\end{array}$

$\begin{array}{ll}17.2 \text { Petrography } & 273\end{array}$

Quartz 273

Feldspar $\quad 274$

Muscovite $\quad 274$

Titanite 274

$\begin{array}{ll}\text { 17.2.2 Non-Silicates } & 274\end{array}$

Calcite 274

$\begin{array}{ll}\text { 17.2.3 Oxides } & 274\end{array}$

Titaniferous Magnetite $\quad 274$

Haematite 276

Ilmenite $\quad 276$

Chromite 279

$\begin{array}{ll}\text { 17.2.4 Sulphides } & 279\end{array}$

Pyrite 279

$\begin{array}{ll}\text { 17.3 Mineral Chemistry } & 279\end{array}$

17.3.1 Titaniferous Haematites $\quad 281$

17.3.2 Sulphides 283

17.3.3 Chromites 283

$\begin{array}{ll}17.4 \text { Diagenesis } & 285\end{array}$

17.4.1 Oxide dissolution $\quad 285$

17.4.2 Sulphide authigenesis $\quad 286$

$\begin{array}{ll}\text { 17.4.3 Weathering oxidation } & 288\end{array}$ 
18.1 Introduction $\quad 289$

18.2 Thermal demagnetisation changes in intensity 290

18.3 Acquisition of isothermal remanent magnetisation and 290 coercivity

18.4 Magnetic Hysteresis $\quad 294$

18.5 Discussion of magnetic parameters of minerals identified $\quad 299$ in the present study

18.5.1 Sulphides

18.5.2 Ilmenites $\quad 299$

18.5.3 Haematites $\quad 300$

18.5.4 Chromites 301

18.6 Origin of remanence in South Wanganui Basin sediments 302

19 Magnetostratigraphy $\quad 305$

19.1 Previous Magnetostratigraphic studies of New Zealand 305

Pre-Pleistocene sediments.

Early studies $\quad 305$

Recent Studies $\quad 306$

19.1.1 Previous studies in the South Wanganui Basin 306

19.2 Age and definition of Biostratigraphic Datums 307

19.2.1 The Miocene-Pliocene boundary 307

19.2.2 The Opoitian-Waipipian boundary 307

19.2.3 The Waipipian-Mangapanian boundary 308

19.2.4 The Hautawa Shell Bed (Fleming, 1953) 308

19.2.5 Crassostrea Ingens 309

19.2.6 Chlamys patagonia delicatula $\quad 309$

$\begin{array}{ll}\text { 19.3 The Wanganui River Record } & 309\end{array}$

$\begin{array}{ll}\text { 19.3.1 Magnetozones } & 309\end{array}$

19.3.2 Correlation to the magnetic polarity timescale $\quad 311$

Chron $5 \quad 311$

Gilbert Epoch $\quad 311$

Gauss Epoch $\quad 313$

Matuyama Epoch $\quad 314$

19.4 The Rangitikei River Record $\quad 314$

$\begin{array}{ll}\text { 19.4.1 Magnetozones } & 314\end{array}$

19.4.2 Correlation to the magnetic polarity timescale $\quad 316$

Gilbert Epoch $\quad 316$

Gauss Epoch $\quad 316$

19.5 Correlations

Matuyama Epoch $\quad 318$

20 Conclusions

20.1 Summary of findings $\quad 321$

20.1.1 Antarctic chronology $\quad 321$

20.1.2South Wanganui Basin chronology 322

20.1.3 The record of Late Neogene Antarctic Ice Volume 323

fluctuation

20.1.4 The record of eustatic sea level variation 323

20.2 Ice volume and sea level relationship in the Late Neogene 324

20.3 The record of ice induced sea level change in the Late Neogene 327

20.4 Implications for the global sea-level model (GSM) 327

20.5 Assessment of the record 328

20.6 Implications for the International Pliocene epoch and the 329

20.7 Future directions 
1 Antarctic Margin Stratigraphic sections and unit descriptions

A1.1 CIROS-2 drillhole

A1.2 DVDP-11 drillhole

2 Reprint of the paper: Wilson and Ditchburn (1992); Beryllium systematics in rock materials and its separation for measurement on an Accelerator Mass Spectrometer, DSIR Physical Sciences report no. 53, 32p.

3 South Wanganui Basin Stratigraphic sections, unit descriptions and sample listings.

A3.1 Wanganui River Section

A3.3 Rangitikei River Section

4 Grain size analyses

5 Magnetic measurements, site by site

1 Geologic map showing sampling localities for the Wanganui River

2 Geologic map showing sampling localities for the Rangitikei River

3 Summary stratigraphic information for South Wanganui Basin 


\section{Figures}

1.1 (modified from Wise et al., 1991) Oxygen isotopic curves for planktonic and benthic foraminifers from Subantarctic DSDP Sites 277, 279, and 281 (left, from Shackleton and Kennett, 1975) and variation in the global sea level curve inferred from seismic sequence analysis (right, from Haq et al., 1987) correlated with major events in the evolution of Cainozoic climate as interpreted by Kennett (1978) and Various subsequent authors. 1 = Harwood et al. (1986); 2 = Breza (1992); 3 = Kemp and Barrett (1975); 4 = Miller et al. (1987); 5 = Harwood et al. (1989); 6 = Leg 119 Shipboard Scientific Party (1988), Leg 120 Shipboard Scientific Party (1988), Barrett et al. (1989); 7 = Prentice and Matthews (1988); 8 = Benson (1975), Benson et al. (1985); 9 Matthews and Poore (1980), Prentice and Matthews (1988).

1.2 Present-day Antarctic Ice Sheet (modified from Denton et al., 1992).

1.3 Location of Geologic evidence studied here for Late-Miocene eustatic sea level variation (South Wanganui Basin, New Zealand) and Antarctic Ice Sheet fluctuation (CIROS-2 and DVDP-11 drillholes in southern Victoria Land, and the Transantarctic Mountains, Antarctica).

2.1 Map of the McMurdo Sound area, showing the main physiographic features, and the locations of the CIROS-2 and DVDP-11 drill-holes, and sketch geologic section parallel to the Taylor and Ferrar Valleys (after Pyne et al., 1985).

2.2 Geological map of the McMurdo Sound area, showing the distribution of the major basement rock types. Cainozoic Valley fill is marked in yellow (modified from Warren, 1969).

3.1 Reconstructions of the Southern Ocean, from Kennett (1982). Left is the earliest Oligocene (pre-psychrosphere), before opening of the Drake Passage, but after separation of Australia and Antarctica. Right is earliest Miocene (post-psychrosphere), with the Drake Passage open and a circum polar current developed.

3.2 A composite benthic $\delta^{18} \mathrm{O}$ record from Miller and Fairbanks (1985), showing an ice/ice free value calculated from present day values.

3.3 A composite planktonic equatorial $\delta^{18} \mathrm{O}$ record from Prentice and Matthews (1988), showing a glacioeustatic sea level and Antarctic ice volume interpretation.

3.4 Location of Sirius drift outcrops in the Transantarctic Mountains (modified from Denton et al., 1992). References are as follows: (1) Mercer (1986);

(2) Doumani and Minshew (1965); (3) Mayewski (1975); (4) LaPrade (1984);

(5) McGregor (1965); (6) Claridge and Campbell (1968); (7) Elliott et al. (1974); (8) Mercer (1972); (9) Barrett and Elliot (1973); (10) Prentice et al. (1986); (11) Denton et al. (1992); (12) Denton et al. (1992); (13) Faure and Taylor (1981); (14) Barrett and Powell (1982); (15) Brady and McKelvey (1979); (16) Denton et al. (1992); (17) Brady and McKelvey (1983); (18) Faure and Harwood (1990).

3.5 Episodes of marine deposition in the Wilkes-Pensacola basins as indicated by the presence of diatoms and other marine microfossils reworked into the Sirius Group tills.(see plate 3.1). Absence of such fossils could indicate times that these basins were occupied by an ice cover (after Wise et al., 1991). 
3.6 Cross-section from the East Antarctic interior through the Transantarctic

Mountains to the Ross Sea, showing the location of Sirius Group deposits and their inferred source in the interior (after Barrett et al., 1992).

3.7 Location map of the McMurdo Sound and Dry Valley Region (after McGinnis, 1981).

4.1 Lithostratigraphic nomenclature of units of the cored Antarctic margin, Late Neogene, strata in McMurdo Sound, southern Victoria Land, Antarctica.

4.2 Lithologic log of the CIROS-2 drill-core (Late Neogene part), Ferrar Fjord, McMurdo Sound, southern Victoria Land, Antarctica.

4.3 Lithologic log of the DVDP-11 drill-core (Late Neogene part), Taylor Valley, McMurdo Sound, southern Victoria Land, Antarctica.

5.1 Facies model for sedimentation around a floating glacier tongue (from Hambrey et al., 1989) (Vertical exaggeration is X10).

5.2 Facies association relationship diagram and vector sequences for the CIROS-2 and DVDP-11 successions. Relationships are calculated using Markov chain analysis. $\mathrm{A}_{1}=$ disconformity surface, erosional; $\mathrm{A}_{2}=$ unconformity surface, erosional; $\mathrm{B}_{1}=$ massive diamictite; $\mathrm{B}_{2}=$ stratified diamictite; $\mathrm{C}=$ stratified sandstone; $\mathrm{D}_{1}=$ massive mudstone; $\mathrm{D}_{2}=$ stratified mudstone; $\mathrm{E}=$ breccia/conglomerate.

5.3 Facies succession 1 as identified by markov chain analysis. a) right; common variation in the lower part of the facies succession (see text for explanation).

5.4 Facies succession 2 as identified by markov chain analysis (see text for explanation).

5.5 Modified facies model for sedimentation around a floating glacier tongue, model now includes winnowed, shallow water deposited, conglomerates (modified from Hambrey et al., 1989) (Vertical exaggeration is X10).

5.6 Lithological interpretation of the Late Neogene sequence cored at CIROS2. Ages are from chapter 9. Curve for the ice front position was obtained using the model presented in figure 5.5 (curve is from Barrett and Hambrey, 1992).

5.7 Lithological interpretation of the Late Neogene sequence cored at DVDP11. Ages are from chapter 9 . Curve for the ice front position was obtained using the model presented in figure 5.5.

5.8 Correlation of the CIROS-2 and DVDP-11 using magnetostratigraphy presented in Chapter 9. Hiatuses in the sequences are identified by magnetostratigraphy. Units, groups, and lithologies are explained in chapter 4.

6.1 The oxygen isotope curve (Miller and Fairbanks, 1985) with ice/ice free interpretation accounting for first-order cooling trend in the benthic oxygen isotope compilations of Miller and Fairbanks (1985). Cainozoic eustatic sea level curve of Haq et al., 1987) is given for comparison (from Harwood, 1986). 
6.2 The record of Late Neogene Ice volume variation on the East Antarctic craton interpreted from the CIROS-2 and DVDP-11 drill-cores and published outcrop information (see text). Chronology is from chapter 9, assuming constant average sediment accumulation between palaeomagnetic reversals. Volume estimation is given as a comparison to the present day volume of the East Antarctic Ice Sheet.

7.1 a, Antarctica, showing the Transantarctic Mountains and the main areas where ice-deposited Sirius Group strata containing 3-Myr-old marine diatoms have been found. Ice thickness contours and flow lines are for the larger ice sheet required to deposit the Sirius Group debris and are taken from ref. 20. The flow pattern indicates and East Antarctic source for the diatoms, and hence marine sedimentation there $\sim 3$ Myr ago. $b$, Cross-section of Ferrar Fjord. The sediment dill includes both ice- and water-laid sand and mud with scattered pebbles. The core also contains a volcanic ash layer $0.3 \mathrm{~m}$ thick at $125 \mathrm{~m}$ b.s.f., and dated here by the $\mathrm{K}-\mathrm{Ar}$ and ${ }^{40} \mathrm{Ar} /{ }^{39} \mathrm{Ar}$ methods at $\sim 3 \mathrm{Myr}$. The ash lies within an interval from 135 to $105 \mathrm{~m}$ b.s.f. dated from Southern Ocean diatom zones as ranging from 3.1 to $2.2 \mathrm{Myr}$ (see figure 7.2), thus validating the use of deep-sea marine diatom biostratigraphy for Pliocene strata on the Antarctic continent. $c$, Crosssection from the East Antarctic interior through the Transantarctic Mountains to the Ross Sea, showing the location of Sirius Group deposits and their inferred source in the interior. In drawing the section we presume that the Transantarctic Mountains were at their present elevation during Sirius deposition, but they may have been much lower at that time ${ }^{30}$.

7.2 Lithological column for the CIROS-2 drillhole, Ferrar Fjord, showing the diatom zones and boundary ages established by D.M. Harwood (personal communication, and ref. 14) and from ODP leg 120 data $^{17}$. The range of $T$. vulnifica (shaded interval) is well dated in the Southern Ocean at between 2.2 and 3.1 $\mathrm{Myr} \mathrm{ago}^{17}$.

7.3 Argon release spectrum for a purified glass concentrate from coarse silt-size volcanic ash from the CIROS-2 drillhole.

8.1 Types of beryllium-10 in the geologic cycle; A) autochthonous crystallographic beryllium-10; B) allochthonous crystallographic beryllium-10; C) allochthonous exotic beryllium-10; and D) autochthonous exotic beryllium-10.

8.2 Sketch of the beryllium-10 cycle, from production in the atmosphere to adsorption in various geologic reservoirs.

8.3 Variation in the production rate of beryllium-10 with respect to geomagnetic latitude (from Amin et al., 1975).

8.4 Comparison of the XRD analyses of CIROS-2 clay fractions with Ferrar and Taylor Valley analyses (data from Claridge and Campbell, 1989).

8.5 a) upper; measurement of absolute ${ }^{10} \mathrm{Be}$ content of mudstone horizons only plotted against a logarithmic scale depicted as age (inferred from half life). b) lower; correction of the core log to an age axis rather than thickness and then assignment of ages to other horizons by extrapolation from the absolute ${ }^{10} \mathrm{Be}$ content curve constructed as shown in figure $8.5 \mathrm{a}$.

8.6 Predicted ${ }^{10} \mathrm{Be}$ stratigraphy for the CIROS-2 drill-core, assuming constant production, no scavenging and ignoring ice volume effect at the Antarctic margin. This curve will provide the best estimate of the age variation within the core. 
8.7 Sketch of the effect of ice sheet melting and regrowth, respectively

inundating and starving the ${ }^{10} \mathrm{Be}$ levels in the Antarctic margin sequences.

8.8 Schematic diagram of the IGNS tandem accelerator mass spectrometry

facility as configured for ${ }^{10} \mathrm{Be}$ measurement.

$8.9{ }^{10} \mathrm{Be}$ and ${ }^{9} \mathrm{Be}$ extracted with authigenic phases and calcium carbonate as 104 function of depth for sediment core RC12-65. Calcium carbonate data are from Hayes et al. (1969) (from Bourles et al., 1989).

8.10 Beryllium-10 measurement spectra from the CIROS-2 drill-hole (normalised to the beryllium-9 current at the analysing magnet. Measurements are number of counts at the detector, with respect to count channel (energy).

8.11 Beryllium-10 measurement spectra for samples measured at LLNL, measurements are of change in energy versus total energy. Samples illustrated are the LLNL10000 and NIST standards, a specially prepared blank, and C2-13 from the CIROS-2 drill-core.

8.12 Absolute concentration of ${ }^{10} \mathrm{Be}$ of CIROS-2, DVDP-11, and Granite Harbour samples versus depth.

8.13a absolute concentration of ${ }^{10} \mathrm{Be}$ of CIROS-2 and Granite Harbour samples only versus depth. Only samples measured at IGNS or LLNL are shown.

8.13b Age interpretation of the absolute ${ }^{10} \mathrm{Be}$ concentration of CIROS-2 samples measured at IGNS and LLNL.

8.14 Age interpretation of the absolute ${ }^{10} \mathrm{Be}$ concentration of DVDP-11 samples measured at IGNS and LLNL, assuming the same zero concentration as calculated for the CIROS- 2 site.

9.1 Late Neogene geological timescale (modified from Edwards et al., 1988). Polarity is from Ness et al. (1980). New Zealand stages are shown for later comparison with the South Wanganui Basin record.

9.2 CIROS-2 polarity magnetozones. These are annotated for reference in the text. $\mathrm{N}$ labelled magnetozones are of normal polarity, $\mathrm{R}$ labelled magnetozones are of reversed polarity, and T labelled magnetozones are of transitional polarity. Magnetogram data are from Hugh Rieck (personal data).

9.3 Correlation of the CIROS-2 magnetozones with the polarity timescale of Ness et al. (1980), showing the main radiometric datums provided by this study. Plot is drawn to shoe the average sedimentation rat of the CIROS-2 strata and identify breaks in deposition. Comparative diatom data are from Harwood (1986).

9.4 DVDP-11 polarity magnetozones as assigned by Ishman and Rieck (1993) and this study. These are annotated for reference in the text. $\mathrm{N}$ labelled magnetozones are of normal polarity, $\mathrm{R}$ labelled magnetozones are of reversed polarity, and $\mathrm{T}$ labelled magnetozones are of transitional polarity. Magnetogram data are from Purucker et al. (1981) and Ishman and Rieck (1993).

9.5 Correlation of the DVDP-11 magnetozones with the polarity timescale of Ness et al. (1980), showing the depositional history of the core (from Ishman and Rieck, 1993). Plot is drawn to show the average sedimentation rate of the CIROS-2 strata and identify breaks in deposition. 
9.6 Summary of correlations of the CIROS-2 and DVDP-11 cores using magnetostratigraphy and radiometric age data. Plot allows easy identification of several reversal boundaries in the sections and consequently a high resolution of chronology of the strata.

10.1 Map of New Zealand, showing the location of the Indian-Pacific plate boundary (The axial shear belt, after Walcott, 1978). Velocity vectors represent the relative motion of the Pacific plate assuming the Indian plate fixed (Stern et al., 1986). Location of the North and South Wanganui Basins, Taranaki Basin and Taupo Volcanic Zone are shown (figure modified from Stern et al., 1986).

10.2 Cross-section of the southward progressing lithospheric wave. Profile runs from south (left) to north. Centre of the figure is the presently subsiding South Wanganui Basin and right hand side of figure is the presently uplifting Wanganui Hinge Zone (from Stern et al., 1992).

11.1 Lithostratigraphic nomenclature of the Rangitikei River sequences.

11.2 Lithostratigraphic nomenclature of the Wanganui River sequences.

11.3 Present day outcrop map of the Matemateaonga, Tangahoe, Whenuakura, and Paparangi Groups as recognised and defined by this study (modified from Morris, in prep.).

12.1 Late Neogene geological timescale for New Zealand (modified from Edwards et al., 1988), showing New Zealand stage names as used in this study. Polarity timescale is from (Ness et al., 1980).

12.2 Summary of the Late Neogene relationships (modified from Edwards, 1987): 154 The magnetic polarity timescale of Ness et al. (1980), stage classifications from Edwards (1987), and important biostratigraphic datums in this study (modified from Edwards, 1987).

12.3 Correlation of Wanganui River magnetozones with the magnetic polarity timescale of Ness et al. (1980), showing the main biostratigraphic datums identified by Collen (1972) and this study. Plot is drawn to show the average sedimentation rate of the Wanganui River strata and identify breaks in deposition.

12.4 Correlation of Rangitikei River magnetozones with the magnetic polarity timescale of Ness et al. (1980), showing the main biostratigraphic datums identified by Collen (1972) and this study. Plot is drawn to show the average sedimentation rate of the Rangitikei River strata and identify breaks in deposition.

12.5 Summary of correlations of the Wanganui River, Hautawa Road, and Rangitikei River sequences using magnetostratigraphy and biostratigraphy. Plot allows easy identification of several reversal boundaries in the sections and consequently a high resolution chronology of the strata.

13.1 Stratal characteristics of a coarsening upwards interbedded mudstone and sandstone facies association.

13.2 Stratal characteristics of a fining upwards interbedded mudstone and sandstone facies association. 
13.3 A diagrammatic representation of the Coarsening facies succession. It varies 174 from 100 to $\mathrm{ca} .350 \mathrm{~m}$ in thickness with the individual facies associations varying as depicted by the relative scale. Percent mud values are given to allow further comparison with the depth models of Swift (1970) and Elliot 1986), see figure 13.5. A general interpretation is one of a gradually shallowing depositional environment.

13.4 Diagrammatic representation of the Fining facies succession. Two main types are recognised; a. a succession containing a fining upward interbedded mudstone facies association; $b$. a succession containing muddy shellbed facies association directly overlying a burrowed surface or hardground. The two successions are between 10 and $30 \mathrm{~m}$ in thickness. They are both inferred to have been deposited in a deepening depositional environment, except succession a is inferred to have been deposited closer to the sediment source.

13.5 A facies model for sedimentation on a wave dominated coast (from Hambrey et al., 1989). It is used to infer variations in water depth of deposition of the facies associations and successions discussed in this chapter.

14.1 Stratal patterns, stacking patterns, and stratal disconformities in a type 1 sequence deposited in a basin with a shelf break (after Van Wagoner et al., 1988).

14.2 Stratal patterns, stacking patterns, and stratal disconformities in a type 2 sequence deposited in a basin with a shelf break (after Van Wagoner et al., 1988).

14.3 Diagrammatic stacking patterns of parasequence sets (from Van Wagoner et al., 1990); a. progradational parasequence sets; b. retrogradational parasequence sets; $b$. aggradational parasequence sets.

14.4 Highstand systems tract (modified from Haq, 1991).

14.5 Lowstand systems tract; a. the lowstand fan; b. the lowstand wedge (modified from Haq, 1991).

14.6 Transgressive systems tract (modified from Haq, 1991).

14.7 a. Morphology of the continental margin as required by the original sequence stratigraphic model (e.g. Posamentier et al., 1988); sedimentation on the margin is integral with margin morphology. b. Morphology of the Continental margin as predicted by the present study; sedimentation takes place on a larger relict shelf formed by external processes.

14.8 Shelf margin systems tract (modified from Haq, 1991).

14.9 Response of topset bed thickness and parasequence sets to eustatic fall. Type 2 sequence boundaries (conformable) separate progradational and retrogradational parasequence sets (modified from Posamentier et al., 1988).

14.10 Accommodation envelope as a function of eustasy and subsidence (from Posamentier et al., 1988). 
14.11 A diagrammatic representation of the coarsening facies succession. It varies from 100 to $c a .350 \mathrm{~m}$ in thickness with the individual facies associations varying as depicted by the relative scale. Percent mud values are given to allow further comparison with the depth models of Swift (1970) and Elliot (1986), see figure 13.5. A general interpretation is one of a gradually shallowing depositional environment.

14.12 Diagrammatic representation of the fining facies succession. Two main type are recognised; a. a succession containing a fining upward interbedded mudstone facies association; $b$. a succession containing muddy shellbed facies association directly overlying a burrowed surface or hardground. The two successions are between 10 and $30 \mathrm{~m}$ in thickness. They are both inferred to have been deposited in a deepening depositional environment, except succession a is inferred to have been deposited closer to the sediment source.

14.13 Bathymetric map of the current continental shelf of Wanganui. The relict shelf break is marked and different from the zone of 'active sedimentation (shaded) and possible depositional shoreline breaks.

14.14 Lithospheric control on sedimentation. The lithospheric wave (see chapter 10) uplifts older sediment to the north and provides a basin to accumulate sediments to the south. As the lithospheric wave progrades southwards earlier deposited sediments are uplifted at the Wanganui Hinge zone and recycled into the basin ahead of the lithospheric wave. The inset shows the resulting aggradation and progradation of stacking sediment wedges within the zone of active sedimentation.

$14.15 \mathrm{a}$. The location of sediment wedges on the shelf and their relationship to still stands of sea level. b. A second, larger order, of eustatic sea level variation, moving the absolute position of the respective wedges on the continental margin. The position of deposition of the Wanganui River sedimentary sequence is shown.

14.16 Development of the continental shelf morphology at Wanganui during a single cycle of eustacy, as predicted by this study. Wedges of sediment prograde beneath still stands of sea-level. Restricted wedges form beneath rising and falling sea-level. a. the pattern of sedimentation beneath the lowest stand of sea-level. b. the pattern of sedimentation beneath a rising sea-level. c. the pattern of sedimentation beneath the highest stand of sea-level. d. the pattern of sedimentation beneath a falling sea-level. Sedimentation is lithospherically controlled, balancing basin subsidence and sediment input. This prevents inundation of the continental margin by sediment (see discussion earlier in this chapter)

15.1 Sedimentary cycles in the Wanganui River Section (polarity and age is from section 4).

15.2 Sedimentary cycles in the Rangitikei River Section (polarity and age is from section 4).

15.3 A sketch depicting the location of the stratigraphic section exposed in the Wanganui River Valley, showing its relationship to the progradationally stacking highstand and lowstand wedges on the continental margin.

15.4 The relative positions oh highstand and lowstand wedges on the Wanganui continental margin during a) a high base level of eustasy (Early - Middle Pliocene) and b) a low base level of eustasy (Late Miocene and Late Pliocene). The position of the site of deposition of the Wanganui River strata is shown to illustrate the effect on the deposition of a change in base levels on these strata. 
15.5 Identification of the changes in the nature of stratal relationships during a full cycle of deposition (see table 15.1 for definitions of toplap, downlap, and onlap), The right hand side of each diagram shows the change in relative sea level during deposition of the cycle. The left hand side depicts type 1 sequences and the right hand side type 2 sequences. LSW $=$ lowstand wedge, $\mathrm{TSW}=$ transgressive wedge, $\mathrm{HSW}=$ highstand wedge, $\mathrm{RSW}=$ regressive wedge.

15.6 An onlap downlap curve for the Wanganui River Section. Onlap/downlap interpretation of sequences is illustrated in figure 15.5. Deposition of highstand wedges creates changes in onlap, with a low base sea level, above the site of deposition of the Wanganui River section. Deposition of lowstand wedges creates changes in downlap, with a high base sea level, above the site of deposition of the Wanganui River section. Right hand side of figure shows the eustatic sea level variation interpreted from the change in onlap and downlap. Ages of major events are from the polarity (see section 4).

15.7 Correlation of the Rangitikei and Wanganui River sedimentary cycles showing the agreement between the two in overall nature. Detailed correlation is difficult.

15.8 The eustatic sea level curve interpreted from the South Wanganui Basin sequences. Chronology is from chapter 12, assuming constant average sediment accumulation between palaeomagnetic reversals. Amplitude estimation is explained in section 15.5.2.

15.9 The existing Late Neogene sea level curve (from Microstrat, 1990).

15.10 Percent mud versus depth for samples from Peka Peka, New Zealand, Monterey Bay, Roussillion Shelf, and Bristol Bay, Bearing Sea (from Perrett, 1990). Values from Peka Peka are expected to be underestimates as applied to the Late Neogene Wanganui basin sequences as they are from a more protected environment with a lower wave reach than is normal in the South Wanganui Bight.

15.11 A model for the Late Neogene eustatic cyclicity recognised by this study. Three orders of variation (0.1-0.5 Ma., $2 \mathrm{Ma}$ and $4 \mathrm{Ma}$.) are recognised as being superimposed on each. No scale of amplitude is shown, but the sketch depicts relative change. Individual sea level events are a depiction for the model only and not exact.

16.1 Core orientation and marking scheme: a) Orientation of core in outcrop. b) Orientation of a single core. A line is marked down the long axis $(+\mathrm{z})$ of the surface of the core. Circumferential marking indicate the +y direction. Core plunge is the angle between the $\mathrm{z}$ axis and the horizontal. c) Marking scheme for individual specimens (from Roberts, 1990).

16.2 Component coercivity or blocking temperature spectra and resulting stereo and vector component plots for a) non-overlapping spectra, b) partial overlap, and c) total overlap. In both a) and b) individual magnetic vectors can be identified and in c) neither can be determined (after Dunlop, 1979).

16.3 Example of remagnetisation great circle analysis: a) through f) are individual specimen measurements, b) is a convergence plot of the individual specimens. The solution is considered ill-conditioned if the circles do not converge within a confined zone (from Roberts, 1990).

16.4 Examples of stepwise demagnetisation data of type A palaeomagnetic behaviour in individual specimens (5\% of all specimens) from South Wanganui Basin sediments (see text for further explanation). 
16.5 Examples of stepwise demagnetisation data of type $\mathrm{B}_{1}$ palaeomagnetic behaviour in individual specimens (23\% of all specimens) from South Wanganui Basin sediments (see text for further explanation).

16.6 Examples of stepwise demagnetisation data of type $\mathrm{B}_{1}$ ' palaeomagnetic behaviour in individual specimens ( $6 \%$ of all specimens) from South Wanganui Basin sediments (see text for further explanation).

16.7 Examples of stepwise demagnetisation data of type $\mathrm{B}_{1}$ " palaeomagnetic behaviour in individual specimens ( $6 \%$ of all specimens) from South Wanganui Basin sediments (see text for further explanation).

16.8 Examples of stepwise demagnetisation data of type $\mathrm{B}_{2}$ palaeomagnetic behaviour in individual specimens (20\% of all specimens) from South Wanganui Basin sediments (see text for further explanation).

16.9 Examples of stepwise demagnetisation data of type $\mathrm{B}_{2}{ }^{\prime}$ palaeomagnetic behaviour in individual specimens ( $2 \%$ of all specimens) from South Wanganui Basin sediments (see text for further explanation).

16.10 Examples of stepwise demagnetisation data of type $\mathrm{C}$ palaeomagnetic behaviour in individual specimens (3\% of all specimens) from South Wanganui Basin sediments (see text for further explanation).

16.11 Examples of stepwise demagnetisation data of type $\mathrm{D}_{1}$ palaeomagnetic behaviour in individual specimens (5\% of all specimens) from South Wanganui Basin sediments (see text for further explanation).

16.12 Examples of stepwise demagnetisation data of type $\mathrm{D}_{2}$ palaeomagnetic behaviour in individual specimens ( $9 \%$ of all specimens) from South Wanganui Basin sediments (see text for further explanation).

16.13 Examples of stepwise demagnetisation data of type $\mathrm{D}_{3}$ palaeomagnetic behaviour in individual specimens ( $12 \%$ of all specimens) from South Wanganui Basin sediments (see text for further explanation).

16.14 Examples of stepwise demagnetisation data of type $\mathrm{D}_{4}$ palaeomagnetic behaviour in individual specimens ( $2 \%$ of all specimens) from South Wanganui Basin sediments (see text for further explanation).

16.15 Examples of stepwise demagnetisation data of type E palaeomagnetic behaviour in individual specimens (3\% of all specimens) from South Wanganui Basin sediments (see text for further explanation).

16.16 NRM intensity versus stratigraphic position for Wanganui River data. Different symbols identify different measurements from the same stratigraphic position.

16.17 Palaeomagnetic end point direction versus stratigraphic position for Wanganui River data. All site directions are solutions from several fully stepwise thermally demagnetised specimens, see table 16.1 for interpretation information.

16.18 Stereoplot of remanence directions from Wanganui River section. Left is the individual specimen NRM directions, right is the stepwise demagnetised site directions.

16.19 Location map of Hautawa Road palaeomagnetic sample sites. Stratigraphic sample heights are given in table 16.2. 
16.20 Palaeomagnetic end point direction versus stratigraphic position for

Hautawa Road data. All site directions are solutions from several fully stepwise thermally demagnetised specimens, see table 16.2 for interpretation information.

16.21 NRM intensity versus stratigraphic position for Rangitikei River data. Different symbols identify different measurements from the same stratigraphic position.

16.22 Palaeomagnetic end point direction versus stratigraphic position for Rangitikei River data. All site directions are solutions from several fully stepwise thermally demagnetised specimens, see table 16.3 for interpretation information. North part of the section is from north of the Rauoterangi Fault and South part is from south of the fault.

16.23 Stereoplot of remanence directions from Rangitikei River section. Left is the individual specimen NRM directions, right is the stepwise demagnetised site directions.

16.24 Stereoplots of stepwise thermally demagnetised site polarities from middle Pliocene Strata from the Wanganui, Turakina (Data from McGuire; 1989) and Rangitikei River. All sample measurements are corrected for bedding and magnetic declination, but no account is taken of the rotation of the Australian Plate about its euler pole. Amount of clockwise rotation is given for each section with alpha-95 confidence intervals.

16.25 Palaeomagnetic rotation directions from the South Wanganui Basin, showing the more westerly extent of shear associated with faulting within the Axial Shear Belt. Magnetic directions are represented as corrected to true north. Turakina magnetic direction is from McGuire (1989). All shear and associated rotation has occurred since the top of the Gauss Chron (2.4 Ma.). Tectonic terrains are taken from Walcott (1981).

17.1 The iron-titanium oxide ternary system with distributions plotted for typical individual ilmenites grains analysed from south Wanganui Basin.

Compositions were determined using the method of Stormer (1983). Plots appear rich in $\mathrm{TiO}_{2}$ because they contain up to $6.5 \mathrm{MnO}$.

17.2 Diagrammatic representation of the overall process of sedimentary pyrite formation (after Berner, 1972).

17.3 Schematic presentation of results of textures developed during sulphurisation reactions (from Sweeney and Kaplan, 1973).

18.1 Examples of zero field thermal demagnetisation $\left(50^{\circ} \mathrm{C}\right.$ steps) of samples that demonstrate a high temperature normal component of magnetisation remaining after removal of an initially reversed component.

18.2 Saturation isothermal remanent magnetisation (SIRM) curve for a sample from site 69 in the Wanganui River section. Negative side of figure is the reversed sample SIRM curve.

18.3 Examples of saturation isothermal remanent magnetisation (SIRM) curves for magnetic extracts from Wanganui River sites, a sample chip SIRM is given for comparison. The low SIRM values are indicate of large domain behaviour of a mineral other than magnetite or haematite.

18.4 A comparison of sediment hysteresis from Wanganui River site 85 (upper) with hysteresis for a magnetic extract from the same site (lower). The poor closure of the hysteresis loop is indicative of antiferromagnetic behaviour. 
18.5 Hysteresis loops for magnetic grain separates from site 69 on the Wanganui River.

18.6 Further hysteresis loops for a single grain (upper) and magnetic grain separate (lower) from site 69 on the Wanganui River. The high degree of right shear of the loops is indicative of ferromagnetic behaviour, suggesting magnetite or titaniferous magnetites are not remanence carriers in these sediments.

18.7 Explanation of the components on natural remanent magnetisation (NRM), and their controls, in sediments from the South Wanganui Basin strata.

18.8 Explanation of the effects and process of diagenesis on natural remanent magnetisation (NRM).

18.9 The complete process of acquisition of NRM, with examples of the component contributions at various stages of sediment maturity.

19.1 Late Neogene Wanganui River polarity magnetozones. These are annotated for reference in the text. $\mathrm{N}$ labelled magnetozones are of normal polarity, $\mathrm{R}$ labelled magnetozones are of reversed polarity, and $\mathrm{M}$ labelled magnetozones are of indeterminate polarity due to necessarily wide sample site spacing.

19.2 Correlation of Wanganui River magnetozones with the magnetic polarity timescale of Ness et al. (1980), showing the main biostratigraphic datums identified by Collen (1972) and this study. Plot is drawn to show the average sedimentation rate of the Wanganui River strata and identify breaks in deposition.

19.3 Late Neogene Rangitikei River polarity magnetozones. These are annotated for reference in the text. $\mathrm{N}$ labelled magnetozones are of normal polarity, $\mathrm{R}$ labelled magnetozones are of reversed polarity, and M labelled magnetozones are of indeterminate polarity due to necessarily wide sample site spacing. Sections either side of the Rauoterangi Fault are combined for ease of annotation and identification.

19.4 Correlation of Rangitikei River magnetozones with the magnetic polarity timescale of Ness et al. (1980), showing the main biostratigraphic datums identified by Collen (1972) and this study. Plot is drawn to show the average sedimentation rate of the Rangitikei River strata and identify breaks in deposition.

19.5 Summary of correlations of the Wanganui River, Hautawa Road, and Rangitikei River sequences using magnetostratigraphy and biostratigraphy. Plot allows easy identification of several reversal boundaries in the sections and consequently a high resolution chronology of the strata.

20.1 Correlation of the eustatic sea level curve (from the South Wanganui Basin, chapter 15) and the Antarctic ice volume curve (predominantly from McMurdo Sound, chapter 6). The resolution of chronology on both curves is $100 \mathrm{k} . \mathrm{y}$. ( $\pm 50 \mathrm{Ka}$.). Sea level variation is reported in amplitude $(\mathrm{m})$ and ice volume is reported as volume (with respect to the present day volume). 
$x x i i$ 
2.1 Aerial view of Ferrar Fjord and Ferrar Glacier from the east, showing the location of the CIROS-2 drill-hole and a cross section of the fjord (from Barrett and Hambrey, 1992).

3.1 Sketch of the Antarctic Ice Sheet during the Cainozoic intervals of deglaciation postulated by Webb et al. (1984) (after Denton, 1985).

3.2 Sirius Group tillite cropping out in the Skelton Glacier area, note the compactness and consolidation of the deposit

3.3 Timing of significant events in the Late Neogene glacial history of Antarctica as dated by diatoms in the Sirius Group (after Harwood and Webb, 1991).

6.1 General Palaeoceanographic configuration for various equilibrium stages in Antarctic Ice Sheet growth (figure prepared by David Harwood).

7.1 Photomicrograph of the CIROS-2 ash grain-mount. Glass coated anorthoclase crystal bottom left, glass shard centre, and diatom top right (Photograph; P.J. Barrett).

8.1 The IGNS tandem accelerator facility. Left is the Tandem accelerator, right upper is the electrostatic deflector and detector line, right lower is a close up of the gas detector facility.

10.1 Location map of the South Wanganui Basin. The major sections studied include those cropping out in the Wanganui and Rangitikei River valleys. The Miocene-Pliocene boundary is shown towards the north of the basin and the Hautawa Shell bed separating Middle and Upper Pliocene strata and also marking the top of the section studied here.

11.1 Greywacke basement in the upper reaches of the Rangitikei River.

13.1 An example of the coarsening upwards interbedded mudstone and sandstone facies association, from the upper part of the Mangataunoka Siltstone, Wanganui River section (Frame of view is $100 \mathrm{~m}$ from top to bottom). It is underlain by the mudstone facies association (section 13.1.3), and overlain by the massive well sorted sandstone facies association (section 13.1.5).

13.2 An example of the fining upwards interbedded mudstone and sandstone facies association, from the Waiouru Sandstone, Rangitikei River section (spade is $1 \mathrm{~m}$ tall).

13.3 An example of the mudstone facies association, from the Mangaweka Mudstone, Rangitikei River Section (sandwich is $10 \mathrm{~cm}$ tall).

13.4 An example of the rhythmically bedded mudstone facies association, from the Mudstone Member of the Kahura Siltstone, Wanganui River Section (lens cap is $7 \mathrm{~cm}$ wide).

13.5 An example of the massive well-sorted sandstone facies association, from the Otuitahi Sandstone, Wanganui River Section (field of view is $50 \mathrm{~m}$ tall).

13.6 An example of the muddy shellbed facies association, from an unnamed shellbed beneath the Hautawa shellbed in the Rangitikei River Section 
(lens cap is $7 \mathrm{~cm}$ wide).

13.7 An example of the sandy shellbed / reef facies association, from the basal part of the Jerusalem Sandstone, Wanganui River Section. It is overlain by the rhythmically bedded mudstone facies association.

13.8 Examples of type A unconformities in strata of the South Wanganui Basin. a. (upper, frame of reference is $20 \mathrm{~m}$ tall) a well developed channel with more than $10 \mathrm{~m}$ of relief, underlain by mudstone facies and overlain by sandstone facies. b. (lower, bluff is $c a .60 \mathrm{~m}$ tall) an angular unconformity like a., but with much less relief developed (photo; Mike Wizevich).

13.9 An example of a type $\mathrm{C}$ paraconformity. A bioturbated mudstone hardground. It is inferred to be relatively deep water in origin.

15.1 An example of the more sandy nature of the sedimentary cycles (W12 - W15) higher in the Wanganui River Section (Bluff is ca. $30 \mathrm{~m}$ high).

15.2 The Wilkies shellbed at its type locality, Wilkies Bluff on the Wanganui River Road. The Crassostrea dominant bluff formed during a long sea level fall that was equal to, or slightly outpaced by basin subsidence.

15.3 An example of the thick uniform sedimentary successions in the Upper reaches of the Rangitikei River. Cycle boundary is commonly marked by a thin and often inconspicuous sandy to silty mudstone horizon.

16.1 The Oxford University, two axis semi-automated Cryogenic Consultants magnetometer which was one of three magnetometers used to measure palaeomagnetic specimens in this study

17.1 Transmitted light (crossed-nicols) photomicrograph of South Wanganui Basin sediment. Opaque grains are oxides. Large dull grey grains are quartz and feldspar grains. Matrix is fine quartz, feldspar, muscovite and sericite (frame of view is $0.1 \mathrm{~mm}$ tall).

17.2 Reflected light (crossed-nicols) photomicrograph of South Wanganui Basin sediment. Large subangular to subrounded browny grey, pitted grains are quartz. Shiny, brassy coloured grains are oxides and sulphides (frame of view is $0.1 \mathrm{~mm}$ tall).

17.3 A backscattered electron image (BEI) of a single titanite grain. Note the Ti rich grain rim. (scale bar is 10 microns).

17.4 Transmitted and reflected light (crossed-nicols) photomicrograph of pyrite framboids formed within a foraminifera test. Framboids are a dull brassy colour and calcite has high fourth order birefringence. (frame of view is 0.1 $\mathrm{mm}$ tall).

17.5 Reflected light (crossed-nicols) photomicrograph of microcrystalline haematite grains filling available pore spaces in South Wanganui Basin sediment. Haematite is translucent to opaque red in the centre of the frame (frame of view is $0.1 \mathrm{~mm}$ tall).

17.6 Transmitted and reflected light (crossed-nicols) photomicrograph of haematite coating pyrite framboids as an alteration product, from late stage oxidation (centre of frame). Haematite is translucent to opaque red and pyrite is brassy light-yellow (frame of view is $0.1 \mathrm{~mm}$ tall).

17.7 A backscattered electron image (BEI) of different ilmenite grains. Note 
exsolution pitting and weathering along cleavage and fracture planes (scale bar is 10 microns).

17.8 A backscattered electron image (BEI) of different ilmenite grains, showing the ubiquitous occurrences of them in the magnetic grain extracts. Note exsolution pitting and weathering along cleavage and fracture planes (scale bar is 100 microns).

17.9 Reflected light (crossed-nicols) photomicrograph of large ilmenite grain. Ilmenite is dull, metallic, brassy-yellow and shows well developed solution weathering along grain weakness planes (frame of view is $0.1 \mathrm{~mm}$ tall).

17.10 A backscattered electron image (BEI) of chromite. Chromite grain is the very bright, late phase mineral holding several feldspar grains together (scale bar is 100 microns).

17.11 Reflected light (crossed-nicols) photomicrograph of South Wanganui Basin sediment, showing ubiquity of brassy yellow pyrite framboids (frame of view is $0.1 \mathrm{~mm}$ tall).

17.12 Dark-field transmission electron microscope image of ilmenite. Light regions are Fe-poor domains and dark regions are Fe-rich domain boundaries (X-phase) from Lawson and Nord (1984); figure 3.

17.13 Reflected light (crossed-nicols) photomicrograph of pyrite framboids formed within a foraminifera test. Framboids are a dull brassy colour (frame of view is $0.1 \mathrm{~mm}$ tall).

17.14 A backscattered electron image (BEI) of single pyrite framboids, showing there spherical form retained from a precursory greigite phase (scale bar is 10 microns).

18.1 Examples of the magnetic separates suspended in non-magnetic Yoohoo glue within non-magnetic perspex cylinders. The left hand specimen has been prepared for electron microprobe analysis. 
xxvi 
5.1 Observed facies transition matrix for core Antarctic margin strata in

McMurdo Sound.

5.2 Predicted facies transition matrix for core Antarctic margin strata in McMurdo Sound.

5.3 Difference matrix, between predicted and observed facies transitions for cored Antarctic Margin strata in McMurdo Sound

7.1 Age data and grain compositions for 32-63 $\mu \mathrm{m}$ separated fractions of the CIROS- 2 ash layer at $125 \mathrm{~m}$ b.s.f.

7.2 Electron microprobe analyses of glass types

7.3 Simultaneous equation calculation of the ages of volcanic and basement endmembers of the CIROS-2 ash.

8.1 Beryllium measurements and results table for cored Antarctic margin strata in McMurdo Sound

8.2 Intercomparison of different standards used for ${ }^{10} \mathrm{Be}$ measurement in the present study. LLNL10000 is a standard prepared by Lawrence Livermore National Laboratory by irradiation. KNSTD3770 is a standard prepared by Kuni Nishiizumi and measured by $\beta$-counting, assuming a $1.5 \mathrm{Ma}$. half-life. The NIST standard is prepared by the National Institute of Standards and Technology (Hoffman et al., 1987)

8.3 IGNS Beryllium results table for cored Antarctic margin strata in McMurdo Sound. Measurements are reported with respect to depth and are all normalised to the LLNL10000 standard.

8.4 Intercomparison of beryllium results from the three different laboratories. Measurements are reported with respect to depth.

8.5a Age data for the CIROS-2 drill-core strata as calculated by absolute ${ }^{10} \mathrm{Be}$ concentration measurement

8.5b Age data for the DVDP-11 drill-core strata as calculated by absolute ${ }^{10} \mathrm{Be}$ concentration measurement

16.1 Site polarity solutions for the Wanganui River Section. All data are from samples that have been fully stepwise demagnetised by thermal means. GC indicates the number of specimens for which end point were determined using the remagnetisation circles method of McFadden and McElhinny (1988). SP indicates the set points determined from a site by analysis of vector component plots. Individual specimen data are presented in appendix 5.

16.2 Site polarity solutions for the Hautawa Road Section. All data are from samples that have been fully stepwise demagnetised by thermal means. GC indicates the number of specimens for which end point were determined using the remagnetisation circles method of McFadden and McElhinny (1988). SP indicates the set points determined from a site by analysis of vector component plots. Individual specimen data are presented in appendix 5 . 
16.3 Site polarity solutions for the Rangitikei River Section. All data are from samples that have been fully stepwise demagnetised by thermal means. GC indicates the number of specimens for which end point were determined using the remagnetisation circles method of McFadden and McElhinny (1988). SP indicates the set points determined from a site by analysis of vector component plots. Individual specimen data are presented in appendix 5 .

16.4 Calculated axial geocentric dipole statistics from Gilbert and Gauss age 269 strata of the South Wanganui basin. Normal and reversed polarity directions have been calculated separately. Values were found to be in close agreement and were therefore averaged. Actual data are shown on a stereo plot 16.24.

17.1 EMPA analyses of single individual homogeneous ilmenite grains

17.2 EMPA analyses of single individual pyrite grains

17.3 EMPA analyses of single detrital chromite grains

18.1 EMPA analyses of chromite ores from the Eastern Desert, Egypt (Data from Refai et al., 1989) 


\section{Acknowledgments}

This study would not have been possible without the help of many people:

Drs. Peter Barrett and Brad Pillans supervised the study. Brad provided endless assistance with stratigraphic problems and Peter well reasoned discussion on Antarctic glacial history problems. Both are thanked for their time and effort in taming my wild ideas and critically reviewing the final manuscript. Dr. Mike Hannah was an excellent sounding board for my speculations on sequence stratigraphy. Prof Paul Vella is also thanked for the many hours of his free time spent critically reviewing the manuscript, especially the written English.

Field assistance, access and accommodation was provided by Paul and Robin Western of Mangaweka. Paul did some expert Jet Boat Driving and Robin provided great accommodation and many good meals in the field. The Department of Conservation, Wanganui provided a permit to work in the Whanganui National Park, as well as Jet boat assistance for sampling. Robert Aspden of Works, Project Services, provided information of benchmarks in the Wanganui River area and 1:10,000 maps of the river prepared by Electricorp in assessing the potential of the river for hydro development. Electricorp funded the duplicating and researching of this material. Malcolm Arnot, Richard Levy, Geoff Rait, Andrew Roberts, Mike Wizevich and Richard Wysoczanski provided assistance with field work. Dennis Cassidy provided assistance and advice in sampling the Antarctic cores (CIROS-2 and DVDP11) and he is particularly thanked for the fantastic Antarctic Core Facility library, Florida State University, U.S.A.

Buffy McClelland, Oxford University England, made facilities available for the measurement of palaeomagnetic samples from the Wanganui Basin, and helped with software and interpretation of measurements. Andrew Roberts provided invaluable help with palaeomagnetic measurement and interpretation, he is particularly thanked for the measurement of many samples on the Gif Cryogenic magnetometer, and tuition in rock magnetic equipment at University of California, Davis, U.S.A.

Rodger Sparks oversaw most of the beryllium-10 measurements and taught me how the particle accelerator works. Bob Ditchburn was instrumental in development of a method of separation of Beryllium from sediments. John Southon and Jay Davis allowed me to make Beryllium-10 measurements on the Accelerator at Lawrence Livermore National Laboratory, University of California, U.S.A. Bill McIntosh helped in obtaining the Ar/Ar measurements and provided advice on geochronologic work.

Dr. Gillian Turner, Dr. Dianne Seward, John Carter, Dr. Rodney Grapes, Rangi Mitaera, Val Hibbert, Stephen Eagar, Dr. Mike Hannah, Cliff Snell, Eric Broughton, Liz Anderson, Albert Wilson and Suzanne Pentecost provided helpful discussion and assistance with various aspects of the work. Sally Rowe, Bret Robertson and Les Maiden are acknowledged for many hours of help in producing the final version of the thesis.

If any one person were to be singled out above my official supervisors, it would be Dr. David Harwood of the University of Nebraska, Lincoln, U.S.A. As an unofficial supervisor Dave was full of endless encouragement, wisdom, energy, and support for my work. A big thankyou Dave.

The work was funded by a New Zealand Vice Chancellors Committee PhD Scholarship: A Fulbright Scholarship allowing an 8 month visit to the University of Nebraska, Lincoln NE, U.S.A.: A Cambridge Arctic Shelf Programme Fellowship, Cambridge University, allowing visits to the Antarctic Core Facility in Florida: A temporary lectureship in the Geology Department, University of Nebraska, Lincoln, U.S.A.: A lecturing tutorship in the Geology Department, Victoria University: A Jacob Joseph award.

Funds to present parts of this work at various conferences and invited talks came from; The Transantarctic Society NZ; The Japan Polar Research Association ; The University of Nebraska, Lincoln, NE, U.S.A.; The Ohio State University, Columbus, OH, U.S.A.; Geological Society of London; International Conference on Geochronology, Cosmochronology, and Isotope Geochemistry 7; Cambridge University, England. 


\section{Chapter - 1 Introduction}

\subsection{The nature of the problem}

"The Paleogene glacial history of the Antarctic was predestined to be a controversial subject because by necessity, that history has been written largely from indirect evidence of glaciation gathered from the oceans beyond that remote, ice shrouded and inhospitable continent" (Wise et al., 1991).

This statement is true not only for the Paleogene but, for the same reason is also true for the Neogene and much of the Pleistocene. A history for the Antarctic ice sheet based on these indirect or proxy records has established the Late Neogene as a time of little variation in the form of the Antarctic ice sheet. In this history the ice sheet was inferred to have formed in middle Miocene times ( $c a .14 \mathrm{Ma}$.) as a cold polar feature, as it is today, and remained essentially like this until the present (e.g. Kennett, 1977) (figure 1.1). At the same time a global sea level model was being constructed by the staff of the EXXON oil company (e.g. Vail et al., 1977) that found large variations in global sea level since the middle Miocene. This variation they attributed to fluctuation in the volume of ice stored in continental ice sheets (figure 1.1). More recently the stability and cold polar nature of the Antarctic Ice Sheet has been challenged by evidence directly from the Antarctic Continent (e.g. Webb et al, 1984), suggesting a more varied glacial history of the continent, including deglaciation as recently as the Pliocene (figure 1.1). It is this prospect of Pliocene deglaciation that provided the impetus for this study.

Indirect methods of observing Antarctic ice volume and sea level variation have been based primarily on the interpretation of varying stable isotope ratios as they reflect climatic variation (Emiliani and Milliman, 1966; Shackleton and Kennett, 1975; Savin, 1977; Matthews and Poore, 1980 and Miller and Fairbanks, 1985). These isotopic ratios vary with changes in temperature and ocean volume. If assumptions about temperature variation hold, then further assumptions between ocean volume variation and its relationship to the volume of ice on land and further the position of this ice on land allows construction of a model of Antarctic ice volume variation. While such a model is based on various other indicators, there is not yet a sufficient calibration of the variation in the stable isotope record for it to be an accurate measure of Antarctic ice volume variation. The interpretation of this proxy record is presented in Chapter 2 as part of a review of the current knowledge of Antarctic Ice Sheet development focused from the standpoint of its bearing on the Late Neogene record. 


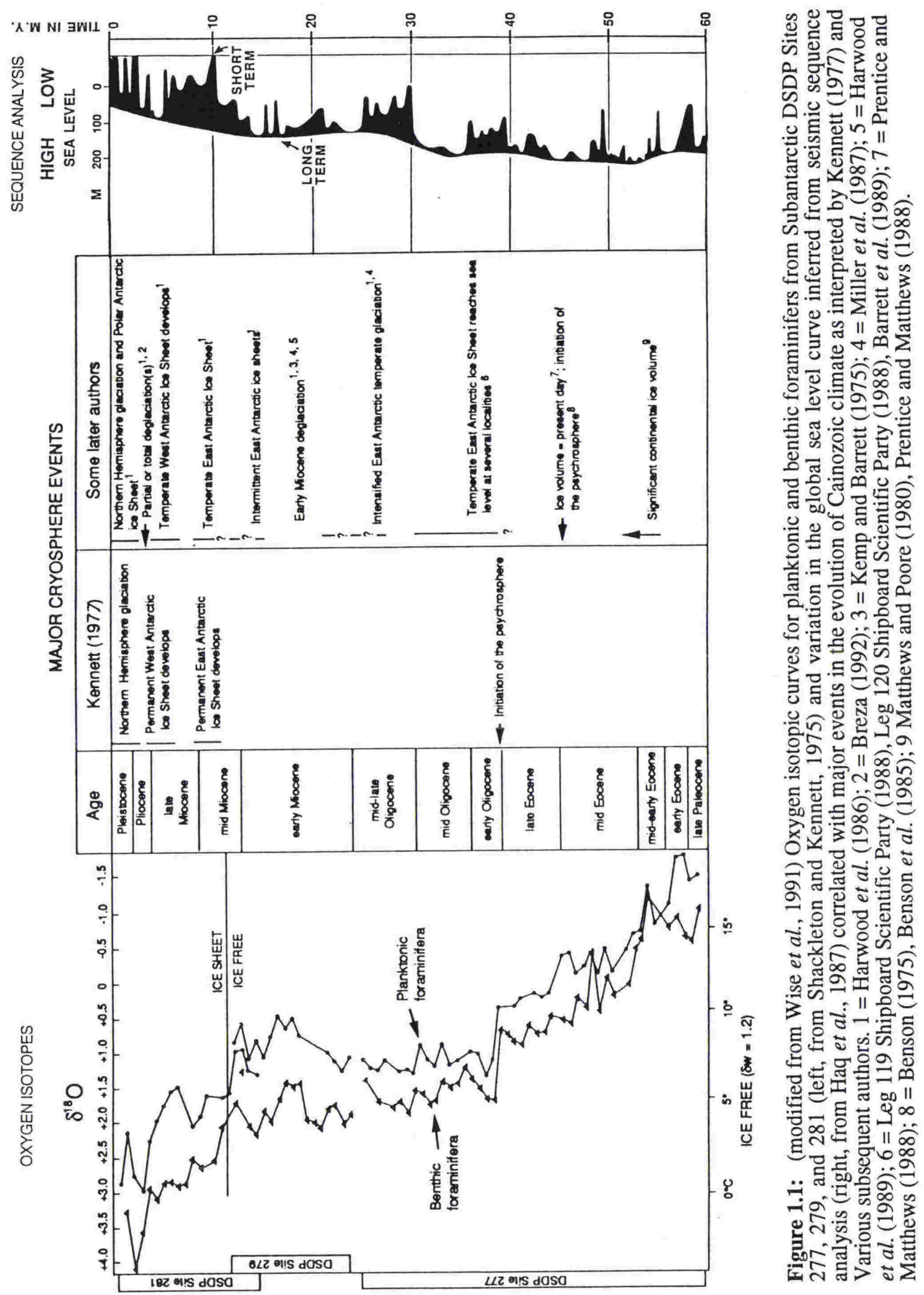




\subsection{Aims of the present study}

The main aim of this thesis is to provide a high resolution Late Neogene record of ice volume variation directly from the Antarctic Continent and relate this to a direct record, with equal resolution, of eustatic sea level variation. These two data sets complement each other allowing construction of a model of ice volume and sea level variation compiled independently of the established proxy records and their inherent inadequacies. A new and more complete model of Antarctic psychrospheric development between 2.4 and $6.0 \mathrm{Ma}$. might then be established. This time range was chosen in the expectation that periods of major deglaciation of Antarctica occurred during the Late Neogene (Webb et al., 1984), but that the resolution of chronology was poor in defining its time range and there was no direct indicator of the extent of glaciation. Further knowledge of eustatic sea level variation (Haq et al., 1988) suggested that a global minimum occurred in the latest Miocene Epoch. Particular evidence of major shallowing is evident from the Messinian salinity crisis (Ryan et al., 1976).

It was considered important not to use the proxy records of Antarctic ice volume or eustatic sea level variation in developing these new models. Then the proxy records could be compared and checked against independent criteria, and hence allow them to be more widely applicable to interpreting Antarctic psychrospheric development and the associated eustatic sea level variations.

An additional aim of the present study is to establish a pattern of Antarctic ice sheet and sea level behaviour to help in predicting future changes. This history of behaviour of the Antarctic ice sheet is very important in predicting its role in future global change. An approach that, to date, has seen little use in predicting the effects of future climate change is in observing a geologic era when conditions were similar to the present day and studying the patterns of change in the geologic record. This is perhaps due to the poor resolution of variation and change currently available from these records. From other studies (e.g. Dowsett et al, 1992) the Pliocene era is known as a time of global warmth, even warmer than the present day (Dowsett et al., 1992), with $\mathrm{CO}_{2}$ levels similar to the present day (Barrett, 1991). In terms of warmth, using $\mathrm{CO}_{2}$ levels as a temperature indicator during the geologic past, the nature and behaviour of the Antarctic Ice Sheet during those times can be used as a basis for prediction of what may happen in the future. This study presents a record with substantially improved resolution providing a detailed account of the Late Neogene (2.4-6.0 Ma.) climatically controlled variation in Antarctic Ice volume and eustatic sea level. It is hoped that this may be used as an indicator of possible changes during predicted global warming. 


\subsection{The Present Physiography of the Antarctic Ice Sheets.}

The Antarctic has two large physiographically different components to the ice sheet (figure 1.2): The West Antarctic Ice Sheet, resting on bedrock well below present sea level, is 3.3 million $\mathrm{km}^{3}$ in volume, a sea level equivalent of $6 \mathrm{~m}$ (Denton et al., 1992). It is buttressed by two ice shelves, the Filchner-Ronne and the Ross, that help to keep the ice sheet in place. The East Antarctic Ice Sheet, resting largely above sea level on an ancient craton, is 26 million $\mathrm{km}^{3}$ in volume, a sea level equivalent of $60 \mathrm{~m}$ (Denton et al., 1992). The East Antarctic Craton does however have basins that are currently below sea level, a portion of which will remain below sea level if the loading ice is removed and isostatic rebound occurs. The four main basins are the Wilkes, Pensacola, Aurora and Amery Subglacial Basins.

The West Antarctic ice sheet is known to be unstable, and its latest deglaciation is supposed to have occurred within the last $400 \mathrm{Ka}$. (Scherer, 1991). Ice volume and associated sea level variation being considered in this study is far greater than the present day $6 \mathrm{~m}$ sea level equivalent of the West Antarctic. Its contribution to the variations observed in the present study is not considered separately from that of the larger East Antarctic ice sheet. For the pre Late Pliocene, variations in the volume of the West Antarctic Ice Sheet is considered to have been synchronous with variations in the volume of the East Antarctic Ice Sheet, but much less than those of the East Antarctic Ice Sheet.

\subsection{Methodology of the present study}

Many of the data and the method of interpreting them presented here are new. Each chapter presents a new idea and is headed by an introductory paragraph that outlines the approach taken in that chapter. Methodology and systematics of the individual models are also presented at the beginning of each chapter, as well as their relationship to other chapters. Each chapter should both stand alone and also fit into the larger framework and aims outlined here. While major findings of the research are presented and summarised in each chapter, the major conclusion and Antarctic ice volume and sea level record are presented and discussed only in the final chapter, which is based on the findings of all previous chapters and is written using supporting findings and conclusions from each of the preceding chapters.

This thesis makes contributions to stratigraphy, sedimentology, sequence stratigraphy, palaeomagnetism, rock magnetism, geochronology, eustacy and the Late Neogene history of Antarctic ice volume and associated sea level variation. 


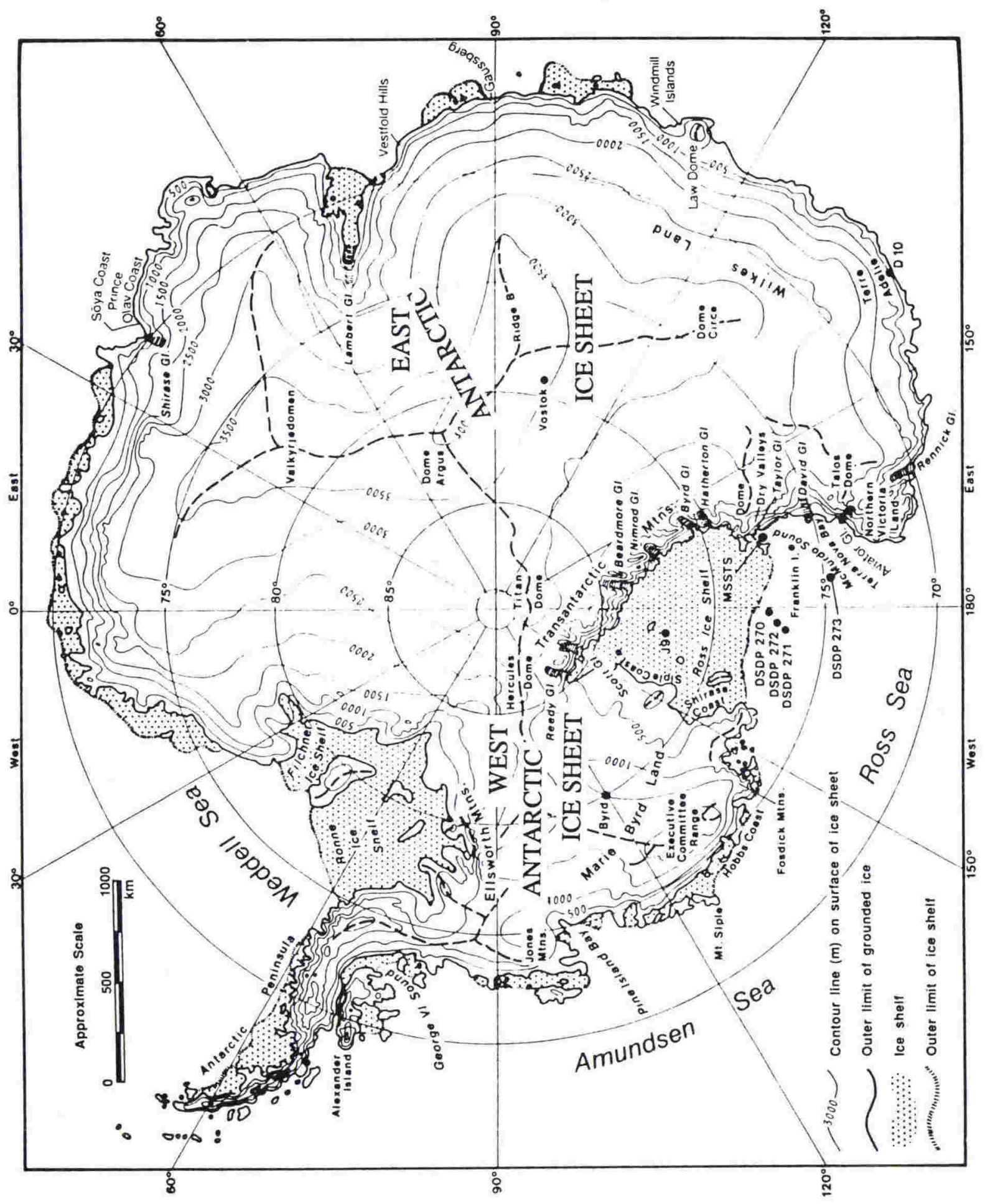

Figure 1.2: Present-day Antarctic Ice Sheet (modified from Denton et al., 1992). 
As already stated, the main aim of this thesis was to provide a high resolution Late Neogene record of ice volume variation on the Antarctic Continent and relate this to a record of eustatic sea level variation of similar resolution. To achieve this, four sub-aims were necessary:

1) The further development of a direct but stratigraphically controlled ice volume variation indicator for the Antarctic continent in the Late Neogene. This included documenting the stratigraphic indicators of variation, particularly the DVDP-11 and CIROS-2 drillholes (figure 1.3), and presentation of a model by which this variation may be interpreted.

2) The development of a high resolution record of eustatic sea level variation, again from direct stratigraphic evidence. Here I use the $4 \mathrm{~km}$ of Late Neogene strata in the South Wanganui Basin, New Zealand, for the same time period (figure 1.3). This also included documentation of the stratigraphic indicators of variation and presentation of a model by which this variation may be interpreted.

3) \& 4) Development and implementation of a high resolution chronology for both records that allowed both dating of individual events and direct correlation of records.

For the Antarctic record this has included; dating of the CIROS-2 ash, and development of beryllium-10 as a dating method for Antarctic margin sediments. This provides a calibration for both the magnetostratigraphic and biostratigraphic record of the Antarctic margin cores being studied and demonstrates the applicability of biostratigraphy within the Antarctic circle.

In the south Wanganui basin this required further understanding of the sedimentary controls on palaeomagnetism and presentation of a model by which this complex signal can be interpreted and detrital remanent magnetisation established for the strata. After this, a reliable magnetostratigraphy and hence chronology could be presented for the new Late Neogene eustatic sea level record.

\subsection{Approach}

The organisation of the thesis is along the same lines as the sub-aims presented above. Chapters are numbered consecutively and are subdivided into 4 sections which address each of the sub-aims. Section 1 deals with the record of Antarctic ice volume variation through the Late Neogene. It is partly a review chapter and partly an extension of models previously suggested for glaciomarine indication of ice volume variation (Hambrey et al., 1989). Chapter 3 presents a review of current knowledge of Late Neogene variation in the Antarctic Ice cover. Chapter 4 presents the stratigraphic framework from the Antarctic 


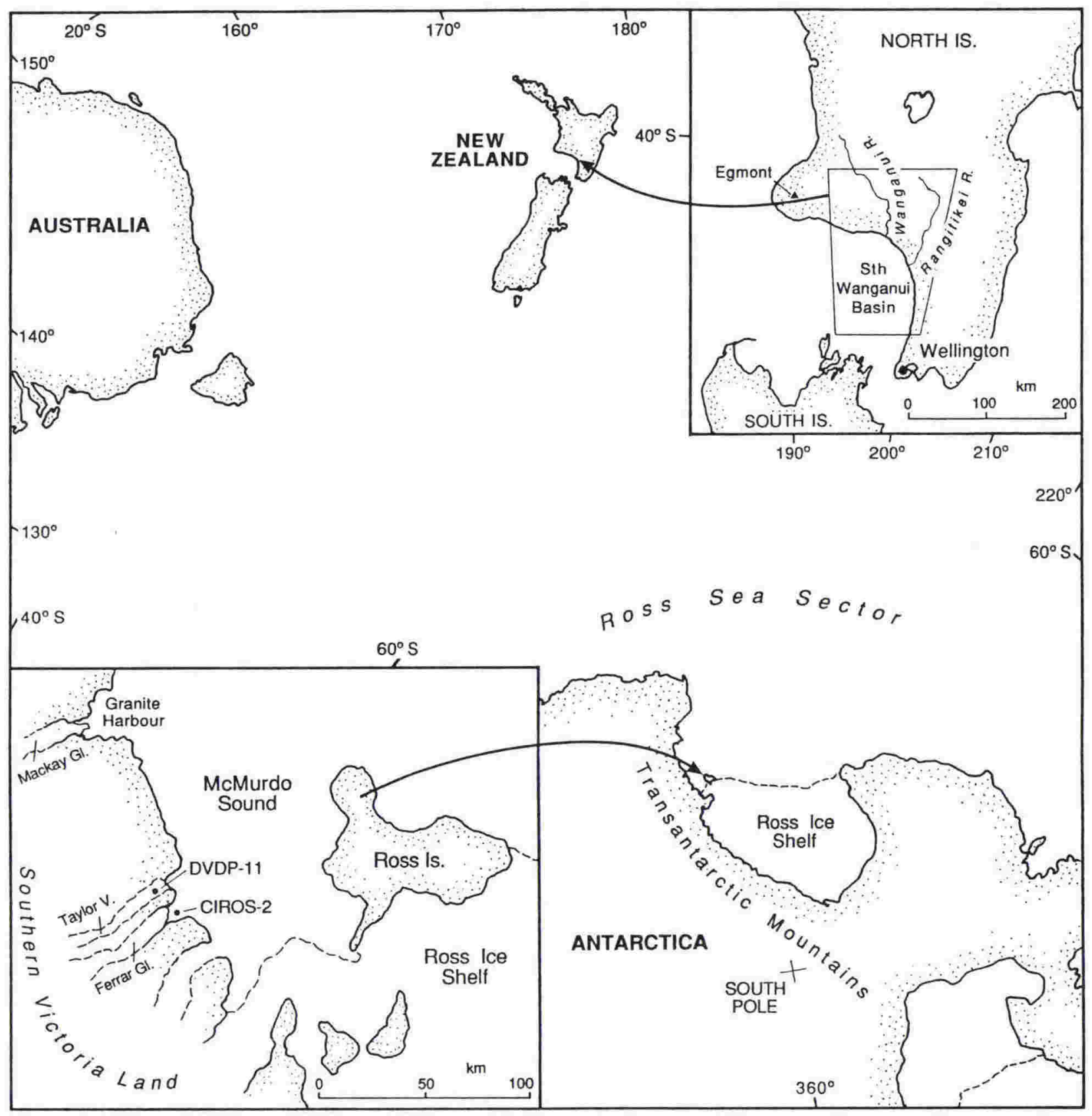

Figure 1.3: Location of Geologic evidence studied here for Late-Miocene eustatic sea level variation (South Wanganui Basin, New Zealand) and Antarctic Ice Sheet fluctuation (CIROS-2 and DVDP-11 drillholes in southern Victoria Land, and the Transantarctic Mountains, Antarctica). 
margin in McMurdo Sound. It is based on two drill-holes CIROS-2 in Ferrar Fjord and DVDP-11 in Taylor Valley. They both sample independent records of Late Neogene variation in glaciers fed directly from the East Antarctic Ice sheet. This provides a more or less continuous record both for the development of increased chronology and a reference for correlation of spot data points from elsewhere on the Antarctic Continent. A facies analysis of these sequences and an interpretation of ice extent from these ice sheet fed glaciers is presented in chapter 5. This builds on the work of Barrett and Hambrey (1992). In particular this section establishes a consistent record of variation from several indicators of variation from different parts of the East Antarctic Craton. The resulting composite record is entirely the work of this thesis and is presented briefly in chapter 6 . Chronology for development of this record is taken from section 2 .

Section 2 details new developments of a high resolution chronology for the stratigraphic sequences described in Section 1. Chapter 7 presents the dating of an ash at $125 \mathrm{~m}$ depth in the CIROS-2 core. Because of contamination it required development of simultaneous equation analysis as part of the $\mathrm{K} / \mathrm{Ar}$ dating procedure. The age was later confirmed by single crystal laser fusion ${ }^{39} \mathrm{Ar} /{ }^{40} \mathrm{Ar}$ dating of erupted feldspar crystals within the ash. The significance of this first radiometric age of these strata is discussed and particularly its calibration of the biostratigraphic chronology used elsewhere on the continent (e.g. Harwood, 1986).

Much time was spent in developing the newly proposed Beryllium-10 method for dating the Late Neogene glaciomarine strata from the Antarctic margin. This work required not only development of the technique to make it applicable to the Antarctic margin, but also development in the sample preparation and measurement procedures. Beryllium systematics and sample preparation procedures are presented in appendix 2. Rodger Sparks of the Institute of Geological and Nuclear Sciences is responsible for development of the Accelerator Mass Spectrometer to measure Beryllium and this will be reported on elsewhere. Because Beryllium dating is such a new procedure it was necessary to make several interlaboratory checks. The collaboration of John Southon of the Lawrence Livermore National Laboratory, U.S.A. and Grant Raisbeck of the Centre de Spectrometrie et de Spectrometrie de Masse (CNRS) is acknowledged in making this possible. This work encountered several problems which took time to resolve. One of them was the discovery that the standard provided by the National Institute of Standards and Technology (NIST), U.S.A. was found to have a different value to that assigned by NIST. The theory, development, and results of beryllium-10 dating is reported in chapter 8 .

The final chapter in section 2 (Chapter 9) deals with palaeomagnetism of the CIROS-2 and DVDP-11 sequences. Measurements were made independently at the United States Geological Survey (USGS) and interpretations have been reported elsewhere (Harwood, 
1986 and Ishman and Rieck, 1993). Here a reinterpretation of the palaeomagnetism from basic measurements is reported (these basic measurements are still as yet unpublished). A magnetostratigraphy is then established for both cores based mainly on the findings of this study.

Sections 3 and 4 deal with the independent record of Late Neogene sea level variation as recorded by stratigraphic sequences in the South Wanganui Basin, New Zealand. Section 3 deals with the stratigraphic record. Basic lithostratigraphy and lithostratigraphic correlation is presented in chapter 11, based on the logged Wanganui and Rangitikei River sections presented in Appendix 3. Formations are defined and described within a Group framework extended from that of Fleming (1953). The complete Late Neogene sea level record from the South Wanganui basin is presented in Chapter 15. It is based on the chronology established in section 4 and summarised in chapter 12 . Chapter 13 presents an analysis of sedimentary facies comprising the South Wanganui Basin strata, constructing a model of common facies successions. A sequence stratigraphic interpretation of these successions is made in chapter 14. Although based on the initial work of the EXXON oil company (Payton, 1977) this chapter provides a new model based on the observations made in chapter 13. This model, which incorporates knowledge of the tectonic development of the basin, is the basis for the new Late Neogene eustatic sea level record interpreted from the stratigraphic sequences of the South Wanganui Basin. The resulting curve is much improved both in accuracy and resolution from that presented by Haq et al. (1988) and Vail et al. (1977).

The development of detailed chronology for strata of the South Wanganui Basin is presented in section 4. Much time was spent developing the palaeomagnetic technique for the coarse and weakly magnetised sediments of the South Wanganui Basin to establish that the resulting record was accurate and reliable. Chapter 16 presents the basic palaeomagnetic observations and interpretations of measurements presented in appendix 4 . To ensure a correct understanding of the magnetic signal and its relationship to the original deposition of the sediments a study was made of the sedimentary petrography and mineralogy and its associated rock magnetic properties. This is presented in chapters 17 and 18 along with a model for the origin of magnetic remanence in the Late Neogene South Wanganui Basin, and other Tertiary New Zealand strata. A complete integrated magnetostratigraphy and hence chronology of the south Wanganui Basin sequences is presented in chapter 19.

The final chapter, chapter 20, presents the correlation of the Antarctic Ice Volume and eustatic sea-level records for the Late Neogene. Their relationship with establish records is discussed and a complete model presented for the variation of the resulting Late Neogene 
record. This record provides a major revision of Kennett's (1977; 1982) model of Antarctic Ice Sheet development and the Global sea-level model (of Haq et al., 1988). 


\section{THE RECORD OF LATE NEOGENE ANTARCTIC ICE VOLUME VARIATION}

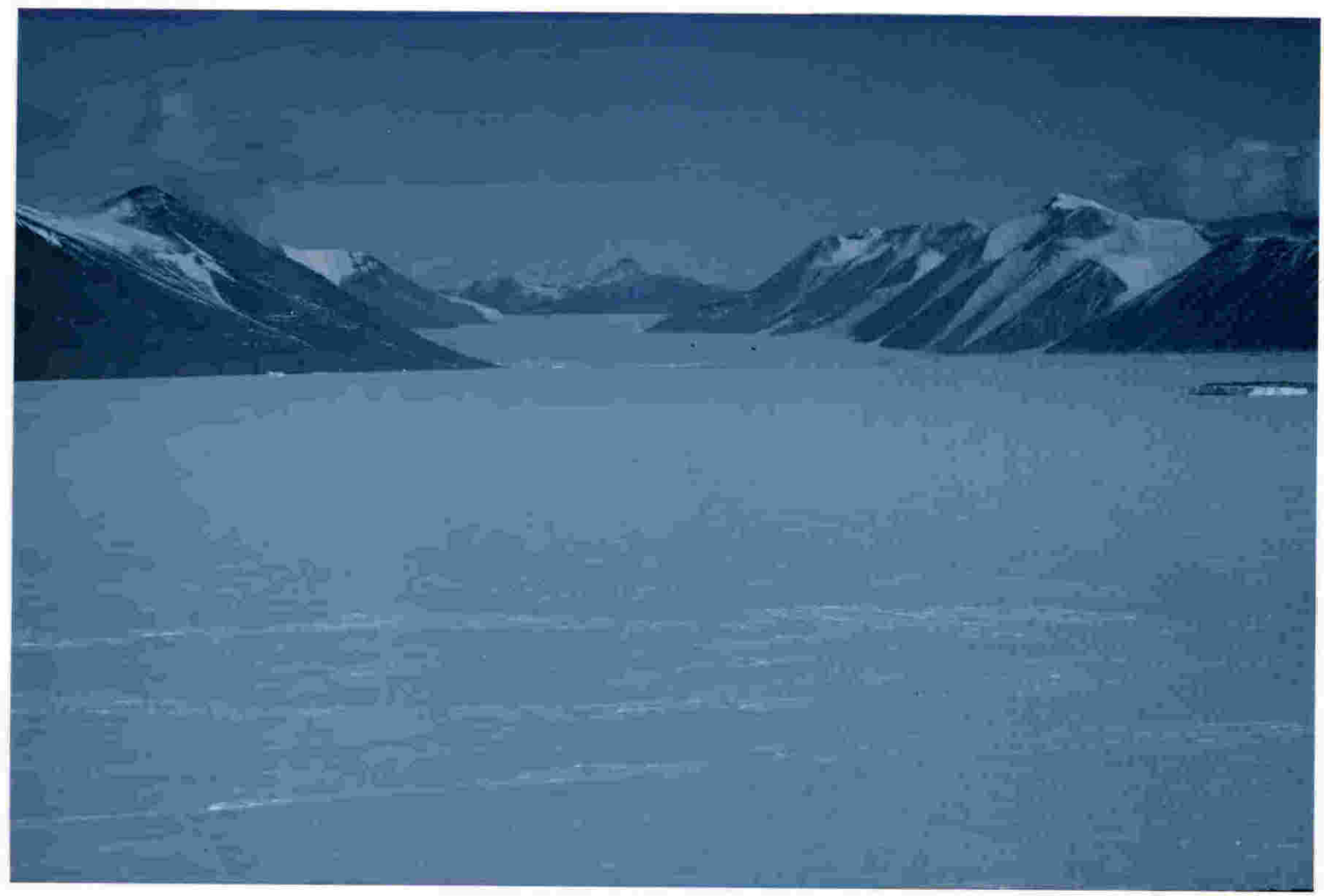

Areal view of Ferrar Valley from the east. In the foreground is the permanent sea ice of New Harbour. The East Antarctic Ice Sheet is beyond the mountains and feeds the Ferrar Glacier.

Chapter - 2: Introduction and aims

Chapter - 3: Synthesis of existing knowledge of the Antarctic Ice Sheet

Chapter - 4: Stratigraphy of Antarctic Margin sediments in McMurdo Sound

Chapter - 5: Facies analysis and interpretation of the CIROS-2 and DVDP-11 drill-cores

Chapter - 6: Late Neogene ice volume history 


\section{Chapter - 2 Introduction}

Section 1 presents the record of Late Neogene ice volume variation on the East Antarctic craton, from previous observations of Antarctic outcrop (chapter 3) and from the record at the Antarctic Margin (chapters 4 and 5). Most of the resolution comes from strata cored in the CIROS-2 and DVDP-11 drillholes, McMurdo Sound, and the extent of variation estimated from observations from other areas on the Antarctic Continent. The resulting model uses new chronology from section 2 and is presented in chapter 6 .

\subsection{Introduction}

Late Neogene strata drilled in the McMurdo Sound area in Taylor Valley (DVDP-10 and 11) and Ferrar Fjord (CIROS-2), reveal a history of glacial advance and retreat over the last several million years. The cores record periodic ice advance from the Transantarctic Mountains and Plio-Pleistocene ice grounding in the Ross Sea due to major expansion of the East and West Antarctic ice sheets.

The CIROS- 2 drill core was drilled in Ferrar Fjord, south western Ross Sea (figure 2.1), in the 1984/85 austral summer, with the aim of understanding the Cainozoic geologic history of southern Victoria Land and the adjacent Ross Sea (Barrett, 1982). The drill site was in $211 \mathrm{~m}$ of water near to the valley axis, about $1 \mathrm{~km}$ offshore from the Ferrar Glacier snout (plate 2.1). A $166.47 \mathrm{~m}$ sequence (67\% recovery) of sand and glacial debris (Pyne et al., 1985) was cored. Drilling terminated when basement gneiss was reached. Wellpreserved marine diatoms in the lower part of the sequence (Harwood, 1986), were dated as Early Pliocene. The highest part of the core ranges up to a possibly Pleistocene age. This chronology is disputed by Burkle and Pokras (1991) and others, who believe the diatom flora could be as old as Early Miocene.

Barrett and Hambrey (1992) suggested that the advances and retreats of the Polar Plateau and Ross Sea Ice are recorded in the CIROS- 2 and DVDP-11 cores. These ice movements should be related to global variations in ice volume and sea level. A more refined chronology is required to understand the relationship and is presented here in section 2 .

The DVDP-11 core was drilled in Taylor Valley, southern Victoria Land (figure 2.1) as part of the multi-national Dry Valley Drilling Project. The project obtained geophysical and stratigraphic 


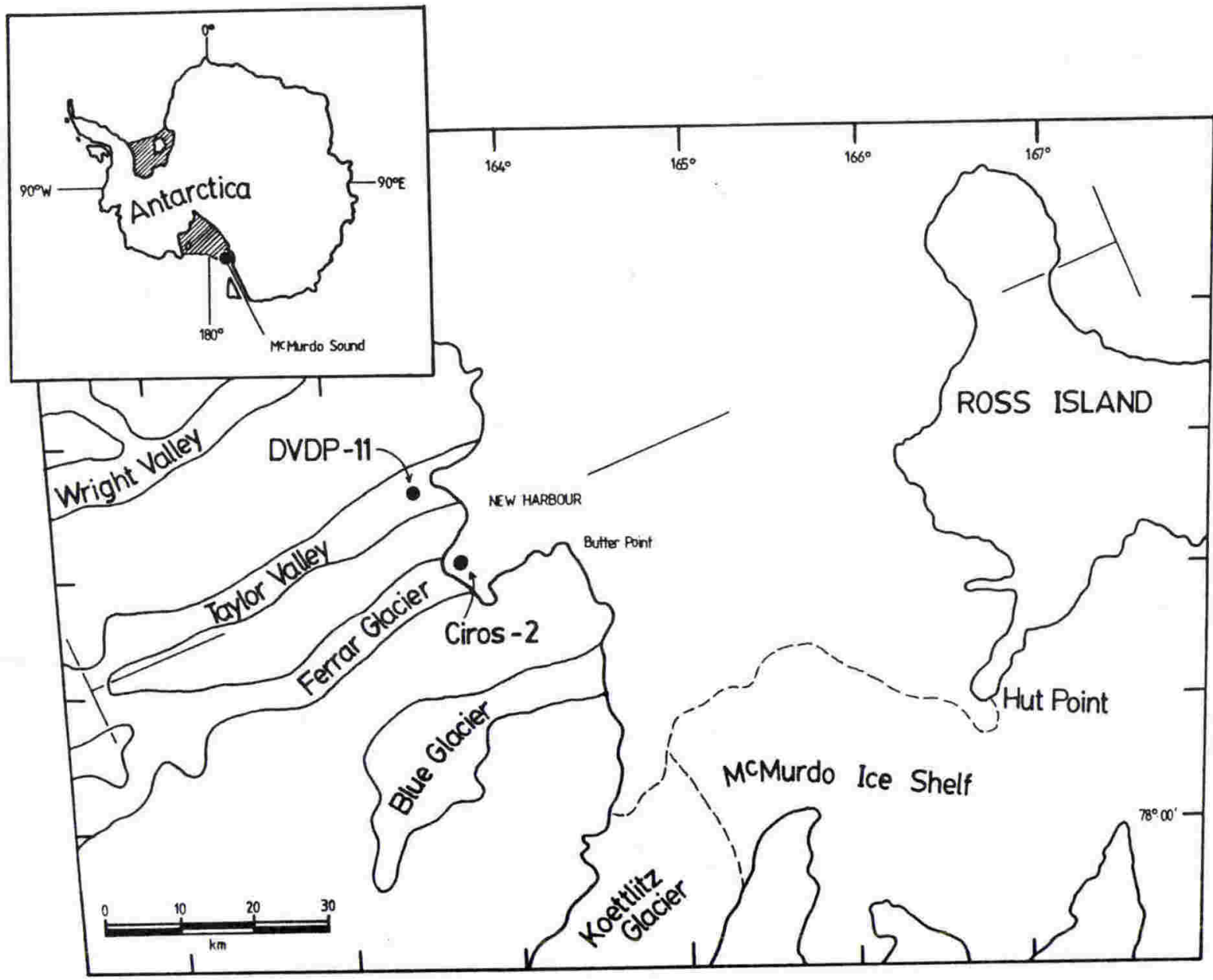

SW

NE

Transantarctic Mts.

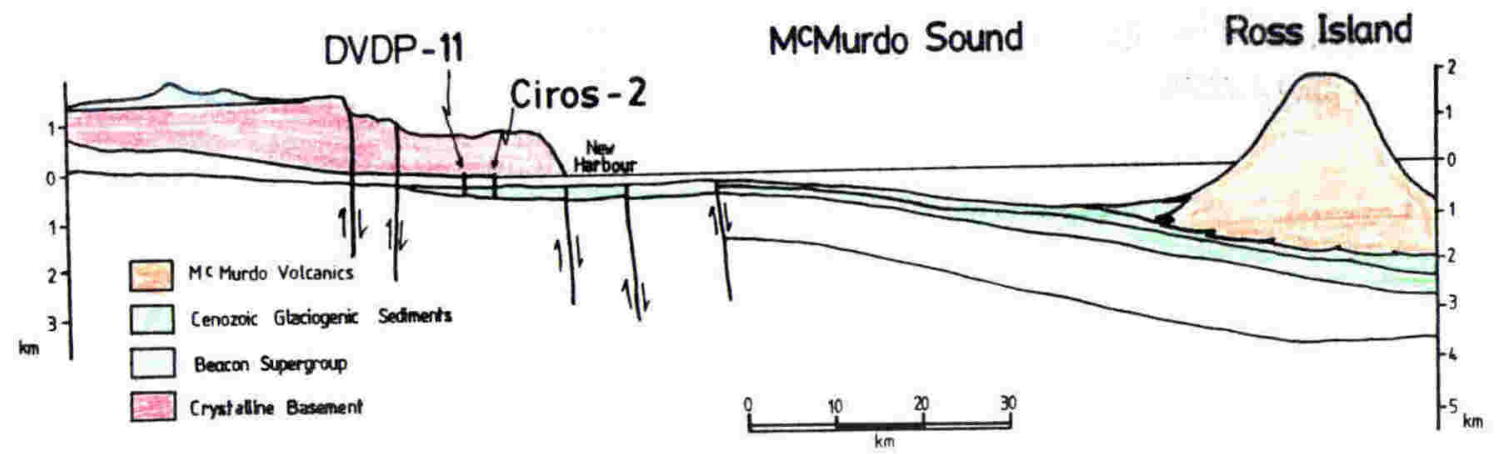

Figure 2.1: Map of the McMurdo Sound area, showing the main physiographic features, and the locations of the CIROS-2 and DVDP-11 drill-holes, and sketch Geologic section parallel to the Taylor and Ferrar Valleys (after Pyne et al., 1985). 


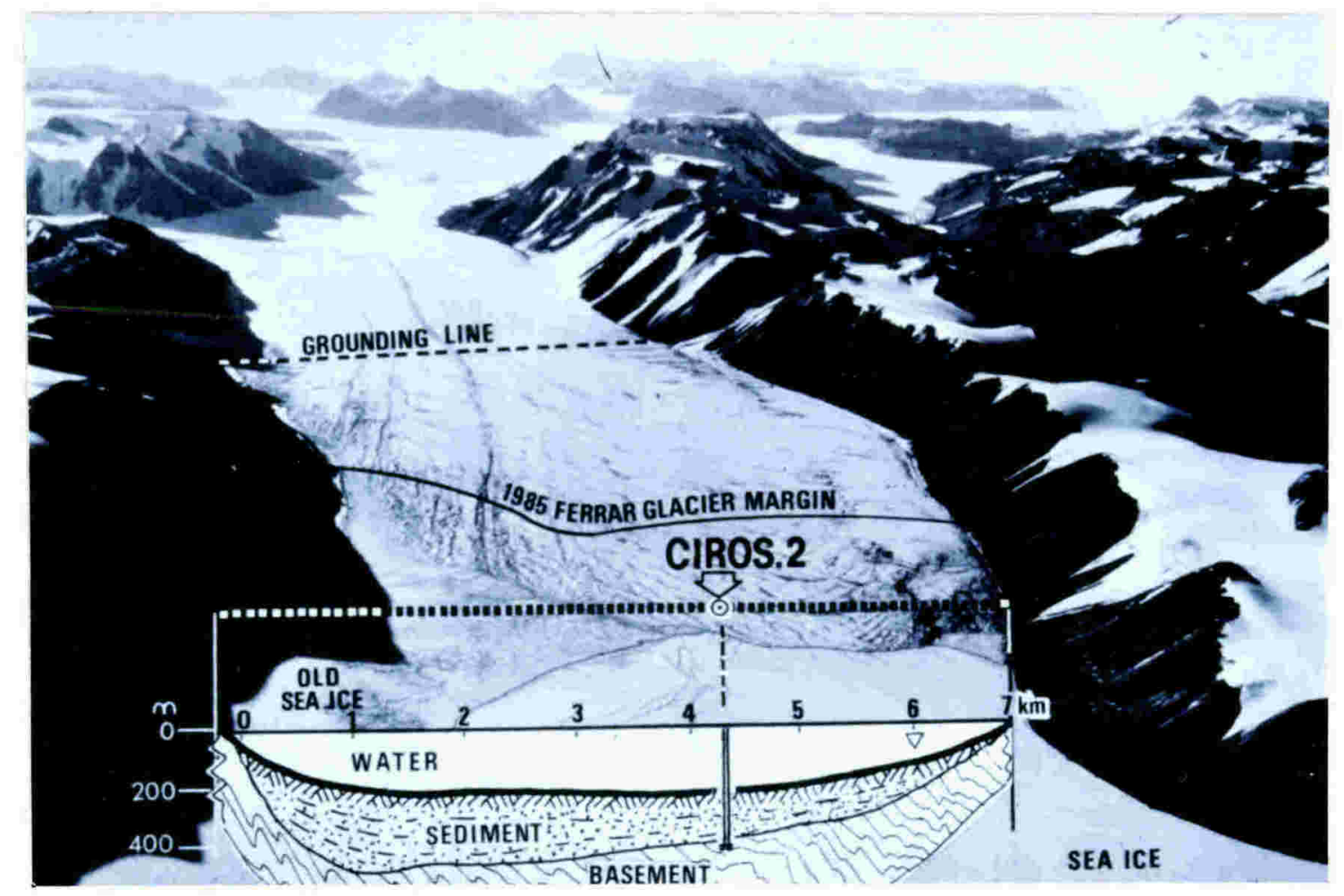

Plate 2.1: Aerial view of Ferrar Fjord and Ferrar Glacier from the east, showing the location of the CIROS-2 drill-hole and a cross section of the fjord (from Barrett and Hambrey, 1992).

information to determine the complex history in the dry valleys, particularly the Cainozoic glacial history (Smith, 1981). Drilling took place $3 \mathrm{~km}$ inland from the coast near the terminus of the Commonwealth Glacier (McKelvey, 1981), at an altitude of $80.2 \mathrm{~m}$. The drillhole was $328 \mathrm{~m}$ deep with $94 \%$ of the core recovered (McKelvey, 1981).

The sequence recovered comprised very poorly sorted sedimentary rocks ranging from laminated sandy mudstones to diamictite and pebble conglomerates (McKelvey, 1981). Initial chronology for the sequence was from biostratigraphy, the lower part of the core from diatom flora (Brady, 1980) and the upper part of the core from foraminifera (Webb and Wren, 1982). These fossils indicate a
Late Miocene age for the oldest part of the core ranging up to a Pleistocene age for the top of the core. Again Burkle and Pokras (1991) disputed the ages of these flora and fauna.

\subsection{Aims}

The aim of this section of the thesis is to present a high resolution record of ice volume variation on the East Antarctic craton. This has required development of new chronology to integrate with existing chronology (presented in Section 2). Sub aims of this section were: 1) To create a reliable and working lithostratigraphic framework for interpretation, correlation and dating of the cored Antarctic Margin strata; 2) To test and extend the glaciomarine facies models of Hambrey 
et al. (1989); 3) To correlate depositional events in the DVDP-11 and CIROS-2 cores both between each other and with other direct records of Late Neogene East Antarctic Ice Sheet variation.

The aims of section 2 were to develop the chronology necessary for a 100 k.y. resolution of the ice volume interpretation record and to correlate it with a similar resolution eustatic sea level record from the South Wanganui Basin, New Zealand. This required development of new dating methods and testing of the existing Antarctic biostratigraphy.

\subsection{Fieldwork methods}

Cores from the DVDP-11 and CIROS-2 drill-holes were relogged at the Antarctic Core Facility, Florida State University with permission of Dennis Cassidy. This was done during two extended visits to the facility.

Only the Late Miocene - Late Pliocene (2.4 - 6.0 m.y.) stratigraphic sections and unit descriptions of the CIROS-2 and DVDP-11 cores are restudied and reported here (Appendix 1). The observations differ from the original stratigraphic logs of Pyne et al. (1985) and McKelvey (1981). The core is reassessed using a facies analysis approach with special emphasis placed on recognising unconformities in the cores and the interpretation of individual facies associations and successions (chapter 5).
Confusion in the depth measurements of core lengths recovered in the DVDP-11 core resulted from the original metric conversion of measurements and repacking of the core for shipping to the U.S. (Dennis Cassidy, pers. comm.). This meant that it was necessary to measure the entire core and its lithostratigraphic units directly. The original hole depths and on-site logs were used as a guide to ensure that correct unit thicknesses and depths are reported for both the DVDP11 and CIROS- 2 cores.

Units assigned in this study are different from those reported by Pyne et al. (1985) and McKelvey (1975) (figure 4.1).

\subsection{Setting}

The Ferrar and Taylor Valleys are Ushaped, formed by pre-Neogene glacial down-cutting through the Transantarctic Mountains. Currently the Ferrar Valley is filled by the Ferrar Glacier which is fed from the polar plateau. It flows beyond its grounding line and floats out into Ferrar Fjord, and appears to be advancing at present (plate 2.1). The Taylor Valley to the north is ice free, the Taylor Glacier terminating close to the head of the valley (figure 2.1).

The two valleys are cut into the crystalline basement complex of Precambrian to Cambrian metamorphic rocks of the Skelton Group, and the Precambrian Granite Harbour intrusive complex which are unconformably overlain by the Palaeozoic and Mesozoic 


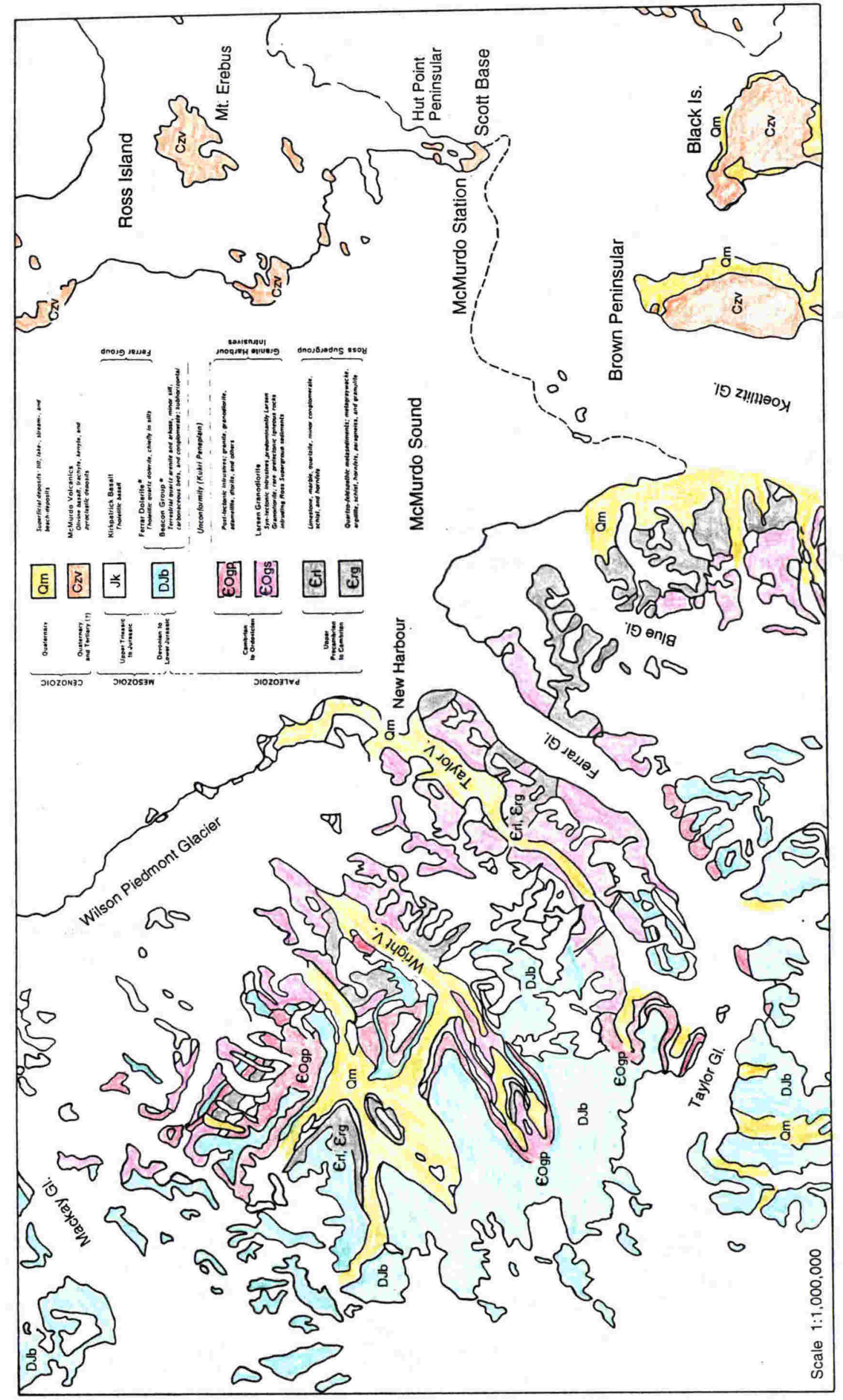

Figure 2.2: Geological map of the McMurdo Sound area, showing the distribution of the major basement rock types. Cainozoic Valley fill is marked in yellow (modified from Warren, 1970). 
sediments of the Beacon Supergroup and the Jurassic Ferrar Dolerite (Gunn and Warren, 1962) (figure 2.2).

The Transantarctic Mountains began to rise about $50 \mathrm{Ma}$. ago (Gleadow and Fitzgerald, 1987) at the western margin of the West Antarctic Rift System (Behrendt and Cooper, 1991). Rifting is causing extension and depression of the Ross Sea region as well as uplift of the Transantarctic Mountains. Associated with the rifting is extensive basaltic volcanism in the Ross Sea region, with the Ross Island volcanoes to the east and extrusives in the Dry Valleys to the west (figure 2.1). The volcanic activity has been active since at least the Late Miocene (Kyle, 1981).

Some phases of uplift in the Transantarctic Mountains may have occurred within the Late Neogene (Behrendt and Cooper, 1991). Evidence for this is from young fault scarps and raised shorelines. This possible late tectonic uplift of the Ross Sea Margin may complicate interpretation of glacial sedimentary facies changes, as may isostatic adjustment to ice loading or unloading. 


\section{Chapter - 3}

\section{Synthesis of existing knowledge of Late Neogene Antarctic ice sheet history.}

This chapter summarises the existing data set, prior to this study, contributing to knowledge of Antarctic glacial history in the Late Neogene. Information is presented both from Southern Ocean floor sediments and from Antarctic continental outcrop. The significance of each data set is discussed in each subsection. Previous models of Antarctic glacial history are discussed to allow later comparison with the new findings of this work (Chapter 6). Evidence from drilling on the Antarctic continental margin is presented later in chapters 4 and 5. An analysis of the evidence presented in this chapter and chapters 4 and 5 is presented in chapter 6 , where it is used to assess the extent of glacial maxima and minima suggested by the higher resolution record from the continental margin (presented in chapter 5).

\subsection{Introduction}

Many other reviews have documented Cainozoic Antarctic glacial history (e.g. Mercer, 1983; Webb, 1990; 1991; Hambrey and Barrett, 1993). Only records relevant to the Late Neogene are discussed here, in as much detail as is available to establish evidence of glacial development of the Antarctic continent. The discussion is also confined mainly to the Late Neogene development of the East Antarctic ice sheet. On the scale of change discussed in this study, the West Antarctic ice sheet is assumed to behave under the influence and in synchrony with the East Antarctic ice sheet.

\subsection{Oceanic evidence for Ice Sheet development}

\subsubsection{The Southern Ocean}

Kennett (1977) first suggested and established the pattern of evolution of the Antarctic psychrosphere. He recognised the interaction of tectonic, oceanographic, atmospheric and geographic controls on developing the psychrosphere and the ways in which sediments in the southern ocean record the developing history. Kennett (1977 and 1982) used several different sedimentary indicators to infer climatic evolution and development of the Antarctic continent. These included: the presence of ice rafted detritus (IRD) in otherwise marine settings; increased bottom water events in the deep marine record, inducing hiatuses (hiatus 
stratigraphy); large

latitudinal movements in siliceous sedimentation patterns; and oxygen stratigraphy jointly indicative of fluctuating temperatures and absolute oceanic volumes.

\subsubsection{Palaeoceanographic Development} of the Southern Ocean

Kennett (1977; 1982) suggested that initiation of the Antarctic psychrosphere occurred during the early Oligocene, instituted by opening of the Drake Passage and the initiation of the circumAntarctic current (figure 3.1). According to Kennett, the development of the circum-Antarctic current began a general trend of cooling of the continent leading to development of sea ice and glaciers.
Further tectonic activity that may have changed the circulation patterns of the southern ocean include isolation of the Mediterranean Sea (Kennett, 1982) in the Late Miocene and closing of the Central American sea way in the Pliocene (Kennett, 1977).

There is still much debate on the development of extensive Northern Hemisphere ice sheets. Shackleton and Berggren (1972) initially suggested that this occurred during the late Pliocene and this timing was adopted by Kennett $e$ t al. (1975). Poore (1982), Shackleton and Opdyke (1977) and Keigwin and Thunell (1979) date this more precisely at ca. 3.0 Ma. Further work (Shackleton and Hall, 1985) has suggested that ice sheet development did not occur until $2.4 \mathrm{Ma}$.
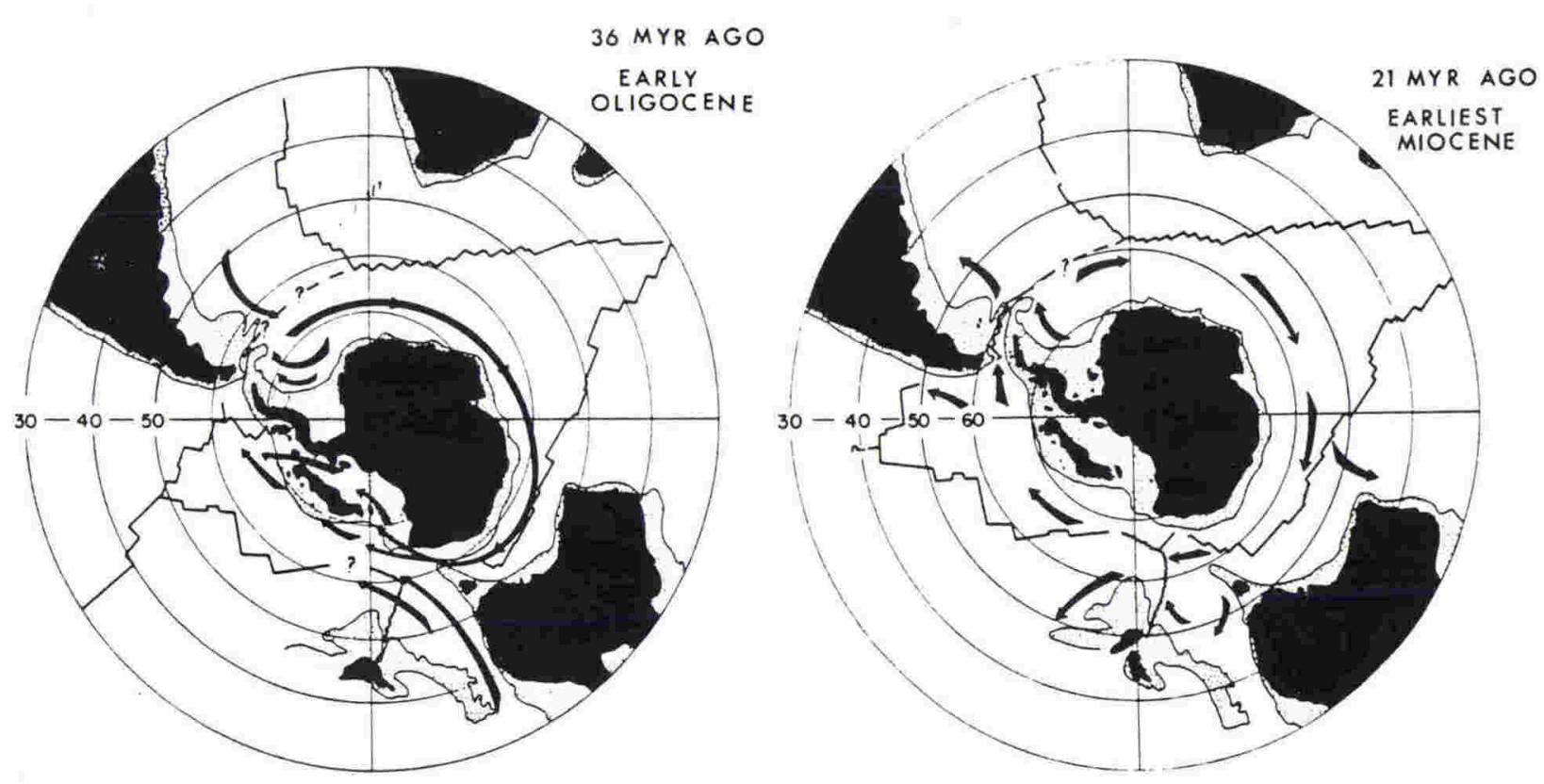

Figure 3.1: Reconstructions of the Southern Ocean, from Kennett (1982). Left is the earliest Oligocene (pre-psychrosphere), before opening of the Drake Passage, but after separation of Australia and Antarctica. Right is earliest Miocene (post-psychrosphere), with the Drake Passage open and a circum polar current developed. 
when the first the major onset of ice rafted debris in the northern Atlantic Ocean. Other workers (e.g. Dowsett and Loubere, 1992) recognise minor ice rafted detritus in some North Atlantic cores around $2.7 \mathrm{Ma}$. and consequently define the preglacial to glacial northern hemisphere transition to occur between 2.0 and 3.0 Ma. With respect to Antarctic glacial development, it is not yet established whether this latest Pliocene development of the northern hemisphere ice sheet was a cause or effect of continued Southern Ocean development.

\subsubsection{The deep sea $\delta^{18} \mathrm{O}$ record}

Oxygen isotope ratios of the world oceans have varied over geologic time (Emiliani and Milliman, 1966; Duplessy, 1978; Shackleton, 1967; Shackleton and Opdyke, 1973; and Kennett, 1982). Most calcareous microfossils precipitate oxygen in the same ratio as the surrounding water column. Two main factors cause fractionation in the ratio of precipitation of oxygen-16 to oxygen-18: Temperature and the preferential removal of ${ }^{16} \mathrm{O}$ from the oceans to terrestrial reservoirs. The $\delta^{18} \mathrm{O}$ record in deep sea strata becomes more positive with decreasing temperature and increasing terrestrial ice.

Analysis of the $\delta^{18} \mathrm{O}$ in specific microfossils in deep sea strata provides a record of fluctuating Cainozoic temperatures and ice sheets. Analysis of solely benthic species should prevent any effect from fluctuating sea surface temperatures. However, measurement of the resulting record will still be a composite of both changing ocean bottom water temperatures and ice volume.

If the effect of temperature can be calculated from another source and removed from the composite record, the remaining portion of the record should be due to ice volume fluctuation alone. Both cooling temperatures and increasing ice volume on land will enrich the relative oxygen-18 value recorded by microfossil tests. Shackleton and Kennett (1975) calculated the value of ${ }^{18} \mathrm{O}$ ocean enrichment by the present ice sheets. Hence, they calculated a lesser value of enrichment beyond which must be accounted for by ice accumulation on land and not temperature alone. Measurement of the changing oxygen isotope ratios from leg 29 (Kennett, 1977) showed three major enrichment phases of $18 \mathrm{O}$ : One at the EoceneOligocene boundary, the second in the middle Miocene (approximately $14 \mathrm{Ma}$.) and the third in the late Pliocene (3.5-3 Ma.). Further composite benthic $\delta^{18} \mathrm{O}$ records were constructed from many more deep sea cores (eg; Miller and Fairbanks, 1985; Miller et al., 1987) to rule out the effect of local temperature fluctuations (figure 3.2). These composite records still contain the major developments proposed by Kennett (1977).

Matthews and Poore (1980) recognise the circularity of previous $\delta^{18} \mathrm{O}$ models in 


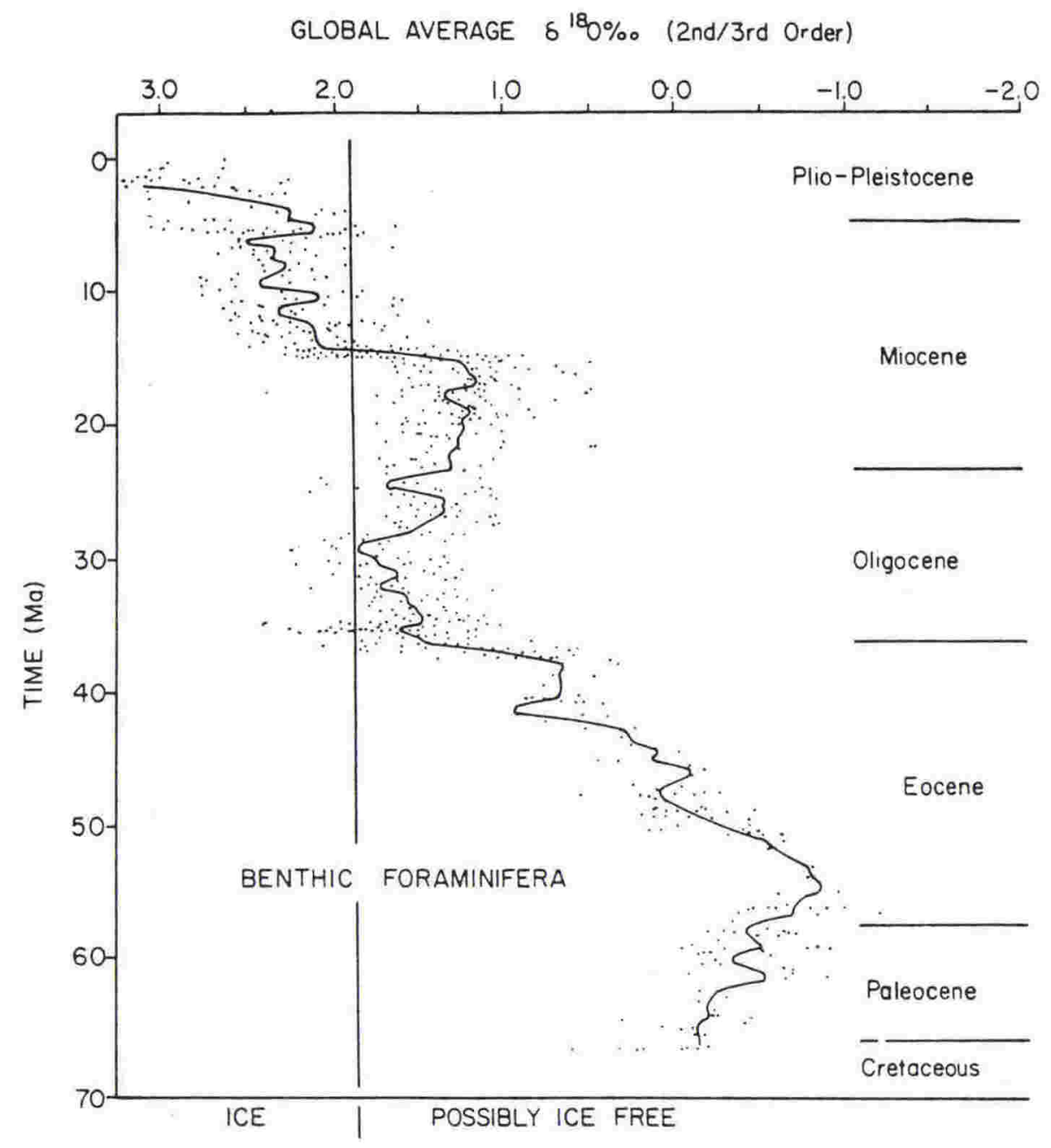

Figure 3.2: A composite benthic $\delta^{18} \mathrm{O}$ record from Miller and Fairbanks (1985), showing an ice/ice free value calculated from present day values.

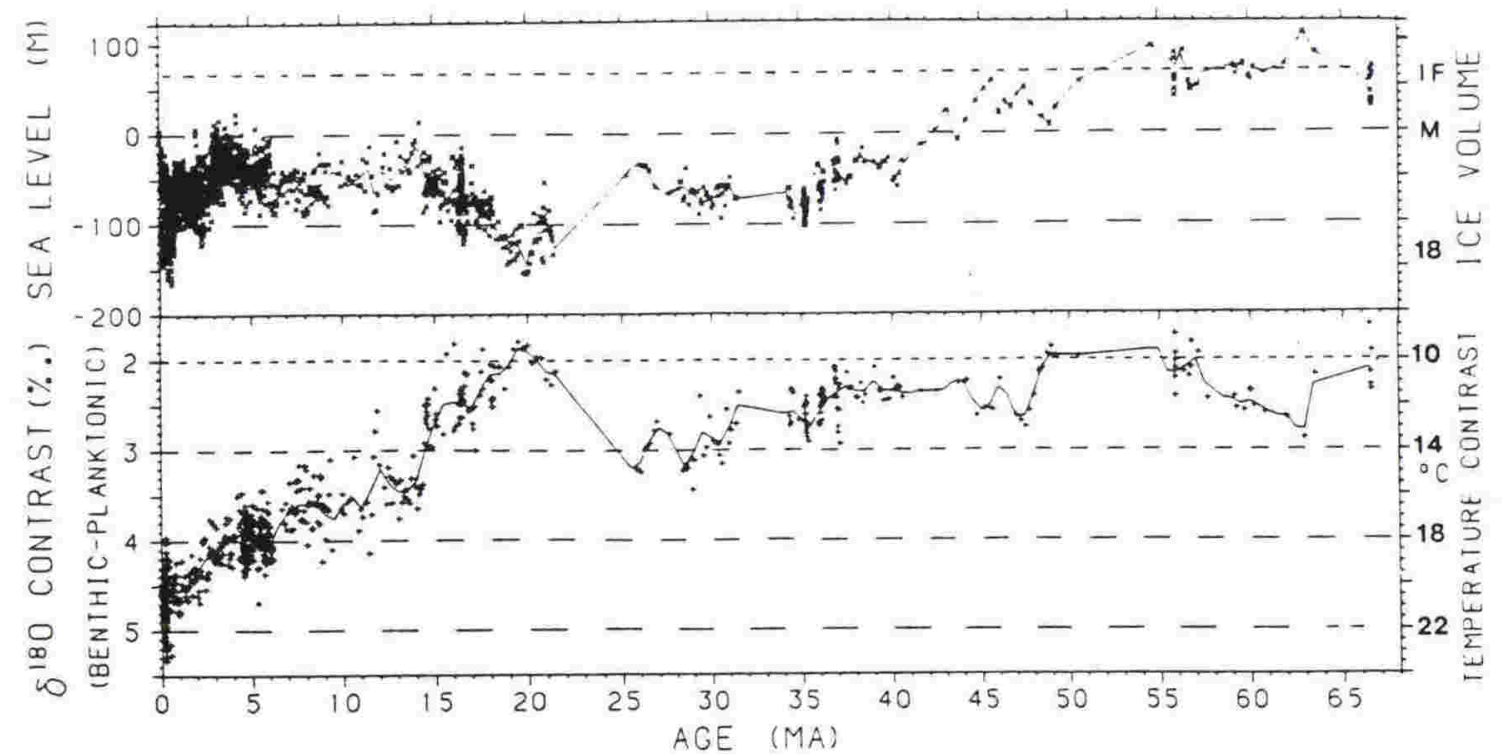

Figure 3.3: A composite planktonic equatorial $\delta^{18} \mathrm{O}$ record from Prentice and Matthews (1988), showing a glacioeustatic sea level and Antarctic ice volume interpretation. 
assessing temperatures and Antarctic ice volume history. They eliminate some of the assumptions inherent in previous models by constructing a model using the planktonic equatorial $\delta^{18} \mathrm{O}$ signal. This assumes constant equatorial sea surface temperatures. Based on the new model they suggest significant periods of ice on land throughout the Cainozoic and Cretaceous. Prentice and Matthews (1988) following the approach of Matthews and Poore (1980) also recognise that the benthic $\delta^{18} \mathrm{O}$ signal dominantly reflects temperature variation. They also recognise that the Antarctic is not the only source of bottom water throughout the Cainozoic. They develop a refined model using the planktonic equatorial $\delta^{18} \mathrm{O}$ signal, again assuming constant equatorial sea surface temperatures throughout the Cainozoic. While they recognise more significant variation in the $\delta^{18} \mathrm{O}$ record than Kennett $(1977 ; 1982)$, with significant ice volume flux since $40 \mathrm{Ma}$. (figure 3.3), they still suggest major glaciation of the Antarctic continent in the middle Miocene, with little variation subsequent to ca. $14 \mathrm{Ma}$.

\subsubsection{The Ross Sea}

Leg 28 of the Deep Sea Drilling Project drilled 4 holes on the Antarctic continental shelf in the Ross Sea (Hayes et al., 1975). Only sites 271 and 272 recovered Late Neogene strata (Hambrey and Barrett, 1993). Core recovery from these two sites was poor, only $7 \%$ in hole 271 , but several events relating to Late Neogene glacial history were recognised.
A pre-Pliocene hiatus in the sequence was related to ice grounding and extension in the Ross Sea Region (Anderson, 1992). What was recovered of the Pliocene strata was mainly diatomaceous, but with a few lonestones. Petrology indicated provenance from West Antarctica (Barrett, 1975). This evidence suggests a glacial advance in the Ross Sea in immediately pre-Pliocene times and a relative retreat and open marine sedimentation pattern during the early-middle Pliocene.

\subsubsection{Prydz Bay}

Two drill sites (739 and 742) on ODP leg 119 recovered Late Neogene strata from Prydz Bay, East Antarctica (Hambrey et al., 1991). The strata recovered was inferred by Hambrey et al. (1991) to be indicative of the general nature of behaviour of the East Antarctic ice sheet. Chronology is based largely on diatom stratigraphy which limits the resolution. Poor core recovery in places also reduces the available resolution. The Late Neogene record is an incomplete and poorly cored sequence that caps a more extensive and complete Cainozoic sedimentary pile.

According to Hambrey et al. (1991) prior to Pliocene times, ice was grounded in Prydz Bay. The Late Miocene to midPliocene is marked by retreat but not total withdrawal of the ice sheet. The Late Pliocene to Pleistocene is characterised by a further advance and grounding of the ice sheet across Prydz 
Bay. Hambrey et al. (1991) recognise ice grounding and fluctuation by the changing nature of depositional lithofacies in the cored sequences. Models of lithofacies variation within glaciomarine environments have previously been presented by Hambrey $e t$ al. (1989) and will be reviewed briefly here in chapter 5 .

\subsection{Continental evidence for East Antarctic Ice Sheet development.}

\subsubsection{The Sirius Group}

The name Sirius Formation was initially proposed by Mercer (1972) for the "compact glacial drift that unconformably covers pre-Tertiary rocks". By this definition the Sirius Formation outcrops as some tens of discrete units along the length of the Transantarctic mountains for $1300 \mathrm{~km}$ (figure 3.4). All deposits occur above $1600 \mathrm{~m}$ elevation, with most occurring above $2000 \mathrm{~m}$ (Mayewski and Goldthwait, 1985). Mercer (1972) had noted that only scattered remnants of these deposits had survived subsequent ice action on the landscape. The deposits themselves all consist of till draped over striated bedrock material, with a few outcrops preserving a stratified member of glaciolacustrine origin. McKelvey et al. (1991), recognising the thickness (greater than $180 \mathrm{~m}$ ), variability, scattered distribution and possible age differences of individual outcrops, raised the Sirius Formation to group status. This allowed individual outcrops to be described as formations, and even each outcrop to contain different formations (eg. the two members of Mayewski and Goldthwait, 1985), or be subdivided into members.

Originally, Mercer (1972) had suggested that these deposits were derived from local ice accumulation at high level plateaus within the Transantarctic mountains. He also noted that the till's thickness, compactness and the evidence of abundant water suggested that the glacial conditions during deposition were temperate, and deposition occurred about the contemporary equilibrium line. From this, Mercer believed that the deposits must date from soon after the formation of ice cover in the Transantarctic Mountains and long before the formation of the present cupoloid East Antarctic Ice Sheet. Mayewski and Goldthwait (1985) from observation of Sirius Group outcrops along the length of the Transantarctic Mountains agreed that the till was waterlain, but suggested that it originated from a continental-scale ice sheet which contained wet based zones as depositional centres. The model of Mayewski and Goldthwait (1985) requires the age of individual Sirius Group outcrops to be similar, with deposition occurring towards the end of East Antarctic Ice Sheet formation and subsequent to geomorphic development of the Transantarctic Mountains. Even if deposition was from a continental-scale ice sheet, flow directions in southern Victoria Land are markedly discordant to 


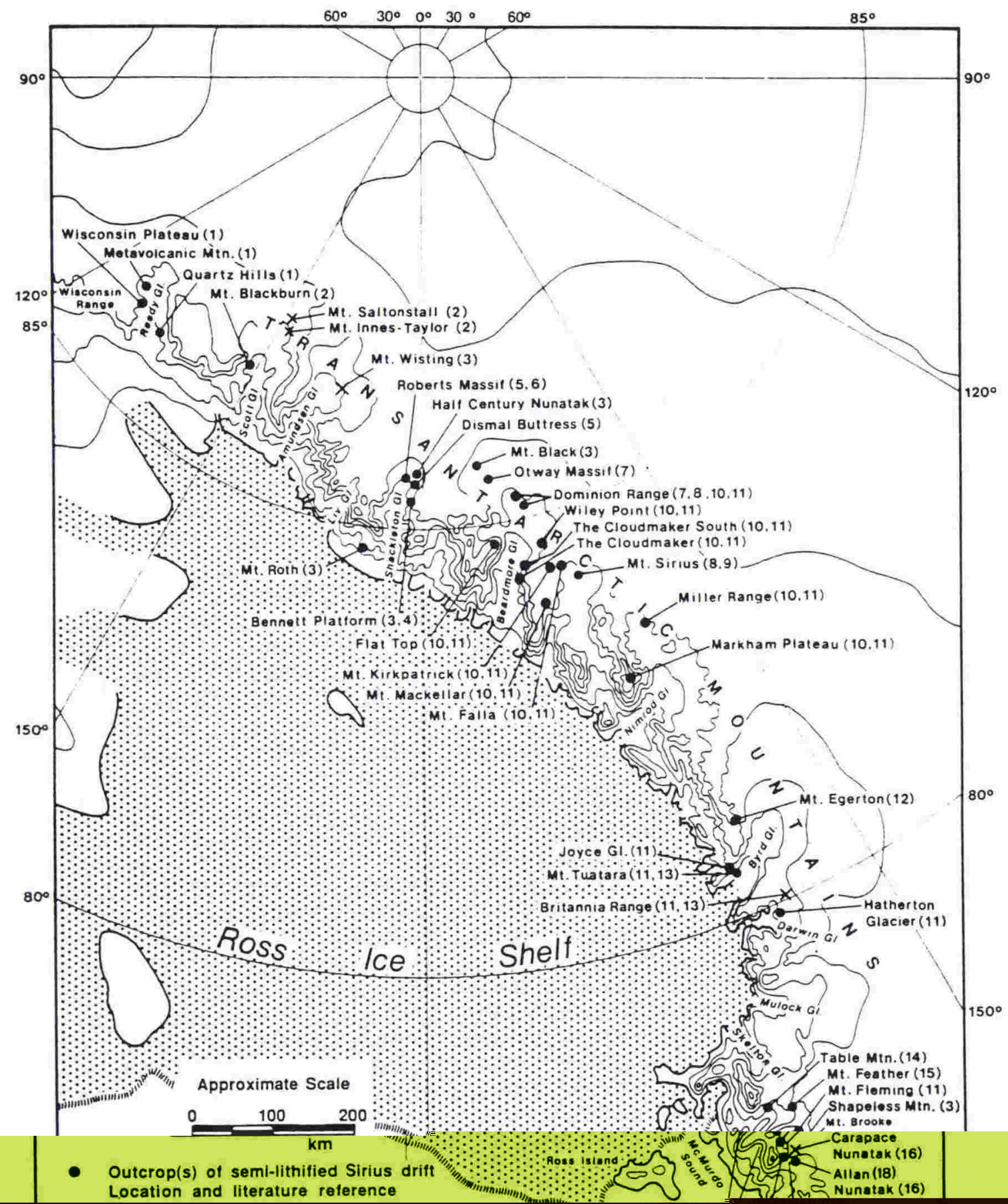


present day ice flow directions (Brady and McKelvey, 1979 and 1983).

Little was known about the significance of Sirius Group deposits until Webb et al. (1984) reported the recovery of marine microfossils from them in the Reedy and Beardmore glacier areas. The assemblages are diverse and include foraminifers, diatoms, radiolarians, sponge spicules, ostracodes and palynomorphs. The microfossils are within the matrix of Sirius Group tills and sometimes included in clasts. Particularly useful in age control are the presence of Late Eocene through late Oligocene, Miocene, and Pliocene diatoms (Harwood, 1986). These age ranges were based on the southern highlatitudes zonal schemes, amongst others, of Gombos and Ciesielski (1983) and Ciesielski (1983). Although the diatoms are reworked into the glacial till, distinct time zones of productivity can be identified (Harwood, 1986; Wise et al., 1991), and included periods of nonproductivity between them (figure 3.5 ). Assemblages from the Reedy Glacier, Dominion Range, Mount Sirius and Mount Feather areas (figure 3.4) include diatoms specific to the Thalassiosira insigna Zone through the Thalassiosira vulnifica Zone (Harwood, 1986), 3.1 to 3.5 Ma. (Harwood et al., 1992). This indicates time of marine productivity about the source of the glacial deposits. Early Pliocene diatoms were also recovered from these same deposits.
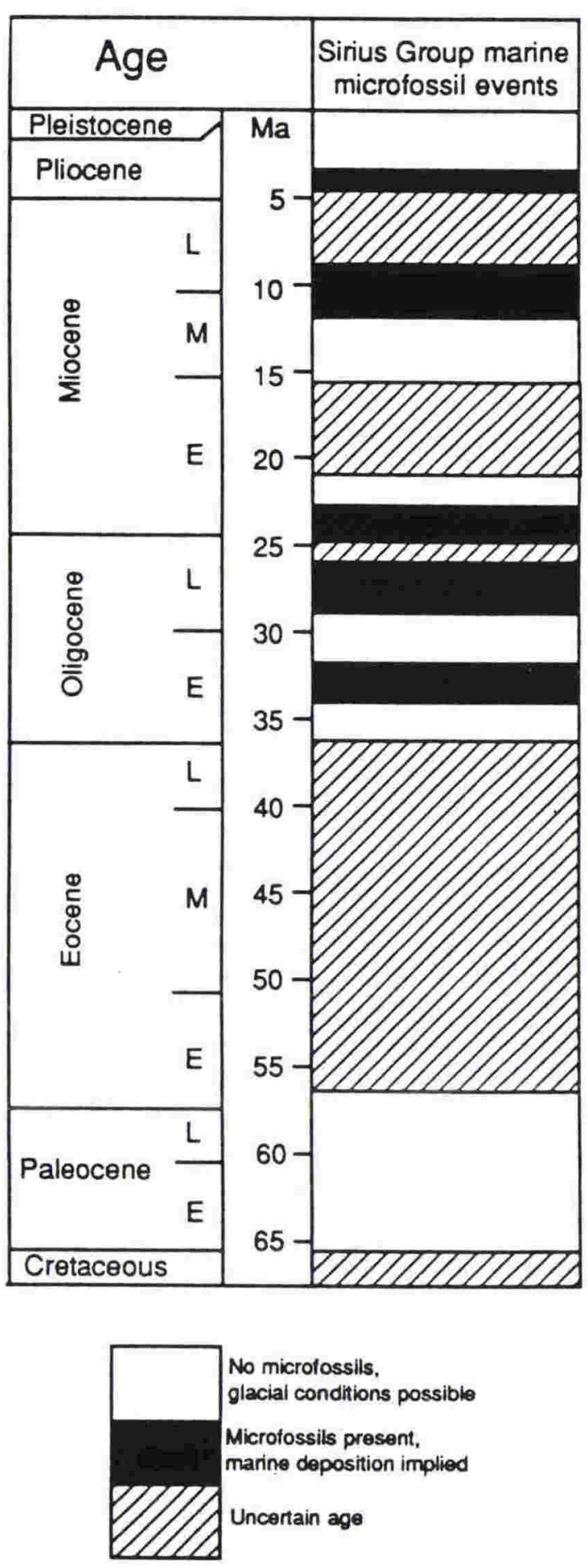

Figure 3.5: Episodes of marine deposition in the Wilkes-Pensacola basins as indicated by the presence of diatoms and other marine microfossils reworked into the Sirius Group tills.(see plate 3.1). Absence of such fossils could indicate times that these basins were occupied by an ice cover (after Wise $e t$ al., 1991). 
Webb et al. (1984) considered two possible sources for the diatoms and other microfossils. Firstly an in situ deposition with Sirius Group deposits subsequently uplifted by at least $2,000 \mathrm{~m}$. Secondly they considered the fossils as reworked from an area closer to the source of the ice on East Antarctica. Two factors support the East Antarctic source: The occurrence of diatoms within glacially transported clasts and the range of ages of the diatoms within these clasts requires reworking prior to glacial emplacement. There is a lack of geologic support for such rapid uplift of the Transantarctic mountains. Present and (reconstructed) past flow lines indicate the source to be the subglacial Wilkes and Pensacola Basins (Drewry, 1983). Large glaciers (such as the Beardmore) transported material from the base of a subsequently formed ice sheet and depositing it high in the Transantarctic Mountains (figure 3.6).

Each time zone of productivity represented by microfossils recovered from Sirius Group outcrops requires the interior Antarctic basins to be free of ice during that time interval. This then required a shrinkage of the East Antarctic Ice Sheet, with open marine conditions in parts of the Antarctic interior at various times (plate 3.1) in the Cainozoic and as recently as only 3.5 to $3 \mathrm{Ma}$. This finding gave support to Mayewski and Goldthwait's (1985) theory of deposition of Sirius group being from a continentalscale ice sheet, the age of which must postdate the youngest fossil assemblage recovered from the tills.

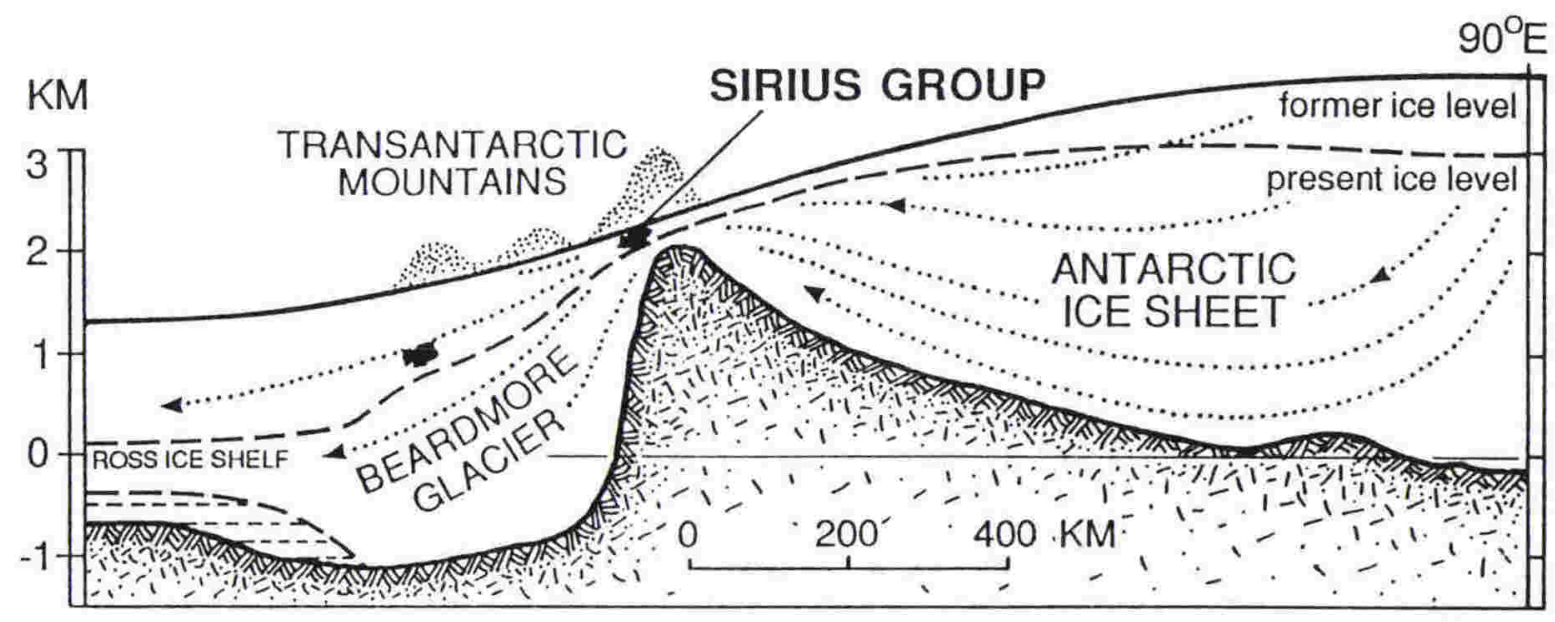

Figure 3.6: Cross-section from the East Antarctic interior through the Transantarctic Mountains to the Ross Sea, showing the location of Sirius Group deposits and their inferred source in the interior (after Barrett et al., 1992). 


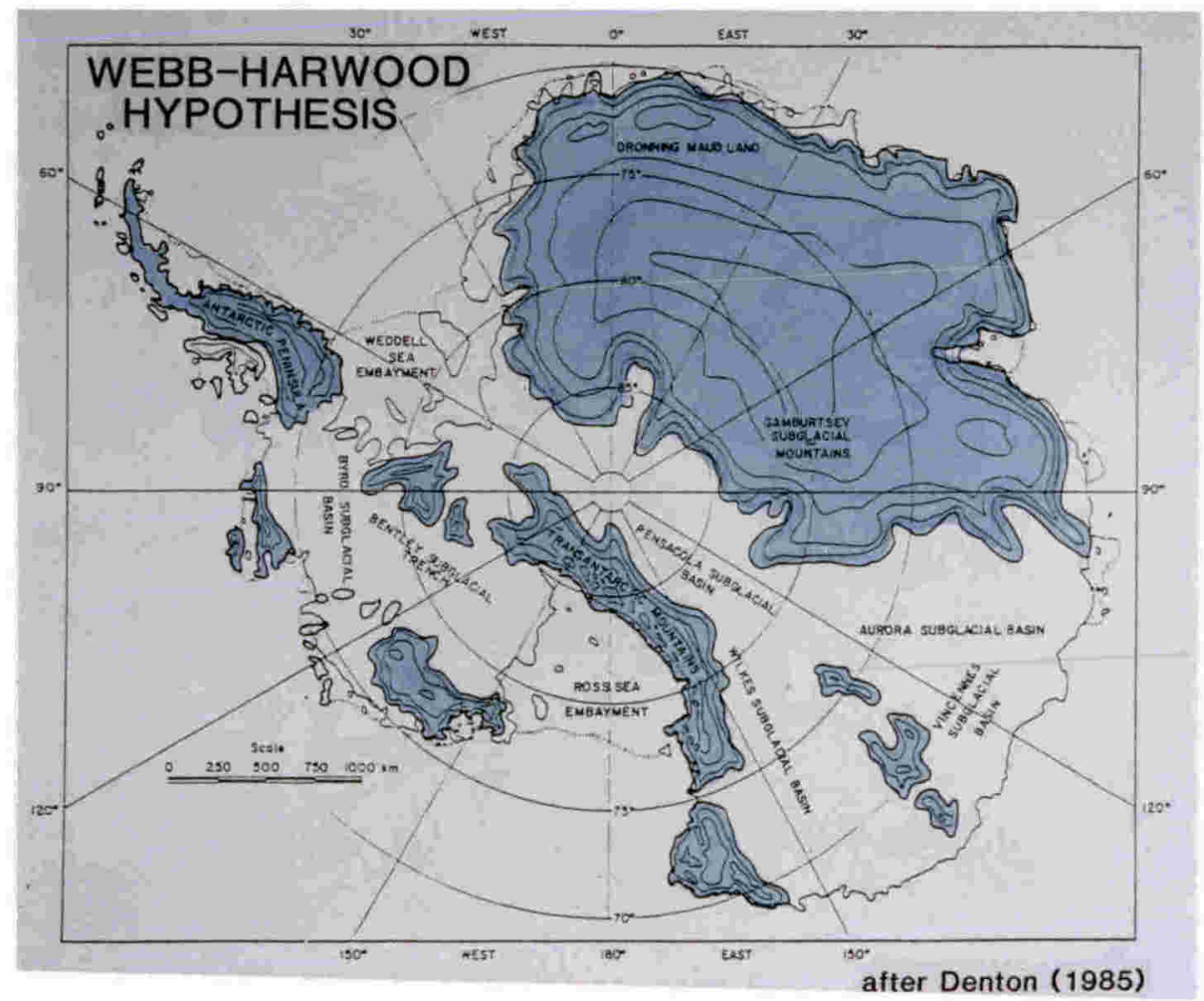

Plate 3.1: Sketch of the Antarctic Ice Sheet during the Cainozoic intervals of deglaciation postulated by Webb et al. (1984) (after Denton, 1985).

The Ross Sea region has been suggested as a possible source for the microfossils and also the possibility of the microfossils being windblown into Sirius Group deposits (Clapperton and Sugden, 1990, Denton et al., 1992). Ice flow directions, petrology of the clasts and matrix in the tillites (Webb et al., 1984), and the occurrence of the same microfossil assemblages in Elephant Moraine, $80 \mathrm{~km}$ west of the Allan Hills (figure 3.4) (Faure and Harwood, 1990), all preclude a Ross Sea origin for the microfossils. The compacted nature of the tills (plate 3.2) and the occurrence of these microfossils within transported clasts precludes a windblown origin.
A Pliocene glacial minimum is also recorded in the wood and leaves of Nothofagus in the Dominion Range and Beardmore Glacier area (Webb et al., 1986; Hill et al., 1991; Webb and Harwood, in press). The leaf mats are bounded by glacial till members containing the Pliocene microfossils derived from the West Antarctic Interior. By the nature of the fossil leaves locality it seems that Sirius Glaciation must have extinguished the surviving trees at least in the Beardmore Glacier region, again at a time postdating the youngest microfossil assemblages in the tills (plate 3.3). Temperatures must have been much warmer in the Beardmore Glacier region to allow survival of the trees at such a southerly latitude. Burkle and Pokras 


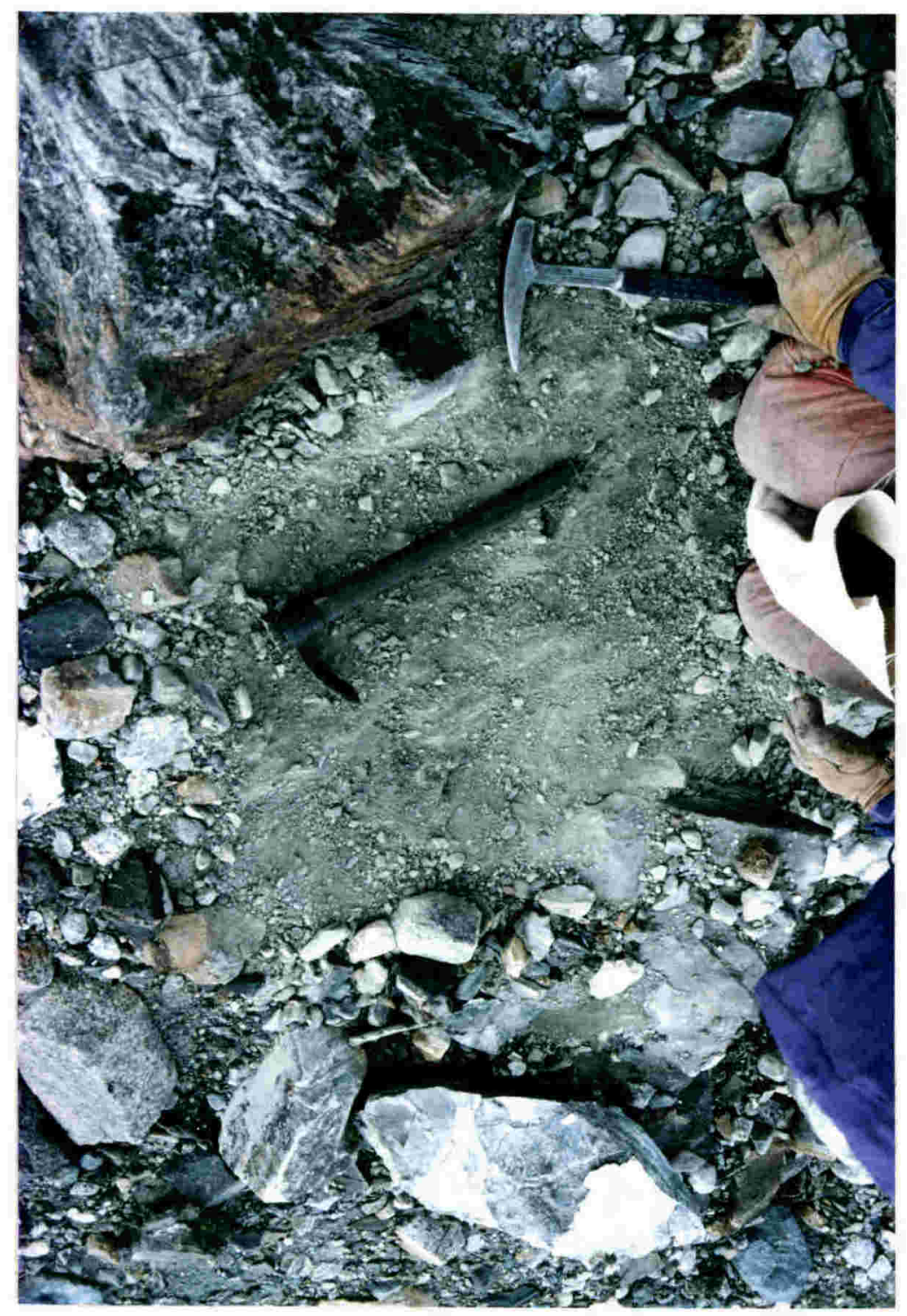

Plate 3.2: Sirius Group tillite cropping out in the Skelton Glacier area, note the compactness and consolidation of the deposit

(1991) discuss possibilities of reestablishing Nothofagus on the Antarctic Continent after a Miocene glaciation must have extinguished growth some 10 Ma. earlier. They conclude that because of the distances and timescales involved, it is not possible to re-establish the tree growth by wind dispersion, bird migration, or seed floating, and that the Nothofagus must have survived in situ up until the time it was extinguished.
The burden of proof for a continued dynamic East Antarctic Ice Sheet history lies on both the reliability of the microfossil origins and their depositional age ranges. Burkle and Abrams (1986) found that under the present glacial regime there is considerable diachrony across the Polar Front, with Antarctic regions showing earlier occurrences of species (by several thousand years) than the Southern Ocean. 
The survival of Nothofagus trees prior to the Sirius Glaciation requires warmer conditions than presently exist in the Antarctic with ice sheets never as big or cold as the Sirius Glaciation. The occurrence of microfossils in the Sirius Group tills requires that at certain times the East Antarctic Ice Sheet has been small enough to expose now ice covered interior Antarctic basins to marine incursion. Both these lines of evidence suggest a more dynamic, warmer and wetter East Antarctic Ice Sheet prior to Sirius Glaciation. What seems to be critical now is age calibration of the Diatom Zones in the Antarctic Interior, a measure of the exact timing of Sirius Glaciation and assessment as to whether the Sirius ice sheet was the direct precursor to the present cupoloid ice sheet covering East Antarctica.

\subsubsection{Southern Victoria Land and McMurdo Sound}

The dry valleys of southern Victoria Land (figure 3.7) had many periods of glacial erosion and deposition. Because of their aspect, these valleys contain both marine deposits of higher relative sea levels and glacial deposits of three different origins: 1) Generally eastward flowing, local valley glaciers; 2) larger local ice caps draining through and across the region, and 3) generally westward flowing valley glaciers sourced from grounded ice in the Ross Sea.

The Jason glaciomarine diamicton (Prentice, 1982) outcrops close to Lake Vanda in the central Wright Valley. It contains sediments and diatom

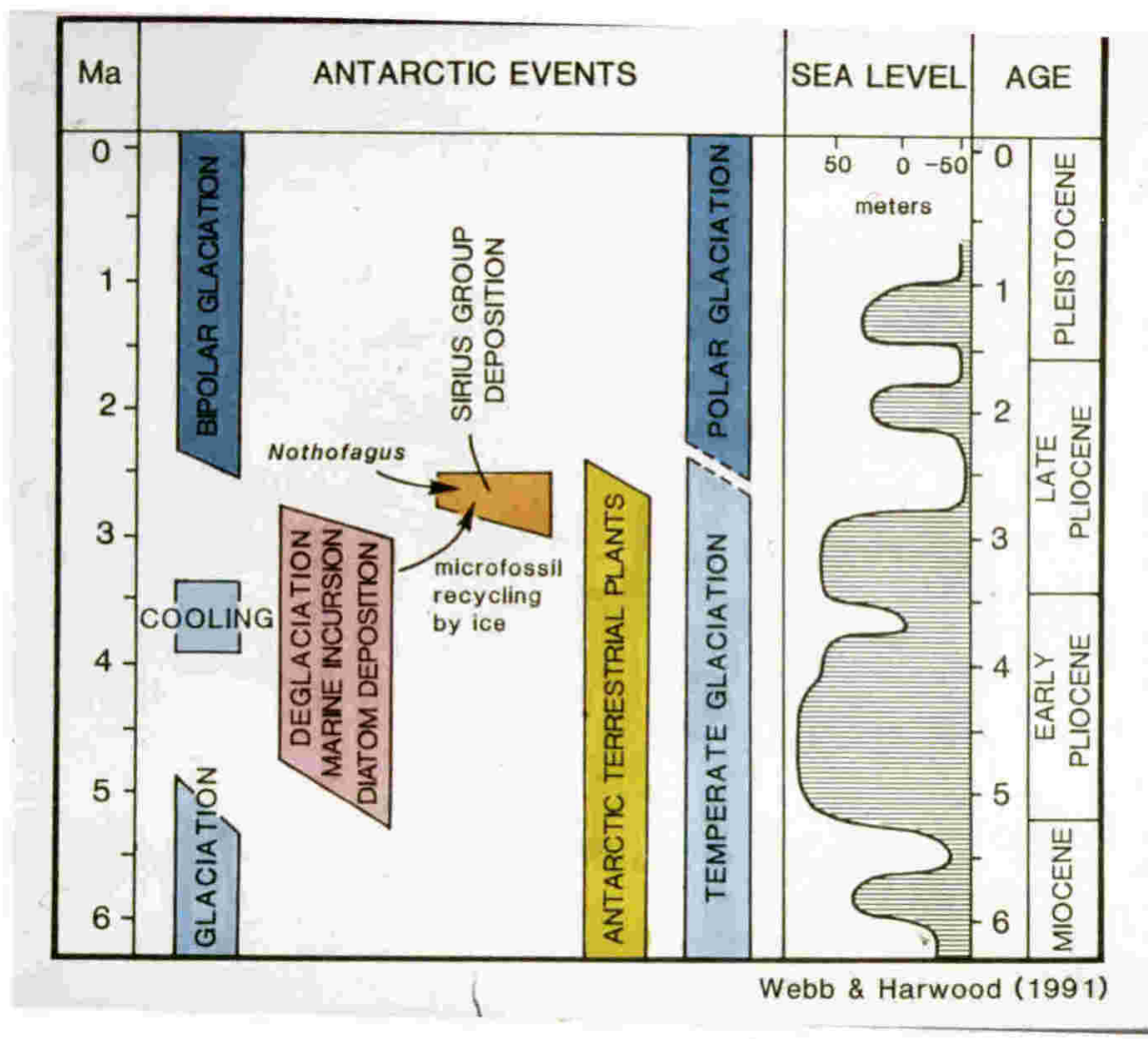

Plate 3.3: Timing of significant events in the Late Neogene glacial history of Antarctica as dated by diatoms in the Sirius Group (after Webb and Harwood, 1991). 


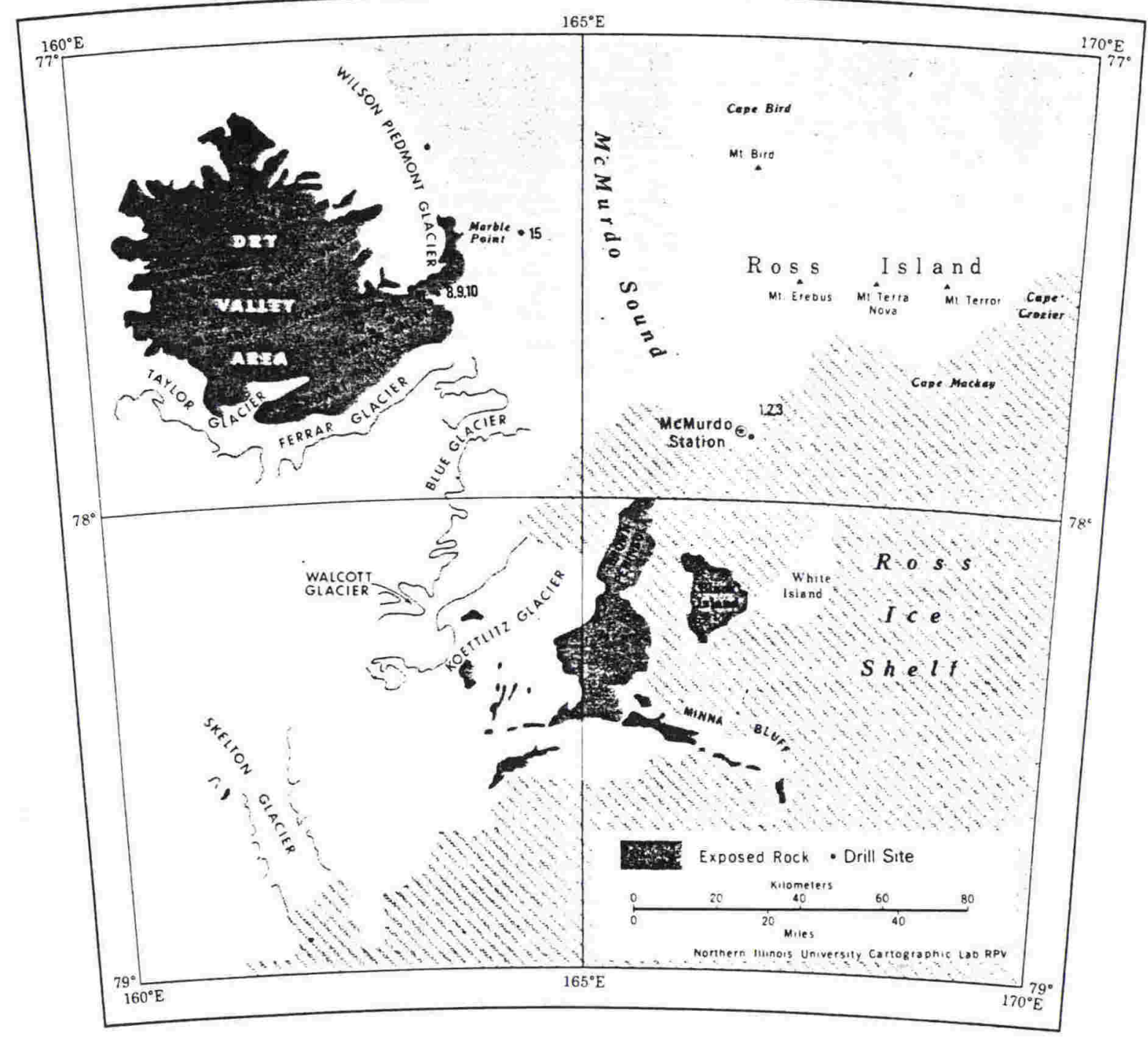

Figure 3.7: Location map of the McMurdo Sound and Dry Valley Region (after McGinnis, 1981).

assemblages indicative of a fjord-like depositional setting (Denton et al., 1992). The Diatoms if they are in-situ and not reworked suggest a late Miocene to early Pliocene age for deposition (Burkle, et al. 1986). It is evident that at the time of deposition of the Jason diamicton, condition were much warmer than they are at present in the Wright Valley.

Further east in the Wright Valley lie the Pecten Gravels (also known as the 
Prospect Mesa Gravels (Prentice, 1982), the base of which is 162 meters above present sea level. It is an in situ shallow water marine deposit of mid-late Pliocene age (Webb, 1974). This gravelly deposit with a fine grained matrix was likely derived from a floating glacier tongue and contains foraminifera and growth position Chlamys tuftensis. The fauna represent an assemblage typical of a fjord setting (Webb, 1972), with average depth of deposition being between $10 \mathrm{~m}$ and $90 \mathrm{~m}$ below sea level. The valley floor would then have been much deeper, around $300 \mathrm{~m}$ below sea level. A combination of uplift of the Transantarctic Mountains and falling eustatic sea levels has brought the deposit to its present position. Webb (1974) used Trochoelphidiella onyxi to correlate the Pecten Gravels with the Scallop Hill formation exposed on Black and White Islands. Diatom assemblages recovered from both the Pecten Gravels and the Jason diamicton (Burkle et al., 1986) suggest both are fjord deposits, but that the Pecten Gravels are more than 2 Ma. younger than the Jason Diamicton.

The Scallop Hill Formation (Speden, 1962), is a fossiliferous, marine, volcaniclastic, conglomerate and tuff (Leckie and Webb, 1979) exposed in coastal localities around southern McMurdo Sound. Unfortunately none of the deposits appear to be in place and have been transported to their present localities by ice action. Some of the deposits have been moved only minimal distances and allow reconstruction of their original stratigraphic sense (Leckie and Webb, 1979) (Eggers, 1979). The faunal and floral assemblages present in the fossiliferous facies of the Scallop Hill formation are typical of a shallow inner shelf environment. They are also indicative of warmer, deglaciated depositional conditions in McMurdo Sound. Subsequent glaciation and expansion of the Ross Ice Shelf moved and lifted the deposits into their present dispositions. The fauna, particularly Chlamys (Zygochlamys) anderssoni and Hexelasma antarcticum (Eggers, 1979) and co-occurrences of dated volcanic rocks (Webb and Andreasen, 1986) suggest that this formation is also late Pliocene and likely deposited during the same interglacial period as that suggested by Webb (1972) for the Pecten Gravels in Wright Valley.

The Pecten Gravels are overlain by the Peleus Till, which crops out over much of the central Wright Valley (Prentice, 1986). It is generally less than $6 \mathrm{~m}$ thick, but ranges in elevation from the valley floor to $1100 \mathrm{~m}$ on the valley sides (Prentice et al., 1987). It is the basal deposit of an extensive wet based valley glacier flowing from west to east, but not of significant magnitude to cover the Transantarctic Mountains (Denton et al., 1992). Burkle et al. (1986) found reworked late Pliocene age diagnostic diatoms (Cosmiodiscus insignis, Nitzschia kerguelensis, and Thalassiosira lentiginosa) in the Peleus Till giving it a maximum age of late Pliocene. Reworking of the diatoms could be by 
glacier ice from local fjord deposits, or by East Antarctic continental ice draining through the Wright Valley, transporting the diatoms from interior Antarctic Basins (Denton et al., 1992). Both of these are possible, as similar diatom assemblages have been found in Sirius Group deposits and also within the underlying Pecten Gravels (Burkle et al., 1986).

The recovery of in situ middle Miocene marine diatom flora from sandy silts beneath Lake Vanda in middle Wright Valley (DVDP-4a) (Brady, 1982) is indicative of fjord development in the Wright Valley at this time. Brady (1982) rules out recent glaciers reworking this material into the lake as late Miocene and Pliocene restricted diatoms are absent from the deposit. Brady (1982) also suggests that the Lake Vanda area of Wright valley has not been glaciated to any major extent since, as major glacial activity would have produced glacial deposits and removed the marine silts. The presence of Peleus Till about Lake Vanda does not support this, and perhaps a better explanation is that subsequent glaciation either did not affect the Lake Vanda silts or eroded later Miocene/early Pliocene age material. Being in the lake depression may have offered the deposit some protection from overriding glacial ice.

Buried desert pavements have been reported from various high altitude ( $>$ $1500 \mathrm{~m}$ ) localities throughout the dry valleys (Denton et al., 1992; Marchant $e t$ al., 1989; 1993). These are reported to be indicative of present glacial conditions persisting in the past. Some of these are covered by in situ volcanic ash (Marchant et al., 1989; 1992; 1993). These ashes range in ages from middle Miocene to late Pliocene in age (Marchant et al., 1992). Marchant et al. (1992); Denton et al. (1992), Sugden (1992) and Marchant et al. (1993) have used this data to argue that the major ice sheet expansions of Denton et al. (1984) antedate these pavements and suggest that present style polar climates have persisted from middle Miocene to the present.

The Dry Valleys contain many data sets that on the surface offer conflicting evidence as to the history of glacial development of the region. It is important to be careful in interpretation of individual deposits to be sure of the climatic indicators that individual deposits retain, the ages and age relationships of particular deposits, and the possibility of a complex rather than simple local glacial history within the Dry Valley and McMurdo Sound regions.

\subsubsection{The Lambert Glacier Region}

Pickard et al. (1988) report a possible correlative of the Pecten Gravels at marine plain in the Vestfold Hills, East Antarctica (figure 1.2).They report a shallow marine (less than $50 \mathrm{~m}$ ) deposit of diatomaceous sands unconformably capped by glaciomarine diamictite. The 
sands are up to $8 \mathrm{~m}$ thick and represent a shallowing upwards sequence with frost wedges in the uppermost part of the section indicating subaerial exposure (Pickard et al., 1988). The diatom assemblage contains amongst others Nitzschia praeinterfrigidaria, and lacks Actinocyclus actinocyclus, Coscinodiscus kolbei, C. vulnificus, and Cosmiodiscus insignis (Harwood, 1986). This suggests early to middle Pliocene deposition, prior to the last episode of deglacial conditions recorded by diatoms in the Sirius Group deposits. A single sandstone horizon (Pickard et al., 1988) is reported to contain the bivalve Chlamys tuftensis, also known from the Pecten Gravels in Wright Valley.

The lack of proximal ice facies within the sands, the marine nature of the deposit, and the warmer water fossil species (Chlamys tuftensis), indicate a much warmer climate than presently exists at the site. Pickard et al. (1988) go as far as to suggest that the earlier Pliocene palaeoenvironment of the Vestfold hills should be regarded as strongly interglacial. This interglacial period is likely to be a partial correlative of the Pecten Gravels in Wright Valley and of early to middle Pliocene marine deposition in Antarctic Interior Basins, as indicated by diatoms recovered from the Pagadroma Tillite and Sirius Group deposits.

The Pagadroma tillite (McKelvey and Stevenson, 1990) with its type section in Pagadroma Gorge (figure 1.2), like the
Sirius Group deposits in the Transantarctic Mountains, is a Cainozoic, semilithified, waterlain, lodgement till (Bardin, 1982). It rests unconformably on Permian Basement and is spread throughout the Prince Charles Mountains, with deposition thought to have occurred from an expanded Lambert Glacier System (McKelvey and Stevenson, 1990). Palaeoflow directions would have been in the same direction as present day (figure 1.2). In 1988 D.M. Harwood discovered marine diatom flora in reworked sedimentary clasts of the Pagadroma Tillite (McKelvey and Stevenson, 1990). The flora, like that of the Sirius Group, is presumed to have been deposited prior to glaciation in an interior marine basin, upflow from the site of till deposition. Two episodes of marine productivity are recognised from the basin (McKelvey and Stevenson, 1990); An upper Miocene episode is recorded by diatoms specific to the Denticulopsis dimorphia and $D$. Hustedtii zones and a middle Pliocene event recorded by diatoms specific to the Cosmiodiscus insignis and Nitzschia kerguelensis zones.

\subsubsection{Drill-hole evidence from the Antarctic Margin.}

Previous work reported on Late Neogene occurrences of drill-hole strata from the Antarctic margin is revised and new work forms a major part of this thesis. This evidence is discussed separately in Chapters 4, 5 and 6. 


\section{Chapter - 4}

\section{Stratigraphy of Antarctic Margin sediments cored in McMurdo Sound}

A new stratigraphic framework is established for the pre Late Pliocene strata of the CIROS-2 and DVDP-11 drillholes, based on the work of Pyne et al. (1985) and McKelvey (1981) and detailed relogging of the two cores. Ten major units are defined for the CIROS2 core and 20 for the DVDP-11 core. A full bed by bed description is presented in Appendix 1. The units are grouped into 4 stratigraphic successions (A through D). Groups A and B encompass the lowest successions of strata cored by DVDP-11. Groups C and D encompass higher lithologically similar strata cored by both DVDP-11 and CIROS-2. Groups are divided from one another by major disconformities. A brief interpretation of the depositional environment of each unit is given, using the facies models and unconformity types defined in chapter 5 . Chapter 5 also presents an interpretation of the depositional history of the two cores.

\subsection{Stratigraphic nomenclature of the CIROS-2 and DVDP-11 drillholes}

Strata of the Antarctic margin in McMurdo Sound have not yet been formally named. Equivalent on-shore strata have been loosely named (see Chapter 3). Present definition of the margin sediments includes letter codes for seismically defined stratigraphic packages, and numbered unit definitions for cored strata.

Barrett et al. (1985) divided the CIROS-2 core into 13 lithological units representing alternating glacial and interglacial conditions, numbered from 1 at the top to 13 at the base (figure 4.1). The lower part of unit 7 and units 8 through 13 represent the same interval of strata studied here. The same unit terminology was adopted by Harwood (1986) and Barrett and Hambrey (1992) although both workers found it necessary to subdivide the units in order to establish a mode of deposition of the sediments.

McKelvey (1975) divided the DVDP-11 core into 8 lithological units (figure 4.1). Some units represent consistently interbedded strata of different lithology (e.g. unit 7). The lower part of unit 5 and units 6 through 8 represent the same interval of strata studied here. This unit terminology was also adopted in subsequent work (McKelvey, 1979; McKelvey, 1981 and Ishman and Rieck, 1993). Ishman and Rieck (1993) like Barrett and Hambrey (1992) found it necessary to subdivide the units to 


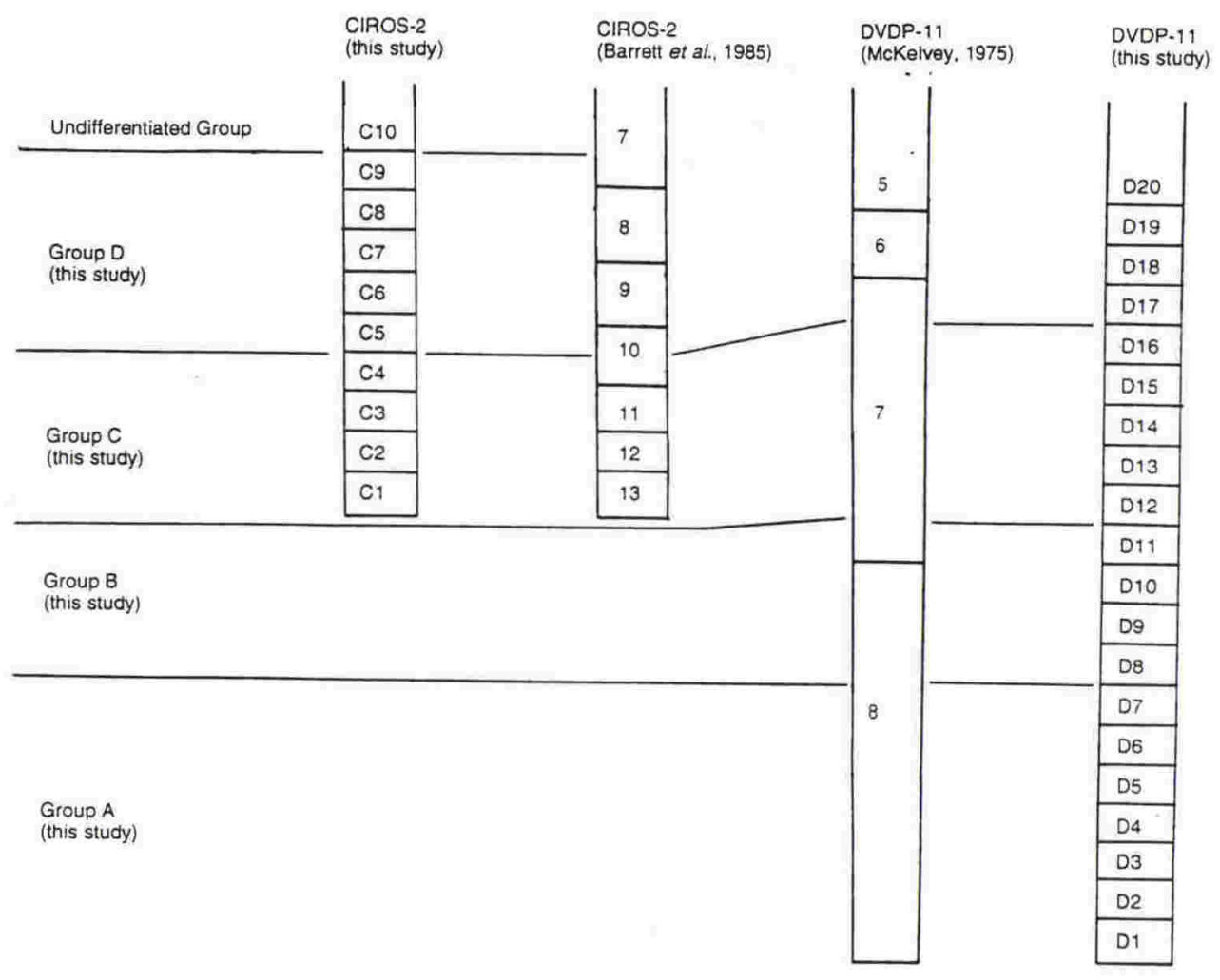

Figure 4.1: Lithostratigraphic nomenclature of units of the cored Antarctic margin, Late Neogene, strata in McMurdo Sound, southern Victoria Land, Antarctica.

establish a mode of deposition of the sediments.

Relogging of the strata from both cores is based on careful discrimination of lithologic facies and of observable stratigraphic disconformities. It builds on the recognition by Barrett and Hambrey (1992) and Ishman and Rieck (1993) that the cores have not previously been adequately subdivided to enable a full genetic interpretation. The observations and models used in this assessment are presented in chapter 5 .

Only the previously recognised Late Miocene to Late Pliocene sections of the two cores are studied here. The study follows on from the work of Barrett and Hambrey (1992) and is more definitive.
The units are numbered from 1 at the base increasing upwards. Each unit number is given a letter prefix, $\mathrm{C}$ for CIROS-2 and D for DVDP-11, which distinguish the newly defined units between cores and also distinguish them from the previously defined units of Barrett et al. (1985) and McKelvey (1975).

The units form 4 groups (figure 4.1). The groups express the natural relationships of units and are applicable to both the Taylor Valley and Ferrar Fjord cores. The four groups are bounded by major discontinuities manifest as the major erosional unconformities in the cores or major intervals of non-recovery of core. 
Groups A and B occur only in the lower part of the DVDP-11 core. The base of group A was not observed and inferred to occur below the base of the DVDP-11 drill-hole. It is a $56.8 \mathrm{~m}$ succession of massive to moderately stratified diamictite units including rare stratified sandy and gravelly mudstone units. This group is equivalent to the lower three quarters of unit 8 of McKelvey (1981). Groups A and B are separated by an erosive and topographic surface 271.14 $\mathrm{m}$ deep in the core. Group B is a $131.6 \mathrm{~m}$ succession of interbedded moderately to well stratified diamictite units, stratified sandy mudstones, and well sorted coarse sand to fine conglomerate units. Many of these conglomeratic units are winnowed and contain little fine matrix. Group B is equivalent to the upper part of unit 8 and lower part of unit 7 of McKelvey (1981).

The boundary between groups B and C is a major erosional unconformity $139.55 \mathrm{~m}$ deep in the DVDP-11 core. It is correlated with the paraconformity between basement Granite Gneiss and sediment which marks the base of group $\mathrm{C}$ in the CIROS-2 core. Group C is 34.4 $m$ thick in the DVDP-11 drill-hole and $23.4 \mathrm{~m}$ in the CIROS -2 drill-hole. It is a succession of non- to moderately stratified diamictite units and interbedded massive to stratified mudstone units. Many diamictite units include minor internal erosional disconformities.

Groups C and D are separated by an erosional disconformity $202.20 \mathrm{~m}$ deep in the DVDP-11 core and within an interval of non recovery of core at 141.05-143.04 m depth in the CIROS-2 core. Group D also represents an interbedded succession of diamictite units, sandy mudstone units and pebble conglomerates. It is more distinctly stratified than Group C.

The top of group D is not observed in the DVDP-11 sequence. In CIROS-2 it is marked by an unconformity surface at 98.83 m depth, overlain by a dominantly sandy and petrologically different succession. Only the basal part of Group $\mathrm{D}$ is relevant to the present study. The top of Group D is the same horizon that Barrett and Hambrey (1992) used to subdivide the CIROS-2 core into its upper and lower sequences. They recognised both lithologic differences and change in the proportion of volcanic debris in the sediment. Above $100 \mathrm{~m}$ depth the CIROS-2 core is up to $50 \%$ volcanic detritus and below $100 \mathrm{~m}$ less than $10 \%$.

\subsection{CIROS-2 Stratigraphy (figure 4.2)}

The $c a .76 \mathrm{~m}$ pre Late-Pliocene succession in the CIROS- 2 core has been divided into 10 major units labelled C1 (lowest) through C10 (highest). The units are described in terms of lithology, thickness, sedimentary structures and the relationship of each to the underlying unit. Because the strata are from drillholes it is not appropriate to define the units as formations, but they do however fulfil the same function. 


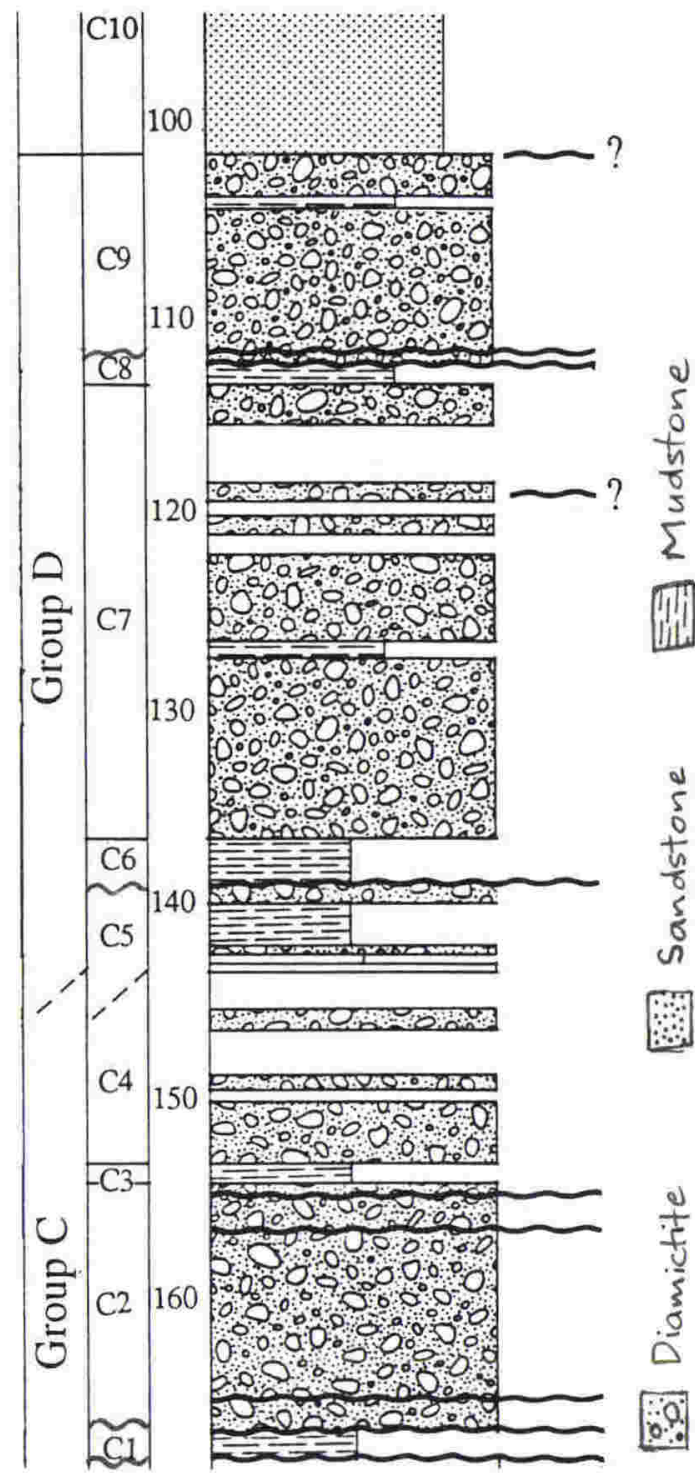

Figure 4.2: Lithologic log of the CIROS-2 drill-core (Late Neogene part), Ferrar Fjord, McMurdo Sound, southern Victoria Land, Antarctica.

\section{Group C}

\section{Unit C1 (165.37-166.47 m)}

Unit C1 is a sandy and diatomaceous mudstone disconformably overlying Granite Gneiss basement (Pyne et al., 1985). It is $1.10 \mathrm{~m}$ thick and equivalent to unit 13 of Barrett et al. (1985). It is moderately soft and moderately stratified with a gravel lag at the base. Barrett and Hambrey (1992) interpreted it to have been deposited offshore in a distal glaciomarine setting.

\section{Unit C2 (152.40-165.37 m)}

Unit C2 is a muddy, sandy and gravelly diamictite, equivalent to unit 12 of Barrett et al. (1985) and $12.97 \mathrm{~m}$ thick. It unconformably overlies unit $\mathrm{C} 1$ with an erosional surface, and is homogeneous and mostly massive, except for internal deformation and sheared surfaces. The upper part fines upwards, becoming less pebbly and more stratified. It is moderately hard and greenish grey. Barrett and Hambrey (1992) interpreted it to be a lodgement till deposited directly beneath grounded ice.

\section{Unit C3 (151.25-152.40 m)}

Unit C3 is a slightly sandy, stratified, diatomaceous mudstone that grades up from the underlying diamictite of unit C2. It is $1.15 \mathrm{~m}$ thick, equivalent to unit 11 of Barrett et al. (1985), moderately soft and a light greenish grey colour. Stratification is defined by sandy and fine gravelly lenses. The unit coarsens upwards becoming more gravelly towards its top. Barrett and Hambrey (1992) interpreted this unit to represent offshore sedimentation in a distal glaciomarine setting, similar to that of unit $\mathrm{C} 1$.

\section{Unit C4 (143.04-151.25 m)}

Unit C4 is a muddy, sandy and gravelly diamictite that grades from the underlying unit. It is $8.21 \mathrm{~m}$ thick and equivalent to the lower part of unit 10 of Barrett et al. (1985). It varies from 
massive to moderately stratified. The basal and upper parts of the unit are dominantly stratified and the middle of the unit is dominantly massive. It is moderately hard to hard with some clay cemented jointing, and greenish grey in colour. The upper contact is not seen. Barrett and Hambrey (1992) interpreted this to represent lodgement and waterlain till with deposition beneath grounded ice and floating basal glacial ice respectively.

\section{Group D}

\section{Unit C5 (137.20-141.05 m)}

Unit C5 is alternating moderately sorted and sandy diatomaceous mudstone with muddy, sandy, and gravelly diamictite. It is $3.85 \mathrm{~m}$ thick and equivalent to the upper part of unit 10 and lower part of unit 9 of Barrett et al., 1985. It is defined differently from unit 9 of Barrett et al. (1985) because a distinct disconformity occurs $137.20 \mathrm{~m}$ deep in the core. The entire unit is moderately to well stratified and moderately hard. The contacts between interbedded sub-units are all gradational. Barrett and Hambrey (1992) interpreted this to represent alternating distal and proximal glaciomarine waterlain till environments of deposition.

\section{Unit C6 (134.69-137.20 m)}

Unit C6 is a sandy and stratified diatomaceous mudstone disconformably overlying the upper diamictite of unit C5. It is $2.51 \mathrm{~m}$ thick and equivalent to the uppermost part of unit 9 of Barrett et al. (1985). The unit is moderately to well stratified. It is sandy at its base, fines and becomes more massive upwards. The very top of the unit becomes more pebbly and stratified once again. This unit is interpreted to have been deposited in a proximal to distal glaciomarine environment.

\section{Unit C7 (111.06-134.69 m)}

Unit C7 is a muddy, sandy, and gravelly diamictite, $23.63 \mathrm{~m}$ thick and equivalent to the lower part of unit 8 of Barrett et al. (1985). The lower part is dominantly massive and the upper part dominantly stratified. The upper part of the unit contains several intervals of no core recovery, probably due to the lack of fine fraction and consequent incoherent lithology. The interval from 124.65$124.94 \mathrm{~m}$ is a white, tuffaceous siltstone within an interval of alternating well stratified diamictite and laminated siltstone. This unit was interpreted by Barrett and Hambrey (1992) to be dominantly lodgement till near the base, and entirely waterlain till towards the top. Presumably currents associated with a nearby grounded ice body have winnowed the fine material from some intervals rendering them incoherent and difficult to recover by coring.

\section{Unit C8 (109.86-111.06 m)}

Unit C8 is a $1.20 \mathrm{~m}$ thick, muddy, medium fine sandstone grading from the underlying diamictite of unit C7. It is 
well stratified with mudstone clasts and sandy lenses delineating $\mathrm{cm}-\mathrm{mm}$ bedding. The unit is interpreted to have been deposited in a proximal to distal glaciomarine environment.

\section{Unit C9 (98.83-109.86 m)}

Unit C9 is muddy, sandy and gravelly. It is $11.03 \mathrm{~m}$ thick and equivalent to the upper part of unit 8 of Barrett et al. (1985). It unconformably overlies unit C8 with a sheared surface. Unit C9 is moderately stratified with sandy and muddy horizons. Some sections are massive with clasts dispersed throughout. Barrett and Hambrey (1992) interpreted it to represent deposition from grounded ice (lodgement till) and rainout from floating basal glacier ice (waterlain till).

\section{Undifferentiated Group}

Unit C10 (<90.00-98.83 m)

Unit C10 is a slightly muddy, medium grained, moderately sorted sandstone. It is more than $8.83 \mathrm{~m}$ thick, the top is not relevant in the present study. It is equivalent to unit 7 of Barrett et al. (1985). The unit consists of soft and well stratified basaltic sands. The base is muddy and unconformably overlies the upper diamictite of unit C9. Barrett and Hambrey (1992) interpreted it to be partly windblown sands deposited in an ice covered lacustrine setting moderately close to a floating glacier tongue.

\subsection{DVDP-11 Stratigraphy (figure 4.3)}

The $c a .178 \mathrm{~m}$ pre Late-Pliocene succession in the DVDP-11 core has been divided into 20 major units labelled D1 (lowest) through D20 (highest). As for CIROS-2, these units are described in terms of lithology, thickness, sedimentary structures and the relationship of each to the underlying unit. Again, it is not appropriate to define these as formations, but they fulfil the same function.

The DVDP-11 succession is divided into Groups A through D, separated by pronounced disconformities. Groups C and $\mathrm{D}$ are lithologic equivalents of groups $\mathrm{C}$ and $\mathrm{D}$ in the CIROS-2 core.

\section{Group A}

Unit DI (325.08->327.96 m)

Unit D1 is a muddy, sandy and gravelly diamictite. It is greater than $2.88 \mathrm{~m}$ thick and equivalent to the basal part of unit 8 of McKelvey (1975). The base of the unit is not seen. It is moderately to well stratified, contains thin mudstone interbeds and is moderately hard and olive green in colour. It is interpreted to have been deposited as a waterlain till.

\section{Unit D2 (324.81-325.08 m)}

Unit D2 is a very fine laminated olive grey diatomaceous mudstone. It is 0.27 $m$ thick and has a sharp basal contact 


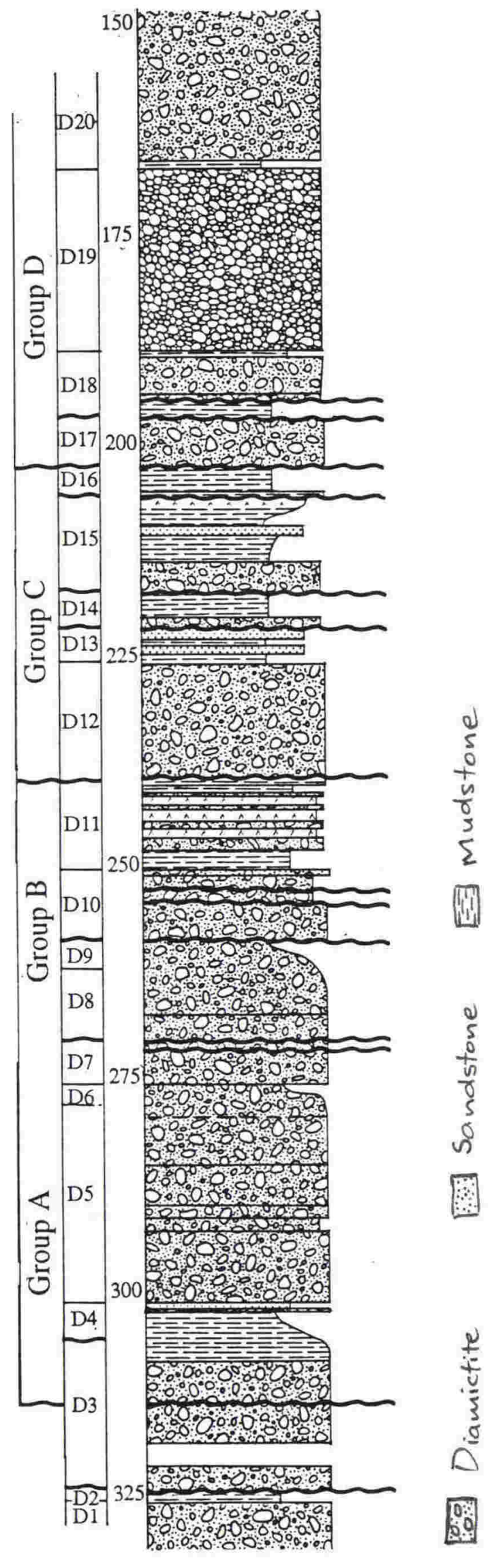

Figure 4.3: Lithologic log of the DVDP-11 drill-core (Late Neogene part), Taylor Valley, McMurdo Sound, southern Victoria Land, Antarctica. with the underlying diamictite, and is moderately soft to moderately hard. It is interpreted to represent deep marine offshore sedimentation in a distal glaciomarine environment.

$$
\text { Unit D3 (307.50-324.81 m) }
$$

Unit D3 is a muddy, sandy and gravelly diamictite unconformably overlying unit D2. It is $17.31 \mathrm{~m}$ thick, poorly stratified at its base and becomes more stratified towards the top. An interval of core is missing from $319.01-321.80 \mathrm{~m}$ and there are several horizons with internal shearing and erosional surfaces. The upper part of the unit fines to well stratified sandy mudstone. The unit is interpreted to represent deposition beneath and close to the grounding line of a glacier as lodgement and waterlain till.

\section{Unit D4 (302.32-307.50 m)}

Unit D4 is a $5.18 \mathrm{~m}$ thick, sandy, diatomaceous mudstone grading from the underlying diamictite. The base of the unit is pebbly but fines up into sandy mudstone interbedded with gravelly mudstones. A single thin stratified muddy diamictite band occurs close to the top of the unit. The unit is interpreted as being deposited in a cycle of retreating and re-advancing glacier ice, depositing proximal to distal glaciomarine/waterlain till facies. 
eroded and scoured surfaces in the basal

Unit D5 is a $25.82 \mathrm{~m}$ thick muddy, sandy and gravelly diamictite unconformably overlying unit D4. Most of it is massive with clasts evenly distributed and evidence of internal shearing. The upper $5 \mathrm{~m}$ becomes increasingly stratified and the large clast proportion reduces. The unit is interpreted as mostly lodgement till deposited by grounded ice. The uppermost part becomes increasingly more waterlain till.

\section{Unit D6 (275.74-176.50 m)}

Unit D6 is a $0.76 \mathrm{~m}$ thick sandy stratified mudstone, grading from the underlying diamictite. Sandy horizons depict the laminations and coarser detritus is distributed throughout. The unit. is interpreted as proximal to distal glaciomarine in origin. The upper part is increasingly more distal glaciomarine.

\section{Unit D7 (271.14-275.74 m)}

Unit D7 is a muddy, sandy and gravelly diamictite. It is $4.60 \mathrm{~m}$ thick, moderately hard and moderately stratified. It is interpreted to be waterlain till.

\section{Group B}

Unit D8 (261.00-271.14 m)

Unit D8 is a $10.14 \mathrm{~m}$ thick muddy, sandy and gravelly diamictite unconformably overlying unit D7. It is moderately stratified with several unconformable, part of the unit. It becomes more massive and less stratified upwards. The upper few metres become more stratified and interbedded with mudstone horizons. It is interpreted as basal and waterlain till, with the upper part of the unit recording retreating ice.

Unit $D 9(258.65-261.00 \mathrm{~m})$

Unit D9 is a laminated, sandy mudstone, $2.35 \mathrm{~m}$ thick, and grades from the underlying stratified diamictite. It is coarse in places, but fines upward throughout. It is interpreted to represent a proximal glaciomarine depositional environment beneath floating icebergs that were shedding debris.

\section{Unit D10 (250.73-258.65 m)}

Unit D10 is poorly sorted gravel, sand and mud; a diamictite, unconformably overlying unit D9. It is $7.92 \mathrm{~m}$ thick and equivalent to the uppermost part of unit 8 and the lowermost part of unit 7 of McKelvey (1981). It is massive and internally sheared towards the base, becoming more stratified and less pebbly towards the top. It is interpreted as a lodgement till, becoming more waterlain towards its top, due to retreat of the grounded ice line.

Unit D11 (239.55-250.73 m)

Unit D11 is interbedded diamictite, mudstone and breccia/conglomerate. It is $11.18 \mathrm{~m}$ thick and equivalent to the lower 
part of unit 7 of McKelvey (1981). It conformably overlies the diamictite of unit D10. The diamictite subunits are moderately to well stratified and are interpreted to be waterlain till. The mudstone subunits are sandy with sand laminations. The sand content decreases then increases upwards. Clasts in the breccia/conglomerates are subrounded to subangular and winnowed of most fine material. This subunit is interpreted as a shallow water fluvioglacially dominated deposit. It might have ben deposited directly by subglacial outwash. The entire unit is interpreted to have been deposited close to an alternately advancing and retreating grounded ice front.

\section{Group C}

Unit D12 (225.96-239.55 m)

Unit D12 is poorly sorted gravel, sand and mud. It is $13.50 \mathrm{~m}$ thick and unconformably overlies unit D11. It is a massive, at places sheared, diamictite interpreted to be a lodgement till deposited directly beneath glacial ice.

\section{Unit D13 (221.56-225.96 m)}

Unit D13 is interbedded sandy mudstone and moderately sorted gravelly sandstone. It is $4.40 \mathrm{~m}$ thick and grades from the underlying diamictite. The sandy units are gravelly and current deposited, showing signs of crossbedding. The mudstone subunits are laminated. Both lithologies are bioturbated and retain fossil fragments. The unit is interpreted to represent a fluctuating proximal to moderately distal glaciomarine environment of deposition.

\section{Unit D14 (217.55-221.56 m)}

Unit D14 is moderately stratified muddy, sandy and gravelly diamictite, $4.01 \mathrm{~m}$ thick and unconformably overlies unit D13. The base contains sandy mudstone rip-up clasts. The upper part is finer grained and stratified. It is interpreted to represent waterlain till to proximal glaciomarine facies.

\section{Unit D15 (205.84-217.55 m)}

Unit D15 is interbedded stratified diamictite, stratified mudstone and well sorted sands. It is $11.71 \mathrm{~m}$ thick and unconformably overlies unit D14. The diamictite subunits are muddy, sandy and slightly gravelly with proportionally fewer clasts than the lower diamictite units in the DVDP-11 core. The mudstone subunits are gravelly and sandy. They are laminated and coarsen upwards into well sorted cross-bedded sandstones and gravelly breccias that lack a fine fraction. This unit is interpreted as waterlain till deposited in a proximal glaciomarine depositional environment, with strong subglacial and proglacial currents.

\section{Unit D16 (202.20-205.84 m)}

Unit D16 is a $3.64 \mathrm{~m}$ thick poorly stratified pebble conglomerate and 
breccia. It unconformably overlies unit D15 with a scoured unconformable surface. The unit grades up into a more stratified finer grained sandy and gravelly mudstone, including scattered lonestones and gravelly lenses. It is bioturbated in muddier horizons. The unit is interpreted to represent a proximal to distal glaciomarine environment of deposition.

\section{Group D}

Unit D17 (196.27-202.20 m)

Unit D17 is muddy, sandy and pebbly diamictite, $5.93 \mathrm{~m}$ thick and well stratified with signs of current reworking and winnowing. The lithology becomes more muddy and clast proportion decreases towards its top. It is interpreted to be very proximal glaciomarine in origin.

\section{Unit D18(188.30-196.27 m)}

Unit D18 is a $7.97 \mathrm{~m}$ thick, stratified, coarsening upward gravelly, sandy and muddy diamictite. It is equivalent to the uppermost part of unit 7 of McKelvey (1981). The base of the unit is a sandy fossiliferous mudstone, which disconformably overlies unit D17. A pebble conglomerate that is current reworked, winnowed and at places sandy occurs in the centre of the unit. The uppermost horizon in the unit is a thin $(0.57 \mathrm{~m})$ sandy mudstone. The unit is interpreted to have been deposited in a shallow proximal glaciomarine to waterlain till environment.

\section{Unit D19 (166.44-188.30 m)}

Unit D19 is poorly sorted fine to medium pebble conglomerate, $21.86 \mathrm{~m}$ thick, and equivalent to unit 6 of McKelvey (1981). It conformably overlies unit D18, fines irregularly upwards and is homogeneous with slight stratification. Where stratification does occur, it is marked by sandier more diamict-like horizons. The unit is marine, includes broken shell fragments, and is interpreted to represent a very shallow, very proximal to sub-ice current worked environment of deposition.

\section{Unit D20 $(<150.00-166.44 \mathrm{~m})$}

Unit 20 is highly variable weakly to moderately stratified muddy, sandy and gravelly diamictite. The is/not relevant to the present study. The unit is greater than $16.44 \mathrm{~m}$ thick and equivalent to the lower part of unit 5 of McKelvey (1981). It varies between weakly stratified gravelly horizons and muddier better stratified horizons. The finer grained fraction is dominantly basaltic sands. The basal 0.63 $\mathrm{m}$ is an interbedded sandy mudstone and muddy sandstone with fewer than $1 \%$ lonestones. Interbeds are massive. The unit is interpreted as a waterlain till becoming more proximal to grounded ice upwards. 


\section{Chapter - 5}

\section{Facies analysis and interpretation of the CIROS-2 and DVDP-11 cores.}

This chapter presents a facies analysis of the CIROS-2 and DVDP-11 strata. Six facies associations are recognised after the model of Hambrey et al. (1989) and interpreted in terms of ice advancing and retreating in a glaciomarine environment. The facies associations construct two facies successions identified by Markov chain analysis. These successions represent alternating glacial advance and retreat in deep and shallow glaciomarine environments respectively. Markov chain analysis supports the glaciomarine depositional environment model of Hambrey et al. (1989) and adds the shallower water proximal breccia or pebble conglomerate to the model. Five types of unconformity in the facies successions are reported. Most of these are disconformities scoured by currents associated with nearby grounded ice. The resulting facies model is used to interpret the sequences described in chapter 4. Correlation of the two cores for this interpretation is from the magnetostratigraphy presented in chapter 9 . The interpretation of the facies successions in the two cores is combined with outcrop data from the Antarctic (chapter 3) to form a model of Late Neogene ice volume variation on the East Antarctic Craton (chapter 6).

\subsection{Introduction}

Individual facies and stratal units of the pre-Late Pliocene strata in the CIROS-2 and DVDP-11 cores as recognised in this study are presented in appendix 1 . Only the commonly occurring associations of these facies are presented here. They are identified purely on observable characteristics (Walker, 1984) and after the definitions presented by Hambrey et al. (1989) for the CIROS-1 drill-hole. The identifications and models presented here for the CIROS-2 core do not differ greatly from that of Barrett and Hambrey (1992). The facies analysis of DVDP-11 is new and follows the same lines as that presented for CIROS-1 by Hambrey et al. (1989). An addition to the interpretive models of Hambrey et al. (1989) and Hambrey et al. (1991) is the application of Markov chain analysis with Waltherian Law (Middleton, 1973) to identify naturally juxtaposed facies associations.

The discussion of stratal unconformities takes the same approach, defining them objectively by their appearance in the cores. A brief interpretation of the genetic origin of each unconformity is given after its definition. 


\subsection{Facies associations.}

Facies associations are described in more detail elsewhere (Barrett and Hambrey , 1992; Hambrey et al., 1989; and Hambrey et al., 1991). They are summarised here as below.

\subsubsection{Massive diamictite}

The massive diamictite facies association is poorly sorted admixture of gravel, sand and mud. Clasts comprise more than 1 per cent of the lithology and are rounded to sub-angular. Some are striated. The lithology is generally massive, the only distinction being internal shear surfaces in places. Hambrey et al. (1989) interpreted the association to be lodgement till resulting from active deposition beneath grounded basal glacier ice.

\subsubsection{Stratified diamictite}

Stratified diamictite consists of poorly sorted gravel, sand and mud. Clasts comprise more than 1 per cent of the lithology and tend to be more rounded than those in the massive diamictite. The matrix surrounding the clasts shows disturbance and dewatering structures. The lithology varies between being poorly and well stratified, with poor to good alignment of clasts in defined horizons. Total diamictite facies association (massive and stratified) comprises $65 \%$ of the pre-Late Pliocene strata in the DVDP- 11 core and $72 \%$ in the CIROS- 2 core Interpretation of the stratified diamictite association by Hambrey et al. (1989) is that this is waterlain till deposited by currents directly beneath melting basal glacier ice. Clasts are commonly dropstones fallen out from the ice floating above. Hambrey et al. (1989) infer stratification to increases seaward from the grounding line.

\subsubsection{Stratified sandstone}

Stratified sandstone is moderately sorted and sometimes muddy and gravelly. It is poorly consolidated at places. Stratification is generally marked by muddy horizons, is on a $\mathrm{mm}$ to $\mathrm{cm}$ scale. Sedimentary structures such as crossbedding are prominent at places. Stratified sandstone comprises $15 \%$ of the pre-Late Pliocene strata in the CIROS- 2 core and only $2 \%$ of the DVDP-11 core. Hambrey et al. (1989) interpreted this facies to have been deposited in a near-shore environment, with minor ice rafting and a windblown component.

\subsubsection{Massive Mudstone}

The massive mudstone is poorly to moderately sorted, diatomaceous and contains rare dropstones. It is moderately hard and sometimes fractured. Hambrey et al. (1989) interpreted it to be a relatively deep water offshore deposit with minor terrigenous sediment in a distal glaciomarine setting. 


\subsubsection{Stratified Mudstone}

The stratified mudstone facies association is poorly to moderately sorted, diatomaceous, and weakly to moderately stratified on a $\mathrm{mm}$ to $\mathrm{cm}$ scale. The stratification results from thin sandy layers. Some horizons are gravelly and dropstones are rare to common. The total mudstone facies association content (massive and stratified) comprises $13 \%$ of the pre-Late Pliocene strata in the CIROS- 2 core and $16 \%$ of the DVDP-11 core. The stratified mudstone facies association was interpreted by Hambrey et al. (1989) to have been deposited in a deep but more nearshore environment than in that of the massive mudstone. There is still a glaciomarine influence and stratification and dropstone concentration increase with proximity to the glacier tongue.

\subsubsection{Breccia/Conglomerate}

The breccia/conglomerate facies association is clast supported subangular to subrounded conglomerate. It is massive to poorly stratified and usually contains little or no matrix. This facies association comprises $17 \%$ of the preLate Pliocene strata in the DVDP-11 core and is not observed in the CIROS-2 core. It was interpreted by Hambrey et al. (1989) to be immediately proglacial to fluvioglacial material, where strong fluvioglacial or subglacial currents have winnowed most of the fines from the deposit.

\subsection{Stratal unconformities}

Five different types of stratal unconformity are recognised in the present study of the CIROS-2 and DVDP-11 cores. The individual surfaces vary greatly in character and are defined not only by the type of the break, but also the lithology above and below the break. Three of the unconformities are erosional (A1-A3) and two are paraconformities (B1 and B2).

A1) A sheared and striated basal contact beneath lodgement till. It is sometimes angular and shows tool markings from clasts in the overriding till. The till itself often contains rip-up clasts from the underlying lithology, this is often mudstone, but can be diamictite. This unconformity is formed from direct erosion by grounded glacial ice shearing and removing the material that it is overriding.

A2) A current formed erosional surface with up to $5 \mathrm{~cm}$ of relief. Underlying lithology is often sandstone or stratified diamictite with rare pebbles. Ripples were observed in one example formed from the currents associated with the erosion. The irregular unconformity surface is overlain by stratified and sometimes crossbedded diamictite. This type of unconformity is formed by currents associated with a proximal grounded ice sheet winnowing and removing material in front of the grounded ice. 
A3) A similar surface to that described as A2, except that the overlying lithology is breccia and/or pebble conglomerate. It is associated with a proximal ice tongue, but inferred to have formed in shallower water environment than type A2 unconformities.

\section{B 1) An angular and irregular} disconformity where the top of a diamictite unit is directly overlain by mudstone that drapes the underlying diamictite. This is interpreted to have formed in a proximal glaciomarine environment where currents associated with the nearby ice body are strong enough to prevent deposition but not erode existing material. After further retreat of the ice body distal glaciomarine sediments (mudstones and sandy mudstones) draped the underlying lithology.

B2) A surface where two mudstone facies associations are separated by a burrowed hardground. This is interpreted to have occurred at times of marine deposition when sediment supply was very slow.

\subsection{Facies successions}

Many workers have related the different facies units to deposition in particular environments (e.g. Hambrey et al., 1989, document individual facies associations and their interpreted depositional environment, but do not recognise facies successions and the changing environment of deposition that they represent). This is possibly because even common successions in the core are difficult to observe and quantify. Hambrey and Barrett (1993) state that the limitations of their lithofacies and process models can be attributed to the limited direct geological observations and the slow depositional rates beneath Antarctic glaciers. Because of this an attempt is made here to help quantify the natural successions and juxtapositions of facies associations and develop the model of Hambrey et al. (1989) (figure $5.1)$ by adding more quantitative and qualitative observations. Application of Waltherian Law to the resulting observations of vertical facies relationships allows inference of the lateral arrangement of facies. In analysing vertical sequences it is important to recognise the contacts between the facies associations and hence the continuum of deposition. Hence, the importance placed by this study on recognition of unconformities in the cores.

Markov chain analysis is employed here to identify significant facies association relationships. It eliminates the variation that might occur from differing lateral proximity to an advancing or retreating ice tongue. This means that position of the respective drill-holes is not critical in constructing facies successions and models.

A markovian process is one "in which the probability of the process being in a given state at a particular time may be 


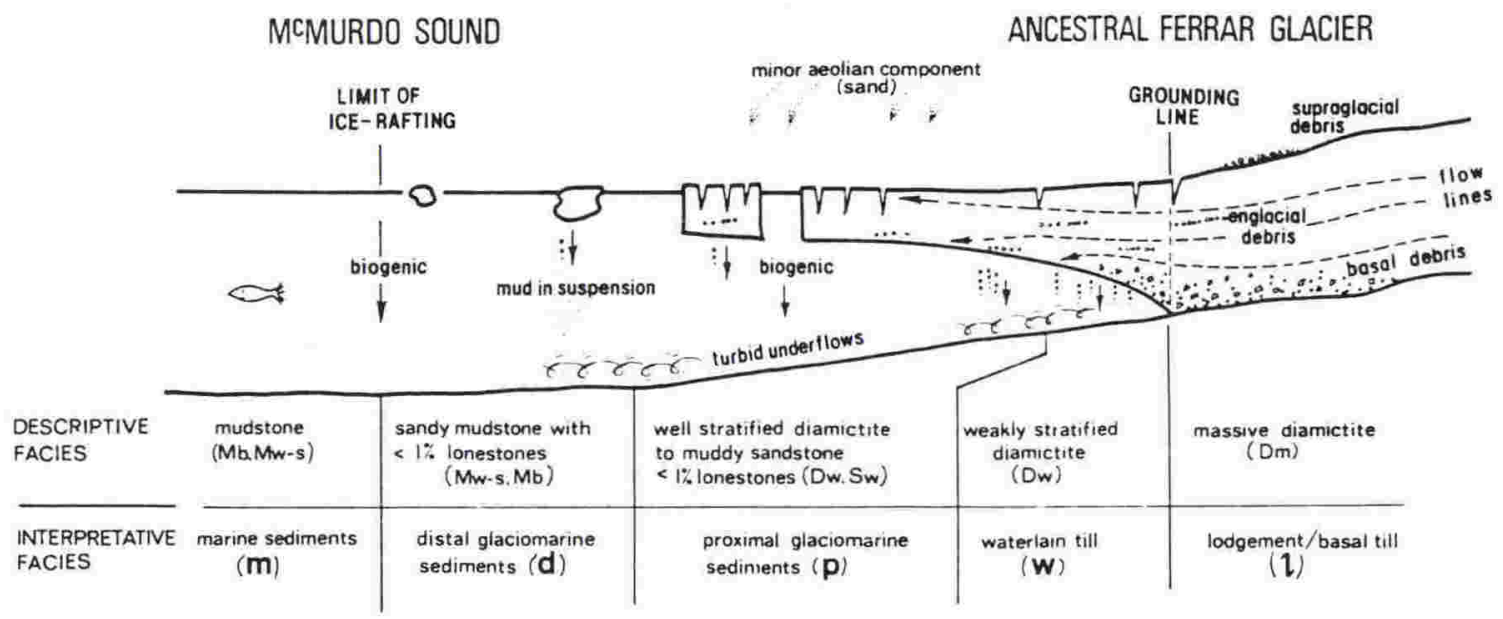

Figure 5.1: Facies model for sedimentation around a floating glacier tongue (from Hambrey et al., 1989) (Vertical exaggeration is X10).

depicted from a knowledge of the immediately preceding state" (Harbaugh and Bohnham-Carter, 1970, p.98). The procedure for analysis was presented in detail by Tucker (1988). The basic principle is that recognised facies transitions are recorded in a matrix form (observed matrix). From this a probability of facies transition matrix (predicted matrix) is constructed by comparison of the total number of transitions to or from any one particular facies with the total number of facies transitions.

Comparison of the two matrices (observed and predicted) depicts the significant facies transitions and hence the facies successions of the CIROS-2 and DVDP-11 drill-holes.
The successions cored by the two drillholes are used in constructing the facies successions and resulting facies models. Although the DVDP-11 core sampled an overall shallower depositional environment (Barrett and Hambrey, 1992), it should still record the same natural lithofacies relationships. It introduces into the model shallower lithofacies that are not recorded by the CIROS-2 drill-hole.

The observed lithofacies used in the present study are:

Disconformity surface, nonerosional (A1); Unconformity surface, erosional (A2); Massive Diamictite (B1); Stratified Diamictite (B2); Stratified Sandstone 
Table 5.1: Observed facies transition matrix for cored Antarctic Margin strata in MeMurdo Sound.

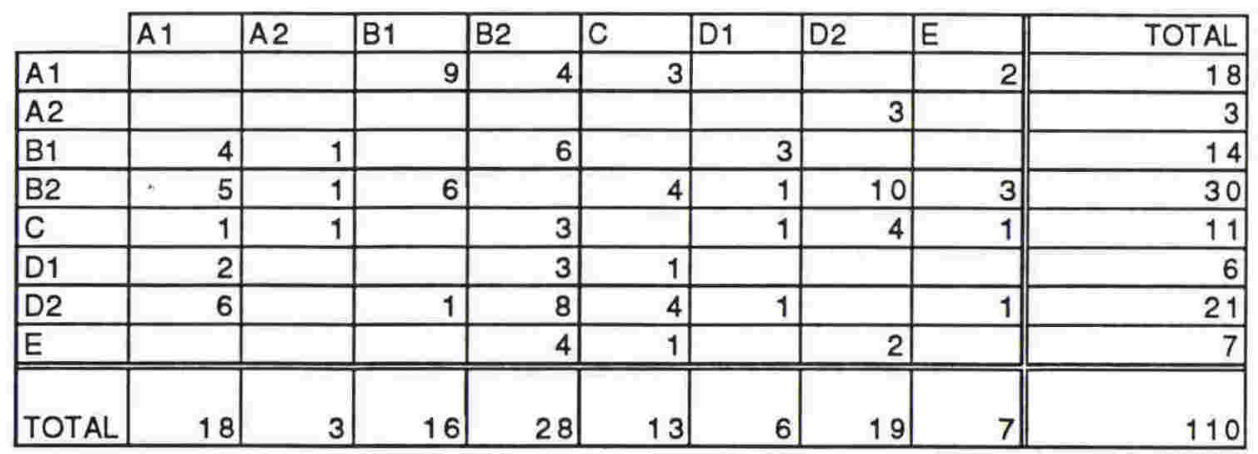

Table 5.2: Predicted facies transition matrix for cored Antarctic Margin strata in McMurdo Sound.

\begin{tabular}{|l|r|r|r|r|r|r|r|r||r|}
\cline { 2 - 10 } \multicolumn{1}{c|}{} & A1 & A2 & B1 & B2 & C & D1 & D2 & E & TOTAL \\
\hline A1 & & 0.49 & 2.62 & 4.58 & 2.13 & 0.98 & 3.11 & 1.15 & 15.06 \\
\hline A2 & 0.49 & & 0.44 & 0.76 & 0.35 & 0.16 & 0.52 & 0.19 & 2.91 \\
\hline B1 & 2.29 & 0.38 & & 3.56 & 1.65 & 0.76 & 2.42 & 0.89 & 11.95 \\
\hline B2 & 4.90 & 0.81 & 4.36 & & 3.55 & 1.64 & 5.18 & 1.91 & 22.35 \\
\hline C & 1.80 & 0.30 & 1.60 & 2.80 & & 0.60 & 1.90 & 0.70 & 9.70 \\
\hline D1 & 0.98 & 0.16 & 0.87 & 1.53 & 0.71 & & 1.04 & 0.38 & 5.67 \\
\hline D2 & 3.44 & 0.57 & 3.05 & 5.35 & 2.48 & 1.15 & & 1.34 & 17.38 \\
\hline E & 1.15 & 0.19 & 1.02 & 1.78 & 0.83 & 0.38 & 0.44 & & 5.79 \\
\hline \hline & & & & & & & & & \\
TOTAL & 15.05 & 2.90 & 13.96 & 20.36 & 11.70 & 5.67 & 14.61 & 6.56 & 90.81 \\
\hline
\end{tabular}

Table 5.3: Difference matrix, between predicted and observed facies transitions for cored Antarctic Margin strata In McMurdo Sound.

\begin{tabular}{|l|r|r|r|r|r|r|r|r||r|}
\cline { 2 - 9 } \multicolumn{1}{c|}{} & A1 & A2 & B1 & B2 & C & D1 & D2 & E & TOTAL \\
\hline A1 & & & 6.38 & & 0.87 & & & 0.85 & 8.10 \\
\hline A2 & & & & & & & 2.48 & & 2.48 \\
\hline B1 & 1.71 & 0.62 & & 2.44 & & 2.24 & & & 7.01 \\
\hline B2 & 0.10 & 0.19 & 1.64 & & 0.45 & & 4.82 & 1.09 & 8.29 \\
\hline C & & 0.70 & & 0.20 & & 0.40 & 2.10 & 0.30 & 3.70 \\
\hline D1 & 1.02 & & & 1.47 & 0.29 & & & & 2.78 \\
\hline D2 & 2.56 & & & 2.65 & 1.52 & & & & 6.73 \\
\hline E & & & & 2.22 & 0.17 & & 1.56 & & 3.95 \\
\hline \hline & & & & & & & & & \\
TOTAL & 5.39 & 1.51 & 8.02 & 8.98 & 3.30 & 2.64 & 10.96 & 2.24 & 43.04 \\
\hline
\end{tabular}

(C); Massive Mudstone (D1); Stratified Mudstone (D2); Breccia/conglomerate (E).

Gradational contacts are interpreted as passive changes from one environment or facies association to another. A sharp contact is less passive, or less closely related. Unconformities or disconformities are treated individually and vary between active erosive processes and passive breaks in deposition. Intervals of non-recovery in the cores are treated as breaks in deposition in the facies transition sequence.

Some 111 facies association transitions are recognised in the pre-Late Pliocene strata from both the CIROS-2 and 
DVDP-11 cores. These are presented in table 5.1 with the predicted facies transitions matrix presented in table 5.2. The significant facies association transitions are underlined in the difference matrix in table 5.3 and presented in figure 5.2.

Two main types of succession are recognised by the Markov chain analysis:

1) (figure 5.3) A sequence beginning with an erosional unconformity surface usually directly overlain by massive diamictite, often including rip-up clasts of the material it has eroded. The diamictite becomes increasingly stratified and decreasingly pebbly until it is a stratified pebbly mudstone. The sequence then coarsens and becomes less stratified until once again it is stratified or massive diamictite. Each sequence does not always begin with an erosional surface, but usually does. Sometimes the diamictite is disconformably overlain by a massive mudstone without the increasingly stratified transitional sequence (figure 5.3a).

2) (figure 5.4) Sometimes the stratified diamictite facies association is conformably overlain by coarser current deposited and winnowed pebble conglomerates or stratified coarser sandy facies associations.

\subsection{Interpretation of successions}

Interpretation of these sequences is presented in figure 5.5. It follows the

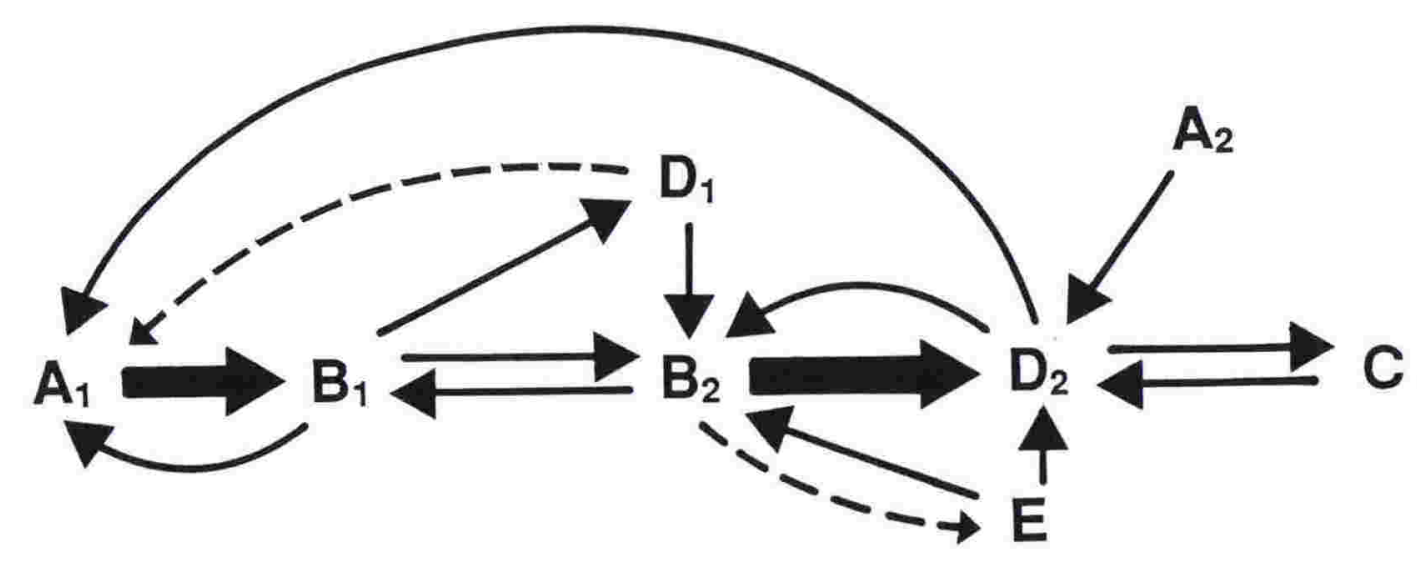

Figure 5.2: Facies association relationship diagram and vector sequences for the CIROS2 and DVDP-11 successions. Relationships are calculated using Markov chain analysis. $\mathrm{A}_{1}$ $=$ disconformity surface, erosional; $\mathrm{A}_{2}=$ unconformity surface, erosional; $\mathrm{B}_{1}=$ massive diamictite; $\mathrm{B}_{2}=$ stratified diamictite $\mathrm{C}=$ stratified sandstone; $\mathrm{D}_{1}=$ massive mudstone $\mathrm{D}_{2}$ $=$ stratified mudstone $\mathrm{E}=$ breccia/conglomerate. 


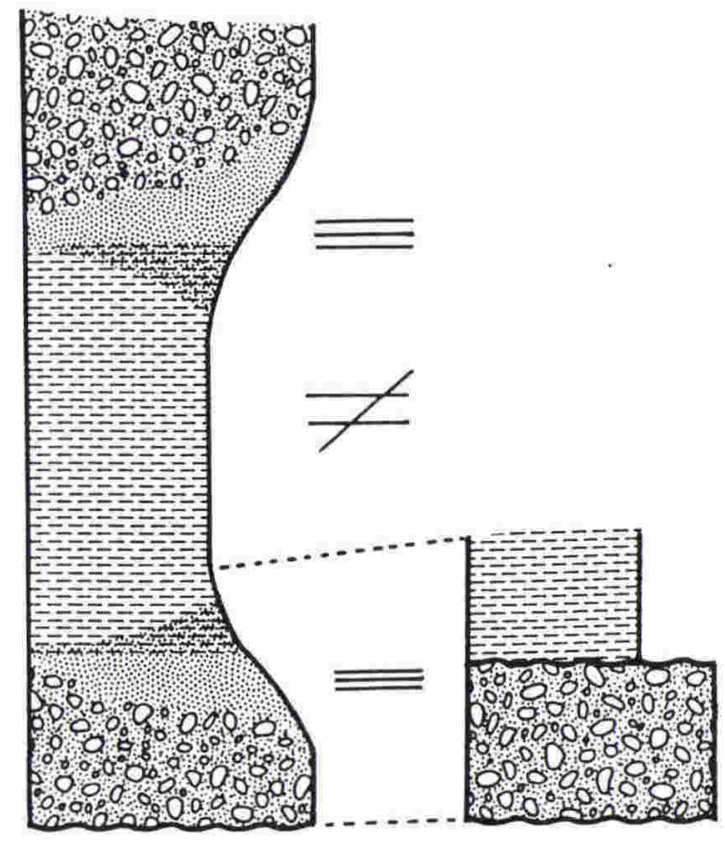

Figure 5.3: Facies succession 1 as identified by markov chain analysis. a) right; common variation in the lower part of the facies succession (see text for explanation).

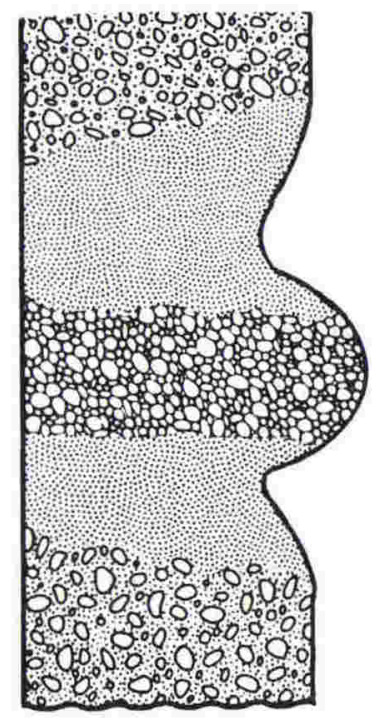

Figure 5.4: Facies succession 2 as identified by markov chain analysis (see text for explanation). interpretation and models presented by Hambrey et al. (1989) Hambrey et al. (1991), Hambrey et al. (1992) and Barrett and Hambrey (1992). The two types of sequences distinguished by Markov chain analysis (see section 5.4) each represent a retreat and readvance of grounded glacial ice into a glaciomarine environment.

An erosion surface represents the initial advance of a grounded ice body. The lodgement till directly above this is material deposited directly from the basal debris layer of the grounded ice above the site of deposition. The increasing stratification and general fining of the facies associations represents a retreating grounded ice body from the site of deposition in a glaciomarine environment. Floating debris laden glacier ice continues to introduce gravelly debris to the site of deposition. Direct deposition of the gravelly material, however, becomes increasingly controlled by currents and then settling with distance from the grounding line of the ice body. The finest grained muddy horizons in the centre of the sequence represent the deepest and most distal glaciomarine phase of deposition, with little or no influence from a grounded or floating ice body.

The upper part of the sequence, an inversion of the lower part of the sequence, represents a readvance of the floating and then grounded debris laden ice body towards and above the site of deposition. 


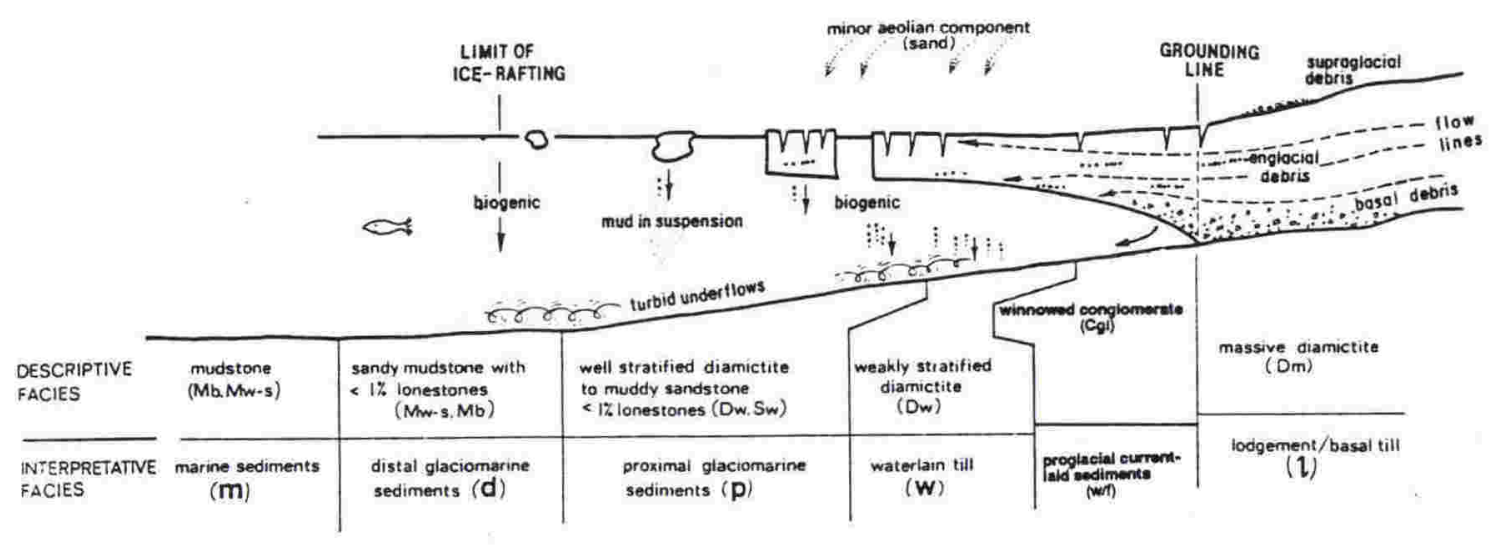

Figure 5.5: Modified facies model for sedimentation around a floating glacier tongue, model now includes winnowed, shallow water deposited, conglomerates (modified from Hambrey et al., 1989) (Vertical exaggeration is X10).

Sequence 2 differs from sequence 1 in that it is inferred to represent the same sequence of glacial retreat and readvance, but in a shallower glaciomarine environment. The facies associations in the centre of the sequence are therefore generally more sandy and more affected by currents associated with both the ice body and the shallow marine deposition. In its shallowest example, the centre of the sequence is represented by coarse, well washed, pebble conglomerates.

\subsection{History of sedimentation in McMurdo Sound as recorded by the CIROS-2 and DVDP-11 cored sequences.}

The two pre-Late Pliocene sequences in CIROS-2 and DVDP-11 are entirely marine (Harwood, 1986; Ishman and Rieck, 1993 and this study, appendix 1).

Barrett and Hambrey (1992) present a model of ice front position with respect to the site of deposition of the CIROS-2 drill-hole (figure 5.6). The pre-Late Pliocene ( $>100 \mathrm{~m}$ depth) section of this is adopted here. Two orders of glacial activity are recognised in the CIROS-2 core: The lesser order was advance and retreat of local ice from down-valley glaciation and the larger order was larger scale glaciation causing grounded ice in the Ross Sea. The grounded ice isolated the McMurdo Sound region so that deposition in the CIROS-2 core became entirely lacustrine and freshwater in origin (Harwood, 1986). The onset of grounding ice in McMurdo Sound is recognised by an increase in volcanic 


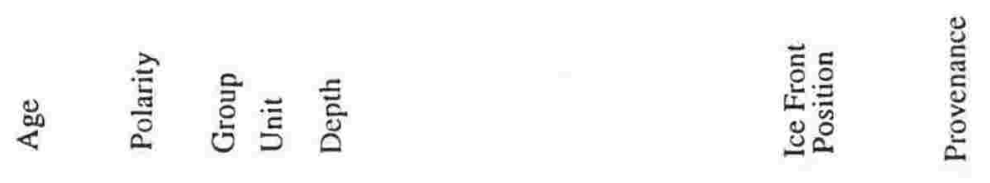
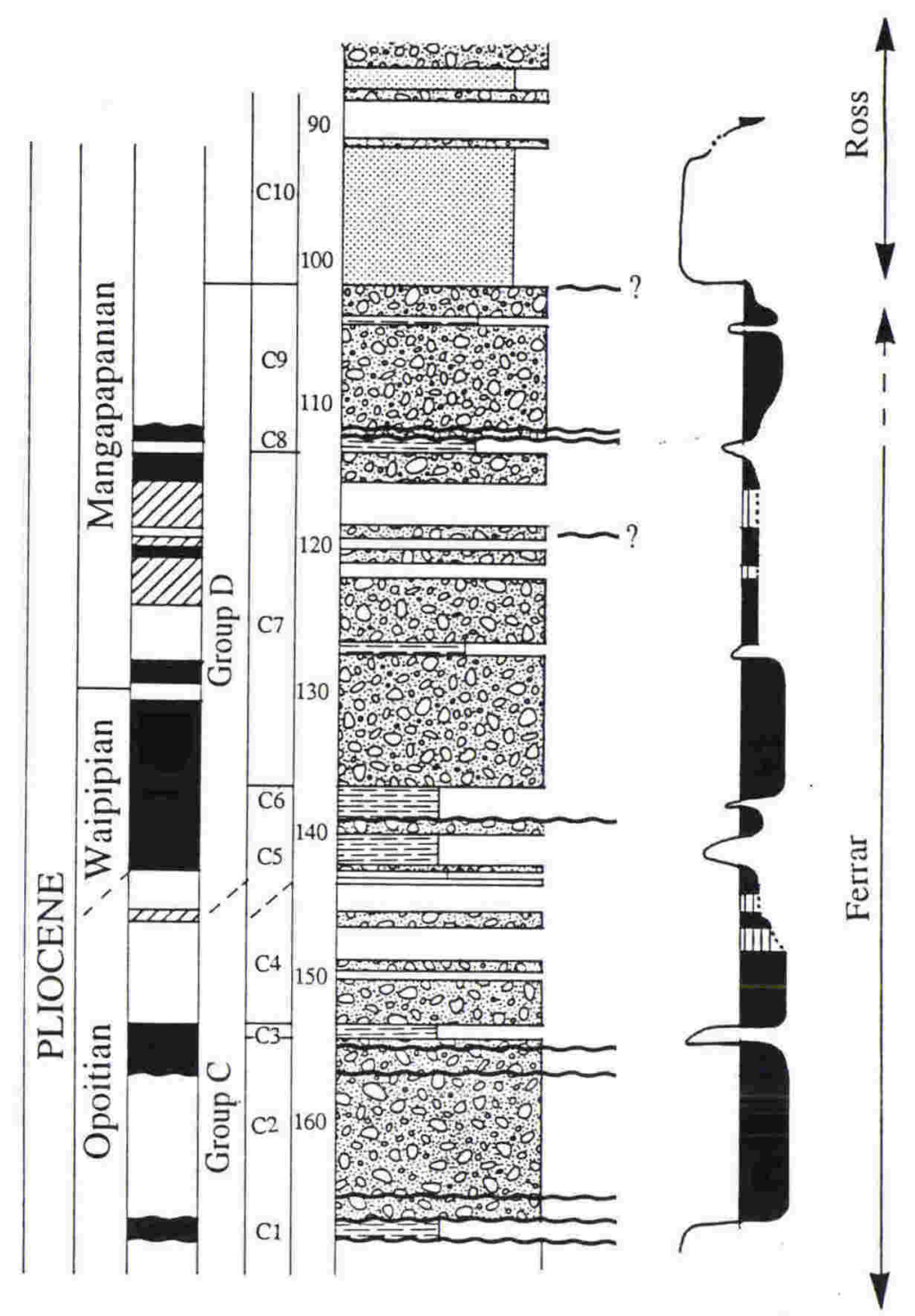

Figure 5.6: Lithological interpretation of the Late Neogene sequence cored at CIROS-2. Ages are from chapter 9 . Curve for the ice front position was obtained using the model presented in figure 5.5 (curve is from Barrett and Hambrey, 1992).

detritus in the CIROS-2 core (Barrett and Hambrey, 1992). An unknown scale of glaciation is recorded in the CIROS-2 drill-hole by the glacial advance that planed the valley floor back to Granite Gneiss basement.

The ice front position curves (figure 5.6 and 5.7) were constructed from the detailed lithofacies interpretations presented in chapter 4 and appendix 1 . The curves reflect proximity to the ice margin, and hence extent of glaciation at the sites of observation.

Successive ice front positions relative to the pre-Late Pliocene DVDP-11 site of deposition (figure 5.7) was compiled using the facies associations and successions presented in sections 5.3 and 


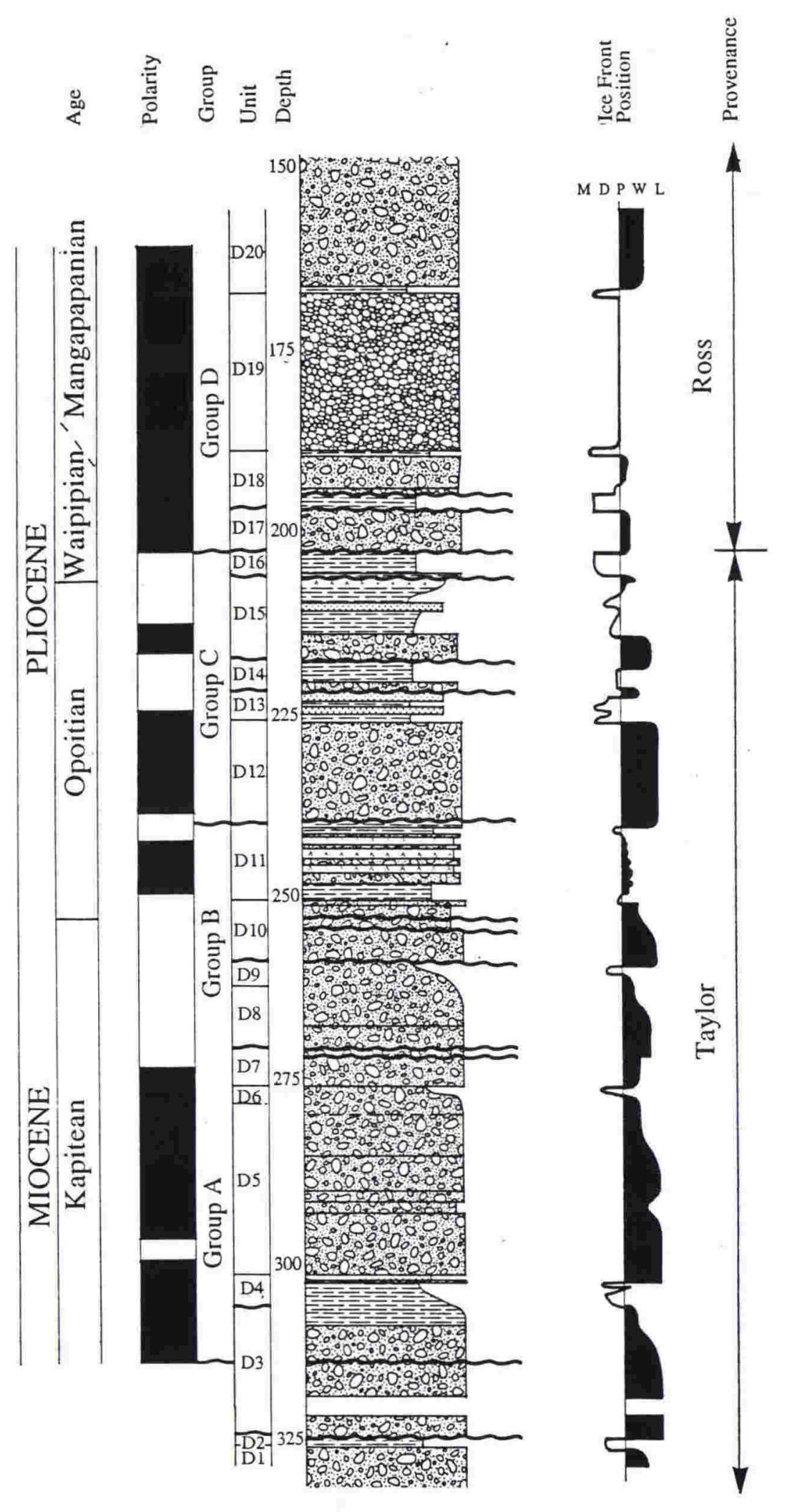

Figure 5.7: Lithological interpretation of the Late Neogene sequence cored at DVDP-11. Ages are from chapter 9. Curve for the ice front position was obtained using the model presented in figure 5.5. 
5.4. Three orders of glacial activity are recognised in the DVDP-11 core: Firstly from advance and retreat of the Taylor Glacier between $c a .205$ and $270 \mathrm{~m}$ depth in the core (Groups B and C), where ice front varies between grounded over the DVDP-11 site and distal. Secondly where grounded ice from an advance of the Taylor Glacier is more extensive (below ca. $270 \mathrm{~m}$ in the core; Group A) and almost constantly grounded over the DVDP-11 site. The third order is from grounded ice in the Ross Sea, recognised by an increase in the volcanic detritus at ca. $202 \mathrm{~m}$ depth (Ishman and Rieck, 1993) like that recognised in the CIROS2 core by Barrett and Hambrey (1992).

Age control is from the magnetostratigraphy presented in chapter 9.

The two cores record much of the Late Neogene history of glaciation in McMurdo Sound (figure 5.8).

The earliest record of sedimentation is in the DVDP-11 core. It contains the only record of sedimentation for the Late Miocene - Early Pliocene. Despite being a single record, the agreement in the upper part of the core with the CIROS-2 record is so good that this is adopted here to be representative of Late Miocene Early Pliocene glacial extent.

Group A strata represent a time of extended glacial advance down the Taylor Valley with deposition at the DVDP-11 site of predominantly lodgement till. Three short intervals of glacial retreat are definitely recorded at ca. 5.4, 5.8 and $6.3 \mathrm{Ma}$. by deposition of distal glaciomarine to marine sediment at the DVDP-11 site. Several more glacial advances are recorded by unconformities and evidence of smaller episodes of lodgement till to waterlain till deposition. Generally as in the facies model presented earlier, the waterlain till directly overlies lodgement till. Further episodes of ice retreat may either not have occurred or evidence of them may have been eroded by subsequent glacial advance. The magnetostratigraphy (chapter 9) suggests that little of the record is missing, supporting the hypothesis of continued deposition from expanded ice in the Taylor Valley in the Group A sediments (Late Miocene).

Deposition of Group B strata was in a less predominantly glacial environment. Glacial advance is recorded mainly by waterlain till deposition at the DVDP-11 site. Large glacial advance events are recorded at 4.9 and $5.3 \mathrm{Ma}$. Intervals of glacial retreat are recognised at $c a$. 4.5, 4.8 and $5.0 \mathrm{Ma}$. by distal glaciomarine to marine sedimentation at the DVDP-11 site. Much of the rest of the Early Pliocene is a time of proximal to distal shallow glaciomarine deposition at the DVDP-11 site, and hence reduced glacial extent than in the Late Miocene.

The top of Group B is marked by a large glacial advance eroding and/or preventing much deposition between 4.3 and 4.6 m.y. This event in DVDP-11 is 


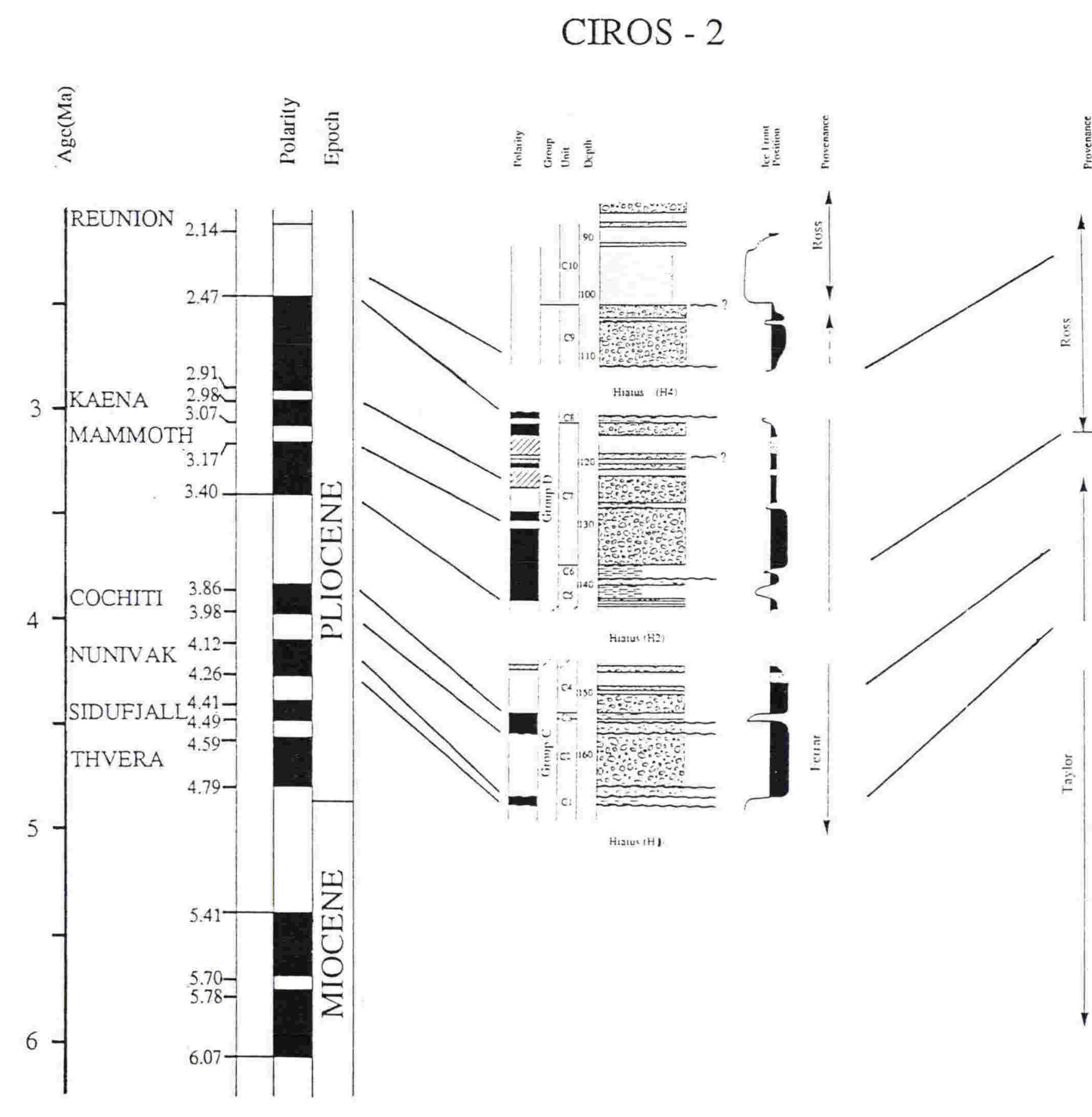

DVDP - II 
correlative with the latest glacial erosion to basement at the CIROS-2 site of deposition in the Ferrar Valley.

Group C strata are sampled by both CIROS-2 and DVDP-11 drill-holes. The lowest member of this group occurs only in the DVDP-11 core (unit D12), is a lodgement till and seems to be associated with glacial advance causing the $\mathrm{H} 1$ hiatus. The remaining Late Pliocene sequence (Group C strata) represents several episodes of glacial advance and retreat, with cyclically varying waterlain till through proximal to distal glaciomarine deposition at the DVDP-11 site. Only lodgement to waterlain till was recovered from this interval in the CIROS- 2 core. Intervals of non-recovery and unconformity in the CIROS-2 core correlate with 'interglacial' sedimentation at the DVDP-11 site. Two deglacial episodes are recorded at 3.3 and $4.1 \mathrm{Ma}$. by distal glaciomarine to marine sedimentation at both the DVDP-11 and CIROS-2 sites of deposition.

Group C and D strata are separated in both CIROS- 2 and DVDP-11 cores by major hiatuses, $c a$. 3.5-3.6 m.y. and 3.03.6 m.y. respectively. This is inferred to represent a major glacial episode causing erosion and/or non-deposition. The episode is more extensive in Taylor Valley to the north.

Late Pliocene sedimentation is recorded only in the CIROS-2 core. Deglaciation is recorded in two episodes between 3.2 and 3.4 Ma., and is followed by a glacial episode from 3.0-3.2 m.y. The upper group C strata (2.5 - 3.0 m.y.) record shallower water sedimentation in a more continuously proximal glaciomarine to waterlain till environment of deposition at both the CIROS- 2 and DVDP- 11 sites. Several episodes of smaller scale glacial advance and retreat are recorded in these strata at both the DVDP-11 and CIROS-2 drill-holes.

A distinct change in the nature of sedimentation occurs in both cores within the Late Pliocene, at about $3.0 \mathrm{Ma}$. at the DVDP-11 site and $2.5 \mathrm{Ma}$. at the CIROS2 site the source of sediment and hence glacial advance is from the Ross Island side of McMurdo Sound. This resulted from a gradual but large increase in the size of the Ross Ice Shelf, causing grounding in the Ross Sea. This is recorded by gradual isolation and Ross Ice Shelf extension into McMurdo Sound. Additional information supporting expansion of the Ross Ice Shelf is available from seismic identification of the 'Pliocene unconformity' in the Ross Sea (Webb, 1990) and the recovery of only fresh water diatom species (Harwood, 1986) above this interval in both the CIROS-2 and DVDP-11 strata. The change occurs above an erosional hiatus $(\mathrm{H} 2 / \mathrm{H} 3$ in DVDP-11 and $\mathrm{H} 4$ in CIROS-2) in both cores. It may be younger in the CIROS-2 core because of a combination of its position further south, added protection from grounding ice by Ross Island, and the greater water depth at the site of deposition. 


\section{Chapter - 6}

\section{Late Neogene ice volume history}

The interpretation of the record of ice volume history on the East Antarctic craton is based on models presented in chapter 5, together with ice volumes interpreted from other direct records of ice extent from the Antarctic continent. Chronology for the record is from section 2. The records from the DVDP-11 core and CIROS-2 core are in good agreement and inferred to be representative of variations in the volume of the East Antarctic ice sheet, or a local ice dome (Drewry, 1980) which feeds the Taylor and Ferrar Glaciers. The record in both cores is quite complete because of the passive nature of glacial advance and retreat caused by the sea-level response to ice volume variation on the East Antarctic craton. The sea-level rise and fall, floats and grounds the ice tongue during a glacial retreat and advance respectively. Ice volume variation is inferred to occur on four orders determined by scale and timing. The smallest scale is $100 \mathrm{k} . y$. duration glacial cycles resulting from limited ice volume variation indicative of the middle Pliocene glacial record. The largest scale is major grounding of ice in the Ross Sea due to development of an ice sheet larger than the present ice sheet. During times of maximum deglaciation, observed in the Early Pliocene (3.5-5.5 m.y.) by this study, the ice sheet is inferred to have been approximately half its present size. During maximum glaciation at $c a .2 .5 \mathrm{Ma}$. the ice sheet is inferred to have grown to less than half as large again as the present ice sheet. This new ice volume record of the East Antarctic ice sheet does not agree with existing interpretations of the oxygen isotope record for the Late Neogene, but the variation is similar in timing and amplitude to variations in the oxygen isotope record.

\subsection{Introduction}

A composite record is reported with the resolution and chronology from the Antarctic margin records and extent of glacial variation available in a limited sense from the cores, and largely from discrete outcrops of Sirius Group till from the Transantarctic Mountains and Lambert Glacier region, and the Dry Valley region on the Antarctic craton. The methodology used for interpretation of the records is presented earlier in this section.

\subsection{Deglaciation and reglaciation?}

The best indicator available for large scale deglaciation of the east Antarctic craton is the occurrence of recycled marine microfossils in the Sirius Group deposits in the Transantarctic mountains and their correlative deposits in the Lambert Glacier region (plate 6.1). As reported in chapter 3, Harwood (1986) inferred that deglaciation of the East Antarctic interior occurred between $c a .5$ and $2.5 \mathrm{Ma}$. The East Antarctic interior is 

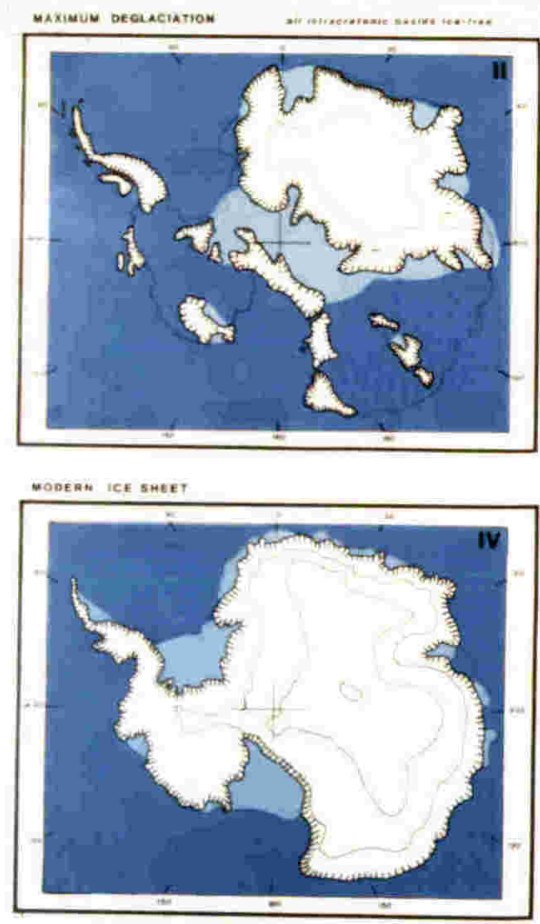
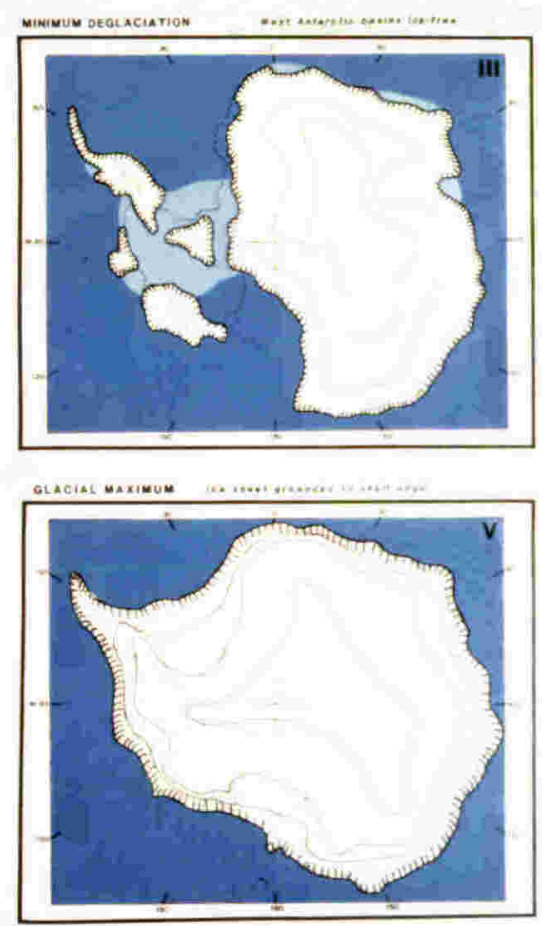

Plate 6.1: General Palaeoceanographic configuration for various equilibrium stages in Antarctic Ice Sheet growth (figure prepared by David Harwood).

inferred to have been fully ice covered prior to $c a$. $5 \mathrm{Ma}$. from the lack of recycled marine microfossils of that age in the Sirius Group and correlative deposits (Harwood, 1986). The biostratigraphic ages are corroborated by the independent radiometric chronology of the biostratigraphic zones in the CIROS-2 and DVDP-11 cores. The cores are from equally high latitudes as deposition predicted for the recycled marine microfossils in the Sirius Group deposits by the model of Webb et al. (1984).

The inferred single glaciation event that deposited the Sirius Group (Mayewski and Goldthwait, 1985) is adopted in this study and must post date the youngest deposition of the marine microfossils in the East Antarctic Interior (ca. 2.5 Ma.).

Further evidence for Pliocene deglaciation is recorded less directly by deposition of fjordal and non ice-related Early Pliocene sediments in the Dry Valley region and McMurdo Sound. These areas have been subsequently glaciated and are still glaciated now.

Large scale glaciation during the late Pliocene is recorded by large scale erosion from ice grounding in the Ross Sea region (plate 6.1). The proposed method of ice grounding is from growth of the Antarctic ice sheet to a larger size than at present (Denton and Hughes, 1981). The resulting ice banked up behind the Transantarctic Mountains, 
possibly flowing over the top of the mountains and grounding across the Ross Sea. It is inferred, by this study, to be the same event that deposited the Sirius Group high in the Transantarctic mountains and marked the change from temperate moderate glacial conditions (Webb and Harwood, 1991) to the cold Polar conditions that exist today.

\subsection{Continued Glaciation?}

Evidence for continued glaciation of the Antarctic Continent throughout the Neogene has been presented from the Oxygen Isotope record (Kennett, 1977) and from buried desert pavements in the dry valley region (Marchant et al., 1989; 1992; and 1993). Both of these arguments use the present day conditions in the Antarctic as a basis for their models. The Sirius Group evidence suggests that the cold Antarctic Ice Sheet of the Pleistocene is a poor analogue for any earlier time. Therefore, each data set must be taken on its own merits. An interpretation accommodating all the data can be the only solution. If the Pleistocene Ice Sheet is a poor analogue for the pre-Pleistocene, then any model that uses it as an indicator must be viewed with caution. The oxygen isotope model of Kennett (1977) and further workers (e.g. Hodell et al., 1988) is therefore treated with some caution here, as the base level they employ to indicate ice build-up on the Antarctic continent is quite possibly invalid prior to the Pleistocene. Harwood's (1986) interpretation of the oxygen isotope record, using inclined base-line for ice sheet development based on cooling global ocean temperatures throughout the Cainozoic (figure 6.1), is probably much closer to the truth.

The claims of Marchant et al. (1989; 1992; and 1993) (see chapter 3) must also be viewed with caution. Further substantiation of the relationship of the ashes to geomorphic elements and evolution is required. If their relationship is inferred correctly by Marchant et al. (1993) the data call for ice free conditions at the time of deposition and minimal or no water flow consequent to deposition. This does not necessarily require the present cold polar conditions.

The writers interpretation of the data sets is one of subpolar conditions with temperate style glaciation prior to 2.5 $\mathrm{Ma}$., with episodic development of temperate style ice sheets across at least the East Antarctic Craton. The latest development of a moderately large temperate ice sheet was in the Messinian (Kapitean time, latest Miocene). At ca. $2.5 \mathrm{Ma}$. B.P. a temperate ice sheet, dammed by the Transantarctic Mountains formed to a greater size than the present ice sheet. While it grounded in the Ross Sea almost to the shelf edge (Hayes and Davey, 1975), aided by associated lower eustatic sea levels, it can not have enveloped the entire Transantarctic Mountain front as suggested by Denton and Hughes (1981). This is because the data of Marchant et al. (1989; 1992; and 1993) require the dry valley region to 


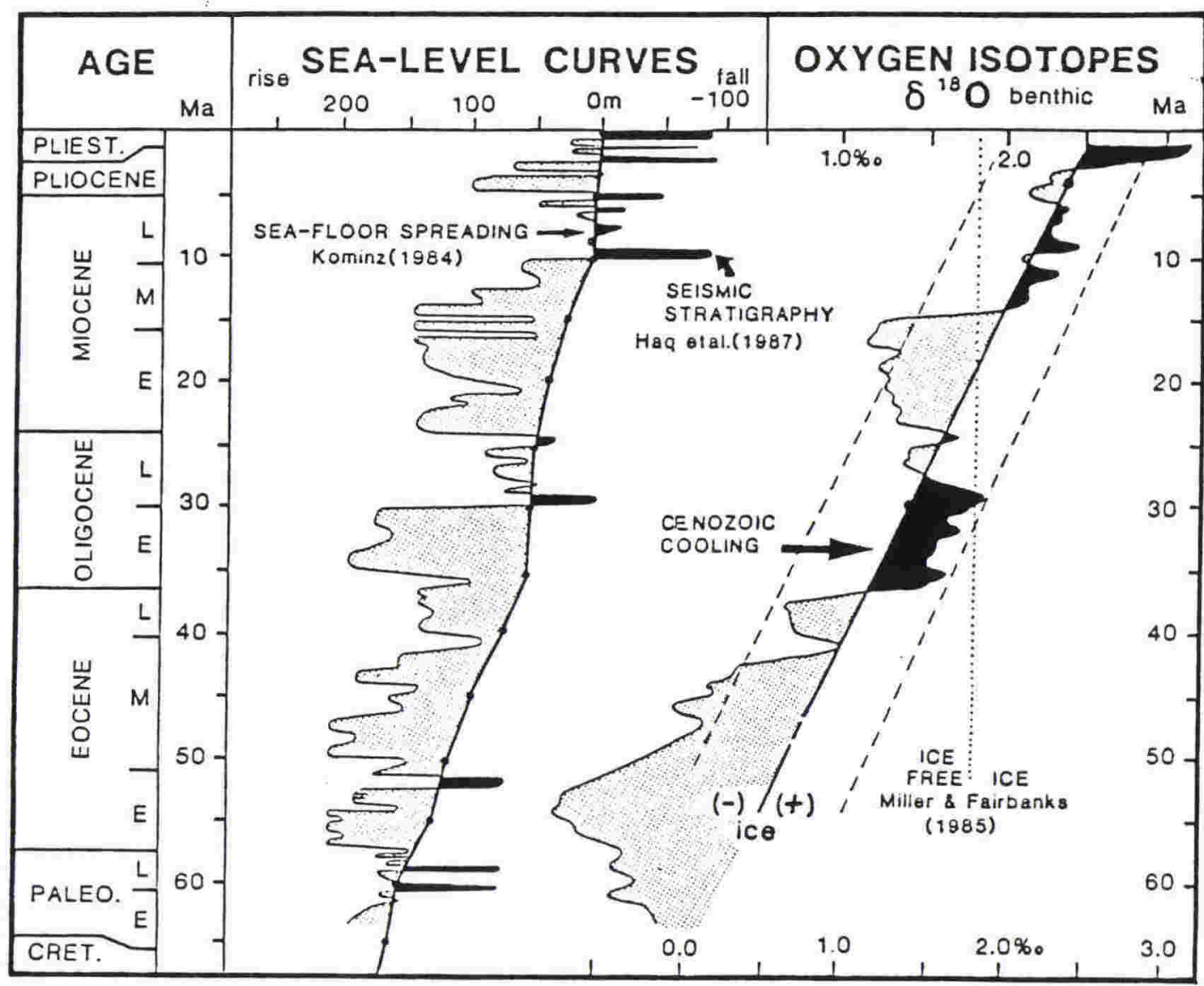

Figure 6.1: The oxygen isotope curve (Miller and Fairbanks, 1985) with ice/ice free interpretation accounting for first-order cooling trend in the benthic oxygen isotope compilations of Miller and Fairbanks (1985). Cainozoic eustatic sea level curve of Haq et al., 1987) is given for comparison (from Harwood, 1986).

have been essentially ice free throughout the time and certainly not proximal to temperate ice and its associated fluvioglacial influence.

\subsection{Evidence from Antarctic margin strata in McMurdo Sound.}

The correlation between the CIROS-2 and DVDP-11 cores, which record glaciomarine deposition in two independent valleys, confirm that changing depositional environments at the site of deposition of these sequences were driven by fluctuations beyond local influence of single glacial surges (Barrett and Hambrey, 1992). In this case the driving force must be the East Antarctic Ice sheet or a large local ice dome (Drewry, 1980) that feeds both the Taylor and Ferrar Glaciers. In effect the depositional record from the CIROS-2 and DVDP-11 drill-holes is a record of glacial advance and retreat in response to fluctuations in the volume of the East Antarctic ice sheet feeding the valley glaciers. 
The record in the two cores is more passive than one might expect from subpolar glacial advance and retreat. This is inferred here to be caused by the eustatic sea level variation associated with fluctuations in the volume of the East Antarctic ice sheet. Deglaciation would raise sea level, lift grounded ice off the McMurdo Sound sea floor and aid its retreat. Conversely, reglaciation would lower sea level placing the Taylor and Ferrar ice tongues back onto the sea floor, enhancing the signal of their advance and allowing the advance to take place much more passively than might be expected from straight glacial advance. This is borne out by the minimal amount of record destroyed by erosional episodes in both the DVDP-11 and CIROS-2 cores (see chapter 9).

In the two cores, the best indicator of climatic and associated glacial and East Antarctic ice volume variation is from the occurrence of mudstone and distal glaciomarine facies in the core representing episodes of deglaciation. The next most reliable indicator is from glacial advance causing slight erosion of the underlying lithology. This represents readvance of glaciers down the valleys and associated growth in the East Antarctic ice sheet resulting in lower eustatic sea-level. Ice advance and retreat is also recorded by the two facies successions reported in chapter 5 , but the relationship between these changing facies and ice volume variation is not clear from the present study. However, changes in the nature of the sedimentary successions and cycles are inferred to represent changes in 'base level' glaciation.

The largest glacial event recorded by the CIROS-2 and DVDP-11 cores is the grounding of ice in the Ross Sea and its gradual encroachment into McMurdo Sound. Initial grounding is dated at $c a$. 3.5-3.6 Ma., followed by a short period of further Pliocene warmth, with grounding becoming most extensive at ca. 2.4-2.5 Ma. The smaller scale glaciation and deglaciation recorded by the DVDP-11 and CIROS-2 cores is reported above (section 5.6) and is adopted directly here. DVDP-11 also records an extended glacial period in the Kapitean (Group A strata, pre 5.4 Ma. in age). This is in agreement with the inferred ice cover of the East Antarctic interior from the absence of marine microfossils in the Sirius Group deposits (Harwood, 1986 and Wise et al., 1991).

\subsection{The record of ice volume variation on the East Antarctic Craton (figure 6.2).}

Chronology of ice volume changes is from chapter 9 (palaeomagnetism) and biostratigraphic correlation supported by the radiometric dating presented in chapters 7 and 8 . A constant average sediment accumulation rate is assumed between palaeomagnetic reversals.

The Late Miocene and Late Pliocene are times of increased ice volume on the East Antarctic Craton with the development of 

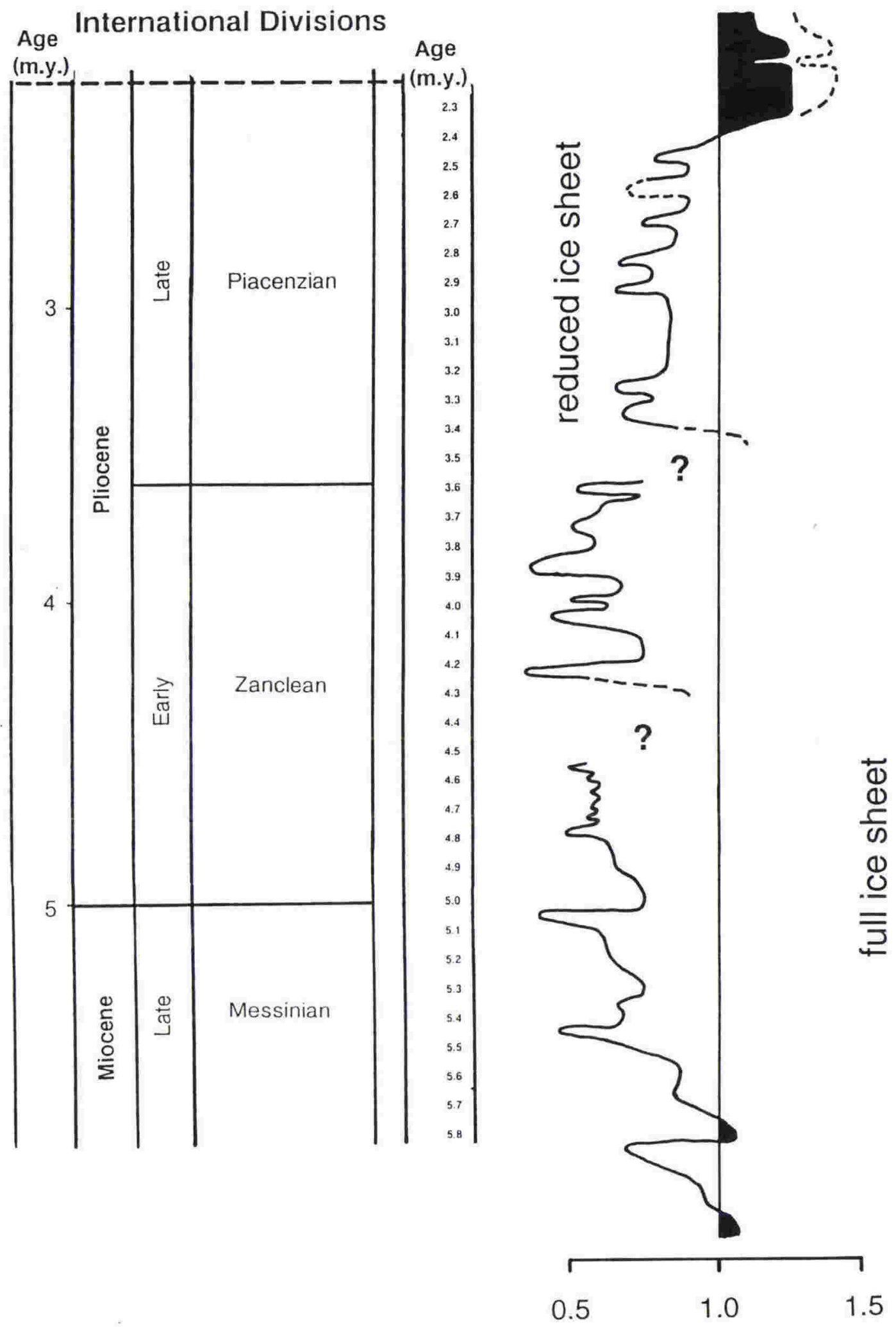

Figure 6.2: The record of Late Neogene Ice volume variation on the East Antarctic craton interpreted from the CIROS-2 and DVDP-11 drill-cores and published outcrop information (see text). Chronology is from chapter 9, assuming constant average sediment accumulation between palaeomagnetic reversals. Volume estimation is given as a comparison to the present day volume of the East Antarctic Ice Sheet. 
continental scale ice sheets. The Late Pliocene ice sheet was larger than the Late Miocene ice sheet and probably the largest ice sheet in the history of Antarctic glaciation. It represents an ice sheet perhaps half as larger in volume than the present day ice sheet. At its largest, the Late Miocene ice sheet was possibly as extensive as the present ice sheet. The inflection points of this base level variation are at $c a .5 .5$ and $2.5 \mathrm{Ma}$. respectively.

The Early Pliocene is marked by smaller glacial cycles of 100 - 500 k.y. duration. A reduced ice sheet on the east Antarctic craton exposed parts of the Antarctic craton allowing marine deposition in the interior. A marked glacial advance resulted in erosion and or non-deposition at the CIROS-2 and DVDP-11 sites between 3.4 and $3.6 \mathrm{Ma}$. This marks a change to 100 k.y. glacial cyclicity with increasing total ice volume on the Antarctic Continent with the largest increase at $c a .2 .5 \mathrm{Ma}$.

This record is in poor agreement with the previously recognised proxy record of Late Neogene glacial extent on the Antarctic Continent inferred from oxygen isotope variation in deep sea sediments (e.g. Kennett, 1977) (figure 3.2). The reasons for this have been outlined previously with discussion of limitation of the oxygen isotope models for predicting ice volume variation (see sections 3.2 and 6.3). The results of this study show that the present interpretation of the oxygen isotope curve in terms of ice volume variation on the Antarctic Continent (e.g. Kennett, 1977 and Hodell et al., 1988) is flawed and probably incorrect. 


\section{NEW CHRONOLOGY OF ANTARCTIC LATE NEOGENE STRATA}

Chapter - 7: Dating of the CIROS-2 ash

Chapter - 8: Beryllium-10 Dating

Chapter - 9: Palaeomagnetism 


\section{Chapter - 7}

\section{Dating of the CIROS-2 ash.}

This chapter presents the radiometric dating of the CIROS-2 ash, using $\mathrm{K}-\mathrm{Ar}$ and ${ }^{39} \mathrm{Ar} /{ }^{40} \mathrm{Ar}$ dating methods. Because of contamination of the ash by relict detrital material, a new approach was necessary to acquire ages for both the fresh volcanic material and the relict detrital material, without being able to physically separate the two. Simultaneous equations analysis with volume percent point count analysis was employed to achieve this. The result was in agreement with single crystal laser fusion and total fusion plateau ${ }^{39} \mathrm{Ar} /{ }^{40} \mathrm{Ar}$ dating. The CIROS-2 ash is assigned an age of $2.8 \pm 0.3 \mathrm{Ma}$. The consequences of this first radiometric age establishing the youthfulness of these strata, are discussed in the paper by Barrett et al. (1992) reprinted herein.

\subsection{Introduction}

There is a long history associated with radiometric (K-Ar and ${ }^{39} \mathrm{Ar} / 40 \mathrm{Ar}$ ) dating the CIROS-2 ash, beginning in 1985 after the core was recovered from Ferrar Fjord. All the attempts yielded ages in excess of $7 \mathrm{Ma}$. Despite endless efforts to separate a pure volcanic fraction from the ash, the detrital contaminant proved too difficult to remove completely. A very small percentage of basement feldspar, if very old, will tend to swamp the Argon signal from the younger material it contaminates.

The numerous attempts at dating had used all the ash material from the New Zealand portion of the core. The present author collected some more material from the Antarctic Core Facility, Florida State University, Tallahassee, Florida, U.S.A., by kind permission of Dennis Cassidy.
A new approach was taken in dating this new material. Percentage volcanic and basement grain volume measurements were used to assess the different contributions of argon from two different, but known mineral separates from the ash layer. The potassium and argon content of these two different separates was measured. Then simultaneous equations were used to calculate the argon contribution of each mineral component and hence its age.

This work was included in a report in nature earlier this year, with several coauthors who provided other $\mathrm{K}$-Ar and ${ }^{39} \mathrm{Ar} / 40 \mathrm{Ar}$ ages on the ash. The present author's contribution was in conception of the new K/Ar approach, sample preparation and some of the writing of the paper. The paper is reprinted here as part of this thesis (section 7.2), followed by supporting information on the 
approach, sample preparation and computations. This information was not included in the original Barrett et al. (1992) manuscript.

7.2 Reprint of the paper: Barrett et al. (1992); Geochronological evidence supporting Antarctic deglaciation three million years ago. Nature, vol. 359, 816-818.

\section{Geochronological evidence supporting Antarctic deglaciation three million years ago}

\section{P.J. Barrett, C.J. Adams, W.C. McIntosh, C.C. Swisher III and G.S. Wilson.}

The response of the Antarctic ice sheets to increased global temperatures is an important unresolved issue in the assessment of future climate change. In particular, considerable controversy exists as to whether the East Antarctic ice sheet suffered extensive deglaciation during the mid-Pliocene epoch ( $3 \mathrm{Myr}$ ago), when temperatures were only slightly warmer than today. Although the ice sheet is widely assumed to have existed in something like its present form for the past $14 \mathrm{Myr}$ (ref. 1), marine diatoms erode from the Antarctic interior have bee found in glacial till deposits high in the Transantarctic Mountains ${ }^{2,3}$, and have been biostratigraphically

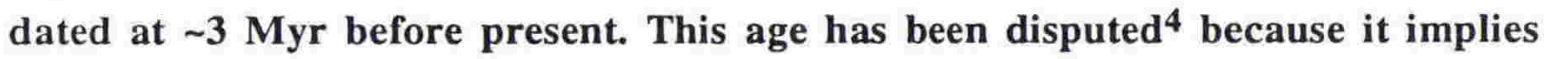
marine deposition in the Antarctic interior, and hence substantial deglaciation, at a time when other evidence has been marshalled for the persistence of cold, polar conditions ${ }^{4}$. Here we report $\mathrm{K}-\mathrm{Ar}$ and ${ }^{40} \mathrm{Ar} /{ }^{39} \mathrm{Ar}$ ages for a volcanic ash bed in diatom-bearing glaciomarine strata cored in Ferrar Fiord (East Antarctica) by the CIROS-2 drill-hole ${ }^{5}$, which confirm the age of the diatoms at $\sim 3 \mathrm{Myr}$, and hence also confirm the mid-Pliocene deglaciation.

The established view of Antarctic glacial history during the Cenozoic period is that considerable cooling occurred $\sim 40 \mathrm{Myr}$ ago, with extensive ice first covering the continent $\sim 14$ Myr ago, and persisting continuously to the present ${ }^{1}$. This is based on oxygen isotope variations in calcareous microfossils from deep-sea cores 6,7 , and geomorphic evidence from the Transantarctic Mountains of cold climates dating back at least $11 \mathrm{Myr}$, including several cold desert pavements 4,8 .

Recent work, however, has described warm mid-Pliocene marine incursions in the area around McMurdo Sound ${ }^{9-11}$, which includes Ferrar Fjord (figure 7.1). These incursions have been age calibrated by potassium-argon (K-Ar) dating of basalt flows and tephra ${ }^{12,13}$. But the crucial evidence for mid-Pliocene deglaciation of the Antarctic continent derives from the discovery, in glacial beds sourced from the East Antarctic interior, of microfossils 


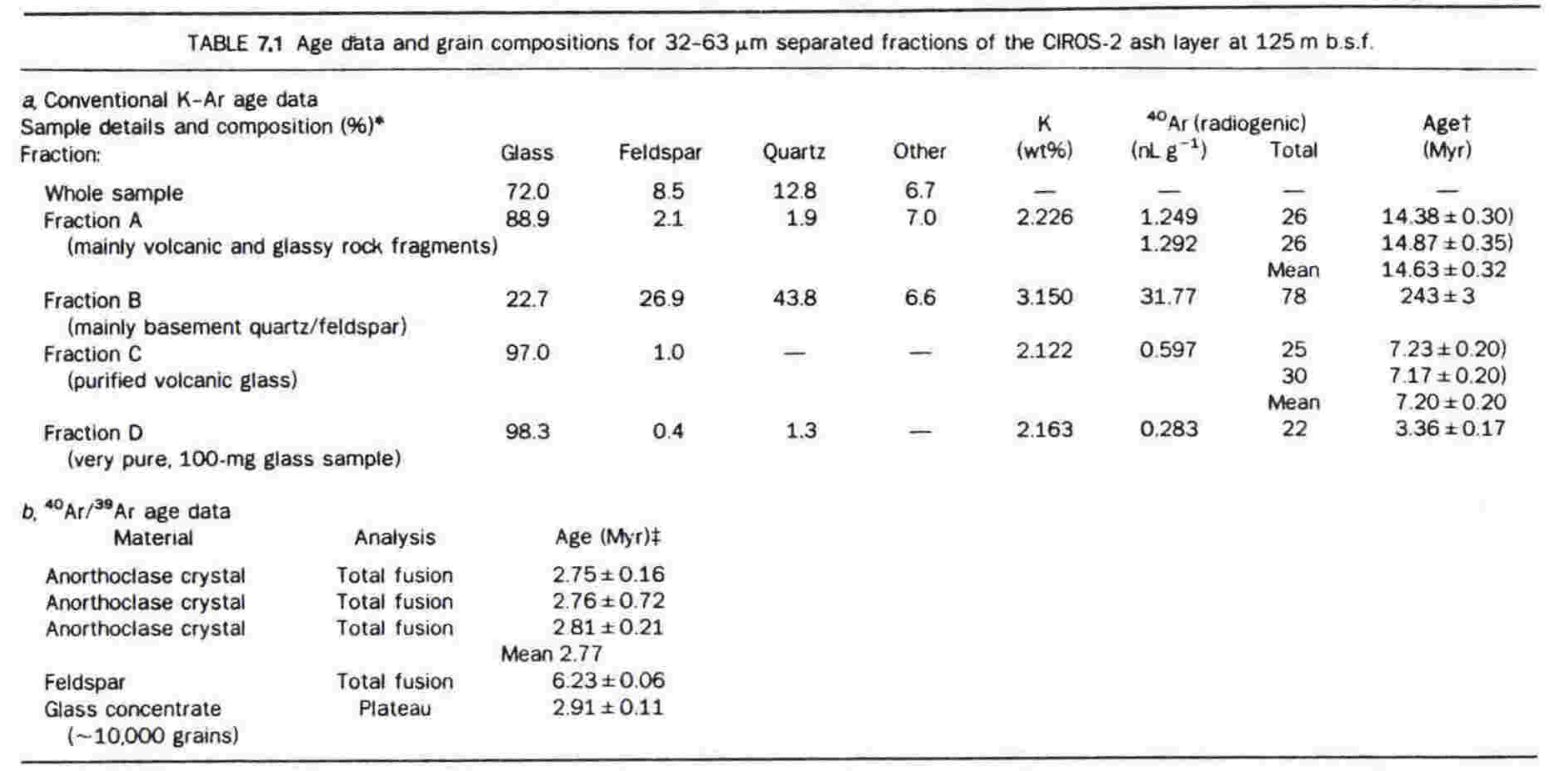

* $\%$ for grain types by counting 6,000 points (fractions $A$ and B) and 300 points (fractions $C$ and D) on grain mounts (magnification $\times 10$ ),

t Decay constants: for ${ }^{40} \mathrm{~K}, \lambda_{\beta}=0.4962 \times 10^{-8} \mathrm{yr}^{-1} ; \lambda_{s}=0.581 \times 10^{-10} \mathrm{yr}^{-1}$. Isotope abundance ${ }^{40} \mathrm{~K} / \mathrm{K}=0.01167 \%$; errors are two standard deviations For experimental techniques, see ref. 31.

$\ddagger$ Age errors are one standard deviation. Fish Canyon Tuff sanidine (27.84 Myr) used as neutron flux monitor.

(diatoms) that includes taxa said to be only $\sim 3$ Myr old 2,3 . This age was based on Thalassiosira insignia and $T$. vulnifica ${ }^{14}$, known to occur only in the age range 3.1 to 2.5 Myr in a well-dated sequence cored on Deep-Sea Drilling Program leg 71 in the south Indian Ocean ${ }^{17}$. The total range of $T$. vulnifica is also well dated there at 3.1 to $2.2 \mathrm{Myr}$.

These diatoms have been extracted with other microfossils, from semilithified glacial till of the Sirius Group at several locations along the Transantarctic Mountains (figure 7.1a). The till has all the features of basal glacial debris ${ }^{18}$, and the diatoms in it are therefore considered to have been eroded, transported and deposited by glacier ice. The distribution of the till, old ice flow directions from till fabric ${ }^{18}$ and flow models for an expanded ice sheet 19,20 indicate that the source of the till is from the interior of East Antarctica (figure 7.1), a region that must have been ice-free and below sea level when the Pliocene marine diatoms, later reworked into the Sirius Group, were living. Because this would require mid-Pliocene deglaciation, which is at variance with circumstantial evidence for persistent cold in Antarctica in Pliocene times ${ }^{21}$, some have suggested ${ }^{4}$ that the diatoms are of midPliocene age only in lower latitudes, and are much older in the Antarctic region.

Figure 7.1: $a$, Antarctica, showing the Transantarctic Mountains and the main areas where ice-deposited Sirius Group strata containing 3-Myr-old marine diatoms have been found. Ice thickness contours and flow lines are for the larger ice sheet required to deposit the Sirius Group debris and are taken from ref. 20. The flow pattern indicates and East Antarctic source for the diatoms, and hence marine sedimentation there $\sim 3 \mathrm{Myr}$ ago. $b$, Cross-section of Ferrar Fjord. The sediment dill includes both ice- and water-laid sand and mud with scattered pebbles. The core also contains a volcanic ash layer $0.3 \mathrm{~m}$ thick at 125 

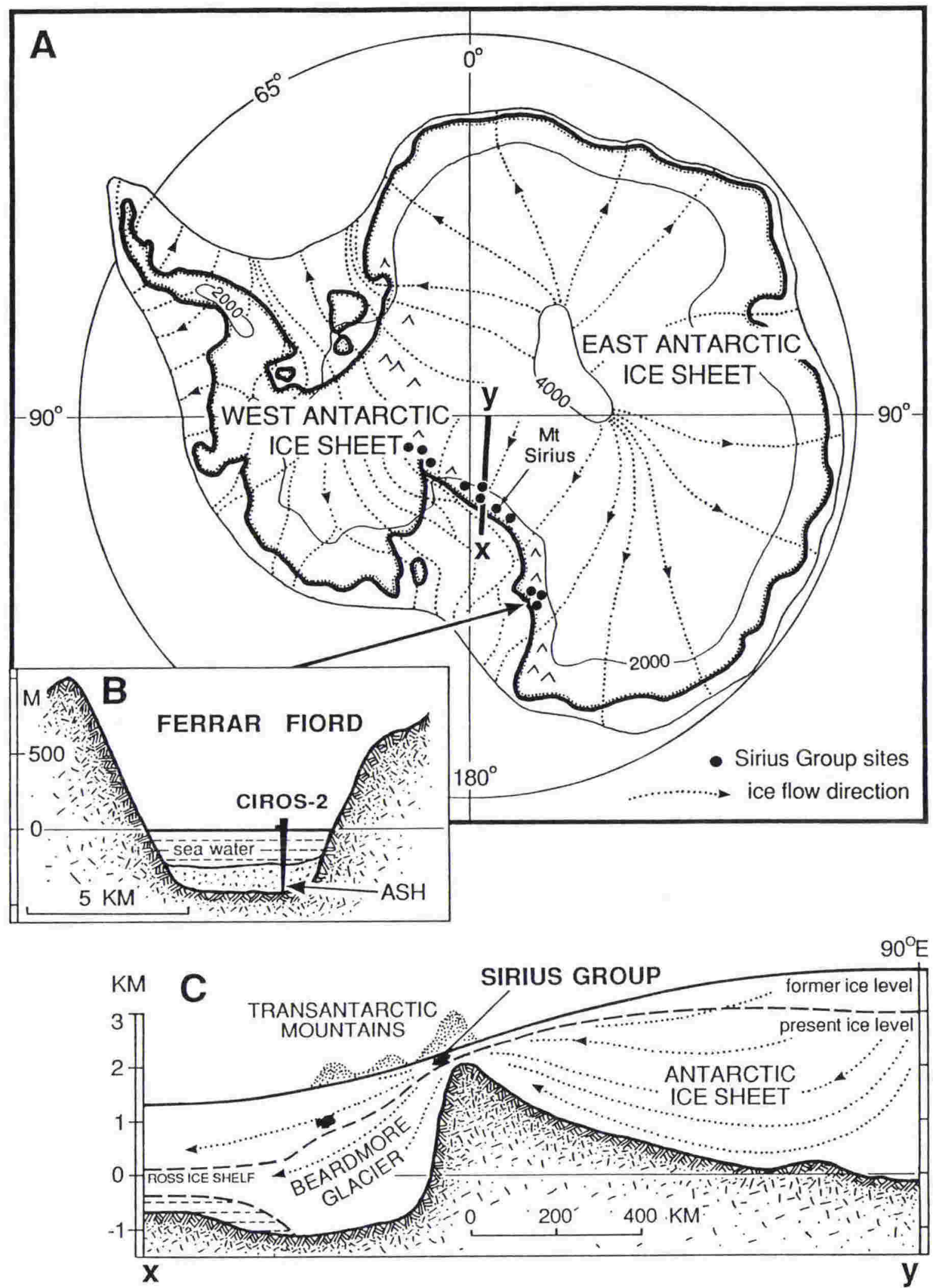

$\mathrm{m}$ b.s.f., and dated here by the $\mathrm{K}-\mathrm{Ar}$ and ${ }^{40} \mathrm{Ar} /{ }^{39} \mathrm{Ar}$ methods at $\sim 3 \mathrm{Myr}$. The ash lies within an interval from 135 to $105 \mathrm{~m}$ b.s.f. dated from Southern Ocean diatom zones as ranging from 3.1 to $2.2 \mathrm{Myr}$ (see figure 7.2), thus validating the use of deep-sea marine diatom biostratigraphy for Pliocene strata on the Antarctic continent. $c$, Cross-section from the East Antarctic interior through the Transantarctic Mountains to the Ross Sea, showing the location of Sirius Group deposits and their inferred source in the interior. In drawing the section we presume that the Transantarctic Mountains were at their present elevation during Sirius deposition, but they may have been much lower at that time $\mathrm{e}^{30}$. 
We present here a radiometric age calibration of the Sirius Group diatoms that shows the mid-Pliocene biostratigraphical age to be roughly correct. The marine diatom species $T$. vulnifica, whose total stratigraphic range defines the combined $T$. insignia- $T$. vulnifica zone, is present in the CIROS-2 core from 137 to $105 \mathrm{~m}$ below the sea floor ( $m$ b.s.f.) ${ }^{11}$. These zones form the upper part of a sequence of zones recognised and palaeontologically dated from Southern Ocean drill cores (figure 7.2). The interval containing $T$. vulnifica includes a $30-\mathrm{cm}$-thick volcanic ash layer at $125 \mathrm{~m}$ b.s.f. (ref. 5), which makes the dating possible. The ash layer lies within a slightly stratified diamictite (mixture of mud, sand and scattered pebbles) deposited from persistent melting of basal glacial debris just seaward of the grounding line of an ancestral Ferrar glacier ${ }^{22}$. The low proportion of nonvolcanic material in the ash (less than $30 \%$, table 7.1 ) indicates rapid deposition and preservation after eruption.

The ash mainly consists of fresh, dark brown or colourless silt-size shards with no chemical etching at the margins. The minor proportion of feldspar, quartz and biogenic silica (diatoms and sponge spicules). Some glass shards are vesicular and contain unzoned microphenocrysts of plagioclase, clinopyroxene, olivine and titanomagnetite. Electron microprobe analyses of glass shards (table 7.2) reveal three distinct compositions, which correspond to glass colour. Using the

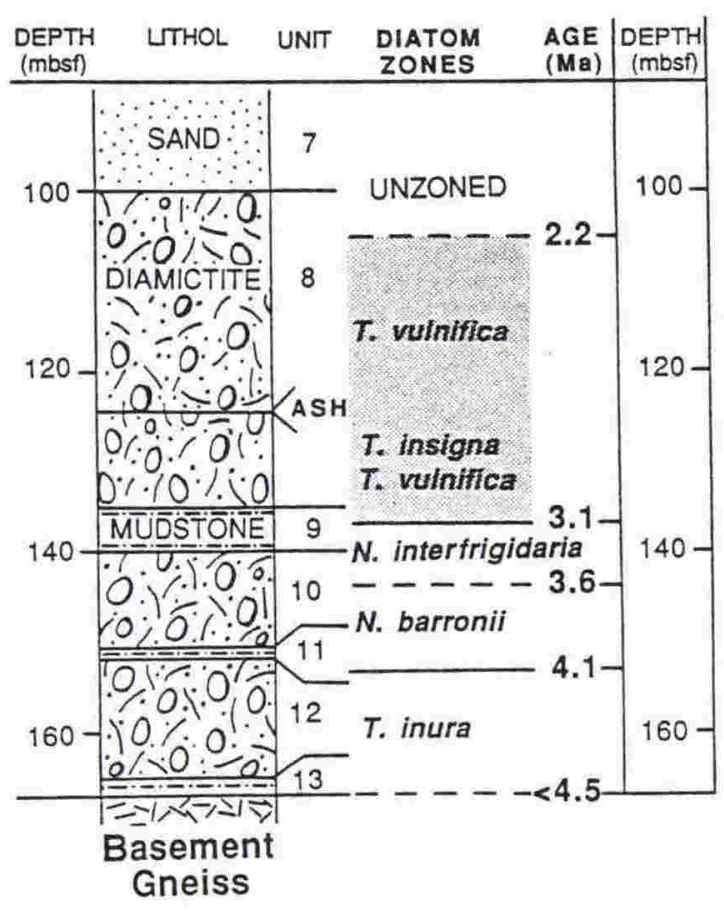

Figure 7.2: Lithological column for the CIROS-2 drillhole, Ferrar Fjord, showing the diatom zones and boundary ages established by D.M. Harwood (personal communication, and ref. 14) and from ODP leg 120 data ${ }^{17}$. The range of $T$. vulnifica (shaded interval) is well dated in the Southern Ocean at between 2.2 and 3.1 Myr ago ${ }^{17}$.

\begin{tabular}{|c|c|c|c|}
\hline \multicolumn{4}{|c|}{ TABLE 7.2 Electron microprobe analyses of glass types } \\
\hline Glass type & $\begin{array}{l}\text { Brown } \\
(N=15)\end{array}$ & $\begin{array}{l}\text { Light brown } \\
\qquad A(N=5)\end{array}$ & $\begin{array}{l}\text { Colouriess } \\
B(N=9)\end{array}$ \\
\hline $\begin{array}{l}\text { IUGS name } \\
\text { Element }\end{array}$ & $\begin{array}{l}\text { Phonolitic } \\
\text { tephrite } \\
\text { Mean (s.d.) }\end{array}$ & $\begin{array}{l}\text { Mugearite } \\
\text { Mean (s.d.) }\end{array}$ & $\begin{array}{l}\text { Benmorite } \\
\text { Mean (s.c.) }\end{array}$ \\
\hline $\begin{array}{l}\mathrm{SiO}_{2} \\
\mathrm{TiO}\end{array}$ & $\begin{array}{r}47.09(0.74) \\
3.64(0.34)\end{array}$ & $\begin{array}{r}54.70(0.86) \\
1.82(0.15)\end{array}$ & $\begin{array}{r}60.52(0.83) \\
1.47(0.05)\end{array}$ \\
\hline $\mathrm{Al}_{2} \mathrm{O}_{3}$ & $17.06(0.32)$ & $19.49(0.13)$ & $16.91(0.72)$ \\
\hline $\mathrm{FeO}^{\circ}$ & $9.80(0.84)$ & $6.46(0.03)$ & $3.97(0.16)$ \\
\hline $\mathrm{MnO}$ & $0.23(0.10)$ & $0.36(0.06)$ & $0.20(0.01)$ \\
\hline $\mathrm{MgO}$ & $3.50(0.23)$ & $1.57(0.08)$ & $1.50(0.12)$ \\
\hline $\mathrm{CaO}$ & $8.09(0.47)$ & $4.73(0.63)$ & $3.48(0.32)$ \\
\hline $\mathrm{Na}_{2} \mathrm{O}$ & $6.06(0.37)$ & $4.07(0.59)$ & $3.05(0.71)$ \\
\hline $\mathrm{K}_{2} \mathrm{O}$ & $3.06(0.25)$ & $2.60(0.25)$ & $4.65(0.37)$ \\
\hline $\mathrm{Cl}$ & $0.11(0.03)$ & $0.22(0.09)$ & $0.13(0.02)$ \\
\hline $\begin{array}{l}\text { Total } \\
\text { (Anhydrous) }\end{array}$ & 98.64 & 96.02 & 95.88 \\
\hline $\begin{array}{l}\text { Water } \\
\text { (by subtraction) }\end{array}$ & 1.36 & 3.98 & 4.12 \\
\hline
\end{tabular}

Samples are from the volcanic ash bed at $125 \mathrm{~m}$ in the CIROS- 2 core Analyst was R. H. Grapes on the JEOL superprobe at Victoria University, - All iron as $\mathrm{FeO}$. 
IUGS classification scheme 23 , we classify the dark brown shards as benmorite. The three distinct compositions suggest that the ash layer was produced by multiple volcanic eruptions, although a single eruption of mixed magma is possible.

Initial conventional K-Ar dating on bulk $(\sim 1 \mathrm{~g})$ volcanic ash samples gave ages of 11.9, 17.0 and $22.9 \mathrm{Myr}$, suggesting a contaminant by old feldspar from the basement detritus ( 450-500 Myr; ref. 24) intermixed with the ash. Microscopy suggested that the ash would have only two groups of grain types contributing to the argon equation: the young volcanic glass with its included microphenocrysts and volcanic feldspar with fringing glass, and 'basement' feldspar. We then magnetically separated a 32-63- $\mu \mathrm{m}$-sized sample fraction into glass-rich (contemporaneous volcanic) and Feldspar-rich (basement) components (fractions A and B, table 7.1a). Mineral proportions were determined by point-counting grain mounts. Using the $\mathrm{K} / \mathrm{Ar}$ ages for fractions $\mathrm{A}$ and $\mathrm{B}, 14.6 \pm 0.3$ and $243 \pm 3 \mathrm{Myr}$ respectively, we solved simultaneous equations to obtain and age of $3.0 \pm 0.4 \mathrm{Myr}$ for the volcanic end-member and $445 \pm 58 \mathrm{Myr}$ for the basement end-member.

The high age errors, which largely reflect the counting error inherent in determining the proportion of glass to basement feldspar, motivated us to purify fraction B further, obtaining a small $(\sim 1 \mathrm{~g})$ fraction $\mathrm{C}$, and a very small $(<0.15 \mathrm{~g})$ fraction D of purified volcanic glass (table 7.1). These yielded ages of 7.20 and $3.36 \mathrm{Myr}$ respectively, confirming our view of contamination by old ( $450 \mathrm{Myr})$ felspar, and our estimate of 3 Myr for the glass component of the CIROS-2 ash.

At the same time ${ }^{40} \mathrm{Ar} /{ }^{39} \mathrm{Ar}$ dating techniques ${ }^{25}$ were applied to four single feldspar crystals from the ash. Each crystal was laser-fused and dated individually, thus obviating contamination by older material ${ }^{26}$. Three out of four crystals, identified as anorthoclase, yielded statistically indistinguishable ages, averaging 2.77 Myr (figure 7.3), which we interpret as the eruptive age of the phonotephrite component of the ash. The fourth feldspar is considered detrital and from an earlier eruptive phase. In addition, a 3-mg glass sample, purified by a combination of magnetic and density liquid separation techniques, was fused to yield a ${ }^{40} \mathrm{Ar} /{ }^{39} \mathrm{Ar}$ spectrum by incremental laser heating to yield a plateau age for the glass (table 7.1b). The age spectrum of the glass concentrate has a low-temperature plateau $^{27}$ at $2.91 \pm 0.11 \mathrm{Myr}$ and a higher-temperature peak of 27.8 Myr considered to represent much older contaminant material. The $2.9 \mathrm{Myr}$ age is regarded as an average eruptive age for the glass.

Although volcanic glass is generally and inferior material for ${ }^{40} \mathrm{Ar} /{ }^{39} \mathrm{Ar}$ and $\mathrm{K}$-Ar dating (because of its low argon retentivity, vulnerability to argon loss, and potassium mobility during dehydration and devitrification) the materials here are well characterised fresh glass with little, if any, burial heating or alteration. The concordance of ${ }^{40} \mathrm{Ar} /{ }^{39} \mathrm{Ar}$ feldspar and 


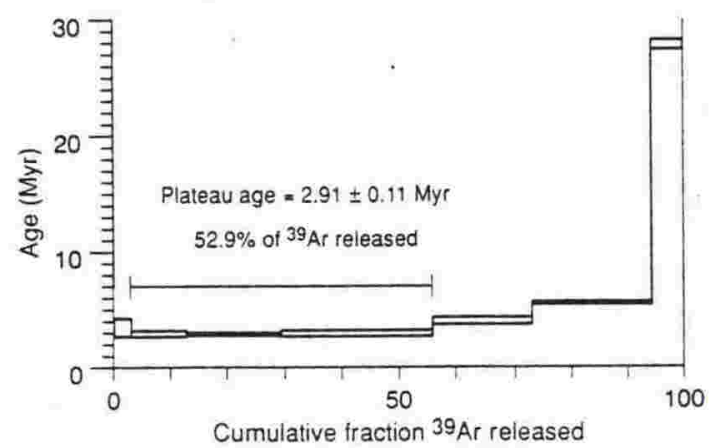

Figure 7.3: Argon release spectrum for a purified glass concentrate from coarse silt-size volcanic ash from the CIROS-2 drillhole. glass ages, and the $\mathrm{K}-\mathrm{Ar}$ glass model age, and the convergence of the purified glass ages on the same value, provide in our view conclusive evidence of a midPliocene $(2.8 \pm 0.3 \mathrm{Myr})$ age for the CIROS-2 ash. This also dates the middle of the total time range of $T$. vulnifica for the region, and a mid-Pliocene marine incursion into the Antarctic interior. This incursion was followed by temperate glaciation depositing the Sirius Group, and by the development of the present polar ice sheet.

The mid-Pliocene deglaciation of Antarctica is inconsistent with the widely accepted idea of increasing thermal isolation of Antarctica and growth of the ice cap to essentially its present form in middle Miocene times ${ }^{1}$. The survival of Nothofagus through to midPliocene times in the Beardmore glacier area also challenges that view 28 . It now seems more likely that for most of the past $40 \mathrm{Myr}$ the Antarctic region was characterised by waxing and waning temperate ice sheets of continental proportions ${ }^{29}$. The present polar ice sheet may not have formed until the latest Pliocene, about the same time as the first northern ice sheets developed. This different climate history will require us to revise our ideas of the evolution of the flora and fauna of the region, and of the role of the ice sheet in past ocean circulation. It also suggests the need to consider the stability of the Antarctic ice sheet if global temperatures rise as the level of atmospheric $\mathrm{CO}_{2}$ reaches or exceeds that of the Pliocene.

Received 30 March; accepted 3 September 1992.

1. Kennett, J.P. Marine Geology (Prentice-Hall, Englewood Cliffs, New Jersey, 1982).

2. Webb, P.N., Harwood, D.M., McKelvey, B.C., Mercer, J.H. \& Stott, L.D. Geology 12, 287-291 (1984).

3. Webb, P.N. \& Harwood, D.M. Quat Sci Rev. 10, 215-223 (1991).

4. Clapperton, C.M. \& Sugden, D.E. Quat Sci Rev. 9, 253-272 (1990).

5. Pyne, A.R. Robinson, P.H. \& Barrett, P.J. Antarctic Data Ser. 11 (Res. School Earth Sci., Victoria Univ., Wellington, 1985).

6. Shackleton, N.J. \& Kennett, J.P. in Init Rep. DSDP 29 (eds Kennett, J.P. \& Houtz, R.E.) 743-756 (U.S. Govt. Printing Office, Washington DC, 1975).

7. Kennett, J.P. \& Shackleton, N.J. Nature 260, 513-515 (1976).

8. Marchant, D.R., Lux, D.R., Swisher, C.C. III \& Denton, G.H. Antarct. J. U.S. 25, 58-59 (1990).

9. Webb, P.N. J. foram Res. 4, 188-199 (1974)

7. Webb, P.N. \& Wrenn. J. in Antarctic Geoscience (ed. Craddock, J.C.) 1117-1122 (Univ. of Wisconsin Press, Madison, 1982).

11. Ishman, S.E. \& Webb, P.N. Rev. Paleobiol. Spec. Vol. 2, Pt 2, 523-551 (1988).

12. Kyle, P.R. in Dry Valley Drilling Project, Am. geophys. Un. Antarct. Res. Series 33 (ed McGinnis, L.D.) 403-412 (1981).

13. Webb, P.N. \& Andreasen, J. Antarct. J. U.S. 21, 59-61 (1986).

14. Harwood, D.M. thesis, Ohio State Univ. (1986).

15. Ciesielski, P.F. Initi. Rep. DSDP 71 (eds Ludwig, W.J. et al.) (U.S. Govt. Printing Office, Washington DC, 1983). 


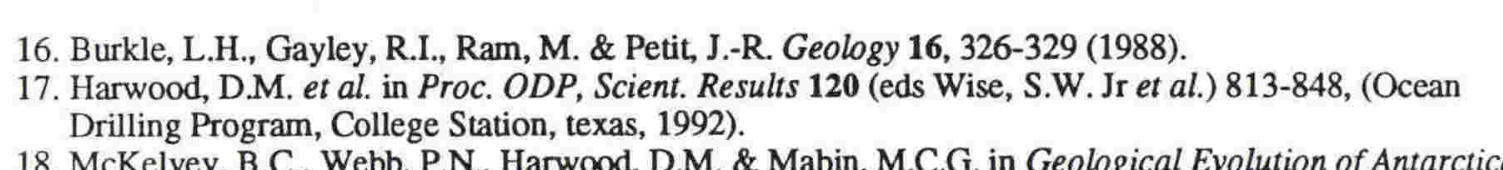


and volcanic minerals is too similar. The best results were obtained using the Frantz electromagnetic separator. The original sample was subject to several progressive runs to obtain the most pure separation. Run 1 used a 0.25 A magnetic setting, with a $20^{\circ}$ fall and $20^{\circ}$ slope. At this setting the glass and other volcanic material is non-magnetic and all the very magnetic material is removed from the sample. The second run was at a $0.6 \mathrm{~A}$ magnetic setting with a $10^{\circ}$ fall and $30^{\circ}$ slope. The glass and volcanic material was now magnetic and most of the nonmagnetic material was removed. The sample was passed through twice at this setting. Run 3 was at a 1.1 A magnetic setting with a $20^{\circ}$ fall and $20^{\circ}$ slope. At this setting almost everything except the volcanic material is non-magnetic. The sample is passed through the Frantz 3 times at this setting to ensure that the purest glass and volcanic material is retained.

After this separation, grain mounts were made of both fractions to allow point counting of the mineral proportions. The final separates of volcanic ( 2 grams) and non-volcanic material ( 0.7 grams), were submitted to DSIR Physical Sciences for $\mathrm{K} / \mathrm{Ar}$ dating.

\subsection{Theory of simultaneous equation K/Ar dating - of a mixed age population.}

The volcanic material in the Tuff layer of the CIROS- 2 core must have a single age, and the detrital material may have a spectrum of ages. However, we can consider the spectrum of detrital ages to be approximated by a single $\mathrm{K} / \mathrm{Ar}$ age for the $\mathrm{K} / \mathrm{Ar}$ dating method. We can therefore treat the separates to be dated as having two age definitive populations within them, which will give a single age for the K/Ar method depending on both the age of the two subpopulations and the quantity of each subpopulation in each separate.

The proportion of each subpopulation can be calculated by point counting grain mounts of each separate. In this circumstance any grain with volcanic glass adhered to it, or glass shard, is counted as a volcanic grain. Quartz grains, sponge spicules, and broken diatom fragments are all counted separately, as they do not contribute argon in the dating process. All other grains are counted as detrital minerals. Identification techniques are described in the following section.

Two of the fractions denoted above, volcanic (A) and non-volcanic (B), were dated using the K/Ar method and the age of the tuff material ( $\mathrm{x}$ ), and the detrital material $(y)$, is obtained by solving the following simultaneous equations;

Eqn 1: $\mathrm{C}_{1} \mathrm{x}+\mathrm{C}_{2} \mathrm{y}=$ age $\mathrm{A}($ Separate $\mathrm{A})$ Eqn 2: $C_{3} \mathrm{x}+\mathrm{C}_{4} \mathrm{y}=$ age $\mathrm{B}($ Separate $\mathrm{B})$

where $\mathrm{C}_{1-4}$ are all percentage volume constants from the proportions of $\mathrm{x}$ and $\mathrm{y}$ in the counted grain mounts of the dated material. 


\subsection{Grain recognition criteria}

Volcanic detritus includes glass shards, volcanic rock fragments (grains with glass adhered to them and volcanic fragments with feldspar crystals within them). Both are brown, vesicular, amorphous, and anisotropic in nature (apart from the feldspar crystals) (plate 7.1).

Sponge Spicules and diatom fragments are anisotropic and patterned with distinct skeletal structures.

Quartz grains are colourless in planepolarised transmitted light, with low interference colours except in thicker sections, where interference colours are slightly higher. The grains are subangular to subrounded, pitted, often have inclusions and sometimes show fracturing. They have moderate relief and exhibit undulose or parallel extinction.

In cross-polarised transmitted light detrital feldspar grains commonly exhibit simple twinning and oblique extinction. They are typically more angular and exhibit lower relief than quartz. They are distinguished by cleavage, alteration (constant extinction distinguishes from altered, hydrated, glass). Interference colours are low to moderate, again due to thickness, in cross polarised light.

Others grain types include igneous rock fragments and hornblende.

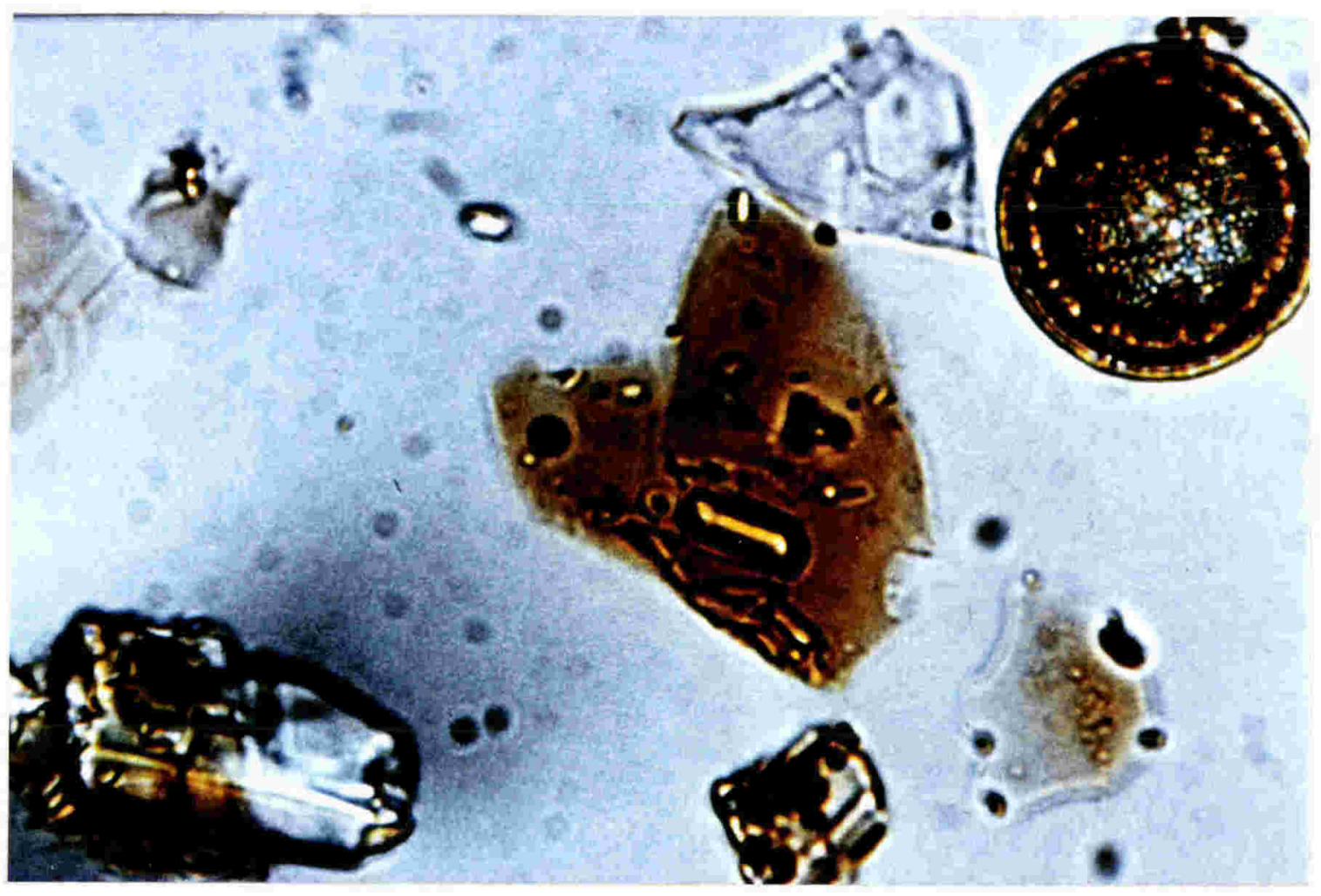

Plate 7.1: Photomicrograph of the CIROS-2 ash grain-mount. Glass coated anorthoclase crystal bottom left, glass shard centre, and diatom top right (Photograph; P.J. Barrett). 


\subsection{Simultaneous equation analysis of $\mathrm{K} / \mathrm{Ar}$ age of the CIROS-2 tuff}

Table 7.1 shows the results of point counting and radiometric analyses $(\mathrm{K} / \mathrm{Ar}$ and 39Ar/40Ar. As the quartz, sponge spicules, and diatom fragments do not contribute argon to the $\mathrm{K} / \mathrm{Ar}$ system, the percentage of Volcanic and detrital material per unit volume (table 7.1) has to be recalculated from the point count values to account for this.

In fraction $\mathrm{A}$, the total volume percentage of mineral grains contributing to the $\mathrm{K}-\mathrm{Ar}$ system is $91.3 \%$. In fraction $\mathrm{B}$, the total volume percentage of mineral

Table 7.3; Simultaneous equation calcualtion of the ages of volcanic and basement endmembers of the CIROS-2 ash.

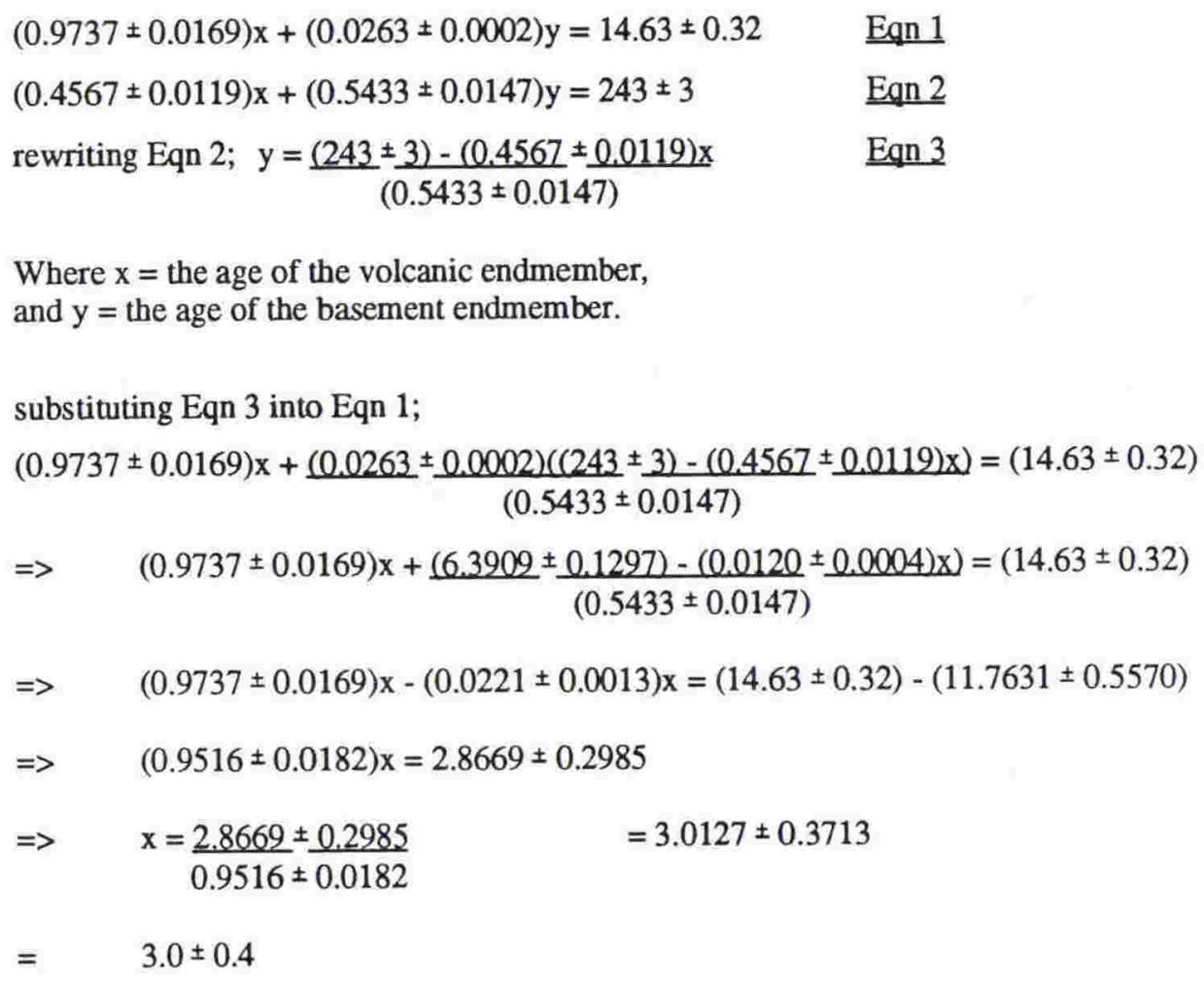


gains contributing to the $\mathrm{K}-\mathrm{Ar}$ system is $49.7 \%$. For the dating procedure, the percentage of igneous minerals (other than quartz) is added to the detrital basement contaminant fraction.

Therefore in Equations 1 and 2;

$$
\begin{array}{ll}
\mathrm{C}_{1}=88.9 / 91.3 & \mathrm{C}_{2}=2.4 / 91.3 \\
\mathrm{C}_{3}=22.7 / 49.7 & \mathrm{C}_{4}=27.0 / 49.7
\end{array}
$$

Errors;

$$
\begin{aligned}
& \mathrm{C}_{1}=0.9737 \pm 0.0169(1.8 \%) \\
& \mathrm{C}_{2}=0.0263 \pm 0.0002(0.8 \%) \\
& \mathrm{C}_{3}=0.4567 \pm 0.0119(2.6 \%) \\
& \mathrm{C}_{4}=0.5433 \pm 0.0147(2.7 \%)
\end{aligned}
$$

$$
\begin{aligned}
& A=14.63 \pm 0.32(2.19 \%) \\
& B=243 \pm 3(1.23 \%)
\end{aligned}
$$

The resulting end member ages are: $\mathrm{x}=$ $3.0 \pm 0.4 \mathrm{Ma}$. and $\mathrm{y}=445 \pm 58 \mathrm{Ma}$. (calculations are given in table 7.3). 
This chapter introduces a new dating method for Antarctic Margin Strata, using Beryllium10 and provides new insight into physical measurement and geologic significance of the method. Previously published data and methods are reviewed, following which analysis and relative dating of sediments using the absolute concentration of ${ }^{10} \mathrm{Be}$ in association with facies analysis of the sediments is proposed. This has required minor development of the Accelerator Mass Spectrometry technique with respect to measuring ${ }^{10} \mathrm{Be}$, and major developments in sample preparation and geologic understanding of ${ }^{10} \mathrm{Be}$ behaviour in geologic reservoirs, providing the necessary control to assign correct magnetostratigraphic intervals to the two cores (Chapter 9). Several discoveries important for the ${ }^{10} \mathrm{Be}$ technique are made: 1) The reported value for NBS/NIST standard for ${ }^{10} \mathrm{Be}$ is found to be incorrect. An old ${ }^{10} \mathrm{Be}:{ }^{9} \mathrm{Be}$ ratio of $3.08 \mathrm{E}-11$ is reported to be the correct value. This replaces the stated value of $2.68 \mathrm{E}-11: 2$ ) The recently reported half life of $1.51 \mathrm{Ma}$. (Hofmann et al., 1987) is reaffirmed. 3) Authigenic cement phases of sediment are proven to be efficient in removing ${ }^{10} \mathrm{Be}$ from adsorbed phases of marine sediments. It is necessary to take this into account in sample preparation.

\subsection{Introduction}

Much previous work has found ${ }^{10} \mathrm{Be}$ to present many difficulties as an absolute dating method (Bourles et al., 1989; Brown et al., 1987; Henkell-Mellies et al., 1990; Jansen et al, 1987; Mangini et al., 1984; Somayajulu, 1977; Somayajulu et al., 1991; Southon et al., 1987). However, recent work has shown that it can be effectively used for dating continental margin sediments (Wilson, 1990; Wilson and Sparks, 1991), exposure age dating of Neogene surfaces (Jha and Lal, 1982, Nishiizumi et al, 1986; van der Wateren and Verbers, 1991; Verbers and van der Wateren, 1991), and to provide models for subduction of sediment into the mantle (Brown et al., 1982; Morris et al., 1990; Tera et al., 1986).

Other research includes: Studies of ice cores (Beer et al., 1987; Elmore et al., 1987; Raisbeck et al., 1978), observing production mechanisms and rates of ${ }^{10} \mathrm{Be}$; studies of ${ }^{10} \mathrm{Be}$ content of soils (Brown, 1987), and studies of the ${ }^{10} \mathrm{Be}$ content of manganese nodules, with implications on growth rates and ocean circulation patterns (Guichard et al., 1978; Segl et al., 1984a and 1984b; Turekian et al., 1979).

In this study, the proposed method is to use the varying content of ${ }^{10} \mathrm{~B} \mathrm{e}$ 
throughout the CIROS-2 and DVDP-11 cores. It is assumed that the variation results, primarily, from the natural decay of ${ }^{10} \mathrm{Be}$ to ${ }^{10} \mathrm{~B}$. Previous work using the ${ }^{10} \mathrm{Be}$ isotope for dating marine sediments has made assumptions that have subsequently been found not to hold. This severely limits the use of ${ }^{10} \mathrm{Be}$ as a tool for dating marine sediment. This study uses the adsorbed and absorbed ${ }^{10} \mathrm{Be}$ content of the sediment and analyses it within a stratigraphic framework. The resulting dating method is a relative one and requires at least one known datum with which to compare further results.

The measurement method, because of low concentrations, has to be by ultrasensitive mass spectrometry, with spiking of the $\mathrm{Be}$ to $\mathrm{BeO}$ allowing detection of ${ }^{10} \mathrm{Be}$ in samples as old as $18 \mathrm{Ma}$. (Raisbeck et al., 1978).

\subsection{Theory}

\subsubsection{Beryllium systematics and definitions}

In nature there are three isotopes of beryllium; ${ }^{7} \mathrm{Be},{ }^{9} \mathrm{Be}$ and ${ }^{10} \mathrm{Be}$. ${ }^{9} \mathrm{Be}$ is stable and exists in all geologic environments, but much of it is contained in occurrences of the mineral beryl. Both ${ }^{7} \mathrm{Be}$ and ${ }^{10} \mathrm{Be}$ are created cosmogenically by spallation reactions between cosmic rays and small atoms (oxygen and nitrogen in the case of ${ }^{10} \mathrm{Be}$ ). ${ }^{7} \mathrm{Be}$, is a gamma emitter with a half life of 53 days and is therefore not useful in dating the geologic record. ${ }^{10} \mathrm{Be}$ is a beta emitter, decaying to ${ }^{10} \mathrm{~B}$ with a half life of 1.5 m.y. (Yiou and Raisbeck, 1972), making it particularly useful for dating strata deposited over the last 15 million years (10 half-lives)

${ }^{10} \mathrm{Be}$ can be created in two possible ways:

1) Cosmic ray spallation of oxygen and nitrogen particles in the atmosphere and stratosphere (Raisbeck and Yiou, 1984). The ${ }^{10} \mathrm{Be}$ is then rained out on the earth's surface and scavenged by clays through adsorption on to grain surfaces before settling to form a sedimentary deposit (Merril et al., 1960; Raisbeck et al., 1979).

2) 'In situ' cosmic ray spallation of oxygen and nitrogen atoms in appropriate mineral phases in the rock directly at the earth's surface (Middleton and Klein, 1987; Nishiizumi et al., 1986).

These two types of beryllium can be classified as follows;

1) Crystallographic beryllium, where the beryllium exists or is created within the crystallographic structure (i.e. within grain boundaries of the rock forming minerals). Crystallographic beryllium can be present in Igneous, Metamorphic, or Sedimentary rocks. It can be autochthonous (created in place or 'in situ') or allochthonous (where erosion and resedimentation of grains has transported crystallographic beryllium to 

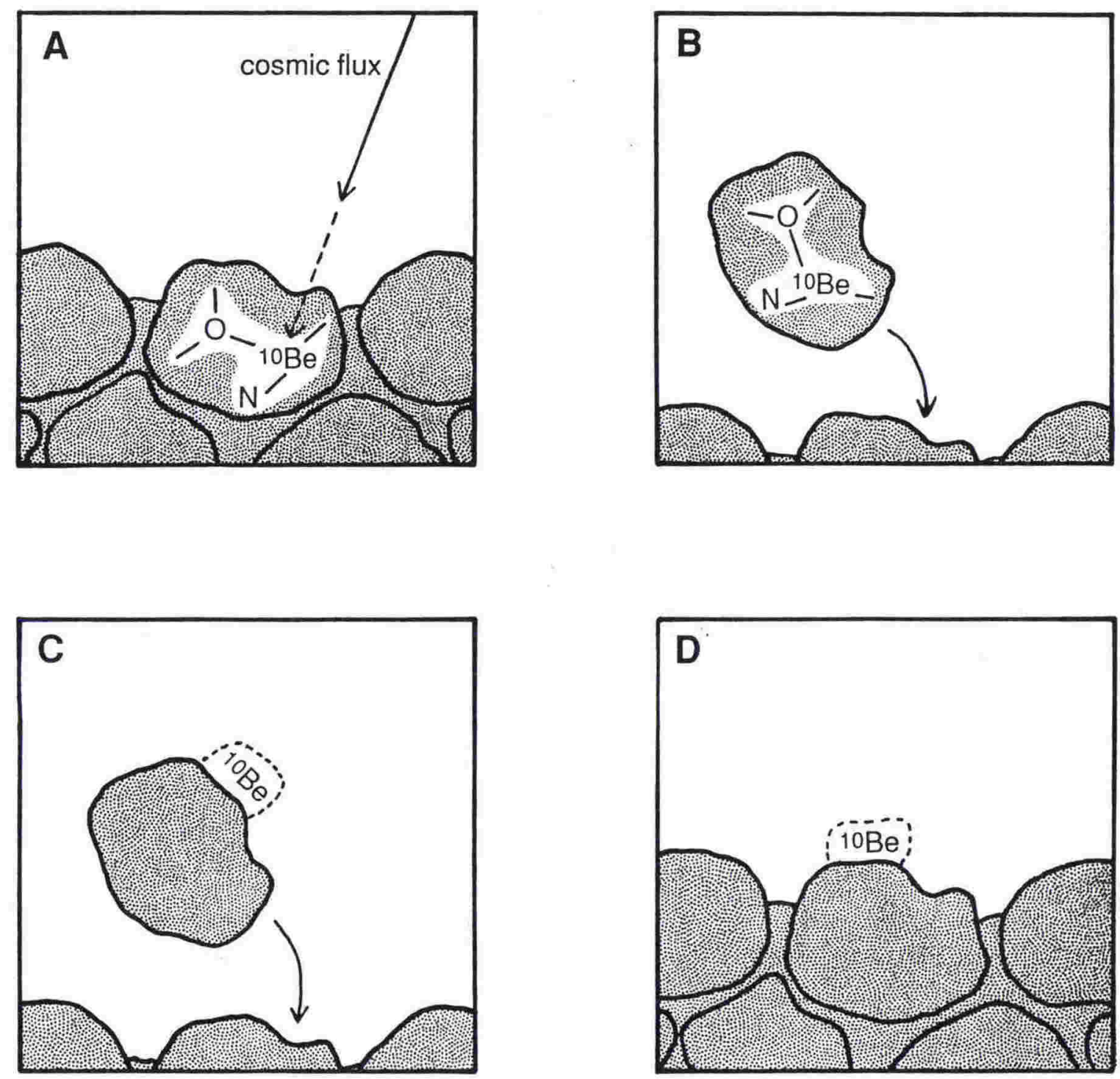

Figure 8.1: Types of beryllium-10 in the geologic cycle; A) autochthonous crystallographic beryllium-10; B) allochthonous crystallographic beryllium-10; C) allochthonous exotic beryllium-10; and D) autochthonous exotic beryllium-10.

a site of sediment deposition) (figure 8.1).

2) Exotic beryllium, where the beryllium is adsorbed to grain surfaces, or absorbed within authigenic clay and cement phases. Exotic beryllium can also be autochthonous (adsorbed at deposition) or allochthonous (adsorbed before deposition and transported to the site of deposition along with the particle it is adsorbed to) (figure 8.1). It is impossible when carrying out an analysis to distinguish between the two types. After deposition, the adsorbed material is easily remobilised to be incorporated into new clay minerals and cements. Previous workers have reported low recovery levels from cement rich sediments 
(Bourles et al., 1989; Southon et al., 1987).

In each of these cases the beryllium can be both ${ }^{9} \mathrm{Be}$ and ${ }^{10} \mathrm{Be}$.

\subsubsection{The Beryllium-10 Cycle (figure}

Almost all ${ }^{10} \mathrm{Be}$ is exotic and created in the atmosphere (Lal, 1962). The production rates of exotic ${ }^{10} \mathrm{Be}$ is dependent on three factors; 1) the variations in cosmic ray flux; 2) the strength of the earth's magnetic field; and 3) the concentration of target atoms (Oxygen and Nitrogen) in the atmosphere. Once produced the ${ }^{10} \mathrm{Be}$ atoms are very effectively removed by precipitation and 'rained out' on the earth's surface. The average global precipitation levels of ${ }^{10} \mathrm{Be}$ in freshly deposited sediment is estimated at $1.8 \mathrm{x}$ $10^{-2}$ by Amin et al. (1975), but this varies significantly with geomagnetic latitude (figure 8.3).

Once at the earth's surface the particles exist in the geologic system as both free ions and adsorbed to the surface of clay particles. At this stage they are incorporated into two types of geologic reservoir - the polar ice caps as free ions (autochthonous), and sedimentary basins adsorbed onto the surface of clay particles (allochthonous). Emplacement into these reservoirs is instantaneous compared to the half-life of the isotope. Once the ${ }^{10} \mathrm{Be}$ is retained and behaves as its host sediment or ice and is subject to

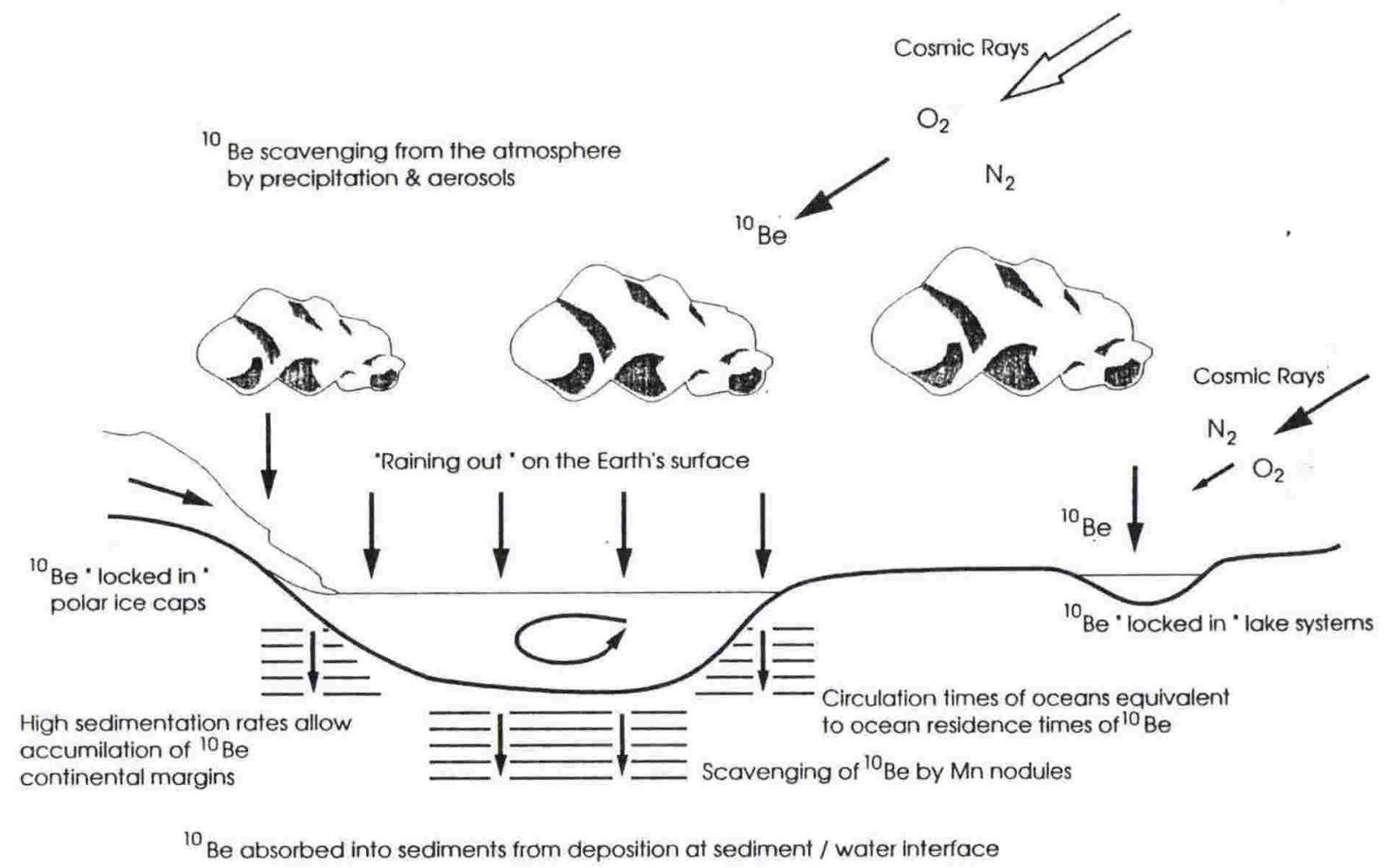

Figure 8.2: Sketch of the beryllium-10 cycle, from production in the atmosphere to adsorption in various geologic reservoirs. 


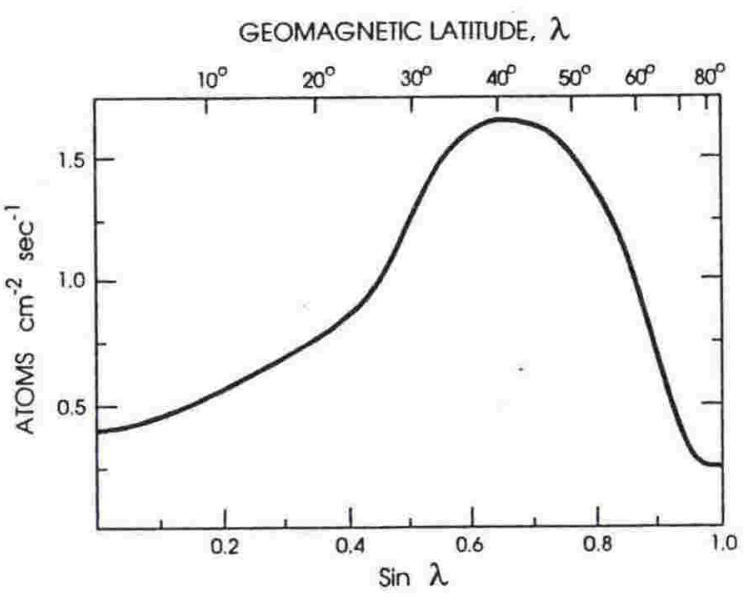

Figure 8.3: Variation in the production rate of beryllium-10 with respect to geomagnetic latitude (from Amin et al., 1975).

the same laws of superposition (In a marine environment it is still subject to bioturbation within the surface sediment of the ocean floor).

At any one horizon in the geologic reservoir the ${ }^{10} \mathrm{Be}$ concentration is dependent on the production rate of ${ }^{10} \mathrm{Be}$ and the adsorption potential of the clay particle fraction accumulating in the reservoir. Because of this method of retention of ${ }^{10} \mathrm{Be}$ by the geologic reservoir, its initial concentration in the reservoir is also dependent on the sedimentation rate within the reservoir and the homogenising effect over the bioturbation interval of the sediment.

Initially, all exotic ${ }^{10} \mathrm{Be}$ will be adsorbed to particle surfaces, but, even early diagenesis will incorporate the adsorbed ${ }^{10} \mathrm{Be}$ into authigenic mineral phases and later into cement phases. The ${ }^{10} \mathrm{Be}$ will become more assimilated as diagenesis proceeds.

\subsubsection{Dating methods using Beryllium-} 10

There are three accepted procedures for beryllium isotope measurement used for dating sedimentary sequences;

1) Measurement of the abundance of ${ }^{10} \mathrm{Be}$ with respect to the stable isotope ${ }^{9} \mathrm{Be}$. The success of this method of measurement requires several assumptions: Constant production and 'rain-out' rates of ${ }^{10} \mathrm{Be}$, constant sedimentation rates in the geologic reservoir, homogeneity of the two isotopes in the depositional environment and no post-depositional complications such as scavenging of Beryllium.

2) Measurement of the absolute concentration of ${ }^{10} \mathrm{Be}$ in a sample. To be successful, this method requires the following assumptions: Constant production and 'rain-out' rates of ${ }^{10} \mathrm{Be}$, constant sedimentation rates in the geologic reservoir and no postdepositional complications such as scavenging of Beryllium. This method also requires an assumption of homogeneous global deposition of ${ }^{10} \mathrm{Be}$ or a known depositional history at the site of measurement.

3) Measurement of the concentration of two cosmogenic isotopes with different half lives. In the case of ${ }^{10} \mathrm{Be}$ it is measured with respect to ${ }^{26} \mathrm{Al}$. If assumptions of constant production and 'rain-out' rates of both isotopes, constant sedimentation rates in the geologic 
reservoir, complete homogeneity of the two isotopes, no fractionation of the two isotopes during post depositional processes and no scavenging of either isotope are correct, the changing ratio of the concentrations of the two isotopes should yield the age of the deposit.

\section{Discussion of the necessary parameters and assumptions}

For any radiometric dating method; the time from isotopic creation to entrapment in the reservoir must be short in comparison to the half-life of the particular radiometric isotope. This requires rapid absorption and 'rain out' of ${ }^{10} \mathrm{Be}$ by precipitation, and rapid transport to the reservoir. This takes only months in the ice caps. In the marine environment, because ${ }^{10} \mathrm{Be}$ is adsorbed onto the surface of clay sized particles, transport time from the surface of the oceans, especially above the continental margin is of the same order as the settling time of those particles (months to years).

Other workers (Lal, 1962; Tanaka et al., 1977; Yokoyama et al., 1978; Mangini et al., 1984; Lal, 1962) have suggested ${ }^{10} \mathrm{Be}$ has a residence time similar to circulation times of the ocean. This would reduce the latitudinal gradient of ${ }^{10} \mathrm{Be}$ 'rain out' (figure 8.3) on the earth's surface. However, oceanic residence times of the isotope must be much less than circulation time, as its method of emplacement into the marine sediment reservoir is independent of free ion mixing (Raisbeck et al., 1979). This is borne out by the ${ }^{10} \mathrm{Be}$ concentrations in ocean bottom sediments being several magnitudes higher than oceanic concentrations (Raisbeck et al., 1979).

Assumptions of homogeneity of ${ }^{10} \mathrm{Be}$ deposition throughout the ocean basins and margins appear to invalid. On a short timescale (less than 2 k.y.) reworking, of deep sea mud by bioturbation smooths temporal fluctuations.

Work to date on production rates has found that on a geologic time-scale the assumption of constant production will hold up until 7 Ma. (Raisbeck \& Yiou, 1984; Ku et al., 1982; Lal, 1962). Any variation that takes place does so on a scale shorter than $2 \mathrm{Ka}$., resulting from solar modulation and geomagnetic variations (Beer et al., 1983a; Beer et al., 1983b; Raisbeck et al., 1981; Raisbeck and Yiou, 1984; Lal, 1962). In a geologic cycle any effect due to this is readily normalised (Tanaka et al., 1977).

Constant sedimentation cannot be assumed in any environment, as the factors controlling deposition are so diverse. This assumption can be avoided if an independent means of dating is applied to test sedimentation rates. Simple lithologic observation may not be enough to deduce a state of constant sedimentation throughout the stratigraphic column.

Homogeneity of ${ }^{9} \mathrm{Be}$ and ${ }^{10} \mathrm{Be}$ in the geologic system is an assumption 
unlikely to hold as the two isotopes occupy different places within the geologic cycle. Added to this, ${ }^{9} \mathrm{Be}$ is an extremely rare element existing almost entirely within the mineral Beryl. In early measurements of ${ }^{10} \mathrm{Be} /{ }^{9} \mathrm{Be}$ ratios for dating the assumption was found not to hold (Raisbeck and Yiou, 1984; Yokoyama et al., 1978).

For the purposes of the dating and modelling procedures addressed here it is assumed that the exotic ${ }^{9} \mathrm{~B}$ e concentrations will be constant at a fixed point of deposition and also that the concentration of crystallographic ${ }^{9} \mathrm{Be}$ will be constant within different mineral phases. The most useful parameter for measurement will be the absolute concentration of the different ${ }^{10} \mathrm{Be}$ types. The measurement technique employed here uses a ${ }^{9} \mathrm{Be}$ carrier in sufficient quantity so as to swamp any effect from variations in natural ${ }^{9} \mathrm{Be}$ concentrations (see Wilson and Ditchburn, 1992; appendix 2).

Unfortunately, initial measurements of ${ }^{10} \mathrm{Be} / 26 \mathrm{Al}$ ratios have demonstrated that there is fractionation in the incorporation of the two isotopes into the reservoir (Bourles et al., 1984; Raisbeck and Yiou, 1984).

It is expected that the input of ${ }^{10} \mathrm{Be}$ into the geologic reservoirs will be nonuniform due both to latitude dependent stratospheric precipitation patterns (Lal and Peters, 1967) (figure 8.3). Other factors such as high winds may increase the content of ${ }^{10} \mathrm{Be}$ in a particular atmospheric region (Broecker, 1961). Therefore, global homogeneity of ${ }^{10} \mathrm{Be}$ cannot be assumed at any level of its cycle. Scavenging of ${ }^{10} \mathrm{Be}$ by manganese nodules on the ocean floor is known to occur (Mangini et al., 1984). This is only a problem in the deep ocean, and nodule growth is not known to occur on the Antarctic Margin.

\subsubsection{Applicability of the ${ }^{10} \mathrm{Be}$ method to the Antarctic Margin}

High sedimentation rates at the Antarctic Margin will mean lower concentrations of ${ }^{10} \mathrm{Be}$. Yiou and Raisbeck (1981) in their study of sediments beneath the Ross Ice Shelf measured concentrations between $10^{6}$ and $10^{8}$ atoms/gram. This is well within the measurable limits of a tandem accelerator (Raisbeck and Yiou, 1984).

There are two main benefits in this study of Antarctic Margin cores that enables several assumptions of the proposed ${ }^{10} \mathrm{Be}$ dating methods to be overcome:

1) The nature of sedimentation at the Antarctic margin is highly variable, recording the slightest change in depositional environment. Facies analysis of the ancient sediments allows assessment of their depositional environment (see Section 1). Understanding of the depositional environment as it varies eliminates the necessity of assumptions of constant sedimentation. Antarctic margin 
sediments deposited in circulating marine waters are best suited to this approach. this includes McMurdo Sound. Domack (1989) and Dunbar (1986 \& 1987) showed that oceanic waters circulate to the coast in the McMurdo Sound area.

2) The study is of marine cores, this reduces the possibility of contamination by more modern ${ }^{10} \mathrm{Be}$ from subsequent exposure. stratigraphic horizons sampled in the cores are all from below the zone of ${ }^{10} \mathrm{Be}$ remobilisation and have never been uplifted and exposed.

Tanaka et al. (1977) suggest that the physical disturbances caused by such events as high-speed current flows near the Antarctic or debris flows near ocean ridges will result in an irregular pattern in the depth profile of ${ }^{10} \mathrm{Be}$. However, this does not seem to be the case at the Antarctic margin and it has been suggested that ${ }^{10} \mathrm{Be}$ is preferentially deposited at ocean margins (HenkenMellies et al., 1990). In marine environments, and particularly at ocean margins because the ${ }^{10} \mathrm{Be}$ is deposited along with the sediments, adsorbed to the surface of clay and other small particles, rather than by trapping of the water containing ${ }^{10} \mathrm{Be}$ by sedimentation. Ocean margins are in fact sites of high particle flux and hence of high scavenging and deposition of ${ }^{10} \mathrm{Be}$ by detrital particles.

Yiou and Raisbeck (1981) and Raisbeck and Yiou (1984) have used the ${ }^{10} \mathrm{Be}$ method to show that sediments beneath the Ross Ice Shelf at site J-9 of RISP, are
Miocene in age, rather than reworked Quaternary deposits as inferred by other workers (Kellogg and Kellogg, 1981,1983,1986).

\section{Clay mineralogy}

Different clays have different adsorption capacities and can therefore alter the absolute concentrations of ${ }^{10} \mathrm{Be}$ recorded in the rocks. It has to be established whether or not varying adsorption capacities affect the ${ }^{10} \mathrm{Be}$ signal, and if clay types vary throughout the column. If this is the case correction can be made using a function of the Cation Exchange Capacity of the clays, as a normalising function for the ${ }^{10} \mathrm{Be}$ concentrations.

It has also been suggested that dilution of the ${ }^{10} \mathrm{Be}$ levels retained by the clays will occur from $\mathrm{CaCO}_{3}$ mineral phases as these preferentially repel ${ }^{10} \mathrm{Be}$ (Bourles et al., 1989). This leaves smectite, illite, kaolinite, quartz, feldspars, and other amorphous silica minerals with the most reliable adsorption potential for ${ }^{10} \mathrm{Be}$ (Henken-Mellies, 1990).

Claridge and Campbell (1989) report that the clay fractions of the CIROS-2 core consist mostly of amorphous silica dissolved from the tests of diatoms, with small amounts of illite, chlorite, quartz and feldspars (figure 8.4). It is inferred from the study of Claridge and Campbell (1989) that varying clay type is not a complicating factor in the present study. 


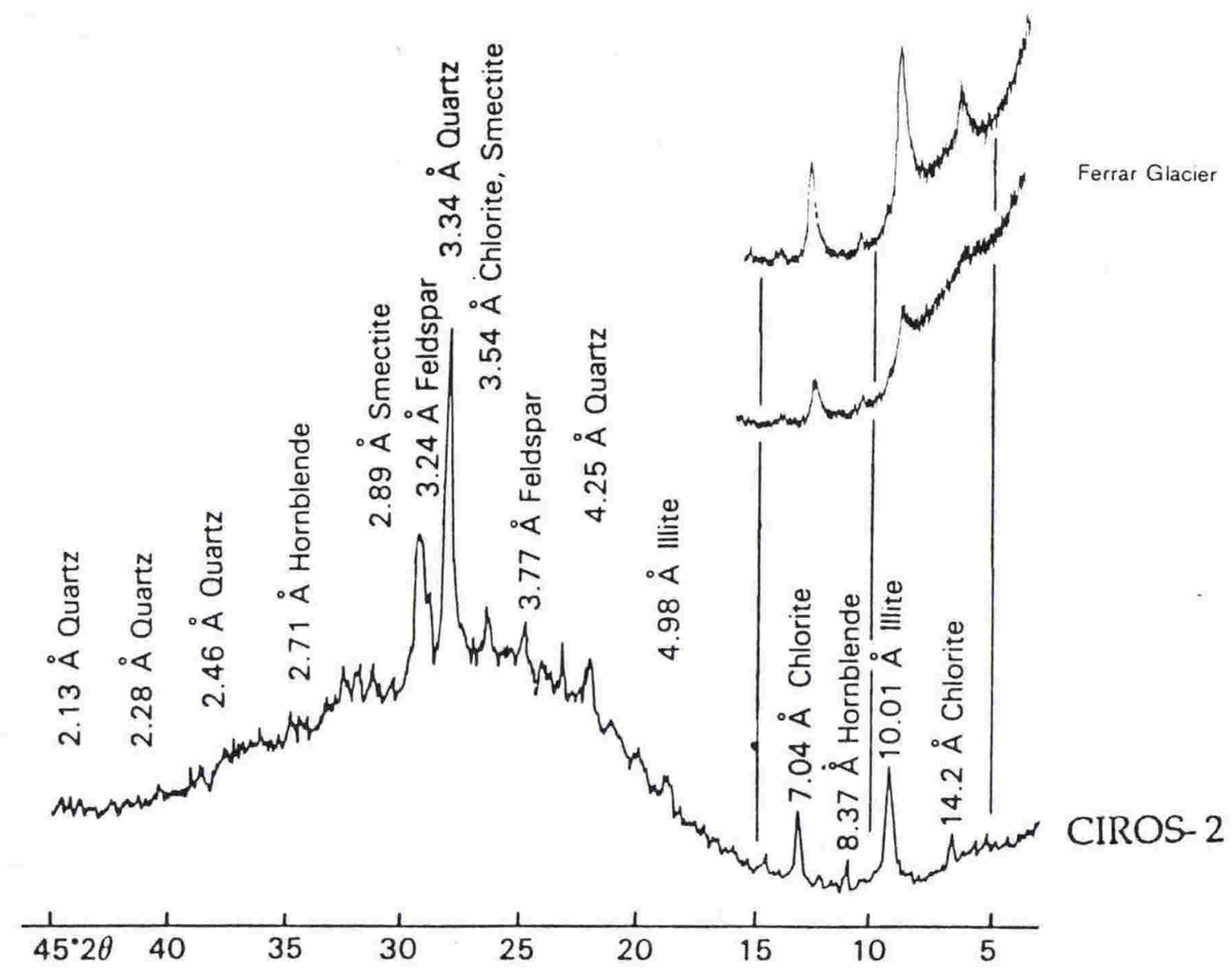

Figure 8.4: Comparison of the XRD analyses of CIROS-2 clay fractions with Ferrar and Taylor Valley analyses (data from Claridge and Campbell, 1989).

\subsubsection{Methodology}

Because of the logarithmic decay of unstable radiometric isotopes, a stratigraphic approach to the use of ${ }^{10} \mathrm{Be}$ as a dating method will show a better understanding of behaviour of the isotope after deposition. An integrated stratigraphic approach ensures that the resulting decay curves represent the correct age bracket. Additionally known datums and modern-day samples from the same environment provide marker reference points on the curve. Because of the problems with methods 1 and 3 in dating sediment (see discussion in section 8.2.3), Method 2, using the absolute concentration of ${ }^{10} \mathrm{Be}$ with depth is most appropriate for the CIROS2 and DVDP-11 cores Here;

$$
\text { Age }=\underline{\ln }\left({ }^{10} \underline{\mathrm{Be})-\ln }{ }_{-\mathrm{X}}^{10} \underline{\mathrm{Be}}_{\mathrm{i}}\right)
$$

Where;

${ }^{10} \mathrm{Be}=$ concentration of beryllium -10 in the sample.

${ }^{10} \mathrm{Be}_{\mathrm{i}}=$ the initial concentration of beryllium-10 when the sample was deposited.

$\mathrm{X}=$ the decay constant $=4.621 \times 10^{-7}$ per year for ${ }^{10} \mathrm{Be}$.

It is known from section 8.2.3 that variations in production rate do not appreciably affect $10 \mathrm{Be}$ levels as recorded by the geologic record. In the 
Antarctic it is expected that there will be much variation due to fluctuations in the levels of precipitation over time. To overcome the limitation from this and the problems from variations in sedimentation rates and to interpret the beryllium age in the core, the history of sedimentation needs to be understood.

As reported in section 1 the CIROS-2 and DVDP-11 cores have been subdivided into many distinct units with distinct facies interpretations. Measurement of Beryllium levels is considered separately within each of these units. The only observational constraint is that ${ }^{10} \mathrm{Be}$ levels must decrease from one unit to the next as you move down the core. Discontinuities in the $10 \mathrm{Be}$ levels must occur at disconformities in the core.

From the sedimentary facies interpretations of the CIROS-2 and DVDP-11 cores, several separate horizons can be identified which represent times when the sedimentary environment was similar. Therefore, in using the ${ }^{10} \mathrm{Be}$ method to establish ages for these horizons, it can be assumed that there were similar controls on the initial ${ }^{10} \mathrm{Be}$ concentrations. Because we are dealing with distinct horizons and environments no assumptions have to be made about sedimentation rates for the length of the core being studied.

The resulting ${ }^{10} \mathrm{Be}$ levels for these horizons, when plotted against a constant age axis, should form a logarithmic curve of the same parameters as the decay curve of ${ }^{10} \mathrm{Be}$ (figure $8.5 \mathrm{a}$ ). Using these horizons, the cores can then be corrected to a log of constant sedimentation, and ages for particular horizons calculated from this logarithmic or normalised curve. Age constant axes can be drawn for the stratigraphic column using these horizons as marker points, and then ages for other horizons extrapolated from the logarithmic curve (figure $8.5 \mathrm{~b}$ ). These horizons can then be recognised in the original stratigraphic columns and the chronology established (figure 8.6).

\section{The ice sheet effect}

The ${ }^{10} \mathrm{Be}$ concentration in the interglacial mudstones define a curve controlled by age alone. ${ }^{10} \mathrm{Be}$ concentrations in marine muds within diamictites represent glacial values and may deviate from the age only decay curve. Variations between expected ${ }^{10} \mathrm{Be}$ levels at horizons within different facies units, from the method proposed above, and measured levels may result from fluctuating precipitation levels, fluctuating input from ice bodies, and different sedimentation rates. For example a much higher actual ${ }^{10} \mathrm{Be}$ level than the expected level will result from major deglaciation of the continent (Somayajulu, 1977).

It is suggested by Henken-Mellies et al . (1990) that up to as much as $300 \%$ of the oceanic concentration of ${ }^{10} \mathrm{Be}$ may be stored by the polar ice sheets. However, they also suggest that fluctuations in ${ }^{10} \mathrm{Be}$ concentrations due to glacial 

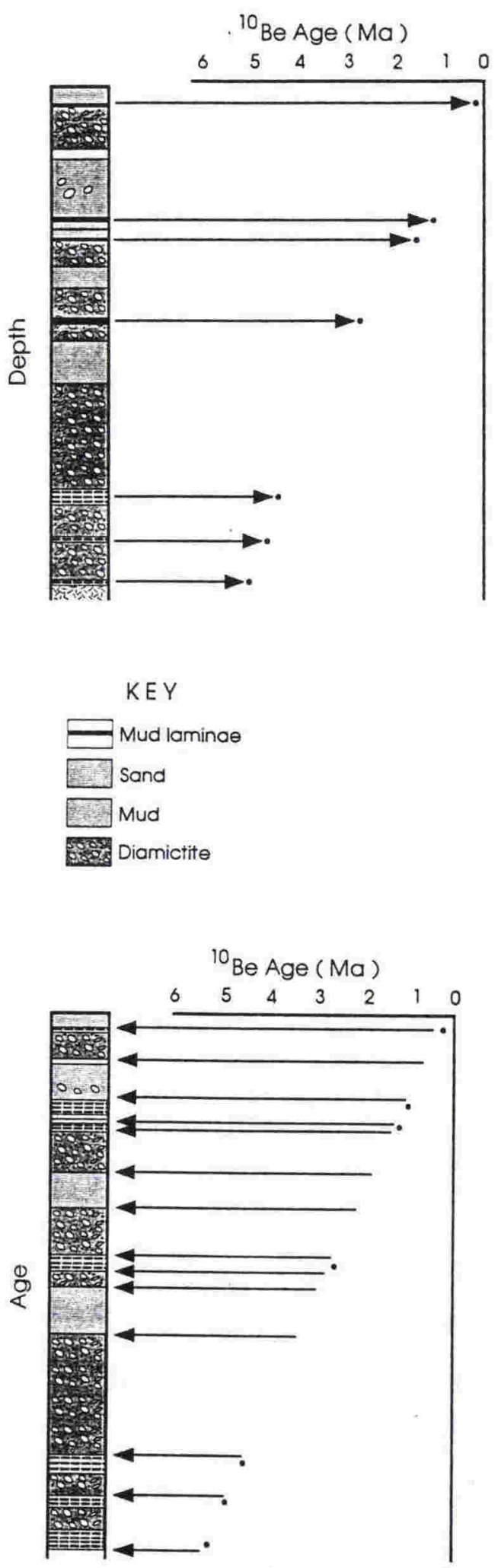

Figure 8.5: a) upper; measurement of absolute ${ }^{10} \mathrm{Be}$ content of mudstone horizons only plotted against a logarithmic scale depicted as age (inferred from half life). b) lower; correction of the core log to an age axis rather than thickness and then assignment of ages to other horizons by extrapolation from the absolute ${ }^{10} \mathrm{Be}$ content curve constructed as shown in figure $8.5 \mathrm{a}$. fluctuation, because of dispersion and bioturbation normalising effects, will not be detected in deep ocean sediments. It is expected that smaller order effects $(\sim 30 \%)$ will be common in the CIROS-2 and DVDP-11 cores.

Due to higher sedimentation rates, differing sedimentation patterns, reduced effects due to bioturbation, the proximity of the sediment to the polar reservoir, and the fact that deposition levels of ${ }^{10} \mathrm{Be}$ are lower towards the poles making the effect of the glacial reservoir greater, it is suggested that the effect will not be overprinted, and that ${ }^{10} \mathrm{Be}$ stratigraphies of Antarctic margin sediments will record ice volume changes of the Polar Ice Sheet (figure 8.7).

Respective flooding and starving of the ${ }^{10} \mathrm{Be}$ levels in the catchment environment could provide a clue to the ice volume glacial pattern during the Pliocene era. Sedimentation rate effects can be calculated as the duration of deposition of a particular facies unit can be calculated. This effect can then be accounted for in assessing the initial concentration levels of ${ }^{10} \mathrm{Be}$ in that particular facies unit. For this effect to be monitored a high measurement resolution is required.

\subsection{Measurement procedure}

\subsubsection{Sample preparation}

Different methods of sample preparation and procedures are reported in detail in 


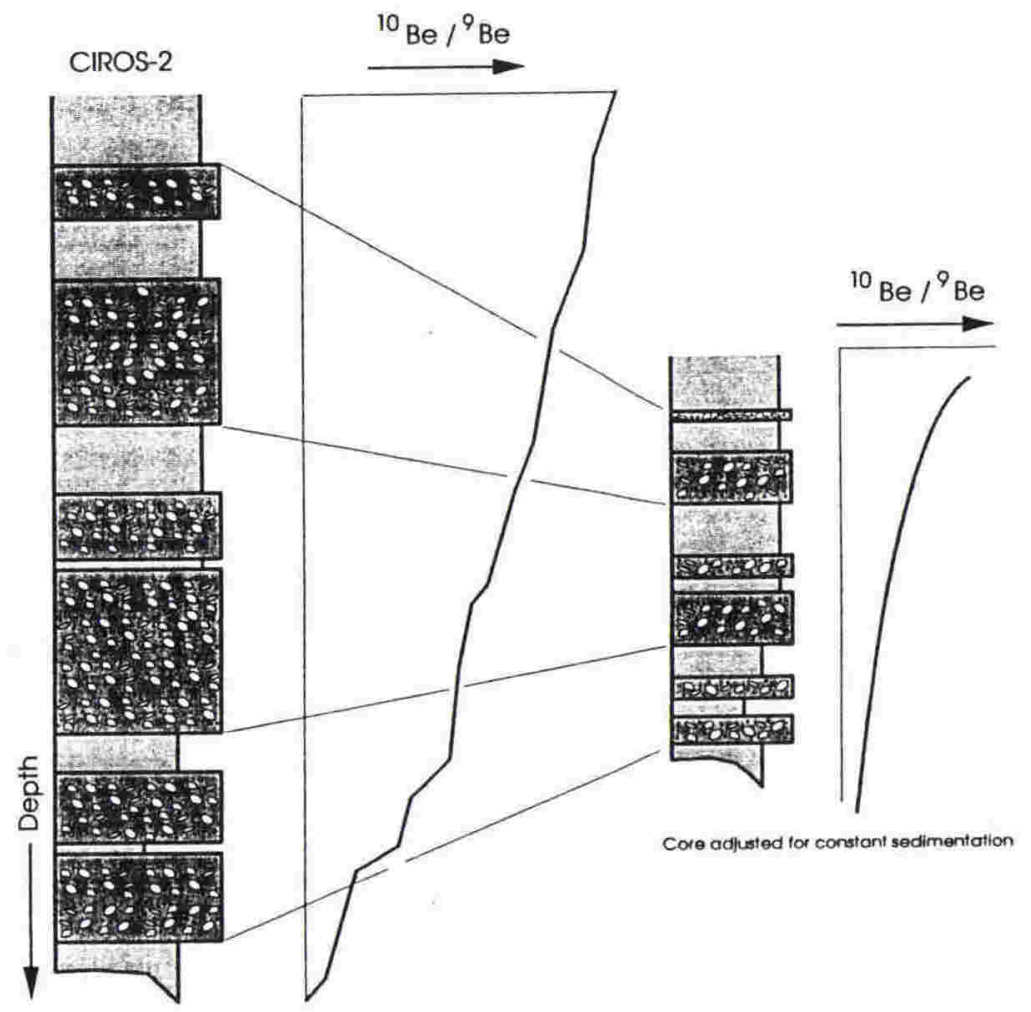

Figure 8.6: Predicted ${ }^{10} \mathrm{Be}$ stratigraphy for the CIROS-2 drill-core, assuming constant production, no scavenging and ignoring ice volume effect at the Antarctic margin. This curve will provide the best estimate of the age variation within the core.

Model for ${ }^{10} \mathrm{Be}$ stratigraphy (Assuming constant sedimentation)

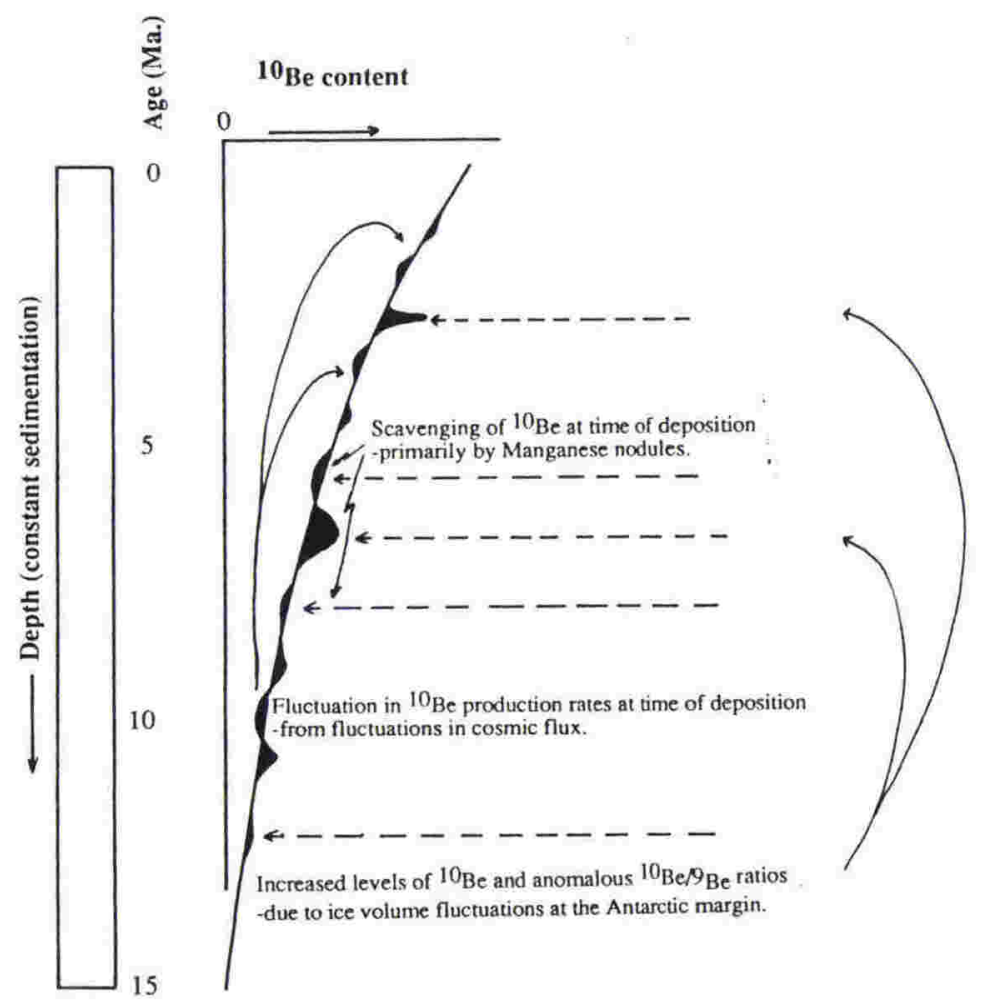

Figure 8.7: Sketch of the effect of ice sheet melting and regrowth, respectively inundating and starving the ${ }^{10} \mathrm{Be}$ levels in the Antarctic margin sequences. 
Wilson and Ditchburn (1992); appendix 1.

In the present study, leaching of samples to remove ${ }^{10} \mathrm{Be}$ adsorbed onto clay particles and within cement phases was considered the best approach. Care must be taken to remove all ${ }^{10} \mathrm{Be}$ in these phases leaving allochthonous crystallographic beryllium behind in the residue. Preferential leaching of one exotic phase or another (as suggested by Bourles et al., 1989) will result in biasing of results, as beryllium atoms move into authigenic cement phases during diagenesis.

Advantages of the separation method used here is that beryllium of different origin is considered separately. This means that a geological understanding of the position of ${ }^{10} \mathrm{Be}$ in the samples is considered, allowing a more accurate and informed measurement of the parameters concerned. Only the exotic ${ }^{10} \mathrm{Be}$ is separated and analysed in the present study.

For samples measured at the Institute of Geological and Nuclear Sciences and Lawrence Livermore National Laboratory the preparation procedure used is detailed in appendix 2. In each case a known weight of dry sediment was leached to remove exotic material. The leachate was then further processed to separate the beryllium from all other metal cations. Resulting beryllium was oxidised and pressed into an AMS target for measurement. Before the separation procedure was carried out a $2 \mathrm{mg}{ }^{9} \mathrm{Be}$ carrier was added to the sample. This served two purposes: Firstly it provided a stable isotope for the AMS to measure ${ }^{10} \mathrm{Be}$ against. Secondly it prevented the need for tracing during the wet chemical preparation procedure, as any Be loss would not affect the original ratio as both ${ }^{9} \mathrm{Be}$ and ${ }^{10} \mathrm{Be}$ would be lost in that same original ratio.

\subsubsection{Accelerator Mass Spectrometry}

Accelerator Mass Spectrometry is a relatively new isotopic measurement technique first employed in the late seventies (Purser, 1976; Muller, 1977). More extensive discussions of the technique and particularly its developments are provided by Purser (1978); Litherland (1984); Woolfli (1987) and Suter (1990). Descriptions of specific machines used to measure samples in the present study can be found in Raisbeck et al. (1984), Southon et al. (1990) and Sparks et al. (1984). Only a brief technical summary is given here.

The central feature of an AMS (figure 8.8 and plate 8.1 ) is a van der Graaf generator that creates a large controlled electric potential. This potential is used to accelerate the particles to high energies. At the high voltage terminal accelerated particles undergo a charge exchange from negative to positive. This exchange is effected by electron stripping of the particles in a carbon foil. The newly positive particle is then further accelerated away from the positively 


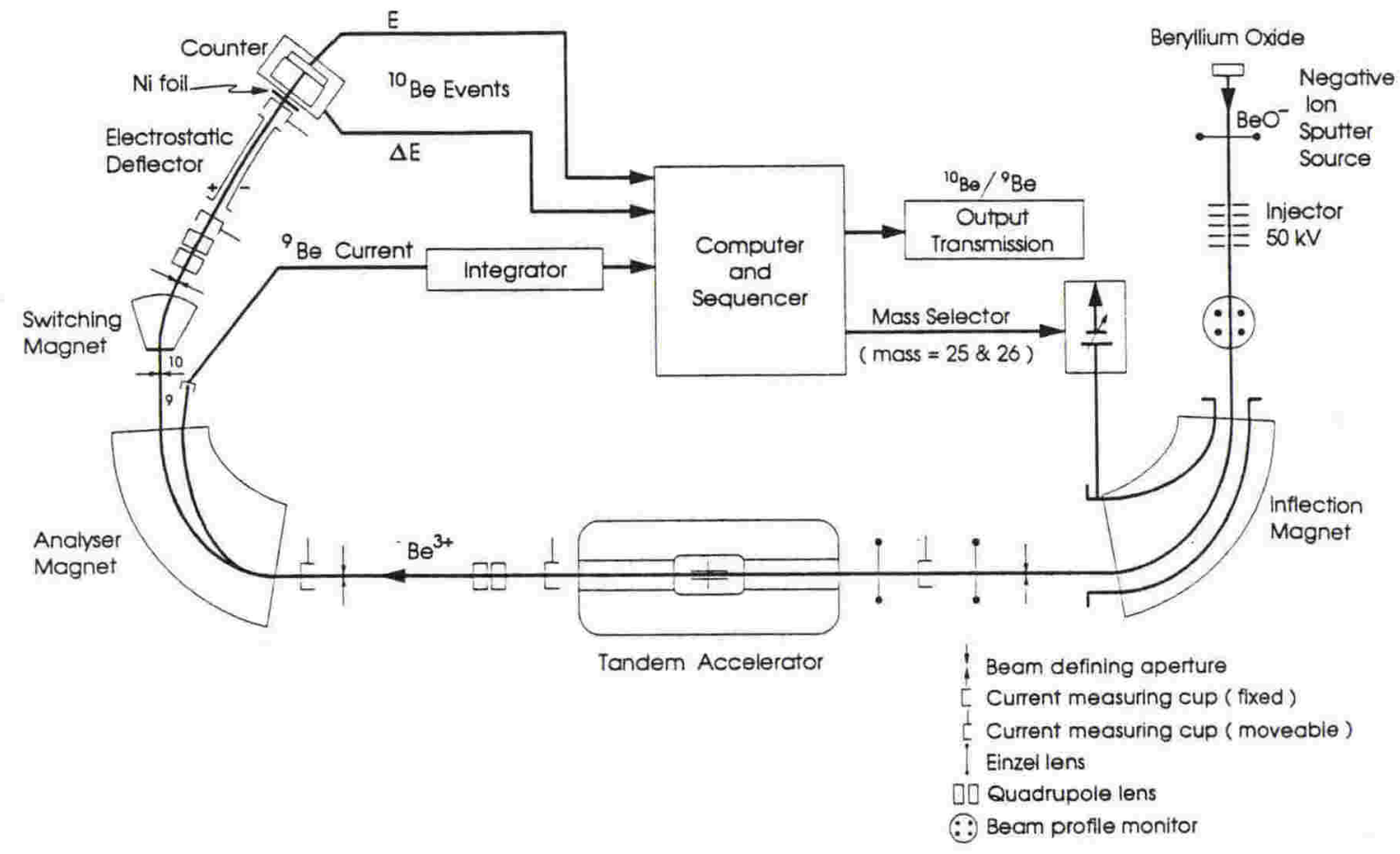

Figure 8.8: Schematic diagram of the IGNS tandem accelerator mass spectrometry facility as configured for ${ }^{10} \mathrm{Be}$ measurement.

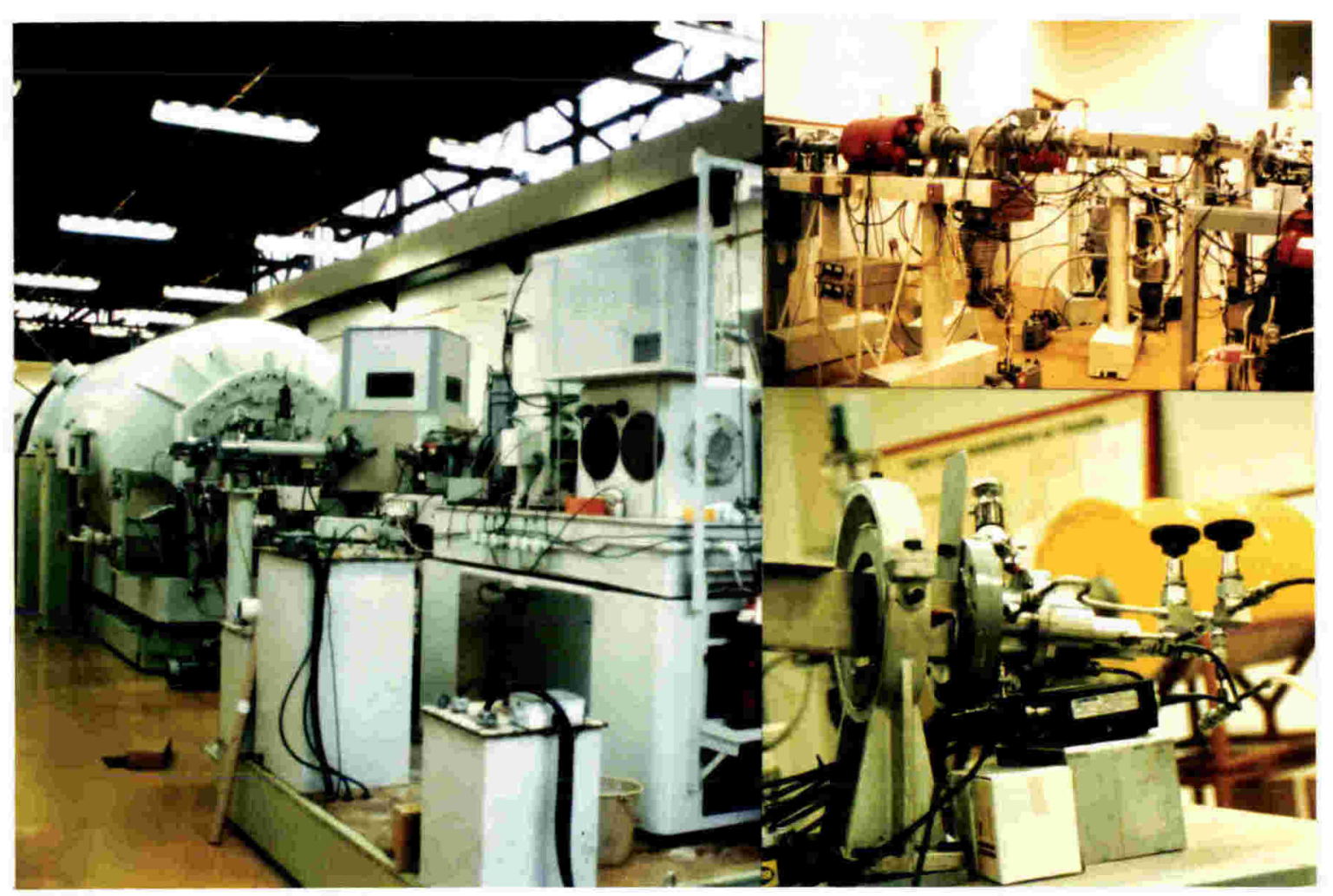

Plate 8.1: The IGNS tandem accelerator facility. Left is the Tandem accelerator, right upper is the electrostatic deflector and detector line, right lower is a close up of the gas detector facility. 
charged stripper or terminal. In the case of $\mathrm{Be} 0$ the molecular structure is also destroyed at the 'stripper'. It is the charge exchange at these high energies that eliminates any molecular contaminants from the system.

A large analysing magnet will then separate isotopes according to their mass. Lower mass isotopes (the majority) are directed towards a faraday cup and their flux measured as a current. Higher mass isotopes are directed towards a nuclear particle detector. The detector uses two independent kinetic parameters to aid in particle identification. The kinetic energy of the particle independent of its charge, and the rate of energy loss as the particle enters the detector. These are measured by the production of ionisation as a particle traverses the gas or solid constituting the detector.

It is usual to have several analysing magnets, electrostatic deflectors and absorbing foils in the system to ensure correct particle selection and separation. Electrostatic and magnetic lenses are used to focus the particle beam and ensure the best possible particle transmission.

A caesium sputter ion source with the aid of a low potential injector is used to create and supply negatively charged particles to the tandem accelerator $\left(\mathrm{C}^{-}\right.$, in the case of carbon and $\mathrm{Be}^{-}$, in the case of Beryllium). The technical operation of negative ion spectroscopy is much more simple than positive ion spectroscopy, and operating background levels are about five orders of magnitude lower (Purser, 1978). $\mathrm{BeO}$ is used because $\mathrm{Be}$ does not form stable negative ions (Kvale et al., 1985).

There are several advantages of Accelerator Mass Spectrometry over conventional Mass Spectrometry. The increased electromagnetic potential effectively eliminates molecular background contribution and multiple mass and energy to charge ratio solutions (Purser, 1978). Increased measurement potential using nuclear detection techniques allows total energy and energy loss of the particles to be calculated. This provides unique particle identification as well as increased sensitivity (Purser, 1978). Accelerators are particularly important as they can uniquely identify and distinguish between ion species (such as Carbon and Beryllium), and they require only very small amounts of source material (only milligrams). They are also far quicker than direct radioactivity counting.

A basic principle of AMS is that higher voltage potentials produce a better beam transmission. The voltage potential in the AMS will determine the charge state that particles leave the stripper in. Better transmission is achieved at voltage potentials greater than $3 \mathrm{MV}$ (Nelson et al., 1984). At this potential Beryllium atoms are leaving the stripper in charge state 3. Higher potentials and beam velocities are more important for Beryllium measurements than, for 
example carbon measurements, because of the large mass of the $\mathrm{BeO}$ molecule (Suter, 1990). Because the beryllium enters the stripper as an oxide molecule; as the smaller beryllium atom is split from the larger oxygen particle it is scattered from the original beam track. Higher potentials reduce the scattering effect of molecular splitting. A quadrupole lens immediately outside the accelerator helps to refocus the beam also.

Loss of energy in absorber foils can be used to separate interfering isobars as well as analysing particles. The isobar ${ }^{10} \mathrm{~B}$ is particularly problematic when measuring ${ }^{10} \mathrm{Be}$. This is the sole reason for the extra nickel foil placed in front of the gas detector. Because the ${ }^{10} \mathrm{~B}$ has a higher atomic number than ${ }^{10} \mathrm{Be}$ it will suffer more energy loss when passing through a solid medium. The foil is sufficiently thick to just stop the ${ }^{10} \mathrm{~B}$, but sufficiently thin to allow the ${ }^{10} \mathrm{Be}$ to continue through to the detector.

Unfortunately a bi-product of this isobaric separation is production of ${ }^{7} \mathrm{Be}$. The ${ }^{10} \mathrm{~B}$ colliding with Hydrogen atoms in the nickel foil causes a nuclear reaction producing ${ }^{7} \mathrm{Be}$. The ${ }^{7} \mathrm{~B} \mathrm{e}$ produces a continuous wide energy background in the detector. This background can be mostly distinguished using a two dimensional detector ( $\mathrm{E}_{\text {tot }} \mathrm{vs}$ $\Delta \mathrm{E}$ ), but can only be truly accounted for by preparation and measurement of a blank with every suite of samples measured. The background level in the blank is used to normalise real sample counts to a known zero.

Results from the AMS are recorded in terms of transmission current of ${ }^{9} \mathrm{Be}$ and number of counts of ${ }^{10} \mathrm{Be}$. The ${ }^{10} \mathrm{Be}$ counts are recorded in a calculated and experimentally defined window of particle energy loss and residual particle energy. The energy loss is recorded by the gas detector as a function of length and pressure of gas traversed by the particles. Both the energy loss and residual energy are measured by the amounts of ionisation energy produced by particle collisions within the detectors. Final results are reported as total particle energy $\left(E_{\text {tot }}=\Delta E+E_{\text {res }}\right)$ versus energy loss.

\subsection{Results}

The number of measurements made as part of the present study is less than satisfactory for full development and establishment of beryllium-10 as a conclusive dating method for antarctic margin sediments. There are two reasons for this:

1) The need to first develop a method of beryllium separation from the sediments that accounts for the origin and location of the ${ }^{10} \mathrm{Be}$. This work was necessary, but prevented adequate time being spent on sample preparation and measurement. This work is presented in Appendix 1.

2) The newness of the AMS technique meant that machine preparation and 
development was also concurrently being undertaken, again slowing the measurement progress. This also meant that results needed to be cross-checked with other laboratories to establish their validity. These cross checks were not always in agreement, usually for technical reasons, requiring further work to establish the nature of the disagreement.

Sample measurements were made in collaboration with The Accelerator section of the Institute of Geological and Nuclear Sciences (IGNS). Cross-checks were made possible with the help of Jay Davis and John Southon at Lawrence Livermore National Laboratory (LLNL), University of California, U.S.A. and Grant Raisbeck of the Laboratoire Rene Bernas (CNRS), Paris, France. Samples measured at the IGNS and LLNL were prepared using the methodology outlined in appendix 2. Samples measured at the CNRS were prepared using the procedure outlined in Bourles et al. (1989).

Sixteen samples were measured from the CIROS-2 core, housed at the Institute of Geological and Nuclear Sciences core store, Wellington. Three samples were measured from DVDP-11, with permission from Denis S. Cassidy of the Antarctic Core Facility, Florida State University, Tallahassee, Florida, U.S.A. Two samples were measured from the ocean floor of Granite Harbour, to use as a modern day reference sample. These samples were selected from the samples collected by Macpherson (1987) for their similar texture to samples measured in the CIROS- 2 and DVDP-11 cores. The measurement results are presented in Table 8.1.

\subsubsection{Discussion of Standards}

Four different standards were used in measuring samples from the two cores. The CNRS standard was one prepared by CNRS and its ${ }^{10} \mathrm{Be}:{ }^{9} \mathrm{Be}$ ratio is unknown to the present author. Measurements at IGNS were made using the NBS/NIST standard (reported ${ }^{10} \mathrm{Be}:{ }^{9} \mathrm{Be}$ ratio of 2.68 E-11). Measurements at LLNL were made using either the LLNL10000 (reported ${ }^{10} \mathrm{Be}:{ }^{9} \mathrm{Be}$ ratio of $1.00 \mathrm{E}-11$ ) or the KNSTD3770 (reported ${ }^{10} \mathrm{Be}:{ }^{9} \mathrm{Be}$ ratio of $3.77 \mathrm{E}-12$ ) standard. Both of these were prepared by LLNL.

An intercomparison was made of the three known standards (NBS/NIST, LLNL10000, and KNSTD3770) using the LLNL Accelerator Mass Spectrometer. This was to ensure that measured sample values from different laboratories would be in agreement and could be freely combined. These intercomparisons are given in table 8.2.

The LLNL10000 and KNSTD3770 standards are in agreement to within $2 \%$. However the NBS/NIST standard was found to differ by $14 \%$, with an intercomparison value of $3.12 \mathrm{E}-11$ (reported value $2.68 \mathrm{E}-11$ ). Hofmann et al. (1987) report the $10 \mathrm{Be}: 9 \mathrm{Be}$ ratio as being $(3.08 \pm 0.08) \mathrm{E}-11$ which is in agreement with the value measured here. 


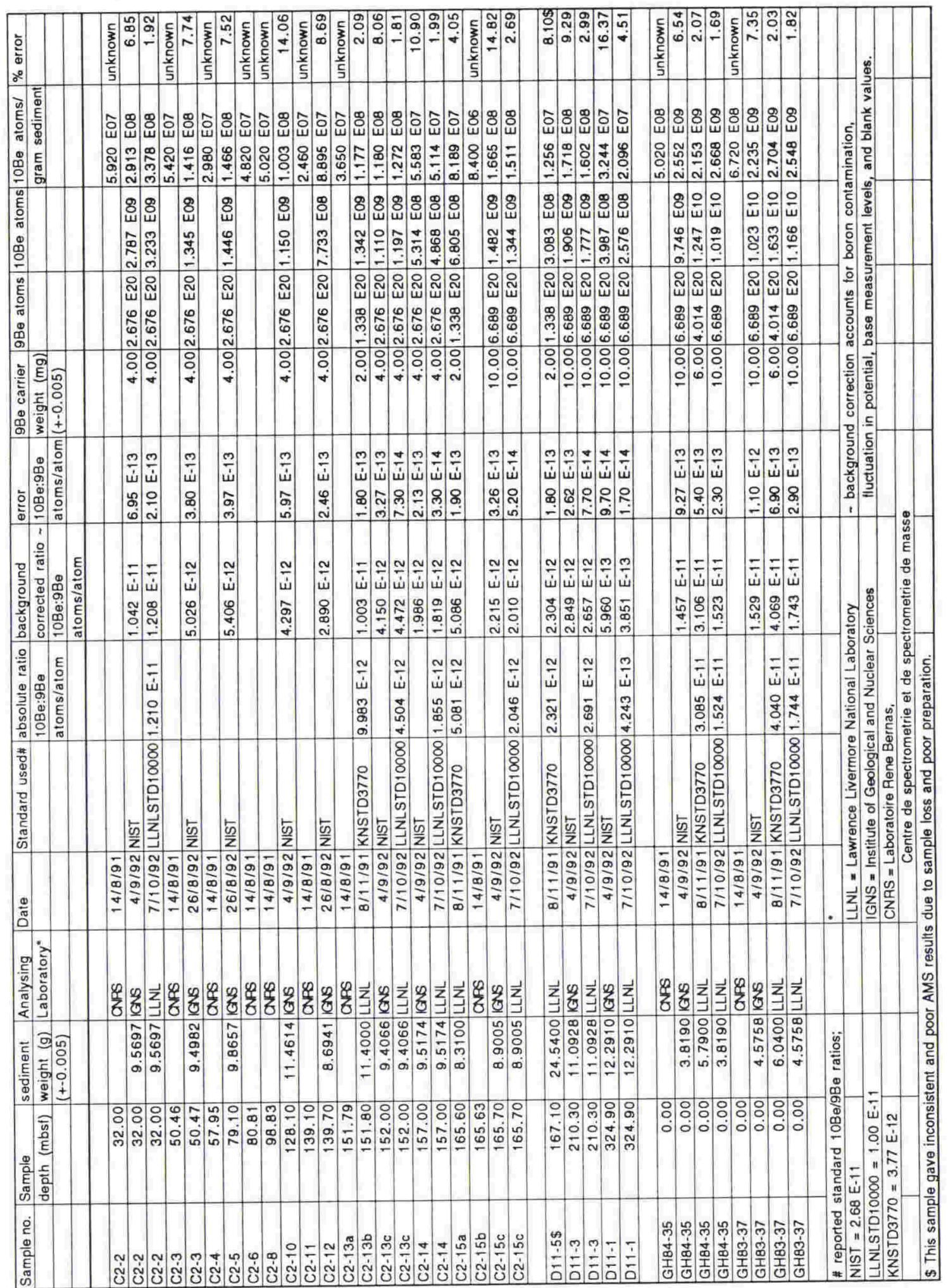

Table 8.1: Beryllium measurements and results table for cored Antarctic margin strata in McMurdo Sound. 
Subsequent to the initial preparation of the NBS/NIST standard (Inn et al., 1987), workers from NBS/NIST reported an error in their calculations (John Southon, pers. comm.). It was thought that a gram/gram value was mistaken for an atom/atom value or visa versa. Later, Grant Raisbeck of the CNRS compared the NBS/NIST standard with his own and found the $2.68 \mathrm{E}-11$ value to agree. He suggested that the reported half-life of Hofmann et al. (1987) was therefore in error (John Southon, pers. comm.)

The LLNL10000 standard was prepared by irradiation of $\mathrm{BeO}$, using a ${ }^{9} \mathrm{~B}$ e thermal capture cross-section of $8.6 \mathrm{mb}$ and assuming pure thermal capture and negligible self-absorption, to give a nominal ${ }^{10} \mathrm{Be}:{ }^{9} \mathrm{Be}$ ratio of $1.0 \mathrm{E}-11$ (John
Southon, pers. comm.). An assumed halflife was not required. The KNSTD 3770 was measured by $\beta$-counting, assuming a half-life of $1.50 \mathrm{Ma}$., giving a ${ }^{10} \mathrm{Be}:{ }^{9} \mathrm{Be}$ ratio of $3.77 \mathrm{E}-12$ within the counter error (Kuni Nishiizumi, pers comm.). Because of the agreement between these two standards (less than 2\%, table 8.2), and their different preparation methods, they are accepted to be reliable.

When intercompared with the NBS/NIST standard, the measured ${ }^{10} \mathrm{Be}:{ }^{9} \mathrm{Be}$ ratio of the NBS/NIST standard was 3.12 E-11 (error; $2.0 \mathrm{E}-13$ ). This is in agreement with the value originally reported by Hofmann et al. (1987). If this value is correct, then the half life of $1.51 \mathrm{Ma}$. also reported by Hofmann et al. (1987) must also be accepted. Within error limits, this

\begin{tabular}{|c|c|c|c|c|c|c|c|c|}
\hline \multirow[t]{2}{*}{ Sample } & \multicolumn{2}{|c|}{ Standard used $10 \mathrm{Be} / 9 \mathrm{Be}$ ratio } & \multicolumn{2}{|c|}{$10 \mathrm{Be} / 9 \mathrm{Be}$ ratio } & \multicolumn{2}{|c|}{ Background ratio } & \multicolumn{2}{|c|}{ Background corrected ratiq } \\
\hline & & of standard & ratio & error & ratio & error & ratio & error \\
\hline \multicolumn{2}{|c|}{ CAMS BeO Blank } & & $8.900 \mathrm{E}-15$ & $5.5 \mathrm{E}-15$ & & & $8.918 \mathrm{E}-15$ & $5.5 \mathrm{E}-15$ \\
\hline LLNL10000 & KNSTD3770 & $3.77 \mathrm{E}-12$ & $9.890 \mathrm{E}-12$ & $1.9 \mathrm{E}-13$ & $2.0 \mathrm{E}-14$ & $1.0 \mathrm{E} \cdot 14$ & 9.949 E-12 & $1.9 \mathrm{E}-13$ \\
\hline LLNL10000 & KNSTD 3770 & 3.77 E-12 & 9.664 E-12 & $1.9 \mathrm{E}-13$ & $2.0 \mathrm{E}-14$ & $1.0 \mathrm{E}-14$ & $9.721 \mathrm{E}-12$ & $1.9 \mathrm{E}-13$ \\
\hline LLNL10000 & KNSTD 3770 & 3.77 E-12 & 9.836 E-12 & $1.7 \mathrm{E}-13$ & $2.0 \mathrm{E}-14$ & $1.0 \mathrm{E}-14$ & 9.894 E-12 & $1.7 \mathrm{E}-13$ \\
\hline LLNL10000 & KNSTD 3770 & 3.77 E-12 & $9.743 \mathrm{E}-12$ & $1.9 \mathrm{E}-13$ & $2.0 \mathrm{E}-14$ & $1.0 \mathrm{E}-14$ & $9.801 \mathrm{E}-12$ & $1.9 \mathrm{E}-13$ \\
\hline KNSTD3770 & LLNL10000 & $1.00 \mathrm{E}-11$ & $3.804 \mathrm{E}-12$ & $1.4 \mathrm{E}-13$ & $3.0 \mathrm{E}-14$ & $1.0 \mathrm{E}-14$ & $3.782 \quad E-12$ & $1.4 \mathrm{E}-13$ \\
\hline KNSTD3770 & LLNL 10000 & $1.00 \mathrm{E}-11$ & $3.747 \mathrm{E}-12$ & $5.6 \mathrm{E}-14$ & $3.0 \mathrm{E}-14$ & $1.0 \mathrm{E}-14$ & 3.724 E-12 & $5.7 \mathrm{E}-13$ \\
\hline KNSTD3770 & LLNL 10000 & $1.00 \mathrm{E}-11$ & $3.848 \mathrm{E}-12$ & $6.4 \mathrm{E}-14$ & 3.0 E-14 & $1.0 \mathrm{E}-14$ & 3.826 E-12 & $6.5 \mathrm{E}-14$ \\
\hline NIST & LLNL10000 & $1.00 \mathrm{E}-11$ & $3.131 \mathrm{E}-11$ & $4.9 \mathrm{E}-13$ & $4.0 \mathrm{E}-14$ & 1.0 E-14 & 3.137 E-11 & $4.9 \mathrm{E}-13$ \\
\hline NIST & LLNL10000 & $1.00 \mathrm{E}-11$ & 3.126 E-11 & $4.6 \mathrm{E}-13$ & 4.0 E-14 & $1.0 \mathrm{E}-14$ & $3.133 \mathrm{E}-11$ & $4.6 \mathrm{E}-13$ \\
\hline NIST & LLNL10000 & $1.00 \mathrm{E}-11$ & $3.090 \mathrm{E}-11$ & $3.4 \mathrm{E}-13$ & $4.0 \mathrm{E}-14$ & $1.0 \mathrm{E}-14$ & $3.096 \mathrm{E}-11$ & $3.4 E-13$ \\
\hline NIST & LLNL10000 & $1.00 \mathrm{E}-11$ & 3.121 E-11 & $4.0 \mathrm{E}-13$ & 4.0 E-14 & $1.0 \mathrm{E}-14$ & $3.128 \quad E-11$ & $4.0 \mathrm{E}-13$ \\
\hline
\end{tabular}

Table 8.2: Intercomparison of different standards used for ${ }^{10} \mathrm{Be}$ measurement in the present study. LLNL10000 is a standard prepared by Lawrence Livermore National Laboratory by irradiation. KNSTD 3770 is a standard prepared by Kuni Nishiizumi and measured by $\beta$-counting, assuming a $1.50 \mathrm{Ma}$. half-life. The NIST standard is prepared by the National Institute of Standards and Technology (Hofmann et al., 1987). 


\begin{tabular}{|c|c|c|c|c|}
\hline Sample & Sample & $10 \mathrm{Be}$ atoms/ & $10 \mathrm{Be}$ atoms/ & $\%$ error \\
\hline & Depth (mbsf) & gram sediment & gram sediment & \\
\hline & & NIST $=2.68 \mathrm{E}-11$ & NIST $=3.08 \mathrm{E}-11$ & \\
\hline C2-2 & 32.00 & 2.913 E09 & 3.348 E09 & 6.85 \\
\hline $\mathrm{C} 2-3$ & 50.47 & 1.416 E08 & 1.627 E08 & 7.74 \\
\hline C2-5 & 79.10 & 1.466 E08 & 1.685 E08 & 7.52 \\
\hline$C 2-10$ & 128.10 & 1.003 E08 & $1.153 \mathrm{E} 08$ & 14.06 \\
\hline C2-12 & 139.70 & 8.895 E07 & 1.022 E08 & 8.69 \\
\hline$C 2-13 c$ & 152.00 & 1.180 E08 & 1.356 E08 & 8.06 \\
\hline C2-14 & 157.00 & 5.583 E07 & 6.416 E07 & 10.90 \\
\hline$C 2-15 c$ & 165.70 & 1.665 E08 & 1.914 E08 & 14.82 \\
\hline D11-3 & 210.30 & 1.718 E08 & 1.974 E08 & 9.29 \\
\hline D11-1 & 324.90 & 3.244 E07 & 3.728 E07 & 16.37 \\
\hline GH84-35 & 0.00 & 2.552 E09 & 2.933 E09 & 6.54 \\
\hline GH83-37 & 0.00 & 2.235 E09 & 2.569 E09 & 7.35 \\
\hline
\end{tabular}

Table 8.3: IGNS Beryllium results table for cored Antarctic margin strata in McMurdo Sound. Measurements are reported with respect to depth and are all normalised to the LLNL10000 standard.

value is in agreement with that assumed in the $\beta$-counting of the KNSTD 3770 standard.

For the purposes of this study the ${ }^{10} \mathrm{Be}$ half life of $1.51 \mathrm{Ma}$. (Hofmann et al., 1987) is accepted, as are the reported values of the LLNL10000 standard (1.00 E-11) and the KNSTD3770 standard (3.77 E-12). The new $2.68 \mathrm{E}-11$ value given for the NBS/NIST standard is not accepted. The previously reported 3.08 E-11 value (Hofmann et al., 1987) for the NBS/NIST standard is accepted, because of its agreement with all the other standards. Because of this different NBS/NIST value, all measurements made at IGNS have been normalised to the new value (table 8.3) to allow intercomparison with the LLNL measurements.

\subsubsection{CNRS Measurements}

The standard used for measurement of these samples is unknown. Because of this, measurements made at the CNRS are not used in the dating of CIROS-2 or DVDP-8. If we accept that the measurements are directly comparable to those made at LLNL and IGNS (table 8.4), the ocean floor samples measured from Granite Harbour by CNRS have ${ }^{10} \mathrm{Be}$ values $70 \%$ lower than the same samples measured at LLNL. However, of all the other samples measured from the CIROS- 2 and DVDP- 11 cores the CNRS values are sometimes more than an order 


\begin{tabular}{|c|c|c|c|c|}
\hline Sample & Sample & CNRS measurement & LLNL measurement & IGNS measuremen \\
\hline & Depth (mbsf) & $10 \mathrm{Be}$ atoms/gram & $10 \mathrm{Be}$ atoms/gram & $10 \mathrm{Be}$ atoms/gram \\
\hline & & sediment & sediment & sediment \\
\hline C2-2 & 32.0 & 5.920 E07 & 3.378 E08 & 3.348 E08 \\
\hline C2-3 & 50.5 & $5.420 \quad$ E07 & & 1.627 E08 \\
\hline C2-4 & 58.0 & 2.980 E07 & & \\
\hline C2-5 & 79.1 & & & 1.685 E08 \\
\hline $\mathrm{C} 2-6$ & 80.8 & 4.820 E07 & & \\
\hline C2-8 & 98.8 & 5.020 E07 & & \\
\hline $\mathrm{C} 2-10$ & 128.1 & & & 1.153 E08 \\
\hline C2-11 & 139.1 & 2.460 E07 & & \\
\hline $\mathrm{C} 2-12$ & 139.7 & & & 1.022 E08 \\
\hline $\mathrm{C} 2-13$ & 151.8 & 3.650 E07 & 1.187 E08 & 1.356 E08 \\
\hline $\mathrm{C} 2-14$ & 157.0 & & 5.114 E07 & 6.416 E07 \\
\hline $\mathrm{C} 2-15$ & 165.7 & 8.400 E06 & 1.196 E08 & 1.914 EO8 \\
\hline D11-5 & 1671 & & $1256 \mathrm{E} 07$ & \\
\hline D11-3 & 210.3 & & 1.602 E08 & 1.974 E08 \\
\hline D11-1 & 324.9 & & 2.096 E07 & 3.728 E07 \\
\hline & & & & \\
\hline GH84-35 & 0.0 & 5.020 E08 & 2.411 E09 & 2.933 EO9 \\
\hline GH85-37 & 0.0 & 6.720 E08 & 2.626 E09 & 2.569 E09 \\
\hline
\end{tabular}

Table 8.4: Intercomparison of beryllium results from the three different laboratories. Measurements are reported with respect to depth.

of magnitude lower than the LLNL values.

The difference in values are attributed to two variables: 1) The lower potential of the Tandetron AMS used by the CNRS, reducing the total percentage yields; and 2) the two different sample preparation techniques. The method of Wilson and Ditchburn (1992) (used in preparation of samples measured at LLNL) removes all the adsorbed ${ }^{10} \mathrm{Be}$ and all the ${ }^{10} \mathrm{Be}$ that is subsequently incorporated into authigenic cement phases during diagenesis. The method of Bourles et al. (1989) (used in preparation of samples measured at CNRS) is much more detailed and only separates the adsorbed ${ }^{10} \mathrm{Be}$ from samples and does not attack any authigenic cement phases.

In figure 2 of Bourles et al. (1989) (reproduced as figure 8.9 here) Beryllium measurements made (using the preparation method of Bourles et al., 1989) from Central Pacific core RC12-65 are shown. This figure also shows the percent Carbonate from the same core. An inverse relationship can be observed between the ${ }^{10} \mathrm{Be}:{ }^{9} \mathrm{Be}$ ratio and the Carbonate content. Above $10 \mathrm{~m}$ in the core, where the Carbonate content is negligible: Bourles et al. (1989) report the adsorbed ${ }^{10} \mathrm{Be}$ content, when compared with palaeomagnetic age, to agree with the $1.51 \mathrm{Ma}$. half-life of Hofmann et al. (1987). Below $10 \mathrm{~m}$ in the core, the adsorbed ${ }^{10} \mathrm{Be}$ content, when compared with palaeomagnetic 


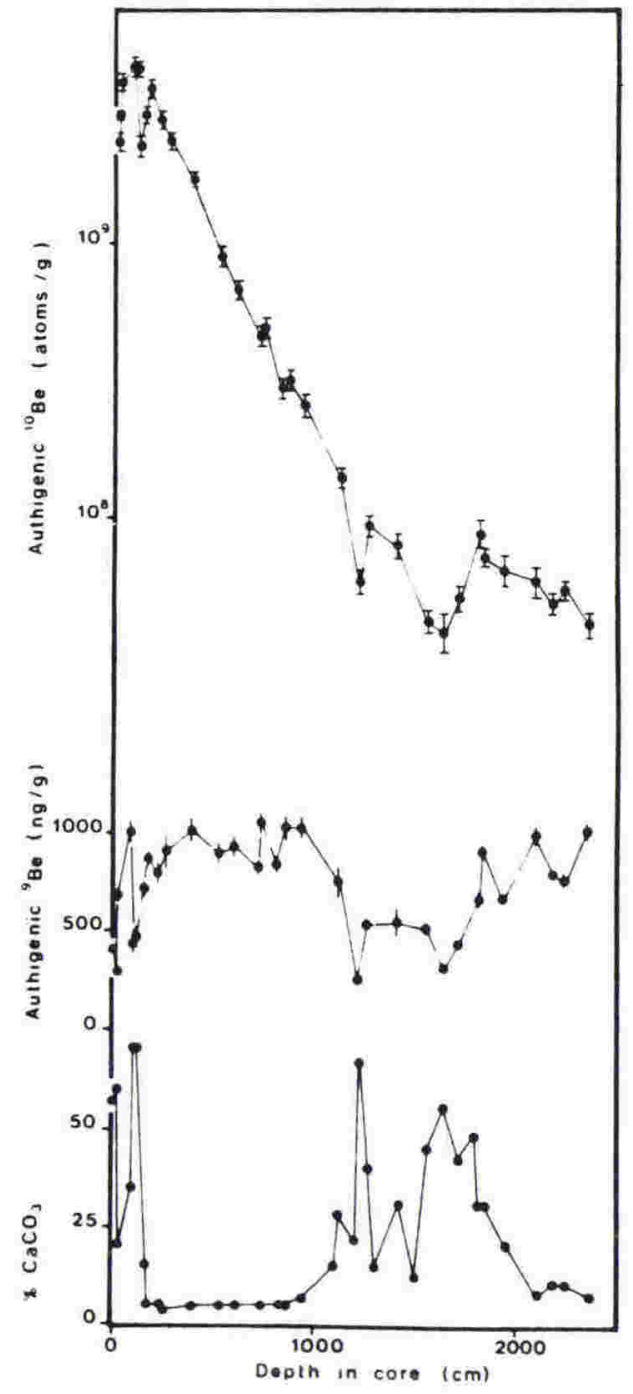

Figure 8.9: ${ }^{10} \mathrm{Be}$ and ${ }^{9} \mathrm{Be}$ extracted with authigenic phases and calcium carbonate as function of depth for sediment core RC12-65. Calcium carbonate data are from Hayes et al. (1969) (from Bourles et al., 1989).

age, suggests a half-life closer to 1.31 Ma.

In order to explain the obvious change in nature at $10 \mathrm{~m}$ in the core, Bourles et al. (1989) suggest using the natural ${ }^{9} \mathrm{Be}$ content of the core as a normalising factor. The result of this still does not agree satisfactorily with the ${ }^{10} \mathrm{Be}$ halflife reported by Hofmann et al. (1987). Bourles et al. (1989) conclude that the half life is in error.
Bourles et al. (1989) suggest that there may be a digenetic effect on the core, but go no further. The present study uses these results as proof that ${ }^{10} \mathrm{Be}$ must be incorporated into authigenic cement phases during diagenesis (in this case carbonate). This explains why the ${ }^{10} \mathrm{Be}$ content changes so markedly in the core, where there is a marked increase in the carbonate content. It also explains why CNRS measurements of the CIROS-2 and DVDP-11 samples vary so markedly from the LLNL and IGNS measurements. This reaffirms the suggestion of Wilson and Ditchburn (1992) that the ${ }^{10} \mathrm{Be}$ must be removed from all authigenic phases to ensure the correct comparable ${ }^{10} \mathrm{Be}$ content is measured (see discussion in section 8.3.1)

\subsubsection{IGNS measurements}

Twelve samples were measured at the Institute of Geological and Nuclear Sciences (IGNS) (figure 8.10), with cross-check measurements made of the same samples at the LLNL. The IGNS measurements were made with respect to the NBS/NIST standard. Table 8.3 reports these measurements normalised to the newly accepted 3.08 E-11 ${ }^{10} \mathrm{Be}:{ }^{9} \mathrm{Be}$ ratio of the NBS/NIST standard.

The values measured at IGNS are up to $30 \%$ higher than those made at LLNL. Those samples with smaller absolute concentrations of ${ }^{10} \mathrm{Be}$ tend to be more in 

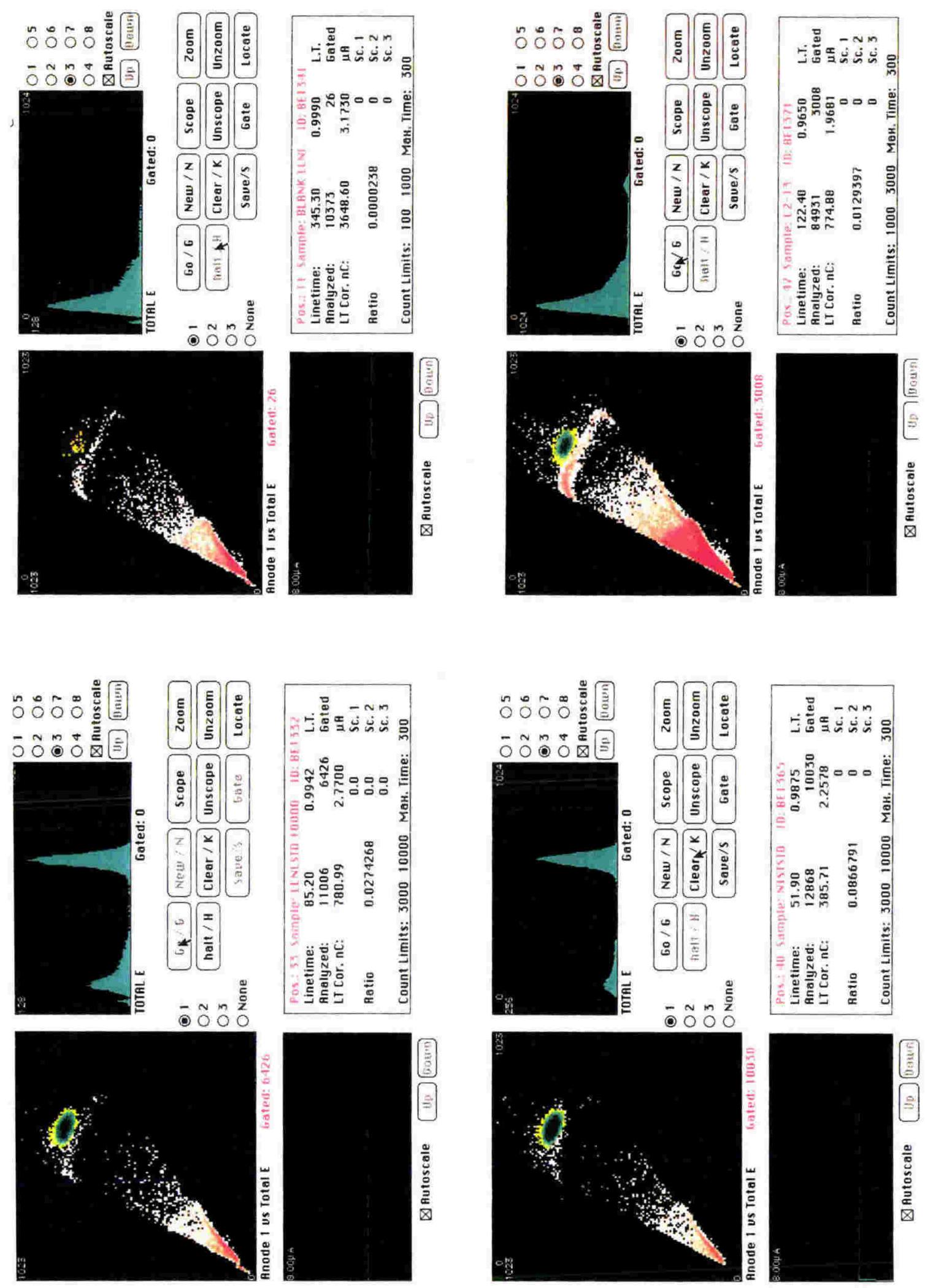

Figure 8.11: Beryllium-10 measurement spectra for samples measured at LLNL, measurements are of change in energy versus total energy. Samples illustrated are the LLNL10000 and NIST standards, a specially prepared blank, and C2-13 from the CIROS2 drill-core. 


\subsubsection{Dating CIROS-2 and DVDP-11 with ${ }^{10} \mathrm{Be}$}

Because of the problems with the CNRS measurements and the high noise interference of the IGNS measurements, it is difficult at this stage to assemble a reliable ${ }^{10} \mathrm{Be}$ decay curve for the two cores. In figure 8.12 the ${ }^{10} \mathrm{~B}$ e concentration of CIROS-2, DVDP-11 and Granite Harbour is shown as a function of depth. The variance of the CNRS measurements can easily be seen. The noise interference of the IGNS values can also be seen (figure 8.12); IGNS values are always greater than LLNL values for the same horizon.

\section{CIROS-2}

Two trends can easily be seen in the data from CIROS-2 (figure 8.13a): 1) There is an exponential decay with depth, as expected; and 2) There is a change in the nature of the curve at $c a .50 \mathrm{~m}$ subbottom depth. The rate of decay appears much faster above $50 \mathrm{~m}$ than below. There are two possible geological reasons for this: 1) There is an hiatus above $50 \mathrm{~m}$ sub-bottom depth in the CIROS-2 core; or 2) the average sedimentation rate is greater above $50 \mathrm{~m}$ sub-bottom depth.

The plot in figure 8.13a is an average decay curve for the CIROS-2 core (see discussion in section 8.2.5). There is obvious variation from the best fit curve. This is greater than that expected from sedimentation rate variation and is probably due to the ice sheet effect (see discussion in section 8.2.5). Unfortunately the number of data points in the present study is not sufficient to establish the true nature of variation. Consequently the age resolution is much poorer than expected.

The base of the core is from CIROS-2 has a ${ }^{10} \mathrm{Be}$ content $c a .4{ }^{10} \mathrm{Be}$ half-lives less than the samples form Granite Harbour. The level of the Ash (ca. 125 $\mathrm{m})$ has a ${ }^{10} \mathrm{Be}$ content $c a .3^{10} \mathrm{Be}$ halflives less than Granite Harbour. This suggests ages of $6 \mathrm{Ma}$. and $4.5 \mathrm{Ma}$. respectively. This result does not agree with the $\mathrm{K} / \mathrm{Ar}$ and $\mathrm{Ar} / \mathrm{Ar}$ age of the ash. The $\mathrm{K} / \mathrm{Ar}$ and $\mathrm{Ar} / \mathrm{Ar}$ age is taken as correct and there are two possible

${ }^{10}$ Be content ( atoms / gram )

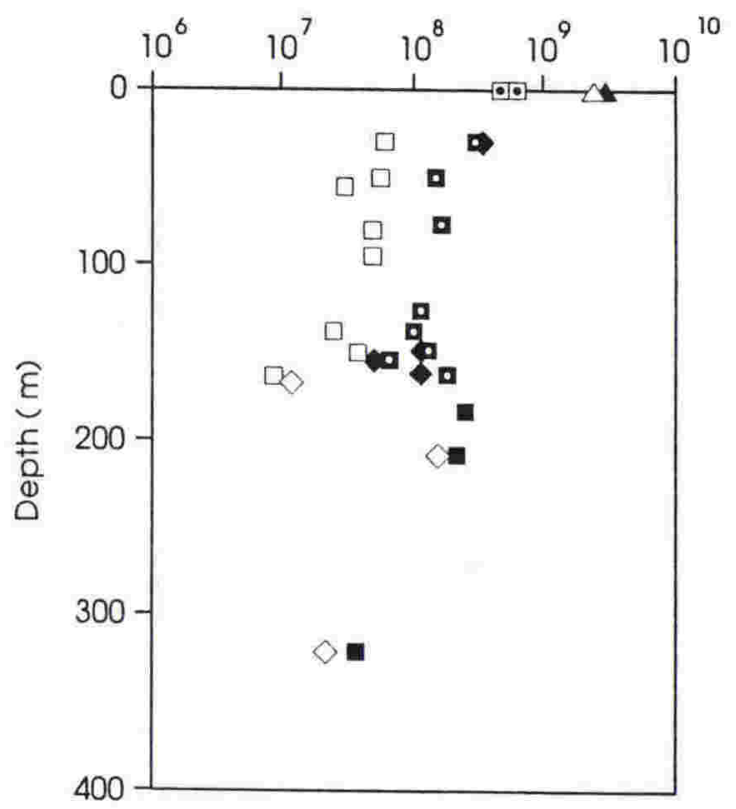

Figure 8.12: absolute concentration of ${ }^{10} \mathrm{Be}$ of CIROS-2, DVDP-11, and Granite Harbour samples versus depth.

\footnotetext{
CNRS CIROS - 2 measurements

- ULNL CIROS - 2 measurements

- IGNS CIROS - 2 measurements

$\checkmark$ LLNL DVDP - 11 measurements

- IGNS DVDP - 11 measurements

- CNRS GH surface measurements

- LLNL GH surface measurements

$\triangle$ IGNS GH surface measurements
} 


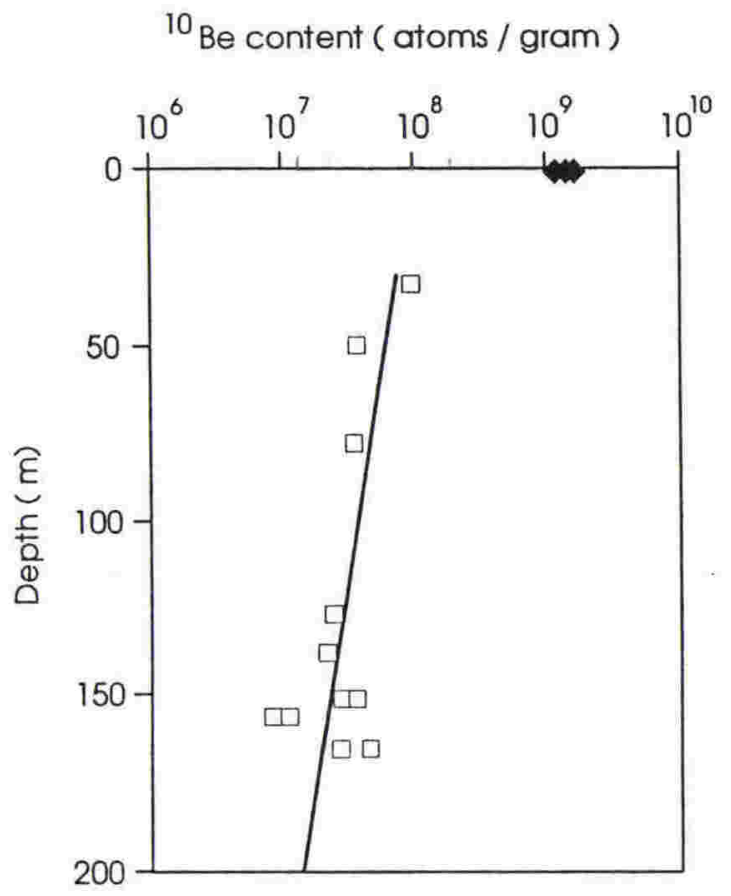

Figure 8.13a: Absolute concentration of ${ }^{10} \mathrm{Be}$ in CIROS-2 and Granite Harbour samples versus depth. Only samples measured at IGNS or LLNL are shown. Ignoring the Granite Harbour samples, the line of best fit of data has equation: $\ln C-\ln C_{0}=-0.00786 x$ depth (error $=28 \%, R$ squared $=0.552$ ). If constant sedimentation is assumed (because of the limited number of data points), the base of the core is $2.6 \pm 0.8^{10} \mathrm{Be}$ half lives $(3.9 \pm 1.2 \mathrm{Ma}$.) older than the top of the core.

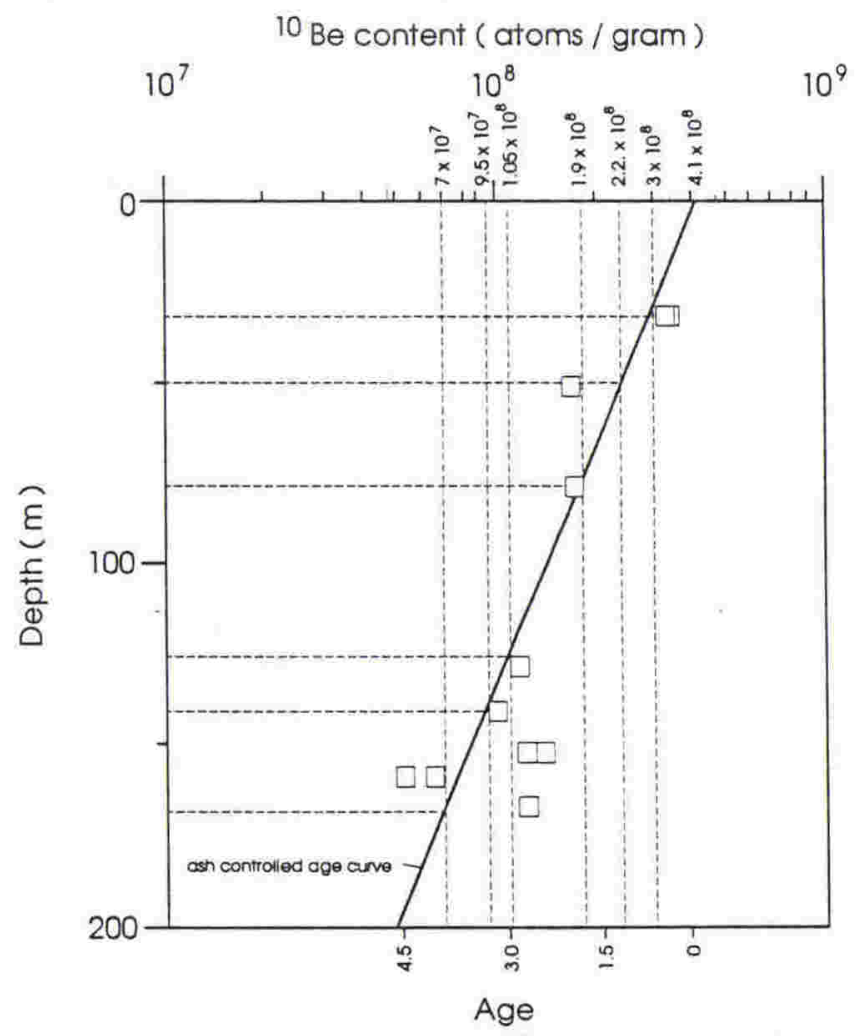

reasons for the ${ }^{10} \mathrm{Be}$ age discrepancy. Both of these are related to the Granite Harbour samples. They are either not good correlatives to the CIROS-2 mudstone horizons, or the process of removal of the ${ }^{10} \mathrm{Be}$ from ocean floor sediments into the stratigraphic column is not directly comparable.

Adopting the K/Ar and Ar/Ar ash age of $2.8 \pm 0.3 \mathrm{Ma}$. (chapter 7), the ${ }^{10} \mathrm{~B} \mathrm{e}$ measurements suggest that the bottom of the CIROS-2 core (167 m sub-bottom depth). is between 1 and $1.5 \mathrm{Ma}$. years older than the Ash horizon, resulting in an age of $4.1 \pm 0.5 \mathrm{Ma}$. (figure $8.13 \mathrm{~b}$ ). It also suggests that the upper $50 \mathrm{~m}$ of the core is deposited with the same average sedimentation rate as the $50-167 \mathrm{~m}$ interval of the core. The expected 
comparative present day ${ }^{10} \mathrm{Be}$ content of McMurdo Sound mudstones (assuming interglacial conditions) is ca. $4.1 \mathrm{E} 08$ atoms/gram (figure $8.13 \mathrm{~b}$ ).

Datums assigned for the CIROS-2 core from the normalised ${ }^{10} \mathrm{Be}$ concentration curve (figure $8.13 \mathrm{~b}$ ) are presented in table $8.5 \mathrm{a}$.

\section{DVDP-11}

Only three horizons were measured in the DVDP-11 core. Sample D11-5 had a very high boron content after the initial processing, making it impossible to measure. The target material was retreated using hyperchloric acid and remeasured. However, very little material remained and the result is somewhat suspect. The other two samples (D11-3 and D11-1) were measured at both LLNL and IGNS and found to be in good agreement. Unfortunately no independent age is yet established for the DVDP-11 core.

If the equivalent modern day ${ }^{10} \mathrm{Be}$ value is used as a zero age for the core (figure 8.14). The ${ }^{10} \mathrm{Be}$ concentration at $210 \mathrm{~m}$

Table 8.5a: Age data for the CIROS-2 drill-core strata adopted using the absolute ${ }^{10} \mathrm{Be}$ concentration defined by the criteria outlined in figure $8.13 \mathrm{~b}$. Errors on age estimates are calculated from variations in actual ${ }^{10} \mathrm{Be}$ concentration measurement and point sedimentation rates.

\begin{tabular}{lcl} 
Depth $(\mathrm{m})$ & absolute & Age (Ma.) \\
\hline & (atoms/gram) & \\
0 & $4.1 \times 10^{8}$ & 0 \\
32 & $3 \times 10^{8}$ & $1.2 \pm 0.1$ \\
50.5 & $2.2 \times 10^{8}$ & $1.4 \pm 0.2$ \\
79.1 & $1.9 \times 10^{8}$ & $1.7 \pm 0.2$ \\
125 & $1.05 \times 10^{8}$ & $2.8 \pm 0.3$ \\
139 & $9.5 \times 10^{7}$ & $3.2 \pm 0.4$ \\
166 & $7 \times 10^{7}$ & $4.0 \pm 0.5$
\end{tabular}

Table 8.5b: Age data for the DVDP-11 drill-core strata adopted using the absolute ${ }^{10} \mathrm{Be}$ concentration defined by the criteria outlined in figure 8.14. Errors on age estimates are calculated from variations in actual ${ }^{10} \mathrm{Be}$ concentration measurement and point sedimentation rates.

\begin{tabular}{|c|c|c|}
\hline Depth (m) & $\frac{\text { absolute }}{\text { (atoms/gram) }} \frac{10 \mathrm{Be} \text { content }}{}$ & Age (Ma. \\
\hline 0 & $4.1 \times 10^{8}$ & 0 \\
\hline 210 & $1.6 \times 10^{8}$ & $3.0 \pm 0.4$ \\
\hline 325 & $2.6 \times 10^{8}$ & $6.0 \pm 0.7$ \\
\hline
\end{tabular}


depth in the core is $2{ }^{10} \mathrm{Be}$ half-lives lower, and the concentration at $325 \mathrm{~m}$ depth is $4^{10} \mathrm{Be}$ half-lives lower. Accordingly, expected ages for the 210 $\mathrm{m}$ and $325 \mathrm{~m}$ depth horizons are $c a$. 3.0 $\mathrm{Ma}$. and 6.0 Ma. This suggests that the three mudstone horizons below the ash in the CIROS-2 core and the three mudstone horizons between $200 \mathrm{~m}$ and $250 \mathrm{~m}$ depth in the DVDP-11 core are comparable.

Datums assigned for the CIROS- 2 core from the normalised ${ }^{10} \mathrm{Be}$ concentration curve (figure 8.14) are presented in table 8.5 .

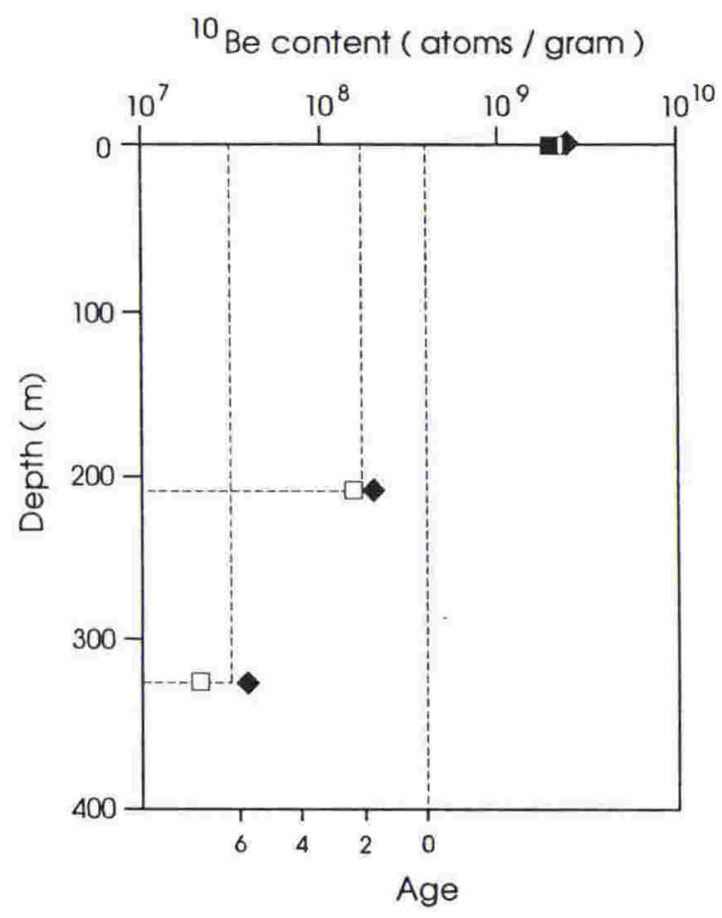

Figure 8.14: Age interpretation of the absolute ${ }^{10} \mathrm{Be}$ concentration of DVDP-11 samples measured at IGNS and LLNL, assuming the same zero concentration as calculated for the CIROS-2 site.

$\square$ UNL. DVDP measurements

- IGNS DVDP measurements

- LLNL GH surface measurements

\subsection{Conclusions}

Previous assumptions necessary for cosmogenic ${ }^{10} \mathrm{Be}$ to be used for dating sediments are found not to be necessary when using absolute concentrations of ${ }^{10} \mathrm{Be}$ in conjunction with facies analysis to date sediments from the Antarctic margin. Because of the nature of glaciomarine sedimentation, horizons deposited in similar environments have the potential to provide a relative dating scheme. These key horizons can provide reference values for constructing a local logarithmic decay curve for each part of the Antarctic margin.

The present study demonstrates the proposed method and its viability. However, the resolution of sampling thus far is not sufficient to be able to establish a model of Antarctic Ice Sheet fluctuation from the variations between measured and predicted levels of ${ }^{10} \mathrm{Be}$ in the cores. Reduced and enriched levels from ice sheet growth and decay respectively.

The ocean floor samples from Granite Harbour did not prove to be good estimates of present day equivalent ${ }^{10} \mathrm{Be}$ concentrations for the CIROS-2 and DVDP-11 cores. This was despite their textural similarity. However, environmentally, there is no question that these sediments are forming in much more glacial conditions than any of the other horizons sampled in either the CIROS-2 or DVDP-11 cores. 
Measurements of this study provide good geochronologic control for palaeomagnetic study of the cores. In particular: The bottom of the CIROS- 2 core is assigned an age of $4.1 \pm 0.5 \mathrm{Ma}$; and the bottom of the DVDP-11 core is assigned an age of $6.0 \pm 0.4 \mathrm{Ma}$. 


\section{Chapter - 9}

\section{Palaeomagnetism}

Magnetozones are defined for the CIROS-2 core and the magnetozones of Ishman and Rieck (1993) are adopted for the DVDP-11 core. The biostratigraphy of Harwood (1986) and Ishman and Rieck (1993) are used in conjunction with radiometric ages (chapters 7 and 8) to correlate the magnetozones with the polarity timescale of Ness et al. (1980). In DVDP-11 chron 5, the Gilbert and Gauss Epochs, and the lowest part of the Matuyama Epoch are identified. In CIROS-2 the upper part of the Gilbert Epoch, the Gauss epoch and the lowest part of the Matuyama Epoch are identified. The magnetostratigraphic correlations show relatively slow sedimentation rates ( $\mathrm{ca} .50 \mathrm{~m} / \mathrm{Ma}$.) but nearly continuous deposition of strata, despite the many glacial advances and retreats (chapter 5). The integrated magnetostratigraphies are the age basis for the history of sedimentation in McMurdo sound (in chapter 5) and the inferred history of East Antarctic ice sheet fluctuation (in chapter 6), through biostratigraphic correlations. The magnetostratigraphy also provides the correlation with the eustatic sea-level record from the South Wanganui Basin.

\subsection{Introduction}

Few palaeomagnetic studies have been carried out in southern Victoria Land. They have concentrated on preCainozoic basement rocks, particularly igneous complexes, with a view to establishing pre-Cainozoic virtual geomagnetic poles.

The DVDP-11 core was studied for its palaeomagnetic properties by Purucker $e t$ al. (1981) as part of a larger study of 4 cores from Taylor Valley. Their work is summarised here with additional information from Ishman and Rieck (1993).

No formal report of the CIROS-2 palaeomagnetism is available, though
Harwood (1986) discusses and uses the magnetostratigraphy in conjunction with diatom biostratigraphy to provide age constraint on the CIROS-2 core.

\subsection{Palaeomagnetism}

Purucker et al. (1981) sampled the DVDP-11 core after it was removed to the Antarctic Core Storage Facility at Florida State University. Measurements were made using a superconducting cryogenic magnetometer housed at the Palaeomagnetics Laboratory of the U.S. Geological Survey at Flagstaff, Arizona, U.S.A. Five percent of samples were subjected to full stepwise alternating field demagnetisation. From analysis of this initial behaviour, the remaining 
samples were cleaned by a single step Alternating Field of 100 to 150 oersteds.

Purucker et al. (1981) sampled only muddy horizons to ensure that samples had attained true magnetic field alignment. Individual sample measurement reliability was assessed using the Koenigsberger ratio.

The measurement procedure for CIROS2 palaeomagnetic samples was the same as for the DVDP-11 samples (Hugh Rieck, pers. comm.)

\subsection{Age and definition of biostratigraphic datums}

\subsubsection{CIROS-2}

Harwood (1986) studied the diatom flora of both the CIROS-2 and DVDP-11 cores. He used existing Subantarctic based diatom stratigraphy (e.g. Ciesielski, 1975; 1983; or more recently Harwood et al., 1992) to establish ages of the same biostratigraphic occurrences in both cores. Harwood (1986) compared the biostratigraphic occurrences with early interpretations of the palaeomagnetic stratigraphy of the cores. The resulting biostratigraphy is summarised here to help in establishing the magnetostratigraphy as used in this study for dating and correlation of the cores.

Barrett et al. (1992) (reproduced in chapter 7 here) calibrated and supported the biostratigraphic scheme of Harwood
(1986) and dispelled speculation about diachroneity of pre-Pleistocene Antarctic flora (e.g. Clapperton and Sugden, 1990). The biostratigraphy of Harwood (1986) and Webb et al. (1984) is therefore adopted here.

Harwood (1986) recovered a diverse and generally well preserved diatom assemblage from the CIROS-2 core, particularly from the lower mudstone units. He recognised a sequence including the Denticulopsis hustedtii through Coscinodiscus vulnificus Partial Range Zones of Ciesielski (1983) in the lower portion of the CIROS-2 core (105$166.5 \mathrm{~m})$. He therefore assigned a discontinuous age range of 2.0- 4.5 Ma. for that section of the core.

Within this pre-Late Pliocene section of the core, Harwood (1986) recognised five diatom assemblages (labelled A-E) that he dated in conjunction with his interpretation of the palaeomagnetic stratigraphy. Therefore, they are not used here in assigning the magnetostratigraphy of the core, but are used as a comparison later (see section 9.5).

\subsubsection{DVDP-11}

Harwood (1986) recognised a similar diatom sequence in DVDP-11 to that which he reported for CIROS-2. He identified the Denticulopsis hustedtii through Coscinodiscus vulnificus partial range zones (Ciesielski, 1983) in the middle of the DVDP-11 core (155-250 
$\mathrm{m})$. Accordingly, he assigned this part of the core an age range of $2.0-\sim 4.5 \mathrm{Ma}$.

Ishman and Rieck (1993) recognise 3 benthic foraminifer zones within DVDP11. The oldest zone (Ammoelphidiella uniforamina zone) they report to occur below $242 \mathrm{~m}$ sub-surface, and to be of Miocene age. The Epistominella exigua Zone occurs between 167.2 and $242 \mathrm{~m}$ sub-surface. The disappearance of Ammoelphidiella uniforamina they report to be indicative of the transition from Miocene to Pliocene in the core. The uppermost foraminifer zone recognised by Ishman and Rieck (1993) is the Trifarina spp. Zone. It occurs between 193 and $202 \mathrm{~m}$ sub-surface and indicates a Late Pliocene age.

\subsection{Ages from radiometric methods.}

Chapter 7 reports the dating of the tuff ca. $125 \mathrm{~m}$ deep in the CIROS-2 core to be $2.8 \pm 0.3 \mathrm{Ma}$. Chapter 8 reports on the beryllium-10 dating of the two cores and provides several independent dates for each of several horizons in both cores. Five ages have been reported for the CIROS-2 core, two of which are within the pre-late Pliocene sequence being studied here: The base of the core (unit $\mathrm{C} 1)$ is assigned an age of $4.0 \pm 0.5 \mathrm{Ma}$. and unit $\mathrm{C} 5$ ( $c a .139 \mathrm{~m}$ deep) is assigned an age of $3.2 \pm 0.4 \mathrm{Ma}$.

Two ${ }^{10} \mathrm{Be}$ ages are reported for the DVDP-11 core. Both are within the preLate Pliocene sequence in the core. Unit

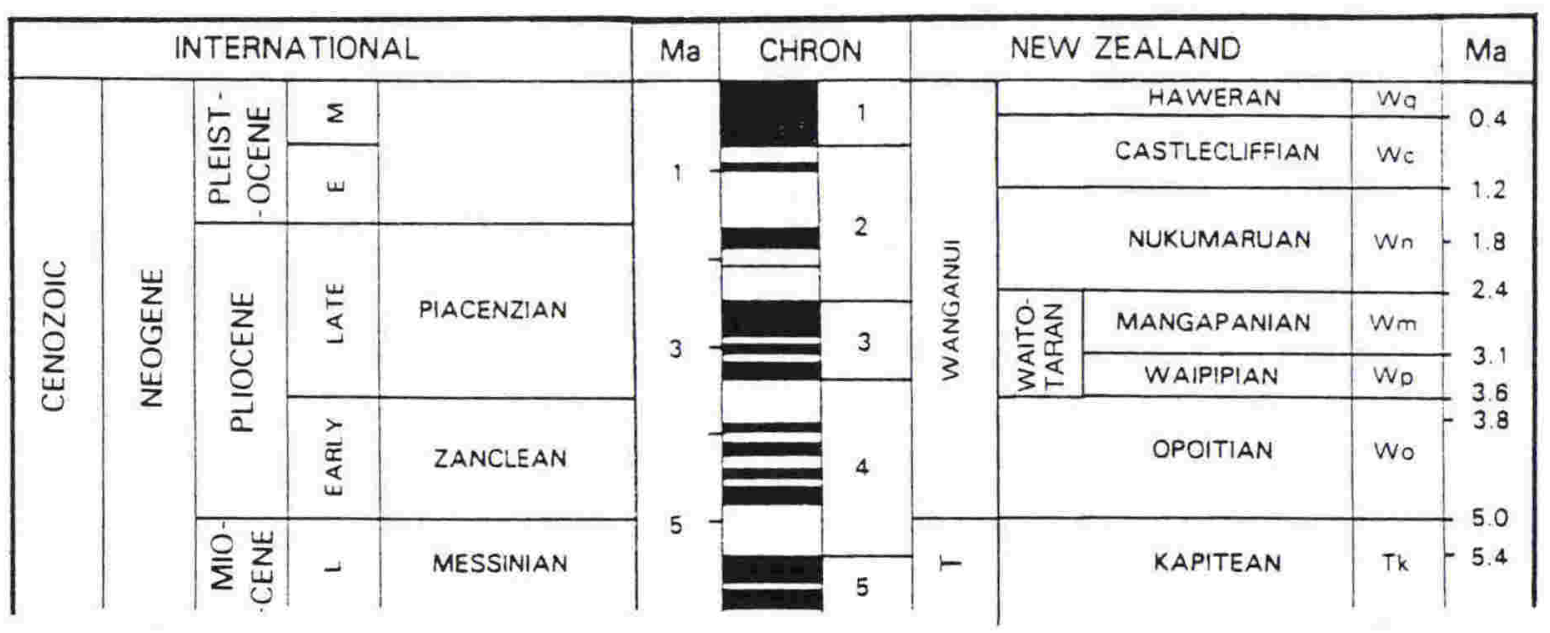

Figure 9.1: Late Neogene geological timescale (modified from Edwards et al., 1988). Polarity is from Ness et al. (1980). New Zealand stages are shown for later comparison with the South Wanganui Basin record. 
D2 (ca. $325 \mathrm{~m}$ deep) towards the base of the drill-hole is assigned an age of $6.0 \pm$ $0.7 \mathrm{Ma}$. A muddy horizon towards the centre of unit D15 (ca. $210 \mathrm{~m}$ deep) is assigned an age of $3.0 \pm 0.4 \mathrm{Ma}$.

\subsection{Magnetostratigraphy}

The polarity timescale used is that of Ness et al. (1980). More recent polarity timescales than that of Ness et al. (1980) have been proposed. Cande and Kent (1992) present a new timescale that suggests the oldest strata in this study are slightly older than reported here. Shackleton et al. (1992) present an 'astronomically tuned' timescale, from ODP Leg 138 strata, that suggests the older strata studied here are younger than reported. Because of this disagreement, neither timescale is adopted here. Correlative New Zealand stages using the timescale of Edwards et al. (1988) are suggested for the purposes of later comparison with the Wanganui Basin records (figure 9.1).

\subsubsection{The CIROS-2 record}

\section{Magnetozones}

Polarity zones for the CIROS-2 core (figure 9.2) include 10 normal, 11 reversed, and 4 of undetermined polarity. The zones are defined by inclination only. Each normal polarity zone is defined by samples only of normal polarity; no normally defined polarity zone includes any reversed polarity samples. Indeterminate polarity zones are identified only where a substantial thickness of core remains unsampled. Reversed polarity zones are determined for any strata that contain samples with measured reversed polarity. If the intensity of normal polarity samples is weak within a zone of dominantly reversed polarity samples, they are considered to be samples retaining a component of normal overprinting.

Only one polarity zone, R6, is defined by one sample. Because this is reversed it is thought to be reliable. Normal polarity zones N1, N7 and N8 are each defined by only two normal polarity samples. In each case the intensity of cleaned signal is high and considered to be a reliable detrital remanence.

Indeterminate polarity zone T4 comprises the top $31 \mathrm{~m}$ of the CIROS-2 core. This zone is indeterminate because of the poor core recovery and the coarseness of the sediment that was recovered, and hence a poor depth sampling interval, and poor reliability of magnetisation.

\section{Correlation to the polarity timescale} (figure 9.3)

\section{Gilbert epoch}

From $c a .140 \mathrm{~m}$ depth in CIROS-2 to the base of the core (ca. $166 \mathrm{~m}$ depth) the magnetic polarity sequence is dominantly reversed with two short intervals of normal polarity (magnetozones N1 - R3, figure 9.3). From the diatom range zone 

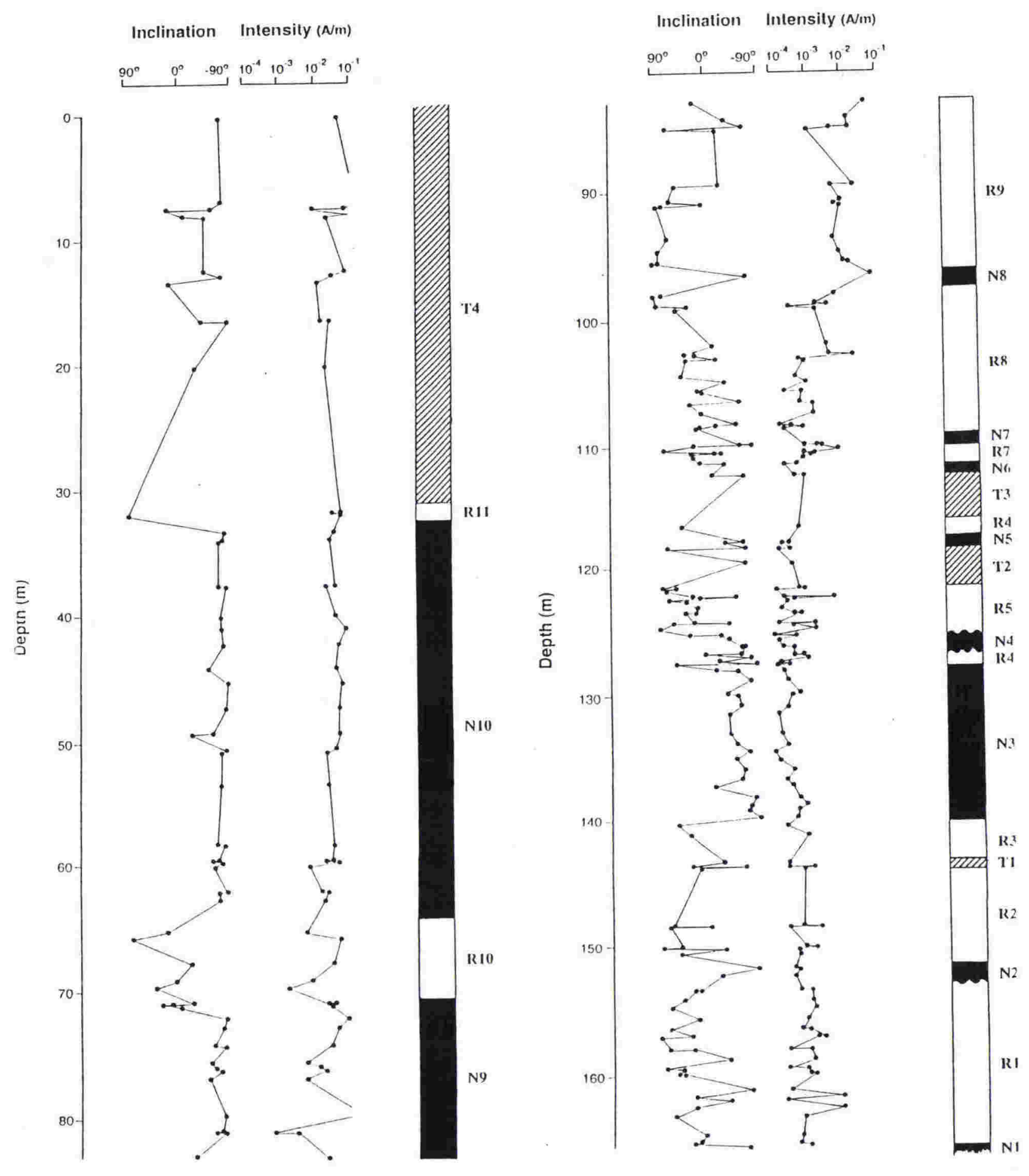

Figure 9.2: CIROS-2 polarity magnetozones. These are annotated for reference in the text. $\mathrm{N}$ labelled magnetozones are of normal polarity, $\mathrm{R}$ labelled magnetozones are of reversed polarity, and $\mathrm{T}$ labelled magnetozones are of transitional polarity. Magnetogram data are from Hugh Rieck (personal data). 


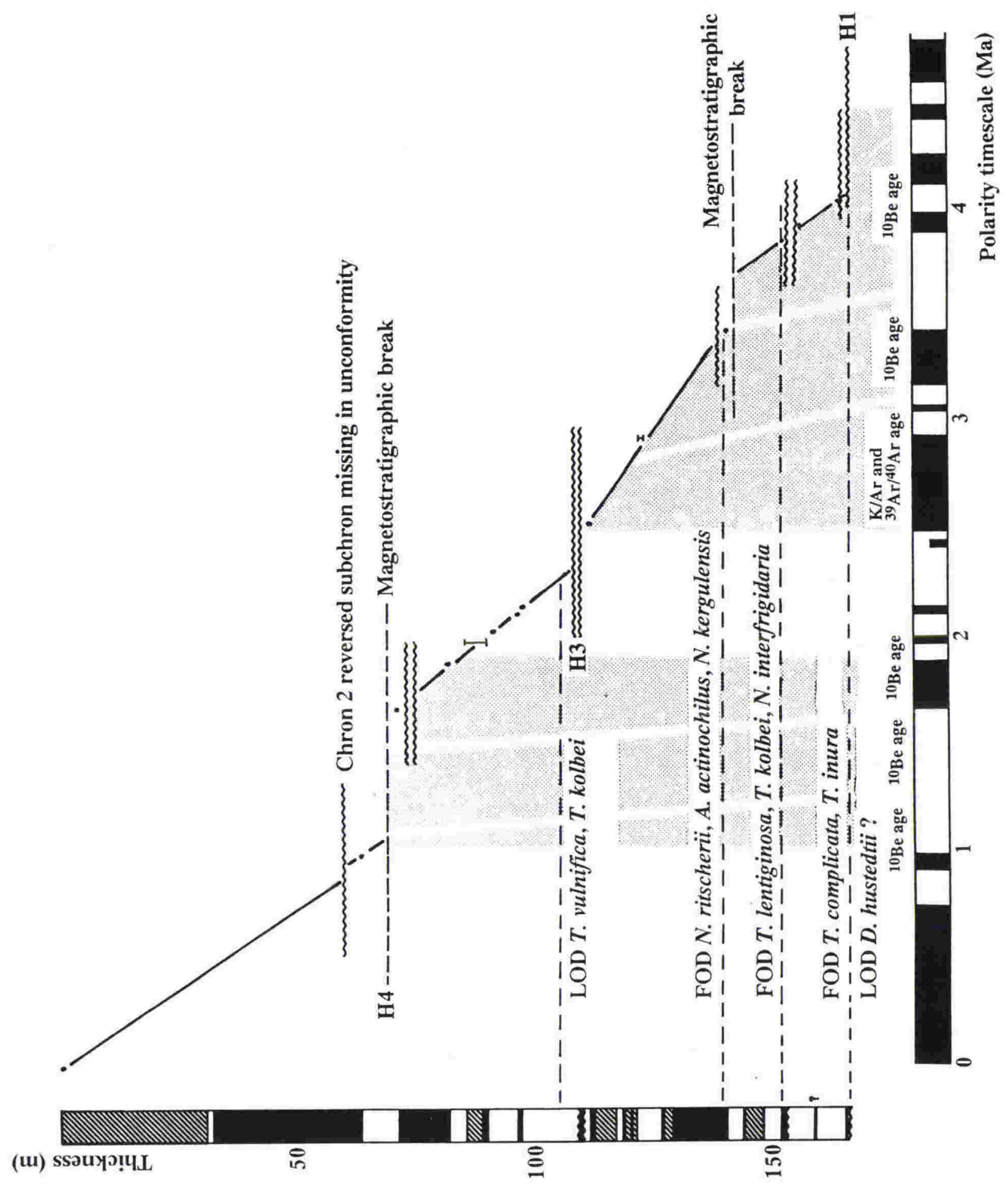

Figure 9.3: Correlation of the CIROS-2 magnetozones with the polarity timescale of Ness et al. (1980), showing the main radiometric datums provided by this study. Plot is drawn to shoe the average sedimentation rat of the CIROS-2 strata and identify breaks in deposition. Comparative diatom data are from Harwood (1986). 
information and the ${ }^{10} \mathrm{Be}$ ages, this sequence is assigned to the upper Gilbert chron. The ${ }^{10} \mathrm{Be}$ age of $3.2 \pm 0.4 \mathrm{Ma}$. $c a$. $139 \mathrm{~m}$ deep in the core coincides with the Gilbert-Gauss magneto-chron as recognised in this study. Ness et al. (1980) assign this an age of $3.40 \mathrm{Ma}$. which is in good agreement. Using the ${ }^{10} \mathrm{Be}$ age of $4.0 \pm 0.5 \mathrm{Ma}$. assigned to the bottom of the sequence, the two short normal polarity magnetozones are assigned to the Cochiti and Nunivak subchrons respectively. This confines the base of the CIROS-2 drill-hole to an age of 4.1-4.2 Ma., which is in good agreement with the diatom biostratigraphic age allocated by Harwood (1986) and much younger than the $c a$. 4.9 Ma. age adopted by Barrett and Hambrey (1992).

\section{Gauss Epoch}

The 110 - $140 \mathrm{~m}$ interval in the CIROS-2 core (magnetozones N3 - N7) is of predominantly normal or unmeasured polarity. The diatom biostratigraphy is used in conjunction with the tuff age to assign this interval to the Gauss normal chron. The Gilbert-Gauss transition is identified at $c a .139 \mathrm{~m}$ depth in the core at the same horizon as the ${ }^{10} \mathrm{Be}$ age of $3.2 \pm 0.4 \mathrm{Ma}$. Two intervals of reversed polarity are identified near the centre of this interval (122-128 $\mathrm{m}$ depth), and are assigned to the Kaena and Mammoth events. In the upper Gauss normal chron, several short intervals of reversed polarity are identified. Similar events are recognised in the South Wanganui Basin sequences (see section 4) and in many other Pliocene sequences (e.g. Liddicoat et al., 1980 and Ronai, 1981). The resolution in this study prevents correlation of these short scale polarity excursions.

\section{Matuyama Epoch}

The base of the Matuyama Epoch is recognised at a depth of $c a .122 \mathrm{~m}$ in the core. The interval from $c a$. 64-122 m depth has predominantly reversed polarity. It includes the top of Harwood's (1986) diatom Denticulopsis hustedtii partial range zone (at $105 \mathrm{~m}$ depth) dated at ca. $2.5 \mathrm{Ma}$. and a ${ }^{10} \mathrm{Be}$ age of $1.7 \pm 0.2$ $\mathrm{Ma}$. at ca. $79 \mathrm{~m}$ depth. The ${ }^{10} \mathrm{Be}$ age dated horizon occurs in the centre of a large normal interval (72-83 $\mathrm{m}$ depth), which is identified as the Olduvai event.

The lower part of the CIROS-2 core (units $\mathrm{C} 1$ through $\mathrm{C} 4$ ) is correlated with the upper Opoitian Stage (early middleupper Pliocene). Units C5 through C8 represent the Waitotaran superstage (upper Pliocene). The base of the Nukumaruan is correlated with the boundary between units $\mathrm{C} 8$ and $\mathrm{C} 9$.

\subsubsection{The DVDP-11 record}

\section{Magnetozones}

The magnetozones reported by Purucker et al. (1981) are adopted here, along with the two further magnetozones identified by Ishman and Rieck (1993). Purucker et al. (1981) assessed individual sample 
reliability using the Koenigsberger ratio (Stacey and Banerjee, 1974), and samples were accepted or rejected accordingly in assigning magnetozones to the DVDP-11 core. Accordingly in the present study; 11 normal polarity zones and 11 reversed polarity zones are adopted (figure 9.4).

\section{Correlation to the magnetic polarity} timescale (figure 9.5)

Ishman and Rieck (1993) assign magnetozones R7 and N7 to chron 5 of the International Timescale. Magnetozones R8 through R11 are assigned to the lower half of the Gilbert reversed Chron. The Sidjuveld magnetosubchron they infer to be missing in their hiatus $\mathrm{H} 1$ at $242 \mathrm{~m}$ subsurface depth. The upper half of the Gilbert Chron they infer to be missing in their $\mathrm{H} 2 / \mathrm{H} 3$ hiatus. Magnetozone N11 above the hiatus they correlate with the upper part of the Gauss normal chron. Strata including Magnetozones R12 through R14 they assign to the Matuyama chron and the remaining strata to the Brunhes Normal Chron. The two Beryllium- 10 ages of $3 \pm 0.5 \mathrm{Ma}$. and $6 \pm$ $0.5 \mathrm{Ma}$. for $210 \mathrm{~m}$ and $325 \mathrm{~m}$ subsurface depth respectively (see chapter 8) corroborate the age assignments of Ishman and Rieck (1993). Consequently, they are adopted here.

The base of the DVDP-11 core is correlative with the lowermost Kapitean stage. Units D1-D7 comprise the Kapitean Stage (latest Miocene). The
Opoitian Stage (Early Pliocene) is represented by units D8 through D15. The remaining pre-Late Pliocene portion of the core (units D16-D19) comprise much of the Waitotaran superstage. The base of the Nukumaruan Stage occurs slightly above the base of unit D20.

\subsection{Discussion and correlation}

Several conclusions can be drawn from correlation of the CIROS-2 and DVDP11 core magnetostratigraphies with the polarity timescale. The record of sedimentation in both cores is subcontinuous, with less than $20 \%$ of total time missing in the recognised unconformities (figures 9.3 and 9.5). Two major unconformities were recognised in the DVDP-11 core by Ishman and Rieck (1993) at $202 \mathrm{~m}$ $(\mathrm{H} 2 / \mathrm{H} 3)$ and $242 \mathrm{~m}(\mathrm{H} 1)$ depth. These are dated at 2.9-3.7 m.y. and 4.3-4.6 m.y. respectively. Three pre-Late Pliocene unconformities are recognised in the CIROS- 2 core. The first is the base of the core at $c a .166 \mathrm{~m}$ that unconformably overlies Granite Gneiss basement. This is dated at pre $4.1 \mathrm{Ma}$. and is correlated with the $\mathrm{H} 1$ unconformity in the DVDP11 core (figure 9.6). The other two unconformities identified in the CIROS-2 core occur at ca. $110 \mathrm{~m}(\mathrm{H} 3)$ and $140 \mathrm{~m}$ (H2) and are dated at 2.4-2.5 m.y. and 3.4-3.8 m.y. respectively. Unconformity $\mathrm{H} 3$ is correlated with the $\mathrm{H} 2 / \mathrm{H} 3$ hiatus in the DVDP-11 core reported by Ishman and Rieck (1993). 

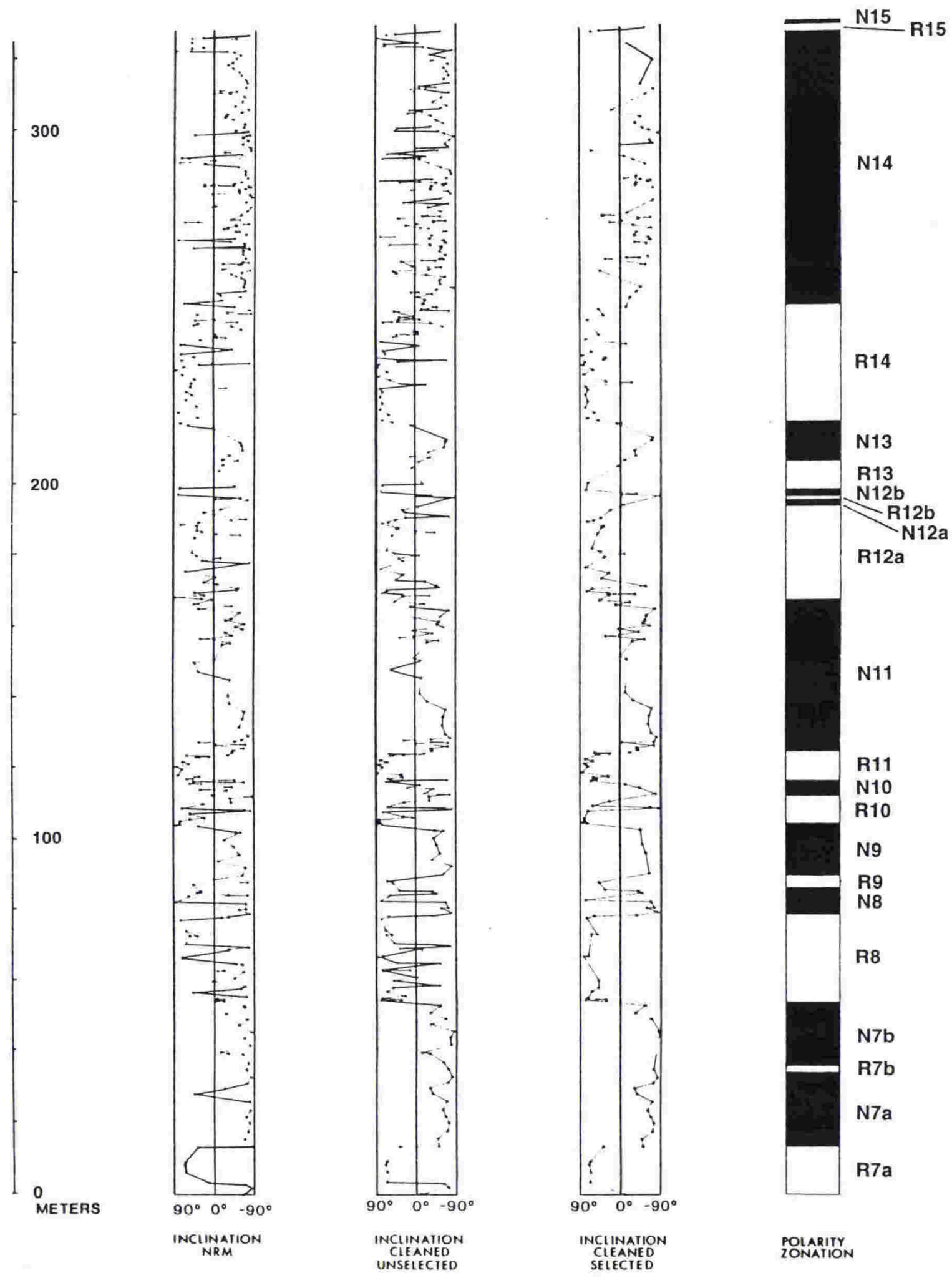

Figure 9.4: DVDP-11 polarity magnetozones as assigned by Ishman and Rieck (1993) and this study. These are annotated for reference in the text. $\mathrm{N}$ labelled magnetozones are of normal polarity, $\mathrm{R}$ labelled magnetozones are of reversed polarity, and $\mathrm{T}$ labelled magnetozones are of transitional polarity. Magnetogram data are from Purucker et al. (1981) and Ishman and Rieck (1993). 


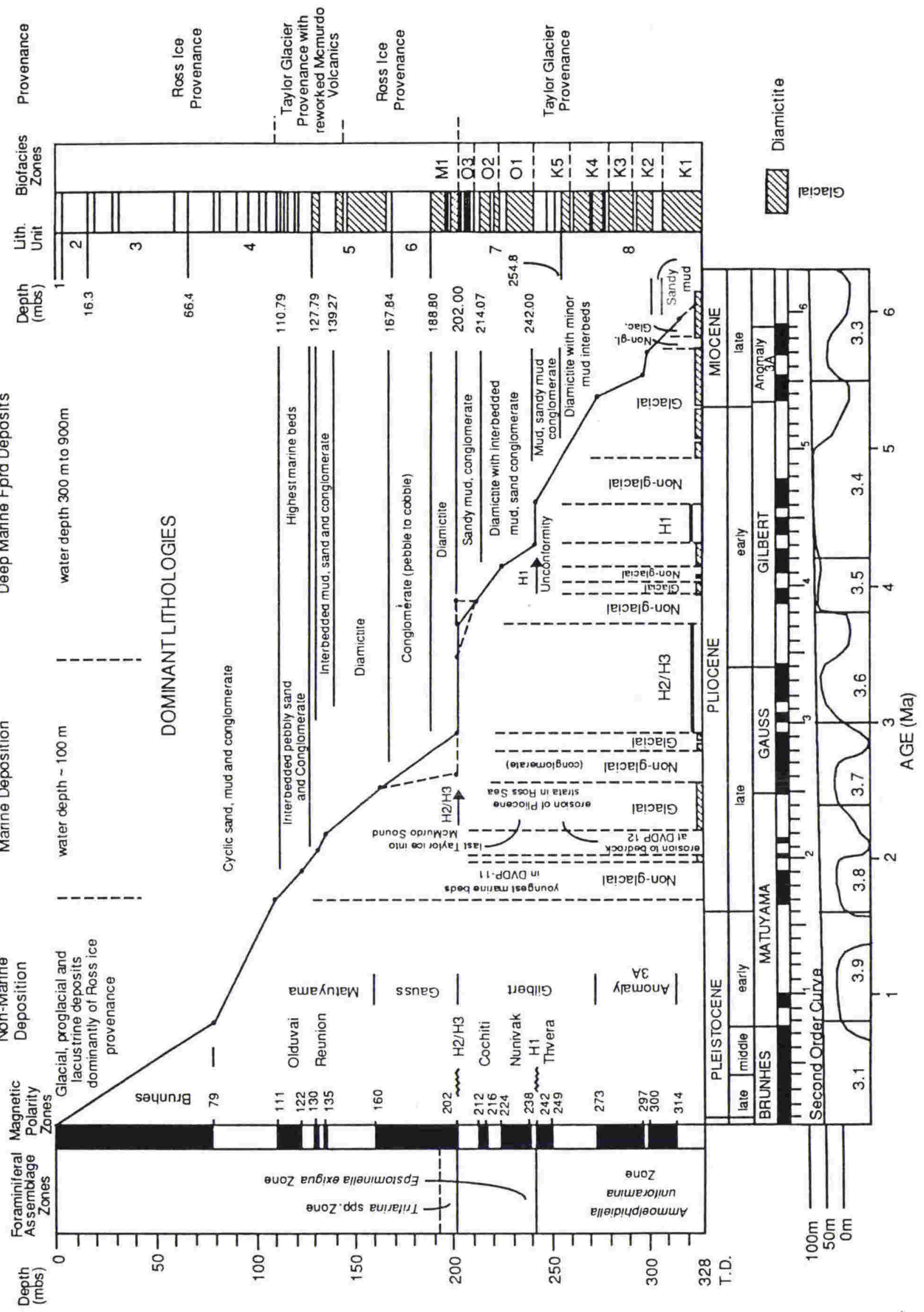

Figure 9.5: Correlation of the DVDP-11 magnetozones with the polarity timescale of Ness et al. (1980), showing the depositional history of the core (from Ishman and Rieck, 1993). Plot is drawn to shoe the average sedimentation rat of the CIROS-2 strata and identify breaks in deposition. 


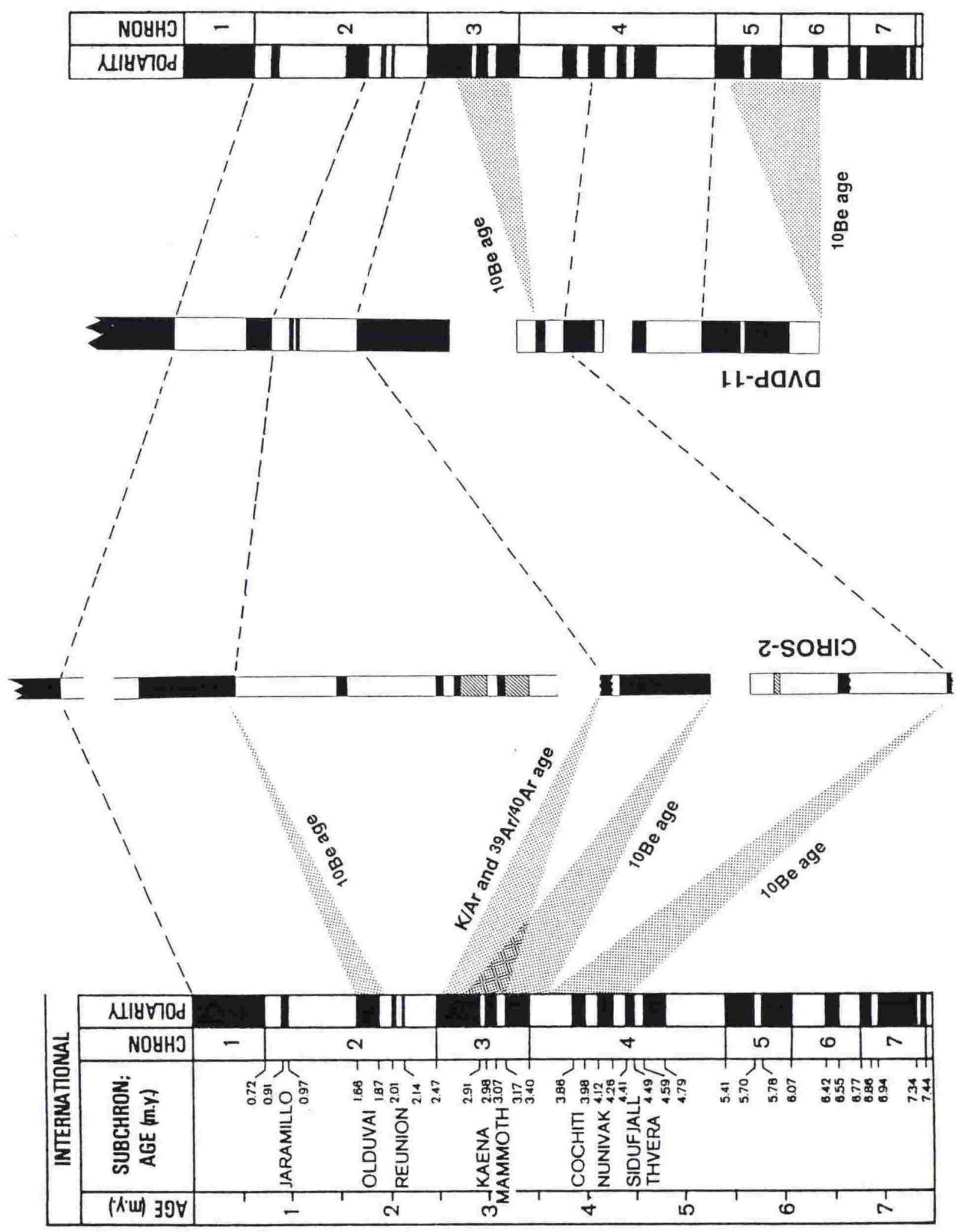

Figure 9.6: Summary of correlations of the CIROS-2 and DVDP-11 cores using magnetostratigraphy and radiometric age data. Plot allows easy identification of several reversal boundaries in the sections and consequently a high resolution of chronology of the strata. 
Units $\mathrm{C} 1-\mathrm{C} 4$ are correlated with units D12-D16. These two successions comprise Group $\mathrm{C}$ as identified in chapter 4. Group D is likewise correlated between the two cores. however, the individual unit correlations are not clear (figure 9.6). 


\section{SECTION - 3}

\section{THE RECORD IN THE WANGANUI BASIN}

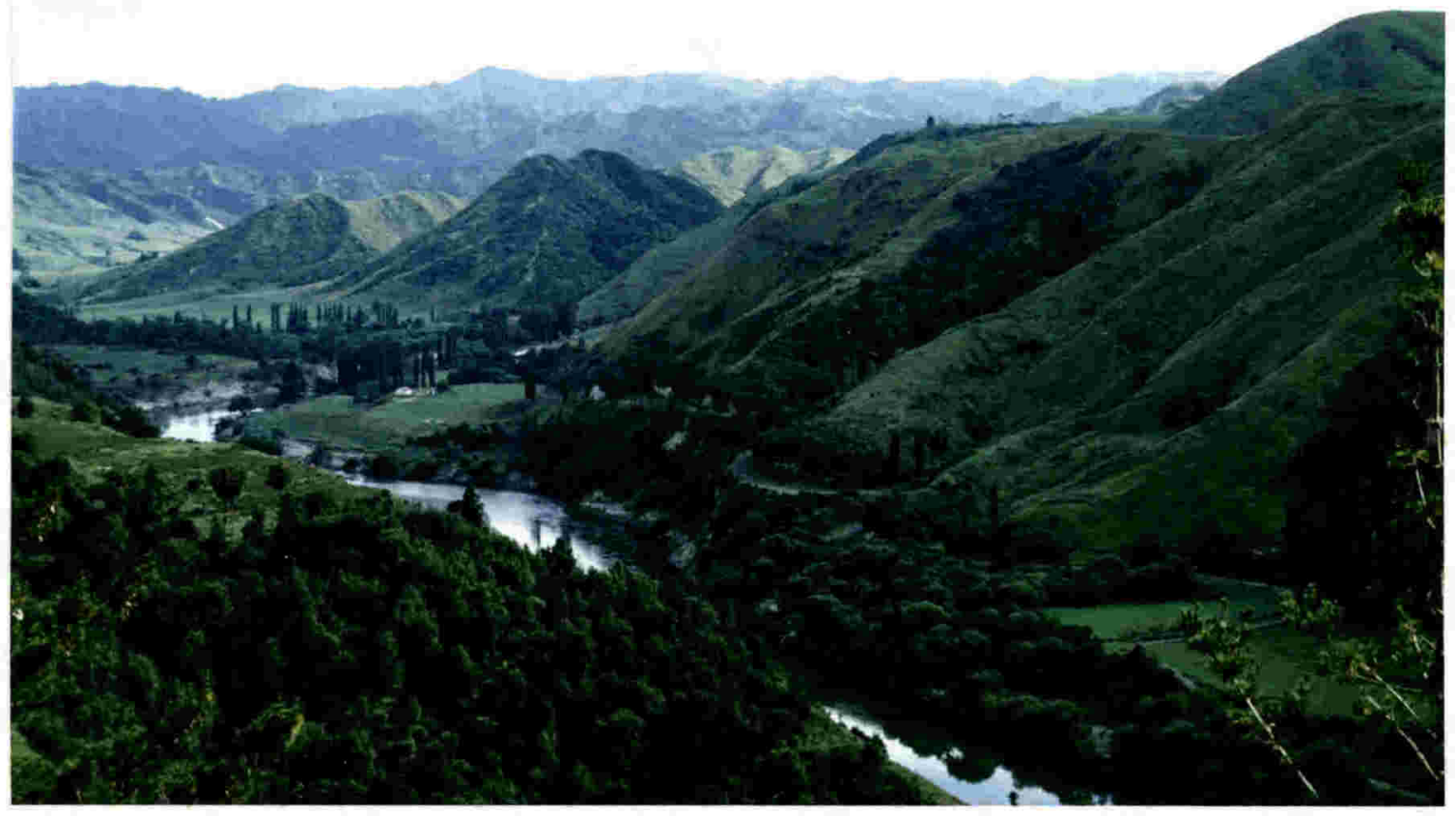

View of the Wanganui River Valley from the south. The Wanganui River Road is in the foreground.

Chapter - 10: Introduction

Chapter - 11: Stratigraphy

Chapter - 12: Age and correlation

Chapter-13: Facies analysis

Chapter - 14: Sequence Stratigraphy

Chapter-15: Late Neogene eustatic sea level history 


\section{Chapter - 10 \\ Introduction}

Section 3 provides detailed observations of the Late Miocene and Pliocene siliciclastic middle to shallow marine strata of the South Wanganui Basin. The strata comprise marine mudstones, sandstones, shell beds, and occasionally conglomerates. These lithofacies types indicate mid.-outer shelf to shoreface depositional environments with marked lithological variation along strike reflecting proximal to localised sediment sources. Chapter 11 presents the stratigraphic framework for interpretation and chapters 13 and 14 the facies and sequence stratigraphic models for interpreting the depositional history. The Late Neogene sea level record interpreted from the South Wanganui basin Strata is presented in chapter 15, chronology for the record is presented in chapter 12 . Geologic maps of the strata cropping out in the Wanganui and Rangitikei River Valleys are presented as enclosures 1 and 2 respectively. This introduction includes an explanation of the tectonic and lithospheric evolution of the North and South Wanganui Basin. A southward progressing lithospheric wave model is adopted and is crucial to interpretation of the sequence stratigraphic elements of the South Wanganui Basin strata.

\section{1 - Introduction and aims}

The aim of this section of the thesis is to present a high resolution record of eustatic sea level variation. This has required development of new chronology for the South Wanganui Basin strata (presented in section 4). Sub aims of this section were 1) create a working lithostratigraphic framework for field identification, interpretation and dating of the Wanganui and Rangitikei River strata; 2) Develop a model of sequence stratigraphic development that allowed a detailed interpretation of eustatic sea level. This required 3) development of facies models so that interpretation could be based directly on stratigraphic outcrop.
Three sections were chosen to study the South Wanganui Basin. Those cropping out in the Wanganui and Rangitikei River Valleys and in the Turakina River Valley at Hautawa Road (plate 10.1).

The latest Miocene (Kapitean) was a time of low eustatic sea level in New Zealand (Roberts, 1990; Edwards, 1987). Therefore, it was thought useful to include enough of the Kapitean Stage of the Wanganui Basin strata to establish the nature of sedimentation in the late Miocene. The base of the section was chosen as the fossiliferous conglomerate cropping out at the Mangaparua Landing, north of Pipiriki. The top of the section was chosen as the Hautawa Shell bed incorporating the first occurrence of the cold water species Chlamys delicatula 
(Fleming, 1953). This was thought to be young enough to include strata indicative of a possible change in oceanic conditions coincident with the postulated late development of the Antarctic ice sheet (Webb et al., 1984). An added advantage with the Hautawa Shell Bed marking the top of the section was its basin-wide occurrence.

The Hautawa Road section was chosen to gain a better definition of the strata surrounding the Hautawa Shell bed, as exposure in the Wanganui river becomes limited above the Wilkies Shell Bed.

The Rangitikei River section from basement to the Hautawa Shell bed was chosen to help corroborate the eustatic sea-level interpretation from the more extensive Wanganui River Section.

\subsection{Fieldwork Methods}

The Wanganui River section was mapped in two different ways; The upper reaches beyond Pipiriki were mapped entirely from the river. Initially an aluminium dingy was used for access and later a jet boat was used. The lower reaches of the river were mapped from continuous cuttings in the Wanganui River Road. The Hautawa Road section was also mapped from road cuttings. The Rangitikei River section was mapped from the river using a jet boat.

Each section was continuously sketched into field notebooks, recording local measurements of thin units and localities of contacts of larger units. Each locality was recorded on the map and an altitude

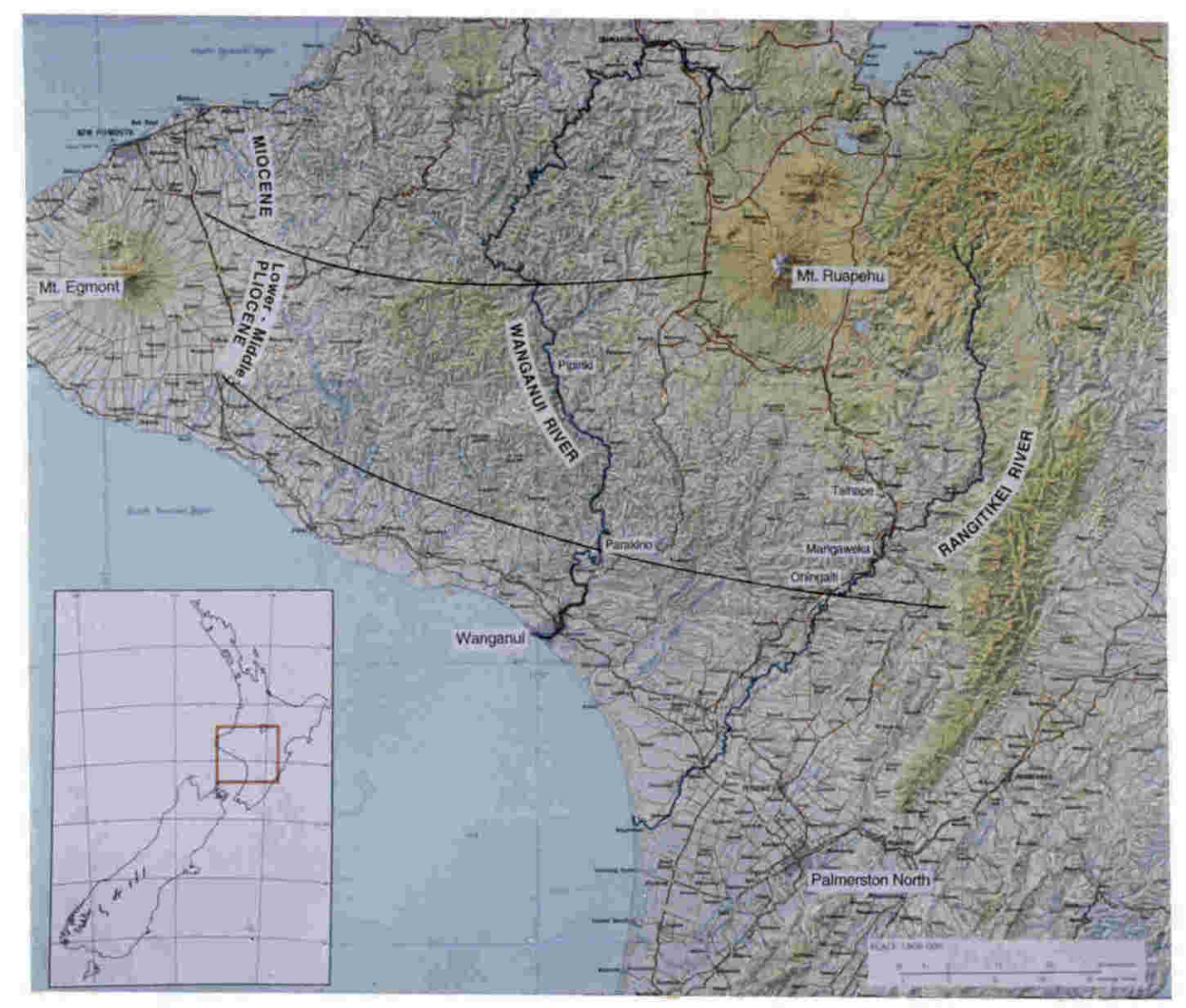

Plate 10.1: Location map of the South Wanganui Basin. The major sections studied include those cropping out in the Wanganui and Rangitikei River valleys. The MiocenePliocene boundary is shown towards the north of the basin and the Hautawa Shell bed separating Middle and Upper Pliocene strata and also marking the top of the section studied here, is shown to the south. 
recorded using a surveying altimeter for later calculation of exact thicknesses of units, and complete sections. Surveying was tied to local bench marks (in the Wanganui River), trig heights and spot heights on the NZMS 260 series maps. Pressure fluctuations were accounted for by assuming linear drift between benchmark measurements.

In the Wanganui River the base map used was a 1:10,000 scale map prepared by Electricorp for possible hydro development of the River. In the Hautawa Road and Rangitikei River sections 1:25,000 scale preparation maps for NZMS 260 series maps were used. The shallow dip angles of the strata in the basin limit the accuracy of stratigraphic thickness measurements to $\pm 3 \mathrm{~m}$.

Where formational definitions did not already exist or observed lithology did not fit into the existing definition, strata were mapped as lithologic units, for later definition or redefinition into groups and formations. Due to the cyclic nature of sedimentation, already recognised by Ker (1973), and the differences in thicknesses and distribution observed, this proved to be easier than initial definition of formal units before logging the strata.

\subsubsection{Tectonic setting}

The North Island of New Zealand forms part of the Australia - Pacific subduction zone, with subduction and shortening occurring within the Central North Island
Axial Tectonic Belt (Walcott, 1978) (figure 10.1). West of this Belt Stern and Davey (1989) recognise two distinct sedimentary basins. One is the Central Volcanic Region (including the North Taranaki Basin, North Wanganui Basin and the Taupo Volcanic Zone), to the north, where the subducted slab is 300 $\mathrm{km}$. deep. Here a high heat flow extensional back arc basin extends from the Axial Tectonic Belt in the east to beyond Mount Taranaki in the west. To the south, is the Wanganui Basin, where the subducted slab is only $200 \mathrm{~km}$ deep. The Wanganui Basin is a much younger compressional basin, between the Axial Tectonic Belt to the east and the PateaTongaporutu High in the West.

The Wanganui Basin of Stern and Davey (1989) is equivalent to the South Wanganui Basin discussed by Anderton (1981) (hereafter referred to as the South Wanganui Basin). The North Wanganui Basin (Anderton, 1981) is now extensional and is more part of the Central Volcanic Region than the South Wanganui Basin (figure 10.1).

Stern et al., (1992) argue that the South Wanganui Basin is developing from lithospheric downwarp as a response to high friction at the plate interface. Here, in a tectonically compressional regime, a sedimentary basin is developing as the Australian Plate is "locked" against the subducting Pacific Plate. This type of basin is ephemeral and not generally seen in the geologic record because later development of the subduction zone 


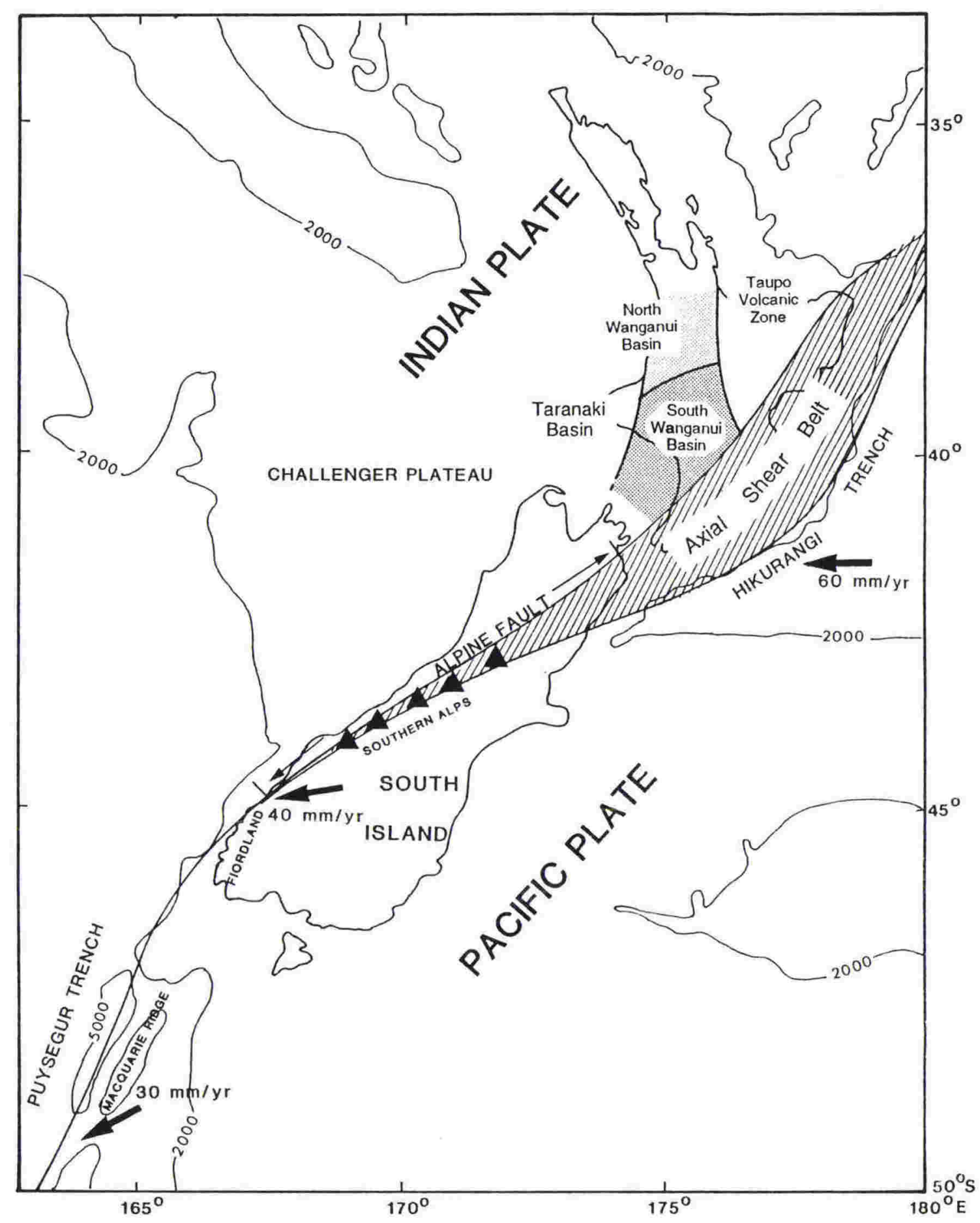

Figure 10.1: Map of New Zealand, showing the location of the Indian-Pacific plate boundary (The axial shear belt, after Walcott, 1978). Velocity vectors represent the relativt motion of the Pacific plate assuming the Indian plate fixed (Stern et al., 1986). Location of the North and South Wanganui Basins, Taranaki Basin and Taupo Volcanic Zone are shown (figure modified from Stern et al., 1986).

overprints the earlier forms of basin development. A zone of uplift, currently centred between Mount Taranaki and Mount Ruapehu (here referred to as the Wanganui Hinge Zone), marks the boundary between the Central Volcanic Region and the South Wanganui Basin. Controlled by the south eastward moving subduction zone (Walcott, 1984), this hinge zone also marks the change in 
tectonic regime, from extension in the north to compression in the south.

In late Miocene times the North Wanganui Basin was also a lithospheric downwarp basin, with sedimentation patterns similar to those of the Pliocene South Wanganui Basin (Stern et al., 1992). During the Late Neogene, the point of maximum sediment accumulation rate and hence the basin centre has moved south eastward (Anderton, 1981) in front of the southward progression of the up warping Wanganui Hinge Zone (figure 10.2). Regional faulting patterns bear out the present tectonic state of the basins, with primarily thrusting in the area south of the Wanganui Hinge Zone and normal faulting north of the Hinge Zone.

Stern et al. (1992) describe the structure of the North and South Wanganui Basin as a progressive, southward travelling, "Lithospheric-wave" with a wavelength of about $200 \mathrm{~km}$ and a period in the order of $20 \mathrm{My}$ (figure 10.2). If so; the late Miocene and Pliocene basin structure would be very similar to the present, with the Wanganui Hinge Zone further to the north and the basin progressing southwards at $10 \mathrm{~km} / \mathrm{My}$. Sediments offlap from the north and onlap to the south throughout the Neogene. Sedimentation in the basin has been very rapid $(\sim 1 \mathrm{~km} / \mathrm{My})$ with sediment accumulation keeping pace with basin downwarp.

\subsubsection{The South Wanganui Basin.}

The South Wanganui Basin is approximately $40,000 \mathrm{~km}^{2}$ in area (figure 10.1), and contains sediment more than 4 $\mathrm{km}$ thick at it's centre (Anderton, 1981). Half the basin lies offshore beneath the

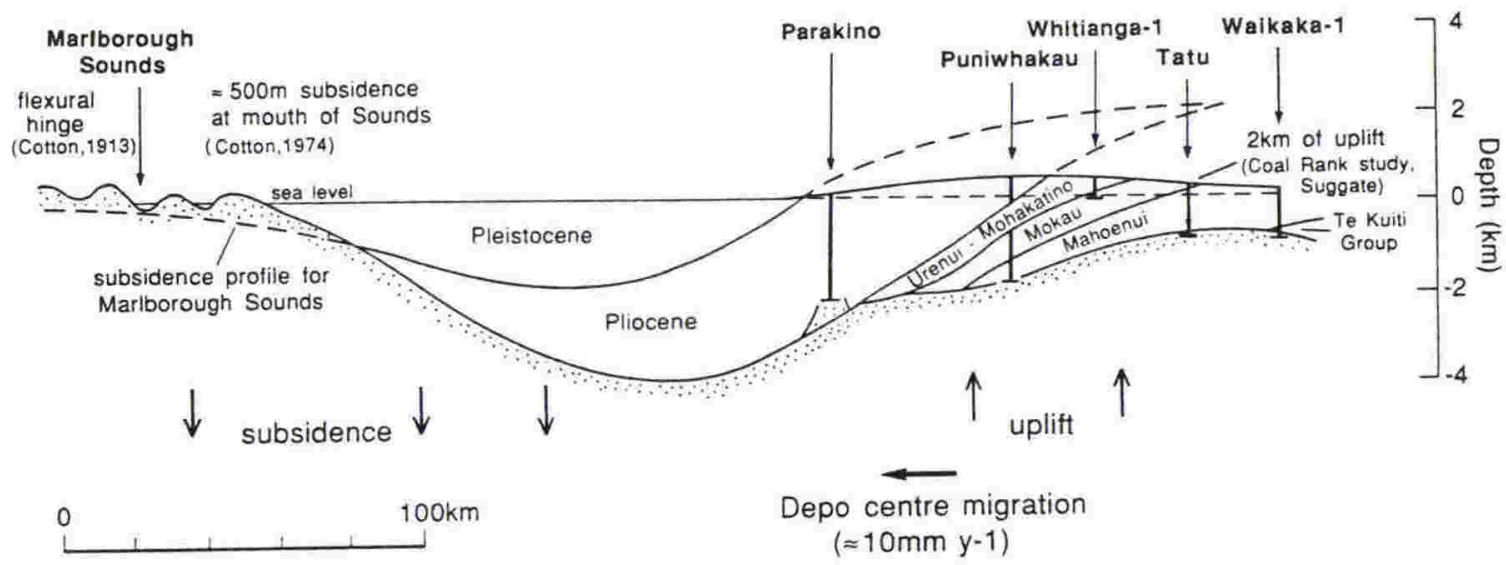

Figure 10.2: Cross-section of the southward progressing lithospheric wave. Profile runs from south (left) to north. Centre of the figure is the presently subsiding South Wanganui Basin and right hand side of figure is the presently uplifting Wanganui Hinge Zone (from Stern et al., 1992). 
Wanganui Bight. The exposed portion of the basin is deeply dissected by rivers, with the largest and longest drainage systems being the Wanganui and Rangitikei Rivers.

The oldest strata in the South Wanganui Basin are earliest Pliocene. Strata of Late Miocene age, formerly part of the South Wanganui Basin, are now being uplifted within the Wanganui Hinge Zone. The youngest on-land strata in the basin are Late Quaternary marine terrace deposits cropping out along the Wanganui coastline. Strata of the North Wanganui Basin are Oligocene and Miocene in age (Hay, 1978) and directly underlie strata of the South Wanganui Basin.

Outcropping strata in the Wanganui and Rangitikei Rivers provide the two main sections for the present study (plate 10.1). Additional stratigraphic information was obtained from a short section near Otairi in the Turakina River Valley. Strata exposed alongside the Wanganui River are mainly muddy sandstones and sandy mudstones with occasional siltstones containing rare interbedded shell beds and thin, well cemented, coquina limestones. These strata represent both the fastest average sedimentation rate throughout the Late Neogene and the most complete record of sedimentation in the South Wanganui Basin. The Wanganui River provides outcrop of strata from Kapitean to Hautawan in age (ca. 6.0 to $2.5 \mathrm{Ma}$., Edwards et al., 1988) more than $4,300 \mathrm{~m}$ thick.
Close to the eastern margin of the basin, strata of Opoitian age rest unconformably on Mesozoic Greywacke basement. Further to the north older strata are preserved beneath a cover of Quaternary volcanic rocks of the Taupo Volcanic Zone. The Rangitikei River provides continuous outcrop of Opoitian and younger marine siltstones and muddy sandstones, with occasional interbedded sandy mudstones and rarer shell limestones. The average depositional rate was slower than that towards the basin centre and the geological record less complete. The studied section is more than $1,700 \mathrm{~m}$ thick excluding $270 \mathrm{~m}$ of section repeated across the Rauoterangi fault (enclosure 2). Strata exposed in the Rangitikei River are not individually correlated with strata cropping out in the Wanganui River. Localised sedimentation patterns created lateral facies and sedimentation rate variations that have caused biostratigraphic marker horizons to be time-transgressive and make east-west basin correlation difficult. In the South Wanganui Basin it is difficult to correlate strata for more than $20 \mathrm{~km}$, whereas in the North Wanganui Basin, strata can be correlated for more than $100 \mathrm{~km}$ (Morris, in prep.).

\subsubsection{Structure.}

Outcrop in the Wanganui and Rangitikei River sections is continuous with few structural complications. Occasionally strata are disrupted by high angle eastwest trending thrust faults with offsets on the order of $10 \mathrm{~m}$. Larger scale northeast- 
southwest thrust faults are more common in the eastern part of the basin, associated with the emergent Ruahine and Kaimanawa ranges at the basins eastern margin. One such fault, the Rauoterangi Fault (referred to as the Omatane Fault by Seward et al., 1986 and Feldmeyer $e t$ $a l, 1943$ ) (enclosure 2) repeats $270 \mathrm{~m}$ of strata cropping out in the Rangitikei River.

The emergent Wanganui Hinge Zone is causing a regional southerly tilt of strata within the basin. Tilt increases from $4^{\circ}$ in the south to $>10^{\circ}$ at the north easternmost edge of the South Wanganui Basin. Stern et al. (1992) argue that a maximum of $6^{\circ}$ tilt can be caused by the lithospheric downwarp. Melhuish (1990) suggests that the exaggerated tilt in the north eastern South Wanganui Basin is due to the added effect of uplift of the Tararua Ranges at the eastern margin of the Basin.
In the Rangitikei River Valley larger scale southeast-northwest thrust faults are associated with the emergent ranges to the east. Unlike the consistently southward dipping strata exposed in the Wanganui River, Opoitian and Waipipian strata in the Rangitikei River Valley are being folded into a series of broad southwest trending anticlines and synclines within the regional southerly tilt. Dips range from horizontal to $15^{\circ}$ in a southwesterly direction. Occasionally small monoclinal structures are observed in the Rangitikei River Valley, where local thrusting in the basement does not pervade to the surface and younger sediments drape over the basement structure. Further to the south, strata cropping out in the Rangitikei River Valley are less disrupted by the emergent ranges and have a constant dip, more consistent with that of the Wanganui River Valley strata. 


\section{Chapter - 11 Stratigraphy}

In this chapter, a new lithostratigraphic framework is established for the Late Neogene strata of the South Wanganui Basin. It is based mainly on the work of Fleming (1953) and Feldmeyer et al. (1943). Formal units of lithostratigraphy are proposed, in line with the North American Stratigraphic code, adopting where appropriate, units previously defined by Fleming (1953), Te Punga (1952) and Ker (1973). A particular effort is made to bridge the gap between previous work in the North Wanganui Basin and work in the South Wanganui Basin. North Wanganui Basin stratigraphy is delimited on a broad scale using reconnaissance definition of units mappable basin wide. South Wanganui Basin stratigraphy is delimited on a fine scale observing individual beds and their significance and grouping them accordingly. The present study maps and defines rocks that are contiguous to both these approaches and appropriate working definitions of the stratigraphy are established. While this account is unpublished it is anticipated that results presented here will also be published and accordingly a formal approach to stratigraphic amendment and establishment is adopted.

\subsection{Stratigraphic nomenclature of the South Wanganui Basin Sequences}

The first subdivision of strata in the South Wanganui Basin was by Park (1910), when he defined the Wanganui System. Much of Park's classification deals with Pleistocene Strata (He refers to it as "Newer Pliocene"). However, the "Older Pliocene" Waitotara and Awatere Series, including the Waitotara, Waverley and Patea Beds, are of PrePleistocene age.

The most wide ranging examination of pre-Pleistocene strata in the South Wanganui Basin was undertaken by the Superior Oil Company from 1939-1943 (Feldmeyer et al., 1943; Turner, 1944).
They subdivided the Pliocene Strata into three stages, Waitotaran, Nukumaruan and Castlecliffian, based on observations in the Rangitikei River, informally recognising four formations in the Waitotaran, two in the Nukumaruan and one in the Castlecliffian.

The most complete study to date on strata of the South Wanganui Basin is the Bulletin of Fleming (1953). He proposed a stratigraphic nomenclature more in line with the American Stratigraphic Code (North American Commission on Stratigraphic Nomenclature, 1983), suggesting a subdivision of the Pliocene strata in to two series; the Wanganui Series and the overlying Hawera Series. Within the Wanganui Series Fleming (1953) retained the three stages of 
Feldmeyer et al. (1943) and subdivided each into 2 substages.

Fleming considered the Waitotaran to be Pliocene and perhaps some of the Nukumaruan, but he was unsure of where the Plio-Pleistocene boundary lay. Beu (1969) raised the Mangapanian and Waipipian to stages, retaining the Waitotaran as a superstage for areas where the Mangapanian and Waipipian can not be easily defined.

Beneath the Okiwa Group (Fleming, 1953) in the Rangitikei River Valley, Te Punga (1952) recognised the Nukumaruan and Waitotaran Stages within the Rangitikei group. Without reference to Turner (1944) and Feldmeyer et al. (1943), he defined two formation equivalents to these stages, the Middle Rangitikei and Lower Rangitikei Formations respectively (figure 11.1). Within the Middle Rangitikei Formation he recognised 4 distinct lithologic units and within the Middle Rangitikei Formation 6 distinct lithological units, but did not formally name them. Seward (1974) and Seward et al. (1986) recognised the lithologic units of TePunga (1952) using the informal formation names of Turner (1944) to define these rather than as members of the Lower Rangitikei Formation (figure 11.1). Informal formation names used were; Mangaweka Mudstone, Utiku Sand, Taihape Mudstone and Reef Bearing Sands. Fleming (1959) had already renamed the Reef Bearing Sands in the Rangitikei River as the Waiouru Sandstone.

Fleming (1953), working further to the west in the Wanganui Subdivision, proposed 3 groups for the Pliocene strata of the Wanganui Basin that he examined: The Okiwa group within which he defined 5 formations and observed many others that he did not differentiate (figure 11.2); the Paparangi Group (Fleming, 1953), including four formations and the Whenuakura Group (Fleming, 1953) also including four formations. Both the work of Te Punga (1952) and Fleming (1953) present very much a reconnaissance observation only of the pre-Nukumaruan strata they defined.

Two further workers have provided more complete definition of Pliocene strata exposed in the Wanganui River. Collen (1972) used the stages of Beu (1969), but retained the Hautawan Stage of Fleming (1953). He informally recognised six formations. Ker (1973) independently of Collen (1972) proposed 5 new formations of the Whenuakura Group (Fleming, 1953) (figure 11.2), based largely on the work of Feldmeyer (1943). $\mathrm{He}$ also proposed the use of three formations within the Paparangi Group (figure 11.2). Collen (1972) also worked in the Rangitikei River Valley informally recognising the lithologic units of TePunga (1952) as formations (figure 11.1). Above the basal unit; Waiouru Sandstone (Fleming, 1959) he recognised four formations; the Taihape Mudstone, Utiku Sandstone, and Mangaweka 


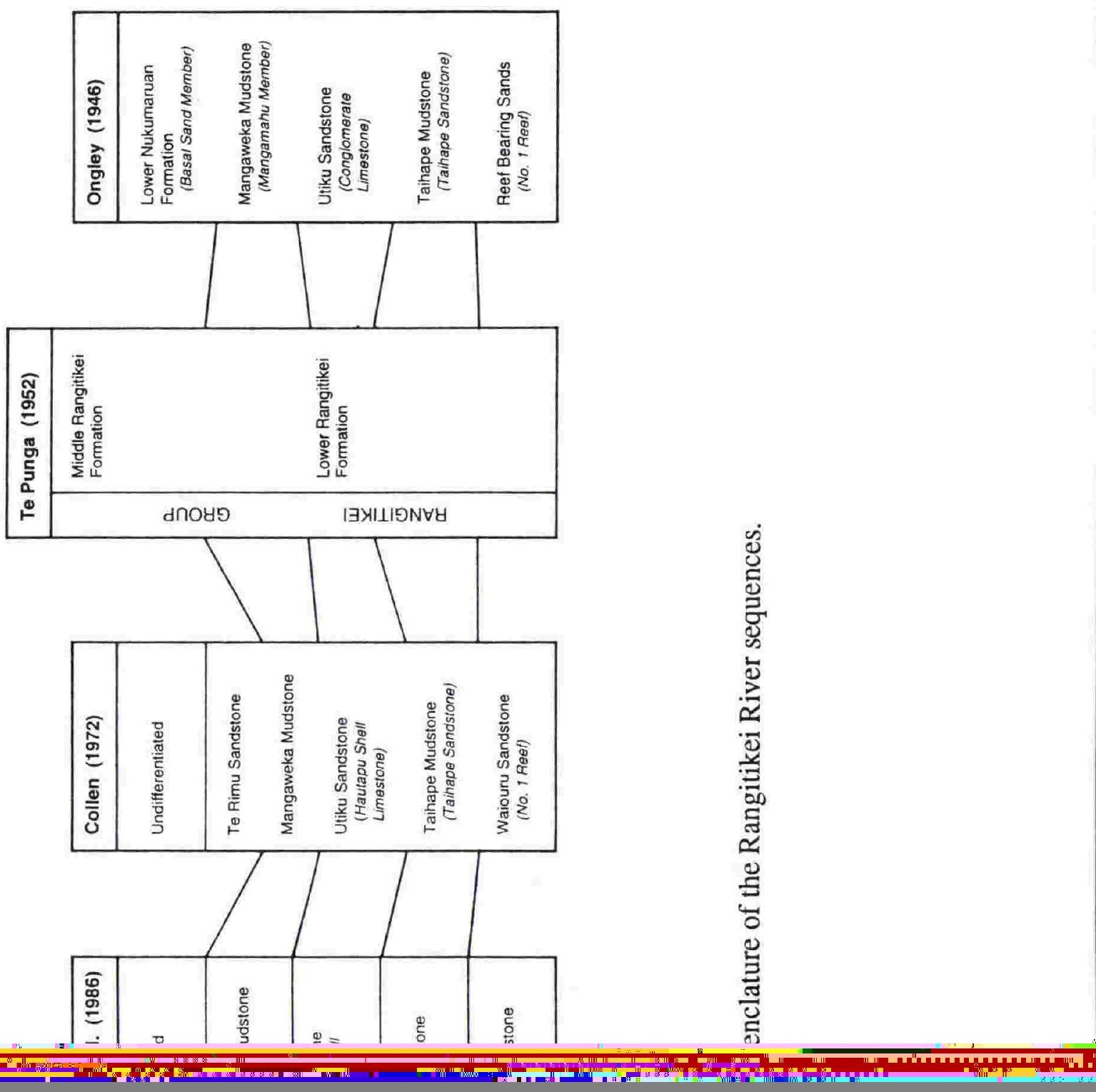




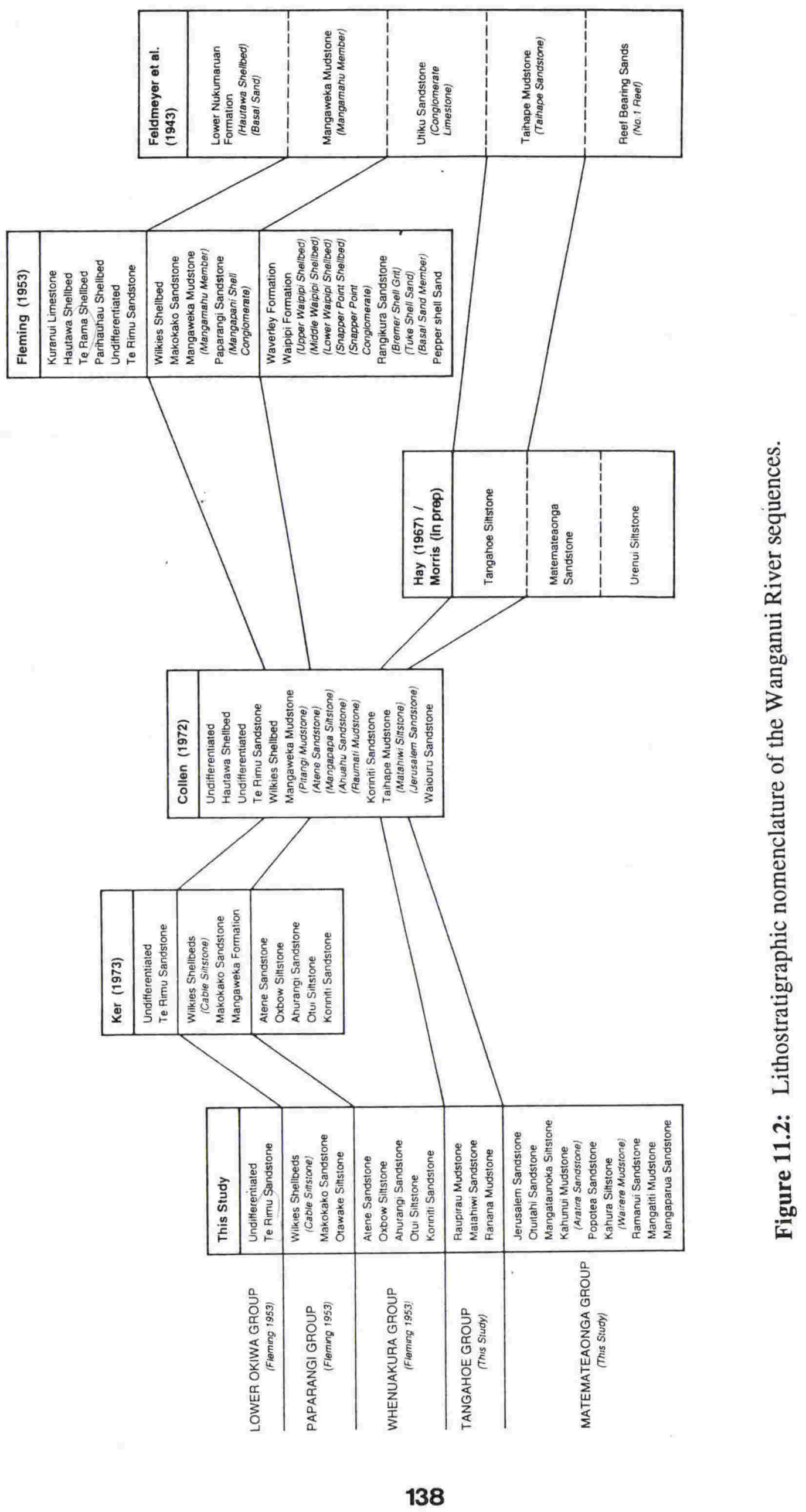


Mudstone respectively (after Te Punga, 1952) and beneath the undifferentiated formations of the Okiwa and Nukumaru Groups he recognised the Te Rimu Sand Formation. Fleming (1978) also recognised the informal units of TePunga (1952) as formations, however, he omitted the Te Rimu Sand. The Utiku Sandstone he further recognises as the Whenuakura Group and the Mangaweka Mudstone as the Paparangi Group above which he observes undifferentiated formations of the Okiwa Group. Fleming (1978) leaves the older formations of the Rangitikei River Valley not grouped. This formation nomenclature is based on informal names of Feldmeyer et al. (1943) and abandons the groupings of TePunga (1952).

Late Miocene and Opoitian strata to the north of the South Wanganui basin, have not been as extensively studied as in the south. Hay (1967) defined three formations; the Urenui Siltstone, the Matemateaonga Sandstone, and the Tangahoe Mudstone (figure 11.2). These replace the Waitotara formation of Morgan and Gibson (1927). Morris (in prep.) mapped the Matemateaonga Formation as far south as Jerusalem in the Wanganui River and to the Ruahine Ranges in the east where corresponds to the Waiouru Sandstone (Fleming 1959).

Underlying the Matemateaonga Sandstone and further to the north is the Urenui Siltstone. Morris (in prep.) recognised this cropping out north of the confluence of the Tangarakau and
Wanganui Rivers. It is not discussed further in this study. The Tangahoe Siltstone, first defined by Morgan and Gibson (1927) as the Urenui Beds, is mapped in various localities to the West of the Wanganui River. Equivalent strata crop out in the Wanganui River and to the east but have not been referred to as the Tangahoe Formation.

Morris (in prep.), in describing the Matemateaonga Formation, noted that many names and subdivisions have been used for this and juxtaposed formations, but that they are limited in geographical extent. He also noted the marked variation in vertical and lateral extent of different lithofacies included within the Matemateaonga Formation.

Following Fleming (1953), the present study continues in line with the North American Stratigraphic Code (North American Commission on Stratigraphic Nomenclature, 1983). A formation is defined as a body of rock identified by lithologic characteristics and stratigraphic position. It is prevailingly but not necessarily tabular and is mappable at the earth's surface. Groups are identified to express the natural relationships of formations. Groups are particularly useful in small scale mapping and stratigraphic analysis (North American Commission on Stratigraphic Nomenclature, 1983).

The groups proposed and used in this study (figures 11.1 and 11.2) are recognised across the South Wanganui 
Basin and into the North Wanganui Basin where applicable with older strata (figure 11.3). A major change proposed here is the abandonment of the Rangitikei Group of Te Punga (1952). This he defined in terms of time and grouping of stages rather than lithologies.

\section{Matemateaonga Group (New)}

(New definition, raised in status from Matemateaonga Formation (Hay, 1967) defined and mapped by Morris (in prep.) across the North and South Wanganui Basins as the Matemateaonga Sandstone). It is equivalent to the lower part of the Waitotara Formation of Morgan and Gibson (1927) and the Waiouru sandstone of Fleming (1959). It overlies the Urenui Siltstone of Hay (1967), and underlies the Tangahoe Group (newly defined here also). In the west formations are as yet undifferentiated. Morris (in prep.) in discussing the Matemateaonga Formation notes the marked lateral variation in facies, with each facies mappable on local to regional scales. He also defines stratotypes throughout the $>2000$ m thick formation including lithologies mappable in their own right. The same strata are observed in the present study and combined with observations of Morris (in prep.) warrant a group definition the Wanganui Basin, and establishment of formations in regions where necessary for more detailed study. In the Wanganui River the Matemateaonga Group includes formations below and including the Mangaparua Sandstone (defined here) to the top of the Jerusalem Sandstone (also defined here) Formations. Eleven formations are defined here within the Matemateaonga Group in the Wanganui River (figure 11.2). To the east in the Rangitikei River it includes the Waiouru Sandstone (Fleming, 1959) and all older strata. The top $100 \mathrm{~m}$ only of the Waiouru Sandstone is observed in this study.

\section{Tangahoe Group (New)}

(New definition, raised in status from the Tangahoe Formation (Hay, 1967)). The Tangahoe Group is equivalent to the Taihape mudstone of Fleming (1978) defined in the Rangitikei River Valley. It overlies the Matemateaonga Group and Underlies the Whenuakura Group (Fleming, 1953). Morris (in prep.) and Hay (1967), noted the thinness of the Tangahoe Formation and also noted the variability of lithology. Although the Group is recognised as a single formation in the Rangitikei River (Taihape formation of Fleming, 1953), in the Wanganui River it includes three formations (figure 11.2), from the base of the Ranana Mudstone, the Matahiwi Sandstone and the Raupirau Mudstone (all newly defined here). To the west no formations are differentiated, but Hay (1967) mentioned informal names of lithologies. Throughout the basin the group is predominantly fine grained in nature. 


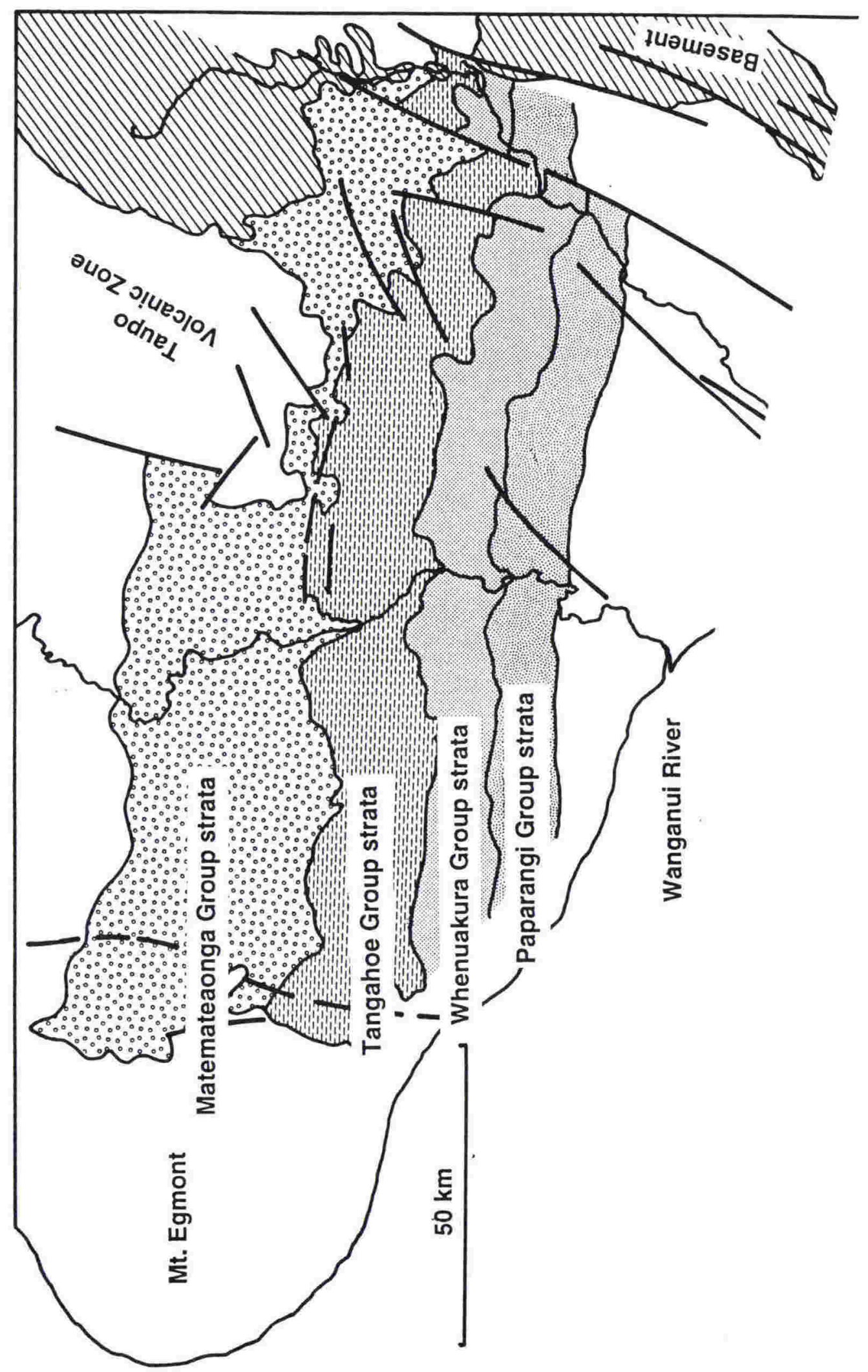

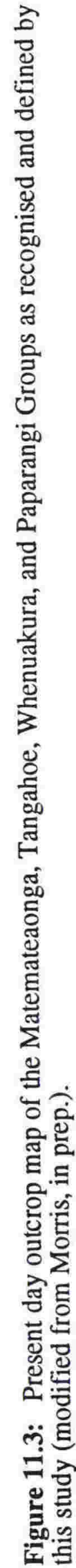


Whenuakura Group (Fleming, 1953)

(The base is redefined here) The Whenuakura Group overlies the Tangahoe Group and underlies the Paparangi Group (Fleming, 1953). In the Wanganui River the base of the Group is the Koriniti Sandstone (Ker, 1973) and the top is the Atene Sandstone (Ker, 1973). In the Rangitikei River Valley to the east the Whenuakura Group is mapped as the Utiku Sandstone (Fleming, 1953). It is variable in lithologic character. Fleming (1953) noted several formations that have been redefined by subsequent workers (Collen, 1972; Ker, 1972). Based on his type locality of the coastal section west of Wanganui, Fleming (1953) defined several members, mostly shellbeds. Further east in the Wanganui and Rangitikei Rivers lateral variation and different lithologies prevent identification and correlation of those members. The members are not discussed further here.

\section{Paparangi Group (Fleming, 1953)}

The Paparangi Group overlies the Whenuakura Group and underlies the Lower Okiwa Group (Fleming, 1953). Lithologically it is similar to the Whenuakura Group and is also variable in character, but is finer grained than the Whenuakura Group at places. In the Wanganui River it is defined as including all formations from the base of the Mangaweka Formation to the top of the Cable Siltstone Member of the Te Rimu
Sandstone Formation (Ker, 1973). In the Rangitikei River the Group is represented entirely by the Mangaweka Mudstone. Fleming (1953) defined many formation members at the type localities in the coastal section. Like the members of Formations he defined in the Whenuakura Group these are mainly shellbeds and difficult to correlate to inland sections. Unless prominent they are not adopted in the present study. Future work may add them to the stratigraphic framework proposed by the present study.

\section{Okiwa Group (Fleming, 1953)}

Only the basal part of the Lower Okiwa Group (Fleming, 1953) was observed during the present study. Fleming (1953) left this group undivided in terms of formations. Ker (1973) defined the Te Rimu Sandstone Formation the basal part being the Cable Siltstone member, which is within the Paparangi Group and the upper more sandy part is in the Lower Okiwa Group. The Hautawa Shell bed is defined as the unit that Fleming (1953) adopted as separating the Upper and Lower Okiwa Groups. Further West, the Kuranui Limestone is within the basal part of the Upper Okiwa Group. To the East in the Rangitikei River Valley several interbedded mudstone and sandstone horizons are recognised, within the Lower Okiwa Group, beneath the Hautawa Shell Bed. The uppermost unit observed in this study is the Ohingaiti Sand, above the base of the Upper Okiwa Group, and a possible 
eastern correlative of the Kuranui Limestone.

\subsection{Wanganui River Stratigraphy}

Formations are described in terms of lithology, thickness, nature and relation to underlying beds. Because only one section is observed here a type section is not designated, unless this has been already specified by previous workers. The description in the Wanganui River may be informally treated as a type section unless otherwise specified in the text. A type locality is specified for each formation and a grid reference given. Enclosure 1 shows the type locality for each formation and maps the outcrop, extent, and location of formations described and used in this study.

\section{Matemateaonga Group (New)}

The lower part of the Matemateaonga Group includes undifferentiated formations not described in this study.

\section{Mangaparua Sandstone Formation}

(New Formation, $93 \mathrm{~m}$ thick) Well sorted Sandstone that fines upwards. Pebbly and fossiliferous at its base with occasional muddy horizons. The mud content increases upwards. It unconformably overlies undifferentiated formations of the lower part of the Matemateaonga Formation. The type locality is designated here as the Mangaparua Landing (R20 796119), which is the origin of the name, on the Wanganui River $23 \mathrm{~km}$ north of Pipiriki.

\section{Mangatiti Mudstone Formation}

(New Formation, $304 \mathrm{~m}$ thick) Alternating mudstone and muddy sandstone, with mudstone predominant. The basal contact is gradational with the underlying Mangaparua Sandstone. Two prominent sandstone horizons crop out at about the middle of the formation. Description from bottom to top; mudstone, $51 \mathrm{~m}$; sandstone, $61 \mathrm{~m}$; mudstone, $54 \mathrm{~m}$; sandstone, $48 \mathrm{~m}$; mudstone, $90 \mathrm{~m}$. The sandstones are muddy and grey in colour. The mudstones tend to be silty with some sand, grey and fractured. The formation becomes more sandy towards its top. The Formation is named after a major tributary to the Wanganui River north of Ramanui Station. The Tangahoe Station's landing, $19 \mathrm{~km}$ north of Pipiriki is designated as the formations type locality ( $R 20$ 811085). The formation is cyclothemic, typical of the many formations in the Wanganui River (Ker, 1973).

\section{Ramanui Sandstone Formation}

(New Formation, $242 \mathrm{~m}$ thick) Well sorted slightly muddy sandstone with a muddy bed $41 \mathrm{~m}$ above the base of the formation. The base is a gradational contact with the underlying Mangatiti Formation. Description from bottom to top; sandstone, $41 \mathrm{~m}$; muddy fine sandstone, $28 \mathrm{~m}$; sandstone $173 \mathrm{~m}$. The 
top of the formation is a prominent $3 \mathrm{~m}$ thick reef horizon; a well cemented sandy horizon of Crassostrea shells. The formation is named after Ramanui Station on the Wanganui River. The type locality is designated here as in the sandstone cliff at the southern end of the station opposite Tieke $\mathrm{Pa}, 15.5 \mathrm{~km}$ north of Pipiriki (R20 815048). The muddy sandstone horizon crops out at the Station Landing.

\section{Kahura Siltstone Formation}

(New Formation, $191 \mathrm{~m}$ thick) A decimetre bedded grey muddy siltstone, that coarsens towards its top over $5 \mathrm{~m}$. The Formation is named after the Kahura Station on the Wanganui River, and the type locality is the Kahura Landing (GR), $11 \mathrm{~km}$ north Pipiriki. The Kahura Formation includes at its base the $131 \mathrm{~m}$ thick Wairere Mudstone Member that is typically rhythmic in appearance, having alternating muddy and slightly sandy horizons. It unconformably overlies the reef horizon of the Ramanui Sandstone. It's type locality is designated here as in the river cliffs (R20 828028), $13 \mathrm{~km}$ north of Pipiriki.

\section{Popotea Sandstone Formation}

(New Formation, $322 \mathrm{~m}$ thick) A light grey well sorted sandstone, that coarsens and becomes more concretionary towards its top. It has a gradational contact with the underlying Kahura Siltstone. The top of the formation is a prominent $2 \mathrm{~m}$ thick reef horizon, again a well cemented
Crassostrea shellbed. The type locality is designated here as $8 \mathrm{~km}$ above Pipiriki at the confluence of the Wanganui and Manganui A Te Ao Rivers (R20 861980).

\section{Kahunui Mudstone Formation}

(New Formation, $378 \mathrm{~m}$ thick) Alternating mudstones, sandstones and siltstones, predominantly mudstone. Description from bottom to top; Mudstone, $65 \mathrm{~m}$; Sandstone, $56 \mathrm{~m}$; Mudstone, $196 \mathrm{~m}$; Siltstone, $61 \mathrm{~m}$. The basal mudstone unconformably overlies the reef horizon of the Popotea Sandstone. The mudstones are sandy and metre to decimetre bedded. The sandstones are muddy and concretionary with prominent well cemented shell horizons that are capped by scoured surfaces. The Formation is named after a hill on the banks of the river; a site of early Maori fortifications. The type section is designated here as $1.5 \mathrm{~km}$ north of Pipiriki on the Wanganui Valley River Road (R20 854911). The $56 \mathrm{~m}$ thick sandstone $65 \mathrm{~m}$ above the base of the formation is named the Aratira Sandstone Member after the river rapid of the same name. It is a muddy sandstone unconformably overlying the mudstone. It has a $0.5 \mathrm{~m}$ thick cemented shell horizon marking it's top. Its type section is designated as in the river cliffs above the Aratira rapid, $4 \mathrm{~km}$ north of Pipiriki (R20 845939) 
(New Formation, $626 \mathrm{~m}$ thick) Alternating sandstone and siltstone, with siltstone predominating. It has a gradational contact with the upper siltstone of the Kahunui Formation. Description from bottom to top; Siltstone, $148 \mathrm{~m}$; Sandstone, $116 \mathrm{~m}$; Siltstone, $43 \mathrm{~m}$; sandy Mudstone, $152 \mathrm{~m}$; Sandstone $163 \mathrm{~m}$. The sandstones are massive, light grey and concretionary with lensoid shell horizons and individual fossils. The siltstones are more massive, slightly sandy and contain only rare fossils. The formation is cyclothemic on a broader scale than the Mangatiti Formation. The top of the formation is marked by another $2 \mathrm{~m}$ thick reef horizon of well cemented sandstone with dominant Crassostrea shells.

The Mangataunoka Formation is named after a major tributary to the Wanganui River near Pipiriki. The type section is designated here in the road cutting on the Pipiriki Landing road (R21 858898). The uppermost sandstone is formally recognised here as the Pipiriki Sandstone Member. This is named after Feldmeyer et al. (1943), who informally recognised the Pipiriki Sands cropping out south of Pipiriki. It is a blue, muddy, medium grained, decimetre bedded sandstone, with a scoured top. The type locality is designated here as a road cutting $2 \mathrm{~km}$ south of Pipiriki (R21 865877).
(New Formation, $167 \mathrm{~m}$ thick) Grading up from the top siltstone of the Mangataunoka Formation, the Otuitahi Formation is a massive well sorted sandstone, with occasional lensoid shell horizons. The top of the formation is a 4 m thick, unconformity bounded, sandy, calcareous Crassostrea reef unit. The Formation is named after the Otuitahi battle that took place in the same locality. Its type locality is designated here as a road cutting at the site of the Otuitahi battle, $3.5 \mathrm{~km}$ north of Jerusalem (R21 872845).

\section{Jerusalem Sandstone Formation}

(New Formation, $178 \mathrm{~m}$ thick) The Formation is named after Feldmeyer $e t$ al. (1943) who informally recognised the Jerusalem sands. It unconformably overlies the top reef horizon of the Otuitahi Sandstone and consists of alternating siltstones, mudstones and sandstones, with sandstone the predominant lithology. A description from bottom to top; Siltstone, $26 \mathrm{~m}$; Sandstone, $20 \mathrm{~m}$; Siltstone, $51 \mathrm{~m}$; Sandstone, $33 \mathrm{~m}$; Mudstone, $18 \mathrm{~m}$; Sandstone, $11 \mathrm{~m}$; Mudstone, $17 \mathrm{~m}$. The sandstones are slightly muddy, medium grained and decimetre bedded, with occasional shell horizons. The finer grained units tend to be sandy with few or no fossils. The type locality is designated here as in a road cutting at the southeastern end of the Jerusalem township (R21 892811). 


\section{Tangahoe Group (New)}

\section{Ranana Mudstone Formation}

(New Formation, $678 \mathrm{~m}$ thick) This is a redefinition of the Taihape Mudstone recognised in the Wanganui River by Collen (1972). A new name is required because the present study shows it is not a direct correlative of the Taihape mudstone defined originally in the Rangitikei River by Fleming (1953). The Ranana Formation is named after the $\mathrm{Pa}$ of Ranana on the Wanganui River. It is a thick uniform succession of mudstones that is fractured and poorly bedded, with abundant borings, but only a few scattered shell horizons in sandier horizons. The formation unconformably overlies the top sandy mudstone of the Jerusalem Sandstone. It fines over its top $60 \mathrm{~m}$ into a well sorted siltstone. $433 \mathrm{~m}$ above its base is a prominent $21 \mathrm{~m}$ thick, light grey, medium grained, homogeneous sandstone with a sharp top. The type locality is designated here as a road cutting $0.5 \mathrm{~km}$ north of the Ranana township school on the Wanganui River Road (S21 901785).

\section{Matahiwi Sandstone Formation}

(New Formation, after Collen (1972), 78 m thick) Collen (1972) recognised the Matahiwi Siltstone as a member of his Taihape Formation. The unit is a fine grained sandstone, conformably overlying the Ranana mudstone. There is an $11 \mathrm{~m}$ thick siltstone bed $12 \mathrm{~m}$ above the base. This new definition is in line with Feldmeyer et al. (1943) who informally recognised the Matahiwi sands in the Wanganui River. The formation is named after the Matahiwi $\mathrm{Pa}$ on the Wanganui River. Its type locality is a road and stream cutting at the bridge on the northern side of the Matahiwi Settlement (S21 955757).

\section{Raupirau Mudstone Formation}

(New Formation, $80 \mathrm{~m}$ thick) A poorly sorted sandy mudstone that grades into the overlying Koriniti Sandstone Formation. It conformably overlies the Matahiwi Sandstone with a sharp contact. The formation is named after a major tributary of the Wanganui River north of Koriniti. Its type locality is designated here as a road cutting $1 \mathrm{~km}$ south of the Matahiwi settlement (S21 964747). The Mudstone grades into the overlying Koriniti Sandstone Formation (Ker, 1973).

\section{Whenuakura Group (Fleming, 1953)}

\section{Koriniti Sandstone Formation}

(Ker, 1973; $181 \mathrm{~m}$ thick) First informally named by Feldmeyer (1943) the type locality is $1600 \mathrm{~m}$ north of the Koriniti $\mathrm{Pa}$ (settlement), in the banks of the Wanganui River (S21 962705). It is a $250 \mathrm{~m}$ thick sandstone with siltstone bands. It has a gradational contact with the underlying Raupirau Mudstone. Ker (1973) recognised five informal members: 3 sandstone units and 2 siltstone units. The sandstones are 
yellow, medium grained, barren of mollusca, $84 \mathrm{~m}, 75 \mathrm{~m}$ and $23 \mathrm{~m}$ thick respectively. The bottom two sandstone units contain interbeds of mudstone. The three sandstone units are separated by two fine, blue siltstone beds $45 \mathrm{~m}$ (lower) and $23 \mathrm{~m}$ (upper) thick respectively. The Koriniti Sandstone formation is inferred by Ker (1973) to be conformably overlain by the Otui Siltstone.

\section{Otui Siltstone Formation}

(Ker, 1973; $171 \mathrm{~m}$ thick, thickness is amended from Ker, 1973) The type locality is $1200 \mathrm{~m}$ north of Otui, in a prominent bluff above the road adjacent to the Wanganui River (S21 952676). Conformably overlying the Koriniti Sandstone, it is massive blue siltstone, with sparse fossils, equivalent to the Raumati Mudstone Member of the Mangaweka Mudstone Formation recognised by Collen (1972). The Otui Siltstone Formation grades upwards into the overlying Ahurangi Sandstone.

\section{Ahurangi Sandstone Formation}

(Ker, 1973; $80 \mathrm{~m}$ thick, thickness is amended from Ker, 1973) First informally named by Feldmeyer (1943), the type locality is a road cutting above the Wanganui River, 1,000 m upriver of the Ahauhu Stream mouth (S21 936650). Grading up from the Otui Siltstone, it is a concretionary crossbedded sandstone. The coarser sands are yellow/brown in colour and fossiliferous horizons are common. The formation fines upward into the overlying Oxbow Siltstone. The formation is equivalent to the Ahuahu Sand Member of the Mangaweka Mudstone (Collen, 1972).

\section{Oxbow Siltstone Formation}

(Ker, 1973; $12 \mathrm{~m}$ thick, thickness is amended from Ker, 1973) The type locality is at the head of the oxbow at Atene Pa on the Wanganui River (S21 940636). Unconformably overlying the Ahurangi Sandstone, it is a thin blue grey siltstone that coarsens upwards into the Atene Sandstone. The present study recognises it as equivalent to the Mangapapa Siltstone Member of the Mangaweka Mudstone Formation as recognised by the study of Collen (1972).

\section{Atene Sandstone Formation}

(Ker, 1973; $187 \mathrm{~m}$ thick, thickness is amended from Ker, 1973) First informally named by Feldmeyer (1943), the type section is in the Western side of the oxbow at Atene $\mathrm{Pa}$ on the Wanganui River (S21 933628). The Atene Sandstone unconformably overlies the Oxbow Siltstone, with a loaded base. It is a thick succession of sandstones with siltstone bands. Ker (1973) recognised three informal members: 2 sandstone units and one siltstone unit. The basal and upper yellow, medium, sandstones are $30 \mathrm{~m}$ and $45 \mathrm{~m}$ respectively. The basal sand contains siltstone partings and the upper sand is highly concretionary, with surface borings. The sands are separated by a $6 \mathrm{~m}$ thick, massive blue 
siltstone that fines upwards. The formation is equivalent to the Atene Sand Member of the Mangaweka Mudstone Formation as recognised by Collen (1972). The Atene Sandstone is conformably overlain by the Mangaweka Formation.

\section{Paparangi Group (Fleming, 1953)}

\section{Otawake Siltstone Formation}

(New name, $249 \mathrm{~m}$ thick, thickness is amended from Ker, 1973) The Otawake Siltstone is the equivalent of the Mangaweka Formation recognised in the Wanganui River Valley by Ongley (1946) and adopted by Ker (1973). It is not the equivalent of the Mangaweka Formation as first defined in the Rangitikei River by Feldmeyer et al. (1943). Its type locality in the Wanganui River is above the Atene Sandstone, type locality in the western side of the oxbow at Atene Pa (Ker, 1973) (S21 935650). The formation conformably overlies the Atene sandstone and is a thick succession of blue massive siltstone, that is sandy at the base. It fines gradually over its entire thickness and is conformably overlain by the Makokako Sandstone. It is named after the highest hill in the area.

\section{Makokako Sandstone Formation}

(Fleming, 1953; $24 \mathrm{~m}$ thick, thickness is amended from Fleming, 1953) The type locality is near the head of the Makokako Stream, a branch of the Waitotara River. In the Wanganui River it conformably overlies the Otawake Siltstone, and crops out in the true left bank above Whauteihi Stream. It is a succession of soft, yellow, medium-coarse, fossiliferous sandstone. Collen (1972) did not recognise this unit and it is presumed he grouped both the Otawake Formation and Makokako Sandstone into his Pitangi Mudstone member of the Mangaweka Mudstone Formation.

\section{Wilkies Shellbeds Formation}

(Laws, 1940; $70 \mathrm{~m}$ thick) The type locality is on the true left bank, one mile above the mouth of the Waitotara River. It crops out in the Wanganui River in a cutting on the Wanganui River Road 5 km north of Parakino (S22 960575). As they crop out in the Wanganui River, the shellbeds themselves are a $15 \mathrm{~m}$ thick succession of muddy sandstone, with abundant Crassostrea. The base of the shellbed is very sandy and densely packed with Crassostrea and unconformably overlies the Makokako Sandstone. It is conformably overlain by the Cable Mudstone Member (New name after Ker, 1973; $15 \mathrm{~m}$ thick). Its type locality is in a road cutting above the Wilkies shellbeds $5 \mathrm{~km}$ north of Parakino (S22 959572). It is a succession of massive fine blue siltstone. It is unconformably overlain by the Te Rimu Sandstone Formation of the Okiwa Group. 
Okiwa Group (Fleming, 1953)

\section{Te Rimu Sandstone Formation}

(Fleming, 1953; $14 \mathrm{~m}$ thick) A well sorted, yellow-brown sandstone. The Te Rimu Sandstone is fossiliferous with similar species to the Wilkies Shell Bed (Ker, 1973). It conformably overlies the Wilkies Shell Beds and grades up into overlying siltstones. Its type locality is in a road cutting on the western side of the Wanganui River at Te Rimu.

Overlying the Te Rimu Sandstone are as yet undifferentiated Formations of the Lower Okiwa Group, described by Fleming (1953) and Ker (1973). They comprise the top $140 \mathrm{~m}$ of the present study. The sequence contains alternating sandstones, siltstones and shellbeds, both conformably and unconformably juxtaposed. The Hautawa Shell Bed (Fleming, 1953) crops out $101 \mathrm{~m}$ above the top of the Te Rimu Sandstone. The shell bed is described in detail by Fleming (1953) and discussed further in chapters 12 and 13 of the present study.

\subsubsection{Hautawa Road Stratigraphy}

The strata logged at Hautawa Road comprise the undifferentiated formations of the Lower Okiwa Group (Fleming, 1953). $124 \mathrm{~m}$ of alternating sandstones, siltstones and shell beds crop out below the Hautawa Shell bed. The shell bed is 2 m thick, containing Chlamys delicatula, C. gemulata, Phialopecten triphooki, Venericardia purpurata and Dentalium marwicki. Fleming (1953) gave a full species list. At least $31 \mathrm{~m}$ of siltstone above the Hautawa Shell Bed comprise the basal part of the Upper Okiwa Group (Fleming, 1953) as it occurs in the Turakina River Valley. The main purpose of the examination of the Hautawa Road Section was to obtain better palaeomagnetic and stratigraphic control than is provided by the top of the Wanganui River Section at Parakino. A description of the section from bottom to top; siltstone, thickness unknown; sandstone, $60 \mathrm{~m}$; shell bed, $6 \mathrm{~m}$; siltstone $58 \mathrm{~m}$; shell bed, $2 \mathrm{~m}$; siltstone, more than $31 \mathrm{~m}$. The two shell beds are different in nature. The lower shell bed has a basal unconformity and fewer shells than the upper that is conformably bounded within siltstone. The lower siltstone is more sandy than the overlying siltstone. Appendix 2 gives a unit by unit description.

\subsection{Rangitikei River Stratigraphy}

Te Punga (1952) named the Upper, Middle and Lower Rangitikei Formations, within the Rangitikei Group. The formations he defined are direct equivalents of the Castlecliffian, Nukumaruan and Waitotaran Stages respectively. These definitions are based on age and are not in line with the North American Stratigraphic Code. Te Punga did not follow the definitions of Ongley (1946) but subsequent workers have (eg; Collen, 1972; Seward et al., 1986). In this study lithologic definitions are 
adopted and formation names are based on Ongley (1946) because of priority of publication. With different formational definitions and names, the grouping of Fleming (1953) is adopted as it was established to group lithologically defined formations.

\section{Matemateaonga Group}

\section{Waiouru Sandstone Formation}

(Fleming, 1959) Correlatives of the Waiouru Sandstone Formation in central Taranaki are in excess of $1500 \mathrm{~m}$ in thickness (Fleming, 1978). In the Rangitikei River the formation unconformably overlies the Kaimanawa Greywacke (plate 11.1), and in the Moawhango-Rangitikei River catchment reaches a thickness of $800 \mathrm{~m}$ (Fleming, 1978). The present study observed only the top $100 \mathrm{~m}$ overlying basement in the Rangitikei River (U21 713684). TePunga (1952) described the contact with basement in many places noting localised conglomeratic facies, shallow water limestones and terrestrial sediments. Te Punga stressed their localised nature and thickness in the order of 1 to $5 \mathrm{~m}$. The Waiouru Sandstone proper (Fleming, 1959 ) is a succession of fine to coarse, poorly bedded sands and bedded sandy muds. The Formation contains many prominent shell horizons, the more prominent of which have been termed reefs. The older strata of the formation are progressively lost eastward as the sediments onlap the Kaimanawa Greywacke. The formation is named

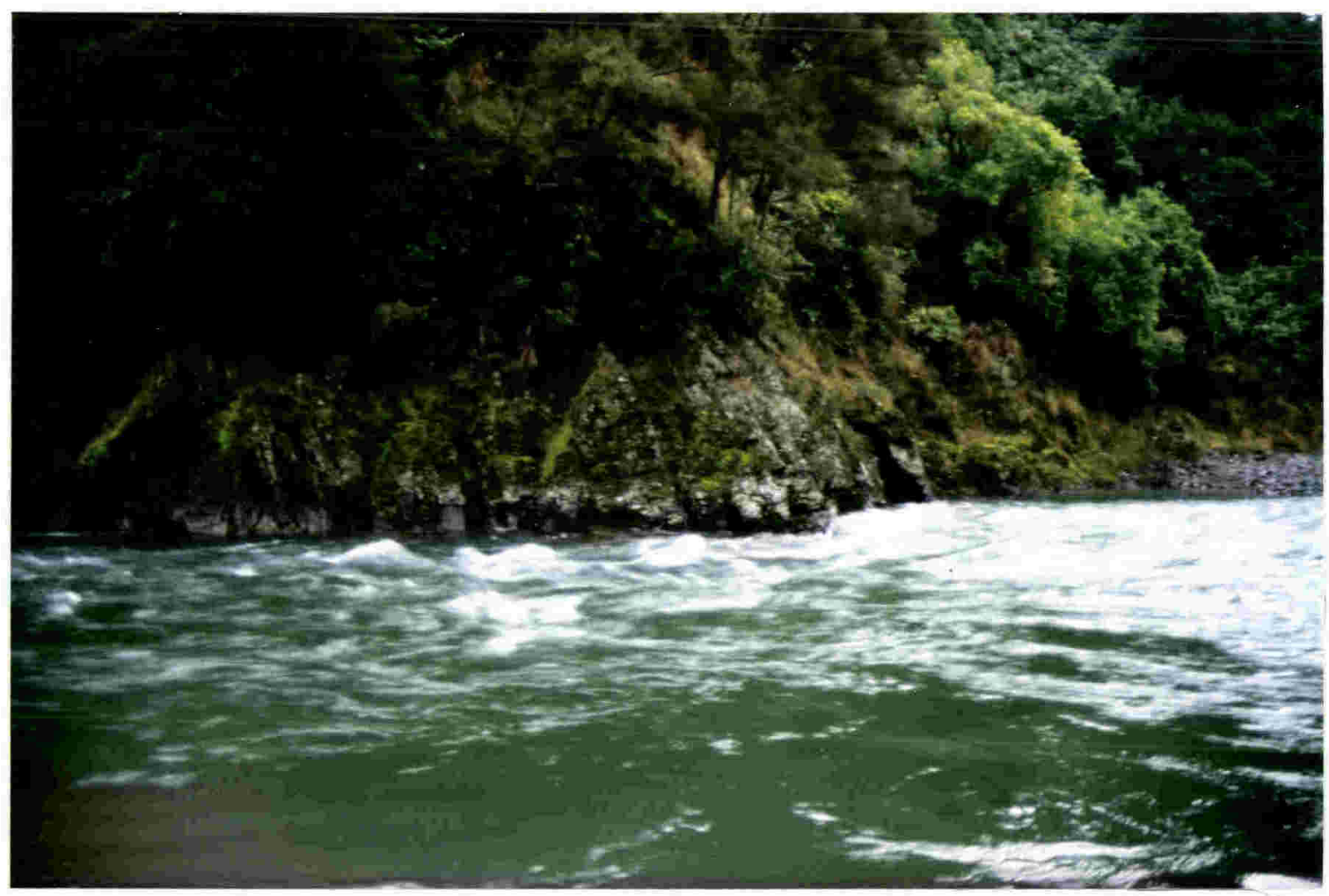

Plate 11.1: Greywacke basement in the upper reaches of the Rangitikei River. 
after the township of Waiouru, where strongly cemented beds of the formation are conspicuous in the surrounding hills. A type locality was not cited by Fleming (1959). Here a north facing river bluff before a prominent 270 degree bend in the Rangitikei River at the northern end of Mokai Station (U21 701665) is nominated. In the Rangitikei River Valley the formation is conformably overlain by the Taihape Mudstone.

\section{Tangahoe Group}

\section{Taihape Mudstone Formation}

(Ongley, 1946) Named after the township of Taihape, the Taihape Formation is a massive dark-grey, mudstone, concretionary and fossiliferous at places. It conformably overlies the Waiouru Sandstone and is conformably overlain by the Utiku Sandstone. At its type locality (Fleming, 1959), on the eastern outskirts of the Township of Taihape, it is more than 500 $\mathrm{m}$ thick. The Taihape Sandstone Member (Fleming, 1959) divides the formation in to an upper and lower half at its type locality. The Taihape Sandstone is a prominent concretionary horizon. In the Rangitikei River the Formation is only $271 \mathrm{~m}$ thick, but the Taihape Sandstone Member is still present, as a 25 m thick concretionary sand lens that is unconformity bounded. In the type locality it is reported to be more than 100 m thick (Fleming, 1959).

\section{Whenuakura Group}

\section{Utiku Sandstone Formation}

(Ongley, 1946) Conformably overlying the Taihape Mudstone, The Utiku Formation is a medium to coarse concretionary sandstone. Ongley (1946) did not specify a type section but described the formation as it crops out in the Rangitikei River Valley. Fleming (1959) observed the thickness as approximately $300 \mathrm{~m}$ at the Rangitikei River, thinning eastwards. The present study logged $500 \mathrm{~m}$ of concretionary sandstones in the Rangitikei River about Utiku Township. Ongley (1946) divided the sandstone into upper and lower parts with a mudstone separating the two parts. Mapping in the present study has found the formation to include several mudstone horizons and also lateral variation at each occurrence. A type locality is nominated here as the road cutting of the Utiku-Kawhatau River access road where the road drops down to river level (S21 529575). The Utiku Sandstone is conformably overlain by the Mangaweka Mudstone Formation.

\section{Paparangi Group}

\section{Mangaweka Mudstone Formation}

(Ongley, 1946; the base is newly defined here) In the definition by Fleming (1959) the base of the Mangaweka Formation is marked by the Hautapu Shell Limestone Member unconformably overlying mudstones. Here the basal contact is $\mathbf{1 3 0}$ 
m below the Hautapu Shell Limestone and gradational with the underlying Utiku Sandstone. The formation is a massive, blue-grey foraminiferal, concretionary mudstone. Ongley (1946) described a $550 \mathrm{~m}$ thick succession in the Rangitikei River Valley thickening and becoming less homogeneous westwards. Fleming (1959) introduced more members westward, eg; the Mangamahu Concretionary Member. The present study mapped $700 \mathrm{~m}$ of mudstone as the Mangaweka Formation, with $550 \mathrm{~m}$ of mudstone above the Hautapu Shell Limestone Member.

The Hautapu Shell Limestone Member (Te Punga, 1952) is a conglomeratic shelly limestone less than $30 \mathrm{~m}$ thick. Its type locality is in the Hautapu Valley, after which it is named. Te Punga (1952) defined it as underlying the Mangaweka Mudstone. Fleming (1959) and Seward et al (1986) described it as the basal member of the Mangaweka Mudstone, and Collen (1972) described it as a member of the Utiku Sandstone. The present study maps it as within the Mangaweka Mudstone Formation.

\section{Okiwa Group}

\section{Te Rimu Sandstone Formation}

(Fleming, 1953) Like in the Wanganui River, the Te Rimu Formation is a porous brown sandstone, concretionary in some parts and crossbedded in others. The type locality is at Te Rimu after which it is named. In the Rangitikei River Valley the formation is $17 \mathrm{~m}$ thick and conformably overlies the Mangaweka Mudstone. It is overlain by undifferentiated formations of the Lower Okiwa Group.

The uppermost unit observed is the Ohingaiti Sandstone Formation (Ongley, 1946) of the Upper Okiwa Group (Fleming, 1953). The Ohingaiti Sandstone is not discussed further as it is not part of the present study. The Hautawa Shell bed is prominent in the Rangitikei River Valley as a $2 \mathrm{~m}$ thick succession of very fossiliferous, muddy sandstone, with common fossils of Chlamys delicatula. The succession of undefined formations of the Lower Okiwa Group is much thinner in the Rangitikei River, with only $42 \mathrm{~m}$ of mudstones, sandstones and shellbeds, some conformably and some unconformably juxtaposed, between the Te Rimu and Ohingaiti Sandstones. More than $200 \mathrm{~m}$ of strata crop out between the two formations in the Wanganui River, Valley to the west. The younger strata are described in detail by Seward (1974). The present study is concerned with all strata beneath the Ohingaiti Sandstone. 
This chapter presents a summary of the age diagnostic information for the South Wanganui Basin stratigraphic sequences. Magnetostratigraphic data are from section 5 of this study and biostratigraphic datums are adopted from previous workers. The strata are correlated with both the New Zealand and International stages of the geological timescale. The 4,200 $\mathrm{m}$ of strata comprising the Wanganui River section span $3.3 \mathrm{~m}$.y. between 2.4 and $5.7 \mathrm{Ma}$., representing an average sedimentation rate of $1.3 \mathrm{~mm} / \mathrm{y}$. The $1400 \mathrm{~m}$ of strata comprising the Rangitikei River section span $1.8 \mathrm{~m}$.y. between 2.4 and $4.2 \mathrm{Ma}$., excluding a ca. 0.5 $\mathrm{Ma}$. unconformity, representing an average sedimentation rate of $1.3 \mathrm{~mm} / \mathrm{y}$. The resolution of chronology from correlation of the magnetostratigraphy is ca. $50 \mathrm{Ka}$. The only large time-break is within two channelled unconformities in the lower part of the Rangitikei River sequence. The chronology developed here is used in chapter 15 with sequence stratigraphic information from chapter 14 to develop a record of eustatic sea level cyclicity in the Late Neogene.

\subsection{Introduction}

This chapter is intended as a summary of all the chronology available for the Strata of the South Wanganui Basin. Three key diagrams (figures 12.3, 12.4 and 12.5) present the chronology adopted for this sequence by the present study. It is used in subsequent chapters to characterise developing stratigraphic cyclicity and to correlate with the stratigraphic record from the Antarctic margin in the McMurdo Sound area. The high resolution magnetostratigraphy developed in Section 5 and summarised here is the key chronologic and correlative tool.

The timescale used here is that of Edwards et al. (1988) (figure 12.1). The magnetic polarity timescale used for correlation is that of Ness et al. (1980), which was subsequently adopted by Edwards (1987) (figure 12.2) and Edwards et al. (1988). Biostratigraphic information is from the studies of Fleming (1953), Collen (1972), Edwards (1987), and Morris (in prep.) and summarised here to help constrain and correlate the chronology within the New Zealand and to the International timescale.

More recently Cande and Kent (1992) and Shackleton et al. (1992) have presented revised polarity timescales. The timescale of Cande and Kent (1992) suggests that the oldest strata in this study are slightly older than reported here and the timescale of Shackleton et 


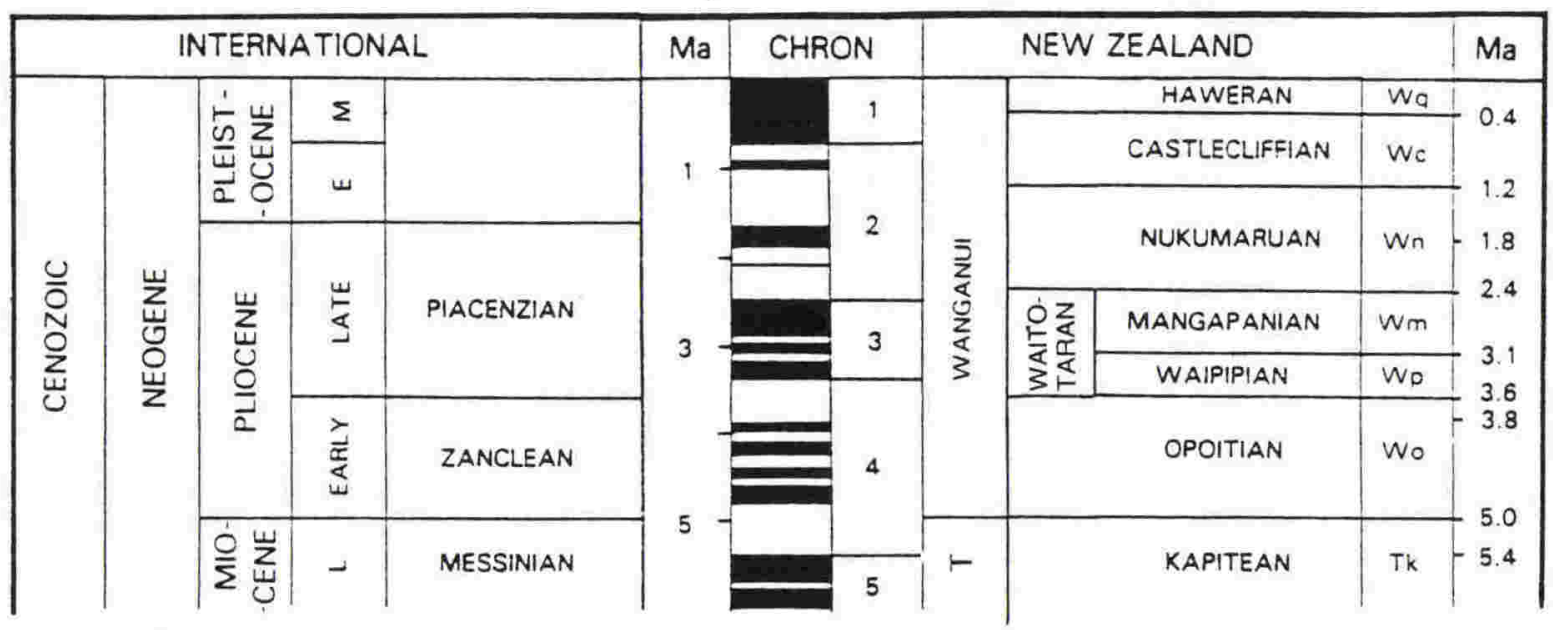

Figure 12.1: Geological Late Neogene timescale for New Zealand (modified from Edwards et al., 1988), showing New Zealand stage names as used in this study. Polarity timescale is from (Ness et al., 1980).

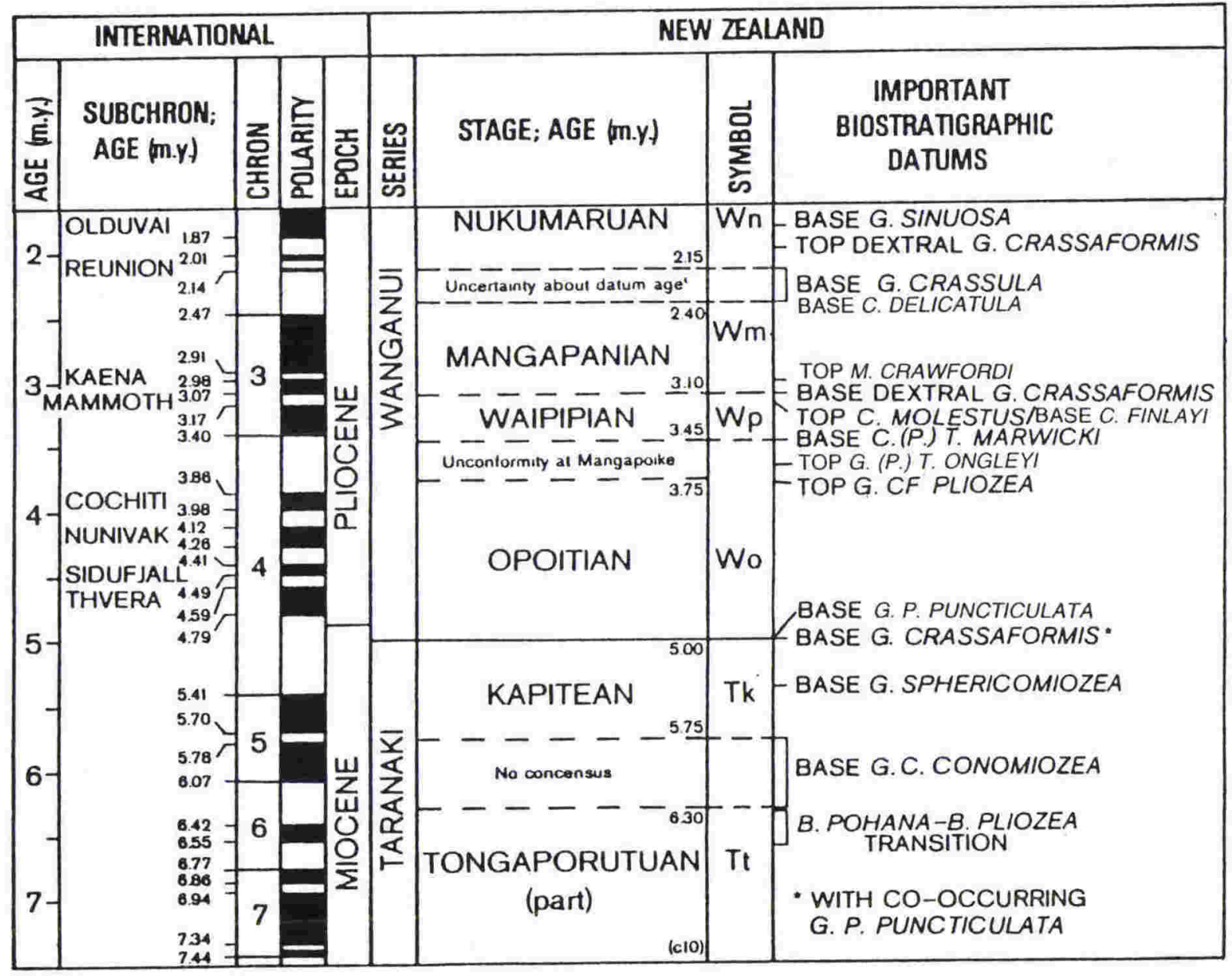

Figure 12.2: Summary of the Late Neogene relationships (modified from Edwards, 1987): The magnetic polarity timescale of Ness et al. (1980), stage classifications from Edwards (1987), and important biostratigraphic datums in this study (modified from Edwards, 1987). 
al. (1992) suggests that these same strata are younger than reported here. Because of this disagreement, neither of these timescales is adopted here. Correlations made between stratigraphic sections in this study will remain valid if the polarity timescale is subsequently revised.

\subsection{New Zealand Stages}

The oldest strata studied here belong to the Kapitean Stage of the Taranaki Series. The majority of the strata studied comprise the entire Opoitian, Waipipian, and Mangapanian stages of the lower Wanganui Series.

The Waitotaran stage has been employed in various studies of New Zealand Strata (Hoskins, 1982). Initially, the lower Wanganui Series comprised the Opoitian and Waitotaran stages. Beu (1969) raised the Waipipian and Mangapanian substages of the Waitotaran Stage to full stage rank. The Waitotaran stage has subsequently been adopted by most workers as a superstage (Beu, 1970; Beu and Maxwell, 1990; Collen, 1972; Edwards, 1987; Edwards et al., 1988; Hoskins, 1982; Jenkins, 1971; Kennett et al., 1970; Kennett and Watkins, 1974). It is generally now only used when the Waipipian and Mangapanian stages cannot be adequately separated in sequences. This usage is adopted here (figure 12.1).

A brief definition of the timescale used here follows. A full historical account of the definition of stages and series of New
Zealand Cainozoic strata is given by Hoskins (1982) and is not repeated here.

\subsubsection{The Kapitean Stage}

Holostratotype; Kapitea Creek (Finlay and Marwick, 1947).

This is arbitrarily equated to the Late Miocene, Messinian Stage of the International Timescale by Edwards $e t$ al. (1988).

In New Zealand the base of the Kapitean is defined by the first occurrences of Sectipecten wolastoni and Austrofusus tuberculatus (coerulescens) (Finlay and Marwick, 1947) and the first occurrence of Globorotalia conomiozea conomiozea. (Edwards et al., 1988). Hoskins et al. (1982) recognise the base to occur just above the base of magnetochron 5 and assign an age of $6.0 \mathrm{Ma}$.

An additional biostratigraphic datum within the Kapitean Stage is the first occurrence of Globorotalia sphericomiozea reported at $5.4 \mathrm{Ma}$. by Edwards et al. (1988).

\subsubsection{The Opoitian Stage}

Lectostratotype; Mangapoike River (Finlay, 1939).

This is equivalent to the Early Pliocene, Zanclean Stage of the International Timescale (Edwards et al, 1988). The base is also the New Zealand and 
International Miocene-Pliocene boundary.

In New Zealand the base of the Opoitian stage is defined by the lowest joint occurrence of Globorotalia puncticulata puncticulata and Globorotalia crassoformis (Edwards, 1987). Edwards et al. (1988) recognise this to occur in the lower part of the Gilbert reversed magnetochron and assign an age of 5.0 Mà. In assigning this age, Edwards et al. (1988) adopted earlier palaeomagnetic studies (Loutit and Kennett, 1979) that were subsequently revised by Roberts (1990). Roberts (1990) observed the first occurrence of $G$. puncticulata and $G$. crassoformis in Blind River to occur just below the Thvera magnetosubchron of the Gilbert reversed magnetochron and assigned an age of $4.8 \mathrm{Ma}$. This is comparable to the $4.84 \mathrm{Ma}$. age of the boundary in the Italian type section (Zijderveld et al., 1986).

The first occurrence of Globorotalia inflata occurs towards the top of the Opoitian at $3.85 \mathrm{Ma}$ (Edwards et al., 1988).

\subsubsection{The Waipipian Stage}

Holostratotype; Wanganui Coast (Morgan, 1924)

Jointly the Waipipian and Mangapanian stages are equivalent to the lower part of the Piacenzian Stage of the International Timescale (Edwards et al., 1988).
In New Zealand, the base of the Waipipian Stage is defined at the last occurrence of the bivalve Chlamys (Phialopecten) triphooki ongleyi and the first occurrence of the bivalve $C .(P$.) triphooki marwicki (Edwards, 1987). Edwards et al. (1988) also report the last occurrences of Reticulofenestra pseudoumbilica and Cibicides finlayi at the base of the Waipipian. It is located in the upper Gilbert reversed magnetochron, and an age of $3.6 \mathrm{Ma}$. is adopted by Edwards et al. (1988).

The Waipipian Stage is equivalent to the foraminiferal molestus zone of Collen (1972).

\subsubsection{The Mangapanian Stage}

Holostratotype; Waitotara Valley (Fleming, 1953)

The Mangapanian Stage is equivalent to the foraminiferal finlayi zone of Collen (1972). It's base is marked by the first occurrence of predominantly dextrally coiled Globorotalia crassiformis (Hornibrook, 1981) and the last occurrences of Cibicides molestus and Mesopeplum crawfordi (Edwards et al., 1988). The base occurs in the middle of the Gauss normal chron and is dated at 3.1 Ma. by Edwards et al. (1988).

\subsection{The Hautawa Shell Bed}

In the South Wanganui Basin, the boundary between the Mangapanian and Nukumaruan Stages is placed at the base 
of the Hautawa Shellbed (Edwards, 1987). It is marked in particular by the last occurrence of Crassostrea ingens, the first occurrence of the cold water species Chlamys patagonica delicatula and the first occurrence of Globorotalia crassula. Traditionally in New Zealand this has also been defined as the PlioPleistocene boundary, particularly marked by the first occurrence of Chlamys patagonica delicatula (Edwards, 1987). This occurs just above the top of the Gauss normal magnetochron and is assigned an age of 2.4 Ma. by Edwards (1987).

\subsection{The South Wanganui Basin Strata}

\subsubsection{Wanganui River Section}

Correlation with the timescale of Ness et al. (1980)/Edwards et al. (1988) is presented in figure 12.3. Magnetostratigraphic datums are detailed in Section 4 (Chapter 19) and summarised here to establish the ages and correlatives of strata.

The Miocene-Pliocene boundary is recognised within the Ramanui Sandstone. Beneath the Ramanui Formation, the Mangatiti and Mangaparua Formations are correlated with the upper half of magnetochron 5 . They comprise the oldest strata observed in the present study.

The base of the Kapitean Stage is not seen in the present study. The Mangatiti,
Mangaparua and the base of the Ramanui Formations are assigned to the upper part of the Kapitean.

Collen (1972) recognises the beginning of his Molestus zone close to the base of the Koriniti Sandstone, marking the top of the Opoitian Stage in the Wanganui River Section. The remaining Matemateaonga Group strata, and all the Tangahoe Group strata are assigned to the Opoitian Stage. The Gilbert reversed magnetochron as recognised in this study (see section 4, chapter 19) comprises most of these formations. The reversed magnetosubchron separating the Nunivak and Sidjuveld normal subchrons is missing in an unconformity within the Kahunui Mudstone.

Collen (1992) recognises the base of his molestus zone in the lower part of the Otui Siltstone. This suggests that the Koriniti Sandstone comprises most of the Waipipian Stage in the Wanganui River Section. It bridges the transition from the Upper Gilbert magnetochron to the lower Gauss normal magnetochron.

The remaining part of the section is assigned to the Mangapanian Stage and represents the remaining part of the Gauss magnetochron and the lowest part of the Matuyama reversed chron. The top of the Wanganui River section is marked by the Hautawa Shellbed at $2.4 \mathrm{Ma}$.

The base of the Wanganui River section is assigned an age of $5.7 \mathrm{Ma}$. (within the Kapitean) and at the top of the section, 

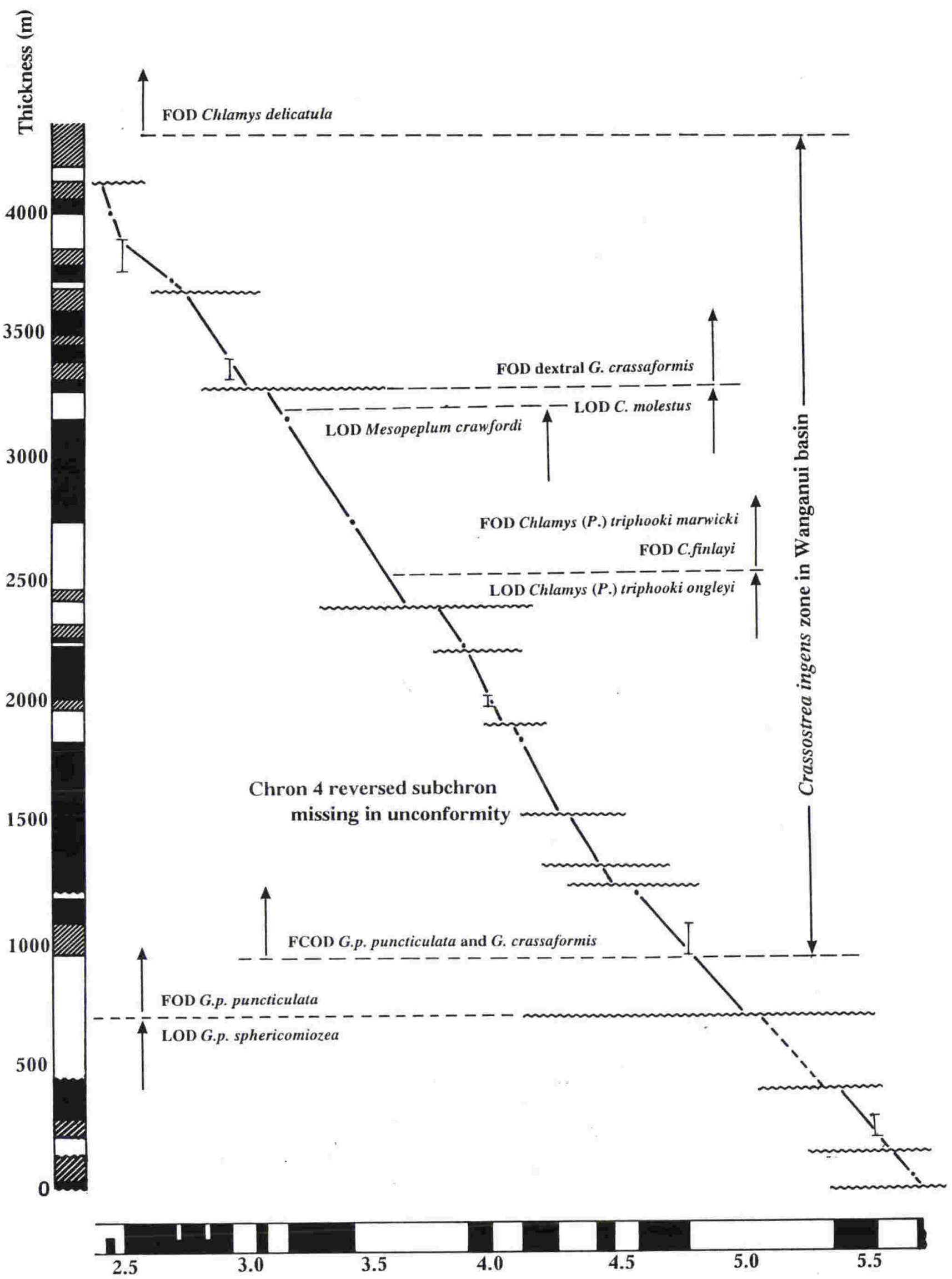

Polarity timescale (Ma)

Figure 12.3: Correlation of Wanganui River magnetozones with the magnetic polarity timescale of Ness et al. (1980), showing the main biostratigraphic datums identified by Collen (1972) and this study. Plot is drawn to show the average sedimentation rate of the Wanganui River strata and identify breaks in deposition. 
the $2.4 \mathrm{Ma}$. age of the Hautawa Shellbed is corroborated. Some $c a \cdot 4,200 \mathrm{~m}$ of strata represent the intervening 3.3 Ma. interval. Despite many hiatuses in the sequence, sedimentation is almost continuous. All the disconformities, apart from two (ca. 1520 and ca. $2400 \mathrm{~m}$ above the base of the section), represent less than 50 k.y. (i.e. shorter than the resolution of the present study) (figure 12.3). The average sedimentation rate is unusually high $(1300 \mathrm{~m} / \mathrm{m} . \mathrm{y} . ; 1.3 \mathrm{~mm} / \mathrm{y})$ even for an active continental margin. This probably reflects the fact that the sequence sampled represents the southward progressing basin depocentre (Anderton, 1981).

\subsubsection{Rangitikei River Section}

Correlation with the timescale of Ness $e t$ al. (1980)/Edwards et al. (1988) is presented in figure 12.4. Magnetostratigraphic datums are also detailed in Section 4. Although this section was studied in two parts, either side of the Rauoterangi Fault, they are combined into a single column here for convenience.

The top of the section is again marked by the Hautawa Shellbed, within the lower Matuyama reversed magnetochron. Beneath a short normal magnetosubchron within the Matuyama magnetochron (the ' $\mathrm{X}$ ' event), most of the Rangitikei River section (Mangaweka and Utiku Formations) is normally magnetised. This part of the section comprises the
Mangapanian and Waipipian stages and is assigned to the Gauss magnetochron.

Towards the top of the Taihape mudstone Collen (1972) recognised the beginning of his Cibicides zone (upper Opoitian). The Taihape Mudstone contains a thin (ca. $200 \mathrm{~m}$ ) reversed-normal-reversed magnetosubchron sequence that is assigned to the top of the Gilbert reversed magnetochron. This timesequence is comparatively much thinner than equivalent strata higher in the sequence within the Gauss normal magnetochron. Much of the upper Gilbert reversed magnetosubchron must be absent to accommodate this. This agrees with Collen's biostratigraphy and there are two large slightly angular channelled unconformities in the lowermost Utiku Sandstone and upper Taihape Mudstone that may account for the missing $0.5 \mathrm{Ma}$. (figure 12.4).

The Waiouru Sandstone is the oldest formation cropping out in the Rangitikei River section. It contains middle Opoitian fossils (Collen, 1972), is normally magnetised and is assigned to the Nunivak magnetosubchron of the Gilbert reversed magnetochron.

Magnetostratigraphic dating suggests that the base of the Rangitikei River Section is ca. 4.2 Ma. old (middle Opoitian). The Hautawa shellbed marking the top of the Rangitikei River Section, may be slightly older than the $2.4 \mathrm{Ma}$ age assigned by Edwards (1987). Without further work this difference in age between the 


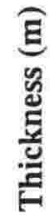

1500

1000
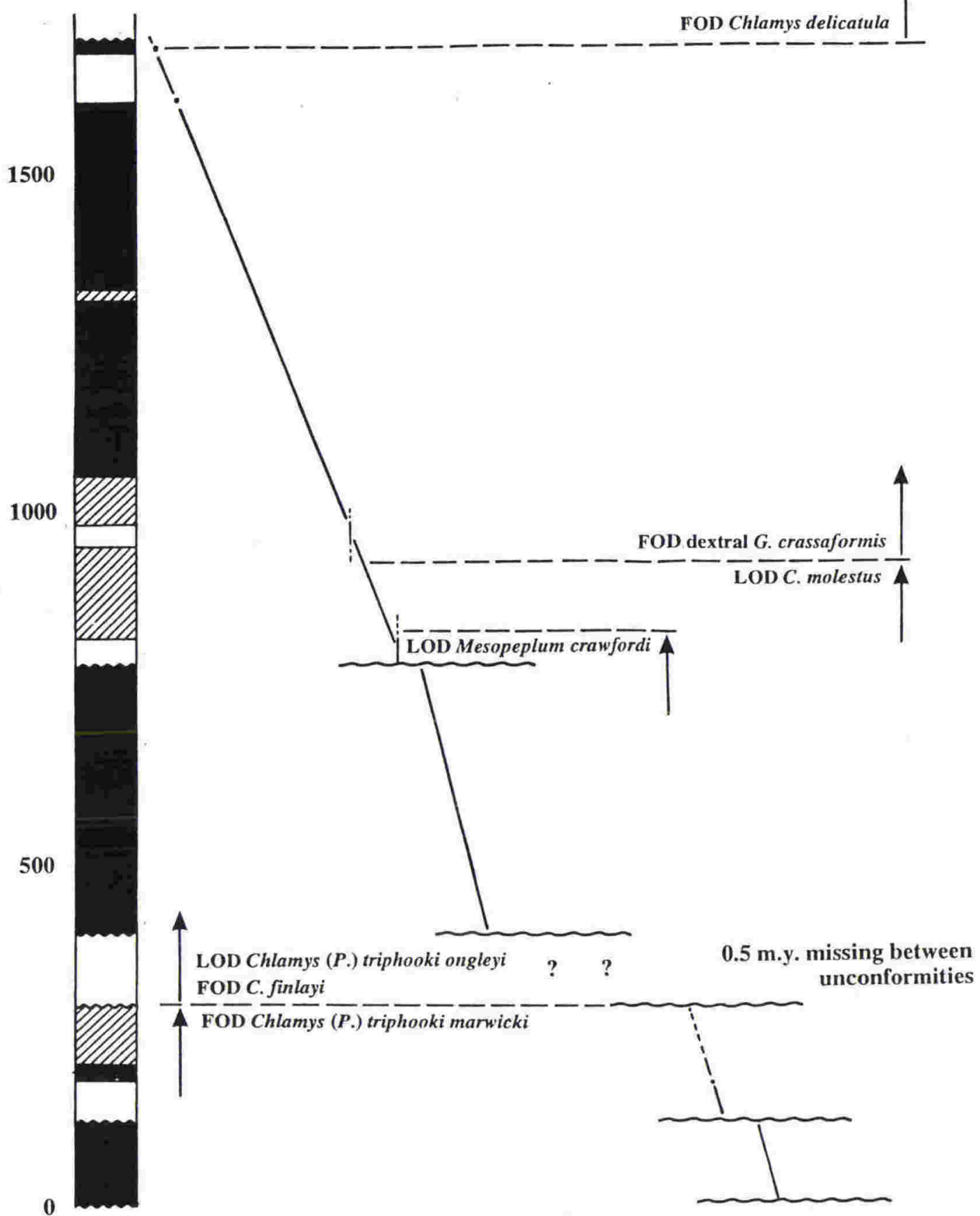

FOD dextral G. crassaformis

$\overline{F O D}$ Chlamys (P.) triphonki marwicki
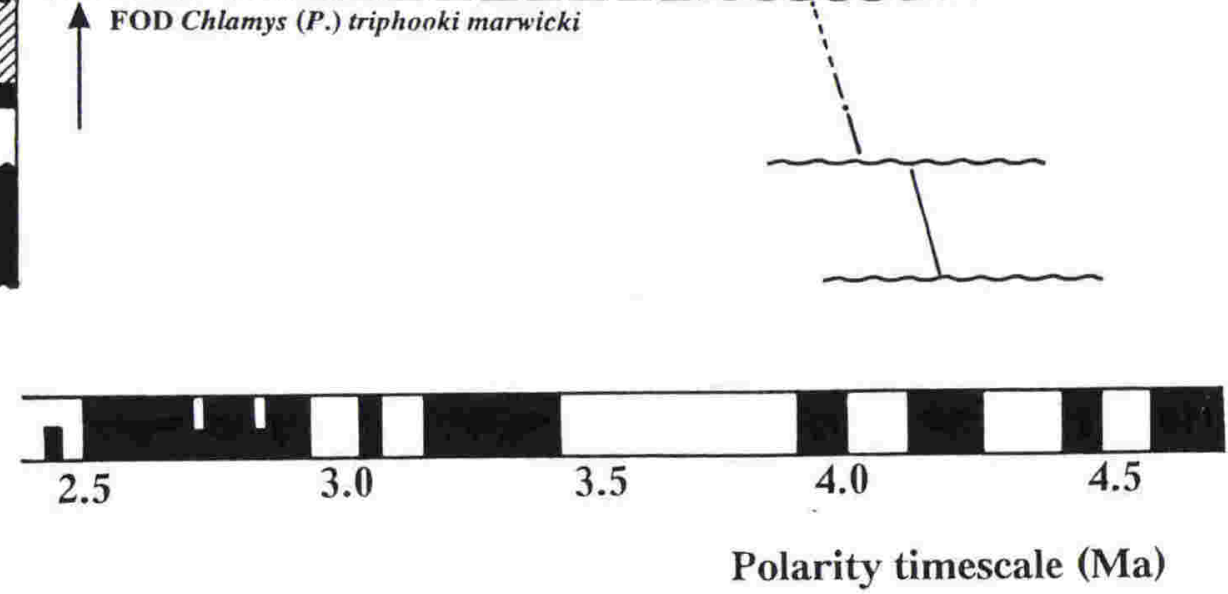

Figure 12.4: Correlation of Rangitikei River magnetozones with the magnetic polarity timescale of Ness et al. (1980), showing the main biostratigraphic datums identified by Collen (1972) and this study. Plot is drawn to show the average sedimentation rate of the Rangitikei River strata and identify breaks in deposition. 


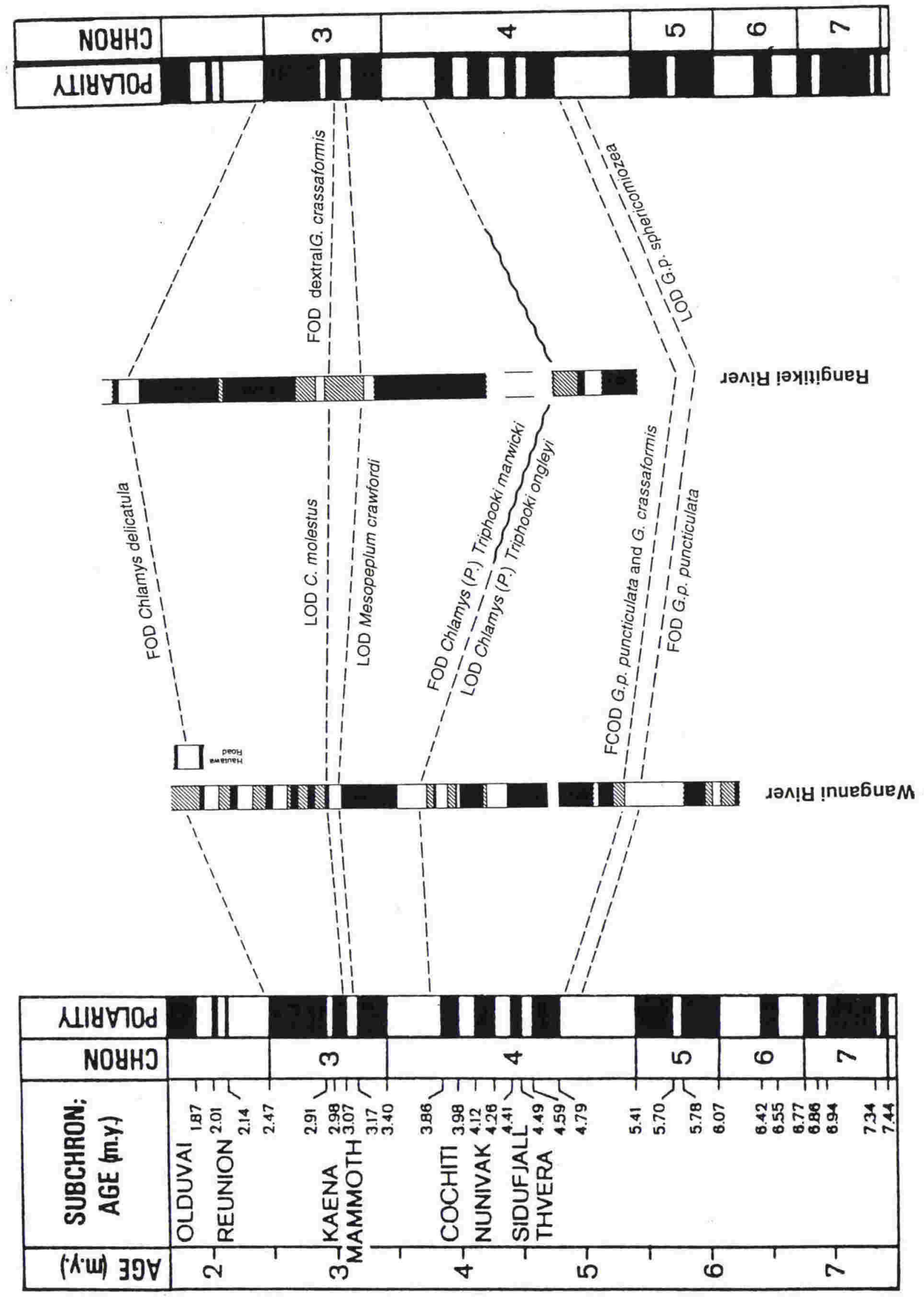

Figure 12.5: Summary of correlations of the Wanganui River, Hautawa Road, and Rangitikei River sequences using magnetostratigraphy and biostratigraphy. Plot allows easy identification of several reversal boundaries in the sections and consequently a high resolution chronology of the strata. 
Rangitikei and Wanganui River sections cannot be substantiated. It is not necessary to do so for the purposes of the present study.

The average sedimentation rate for the Rangitikei River Section is ca. 940 $\mathrm{m} / \mathrm{Ma}$. ( $1 \mathrm{~mm} / \mathrm{y})$. If the $0.5 \mathrm{Ma}$. missing in the large unconformities recognised in the lowermost Utiku Sandstone and Taihape Mudstone are accounted for, the sedimentation rate is nearly the same as that of the Wanganui River Section. Most disconformities recognised, like those of the Wanganui River sequence represent less than $50 \mathrm{k} . \mathrm{y}$. (i.e. less than the resolution of the present study).
Deposition in the South Wanganui Basin during Pliocene times thus was quite widespread and consistent along the margin of the palaeoshelf.

B iostratigraphic and magnetostratigraphic correlations of strata across the South Wanganui Basin to the polarity timescale of Ness et al. (1980) and timescale of Edwards et al. (1988) are summarised in figure 12.5. These correlations are independent of Edwards (1987) and are used as the basis of correlation and establishment of the Late Neogene glacio-eustatic sea level cyclicity model of this study. 


\section{Chapter - 13}

\section{Facies analysis.}

This chapter presents a facies analysis of the South Wanganui Basin strata. Eight facies associations are recognised and their origins presented in terms of a graded shelf model. These facies associations usually construct two facies successions. One of these coarsens upwards and the other fines upwards. Textural and faunal variation suggests that the origin of these is a respective shallowing and deepening of the continental shelf. Seven unconformities in the facies successions are reported. Most of these are channelled or scoured disconformities and the remainder are hardground paraconformities. The facies associations and successions are the basic building blocks that are used in chapter 14 to form a model of Late Neogene continental shelf evolution in the South Wanganui Basin. Once this evolutionary model is constructed, the nature of eustatic sea level change throughout the Wanganui and Rangitikei River sequences can be deduced. This is presented in Chapter 15, using the chronology detailed in chapter 12.

\subsection{Introduction}

A brief glossary of sedimentologic and stratigraphic terms used in this chapter is given in table 13.1 .

Individual facies and stratal units of the Wanganui River, Hautawa Road, and Rangitikei River sections are presented and defined in appendix 3. Only the commonly occurring associations of these facies are presented here. The thickness of the sections being studied here means that the facies associations grouped here are generally thicker than $30 \mathrm{~m}$. The facies associations are defined here, like the facies, purely on observable characteristics (Walker, 1984). An interpretation is presented for each facies association, but this is made only after objective definition. Once constructed an interpretation for the formation of each succession is given.

The discussion of stratal unconformities takes the same approach, defining them objectively from their outcrop appearance. A brief interpretation of the genetic origin of each unconformity is given after it has been defined objectively. The facies associations, successions and unconformity surfaces are interpreted in a sequence stratigraphic sense in Chapter 14. There, the evolution of the Late Neogene South Wanganui continental shelf is discussed and its record of eustatic sea level fluctuation established. 


\section{Table 13.1: Glossary of genetic stratigraphic terms as used in this thesis}

Disconformity; a surface separating parallel younger and older strata, along which there is evidence of erosion, with an hiatus indicated (This study, after Prothero, 1989).

Facies; a body of rock characterised by a particular combination of lithology, physical and biological structures that bestow an aspect different from the bodies of rock above, below and laterally adjacent (Walker, 1984; 1992).

Facies Association; groups of facies genetically related to one another and which have some environmental significance (Collinson, 1969; Walker, 1992).

Facies Succession; a vertical succession of facies characterised by a progressive change in one or more parameters, e.g. abundance of sand, grain-size or sedimentary structures (Walker, 1992). This replaces the original term; facies sequence (Walker, 1992).

Facies model; a general summary of a particular depositional system, involving many individual examples from recent sediments and ancient rocks (Walker, 1992).

Paraconformity; a surface separating parallel younger and older strata, along which there is no evidence of erosion, but an hiatus may be indicated by non-Waltherian behaviour (This study, after Prothero, 1989).

Unconformity; an all encompassing term referring to a surface separating younger from older strata where there is an hiatus and Waltherian law does not hold (This study, after Prothero, 1989).

\subsection{Sedimentary Facies Associations}

The strata observed in the present study include many different facies, representing environments of deposition across the entire shelf, from shoreface sands and estuarine/tidal shellbeds to outer shelf siltstones and mudstones.

\subsubsection{Coarsening upward interbedded mudstone and sandstone.}

A typical occurrence of this facies is in the upper part of the Mangataunoka Siltstone, Wanganui River section, an interbedded mudstone and sandstone association. The muds are silty and sandy and a blue-grey colour. The sands are poor to moderately bedded with occasional metre crossbedding. Both the mudstone and sandstone interbeds coarsen upwards. The mudstone beds are thickest and most dominant at the base. Sandstone:mudstone ratio increases upwards (plate 13.1; figure 13.1). Individual bed thicknesses vary between 2 and $20 \mathrm{~m}$, the mudstones being thickest at the base of the unit and the sandstones thickest at the top.

The unit contains occasional oyster rich shell lags. The beds are thin $(<20 \mathrm{~cm})$ and the shells are sometimes broken, commonly rounded and not in growth position. The facies association is typically $30-80 \mathrm{~m}$ thick and has a 
conformable relationship with the underlying and overlying facies.

This facies association is interpreted as being a transition from mid depth shelf environments of deposition to nearshore sands. The well sorted sandy texture and shell reworking are indicative of deposition above storm weather wave base. The muds are inner shelf deposits from below storm weather wave base.
13.2.2 Fining upward interbedded mudstone and sandstone.

The upper part of the Waiouru Sandstone, Rangitikei River Section, is a typical occurrence of this facies association (plate 13.2). This is also an interbedded mudstone and sandstone association. The muds are sandy and sometimes blue-grey in colour. The sands are poorly bedded to massive moderately sorted muddy, yellow/brown sands. There are infrequent to common discontinuous shell lags

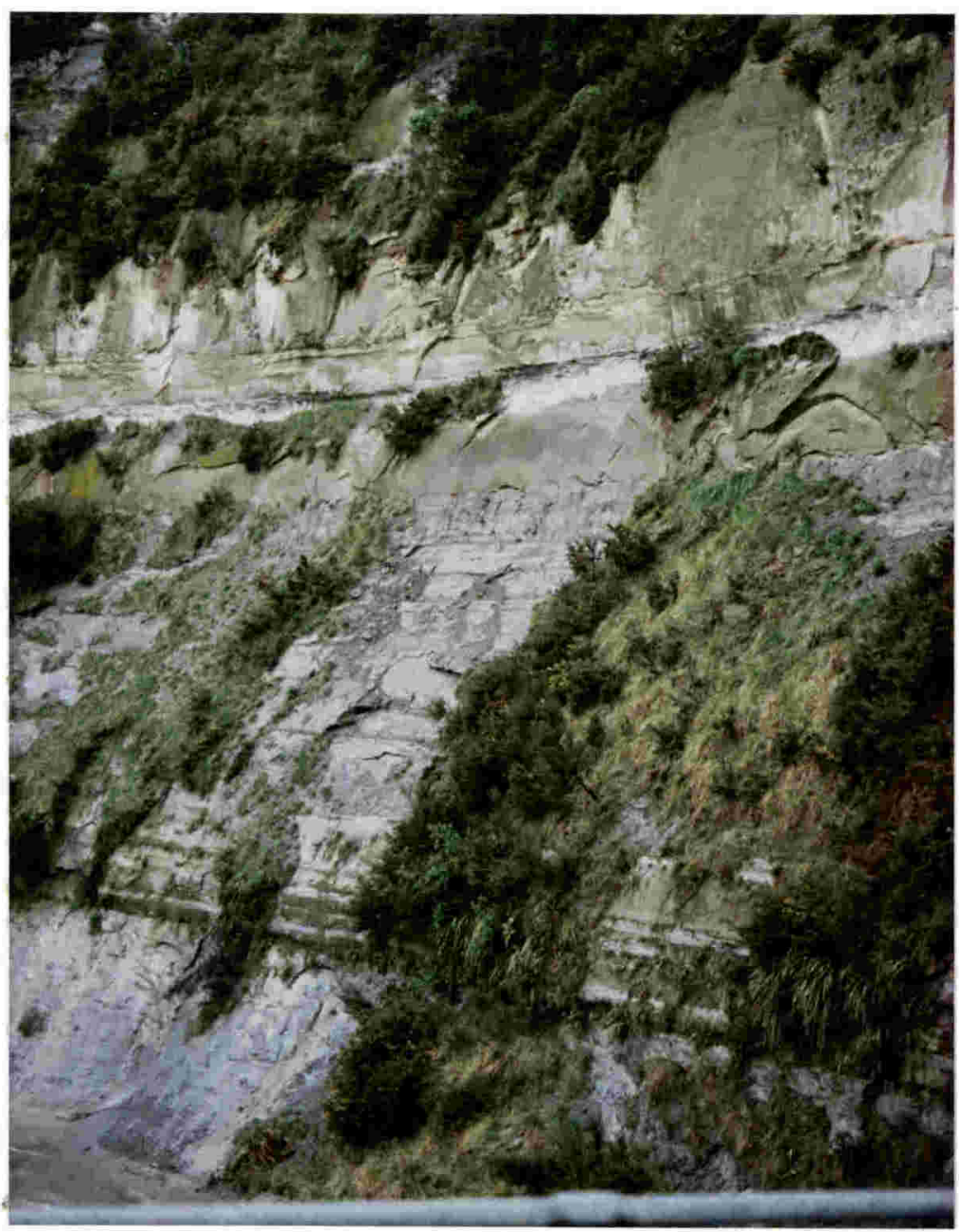

Sandstone

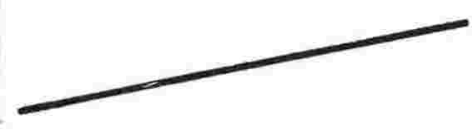

Interbedded

sandstone and

mudstone

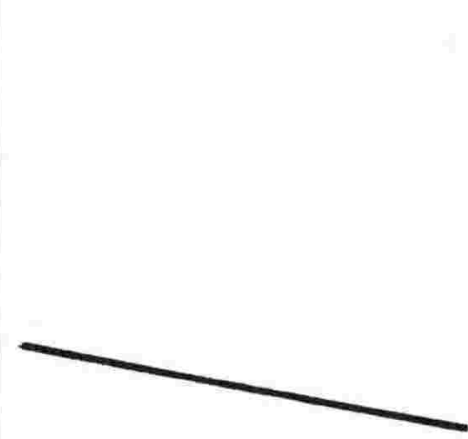

Mudstone

Plate 13.1: An example of the coarsening upwards interbedded mudstone and sandstone facies association, from the upper part of the Mangataunoka Siltstone, Wanganui River section (Frame of view is $100 \mathrm{~m}$ from top to bottom). It is underlain by the mudstone facies association (section 13.1.3), and overlain by the massive well sorted sandstone facies association (section 13.1.5). 


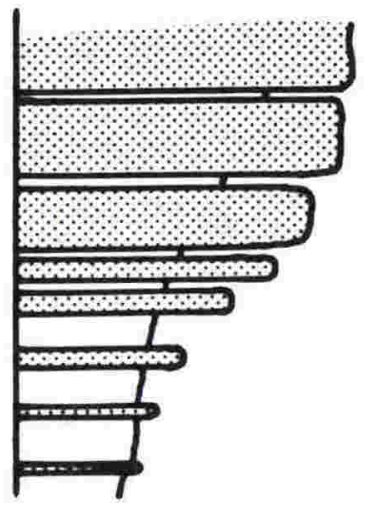

\title{
Within each association:
}

\author{
Sandstone beds thicken upwards
}

Sandstone:mudstone ratio increases upwards

Grain size increases upwards

Each facies unit shoals upwards

Bioturbation decreases upwards

Figure 13.1: Stratal characteristics of a coarsening upwards interbedded mudstone and sandstone facies association.

\section{Within each association:}

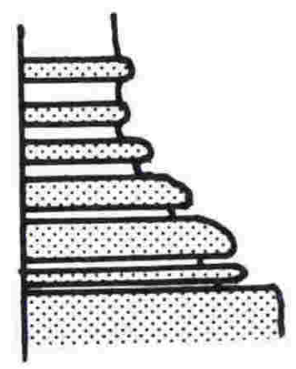

Sandstone beds thin upwards

Sandstone:mudstone ratio decreses upwards

Grain size decreases upwards

Each facies unit deepens upwards

Bioturbation increases upwards

Figure 13.2: Stratal characteristics of a fining upwards interbedded mudstone and sandstone facies association. 


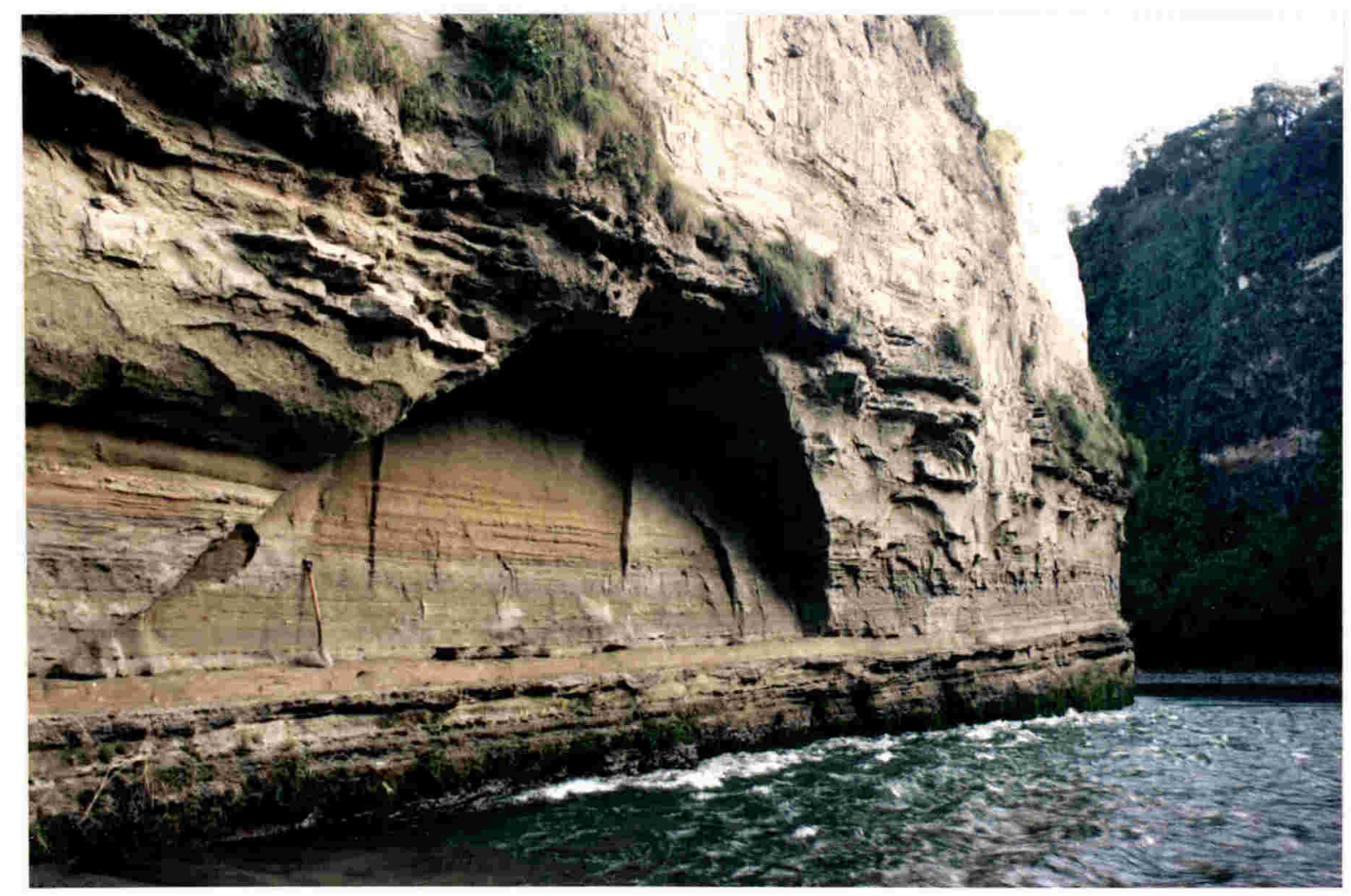

Plate 13.2: An example of the fining upwards interbedded mudstone and sandstone facies association, from the Waiouru Sandstone, Rangitikei River section (spade is $1 \mathrm{~m}$ tall).

that have a similar distinctive fauna to that of the muddy shellbed facies (see section 13.1.6), with obvious reworking. Sandstone beds are thickest and most dominant at the base. The mudstone beds become thicker and more dominant upwards (figure 13.2). Interbeds are thinner than the coarsening upwards transitional association, with thickness varying from 0.5 to $5 \mathrm{~m}$. The association is typically $8-10 \mathrm{~m}$ thick and is conformable with underlying and overlying facies.

It is interpreted to represent a transition from an innermost shelf environment to a mid-depth shelf environment. The moderately sorted sands are interpreted as being deposited about wave base.
Some of the broken shell lags suggest deposition above storm weather wave base. Abbott and Carter (1990) observed a similar facies that they name their Transitional Association and interpret to correspond to the transition zone (Reineck and Singh, 1986) between the sandy shoreface and offshore muds.

\subsubsection{Mudstone}

This facies association is generally massive, silty but often sandy and a typical occurrence is in the Mangaweka Mudstone, Rangitikei River Section. It is commonly highly fractured in places, and there are occasional sand horizons. Fossils are rare to abundant, and some strata are concretionary (plate 13.3). 


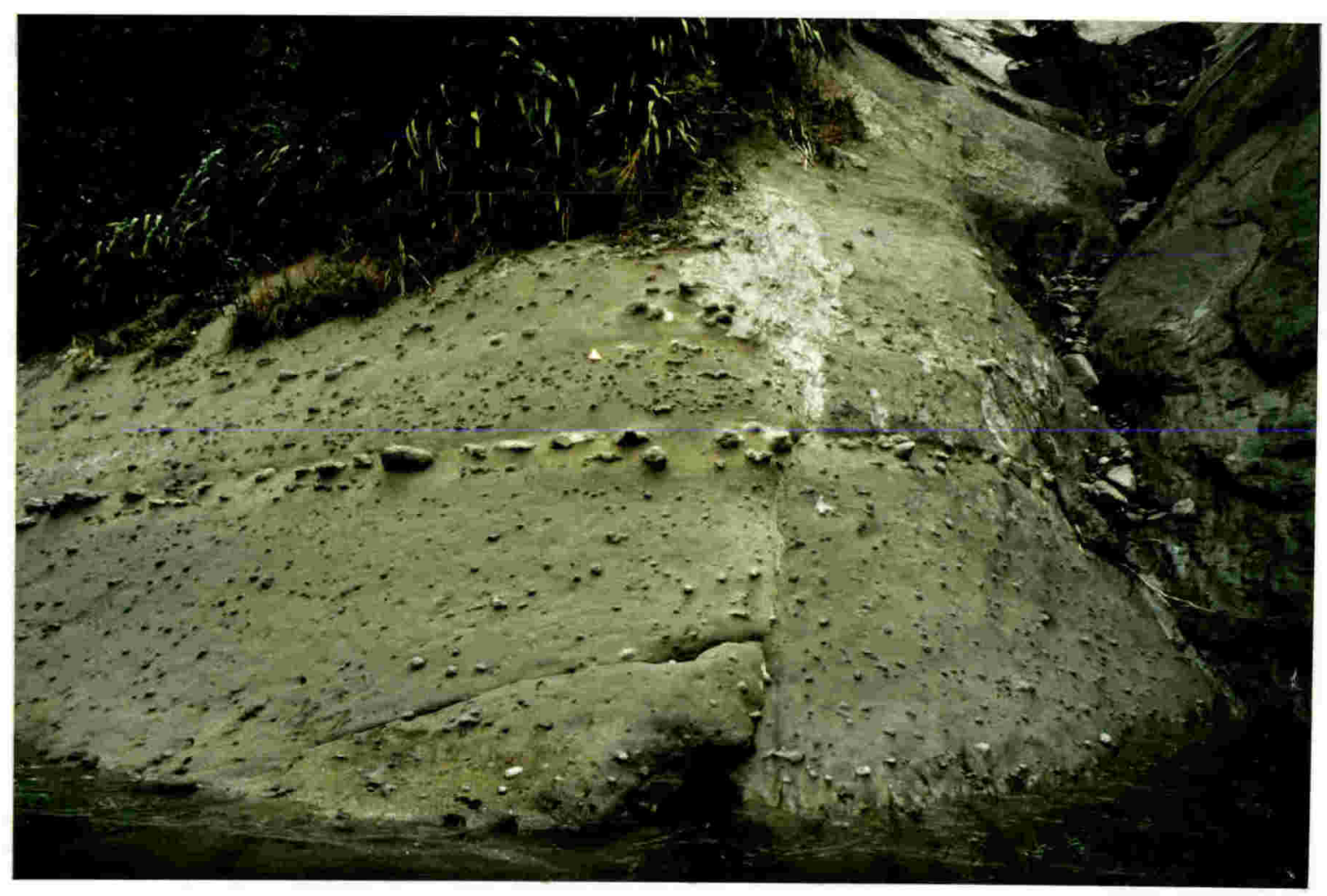

Plate 13.3: An example of the mudstone facies association, from the Mangaweka Mudstone, Rangitikei River Section (sandwich is $10 \mathrm{~cm}$ tall).

There are often scattered specimens of Pelicaria sp. in sandier horizons, perhaps washed in from shallower environments. The top of this association is generally a sharp contact and sometimes a well developed erosion surface. The mudstone facies associations are typically 100-500 $\mathrm{m}$ thick.

The fossil assemblages are indicative of depths as great as $100 \mathrm{~m}$ (Fleming, 1953). Some of the foraminifera are more depth specific, suggesting a depth more in the $30-40 \mathrm{~m}$ range (Collen, 1972 and Hornibrook et al., 1989). Sandier facies probably represent shallower water depth's of deposition and facies with no sand content at all represent deeper water facies, but still within ca. $50 \mathrm{~m}$ water depth. A finer resolution of depth of the depositional environment is not possible, because proximity of the active sediment lobe is also a factor.

\subsubsection{Rhythmically bedded mudstone}

A typical ocurrence of this alternating mudstone and sandy mudstone facies association is in the Wairere Mudstone member of the Kahura Siltstone, Wanganui River Section. Alternating beds are less than $10 \mathrm{~cm}$ thick (plate 13.4). This facies association always has an unconformable base; and its top is in some cases slightly erosional and in others conformable. The association is typically $30-100 \mathrm{~m}$ thick, and contains on average greater than $70 \%$ mud with the 
muddier interbeds being almost $90 \%$ mud. In the Wanganui Bight today textures this fine represent depths of deposition of 50 to $60 \mathrm{~m}$ (appendix 4).

This facies association is interpreted to be the deepest and most offshore deposit in the sequence studied. The fine grained muds indicate outer shelf deposition. The slightly sandy and coarser mud horizons are interpreted as pulses of sediment reaching the outer shelf. The general interpretation of this depositional environment is an outer shelf environment semi-starved of terrigenous sediment, with gravity deposits being the only source of siliciclastic sediment. Depositional rates are expected to be much slower than any other facies observed in the present study.

\subsubsection{Massive well-sorted sandstone}

A typical occurrence of this facies association is the Otuitahi Sandstone in the Wanganui River Section. A decimetre bedded to massive, concretionary, light grey, well sorted, homogeneous, medium-grained, quartzofeldspathic sandstone (plate 13.5). The sand is crossbedded on a metre scale at places, generally is weathered brown, and is poorly consolidated. It contains occasional muddy and lensoid reworked shell lag horizons, with amongst others, species of Maorimactra, Phialopecten, Sectipecten, Crassostrea and Sectipecten. The association is generally $100-300 \mathrm{~m}$ thick with a gradational base and a sharp slightly

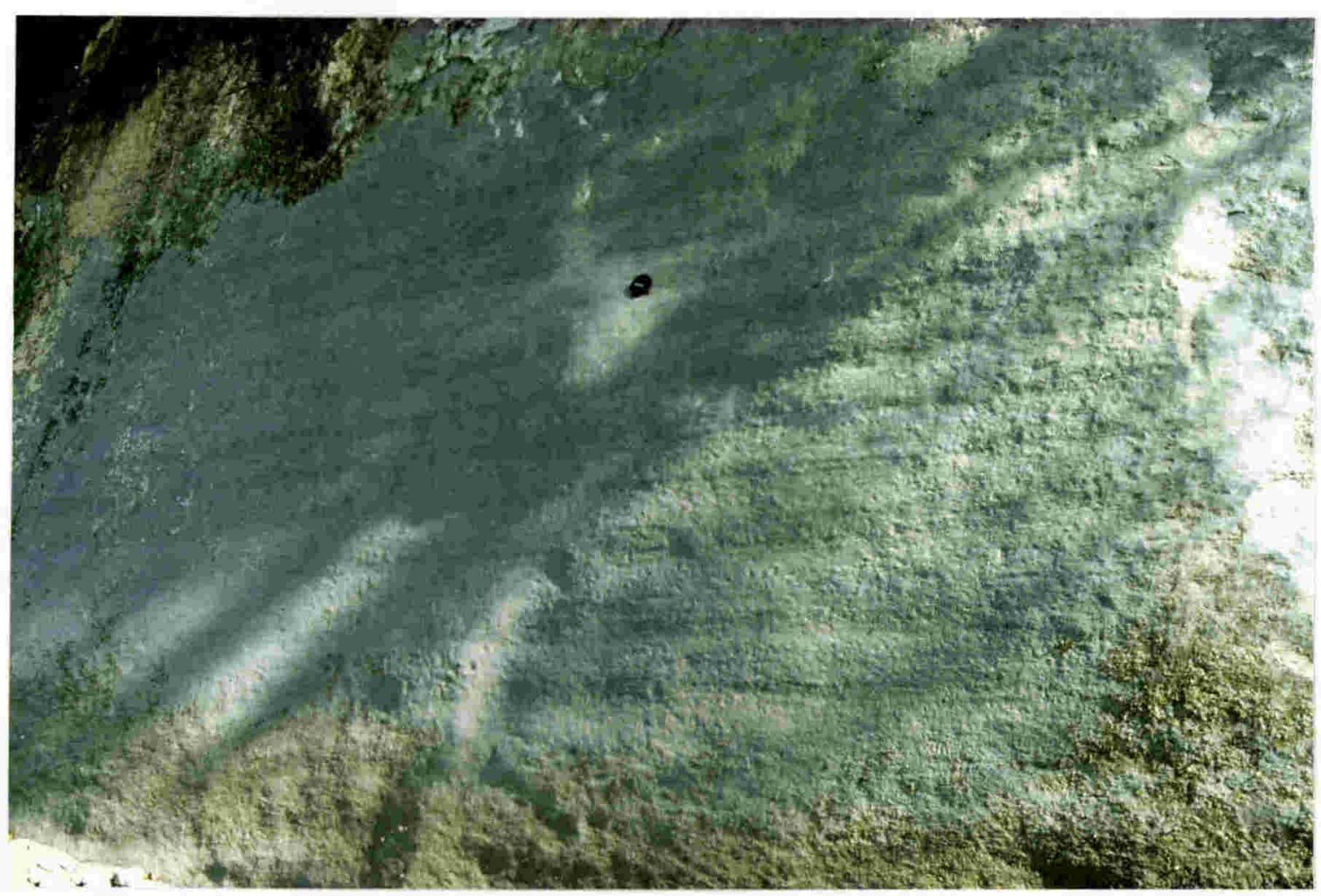

Plate 13.4: An example of the rhythmically bedded mudstone facies association, from the Mudstone Member of the Kahura Siltstone, Wanganui River Section (lens cap is $7 \mathrm{~cm}$ wide). 


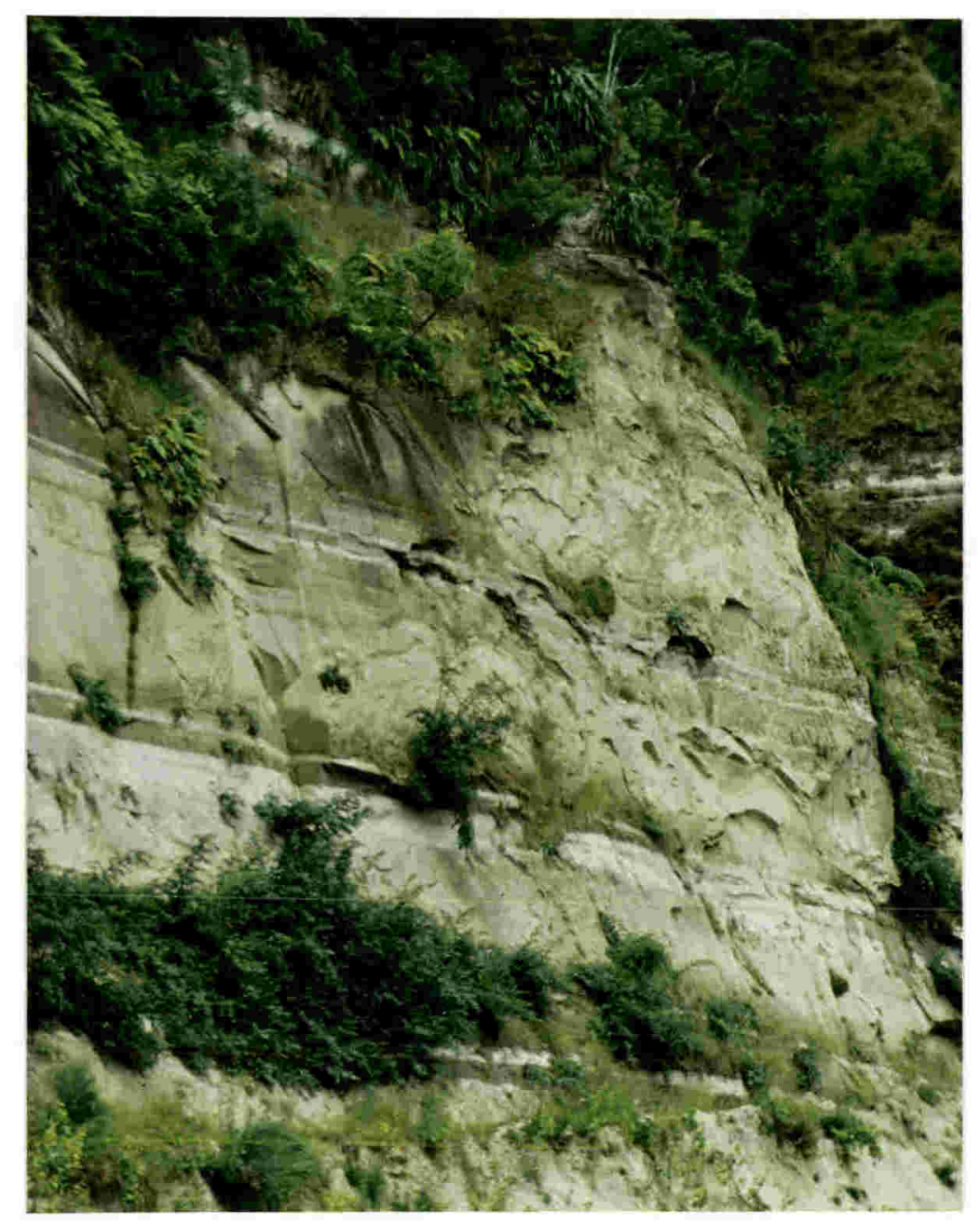

Plate 13.5: An example of the massive wellsorted sandstone facies association, from the Otuitahi Sandstone, Wanganui River Section (field of view is $50 \mathrm{~m}$ tall).

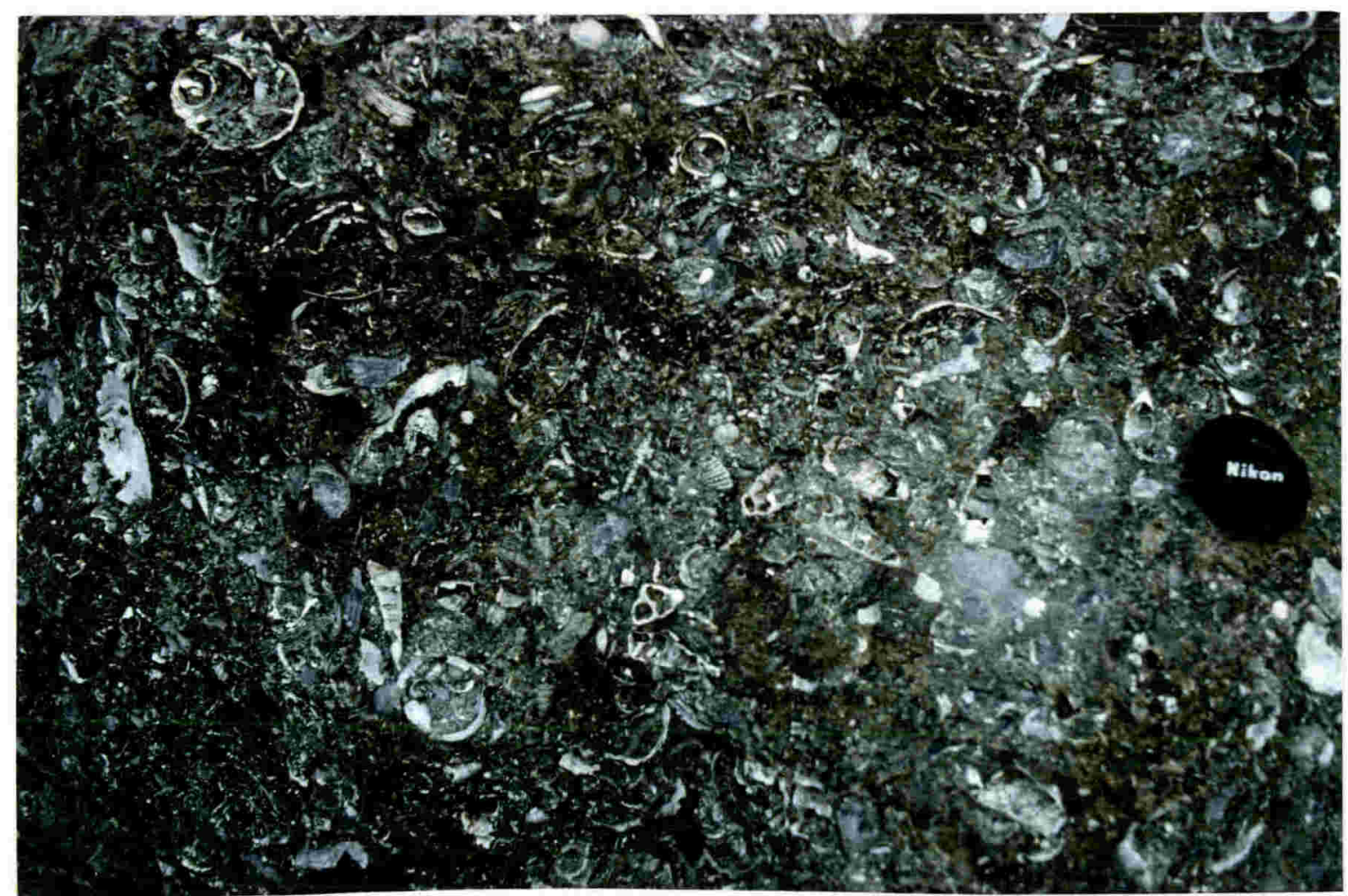

Plate 13.6: An example of the muddy shellbed facies association, from an unnamed shellbed beneath the Hautawa shellbed in the Rangitikei River Section (lens cap is $7 \mathrm{~cm}$ wide). 
eroded top. Very occasionally conglomeratic lenses are observed within this association.

The texture, lack of fine grained material, usually less than $40 \%$ mud content, good sorting, and the presence of transported estuarine species, and also muddier drapes of sediment suggest this association represents an open shoreface from beneath tidal influence to within the tidal influence of the coastline.

\subsubsection{Muddy shellbed}

A typical occurrence of this facies association is the Hautawa Shellbed, in the Wanganui, Hautawa Road, and Rangitikei River sections. This association usually consists of a thin shell lag of broken and whole shells (plate 13.6) which quickly grades up into more consistently whole shells in a more muddy matrix. The facies association generally has a sharp basal contact that is usually slightly eroded. The top contact is sometimes sharp, but usually conformable. Typical fauna includes species of Chlamys, Phialopecten, Venericardia, Dentalium, and bryozoans. The shellbeds are typically only 1-2 m thick. They are not common in the sequences studied and can be seen only in the top and bottom of the Wanganui River section and in a few places throughout the Rangitikei River section.

The muddy matrix of the of the facies association, and the fossil species (Chlamys and bryozoan species) suggest that this is an intermediate depth offshore deposit. It is probably deposited seaward of the maximum extent of active sand distribution onto the continental shelf. The shellbed usually rests on a slight unconformity and the basal part has been reworked and placed on this surface, becoming more 'in situ' towards the top of the shellbed. This suggests an increasing depth of deposition, with initial deposition taking place above storm weather wave base.

\subsubsection{Sandy shellbed / reefs}

A typical occurrence of this facies association occurs in the basal part of the Jerusalem Sandstone, Wanganui River Section. This association is a ca. $2 \mathrm{~m}$ thick shell-bed of densely packed mostly Crassostrea ingens and some other species, some in situ, others reworked. The mud content is less than $35 \%$. The matrix is generally a gritty quite coarse sand, with common burrows. The facies generally occurs as a prominent reef, often strongly cemented with $>30 \%$ calcite cement (plate 13.7). It is always unconformity bounded with the upper unconformity having much greater relief $(\sim 1 \mathrm{~m})$ than the underlying unconformity $(\sim 1 \mathrm{~cm})$.

Crassostrea ingens is an intertidal oyster species, occupying shallow water estuarine and intertidal areas much as Crassostrea virginica does today (Beu and Maxwell, 1990). This is interpreted as a very shallow water sediment whose deposition is associated with high velocity tidal 


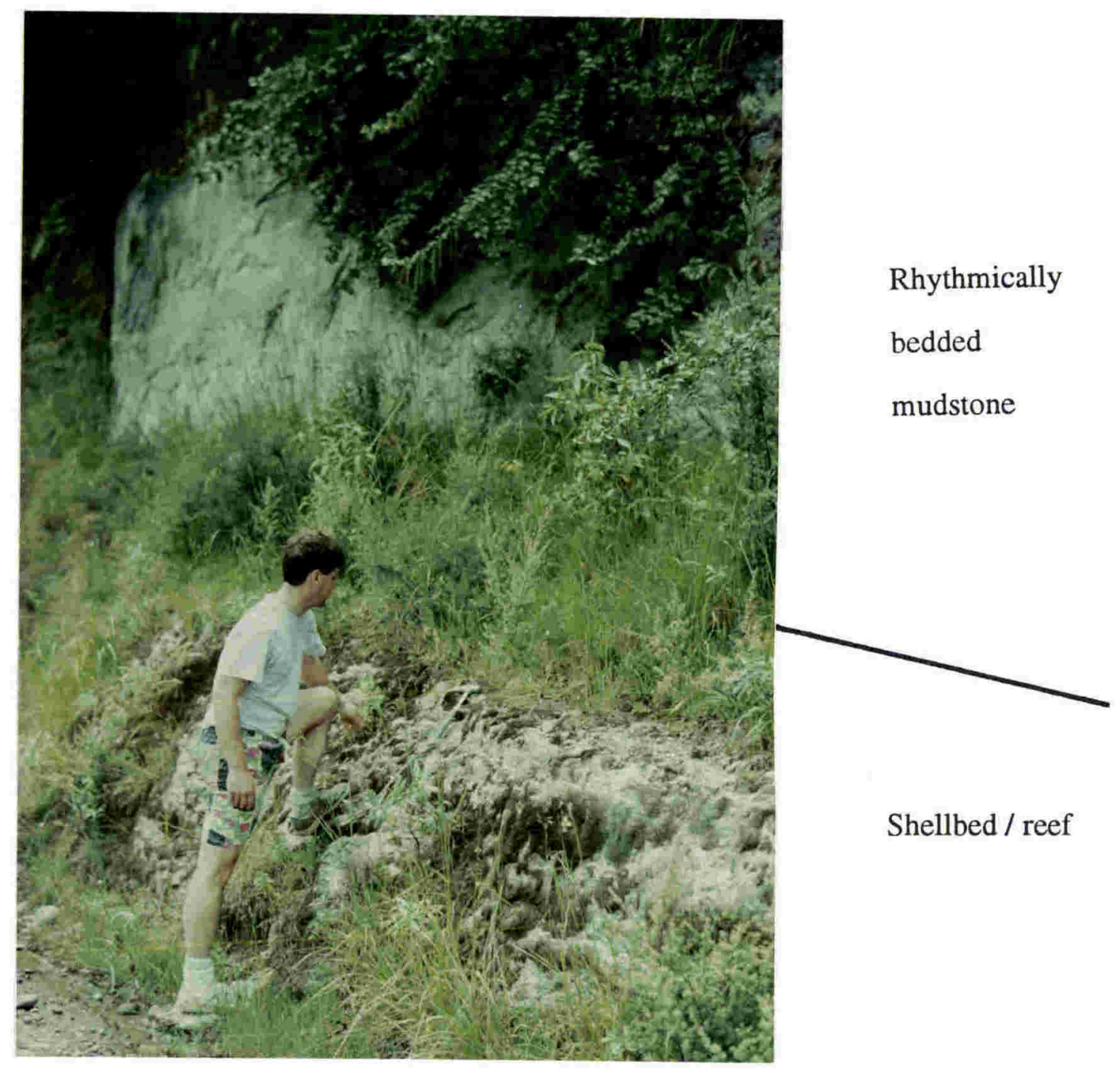

Plate 13.7: An example of the sandy shellbed / reef facies association, from the basal part of the Jerusalem Sandstone, Wanganui River Section. It is overlain by the rhythmically bedded mudstone facies association.

currents maintaining a clear substrate for development of the oyster reef. The coarse sands and shelly lag material are deposited between the Crassostrea shells by high velocity currents. This is interpreted to be the most landward deposit/facies on the continental shelf observed by the present study.

\subsubsection{Siltstone}

A typical occurrence of this facies association is above the Hautawa
Shellbed, in the unnamed beds towards the base of the Lower Okiwa Group, in the Rangitikei River section. This association is of massive, sometimes slightly sandy siltstones, poorly to moderately fossiliferous, but intensely bioturbated. It includes scattered fossils in growth position and locally is concretionary. The unit is typically less than $100 \mathrm{~m}$ thick, and at places is well bedded and laminated. Occasionally there is some pyritisation within this facies association. 
The fauna is generally a soft-bottom assemblage of less than $100 \mathrm{~m}$ water depth (Fleming, 1953). It is interpreted to be of a similar depositional environment to the Mudstone facies association, with mid shelf water depth foraminifera (Collen, 1972). The difference is that the mudstone facies is deposited further from the active sediment lobe, at a position laterally equivalent on the continental shelf. Percent mud figures from Perrett (1990) suggest depth of deposition for the siltstone facies to be similar to the mudstone facies, that is, on the order of 50-60 m.

\subsection{Facies Successions}

Two successions of the previously described facies associations are common in the South Wanganui Basin. Both of these successions are unconformity bounded.

\subsubsection{Coarsening (figure 13.3)}

This is the most common succession, particularly in the Wanganui River Section. The base of the sequence is an erosion surface that is commonly bioturbated. It is overlain by the rhythmically bedded mudstone facies association. This is conformably overlain by a thicker bedded mudstone or siltstone facies association, grading up to a transitional coarsening association with the sandstone becoming much more dominant. The sandstones always downlap over a sharp, often slightly erosional contact with the underlying mudstone.

A massive 100-300 m thick sandstone overlies the coarsening transitional facies (plate 13.1). It is sometimes crossbedded and can have fine interbeds but these are not common. The massive sandstone and the top of the succession is capped by a prominent 2-4 m thick gritty, sandy oyster reef with channelling and scouring within it. This is then unconformably overlain by another finer grained facies association. The entire succession, when complete, ranges from 200 to greater than $500 \mathrm{~m}$ in thickness.

\subsubsection{Fining (figure 13.4)}

The other succession observed in the present study is of a generally fining upwards nature. It is less common, but dominates much of the Rangitikei River section. In the Wanganui River section it is observed in the lower Matemateaonga Group sediments in the base of the section, within the Mangaparua and Mangatiti Formations. It is also observed in the uppermost part of the Wanganui River section, within the Lower Okiwa Group strata only.

The fining upwards successions are much thinner than those that coarsen upwards. Individual examples vary from 40 to 100 $\mathrm{m}$ in thickness, and they vary in their internal facies associations. Again the base of the sequence is an unconformity, which can be a large channelled surface, with $50 \mathrm{~m}$ or more of relief. This is 


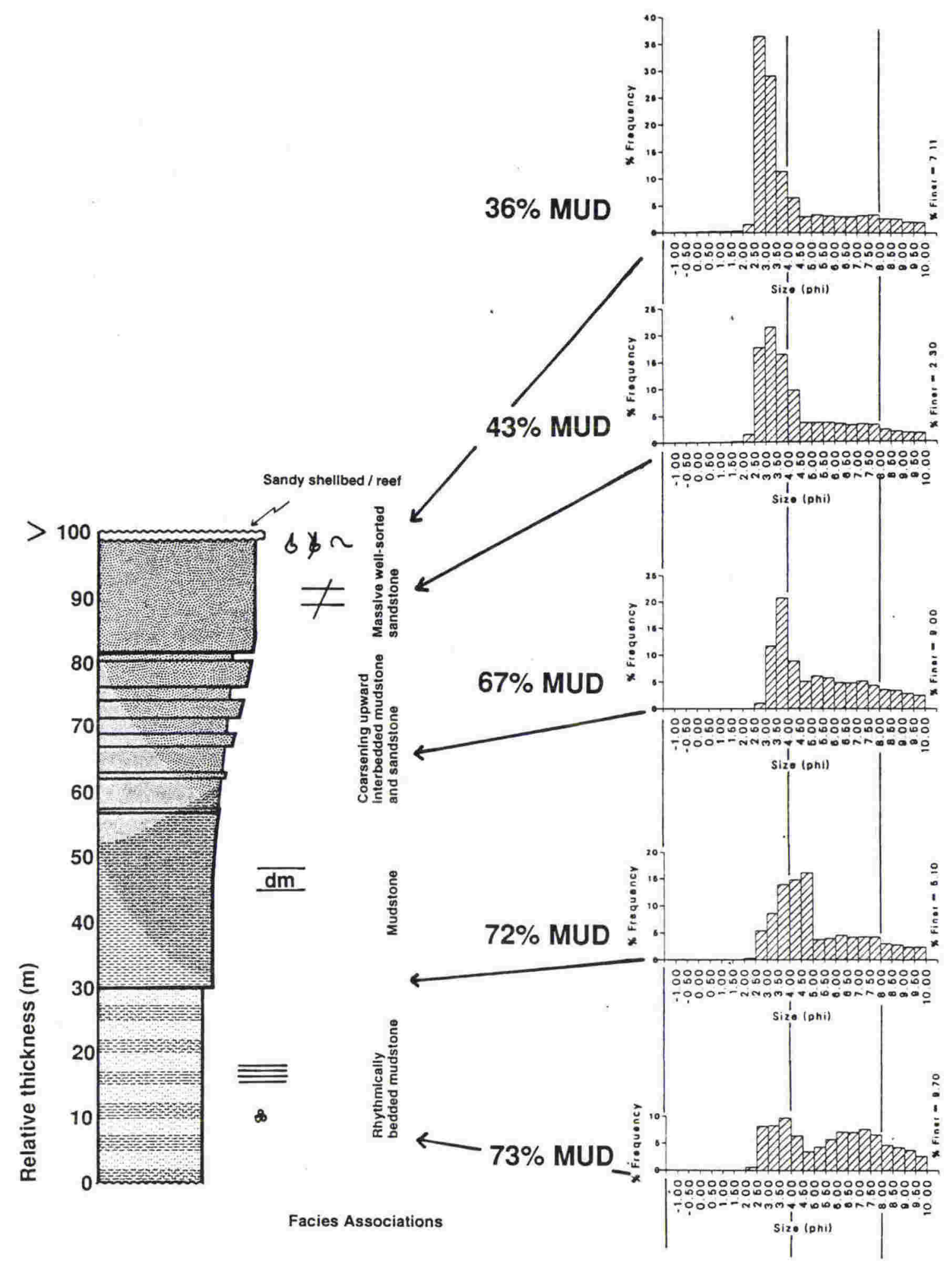

Figure 13.3: A diagrammatic representation of the Coarsening facies succession. It varies from 100 to $c a .350 \mathrm{~m}$ in thickness with the individual facies associations varying as depicted by the relative scale. Percent mud values are given to allow further comparison with the depth models of Swift (1970) and Elliot (1986), see figure 13.5. A general interpretation is one of a gradually shallowing depositional environment. 
a

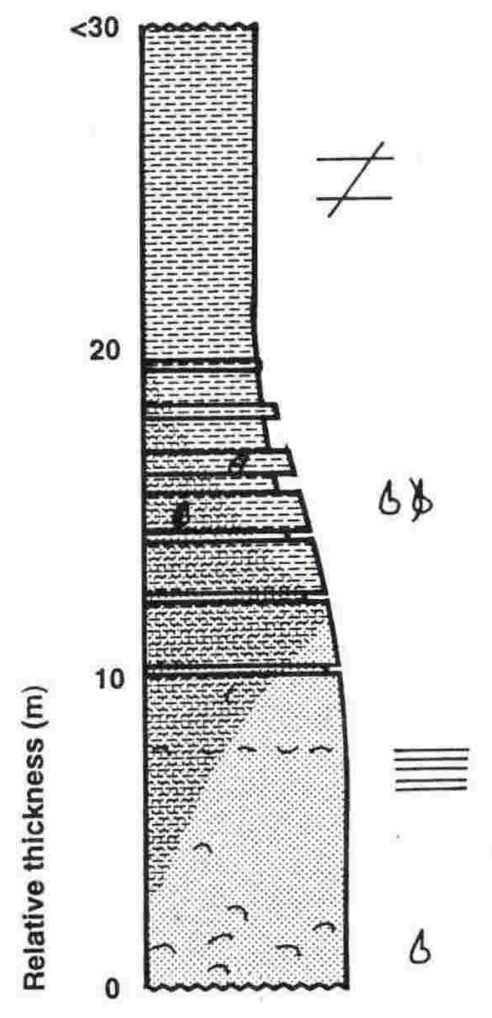

b

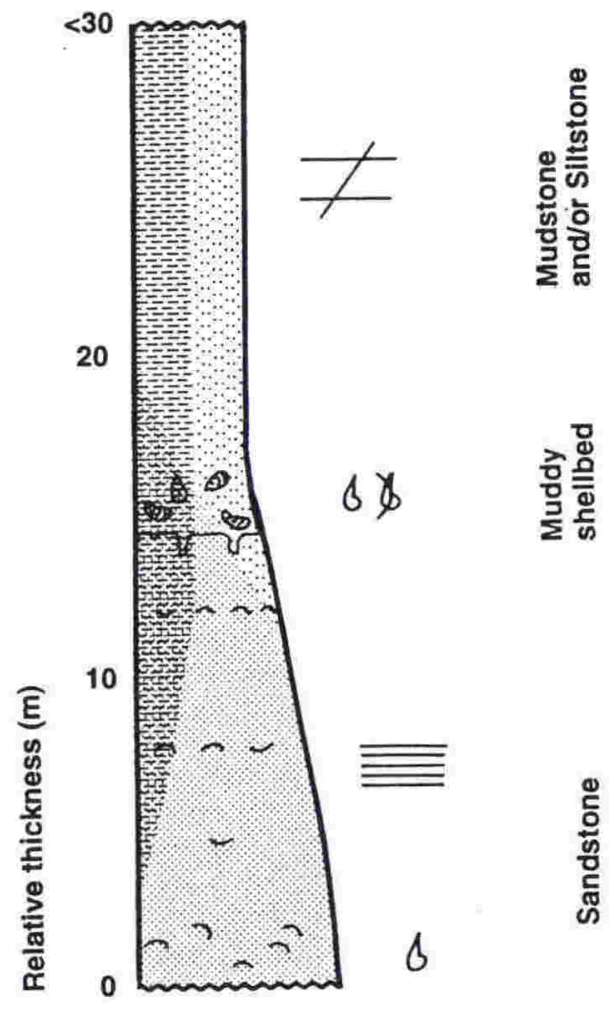

Facies Associations

Facies Associations

Figure 13.4: Diagrammatic representation of the Fining facies succession. Two main types are recognised; a. a succession containing a fining upward interbedded mudstone facies association; b. a succession containing muddy shellbed facies association directly overlying a burrowed surface or hardground. The two successions are between 10 and 30 $\mathrm{m}$ in thickness. They are both inferred to have been deposited in a deepening depositional environment, except succession a is inferred to have been deposited closer to the sediment source.

commonly overlain by a massive to well bedded, sometimes muddy, sandstone association which is generally quite thin (only a few tens of meters). In places this quickly grades into a fining interbedded association, and in other places it is directly overlain by a muddy shellbed association. In a few places the fining interbedded association directly overlies the unconformity.

The muddy shellbed association is conformably overlain by a mudstone or siltstone association (figure 13.4a). Alternatively the fining interbedded association grades up into a mudstone or siltstone association (figure 13.4b). The fining interbedded association can contain thin shell lags which are weakly developed muddy shellbed associations. The mudstone or siltstone associations are truncated by an erosional unconformity.

\subsubsection{Interpretation}

Interpretation of these two successions is based on the seaward fining model of Swift (1970); Swift et al. (1987) and Elliot (1986) (figure 13.5).

Interpretation of the coarsening facies succession is that it has developed on the continental shelf during an overall 
decreasing depth of deposition, with the depositional environment changing from an outer shelf environment of 50-60 metres water depth to a shallow intertidal environment. There are smaller scale variations within this shallowing succession, which were caused by differential progradation of sediments across the shallowing continental shelf.

The fining upward facies succession is interpreted to have developed on the continental shelf during an overall increasing depth of deposition. The depositional environment changes from an intertidal sandy environment to a midshelf environment of greater than 30 metres, perhaps as much as $100 \mathrm{~m}$ in some cases. Again there are smaller scale variations within the succession, caused by differential progradation of sediments onto the deepening continental shelf.

\subsection{Stratal unconformities}

Seven different types of stratal unconformity are recognised in the present study of Late Neogene strata in the South Wanganui Basin. Six are disconformities and the seventh is a paraconformity (see table 13.1 for definitions). The individual surfaces vary greatly in character and can be defined not only by the type and nature of the break in the record, but also the nature of strata above and below.

Disconformable erosion surfaces (disconformities) in the basin vary from large channel development and surfaces associated with large channel development (A) (plate 13.8a and 13.8b), to surface scouring associated with smaller scale erosion (B). Type A disconformities are inferred to be

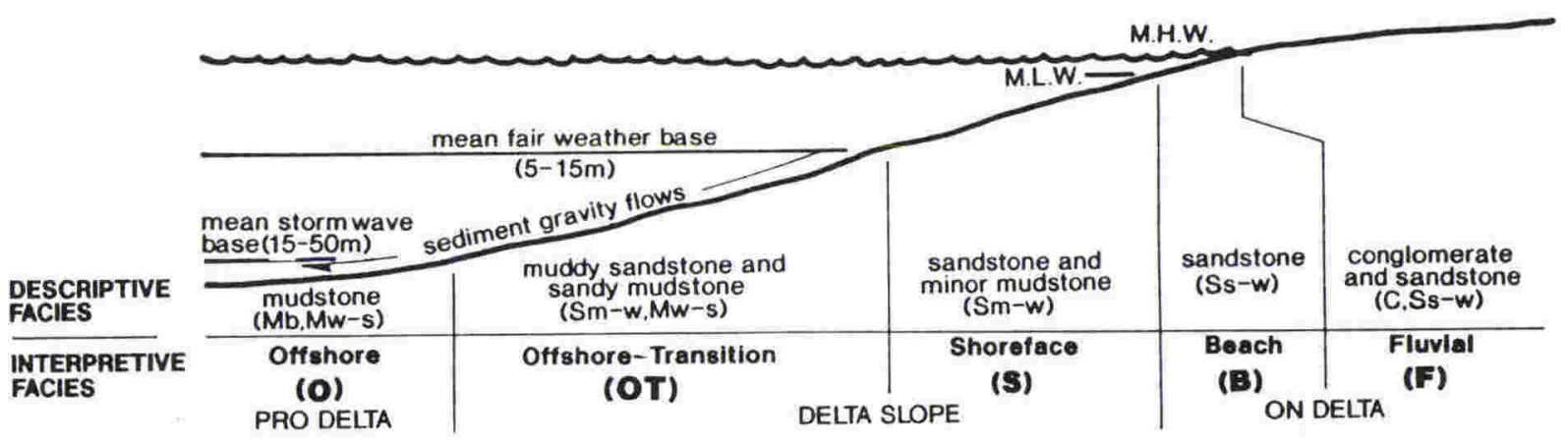

Figure 13.5: A facies model for sedimentation on a wave dominated coast (from Hambrey et al., 1989). It is used to infer variations in water depth of deposition of the facies associations and successions discussed in this chapter. 

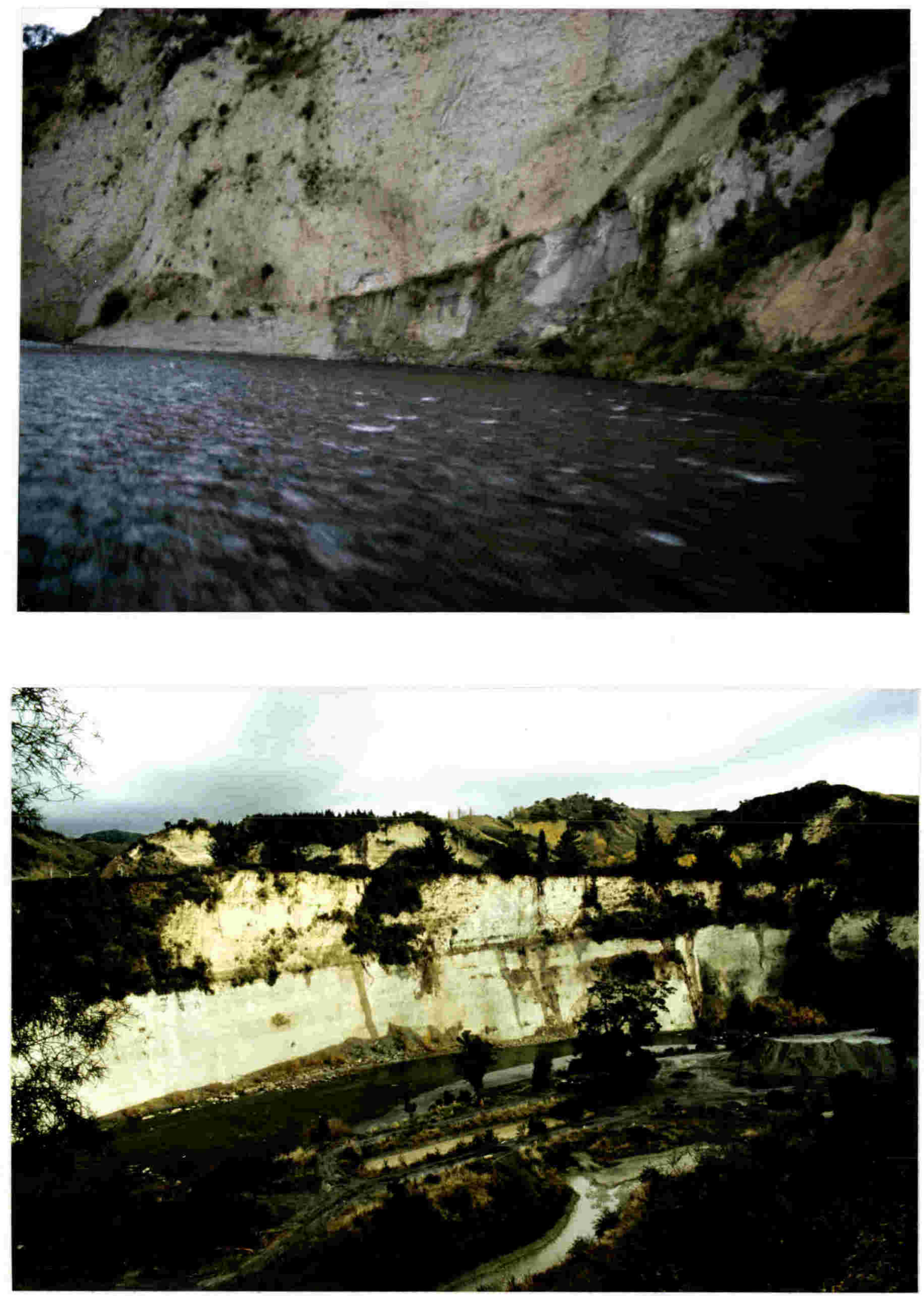

Plate 13.8: Examples of type A unconformities in strata of the South Wanganui Basin. a. (upper, frame of reference is $20 \mathrm{~m}$ tall) a well developed channel with more than $10 \mathrm{~m}$ of relief, underlain by mudstone facies and overlain by sandstone facies. b. (lower, bluff is $c a$. $60 \mathrm{~m}$ tall) an angular unconformity like a., but with much less relief developed (photo; Mike Wizevich). 
associated with subaerial exposure of the site of deposition. Type B disconformities are inferred to have formed in a submarine environment in response to a change in depositional parameters. A further type of disconformity encountered in this study (type C) is a marine hardground.

A1) The channels have widths on the order of a kilometre, and truncate the underlying beds with angles between 1 and 20 degrees. Overlying strata are always (within measurement error) parallel to the truncated strata. This channel development is observed only in three localities in the Rangitikei River Section, and is not seen in the Wanganui River Section. These large channelled disconformities usually truncate a mudstone or siltstone facies association and are always overlain by a sandy or muddy sand facies association.

A2) Similar stratal relationships are observed in the lowest and highest parts of the Wanganui River Section (Mangaparua and Mangatiti Formations and Lower Okiwa Group strata). There are definite signs of unconformity between the truncated finer grained facies association, and the overlying coarser grained facies association. However, large channels were not observed in the outcrop available in the Wanganui River section. In this study these unconformities are inferred to result from subaerial exposure like A1 disconformities, the channelling is merely not developed to the same extent.
B) Scoured surfaces developing between $1 \mathrm{~cm}$ and $3 \mathrm{~m}$ of relief are ubiquitous in the sections studied. The surfaces are generally indicative of traction currents on the continental shelf. Four main types observed. The most common is where a relatively coarse shallow water facies is truncated by a scoured surface, which is directly overlain by a finer grained deeper water facies.

B1) The most deeply scoured surface occurs where the sandy shellbed or reef facies is directly overlain by the rhythmic mudstone facies. Here, a scoured and sometimes burrowed surface with several metres of relief separates the two facies.

B2) Occasionally the B1 type of disconformity is directly overlain by a gritty, shelly lag derived from the underlying strata.

B3) Often the B1 disconformity occurs where a bioturbated sandstone is directly overlain by a deeper water siltstone or mudstone, with a scoured surface (less than $1 \mathrm{~m}$ of relief) separating the two facies. In this case a shell lag (muddy shellbed facies) often overlies the scoured surface and then grades into the overlying mudstone or siltstone.

B4) Another common scoured surface, like the B1 surface, where a finer grained facies, usually a mudstone, with only a few centimetres of relief is directly overlain by a sandy mudstone. In this instance coarser shallower facies are 
prograding seaward, with associated currents eroding the existing surface.

C) The most common paraconformity surface observed in the South Wanganui Basin strata is restricted to the finer grained facies. This is where two mudstones and/or siltstones units are separated by a strongly burrowed hardground (plate 13.9). Often the burrows are filled with slightly coarser sediment. On a larger scale the bored surface of the reef facies can also be considered a hardground. These originated in shallow water, whereas the mudstone facies hardgrounds originated on the mid to outer shelf.

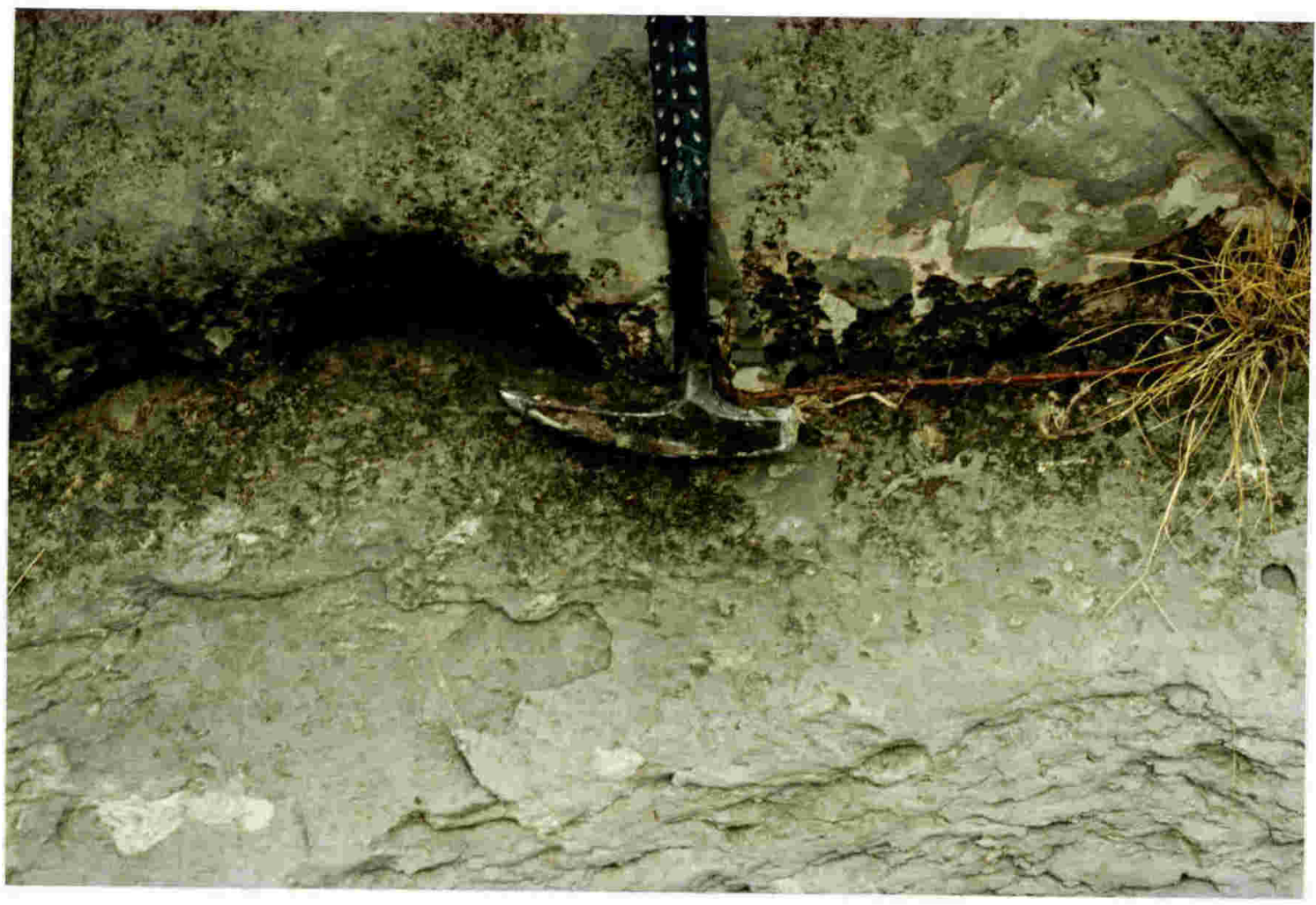

Plate 13.9: An example of a type $C$ paraconformity. A bioturbated mudstone hardground. It is inferred to be relatively deep water in origin. 


\section{Chapter - 14}

\section{Sequence Stratigraphy}

This chapter discusses the sequence stratigraphy of the Late Neogene strata of the South Wanganui Basin. The existing sequence stratigraphic framework (sensu Payton, 1977 and Wilgus et al., 1988) is described for comparison. Terminology is defined to prevent continued misunderstanding of eustatically controlled sedimentation on the continental margin. Assumptions of this existing framework are discussed in the light of the South Wanganui Basin morphology (from chapter 10). and sedimentation (from chapter 13). The South Wanganui Basin is unusual in that sedimentation balances subsidence, despite the high sedimentation rate $(1.3 \mathrm{~mm} / \mathrm{y}$; from chapter 19$)$. This leaves eustasy as the only factor affecting space for accommodation in the basin during deposition.

Existing assumptions of shelf morphology are found not to hold. Consequently a different model of eustatically controlled sedimentation and its manifestation on the continental shelf is established for South Wanganui Basin sequence architecture in the Late Neogene. Lowstand, Transgressive, Highstand, and Regressive Sediment Wedges are defined and their integral relationship to lowstand, highstand, transgressing and regressing sea level explained. The two sequence types are recognised by the present study as manifestations of their position of formation on the palaeo-continental shelf.

\subsection{Introduction}

Van Wagoner et al. (1988) define Sequence Stratigraphy as the study of rock relationships within a chronostratigraphic framework. Strata are grouped in terms of continuity of deposition. Continuous episodes of deposition are termed sequences. Bounding the sequences are breaks in deposition. These can be erosion surfaces (unconformities) or merely episodes of non-deposition (paraconformities).
Sequence stratigraphic methods have recently been revived as geologic interpretive methods (Payton, 1977; Wilgus et al., 1988; Van Wagoner et al., 1990; Vail et al., 1991). The same concepts of time-stratigraphy, with lithologic units being deposited in restricted areal and geometric patterns by changing relative sea-level (influenced by both eustasy, sediment supply and tectonism) was first documented by Sloss in the late 1940's (Sloss et al., 1949 and Sloss, 1950). Vella (1953; 1963a; 1963b) also recognised eustatic sea level variation as a controlling factor in 
shallow marine sedimentation of PlioPleistocene strata in New Zealand.

The new sequence stratigraphic method was developed by a team from the EXXON Oil Co. (Payton, 1977) from assessment of seismic images of many coastal stratigraphic sedimentary sequences. It relies on recognition of genetic sedimentary packages and patterns within these seismic images.

Carter et al. (1991) separate the temporal and spatial components of sequence stratigraphy into the Global Sea-level Model (GSM), a study of the eustatic record over geologic time, and the Sequence Stratigraphic Model (SSM), a study of the architecture of sedimentation on the continental margin. In this chapter, discussion of sequence stratigraphy is limited to the $S S M$ definition of Carter et al. (1991). Chapter 15 makes contributions to the GSM.

\subsubsection{Terminology}

A new set of terminology has grown with the revival of the sequence stratigraphic technique. New names have been used to replace old. A model or framework has been to built from seismic stratigraphic observations and then lithologic observations fitted to the model. As lithologic characteristics were found to fit within the new framework they were assigned new names, even though these characteristics have long been named for their direct sedimentologic features. The approach in this study is to use facies terminology when working directly with stratigraphic outcrop (Chapter 13; Table 13.1) and make interpretations accordingly. The new sequence stratigraphic terminology is used only after a genetic interpretation has been made (this chapter). Two terms may refer to the same assemblage of strata: One is descriptive and classifies the rock in terms of its appearance and the other is interpretive of the genesis of the delimited strata.

Definitions of sequence stratigraphic terms as used here are given in table 14.1. This glossary is necessary because of the prolific growth of sequence stratigraphic terminology. Many previous workers have used these terms incorrectly or with poor understanding. Clarification is given here to prevent further confusion. New terms are introduced only to define situations that are not adequately described by existing terminology. A clear distinction is made between observational or descriptive terms (table 13.1) and those that are genetic (table 14.1).

\subsection{Sequences and their boundaries}

A depositional sequence is the basic stratigraphic unit of sequence stratigraphy. Sequences and their stratal components are interpreted to be formed in response to the interaction between rates of eustasy, subsidence, and sediment supply (Van Wagoner et al., 1988). A complete sequence represents 


\section{Table 14.1: Glossary of sequence stratigraphic terms as used in this thesis}

Accommodation; The space made available for potential sediment accumulation (Jervey, 1988).

Architectural Element; a morphological subdivision of a particular depositional system characterised by a distinctive assemblage of facies, facies geometries, and depositional Processes (Walker, 1992). In essence this has the same meaning as facies association. In this study, facies association is used when looking directly at outcrop and architectural element is used once a genetic interpretation is made.

Bed sets; a relatively conformable succession of genetically related beds bounded by surfaces of erosion, non-deposition, or their correlative conformities (Van Wagoner et al., 1990).

Bounding Discontinuity; a laterally traceable discontinuity; can be an unconformity, ravinement surface, onlap or downlap surface, condensed horizon or hardground (Walker, 1992). May be diachronous, but this fact is not considered by most workers (This study).

Composite Sequence; A stratal package bounded by unconformities but internally composed of high frequency genetically related sequences in which the individual sequences stack into lowstand, transgressive, and highstand sequence sets (Mitchum and Van Wagoner, 1991).

Condensed Section; A thin marine stratigraphic interval characterised by very slow depositional rates (Vail et al, 1984). It consists of hemipelagic and pelagic sediments, starved of terrigenous material, deposited on the middle to outer shelf, slope, and basin floor during a period of maximum relative sea-level rise and maximum transgression of the shoreline (Loutit et al, 1988).

Cycle Architecture; A facies sequence that has been assigned to a complete sea level sequence, it's nature can vary depending upon the height that the sequence was deposited on the shelf (This study).

Depositional environment; Geographic and/or Geomorphic area (Walker, 1992).

Depositional shoreline break; The concurrent physiographic break, landward of which the sea floor is at or near base level and seaward of which the sea floor is below base level. The break may occur at or seaward of the shoreline. Consequently it refers to an active depositional physiographic break at the edge of the continental shelf (Posamentier and Vail, 1988).

Depositional System; A three-dimensional assemblage of lithofacies, genetically linked by active or inferred processes and environments (Brown and Fisher, 1977).

Downlap; the situation where an initially inclined layer terminates down dip against and initially horizontal or inclined surface (Mitchum et al., 1977).

Equilibrium Point; The point along a depositional profile where the rate of eustatic change equals the rate of subsidence/uplift. It separates zones of rising and falling relative sea level (Posamentier et al., 1988).

Highstand wedge; the sediment package that nucleates and progrades beneath the highest stand of relative sea level (This study). It is always deposited high on the continental shelf.

Lowstand wedge; the sediment package that nucleates and progrades beneath the lowest stand of relative sea level (This study). It is always deposited on the outer continental shelf and sometimes beyond the shelf.

Marine Flooding Surface; a surface separating younger from older strata across which there is evidence of an abrupt increase in water depth (Van Wagoner et al., 1990).

Maximum Flooding Surface; the largest marine flooding surface in a sequence. It separates the Lowstand Systems Tract from the overlying Transgressive Systems Tract. It is still marked by deeper water facies directly overlying shallower water facies. It is a time-transgressive surface (New definition, modified from Walker, 1992).

Onlap; the situation where an initially horizontal stratum laps out against an initially inclined surface (Mitchum et al., 1977). 
Parasequence; a relatively conformable succession of genetically related beds or bedsets bounded by marine flooding surfaces and their correlative surfaces (Van Wagoner, 1985 and Van Wagoner et al., 1988).

Parasequence set; a succession of genetically related parasequences that form a distinctive stacking pattern, generally bounded by major marine flooding surfaces and their correlative surfaces (Van Wagoner, 1985 and Van Wagoner et al., 1988).

Ravinement Surface; an erosion surface produced during marine transgression, with finer material moved seaward and coarser material left as a lag on the surface (Weimer, 1988). Also known as a transgressive surface (Van Wagoner et al., 1988).

Sequence; A relatively conformable succession of genetically related strata bounded at its top and base by unconformities and their correlative conformities (Vail et al, 1977)... it is composed of a succession of systems tracts and is interpreted to be deposited between eustatic fall inflection points (Posamentier et al., 1988).

Sequence architecture; The particular sequence of facies characteristic of a sequence. This changes depending on varying accommodation space (This study).

Sequence set; A set of sequences arranged in a distinctive progradational, aggradational, or retrogradational stacking pattern (Mitchum and Van Wagoner, 1991). Sequence sets in composite sequences are analogous to systems tracts in sequences (Mitchum and Van Wagoner, 1991).

Sequence Stratigraphy; The study of rock relationships within a chronostratigraphic framework wherein the succession of rocks is cyclic and is composed of generically related stratal units (Posamentier et al., 1988).

Shelf Break; The pre-existing physiographic break at the edge of the continental shelf (Posamentier and Vail, 1988). It is independent of any short-term sedimentation occurring on the shelf, and usually has a depth between 50 and $200 \mathrm{~m}$ which is controlled by the long-term interplay of sediment supply, subsidence and eustacy (Carter et al., 1991). This is sometimes referred to as the true shelf edge.

Systems tract; a linkage of contemporaneous depositional systems (Brown and Fisher, 1977).

Transgressive surface; see Ravinement surface.

deposition within a single cycle of eustatic sea-level change. Because of the many cyclic orders of eustatic sea level change (Vail et al, 1991), sequences can occur on many scales. The term sequence is reserved for the smallest stratal order that can be subdivided into its constituent systems tracts (This study). Larger genetic stratal cycles are referred to as composite sequences and sequence sets (Mitchum and Van Wagoner, 1991). A sequence can be subdivided into parasequences and parasequence sets.
Vail et al.(1977) originally defined the type 1 sequence boundary (figure 14.1) as the most prominent depositional unconformity. Genetically, this occurs when relative sea level is at its lowest point in the cycle. The entire continental shelf is subaerially exposed and prone to erosion and channel development, by stream rejuvenation. They also recognised another type of sequence boundary (type 2) (figure 14.2) which occurs, genetically, when sea level does not fall below the shelf margin. In this case there is a basinward shift in facies, 


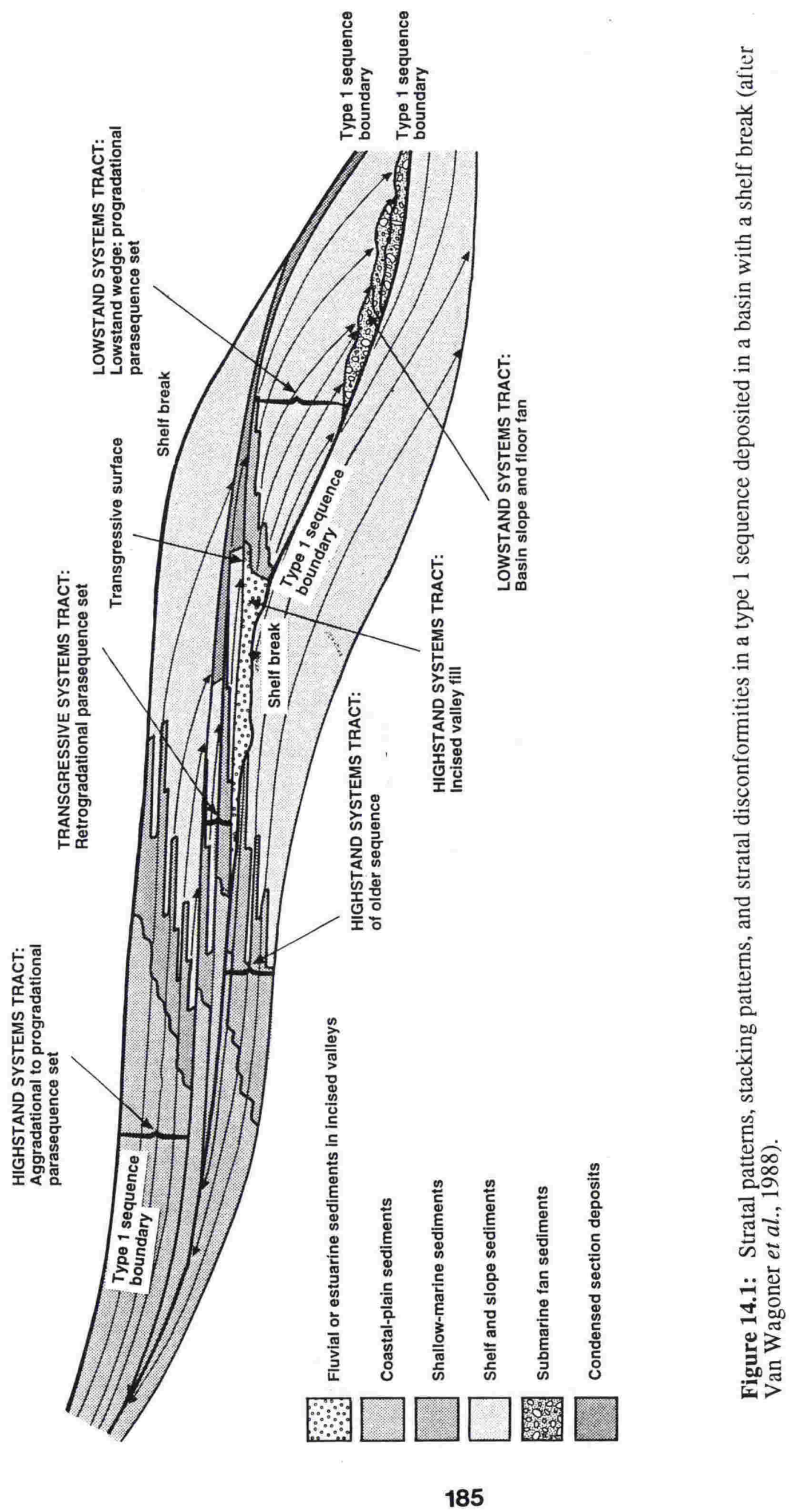




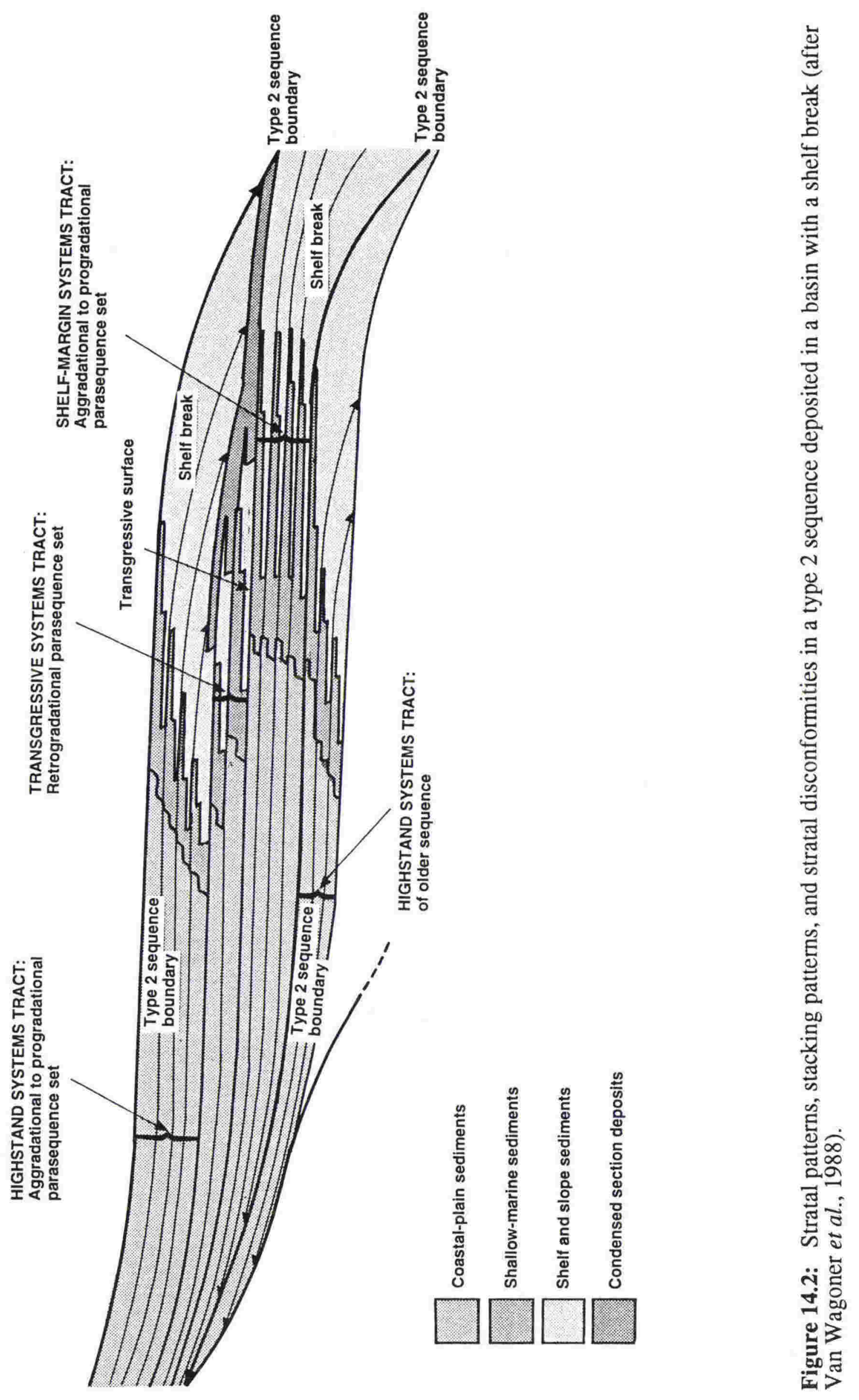


with sediment bypassing the continental shelf. Erosion is not as well developed (Vail et al., 1977) as in a type 1 sequence boundary. The definition of sequence boundaries was expanded by Mitchum (1977) to include not only the unconformity surfaces but its correlative conformable surfaces where no erosion has taken place (for example seaward of the lowest point of subaerial exposure on the continental shelf).

Genetically, Posamentier and Vail (1988) interpreted the two types of disconformity as developing from a fast (type 1) and slow (type 2) relative sea level fall respectively. Deposition above the different types of sequence boundary is different. The two corresponding sequence types are referred to as type 1 (figure 14.1) and type 2 (figure 14.2) sequences (Vail et al., 1977). A type 1 sequence develops above a type 1 boundary and a type 2 sequence develops above a type 2 boundary. These two sequence are distinguished by their different stratal components. By definition (Posamentier and Vail, 1988) a type 1 sequence is deposited during a slow rise and high stand of relative sea level, and a type 2 sequence during a fast rise and high stand of relative sea level.

\subsubsection{Marine Flooding Surfaces}

A rising sea level will cause deeper water facies to be deposited directly above shallower water facies. Depending on the rate of sea level rise this may be conformable or non-conformable. When the rate of sea level rise is relatively fast, this transition may be marked by minor submarine erosion. Vail (1990) has termed this slightly eroded surface a ravinement surface. This same surface between older/shallower and younger/deeper facies is termed a marine flooding surface (Van Wagoner et al., 1990). A key observation is that the marine flooding surface can occur on any number of scales. On a sequence scale a marine flooding surface separates the low stand systems tract from the transgressive systems tract (figure 14.1). On a smaller scale a marine flooding surface separates parasequences in a parasequence set (figure 14.3). Van Wagoner et al. (1988) referred to these as major and minor marine flooding surfaces respectively.

The term maximum flooding surface is used here to represent the largest marine flooding surface in a sequence. It separates the Lowstand and Transgressive Systems Tracts. High on the shelf the maximum flooding surface is also a type 1 sequence boundary (figure 14.1).

The definition of Walker (1992) that a maximum flooding surface is a chronostratigraphic line coeval with the highest point of sea level rise during a sea level cycle, and that it commonly separates the transgressive systems tract and overlying highstand systems tract - is not adopted here. In this study the base of the Highstand Systems Tract is taken to be marked by downlapping strata (figure 14.1). Van Wagoner et al's. (1990) 

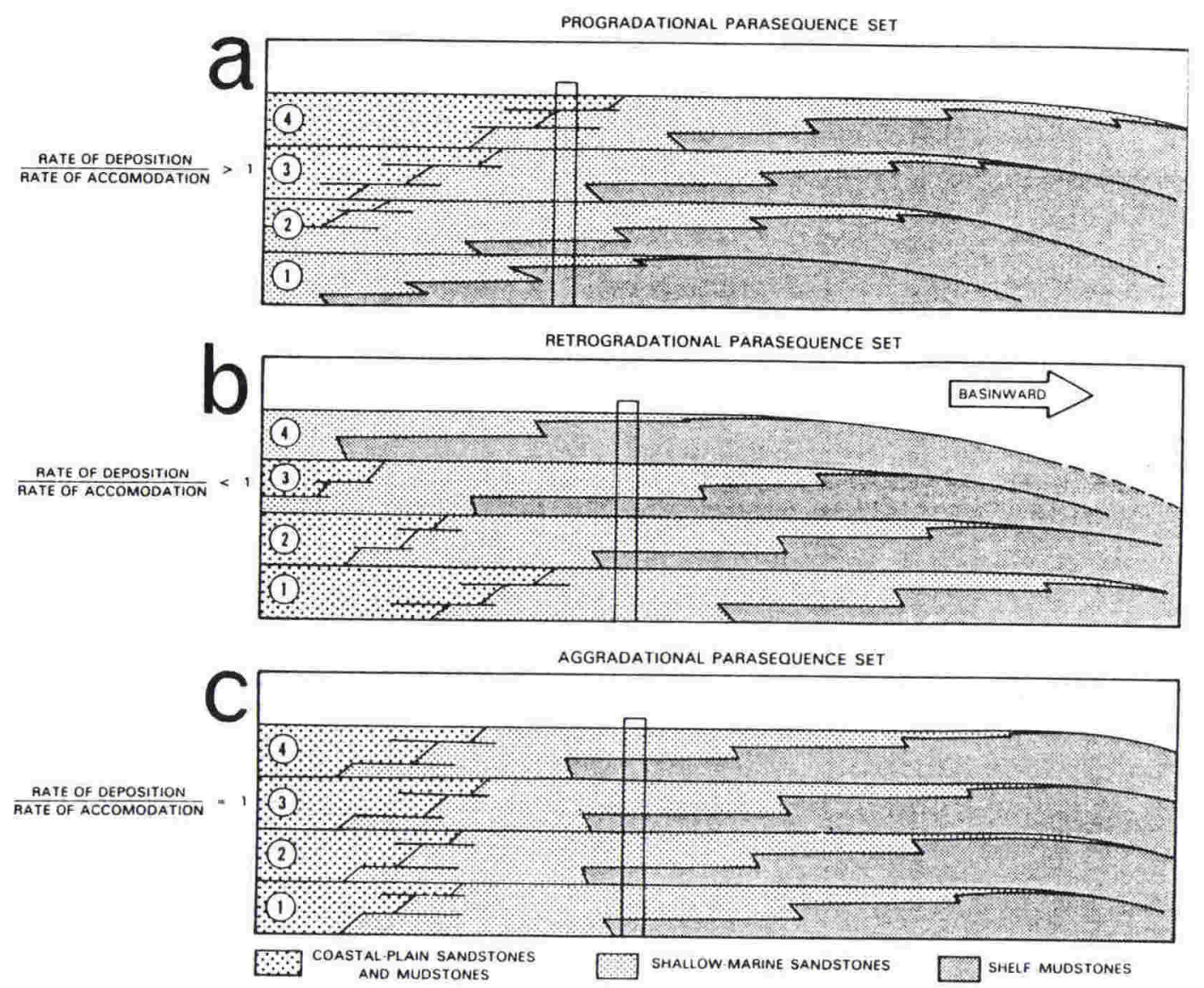

(1) (4) individual pataseouences

Figure 14.3: Diagrammatic stacking patterns of parasequence sets (from Van Wagoner et al., 1990); a. progradational parasequence sets; b. retrogradational parasequence sets; b. aggradational parasequence sets.

suggestion that the maximum flooding surface is not observed lower on the shelf and is marked by the condensed section is also not accepted by this study. Lower on the continental shelf, the Maximum flooding surface is the basal surface of the condensed section (This study) (figure 14.1).

\subsubsection{Parasequences}

Van Wagoner et al. (1988) defined parasequences as the fundamental building blocks of sequences. They are merely shorter order sea level cycles, than those that produce sequences, and they do not develop full systems tracts on the continental shelf.

Parasequences can be progradational, retrogradational, or aggradational (Van Wagoner et al., 1988) (figure 14.3). Genetically, this is dependent on whether longer order relative sea levels are rising, falling or remaining stationary. If the parasequences are prograding, parasequence bed sets will coarsen and thicken upwards (figure 13.1). If they are retrograding parasequence bed sets will thin and fine upwards (figure 13.2). Under aggradation they will merely stack and not change in nature (figure 14.3). 
Mitchum and Van Wagoner (1991) explain several mechanisms by which parasequences form: Rapid increase in water depth from compaction associated with delta lobe switching, rapid tectonic subsidence, and high frequency eustatic cyclicity. Parasequences are best developed in shallow-marine sediments (Mitchum and Van Wagoner, 1991) where small changes in relative sea level cause marked changes in facies distributions.

\subsection{Systems Tracts}

A sequence can be subdivided into systems tracts, depending on the interpretation of their position of deposition on the continental shelf (figures 14.1 and 14.2). Posamentier et al. (1988) define these systems tracts as linkages of contemporaneous depositional systems. They are genetically related to maxima and minima of relative sea level, and defined by the geometry of the sediment package produced on the continental shelf. Internal characteristics that define these sedimentary packages are the nature of onlap and offlap of strata and changes in the nature of sedimentation between appreciable hiatuses in deposition. It is key changes in relative sea level that separate sequences into their component systems tracts.

Systems tracts are defined objectively using four criteria; type of bounding surfaces, position within a sequence, nature of parasequence sets and geometry. However, it is understood in the definitions that the driving force of these changing depositional environments and systems tracts is eustatic sea level variation (Posamentier et al., 1988). Sequences are composed of three basic systems tracts: Highstand systems tract (figure 14.4), which develops during a high stand of relative sea level; Lowstand systems tract (figure 14.5), which develops during a lowstand

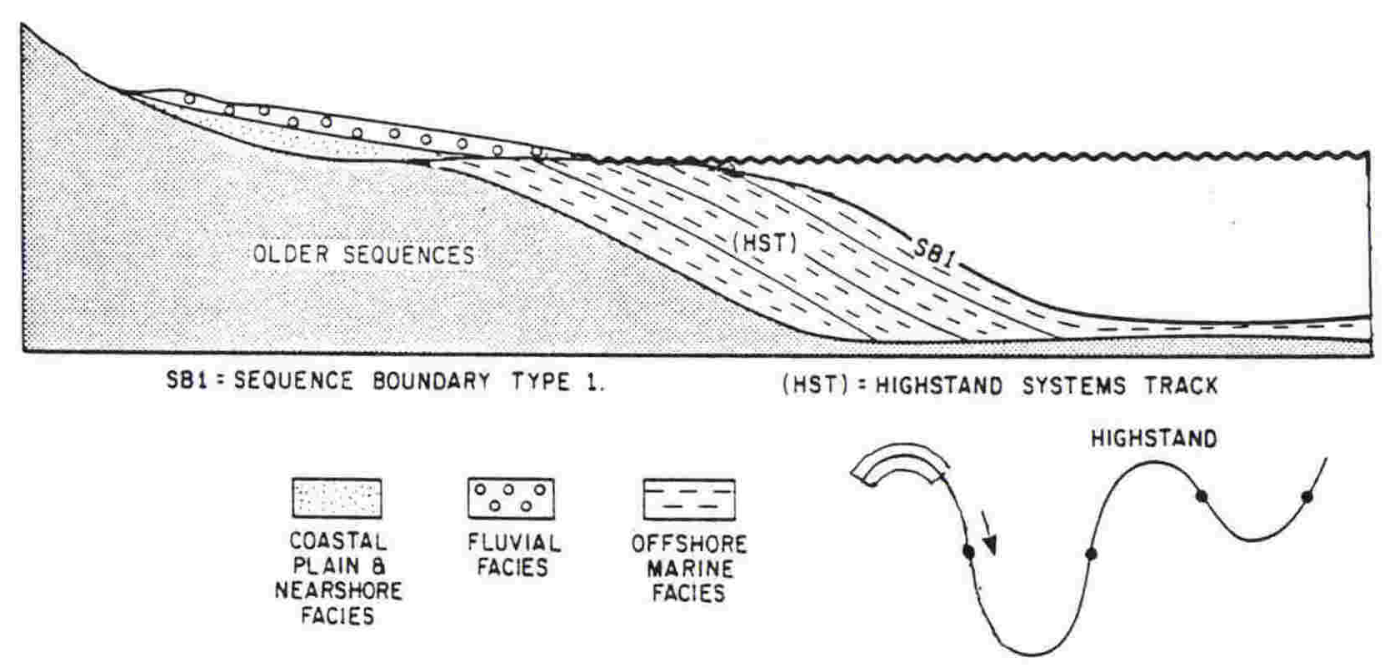

Figure 14.4: Highstand systems tract (modified from Haq, 1991). 


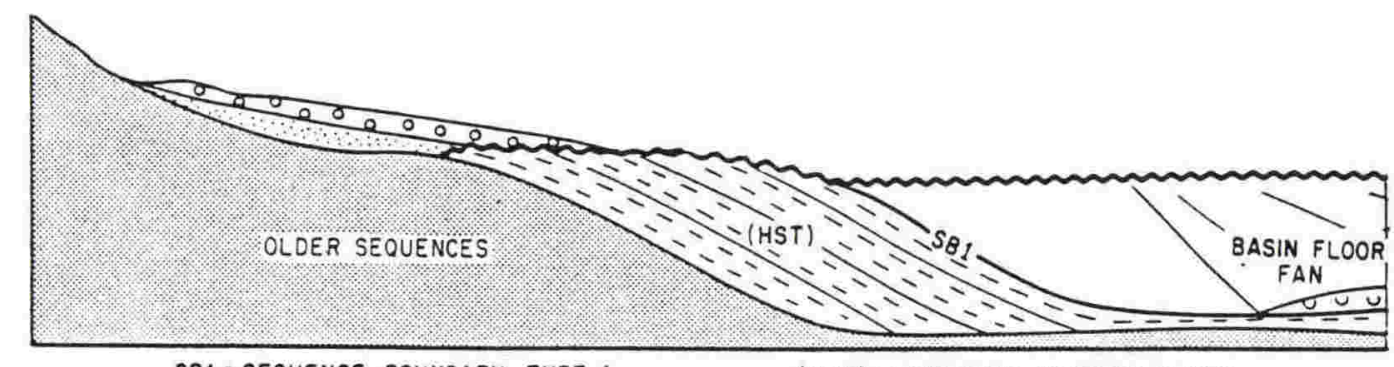

SB1 = SEQUENCE BOUNDARY TYPE 1.

(HST) : HIGHSTAND SYSTEMS TRACK
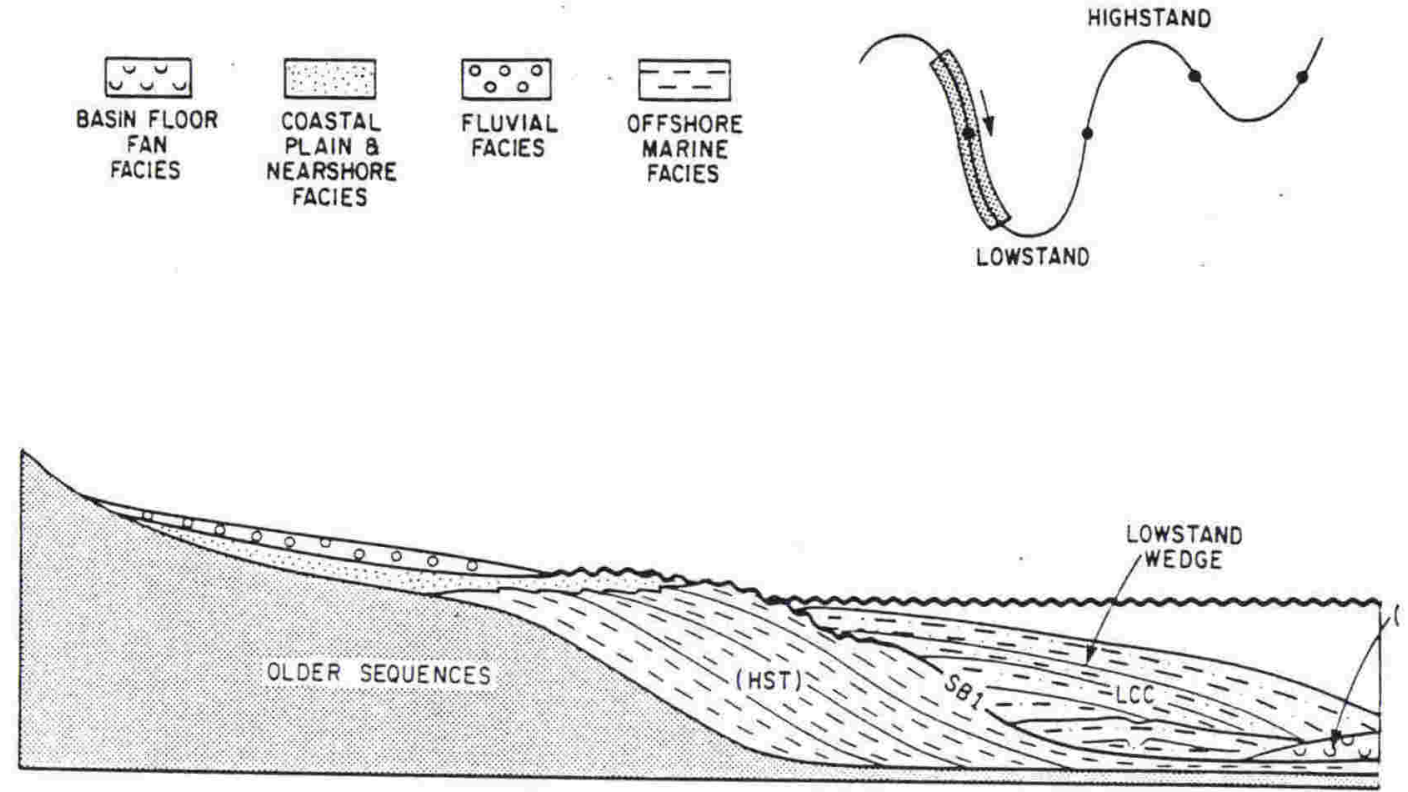

LCC: LEVEED CHANNEL COMPLEX

$(B F F)=B A S I N$ FLOOR FAN
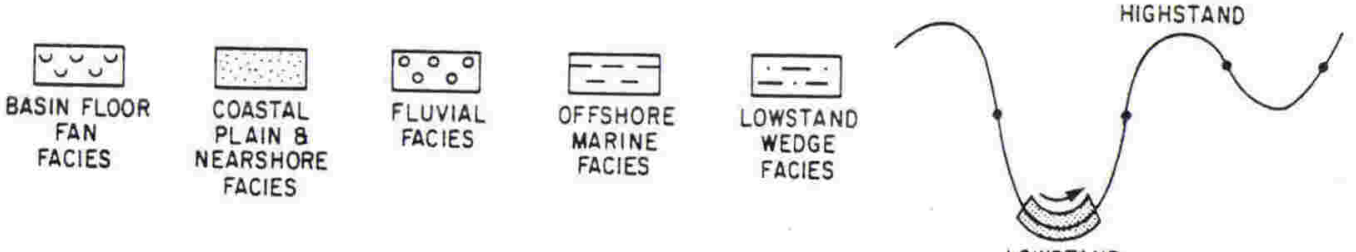

LOWSTAND

Figure 14.5: Lowstand systems tract; a. the lowstand fan; b. the lowstand wedge (modified from Haq, 1991).

of relative sea level; and a Transgressive systems tract (figure 14.6) that develops during a rising relative sea level.

It is integral to the sequence stratigraphic model that the different systems tracts constitute the continental margin. They continually reform and shape the continental margin into its constituent geographic/depositional regions; shelf, slope and basin (figure 14.7a).

\subsubsection{Lowstand Systems Tract (figure 14.5)}

The lowstand systems tract is dominantly preserved in siliciclastic sequences and on the continental shelf (Van Wagoner et al., 1990). It lies directly on a type 1 sequence boundary (Van Wagoner et al., 1988) and occupies the lowest part of a sequence. Genetically, it is deposited beneath the lowest stand of relative sea 

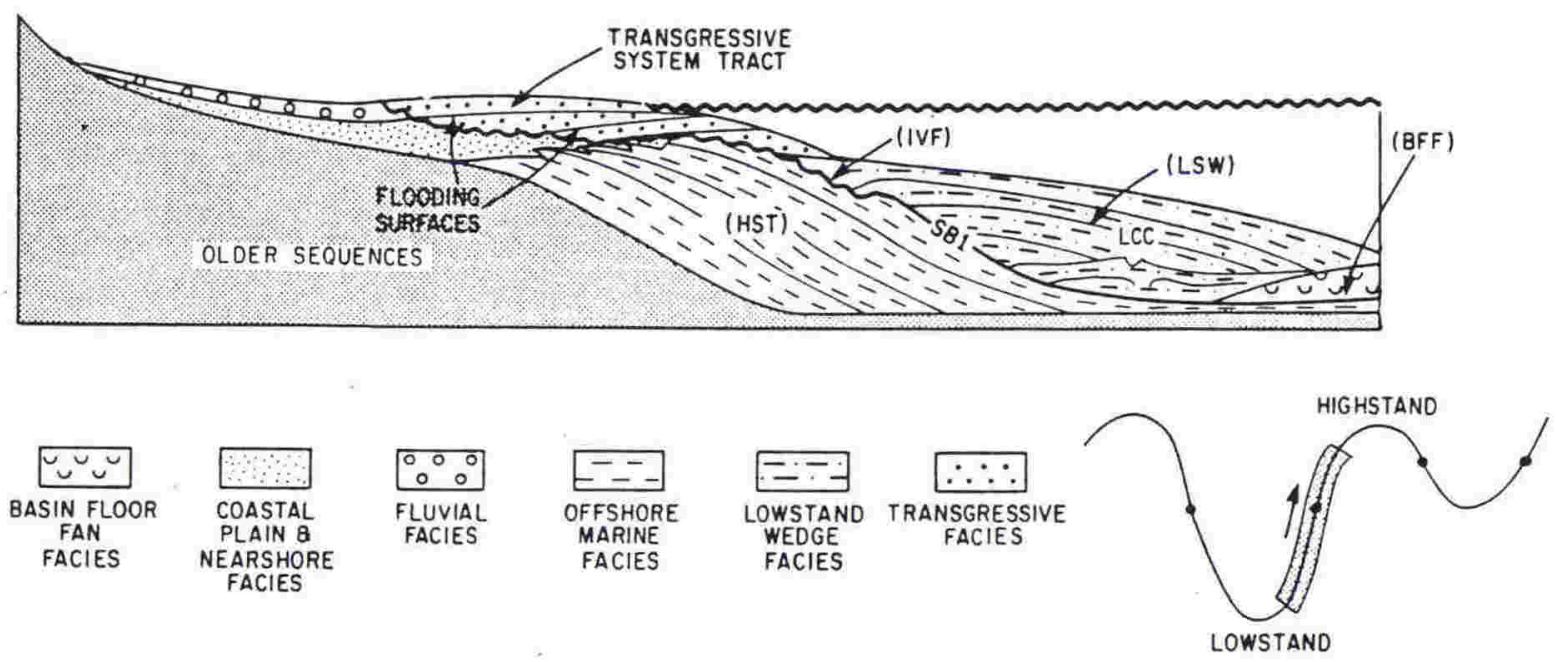

Figure 14.6: Transgressive systems tract (modified from Haq, 1991).
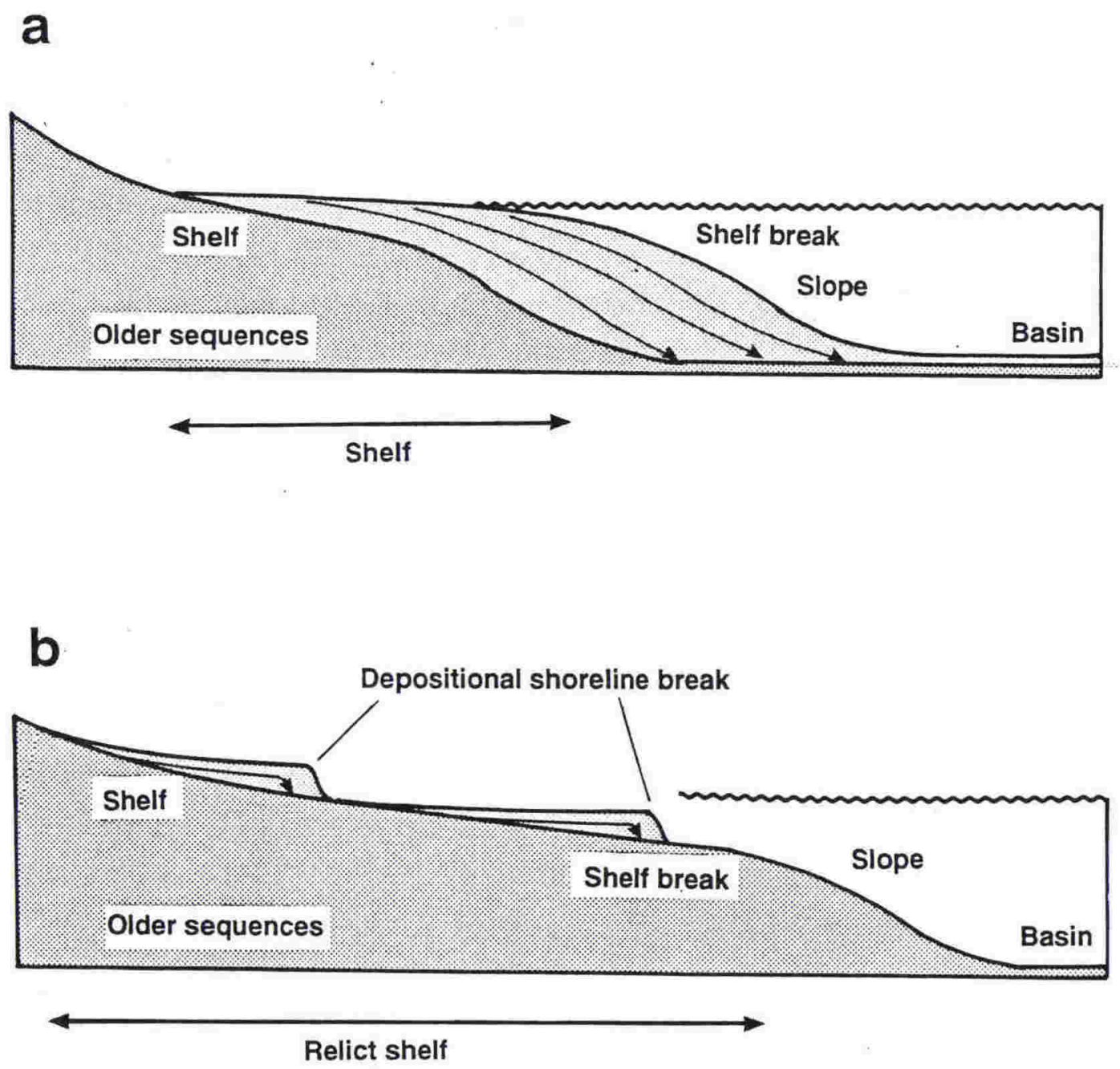

Figure 14.7: a. Morphology of the continental margin as required by the original sequence stratigraphic model (e.g. Posamentier et al., 1988); sedimentation on the margin is integral with margin morphology. b. Morphology of the Continental margin as predicted by the present study; sedimentation takes place on a larger relict shelf formed by external processes. 


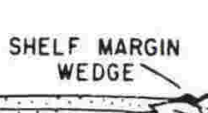


sedimentary sequences within them or associated with them. Posamentier and Vail (1988) report that the two sequence types can be distinguished by the nature of their constituent parasequence sets, but no examples are given. Both lowstand and shelf margin systems tracts onlap sequence boundaries in a landward direction and downlap sequence boundaries in a seaward direction. In this study, the shelf margin systems tract is treated as a subset of the lowstand wedge, and not as a systems tract in its own right.

The top of the lowstand (and shelf margin) systems tracts are marked by marine flooding surfaces which are directly overlain by the transgressive systems tract (figures 14.1 and 14.2).

\subsubsection{Transgressive Systems Tract (figure 14.6)}

The transgressive systems tract comprises backstepping, retrogradational parasequence sets (Van Wagoner et al., 1988) (figure 14.3b). They are repeated progradations of sediment during a progressive flooding of the shelf and landward movement of facies. Each parasequence is therefore bounded by a marine flooding surface.

Abbott and Carter (1990) and Carter et al. (1991) recognised the transgressive systems tract to be a complex feature, varying with the rate of sea level rise and sediment supply. They observed that the transgressive systems tract can vary from merely a shell lag above the ravinement surface to a thick $(30-100 \mathrm{~m})$ single sedimentary cycle. This incorporates lateral equivalents of the highstand systems tract (condensed section) as its latest stage of development. Abbott and Carter (1990) also recognised several marine flooding surfaces, suggesting that the sequences they observed in Wanganui are basinward correlatives of the backstepping retrogradational parasequences of Posamentier and Vail (1988). They fine upwards as the facies move landward. The parasequences become progressively thinner and finer grained.

The top of the transgressive systems tract is marked by a down lap surface of the prograding overlying highstand systems tract wedge (figures 14.1 and 14.2). Van Wagoner et al. (1988) recognised that this surface when conformable represents a change from retrogradational to progradational parasequence sets (figure 14.9).

\subsubsection{Highstand Systems Tract (figure 14.4)}

The highstand systems tract develops under the highest stand of relative sea level and is commonly widespread on the shelf (Van Wagoner et al., 1988). It is characterised by an increasingly progradational parasequence stacking pattern (Posamentier and Vail, 1988) (figure 14.9). Posamentier and Vail (1988) infer the highstand systems tract to be deposited between the rising and 


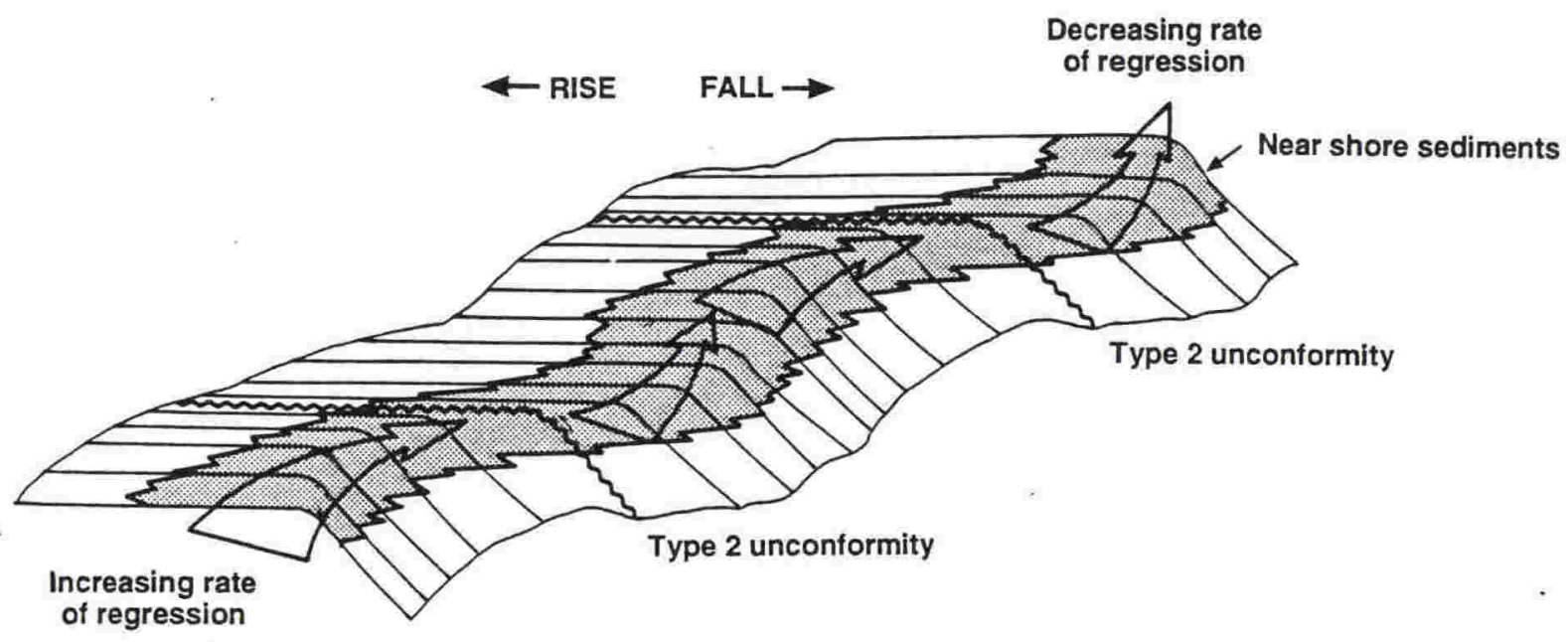

Figure 14.9: Response of topset bed thickness and parasequence sets to eustatic fall. Type 2 sequence boundaries (conformable) separate progradational and retrogradational parasequence sets (modified from Posamentier et al., 1988).

falling eustatic sea level inflection point. The base of the tract is marked by a downlap surface higher on the shelf and a condensed section lower on the shelf (figure 14.1), and the top must by definition be either a type 1 or 2 sequence boundary with some degree of erosion.

Seaward of the prograding and offlapping highstand systems tract deposition is restrained but continuous. The stratigraphic expression of this slow deposition is known as the condensed section (Vail et al, 1977) (figure 14.1). Its relationship with the three systems tracts has been poorly documented and explained to date. It is generally considered to be coeval with highstand systems tract development, but can also be coeval with transgressive systems tract development (this study). This means that in some cases it may represent much of the sequence.

\subsection{Discussion of variables}

Jervey (1988) in a set of computer simulations of interacting basin subsidence, eustatic sea level fluctuation and sediment influx, found sequence boundaries to be located at or near inflection points in eustatic sea level fluctuation. The dominant factor in shaping the depositional systems tracts and sequences is changing accommodation both areally and temporally.

\subsubsection{Accommodation Space}

Marine sediments will only accumulate if there is sufficient space available below the sea level (termed base level of erosion by Jervey, 1988). This space is defined as the accommodation space (Vail et al., 1988). It is directly controlled by relative sea level at the 
continental margin. By necessity, it is a function of interacting eustatic sea level, basin subsidence and sediment input (figure 14.10). If these parameters are considered separately; basin subsidence can only increase accommodation space, and sediment input can only decrease accommodation space, but eustatic sea level variation can both increase or decrease the accommodation space.

The interaction of these three parameters can only affect accommodation space in three ways: It can be maintained, decreased or increased. Decreasing accommodation space causes progradation seaward of the depositional shoreline break and erosion landwards of the depositional shoreline break. Increasing accommodation space causes retrogradation and stratal backstepping across the entire shelf. Maintained accommodation space causes direct aggradation seaward of the depositional shoreline break.

\subsubsection{Sediment Supply}

Sediment supply to a basin is controlled by sediment availability and the nature of depositional process. A basin supports many zones of active transport and deposition. These are separated by zones of less active transport and deposition, much like lobes of a river delta. Therefore, at a point source, sediment influx is also controlled by the proximity of active sediment transport paths (Jervey, 1988). Lowering relative sea levels exposing the continental shelf increase the potential for sediment input to the basin, as there is increased areal extent of available sediment for supply. The newly exposed sediment is also more prone to erosion and resedimentation.

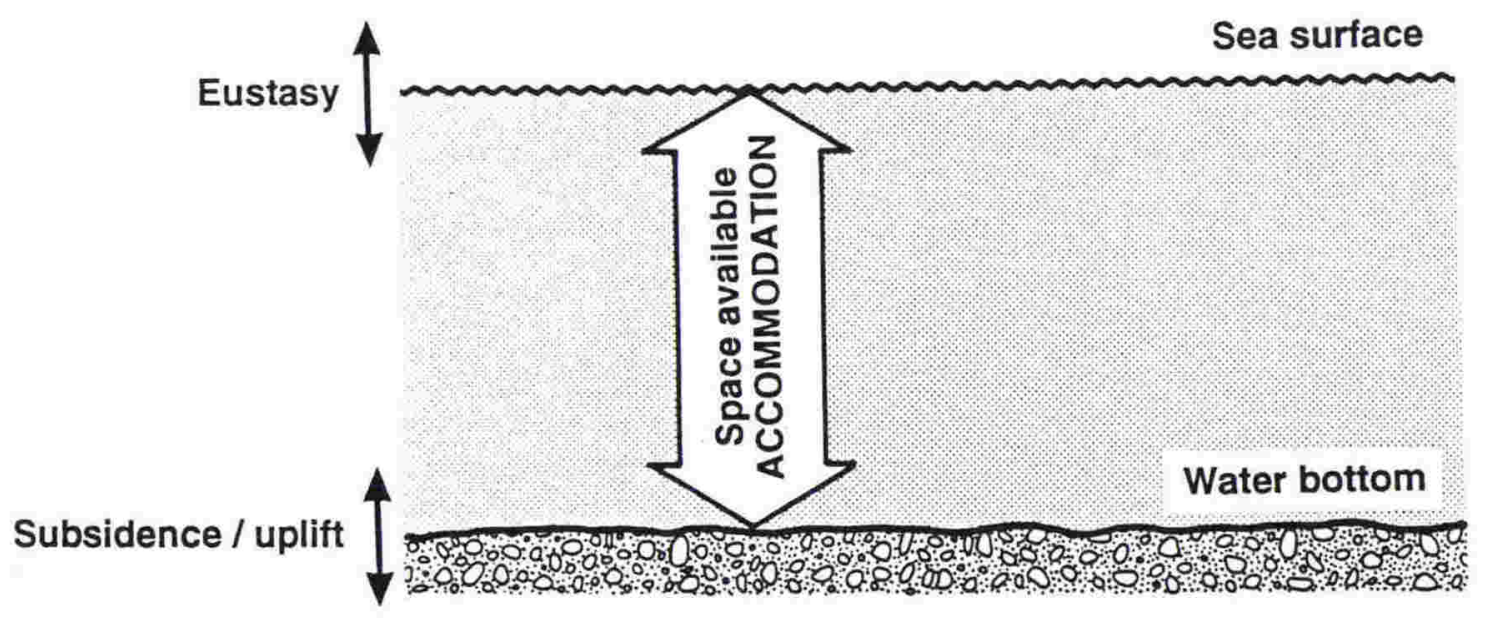

Figure 14.10: Accommodation envelope as a function of eustasy and subsidence (from Posamentier et al., 1988). 


\subsubsection{Eustatic Sea Level}

Eustatic sea level is assumed to vary cyclically with many orders of magnitude and timing (Mitchum and Van Wagoner, 1991). Support for this is proposed from several sources:

1) The oxygen isotope record (Williams, 1988)

2) Documented cyclic variation in the volume of ocean basins (Worsley et al., 1984; Ramsbottom, 1979).

3) The record of fluctuating volumes of ice on land (Hambrey and Harland, 1981).

4) Global correlation of sea level variations at continental margins suggesting synchronous global cyclic variations in sea level (Haq et al., 1987; Haq et al., 1988).

The points of fastest eustatic sea level fall or rise are known as inflection points when the change of sea level reverses. This in turn alters the accommodation space.

\subsection{Assumptions of the sequence stratigraphic model.}

The assumptions discussed here are those intrinsic to the Sequence Stratigraphic model (Vail et al., 1977) and not the Global Sea Level Model (Haq et al., 1987).
1) Eustatic sea level variation is quasi sinusoidal on many scales (Posamentier et al., 1988) (already discussed in section 14.4.3).

2) Relative sea level fall occurs on a much shorter timescale than stillstands and sea level rise. It has been further assumed that because the relative sea level fall is rapid, it results only in erosion of the continental margin with no deposition until the lowstand is reached. This is assumed because of an incorrect interpretation of the onlap curve (Prothero, 1989) and underlying assumptions of shelf morphology (discussed later).

3) Point sea floor subsidence occurs at a constant rate and that the rate increases basinward (Posamentier et al., 1988).

4) Between unconformities, there is essentially continuous deposition, and the major breaks are represented by the unconformities. If the sequence defined is the smallest stratal order that can be subdivided into its constituent systems tracts, this will hold.

5) The continental margin has a morphology including a single shelf, shelf break, and a change in slope beyond the shelf break (sometimes referred to as the basin margin) (figure 14.7a) (Posamentier et al., 1988). The shelf itself is assumed to be narrow in comparison with the height of change of relative sea level (i.e. height between maximum and minimum sea levels 
against the continental margin). This will obviously direct the pattern in the stratigraphic record.

The definition of shelf - slope break has been very confusing in the Sequence Stratigraphic Model. The original definition assumed only one shelf break integrally related to the sedimentation pattern on the continental margin (figure 14.7a). However, other workers have reported cases where the continental shelf break is not integrally related to the sedimentation processes on the margin (Carter et al., 1991; Carter et al., 1985; Martin and Fleming, 1986; Mougenot et al., 1983) and is located at much greater depth and more distant from the coastline (figure 14.7b). Here, the two slope breaks are distinguished as the shelf break (relict) and depositional shoreline break (active) (see table 14.1). Any relative stillstand of sea level can perpetrate a depositional shoreline break, and these can be manifest at any point on the continental margin. However, there is only one shelf break.

6) A deficiency of the Sequence Stratigraphic Model is that it is constructed conceptually and then data are assumed to fit within it, often by use of circular reasoning. This has been alleviated to some extent in the last few years by outcrop observation (e.g. Van Wagoner et al., 1990). However, the continuing development is from coarser to finer units and time periods. The approach should be to construct smaller scale models from observed facies relationships, and then increase the scale, from further observation, to depositional systems. That is the approach taken in the present study.

\subsection{The South Wanganui Basin sequence architecture}

The Sequence architecture of the Late Neogene strata of the South Wanganui Basin has already been developed in Chapter 13. Two sequences are recognised; the sequences and their architectural elements are described below. These were constructed as models from observing many of the complete and incomplete successions cropping out in the stratigraphic sections studied:

\subsubsection{Sequence 1 (figure 14.11)}

Sequence 1, when complete, is $200-500$ $\mathrm{m}$ thick. It is completely marine, shows no evidence of subaerial exposure, and contains 7 architectural elements which are described below in ascending stratigraphic order;

1) A basal erosional unconformity, which is the lower sequence boundary. It is only slightly eroded, sometimes bioturbated, and represents a surface of marine transgression or a ravinement surface. It is not a sequence boundary after the definition of Vail et al. (1977), because it does not represent a basinward shift in facies. But, it is the most developed unconformity surface across which Waltharian Law does not hold. It is the 


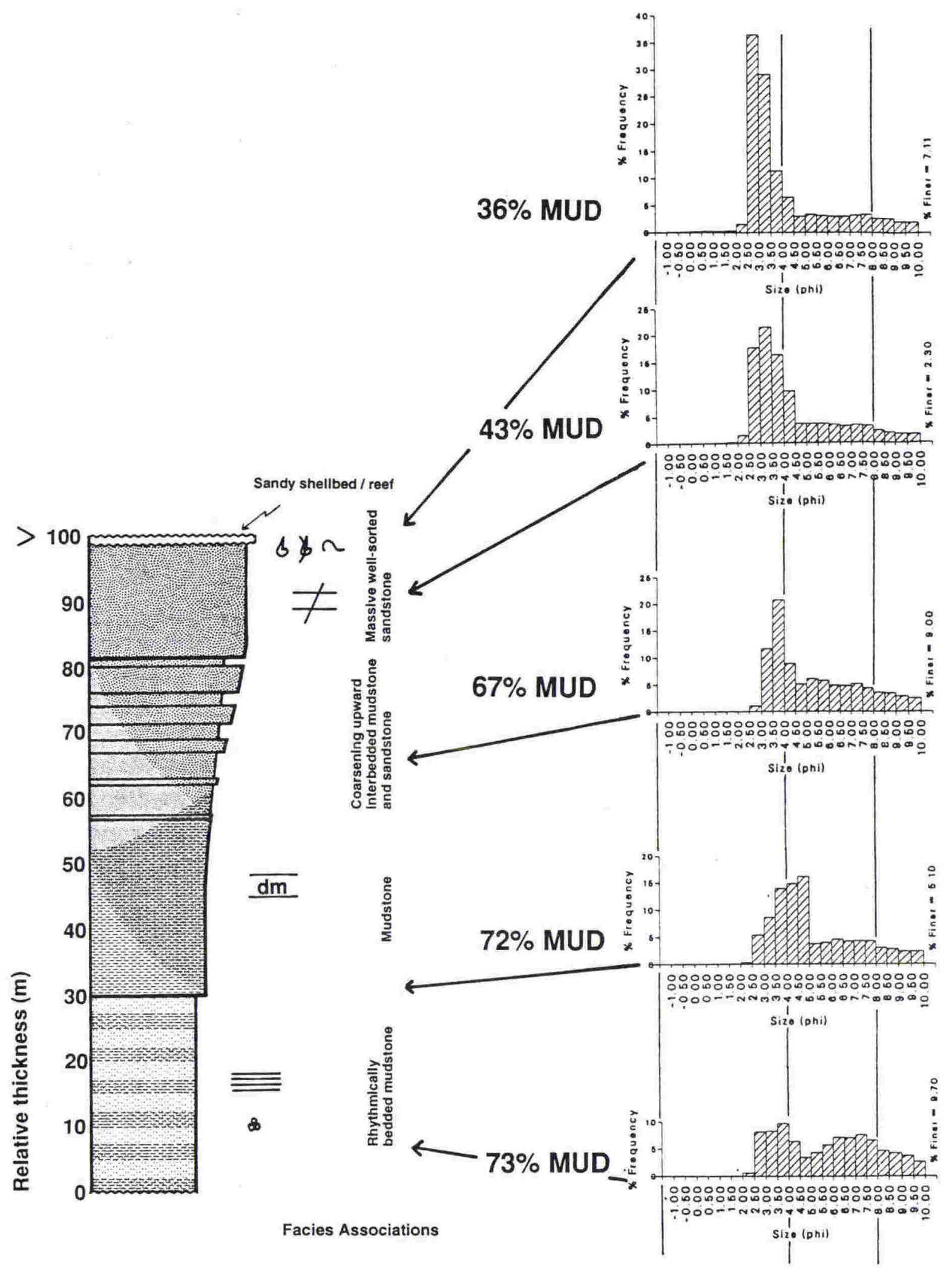

Figure 14.11: A diagrammatic representation of the coarsening facies succession. It varies from 100 to $c a .350 \mathrm{~m}$ in thickness with the individual facies associations varying as depicted by the relative scale. Percent mud values are given to allow further comparison with the depth models of Swift (1970) and Elliot (1986), see figure 13.5. A general interpretation is one of a gradually shallowing depositional environment. 
a

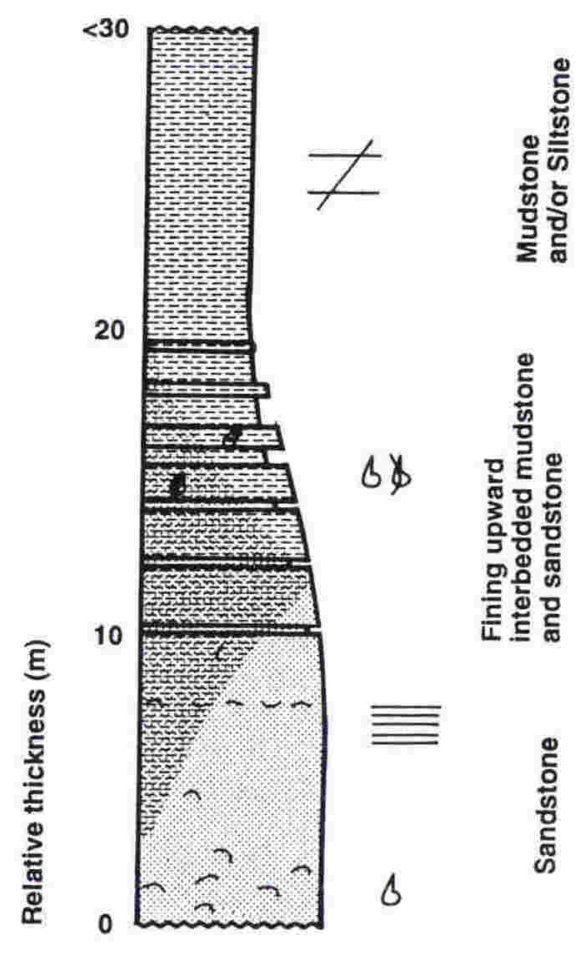

b

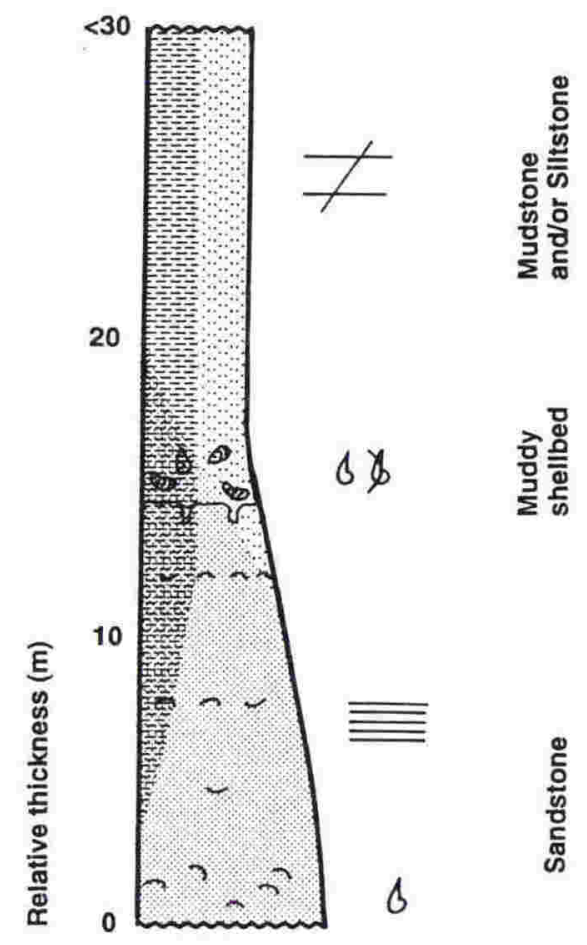

Facies Associations

Figure 14.12: Diagrammatic representation of the fining facies succession. Two main type are recognised; a. a succession containing a fining upward interbedded mudstone facies association; $b$. a succession containing muddy shellbed facies association directly overlying a burrowed surface or hardground. The two successions are between 10 and 30 $\mathrm{m}$ in thickness. They are both inferred to have been deposited in a deepening depositional environment, except succession a is inferred to have been deposited closer to the sediment source.

most obvious place sedimentologically to place a sequence boundary.

2) A deep water rhythmically bedded mudstone indicative of relatively slow sedimentation on the outer shelf, which directly overlies the basal unconformity. Generally it is between 5 and $30 \mathrm{~m}$ thick.

3) A Downlap surface that appears conformable. Faunal and textural evidence suggests that the downlapping sediments are more shallow in origin than the underlying strata.
4) A downlapping open shelf mudstone or Siltstone, that is between 20 and $50 \mathrm{~m}$ thick.

5) A coarsening upward interbedded mudstone and sandstone indicating a progradation of the palaeoshoreline, with shoreface sands persisting into a nearshore environment. It grades from the underlying mudstone/siltstone. It ranges between 10 and $100 \mathrm{~m}$ thick.

6) A massive well sorted open shoreface sandstone grading from the underlying nearshore association. It is generally between 100 and $300 \mathrm{~m}$ thick. 
7) An unconformity bounded intertidal reef association, $1-4 \mathrm{~m}$ thick. Its top is the disconformity described as element 1 and the beginning of the next sequence.

\subsubsection{Sequence 2 (figure 14.12)}

Sequence 2 when complete is always less than $100 \mathrm{~m}$ thick, and more usually less than $50 \mathrm{~m}$ thick. It is also completely marine, but shows distinct evidence of subaerial exposure. It contains 4 main architectural elements which are described below in ascending stratigraphic order;

1) A basal erosional unconformity is the lower sequence boundary. It is sometimes a type 1 sequence boundary (channelled erosion surface) representing extensive subaerial exposure. Evidence of channel development is rare, but erosion and bioturbation are always well developed., suggesting that it is more often a type 2 sequence boundary. This is the most prominent disconformity in the sequence. It also represents a transgressive (ravinement) surface as well as a disconformable sequence boundary.

2) Open shoreface sandstone to muddy sandstone association, sometimes containing thin shell lags. Coarse traction current emplaced sediment directly overlies the basal disconformity. Sometimes, it is a sandy shell lag, and it is usually thinner than $10 \mathrm{~m}$. 3a) A fining interbedded mudstone and sandstone, indicating a retrogradation of the palaeoshoreline with shoreface sands retreating from a nearshore environment. It grades from the underlying sandstone. This element is between 5 and $10 \mathrm{~m}$ thick.

or

3b) A transgressive muddy shellbed representing a starved shelf environment allowing a shellbed to develop. The shellbed is relatively thin and usually ca. $2 \mathrm{~m}$ thick.

4) A downlapping open shelf massive mudstone or Siltstone that is usually 20$30 \mathrm{~m}$ thick, and often barren of fossils.

\subsection{Model for formation of the Late Neogene South Wanganui Basin sequences.}

The present continental shelf of Wanganui is used here as a model for the Late Neogene shelf. Seismic and lithospheric evidence suggests that the extent of the continental shelf has not changed appreciably during the Late Neogene (Stern pers comm.) It is a wide, relict feature that is not integral to active sedimentation (figure 14.13). Most sedimentation occurred above the shelf break creating several depositional shoreline breaks depending on the height of relative still stands of sea level.

Above the shelf break, the sediment supply is controlled by tectonism, with 


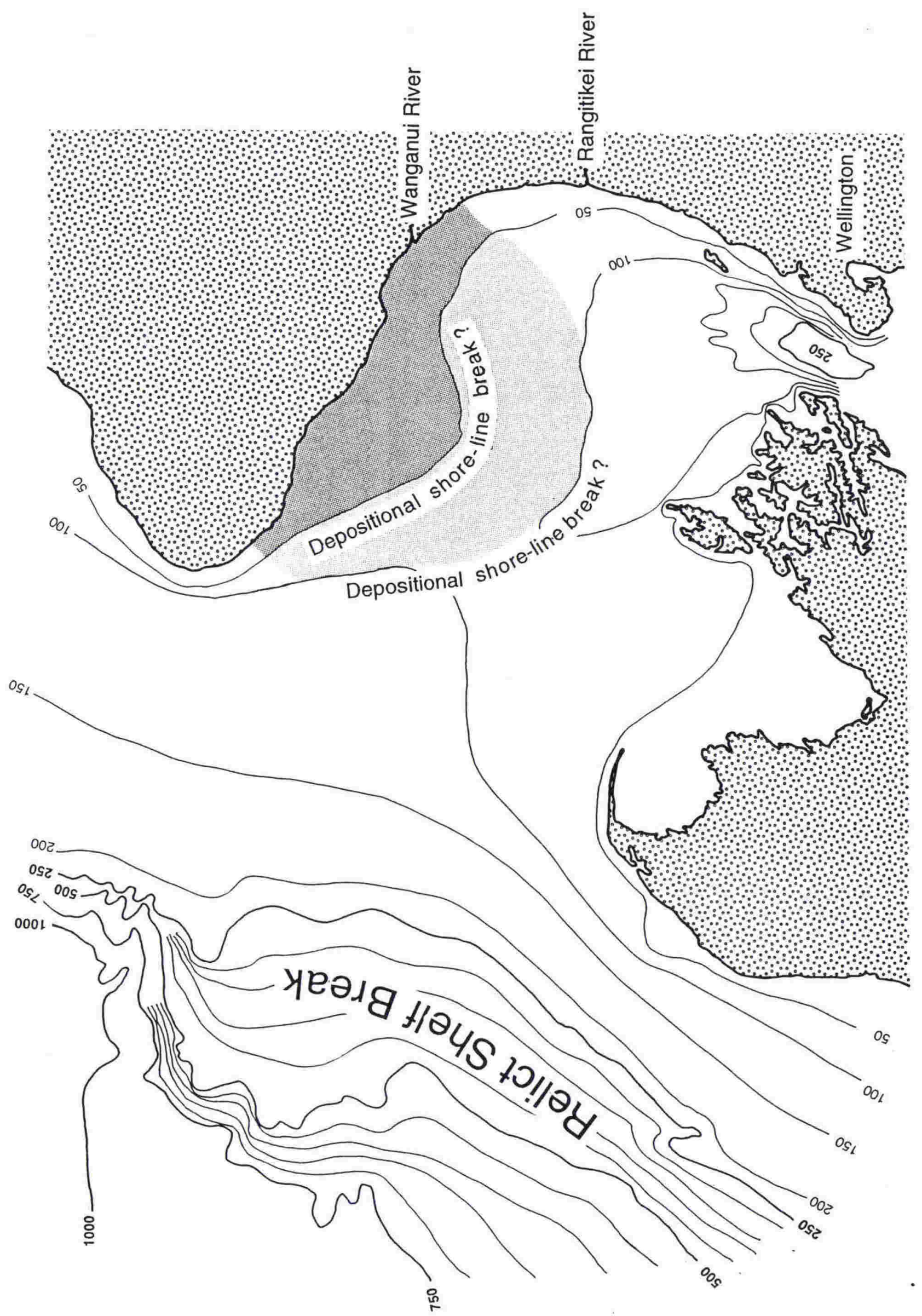

Figure 14.13: Bathymetric map of the current continental shelf of Wanganui. The relict shelf break is marked and different from the zone of 'active sedimentation (shaded) and possible depositional shoreline breaks. 
the uplifting Wanganui palaeo-hinge zone being the main source of sediment. The lithospheric wave basin progressing in front of this hinge is accumulates sediment (figure 14.14). With southward progression of this lithospheric wave, earlier deposited sediments become uplifted at the hinge zone and are recycled into the basin ahead of the lithospheric wave (see chapter 10). The process is cyclic with sediment source and basin subsidence being integrally related, so that sedimentation will never outpace basin subsidence but always equal it. Therefore, sedimentation will never prograde further than a defined limit beyond the depositional shoreline break, and subsequent episodes of sedimentation will merely stack up, but in a progradational sense controlled by the southward moving lithospheric wave only (figure 14.14).

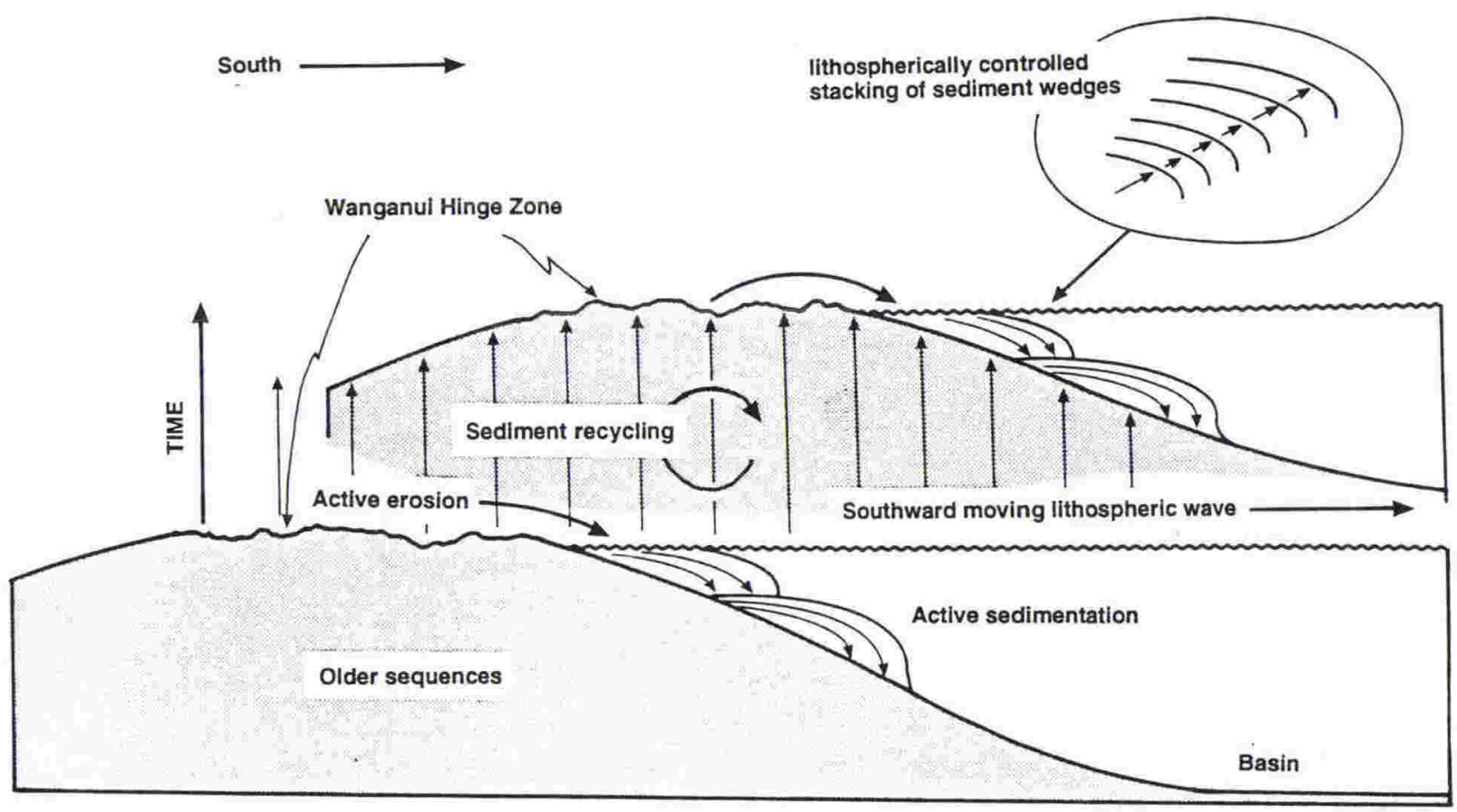

Figure 14.14: Lithospheric control on sedimentation. The lithospheric wave (see chapter 10) uplifts older sediment to the north and provides a basin to accumulate sediments to the south. As the lithospheric wave progrades southwards earlier deposited sediments are uplifted at the Wanganui Hinge zone and recycled into the basin ahead of the lithospheric wave. The inset shows the resulting aggradation and progradation of stacking sediment wedges within the zone of active sedimentation. 
The rate of southward progradation will be the base level of relative sea level change recorded by the South Wanganui Basin sequences, a time period of 20 m.y. (Stern et al., 1992). Any change on a scale less than 20 m.y. (including the entire present study) must be due to either secondary (shorter order) tectonic effects or eustatic sea level fluctuation affecting accommodation space. Tectonic effects are not suspected, because the sequences are quite extensive and internally coherent. Sedimentary sequences are also cyclic on a timescale much greater than expected from seismic events (see chapter 15). Anderton (1981) demonstrates no tectonic change in the basin on a scale less than Stern et al's. (1992) lithospheric wave.

This tectonic regime is expected to support the assumptions of constant point sedimentation increasing basinward.

The assumption of quasi sinusoidal eustasy has been substantiated to some extent (discussed earlier) and is accepted, and further substantiated, by the conclusions of the present study (see chapter 15). The assumption of a fast relative sea level fall in the cycle does not hold if sinusoidal eustatic cyclicity and balanced sedimentation and subsidence are accepted.

Because the previously accepted assumptions of continental margin morphology do not hold on the Wanganui Margin, a different palaeomorphological model of sedimentation on the shelf is used here. The sequences are not slotted into the systems tract model, but interpreted in terms of position on the shelf with sediment wedges nucleating beneath the depositional shoreline break, controlled by eustatic sea level fluctuation. Sedimentation and basin subsidence have already been shown not to affect accommodation space, merely enhance the effects of eustasy. Stillstands of sea level cause nucleation and development of a sediment wedge on the margin (figure 14.15a).

A fundamental change takes place when eustatic sea level moves, preventing nucleation of sediment wedges, and changing the pattern of sedimentation rather than developing it.

An initial interpretation of sequence 1 (coarsening) would suggest it is comparable to a high stand systems tract prograding over a condensed section. However, several things point to it being different from a type 1 sequence. Firstly, the sequence boundary is not a channelled disconformity. The coarsening parasequence sets and the sequence itself is much thicker than expected (up to $500 \mathrm{~m}$ thick rather than less than $100 \mathrm{~m}$ thick), and the sequence is never subaerially exposed. Because the sequence is not subaerially exposed, it must have developed entirely below the lowest stand of the eustatic sea level cycle. 
a)

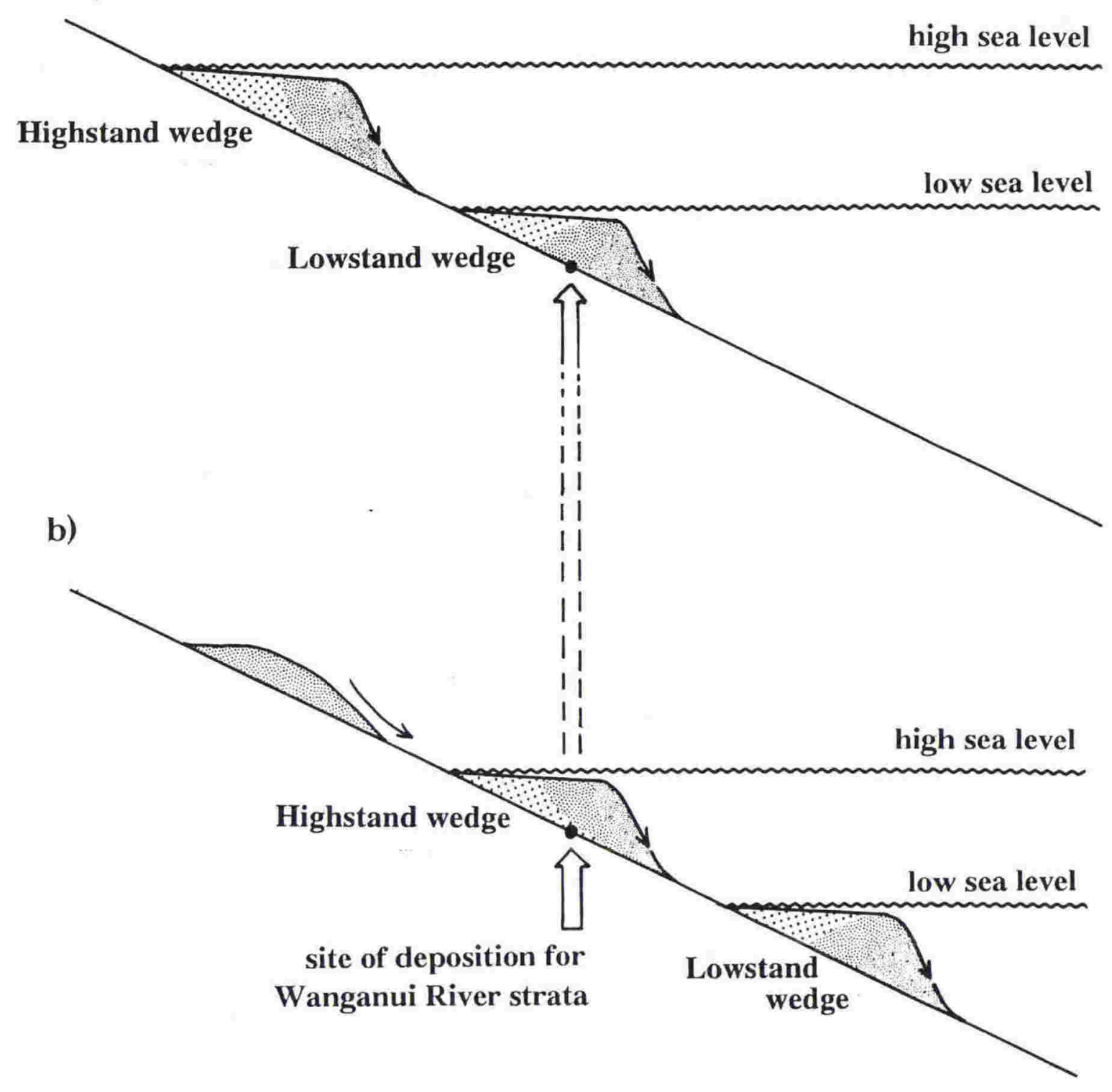

Figure 14.15: a. The location of sediment wedges on the shelf and their relationship to still stands of sea level. b. A second, larger order, of eustatic sea level variation, moving the absolute position of the respective wedges on the continental margin. The position of deposition of the Wanganui River sedimentary sequence is shown.

The lack of a type 1 sequence boundary suggests formation of a type 2 sequence, but, the shelf margin systems tract is missing from the sequence.

If sedimentation and the depositional shoreline breaks are confined above the shelf break (as they are in the South
Wanganui Basin), it follows that a high stand type systems tract will prograde beneath a still stand of sea level, regardless of whether it is at the highest or lowest turn in its cycle. Because of the balance of sediment input and subsidence, this highstand type systems tract will not inundate the shelf with 
sediment and force a marked regression of the shoreline (figure 14.15a).

If the sediment wedge were developed beneath the lowstand of eustatic sea level, it would develop an exaggerated thickness due to the additional sediment from the exposed coast. This wedge must begin to form during the eustatic fall, encouraging a thicker sequence, and continue during the ensuing lowstand.

The eustatic rise will develop a maximum flooding surface which will be overlain by a condensed section (figure $14.15 \mathrm{~b})$, while sedimentation is continued beneath the depositional shoreline break now located much further offshore, therefore, existing terminology cannot adequately name and describe this sequence and it is named here a Lowstand Wedge (figure 14.15). The lowstand wedge records a full cycle of eustatic sea level without the breaks caused by erosion of wedges developing higher on the palaeoshelf.

Sequence 2 of this study is partly subaerially exposed and therefore must have been formed higher on the shelf than sequence 1 (figure 14.15b). Much of sequence 2 represents a rising sea level above the point of deposition with the upper mudstone/siltstone representing a seaward equivalent of the high stand systems tract. Where sediment supply does not outpace basin subsidence and prograde across the entire continental shelf.
14.8 The South Wanganui Basin Late Neogene Sequence Lithostratigraphic framework.

Here, sequences are defined in terms of their relationship to eustatic sea level cycles. Four sediment packages are recognised within a single cycle; lowstand wedge, transgressive wedge, highstand wedge, and regressive wedge (figure 14.16). The regressive wedge has recently been recognised by Hunt and Tucker (1992) and Posamentier et al. (1992) as stranded parasequences and forced regressive wedge systems tract. They use the term forced regression to explain a slow relative sea level fall pushing the highstand systems tract down the continental shelf. This is a contradiction. The objective of sequence stratigraphic analysis is to interpret sea level cycles in terms of sedimentation response to naturally occurring eustatic cyclicity. The term forced is used to maintain assumptions of shelf morphology that are not observed or accepted by the present study (see section 14.5). Here, they are considered as natural regressions.

The highstand and lowstand wedges nucleate and develop beneath the highstand and lowstand of relative/eustatic sea level respectively (figure 14.15a). The two wedges develop similarly in theory except: 1) The lowstand wedge will be much thicker than the highstand wedge as it begins to form during regression: 2) The highstand wedge will be truncated by a type 1 
a

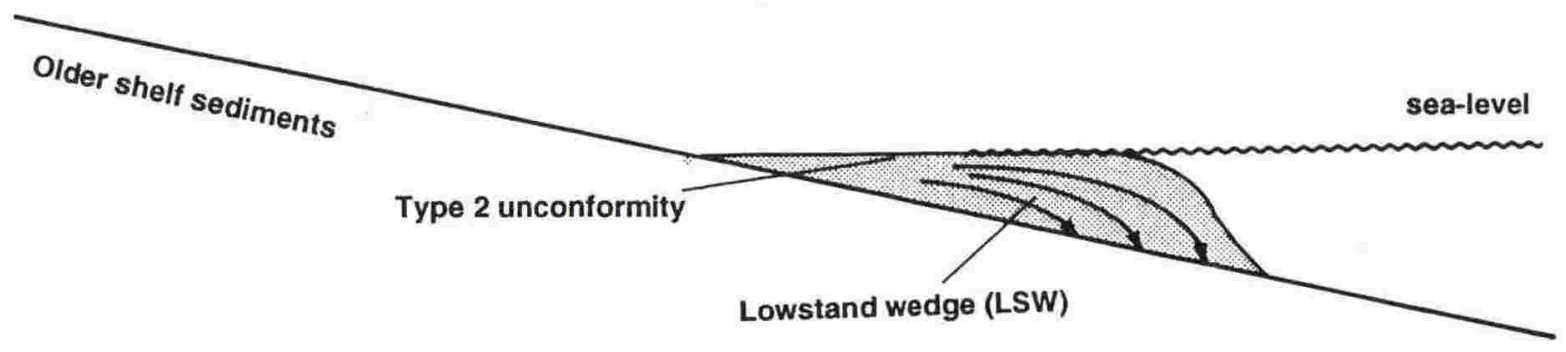

b
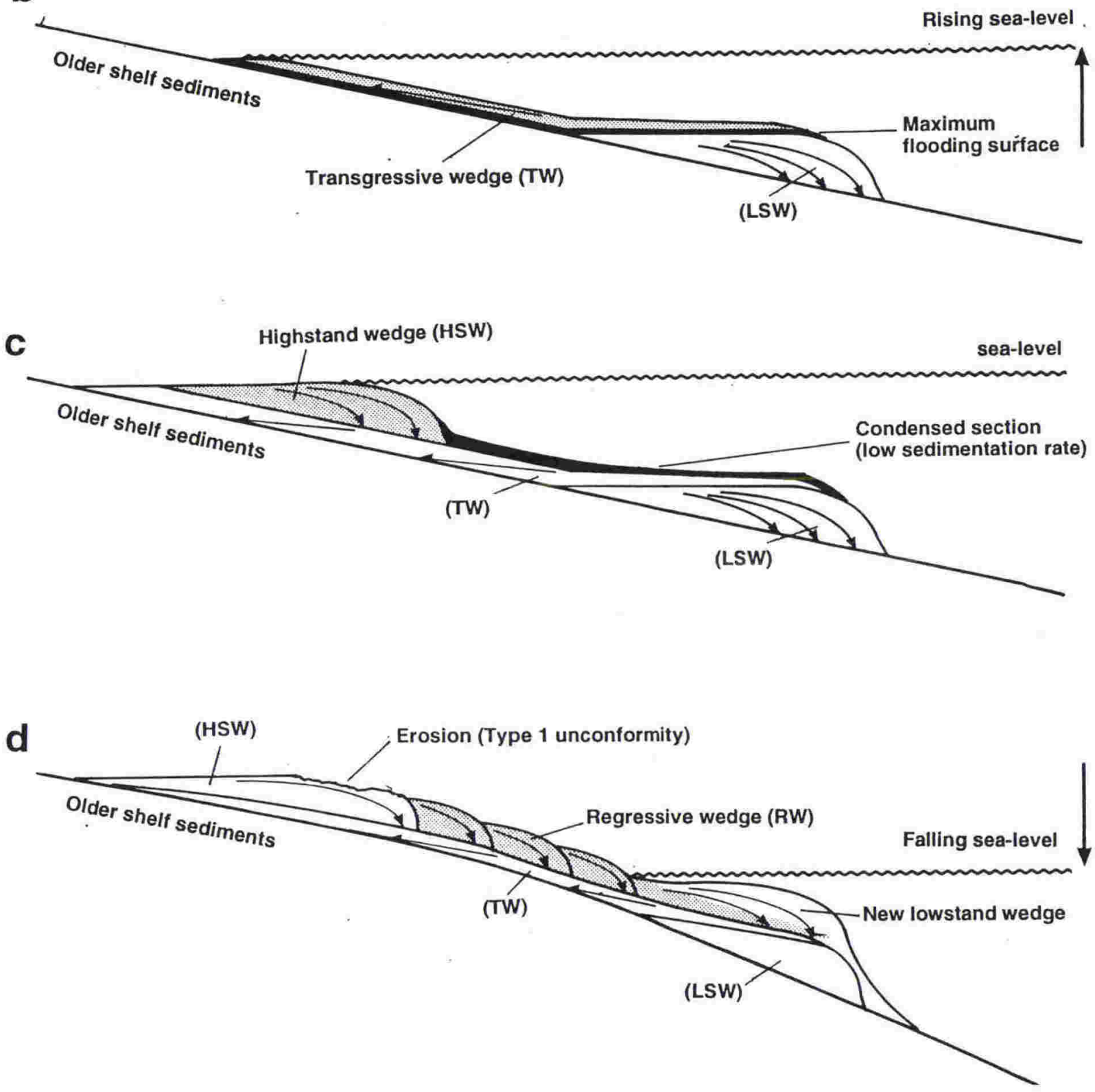

Figure 14.16: Development of the continental shelf morphology at Wanganui during a single cycle of eustacy, as predicted by this study. Wedges of sediment prograde beneath still stands of sea-level. Restricted wedges form beneath rising and falling sea-level. a. the pattern of sedimentation beneath the lowest stand of sea-level. b. the pattern of sedimentation beneath a rising sea-level. c. the pattern of sedimentation beneath the highest stand of sea-level. d. the pattern of sedimentation beneath a falling sea-level. Sedimentation is lithospherically controlled, balancing basin subsidence and sediment input. This prevents inundation of the continental margin by sediment (see discussion earlier in this chapter) 
unconformity (sequence boundary) and the lowstand wedge will be truncated by a type 2 unconformity (sequence boundary) (figure 14.16a). While the highstand wedge is forming, a condensed period of sedimentation continues basinward of the developing highstand wedge (figure 14.16c).

The transgressive wedge is equivalent to a retrogradational parasequence stacking (sets), that blankets the lowstand wedge and the entire maximum flooding surface (figure 14.16b). Its internal nature varies extensively with proximity to the basin margin: At its most basinward extent it is a condensed section with a slow rate of sedimentation. Closer to the margin it is a fining upwards sequence changing as the depositional shoreline break moves marginward.
The regressive wedge is manifest in a series of progradational parasequence sets that progressively step down the continental shelf beneath the basinwards moving depositional shoreline break (figure 14.16d). They are termed stranded parasequences by Hunt and Tucker (1992). The final step begins a wedge that continues to develop under the lowstand depositional shoreline break as the lowstand wedge. Erosion occurs landward of the lowstand depositional shoreline break.

Sequence 1 is formed low on the shelf, beneath the lowstand of eustatic sea level (figure 14.16). Sequence 2 is formed higher on the shelf about the basinward extent of the developing highstand wedge (figure 14.16). 
208 


\section{Chapter - 15}

\section{Late Neogene eustatic sea level history}

This chapter presents the inferred record of sea level cycles recorded by the South Wanganui Basin sections. The interpretation of the record is based on models discussed and presented in chapter 14 and chronology summarised in Chapter 12. A new approach using relative downlap as well as relative onlap is found to record a more complete history of sea level variation. The lithospheric control on development of South Wanganui Basin stratigraphic successions has ensured that sediment influx and basin subsidence compliment each other. The southward progressing outcrop sampled by the Wanganui and Rangitikei Rivers ensures that the record is one of eustatic variation only. Variation in eustatic sea level is interpreted mainly from the Wanganui River Section and supported by evidence from the Rangitikei River Section. Eustatic variation occurs on four orders of timing; A base level of 3-4 m.y. duration and three shorter order cyclicities of ca. 2 m.y., 100-500 m.y., and 40-100 k.y. respectively. Amplitudes of eustatic sea level variation are ca. $40 \mathrm{~m}$ for the base eustatic sea level curve, and 40-50 $\mathrm{m}$ and less for the shorter order cycles. A total variation in sea level of $c a .80 \mathrm{~m}$ for the Late Neogene is therefore proposed. Agreement between the South Wanganui Basin curve and the EXXON global sea level curve for the same time period is poor. However, the Wanganui Basin curve has superior resolution and chronostratigraphic control and is proposed as a much improved Late Neogene (2.4-6.0 m.y.) global sea level curve.

\subsection{Introduction}

Direct observations of stacked cycles from the South Wanganui basin are reported. Interpretation of the origin of these cycles uses a different approach to that of Vail et al. (1977). Because the original sequence stratigraphic model was developed in ignorance of an independent shelf and depositional shoreline break, it was presumed that onlap was the best indicator of relative sea level variation (Vail et al., 1977). However, it was later found that this interpretation required incorrect assumptions about eustatic fluctuations of sea level (Van Wagoner et al., 1988; Posamentier et al., 1988; and this study).

The South Wanganui Basin sequences are interpreted in terms of onlap and downlap. This is possible because of both the lithospheric control on sedimentation patterns and a wide palaeo-shelf. The Wanganui River section is found to record a nearly complete record of the Late Neogene (2.5 - 6.0 m.y.). Evidence from the Rangitikei River supports the interpretations of the origin of the Wanganui River sequences. 
The crux of the interpretation presented in this chapter is that the sampled section is consistent with the southward progressing point of deposition of the section. The cyclic development of sediment wedges within the sequence resulted from eustatic sea level fluctuation. The position of the depositional sequence tract on the shelf remained stationary; the variation is merely within this. A shift in base levels of this eustatic cyclicity (longer order eustatic changes) caused the depositional sequence tract to move landward or seaward on the continental margin in response to large order eustatic rising or falling of sea level respectively.

\subsection{The South Wanganui Basin Record}

\subsubsection{The Wanganui River Section}

Some 17 cycles of sedimentation are recognised in the Wanganui River Section (figure 15.1). Each cycle is bounded by a type 1 or 2 sequence boundary, depicted by an unconformity or disconformity in the sequence. Cycles $\mathrm{W} 1$ and $\mathrm{W} 2$ are classic type 2 sequences (see chapter 14) that are here assigned to the transgressive wedge. They do not contain any progradational highstand or lowstand wedge sediments. The $\mathrm{W} 3$ cycle contains a type 2 sequence conformably overlain by a type 1 sequence. This is interpreted as a transgressive wedge conformably overlain by a lowstand wedge, suggesting a shoreward movement in depositional facies. Cycles
W4 through W8 represent typical type 1 sequences originating in the lowstand wedge. Only cycle W6 is not complete.

Cycle W9 is complex. It contains several interbedded mudstones and sandstones that are difficult to assign a genetic origin to. The general trend of the sequences is coarsening upwards. It seems equivalent to a thick progradational parasequence set of Van Wagoner et al. (1988). Here it is tentatively assigned to the regressive wedge. The point of observation is shoreward of the developing lowstand wedge. The depositional environment is located higher on the shelf than through cycles W3-W8. Cycle W9 represents the beginning of a change in the nature of the sequences in the Wanganui River Section. Above $2200 \mathrm{~m}$ (the start of cycle W9) in the section, the sedimentary sequences become more disjoint, than sequences lower in the section, and more continuously sandy in nature.

Cycle W10 represents an extensive deepwater sequence, with little terrigenous influence on the sedimentation pattern. The active sediment wedge was a long way shoreward of the point of deposition of this cycle. The very top of cycle W10 includes a coarser sandstone unit suggesting encroachment of the Regressive Wedge over the point of deposition. Cycle W11 is much more typical of the sequences described by Van Wagoner et al. (1988) and Posamentier et al. (1988). It is an extended fining upwards sequence, much 


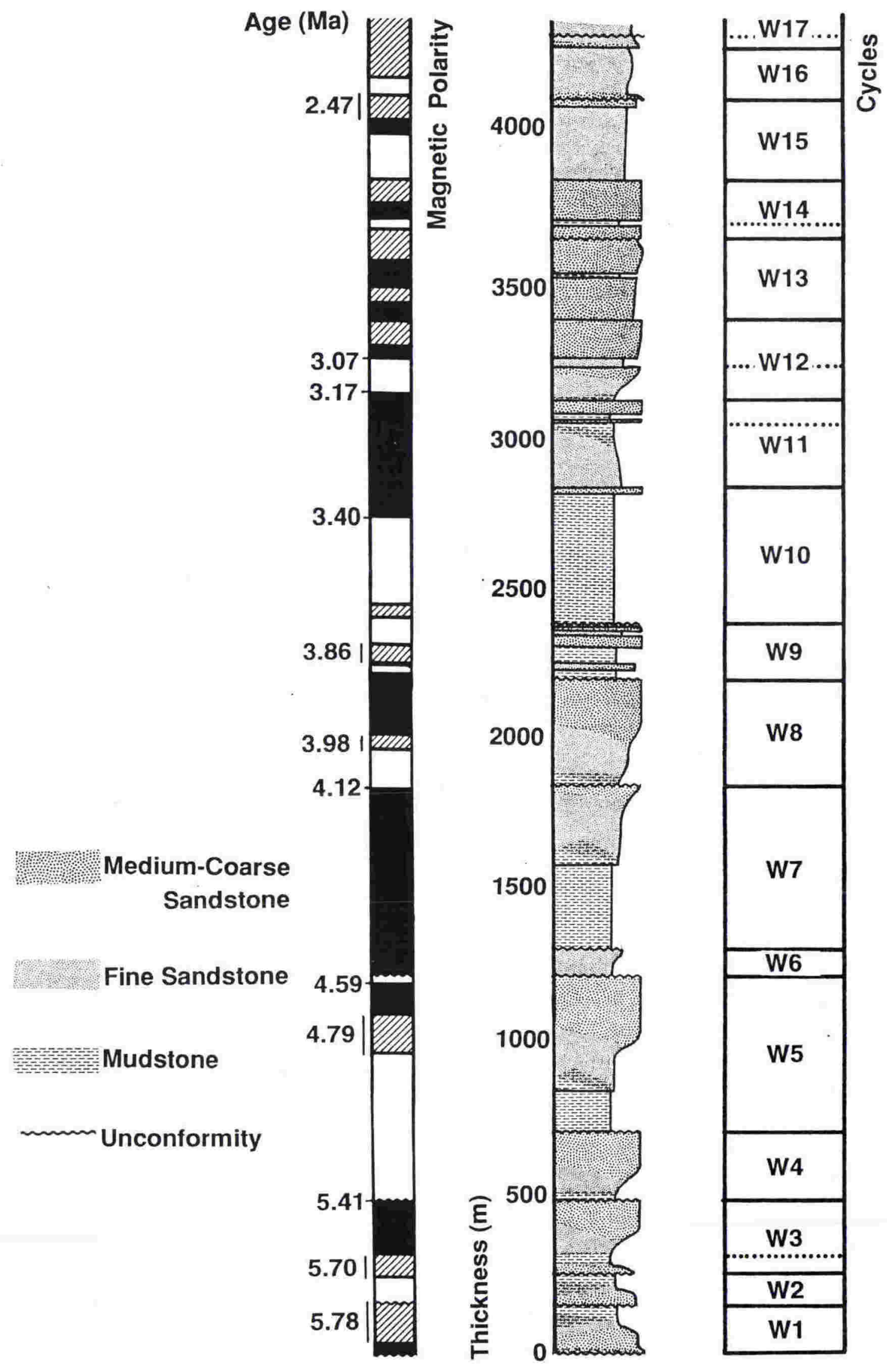

Figure 15.1: Sedimentary cycles in the Wanganui River Section (polarity and age is from section 4). 
thicker than a typical type 2 sequence, topped by a prograding sandy Highstand Wedge sequence. The Transgressive Wedge is some $200 \mathrm{~m}$ thick and is interpreted to represent a more gradual deepening of the depositional environment than that depicted by a type 2 sequence.

Cycles W12 through W15 are again like type 1 sequences. They are coarsening upwards sandy facies successions with disconformities separating them. They are not as thick as the lower sequences in the section (cycles W3-W8) and do not often contain any of the muddier facies associations (plate 15.1). They are very similar in nature to the stranded parasequences of Hunt and Tucker (1992). Here they are assigned to the Regressive Wedge. These cycles contain thin mudstone horizons of a shorter order origin than the cycles identified in this study. The shallower depth of deposition of these sequences has enhanced their sensitivity to record shorter order and smaller cycles of sea level variation that cannot be recorded by deeper water facies.

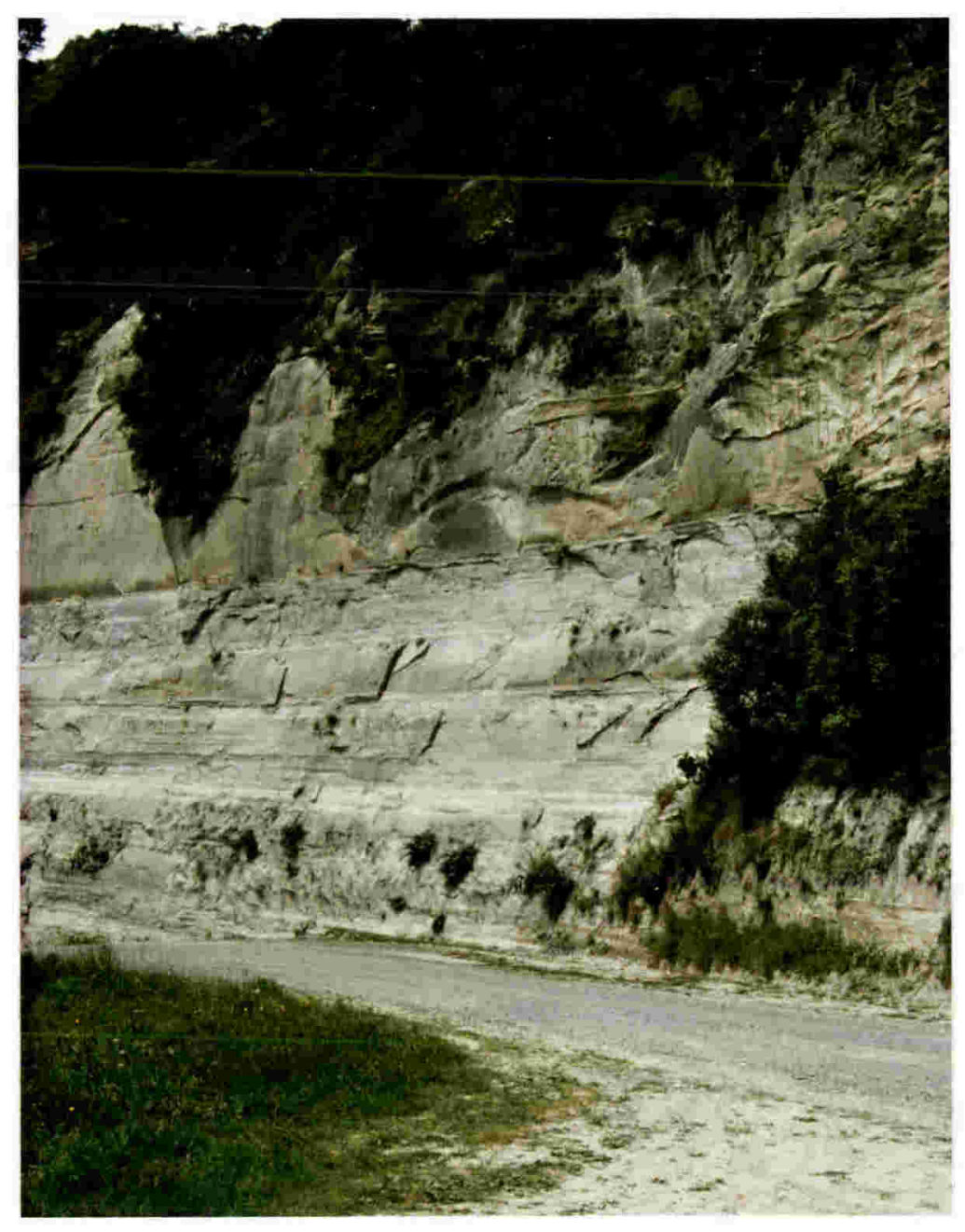

Plate 15.1: An example of the more sandy nature of the sedimentary cycles (W12 - W15) higher in the Wanganui River Section (Bluff is ca. $30 \mathrm{~m}$ high, and is within cycle W(4). 


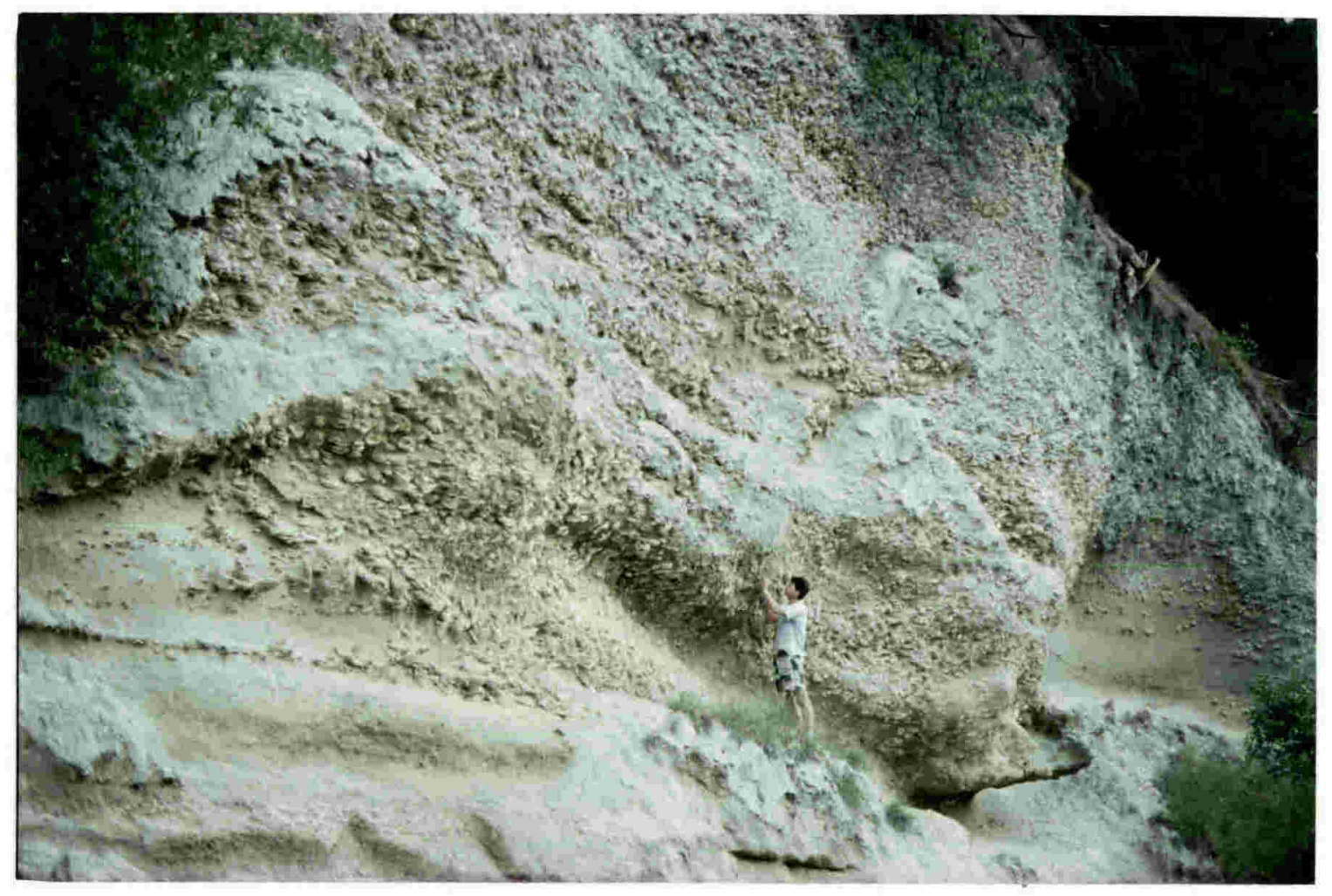

Plate 15.2: The Wilkies Shellbed at its type locality, Wilkies Bluff on the Wanganui River Road. The Crassostrea dominant bluff formed during a long sea level fall that was equal to, or slightly outpaced by basin subsidence.

Above $4,000 \mathrm{~m}$ in the Wanganui River section (cycles W16 and W17) the successions again begin to fine upwards and type 2 sequences once again dominate. The transition in the cycles occurs at the Wilkies Shellbed, where extensive and long-lived currents from a long and slow sea level fall have encouraged the development of the thick oyster bed (plate 15.2).

\subsubsection{The Rangitikei River Section}

The cycles in the Rangitikei River section are more complex than those in the Wanganui River section. This is because the point of deposition of the sequence was closer to the basin margin and consequently in a more shoreward position on the palaeo continental shelf. Some 8 cycles are recognised between greywacke basement and the Ohingaiti Sandstone (figure 15.2). None of the cycles contain non-marine sediments. The complete succession does contain channelled type 1 sequence boundaries representing subaerial exposure and fluvial development. Therefore, it is inferred that the Rangitikei River succession represents deposition in an environment part way between that of the Wanganui River sequences (the basin depocentre) and the basin shoreline. Easily defined sequences are not so common in the Rangitikei River Section. They usually separate 200-500 m thick successions of mudstone and sandstone associations (plate 15.3). 


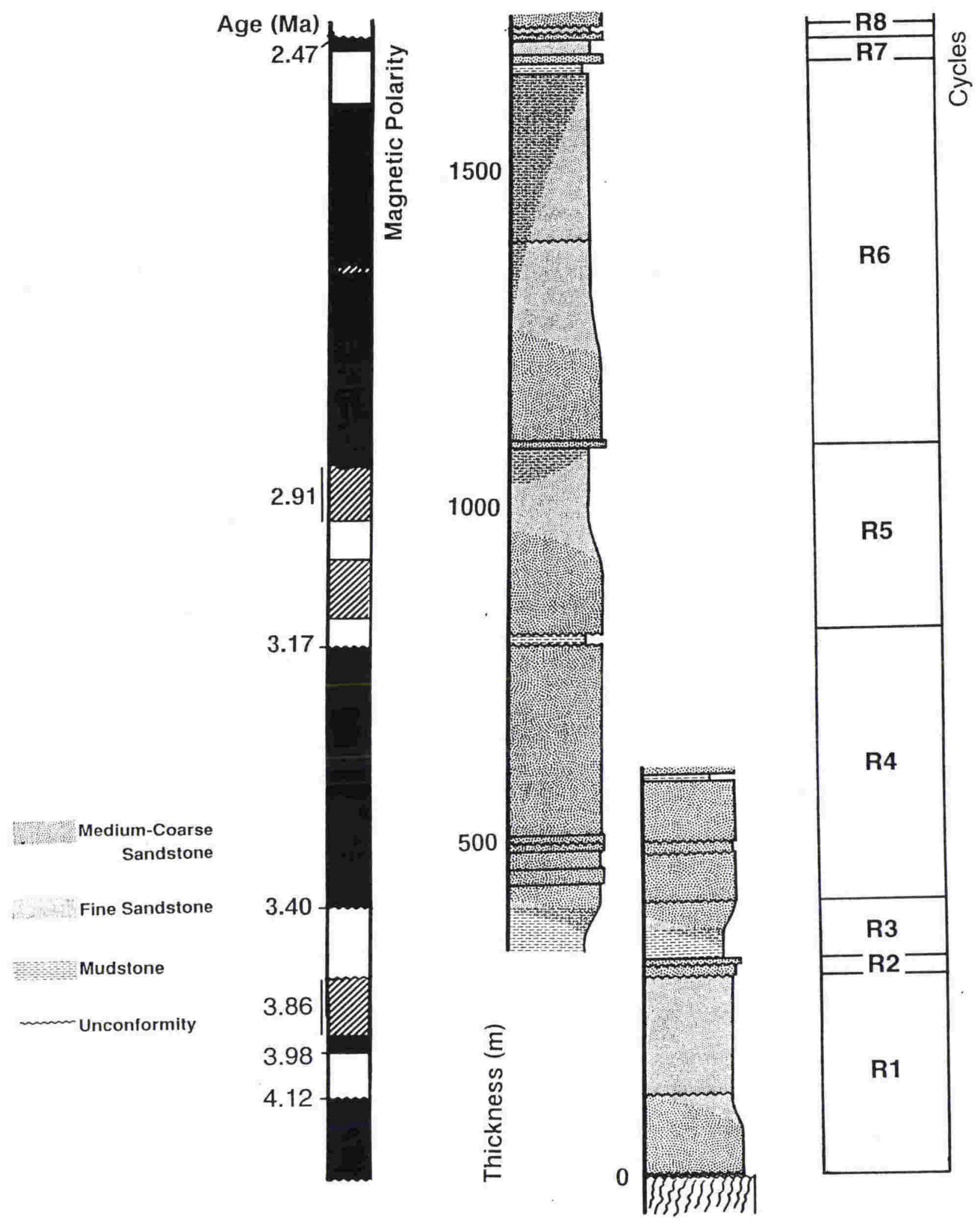

Figure 15.2: Sedimentary cycles in the Rangitikei River Section (polarity and age is from section 4). 


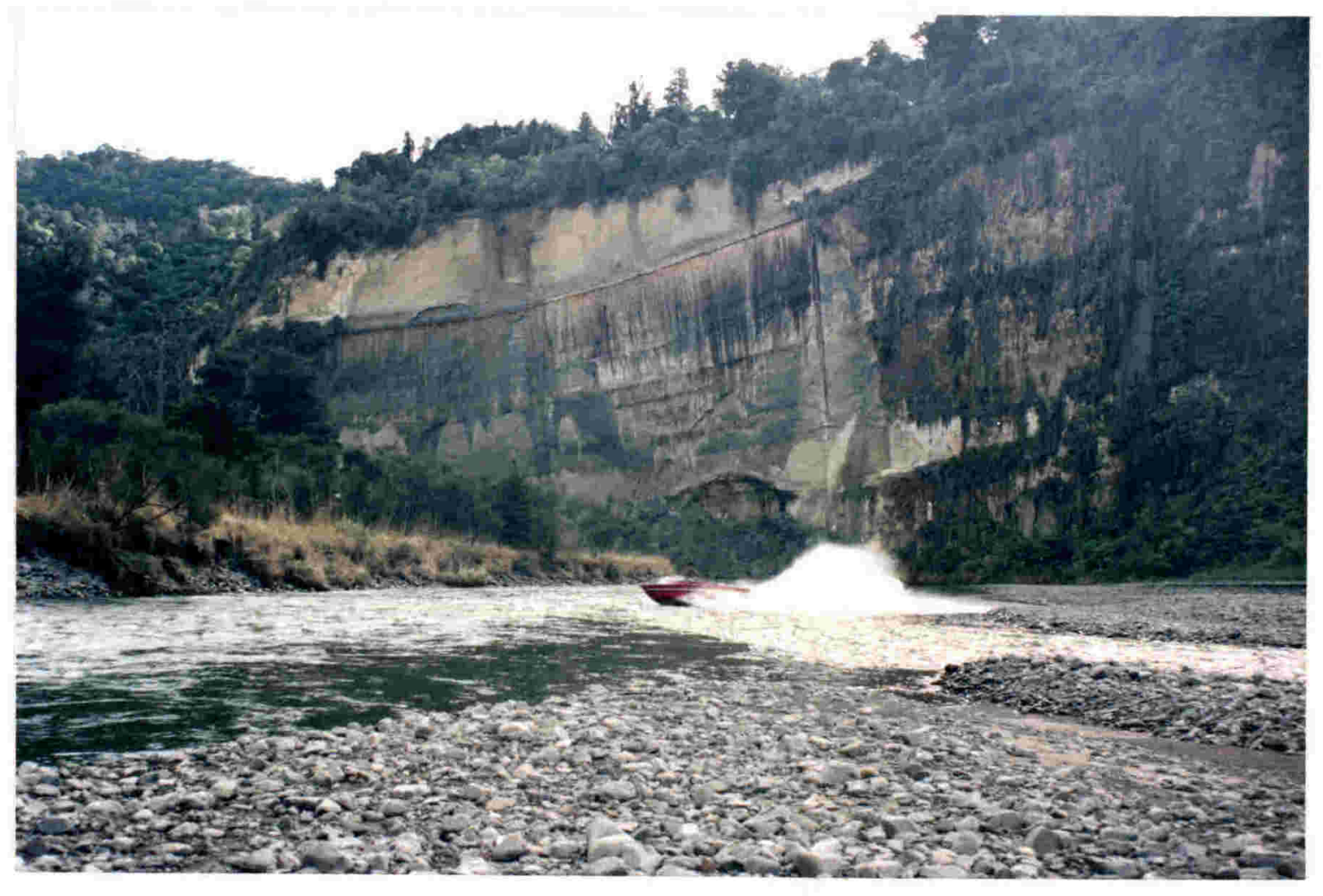

Plate 15.3: An example of the thick uniform sedimentary successions in the Upper reaches of the Rangitikei River. Cycle boundary is commonly marked by a thin and often inconspicuous sandy to silty mudstone horizon.

Generally the cycles are more disjoint than in the Wanganui River section. Due to their more shallow average depositional environment they are complicated by shorter order sea level variation parasequences. The following interpretation of cycles is therefore tentative. Only the general nature of overall depth of deposition is used later to support interpretation of changes of sea level inferred from the Wanganui River section.

Cycle R1 encompasses the Waiouru Sandstone and much of the Taihape Mudstone. It is a thick fining upwards (type 2) sequence that contains a complex set of retrogradational parasequence sets. These do not easily resolve into individual sequences. Cycle
R2 encompasses the Taihape Sandstone member of the Taihape Mudstone. It encompasses a single highstand wedge sequence. It overlies a type 1 channelled sequence boundary and is overlain by a type 2 sequence boundary. Cycle R 3 is a type 1 sequence, with its top truncated by a type 1 channelled sequence boundary.

Cycles R4-R6 are thick (250-500 m) and complex. Overall they fine upward, but each cycle contains many apparently retrogradational parasequence sets, especially in the lower part of the section (cycle R4). The Mangaweka Mudstone comprises the upper part of sequence R5 and sequence R6. Its abundant concretionary layers and sandiness suggest shallow water depositional environments compared with the Taihape 
Mudstone. The same coarsening transition is seen at the same horizon in the Wanganui River section. Cycles R7 and $\mathrm{R} 8$ are thin type 2 sequences like those described by Abbott and Carter (1990) in Castlecliffian strata higher in the same section. These younger cycles have been observed to contain nonmarine sediments (Brad Pillans pers. comm.) suggesting they have formed higher on the shelf than any of the other cycles observed in the present study.

\subsection{Origin of the Successions}

The model of development of sediment wedges and their relationship to sedimentary facies successions has ahready been presented in section 14.7. The balance of basin subsidence by sediment input is again stressed here. Variation from southward progression of wedge stacking is also eliminated in the present study. The natural outcrop pattern in the onshore South Wanganui Basin rivers exposes the sequence through this southwards progression (figure 15.3). The nature of development of the cycles described above can be attributed solely to the variation in eustatic sea level.

The largest order of sea level variation is one that develops the highstand, transgressive, lowstand and regressive sediment wedges within a single sea level cycle. The nature of the particular sedimentary succession over time will depend on the position of the point of deposition on the shelf. For example, high on the shelf, only highstand and

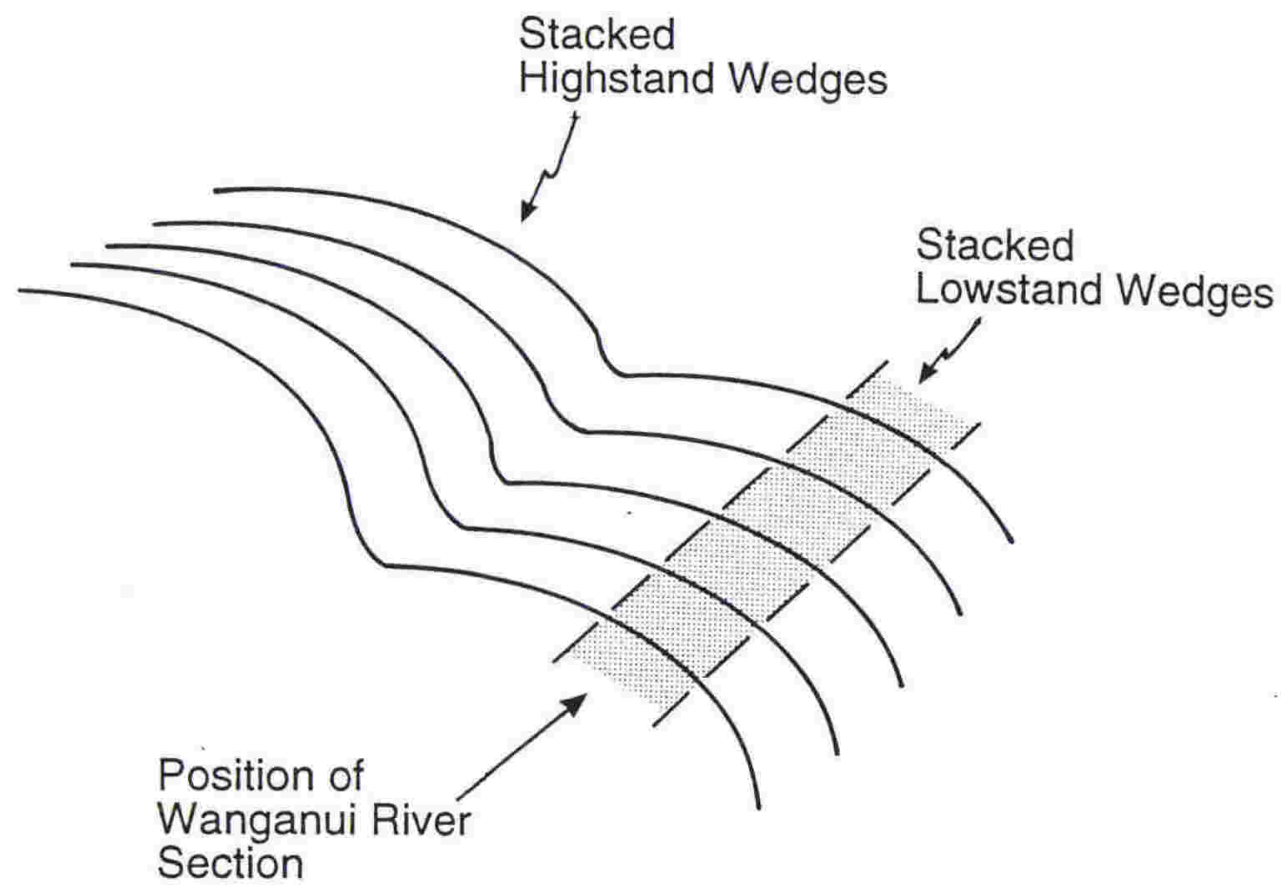

Figure 15.3: A sketch depicting the location of the stratigraphic section exposed in the Wanganui River Valley, showing its relationship to the progradationally stacking highstand and lowstand wedges on the continental margin. 
transgressive wedges will be sampled by the point of deposition. Each of these packages will be separated by a type 1 channelled unconformity. Lower on the shelf, the point of deposition will sample the regressive and lowstand wedges. At some intermediate level on the shelf the point of deposition will sample mainly the transgressive or regressive wedges with a small portion of the lowstand or highstand wedges.

Because of the lithospheric control on basin development, if eustatic cyclicity is constant, similar sedimentary cycles should stack up regardless of the type of sequence sampled by the point of deposition. If the nature of the sequence changes at the same point of deposition this must be attributed to a larger order of change in eustatic cyclicity. Smaller order changes in sedimentation that cannot be resolved into full cycles (parasequences) are attributed to a shorter order of change in eustatic cyclicity.

For example, in the Wanganui River section the change from type 2 sequences to type 1 sequences (in cycle W3) represents a relative move of the point of deposition (and hence sampling) to lower on the palaeo-shelf. Because of the lithospheric control on basin development this change must be attributed to a larger order eustatic change. This raised the base level of the eustatic cyclicity controlling the individual cycles of the Wanganui River section. Thus, the entire depositional package, consisting of the highstand, regressive, lowstand and transgressive wedges is moved higher on the palaeoshelf (figure 15.4).

\subsection{Onlap, Downlap, Toplap and the eustatic curve}

The most reliable indicators of relative changes of sea level are the depositional limits of onlap and toplap (Vail et al., 1977) (For definition of terms see table 15.1). However, in certain conditions, such as where basin subsidence and sediment input are balanced, the change in downlap can also be a useful indicator of relative sea level change. Consequently, facies variation can also be useful indicators of sea level variation. This is inherent in the approach of Van

\section{Table 15.1: Definition of terms}

Downlap; A base discordant relation in which initially inclined strata terminate down dip against an initially horizontal or inclined surface (Mitchum, 1977). A shallowing facies association occurs above the downlap surface.

Onlap; A base discordant relation in which initially horizontal strata terminate progressively against an initially inclined surface (Mitchum, 1977). A deepening facies association occurs above the onlap surface.

Toplap; Termination of strata against an overlying surface mainly as a result of non-deposition (sedimentary bypassing) with perhaps only minor erosion (Mitchum, 1977). 


\section{a) Early-Middle Pliocene}

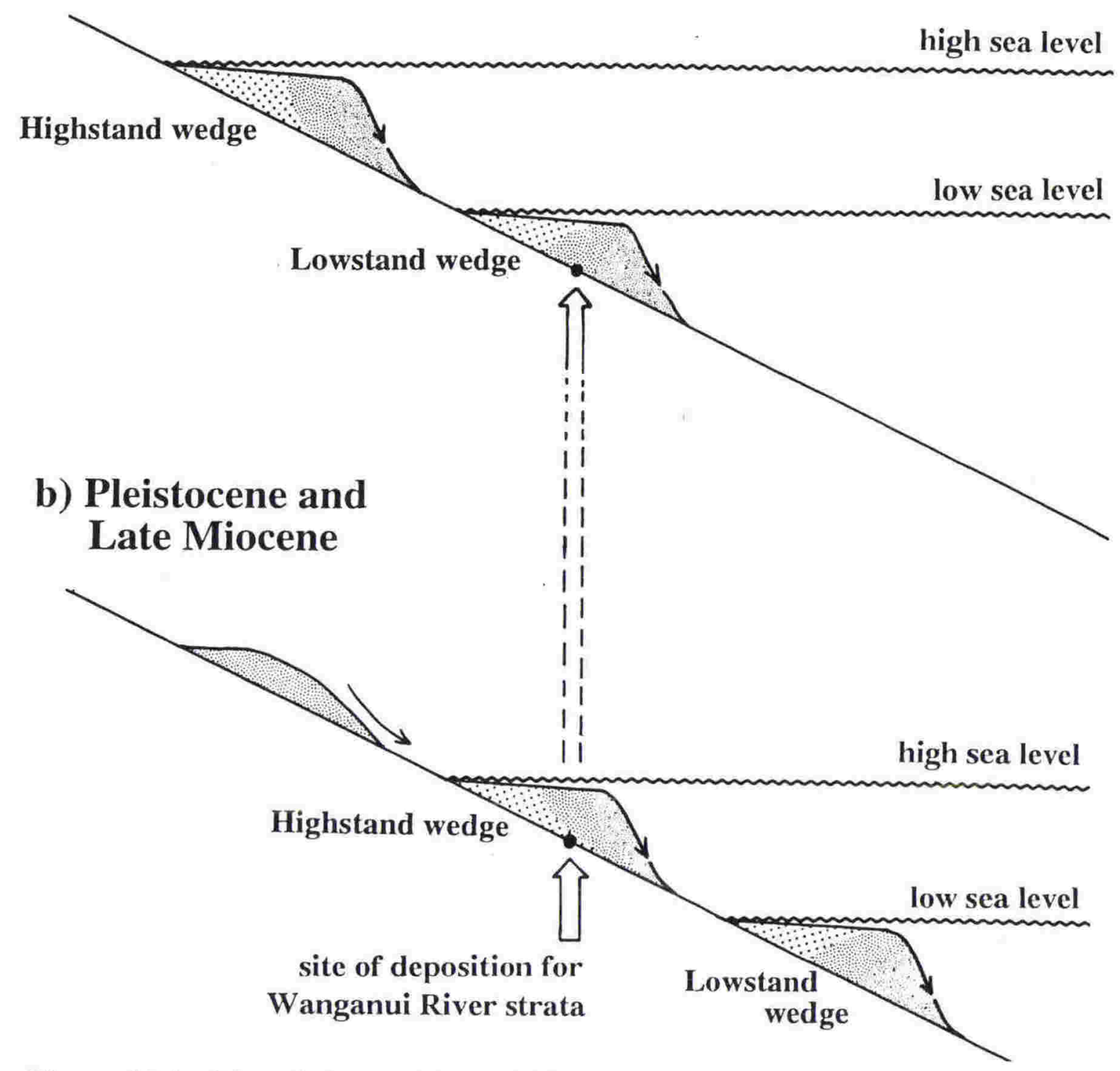

Figure 15.4: The relative positions oh highstand and lowstand wedges on the Wanganui continental margin during a) a high base level of eustasy (Early - Middle Pliocene) and b) a'low base level of eustasy (Late Miocene and Late Pliocene). The position of the site of deposition of the Wanganui River strata is shown to illustrate the effect on the deposition of a change in base levels on these strata.

Wagoner et al. (1990) to sequence stratigraphy.

Vail et al. (1977) suggest that in the sequences they have studied, the nature of the fall of sea level is indicated by a very abrupt shift. Consequently they do not observe development of the regressive wedge or as Vail et al. (1977) put it "a downward shift of coastal onlap". They go further and state that " an actual fall in sea level, especially a gradual one, might not be detected by using coastal onlap as a criterion".

Because of this deficiency in initial observations of only sequences that develop high on the shelf, it was thought that progradation and development of downlap occurred only as part of the 
highstand systems tract and was mainly controlled by sediment input. Downlap must also occur within the lowstand wedge and this is partly due to a regressing relative sea level and development of the regressive wedge.

This downlap occurs in the cycle at the point where the highstand wedge becomes subaerially exposed and eroded, developing a type 1 channelled sequence boundary. If only the highstand wedge is observed in the record then the eustatic sea level interpreted from the record will be solely from onlap and very asymmetric in nature. Posamentier et al. (1988) recognised this deficiency and proposed that the sea level fall was recorded by prograding freshwater facies, that were not always preserved. On a wide shelf the falling sea level and downlap can be observed seaward of the highstand wedge in the regressional wedge (stranded parasequences) and lowstand wedge. This is the case in the South Wanganui basin.

Interpretation of the South Wanganui Basin cycles is in terms of change at the point of deposition as highstand, lowstand, regressive and transgressive wedges develop above, beyond, or at the point of deposition of the studied section. In a single sequence the simplest depiction of this change is in terms of the changing extent of onlap and downlap of sediment depicted in the studied section. Figure 15.5 depicts these changes for individual Wanganui Basin sequences. The relative change in depositional onlap
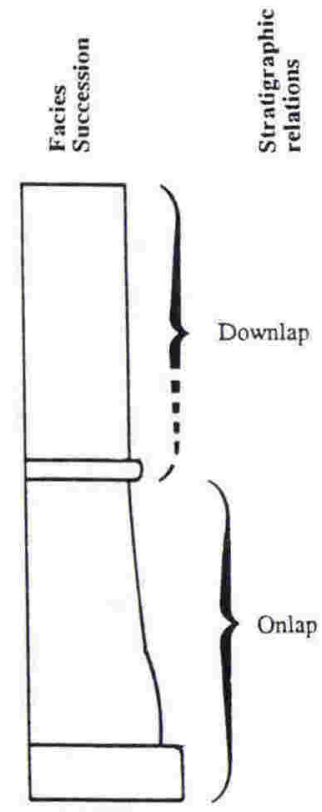

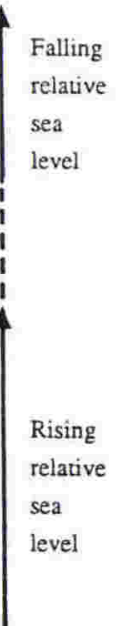

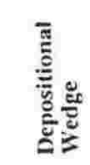
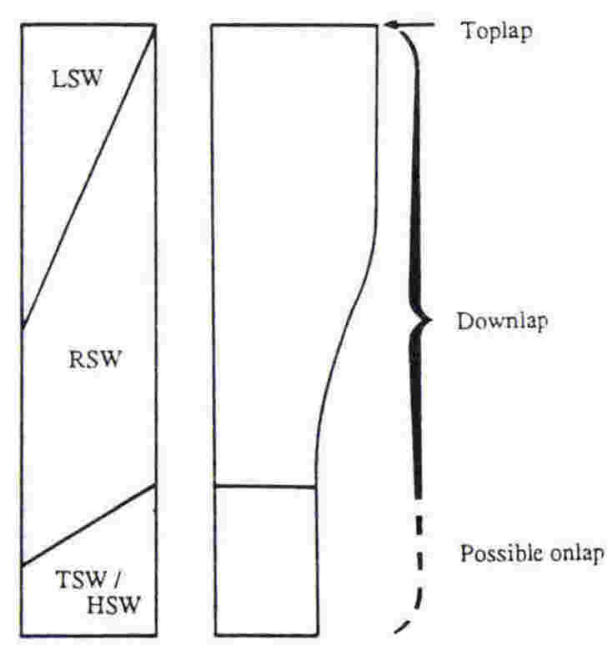
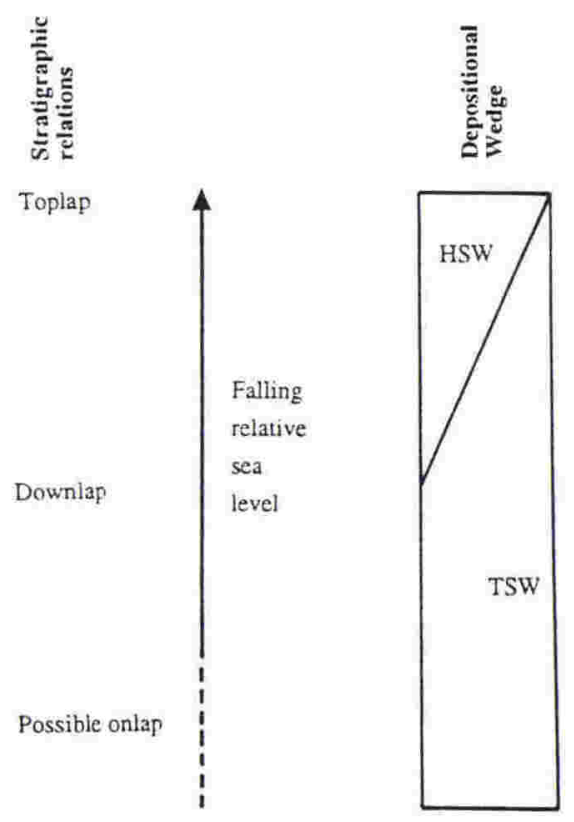

Figure 15.5: Identification of the changes in the nature of stratal relationships during a full cycle of deposition (see table 15.1 for definitions of toplap, downlap, and onlap), The right hand side of each diagram shows the change in relative sea level during deposition of the cycle. The left hand side depicts type 1 sequences and the right hand side type 2 sequences. LSW $=$ lowstand wedge, TSW $=$ transgressive wedge, $\mathrm{HSW}=$ highstand wedge, $\mathrm{RSW}$ = regressive wedge. 
or downlap is depicted by shoreward or seaward moving facies at the point of deposition. Toplap is depicted by a truncation of the facies at the point of deposition, with a slight unconformity.

Figure 15.6 illustrates the pattern of change through the complete Wanganui River Section. This interpretation of the onlap and downlap is not possible for the
Rangitikei River section, because of its relatively higher position on the shelf and the complex nature of parasequence sets within cycles. It $s$ general nature of change supports those changes better defined in the Wanganui River Section. This includes a major shallowing in the early Gauss magnetochron and further shallowing in the early Matuyama magnetochron (figure 15.7).

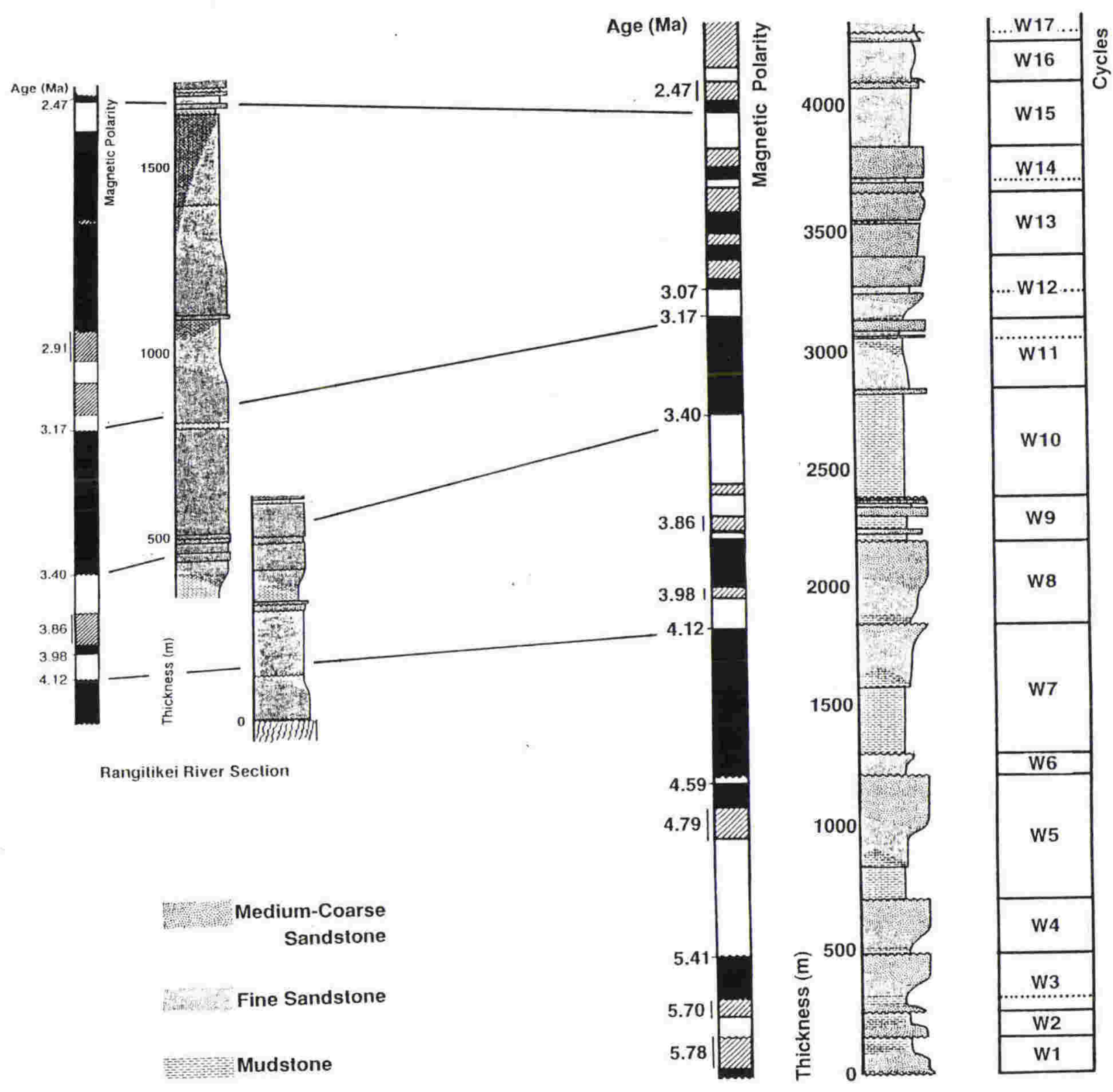

Wanganui River Section

Figure 15.7: Correlation of the Rangitikei and Wanganui River sedimentary cycles showing the agreement between the two in overall nature. Detailed correlation is difficult. 

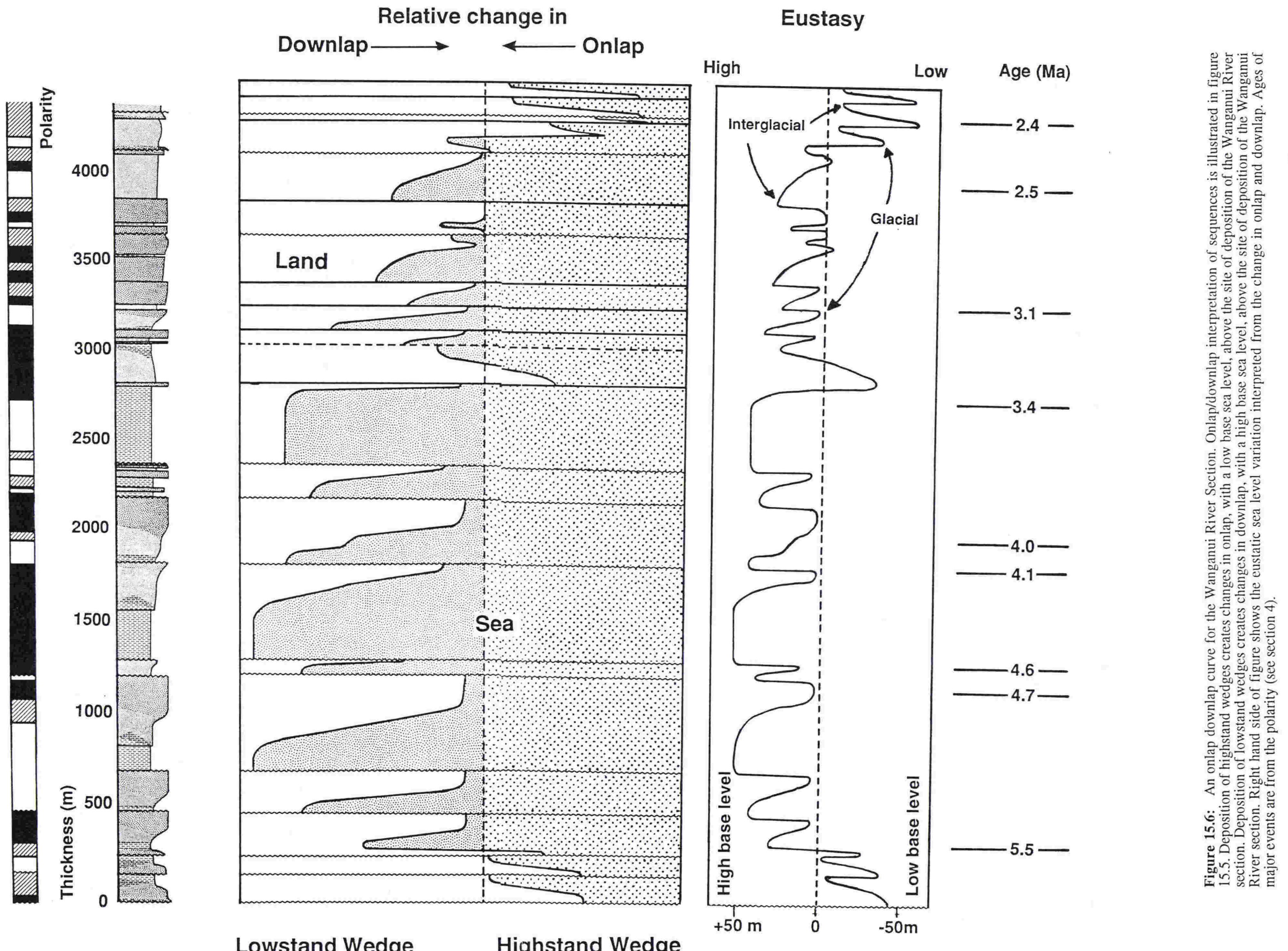
15.5 The Eustatic Sea Level record

This is shown in figure 15.8. Chronology is from chapter 12. A constant average sediment accumulation rate is assumed between palaeomagnetic reversals.

The Late Miocene and Late Pliocene are times of low base level eustatic cyclicity with highstand/transgressive wedge systems at the point of deposition of the Wanganui River Section. The earlymiddle Pliocene is a time of high base level eustatic cyclicity with regressive/lowstand wedge systems at the point of deposition of the Wanganui River Section. The major inflection points of this base level variation are at ca. $5.5 \mathrm{Ma}$. and $2.5 \mathrm{Ma}$. respectively. The

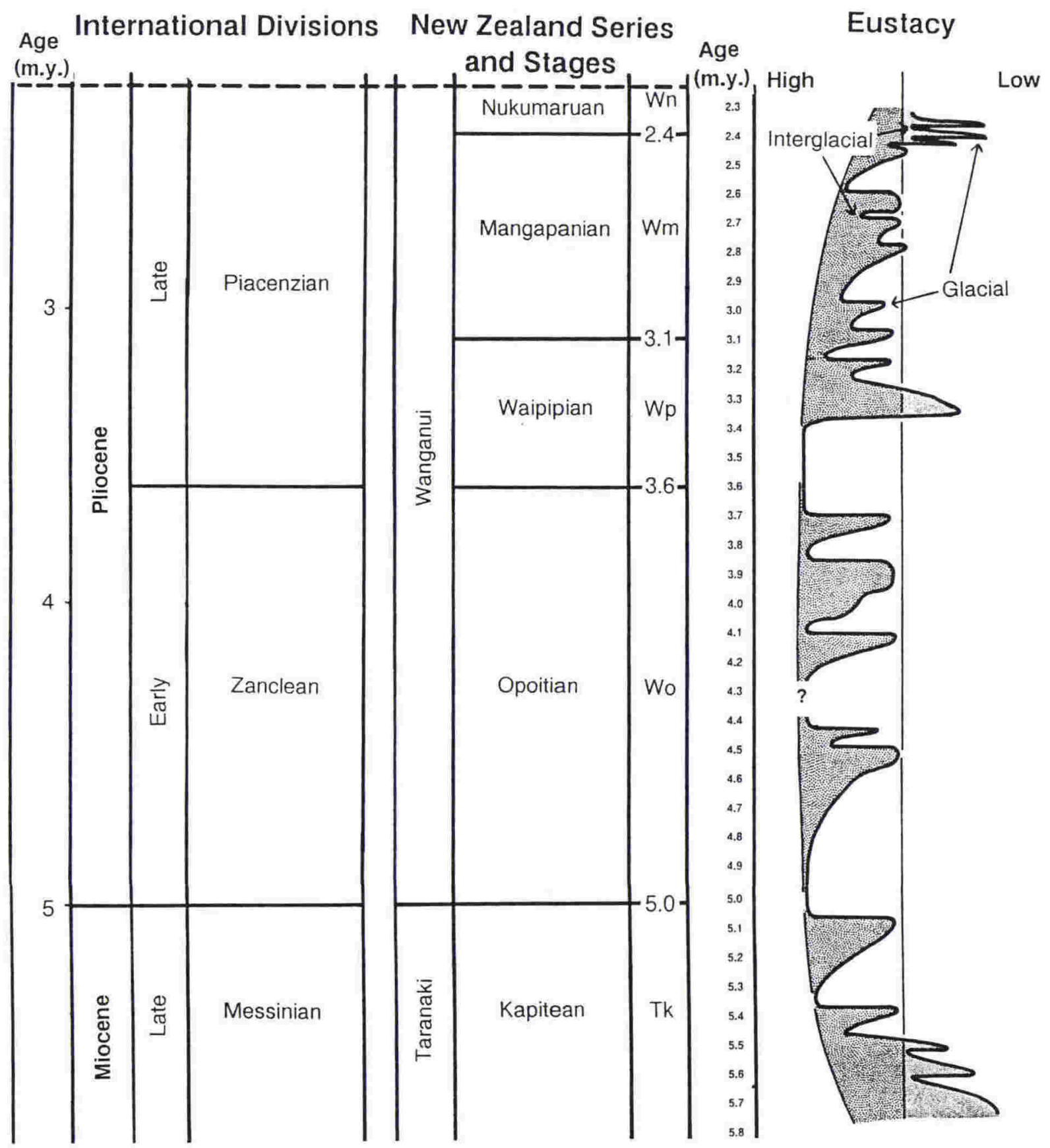

Figure 15.8: The eustatic sea level curve interpreted from the South Wanganui Basin sequences. Chronology is from chapter 12 , assuming constant average sediment accumulation between palaeomagnetic reversals. Amplitude estimation is explained in section 15.5.2. 
wavelength of this base level cyclicity is 3-4 m.y.

Early Pliocene cyclicity (3.4 - 5.5 m.y.) is marked by cycles of $100-500 \mathrm{k} . \mathrm{y}$. duration with a high base eustatic sea level. A major shallowing at $3.4 \mathrm{Ma}$. marks a change to 100 k.y. cyclicity superimposed on a moderate base eustatic sea level. This characterises the sea level cyclicity of the middle Pliocene (2.5 - 3.4 m.y.). Late Miocene and Late Pliocene cyclicity is characterised by short order cyclicity (40 - 100 k.y.) superimposed on a low base eustatic sea level.

The nature of this variation is very similar in timing and relative amplitude to the variation in the oxygen isotope curve of Shackleton and Opdyke (1977) revised by Shackleton et al. (1992).

\subsubsection{Comparison with the EXXON global sea level curve}

The Plio-Pleistocene portion of the eustatic sea level curve of Haq et al. (1987) has been presented in the most detail by Microstrat inc. (1990) (figure 15.9). This curve recognises only 5 cycles between 2.4 and $6.0 \mathrm{~m} . \mathrm{y}$. before present. The comparison with the South Wanganui Basin is very poor. A shallowing in base level is evident between 3.8 and 2.4 m.y. but the control is very poor. In the EXXON curve low sea level events occur at 5.4, 4.2, 3.7, 2.8 and $2.3 \mathrm{Ma}$. Possible correlatives for all but the $4.2 \mathrm{Ma}$. low sea level events can be observed in the South Wanganui Basin record, but none of these are prominent events in the South Wanganui Basin record. The 4.2 Ma. event of the EXXON curve could be missing in an unconformity of that age, identified by magnetostratigraphy, in the South Wanganui Basin Section. A similar age event is recorded in the oxygen isotope curve of Shackleton et al. (1992).

There are three main reasons for the differences in the two records: 1) The South Wanganui Basin is at an active continental margin with high sediment influx and basin subsidence. The high sediment accumulation rate provides a much increased resolution of sea level variation than that available at passive margins; 2) Much of the record comes from low on the shelf beneath the lower stands of eustatic sea level ensuring that it is preserved and not eroded; 3 ) The magnetostratigraphic age control on the South Wanganui Basin sequence has far better resolution than the biostratigraphic control of the EXXON curve.

\subsubsection{A mplitude of Eustatic Sea Level variation.}

Although relative onlap and downlap have been used to construct a relative sea level curve; it is not possible to measure the variation in sea levels from the two dimensional onlap pattern of the strata. Estimation of the amplitude of sea level variation is possible by estimating the depth of deposition of the different facies associations, and comparing this with 


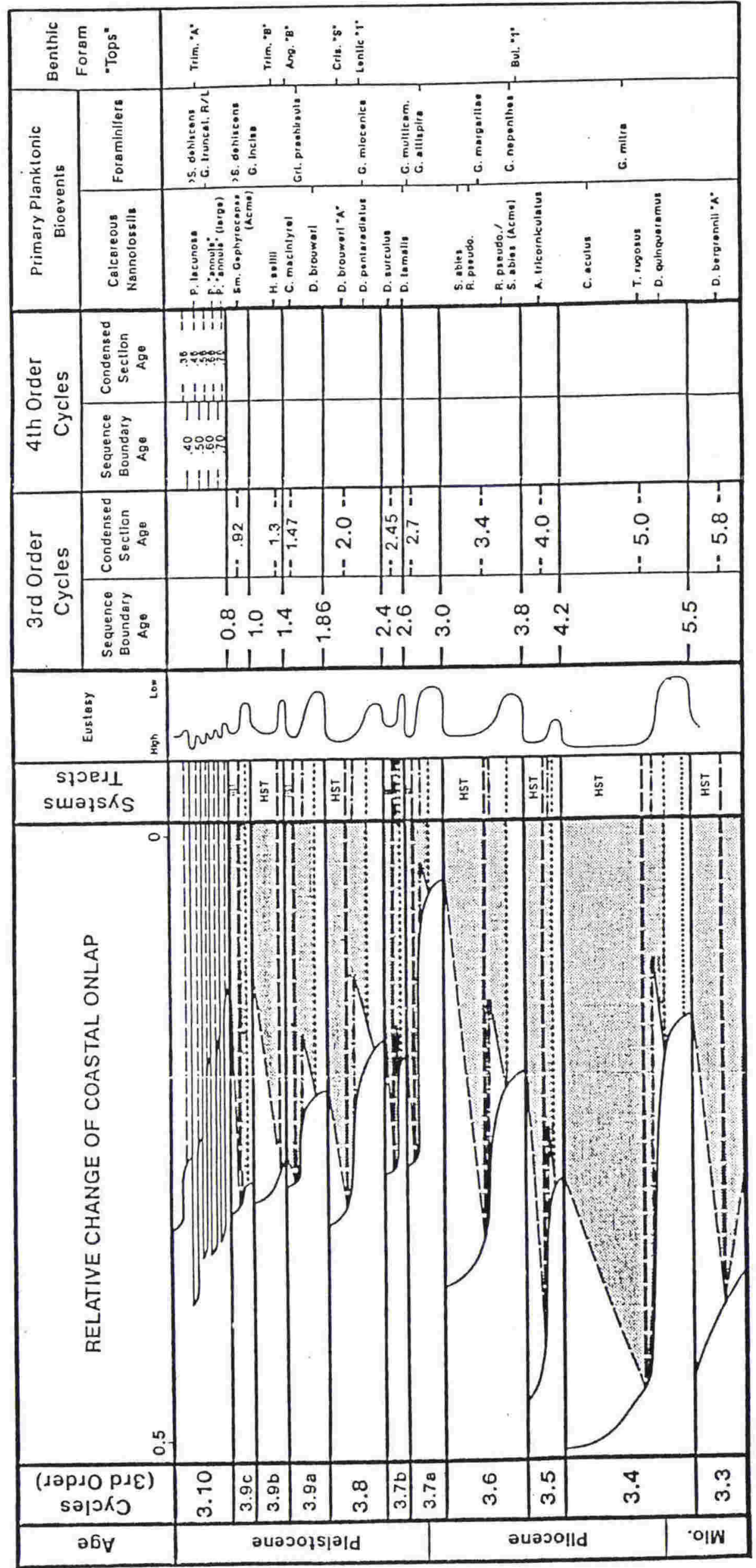

Figure 15.9: The existing Late Neogene sea level curve (from Microstrat, 1990). 
their position in the development of the eustatic curve. Perrett (1990) compared the percent mud content of modern coastal sediments from the PekaPeka coast in the South Wanganui Basin (figure 15.10). Using this textural/depth curve, as a minimum, the percent mud variation of a full Pliocene South Wanganui Basin cycle (figure 16.3) is expected to represent a $40-50 \mathrm{~m}$ amplitude. Incomplete cycles are inferred to represent a smaller amplitude.

PERCENT MUD

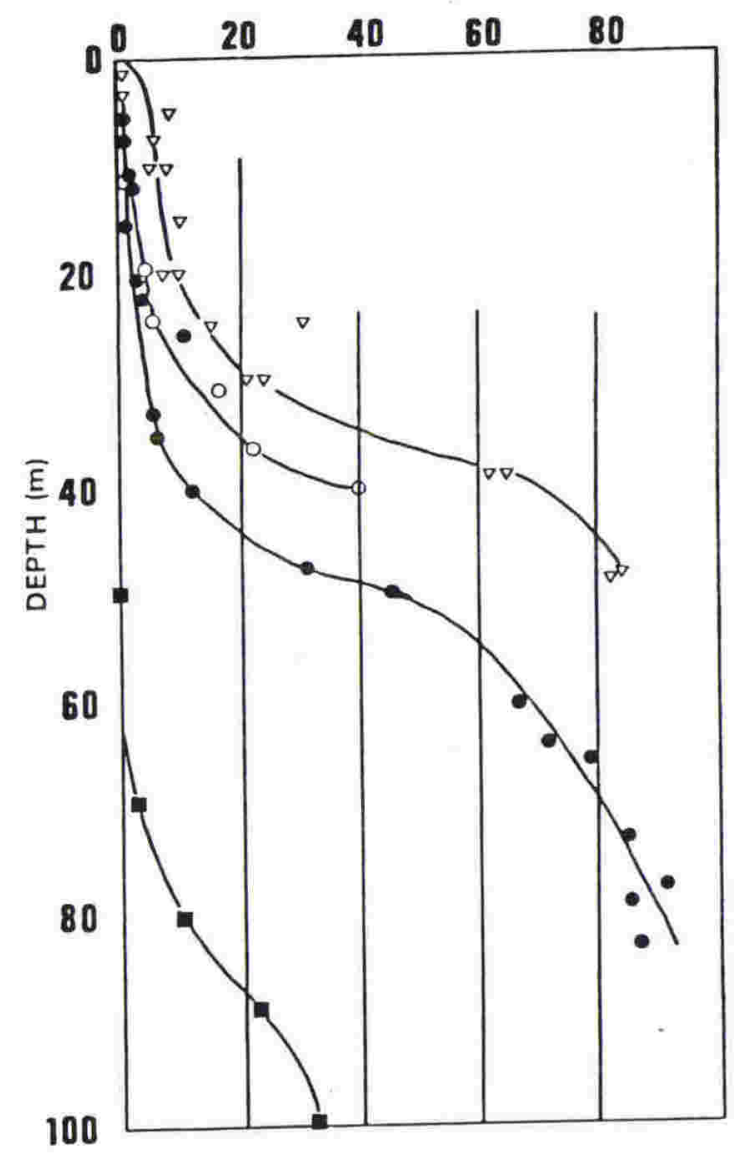

Figure 15.10: Percent mud versus depth for samples from Peka Peka, New Zealand $(\nabla)$, Monterey Bay $(\bullet)$, Roussillion Shelf (o), and Bristol Bay, Bearing Sea (-) (from Perrett, 1990). Values from Peka Peka are expected to be underestimates as applied to the Late Neogene Wanganui basin sequences as they are from a more protected environment with a lower wave reach than is normal in the South Wanganui Bight.
Variation in the eustatic base level is more difficult to estimate. In the sediment wedge model presented in section 15.7 it was expected that the overlap between the highstand and lowstand wedge positions on the shelf was minimal. It is therefore likely that the base level variation is on the order of $40 \mathrm{~m}$ amplitude, to force the highstand wedge to be directly replaced by the lowstand wedge and visa versa in the Wanganui River depositional succession.

\subsection{A model for Eustatic Cyclicity in the Late Neogene (2.4 - 6.0 m.y.)}

Three orders of cyclicity are apparent in the South Wanganui basin and a fourth is inferred (figure 15.11). The longest order cycle has a wavelength of 3-4 m.y. and provides the base level of all the South Wanganui Basin cycles. Two medium order cycles are also present; an inferred cycle of $c a .2$ m.y. duration and an apparent cyclicity of 100-500 k.y. duration. The shortest order cyclicity in the South Wanganui Basin sequences are of 40-100 k.y. duration.

The two longer order cycles must be subdivisions of the 3 rd order cyclicity recognised by Vail et al. (1977). The shorter order cycles of 100-500 k.y. and 40-100 k.y. duration are equivalent to the 4 th and 5 th order cycles of Vail et al. (1991) respectively.

In the South Wanganui Basin sequences, the 4 th order cycles predominate during 
high base eustatic sea levels and the 4 th order cycles predominate during low base eustatic sea levels.

2.0

3.0
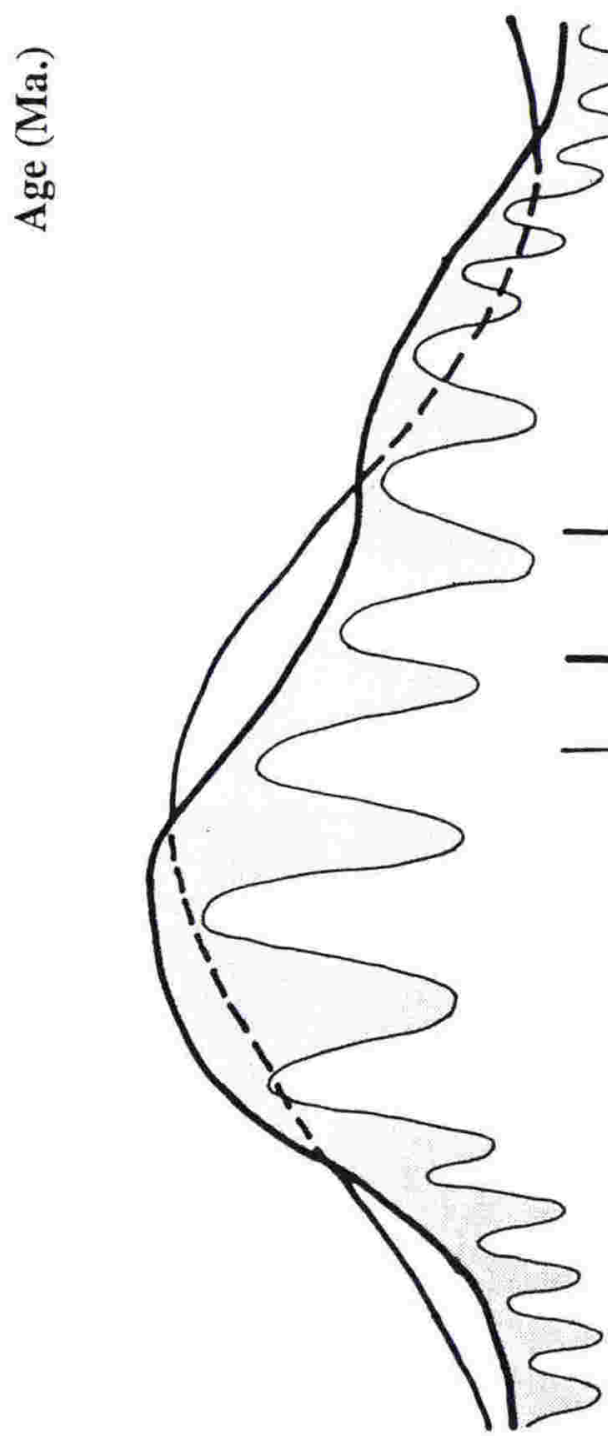

4 m.y. cyclicity (Antarctic ice sheet fluctuation)

4.0

2 m.y. cyclicity

$0.1-0.5$ m.y. cyclicity

3rd order

4-5th order

(after the scheme of Fulthorpe, 1991)

5.0

6.0

Figure 15.11: A model for the Late Neogene eustatic cyclicity recognised by this study. Three orders of variation (0.1-0.5 Ma., $2 \mathrm{Ma}$. and $4 \mathrm{Ma}$.) are recognised as being superimposed on each other. No scale of amplitude is shown, but the sketch depicts relative change. Individual sea level events are a depiction for the model only and not exact. Comparative scale of order is from Fulthorpe (1991). 


\section{SECTION - 4}

\section{PALAEOMAGNETISM OF SOUTH WANGANUI BASIN STRATA}

Chapter - 16: Palaeomagnetism

Chapter - 17: Sedimentary Petrography and Mineralogy

Chapter - 18: Rock Magnetism

Chapter - 19: Magnetostratigraphy 


\section{Chapter - 16}

\section{Palaeomagnetism}

Palaeomagnetic techniques used in assessment of individual sample behaviour and assignment of polarity and direction to sites from the Wanganui, Rangitikei, and Hautawa Road sections are presented below. Comparisons are made with other findings on palaeomagnetic behaviour of New Zealand Tertiary sediments. Orthogonal vector and stereographic projection plots have allowed palaeomagnetic behaviour to be divided into 5 main categories. Only $3 \%$ of total specimen analyses yielded no useful palaeomagnetic information. A combination of Principle Component Analysis and Remagnetisation Great Circle analysis permitted polarity solutions for all but 1 site. Results are presented in tables, magnetograms and stereographic plots for each stratigraphic section. No inclination error in these results suggests that directions are truly representative of the ambient field at the time of acquisition of magnetisation. Results are of sufficient quality to enable construction of accurate magnetostratigraphic records for each of the sections (presented in Chapter 19), to comment on tectonic rotation of the eastern margin of the Wanganui Basin, and also to aid in defining the process of magnetisation and post depositional effects on the magnetic signal, both diagenetic (presented in chapters 17 and 18, and tectonic (presented in this chapter).

\subsection{Introduction}

Palaeomagnetic study of the Wanganui and Rangitikei River sections was undertaken to provide chronology through magnetostratigraphy. Previous work in the Basin (Fleming, 1953; Collen, 1972; Ker, 1973) showed that molluscan or foraminiferal biostratigraphy could not provide sufficient time resolution. Therefore, it was decided to undertake a palaeomagnetic study at the same time as the lithostratigraphic and sedimentologic study.
The magnetostratigraphy was expected to be the key tool in correlating strata, both across the Wanganui Basin, and between the Wanganui Basin and the Antarctic margin. The magnetic reversals provide global markers of time instants. As the global time scale is refined using new criteria (e.g. Cande and Kent, 1992; Shackleton et al., 1992), ages of events reported in this study may be refined, but the relationship between all sections will remain as outlined here.

\subsection{Field and laboratory work}

Approximately 30 days were spent collecting palaeomagnetic samples in the 
field, location of suitable sampling sites, cleaning of outcrop and drilling of cores. A total of 424 cores were collected from 124 sites and these were later cut into more than 1200 specimens. Some 215 cores were collected from the Wanganui River section, 144 from the Rangitikei River section, and 65 from the Hautawa Road section.

\subsubsection{Sampling}

Samples for palaeomagnetism were, where possible, drilled from fresh unweathered wet sediment. Every attempt was made to sample the finest grained sediment, although the nature of the sediments necessitated sampling a range of textures to gain stratigraphically closely spaced sample sites to control magnetostratigraphy. While other studies have precalculated the sampling interval necessary to recognise all magnetic reversals (McGuire, 1989 for example), the approach in this study was to sample all fine grained horizons and later fill gaps to give a sampling interval of less than $50 \mathrm{~m}$. This gives a time interval in sampling of $<40,000$ years. Where unconformities were recognised in the strata additional samples were taken and where possible these were taken immediately underlying and overlying the unconformity.

Oriented samples were taken by using either an electric drill connected to a gasoline driven electric generator or a direct drive Pomeroy gasoline drill. While the electric drill produced more uniform cores and made drilling easier, the Pomeroy drill offered more portability, which was very important working in the isolated higher reaches of the rivers. Both drills used diamond tipped non-magnetic drill barrels with an internal diameter of $25 \mathrm{~mm}$. The drill bit was lubricated and cooled by pressurised water flow directed through the inside of the drill bit.

A minimum of three cores were drilled at each site with a maximum stratigraphic difference of $30 \mathrm{~mm}$ between highest and lowest samples (average sedimentation rate is approximately $1.3 \mathrm{~mm} / \mathrm{yr}$, so 30 $\mathrm{mm}=\sim 30$ years), this should be a short enough time interval that each core records the same magnetic orientation (the average time interval a magnetic reversal occurs on is less than 1000 years; Tarling, 1983).

Once each core was drilled, the plunge and trend of the core was measured using an aluminium orienting device. The $y$ azimuth (the angle of declination the core makes with the present magnetic field) was measured using a magnetic compass placed on top of the orienting device. Both the y-azimuth and plunge (the dip angle of the core axis with respect to a horizontal plane) of the core were recorded to 0.5 of a degree. Once measured a line was scribed along the top of the core and markings made along the core to show the plus y-azimuth direction giving each core an unique identification so that it can be accurately reoriented 
during laboratory measurement (figure 16.1).

A sample name was also added to each core as it was collected. Each sample was given a letter code for its section identification (W for Wanganui River, $\mathbf{R}$ for Rangitikei River, and $\mathrm{H}$ for Hautawa Road), followed by three numbers for the site locality and a further three numbers
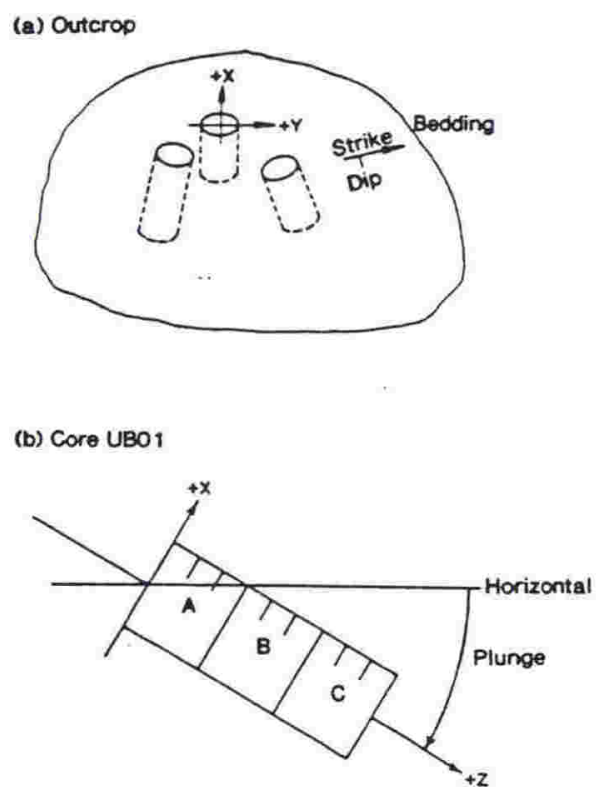

(c) Specimen

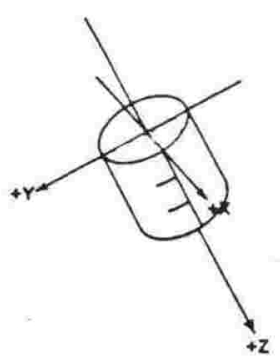

Figure 16.1: Core orientation and marking scheme: a) Orientation of core in outcrop. b) Orientation of a single core. A line is marked down the long axis $(+z)$ of the surface of the core. Circumferential marking indicate the $+y$ direction. Core plunge is the angle between the $\mathrm{z}$ axis and the horizontal. $\mathrm{c}$ ) Marking scheme for individual specimens (from Roberts, 1990). for each core from the site. A core numbered thus W023005 would be core five from site 23 in the Wanganui River section. During initial sampling site numbers from all sections did not run stratigraphically consecutively (as explained above), once the sampling was completed for the entire study, site numbering was altered so that site numbers were consecutive starting at the stratigraphic base with 001 and increasing in the younging direction. Stratigraphic location of samples was achieved by using a combination of large scale maps and altimeter measurements tied to local benchmarks and trig stations (see section 3).

As each core was collected, it was labelled, wrapped in newspaper (to slow drying), and placed directly into a mumetal shield to prevent magnetic overprinting during drying and transport. Previous palaeomagnetic studies of New Zealand Cainozoic sediments (McGuire, 1989; Roberts, 1990 and Wright, 1986) had found the magnetisation of these sediments to be extremely weak and already contain several components. Every precaution was therefore taken to maintain the signal in its primary condition, and to prevent formation of further viscous remanent components.

Before measurement, the cores were cut into $22 \mathrm{~mm}$ length specimens, using a diamond saw, and cleaned before drying in a mumetal shield. The resulting specimen has a height and diameter ratio of 0.88 , well within the optimal range for 
measurement on modern magnetometers (Tarling, 1983). Each specimen was given a decimal identifier, with the specimen from deepest within the outcrop being given a .1 identifier added to the original name and the next .2 and so on until the outcrop end of the core was reached. At this stage samples were stored in the mumetal shield until measurements could be made.

\subsubsection{Laboratory measurements}

All palaeomagnetic measurements were made using cryogenic magnetometers (plate 16.1). At the measurement stage, site numbers were given a further identifier, a letter suffix; $\mathrm{V}$ for samples measured made on the two axis ScT cryogenic magnetometer at the Institute of Geophysics, Victoria University of Wellington; O for samples measured on the two axis semi-automated Cryogenic Consultants magnetometer at the Geology Department, Oxford University, England; and $\mathrm{G}$ for samples measured on a 2G Enterprises horizontal, 3 axis, cryogenic magnetometer in a magnetically shielded room at the Centre des Faibles Radioactivites, Gif-surYvette. Measurements made on the Gifsur-Yvette cryogenic magnetometer were carried out by Dr. Andrew Roberts using the same criteria as the author.

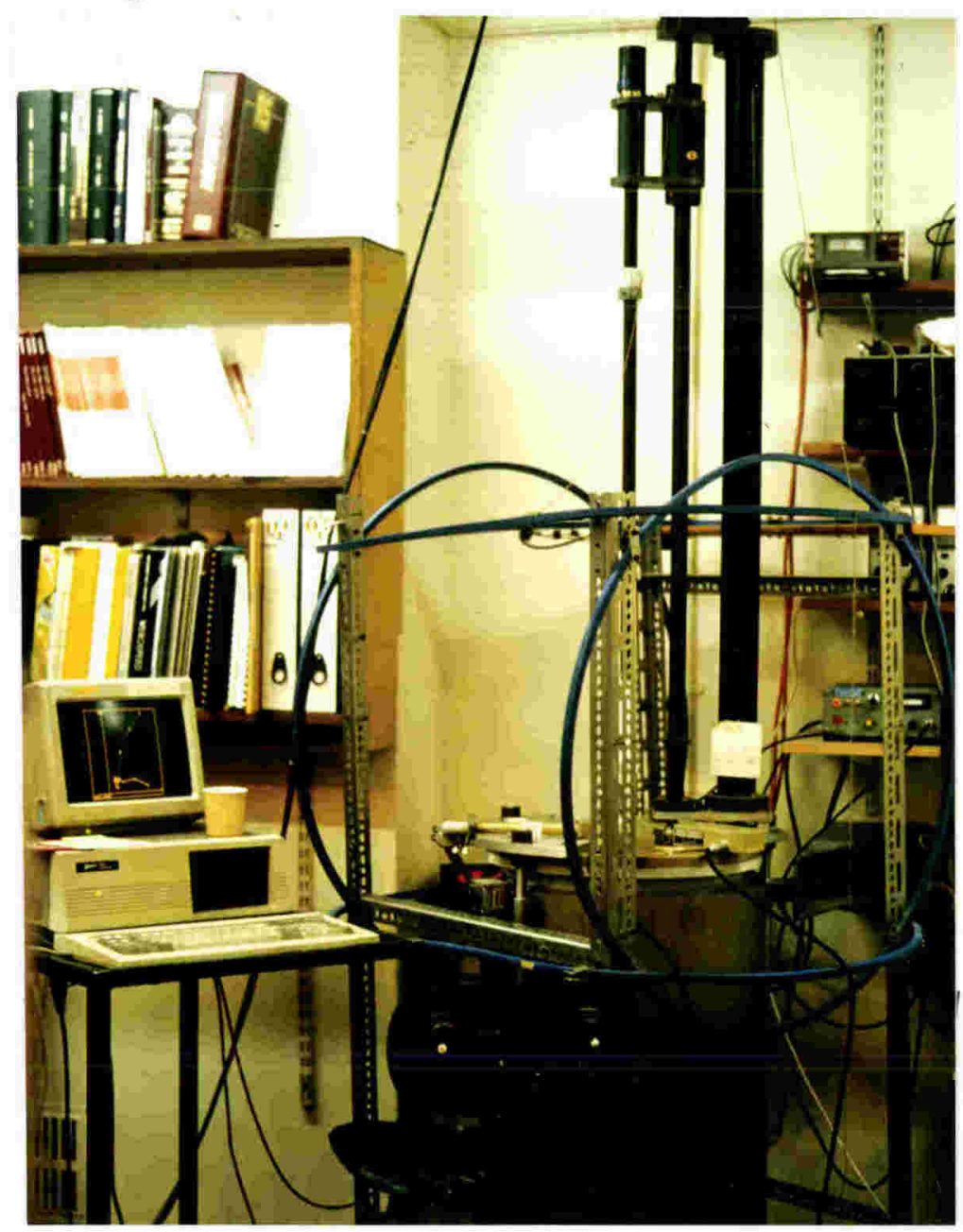

Plate 16.1: The Oxford University, two axis semi-automated Cryogenic Consultants magnetometer which was one of three magnetometers used to measure palaeomagnetic specimens in this study 
No pilot studies were carried out with the samples to determine reliability of sample magnetisation and demagnetisation techniques as experience with these and similar sediments had been gained previously (McGuire, 1989; Roberts, 1986; Turner et al., 1989; Wright, 1986). These studies showed that the most efficient and reliable cleaning technique is thermal demagnetisation. Thermal demagnetisation allows several components of magnetisation to be identified and easy separation of these components.

The NRM of all samples in this study was routinely measured and the samples with the highest NRM (at least one from each core) routinely thermally demagnetised at $50^{\circ} \mathrm{C}$ intervals to $300^{\circ}$ C. $300^{\circ} \mathrm{C}$ was chosen as an upper limit because at temperatures slightly above this the clay component of the samples alters to produce a new magnetic mineral which interferes with magnetic measurement. The ovens used to thermally demagnetise the samples varied between institutions where measurements were made. At Victoria University demagnetisation was carried out in a zero field oven constructed by Mr. Eric Broughton of the Institute of Geophysics. The oven has two parts, a heating chamber and a fan assisted cooling chamber. Three mumetal shields cooled by circulating water surround the heating chamber and six mumetal shields surround the cooling chamber. A thermocouple sensed microprocessor controls the temperature. A $10^{\circ} \mathrm{C}$ gradient over the length of the oven requires that the thermocouple, which is in the centre, be set to $5^{\circ}$ higher than that required and then samples range $5^{\circ}$ either side of the desired temperature. Further characteristics of this oven were described by Roberts (1990).

At Gif-sur-Yvette the demagnetisation was carried out in a commercially available, French made oven. Both heating and fan assisted cooling was carried out in the same mumetal shielded chamber. Heating was controlled by three separate microprocessor temperature controllers, resulting in negligible thermal gradient along the length of the oven. The thermal demagnetisation at Oxford was carried out in an automated Magnetic Measurements Thermal Demagnetiser. Again both heating and fan assisted cooling are carried out in the same chamber. The chamber is shielded by 4 layers of mumetal and heating is controlled by thermocouple sensors reducing the gradient along its length to plus or minus $5^{\circ} \mathrm{C}$, similar to the VUW oven.

After each measurement on the cryogenic magnetometer the low frequency magnetic susceptibility of each specimen was measured using a Bartington Instruments M.S.1 magnetic susceptibility meter. This gave an estimate of ferro- and ferri- magnetic mineral concentrations. When a change was observed, it showed a change in the 
nature of the magnetic carriers in the sample. Usually this was due to thermal alteration of clay minerals to a magnetic carrier. At this point thermal demagnetisation was ceased. A change in magnetic susceptibility occurred in all specimens at between $300^{\circ} \mathrm{C}$ and $380^{\circ} \mathrm{C}$ of heating.

\subsubsection{Data Processing}

In all cases output from the cryogenic magnetometers was interactively processed and stored on IBM personal computers interfaced to each of the magnetometers. Palaeomagnetic directions were calculated from raw components of magnetisation measured by the magnetometer. This was done using orientation information from sample collection entered into the computer at the time of measurement by the operator. Information used in true palaeogeographical orientation apart from sample orientation also include a tilt correction for the bedding plane, as at the time of remanence acquisition the strata would have been horizontal. Data analysis was carried out either using programs on the VUW Silicon Graphics 4D/340S mainframe research computer or various Personal Computers. These computer programs generated, for each sample, plots of normalised magnetic intensity versus demagnetisation temperature; orthogonal vector component plots (Zijderveld 1967, 1975); and equal-area stereographic projections. These plots were routinely analysed both by hand and using additional computer programs (discussed later) to produce reconstructions of site palaeomagnetism.

In most other palaeomagnetic studies (eg; Roberts, 1990; McGuire, 1989), various statistical criteria are presented within which measured parameters are acceptable, and outside of which data are not included in the analysis. Here, all data are included in the study and accounted for accordingly. Cryogenic magnetometer measurements were routinely carried out both on the upright sample and the inverted sample. Where the agreement between these two measurements proved not reliable, the measurements were repeated to try to reduce the variation. Very rarely was it not possible to reduce the variation to an acceptable level. All measurements from the magnetometers are presented in appendix 5 and used in this section to interpret the palaeomagnetic behaviour of the South Wanganui Basin sediments.

\subsection{Palaeomagnetism}

\subsubsection{Introduction}

\section{Palaeomagnetic behaviour of New Zealand Cainozoic sediments}

Tertiary sediments of New Zealand typically have very low magnetic intensities. These are generally less than 10-2 $\mathrm{Am}^{-1}$ (Roberts, 1990) and are commonly accompanied by secondary components of magnetisation that are close or equal in strength. Because of 
this, early work in New Zealand using spinner magnetometers often had trouble identifying primary polarity, leading to uncertain correlations of strata (Lienert $e t$ al, 1972; Kennett et al., 1971; Kennett and Watkins, 1974).

More recently studies in New Zealand Tertiary sediments have been carried out comparing demagnetisation behavioural differences between alternating field and thermal demagnetisation results (Wright, 1986; Wrightand Vella, 1988; McGuire, 1989; Turner et al., 1989; Roberts, 1990). Wright et al. (1988) worked on Miocene sediments in Hawkes Bay, finding that thermal demagnetisation was effective in removing secondary components of both normal and reversely magnetised samples, with very few specimens in the study showing ambiguous primary directions. Alternating field measurement failed to remove the secondary components and made primary direction interpretation difficult.

A five fold increase in susceptibility at the $320^{\circ} \mathrm{C}$ heating step suggested thermal alteration of the samples occurred at this temperature. Wright (1986) used both isothermal remnant measurements and electron microprobe analysis to deduce that the only magnetic mineral in the samples he measured was titanomagnetite. In studies of Late Neogene strata from the Marlborough region, Turner et al. (1989) also found thermal demagnetisation to be more efficient and reliable in separating secondary and primary components of magnetisation. All of the samples studied, both reversed and normal, proved to have a major present field overprint.

Turner et al. (1989) also found growth of an anomalous magnetisation between $350^{\circ} \mathrm{C}$ and $380^{\circ} \mathrm{C}$. They do not discuss the magnetic minerals involved, but Roberts and Turner (submitted) from electron microprobe, thermomagnetic, isothermal remanence and X-ray fluorescence analyses concluded that magnetic remanence carrying minerals in sediments from the Awatere Valley were mainly greigite and pyrrhotite with a small component of titanomagnetite. Roberts and Turner (submitted) used Xray diffraction techniques to also identify ilmenite in sediments from Blind River. This he suggested was paramagnetic at room temperature and hence not contributing to the remanence of the sediments. McGuire (1989) working in the South Wanganui Basin and using similar techniques found sediments in the Turakina River to hold a very weak remanence and that thermal demagnetisation was more reliable in isolating remanence directions. McGuire also studied the different properties of the remanence and discovered a hard secondary remanence was created merely from drying of the sediments. He found trace amounts of haematite and titanomagnetite in the sediment but concluded from rock magnetic studies that the main holder of remanence was probably pyrrhotite. 
The most reliable method of identifying primary remanence is using orthogonal vector component plots of thermal demagnetisation data. However, when multi-component remanence is being analysed and a clear picture is not seen before thermal alteration of the sediments prevents any more data retrieval this method alone is not conclusive. Various further analytical techniques to aid in finding a solution in these instances are discussed later in this chapter. Typical behaviour of New Zealand Tertiary sediments during thermal demagnetisation include;

A) Moderately intense, stable magnetisations that are directed to the origin of vector component plots (Roberts, 1990; Roberts and Turner, submitted; Wright, 1986; Wright and Vella, 1988; Turner et al., 1989);

B) Moderately intense, stable magnetisations that are linear in behaviour but not directed towards the origin of vector component plots (Wright, 1986; Wright and Vella, 1988);

C) Magnetisations strongly overprinted by a present day field, but which cleans to the origin of a vector component plot with moderate temperatures of thermal demagnetisation (Turner et al., 1989; McGuire, 1989);

D) Magnetisations, altered to such an extent that a stable direction is not reached before thermal alteration occurs
(Roberts, 1990; Roberts and Turner, submitted; McGuire, 1989);

E) Unstable magnetisation that prevents retrieval of a useful palaeomagnetic signal (Roberts, 1990; Roberts and Turner, submitted; Wright, 1986; Wright and Vella, 1988; Turner et al., 1989; McGuire, 1989).

All sample types include a weak viscous overprint that is easily remove in the first few steps of heating.

\section{Palaeomagnetic analysis techniques}

In order to identify primary remanence directions in such samples two main interpretative methods of analysing orthogonal data have been discussed in the international literature;

1) Principal component analysis. This approach turns away from using a specifically identified level of demagnetisation to clean all samples at and requires stepwise demagnetisation of all samples. The analysis is then carried out on the orthogonal vector diagram. A line of best fit can be chosen using three criteria; 1) forcing the line to pass through the origin; 2 ) treating the origin as a separate datum point; and 3 ) not using the origin at all. The assumption being applied in the use of the origin is that as higher levels of cleaning are being undertaken the sample must eventually lose all its intensity and equal zero (ie. reach the origin along a vectorial trajectory). The 2 nd method using the 
origin as a separate datum point is the least valid, as according to the assumption the vector must clean to the origin. Forcing the vector through the origin is only valid if the vector you identify is the final component of highest temperature. The final method of free line fit (Butler, 1992) is the most valid. It identifies linear trends in orthogonal plots and allows the identification of several components of magnetisation. This includes a final component that passes through the origin, only if the cleaning steps allow identification of this component before complete loss of intensity of signal or thermal alteration of the sample occurs.

Various methods of statistical analysis are available to asses the scatter of points and the validity of line fits (Dunlop, 1979; Hoffman and Day, 1978; Kirschvink, 1980). The method used in this study is one developed by Torsvik (1986). Once primary directions have been established for several samples from a single site, the most common method of analysing the distribution of directions is by using fisher statistics of dispersion on a sphere of the pole directions (Fisher, 1953; Fisher, 1986; Fisher and Lewis, 1983). Average values are reported with a $95 \%$ confidence interval. This technique is useful when the analysed sample contains multiple magnetic components that do not overlap in their blocking temperature spectrum. In this case the resulting orthogonal vector plot will include straight line components only. If the components overlap in blocking temperature spectra very slightly only this technique can still be used. However if they overlap to a large degree the resulting orthogonal vector plot will be curved and prevent component analysis (figure 16.2).

2) Remagnetisation great circle analysis: There are two specific types of behaviour when this becomes a useful technique; 1) When the thermal demagnetisation does not allow identification in individual samples before thermal alteration or loss of intensity, and 2) When multiple components exist with overlapping blocking temperature spectra. Analysis of an orthogonal vector plot will allow separation of non overlapping and partially overlapping blocking spectra components only. The basic theory, first presented by Hoffman and Day (1978) is that if a sample contains more than one remanence, as one is preferentially cleaned the vector difference pole will trace a great circle arc until only one component remains. At this time the pole will remain stationary on a stereographic plot (figure 16.3). If two or more samples with differing overprints of the primary remanence are analysed the point at which the pole of each sample becomes stationary on a stereographic projection should be the same for all samples. If this point is not reached for any of the samples, it can be approximated by the intersection point of the great circles from each sample, as it will be the point that each of the poles tracing the great circles will be heading towards (figure 16.3). 

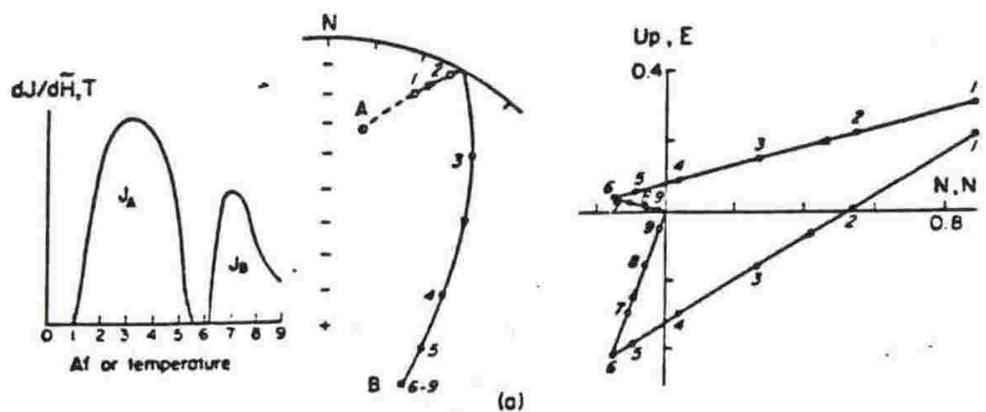

(a)
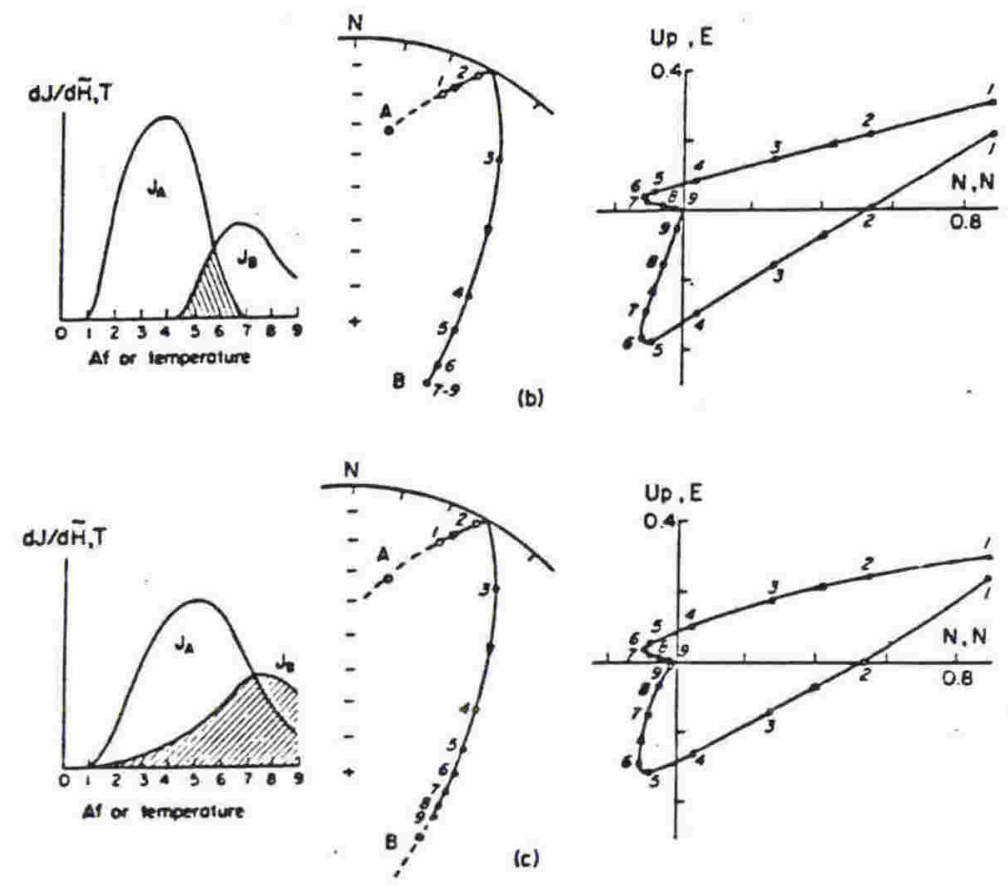

Figure 16.2: Component coercivity or blocking temperature spectra and resulting stereo and vector component plots for a) non-overlapping spectra, b) partial overlap, and c) total overlap. In both a) and b) individual magnetic vectors can be identified and in c) neither can be determined (after Dunlop, 1979).

Schmidt (1985) points out that unless solutions are obtained from anti-parallel circle convergences for two specimens in an analysis the solution may be illconditioned (figure 16.3). For this reason it is necessary to use at least three great circles to estimate a stable endpoint direction. McFadden and McElhinny (1988) pointed out that remagnetisation great circle analysis is only valid when combined with information from direct observation of orthogonal vector plots to assess the validity of circle analysis. In this way it may be possible to use the technique to assess several components of magnetisation and identify a combination of arcs for individual samples. For situations where the final high temperature component is not observed on the orthogonal vector plot it 
might be that this is not identified by remagnetisation great circle analysis. It also might be that the final or highest temperature component is not the primary remanence direction (for example secondary chemical remanence's may have higher blocking temperatures than the a primary detrital remanence).

Assuming 3 samples will behave the same in terms of blocking temperatures, a site analysis may, by picking of the different arcs, be able to define end points for different components of the magnetic signal of the sediments. This cannot be done without concurrent observation of orthogonal vector plots and assessment of the temperature at which components change. This is particularly valuable in analysis of New Zealand Tertiary sediments as other workers (McGuire, 1989; and Turner and Kamp, 1990) have identified a high temperature component thought to be a postdepositional chemical remanence that has grown at stable single domain size a

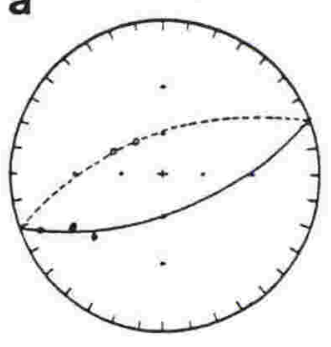

C

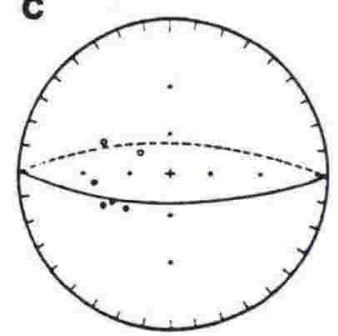

e

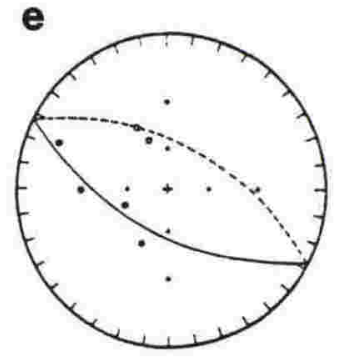

b

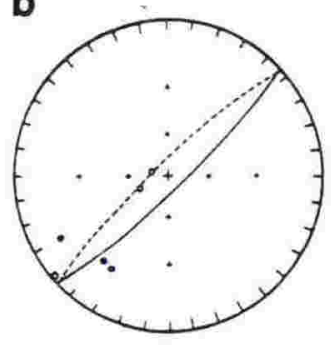

d

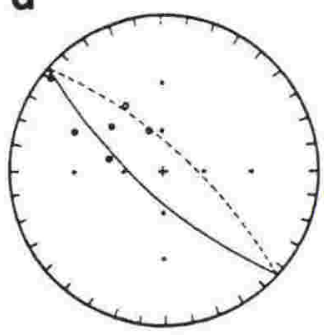

f

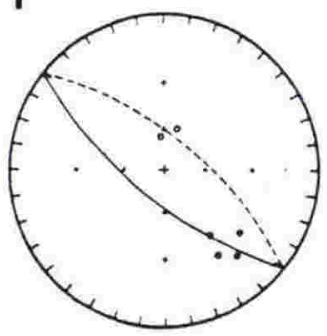

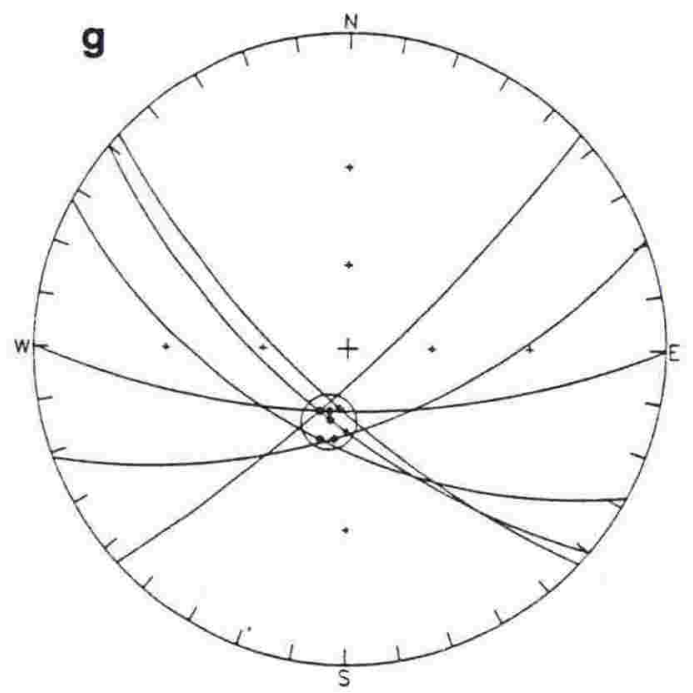

Figure 16.3: Example of remagnetisation great circle analysis: a) through f) are individual specimen measurements, $b$ ) is a convergence plot of the individual specimens. The solution is considered ill-conditioned if the circles do not converge within a confined zone (from Roberts, 1990). 


\subsubsection{Palaeomagnetic behaviour of South Wanganui Basin Sediments.}

Twelve types of palaeomagnetic behaviour have been identified from the present study. All 12 types are described below with orthogonal and stereo plots illustrating the behaviour. Interpretive techniques best suited to the sample behaviour are also explained;

\section{A) (5\% of specimens) Moderately} intense, stable magnetisations that are directed to the origin of vector component plots. The signal to noise ratio is low and components are straight or nearly straight lines tending to the origin (figure 16.4). Secondary components can exist (figure 16.4c) but these are generally soft and removed at low demagnetisation temperatures. Primary remanence directions can be identified by angle measurement of straight line directions on the orthogonal vector plots.

\section{B1) (23\% of specimens) Moderately} intense, stable magnetisations that are essentially linear in behaviour but not directed towards the origin of vector component plots. The signal to noise ratio is low and the two components are directed to a common origin (figure 16.5). Another high temperature component must exist preventing the vector components from being directed towards the origin. In this study it has not been possible to isolate this component due to thermal alteration of the specimens during demagnetisation. At the lower end of the blocking spectrum soft secondary components are also common, but again these are removed at low demagnetisation temperatures. The primary component is taken as the most persistent and stable component in the middle of the blocking temperature range (figure 16.5d). Primary remanence directions can be identified by angle measurement of straight line directions on the orthogonal vector plots. New origins are approximated by the intersection of the projection of the two components and measurement is with respect to a redefined grid about this origin (figure $16.5 \mathrm{c}$ ).

\section{$\mathrm{B}_{1}{ }^{\prime}$ ) (6\% of specimens) Behaviour as} described for $\mathrm{B}_{1}{ }^{\prime}$ type specimens. Primary stable components in the middle of the blocking temperature range are not directed towards a common origin due to an unidentified high temperature component having subequal intensity (figure 16.6). If the stable middle blocking spectrum direction persists to $300^{\circ} \mathrm{C}$ it is taken as the primary component and identified by angular measurement of the quasi straight line direction with respect to the intersection point origin of the vector components on the orthogonal vector plots. If overlapping blocking spectra components exist a straight line will not be identified on the orthogonal vector plot (figure $16.6 \mathrm{~b})$ and the higher temperature, true primary component must be identified by remagnetisation great circle analysis. 

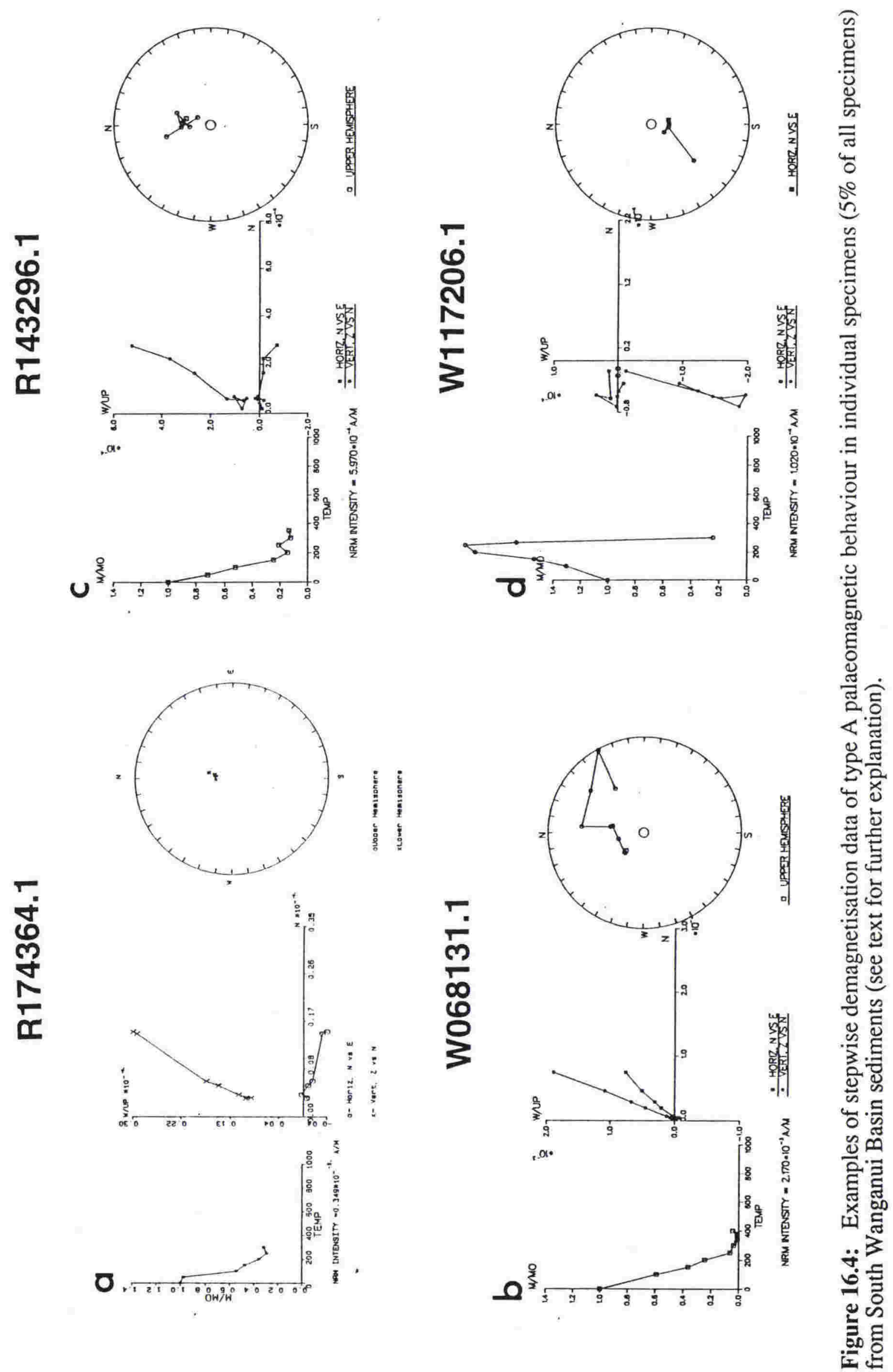

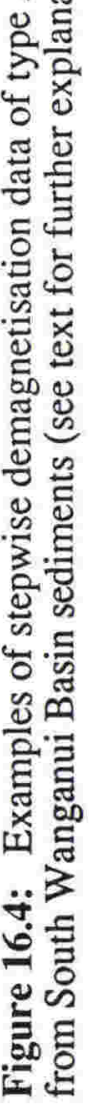




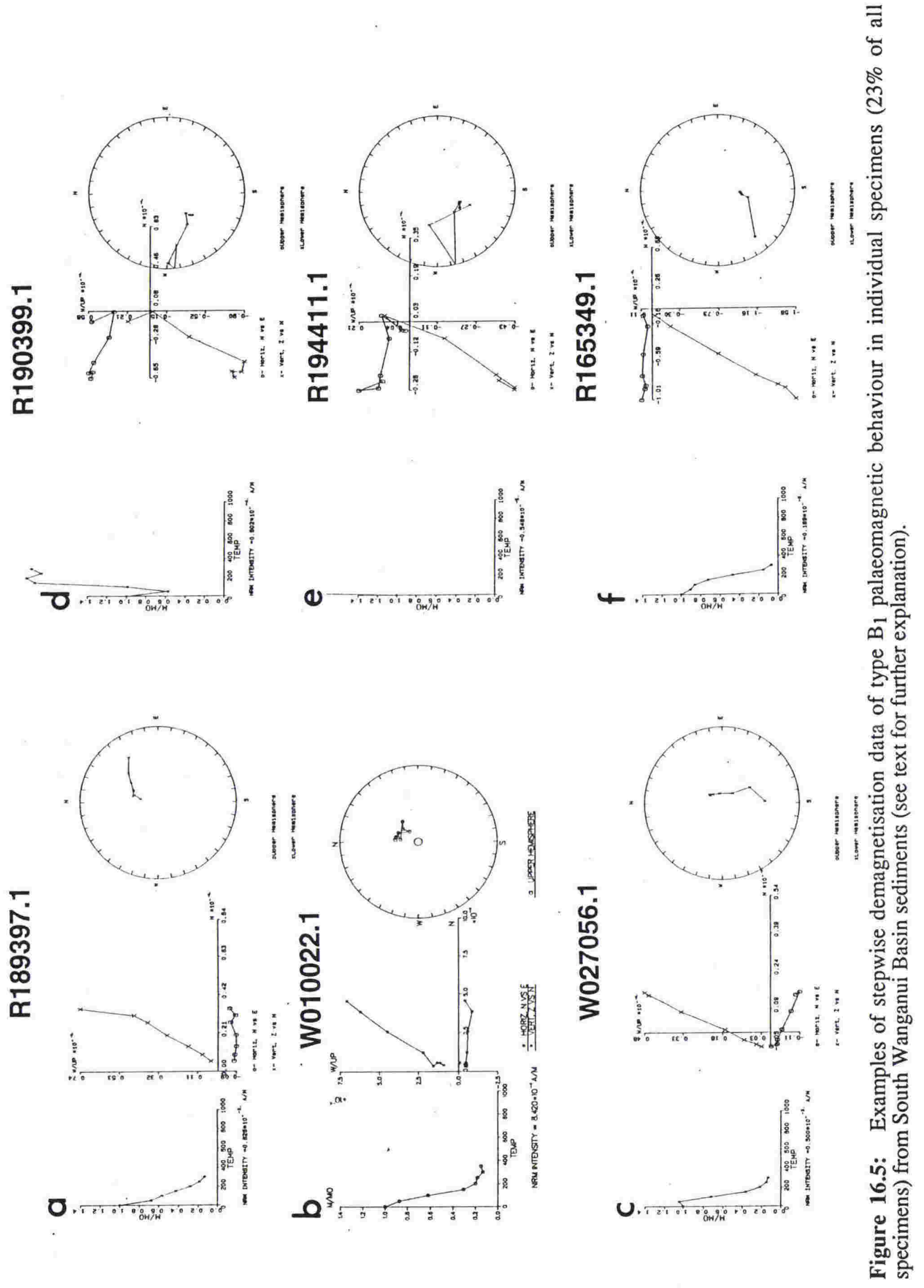



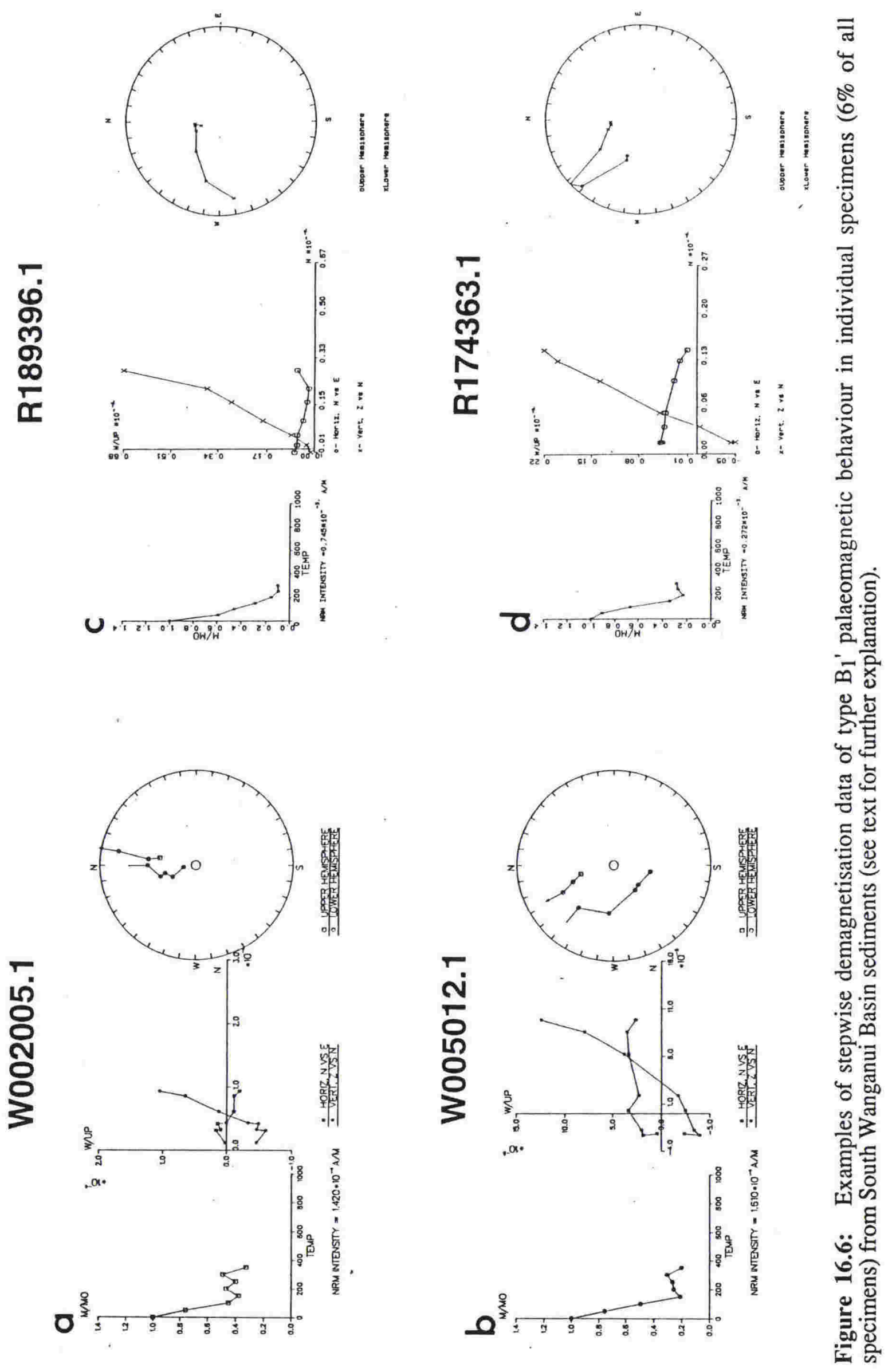
B $_{1 ")}$ ( $6 \%$ of specimens) Behaviour as described for $B_{1}$ type specimens (or rarely type A specimens), but the primary direction identified by the orthogonal vector plot is of an intermediate nature due to equal and overlapping blocking temperature spectra, or intermediate field (figure 16.7). Analysis of several specimens from the same site will distinguish the origin of this behaviour allowing remagnetisation great circle analysis, or, if applicable, identification of directions from angle measurement of straight line components on the orthogonal vector plots, if necessary with respect to a redefined origin.

B $_{2}$ ) (20\% of specimens) Like type $\mathrm{B}_{1}$, these specimens are moderately intense, stable magnetisations that are essentially linear in behaviour. They do not tend towards the origin, but reach a stable endpoint in the middle of the blocking temperature range (figure 16.8). Generally this endpoint represents the quasi origin that type $\mathrm{B}_{1}$ specimens tend towards. This is not always the case. In a few specimens very erratic behaviour is observed once the stable endpoint is passed (figure 16.8d). Like type $B_{1}$ specimens the primary remanence is taken as the most persistent and stable component in the middle of the blocking temperature range (figure 16.8a). Primary remanence directions can be identified by angle measurement of straight line directions on the orthogonal vector plots, with respect to the redefined origin. High temperature components are not isolated and are thought to be secondary in origin.

$\left.\mathbf{B}_{2}{ }^{\prime}\right)$ (2\% of specimens) Behaviour like type $B_{2}$ specimens, but where the straight line components do not tend towards an origin and reach a stable endpoint towards the end of the middle blocking temperature range that is controlled by a weak higher temperature component (figure 16.9). The primary remanence is again taken as the most persistent and stable component in the middle of the blocking temperature range and can be identified by angle measurement of the straight line component on the orthogonal vector plots, with respect to a new origin defined by the intersection of the two component vectors.

C) (3\% of specimens) Magnetisations strongly overprinted by a present day field, but which clean to the origin or quasi origin of a vector component plot with moderate temperatures of thermal demagnetisation. This is only visible with normally overprinted reversed magnetised specimens (figure 16.10). Weak high temperature components may prevent cleaning to the origin of the vector component plot. Secondary low end blocking temperature components may also exist, but are cleaned by low heating steps. Two quasi stable directions are identified in the middle of the blocking temperature spectrum, commonly with slightly overlapping blocking spectra. The primary remanence of the specimen is represented by the higher temperature component of the 


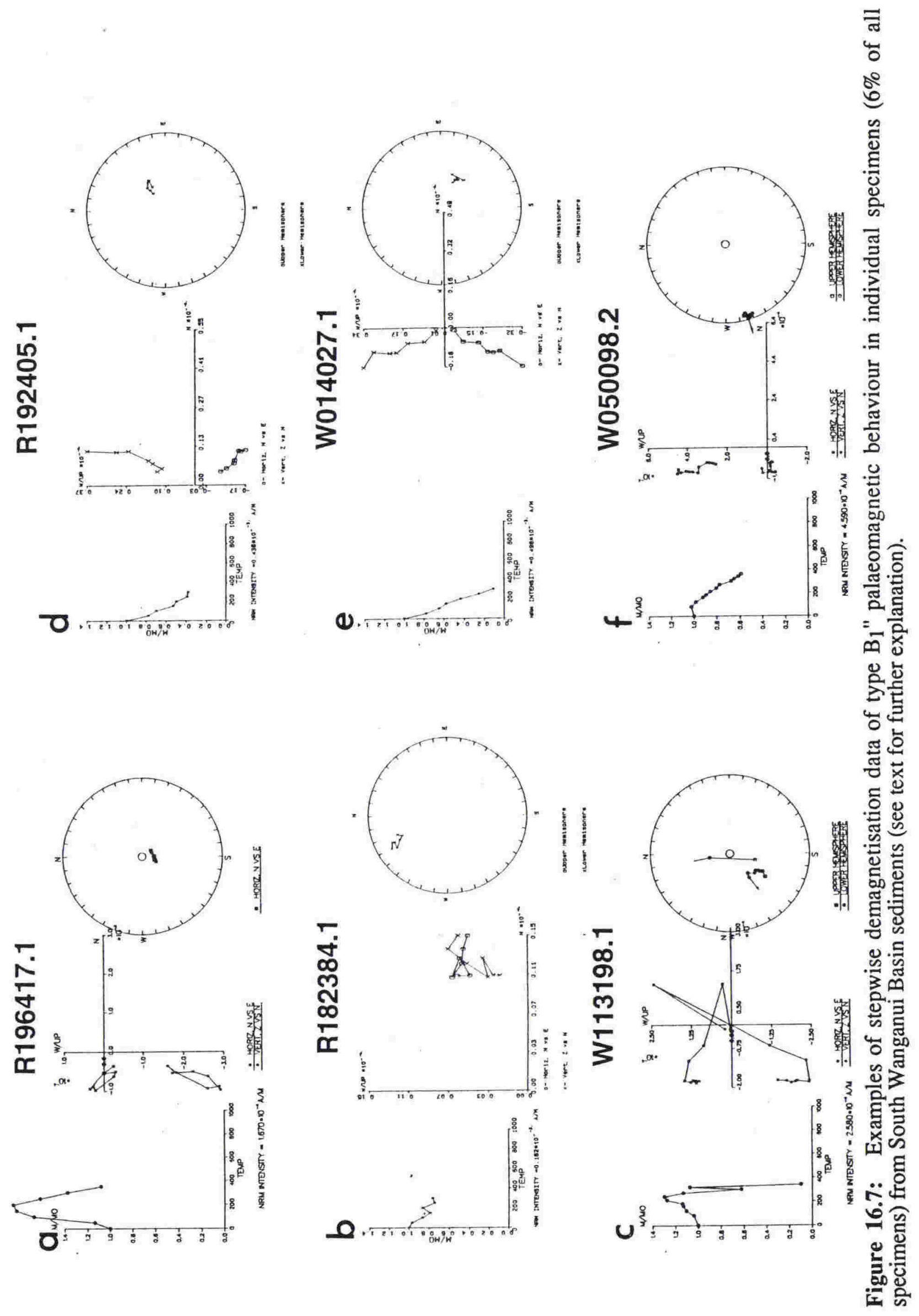




\section{W073140.1}

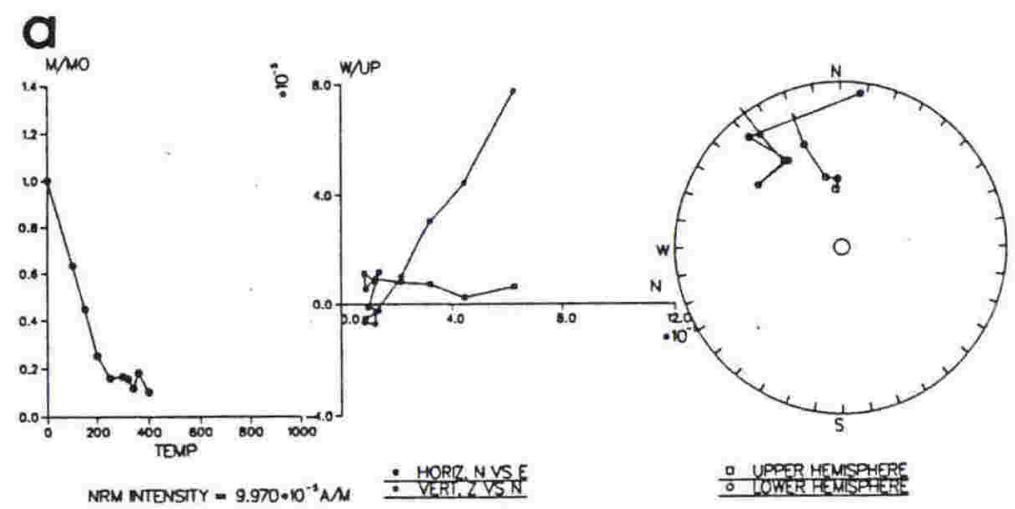

W079144.1

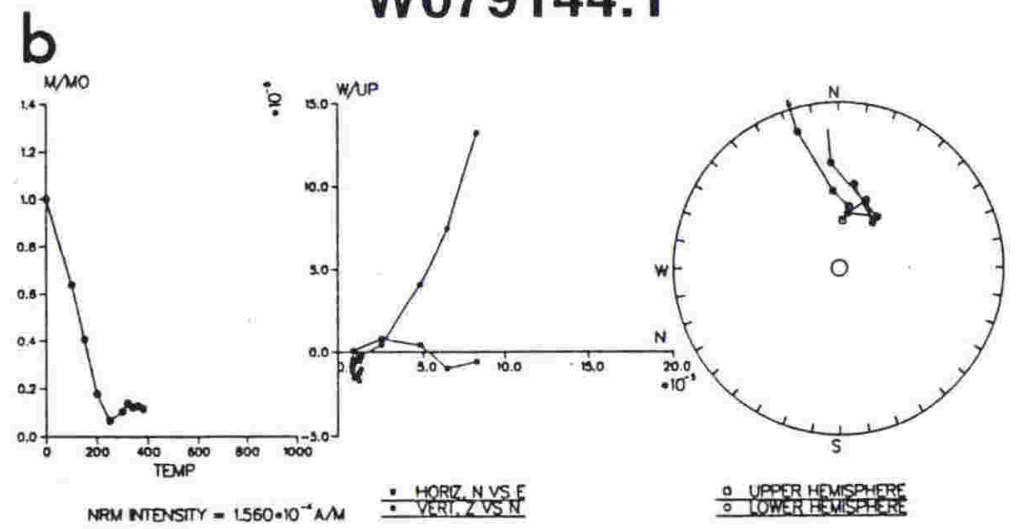

Figure 16.9: Examples of stepwise demagnetisation data of type $\mathrm{B}_{2}{ }^{\prime}$ palaeomagnetic behaviour in individual specimens ( $2 \%$ of all specimens) from South Wanganui Basin sediments (see text for further explanation).

two. It's direction can be identified from angle measurement it's straight line components on the orthogonal vector plots, if necessary with respect to a redefined origin (figure $16.10 \mathrm{~b}$ ).

D) (32\% of specimens) Magnetisations, remagnetised to such an extent that a stable primary direction is not identified before thermal alteration of the specimen occurs. It is possible to fit well constrained remagnetisation great circles to demagnetisation data from these specimens and hence identify a stable primary remanence from three or more specimens from the same site. When no stable endpoints are available for individual specimens from a site the solution may be illconditioned where converging great circles are not anti- 


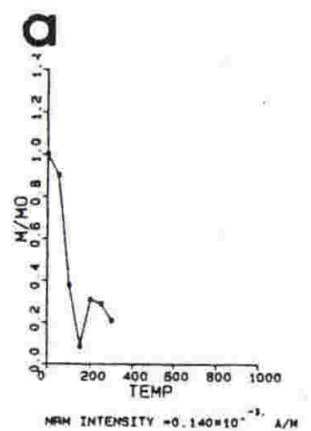

W015030.1
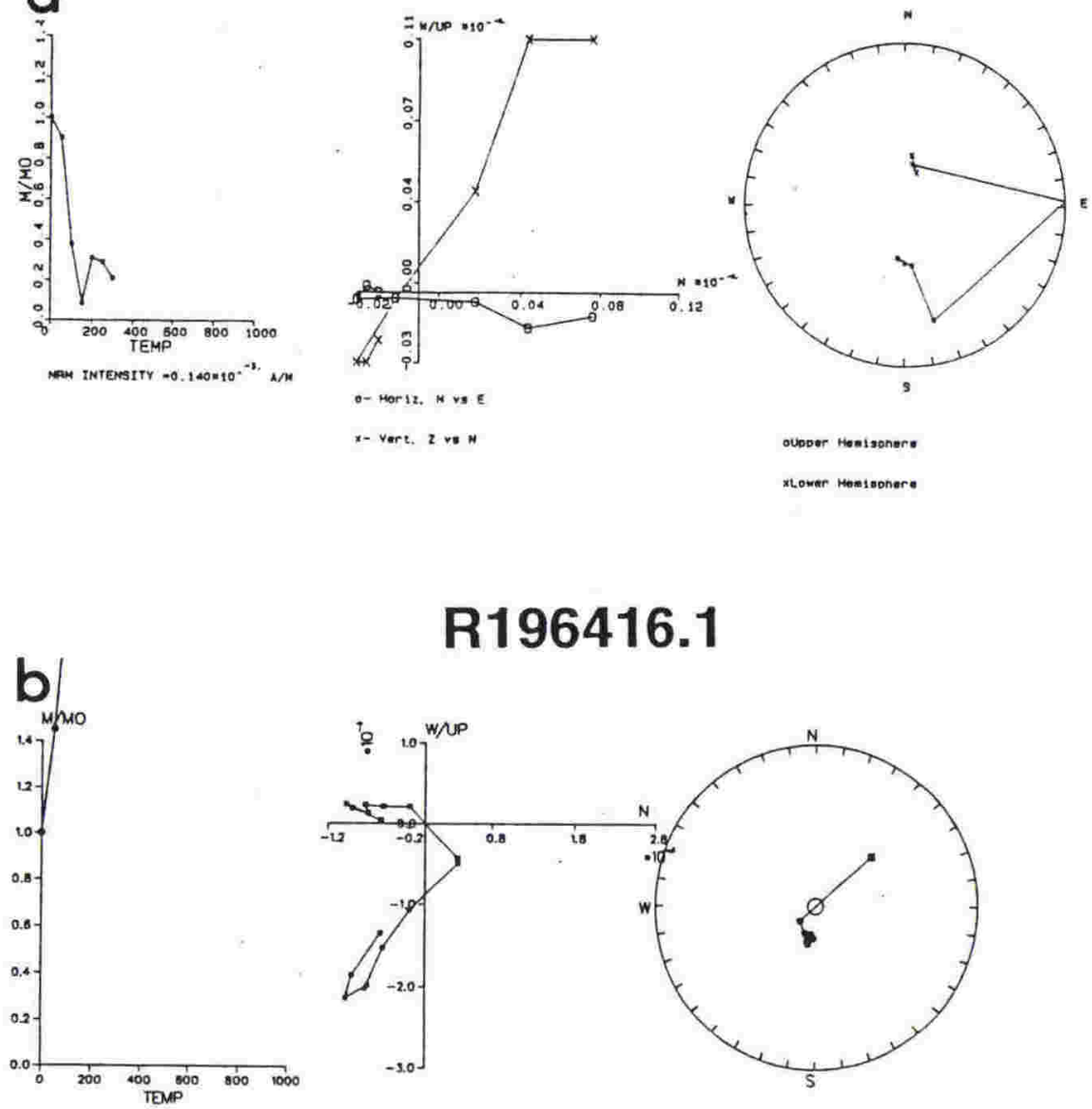

R196416.1

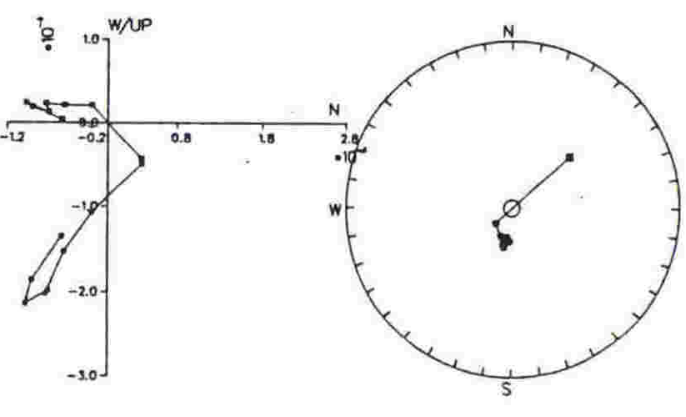

NRM NTENSTY $=7.650 \cdot 10^{-1} \mathrm{AMM}$

$\div$ HORR.NUSE

- horz.nvSE

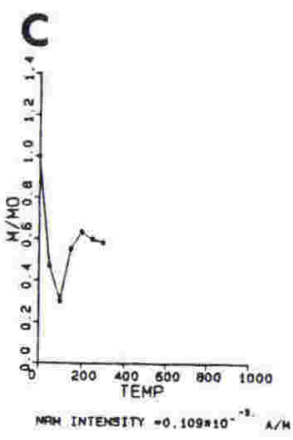

R151315.1

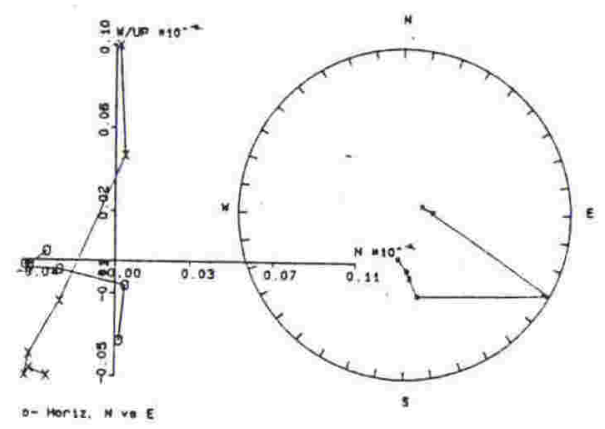

$x-$ vert, $z$ ve $N$

Oubooer Mas isonere

xhower Heas sonero

Figure 16.10: Examples of stepwise demagnetisation data of type $C$ palaeomagnetic behaviour in individual specimens (3\% of all specimens) from South Wanganui Basin sediments (see text for further explanation). 
parallel. Four different types of behaviour are recognised in this category and represent differing reliability's in identifying a primary remanence direction;

D 1 ) (5\% of Specimens) In this type of behaviour considerable overlap in blocking temperature spectra exist for the middle temperature range components of magnetisation. No straight line components are depicted on the orthogonal vector plots and it is not possible to identify a primary component of magnetisation (figure 16.11). Soft secondary components at the lower end of the blocking temperature spectrum are easily cleaned, but primary remanence is still not identified. Occasionally there can be more than two components of magnetisation in the middle of the blocking temperature spectrum, for example in figure $16.11 \mathrm{~d}$ where four components exist in two adjoining sets of overlapping blocking temperature spectra. Primary remanence can be identified only by remagnetisation great circle analysis of the highest middle temperature blocking spectrum component of several specimens from the same site.

$\mathbf{D}_{2}$ ) (9\% of Specimens) This type of behaviour is exactly the same as type $D_{1}$ except that the signal to noise ratio is lower and identification of primary remanence is more difficult than in type $D_{1}$ specimens (figure 16.12). Remagnetisation great circle analysis can still easily define a primary normal or reversed direction of several specimens from the same site. Several components of magnetisation can co-exist in the middle range of the blocking temperature spectrum and well defined great circle progression can still be observed in a stereographic plot, as long as secondary components progressively overlap in their blocking temperature (figure 16.12f). This can provide excellent great circle remagnetisation results using several specimens from the same site.

D3) (12\% of Specimens) High noise to signal ratio examples of $\mathrm{D}_{2}$ type behaviour (figure 16.13). Samples also have lower magnetisation intensity. Orthogonal vector plots still suggest multiple components in the middle range blocking temperature spectrum and with some editing of the noise remagnetisation great circle analysis can produce reasonable to good solutions using several specimens from the same site.

D4) (2\% of Specimens) Very high noise to signal ration examples of $\mathrm{D}_{2}$ type behaviour with very low intensities (figure 16.14). The noise level prevents orthogonal vector plots from defining any trends in magnetisation. Stereo plots can allow reasonable great circle fits to edited demagnetisation data, allowing poor to reasonable solutions from remagnetisation great circle analysis of many specimens from one site.

E) (3\% of specimens) Unstable magnetisation that prevents retrieval of a useful palaomagnetic signal (figure 16.15). 


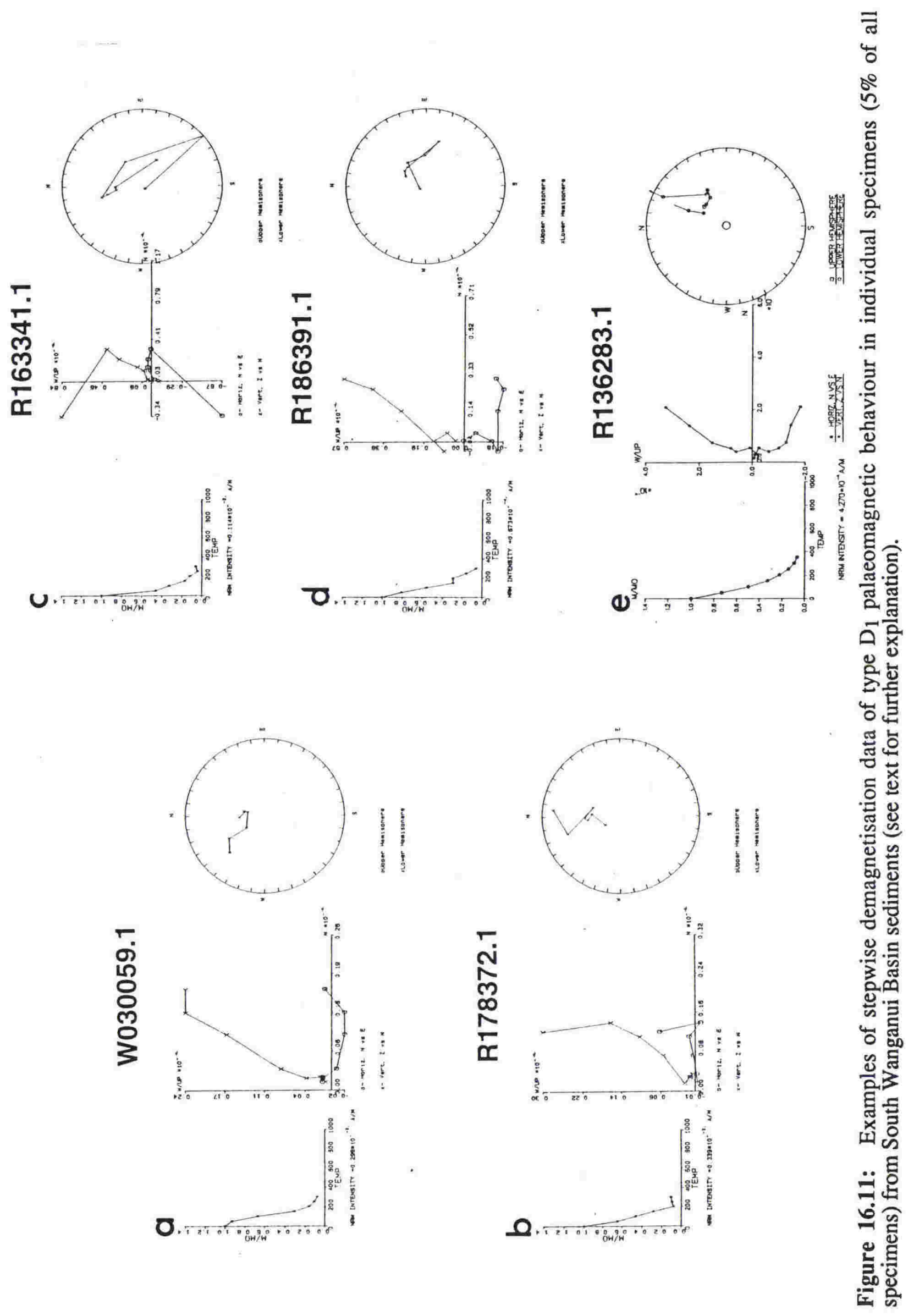




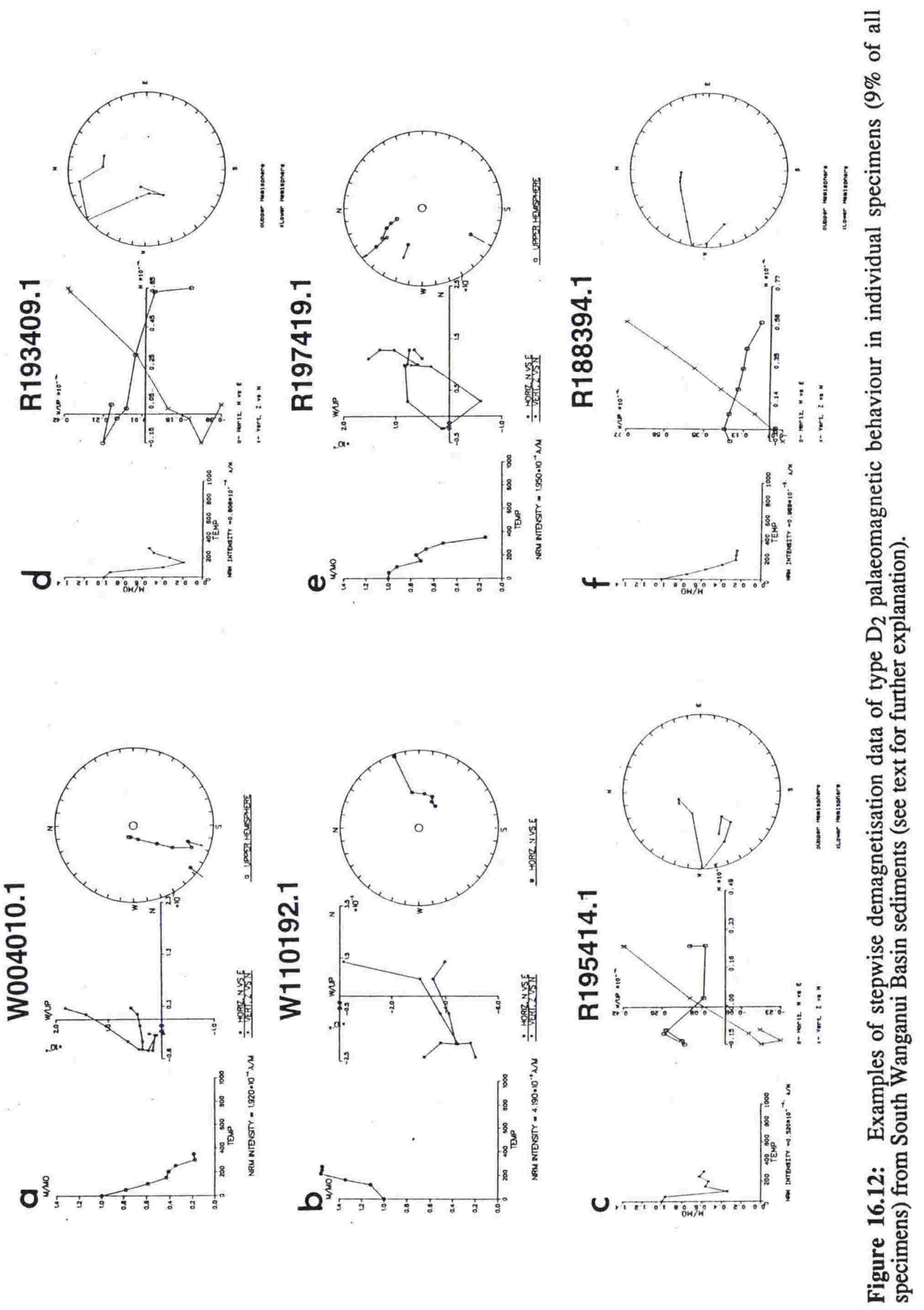



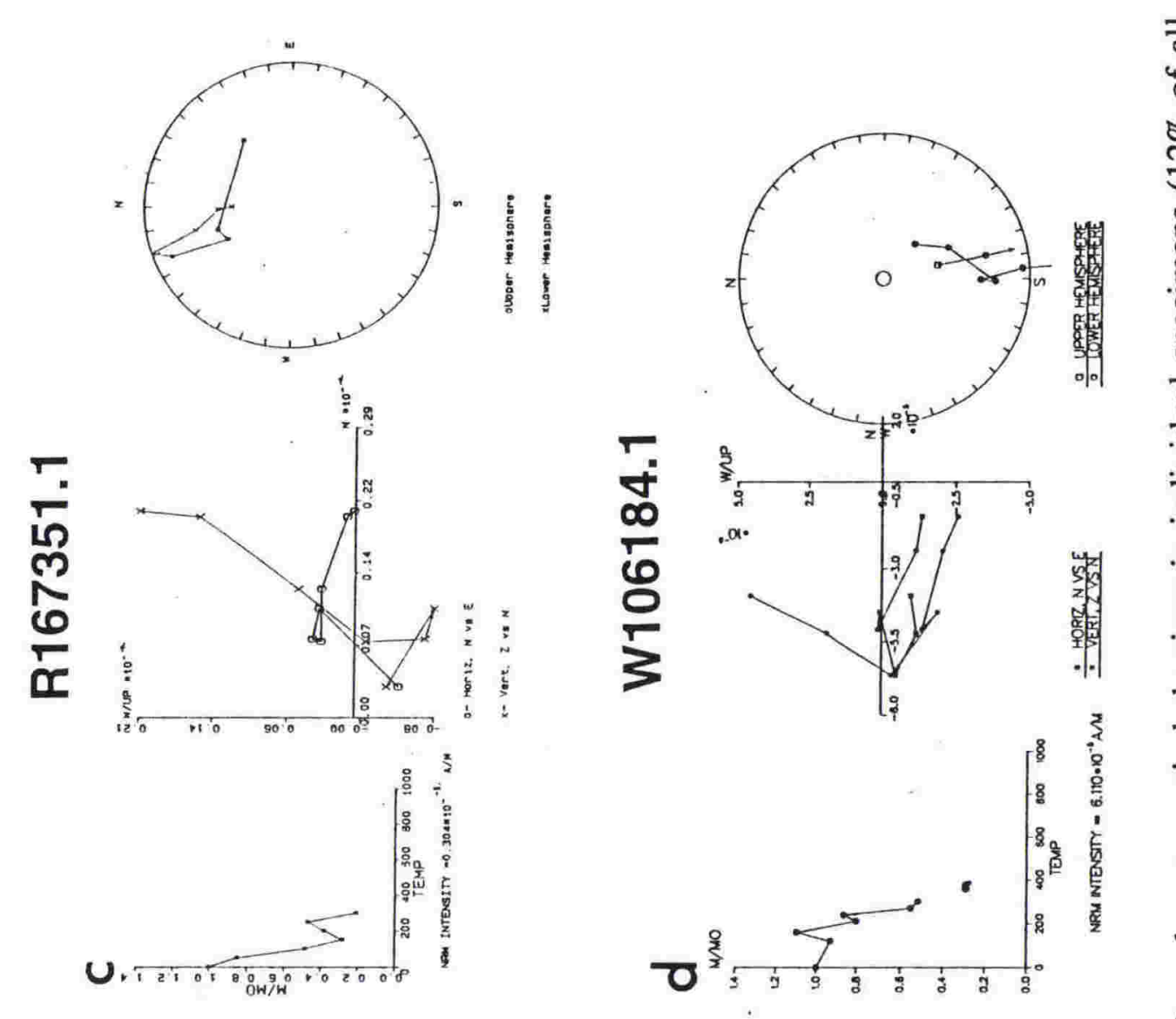

ส

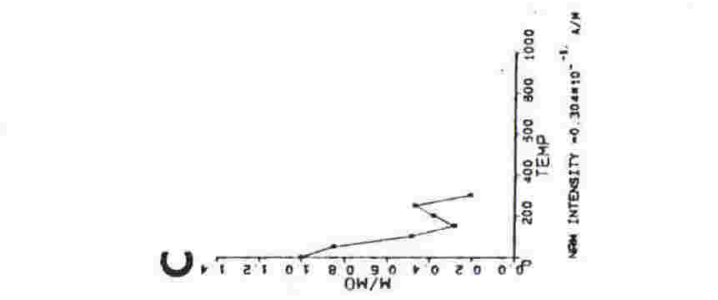

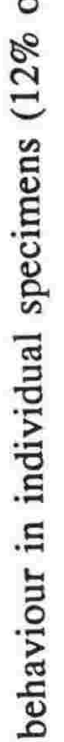

总

ติ

․․

䜦
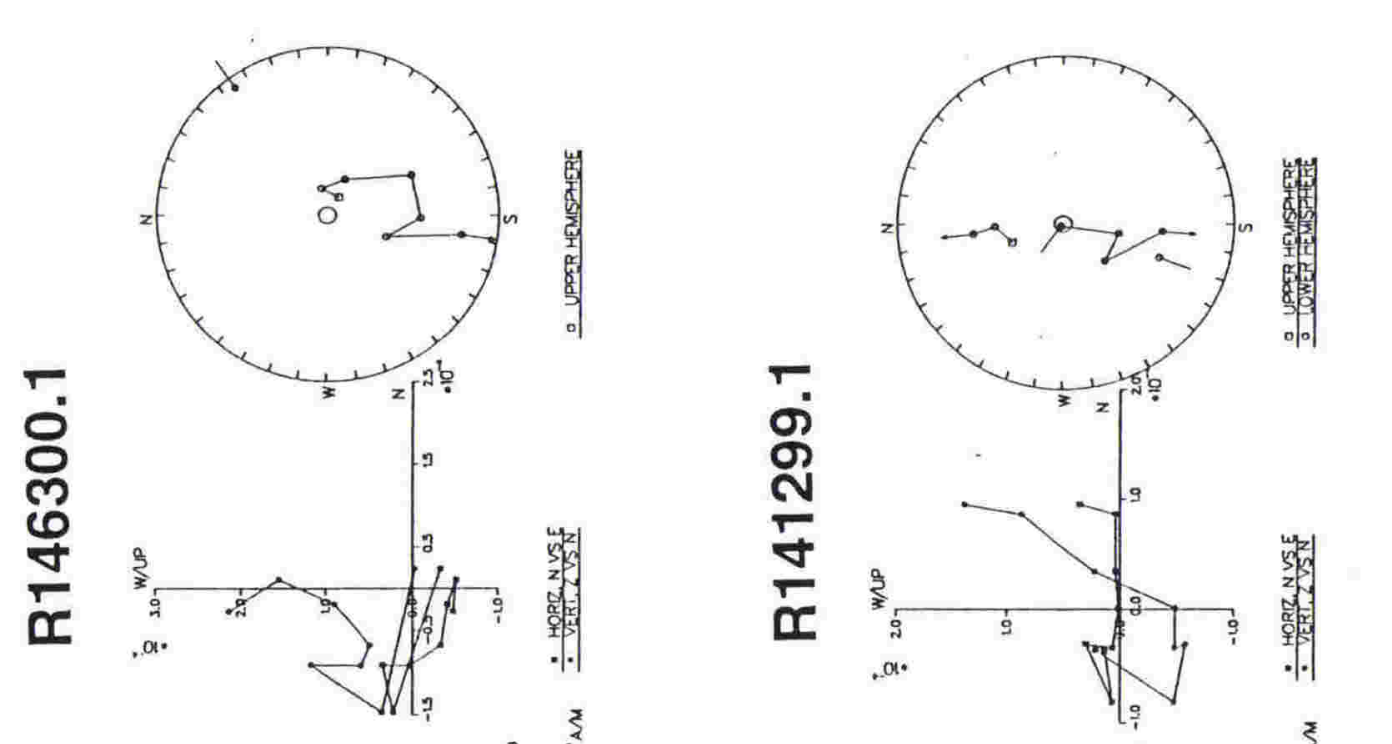

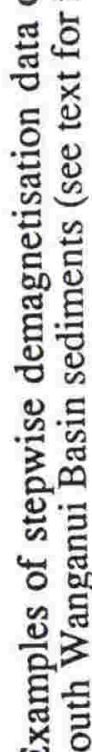
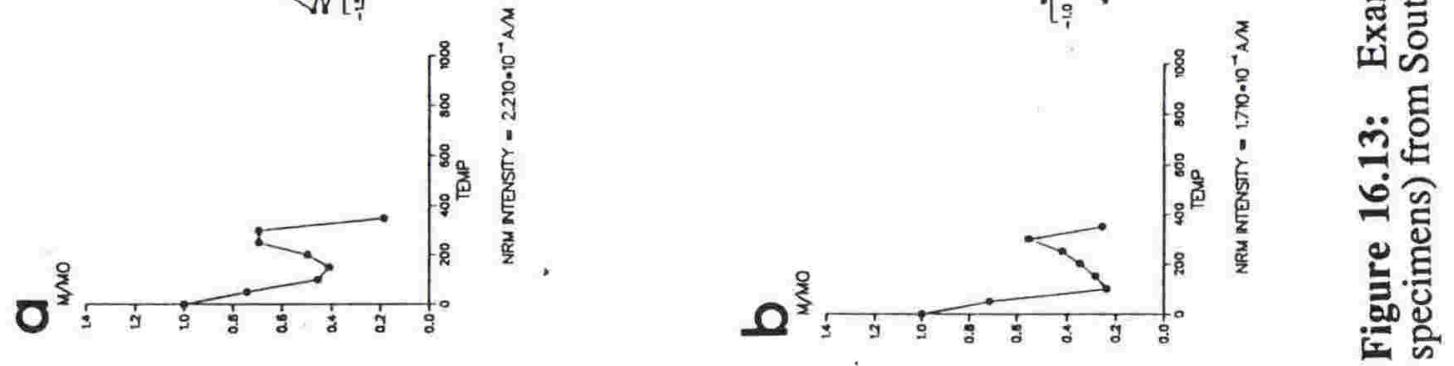


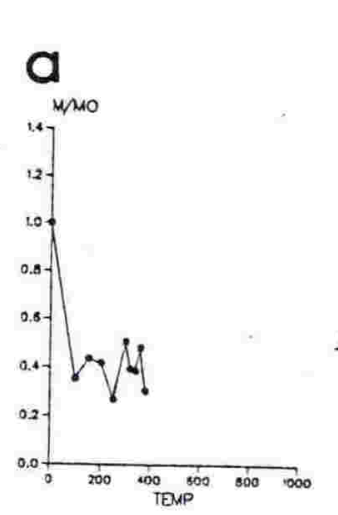

\section{W084154.1}

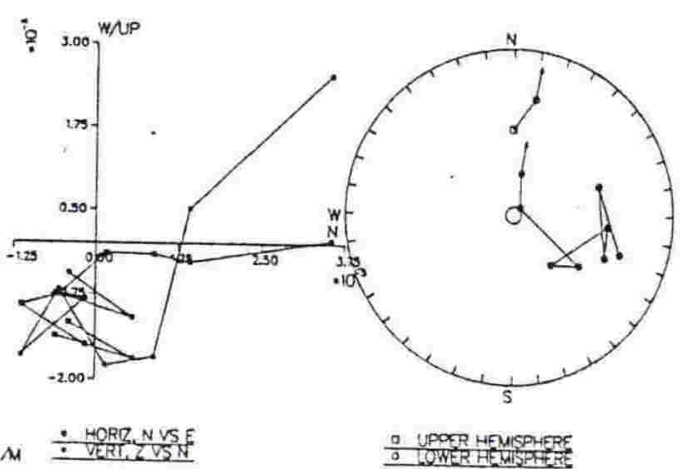

\section{W097171.1}

b

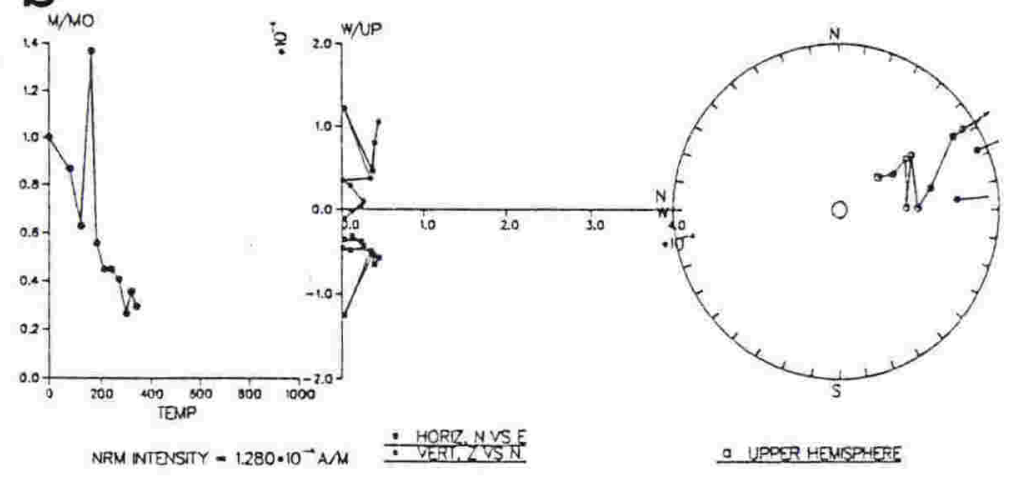

Figure 16.14: Examples of stepwise demagnetisation data of type $\mathrm{D}_{4}$ palaeomagnetic behaviour in individual specimens (2\% of all specimens) from South Wanganui Basin sediments (see text for further explanation).

Specimens of this type are typically very weakly magnetised. Such behaviour could be due to the presence of unstable magnetic phases or from several components of magnetisation all with overlapping blocking temperature spectra. This type of behaviour when it occurs is restricted to only one specimen per site and other specimens allow identification of a primary remanence direction for the particular site.

16.3.3 Palaeomagnetism of the Wanganui River Section.

Lithostratigraphy of the Wanganui River section is presented in section 3 , chapter 11. In the $4,300 \mathrm{~m}$ of strata, over 215 cores were collected from 67 sites 


\section{R148309.1}

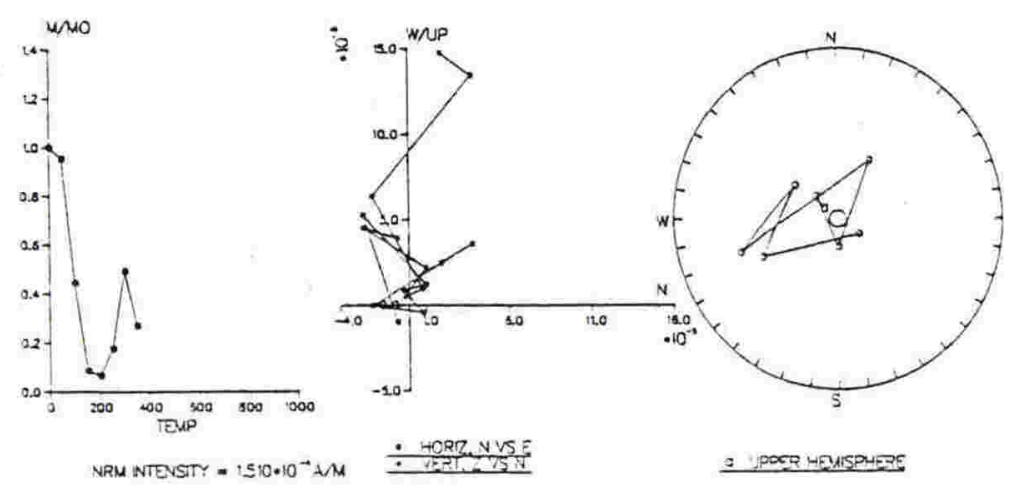

Figure 16.15: Example of stepwise demagnetisation data of type E palaeomagnetic behaviour in individual specimens (3\% of all specimens) from South Wanganui Basin sediments (see text for further explanation).

throughout the section. Enclosure 1 shows all sampling sites for the Wanganui River Section. At least 1 specimen was analysed from each of these cores by full stepwise thermal demagnetisation. Each individual measurement can be found in Appendix 5 .

In terms of palaeomagnetic behaviour the section can be divided in two halves of equal thickness. NRM intensities versus stratigraphic height for each measured specimen are plotted in figure 16.16. NRM intensities are higher for the lower $2150 \mathrm{~m}$ than the upper $2150 \mathrm{~m}$. This is related to the finer mean grain-size of the strata in the lower half of the section. The palaeomagnetic behaviour of the lower portion of the section is good, with fewer remagnetisation great circle analyses necessary than in the upper portion, where palaeomagnetic behaviour was less ideal. Despite poorer behaviour in the upper portion polarity solutions could be calculated for all but 1 of the 67 sites.

Site analyses and polarities are presented in table 16.1. Typical sample behaviour types are a combination of types $\mathrm{B}$ and D. In total there were 35 normal polarity sites, 32 reversed polarity sites and 1 site where it was not possible to determine polarity (figure 16.17). Polarity is clearly defined with inclination and declination components of magnetic directions in clear agreement.

The $95 \%$ confidence interval for site analyses was generally low, with the 


\begin{tabular}{|c|c|c|c|c|c|c|c|c|}
\hline Site Number & Declination & Inclination & Alpha-95 & $N$ & G.C. S & S.P. & Comment & Polarity \\
\hline W001 & 339.1 & -63.5 & 12.3 & 5. & - & 5 & Noisy data, O.K. solution & $\mathrm{N}$ \\
\hline W002 & 020.9 & -62.6 & 5.6 & 3. & - & 3 & Noisy data, reasonable solution & $N$ \\
\hline W004 & 183.9 & 52.6 & 2.4 & 3. & - & - & Poorly conditioned solution & $\mathrm{R}$ \\
\hline W005 & 192.4 & 60.0 & 5.8 & 3 & 3 . & - & Good solution & R \\
\hline W007 & 344.8 & -54.8 & 7.8 & 3. & - & 3 & Good solution & $N$ \\
\hline W009 & 357.1 & -56.2 & 1.7 & 5. & - & 5 & Excellent solution & $\mathrm{N}$ \\
\hline W010 & 355.2 & -56.1 & 6.6 & 5. & - & 5 & Excellent solution & $\mathrm{N}$ \\
\hline W014 & 205.7 & 62.0 & 4.7 & 3 & 3. & - & III-conditioned solution, poss. trans. & A \\
\hline W015 & 182.5 & 56.3 & 8.8 & 3. & - & 3 & Excellent solution & $\mathrm{A}$ \\
\hline W018 & 205.1 & 54.5 & 2.3 & 4. & - & 4 & Good solution & R \\
\hline W019 & 175.6 & 62.0 & 8.4 & 5 & 5 . & - & Reasonable solution & $\mathrm{A}$ \\
\hline W020 & 177.7 & 46.8 & 13.1 & 3 & 3- & - & III-conditioned solution & A \\
\hline W021 & 176.2 & 63.0 & 4.2 & 3 & 3. & - & III-conditioned solution & R \\
\hline W022 & 013.1 & -65.8 & 13.4 & 3. & - & 3 & Good solution & $\mathrm{N}$ \\
\hline W023 & 004.3 & -52.6 & 6.4 & 3 . & - & 3 & Excellent solution & $\mathrm{N}$ \\
\hline W026 & 202.8 & 68.4 & 2.7 & 4. & 4. & - & Good solution & A \\
\hline W027 & 017.4 & -64.6 & 3.2 & 3. & - & 3 & Good solution & $\mathrm{N}$ \\
\hline W030 & 005.0 & -63.8 & 6.2 & 3 . & - & 3 & Excellent solution & $N$ \\
\hline W031 & 017.3 & -66.7 & 7.2 & 3. & - & 3 & Good solution & $\mathrm{N}$ \\
\hline W032 & 351.2 & -60.1 & 3.6 & 4. & - & 4 & Excellent solution & $N$ \\
\hline W034 & 014.4 & -53.1 & 9.1 & 3. & - & 3 & Reasonable solution & $\mathrm{N}$ \\
\hline W036 & 013.6 & -63.6 & 14.2 & 3. & - & 3 & Reasonable solution & $N$ \\
\hline W037 & 176.9 & 58.7 & 3.0 & 3. & 3 . & - & Excellent solution & R \\
\hline W038 & 239.1 & 51.6 & 13.0 & 3. & 3 . & - & III-conditioned solution & A \\
\hline W039 & 180.7 & 61.4 & 11.5 & 4. & 4. & - & Good solution & R \\
\hline W040 & 196.5 & 52.0 & 7.8 & 3 & 3 . & - & Good solution & $R$ \\
\hline W041 & 025.0 & -69.3 & 8.7 & 3. & - & 3 & Reasonable solution & $N$ \\
\hline W047 & 016.8 & -54.1 & 9.1 & 3 . & - & 3 & High intensity, stable & $N$ \\
\hline W049 & 000.8 & -64.3 & 6.6 & 5. & - & 5 & Excellent solution & $N$ \\
\hline W050 & 162.4 & 68.2 & 2.6 & 3 & 3.- & - & Excellent solution & A \\
\hline W051 & 029.8 & -58.2 & 7.0 & 3 . & - & 3 & High Intensity, stable & $\mathrm{N}$ \\
\hline W058 & 200.4 & 52.5 & 1.0 & 3. & 3. & - & Good solution & $\mathrm{R}$ \\
\hline W059 & 159.1 & 27.3 & 9.4 & 3 & 3 - & - & III-conditioned solution & $R$ \\
\hline W060 & 166.8 & 54.6 & 7.1 & 3 & 31. & - & Reasonable solution & $\mathrm{R}$ \\
\hline W061 & 003.7 & -66.7 & 4.0 & 3. & - & 3 & Excellent solution & $\mathrm{N}$ \\
\hline W063 & 170.5 & 67.3 & 6.5 & 3 & 3 - & - & Reasonable solution & A \\
\hline W064 & 125.9 & 56.1 & 11.1 & 3 & 3 . & - & III-conditioned solution & $R$ \\
\hline W065 & 235.1 & 85.2 & 3.3 & 3 & 3!- & - & III-conditioned solution & $R$ \\
\hline W066 & 197.2 & 61.4 & 2.5 & 3 & 3 . & - & noisy data & $R$ \\
\hline W067 & 161.1 & 62.0 & 8.8 & 3 & 3 - & - & Good solution & $R$ \\
\hline W068 & 016.5 & -53.1 & 18.9 & 3 . & - & 3 & High intensity, O.K. solution & $N$ \\
\hline W070 & 000.4 & -59.4 & 9.8 & 3. & - & 3 & Reasonable solution & $N$ \\
\hline W072 & 346.2 & -65.5 & 3.4 & 3.- & - & 3 & Good solution & $N$ \\
\hline W073 & 007.9 & -65.3 & 8.8 & 3 . & - & 3 & Excellent solution & $N$ \\
\hline W075 & 000.3 & -55.0 & 5.5 & 3. & - & 3 & Excellent solution & $\mathrm{N}$ \\
\hline W079 & 001.8 & -53.7 & 5.7 & 3. & - & 3 & Excellent solution & $N$ \\
\hline W080 & 192.2 & 48.3 & 12.2 & 3 & 1. & 2 & Unusual behaviour & R \\
\hline W081 & 157.6 & 68.0 & 4.8 & 4. & 4 - - & - & Reasonable solution & $\mathrm{R}$ \\
\hline W084 & 175.4 & 59.5 & 5.8 & 3 & 3 - & - & Excellent solution & $R$ \\
\hline W086 & 009.0 & -60.7 & 13.0 & 3. & - & 3 & Good solution & $\mathrm{N}$ \\
\hline W089 & 000.0 & .54 .7 & 7.7 & 3. & - & 3 & Good solution & $\mathrm{N}$ \\
\hline W091 & 353.2 & -64.2 & 6.2 & 3. & - & 3 & Excellent solution & $N$ \\
\hline W093 & - & - & - & 3 . & - & 3 & Very noisy, no solution & $?$ \\
\hline W095 & 010.5 & -67.0 & 3.8 & 3. & - & 3 & Excellent solution & $\mathrm{N}$ \\
\hline W097 & 001.1 & -68.9 & 10.7 & 3 . & - & 3 & Noisy data, good solution & $\mathrm{N}$ \\
\hline W100 & 018.7 & -57.8 & 10.4 & 3. & - & 3 & Reasonable solution & $\mathrm{N}$ \\
\hline W101 & 343.4 & .56 .7 & 14.7 & 3 . & - & 3 & Poor solution & $\mathrm{N}$ \\
\hline W104 & 151.2 & 58.5 & 10.9 & 3 & 3 - & - & Noisy data, poorly constrained & $\mathrm{R}$ ? \\
\hline W106 & 242.0 & 67.9 & 8.7 & 3. & 3 . & - & III-conditioned solution & A \\
\hline W107 & 011.9 & -62.0 & 9.1 & 3. & - & 3 & Good solution & $N$ \\
\hline W108 & 165.8 & 56.3 & 9.1 & 3. & 3 - & $=$ & Good solution & $\mathrm{R}$ \\
\hline W110 & 176.0 & 60.0 & 2.8 & 3 & 3. & - & Excellent solution & A \\
\hline W111 & 020.6 & -64.2 & 9.4 & 3. & - & 3 & Reasonable solution & $N$ \\
\hline W113 & 199.7 & 57.1 & 11.3 & 3. & 1 & 2 & Good solution & $\mathrm{A}$ \\
\hline W116 & 186.2 & 71.7 & 0.7 & 3 & 3 - & - & Excellent solution & A \\
\hline W117 & 167.0 & 63.4 & 10.3 & 3 & 1 & 2 & Good solution & $\mathrm{R}$ \\
\hline W118 & 181.0 & 57.9 & 2.6 & 3 & 3. & - & Good solution & $N$ \\
\hline W123 & 356.5 & -51.4 & 1.5 & 4. & - & 4 & Excellent solution & $N$ \\
\hline
\end{tabular}

Table 16.1: Site polarity solutions for the Wanganui River Section. All data are from samples that have been fully stepwise demagnetised by thermal means. GC indicates the number of specimens for which end point were determined using the remagnetisation circles method of McFadden and McElhinny (1988). SP indicates the set points determined from a site by analysis of vector component plots. Individual specimen data are presented in appendix 5. 


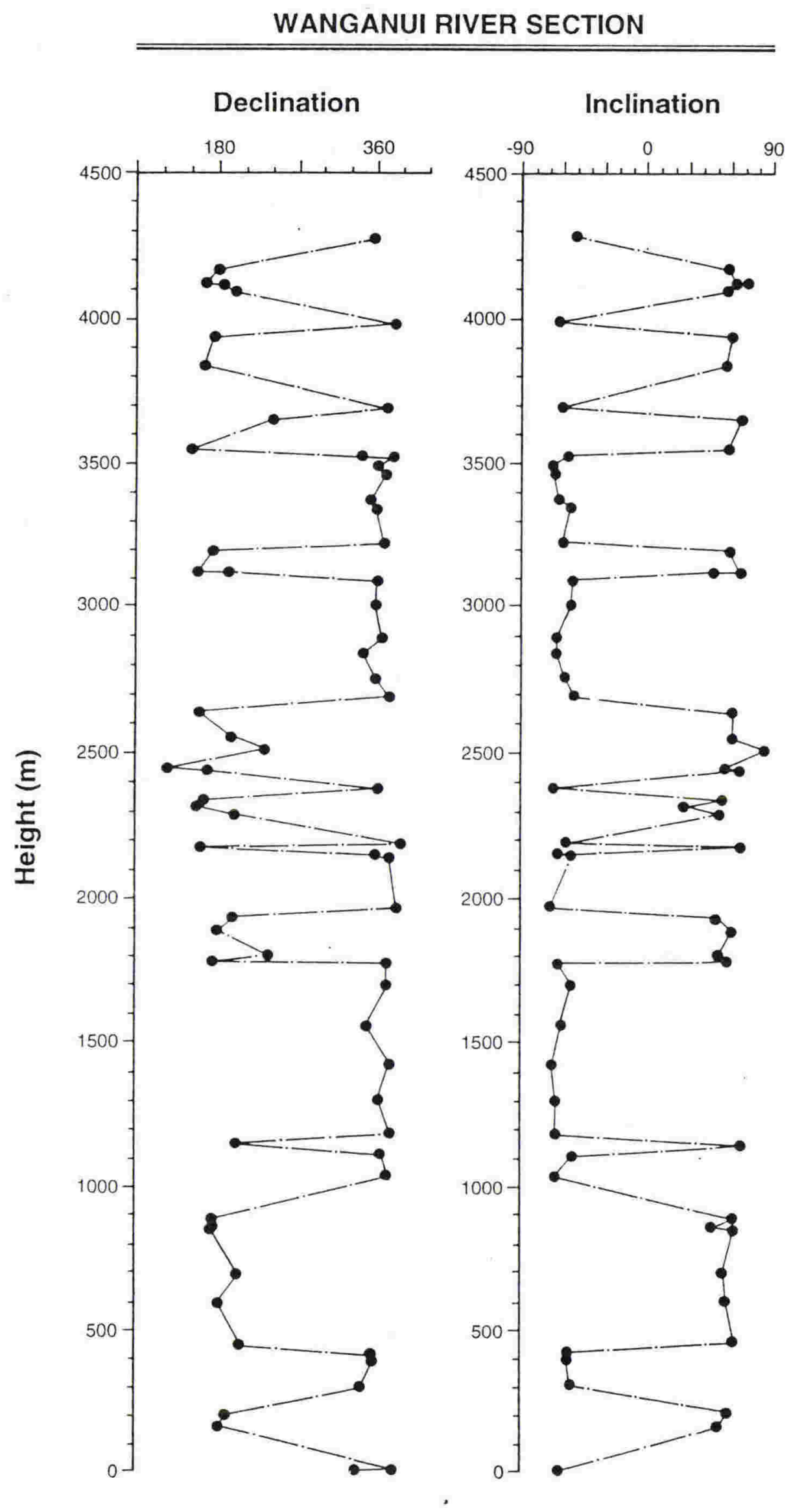

Figure 16.17: Palaeomagnetic end point direction versus statigraphic position for Wanganui River data. All site directions are solutions from several fully stepwise thermally demagnetised specimens, see table 16.1 for interpretation information. 


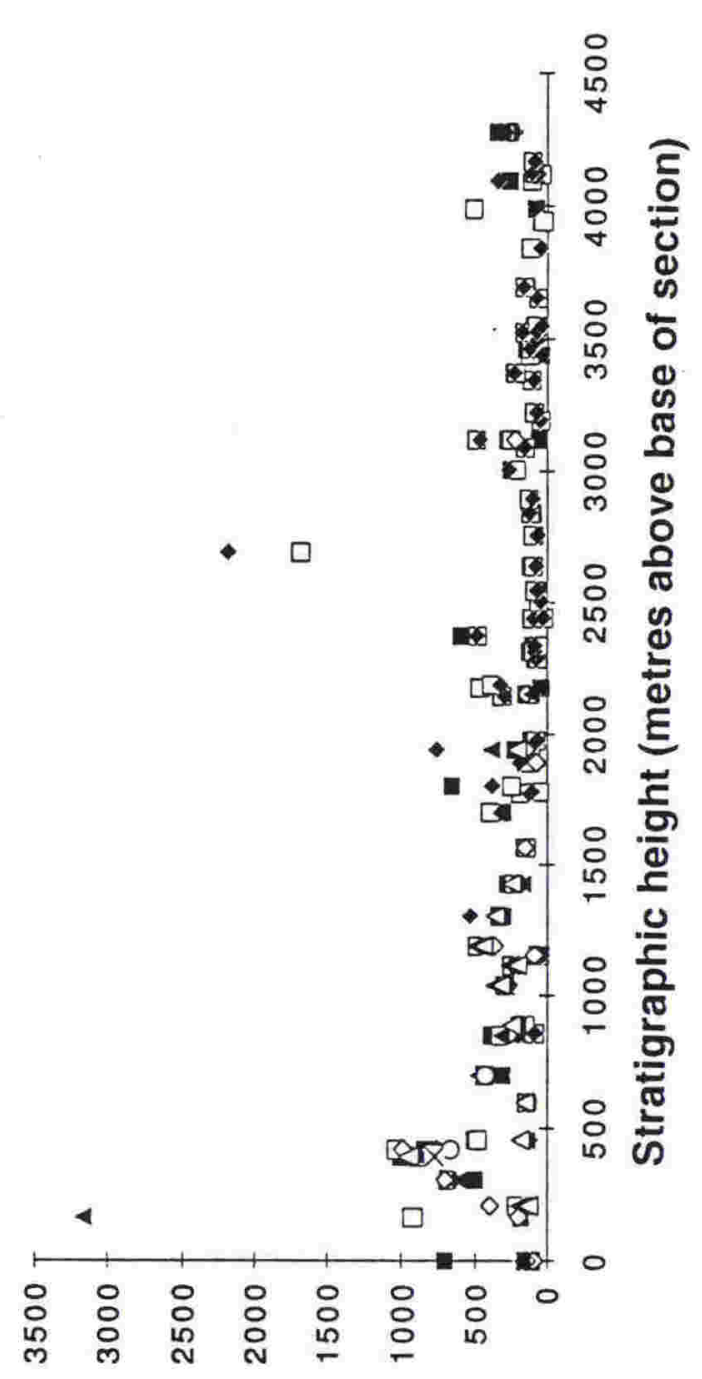

NRM intensity $\left(\mathrm{A} / \mathrm{m} \mathrm{x10^{6 }}\right)$

Figure 16.16: NRM intensity versus stratigraphic position for Wanganui River data. Different symbols identify different measurements from the same stratigraphic position.

highest being 18.9 , the lowest 0.7 , and the average 7.3 degrees. NRM directions are well scattered on a stereo plot (figure 16.18) showing the extensive overprinting from present day field. Cleaned directions are well grouped with a $95 \%$ confidence interval of 3 degrees (figure 5.18). Some 28 specimens had reversed inclination NRM's and $40 \%$ of total specimens had abnormal NRM declinations. In the final analysis $48 \%$ of specimens had reversed field polarity. Overprinting from the present day field evidently is seldom stronger in intensity than the depositional remanence of the sediments. Primary remanence while obscured can be reliably elicited using careful analysis techniques. Cleaned directions are a little more scattered for reversed field sites than normal field site directions, due to some poor remagnetised great circle solutions. The average polarity directions are well defined and within $95 \%$ confidence limits normal and reversed field directions are antipodal. This combined with absence of inclination error (Tarling, 1983) implies that directions are truly representative of the ambient field at the time of acquisition of magnetisation. The mean declination is displaced slightly clockwise, but no more than might be expected from the rotation of the Indo-Australian plate about its euler pole.

\section{Palaeomagnetism of the Hautawa Road Section.}

In general this section is an order of magnitude more weakly magnetised than the Wanganui River section. Outcrop tended to be more weathered than in the Wanganui River with periodic drying of strata reducing the intensity of the depositional remanence and increasing the strength of the present day field overprint. Only $170 \mathrm{~m}$ of strata were logged and sampled (see section 3, chapter 11) but because of the weaker 

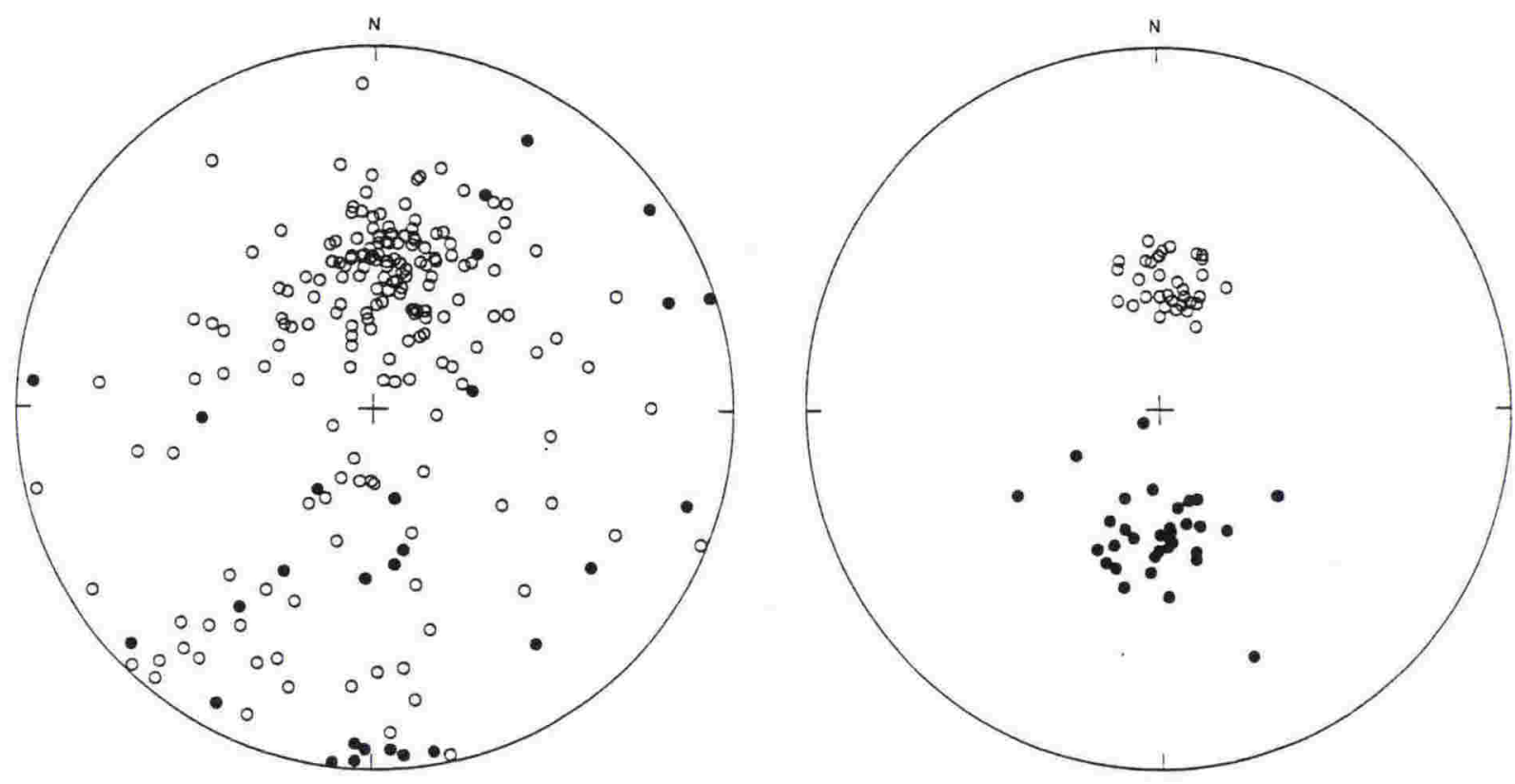

Figure 16.18: Stereoplot of remanence directions from Wanganui River section. Left is the individual specimen NRM directions, right is the stepwise demagnetised site directions.

signal 65 cores were drilled from only 9 sites and over 80 specimens stepwise thermally demagnetised. The sampling interval was tighter for this section as it was intended as a more reliable tie point between the top of the Rangitikei and Wanganui River Sections. Sampling localities are shown on figure 16.19. The elicited detrital remanences are less reliable than Wanganui River Section data, but are adequate for magnetostratigraphy.

The resulting declinations are consistent with Wanganui River Section directions but are not definitive. Site analyses and polarities are presented in table 16.2. Two sites are of normal field polarity and the remaining 7 sites have reversed field polarity. A magnetogram is presented in figure 16.20 , again with polarity clearly defined and declination and inclination angles in clear agreement. Hautawa Road site solutions have $95 \%$ confidence intervals that average 5.0 degrees. However, this does not reflect the consistent type D palaeomagnetic behaviour of specimens and the data editing necessary to distinguish the signal from the noise level of specimen raw measurement data.

16.3.4 Palaeomagnetism of the Rangitikei River Section.

The Rangitikei River Section exposes strata deposited simultaneously to the upper portion of the Wanganui River Section, but in shallower water (see section 3 , chapter 10). Two previous 


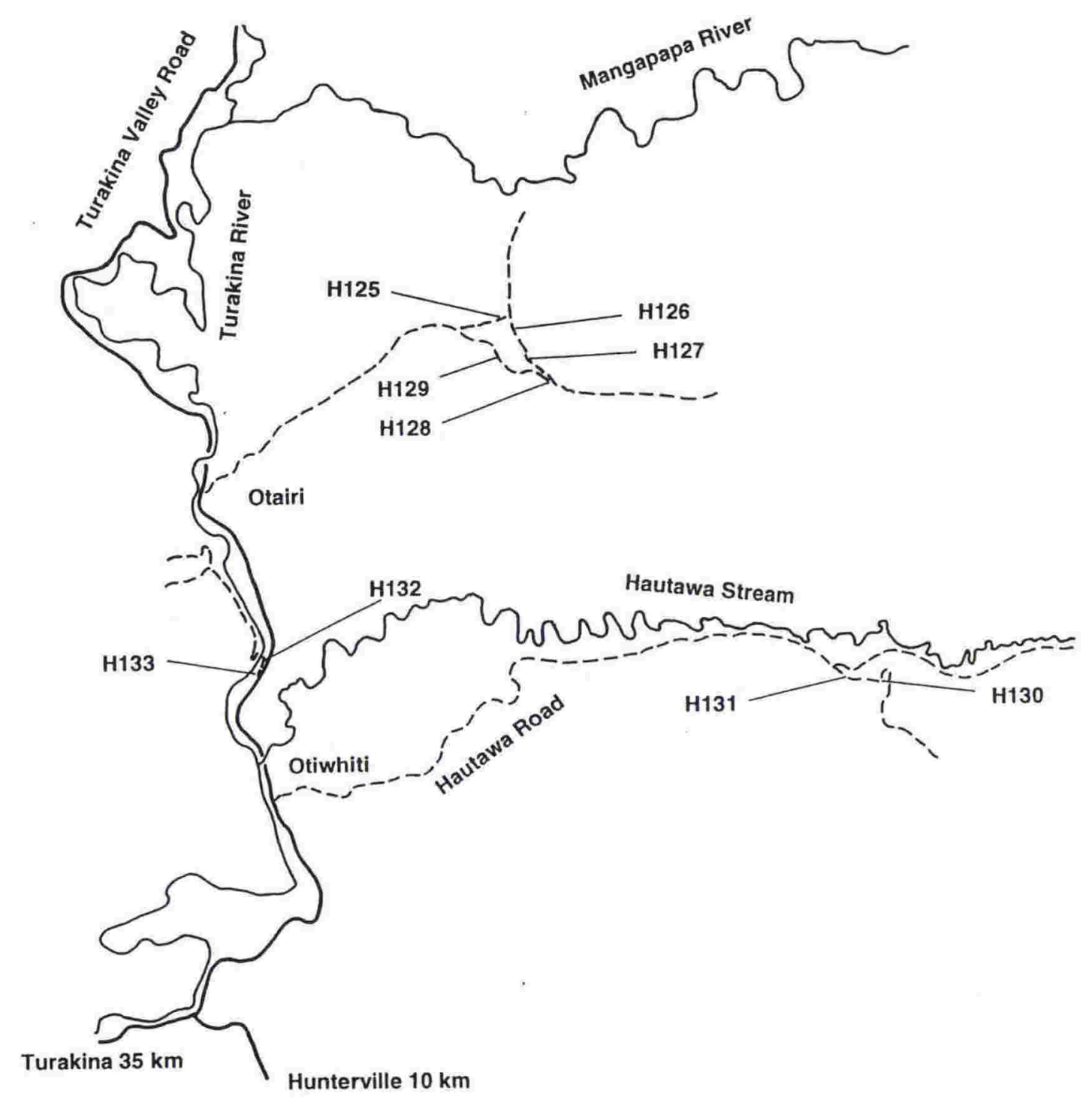

Figure 16.19: Location map of Hautawa Road palaeomagnetic sample sites. Stratigraphic sample heights are given in appendix 5.

HAUTAWA ROAD SECTION

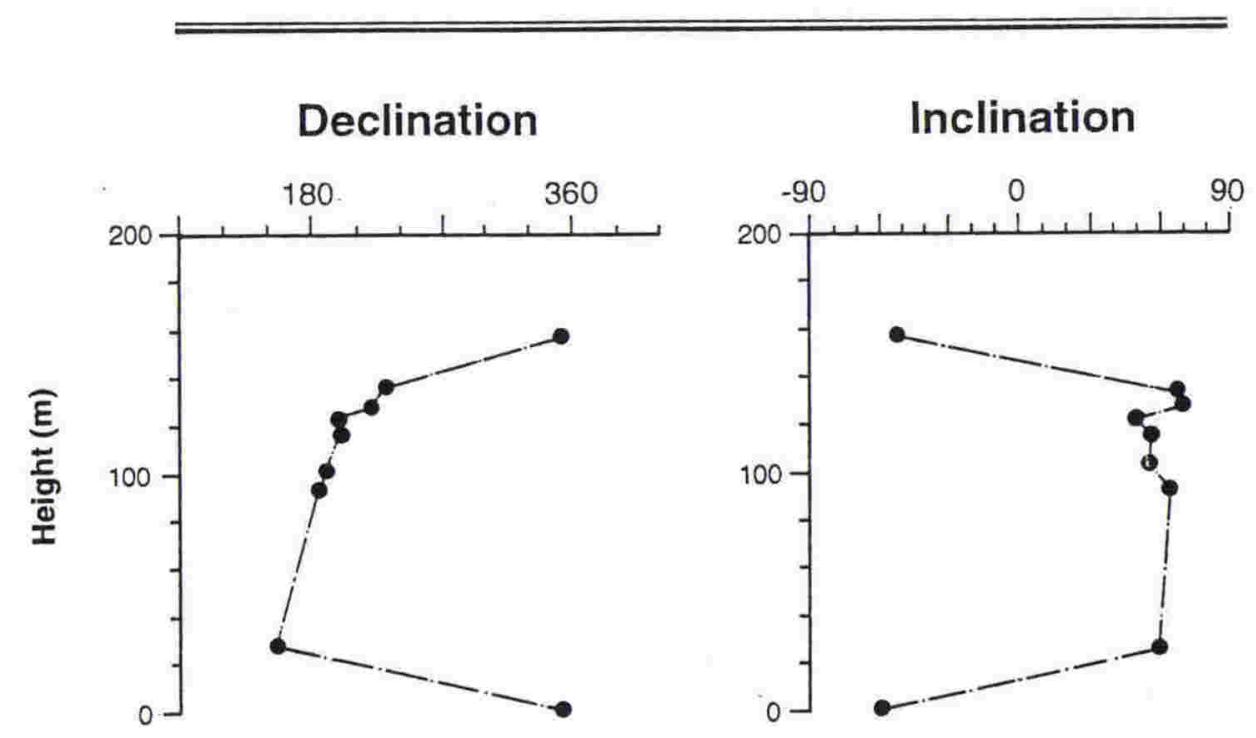

Figure 16.20: Palaeomagnetic end point direction versus statigraphic position for Hautawa Road data. All site directions are solutions from several fully stepwise thermally demagnetised specimens, see table 16.2 for interpretation information. 


\begin{tabular}{|l|r|r|r|r|r|r|l|l|}
\hline Site Number & Declination & Inclination & Alpha-95 & N & G.C. & S.P. & Comment & Polarity \\
\hline & & & & & & & & \\
\hline $\mathrm{H} 125$ & 356.4 & -51.9 & 6.0 & 5 & - & 5 & Good solution & $\mathrm{N}$ \\
\hline $\mathrm{H} 126$ & 225.4 & 65.6 & 5.8 & 4 & 4 & - & Ill-conditioned solution & $\mathrm{R}$ \\
\hline $\mathrm{H} 127$ & 219.0 & 69.3 & 2.2 & 5 & 5 & - & Reasonable solution & $\mathrm{R}$ \\
\hline $\mathrm{H} 128$ & 200.2 & 48.9 & 2.1 & 4 & 4 & - & Good solution & $\mathrm{A}$ \\
\hline $\mathrm{H} 129$ & 204.9 & 54.2 & 6.6 & 4 & - & 4 & Good solution & $\mathrm{R}$ \\
\hline $\mathrm{H} 130$ & 192.3 & 53.7 & 2.8 & 6 & 4 & 2 & Excellent solution & $\mathrm{R}$ \\
\hline $\mathrm{H} 131$ & 185.1 & 64.3 & 6.6 & 7 & - & 7 & Good solution & $\mathrm{R}$ \\
\hline $\mathrm{H} 132$ & 158.8 & 57.6 & 9.9 & 5 & 5 & - & Poorly constrained & $\mathrm{R}$ \\
\hline $\mathrm{H} 133$ & 010.4 & -60.3 & 3.2 & 5 & - & 5 & Excellent solution & $\mathrm{N}$ \\
\hline
\end{tabular}

Table 16.2: Site polarity solutions for the Hautawa Road Section. All data are from samples that have been fully stepwise demagnetised by thermal means. GC indicates the number of specimens for which end point were determined using the remagnetisation circles method of McFadden and McElhinny (1988). SP indicates the set points determined from a site by analysis of vector component plots. Individual specimen data are presented in appendix 5 .

palaeomagnetic studies have been carried out in the Rangitikei River Valley. Seward (1974) sampled and measured Pleistocene strata further south of the area studied here. Seward et al. (1986) examined the entire Pliocene exposure in the upper reaches of the Rangitikei River as well as most of the lower Pleistocene exposed in the lower reaches of the river. Seward (pers comm, 1989) suggested that the Pliocene portion of this study was less reliable and palaeomagnetic behaviour poorly understood by Seward et al. (1986). Demagnetisation of samples was carried out using alternating field methods with clearly normal and reversed behaviour being reported to result from this procedure. Normal and reversed field results were antipodal within confidence limits and normal directions approximated the present day field, a solution they consider to be in line with current tectonic models of plate motions in the region.
Many other studies (eg; Roberts, 1990; McGuire, 1989; Roberts and Turner, submitted; Wright and Vella, 1986) have found behaviour during alternating field demagnetisation to be irregular in nature and at times insufficient for eliciting detrital remanences from New Zealand Tertiary sediments. For this reason and the reservation of Seward (pers comm) it was decided to repeat the sampling of the Upper Rangitikei River Section. Apart from more definitive palaeomagnetic analysis, this would also allows better locating of sampling sites into the new detailed allostratigraphic framework also established by this study (see section 3 , chapter 11).

While the interval sampled in the Rangitikei River for palaeomagnetic study was in excess of $2000 \mathrm{~m}$, more than $200 \mathrm{~m}$ of this is section repeated across the Rauoterangi Fault (see enclosure 1). Litho- and magnetostratigraphy allow accurate correlation of 
strata across the fault and a complete stratigraphy to be completed for the Rangitikei River.

Palaeomagnetic behaviour is very good with very few great circle remagnetisation analyses being needed in comparison with the Wanganui River sites. Table 16.3 presents individual site analyses and polarities for the Rangitikei River Section. Sample locations are marked in enclosure 2 . The intensity of NRM is on average 5 times that of the equivalent strata in the Wanganui River Section. Behaviour is consistent throughout the section with a few more

\begin{tabular}{|c|c|c|c|c|c|c|c|c|}
\hline Site Number & Declination & Inclination & Alpha-95 & $\mathrm{N}$ & G.C. & S.P. & Comment & Polarity \\
\hline R135 & 015.5 & -47.4 & 2.6 & 3 . & . & 3 & Good solution & \\
\hline R136 & 021.3 & -49.8 & 8.6 & 3 - & - & 3 & Good solution & $\mathrm{N}$ \\
\hline R138 & 023.8 & -62.7 & 8.0 & 3 - & - & 3 & Good solution & $\mathrm{N}$ \\
\hline R141 & 187.6 & 76.9 & 0.3 & 3 & 3 & - & Excellent solution & $\mathrm{A}$ \\
\hline R142 & 212.7 & 54.3 & 0.7 & 3 & 3 & - & Excellent solution & A \\
\hline R143 & 005.9 & -61.2 & 4.0 & 3 - & - & 3 & Excellent solution & $\mathrm{N}$ \\
\hline A145 & 203.7 & 61.1 & 2.0 & 3 & 3 & - & III-conditioned solution & $\mathrm{R}$ \\
\hline R146 & 238.1 & 78.0 & 7.4 & 3 & 3 & - & noisy data, II-conditioned solution & A \\
\hline R147 & 011.8 & -60.0 & 7.3 & 3 - & - & 3. & Good solution & $\mathrm{N}$ \\
\hline $\mathrm{R} 148$ & 022.7 & -64.2 & 5.6 & 3.- & - & 3 & Good solution & $\mathrm{N}$ \\
\hline A149 & 019.9 & -66.9 & 7.6 & 4. & - & 4. & Good solution & $\mathrm{N}$ \\
\hline R151 & 188.2 & 60.3 & 6.1 & 4. & 2 & 2 & Excellent solution & A \\
\hline $\mathrm{R} 152$ & 341.0 & -67.4 & 30.2 & 3 - & - & 3. & Poor solution, probably transitional & $\mathrm{Tr}$ \\
\hline R153 & 001.0 & -59.2 & 17.0 & 3 - & - & 3 & Poorly constrained & $\mathrm{N}$ \\
\hline R154 & 012.7 & -57.6 & 9.8 & 3 - & - & 3 & Good solution & $\mathrm{N}$ \\
\hline $\mathrm{A} 155$ & 014.4 & -58.3 & 11.7 & 2 . & - & 2 & Poorly constrained, but O.K. solution & $N$ \\
\hline R156 & 028.9 & -61.3 & 11.7 & 3.- & - & 3 & Reasonable solution & $\mathrm{N}$ \\
\hline R157 & 015.1 & -65.9 & 5.4 & 3 . & - & 3 & Excellent solution & $N$ \\
\hline A160 & 012.6 & -60.7 & 3.9 & 3 - & & 3 & Excellent solution & $\mathrm{N}$ \\
\hline R162 & 014.3 & -59.5 & 5.1 & 3 - & - & 3 & Excellent solution & $\mathrm{N}$ \\
\hline R163 & 001.6 & -56.8 & 6.1 & 3.- & - & 3 & Good solution & $N$ \\
\hline R164 & 007.0 & -56.9 & 5.4 & 3 . & - & 3 & Good solution & $N$ \\
\hline R165 & 185.9 & 59.1 & 2.9 & 3 - & - & 3 & Excellent solution & R \\
\hline R167 & 177.7 & 46.5 & 0.8 & 3 & 3 & - & Excellent solution & A \\
\hline R169 & 014.4 & -50.2 & 5.7 & 3 - & - & 3 & Excellent solution & $\mathrm{N}$ \\
\hline R171 & 028.1 & -65.3 & 5.8 & 3 . & - & 3 & Good solution & $N$ \\
\hline $\mathrm{R} 172$ & 017.1 & .58 .9 & 4.5 & 3 - & & 3 & Excellent solution & $N$ \\
\hline R174 & 013.6 & -64.6 & 5.3 & 3 . & - & 3 & Excellent solution & $\mathrm{N}$ \\
\hline R176 & 013.2 & -57.7 & 4.6 & 3 . & - & 3. & Excellent solution & $N$ \\
\hline A177 & 021.6 & -55.5 & 11.0 & 3 . & - & 3 & Good solution & $N$ \\
\hline A178 & 358.6 & -58.3 & 8.8 & 3 - & - & 3 & Good solution & $\mathrm{N}$ \\
\hline R179 & 006.1 & -63.4 & 6.0 & 3 . & - & 3. & Excellent solution & $\mathrm{N}$ \\
\hline A180 & 001.1 & -63.2 & 6.6 & 3 . & - & 3 & Excellent solution & $\mathrm{N}$ \\
\hline R181 & 215.1 & 52.9 & 11.2 & 3 & 3. & - & Poorly constrained & A \\
\hline R182 & 187.0 & 67.2 & 12.5 & 3 & 3. & - & III-conditioned solution & $R$ \\
\hline R185 & 205.1 & 56.8 & 0.1 & 3 & 3. & - & Excellent solution & $\mathrm{A}$ \\
\hline R186 & 238.7 & 59.5 & 5.2 & 3 & 3. & - & Poorly constrained & A \\
\hline R188 & 187.5 & 47.7 & 3.7 & 3 & 3. & - & Good solution & $\mathrm{A}$ \\
\hline R189 & 006.8 & -60.6 & 2.7 & 3 - & - & 3 & Excellent solution & $\mathrm{N}$ \\
\hline R190 & 192.2 & 56.3 & 6.9 & 3 & 3. & - & Good solution & $R$ \\
\hline R191 & 006.4 & -70.9 & 6.6 & 3 - & - & 3 & Good solution & N \\
\hline R192 & 027.5 & -71.7 & 13.1 & 3. & - & 3 & Reasonable solution & $\mathrm{N}$ \\
\hline R193 & 202.9 & 48.7 & 20.0 & 3 & 2 & 1 & Poor solution, probably transitional & $\mathrm{Tr}$ \\
\hline R194 & 200.6 & 53.7 & 8.4 & 3 & 1 & 2 & Good solution & $\mathrm{R}$ \\
\hline R195 & 203.1 & 53.6 & 2.8 & 3 & 3. & - & Excellent solution & A \\
\hline R196 & 197.7 & 63.0 & 2.0 & 3. & - & 3 & Excellent solution & $\mathrm{R}$ \\
\hline R197 & 187.0 & 69.7 & 2.5 & 3 & 3. & - & noisy data, good solution & $\mathrm{R}$ \\
\hline
\end{tabular}

Table 16.3: Site polarity solutions for the Rangitikei River Section. All data are from samples that have been fully stepwise demagnetised by thermal means. GC indicates the number of specimens for which end point were determined using the remagnetisation circles method of McFadden and McElhinny (1988). SP indicates the set points determined from a site by analysis of vector component plots. Individual specimen data are presented in appendix 5 . 
intense samples in the middle $700 \mathrm{~m}$ of strata (figure 16.21), again due to the finer grained nature of the sampling horizons. Roberts (1990) also noted the correlation between more intense magnetic signals and finer grained lithologies.

A total of 47 sites were analysed for the Rangitikei River section. Specimens

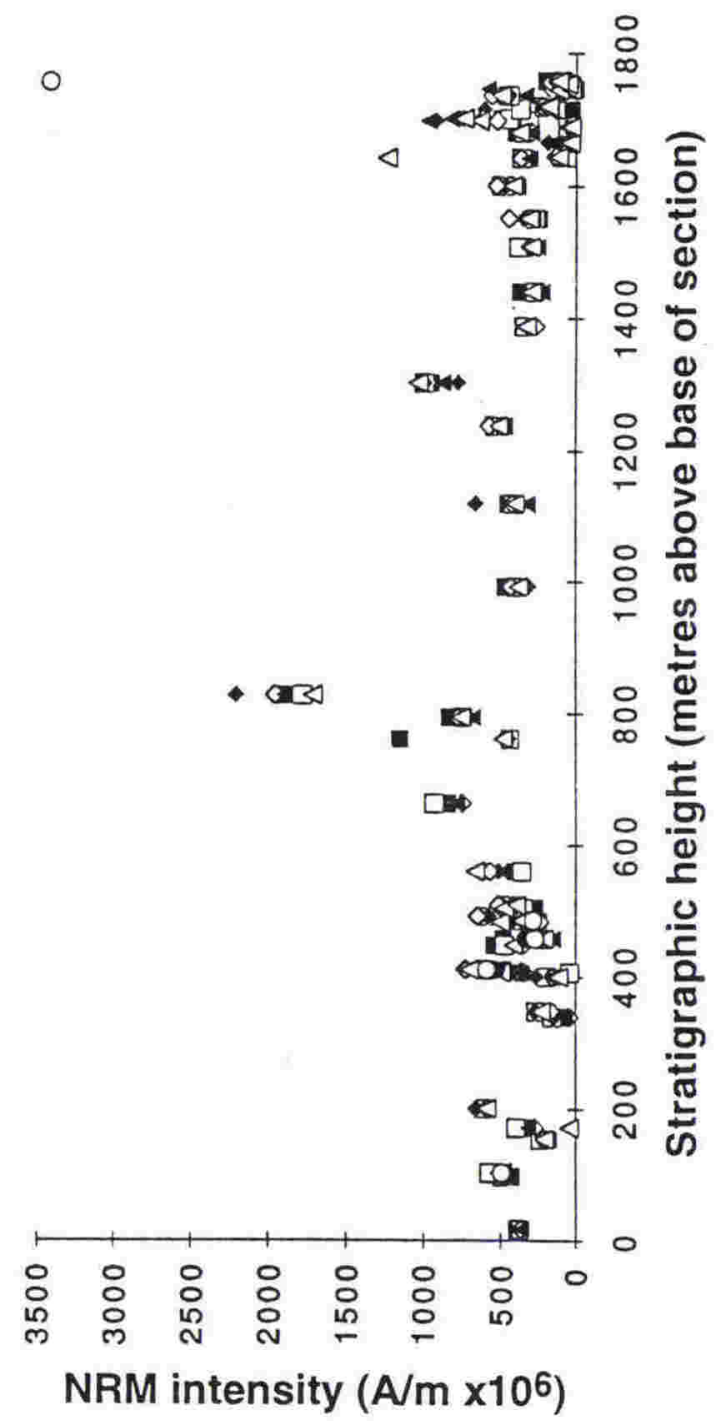

Figure 16.21: NRM intensity versus stratigraphic position for Rangitikei River data. Different symbols identify different measurements from the same stratigraphic position. were well behaved during demagnetisation procedures with $\mathrm{A}$ and B type specimens more common. 28 of the sites recorded normal polarity magnetic fields, 17 reversed polarity fields, and 2 are thought to be from transitional polarity fields (figure 16.22). The $95 \%$ confidence interval is very low, averaging 6.1 degrees, with highest 17.0 degrees and lowest 0.1 degrees. This excludes two sites who's polarity are thought to be transitional, they have 95 $\%$ confidence intervals of $20^{\circ}$ and $30.2^{\circ}$ respectively. Polarity solutions for the entire section are well grouped on a stereo plot with normal field polarities having a $95 \%$ confidence interval of $2.3^{\circ}$ and the reversed field polarities a $95 \%$ confidence interval of $5.0^{\circ}$. Stereo plots of both NRM and thermally analysed directions are presented in figure 16.23. Present day field overprinting was much more evident in the Rangitikei River samples than the Wanganui Samples. Thermal cleaning was effective for eliciting detrital remanence, and absence of inclination error indicates that the demagnetised solutions are representative of the ambient field at the time of acquisition of magnetisation. Seward $e t$ al. (1986) reported inclinations of $-53^{\circ}$ for normal field sites and $65^{\circ}$ for reversed field sites, which are 5-70 different than results of this study. The present study also found reversed and normal polarities to be antipodal, however declination direction are displaced clockwise by $15^{\circ}$. Only $2^{\circ}$ of this can be attributed to rotation of the Indo-Australian plate about its euler pole. 


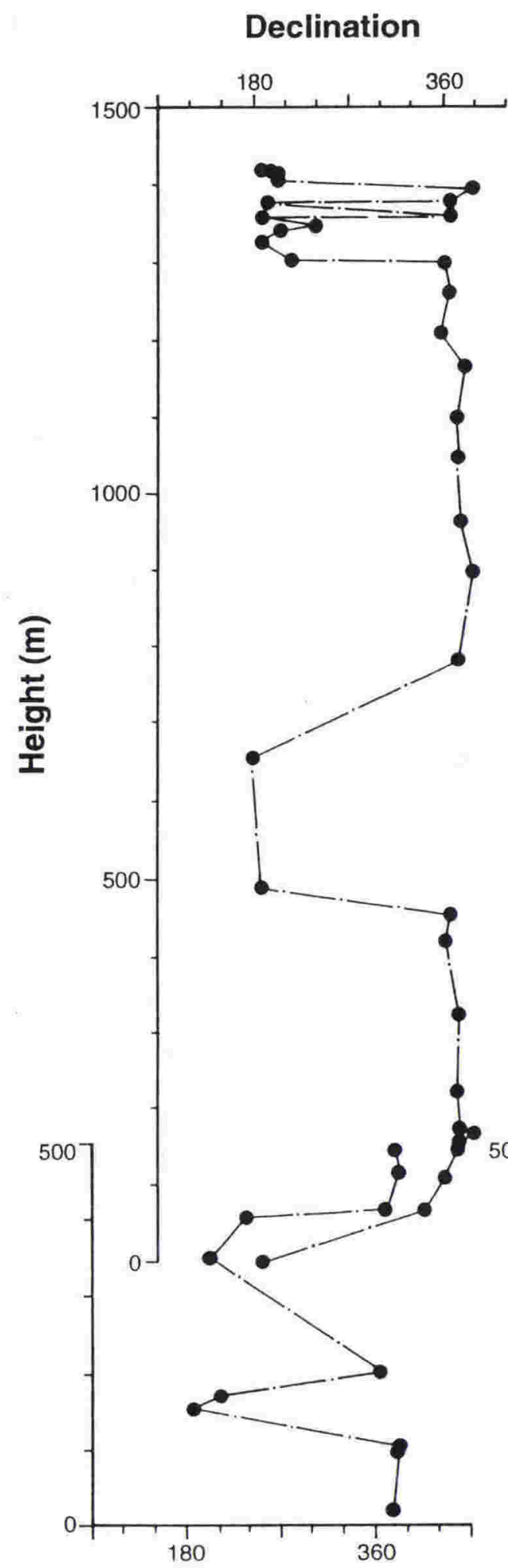

Declination
Inclination

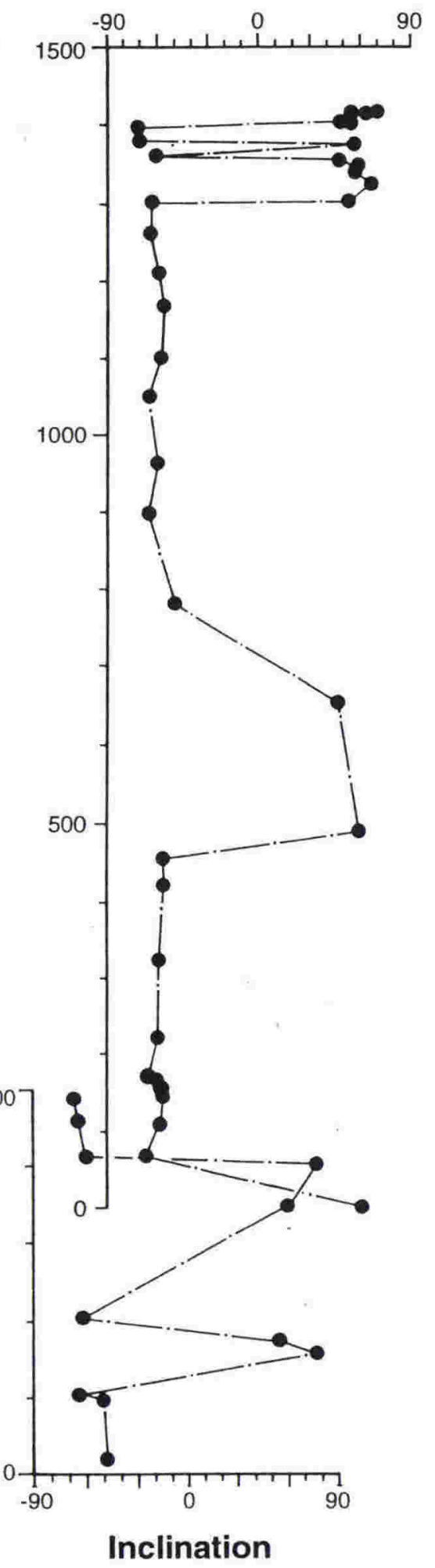

\section{RANGITIKEI RIVER SECTION (N)}

Figure 16.22: Palaeomagnetic end point direction versus stratigraphic position for Rangitikei River data. All site directions are solutions from several fully stepwise thermally demagnetised specimens, see table 16.3 for interpretation information. North part of section is from north of the Rauoterangi Fault and South part is from south of the fault. 

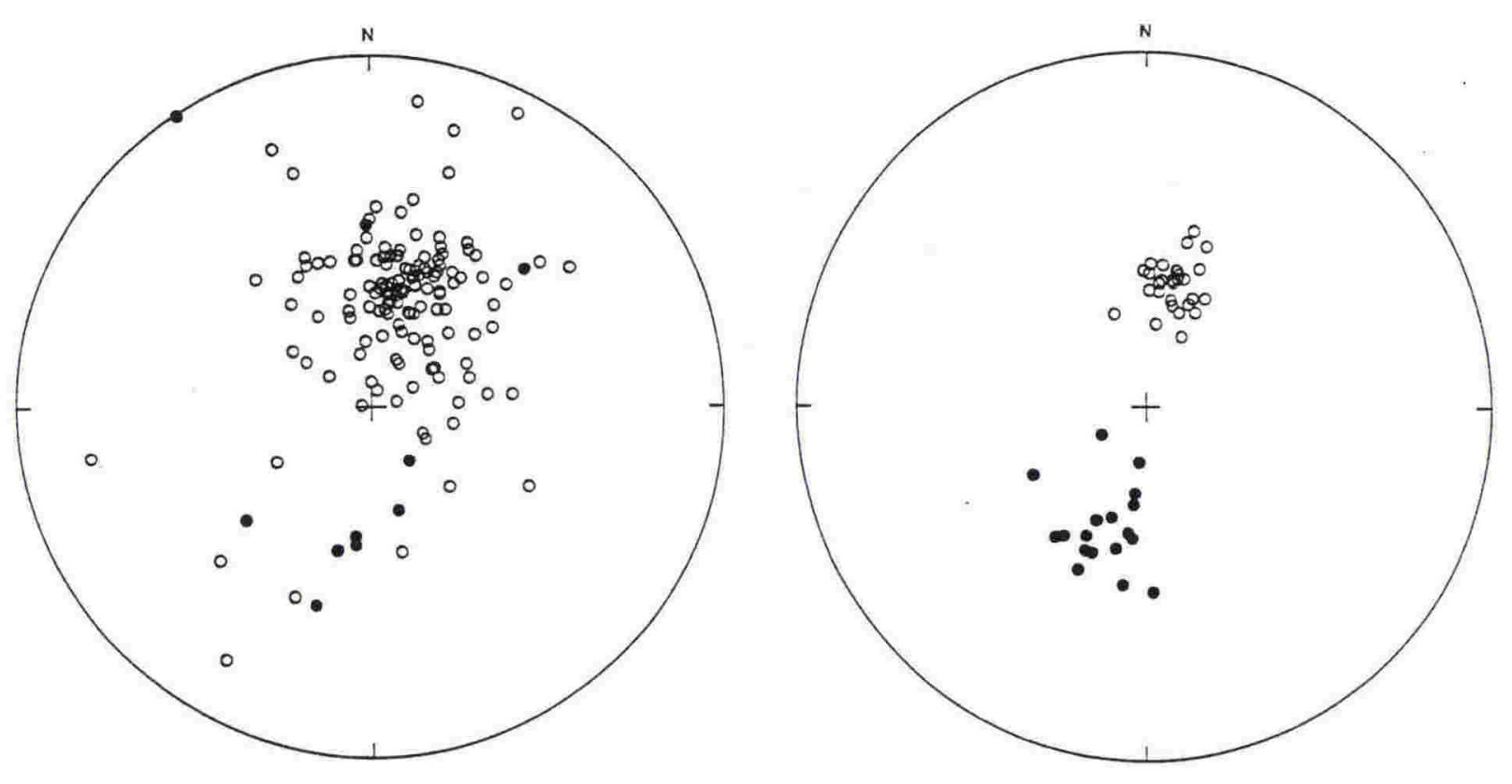

Figure 16.23: Stereoplot of remanence directions from Rangitikei River section. Left is the individual specimen NRM directions, right is the stepwise demagnetised site directions.

\subsection{Tectonic Considerations}

Lamb (1989), Walcott (1984) and Walcott (1987) discuss palaeomagnetic measurements east of the New Zealand axial tectonic shear zone (figure 10.1) that indicate recent crustal block rotations much larger than expected from only the clockwise rotation of the IndoAustralian plate with respect to the Pacific Plate. The large clockwise block rotations are said to be due to accommodation of motion between parallel transcurrent faults. This model of plate boundary deformation does not account for any crustal block rotations west of the axial tectonic shear zone. McGuire (1989) reports the first observation west of the axial tectonic shear zone of crustal rotation clockwise that is greater than that expected rotation of the Australian plate alone. The rotation is small and he was unsure about its validity.

The present study provides more crustal rotation data reported with respect to the Australian Plate. Figure 16.24 is a plot of site means for all measurements in the Wanganui and Rangitikei Rivers (this study) and Turakina River (data from McGuire, 1989). These three data sets are constructed from Gauss and Gilbert age strata combined. In assessing rotational information both this study and McGuire (1989) have made observations of data versus time throughout the measured sections and in all cases it was found that prior to the end of the Gauss normal chron no visible trend in rotation 

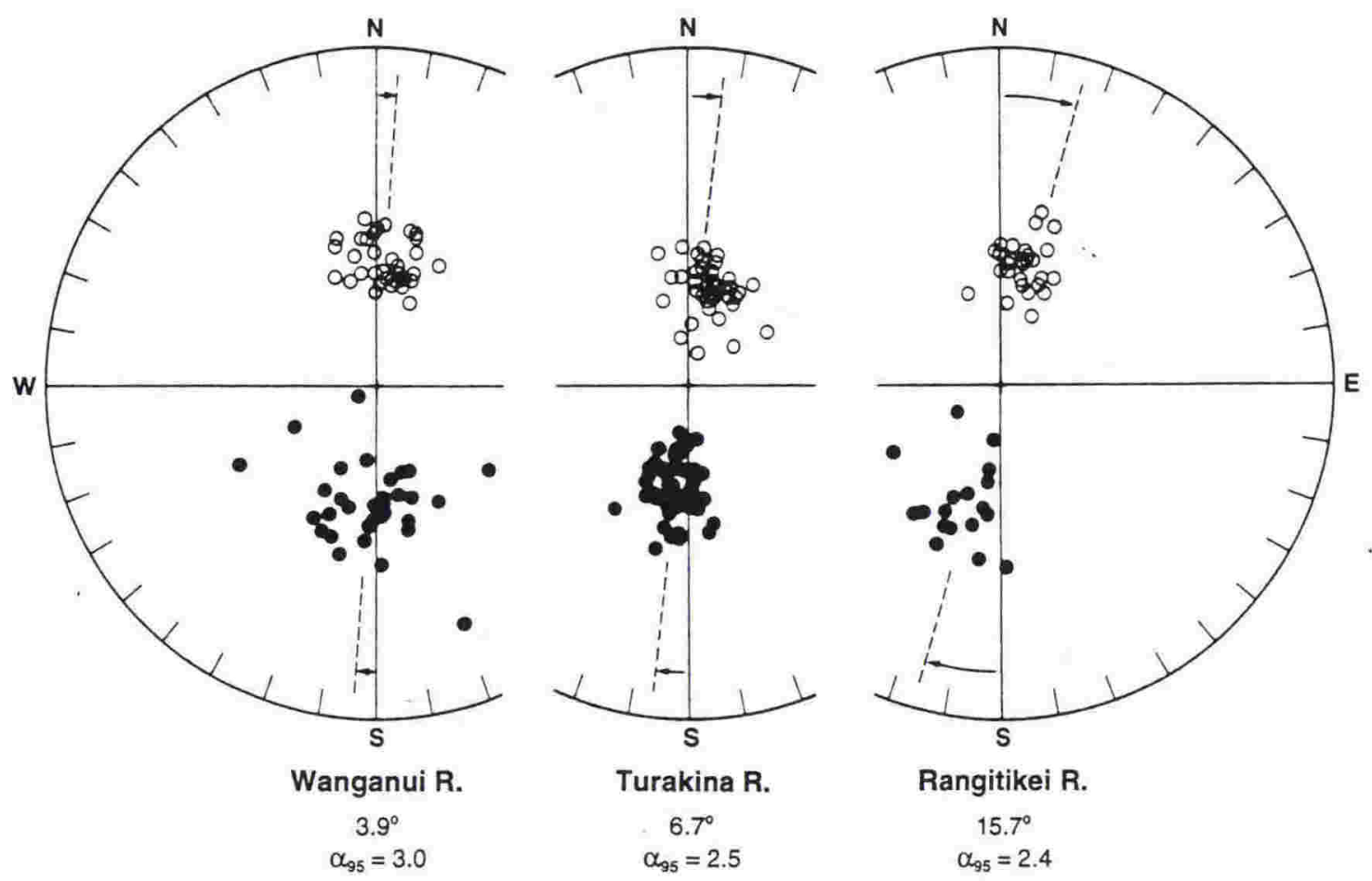

Figure 16.24: Stereoplots of stepwise thermally demagnetised site polarities from middle Pliocene Strata from the Wanganui, Turakina (Data from McGuire; 1989) and Rangitikei River. All sample measurements are corrected for bedding and magnetic declination, but no account is taken of the rotation of the Australian Plate about its euler pole. Amount of clockwise rotation is given for each section with alpha-95 confidence intervals.

with time is observed. Therefore rotation data reported here has occurred since 2.5 Ma.

In the stereographic projections much of the scatter of data (in all sections the $95 \%$ confidence interval is $3^{\circ}$ or less) is probably due to secular variation. Averaging of information from each section is for more than 1 my of time and the result should therefore be representative of the axial geocentric dipole (McElhinny, 1973). Table 16.4 presents the results of statistical analyses in calculating the axial geocentric dipole at each section of data collection. Rotation in the Wanganui River Valley is consistent with Australian Plate rotation only. Further east in the Turakina River Valley McGuire (1989) measured a clockwise rotation of $4^{0} \pm 2^{\circ}$ since the Gauss Normal Chron. In the Rangitikei River Valley, much closer to the axial Tectonic Shear Zone the rotation is $13^{\circ} \pm$ $2^{\circ}$.

One explanation of this progressive increase in crustal rotation is that it is due to increased shear drag closer to the zone of movement between the Australian and Pacific Plates (Axial Tectonic Shear Zone). This is in contrast to different individual crustal block rotations reported east of the Shear Zone (Roberts, 1990) (figure 16.25). These data suggest that the western extent of the region affected by shearing between the two plates is wider than thus far reported, and that some of the transcurrent movement between the two plates is taken up by 


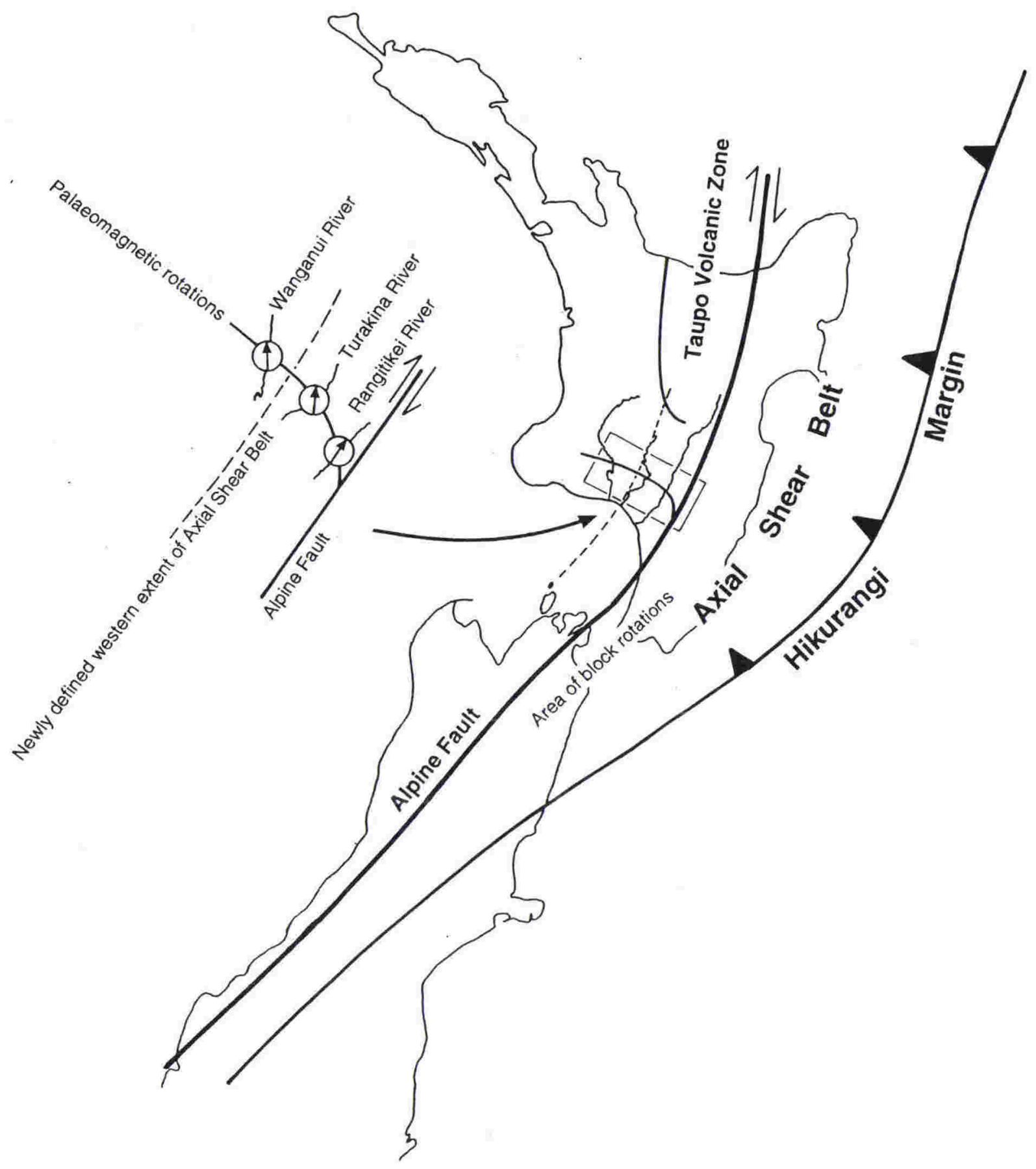

Figure 16.25: Palaeomagnetic rotation directions from the South Wanganui Basin, showing the more westerly extent of shear associated with faulting within the Axial Shear Belt. Magnetic directions are represented as corrected to true north. Turakina magnetic direction is from McGuire (1989). All shear and associated rotation has occurred since the top of the Gauss Chron (2.4 Ma.). Tectonic terrains are taken from Walcott (1978). 
shear drag against the fault zone, as well as transcurrent motion. Offset on the north-south trending faults in the Rangitikei River Valley is right lateral thrust faulting, consistent with the Axial Tectonic Shear Belt sense of displacement. Crustal fracturing subperpendicular to this faulting must exist to allow progressive block rotation eastwards, though it was not observed during the course of this study.

Another possible explanation is that the Taupo Volcanic Zone extends further to the south than currently thought (e.g. Cole, 1979) and associated extension has allowed crustal rotation clockwise against the axial tectonic shear zone accommodating this extension.

\begin{tabular}{|l|rrr|}
\cline { 2 - 4 } \multicolumn{1}{c|}{} & Wanganui River & Turakina River & Rangitikei River \\
\hline Declination & & & \\
Inclination & 183.9 & 186.7 & 195.7 \\
K & 62.1 & 57.8 & 60.7 \\
Alpha-95 & 33.2 & 66.1 & 78.1 \\
\hline
\end{tabular}

*Data from McGuire (1989)

Table 16.4: Calculated axial geocentric dipole statistics from Gilbert and Gauss age strata of the South Wanganui Basin. Normal and reverse polarity directions have been calculated separately. Values were found to be in close agreement and were therefore averaged. Actual data are shown on a stereo plot in figure 16.24. 
270 


\section{Chapter - 17}

\section{Sedimentary Petrography and Mineralogy}

This chapter provides the mineralogical background necessary for understanding the process by which New Zealand Tertiary sediments, particularly the South Wanganui Basin sediments, acquire their magnetic signal. This allows the palaeomagnetic behaviour of the sediments to be categorised and ensures that the analytical techniques presented in chapter 16 are correctly interpreted to decipher the magnetostratigraphy of the sections under study (presented in chapter 19). Here sedimentary petrography, mineral chemistry, and diagenetic alteration are described using optical thin-section analysis, X-ray diffraction, and electron microprobe analysis. All detrital magnetite and titaniferous magnetite grains have been completely dissolved in the presence of sulphate reducing bacteria. Less reactive Ilmenite has also been attacked along weak planes in grains. Complete sulphide authigenesis has occurred simultaneously with oxide dissolution. The Iron produced by dissolution reacts with hydrogen sulphide from the reducing bacteria to produce metastable sulphides such as mackinawite and pyrrhotite. Continued reduction has resulted in complete pyritisation, via the greigite phase, with pyrite in the form of framboids retaining the spheroidal greigite shape. Finally weathering of sediment has resulted in oxidation of pyrite framboids and clay phases. Chromite was found in trace amounts at some localities in the South Wanganui Basin. It remains unblemished by diagenetic processes.

\subsection{Introduction}

Because of the complex nature of magnetic signals from strata in the Wanganui Basin it was thought important to understand the mechanism by which these sediments obtained and retained their remanent magnetisations. From previous studies of New Zealand tertiary sediments (Wright, 1986; McGuire, 1989; Turner et al., 1989; Roberts, 1990; and Roberts and Turner, submitted) it is known that magnetic remanences are likely to be held by a range of oxide and sulphide minerals. To establish the origin of magnetic remanence two approaches were taken. Firstly, a sedimentary petrographic and mineralogic study, focusing on oxide and authigenic phases present in the South Wanganui Basin sediments (the subject of this chapter),. and secondly, a study of the magnetic properties of the same lithotypes examined for their petrographically and mineralogically (Chapter 18).

The approach includes two procedures: The first was a study of representative sedimentary textures in thin section, in order to determine mineral occurrences, 
textures, interrelationships, and petrogenetic history. Tucker (1991), Shelly (1980) and Deer et al. (1989) were used for reference in both thin section and electron microprobe analysis, to establish mineralogy and mineralogic relationships. The second part of the study involved preparing magnetic separates from the representative lithotypes. Magnetic properties and magnetic behaviour of the separates was first established, and then grains were analysed in thin section to establish mineralogy and their place in petrogenetic development of the sediments. This combined approach allows determination of sedimentary petrogenetic development and associated magnetic signals. The results ensure that complex magnetic signals within the sediments are interpreted correctly, establishing correct detrital remanence (also presented in chapter 16), and preparation of magnetostratigraphies (presented in chapter 19).

Twelve sites were selected from the Wanganui River Section for their varying textural nature and thin sections prepared from cored samples of the lithology. These sediment plugs were first vacuum impregnated using a system developed by Dr. Warren Dickinson at VUW. Resin is introduced to the sample while it is already in a vacuum ensuring that air bubbles are not trapped within the pore spaces by the resin that is penetrating them. Thin sections were prepared by hand.
Several sediment cores were used from five of the sites selected for thin sectioning. Magnetic Grain separates were prepared using the Frantz electromagnetic separator both for rock magnetic studies and later for microprobe analysis. To prepare the magnetic grain separates, the cores were dried at $40^{\circ} \mathrm{C}$ and crushed between wooden blocks. Grain disaggregation was completed by suspending the resulting sediment in an ultrasonic tank. Once disaggregated, each sample was wet sieved at both 30 and 60 microns. The 30-60 micron fraction was retained as this was found to be the optimal size for magnetic grain segregation using the Frantz electromagnetic separator. Initially the sample was passed through the separator at a high amperage to remove all non electromagnetic material from the separate. Then the sample was re-run using progressively lower amperages, the separates becoming progressively more naturally magnetic. The five most magnetic separates were suspended in Yoohoo glue in a perspex cylinder for rock magnetic experiments (see chapter 18). Once these experiments were complete, the plugs were thin sectioned and prepared for electron microprobe analysis to combine observations on magnetic properties and mineralogy.

To understand the opaque mineral petrology, three different laboratory techniques were used; Optical thin section study, X-ray diffraction analysis and Electron microprobe analysis and analysis. The textural nature of the 
samples ranges from sandy mudstone, to slightly sandy mudstone and therefore analytical techniques were needed that would allow the petrography and mineralogy of the silt and clay sized particles to be determined.

\subsection{Petrography}

Sediments are composed of $20-70 \%$ detrital grains and 70-20\% matrix, with the remaining $10 \%$ being generally calcite cement. In rare samples, for example reef horizons and shell limestones, calcite content is more than $50 \%$. These rock types are less than $1 \%$ of the stratigraphic sections studied and are not assessed separately here. Optically, the matrix of the sediments contains finely divided muscovite and sericite. Other minerals are present, but it is difficult to distinguish them with the optical microscope. X-ray diffraction analysis and back-scattered electron imaging of matrix fractions of the sediments show that they are predominantly very fine quartz and feldspar (plate 17.1). The sediments are typically composed of $\sim 80 \%$ silicates and about $10 \%$ opaques (this includes the matrix fraction), with the remaining $10 \%$ calcite, typically as foraminifer tests (Plate 17.4).

\section{Quartz}

These are colourless in plane-polarised transmitted light and exhibit low interference colours in cross-polarised transmitted light. In reflected light both

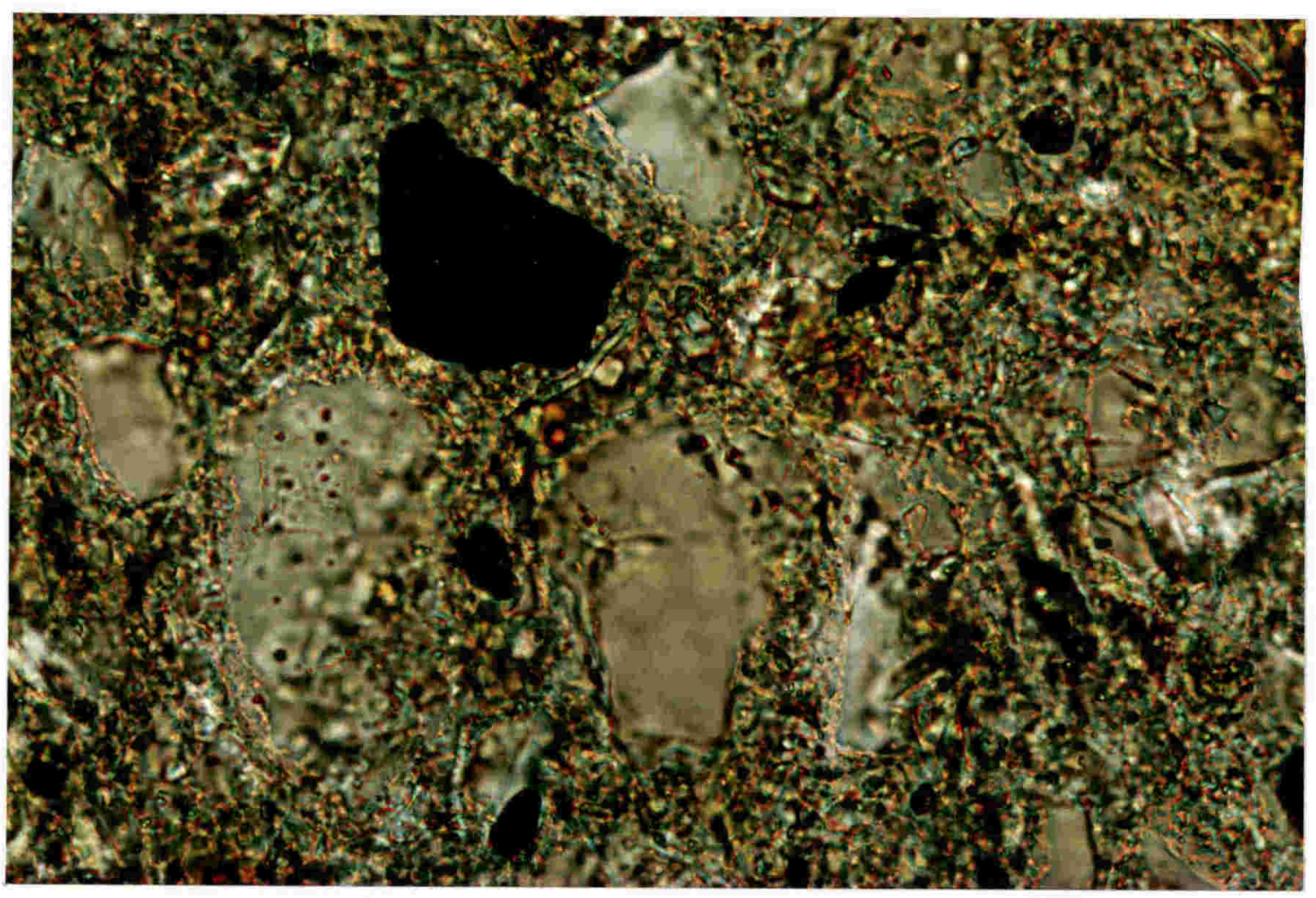

Plate 17.1: Transmitted light (crossed-nicols) photomicrograph of South Wanganui Basin sediment. Opaque grains are oxides. Large dull grey grains are quartz and feldspar grains. Matrix is fine quartz, feldspar, muscovite and sericite (frame of view is $0.1 \mathrm{~mm}$ tall). 
quartz and feldspar grains and matrix exhibit a dull grey colour with a poorly metallic lustre in reflected light. The grains are subangular to subrounded, pitted, often have inclusions and are sometimes fractured (plate 17.2). They have low relief, low birefringence, exhibit no cleavage, are uniaxial, and in basal sections a positive optic figure is commonly observed. It is one of the most common minerals observed in the present study of South Wanganui Basin sediments.

\section{Feldspar}

In reflected light feldspar grains are optically very similar to quartz grains. In cross-polarised transmitted light they commonly exhibit simple twinning, typical of plagioclase, and occasionally cross-hatched twinning, typical of microcline. Like Quartz, the grains are typically subrounded to subangular and are easily distinguished by their obvious cleavage and solution weathering. Fracturing and solution weathering are commonly developed preferentially along the cleavage. Optically the feldspars are of low relief, and biaxial, with both positive and negative optic figures observed in basal sections. Interference colours are very low in cross polarised light.

\section{Muscovite}

Compared to quartz and feldspar muscovite is of minor occurrence in the Wanganui Basin sediments. It occurs as matrix restricted phase, and although a less common mineral it is ubiquitous (Plates 17.1 and 17.4). Optically, the muscovite is colourless and transparent in plane polarised transmitted light and exhibits high order birefringence in cross-polarised transmitted light.

\section{Titanite}

Titanite as rare rounded and yellowbrown to semi-opaque grains (plate 17.3). These exhibit very high relief and very high birefringence in crosspolarised transmitted light.

\subsubsection{Non-Silicates}

\section{Calcite}

Calcite is common in South Wanganui Basin sediments, both as foraminiferal tests and as a secondary cement phase in the matrix. Optically it is colourless in plane polarised light, but can be very pale yellow. It gives the matrix very high speckled birefringence in cross polarised light. Skeletal form of foraminiferal tests is clearly visible and they are commonly associated with pyrite framboids (Plate 17.4).

\subsubsection{Oxides}

\section{Titaniferous Magnetite}

Occurrences of Ti-magnetite in South Wanganui Basin sediments are not common. Grains tend to be subangular, square or diamond shaped, with pitted 


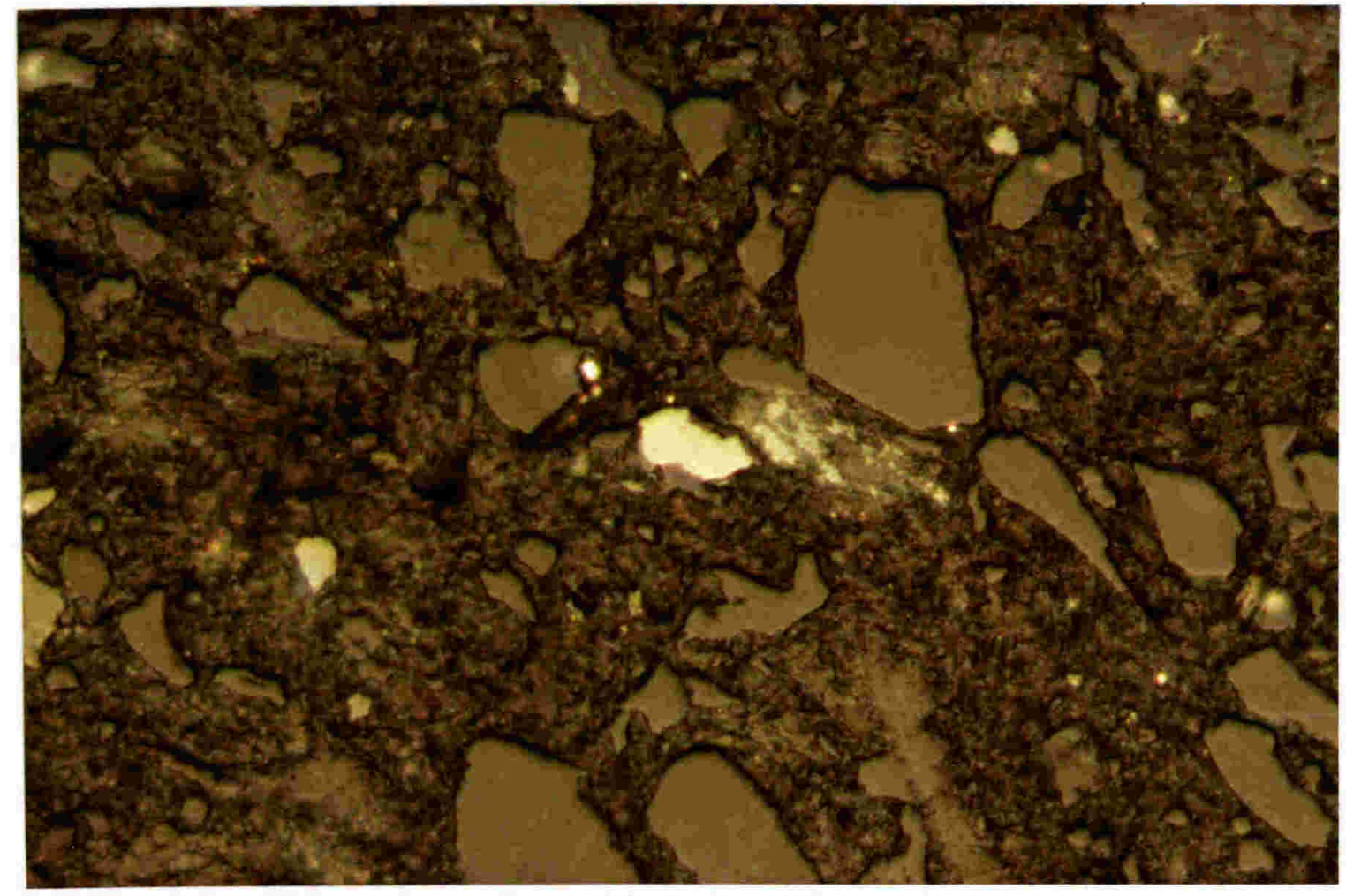

Plate 17.2: Reflected light (crossed-nicols) photomicrograph of South Wanganui Basin sediment. Large subangular to subrounded browny grey, pitted grains are quartz. Shiny, brassy coloured grains are oxides and sulphides (frame of view is $0.1 \mathrm{~mm}$ tall).

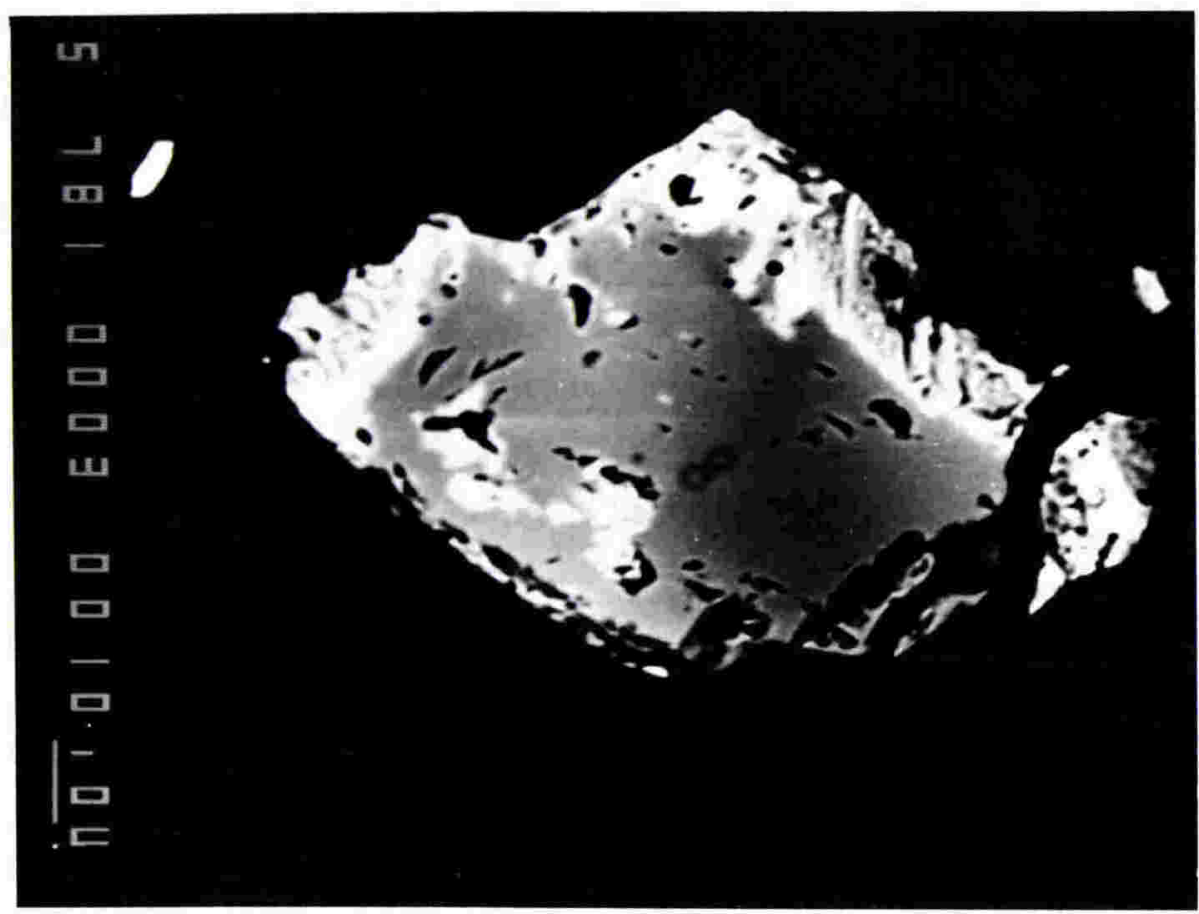

Plate 17.3: A backscattered electron image (BEI) of a single titanite grain. Note the Ti rich grain rim. (scale bar is 10 microns). 


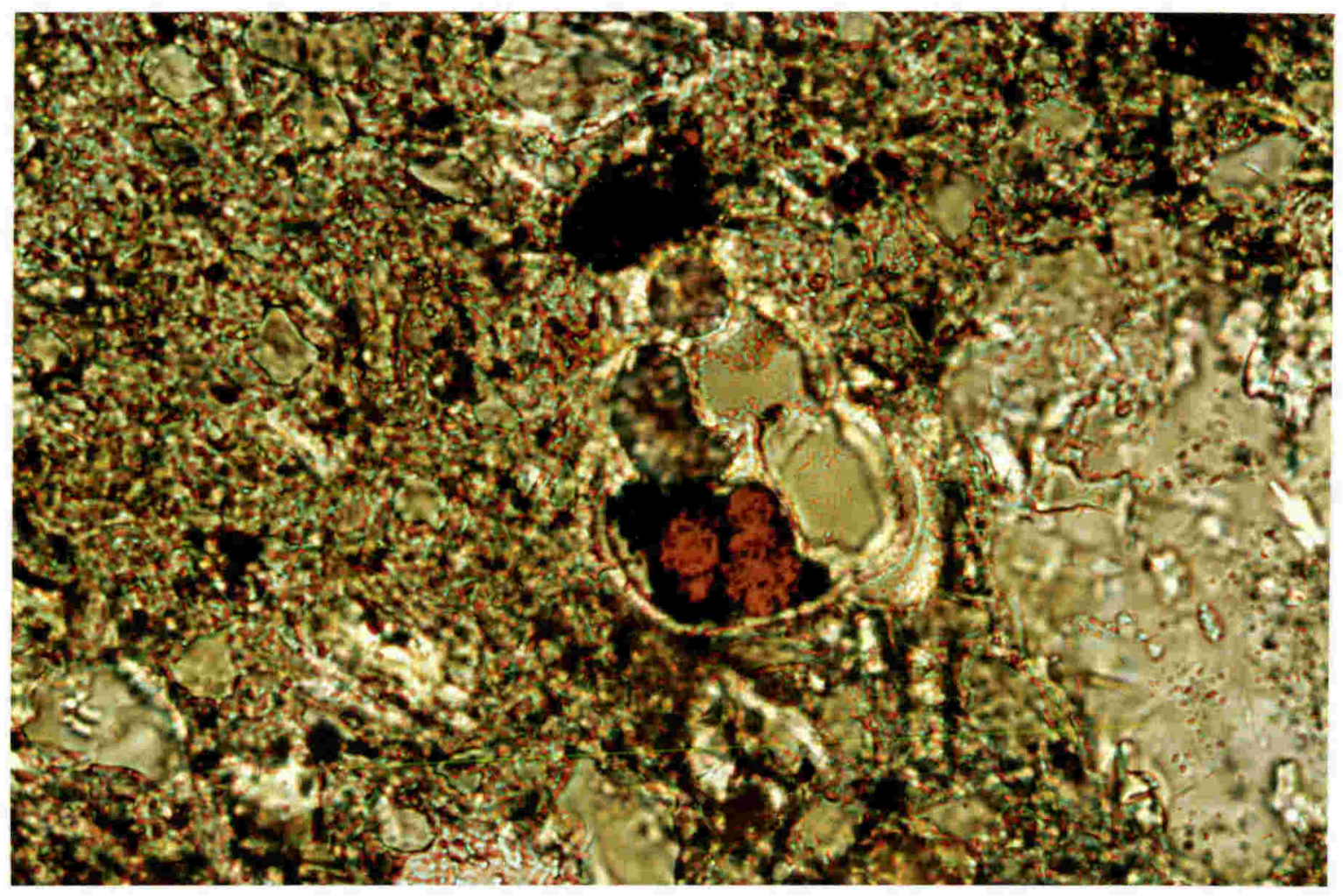

Plate 17.4: Transmitted and reflected light (crossed-nicols) photomicrograph of pyrite framboids formed within a foraminifera test. Framboids are a dull brassy colour and calcite has high fourth order birefringence. (frame of view is $0.1 \mathrm{~mm}$ tall).

surfaces, and commonly display extensive solution weathering. Optically they are opaque in transmitted light and a dark blue-grey colour with a metallic lustre in reflected light. The grains have a similar colour to ilmenite in reflected light but they are not pleochroic.

\section{Haematite}

Haematite is a ubiquitous authigenic mineral in coarser grained sediments, that often appear iron stained. Haematite fills pore spaces between matrix grains (Plate 17.5). The grain size of haematite is less than 3 microns and too small for electron microprobe analysis. Optically, the haematite is an iridescent red, and quite translucent in transmitted light. It is a bright white colour in reflected light. Apart from infilling pore space, haematite is commonly associated with pyrite framboids, as an alteration product coating pyrite grains (plate 17.6).

\section{IImenite}

Ilmenite is the most common oxide in the South Wanganui Basin sediments. Grains are angular to sub-angular and they are commonly elongate, layered and fragmented (plates 17.7 and 17.8). Surfaces vary from being uniform and unblemished to pitted and fractured (Plate 17.9). Optically the ilmenite grains are opaque in transmitted light and dark with a metallic lustre in reflected light. They have a weak pleochroism, that 


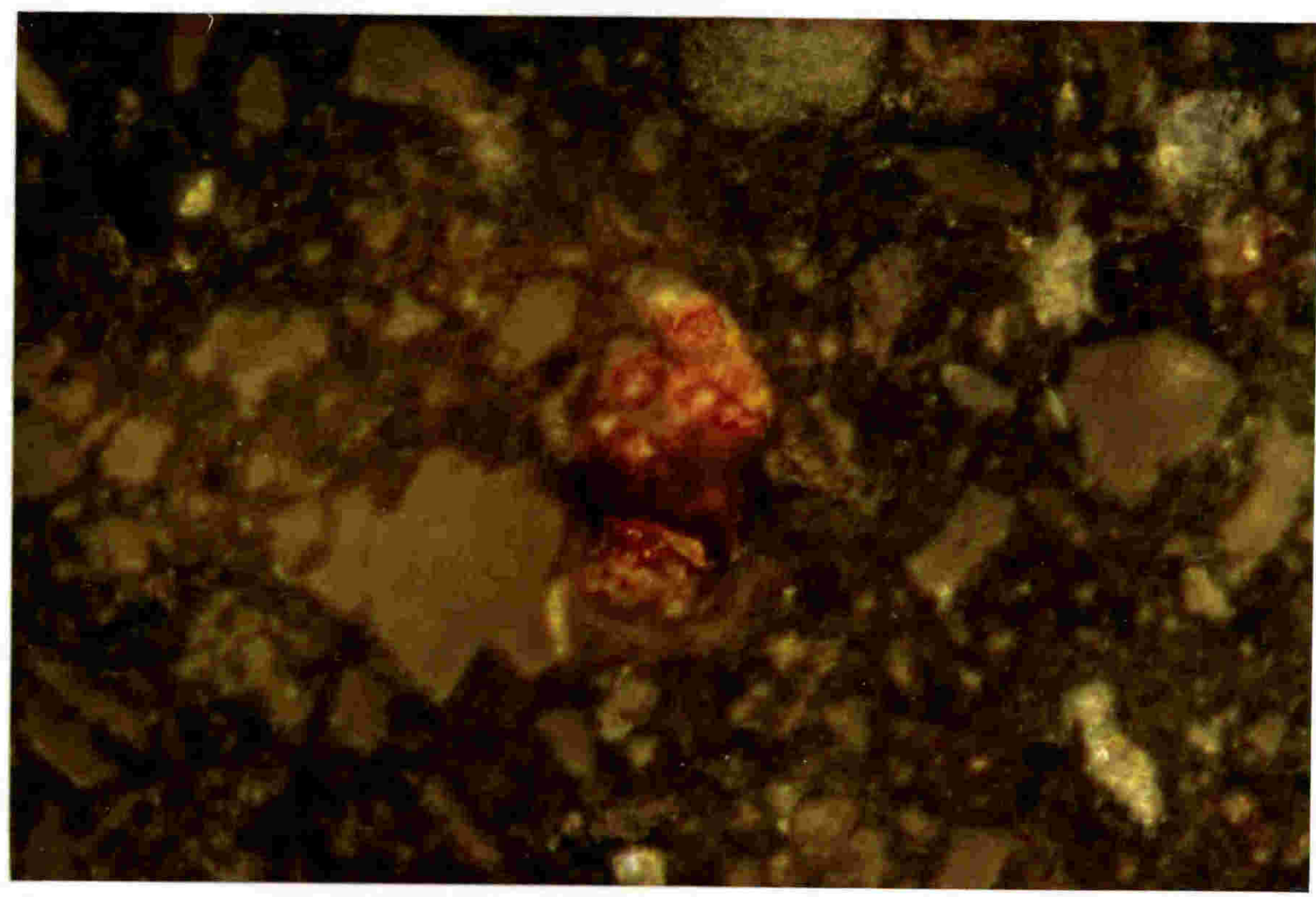

Plate 17.5: Reflected light (crossed-nicols) photomicrograph of microcrystalline haematite grains filling available pore spaces in South Wanganui Basin sediment. Haematite is translucent to opaque red in the centre of the frame (frame of view is $0.1 \mathrm{~mm}$ tall).

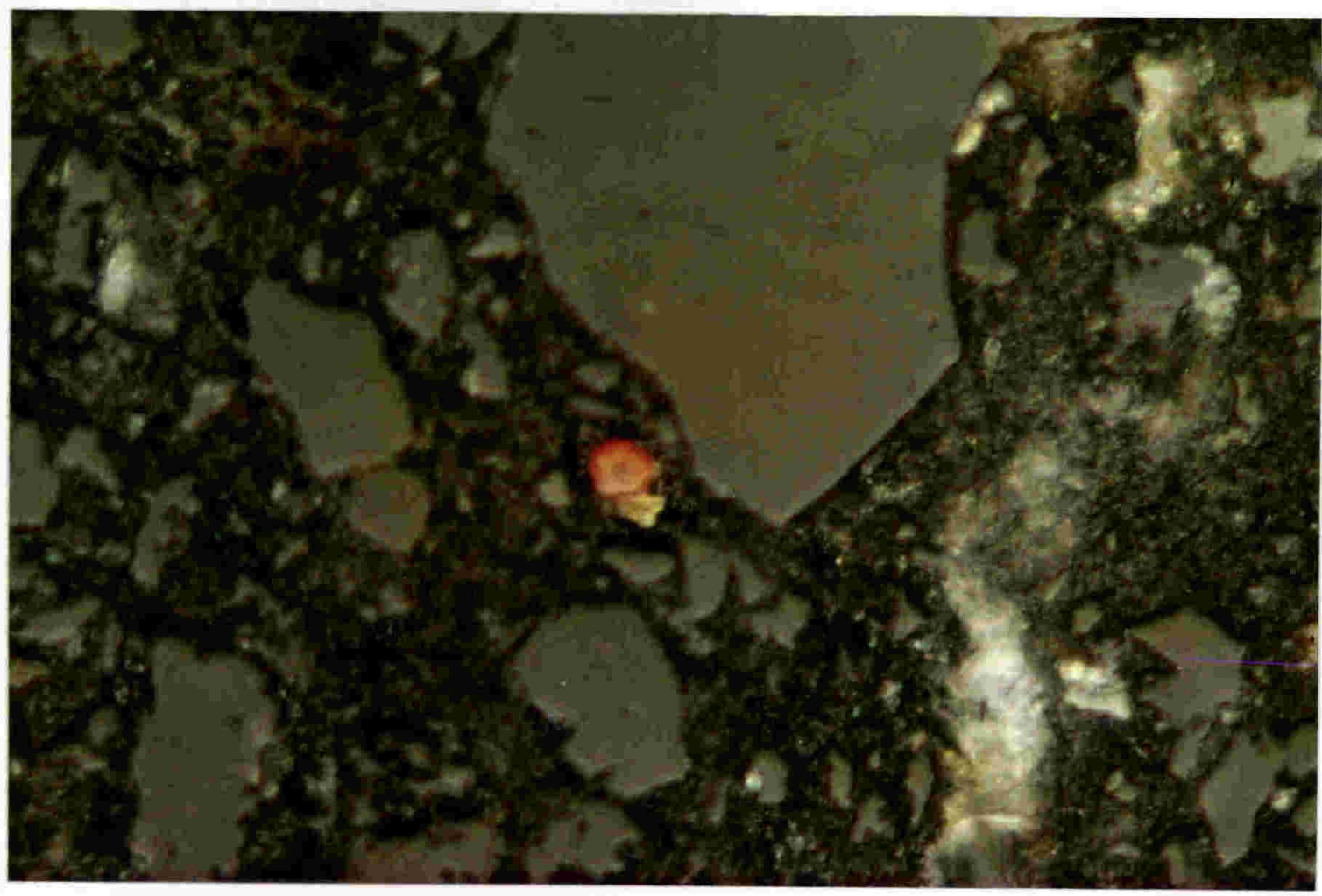

Plate 17.6: Transmitted and reflected light (crossed-nicols) photomicrograph of haematite coating pyrite framboids as an alteration product, from late stage oxidation (centre of frame). Haematite is translucent to opaque red and pyrite is brassy light-yellow (frame of view is $0.1 \mathrm{~mm}$ tall). 


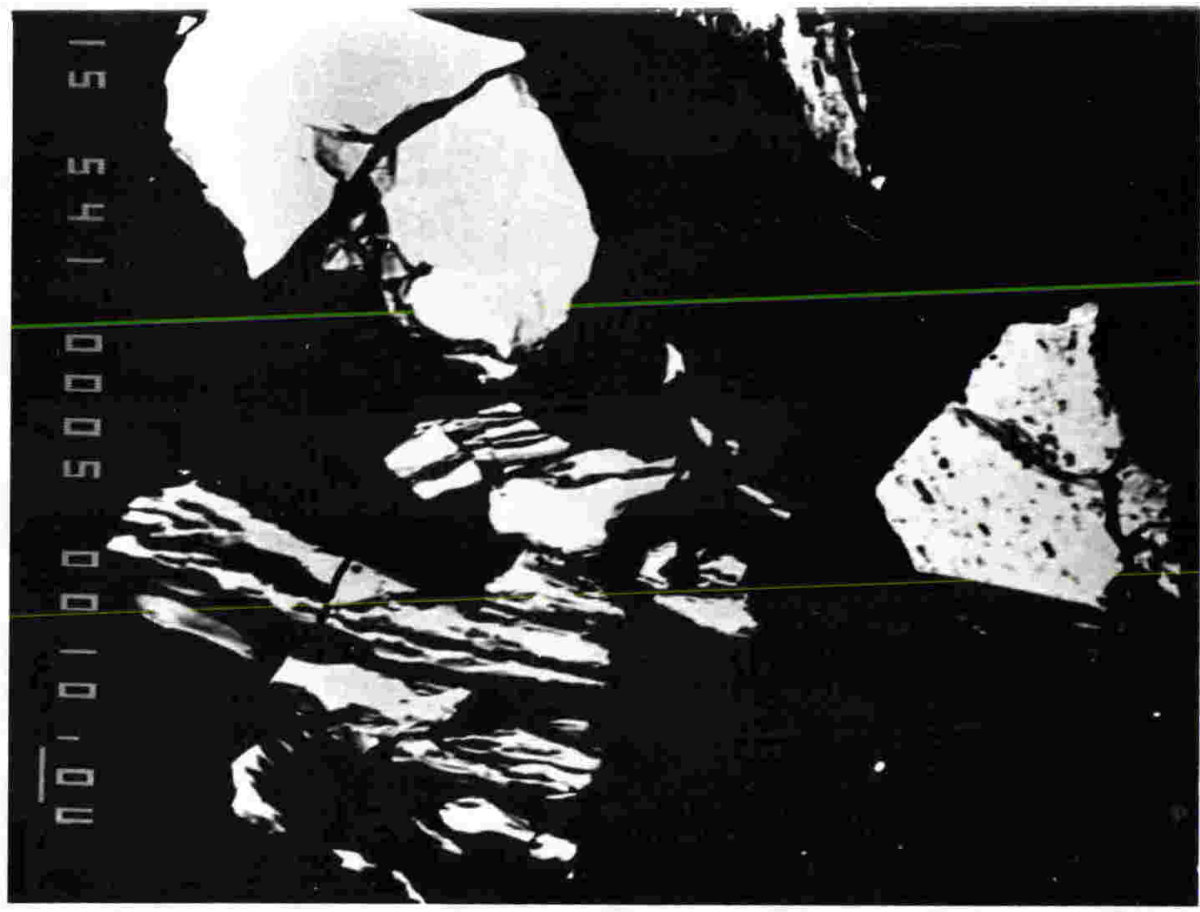

Plate 17.7: A backscattered electron image (BEI) of different ilmenite grains. Note exsolution pitting and weathering along cleavage and fracture planes (scale bar is 10 microns).

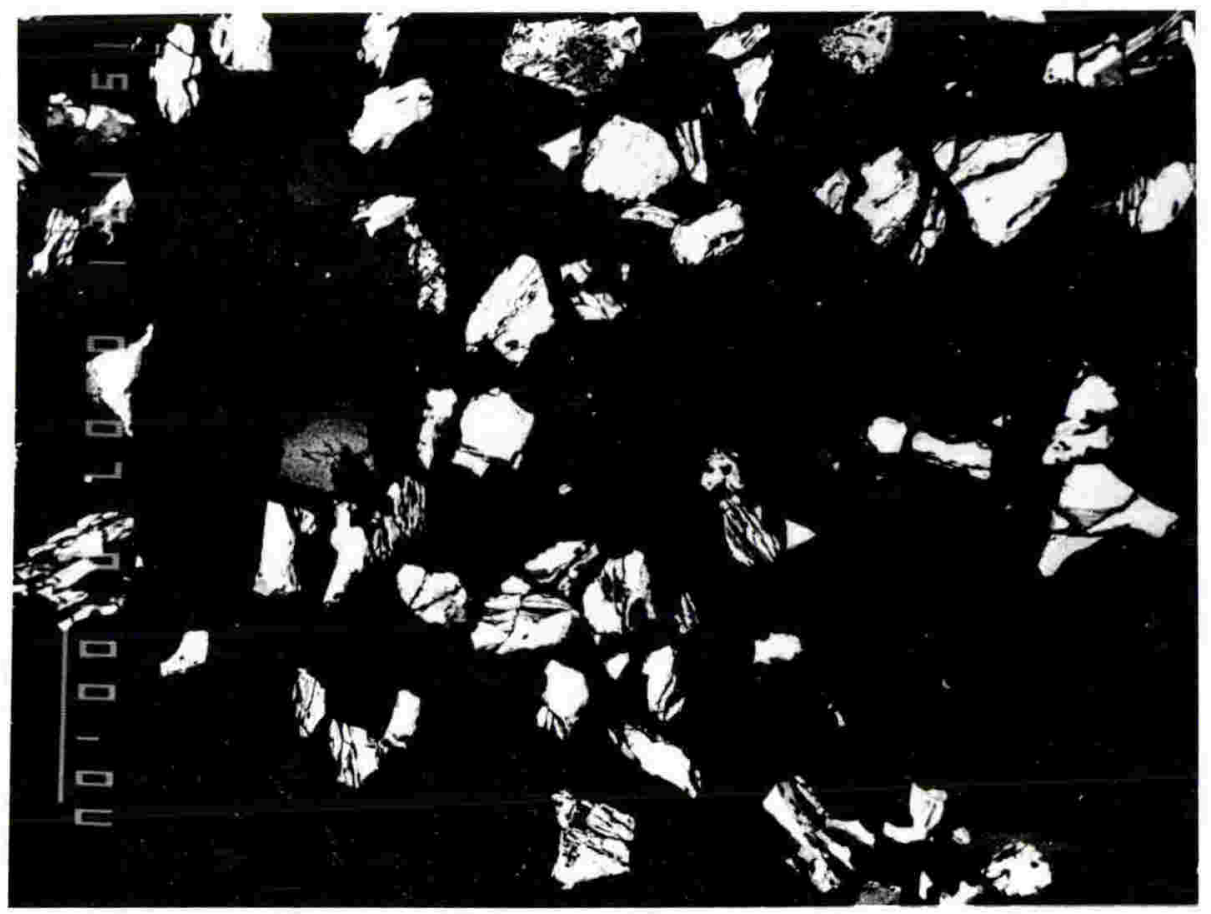

Plate 17.8: A backscattered electron image (BEI) of different ilmenite grains, showing the ubiquitous occurrences of them in the magnetic grain extracts. Note exsolution pitting and weathering along cleavage and fracture planes (scale bar is 100 microns). 
dist nguishes it from titaniferous magnetite.

\section{Chromite}

Chromite (sensu stricto) is very rare in Wanganui Basin sediments, but chromium rich minerals are a more common. The chromite grains are square in shape with high relief (plate 17.10). They are opaque in transmitted light sometimes with translucent margins. They are hard to distinguish from titaniferous magnetite, but are possibly brighter under reflective light.

\subsubsection{Sulphides}

Pyrite

Pyrite is ubiquitous as framboidal granules and cubes (Plate 17.11). Individual grains are less than 5 microns, opaque in transmitted light and brassy yellow with a metallic lustre in reflected light. Framboids are commonly formed within and surround foraminiferal tests. Pyrite framboid surfaces are often altered to haematite.

\subsection{Mineral Chemistry}

Chemical analyses were undertaken to determine the composition of the oxide and sulphide minerals most likely to contribute to the magnetic signal of the sediments. Both thin sections and magnetic separates were prepared for analysis using a JEOL 733 electron probe microanalyser (EMPA) in the Analytical Facility, Victoria University of Wellington. Magnetite and Ti-magnetite were not detected in either optical, microprobe, or X-ray diffraction analyses of magnetic separates of sediments. Roberts (1990) identified iron

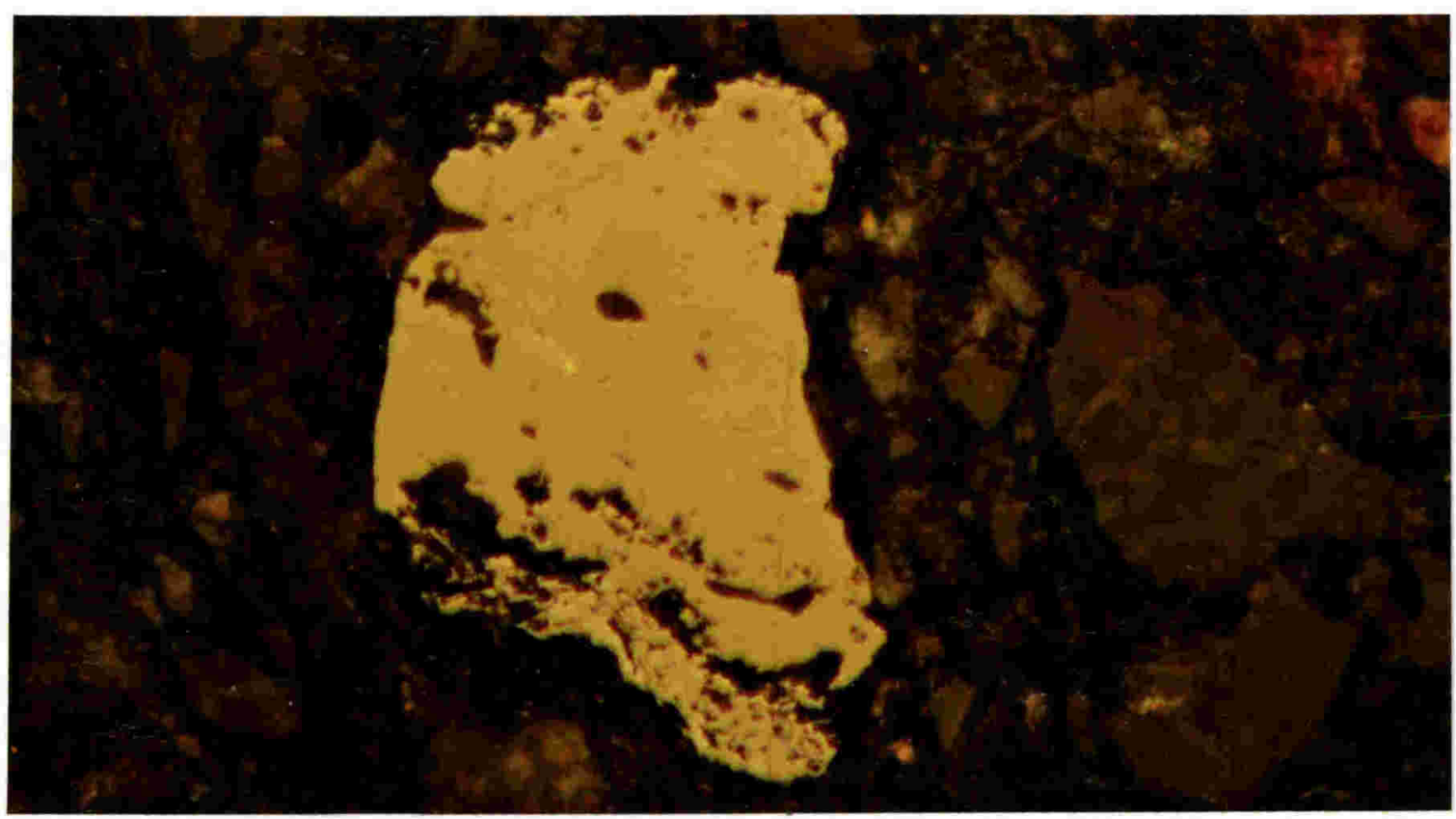

Plate 17.9: Reflected light (crossed-nicols) photomicrograph of large ilmenite grain. Ilmenite is dull, metallic, brassy-yellow and shows well developed solution weathering along grain weakness planes (frame of view is $0.1 \mathrm{~mm}$ tall). 


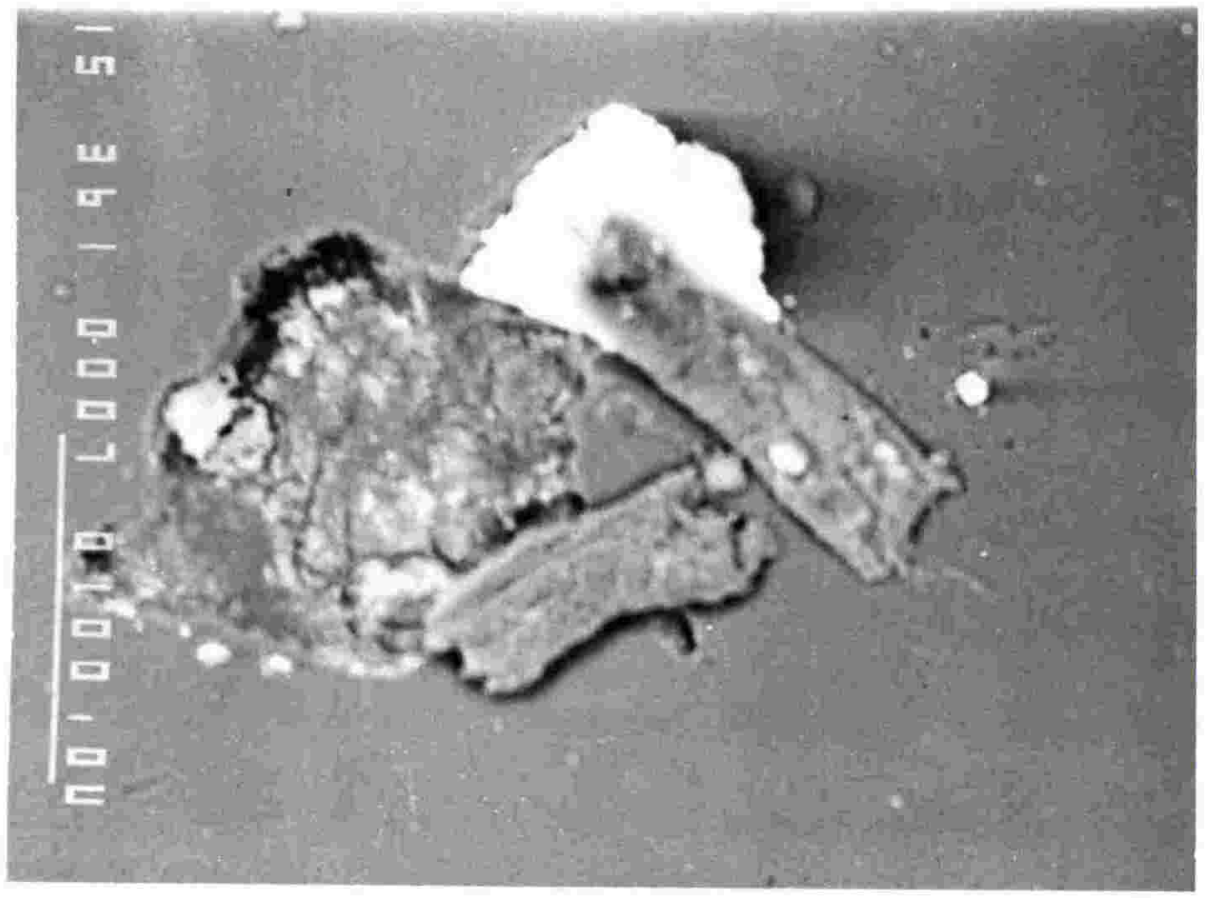

Plate 17.10: A backscattered electron image (BEI) of chromite. Chromite grain is the very bright, late phase mineral holding several feldspar grains together (scale bar is 100 microns).

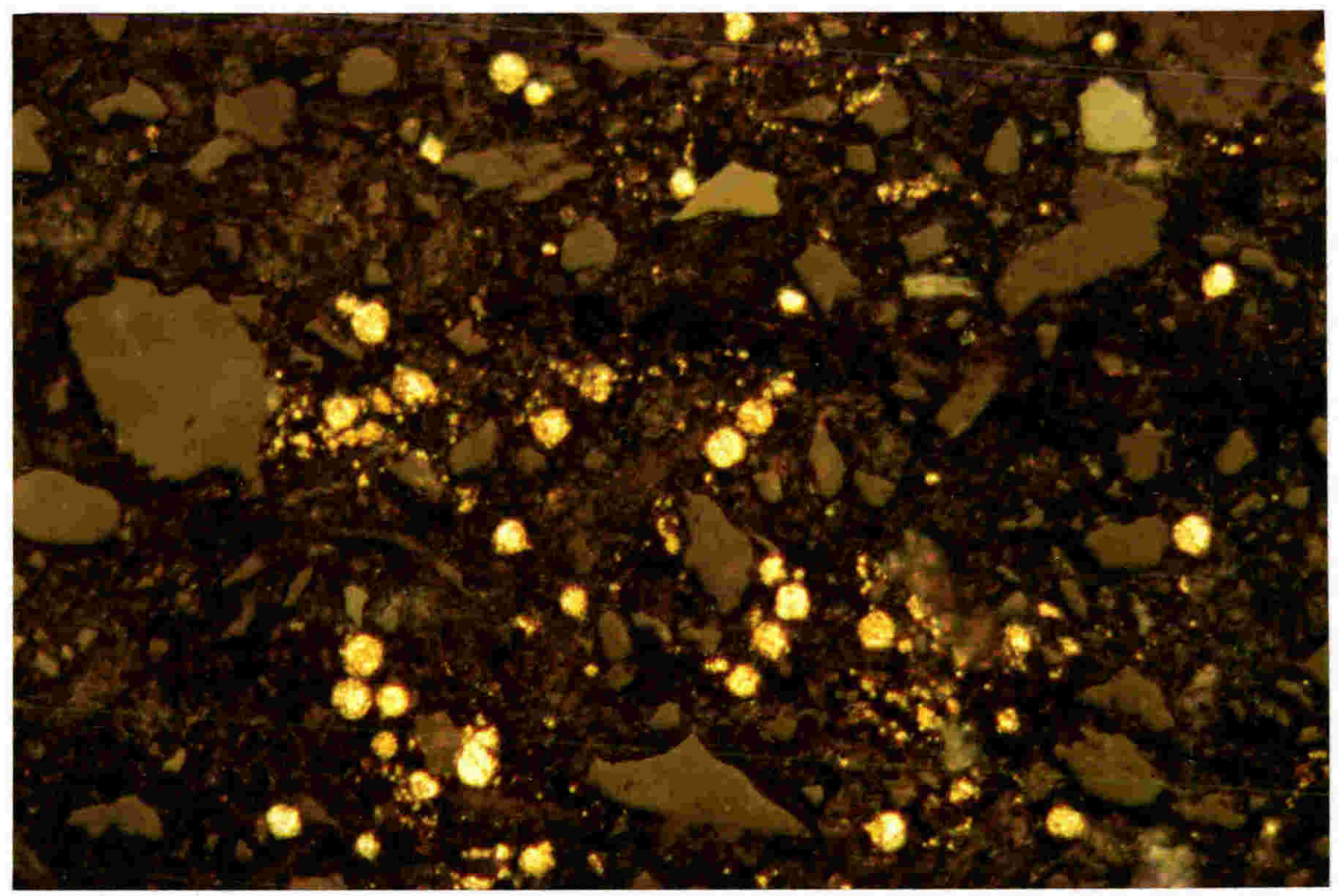

Plate 17.11: Reflected light (crossed-nicols) photomicrograph of South Wanganui Basin sediment, showing ubiquity of brassy yellow pyrite framboids (frame of view is $0.1 \mathrm{~mm}$ tall). 
oxides and iron sulphides as possible remanence carriers in Tertiary Strata of Marlborough. McGuire (1989) suggested iron sulphides were possible holders of remanence in South Wanganui Basin sediments. The present study identified chromite in the South Wanganui Basin sediments and chromite (sensu stricto) is known to be magnetic (Deer et al., 1989).

\subsubsection{Titaniferous Haematites}

All iron-titanium oxides in both thin sections and magnetic separates were analysed to determine individual grain phase relationships find out whether magnetite and Ti-magnetite occurs as single and/or composite grains. Analyses of rhombohedral phase oxides (ilmenite haematite solid solution series (Buddington and Lindsley, 1964)) were

Table 17.1: EMPA analyses of single individual homogeneous ilmenite grains

\begin{tabular}{lrrrrrrrrrr}
\hline $\mathrm{SiO} 2$ & 0.09 & 0.09 & 0.04 & 0.01 & 0.12 & 0.14 & 0.06 & 0.00 & 0.00 & 0.00 \\
$\mathrm{TiO} 2$ & 48.83 & 52.50 & 49.99 & 49.84 & 52.50 & 50.41 & 49.42 & 50.25 & 52.43 & 49.51 \\
$\mathrm{Al2O} 3$ & 0.05 & 0.05 & 0.00 & 0.00 & 0.16 & 0.10 & 0.14 & 0.05 & 0.06 & 0.07 \\
$\mathrm{FeO}$ & 41.40 & 39.52 & 41.94 & 38.37 & 36.78 & 38.70 & 42.43 & 43.56 & 45.65 & 42.14 \\
$\mathrm{Fe} 2 \mathrm{O} *$ & 7.09 & 0.49 & 6.83 & 6.48 & 0.92 & 4.43 & 7.96 & 2.59 & 0.83 & 0.88 \\
$\mathrm{MnO}$ & 2.09 & 6.58 & 2.72 & 5.83 & 9.35 & 6.44 & 2.04 & 1.38 & 1.37 & 1.96 \\
$\mathrm{MgO}$ & 0.25 & 0.07 & 0.11 & 0.22 & 0.04 & 0.06 & 0.08 & 0.11 & 0.01 & 0.20 \\
$\mathrm{CaO}$ & 0.04 & 0.71 & 0.06 & 0.06 & 0.70 & 0.06 & 0.05 & 0.03 & 0.01 & 0.03 \\
$\mathrm{NiO}$ & 0.00 & 0.10 & 0.04 & 0.09 & 0.14 & 0.10 & 0.01 & 0.00 & 0.08 & 0.00 \\
& & & & & & & & & & \\
\hline TOTAL & 99.84 & 100.11 & 101.72 & 100.90 & 100.71 & 100.43 & 101.99 & 97.97 & 100.44 & 100.79 \\
\hline \hline & & & & & & & & & & \\
(total FeO & 47.78 & 39.96 & 48.08 & 44.20 & 37.61 & 42.68 & 49.39 & 45.89 & 46.40 & 48.33 ) \\
\hline \% Ilmenite & 93.04 & 99.50 & 93.39 & 93.43 & 99.02 & 95.46 & 92.37 & 97.44 & 99.20 & 93.33 \\
\hline
\end{tabular}

\begin{tabular}{lrrrrrrrrrr}
\hline $\mathrm{SiO} 2$ & 0.06 & 0.03 & 0.05 & 0.04 & 0.06 & 0.07 & 0.07 & 0.00 & 0.04 & 0.01 \\
$\mathrm{TiO} 2$ & 50.71 & 49.68 & 46.70 & 49.70 & 48.14 & 49.11 & 49.25 & 49.45 & 49.01 & 51.63 \\
$\mathrm{Al} 2 \mathrm{O} 3$ & 0.01 & 0.04 & 0.07 & 0.07 & 0.11 & 0.19 & 0.07 & 0.08 & 0.05 & 0.06 \\
$\mathrm{FeO}$ & 43.39 & 43.61 & 40.61 & 41.72 & 40.42 & 38.89 & 41.89 & 38.98 & 42.18 & 45.46 \\
$\mathrm{Fe} 2 \mathrm{O} 3^{*}$ & 3.41 & 6.70 & 11.87 & 5.93 & 8.20 & 7.13 & 6.16 & 7.23 & 7.99 & 3.60 \\
$\mathrm{MnO}$ & 1.84 & 0.87 & 0.35 & 2.58 & 2.48 & 5.04 & 2.01 & 4.96 & 0.68 & 0.60 \\
$\mathrm{MgO}$ & 0.20 & 0.06 & 0.60 & 0.11 & 0.11 & 0.10 & 0.25 & 0.05 & 0.68 & 0.16 \\
$\mathrm{CaO}$ & 0.02 & 0.04 & 0.00 & 0.05 & 0.00 & 0.06 & 0.00 & 0.29 & 0.03 & 0.07 \\
$\mathrm{NiO}$ & 0.04 & 0.06 & 0.02 & 0.15 & 0.24 & 0.00 & 0.00 & 0.00 & 0.00 & 0.00 \\
& & & & & & & & & & \\
\hline TOTAL & 99.68 & 101.09 & 100.27 & 100.35 & 99.76 & 100.58 & 99.70 & 101.04 & 100.66 & 101.59 \\
\hline \hline & & & & & & & & & & \\
(total FeO & 46.46 & 49.64 & 51.29 & 47.06 & 47.80 & 45.30 & 47.43 & 45.49 & 49.37 & 48.70 ) \\
\hline \% Ilmenite & 96.66 & 93.61 & 88.55 & 94.18 & 91.90 & 92.82 & 93.96 & 92.75 & 92.30 & 96.59 \\
\hline
\end{tabular}

*recalculated after method of Stormer (1983) 


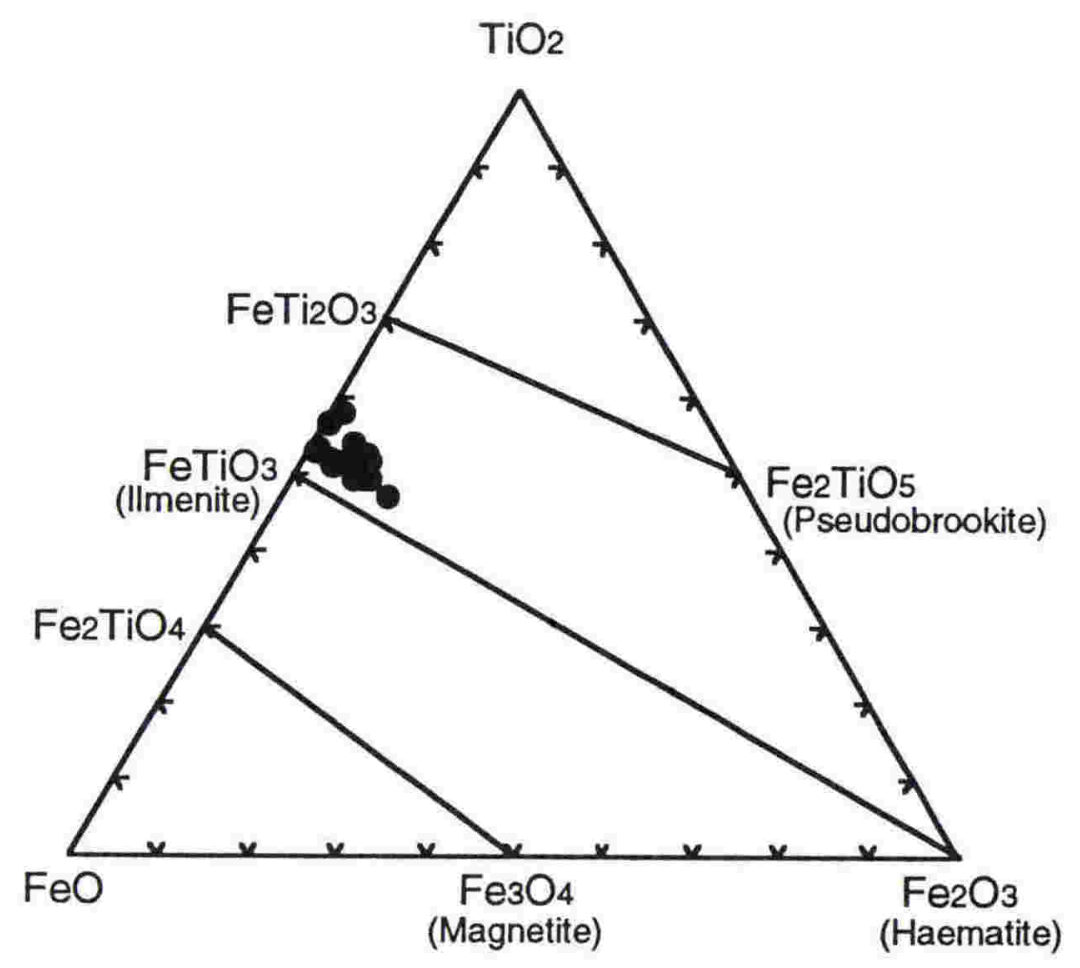

Figure 17.1: The iron-titanium oxide ternary system with distributions plotted for typical individual ilmenites grains analysed from south Wanganui Basin. Compositions were determined using the method of Stormer (1983). Plots appear rich in $\mathrm{TiO}_{2}$ because they contain up to $6.5 \mathrm{MnO}$.

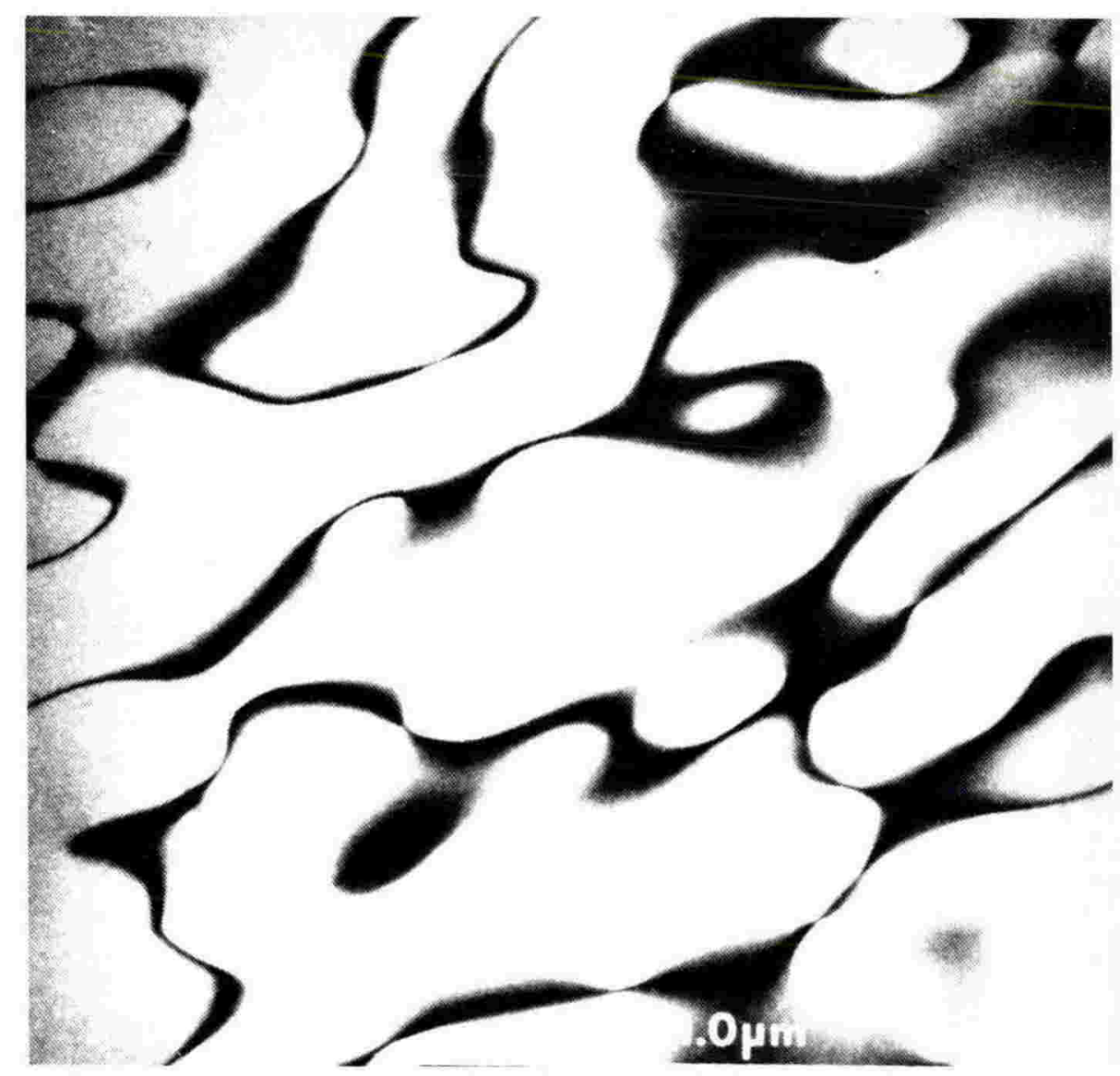

Plate 17.12: Dark-field transmission electron microscope image of ilmenite. Light regions are Fe-poor domains and dark regions are Fe-rich domain boundaries (X-phase) from Lawson and Nord (1984); figure 3. 
recalculated to determine $\mathrm{Fe}^{2+}$ to $\mathrm{Fe}^{3+}$ ratios. Representative EMPA analyses are presented in table 17.1. No spinel phase oxides (ulvospinel - magnetite solid solution series (Buddington and Lindsley, 1964)) were observed. All grains consisted of ilmenite-haematite solid solutions with between $47 \%$ - $52 \%$ $\mathrm{TiO}_{2}$, and close to pure ilmenite stoichiometry (figure 17.1). Ilmenite contained up to $10 \% \mathrm{MnO}$. Recalculation of the analyses to determine the $\mathrm{Fe}^{2+}$ to $\mathrm{Fe}^{3+}$ ratio indicates that the ilmenite composition varies between $\operatorname{Ilm}_{(88-99)} \operatorname{Hem}_{(12-1)}$ (figure 17.1). The lack of magnetite and Timagnetite explains the weakness of magnetic remanence in the South Wanganui Basin sediments compared to other New Zealand Tertiary sediments. Many early palaeomagnetic workers believed ilmenite to be paramagnetic (eg; Nagata, 1961; McElhinny, 1973) and this view has been adopted by Roberts (1990), and Roberts and Turner (1993) when discussing the magnetic mineralogy of Tertiary sediments in New Zealand.

Synthetic experiments by Carmichael, (1961); Westcott-Lewis and Parry (1971) and Burton (1985) have identified the potential of Ti-haematite to hold a magnetic remanence. These studies indicate the presence of Fe-rich exsolution domains within grains. Such domains and lamellae are clearly visible using transmission electron microscopy (TEM) electron backscattered imaging (EBI) (plate 17.12). It was not possible to establish directly whether grains of ilmenite from South Wanganui Basin samples exhibit this exsolution behaviour, but this behaviour is expected.

\subsubsection{Sulphides}

The only sulphide found in the sediments is pyrite. EMPA were undertaken to establish whether exsolution phases of pyrrhotite or greigite were present within pyrite as these phases have been shown or suggested to hold magnetic remanence (Robertson, 1963; Kobayashi and Nomura, 1972; McGuire, 1989; Roberts, 1990; Lowrie, 1990; and Roberts and Turner, submitted). Representative analyses of pyrite from the south Wanganui Basin sediments are presented in table 17.2. All forms of pyrite were found to be homogeneous, with the highest iron to sulphur ratio being 1:1.93. Pyrrhotite stoichiometry has an iron to sulphur ration of $1: 1.33$. Scanning electron microscopy was used to identify possible exsolution phases within pyrite grains. Within the resolution of the electron beam no exsolution phases were identified. Pyrite is known to be paramagnetic (Roberts and Turner, submitted) within the strength of the earth's magnetic field and the measuring limits of cryogenic magnetometers.

\subsubsection{Chromites.}

Chromite is rare in sediments from the South Wanganui Basin. It is generally associated with other oxides grains or more rarely as individual grains. 
Table 17.2: EMPA analyses of single individual pyrite grains

\begin{tabular}{|c|c|c|c|c|c|c|c|c|c|c|c|}
\hline$\overline{\mathrm{Fe}}$ & 46.02 & 46.28 & 46.62 & 46.85 & 45.16 & 47.52 & 47.10 & 46.25 & 44.17 & 45.06 & 45.66 \\
\hline $\mathrm{Mn}$ & 0.01 & 0.00 & 0.00 & 0.03 & 0.35 & 0.03 & 0.15 & 0.07 & 0.49 & 0.02 & 0.00 \\
\hline $\mathrm{Cu}$ & 0.02 & 0.09 & 0.01 & 0.03 & 0.05 & 0.01 & 0.00 & 0.02 & 0.05 & 0.02 & 0.14 \\
\hline $\mathrm{Sb}$ & 0.02 & 0.00 & 0.03 & 0.03 & 0.06 & 0.00 & 0.04 & 0.00 & 0.01 & 0.05 & 0.02 \\
\hline As & 0.22 & 0.09 & 0.15 & 0.07 & 0.19 & 0.09 & 0.09 & 0.09 & 0.12 & 0.08 & 0.12 \\
\hline$S$ & 53.25 & 52.46 & 51.59 & 53.72 & 52.83 & 52.12 & 52.48 & 53.69 & 52.90 & 52.78 & 52.27 \\
\hline TOTAL & 99.54 & 98.91 & 98.38 & 100.72 & 98.64 & 99.77 & 99.87 & 100.12 & 97.73 & 98.00 & 98.20 \\
\hline Fe:S & $1: 2.02$ & $1: 1.97$ & $1: 1.93$ & $1: 2.00$ & $1: 2.04$ & $1: 1.91$ & $1: 1.94$ & $1: 2.02$ & $1: 2.09$ & $1: 2.04$ & $1: 1.99$ \\
\hline
\end{tabular}

\begin{tabular}{|c|c|c|c|c|c|c|c|c|c|c|c|}
\hline $\mathrm{Fe}$ & 44.56 & 45.00 & 45.70 & 46.14 & 45.91 & 45.49 & 46.67 & 45.36 & 46.41 & 46.49 & 46.42 \\
\hline $\mathrm{Mn}$ & 0.48 & 0.39 & 0.11 & 0.04 & 0.05 & 0.35 & 0.02 & 0.04 & 0.01 & 0.03 & 0.18 \\
\hline $\mathrm{Cu}$ & 0.04 & 0.07 & 0.05 & 0.12 & 0.07 & 0.09 & 0.00 & 0.05 & 0.02 & 0.02 & 0.05 \\
\hline $\mathrm{Sb}$ & 0.01 & 0.03 & 0.03 & 0.01 & 0.01 & 0.00 & 0.01 & 0.00 & 0.00 & 0.01 & 0.02 \\
\hline As & 0.10 & 0.13 & 0.12 & 0.19 & 0.07 & 0.14 & 0.08 & 0.02 & 0.06 & 0.12 & 0.16 \\
\hline S & 54.29 & 53.05 & 52.58 & 53.51 & 53.69 & 53.39 & 53.08 & 53.06 & 52.35 & 52.32 & 52.21 \\
\hline TOTAL & 99.48 & 98.66 & 98.59 & \#\#\# & 99.80 & 99.45 & 99.85 & 98.53 & 98.85 & 98.98 & 99.04 \\
\hline$e: S$ & $1: 2.12$ & $1: 2.05$ & $1: 2.00$ & $1: 2.02$ & $1: 2.04$ & $1: 2.04$ & $1: 1.98$ & $1: 2.04$ & $1: 1.96$ & $1: 1.96$ & $1: 1.9$ \\
\hline
\end{tabular}

Table 17.3: EMPA analyses of single detrital chromite grains

\begin{tabular}{|c|c|c|c|c|c|c|c|}
\hline$\overline{\mathrm{SiO} 2}$ & 0.10 & 0.13 & 0.11 & 0.05 & 0.18 & 2.51 & 0.01 \\
\hline $\mathrm{TiO} 2$ & 0.19 & 0.35 & 0.13 & 0.30 & 0.13 & 0.11 & 0.01 \\
\hline $\mathrm{A} 12 \mathrm{O} 3$ & 24.86 & 8.46 & 10.76 & 24.08 & 25.49 & 11.77 & 29.19 \\
\hline $\mathrm{FeO}$ & 21.82 & 26.98 & 27.29 & 23.92 & 19.32 & 24.32 & 16.22 \\
\hline $\mathrm{Fe} 2 \mathrm{O} 3 *$ & 2.27 & 13.06 & 15.74 & 0.46 & 7.10 & 20.35 & 0.89 \\
\hline $\mathrm{MnO}$ & 0.42 & 0.58 & 0.55 & 0.36 & 0.18 & 2.51 & 0.21 \\
\hline $\mathrm{MgO}$ & 8.95 & 2.35 & 3.80 & 8.81 & 11.04 & 7.31 & 13.02 \\
\hline $\mathrm{CaO}$ & 0.11 & 0.07 & 0.02 & 0.01 & 0.10 & 0.07 & 0.03 \\
\hline $\mathrm{Cr} 2 \mathrm{O} 3$ & 41.68 & 41.78 & 42.15 & 47.94 & 37.32 & 34.63 & 39.89 \\
\hline $\mathrm{NiO}$ & 0.11 & 0.19 & 0.08 & 0.08 & 0.17 & 0.04 & 0.21 \\
\hline $\mathrm{ZnO}$ & 0.44 & 0.56 & 0.41 & 0.48 & 0.00 & 0.00 & 0.00 \\
\hline $\begin{array}{l}\text { TOTAL } \\
\end{array}$ & 100.95 & 94.51 & 101.05 & 106.49 & 101.03 & 103.62 & 99.68 \\
\hline (total FeO & 23.86 & 38.73 & 41.46 & 24.33 & 25.71 & 42.63 & 17.02) \\
\hline \% Ulvospinel & 77.84 & 19.29 & 5.90 & 99.34 & 17.86 & 2.37 & 47.43 \\
\hline
\end{tabular}


Representative analyses are presented in table 17.3. The chromite contains between $35 \%$ to $48 \% \mathrm{Cr}_{2} \mathrm{O}_{3}, 8 \%$ to $29 \%$ $\mathrm{Al}_{2} \mathrm{O}_{3}$, and $2 \%$ to $13 \% \mathrm{MgO}$. Little is understood about the role of chromites in palaeomagnetism. Because of the magnetic nature of chromite it is assumed that $\mathrm{Cr}$-bearing magnetite will be at least as magnetic if not more so than Ti-magnetite. This has yet to be proven experimentally. However, some samples discussed in chapter 16 exhibit relatively strong NRM behaviour. Because magnetite, Ti-magnetite, pyrrhotite or greigite are not present in the sediments, chromite can be the only oxide that can hold magnetic remanence. However, both the occurrence of chromite and the presence of moderately intense NRM are rare in the South Wanganui Basin sediments.

\subsection{Diagenesis}

\subsubsection{Oxide dissolution}

All oxide phases in the South Wanganui Basin sediments exhibit exsolution, particularly the $\mathrm{Cr}$ and $\mathrm{Ti}$ poor oxides. Exsolution is particularly well developed along planes of weakness in the grains, such as pitting surfaces and cleavage (Plates 17.7 and 17.9). A possible source for the oxides is most likely to be the Taupo Volcanic Zone. Cranfield and Berner (1987) note that detrital ulvospinel, magnetite, and ilmenite are ubiquitous in marine sediments.
At continental margins with active sulphur reduction processes occurring, magnetite is commonly dissolved and iron sulphide phases remain as a biproduct of this process (Chanell et al., 1990; Chanell and Hawthorne, 1990; Bloemendal et al., 1988; Tarafa et al., 1987; Prince et al., 1980). Magnetite and Titaniferous Magnetite dissolution in marine sediments has been observed in cores recovered from the Ocean Drilling Program (Chanell et al., 1990; Chanell and Hawthorne, 1990; Bloemendal et al., 1988; Tarafa et al., 1987; Prince et al., 1980). Cranfield and Berner (1987) have documented active occurrence of this process on the eastern continental margin of the United States. They observe progressive dissolution with depth initially developing along grain weaknesses and at surface inhomogeneities. Karlin and Levi (1985) also noted etching of magnetite associated with pyrite rich environments.

In the present study magnetite has not been found in the sediments, but pyrite is ubiquitous. With dissolution of $\mathrm{Ti}$ and Cr-rich oxides, it is expected that any less resistant oxides would have been completely dissolved by sulfate reducing pore fluids. Modern sediments accumulating in the Wanganui Basin include magnetite, Ti-magnetite, haematite, and Ti-haematites (Pillans et al, submitted; Roberts and Pillans, submitted; Turner and Kamp, 1990). Measurements by Canfield and Berner (1978) suggest that dissolution and 
magnetite occurs less than 500 years after deposition.

\subsubsection{Sulphide authigenesis}

The formation of authigenic sulphides in continental margin sediments has been documented by Berner (1970); Gardner (1973); Sweeney and Kaplan (1973); Berner (1980) and Berner (1984) (figure 17.2). Authigenic pyrite formation occurs during early diagenesis from the reaction of detrital iron minerals with $\mathrm{H}_{2} \mathrm{~S}$ via a series of metastable iron sulphide phases (figure 17.3). $\mathrm{H}_{2} \mathrm{~S}$ is produced by reduction of interstitial sulphate by organic matter (also a possible sulphate source). Controlling factors appear to be the supply of dissolved sulphate, organic matter and reactive detrital $\mathrm{Fe}$-oxides in the sediments.

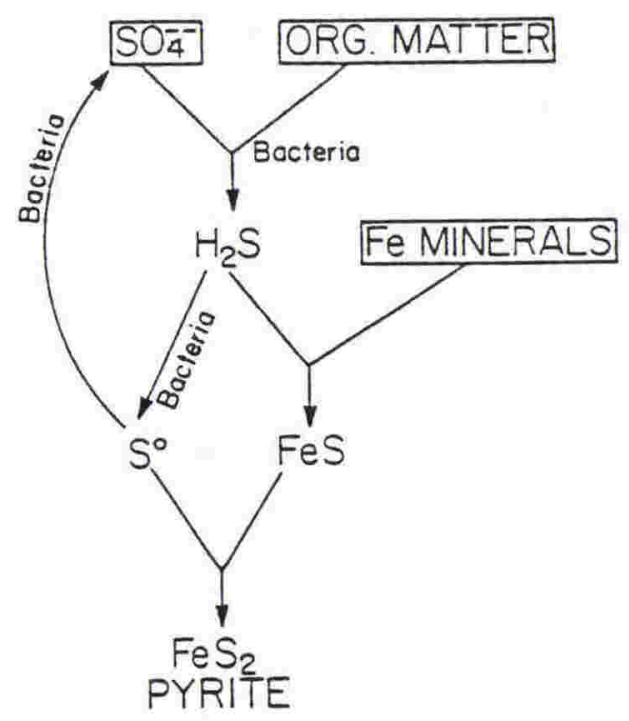

Figure 17.2: Diagrammatic representation of the overall process of sedimentary pyrite formation (after Berner, 1972).

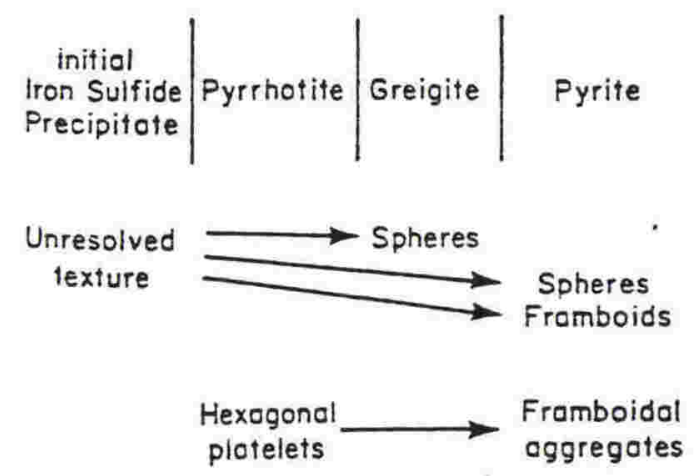

Figure 17.3 Schematic presentation of results of textures developed during sulphurisation reactions (from Sweeney and Kaplan, 1973).

In the South Wanganui Basin pyrite framboids are ubiquitous and are typically associated with organic sources and occur in pore spaces in the sediment (plate 17.13). Other sulphide phases were not observed in the present study. Roberts (1990) demonstrated the presence of greigite in Miocene sediments in Marlborough, New Zealand. Sweeney and Kaplan (1973) consider that spherical pyrite framboids are only formed by reduction of greigite spherules, and that this process occurs commonly within carbonate tests, with the tests providing the available space for the full development of pyrrhotite and greigite so that continued reduction to pyrite causes retention of the spherical form of its precursory greigite (plate 17.14). 


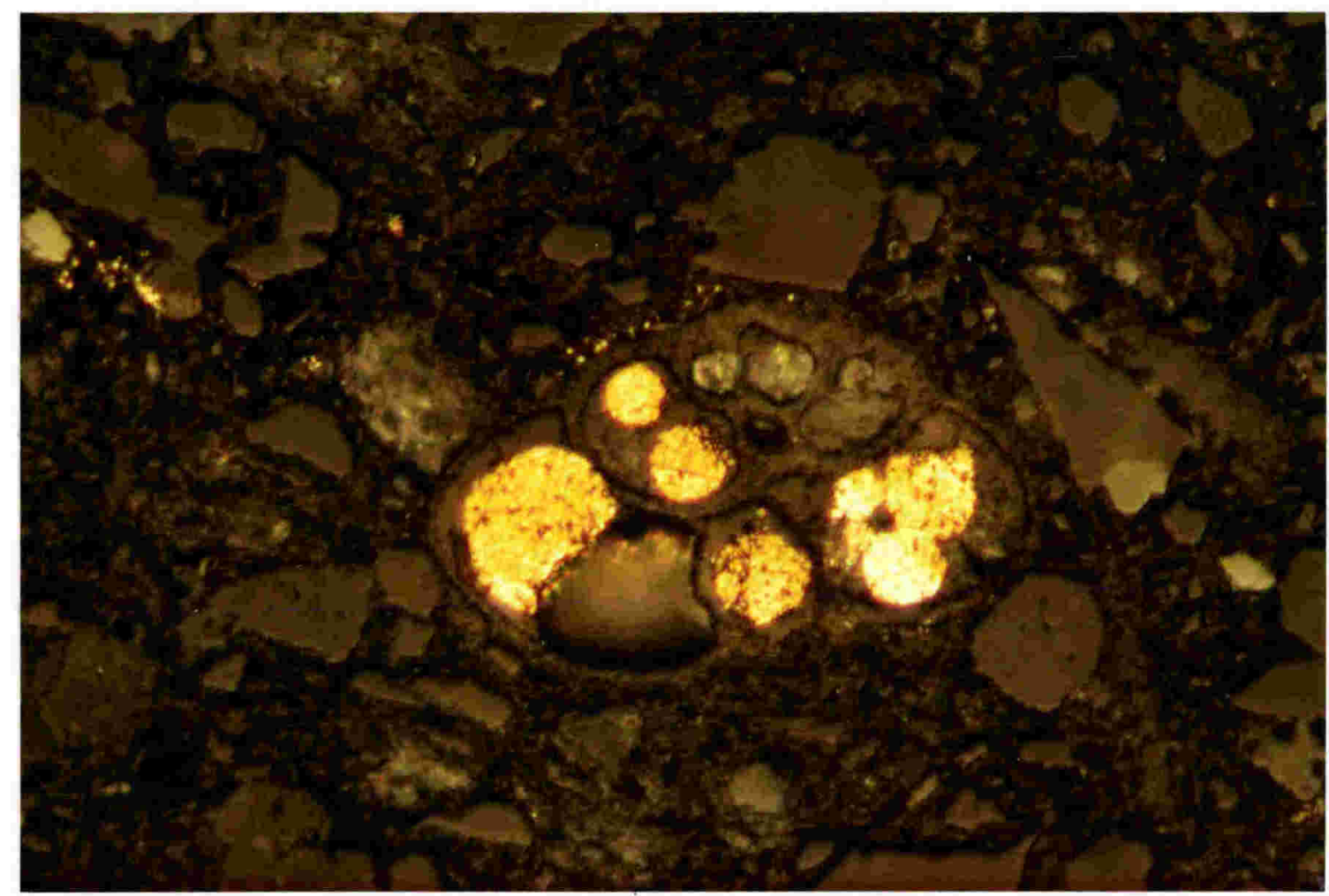

Plate 17.13 Reflected light (crossed-nicols) photomicrograph of pyrite framboids formed within a foraminifera test. Framboids are a dull brassy colour (frame of view is $0.1 \mathrm{~mm}$ tall).

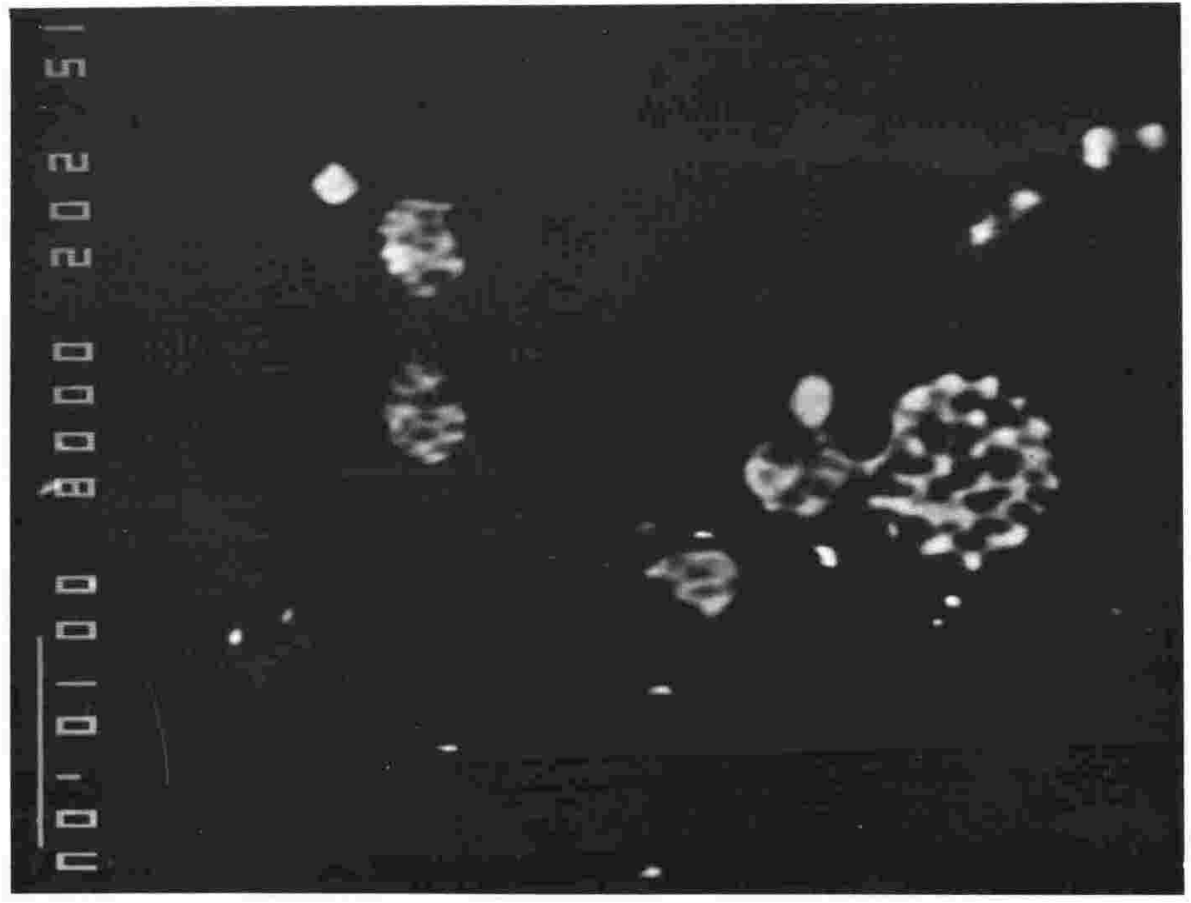

Plate 17.14: A backscattered electron image (BEI) of single pyrite framboids, showing there spherical form retained from a precursory greigite phase (scale bar is 10 microns). 


\subsubsection{Weathering oxidation}

A further phase of diagenesis observed in the present study is the late stage oxidation of the pyrite. Pyrite framboids are commonly coated with a thin $(<1$ micron thick) layer of haematite (plate
17.6). A secondary phase of $\mathrm{Fe}$ remobilisation is common in coarser grained sediments of the Wanganui Basin in the form of iron staining, a feature common in much of the Tertiary strata of New Zealand (Suggate et al., 1978). 


\section{Chapter - 18}

\section{Rock magnetism}

This part of the study was undertaken particularly to identify the minerals carrying the remanence and hence the origin of the signal measured and reported in Chapter 16. This complements the petrographic information in chapter 17 and establishes which mineralogic phase is contributing to the magnetic signal retained in the rock. This can then be placed in a petrogenetic framework, to establish whether magnetic components are Primary or Secondary. In the present study chromite, ilmenite, and haematite are the only possible remanence carriers. Chromite and ilmenite hold Detrital Remanent Magnetisations and haematite holds a Chemical Remanent Magnetisation inversely aligned to the Detrital remanence direction. Primary remanence directions are reflected by stable signals recorded between 150 and $350^{\circ} \mathrm{C}$ during thermal demagnetisation, before thermochemical alteration of the sediment. An explanation of the development of Natural Remanent Magnetisation is presented and common behaviour of samples from the present study is shown. This model allows correct identification of primary remanence directions in New Zealand Tertiary strata, even when signal to noise ratios are high and remagnetisation great circle analysis is necessary to identify this direction. A key discovery is the identification of haematite as a high temperature secondary chemical remanent that complicates the primary remanence. This invalidates a standard palaeomagnetic technique which identifies the highest temperature magnetic component as the primary remanence.

\subsection{Introduction}

Several different rock magnetic techniques are available to establish the nature of magnetic behaviour in sediments. Parameters involved are mineralogy, grain or domain size, and domain boundary interactions on macro and micro scales. Here, simple techniques are used to validate optical microscope and electron microprobe identifications of possible palaeomagnetic behaviour (see chapter 17). Raw sample measurements of magnetic properties are made and compared with the magnetic properties of grain separates. This type of definitive work is not common for New Zealand Tertiary sediments. The pioneering work of Roberts (1990) and Roberts and Turner (submitted) is built on, to establish common remanence development processes in New Zealand Tertiary sediments. This model is likely to be applicable to the magnetic behaviour and development of Tertiary sediments worldwide. It is clear that low temperature magnetic components of remanence can be relied on to record primary palaeomagnetic signals faithfully. 


\subsection{Thermal Demagnetisation changes in intensity}

Results of demagnetisation by heating are presented in chapter 16 , with data presented by sample in appendix 5 . Certain behaviour can be documented that is useful in determining the nature and behaviour of minerals retaining a magnetic signal in the South Wanganui Basin sediments. Four categories of behaviour during thermal demagnetisation are typical of South Wanganui Basin sediments, and are useful in isolating the mineralogies retaining the remanence.

1) Loss of much of the intensity of signal during the first $150^{\circ} \mathrm{C}$ to $200^{\circ} \mathrm{C}$ of heating.

2) Then a stable signal until a chemical change above $300^{\circ} \mathrm{C}$.

3) Obvious remanence component retained at a higher temperature than $350^{\circ} \mathrm{C}$, but of very weak intensity. It is generally opposite in direction to the stable component that predominates in the $200^{\circ} \mathrm{C}$ to $350^{\circ} \mathrm{C}$ range. This component is easily recognised by the examples where obvious low temperature reversed direction signals have a high temperature normal component (figure 18.1).

4) Loss of signal between $320^{\circ} \mathrm{C}$ and $350^{\circ} \mathrm{C}$ due to growth of secondary magnetic minerals. The growth of a new mineral phase is recognised by a change in the magnetic susceptibility of individual samples. The most likely cause for this behaviour is from the alteration of pyrite to magnetite at temperatures greater than $300^{\circ} \mathrm{C}$ (Tarling, 1983). The equipment used in the present study does not prevent alignment of alteration product magnetic minerals with laboratory induced fields. Therefore, remanence measurement is halted once magnetic susceptibility changes.

If magnetite and haematite were present in a significant quantity the intensity of signal would be much stronger than that recognised in South Wanganui Basin samples. The chemical alteration product at $320^{\circ} \mathrm{C}$ to $350^{\circ} \mathrm{C}$ would be very small in comparison to the signal of haematite or magnetite and the intensity of signal would persist above $350^{\circ} \mathrm{C}$. Minerals that would lose magnetic intensity below $400^{\circ} \mathrm{C}$ are very titaniferous magnetites, titaniferous haematites, or sulphide minerals such as pyrrhotite or greigite. The signal persisting to higher temperatures could be magnetite or haematite. However, magnetite is not likely because the intensity of the signal is so weak.

\subsection{Acquisition of isothermal remanent magnetisation and coercivity.}

Initially the acquisition of isothermal remanent magnetisation method was used in the present study, merely to identify the fact that grain separates were 


\section{R190399.1}
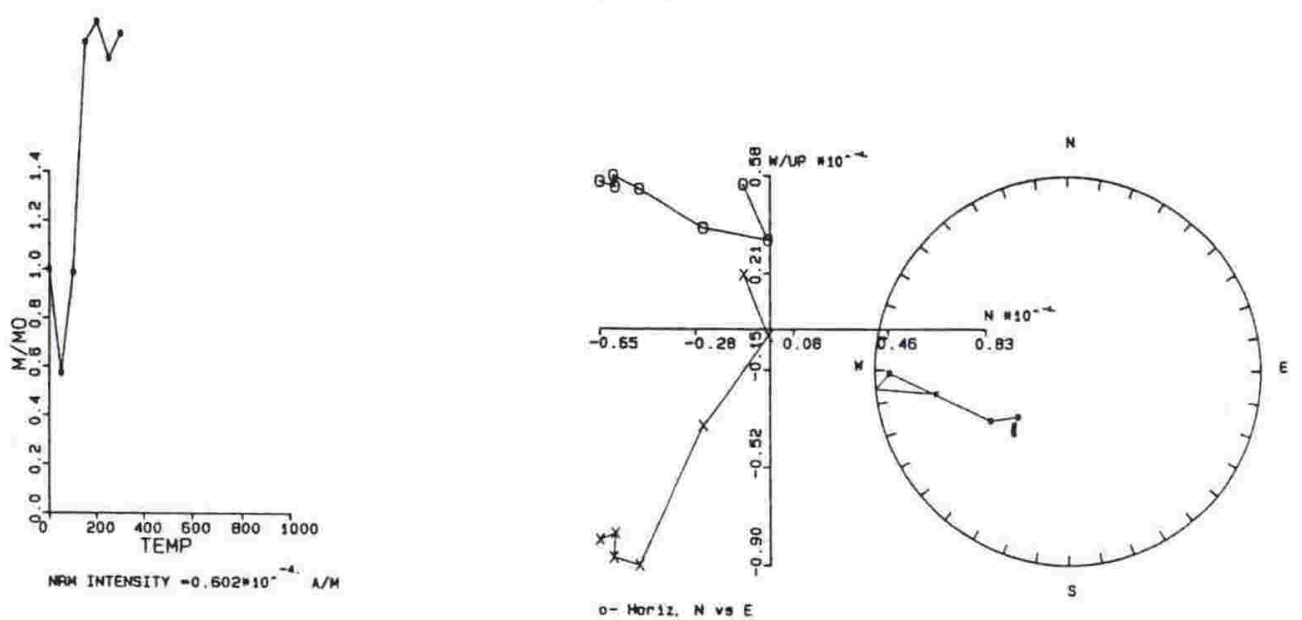

$x$ - vert, $z$ vo

OUpoer Hemisphare

\section{R194411.1}
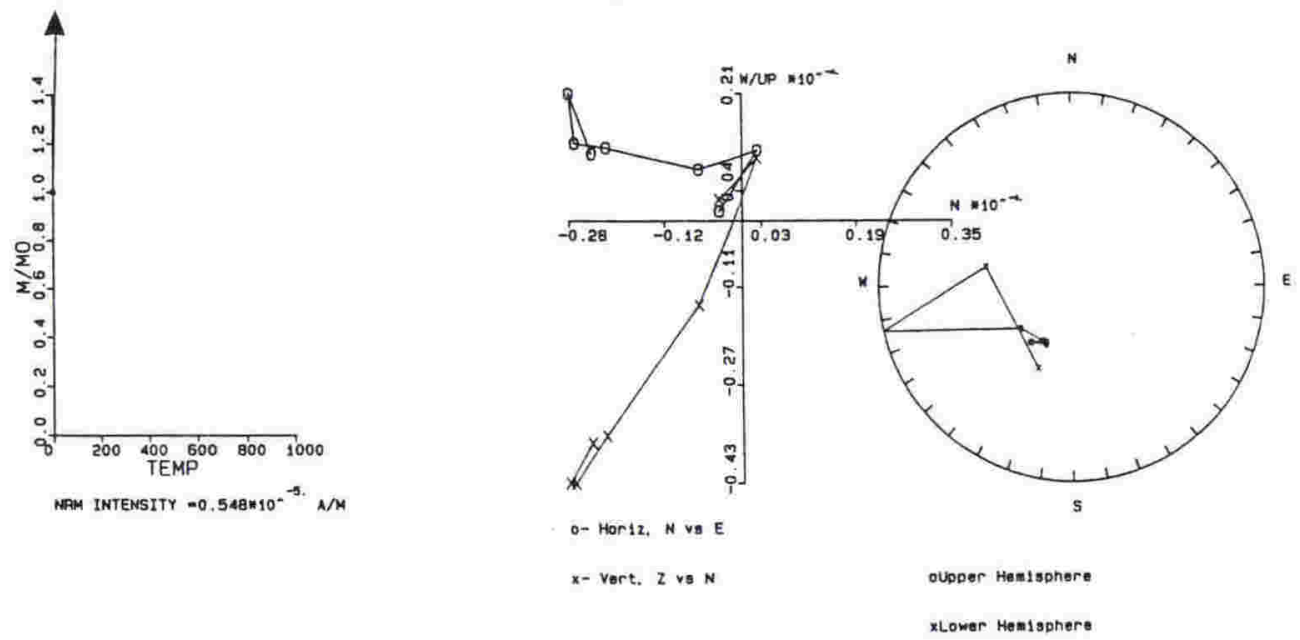

R165349.1
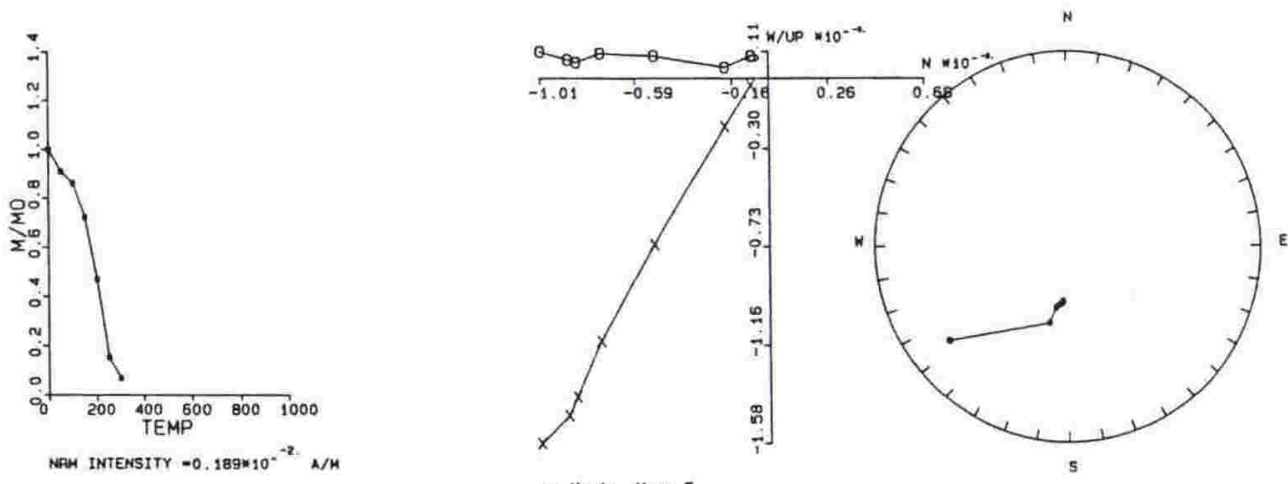

$x$ - vert. $Z$ vs $N$

oupper Hemisphere

Figure 18.1: Examples of zero field thermal demagnetisation $\left(50^{\circ} \mathrm{C}\right.$ steps $)$ of samples that demonstrate a high temperature normal component of magnetisation remaining after removal of an initially reversed component. 
able to carry a magnetic remanence. It was then established that the separates behaved similarly to measurements of real samples. Further measurements were made to establish how reliable the mineralogy under examination was at retaining a remanence over geologic time. Saturation Isothermal Remanent Magnetisation can also be used to establish the nature of the mineral phase that is retaining magnetisation. The method has been used almost exclusively for establishing whether the magnetic remanence is being carried by rhombohedral (Haematite end member) or spinel (Magnetite end member) phase iron oxides.

This procedure was carried out on three sets of samples. Standard palaeomagnetic core samples, grain separates prepared using the Frantz electromagnetic separator, and grain separates prepared without size discrimination. As well as the magnetic extracts prepared using the Frantz electromagnetic separator, several extracts, some of individual grains, were made independent of grain size. Again the cores were crushed using wooden blocks, and grains disaggregated by suspending the sediment in an ultrasonic tank. The disaggregated slurry was then recirculated past a magnet using a peristaltic pump. Grains that collected on the magnet were isolated and their magnetic behaviour established and used to assess possible contribution to remanence within the sediments being studied.
The magnetic separates prepared using the Frantz electromagnetic separator were suspended within perspex cylinders using Yoohoo glue as a fixative (plate 18.1). The Perspex and Yoohoo glue were chosen for their proven nonmagnetic nature. To ensure they do not contribute to the magnetic behaviour of the grain separates another cylinder was prepared with only Yoohoo fixative and no grain separate. This blank was used to establish a background level for the present study. The Blank exhibited pure paramagnetic behaviour and recorded no remanence measurable using a MOLSPIN magnetometer. The motivation behind this preparation was to establish whether these grain separates were capable of holding a remanence, establishing the nature of the remanence, and then preparing thin sections of the cylinders and establishing the mineralogy of the separates.

The IRM was grown in the cylinders using a pulse magnetiser at VUW, magnetising the cylinders along the same axis at progressively increasing fields. The magnetisation steps were every 50 $\mathrm{mT}$ from 0 to $800 \mathrm{mT}$. After each step the intensity of magnetisation induced in the grain separate was measured using a MOLSPIN magnetometer. Once Saturation Magnetisation was established, the axis of magnetisation was reversed, and the same sample stepwise magnetised in $50 \mathrm{mT}$ steps, from 0 to $800 \mathrm{mT}$ (figure 18.2). This approach established the saturation magnetisation of the grain separates. It 


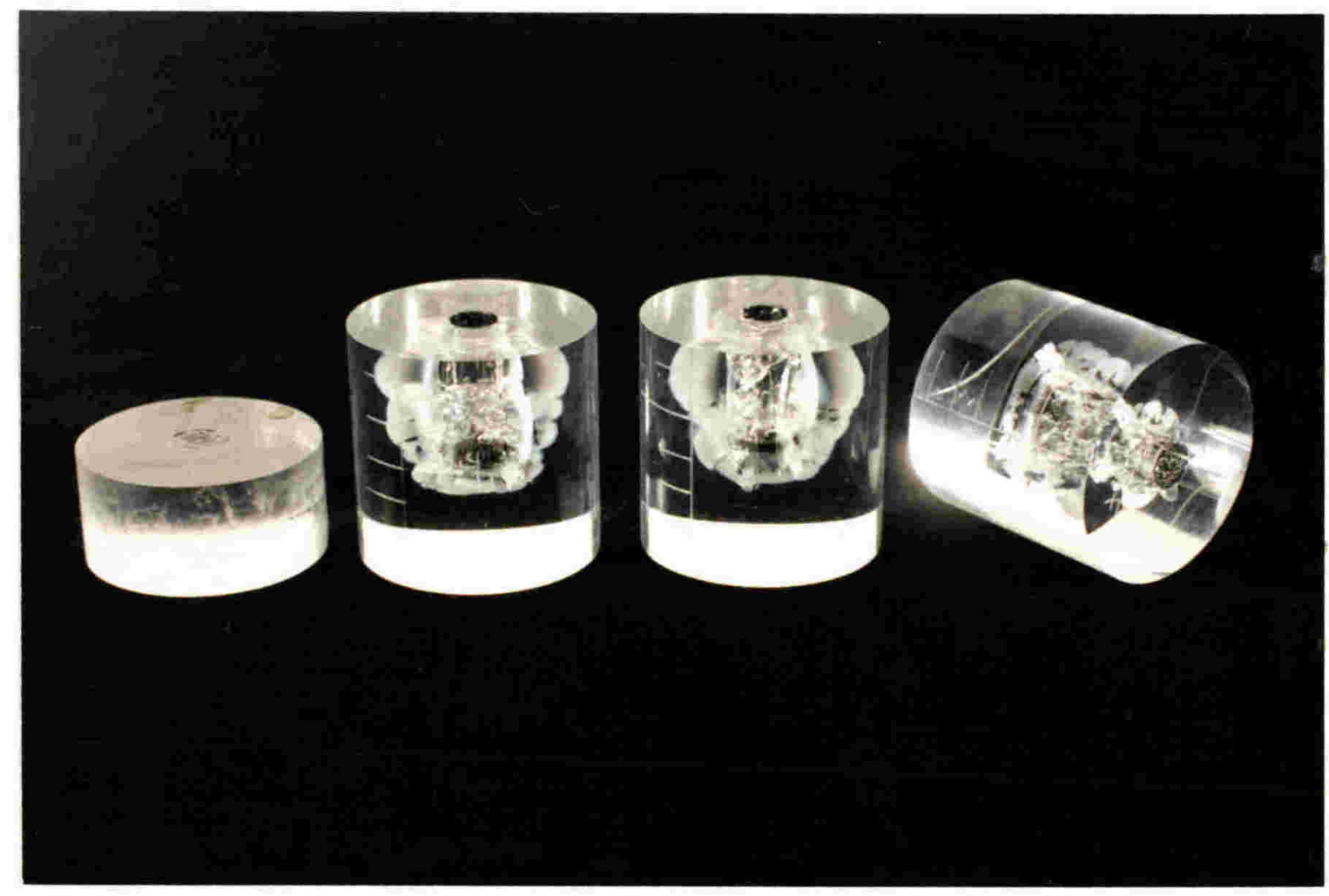

Plate 18.1: Examples of the magnetic separates suspended in non-magnetic Yoohoo glue within non-magnetic perspex cylinders. The left hand specimen has been prepared for electron microprobe analysis.

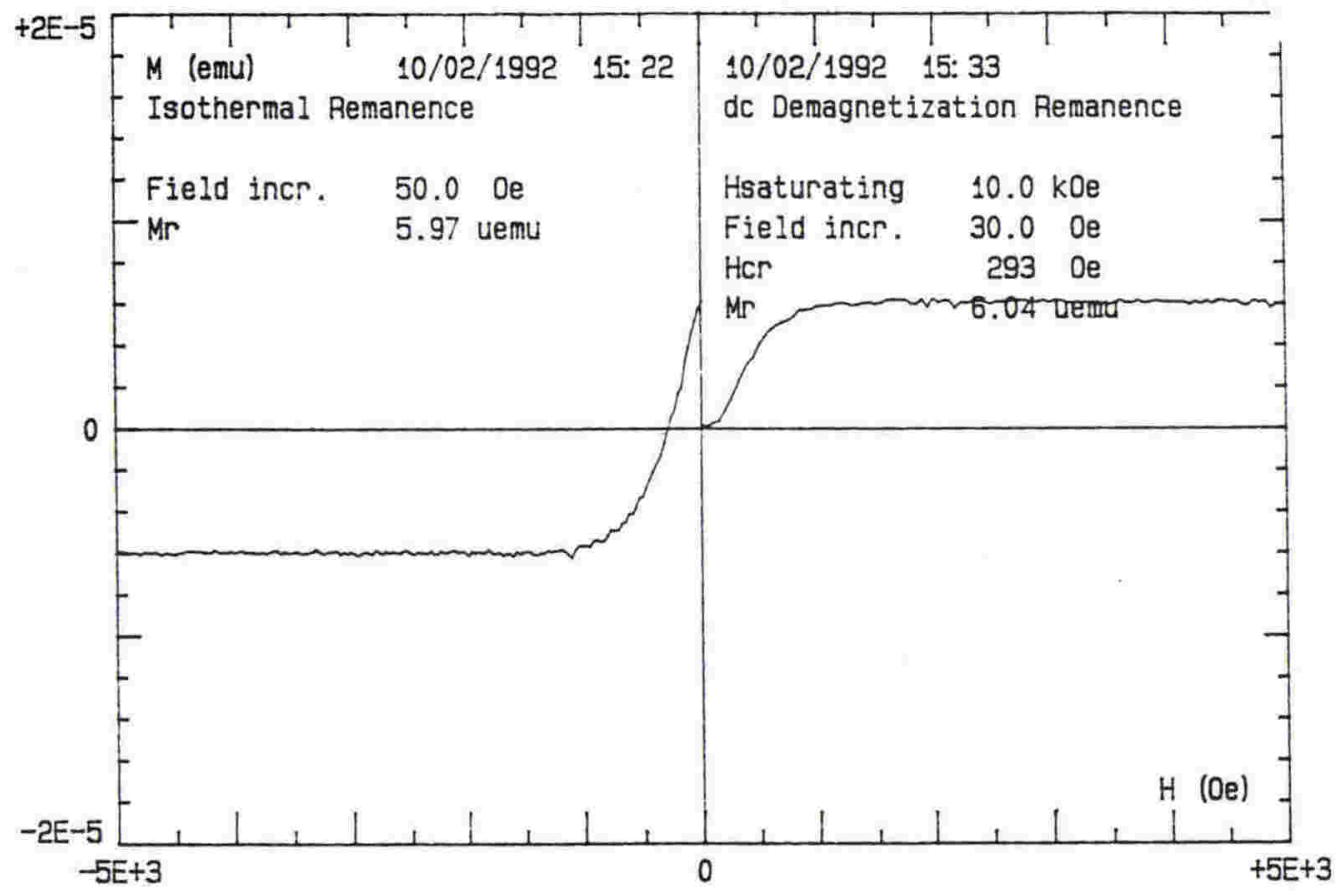

WANGANUI SITE 69 - SIRM

Figure 18.2: Saturation isothermal remanent magnetisation (SIRM) curve for a sample from site 69 in the Wanganui River section. Negative side of figure is the reversed sample SIRM curve. 
also established the separates' ability to hold a remanence outside of the inducing field. This is born out by the separates exhibiting a coercivity of remanence of 300 - 500 oersteds. Non grain size discriminatory samples were also measured using a Princeton Measurements Corporation Micromag Alternating Gradient Magnetometer, housed at the University of California, Davis. Measurements were by permission of Dr. Ken Verosub of the Geology Department, U.C. Davis. Measurements were made under the direction of Dr. Andrew Roberts, also of the Geology Department, U.C. Davis.

Samples showed an IRM that was not that expected of Magnetite nor or Haematite, but possibly a combination. Behaviour is certainly representative of ferromagnetic rather than ferrimagnetic behaviour (figure 18.3). Initial low field IRM suggests large grain size remanence carriers, on the order of 5 microns (Thompson and Oldfield, 1986). Saturation IRM is very low, suggesting that the remanence is not held by Magnetite but some complex oxide, perhaps titaniferous magnetite or titaniferous haematite. These results proved similar to the measurement of actual sample IRM and SIRM, once the paramagnetic signal is removed from the signal (figure 18.3). The variation in coercivity of remanence is indicative of either varying grain size of remanence carriers or varying mineralogy, or mineralogic proportions, of remanence carriers. IRM and SIRM measurements establish that minerals identified in chapter 17 are capable of carrying remanence over geologic time. However, they are not conclusive in establishing the exact nature of the mineralogy holding the remanence. They suggest that grain sizes holding the remanence are comparatively large.

\subsection{Magnetic Hysteresis}

As reported elsewhere (e.g. Thompson and Oldfield, 1986), hysteresis is the ability of a mineral or minerals to retain a remanence after being subjected to an external magnetic field. In short hysteresis is a measurement of the mineral's ability to react to the externally applied field. As different minerals have different properties controlling their response, sample behaviour under a cyclic magnetic field is dependent on the mineral types, mineral proportions within the sample, and grain size distribution of remanence carriers.

Hysteresis was measured on palaeomagnetic core samples and non grain size discriminant separates, using the Geology Department, U.C. Davis, Princeton Measurements Corporation Micromag Alternating Gradient Magnetometer. Sediment sample measurements indicated a very high paramagnetic component and a weak ferromagnetic component to hysteresis (figure 18.4). The poor closure of the hysteresis loop is indicative more of antiferromagnetic behaviour. Hysteresis loops for grain separates (figure 18.5) are 

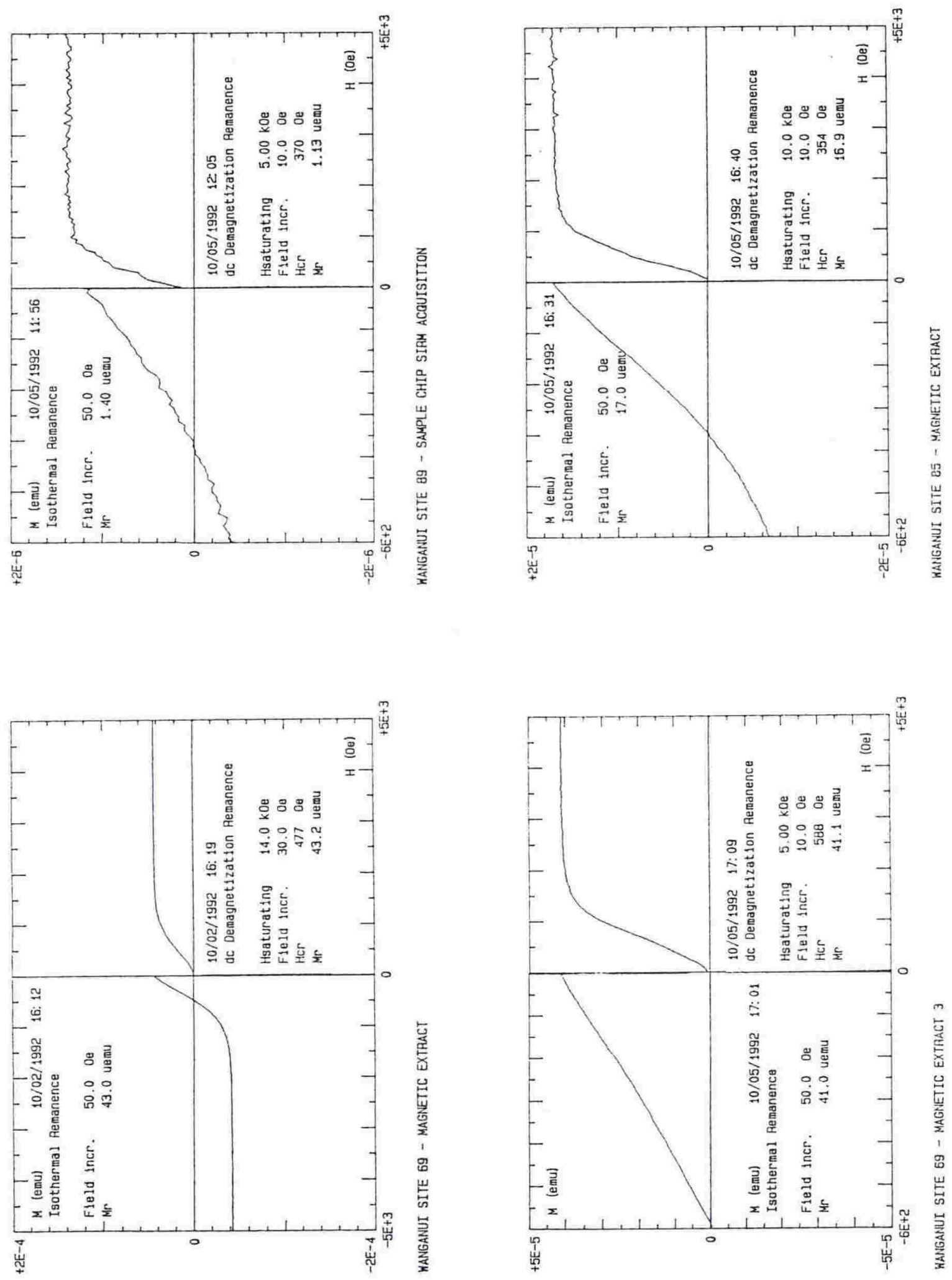

Figure 18.3: Examples of saturation isothermal remanent magnetisation (SIRM) curves for magnetic extracts from Wanganui River sites, a sample chip SIRM is given for comparison. The low SIRM values are indicate of large domain behaviour of a mineral other than magnetite or haematite. 


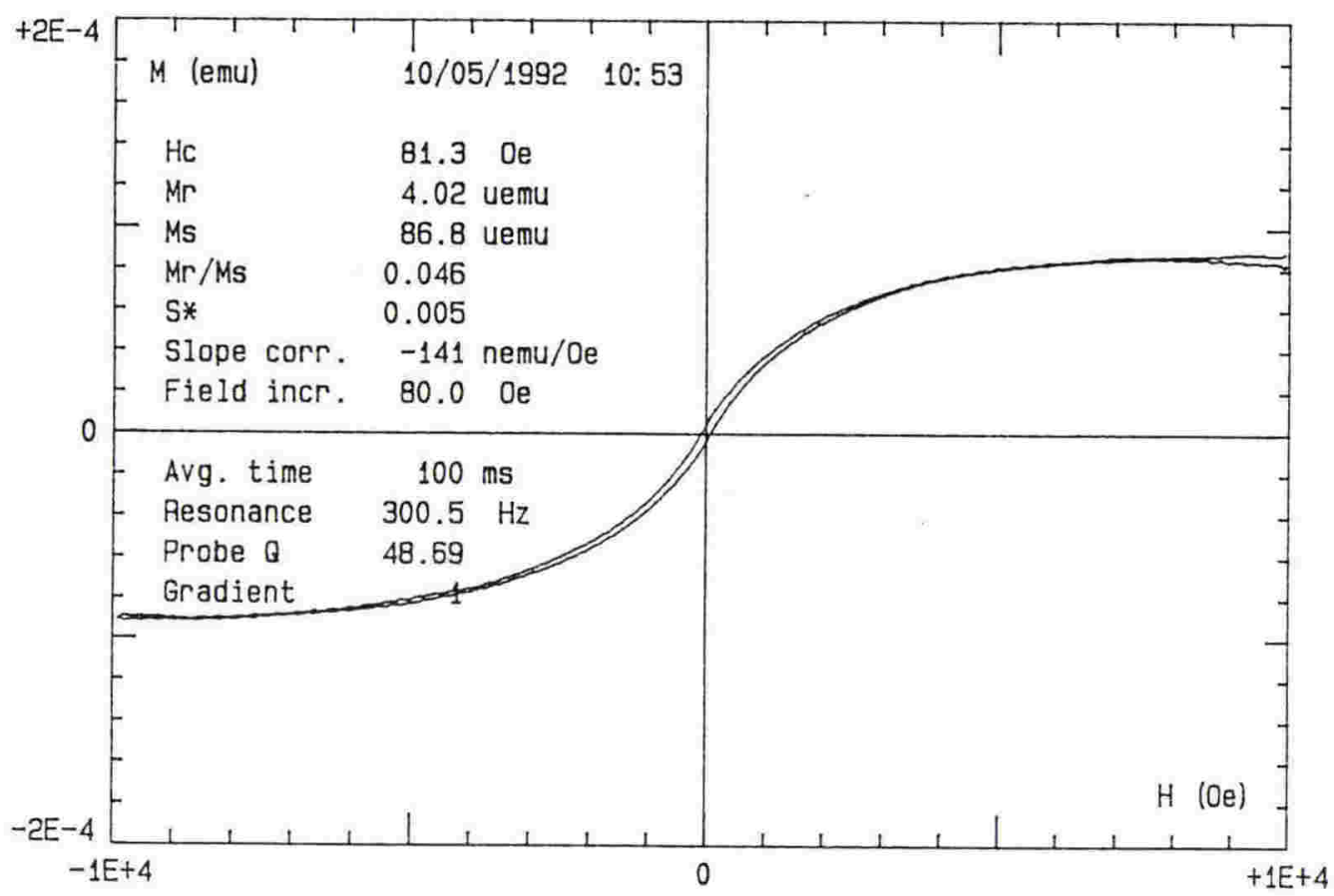

WANGANUI SITE 85 - SEDIMENT HYSTERESIS

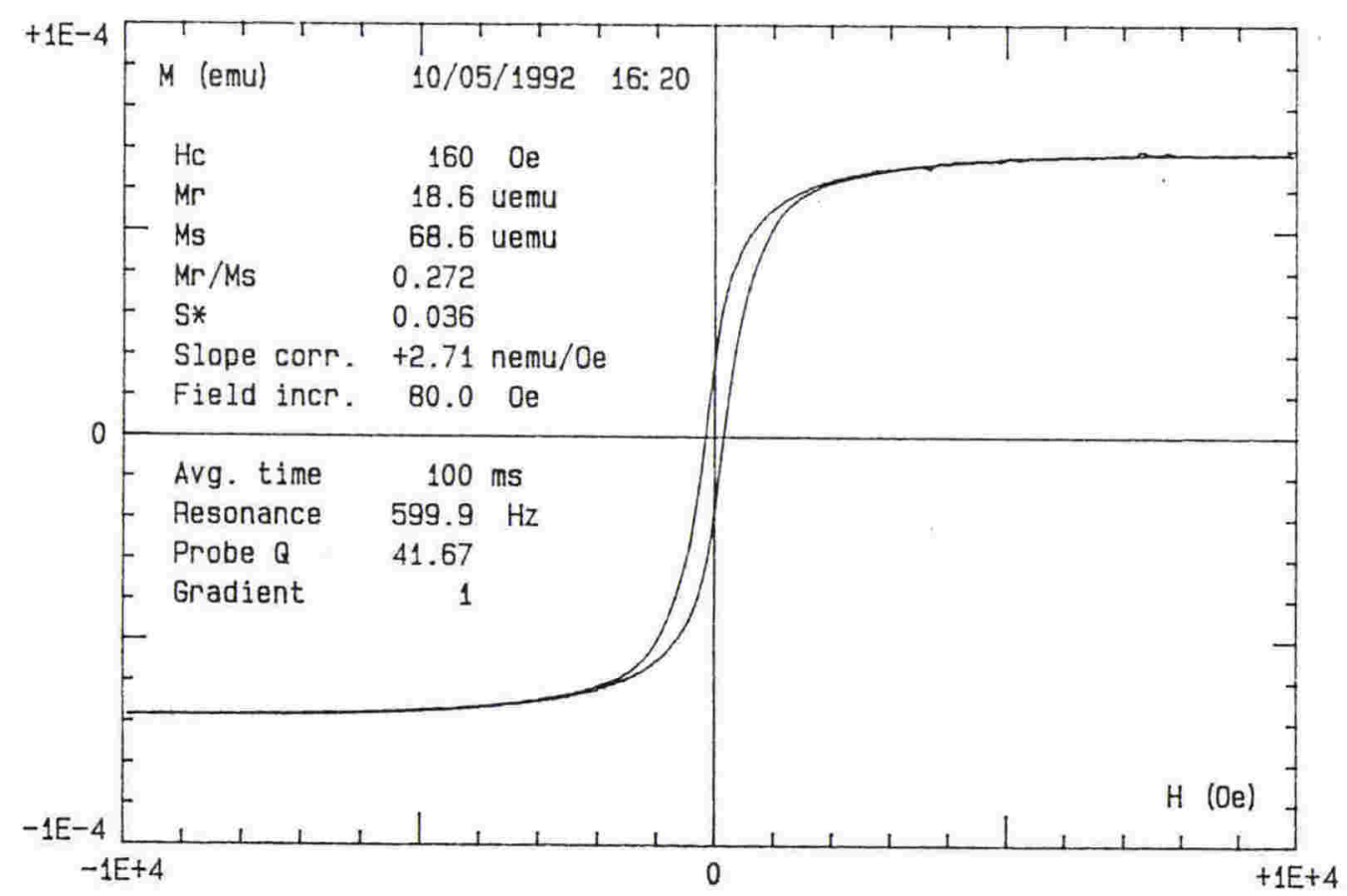

WANGANUI - SITE 85 MAGNETIC EXTAACT

Figure 18.4: A comparison of sediment hysteresis from Wanganui River site 85 (upper) with hysteresis for a magnetic extract from the same site (lower). The poor closure of the hysteresis loop is indicative of antiferromagnetic behaviour. 


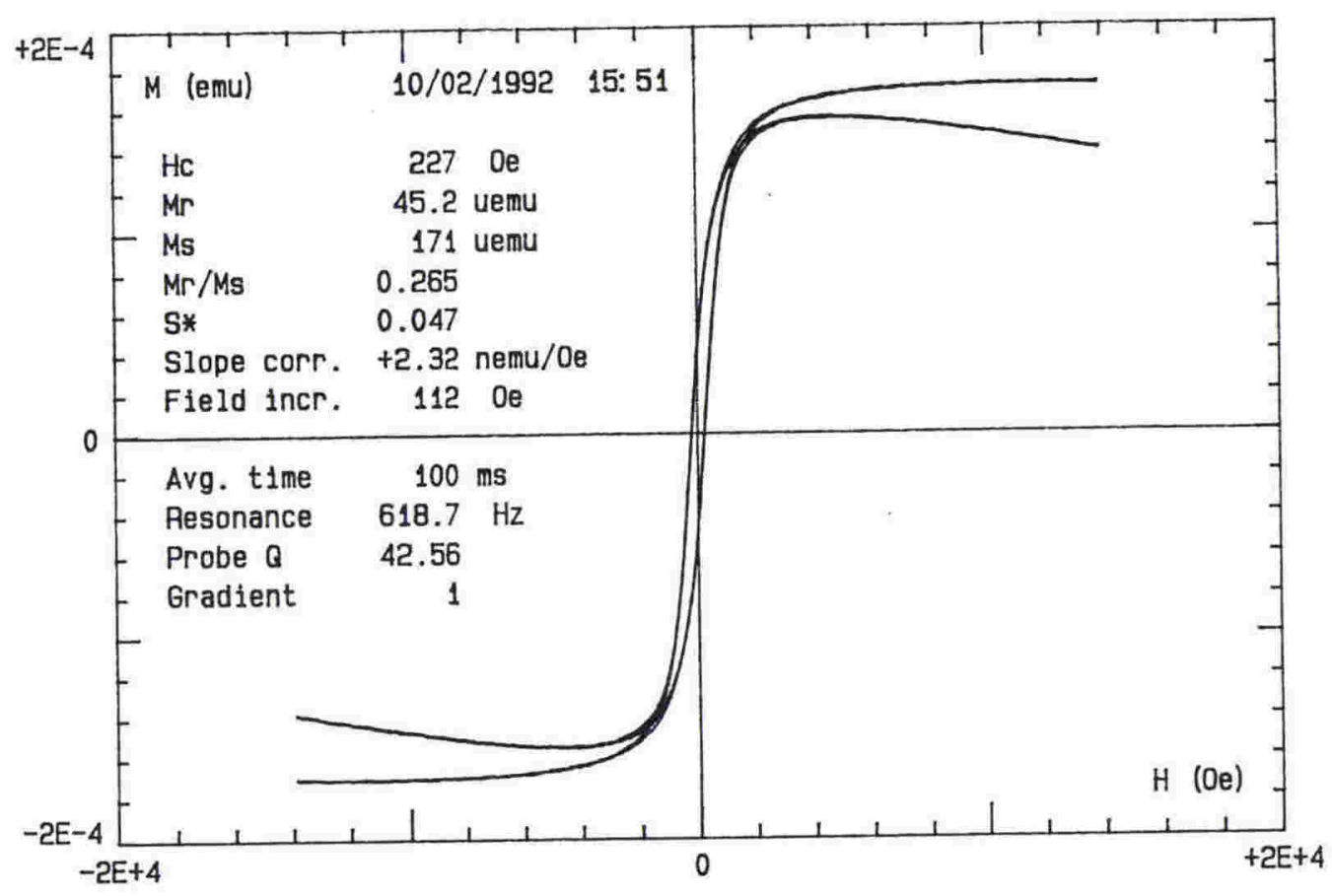

WANGANUI SITE 69 - MAGNETIC EXTRACT

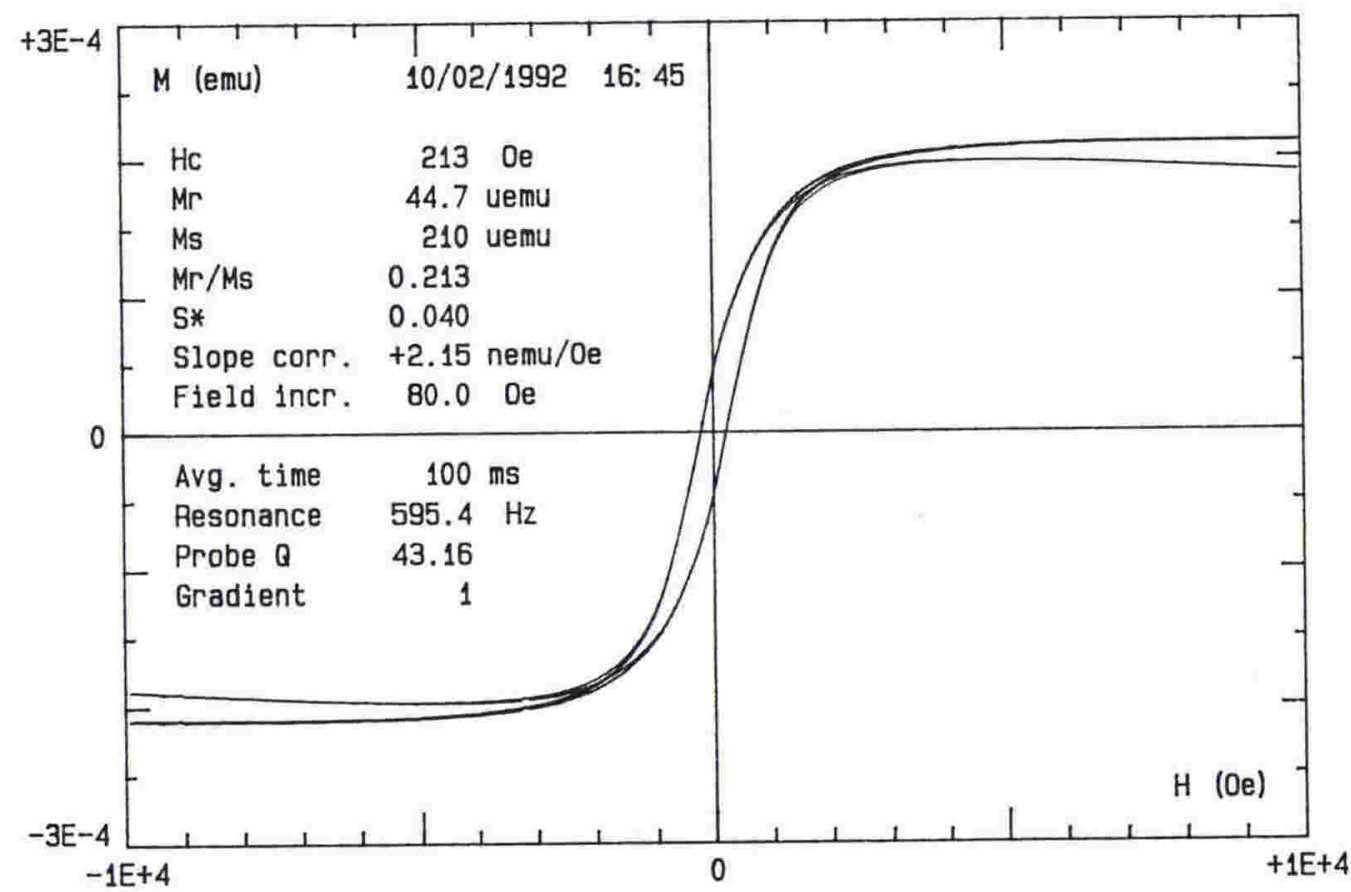

WANGANUI SITE 69 - MAGNETIC EXTRACT 3

Figure 18.5: Hysteresis loops for magnetic grain separates from site 69 on the Wanganui River. 


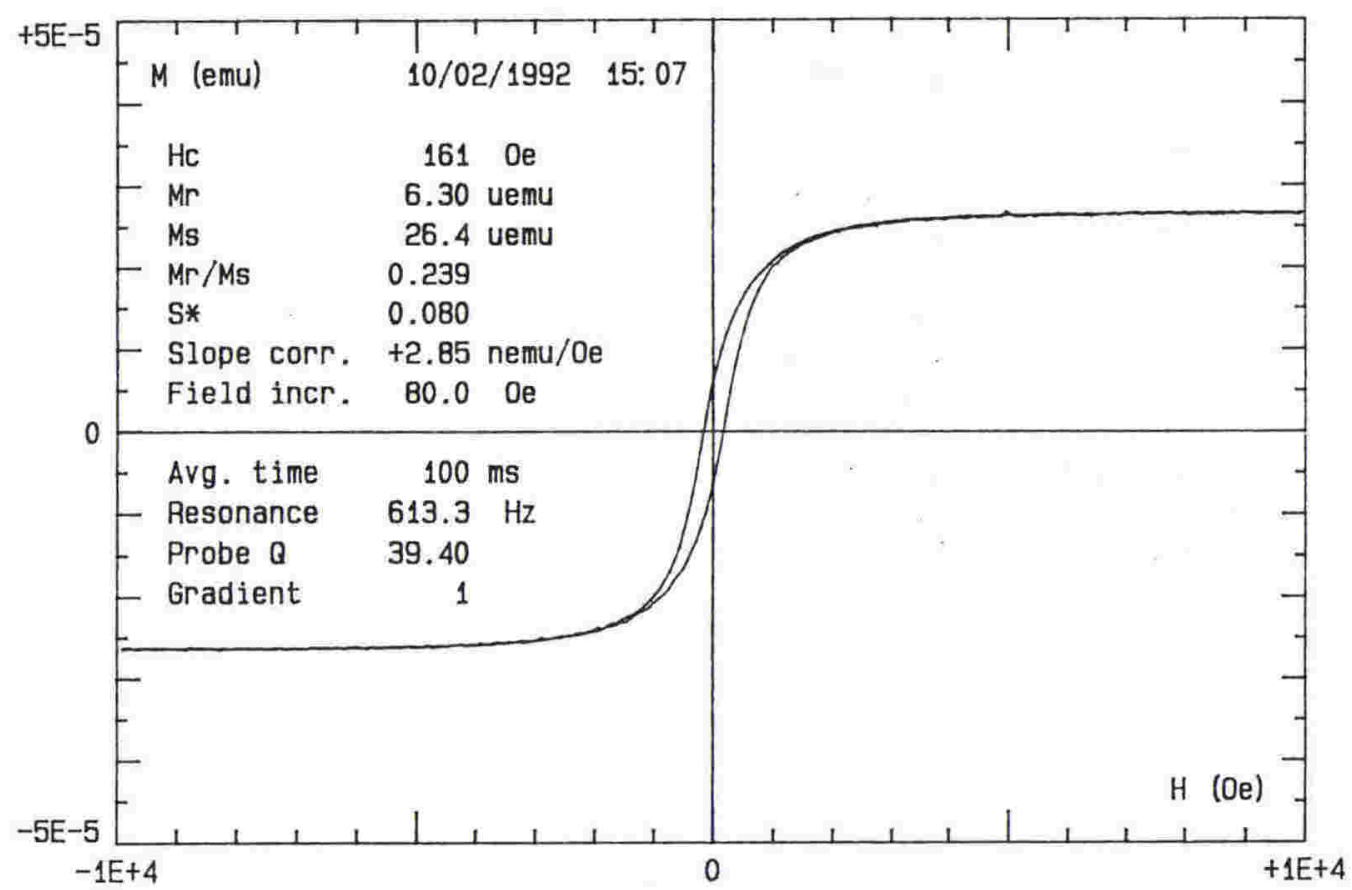

wanganui site 69 single grain

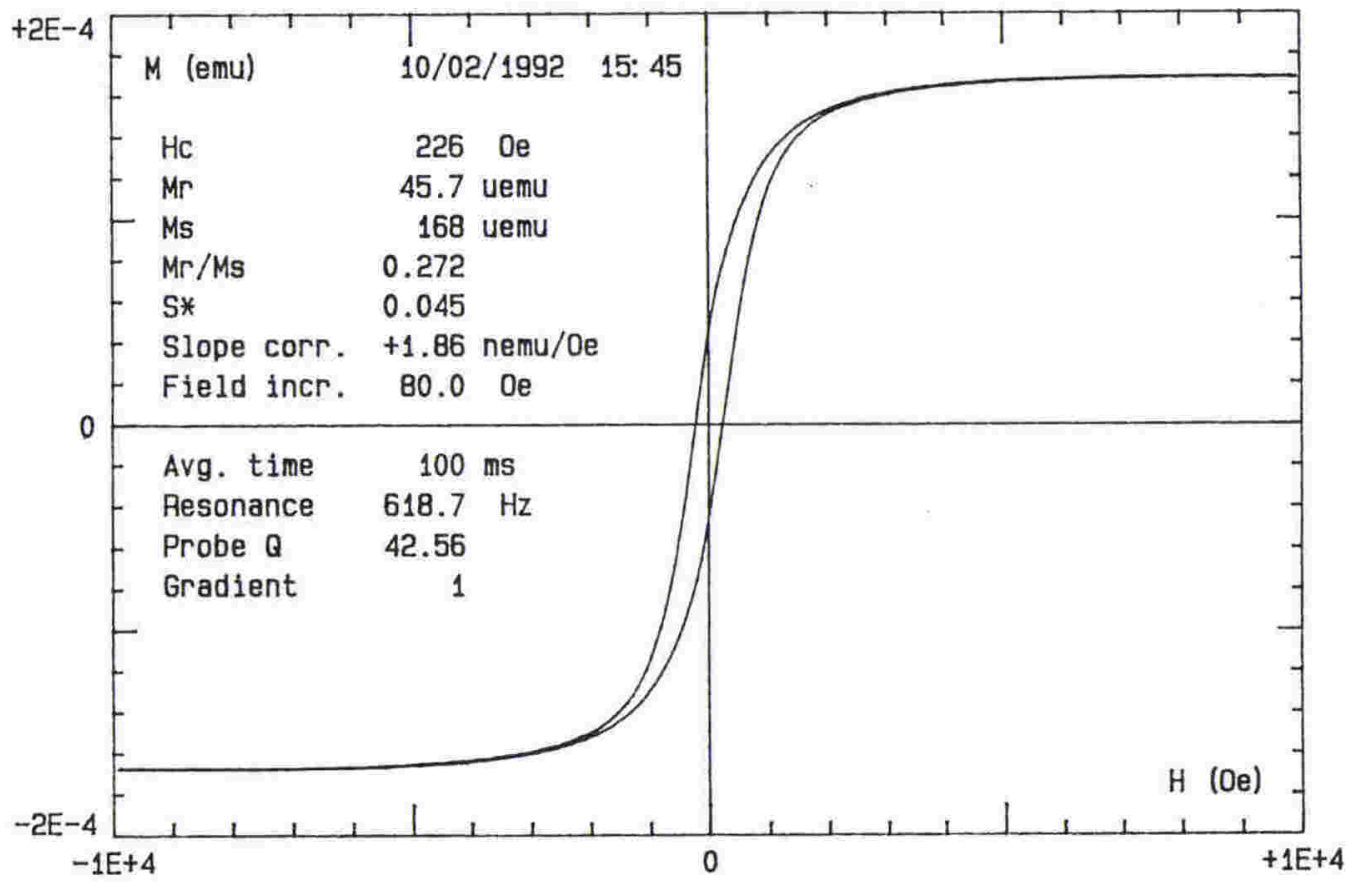

WANGANUI SITE 69 - MAGNETIC EXTRACT

Figure 18.6: Further hysteresis loops for a single grain (upper) and magnetic grain separate (lower) from site 69 on the Wanganui River. The high degree of right shear of the loops is indicative of ferromagnetic behaviour, suggesting magnetite or titaniferous magnetites are not remanence carriers in these sediments. 
indicative of multidomain grains holding the remanence (Thompson and Oldfield, 1986). The high degree of right shear of the hysteresis loops measured for grain separates (figure 18.6) is representative of ferromagnetic carriers rather than ferrimagnetic carriers (Thompson and Oldfield, 1986). This would suggest that neither magnetite or titaniferous magnetite are contributing to the magnetic signal. If they were present as even a few percent of remanence carriers they would tend to dominate the hysteresis properties of the samples (Thompson and Oldfield, 1986). Hysteresis measurements indicate magnetic remanence to be carried by multidomain antiferromagnetic mineral grains, probably haematitic.

\subsection{Discussion of magnetic parameters of minerals identified in the present study.}

\subsubsection{Sulphides}

The two sulphide phases reported to carry a magnetic remanence are Pyrrhotite $\left(\mathrm{Fe}_{7} \mathrm{~S}_{8}\right)$ and Greigite $\left(\mathrm{Fe}_{3} \mathrm{~S}_{4}\right)$ (e.g. Tarling, 1983; Roberts, 1990; Butler, 1992). As reported in chapter 17, the only phase present in the south Wanganui Basin sediments is pyrite. Extensive effort in electron microprobe analysis and optical thin section work was undertaken to establish the possibility of partially reduced grain portions. None were observed in the thin sections prepared for the present study.
Many previous workers have reported pyrite to be paramagnetic (e.g. Roberts et al, submitted; Nagata, 1961) and the SIRM of collection quality pyrite has been measured and shown to be paramagnetic (Andrew Roberts, pers. Comm.). Trace amounts of zinc or chromium in pyrite framboids may increase the mineral's ability to retain a remanence of relatively weak intensity. Analyses presented in table 17.2 show the authigenic sulphides measured in the present study to be almost pure pyrite, which has no ability to maintain a magnetic remanence. Therefore, pyrite cannot have contributed to the remanence of South Wanganui Basin Sediments.

\subsubsection{Ilmenites}

Ilmenites (sensu stricto) are paramagnetic in magnetic behaviour (Nagata, 1961). Titaniferous haematites of ilmenite composition greater than $73 \%$ in the ilmenite - haematite solid solution series are reported to be paramagnetic at room temperature (Lawson and Nord, 1984). This reported behaviour assumes grain homogeneity. On the scale of resolution of electron microprobe analysis ( $>1$ micron) this is observed in South Wanganui Basin sediments (chapter 17).

Measurements reported earlier in this chapter combined with electron microprobe analyses and electron backscatter images (chapter 17) shows that titaniferous haematites of ilmenite composition $90 \%$ and greater are the 
main mineral holding magnetic remanence in South Wanganui Basin sediments. This behaviour has been reported previously by Lawson and Nord (1984), but not with Ilmenite percentages as high as the present study. They attribute the magnetic behaviour to be due to much more Fe rich single domain like material within the Titaniferous Haematite grains. They further document the existence of magnetic grain boundaries enriched in Iron compared to the main domain region, which has an equivalent Iron to Titanium ratio (plate 17.12).

Iron-enriched domains within titaniferous ilmenites were first discussed by Ishikawa and Syono (1963). They termed these domains the $\mathrm{X}$-phase, but did not describe their physical manifestation. Warner et al. (1972) and Allen and Shive (1974) document the existence of the Xphase using the Mossbauer Effect. Further work has concentrated on documenting the phenomenon know as self-reversal in Titaniferous Haematites of certain Ilmenite percentages of the solid solution series (Carmichael, 1961; Westcott-Lewis and Parry, 1971; Nord and Lawson, 1989; Haag et al., 1990; and Hoffman, 1992). Some of these papers document the formation and existence of this self-reversal phenomenon. It is not discussed further here as the remanence being measured is a detrital remanence and hence temperature induced self reversal does not affect polarity interpretation. An important paper by Lawson et al. (1981) documents the temperature dependence of X-phase domain boundary density. Titaniferous haematites formed at high temperatures have a higher density of $\mathrm{X}$ phase grain boundaries, where as titaniferous-haematites formed at lower temperatures have a lower density. The higher density $\mathrm{X}$-phase titaniferous haematites are more prone to selfreversal.

Detrital ilmenites from the South Wanganui Basin sediments contain a moderate density of $\mathrm{X}$-phase domain boundaries. These domains are aligned with the palaeogeomagnetic field during sediment deposition, preventing any distinction between originally normally and self-reversed components. The domains exhibit behaviour that is more ferromagnetic than ferrimagnetic. The Xphase domain boundaries are too small to be observed by electron backscatter images. Titaniferous haematite is the major contributor to the magnetic remanence of south Wanganui Basin sediments.

\subsubsection{Haematites}

Haematite is a strong carrier of magnetic remanence. It is antiferromagnetic in its behaviour and consequently not as simple to isolate magnetically and understand as magnetite and titaniferous magnetite. Although rock magnetic experiments suggest antiferromagnetic behaviour, these are not conclusive and do not suggest that the main component of remanence is held by haematite. 
Detrital Haematite is not present in the sediments observed as part of the present study of the South Wanganui Basin. However, very fine grained authigenic Haematite is present.

The finest grained haematite is likely to be superparamagnetic (Thompson and Oldfield, 1986). Much of the authigenic haematite in the South Wanganui Basin sediments is expected to lie within this size range, leaving only a very small antiferromagnetic component. This must contribute to the high temperature component of sample remanence. The authigenic Haematite is more likely to be aligned in the field induced by the sedimentary magnetic remanence, rather than the geomagnetic field. If the field of sedimentary remanence is strong enough the Haematite component (persisting to high temperatures during demagnetisation) will be inversely aligned to the detrital component. This is observed in sediments from the South Wanganui Basin (figure 18.1).

\subsubsection{Chromites}

Deer et al. (1989) report that chromites are often slightly magnetic. Despite magnesiochromite $\left(\mathrm{MgCr}_{2} \mathrm{O}_{4}\right)$ being the most commonly occurring member of the chromite Series (Deer et al, 1989), the detrital mineral observed here in the Wanganui Basin is a true chromite $\left(\mathrm{FeCr}_{2} \mathrm{O}_{4}\right)$. As shown by table 17.3 there is a degree of iron replacement by magnesium, but iron is more dominant than magnesium in these mineral grains.
Refai et al. (1989) report chromite ores from the Eastern Desert, Egypt to hold a strong and stable palaeomagnetic remanence. These ores are magnesiochromites, but with similar iron and chromium contents to the chromites in the south Wanganui Basin (table 18.1). These ores have moderate to high intensities. Mukherjee (1962) also report moderate to high magnetism in chromite ores from Nausahi, India. The behaviour of both these ores is indistinguishable from that of pseudo-single domain magnetite grains (Refai et al., 1989). Kumar and Bhalla (1984 a and b) suggest that such high fields indicate that these and hence the Wanganui Basin chromites are efficient carriers of remanence over long periods of time.

Table 18.1: EMPA analyses of chromite ores from the Eastern Desert, Egypt (Data from Refai et al., 1989)

\begin{tabular}{lrrrr}
\hline $\mathrm{Al} 2 \mathrm{O} 3$ & 11.52 & 12.13 & 24.47 & 32.94 \\
$\mathrm{FeO}$ & 8.50 & 5.06 & 3.62 & 12.81 \\
$\mathrm{Fe} 2 \mathrm{O} 3^{*}$ & 17.30 & 12.03 & 9.79 & 0.13 \\
$\mathrm{MgO}$ & 17.42 & 19.15 & 20.04 & 16.07 \\
$\mathrm{Cr} 2 \mathrm{O} 3$ & 50.01 & 53.36 & 37.40 & 38.45 \\
& & & & \\
\hline TOTAL & 104.75 & 100.52 & 95.32 & 100.40 \\
\hline \hline & & & & \\
(total $\mathrm{FeO}$ & 24.07 & 15.88 & 12.43 & 32.94 )
\end{tabular}

*recalculated after method of Stormer (1983) 
The exact behaviour of Wanganui Basin chromite grains could not be established magnetically in this study, but being chemically similar to the Egyptian and Indian chromites they are expected to contribute to the measurements observed when NRM intensities are strong (on the order of $10^{-2} \mathrm{~A} / \mathrm{m}$ ).

\subsection{Origin of Remanence in South Wanganui Basin sediments.}

Natural Remanent Magnetisation in the South Wanganui Basin sediments has three components. A Detrital Remanent Magnetisation, a Chemical Remanent Magnetisation and a Viscous Remanent Magnetisation. Controls on these components are illustrated in figure 18.7.
The interrelationships of these different components are not simple. The controlling factor is sediment diagenesis. The most simple remanence combination prevails if diagenesis is allowed to continue to a completely reduced state. Controls on this are the availability of Iron and Sulphide only. This is the case in the South Wanganui Basin. Less resistant oxides, such as magnetite or titaniferous magnetite, are completely dissolved (their remanence lost) and all sulphides are reduced to pyrite.

If diagenetic reduction of the sediments is arrested at some point, more of the detrital oxide phases will remain. Depending on the point of arrest of diagenesis, magnetic sulphide phases such as pyrrhotite and greigite may

\section{NRM Components of Sediments}

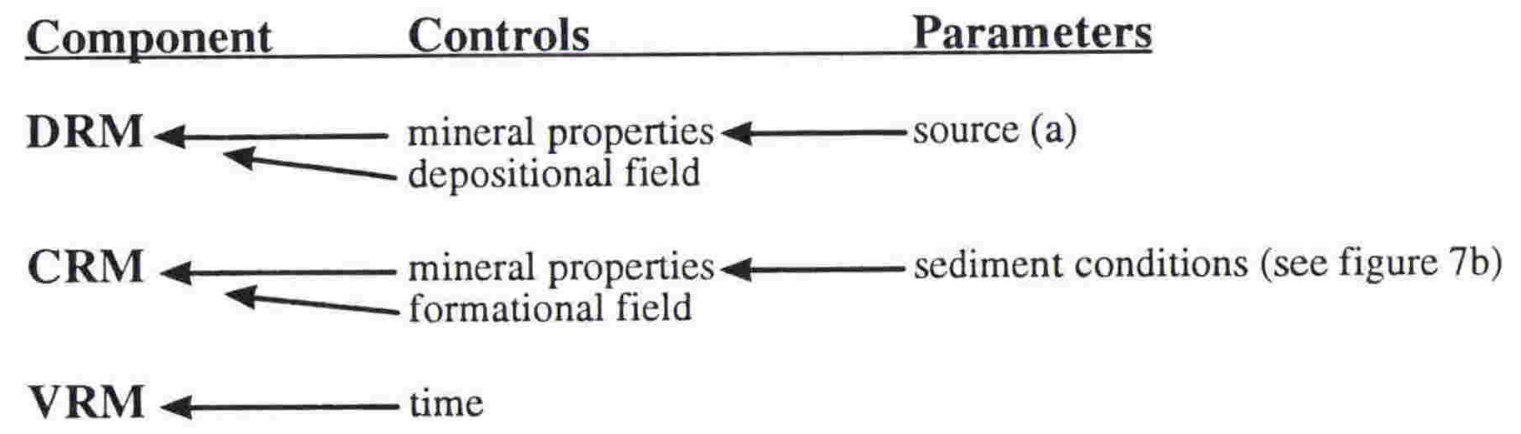
a) Resistant detrital minerals;
Magnetite
Titanomagnetite
Ilmenite

Figure 18.7: Explanation of the components on natural remanent magnetisation (NRM), and their controls, in sediments from the South Wanganui Basin strata. 
co-exist with remaining oxide phases. Canfield and Berner (1978) suggest complete reduction diagenesis occurs on a timescale of less than 500 years. The sediment NRM will be much higher if partial reduction only occurs in the sediments, but it will be retained by many different mineral phases (figure 18.8) and thermal demagnetisation data will be very complex to interpret. A final stage of diagenesis of sediments is oxidation of the sediments and the formation of authigenic haematite. The palaeomagnetic signal from the haematite tends to be inversely aligned to the Detrital Remanent Magnetisation.
Full diagenetic alteration and development of remanence is illustrated in figure 18.9.

When strong intensities are observed (less than $5 \%$ of samples) this is due to the presence of chromite grains in the respective sediments. The presence of Chromite has not been reported in other New Zealand Tertiary sediments. However, magnetic studies have reported the presence of pseudo-single domain magnetites holding the remanence (e.g. Wright, 1986 and Roberts, 1990). This could in fact be chromite.

\section{Effects of Diagenesis on NRM}

\section{Magnetic effects}

\section{1) Early diagenesis (in reducing conditions)}

Titanium poor oxides

Titanium rich oxides $\mathrm{H}_{2} \mathrm{~S}$ $\mathrm{FeS}_{2}$ (pyrite) little dissolution

\section{2) Late diagenesis (in oxidising conditions)}

Partial loss of DRM

Addition of CRM

Figure 18.8: Explanation of the effects and process of diagenesis on natural remanent magnetisation (NRM). 


\section{Stages of NRM development}

\section{1) At deposition;}

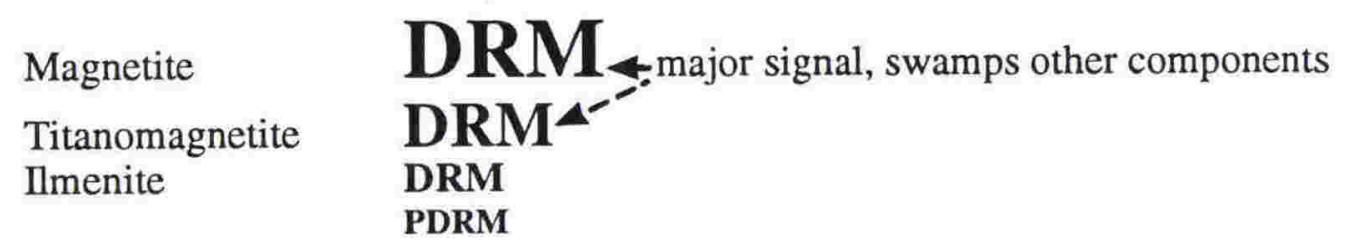

2) Partial reduction;

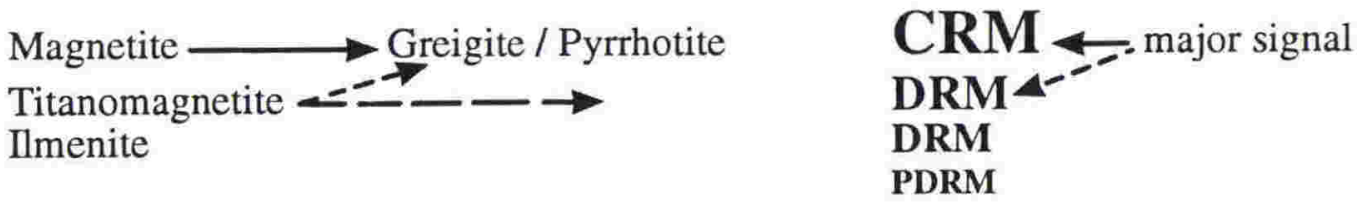

\section{3) Full reduction;}

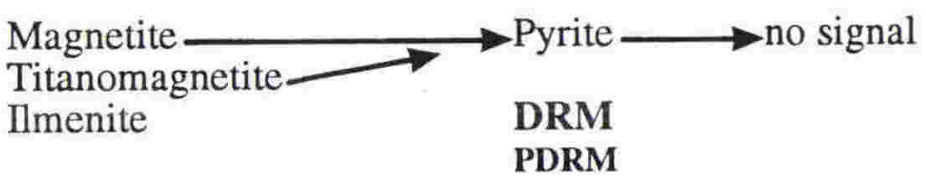

\section{4) Oxidation;}

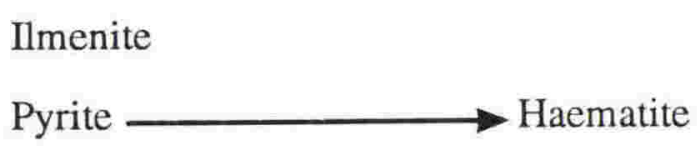

DRM

PDRM

CRM $\longrightarrow$ complicates signal

5) Time; $\quad$ VRM

Figure 18.9: The complete process of acquisition of NRM, with examples of the component contributions at various stages of sediment maturity. 


\section{Chapter - 19}

\section{Magnetostratigraphy}

The results of chapter 16 are here developed into magnetostratigraphic controls for both the Wanganui and Rangitikei River Sections. Techniques and results are compared with previous magnetostratigraphic studies both within the South Wanganui Basin and New Zealand wide. Magnetozones are defined and, using biostratigraphic datums, are correlated with the magnetic polarity timescale. Key biostratigraphic datums used are the New Zealand Pliocene Stage boundaries. These are identified using macro and microfaunal evidence. The Hautawa Shell bed is a particularly important biostratigraphic datum marking the topmost part of the sections studied here. In the Wanganui River Section the upper part of Chron 5, all of the Gilbert and Gauss Epochs and the lowest part of the Matuyama Epoch are identified. In the Rangitikei River section the upper half of the Gilbert, the entire Gauss and the lowest part of the Matuyama Epochs are identified. Particularly high sedimentation rates are deduced from the magnetostratigraphic study. Consequently, some short lived reversal events not reported in the polarity timescale are recorded by South Wanganui Basin strata. Magnetostratigraphic study has aided the correlation of the Northern and Southern segments of the Rangitikei River Section. It has also identified key unconformities in the Rangitikei River Section, and allowed correlation of significant unconformities and sedimentologic events across the South Wanganui Basin.

\subsection{Previous Magnetostratigraphic studies of New Zealand Pre- Pleistocene sediments.}

\section{Early studies}

Three early studies of Magnetic polarity established the usefulness of Magnetostratigraphy as a tool for dating and correlating New Zealand and global Stratigraphic sequences. The earliest of these Lienert et al. (1972) established a chronology for Upper Miocene-Pliocene sediments in the south-eastern North Island. Kennett and Watkins (1974) worked on Miocene sediments in
Marlborough and Loutit and Kennett (1979) refined the correlation of Kennett and Watkins (1974) with the polarity time-scale, highlighting the importance of an integrated approach where possible in correlating short magnetostratigraphic sequences to a general timescale.

All of these studies used spinner magnetometers to determine polarities. Weakness of intensity and poor understanding of diagenetic alteration of magnetic carriers led to some unreliable polarity determinations and consequently uncertain correlations. 


\section{Recent Studies}

Two more recent studies have used cryogenic magnetometers to determine polarities of sedimentary sequences. Wright and Vella (1988) studied a Late Miocene sequence in the eastern North Island. Their study was integrated with biostratigraphic and glacioeustatic observations. Roberts (1990) Restudied the same Miocene-Pliocene Sequence as Kennett and Watkins (1974) and Loutit and Kennett (1979) in Marlborough. He added observations from a new section he studied in nearby Upton Brook, and collected further biostratigraphic information to add to the existing information and ensure correct correlations with the New Zealand time scale (Edwards et al., 1988). These are used as reliable New Zealand correlatives for definition in the present study.

\subsubsection{Previous studies in the South Wanganui Basin}

Two previous studies (Seward et al., 1986 and McGuire, 1989) have determined the magnetic polarity of stratigraphic sequences in the South Wanganui Basin. Seward et al. (1986) studied a $2,700 \mathrm{~m}$ section in the Rangitikei River, resurveyed in part by the present study. With the aid of tephrochronology, in the topmost portion of the section, they identified the lower part of the Matuyama reversed chron, all of the Gauss normal chron and the upper part of the Gilbert reversed chron. As discussed earlier in this section the treatment of samples in the study of Seward et al. (1986) is unreliable. They suggested a number of events not recognised in the standard polarity timescale of Ness et al. (1980). From the present study it is thought that some of their normal intervals resulted from failure to remove present field overprinting. The magnetostratigraphy of Seward et al. (1986) is accepted in part by this study but not completely.

McGuire (1989) studied 2,250 $\mathrm{m}$ of middle Pliocene strata in the Turakina River. He provided a detailed magnetostratigraphy integrated with Foraminiferal observations. His lithostratigraphy was inadequate for the purposes of correlation. McGuire (1989) made several advancements in understanding the palaeomagnetic behaviour of South Wanganui Basin sediments, but did not identify the remanence carrier and the process of magnetisation of the strata. His study is also accepted in part only by this study. A single fission track age of $3.6 \pm 0.8$ Ma. ensures that magnetozones are identified correctly in comparison with the polarity timescale. McGuire (1989) provided some useful magnetic and biostratigraphic correlation in the South Wanganui Basin. The biostratigraphic datums concerned are LOD Cibicides finlayi, FOD dextral Globorotalia crassaformis, LOD Cibicides molestus, and LOD Globorotalia puncticulata. 


\subsection{Age and definition of Biostratigraphic Datums}

Here, individual species first and last occurrence datums are not presented unless prominent. The main aim is to identify biostratigraphic boundaries in the sections that are well constrained and recognisable in other New Zealand and in some cases international sections. This will aid in correlating magnetozones to the polarity timescale and correlating magnetostratigraphic studies of strata in the South Wanganui Basin.

\subsubsection{The Miocene-Pliocene boundary}

In New Zealand this boundary is defined as the first concurrent occurrence of Globorotalia puncticulata puncticulata and Globorotalia crassaformis. This was first suggested by Scott (1982) as an alternative to the first appearance of Globorotalia sphericomiozea proposed by Loutit and Kennett (1979). It was subsequently adopted by Hoskins (1982) and Hornibrook et al. (1989) as the marker of the Miocene-Pliocene boundary in New Zealand.

Edwards (1987) reported the age of the first co-occurrence to be $5.00^{\prime} \mathrm{Ma}$. However, Roberts (1990) worked extensively on strata of this age in Marlborough combining magnetostratigraphic and palaeontologic observations. He observed the first cooccurrence of puncticulata and crassaformis to be younger. Hence, he defined the Miocene-Pliocene boundary at ca. 4.8 Ma., just below the Thvera subchron of the Gilbert reversed chron. Poor exposure prevented better definition.

The 4.8 Ma. age was much younger than previously recognised, but more in line with the Italian type section boundary (Cita, 1975) age of 4.86 Ma. (Hilgen and Langereis, 1988). Wright and Vella (1988) were unable to identify this boundary in their magnetostratigraphic study of Mangapoike stream due to a $c a$. $1 \mathrm{Ma}$. unconformity encompassing the boundary. Edwards (1987) in his integration of stratigraphic markers 5 New Zealand sections (including DSDP site 284) reports that Notorotalia kingmai first ocaurs at the Mioceno-Pliocene boundary also.

\subsubsection{The Opoitian-Waipipian boundary}

The three lowest stages of the New Zealand Pliocene (Opoitian, Waipipian, and Mangapanian) are poorly defined in terms of their age ranges. In the central region of New Zealand many workers have assigned ages to the stage boundaries. Edwards (1987) provides a summary of most of these and Collen (1972) and McGuire (1989) provide additional information specific to the Wanganui Basin.

The Waipipian Stage in the South Wanganui Basin is equivalent to the Molestus zone as defined by Collen (1972). This zone is defined by the cooccurrence of Notorotalia finlayi and Cibicides molestus. The base of the zone 
is marked by the last occurrence of Cibicides finlayi. at 3.6 Ma. (Edwards et al., 1988) (3.45 Ma.; Hornibrook et al., 1989; 3.27 Ma.; McGuire, 1989). Hornibrook et al. (1989) considered the first co-occurrence to be time transgressive across the southern half of the North Island.

At the Opoitian lectostratotype (Edwards, 1987), the Opoitian-Waipipian boundary is marked by the last occurrence of the Opoitian restricted Chlamys (Phialopecten) triphooki ongleyi and the first occurrence of Chlamys (Phialopecten) triphooki marwicki.

However, at the Opoitian lectostratotype the boundary is encompassed in an unconformity (Edwards, 1987). Edwards (1987) reports the last known occurrence of Cibicides finlayi to be several hundred meters below the unconformity.

In this study the foraminiferal datum is used as the boundary. The molluscan transition is also recognised but because of its poorly defined age is recognised as an approximation of the same stage boundary.

\subsubsection{The Waipipian-Mangapanian boundary}

The Mangapanian stage in the Wanganui Basin is equivalent to the finlayi zone of Collen (1972). The lower boundary is marked by two co-occurring foraminiferal datums. The first appearance of the predominantly dextrally coiled Globorotalia crassaformis (Edwards, 1987), and the last occurrence of Cibicides molestus (Collen, 1972). Hornibrook et al. (1989) assigned an age of $3.1 \mathrm{Ma}$. to the boundary (3.2 Ma.; Edwards, 1987; and 3.02 Ma.; McGuire, 1989).

The Mollusc Mesopeplum crawfordi last appears just beneath the defined stage boundary (Edwards, 1987). This datum is also used in the present study as an approximation of the WaipipianMangapanian stage boundary.

\subsubsection{The Hautawa Shell Bed (Fleming, 1953)}

The Hautawa Reef Horizon was first recognised by Feldmeyer et al. (1943) and named the Hautawa Shell Bed by Fleming (1953). Fleming reported its occurrence from the Coast west of Wanganui to the Rangitikei River in the east. In the South Wanganui Basin it is coeval with the first occurrence of Chlamys Delicatula. For the last 40 years, New Zealand stratigraphers have taken the first occurrence of Chlamys delicatula as marking the PlioPleistocene boundary (Fleming, 1953). Consequently its occurrence in New Zealand has been studied and dated in many sections. From his integrated stratigraphy study, Edwards (1987) recognises its age as $2.4 \mathrm{Ma}$. (i.e. within the Upper Pliocene).

Fleming (1953) recognised the shell-bed as a moderate depth muddy sand horizon with abundant benthic shells 
concentrated by bottom currents. A more detailed setting of this shell-bed was discussed in Section 3. It is important to recall here the facies and depth dependence of the shell-bed occurrence in the Wanganui Basin and note the possibility of slight diachroneity.

\subsubsection{Crassostrea Ingens}

Crassostrea Ingens in the Wanganui Basin continues from the base of the Opoitian to the top of the Mangapanian. Its earliest occurrence in New Zealand is in the early Tongaporutuan in Palliser Bay (Beu and Maxwell, 1990), but Beu and Maxwell (1990) reported that they were not aware of any Kapitean records. It is not observed in the Kapitean rocks studied here. Its last occurrence in the South Wanganui Basin is in the base of the Hautawa Shell Bed (Beu and Maxwell, 1990), giving it an age range 4.8-2.4 m.y. Edwards (1978), reported it to have a short overlap with the first occurrence of Chlamys Delicatula. In this study it was not observed above the base of the Hautawa Shell Bed.

\subsubsection{Chlamys patagonica delicatula}

Chlamys patagonica delicatula is a very important indicator fossil that is widespread in New Zealand Late Pliocene and Pleistocene strata. It is a cold water species with a first occurrence datum of $2.4 \mathrm{Ma}$. in most New Zealand strata. Where magnetostratigraphic information is available the first occurrence of Chlamys delicatula in those sections is slightly younger than the top of the Gauss normal Chron. However, Edwards (1987) reported its first occurrence in the Mangaopari area of the Southern Wairarapa to be as young as $2.1 \mathrm{Ma}$. This is the only non $2.4 \mathrm{Ma}$. age reported. In the South Wanganui Basin its first occurrence is in the base of the Hautawa Shellbed (Fleming, 1953).

\subsection{The Wanganui River Record}

\subsubsection{Magnetozones}

Polarity zonations are presented in figure 19.1. Some 14 normal polarity zones, 11 reversed polarity zones, and 12 magnetozones of undetermined polarity are identified. These zones are clearly defined by declinations and inclinations. Each sample site horizon is treated independently, and there is no zone that includes opposing polarities. This is different from McGuire (1989) and other workers, who have defined their zones by predominant polarities. Where neither polarity predominates, they record this as an unknown polarity zone. In the Wanganui River Section (this study) indeterminate polarity zones are identified where a stratigraphic interval representing more than $100 \mathrm{k}$.y. is not sampled.

Three additional magnetozones are recognised in the Hautawa Road; N15, $\mathrm{R} 12$, and N16. These zones all correlate with zone M12 in the Wanganui River Section. The objective in sampling this 


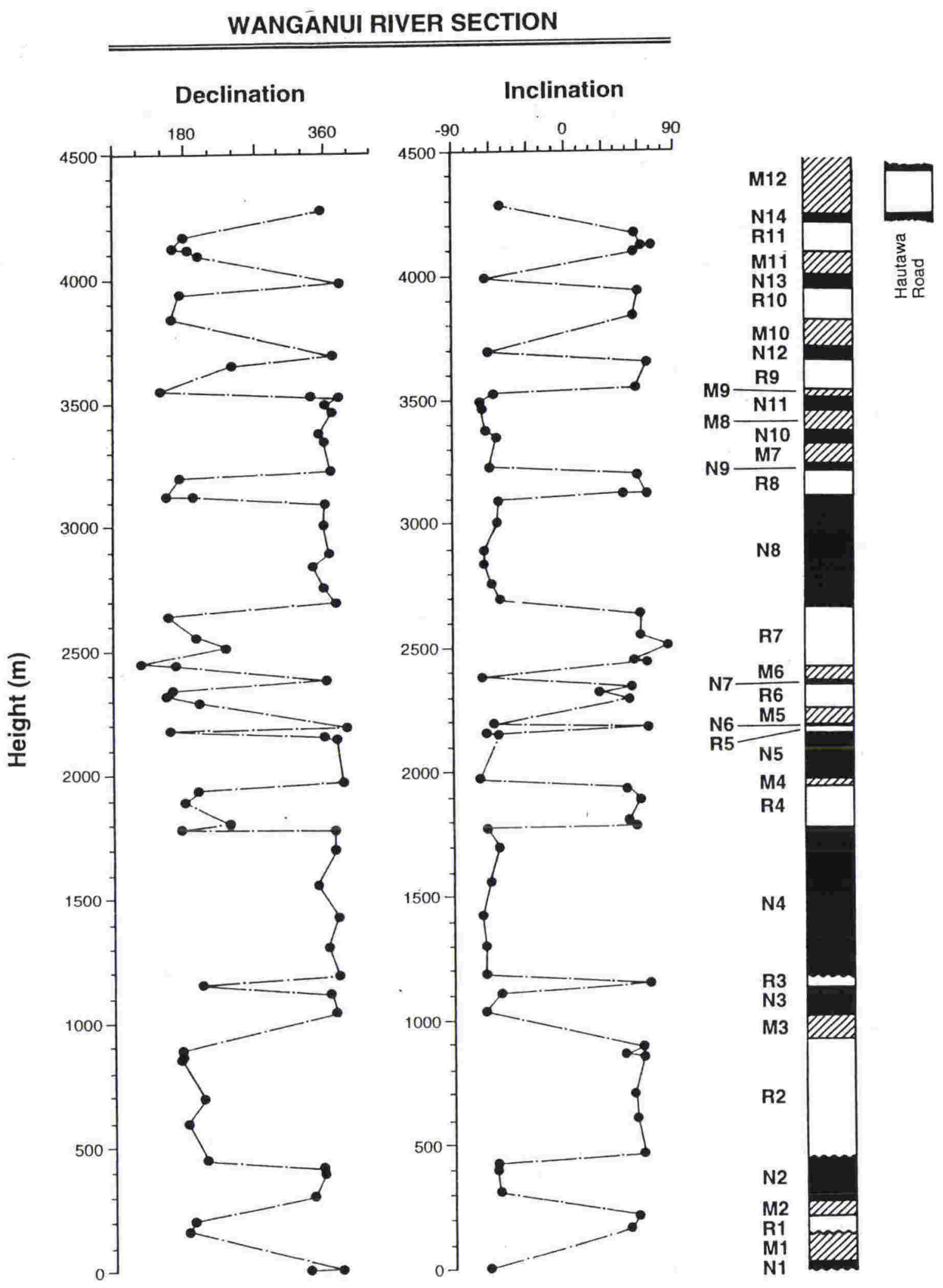

Figure 19.1: Late Neogene Wanganui River polarity magnetozones. These are annotated for reference in the text. $\mathrm{N}$ labelled magnetozones are of normal polarity, $\mathrm{R}$ labelled magnetozones are of reversed polarity, and $\mathrm{M}$ labelled magnetozones are of indeterminate polarity due to necessarily wide sample site spacing. 
sequence was to obtain a record where sample behaviour in the Wanganui River Section was too poor to establish site polarity.

Polarity zones R3, R5, N6, N7, N12, N13 and N14 are defined by only one site. However, these are deemed to be reliable due to the rigorous treatment of individual specimens and site analyses (see Chapter 16).

\subsubsection{Correlation to the magnetic} polarity timescale (figure 19.2)

The timescale used by the present study for correlation is the New Zealand timescale of Edwards et al. (1988). It is based on the polarity timescale of Ness $e t$ where indeterminate polarity is recorded, due to poor sampling intervals. Both of these magnetozones, M1 and M2 are thought to be normal. Combined with magnetozones $\mathrm{N} 1$ and $\mathrm{N} 2$ they comprise most of Chron 5 of the polarity timescale. A short reverse magnetised zone, R1, separate these two normal events. This same reversed event is recognised in the magnetic polarity timescale (Ness et al., 1980). The base of chron 5 is not observed in the present study. The top of chron 5 is placed at 468 $\mathrm{m}$ above the base of the section within a recognised unconformity.

\section{Gilbert Epoch}

From 468 to $2679 \mathrm{~m}$ the sequence has 

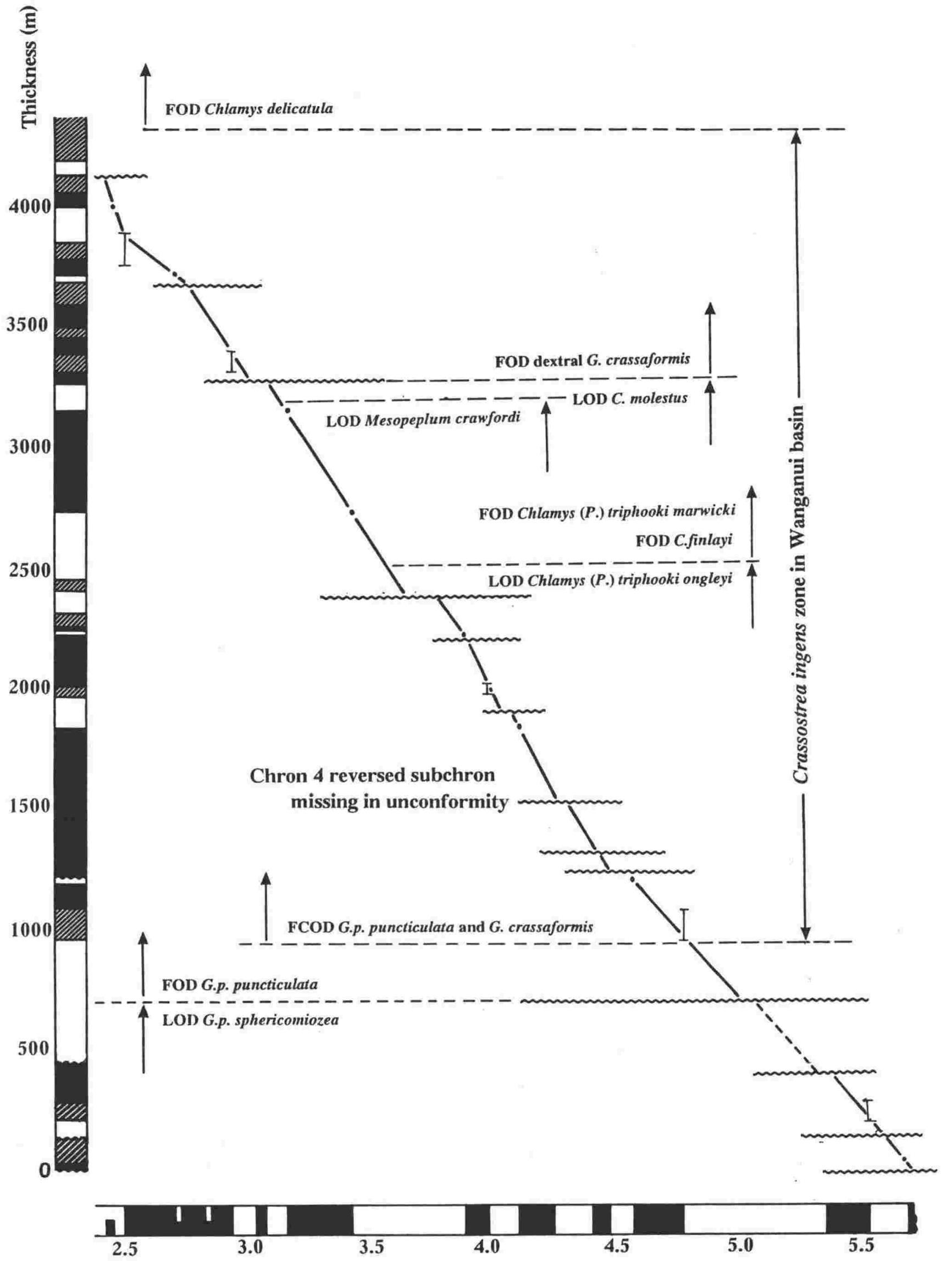

Polarity timescale (Ma)

Figure 19.2: Correlation of Wanganui River magnetozones with the magnetic polarity timescale of Ness et al. (1980), showing the main biostratigraphic datums identified by Collen (1972) and this study. Plot is drawn to show the average sedimentation rate of the Wanganui River strata and identify breaks in deposition. 
the four normal chrons of the Gilbert Epoch (figure 19.2). The oldest normal subchron N3, and most of M3 which is also thought to be normal, by inference from the sedimentation rate curve, is correlated with the Thvera subchron of the polarity timescale. The normal polarity interval from 1199 to $1808 \mathrm{~m}$ is abnormally long assuming the already high average sedimentation rate adopted earlier. It is expected that the reversed polarity interval separating the Sidjuveld and Nunivak normal subchrons is missing in the unconformity recognised by an eroded and bioturbated surface in the Kahunui Mudstone $1524 \mathrm{~m}$ above the base of the section.

Magnetozones N5 and N6, although poorly defined due to a poor sampling interval about this interval, are correlated to the Cochiti normal subchron of the polarity timescale. Close to the top of this subchron a short reversed magnetozone (R5), not included in the polarity timescale, is recognised in the present study. The presence of this and further new magneto-events in strata of the Wanganui Basin is not unexpected, because of the high sedimentation rates observed. This increased the possibility for preserving short lived polarity changes, that may not be observed within standard palaeomagnetic sampling intervals of deep sea cores.

\section{Gauss Epoch}

The interval from 2735 - $4122 \mathrm{~m}$ above the base of the section predominantly normal, with several magnetozones of indeterminate polarity above $3300 \mathrm{~m}$. It was not possible to determine the polarity of these intervals because the sandy nature of the Whenuakura and Paparangi Group strata prevented a more desirable sampling interval. Close to the centre of this normal polarity interval at ca. $3200 \mathrm{~m}$, within the Matahiwi Sandstone, Collen (1972) recognises the start of his finlayi zone. Collen (1972) did not define an exact height because of sandy facies affecting the extinction and evolution species. In the present study this datum, although poor, is recognised as the Waipipian-Mangapanian boundary with an age of $c a$. 3.1 Ma.

This extensive period of normal polarity is correlated with the Gauss chron. Three brief reversed polarity events ( $R 8, R 9$, and $\mathrm{R} 10$ ) are recorded within this interval. This is not consistent with the polarity timescale, but again due to the high average sedimentation rate it is expected that this section will record short reversal events not reported in the polarity timescale. R8 is correlated with the Mammoth event of the Polarity timescale. The Kaena event is not observed but it is likely that it occurs within magnetozone M7 where polarity could not be determined.

Previous studies have recognised short scale reversed events in the Gauss Epoch (eg; Ronai, 1981; Liddicoat et al., 1980). It is possible that R9 correlates with either R1 or R2 identified by Liddicoat $e t$ al., in Searles Lake, California. It is 
unlikely that magnetozone R10 in the Wanganui River Section correlates with either of these as it is too close to the top of the Gauss Chron (as identified in the present study). The top of the Gauss Chron as recognised in the present study is within the indeterminate polarity magnetozone M11 at ca. $4100 \mathrm{~m}$.

\section{Matuyama Epoch}

By continuance, the reversed interval (magnetozone $\mathrm{R} 11$ ) recognised above $4100 \mathrm{~m}$ in the Wanganui River Section is correlated with the early part of the Matuyama epoch. It was not possible to determine polarity above $4,200 \mathrm{~m}$, due to the sandiness of the strata. The equivalent Lower Okiwa Group strata in the Turakina River Valley was studied to provide better magnetostratigraphic control of this interval. Correlation between these two nearby sections relied on the Hautawa Shellbed as a datum plane.

Magnetostratigraphic results from the Turakina River Valley are considered less reliable than those from the Wanganui River Valley. The samples were very weakly magnetised and it proved difficult to establish polarity. Data from the Turakina River Valley (Hautawa Road Section) suggest that magnetozone M12 of the Wanganui River Section is dominantly reversed with one or more short normal polarity events.
The average sedimentation rate of the Wanganui River Section is $1300 \mathrm{~m} / \mathrm{m}$.y. (ca. $1.3 \mathrm{~mm} / \mathrm{y}$ ). Correlation with the polarity timescale and the sedimentation rate curve (figure 19.2) indicate minimal time loss $(<10,000$ years $)$ at unconformities recognised throughout the sequence. It also demonstrates almost continuous sedimentation of Late Neogene strata of the South Wanganui Basin in the vicinity of the current Wanganui River. This supports the conclusion in section 3 that type 1 sequence boundaries are rare in the Wanganui River Section.

\subsection{The Rangitikei River Record}

The Rangitikei River section is naturally divided into two segments by the Rauoterangi Fault. The fault trace cuts the river $4.5 \mathrm{~km}$ due east of Utiku (see enclosure 2). Some $250 \mathrm{~m}$ of strata are repeated from thrusting. These two segments are referred to in the following discussion as north and south segments. The north segment on-laps basement and the south segment is somewhat younger.

\subsubsection{Magnetozones}

Polarity zonations for the Rangitikei River Section are presented in figure 19.3. Six normal polarity zones, 6 reversed polarity zones, and 3 magnetozones of undetermined polarity are identified. Again, these zones are clearly defined by declinations and inclinations, with each sample site 


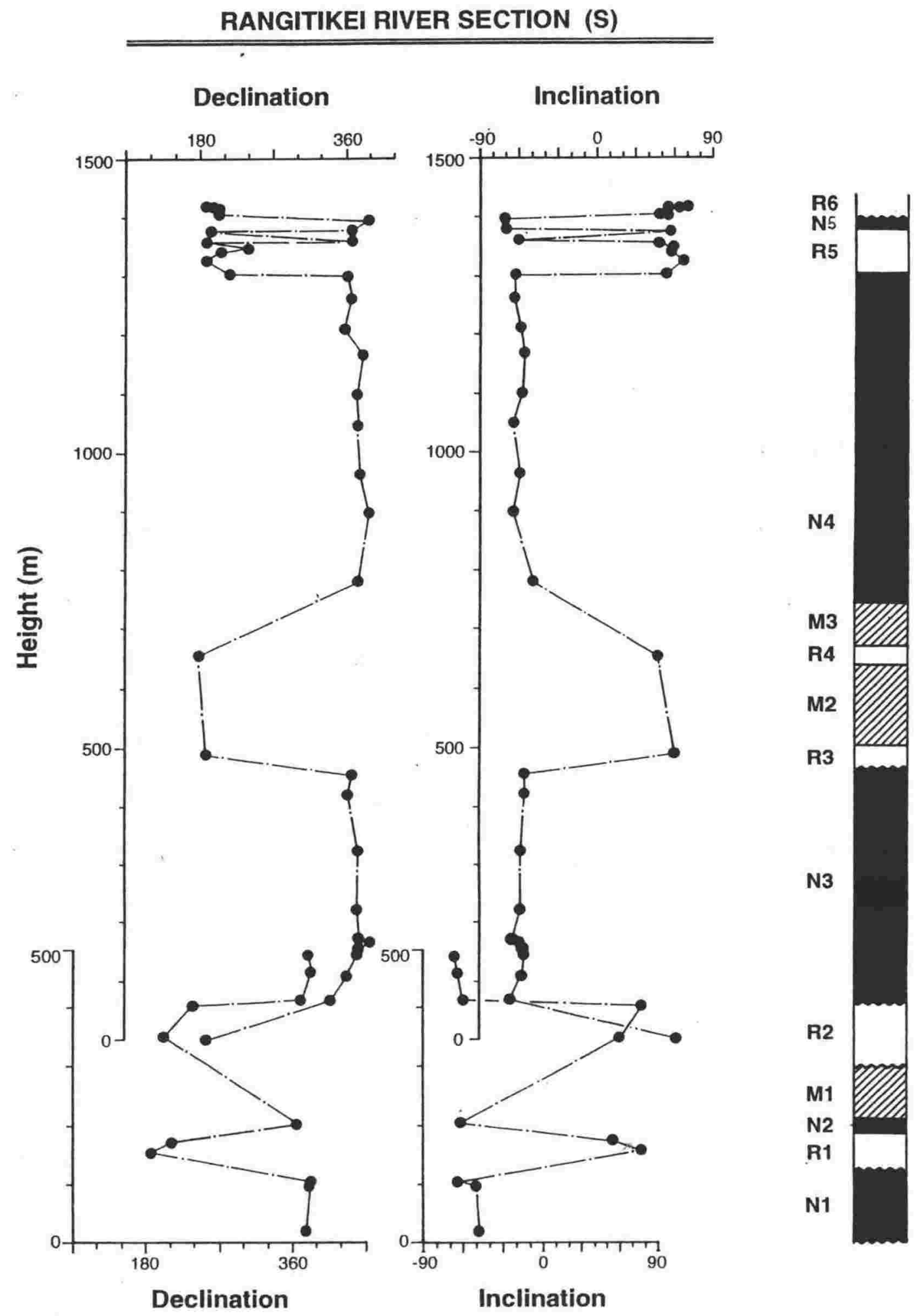

RANGITIKEI RIVER SECTION (N)

Figure 19.3: Late Neogene Rangitikei River polarity magnetozones. These are annotated for reference in the text. $N$ labelled magnetozones are of normal polarity, $\mathrm{R}$ labelled magnetozones are of reversed polarity, and $\mathrm{M}$ labelled magnetozones are of indeterminate polarity due to necessarily wide sample site spacing. Sections either side of the Rauoterangi Fault are combined for ease of annotation and identification. 
horizon treated independently. Zone R5, contains one normal polarity site. It is thought due to the unusually poor behaviour of samples from this site that a normal overprint was not removed or recognised during the demagnetisation procedure.

All indeterminate polarity zones are identified, as in the Wanganui River section, where a stratigraphic interval of more than 100 k.y. is not sampled. Polarity zone N2 is defined by only one site. Again, this is deemed to be reliable due to the rigorous treatment of individual specimens and site analyses.

Magnetozones R2 and N3 are represented in both north and south Rangitikei River segments. They are separated by an unconformity in both segments and this is used as a key datum for correlating the two segments across the fault. In the north segment the unconformity is recognised as a paraconformity, representing a channel formed during a low sea level event (see section 3, chapter 13).

\subsubsection{Correlation to the magnetic polarity timescale (figure 19.4)}

\section{Gilbert Epoch}

The lower $c a .400 \mathrm{~m}$ of the sequence, mostly the northern segment of the section, has several reversed and normal polarity intervals. The unconformable top of this interval represents a considerable time loss. This is shown by the inferred average sedimentation rate curve (figure 19.4). The magnetostratigraphy is similar to that reported by Seward et al. (1986).

Collen (1972) placed the beginning of his Cibicides zone towards the top of the Taihape Mudstone. This is inferred to be within the Taihape Sandstone Member recognised in this study. This interval is assigned this interval to the Gilbert epoch. The base of the section is assigned an age of $c a$. 4.2 Ma. (slightly younger than that assigned by Seward $e t$ al., 1986). As much as half of the uppermost reversed polarity subchron is missing within the two type 1 sequence boundaries in the uppermost part of the Taihape Mudstone.

The present study does not recognise the short reversed polarity interval of Seward et al. (1986) at the base of the section.

\section{Gauss Epoch}

Collen (1972) recognised the transition between his Cibicides and finlayi zones $150 \mathrm{~m}$ above the Hautapu Shell Limestone ( $300 \mathrm{~m}$ above the base of the Mangaweka Mudstone; present study). Just beneath this is the last occurrence of Mesopeplum crawfordi. The present study recognises this as the WaipipianMangapanian boundary in the Rangitikei River section.

The stratigraphic interval from 400 $1650 \mathrm{~m}$ above the base of the section (Utiku Sandstone and Mangaweka Mudstone) is predominantly normal. It 


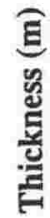

1500

1000
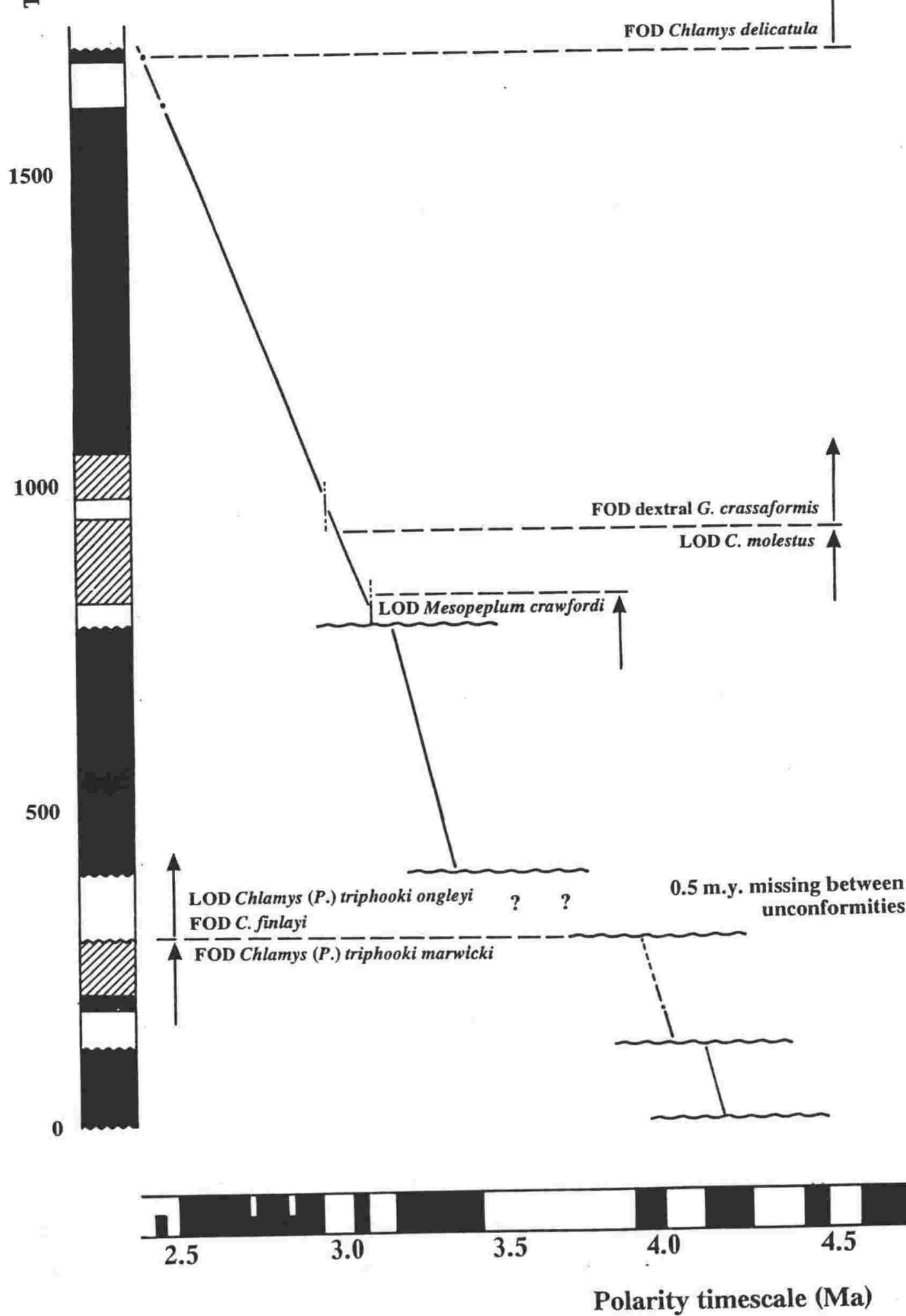

Figure 19.4: Correlation of Rangitikei River magnetozones with the magnetic polarity timescale of Ness et al. (1980), showing the main biostratigraphic datums identified by Collen (1972) and this study. Plot is drawn to show the average sedimentation rate of the Rangitikei River strata and identify breaks in deposition. 
contains the $c a$. 3.1 Ma. WaipipianMangapanian boundary and is therefore assigned to the Gauss Epoch. Two short reversed magnetozones (R3 and R4) separated by an indeterminate magnetozone (M2) are recognised between 750 and $1000 \mathrm{~m}$ above the base of the section. These are correlated to the Mammoth and Kaena events of the polarity timescale. Unlike Seward et al. (1986), the present study does not recognise any short reversed polarity intervals above the Kaena event.

\section{Matuyama Epoch}

Only the basal part of this epoch is observed in the present study. The top of the Gauss Epoch is recognised $55 \mathrm{~m}$ below the top of the Mangaweka Mudstone. Some $50 \mathrm{~m}$ above this, the Hautawa shell bed crops out. Its age of 2.4 Ma. places it well into the Matuyama Reversed Epoch. A short normal polarity event with an unconformity bounded top is recognised towards the base of the Matuyama Epoch. This is correlated with the ' $\mathrm{X}$ ' event, also recognised by Liddicoat et al. (1980) and Ronai (1981). Seward et al. (1986) also reported the 'X' event in the Rangitikei River, but at a different stratigraphic interval than in the present study.

The average sedimentation rate in the Rangitikei River Section is 940 m/m.y. (ca. $1 \mathrm{~mm} / \mathrm{y})$. If the large unconformities recognised in the Lower Utiku Sandstone and Upper Taihape Mudstone are accounted for, the sedimentation rate is more compatible with the $1.3 \mathrm{~mm} / \mathrm{y}$ observed in the Wanganui River Section.

\subsection{Correlations (figure 19.5)}

The top ca. $2,800 \mathrm{~m}$ of strata in the Wanganui River section are correlated with the complete $1700 \mathrm{~m}$ sequence studied in the Rangitikei River. While the general nature of lithology and facies sequences are the same between sections, it is clear that the lithologic groupings proposed in chapter 11 are time transgressive.

Several key unconformities can be correlated between the two sections (figure 19.5). The unconformity bounded Taihape Sandstone, in the Rangitikei River Section, and the upper sandstone members of the Jerusalem Sandstone, in the Wanganui River Section. An unconformity bounded mudstone member of the Utiku Sandstone is correlated with the lower mudstone member of the Koriniti Sandstone in the Wanganui River.

A sequence boundary identified at the base of the Gauss Normal Chron is prominent in both sections. Above this sequence boundary, both sections show a marked shallowing and comprise more sandy facies. This change is also recognised in the Turakina River by McGuire (1989), but poor stratigraphic control prevents good correlation.

The ' $\mathrm{X}$ ' event recognised in the Rangitikei River Section probably occurs 


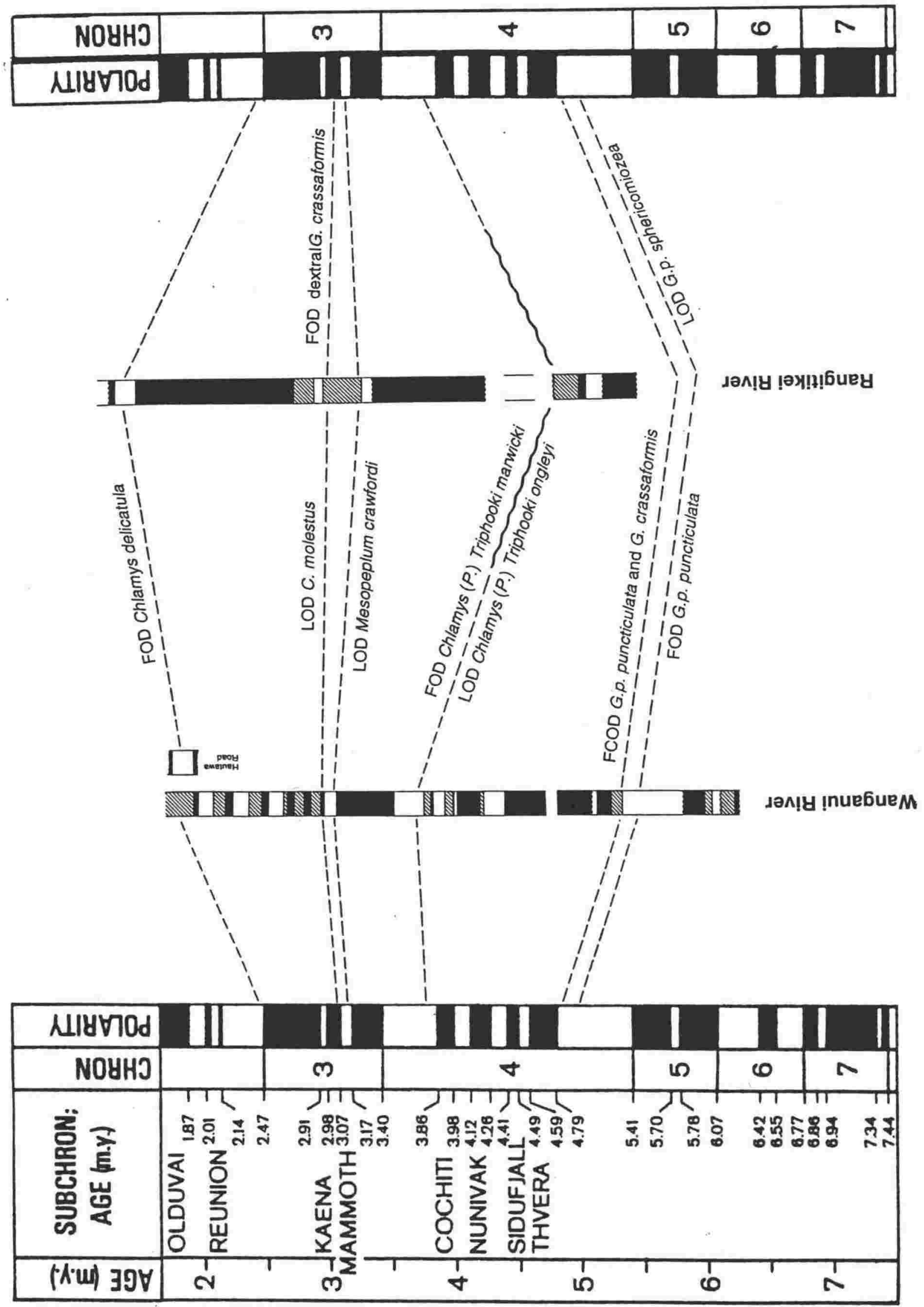

Figure 19.5: Summary of correlations of the Wanganui River, Hautawa Road, and Rangitikei River sequences using magnetostratigraphy and biostratigraphy. Plot allows easy identification of several reversal boundaries in the sections and consequently a high resolution chronology of the strata. 
within the indetermined polarity zone, M12, in the Wanganui River Section, just beneath the Hautawa Shell Bed.

Two prominent shell beds do not seem to be persistent across the basin: The Wilkies Shell Bed cropping out in the
Wanganui River Section has no correlative in the Rangitikei River Section. The Hautapu Shell Limestone exposed in the Rangitikei River does not have a correlative in the Wanganui River Section. 


\section{Chapter - 20 \\ Conclusions}

\subsection{Summary of findings}

\subsubsection{Antarctic chronology}

The CIROS-2 ash is assigned a Pliocene age of $2.8 \pm 0.3 \mathrm{Ma}$. It was dated using the $\mathrm{K} / \mathrm{Ar}$ and single crystal laser fusion ${ }^{39} \mathrm{Ar} / 40 \mathrm{Ar}$ dating methods. Simultaneous equations were employed to account for the age contributions of the intermixed volcanic and basement detritus. This age corroborated biostratigraphic chronology of the CIROS-2 core and showed that Late Neogene diatom biostratigraphy developed in the Southern Oceans is applicable at high latitudes in the Antarctic interior, and confirms that Late Pliocene deglaciation recorded by diatoms in the Sirius Group deposits (Webb et al., 1984).

The beryllium-10 relative dating technique was developed and applied to cored Antarctic margin strata (CIROS-2 and DVDP-11) in McMurdo Sound. The most applicable method of dating of the CIROS-2 and DVDP-11 strata was found to be measurement of the absolute content of the leached exotic ${ }^{10} \mathrm{Be}$ from authigenic sedimentary phases. Facies analysis identified horizons of similar depositional environment, thus preventing the need to make assumptions of a constant sedimentation rate throughout each core. Using the CIROS-2 ash for calibration 5 further horizons were dated in the CIROS- 2 core and 2 horizons were dated in the DVDP-11 core. The strata in the base of the CIROS-2 and DVDP-11 holes were dated at 4.1 $\pm 0.5 \mathrm{Ma}$. and 6.0 $\pm 0.7 \mathrm{Ma}$. respectively. These new data further corroborate the existing diatom biostratigraphy of CIROS-2 and DVDP-11 (Harwood, 1986) and the foraminiferal biostratigraphy of DVDP-11 (Ishman and Rieck, 1993).

Magnetostratigraphy, with polarity zones assigned using the radiometric ages detailed above and assuming constant average sedimentation rates between polarity reversals and disconformities, provides a chronology of $c a$. $100 \mathrm{Ka}$. resolution for both the CIROS-2 and DVDP-11 cores. Absolute ages are assigned by correlation with the polarity timescale of Ness et al. (1980). The magnetostratigraphy has identified major hiatuses in both cores, but suggests that sedimentation is slow (ca. $50 \mathrm{~m} / \mathrm{m} . \mathrm{y}$.) and remarkably continuous within the $100 \mathrm{Ka}$. ( $\pm 50 \mathrm{Ka}$.) dating resolution, despite sedimentation being from the advance and retreat of glaciers. The CIROS-2 core provides a record of sedimentation between 0 and 4.1 Ma., with breaks at 3.4-3.5 Ma. and 2.4-2.5 Ma. The DVDP-11 core provides a record 
of sedimentation between 0 and $6.0 \mathrm{Ma}$. with breaks at 4.3-4.5 Ma. and 3.2 and $3.5 \mathrm{Ma}$. Events in both cores between 2.4 and $4.1 \mathrm{Ma}$ are correlative.

\subsubsection{South Wanganui Basin chronology}

The Wanganui and Rangitikei River sections of the South Wanganui Basin are dated using magnetostratigraphy integrated with existing biostratigraphy. A resolution of $c a$. $100 \mathrm{Ka}$. was obtained assuming constant average sedimentation rates between polarity reversals and unconformities. Absolute ages are assigned by correlation with the magnetic polarity timescale of Ness et al. (1980). The magnetostratigraphy has identified that the $4,200 \mathrm{~m}$ of strata comprising the Wanganui River section spanned $3.3 \mathrm{~m} . \mathrm{y}$. between 2.4 and $5.7 \mathrm{Ma}$., representing an average sedimentation rate of $1.3 \mathrm{~mm} / \mathrm{y}$, with a single disconformity at 4.3-4.4 Ma. The $1400 \mathrm{~m}$ of strata comprising the Rangitikei River section spanned $1.8 \mathrm{~m} . \mathrm{y}$. between 2.4 and $4.2 \mathrm{Ma}$., excluding a ca. $0.5 \mathrm{Ma}$. unconformity within two channelled disconformities in the lower part of the Rangitikei River sequence. Large order events in both sections are correlative.

Despite the weak intensity of the magnetic remanence of the South Wanganui basin sediments, they faithfully retain their original detrital remanent magnetisation (DRM). The DRM is complicated by secondary magnetisation developed during diagenesis of the sediments. Optical and electron microprobe analysis of sediments and grain separates combined with rock magnetic studies of the same sediments and separates has established that the DRM is retained by iron rich boundary phases in ilmenite grains and rarely by chromite, with chemical overprinting from authigenic haematite growth. The ilmenite signal can only be deciphered by thermal demagnetisation, and usually persists to temperatures between $300^{\circ} \mathrm{C}$ and $400^{\circ} \mathrm{C}$. The haematite signal is usually antipodal to the DRM and persists to higher temperatures. Thermal alteration of clays within the sediments prevents cleaning above $300^{\circ} \mathrm{C}$ to $350^{\circ} \mathrm{C}$.

Sediment diagenesis affects the natural remanent magnetisation (NRM) in two ways: Firstly, reduction dissolves iron-rich oxides weakening the NRM and providing iron for the growth of sulphide phases, initially greigite and pyrrhotite and finally pyrite, which is paramagnetic. Secondly, oxidation of the pyrite to haematite provides a chemical remanent magnetisation (CRM) that develops aligned with the magnetic field in the strata, rather than the geomagnetic field. The mid temperature signal during stepwise thermal demagnetisation $\left(150^{\circ} \mathrm{C}-300^{\circ} \mathrm{C}\right)$ is from DRM. 


\subsubsection{The record of Late Neogene Antarctic Ice Volume fluctuation}

Drill-cores on the Antarctic margin in McMurdo Sound provide a stratigraphic framework for interpretation of local and continental ice volume variation and a correlation point for several indicators of ice volume variation, in this case deposits in the Transantarctic Mountains, Dry Valleys and Lambert Glacier region. The facies model of Hambrey et al. (1989) is developed further to include shallower water proximal breccia or pebble conglomerate. Markov chain analysis with Waltherian law establishes the relationships of six glaciomarine facies into two facies successions identified in the CIROS-2 and DVDP11 cores and allows interpretations of them in terms of ice advancing and retreating in a glaciomarine environment. Five types of unconformity are identified as part of the facies successions. Most are disconformities scoured by currents associated with nearby grounded ice, and are indicative of glacial advance.

The records from the DVDP-11 core and CIROS-2 core are in good agreement and inferred to be representative of variations in the volume of the East Antarctic ice sheet, which feeds the Taylor and Ferrar Glaciers. The record in both cores is quite complete because of the passive nature of glacial advance and retreat caused by the sea-level response to ice volume variation on the East Antarctic craton. The sea-level rise and fall floats and grounds the ice tongue during a glacial retreat and advance respectively. Ice volume variation is inferred to occur on four orders determined by scale and timing. The smallest scale is $100 \mathrm{k} . \mathrm{y}$. duration glacial cycles resulting from limited ice volume variation indicative of the middle Pliocene glacial record. The largest scale is major grounding of ice in the Ross Sea due to development of an ice sheet larger than the present ice sheet. During times of maximum deglaciation, observed in the Early Pliocene by this study, the ice sheet is inferred to have been approximately half its present size. During maximum glaciation at $c a .2 .5 \mathrm{Ma}$. the ice sheet is inferred to have grown to less than 1.5 times the present ice sheet. This new ice volume record of the East Antarctic ice sheet does not agree with existing interpretations of the oxygen isotope record for the Late Neogene, but the variation is similar in timing and amplitude to variations in the oxygen isotope record.

\subsubsection{The record of eustatic sea level variation.}

Deposits in the South Wanganui Basin, New Zealand provide a stratigraphic framework for interpretation of Late Neogene global sea level variation. The strata are mapped in the Wanganui and Rangitikei Rivers and subdivided lithologically into formations, mappable on a 5-50 km scale, and groups mappable across the entire basin. The stratal successions are interpreted within a new sequence stratigraphic model. This model is deduced from direct observation of the facies associations, facies successions and sequence architecture 
of the strata. Eight facies associations are recognised to originate from deposition in different positions on a graded shelf. Two facies successions (fining and coarsening) record rising and falling sea level. Seven unconformities separate the facies successions. Most of these are channelled or scoured disconformities and the remainder are hardground paraconformities.

Lowstand, Transgressive, Highstand, and Regressive Sediment Wedges are defined, their formation governed by lowstand, highstand, transgressing and regressing eustatic sea level respectively. The two sequence types (coarsening and fining) result from the position of sedimentation on the palaeo-continental shelf, with respect to highstands and lowstands of sea level. All of these form above the shelf break with two separate depositional shoreline breaks related to the highstands and lowstands of sea level. A southward progressing lithospheric wave controls sedimentation and basin subsidence, balancing them and ensuring that resulting sequences are moulded only by eustatic sea level fluctuation. This new model is different from the existing sequence stratigraphic framework (sensu Payton, 1977 and Wilgus et al., 1988) and not bound by the same assumptions.

The southward progressing outcrop sampled by the Wanganui and Rangitikei Rivers ensures that the record is one of eustatic variation only. Eustatic sea level variation is interpreted mainly from the Wanganui River Section, using downlap as well as onlap of strata, supported by evidence from the Rangitikei River Section. The Wanganui River strata were deposited mainly below the lowstand depositional shoreline break and consequently contains a nearly complete record of Late Neogene eustatic sea level variation, with more than 17 cycles. The eustatic variation occurs on four orders of timing; A base level of 3-4 m.y. duration and three shorter order cyclicities of ca. 2 m.y., 100-500 m.y., and 40-100 k.y. respectively. Amplitudes of eustatic sea level variation are ca. $40 \mathrm{~m}$ for the base eustatic sea level curve, and 40-50 m and less for the shorter order cycles. A total variation in sea level of $c a .80 \mathrm{~m}$ for the Late Neogene is therefore proposed. Agreement between the South Wanganui Basin curve and the EXXON global sea level curve for the same time period is poor. However, the Wanganui Basin curve has superior resolution and chronostratigraphic control and is proposed as a much improved Late Neogene (2.4-6.0 m.y.) global sea level curve.

\subsection{Ice volume and sea level relationship in the Late Neogene}

Figure 20.1 presents both the Antarctic ice volume curve (from chapter 6) and the eustatic sea level curve (from chapter 15). Alignment of the two curves is by magnetostratigraphic control. The two curves both vary on several orders $(<0.1,0.1-0.5$, and 2-4 Ma.). Major inflections occur in both curves at ca. 2.4, 3.4, 4.3 and 5.5 Ma. The two curves seem to vary in synchrony on all orders and at all major inflection points, except for the time interval 4.8-5.3 Ma. when the curves appear to be almost mirror images. 


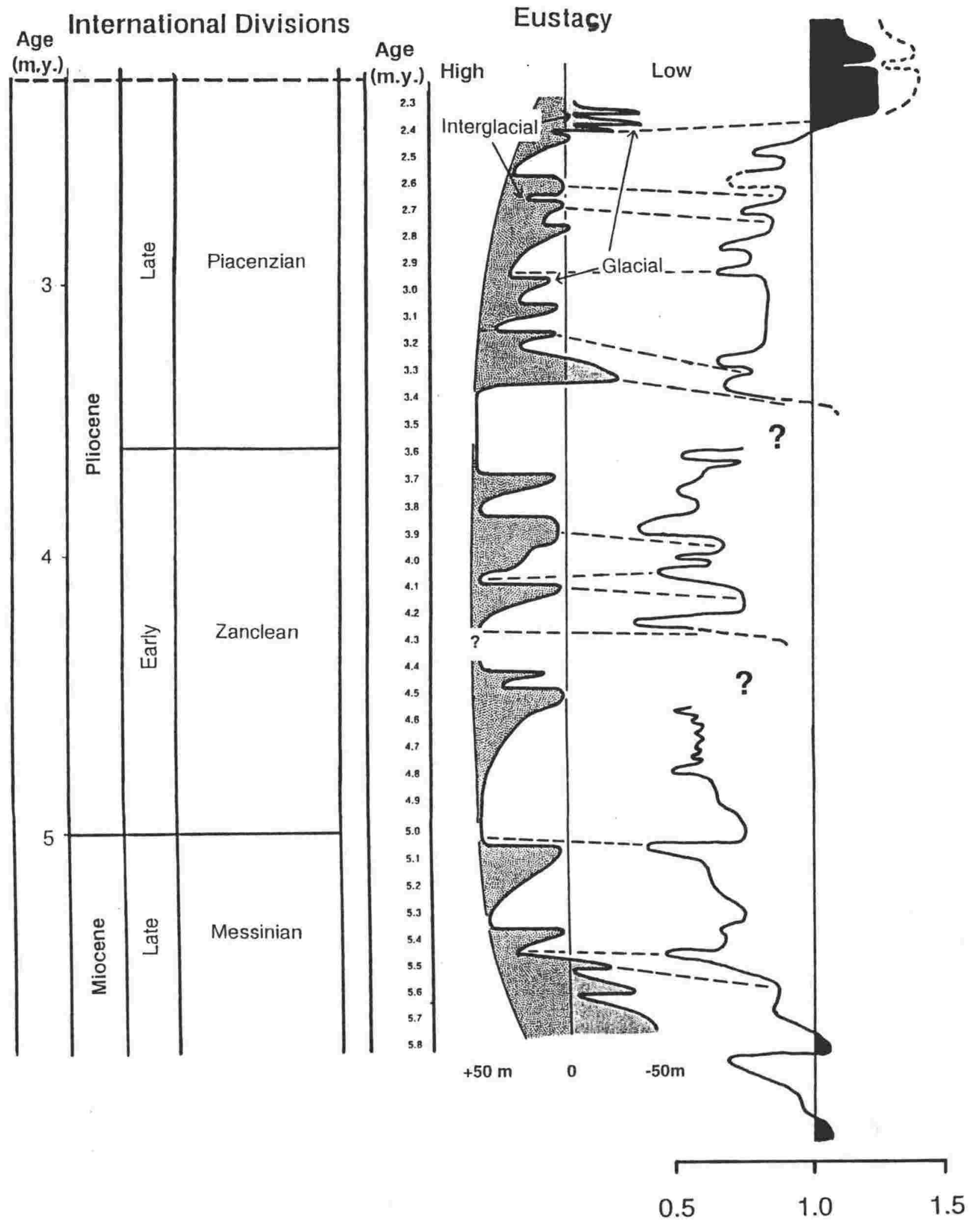

Figure 20.1: Correlation of the eustatic sea level curve (from the South Wanganui Basin, chapter 15) and the Antarctic ice volume curve (predominantly from McMurdo Sound, chapter 6). The resolution of chronology on both curves is 100 k.y. ( $\pm 50 \mathrm{Ka}$.). Sea level variation is reported in amplitude (m) and ice volume is reported as volume (with respect to the present day volume). 
Considering the $100 \mathrm{Ka}$. $( \pm 50 \mathrm{Ka}$.) resolution of each record, agreement between the two is very good. They can be considered to match in a number of respects:

1) Eustatic highstands recorded by the South Wanganui Basin are matched by glacial retreats and deposition of interglacial sediments in the Ferrar and Taylor Valleys.

2) Eustatic lowstands in the South Wanganui Basin record are matched by glacial advances and grounding of ice in the Ferrar and Taylor Valleys/Fjords.

3) Large scale ice grounding events in McMurdo Sound, recorded by erosional events are matched by the lowest stands of eustatic sea level, represented by very shallow water facies (highstand wedges) or subaerial exposure and erosion in the South Wanganui Basin. In each of these cases some of the previous record is missing from erosion and the lowest sea level events, where recorded, are expected to coincide with the latest part of the hiatuses in McMurdo Sound. These are recognised at ca. 3.4 and 4.3 Ma.

4) The order of change predicted by the Sirius group deposits, with partial deglaciations of the Antarctic continent and subsequent regrowth of the ice sheet is matched in the Late Neogene by equivalent rising and lowering, respectively, of the 'base sea level' for eustatic fluctuation.

5) A gradual, but fluctuating, change of the Antarctic Ice Sheet into 'glacial mode' between ca. 3.2 and $2.4 \mathrm{Ma}$. is matched by a gradual, eustatic falling from 'high base level' fluctuation to 'low base level' fluctuation over the same time period.

Wanganui Basin sea level variation predicts ca. $40 \mathrm{~m}$ of sea level change between the highstand and lowstand wedges and therefore a base level change on the order of $40 \mathrm{~m}$ to superimpose highstand wedges within a lowstand succession and visa versa. Sirius Group evidence requires that the Wilkes and Pensacola Basins will remain sub-marine during deglaciation. Lithospheric models that have been proposed to predict isostatic rebound of the Antarctic continent, caused by deglaciation are found to be incorrect. Two factors prevent rebound above sea level: 1) They can be maintained below sea level by a reduced ice volume remaining on the continent and 2) partial deglaciation of the Antarctic continent causes associated higher sea levels; at sea level rises up to $c a .40 \mathrm{~m}$ this is significant.

The amplitude of sea level change predicted by the South Wanganui basin strata supports only partial deglaciation of the continent, by approximately half its present volume, throughout the Early Pliocene, and growth to a volume half as much again as the present day at ca. 2.5 Ma. co-incident with major ice grounding and erosion in the Ross Sea. 
An order of magnitude approximation in behaviour of the Antarctic ice sheet predicts that deglaciation resulting in marine incursion into the interior basins would provide approximately $40 \mathrm{~m}$ of sea level equivalent.

Much of the global signal of climatic change at $2.4 \mathrm{Ma}$. results from growth of the Antarctic Ice Sheet to the cold polar feature that it is today.

\subsection{The record of ice induced sea level change in the Late Neogene}

The Late Miocene (older than 5.5 Ma.) and Late Pliocene (younger than $2.4 \mathrm{Ma}$.) are times of low 'base level' glacioeustasy (here termed glacialism, rather than glacial), with growth of continental scale ice sheets on the Antarctic continent causing a lowering of global sea level. The early Pliocene was a time of high 'base level' glacioeustasy (here termed interglacialism, rather than interglacial), driven by collapsing of continental scale ice sheets to local and subcontinental ice caps. The middle Pliocene (2.5-3.4 Ma.) is marked by a move into glacialism with an increasing 'base level' of glacioeustatic fluctuation. Higher order glacial advances and associated eustatic sea-level lowering occurred at $c a$. 3.5 Ma. ca. 4.3 Ma., separating the Early Pliocene into 3 sea level stages (older than 4.3 Ma., 3.5 - 4.3 Ma., and 2.4 - 3.5 Ma.). Still higher order glacioeustatic fluctuations are recognised in this study, with durations of $50 \mathrm{Ka}$. and $100 \mathrm{Ka}$. $300 \mathrm{Ka}$. The $100 \mathrm{Ka}$. $300 \mathrm{Ka}$. duration cycles are prominent during interglacialisms, and the $50 \mathrm{Ka}$. duration cycles are prominent during glacialisms. These shorter duration fluctuations in glacioeustasy have already been defined as glacial/deglacial cycles from detailed studies of the Quaternary.

\subsection{Implications for the global sea-level model (GSM)}

1) Four orders of sea-level fluctuation are recognised within the Late Neogene, These are of ca. 0.05 Ma., 0.1-0.3 Ma., ca. $2 \mathrm{Ma}$., and ca. $4 \mathrm{Ma}$. in duration. The $2 \mathrm{Ma}$. and $4 \mathrm{Ma}$. duration cycles are subdivisions of the 3 rd order cyclicity recognised by Vail et al. (1991) (referred to here as cyclicity order $3 \mathrm{a}$ and $3 \mathrm{~b}$ ). The 0.1-0.3 Ma. duration cycles are a subset of the 4 th order cyclicity recognised Vail et al. (1991), and the ca. $0.05 \mathrm{Ma}$. duration cycles are a subset of the 5 th order cyclicity recognised by Vail et al. (1991).

2) $3 \mathrm{a}, 3 \mathrm{~b}$ and 4 th order sea level fluctuations are driven by fluctuations in the volume of the Antarctic Ice Sheet. 5 th order sea level fluctuations are also predicted to be at least partially driven by fluctuations in the volume of the Antarctic Ice Sheet.

3) Milankovitch cyclicities in glacioeustasy ( $<100 \mathrm{Ka}$., 5 th order cyclicity) are prominent in the geologic record at times when there is large scale glaciation (glacialism) of the 
Antarctic Continent (e.g. for the Pleistocene). At times when the Antarctic continent is in a deglaciated state (deglacialism) 4 th order cyclicity is more prominent, with Milankovitch cyclicities although present at a parasequence level, not the most prominent signal.

A possible explanation for this is that the south pole of the earth is most affected by the perturbations in the earth's orbital parameters (known as Milankovitch cycles) and consequently most affected by associated climatic forcing. When there is a large ice sheet on the Antarctic continent it grows and diminishes in volume in response to the orbital forcing and dominates the geologic record of glacial and deglacial glacioeustasy. When the large ice sheet is absent from the continent or reduced to local ice caps, there is less ice volume available for response to orbital forcing and larger order cycles are more prominent in the geologic record.

\subsection{Assessment of the record}

This new record of Late Neogene glacioeustasy does not agree with accepted interpretations of the Oxygen Isotope record for the same time period (e.g. Kennett, 1977), but it does agree with interpretations of Harwood (1986) (figure 6.1) and Shackleton et al. (1992) that make some attempt to account for the effect of gradual Cainozoic global cooling. The record of glacioeustasy inferred from oxygen isotopic evidence by Shackleton et al. (1992) is in good agreement with the findings of this study, suggesting that many of the assumptions in the model of Shackleton et al. (1992) are correct.

The EXXON global sea level curve (Haq et al., 1987) as already discussed has much poorer age resolution than this study and this study is better for assessing global climate evolution in the Late Neogene.

Support for the findings of this study is available from the record of global warmth and lower sea temperature gradients throughout the Early Pliocene (Dowsett et al., 1992; Dowsett and Loubere, 1992; Gladenkov et al., 1991; Cronin, 1991).

Sea level evidence from the U.S. middle Atlantic plain (Dowsett and Cronin, 1990; Krantz, 1991), although of poorer resolution that this study, corroborate major events reported here. This includes major sea level lowstands at ca. $5.5 \mathrm{Ma}$, high 'base sea-level' at ca. 3.2 and 5.0 Ma., and gradual 'base sea-level' shallowing between 2.4 and 3.2 Ma., with major sea-level reduction at $2.4 \mathrm{Ma}$. Smaller order cycles are also suggested but the resolution of the chronology is not high enough to correlate with this study. 
Major Late Miocene low glacioeustatic sea-levels have been documented for a long time by studies of the Messinian salinity crisis (e.g. Ryan et al., 1976; Adams et al., 1977), supporting the claim of this study of glacialism conditions during the Late Miocene.The greatest glacialism developed at $2.4 \mathrm{Ma}$. and has been documented from many regions by deep sea drilling (e.g. Dunbar et al., 1992; Shackleton and Kennett, 1975; Kennett et al., 1975; Berggren, 1972a).

\subsection{Implications for the International Pliocene epoch and the Plio- Pleistocene boundary.}

Current international definition of the Pliocene Epoch, from biostratigraphic and palaeomagnetic information has proved somewhat hard to apply in a global sense. The traditional place for the Plio-Pleistocene boundary in New Zealand has been at ca. 2.4 Ma. marked by, amongst others, the first occurrence of the cold water species Chlamys Delicatula. The present study advocates that this cooling event is correlative with the cold polar glaciation of the Antarctic continent and associated marked lowering of global sea levels. This must provide a significant global marker of climatic change that could be applied much more convincingly as the Plio-Pleistocene boundary.

The Pliocene would then be the time period from 2.4-4.8 Ma., and could be simply subdivided into early, middle and late (older than 4.3 Ma., 3.5 - 4.3 Ma., and 2.4 - 3.5 Ma.) by major sea level lowstands and global cooling at ca. 3.5 and $4.3 \mathrm{Ma}$. Because of global changes at these datums it is expected that correlative changes in biostratigraphy will also exist to aid in identification.

\subsection{Future directions}

The current study provides an unequalled record of Late Neogene glacioeustasy and while increasing the understanding of ice sheet and sea level behaviour and interactions, the new model now must be tested against new records of equal resolution from other parts of the earth.

The potential is available to define the record for much of the Miocene, both from the North and South Wanganui Basin and the MSSTS-1 (McMurdo Sound Sediment and Tectonic Studies) and CIROS-1 drillholes. The Late Pliocene and Pleistocene can also be correlated from the Wanganui Basin to McMurdo Sound.

The resolution of sea-level fluctuation from the South Wanganui basin can be increased to include at least 6 th order cycles labelled as parasequences by this study. Isotopic analyses 
of foraminifera from this section may help in correlating the global oxygen isotope curve to the new sea-level curve.

Further outcrop evidence in McMurdo Sound is available to develop a high resolution Late Neogene composite reference section in the Western Ross Sea Region for correlation and interpretation of isolated outcrops from the Antarctic Continent that indicate climatic variation. 


\section{APPENDICES}

Appendix - 1: Antarctic Margin stratigraphic sections and unit descriptions

Appendix - 2: Reprint of the paper: Wilson and Ditchburn (1992); Beryllium systematics in rock materials and its separation for measurement on an Accelerator Mass Spectrometer, DSIR Physical Sciences report no. 53, 32p.

Appendix - 3: South Wanganui Basin stratigraphic sections, unit descriptions and sample listings

Appendix - 4: Grain size analyses

Appendix - 5: Magnetic measurements 


\section{Appendix - 1 \\ Antarctic margin stratigraphic sections and unit descriptions.}

Only the Late Miocene - Late Pliocene (2.4 - 6.0 m.y.) stratigraphic sections and unit descriptions of the CIROS-2 and DVDP-11 cores are reported here. Full core logs for both these cores have previously been reported for the CIROS-2 core by Pyne et al. (1985) and for the DVDP-11 core by McKelvey (1981). Here a reassessment of the Late Miocene to Late Pliocene sections of both cores is reported, using a facies analysis approach with special emphasis placed on recognising unconformities in the cores. The new log is sufficiently different from Pyne et al. (1985) and McKelvey (1981) to warrant its reporting here.

The two cores were relogged during two visits to the Florida State University Antarctic Core Repository. A mix-up in the depth measurements of core lengths recovered in the DVDP-11 core resulted from both repacking of the core and metric conversion of measured thicknesses (Dennis Cassidy, pers. comm.). This meant that it was necessary to measure the entire core and its lithostratigraphic units directly. The original hole depths and on-site logs were used as a guide to ensure the correct unit thicknesses and depths are reported for both the DVDP-11 and CIROS-2 cores.

Each core is subdivided into lithologic units numbered at 1 from the base upwards. Each description is preceded by the unit thickness and its position below the top of the core ( $\mathrm{U}=$ unit thickness, $\mathrm{S}=$ unit interval below the top of the core). Each unit description includes lithology, bedding properties, colour, textural variation, the nature of contact with underlying and overlying unit and any other relevant comments where applicable, such as fossil content or sand petrology. For thicknesses where no core was recovered, these are reported as units of no core recovery. 
A1.1 CIROS-2 drill-hole core log

$1(\mathrm{U}=>1.62 \mathrm{~m} ; \mathrm{S}=166.47->168.09 \mathrm{~m})$

Base of unit not seen. Granite Gneiss basement, basement surface is planar and inclined at 30 degrees and not striated. Two joints at $167.30 \mathrm{~m}$ inclined 25 degrees are mud smeared.

$2(\mathrm{U}=1.10 \mathrm{~m} ; \mathrm{S}=165.37-166.47 \mathrm{~m})$

Mudstone, sandy and diatomaceous. Slightly wavy $\mathrm{mm}$ bedding with mudstone clasts and burrowing. Greenish grey. Soft to moderately soft and calcareous. Diatoms and spicules are abundant. Granule layer in mudstone on basement surface. Top of mudstone is an unconformity with several $\mathrm{cm}$ of topography.

$3(\mathrm{U}=1.97 \mathrm{~m} ; \mathrm{S}=163.40-165.37 \mathrm{~m})$

Mudstone, sandy and gravelly diamictite. slightly bedded in places. Dark greenish grey and greenish grey. Moderately hard with subhorizontal clay slickenside surface on post drill fractures. Slightly calcareous to non calcareous. Unit is unconformity bounded.

$4(\mathrm{U}=8.40 \mathrm{~m} ; \mathrm{S}=155.00-163.40 \mathrm{~m})$

Mudstone, sandy and gravelly diamictite. slightly bedded in places. Dark greenish grey and greenish grey. Moderately hard with subhorizontal clay slickenside surface on post drill fractures. Slightly calcareous to non calcareous. Unit is unconformity bounded.
$5(\mathrm{U}=2.28 \mathrm{~m} ; \mathrm{S}=152.72-155.00 \mathrm{~m})$

Mudstone, sandy and gravelly diamictite. slightly bedded in places. Dark greenish grey and greenish grey. Moderately hard with subhorizontal clay slickenside surface on post drill fractures. Slightly calcareous to non calcareous. Unit is unconformity bounded.

$6(\mathrm{U}=0.32 \mathrm{~m} ; \mathrm{S}=152.40-152.72 \mathrm{~m})$

Mudstone, sandy and gravelly diamictite. slightly bedded in places. Dark greenish grey and greenish grey. Moderately hard with subhorizontal clay slickenside surface on post drill fractures. Slightly calcareous to non calcareous. Top of unit grades into overlying mudstone.

$7(\mathrm{U}=1.15 \mathrm{~m} ; \mathrm{S}=151.25-152.40 \mathrm{~m})$

Mudstone, grades from underlying diamictite. Slightly sandy, diatomaceous. Slight $\mathrm{mm}$ bedding, gravel lenses and burrowed. Greenish grey. Soft to moderately soft. Diatoms and Spicules abundant. Grades into overlying diamictite.

$8(\mathrm{U}=3.53 \mathrm{~m} ; \mathrm{S}=\mathbf{1 4 7 . 7 2 - 1 5 1 . 2 5 \mathrm { m } )}$

Mudstone, sandy and gravelly, very poorly sorted, diamictite. Alternates between intervals of massive and intervals of $\mathrm{cm}$-mm bedding. Moderately hard to hard with clay cemented crossed joints. Upper part of unit is noncalcareous.

$9(\mathrm{U}=\mathbf{0 . 3 2} \mathrm{m} ; \mathrm{S}=\mathbf{1 4 7 . 4 0 - 1 4 7 . 7 2} \mathrm{m})$

No core recovered from this interval. 
$10(\mathrm{U}=0.69 \mathrm{~m} ; \mathrm{S}=146.71-147.40 \mathrm{~m})$

Mudstone, sandy and gravelly, very poorly sorted, diamictite. Alternates between intervals of massive and intervals of $\mathrm{cm}$-mm bedding. Moderately hard to hard with clay cemented crossed joints. Slightly calcareous.

11 ( $\mathrm{U}=\mathbf{2 . 5 9} \mathrm{m} ; \mathrm{S}=\mathbf{1 4 4 . 1 2 - 1 4 6 . 7 1} \mathrm{m})$

No core recovered from this interval.

$12(\mathrm{U}=1.08 \mathrm{~m} ; \mathrm{S}=143.04-144.12 \mathrm{~m})$

Mudstone, sandy and gravelly, very poorly sorted, diamictite. Alternates between intervals of massive and intervals of $\mathrm{cm}$-mm bedding. Moderately hard to hard with clay cemented crossed joints. Slightly calcareous.

$13(\mathrm{U}=1.99 \mathrm{~m} ; \mathrm{S}=\mathbf{1 4 1 . 0 5 - 1 4 3 . 0 4} \mathrm{m})$

No core recovered from this interval.

14 ( $U=0.08 \mathrm{~m} ; \mathrm{S}=\mathbf{1 4 0 . 9 7 - 1 4 1 . 0 5} \mathrm{m}$ )

Mudstone, sandy and gravelly, very poorly sorted, diamictite. Alternates between intervals of massive and intervals of $\mathrm{cm}$-mm bedding. Moderately hard to hard with clay cemented crossed joints. Slightly calcareous. Sharp but seemingly conformable upper contact.

15 ( $U=0.45 \mathrm{~m} ; \mathrm{S}=\mathbf{1 4 0 . 5 2 - 1 4 0 . 9 7} \mathrm{m}$ )

Sharp contact with underlying diamictite. Mudstone, sandy. Slight $\mathrm{cm}$ bedding. Greenish grey. Soft to moderately soft and non-calcareous. Top contact is gradational with overlying diamictite.
$16(\mathrm{U}=0.60 \mathrm{~m} ; \mathrm{S}=139.92-140.52 \mathrm{~m})$

Gradational contact with underlying mudstone. Mudstone, sandy and gravelly, very poorly sorted, diamictite. Quite well stratified with $\mathrm{cm}-\mathrm{mm}$ bedding. Moderately hard to hard with clay cemented crossed joints. Slightly calcareous. Gradational top contact with overlying mudstone.

$17(\mathrm{U}=\mathbf{2 . 3 6} \mathrm{m} ; \mathrm{S}=\mathbf{1 3 7 . 5 6 - 1 3 9 . 9 2} \mathrm{m})$

Gradational contact with underlying diamictite. Mudstone, sandy, moderately well sorted. Slightly stratified in places with sandy $\mathrm{cm}$ bedding. Olive grey to dark greenish grey. Soft to moderately hard. Abundant diatoms. Gradational top contact with overlying diamictite.

$18(\mathrm{U}=\mathbf{0 . 3 6} \mathrm{m} ; \mathrm{S}=\mathbf{1 3 7 . 2 0 - 1 3 7 . 5 6 \mathrm { m } )}$

Gradational contact with underlying mudstone. Mudstone, sandy and slightly gravelly, moderately poorly sorted, diamictite. Poorly to moderately stratified. Dark greenish grey. Moderately soft and crumbly. Gravel component is $2-3 \%$. Top contact is an unconformable surface with $\sim 5 \mathrm{~cm}$ of topography.

$19(\mathrm{U}=\mathbf{2 . 5 1} \mathrm{m} ; \mathrm{S}=\mathbf{1 3 4 . 6 9 - 1 3 7 . 2 0} \mathrm{m})$ Disconformably overlies diamictite. Mudstone, moderately sorted and sandy at its base grading to silty at its top. Moderately stratified $\mathrm{cm}$-mm bedding. This is more sandy towards the base. Dark greenish grey and olive grey. Moderately hard to soft and crumbly. 
Diatoms abundant. Top of unit grades into overlying diamictite over $30 \mathrm{~cm}$.

20 (U = 9.75 m; $\mathrm{S}=124.94-134.69 \mathrm{~m})$

Gradational contact with underlying mudstone. Mudstone, very sandy and gravelly, diamictite. Generally massive, but slight $\mathrm{mm}-\mathrm{cm}$ bedding in places. Dark greenish grey. Moderately soft and rarely calcareous. Top metre of core is moderately stratified. Sharp contact with overlying tuff.

21 ( $U=0.29 \mathrm{~m} ; \mathrm{S}=\mathbf{1 2 4 . 6 5 - 1 2 4 . 9 4 ~ m )}$

Sharp contact with underlying diamictite. Siltstone, well sorted, Tuff. Stratified with $\mathrm{mm}$ mudstone beds and laminae mudstone clasts, $\mathrm{mm}$ beds alternating with siltstone (tuff) dipping up to 25 degrees, convoluted top, diffuse wavy bedding in siltstone. Brownish black to greyish white in colour. Top contact is sharp.

$22(\mathrm{U}=\mathbf{5 . 1 8} \mathrm{m} ; \mathrm{S}=\mathbf{1 1 9 . 4 7 - 1 2 4 . 6 5 \mathrm { m } )}$

Sharp contact with underlying tuff. Mudstone, very sandy and gravelly, diamictite. Generally massive, but slight $\mathrm{mm}-\mathrm{cm}$ bedding in places. Stratification increases towards top unit. Dark greenish grey. Moderately soft and rarely calcareous. Bottom metre of unit is moderately stratified.

$23(\mathrm{U}=0.97 \mathrm{~m} ; \mathrm{S}=\mathbf{1 1 8 . 5 0 - 1 1 9 . 4 7} \mathrm{m})$

No core recovered from this interval.

$24(\mathrm{U}=\mathbf{0 . 8 0} \mathrm{m} ; \mathrm{S}=\mathbf{1 1 7 . 7 0 - 1 1 8 . 5 0} \mathrm{m})$

Mudstone, very sandy and gravelly, diamictite. Moderately to well stratified.
Mudstone clasts increase in proportion towards the top of the unit. Dark greenish grey. Moderately soft and rarely calcareous.

$25(\mathrm{U}=\mathbf{0 . 8 2} \mathrm{m} ; \mathrm{S}=\mathbf{1 1 6 . 8 8}-\mathbf{1 1 7 . 7 0} \mathrm{m})$

No core recovered from this interval.

$26(\mathrm{U}=\mathbf{0 . 9 8} \mathrm{m} ; \mathrm{S}=\mathbf{1 1 5 . 9 0 - 1 1 6 . 8 8} \mathrm{m})$ Mudstone, very sandy and gravelly, diamictite. Moderately to well stratified. Mudstone clasts increase in proportion towards the top of the unit. Dark greenish grey. Moderately soft and rarely calcareous.

$27(\mathrm{U}=\mathbf{2 . 6 5} \mathrm{m} ; \mathrm{S}=\mathbf{1 1 3 . 2 5 - 1 1 5 . 9 0} \mathrm{m})$

No core recovered from this interval.

$28(\mathrm{U}=\mathbf{2 . 1 9} \mathrm{m} ; \mathrm{S}=\mathbf{1 1 1 . 0 6 - 1 1 3 . 2 5 ~ m})$

Mudstone, very sandy and gravelly, diamictite. Moderately to well stratified. Mudstone clasts increase in proportion towards base of unit. Dark greenish grey. Moderately soft and rarely calcareous. Gradational top contact with overlying sandstone.

$29(\mathrm{U}=\mathbf{1 . 2 0} \mathrm{m} ; \mathrm{S}=\mathbf{1 0 9 . 8 6}-\mathbf{1 1 1 . 0 6} \mathrm{m})$

Gradational contact with underlying diamictite. Sandstone medium to fine, moderately well sorted with muddy interbeds. Well stratified $\mathrm{cm}-\mathrm{mm}$ bedding with mudstone clasts dipping at 20-25 degrees. Dark greenish grey. Soft and non calcareous. Diatoms and Sponge Spicules. top contact is an unconformable surface with 1-2 cm of relief. 
$30(\mathrm{U}=0.56 \mathrm{~m} ; \mathrm{S}=109.30-109.86 \mathrm{~m})$

Unconformably overlies mudstone. Mudstone, very sandy and gravelly. Moderately to slightly stratified with $\mathrm{cm}$ $\mathrm{mm}$ bedding. Dark olive grey. Moderately soft with some hard horizons. Non-calcareous. Top of unit is a sheared unconformity surface.

$31(\mathrm{U}=7.30 \mathrm{~m} ; \mathrm{S}=102.00-109.30 \mathrm{~m})$

Unconformably overlies mudstone. Mudstone, very sandy and gravelly, diamictite. alternating massive and moderately stratified intervals. Stratified intervals are moderately bedded on a $\mathrm{mm}-\mathrm{cm}$ scale. Dark olive grey. Moderately soft with some hard horizons. Non-calcareous. Sharp but seemingly conformable top contact with overlying sandstone.

$32(\mathrm{U}=0.60 \mathrm{~m} ; \mathrm{S}=101.40-102.00 \mathrm{~m})$

Sharp contact with underlying sandstone. Sandstone, muddy and gravelly, Diamictite. Abundant angular to subrounded mudstone clasts. Dark greenish grey. Soft to moderately soft. Sharp contact with overlying diamictite.

$33(\mathrm{U}=2.57 \mathrm{~m} ; \mathrm{S}=98.83-101.40 \mathrm{~m})$

Sharp contact with underlying sandstone. Mudstone, very sandy and gravelly, diamictite. alternating massive and moderately stratified intervals. Stratified intervals are moderately bedded on a $\mathrm{mm}-\mathrm{cm}$ scale. Dark olive grey. Moderately soft with some hard horizons. Non-calcareous. Unit grades into a well sorted muddy sandstone over top $50 \mathrm{~cm}$. Top of unit is a sharp erosional surface.

$34(\mathrm{U}=>\mathbf{8 . 8 3} \mathrm{m} ; \mathrm{S}=<\mathbf{9 0 . 0 0 - 9 8 . 8 3} \mathrm{m})$ Unconformably overlies sandy diamictite. Sandstone, medium, slightly muddy, moderately to well sorted. Unstratified except slightly mm bedded mudstone towards base of unit. Grey to black. Soft to moderately soft. Top of unit not observed in the present study.

\section{A5.2 DVDP-11 drill-hole core log}

$1(\mathrm{U}=>2.88 \mathrm{~m} ; \mathrm{S}=325.08->327.96 \mathrm{~m})$ Base of unit not seen. Mudstone, sandy and gravelly diamictite. Moderately to well stratified. $\mathrm{Cm}-\mathrm{mm}$ mudstone interbeds at several horizons. Dark greenish grey and greenish grey. Moderately hard to hard. Top of unit is a sharp contact with overlying mudstone.

$2(\mathrm{U}=\mathbf{0 . 2 7} \mathrm{m} ; \mathrm{S}=\mathbf{3 2 4 . 8 1 - 3 2 5 . 0 8 \mathrm { m } )}$

Sharp contact with underlying diamictite. Mudstone, very fine and laminated on a $\mathrm{mm}$ scale. Olive grey to dark greenish grey. Soft to moderately hard. Diatomaceous. Unconformable sheared top to unit.

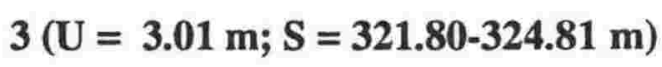
Unconformably overlies mudstone. Mudstone, sandy and gravelly, very poorly sorted, diamictite. Massive with no stratification, clasts distributed throughout. Moderately hard to hard. Dark greenish grey and greenish grey. 
$4(\mathrm{U}=2.79 \mathrm{~m} ; \mathrm{S}=319.01-321.80 \mathrm{~m})$

No core recovered from this interval.

$5(\mathrm{U}=4.46 \mathrm{~m} ; \mathrm{S}=314.55-319.01 \mathrm{~m})$

Mudstone, sandy and gravelly, very poorly sorted, diamictite. Stratified and moderately bedded on a cm-mm scale. Clasts distributed throughout. Moderately hard to hard. Dark greenish grey and greenish grey. Eroded and sheared unconformable top to unit.

$6(\mathrm{U}=5.45 \mathrm{~m} ; \mathrm{S}=309.10-314.55 \mathrm{~m})$

Unconformably overlies diamictite. Mudstone, sandy and gravelly, very poorly sorted, diamictite. Massive with no stratification, clasts distributed throughout. Basal part of unit includes rip up clasts of diamictite. Moderately hard to hard. Dark greenish grey and greenish grey. Top of unit is gradational with overlying diamictite.

$7(\mathrm{U}=\mathbf{6} .25 \mathrm{~m} ; \mathrm{S}=\mathbf{3 0 2 . 8 5}-309.10 \mathrm{~m})$

Gradational contact with underlying diamictite. Lower $2 \mathrm{~m}$ is Mudstone, sandy and gravelly, very poorly sorted, diamictite. Stratified and moderately bedded on a cm-mm scale. Intervals with fewer clasts. Moderately hard to hard. Dark greenish grey and greenish grey. Unit grades through interbedded diamictite and mudstone horizons into a sandy mudstone, containing fine sandstone laminae. Dispersed coarse detritus throughout. Greenish grey in colour and moderately hard. Top contact is sharp with overlying diamictite.
$8(U=0.18 \mathrm{~m} ; \mathrm{S}=302.67-302.85 \mathrm{~m})$

Sharp contact with underlying mudstone. Mudstone, sandy and gravelly diamictite. Massive. Moderately hard to hard. Dark greenish grey. Sharp contact with overlying siltstone.

$$
9(\mathrm{U}=0.35 \mathrm{~m} ; \mathrm{S}=\mathbf{3 0 2 . 3 2 - 3 0 2 . 6 7 \mathrm { m } )}
$$

Sharp contact with underlying diamictite. Siltstone, sandy and slightly gravelly. Massive. Greenish grey. Moderately soft to moderately hard. Top of unit is a scoured surface.

10 (U = 9.13 m; $\mathrm{S}=293.19-302.32 \mathrm{~m}$ )

Unconformably overlies siltstone. Mudstone, sandy and gravelly diamictite. Massive. Base of unit incorporates rip-up clasts from underlying siltstone. Dark greenish grey and greenish grey. Gradational contact with overlying diamictite.

\section{$11(\mathrm{U}=1.64 \mathrm{~m} ; \mathrm{S}=\mathbf{2 9 1 . 5 5 - 2 9 3 . 1 9} \mathrm{m})$}

Gradational contact with underlying diamictite. Mudstone, sandy and gravelly diamictite. Massive. Fewer clasts than underlying unit. Dark greenish grey and greenish grey. Gradational contact with overlying diamictite.

$$
12(U=1.42 \mathrm{~m} ; \mathrm{S}=\mathbf{2 9 0 . 1 3 - 2 9 1 . 5 5} \mathrm{m})
$$

Gradational contact with underlying diamictite. Mudstone, sandy and gravelly diamictite. Massive. Dark greenish grey and greenish grey. Gradational contact with overlying diamictite. 
$13(\mathrm{U}=4.70 \mathrm{~m} ; \mathrm{S}=\mathbf{2 8 5 . 4 3 - 2 9 0 . 1 3} \mathrm{m})$

Gradational contact with underlying diamictite. Mudstone, sandy and gravelly diamictite. Massive to slightly stratified on a mm-cm scale. Moderately hard to hard. Dark greenish grey. Gradational contact with overlying diamictite.

$14(\mathrm{U}=9.69 \mathrm{~m} ; \mathrm{S}=\mathbf{2 7 5 . 7 4 - 2 8 5 . 4 3 \mathrm { m } )}$

Gradational contact with underlying diamictite. Mudstone, sandy and gravelly diamictite. Massive. Moderately hard to hard. Dark greenish grey. Unit grades through interbedded diamictite and mudstone horizons into a sandy mudstone, containing fine sandstone laminae. Dispersed coarse detritus throughout. Greenish grey in colour and moderately hard. Top contact is erosional with overlying diamictite

$$
15(\mathrm{U}=\mathbf{4 . 6 0} \mathrm{m} ; \mathrm{S}=\mathbf{2 7 1 . 1 4 - 2 7 5 . 7 4} \mathrm{m})
$$

Unconformably overlies mudstone of unit 14. Mudstone, sandy and gravelly diamictite. Slightly to moderately stratified on a mm-cm scale. Moderately hard to hard. Dark greenish grey. Top of unit is an unconformable surface with 1$2 \mathrm{~cm}$ of relief.

$16(\mathrm{U}=\mathbf{0 . 6 2} \mathrm{m} ; \mathrm{S}=\mathbf{2 7 0 . 5 2 - 2 7 1 . 1 4 \mathrm { m } )}$ Unconformably overlies diamictite. Mudstone, sandy and slightly gravelly diamictite. Moderately stratified on a $\mathrm{mm}-\mathrm{cm}$ scale. Moderately soft to moderately hard. Greenish grey. Top of unit is and unconformable surface with $1-2 \mathrm{~cm}$ of relief.
$17(\mathrm{U}=\mathbf{3 . 1 2} \mathrm{m} ; \mathrm{S}=\mathbf{2 6 7 . 4 0 - 2 7 0 . 5 2 \mathrm { m } )}$ Unconformably overlies diamictite. Mudstone, sandy and gravelly diamictite. Slightly to moderately stratified on a mm-cm scale. Moderately hard to hard. Dark greenish grey. Gradational contact with overlying diamictite.

$18(\mathrm{U}=\mathbf{8 . 7 5} \mathrm{m} ; \mathrm{S}=\mathbf{2 5 8 . 6 5 - 2 6 7 . 4 0 \mathrm { m } )}$

Gradational contact with underlying diamictite. Mudstone, sandy and gravelly diamictite. Massive. Moderately hard to hard. Dark greenish grey. Unit grades through interbedded diamictite and mudstone horizons into a sandy mudstone, containing fine sandstone laminae. Dispersed coarse detritus throughout. Greenish grey in colour and moderately hard. Sheared top to unit with $1-2 \mathrm{~cm}$ of relief.

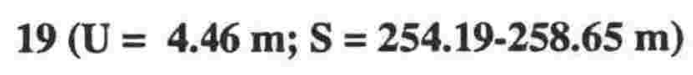

Unconformably overlies mudstone. Mudstone, sandy and gravelly diamictite. Massive. Moderately hard to hard. Dark greenish grey. Disconformable top with $2-3 \mathrm{~cm}$ of relief.

$$
20(\mathrm{U}=\mathbf{1 . 3 4} \mathrm{m} ; \mathrm{S}=\mathbf{2 5 2 . 8 5 - 2 5 4 . 1 9} \mathrm{m})
$$

Disconformably overlies diamictite. Interbedded mudstone and diamictite. Sandy mudstones laminated, bioturbated and slightly gravelly in places. Mudstone, sandy and gravelly diamictite. Stratified and sandy. Scoured top contact to unit with $\sim 1 \mathrm{~cm}$ of relief. 
$21(\mathrm{U}=\mathbf{2 . 1 2} \mathrm{m} ; \mathrm{S}=\mathbf{2 5 0 . 7 3 - 2 5 2 . 8 5} \mathrm{m})$

Unconformably overlies diamictite. Granule conglomerate, well washed with no fines. Clasts are sub-angular. Some horizons are coarse sandy beds. Grades up into mudstone, sandy and gravelly diamictite. Moderately stratified. Large clasts, $>1 \mathrm{~m}$ in diameter. Gradational contact with overlying mudstone.

$22(\mathrm{U}=\mathbf{2 . 9 8} \mathrm{m} ; \mathrm{S}=\mathbf{2 4 7 . 7 5 - 2 5 0 . 7 3} \mathrm{m})$

Gradational contact with underlying diamictite. Silty mudstone with dispersed medium-fine sand admixture grading down. Bioturbated, horizontal burrows. Occasional coarse sandy horizon. Slightly gravelly in places. Very muddy towards the top of the unit. Sharp contact with overlying diamictite.

$23(\mathrm{U}=\mathbf{8 . 2 0} \mathrm{m} ; \mathrm{S}=\mathbf{2 3 9 . 5 5 - 2 4 7 . 7 5} \mathrm{m})$

Sharp contact with underlying mudstone. Alternating diamictite, breccia and mudstone. Interbeds occur on a metre scale. Individual units are well stratified. Mudstone, sandy and gravelly diamictite. Moderately soft to moderately hard. Dark greenish grey. Breccia, well washed angular clasts conglomerate. few fines. Mudstone, sandy and well stratified. Greenish grey. Top of unit is sharp unconformable surface with $<1 \mathrm{~cm}$ of relief.

$24(\mathrm{U}=13.59 \mathrm{~m} ; \mathrm{S}=\mathbf{2 2 5 . 9 6 - 2 3 9 . 5 5 ~ m})$ Unconformably overlies diamictite. Mudstone, sandy and gravelly, very poorly sorted, diamictite. Massive. Clasts are generally rounded to subangular. Moderately hard to hard. Dark greenish grey to greenish grey. Gradational upper contact with overlying mudstone.

$25(\mathrm{U}=1.39 \mathrm{~m} ; \mathrm{S}=\mathbf{2 2 4 . 5 7 - 2 2 5 . 9 6} \mathrm{m})$

Gradational contact with underlying diamictite. Sandy mudstone, with a slight lamination and a conchoidal fracture. Unit becomes more dominantly sandy towards its top. Basal $10 \mathrm{~cm}$ of the unit is gravelly. Greenish grey. Gradational contact with overlying sandstone.

$26(U=1.27 \mathrm{~m} ; \mathrm{S}=\mathbf{2 2 3 . 3 0 - 2 2 4 . 5 7} \mathrm{m})$

Gradational contact with underlying mudstone. Sandstone, medium and well sorted, gravelly in places. Sands and gravels are well-washed with little fine content. Laminated and cross-bedded. Bioturbated and burrowed. Dark greenish grey. Soft to moderately soft. Sharp contact with overlying mudstone.

$27(\mathrm{U}=\mathbf{0 . 5 9} \mathrm{m} ; \mathrm{S}=\mathbf{2 2 2 . 7 1 - 2 2 3 . 3 0 \mathrm { m } )}$

Sharp contact with underlying sandstone. Mudstone, slightly sandy and gravelly. Laminated. Greenish grey. Sharp contact with overlying diamictite.

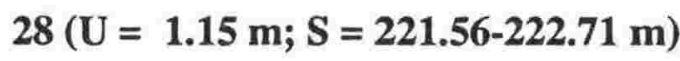

Sharp contact with underlying mudstone. Mudstone, sandy and gravelly, diamictite. Moderately sorted. Sand and gravel is washed and fine content is reduced. Dark greenish grey to greenish grey. Gravel and clast content becomes reduced towards the top of the unit. Top $50 \mathrm{~cm}$ is sandy laminated mudstone. 
Sharp eroded and unconformable upper contact.

$29(\mathrm{U}=1.44 \mathrm{~m} ; \mathrm{S}=\mathbf{2 2 0 . 1 2 - 2 2 1 . 5 6} \mathrm{m})$ Unconformably overlies mudstone. Mudstone, sandy and gravelly diamictite. Slightly to moderately stratified on a mm-cm scale. Rip-up mudstone clasts. Moderately hard to hard. Dark greenish grey. Gradational contact with overlying mudstone.

$30(\mathrm{U}=\mathbf{2 . 5 7} \mathrm{m} ; \mathrm{S}=\mathbf{2 1 7 . 5 5 - 2 2 0 . 1 2} \mathrm{m})$ Gradational contact with underlying diamictite. Mudstone, sandy and gravelly. Laminated on a mm-cm scale. Bedded with some coarser horizons and more pebbly horizons. Greenish grey. Sharp erosional top to the unit.

$31(\mathrm{U}=\mathbf{4 . 0 4} \mathrm{m} ; \mathrm{S}=\mathbf{2 1 3 . 5 1 - 2 1 7 . 5 5} \mathrm{m})$ Unconformably overlies mudstone. Mudstone, sandy and gravelly diamictite. Slightly to moderately stratified on a mm-cm scale. Rip-up mudstone clasts. Large $20 \mathrm{~cm}$ diameter rip-up mudstone clast towards base of unit. Moderately hard to hard. Dark greenish grey. Gradational contact with overlying mudstone.

$32(\mathrm{U}=3.25 \mathrm{~m} ; \mathrm{S}=\mathbf{2 1 0 . 2 6 - 2 1 3 . 5 1 ~ \mathrm { m } )}$ Gradational contact with underlying diamictite. Interbedded mudstone and diamictite. Interbeds are $20-50 \mathrm{~cm}$ thick and beds coarsen slightly towards top of unit. Mudstone, slightly sandy and laminated. Mudstone, sandy and gravelly diamictite. Slightly to moderately stratified on a mm-cm scale.
Rip-up mudstone clasts. Top of unit is a sharp angular unconformable contact.

$33(\mathrm{U}=1.30 \mathrm{~m} ; \mathrm{S}=\mathbf{2 0 8 . 9 6 - 2 1 0 . 2 6} \mathrm{m})$ Unconformably overlies mudstone. Coarse, well-sorted, sandstone grading up into finer well sorted sandstone. Moderately soft to moderately hard. Greenish olive grey. Gradational contact with overlying mudstone.

$34(\mathrm{U}=\mathbf{3 . 1 2} \mathrm{m} ; \mathrm{S}=\mathbf{2 0 5 . 8 4 - 2 0 8 . 9 6} \mathrm{m})$

Gradational contact with underlying sandstone. Massive, sandy mudstone. Unit coarsens upwards and becomes more pebbly towards top. Olive grey in colour. Top of unit contains a $2 \mathrm{~cm}$ basaltic tuff. Tuff is brown black. Top of unit is an erosional, slightly angular and unconformable surface.

$35(\mathrm{U}=\mathbf{0 . 6 8} \mathrm{m} ; \mathrm{S}=\mathbf{2 0 5 . 1 6 - 2 0 5 . 8 4} \mathrm{m})$ Unconformably overlies mudstone. Pebble conglomerates and breccias. No stratification. Conglomerates are well washed and contain no fines. Greenish grey. Moderately hard, friable in places. Gradational contact with overlying mudstone.

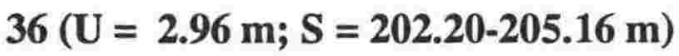

Gradational contact with underlying breccia. Sandy mudstone with very coarse sand and granule grade admixture. Scattered pebbles. Bioturbation. Yellowish grey. Another basaltic tuff at $204.80 \mathrm{~m}$. Tuff is browny black. Upper contact is sharp. 


$$
37(\mathrm{U}=5.93 \mathrm{~m} ; \mathrm{S}=196.27-202.20 \mathrm{~m})
$$

Sharp contact with underlying mudstone. Mudstone, sandy and gravelly, diamictite. Well stratified, with some horizons current worked and winnowed of fines. Some mudstone horizons. Unit grades from being coarse an well sorted at its base to finer and more poorly sorted at its top. Top contact is sharp and possibly unconformable.

$38(\mathrm{U}=1.38 \mathrm{~m} ; \mathrm{S}=194.89-196.27 \mathrm{~m})$

Sharp contact with underlying diamictite. Sandy to silty mudstone. Contains dispersed coarse sand detritus. Unit has a prominent lamination and contains bivalve fragments. Sharp seemingly conformable contact with overlying breccia.

$39(\mathrm{U}=1.49 \mathrm{~m} ; \mathrm{S}=193.40-194.89 \mathrm{~m})$

Sharp contact with underlying sandstone. Pebble conglomerate. poorly sorted variable sized subrounded clasts. Pebbles are well washed and winnowed of fines. moderately hard to friable. Gradational contact with overlying diamictite.

$40(\mathrm{U}=4.53 \mathrm{~m} ; \mathrm{S}=\mathbf{1 8 8 . 8 7}-193.40 \mathrm{~m})$ Gradational contact with underlying breccia. Mudstone, very sandy and gravelly, diamictite. Moderately to well stratified. Dark greenish grey. Moderately soft. Mudstone horizons become more dominant towards the top of the unit. Gradational contact with overlying mudstone.
$41(\mathrm{U}=0.57 \mathrm{~m} ; \mathrm{S}=188.30-188.87 \mathrm{~m})$

Gradational contact with underlying diamictite. Sandy mudstone, pebbly with coarse sandy horizons. Soft to moderately soft. Some soft sediment deformation. Browny green. Gradational contact with overlying conglomerate.

$42(\mathrm{U}=21.86 \mathrm{~m} ; \mathrm{S}=166.44-188.30 \mathrm{~m})$ Gradational contact with underlying mudstone. Fine to medium pebble conglomerates. Poorly sorted. Clasts are well washed and fines are winnowed. Stratification is indistinct. Pebble orientation suggests horizontal strata. Bivalve fragments. Gradational contact with overlying mudstone.

$43(\mathrm{U}=0.63 \mathrm{~m} ; \mathrm{S}=165.81-166.44 \mathrm{~m})$

Gradational contact with underlying conglomerate. Interbedded mudstone and sandstone. Massive to poorly stratified. Moderately soft to moderately hard. Gradational contact with overlying diamictite.

$44(\mathrm{U}=>15.81 \mathrm{~m} ; \mathrm{S}=<150-165.81 \mathrm{~m})$ Gradational contact with underlying mudstone. Mudstone, sandy and gravelly, diamictite. Highly variable from massive to moderately stratified. Dark olive grey. Moderately soft with some hard horizons. Top of unit not observed in present study. 


\section{Appendix - 2}

Reprint of the paper: Wilson and Ditchburn (1992);

Beryllium systematics in rock materials and its separation for measurement on an Accelerator Mass Sectrometer, DSIR Physical Sciences report, no. 53, 32p. 

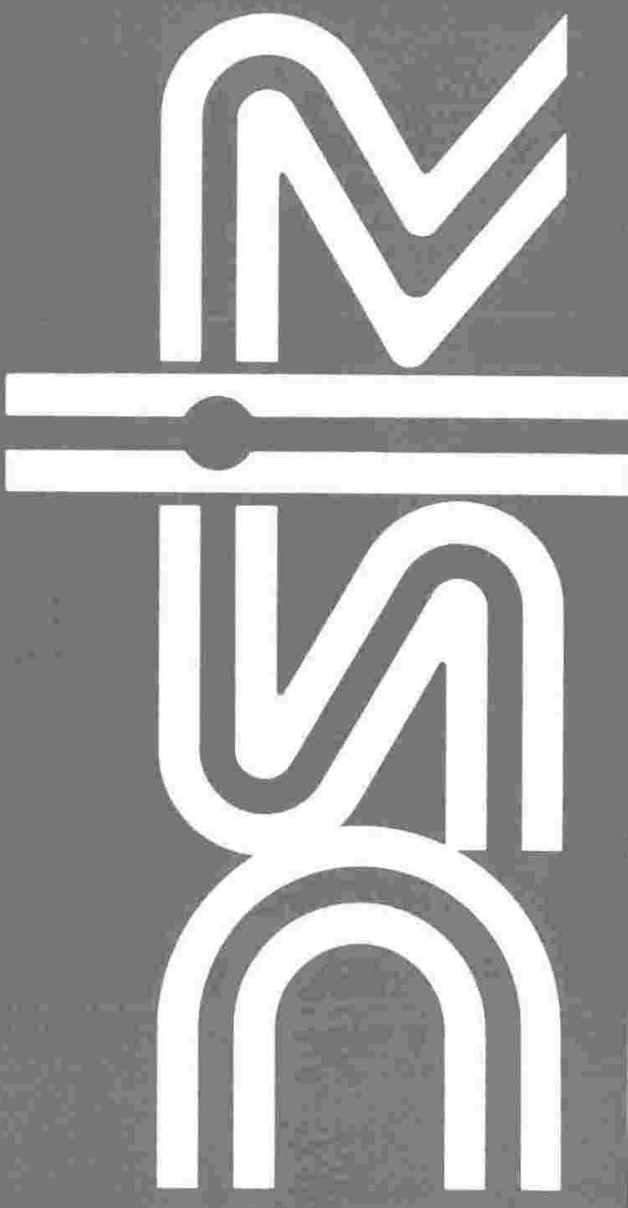


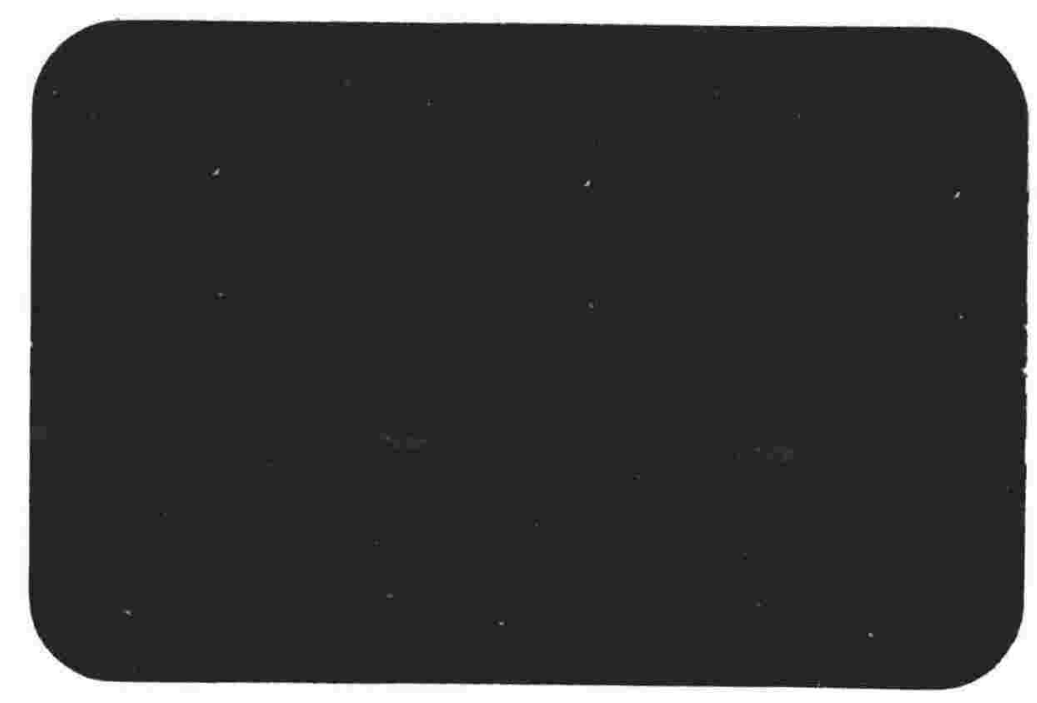


DSIR Physical Sciences report 53

BERYLLIUM SYSTEMATICS IN

ROCK MATERIALS AND ITS

SEPARATION AND PURIFICATION FOR

MEASUREMENT ON AN ACCELERATOR MASS SPECTROMETER

G S Wilson and R G Ditchbirn 


\begin{abstract}
DSIR Physical Sciences report 53
BERYLLIUM SYSTEMATICS IN ROCK MATERIALS AND ITS SEPARATION AND PURIFICATION FOR MEASUREMENT ON AN ACCELERATOR MASS SPECTROMETER.
\end{abstract}

by

G S Wilson* and R G Ditchburn\#

* Geology Department and Antarctic Research Centre, Research School of Earth Sciences, Victoria University of Wellington, P.O. Box 600, Wellington, New Zealand.

\# Nuclear Sciences Group, Physical Sciences, Department of Scientific and Industrial Research, P.O. Box 31312, Lower Hutt, New Zealand.

June 1992

Nuclear Sciences Group

DSIR Physical Sciences

P O Box 31312, Lower Hutt

New Zealand 
2.1 Dating of Sediment

2.1.1 Dating of marine sediments

2.1.2 Dating of lacustrine sediments and soils

2.1.3 Dating and growth rates of manganese nodules

2.2 Dating of continental ice sheets

2.3 Exposure dating of geologic surfaces

2.4 Tracing of magma sources and subducted sediment volumes in volcanic rocks

3 PRECAUTIONS WHEN WORKING WITH BERYLLIUM

3.1 Potential hazards of beryllium

3.2 Guidelines for operations with beryllium

4 PROCEDURES FOR SEPARATION OF ${ }^{10}$ Be CONTENT OF SAMPLES

4.1.1 Dating of continental margin sediments

4.1.2 Analysis of exposure ages of geologic surfaces

4.1.3 Magmatic evolution and subducted sediment models

4.1.4 Soil development and dating

4.2 Chemical procedures for the separation of beryllium from rocks

4.2.1 Apparatus and reagents

4.2.2 Acid leaching of exotic material from samples

4.2.2.1 Procedure

4.2.3 Decomposition of crystallographic material from samples

4.2.3.1 Procedure

4.2.4 Acid digest of all sample material

4.2.4.1 Procedure

5.1 Titration with Ammoniacal Complexing Agent.

5.1.1 CDTA titration procedure

5.2 Ion exchange

5.2.1 Ion exchange procedure

6 CONVERSION TO BERYLLIUM OXIDE

6.1 Procedure

7 REFERENCES 


\section{ABSTRACT}

Beryllium-10 is a cosmogenically produced radionuclide that is introduced into geologic reservoirs by both 'rain-out', from the atmosphere, and 'in-situ' production, from cosmic flux striking surface rocks directly. ${ }^{10} \mathrm{Be}$ decays with a half life of $1.5 \mathrm{Ma}$ making it detectable by Accelerator Mass Spectrometry in rock materials as old as $15 \mathrm{Ma}$. The stable isotope ${ }^{9} \mathrm{Be}$ occupies a different place within the geologic cycle, and consequently does not provide a reliable base value for ${ }^{10} \mathrm{Be} /{ }^{9} \mathrm{Be}$ ratio measurement. The absolute concentration of ${ }^{10} \mathrm{Be}$ atoms in a sample is the most accurate and least flawed measure of geologic development. Because many different geologic reservoirs can contain ${ }^{10} \mathrm{Be}$, it is particularly useful as a dating and tracing material.

Four different types of beryllium may be present in any one sample. The beryllium can be either crystallographic or exotic, with each of these being autochthonous or allochthonous. Exotic beryllium is associated with sedimentation (adsorbed to particle surfaces and incorporated into authigenic phases) and direct atmospheric 'rain-out'. Crystallographic beryllium is held within mineral phases, by 'in situ' creation or assimilation, from other sources during rock formation.

The different types of beryllium are representative of different processes and separation is essential to ensure reliable measurement of individual geologic processes. A system of sample leaching and digestion allows the different types to be separated and then titrated against ammoniacal CDTA, to remove impurities (mainly iron and aluminium), to an approximate endpoint. Remaining beryllium is purified using cation exchange. ${ }^{9} \mathrm{Be}^{++}$ carrier is introduced to the sample at a critical point to prevent the need for a tracer in the wet chemistry and to provide a known ${ }^{9} \mathrm{Be}$ content for back calculation of absolute ${ }^{10} \mathrm{Be}$ concentration.

\section{KEY WORDS}

Be-10; Beryllium isotopes; TAMS; Radioactive age determination; Titration Ion exchange; Separation; Purification; Radiochemistry; Sample preparation; Sediments; Marine sediments; Volcanic rocks; Magmas; Ice sheets. 
352 


\section{INTRODUCTION AND DEFINITIONS}

Measurement of beryllium-10 using a tandem accelerator is a newly developing technique. It has many possible applications in dating and tracing of geologic processes.

Much previous work has found ${ }^{10} \mathrm{Be}$ to present many difficulties as an absolute dating method (Bourles et al., 1989; Brown et al., 1987; Henkell-Mellies et al., 1990; Jansen et al, 1987; Mangini et al., 1984; Somayajulu, 1977; Somayajulu et al., 1991; Southon et al., 1987). However, recent work has shows that it can be effectively used for dating continental margin sediments (Wilson, 1990; Wilson and Sparks, 1991), exposure age dating of Neogene surfaces (Jha and Lal, 1982, Nishiizumi et al, 1986; van der Wateren and Verbers, 1991; Verbers and van der Wateren, 1991), and to provide models for subduction of sediment into the mantle (Brown et al., 1982; Morris et al., 1990; Tera et al., 1986). Other research includes: Studies of ice cores (Beer et al., 1987; Elmore et al., 1987; Raisbeck et al., 1978), observing production rates and mechanisms of ${ }^{10} \mathrm{Be}$; studies of ${ }^{10} \mathrm{Be}$ content of soils (Brown, 1987), and studies of the ${ }^{10} \mathrm{Be}$ content of manganese nodules, with implications on growth rates and ocean circulation patterns (Guichard et al., 1978; Segl et al., 1984a and 1984b; Turekian et al., 1979). Here we present a new and more efficient method for the separation of beryllium from rock materials and its purification to allow measurement on an Accelerator Mass Spectrometer.

Advantages of the method of separation proposed here is that beryllium of different origin is considered separately. This means that a geological understanding of the position of ${ }^{10} \mathrm{Be}$ in the samples is considered, allowing a more accurate and informed measurement of the parameters concerned, particularly as to whether one is interested in exotic or crystallographic ${ }^{10} \mathrm{Be}$.

In nature there are three isotopes of beryllium; ${ }^{7} \mathrm{Be},{ }^{9} \mathrm{Be}$ and ${ }^{10} \mathrm{Be} .{ }^{9} \mathrm{Be}$ is stable and exists in all geologic environments, but much of it is contained in occurrences of the mineral beryl. Both ${ }^{7} \mathrm{Be}$ and ${ }^{10} \mathrm{Be}$ are created cosmogenically by spallation reactions between cosmic flux and small atoms (oxygen and nitrogen in the case of ${ }^{10} \mathrm{Be}$ ). ${ }^{7} \mathrm{Be}$, is a gamma emitter with a half life of 53 days and is therefore not useful in dating the geologic record. ${ }^{10} \mathrm{Be}$ is a beta emitter, decaying to ${ }^{10} \mathrm{~B}$ with a half life of $1.5 \mathrm{~m} . \mathrm{y}$. (Yiou and Raisbeck, 1972), making it very useful for working with materials younger than $14 \mathrm{Ma}$. In a geologic sense ${ }^{10} \mathrm{Be}$ can be produced in two possible ways: 1) Cosmic ray spallation of oxygen and nitrogen particles in the atmosphere and stratosphere (Raisbeck and Yiou, 1984). The ${ }^{10} \mathrm{Be}$ is then rained out on the earth's surface and scavenged by particle flux to be incorporated into geologic reservoirs adsorbed onto grain surfaces (Merril et al., 1960; Raisbeck et al., 1979): 2) Alternatively ${ }^{10} \mathrm{Be}$ can be created 'in situ' by cosmic ray spallation of oxygen and 
nitrogen atoms in appropriate mineral phases in the rock directly at the earth's surface (Middleton and Klein, 1987; Nishiizumi et al., 1986). These two types of beryllium can be classified as follows;

1) Crystallographic beryllium, where the beryllium exists or is created within the crystallographic structure (i.e. within grain boundaries of the rock forming minerals). Crystallographic beryllium can be present in Igneous, Metamorphic, or Sedimentary rocks. Crystallographic beryllium can be autochthonous (created in place or 'in situ') or allochthonous (where erosion and resedimentation of grains has transported crystallographic beryllium to a site of sediment deposition) (Figure 1).

2) Exotic beryllium, where the beryllium is adsorbed to grain surfaces, or absorbed within authigenic clay and cement phases. Exotic beryllium can also be autochthonous (adsorbed at deposition) or allochthonous (adsorbed before deposition and transported to the site of deposition along with the particle it is adsorbed to). It is impossible when carrying out an analysis to distinguish between the two types. After deposition the adsorbed material is readily incorporated into different phases of diagenesis, such as clay minerals and cements. Previous workers have reported low recovery levels from cement rich sediments (Bourles et al., 1989; Southon et al., 1987).

In each of these cases the beryllium can be both ${ }^{9} \mathrm{Be}$ and ${ }^{10} \mathrm{Be}$. It must be recognised that ${ }^{9} \mathrm{Be}$ and ${ }^{10} \mathrm{Be}$ occupy different places within the geologic cycle. Therefore, for the purposes of the dating and modelling procedures addressed here it is assumed that the exotic ${ }^{9} \mathrm{Be}$ concentrations will be constant at a fixed point of deposition and also that the concentration of crystallographic ${ }^{9} \mathrm{Be}$ will be constant within different mineral phases. The most useful parameter for measurement will be the absolute concentration of the different ${ }^{10} \mathrm{Be}$ types (Wilson, in prep). In the following separation procedures we are concerned only with finding the absolute concentrations of;

\section{1) Autochthonous crystallographic ${ }^{10} \mathrm{Be}$ \\ 2) Allochthonous crystallographic ${ }^{10} \mathrm{Be}$}

3) Autochthonous and allochthonous exotic ${ }^{10}$ Be together (including that which is incorporated into various diagenetic phases after deposition).

Identification of these different types of beryllium is very important, so that not only can different geologic processes be observed from the same materials, but that error is not introduced into each of the methods by incorporation of ${ }^{10} \mathrm{Be}$ from the different geologic processes. 

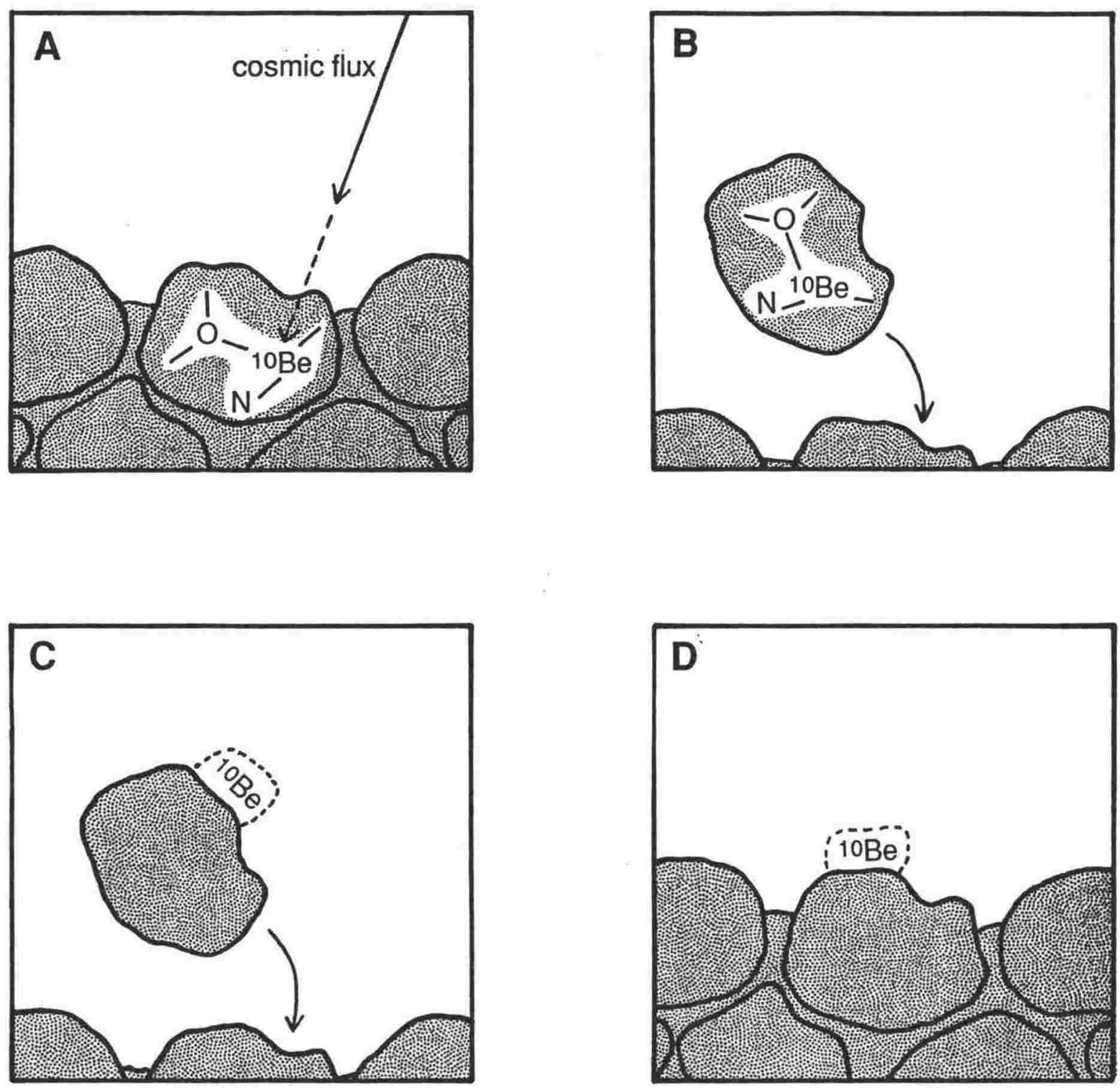

Figure 1: Types of beryllium-10 in the geologic cycle; $A$ ) autochthonous crystallographic beryllium-10; B) allochthonous crystallographic beryllium-10; C) allochthonous exotic beryllium-10; and D) autochthonous exotic beryllium-10. 


\subsection{Dating of Sediment}

2.1.1 Dating of marine sediments (Amin et al., 1975; DeBoer et al., 1987; Bourles et al., 1989; Inoue and Tanaka, 1976; Jansen et al., 1987; Mangini et al., 1984; Tanaka et al., 1977; Yiou and Raisbeck, 1981): Varying parameters that affect ${ }^{10} \mathrm{Be}$ concentration and hence age are; production rates of ${ }^{10} \mathrm{Be}$, sedimentation rates in the sedimentary reservoir, and time (for ${ }^{10} \mathrm{Be}$ decay). If assumptions or estimates of production rate and sedimentation rate can be made then age can be calculated. Integration of facies modelling with ${ }^{10} \mathrm{Be}$ measurement allows a relative dating method for continental margin sediments, without assumptions about other parameters (Wilson, 1990; Wilson and Sparks, 1991).

2.1.2 Dating of lacustrine sediments and soils (Brown et al., 1981): Continental sediment contains one tenth of the ${ }^{10} \mathrm{Be}$ in deep sea sediments, reducing accuracy and making detection more difficult. Here dating procedures are not only dependent on assumptions of production rates and sedimentation rates, but also proportions of authigenic clay sized particles (as adsorption of ${ }^{10} \mathrm{Be}$ increases with decreasing grain-size (Brown et al., 1981)), rain-out patterns and 'in situ' production of material exposed at the earth's surface.

2.1.3 Dating and growth rates of manganese nodules (Guichard et al., 1978; Segl et al., 1984a and 1984b; Turekian et al., 1979): It is well established that manganese nodules scavenge metal ions in ocean water. As concentrations of ${ }^{10} \mathrm{Be}$ in ocean water can be estimated (Kusakabe et al., 1987; Lal, 1962; Measures and Edmonds, 1982; Raisbeck et al., 1979; Raisbeck et al., 1980; Segl et al., 1987; Yokoyama et al., 1978) growth rates for Mn nodules can be estimated and hence the nodules dated and oceanic processes observed.

2.2 Dating of continental ice sheets (Beer et al., 1987; Elmore et al., 1987; Oeschger, 1987; $\mathrm{M}^{\mathrm{C}}$ Corkell et al., 1967; Nishiizumi et al., 1983; Raisbeck et al., 1978): The Greenland and Antarctic ice sheets are geologic reservoirs of cosmogenic radionuclides. They record direct 'rain-out' of ${ }^{10} \mathrm{Be}$ and hence provide clues about production rates, as well as a method for dating ice accumulation. ${ }^{10} \mathrm{Be}$ concentrations are small in comparison to pelagic sediments. 
2.3 Exposure dating of geologic surfaces (Jha and Lal, 1982; Nishiizumi et al., 1986; Verbers and van der Wateren, 1991; van der Wateren and Verbers, 1991): Cosmic Flux striking minerals in rocks exposed at the earth's surface causes spallation of oxygen and nitrogen into ${ }^{10} \mathrm{Be}$. The spallation reactions are best understood in quartz minerals, because quartz has the best ratio of target atoms and hence more easily measured quantities of ${ }^{10} \mathrm{Be}$. As long as the production rate of ${ }^{10} \mathrm{Be}$ can be estimated and it out paces the decay rate of ${ }^{10} \mathrm{Be}$, then the time that the material has been exposed to cosmic flux can be calculated.

\subsection{Tracing of magma sources and subducted sediment volumes in volcanic} rocks (Brown et al., 1982; Morris et al., 1990; Tera et al., 1986): High proportions of ${ }^{10} \mathrm{Be}$ in arc lavas can be derived from homogenisation of ocean floor sediments with the subducting slab under the arc. This could be either a mechanical or chemical process. It has also been suggested that high ${ }^{10} \mathrm{Be}$ concentrations in arc lavas can be due to assimilation of near surface sediments (Monaghan et al., 1986). In this case ${ }^{9} \mathrm{Be}$ concentrations may also vary. Assessment will need to be made of the value of ${ }^{9} \mathrm{Be}:{ }^{10} \mathrm{Be}$ ratio, as well as ${ }^{10} \mathrm{Be}$ concentration, along with some other normalising factor (such as ${ }^{10} \mathrm{~B}$ ). Care must be taken to avoid (or account for) contamination from 'in-situ' creation of $10 \mathrm{Be}$ within the lavas.

\section{PRECAUTIONS WHEN WORKING WITH BERYLLIUM}

\subsection{Potential Hazards of Beryllium:}

Beryllium metals, its compounds and alloys containing more than $2 \%$ of beryllium are toxic and any tissue of the body may be damaged by beryllium. The principle dangers are to the lung by inhalation, to the skin by contact, particularly if the skin is broken (Fairhall, 1960).

\subsection{Guidelines for operations with beryllium:}

Operations using significant quantities of beryllium or its compounds which may give rise to beryllium dust and fumes should be carried out in appropriate containment enclosures with extract ventilation and filtration. The operator/experimenter should always use gloves when dealing with such compounds. If practical use fume cupboards or non-airflow containers with emergency extraction procedures when dealing with significant dry quantities of beryllium. All care should be taken during each stage of the preparation to 
avoid the situation of oxide dust developing and being breathed in by anyone. All stages of preparation can be easily and safely carried out as long as the compounds are treated with the respect they deserve. Simple and safe precautions are the best approach as detailed and elaborate methods are likely to create an accident prone environment.

Previously suggested levels for handling beryllium in open areas are;

Dry form; $<1$ milligram

Wet form; $<10$ milligrams

Where possible, use a fume hood or glove box and these limits can be increased by an order of magnitude. Storage of materials should be in sealed unbreakable and fire-proof containers and then there is no limit to the amount of material that can be stored.

It is normal to mark areas where beryllium is being used or stored with a sign (The letters Be in black inside a black circle on a white background).

During the sample preparation cleanliness and meticulous methods are important, as the beryllium amounts are so small contamination is a constant problem, and even the slightest contamination will create anomalous results.

\section{PROCEDURES FOR SEPARATION OF ${ }^{10}$ Be CONTENT OF SAMPLES;}

To prepare a target for the Accelerator Mass Spectrometer (AMS) there are three necessary steps;

1) Separation of required crystallographic and or exotic phases from the sample material and dissolution of this material.

\section{2) Separation of beryllium from the resulting solution.}

\section{3) Conversion to beryllium oxide and preparation of an AMS target.}

As the proposed method uses the absolute concentration of ${ }^{10} \mathrm{Be}$ in the sample (as discussed earlier), it is important to know the percentage of ${ }^{10} \mathrm{Be}$ removed from the sample and retained for analysis (as opposed to that remaining within the sediment, and being lost during the extraction and separation); i.e. the percentage in the final yield for measurement in the AMS. As the AMS will only measure atomic ratios, a known amount of ${ }^{9} \mathrm{Be}$ carrier will need to be introduced to the sample before the AMS target is prepared. The ${ }^{9} \mathrm{Be}$ spike 
will need to be added before actual separation of ${ }^{10} \mathrm{Be}$ begins in the analysis. The ratio of the two will therefore still be truly representative of the absolute concentration of the ${ }^{10} \mathrm{Be}$ for the sample can be calculated. This will act to satisfy these two necessary parameters of the analysis; 1) to provide some ${ }^{9} \mathrm{Be}$ for the AMS to measure a ratio of ${ }^{10} \mathrm{Be} /{ }^{9} \mathrm{Be}$, and 2 ) to prevent the necessity of a tracer throughout the wet chemistry preparation of the samples, as the same percentage of ${ }^{10} \mathrm{Be}$ and ${ }^{9} \mathrm{Be}$ will be recovered for measurement in the AMS.

\subsubsection{Dating of continental margin sediments}

Exotic (adsorbed by clay minerals and cements) ${ }^{10} \mathrm{Be}$ content is indicative of sediment age. However, because of differing sedimentation rates, production rates, depositional environments and precipitation rates, sampling must be within a stratigraphic framework allowing a relative dating method (either to present day or some other known datum) to be set up for each environment of measurement (Wilson, 1990).

Leaching of samples to remove adsorbed, clay and cement material is the best approach. Care must be taken to remove all ${ }^{10} \mathrm{Be}$ in these phases leaving allochthonous crystallographic beryllium behind in the residue. Preferential leaching of one exotic phase or another (as suggested by Bourles et al., 1989) will result in biasing of results, as beryllium atoms are incorporated into different phases during diagenesis (Wilson, in prep).

Initially all exotic ${ }^{10} \mathrm{Be}$ will be adsorbed to particle surfaces, however, even early diagenesis will incorporate the adsorbed ${ }^{10} \mathrm{Be}$ into authigenic mineral phases and later into cement phases. The ${ }^{10} \mathrm{Be}$ will become more assimilated into the rock as diagenesis proceeds and hence become harder to remove without incorporating crystallographic material. $6 \mathrm{M} \mathrm{HCl}$ acid leaching will remove these authigenic phases without attacking the grains. Acid digestion and analysis of the leachate material will provide the necessary data for age diagnosis. The sediment residue is discarded.

\subsubsection{Analysis of exposure ages of geologic surfaces}

Autochthonous crystallographic ${ }^{10} \mathrm{Be}$ content is indicative of exposure age. However, because of differing production rates at different latitudes (Lal, 1962), sample latitudes must be accurately known along with cosmic flux variation at that latitude. Thickness of overburden at the sampling site will also affect the amount of flux striking target atoms.

Samples must initially be leached to remove all exotic ${ }^{10} \mathrm{Be}$. This prevents contamination from adsorbed ${ }^{10} \mathrm{Be}$ in the analysis which will result in an anomalously old age being 
estimated. Leaching is as above with $6 \mathrm{M} \mathrm{HCl}$. Here, however, the leachate is discarded and the residue retained for acid digestion and analysis.

The limiting factor in exposure age dating is knowledge of the rate at which spallation occurs in the rocks different constituent minerals. These are best understood for quartz (Morris, 1991). More data is improving knowledge of production rates in other mineral phases. The possible options are; 1) To separate the mineral phase needed before analysis, or; 2) To analyse the entire sample and calculate proportions using point counting of a thin section of the material to be analysed.

\subsubsection{Magmatic evolution and subducted sediment models}

Here it is the allochthonous crystallographic ${ }^{10} \mathrm{Be}$ that is indicative of sediment subduction and magmatic processes. If the sampling depth is $>4 \mathrm{~m}$ then there will be minimal affect from autochthonous ${ }^{10} \mathrm{Be}$ ('in-situ' production). If sampling is at or near the surface, account must be made for the amount of 'in-situ' production. This can be calculated if both latitude (for cosmic flux intensity) and age are known. The allochthonous crystallographic ${ }^{10} \mathrm{Be}$ will be homogeneously distributed within the rock. However, any autochthonous crystallographic ${ }^{10} \mathrm{Be}$ will be mineral specific. This must be accounted for (by point counting mineral proportions) in the calculation of ${ }^{10} \mathrm{Be}$ contributions from different processes.

Checks for the differing contributions may be kept by simultaneous measurement of boron content, as well as absolute ${ }^{10} \mathrm{Be}:{ }^{9} \mathrm{Be}$ ratios, as these are also indicative of magmatic evolution process.

As above, samples must be leached (with $6 \mathrm{M} \mathrm{HCl}$ ) to remove all exotic ${ }^{10} \mathrm{Be}$ and the leachate discarded, with acid digestion and analysis carried out on the residue.

\subsubsection{Soil development, analysis, dating, and erosion studies}

Here both crystallographic and exotic ${ }^{10} \mathrm{Be}$ are useful for assessing soil development and age. Although ${ }^{10} \mathrm{Be}$ migration in soils is complex, certain parameters are common to all sites. The ${ }^{10} \mathrm{Be}$ inventory in the soil column increases as a function of time and deposition, eventually reaching a quasi equilibrium in the soil profile (Morris, 1991). Before ${ }^{10} \mathrm{Be}$ content can be attributed to various processes, certain assumptions need to be made about; 1) ${ }^{10} \mathrm{Be}$ retentivity of the soil; 2) proportions of ${ }^{10} \mathrm{Be}$ incorporated from weathered bedrock, and; 3) 'in-situ' production as opposed to accumulation from 'rain-out' (this may 
be minimised if insufficient target atoms are present in the soil).

Depending on the parameters that are most useful, both a leaching approach or a total digest can be useful. Care will need to be taken during separation as soils retain a complex array of ions. This will make separation more complex.

\subsection{Chemical procedures for the separation of beryllium from rocks.}

\subsubsection{Apparatus and reagents}

$N B$; All beakers and materials used in the chemical separation procedures must be nonglass. This is because the AMS is measuring individual atoms and a boron contaminant from the glassware will mask the measurement window for ${ }^{10} \mathrm{Be}$.

Care must be taken to ensure all acidic reagents are as free of boron as possible, if pure reagents in non-glass containers cannot be used. Reagents must be purified using a teflon bend and low temperature distillation.

- $\quad$ Centrifuge tubes (50-100 ml, teflon)

- $\quad$ Centrifuge (up to $2000 \mathrm{rpm}$ )

- $\quad$ Balance (up to $200 \mathrm{~g}$, accurate to $0.001 \mathrm{~g}$ )

- Crushing blocks (wooden)

- $\quad$ Drying oven $\left(40^{\circ}-50^{\circ} \mathrm{C}\right)$

- Steam bath

- $\quad$ Beakers (100 ml, teflon; and $400 \mathrm{ml}$, polypropelene)

- $\quad$ Sand bath (up to $300^{\circ} \mathrm{C}$ )

- $\quad$ Bunsen (up to $1000^{\circ} \mathrm{C}$ )

- $\quad$ Basin (100 ml, $7 \mathrm{~cm}$ diameter, $3 \mathrm{~cm}$ depth, platinum)

- $\quad$ Tongs (platinum tipped, or tungsten)

- $\quad$ Burette (25-50 ml, polypropelene, with teflon tap)

- $\quad$ Magnetic stirrer and teflon bar

- $\quad$ Digital $\mathrm{pH}$ meter and probe

- Cation exchange column (length $130 \mathrm{~mm}$, internal diameter $16 \mathrm{~mm}$, polypropelene or teflon, with teflon tap)

- $\quad$ Dowex AG50WX8 resin

- $\quad$ Teflon wool

- $\quad$ Test tubes (20 ml, polypropelene, some with lids)

- $\quad$ Crucibles (10-20 ml, platinum) 
- $\quad$ Furnace (up to $1000^{\circ} \mathrm{C}$ )

- $\quad$ Storage containers (10 $\mathrm{ml}$, polypropelene)

- $\quad$ Eye dropper (polypropelene)

- $\quad{ }^{9} \mathrm{Be}^{++}$carrier solution $(1.000 \mathrm{mg} / \mathrm{ml})$

- Hydrochloric acid $(10 \%, 2.5 \mathrm{M}, 6 \mathrm{M})$

- $\quad$ Distilled water

- $\quad$ Sulphuric acid ( $0.2 \mathrm{M}, 1 \mathrm{M}$, conc.)

- $\quad$ Hydrofluoric acid (40\%)

- $\quad$ Nitric acid (conc.)

- $\quad$ Ammonia solution (1\%, 25\%)

- $\quad$ Hydrogen peroxide (5\%, conc.)

- $\quad$ Ammoniacal Cyclo-hexane Diamine Tetra-acetic Acid (CDTA) solution (1\%, 100\%)

(hydrogen CDTA is soluble in ammonia solution. To make 1 litre of $0.5 \mathrm{M}$ CDTA/ 4.0 $\mathrm{M} \mathrm{NH}_{4} \mathrm{OH}$ :

\section{$182.2 \mathrm{~g}$ CDTA}

$157.6 \mathrm{ml} 25 \%$ Ammonia solution

In a (non glass) $1000 \mathrm{ml}$ volumetric flask add about $700 \mathrm{ml}$ of distilled water to the solid CDTA. Add Ammonia and stir until CDTA dissolves. Dilute to 1 litre.

- $\quad$ Sodium sulphate (anhydrous)

- Aluminium nitrate

- $\quad$ Potassium fluoride

\subsubsection{Acid leaching of exotic material from sample;}

Beryllium is leached from the sediment using sufficiently strong hydrochloric acid to dissolve authigenic phases, but not attack detrital grains. Sulphuric and hydrofluoric acids are added to the leachate which is then evaporated to decompose silicate. The temperature is elevated until the sulphuric acid is fuming. This ensures that residual hydrochloric acid is removed (avoids attack of platinum basin later) and carbonises the organic matter. A little nitric acid is added to the moderately hot mixture and further heating rapidly oxidises the carbon. Fluoride is eliminated with a pyrosulphate fusion; equimolar sulphuric acid and anhydrous sodium sulphate (Sill, 1976). The resulting cake is cooled and dissolved in dilute hydrochloric acid. Hydroxides are then precipitated with ammonia solution, centrifuged and washed. After redissolving the hydroxide in hydrochloric acid, any barium is removed by centrifuging, the supernate being taken for $\mathrm{pH}$ adjustment and titration with a complexing agent.

A total decomposition of the material to be measured will incorporate all phases of beryllium 
into the resulting solute, and depending on the complexity of the rock history this will complicate the nature of the measurement and its meaning. An acid leach of the sample will remove all the exotic ${ }^{10} \mathrm{Be}$ into solution, and leave the crystallographic beryllium components in the residue.

Before the leach is begun it is important to know the initial weights of the sample accurately, as the final result will be recorded as a weight percent value. Somewhere between 5 and 10 grams of sample should provide plenty of material for accurate measurement of the ${ }^{10} \mathrm{Be}$ concentration. After the initial dry weight is recorded the ${ }^{9} \mathrm{Be}^{++}$ carrier should be added preventing the need for a tracer and allowing measurement of the absolute concentration of ${ }^{10} \mathrm{Be}$, by back calculation from the ${ }^{10} \mathrm{Be} /{ }^{9} \mathrm{Be}$ ratio measured by the AMS.

\subsubsection{Procedure;}

1) Dry 5-10 grams of sample in a moderate oven $\left(40^{\circ}-50^{\circ} \mathrm{C}\right)$.

2) Crush (using wooden blocks only) and add to a $100 \mathrm{ml}$ centrifuge tube.

3) Obtain the exact weight of sediment.

4) Add $2 \mathrm{mg}$ of ${ }^{9} \mathrm{Be}^{++}$carrier to the dry sediment.

5) Test sample for carbonates with a small amount of dil. $\mathrm{HCl}$. If carbonate present, then dissolve carefully using dil. $\mathrm{HCl}$, centrifuge and retain solute in a $100 \mathrm{ml}$ teflon beaker.

6) Evaporate solution down over a steam bath.

7) Leach sediment using $40-50 \mathrm{ml}$ of $\mathrm{HCl}(6 \mathrm{M})$ over a steam bath for $1 \mathrm{hr}$.

8) Centrifuge, decant and add solute to the $100 \mathrm{ml}$ teflon beaker evaporating over steam bath.

9) Wash sediment residue using $\mathrm{HCl}(6 \mathrm{M})$, centrifuge, decant and add solute to evaporating teflon beaker.

10) Discard residue.

11) Evaporate solute down on water bath.

12) Before evaporation is complete (about $10 \mathrm{ml}$ remaining), cool, and add $5 \mathrm{ml}$ c. $\mathrm{H}_{2} \mathrm{SO}_{4}$ and $5 \mathrm{ml} \mathrm{c.HF}$.

13) Evaporate down on steam bath and then heat until the $\mathrm{H}_{2} \mathrm{SO}_{4}$ fumes weakly.

14) Cool and add $10 \mathrm{ml}$ c.HF.

15) Evaporate to fumes on slightly higher heat.

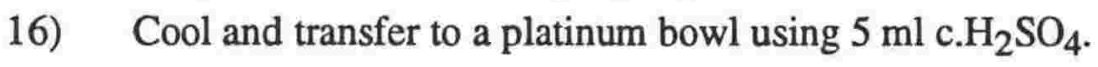

17) Heat on a hot sand bath until fuming, once fuming begins, continue heating for 1 hr to ensure the $\mathrm{HCl}$ is removed and the organic matter is carbonised.

18) Cool slightly and add a few drops of $\mathrm{c} \cdot \mathrm{HNO}_{3}$. Heat to oxidize the carbon. Repeat 
if the carbon persists.

19) Add $5 \mathrm{ml} \mathrm{c.HF}$ and heat over hot flame to dissolve most of remaining solid.

20) Add $8 \mathrm{ml} \mathrm{c} \cdot \mathrm{H}_{2} \mathrm{SO}_{4}$ and $10 \mathrm{~g}$ of anhydrous $\mathrm{Na}_{2} \mathrm{SO}_{4}$ (pyrosulphate fusion) and continue heating on hot flame, until browny liquid is formed with no solid remaining.

21) Cool to form bisulphate cake in the bottom of the platinum dish.

22) Transfer to beaker and dissolve in dilute $\mathrm{HCl}$.

23) $\mathrm{Add} \mathrm{NH}_{4} \mathrm{OH}$ to precipitate hydroxides at $\mathrm{pH} 9.1$ - 9.2.

24) Centrifuge and wash.

25) Dissolve hydroxide with $5 \mathrm{ml}$ conc. $\mathrm{HCl}$.

26) Dilute and centrifuge to separate any $\mathrm{BaSO}_{4}$.

27) Decant supernate into beaker containing magnetic stirrer bar.

28) Suspend any $\mathrm{BaSO}_{4}$ in a little water, centrifuge, and add wash to beaker.

\subsubsection{Decomposition of crystallographic material from sample}

If it is only crystallographic ${ }^{10} \mathrm{Be}$ that is required for analysis, the exotic ${ }^{10} \mathrm{Be}$ must first be removed by a $6 \mathrm{M} \mathrm{HCl}$ leach and the leachate discarded. The residue can then be washed and decomposed. The washing should be extremely thorough, as adsorbed material from leaching can be problematic to remove. The ${ }^{9} \mathrm{Be}$ carrier is not added until after the washing is complete.

Hydrofluoric acid is again used to attack silicate in the washed crystallographic material. This is followed by a potassium fluoride fusion to ensure total decomposition (Sill, 1976). Any organic matter is rapidly oxidised. The remainder of the procedure, including the pyrosulphate fusion, is similar to that described in section 4.2.2.

If crystallographic and exotic ${ }^{10} \mathrm{Be}$ are both to be analysed for in the same sample; the sample should first be split. Each split can be analysed as two separate samples, one with a leach procedure and the other with a digest procedure.

\subsubsection{Procedure}

1) Dry $\sim 10 \mathrm{~g}$ of sample in a moderate oven $\left(40^{\circ}-50^{\circ} \mathrm{C}\right)$.

2) Crush to fit into teflon tube.

3) Leach sample using $40-50 \mathrm{ml}$ of $\mathrm{HCl}(6 \mathrm{M})$ over a steam bath for 1 hour.

4) Centrifuge, decant and discard the leachate.

5) Wash sample using $\mathrm{HCl}(6 \mathrm{M})$ and d. $\mathrm{H}_{2} \mathrm{O}$ to remove all $\mathrm{HCl}$. 
6) Dry residue sample in a moderate oven $\left(40^{\circ}-50^{\circ} \mathrm{C}\right)$.

7) Obtain the exact weight of residue.

8) Add $2 \mathrm{mg}$ of ${ }^{9} \mathrm{Be}^{++}$carrier to the dry residue.

9) Transfer sample to platinum basin using a little d. $\mathrm{H}_{2} \mathrm{O}$.

10) Slowly add $40 \mathrm{ml}$ of c.HF.

11) Evaporate to near dryness.

12) Mix $30 \mathrm{~g}$ of $\mathrm{KF}$ into sample.

13) Fuse mix at $850^{\circ} \mathrm{C}$ over hot flame.

14) Cool to form potassium fluoride cake in the bottom of platinum dish.

15) Add $8 \mathrm{ml} \mathrm{c.} \mathrm{H}_{2} \mathrm{SO}_{4}$ and $10 \mathrm{~g}$ of anhydrous $\mathrm{Na}_{2} \mathrm{SO}_{4}$ (pyrosulphate fusion) and continue heating on hot flame, until browny liquid is formed with no solid remaining.

16) Cool to form bisulphate cake in the bottom of the platinum dish.

17) Transfer to beaker and dissolve in dilute $\mathrm{HCl}$.

18) $\mathrm{Add} \mathrm{NH}_{4} \mathrm{OH}$ to precipitate hydroxides at $\mathrm{pH} 9.1-9.2$.

19) Centrifuge and wash.

20) Dissolve hydroxide with $5 \mathrm{ml}$ conc. $\mathrm{HCl}$.

21) Dilute and centrifuge to separate any $\mathrm{BaSO}_{4}$.

22) Decant supernate into beaker containing magnetic stirrer bar.

23) Suspend any $\mathrm{BaSO}_{4}$ in a little water, centrifuge, and add wash to beaker.

\subsubsection{Acid digest of all sample material}

Here no initial acid leach is necessary. This approach will only be useful when dealing with the total beryllium content of soils. The entire sample is decomposed directly, without separating the crystallographic and exotic phases, using a preliminary HF treatment followed by potassium fluoride fusion. That way all the ${ }^{10} \mathrm{Be}$ in the sample is separated for analysis.

\subsubsection{Procedure}

1) Dry 5-10 grams of sample in a moderate oven $\left(40^{\circ}-50^{\circ} \mathrm{C}\right)$.

2) Crush (using wooden blocks only) and add to a $100 \mathrm{ml}$ teflon beaker.

3) Obtain the exact weight of sediment.

4) Follow steps 8) - 23) of procedure 4.2.3.1. 


\section{SEPARATION OF BERYLLIUM FROM THE PREPARED SOLUTE}

This is carried out in two stages;

1) An ammoniacal cyclo-hexane diamine tetra-acetic Acid (CDTA) titration to complex impurities, mainly iron and aluminium, to an approximate end point.

2) Cation exchange separation of beryllium from the remaining impurities, mainly titanium and aluminium. Any boron should be flushed through the column.

\subsection{Titration with Ammoniacal Complexing Agent}

The complexing agent, ethylene diamine tetra-acetic acid (EDTA) has previously been used in separating beryllium for ${ }^{10} \mathrm{Be}$ dating (Thomas et al., 1981; Merril et al., 1960). Beryllium forms a relatively weak EDTA complex compared with those of iron and aluminium.

Although development was incomplete, an alternative easy method (Ditchburn and McCabe, 1991) was established. Earlier work, with ${ }^{7} \mathrm{Be}$ tracer, indicated that yields of around $90 \%$ should be attainable. However, problems were encountered and a better understanding of the chemistry is required.

The complexing reaction with metal cations is given by;

$$
\mathrm{M}^{\mathrm{n}+}+\mathrm{H}_{2} \mathrm{Y}^{--}<-->(\mathrm{MY})^{(\mathrm{N}-4)+}+2 \mathrm{H}^{+}
$$

If a weakly acidic solution of a cation is titrated with an appropriate mixture of complexing agent and ammonia, then the $\mathrm{pH}$ will remain fairly steady while the ammonia is neutralizing acid which is being generated by the reaction. At the end-point, there will be a sharp rise in $\mathrm{pH}$ due to an excess of ammonium hydroxide.

When EDTA was used, some titanium appeared to be hydrolysing during the titration and precipitating as ortho-titanic acid. In some cases, insoluble phosphates also may have formed. Residual fluoride, due to inadequate treatment in earlier pyrosulphate fusions, may also have contributed to the difficulties. The end result was that too much aluminium and titanium remained uncomplexed and overloaded the cation exchange column in the next stage. It was recommended (N. Milestone, pers. comm.) that the stronger complexing agent, CDTA, be used and this has minimised the problems (Table 1). 


$\begin{array}{lllll} & \mathrm{Be}^{2+} & \mathrm{Fe}^{3+} & \mathrm{Al}^{3+} & \mathrm{TiO}_{2}{ }^{2+} \\ \text { EDTA } & 3.8 & 25 & 16 & 17 \\ \text { CDTA } & 10 & 29 & 18 & <10\end{array}$

\section{Table 1: Log Stability constants (K1) for complexing reactions}

During the titration, ammoniacal CDTA is added in small quantities (1-2 $\mathrm{ml}$ at a time). A graph of $\mathrm{pH}$ versus volume added is plotted (Figure 2). The initial $\mathrm{pH}$ is about 1.2. Iron is titrated first and the $\mathrm{pH}$ remains low $(<2)$, but as the end point is reached, the $\mathrm{pH}$ rises until the aluminium begins to complex. Throughout the rest of the titration, the $\mathrm{pH}$ gradually increases until near the end point for aluminium. At this point the reaction rate is so slow that after each addition of titre the $\mathrm{pH}$ will rise sharply and then slowly decrease as the reaction proceeds. The end point is reached when the $\mathrm{pH}$ rises after an addition $(1 \mathrm{ml})$ but does not slowly fall back. A little aluminium is then added to the aliquot at this stage ensuring that the beryllium is not complexed.

\subsubsection{CDTA titration procedure;}

1) Place beaker on magnetic stirrer and insert $\mathrm{pH}$ electrode.

2) Add ammonia solution to the aliquot to bring the $\mathrm{pH}$ to 1.0-1.5 (until the precipitate formed from a small amount of ammonia addition will just redissolve).

3) Prepare to plot a graph of $\mathrm{pH}$ versus column of $\mathrm{CDTA} / \mathrm{NH}_{4} \mathrm{OH}$ solution.

4) Titrate using $\mathrm{NH}_{4} \mathrm{OH} / \mathrm{CDTA}$ titre, adding $2 \mathrm{ml}$ at a time (the solution will darken as the iron complexes) until all the iron and most of the aluminium has been complexed.

5) When the shoulder of the titration rises and the $\mathrm{pH}$ 'kicks' begin adding only $1 \mathrm{ml}$ of titre and allow the $\mathrm{pH}$ to settle before adding more.

6) Continue to add the titre until the $\mathrm{pH}$ rises and does not drop back.

7) Acidify the aliquot with dil. $\mathrm{HCl}(5 \mathrm{ml})$ and add $0.5 \mathrm{~g}$ of $\mathrm{Al}\left(\mathrm{NO}_{3}\right)_{3}$.

8) $\quad$ Add $\mathrm{NH}_{4} \mathrm{OH}$ to the aliquot, to a $\mathrm{pH}$ of 9.1-9.2.

9) Allow precipitation to flocculate, centrifuge, and wash using d. $\mathrm{H}_{2} \mathrm{O}$.

\section{Notes;}

- The amount of $\mathrm{NH}_{4} \mathrm{OH} / \mathrm{CDTA}$ titre necessary will vary from sample to sample depending 
on the concentration of iron and aluminium in the aliquot. Graphing of all titrations is therefore necessary to ensure the correct endpoints are reached.

- $0.5 \mathrm{~g}$ of $\mathrm{Al}\left(\mathrm{NO}_{3}\right)_{3} .9 \mathrm{H}_{2} \mathrm{O}$ should be a suitable excess provided that the titration is halted immediately the $\mathrm{pH}$ begins to rise without falling back.

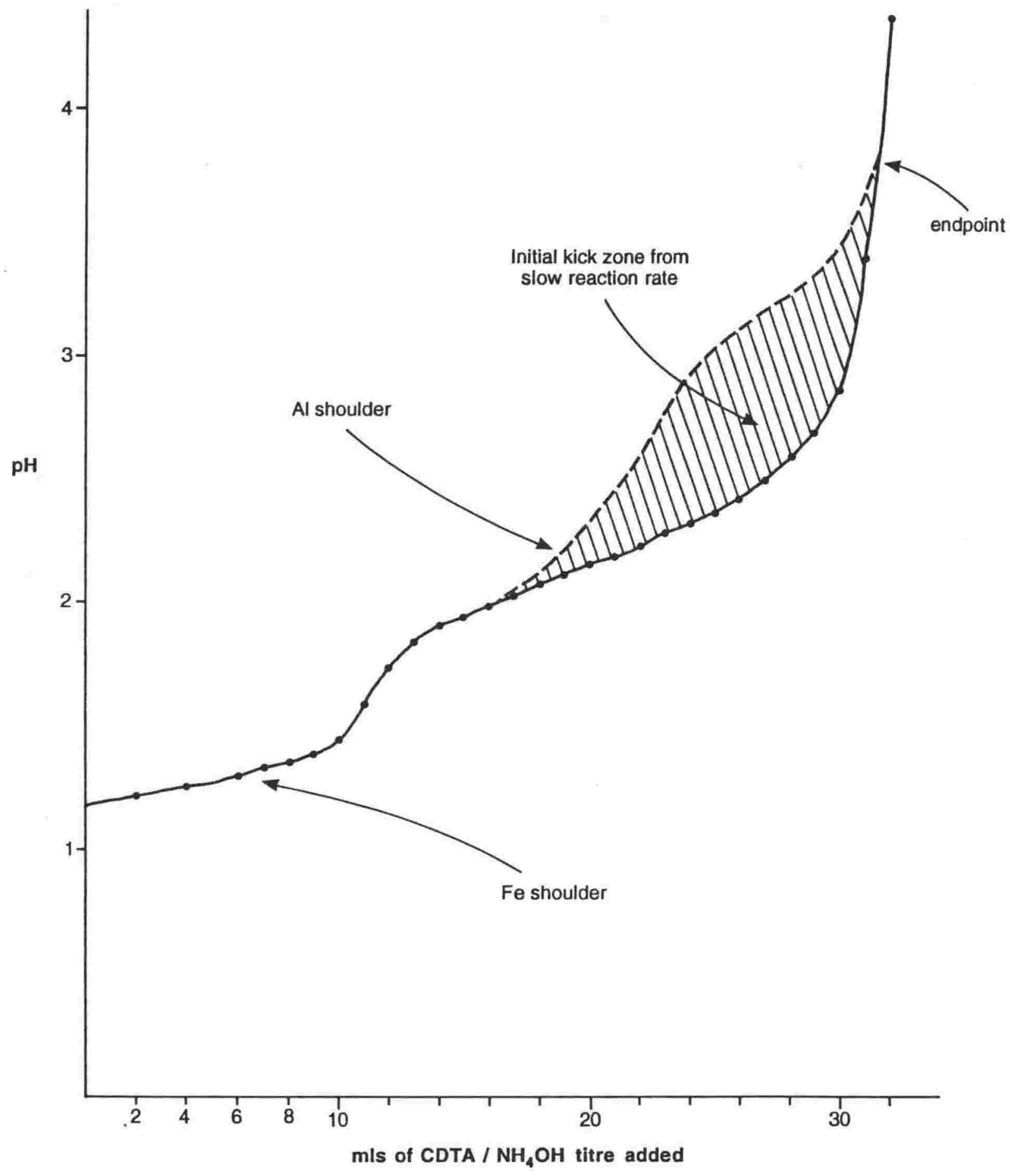

Figure 2: An example of the $\mathrm{pH}$ behaviour during the ammoniacal titration. 


\subsection{Ion exchange}

This will separate out the remaining ions in the solute. Precautions must be taken to prevent hydrolysis and precipitation of titanium, especially if the amount is excessive. The precipitate is slurried with a small amount of hydrogen peroxide before dissolving in cold sulphuric acid, this will keep the titanium in solution. This solute is then diluted to a $50 \mathrm{ml}$ volume and added to a AG50WX8 cation exchange column. As the sample is loaded onto the column some of the titanium and any interfering anions will run straight through the column. Elution using sulphuric acid will remove the remaining titanium from the column. The $\mathrm{TiO}_{3} \cdot \mathrm{nH}_{2} \mathrm{O}$ will usually form a confined brown band on the column, that can be seen moving down as sulphuric acid is added.

Further elution with sulphuric acid will remove the beryllium from the column. This can be collected in $10 \mathrm{ml}$ lots and ammonia solution added to each lot to precipitate the beryllium as beryllium hydroxide. This should occur after about $60 \mathrm{ml}$ of elution. Aluminium may follow the beryllium, the two should be separated by at least one clear collection lot. The remaining aluminium can be removed from the column using an $\mathrm{HCl}$ wash (this will also clean the column).

If significant anion contamination from phosphate or fluoride occurs; the sample will smear down the column on loading. If smearing occurs on loading the column; the loading elutant can be discarded. The column can then be stripped using hydrochloric acid and the sample reloaded. This time, loading should occur in a much tighter band as the interfering anions will have been discarded in the first loading.

\subsubsection{Ion exchange procedure;}

1) Condition the cation exchange column by eluting with $50 \mathrm{ml} 0.2 \mathrm{M} \mathrm{H}_{2} \mathrm{SO}_{4}$.

2) Dissolve the precipitate using a few drops of $\mathrm{HCl}(6 \mathrm{~mol})$.

3) Dilute using d. $\mathrm{H}_{2} \mathrm{O}$ and reprecipitate using $\mathrm{NH}_{4} \mathrm{OH}$.

4) Centrifuge and wash using dil. $\mathrm{NH}_{4} \mathrm{OH} / \mathrm{CDTA}(1 \%)$, centrifuge and discard the liquid.

5) Add a few drops of $\mathrm{H}_{2} \mathrm{O}_{2}(5 \%)$ to the precipitate, and slurry using a teflon rod.

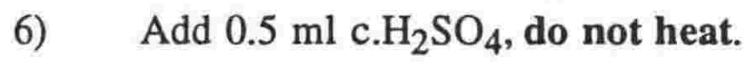

7) Add $40 \mathrm{ml}$ of d. $\mathrm{H}_{2} \mathrm{O}$ and centrifuge to check for solid titanium.

8) Load sample onto column, wash on with $0.2 \mathrm{M} \mathrm{H}_{2} \mathrm{SO}_{4}$.

9) Elute with $50 \mathrm{ml}$ of $1 \mathrm{M} \mathrm{H}_{2} \mathrm{SO}_{4}$ and a few drops of $5 \% \mathrm{H}_{2} \mathrm{O}_{2}$.

10) Discard effluent containing the orange titanium band.

11) Elute with $60 \mathrm{ml}$ of $1 \mathrm{M} \mathrm{H}_{2} \mathrm{SO}_{4}$.

12) Collect the run off in $10 \mathrm{ml}$ lots (nos. 2,3 and 4 should contain beryllium). 
13) Precipitate the beryllium as hydroxide using $\mathrm{NH}_{4} \mathrm{OH}$.

14) Clean the column using $60 \mathrm{ml}$ of $\mathrm{HCl}(2.5 \mathrm{~mol})$.

15) Wash column through using d. $\mathrm{H}_{2} \mathrm{O}$.

16) Centrifuge an wash the beryllium precipitate using $\mathrm{NH}_{3}(1 \%)$.

\section{CONVERSION TO BERYLLIUM OXIDE}

The choice of beryllium Oxide as target material is based on the negative ion yield of $\mathrm{BeO}^{-}$ from the sputtered target. $\mathrm{Be}^{-}$ions are not created at the source.

Conversion of $\mathrm{Be}(\mathrm{OH})_{2}$ to $\mathrm{BeO}$ occurs above $950^{\circ} \mathrm{C}$. Any furnace that heats to $1000^{\circ} \mathrm{C}$. can be used.

If boron contamination is still a possibility, it is easily removed prior to the oxide conversion. Boric acid can be volatilised using perchloric acid in a platinum basin. After cooling and diluting, beryllium hydroxide is reprecipitated with purified ammonia solution.

High levels of boron in the AMS cause problems at measurement. ${ }^{10} \mathrm{~B}$ has the same energy as beryllium but the two can be separated from each other using nickel foils. However, if hydrogen is present in the foils; it will react with the boron to produce ${ }^{7} \mathrm{Be}$. The ${ }^{7} \mathrm{Be}$ forms

a background under the ${ }^{10} \mathrm{Be}$ signal that limits the attainable sensitivity.

\subsection{Procedure}

1) Wash $\mathrm{Be}(\mathrm{OH})_{2}$ precipitate into a $20 \mathrm{ml}$ platinum crucible and cover with platinum lid.

2) Place crucible in furnace before bringing to temperature.

3) Heat to $1000^{\circ} \mathrm{C}$.

4) $\mathrm{BeO}$ can be removed after cooling and stored in a suitable receptacle until measurement on the AMS.

\section{ACKNOWLEDGEMENTS}

Internal Grants Committee (Victoria University of Wellington) and FORST provided funds for materials. Bill McCabe is thanked for discussion on the radiochemistry of beryllium and Roger Sparks for contributions on practical aspects of Accelerator Mass Spectrometry and sample measurement. Peter Barrett and Rodger Sparks reviewed the manuscript. 


\section{REFERENCES}

B S AMIN, D LAL and B L K SOMAYAJULU (1975); Chronology of marine sediments using the ${ }^{10} \mathrm{Be}$ method: Intercomparison with other methods. Geochimica et Cosmochimica Acta 39: 1187-1192.

J BEER, G BONANI, H J HOFMANN, M SUTER, A SYNAL, W WOLFLI, H OESCHGER, U SIEGENTHALER and R C FINKEL (1987); ${ }^{10} \mathrm{Be}$ measurements on polar ice: comparison of Arctic and Antarctic Records. Nuclear Instruments and Methods in Physics Research. B29: 203-206.

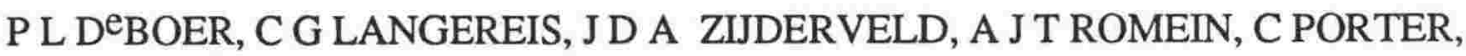
A F M DeJONG, C ALDERLIESTEN and K van der BORG (1987); Beryllium-10 data from redeposited Late Miocene pelagic sediments (East Java, Indonesia). Nuclear Instruments and Methods in Physics Research. B29: 322-326.

D BOURLES, G M RAISBECK and F YIOU (1989); ${ }^{10} \mathrm{Be}$ and ${ }^{9} \mathrm{Be}$ in marine sediments and their potential for dating. Geochimica et Cosmochimica Acta. 53: 443-452.

L BROWN (1987); ${ }^{10} \mathrm{Be}$ : recent applications in Earth Sciences. Philosophical Transactions of the Royal Society of London. A323: 75-86.

L BROWN, J KLEIN, R MIDDLETON, I SELWYN SACKS and F TERA (1982); ${ }^{10} \mathrm{Be}$ in island-arc volcanoes and implications for subduction. Nature. 299: 718-720.

L BROWN, I S SACKS, F TERA, J KLEIN and R MIDDLETON (1981); Beryllium-10 in continental sediments. Earth and Planetary Science Letters. 55: 370-376.

T A BROWN, D E NELSON, J R SOUTHON and J S VOGEL (1987); ${ }^{10}$ Be production rate variations as recorded in a mid-latitude lake sediment. Nuclear Instruments and Methods in Physics Research. B29: 232-237.

R G DITCHBURN and W J McCABE (1991); Provisional manual for separating ${ }^{10} \mathrm{Be}$ from sediments. DSIR Physical Sciences Manual 10. 
D ELMORE, N J CONRAD, P W KUBIK, H E GOVE, M WAHLEN, J BEER and M SUTER (1987); ${ }^{36} \mathrm{Cl}$ and ${ }^{10} \mathrm{Be}$ profiles in Greenland Ice: dating and production rate variations. Nuclear Instruments and Methods in Physics Research. B29: 207210.

A W FAIRHALL (1960); The Radiochemistry of Beryllium. A report prepared for the Subcommittee on Radiochemistry, National Academy of Sciences - National Research Council, U.S.A: 58 p.

F GUICHARD, J -L REYSS and Y YOKOHAMA (1978); Growth rate of a manganese nodule measured with ${ }^{10} \mathrm{Be}$ and ${ }^{26} \mathrm{Al}$. Nature. 272 : $155-156$.

W U HENKEN-MELLIES, J BEER, F HELLER, K J HSU, C SHEN, G BONANI, H J HOFMANN, M SUTER and W WOLFLI (1990); ${ }^{10} \mathrm{Be}$ and ${ }^{9} \mathrm{Be}$ in South Atlantic DSDP Site 519: Relation to geomagnetic reversals and to sediment composition. Earth and Planetary Science Letters. 98: 267-276.

T INOUE and S TANAKA (1976); ${ }^{10} \mathrm{Be}$ in marine sediments. Earth and Planetary Science Letters. 29: 155-160.

J H F JANSEN, C ALDERLIESTEN, A J van BENNEKOM, $\mathrm{K}$ van der BORG and A F M DeJONG (1987); Terriginous supply of ${ }^{10} \mathrm{Be}$ and dating with ${ }^{14} \mathrm{C}$ and ${ }^{10} \mathrm{Be}$ in sediments of the Angola Basin (SE Atlantic). Nuclear Instruments and Methods in Physics Research. B29: 311-316.

R JHA and D LAL (1982); On cosmic ray produced isotopes in surface rocks. In ; K G VOHRA, K C PILAI, U C MISHRA and S SADADIVAN (Eds.): Natural Radiation Environment. Wiley Eastern Ltd, New Delhi, India: 629-635.

M KUSAKABE, T L KU, J R SOUTHON, J S VOGEL, D E NELSON, C I MEASURES and Y NOZAKI (1987); The distribution of ${ }^{10} \mathrm{Be}$ and ${ }^{9} \mathrm{Be}$ in ocean water. Nuclear Instruments and Methods in Physics Research. B29: 306-310.

D LAL (1962); Cosmic Ray Produced Radionuclides in the Sea. Journal of the Oceanographical Society of Japan. 20th Anniversary Volume: 600-614.

R McCORKELL, E L FIREMAN and C C LANGWAY Jr. (1967); Aluminium-26 and beryllium-10 in Greenland Ice. Science. 158: 1690-1692. 
A MANGINI, M SEGL, G BONANI, H J HOFMANN, E MORENZONI, M NESSI, M SUTER, W WOLFLI and K TUREKIAN (1984); Mass-spectrometric ${ }^{10} \mathrm{Be}$ dating of deep-sea sediments applying the Zurich Tandem Accelerator. Nuclear Instruments and Methods in Physics Research. B5: 353-358.

C I MEASURES and J M EDMOND (1982); Beryllium in the water column of the central North Pacific. Nature. 297: 51-53.

J R MERRIL, E F X LYDEN, M HONDA and J R ARNOLD (1960); Sedimentary Geochemistry of the beryllium isotopes. Geochimica et Cosmochimica Acta. 18: $108-129$.

R MIDDLETON and J KLEIN (1987); ${ }^{26} \mathrm{Al}$ : measurement and applications. Philosophical transactions of the Royal Society, London. Series A. 323: 121-143.

M MONAGHAN, J KLEIN and C I MEASURES (1986); The origins of ${ }^{10} \mathrm{Be}$ in island arc volcanic rocks. Earth and Planetary Science Letters. 89: 288-298.

J D MORRIS (1991); Applications of Cosmogenic ${ }^{10} \mathrm{Be}$ to problems in the Earth Sciences. Annual Reviews of Earth and Planetary Sciences. 19: 313-350.

J D MORRIS, W P LEEMAN and FTERA (1990); The subducted component in island arc lavas: constraints from Be isotopes and B-Be systematics. Nature. 344: 31-36.

K NISHIIZUMI, J R ARNOLD, D ELMORE, X MA, D NEWMAN and M E GROVE (1983); ${ }^{36} \mathrm{Cl}$ and ${ }^{53} \mathrm{Mn}$ in Antarctic meteorites and ${ }^{10} \mathrm{Be}-{ }^{36} \mathrm{Cl}$ dating of Antarctic ice. Earth and Planetary Science Letters. 62: 407-417.

K D NISHIIZUMI, D LAL, J KLEIN, R MIDDLETON and J R ARNOLD (1986); Production of ${ }^{10} \mathrm{Be}$ and ${ }^{26} \mathrm{Al}$ by cosmic rays in terrestrial quartz in situ and implications for erosional rates. Nature. 319: 134-136.

H OESCHGER (1987); Accelerator Mass Spectrometry and ice core research. Nuclear Instruments and Methods in Physics Research. B29: 196-202.

G.M.RAISBECK and F.YIOU (1984); Production of Long-Lived Cosmogenic Nuclei and their applications. Nuclear Instruments and Methods in Physics Research. B5: 9199. 
G M RAISBECK, F YIOU, M FRUNEAU, M LIEUVIN and J M LOISEAUX (1978);

Measurement of ${ }^{10} \mathrm{Be}$ in 1,000- and 5,000-year-old Antarctic ice. Nature. 275: 731-732.

G M RAISBECK, F YIOU, M FRUNEAU, J M LOISEAUX and M LIEUVIN (1979);

${ }^{10} \mathrm{Be}$ concentration and residence time in the ocean surface layer. Earth and Planetary Science Letters. 43: 237-240.

G M RAISBECK, F YIOU, M FRUNEAU, J M LOISEAUX, M LIEUVIN, J C RAVEL, Y M REYSS and F GUICHARD (1980); ${ }^{10} \mathrm{Be}$ concentration and residence time in the deep ocean. Earth and Planetary Science Letters. 51: 275-278.

M SEGL, A MANGINI, J BEER, G BONANI, M SUTER, W WOLFLI and C MEASURES (1987); ${ }^{10} \mathrm{Be}$ in the Atlantic Ocean, a transect at $25^{\circ} \mathrm{N}$. Nuclear Instruments and Methods in Physics Research. B29: 332-334.

M SEGL, A MANGINI, G BONANI, H J HOFMANN, E MORENZONI, M NESSI, M SUTER and W WOLFLI (1984a); ${ }^{10} \mathrm{Be}$ dating of the inner structure of Mnencrustations applying the Zurich Tandem Accelerator. Nuclear Instruments and Methods in Physics Research. B5: 359-364.

M SEGL, A MANGINI, G BONANI, H J HOFMANN, M NESSI, M SUTER, W WOLFLI, G FRIEDRICH, W L PLUGER, A WIECHOWSKI and J BEER (1984b); ${ }^{10} \mathrm{Be}$ dating of a manganese crust from Central North Pacific and implications for oceanic palaeocirculation. Nature. 309: 540-543.

C W SILL (1976); Accuracy in Trace Analysis: Sampling, Sample Handling, and Analysis. National Bureau of Standards Special Publication 422.

B L K SOMAYAJULU (1977); Analysis of causes for the beryllium-10 variations in deep sea sediments. Geochimica et Cosmochimica Acta. 41: 909-913.

B L K SOMAYAJULU, P SHARMA, J KLEIN, R MIDDLETON, D F WILLIAMS and W S MOORE (1991); Changes in the depositional flux of ${ }^{10} \mathrm{Be}$ in the Orca Basin, Gulf of Mexico: Inverse correlation with ${ }^{18} \mathrm{O}$. Chemical Geology (Isotope Geoscience Section). 86: 253-258.

J R SOUTHON, T L KU, D E NELSON, J L REYSS, J C DUPLESSY and J S VOGEL (1987); ${ }^{10} \mathrm{Be}$ in a deep-sea core: implications regarding ${ }^{10} \mathrm{Be}$ production changes over the past $420 \mathrm{ka}$. Earth and Planetary Science Letters. 85: 356-364. 
S TANAKA, T INQUE and M IMAMURA (1977); The ${ }^{10} \mathrm{Be}$ method of dating sediments - comparison with the Paleomagnetic method. Earth and Planetary Science Letters. 37: 55-60.

F TERA, L BROWN, J MORRIS and I SELWYN SACKS (1986); Sediment incorporation in island-arc magmas: Inferences from ${ }^{10} \mathrm{Be}$. Geochimica et Cosmochimica Acta. 50: 535-550.

J THOMAS, A MANGINI and P PARKER (1981); Improvements in an Accelerator based Mass Spectrometer for measuring ${ }^{10} \mathrm{Be}$. IEEE Transactions on Nuclear Science. NS-28 No. 2: 1478-1480.

K K TUREKIAN, J K COCHRAN, S KRISHNASWAMI, W A LANFORD, P D BARKER and K A BAUER (1979); The measurement of ${ }^{10} \mathrm{Be}$ in manganese nodules using a tandem Van der Graff Accelerator. Geophysics Research Letters. 6: 417-420.

A L L M VERBERS and F M van der WATEREN (1991); A glacial geological reconnaissance of the Southern Prince Albert Mountains, Victoria Land, Antarctica. (Abstract) in proceedings; Sixth International Symposium on Antarctic Earth Sciences; Tokyo, Japan: 637.

F M van der WATEREN and A L L M VERBERS (1991); Glacial geology and mountain uplift in North Victoria Land. (Abstract) in proceedings; Sixth International Symposium on Antarctic Earth Sciences; Tokyo, Japan: 637.

G S WILSON (1990); Beryllium-10; A method for tracing and dating Antarctic ice sheet fluctuation in the Pliocene Era. (Abstract) in proceedings; Seventh International Conference on Geochronology, Cosmochronology and Isotope Geology; Canberra, Australia: 112.

G S WILSON and R J SPARKS (1991); Dating of Pliocene Antarctic margin sediments; A new development of the ${ }^{10} \mathrm{Be}$ dating procedure. (Abstract) in proceedings; Sixth International Symposium on Antarctic Earth Sciences; Tokyo, Japan: 650.

F YIOU and G M RAISBECK (1972); Half-life of ${ }^{10}$ Be. Physical Review Letters. 29: 372-375. 
F YIOU and G M RAISBECK (1981); The age of sediments beneath the Ross Ice Shelf as implied by cosmogenic ${ }^{10} \mathrm{Be}$ concentrations. (Abstract) Transactions of the American Geophysical Union (EOS). 62: 297.

Y F YOKOHAMA, Y F GUICHARD, J -L REYSS and N H VAN (1978); Oceanic residence times of dissolved beryllium and aluminum deduced from cosmogenic tracers ${ }^{10} \mathrm{Be}$ and ${ }^{26} \mathrm{Al}$. Science. 201: 1016-1017. 


\section{Appendix - 3}

\section{South Wanganui Basin Stratigraphic sections, unit descriptions, and sample listings.}

Stratigraphic sections were measured by hand levelling of local outcrop and surveying of large scale areas and sequences. The surveying was carried out by noting localities on large scale maps and checking altitudes using a surveying altimeter. The surveying was tied to local bench marks (in the Wanganui River), and trig and spot heights on the NZMS 260 series maps (in both the Wanganui and Rangitikei Rivers). Pressure fluctuations were accounted for by assuming linear drift between benchmark measurements. In the Wanganui River the base map used was a 1:10,000 scale map prepared by Electricorp for possible hydro development of the River, with associated local benchmarks. In the Hautawa Road and Rangitikei River sections 1:25,000 scale preparation maps for NZMS 260 series maps were used. With the shallow dip angle of the strata in the basin, resulting Stratigraphic thickness and sample height measurements are accurate to $\pm 3 \mathrm{~m}$.

Each section is subdivided into lithologic units numbered at 1 from the base upwards. Each description is preceded by the unit and section thickness ( $U=$ unit thickness, $S=$ total section thickness). Lithologic, palaeontologic, and palaeomagnetic samples are listed after the unit from which they were taken, and their stratigraphic location is given in meters above the base of the section. Sample labelling is in 3 parts; a letter prefix (W for Wanganui River Section; $H$ for Hautawa Road Section; or R for Rangitikei River Section) for the section name; a three digit sample number; and letter suffixes describing the nature of the sample ( $\mathrm{S}$ for sediment sample; $\mathrm{F}$ for palaeontologic sample; and $\mathrm{P}$ for palaeomagnetic sample). Each unit description includes lithology, bedding properties, colour, grain size, the nature of contact with underlying and overlying unit and any other relevant comments where applicable, such as fossil content or sand petrology. 


\section{A3.1 Wanganui River section}

$1(\mathrm{U}=>20 \mathrm{~m} ; \mathrm{S}=\mathbf{2} \mathrm{m})$

Base of unit not seen. Unit is a well sorted, poorly-fossiliferous, blue-grey, muddy siltstone. It is metre to decimetre bedded and contains poorly preserved valves of Sectipecten woolastoni. Top of unit is a scoured surface, with up to 10 $\mathrm{cm}$ of topography.

W001 S, P (0.5 m)

$2(\mathrm{U}=63 \mathrm{~m} ; \mathrm{S}=65 \mathrm{~m})$

Unconformably overlies siltstone unit. Base of unit is a pebbly, fossiliferous, calcite cemented, muddy sandstone. Shells are broken and worn indicating transport. Unit quickly becomes a well sorted, yellow, quartzofeldspathic, massive sandstone. Top of unit grades into finer grained sandstone.

W002 P (2 m)

\section{$3(\mathrm{U}=30 \mathrm{~m} ; \mathrm{S}=95 \mathrm{~m})$}

Gradational contact with underlying sandstone. Poorly bedded, grey, muddy, medium-fine sandstone. Unit fines up with the muddy fraction becoming more dominant. Upper contact is gradational, boundary between this and overlying unit is marked by a thin, but persistent, concretionary band.

$4(\mathrm{U}=51 \mathrm{~m} ; \mathrm{S}=146 \mathrm{~m})$

Gradational contact with underlying sandstone. Fractured, muddy and sandy, siltstone, massive in places, laminated in others. Unit is fossiliferous with mainly Struthiolaria in growth positions. Top of unit is a scoured and bioturbated surface.
$5(\mathrm{U}=61 \mathrm{~m} ; \mathrm{S}=207 \mathrm{~m})$

Unconformably overlies siltstone unit. Bottom part of unit is a slightly muddy, medium coarse, moderately sorted, decimetre bedded, quartzofeldspathic sandstone. Unit fines up into a muddy fine grained sandstone. Upper part of unit becomes more concretionary and top of unit is a $1 \mathrm{~m}$ thick sequence of concretionary bands. Top contact is conformable with overlying siltstone.

$$
\begin{aligned}
& \text { W003 S (154 m) } \\
& \text { W004 S, P (166 m) }
\end{aligned}
$$

$$
6(\mathrm{U}=54 \mathrm{~m} ; \mathrm{S}=261 \mathrm{~m})
$$

Conformably overlies concretionary band at the top of underlying sandstone. Laminated, fractured slightly sandy fossiliferous siltstone. Struthiolaria in growth position. Top of unit is a scoured and bioturbated surface.

$$
\text { W005 P, S (211 m) }
$$

$7(\mathrm{U}=\mathbf{4 8} \mathrm{m} ; \mathrm{S}=\mathbf{3 0 9} \mathrm{m})$

Unconformably overlies siltstone unit. Unit fines from a slightly muddy, medium coarse, moderately sorted, decimetre bedded, quartzofeldspathic sandstone in the base to a muddy fine grained sandstone at its top. Upper part of unit becomes more concretionary. Top of unit grades into sandy siltstone

$$
\text { W007 P, S (309 m) }
$$

$8(\mathrm{U}=31 \mathrm{~m} ; \mathrm{S}=340 \mathrm{~m})$

Gradational contact with underlying sandstone. Laminated, slightly sandy fossiliferous siltstone. Struthiolaria in growth position. Slightly concretionary 
in places. Unit grades into overlying sandstone.

$9(\mathrm{U}=\mathbf{5 9} \mathrm{m} ; \mathrm{S}=\mathbf{3 9 9} \mathrm{m})$

Gradational contact with underlying siltstone. Decimetre bedded, grey, muddy, medium-fine, sandstone. Unit grades from being muddy in the base to a well sorted medium sandstone at its top. Upper contact is gradational.

W008 S (370 m)

W009 P, S (395 m)

$10(\mathrm{U}=\mathbf{4 1} \mathrm{m} ; \mathrm{S}=\mathbf{4 4 0} \mathrm{m})$

Gradational contact with underlying sandstone. Decimetre bedded, muddy, moderately hard, medium-coarse, sandstone. Sand is quartzofeldspathic and weathers browny grey. Contains poorly preserved microfossils. Top of unit is a scoured and bioturbated surface with $10 \mathrm{~cm}$ of topography.

W010 P, S (422 m)

W011 S (425 m)

$11(\mathrm{U}=\mathbf{2 8} \mathrm{m} ; \mathrm{S}=\mathbf{4 6 8} \mathrm{m})$

Unconformably overlies unit 10 . Uniform, metre bedded, very muddy, grey, fine sandstone. Fossiliferous and concretionary in places. Grades into overlying sandstone.

W013 S (457 m)

W014 (458 m)

$12(\mathrm{U}=\mathbf{4 2} \mathrm{m} ; \mathrm{S}=\mathbf{5 1 0} \mathrm{m})$

Gradational contact with underlying sandstone. Decimetre bedded, grey, muddy, medium-fine, sandstone. Unit grades from being muddy in the base to a well sorted medium sandstone at its top. Upper contact is gradational.

$13(\mathrm{U}=128 \mathrm{~m} ; \mathrm{S}=638 \mathrm{~m})$

Gradational contact with underlying sandstone. Massive, concretionary, light grey, well sorted, medium, Quartzofeldspathic sandstone. Occasional lensoid shell horizons. Top of unit is a scoured surface with $50 \mathrm{~cm}$ of topography.

$$
\text { W015 P, S (599 m) }
$$$$
\text { W016 S (656 m) }
$$

$14(\mathrm{U}=3 \mathrm{~m} ; \mathrm{S}=641 \mathrm{~m})$

Disconformably overlies unit 13 . Hard fossiliferous medium-coarse well cemented sandstone. Unit is more than $30 \%$ calcite cement, with both reworked and in-situ Crassostrea shells. Reef forming unit. Top surface is scoured and has a topography of $50 \mathrm{~cm}$.

W017 S (657 m)

$$
15(\mathrm{U}=131 \mathrm{~m} ; \mathrm{S}=\mathbf{7 7 2} \mathrm{m})
$$

Unconformably overlies unit 14 . Decimetre bedded, slightly sandy, muddy siltstone, with a loaded base. Unit is rhythmic on a $\mathrm{cm}$ scale alternating from muddy siltstone to slightly sandy, muddy siltstone. Top of unit is a sharp contact with overlying Siltstone.

W018 P, S (701 m)

$16(\mathrm{U}=60 \mathrm{~m} ; \mathrm{S}=832 \mathrm{~m})$

Conformably overlies siltstone of unit 15. Unit is a metre to decimetre bedded, grey, muddy, sandy siltstone. Unit coarsens upwards with an increasing 
sand content. Top of unit grades into sandstone

$$
17(\mathrm{U}=124 \mathrm{~m} ; \mathrm{S}=956 \mathrm{~m})
$$

Gradational contact with underlying siltstone. Decimetre bedded, grey, muddy, medium-fine, sandstone. Unit grades from being muddy in the base to a well sorted medium sandstone at its top. Upper contact is gradational.

$$
\begin{aligned}
& \text { W019 P, S (852 m) } \\
& \text { W020 P, S (858 m) } \\
& \text { W021 P, S (890 m) }
\end{aligned}
$$

$$
18(\mathrm{U}=196 \mathrm{~m} ; \mathrm{S}=1145 \mathrm{~m})
$$

Gradational contact with underlying sandstone. Massive, concretionary, light grey, well sorted, homogeneous, medium-grained, Quartzofeldspathic sandstone. Occasional lensoid shell horizons. Top of unit is a scoured surface with $50 \mathrm{~cm}$ of topography.

$$
\begin{aligned}
& \text { W022 P, S (1039 m) } \\
& \text { W023 P, S (1115 m) }
\end{aligned}
$$

$19(\mathrm{U}=2 \mathrm{~m} ; \mathrm{S}=1147 \mathrm{~m})$

Disconformably overlies massive sandstone. Hard fossiliferous mediumcoarse well cemented sandstone. Unit is more than $35 \%$ calcite cement, with both reworked and in-situ Crassostrea shells. Reef forming unit. Other shells also, but material is too recemented to allow identification. Top surface is scoured and has a topography of $50 \mathrm{~cm}$.

$$
\text { W024 S (1146 m) }
$$

$$
20(\mathrm{U}=65 \mathrm{~m} ; \mathrm{S}=1212 \mathrm{~m})
$$

Unconformably overlies unit 19. A muddy, sandy, decimetre bedded siltstone. Laminated in places on a centimetre to 10 centimetre scale. Unit coarsens upwards into a fine sandstone. Top of unit is a shell bed, less than $1 \mathrm{~m}$ thick. Shells are worn and broken. Shell bed is predominantly sandy, with dispersed crassostrea ingens and rare Pelicaria sp. Top of shell bed is a scoured surface with $20 \mathrm{~cm}$ of relief.

$$
\begin{aligned}
& \text { W025 S (1148 m) } \\
& \text { W026 P, S (1152 m) } \\
& \text { W027 P, S (1187 m) } \\
& \text { W028 S (1212 m) }
\end{aligned}
$$

$21(\mathrm{U}=56 \mathrm{~m} ; \mathrm{S}=\mathbf{1 2 6 8} \mathrm{m})$

Unconformably overlies unit 20. A muddy decimetre bedded sandstone, coarsens upwards into a $1 \mathrm{~m}$ thick shell bed, again mainly Crassostrea ingens. Shell bed is about $20 \%$ calcite cemented and more prominent than shell bed that marks the top of unit 21. Top of shell bed is a scoured surface with about $10 \mathrm{~cm}$ of relief.

W029 S (1268 m)

\section{$22(\mathrm{U}=196 \mathrm{~m} ; \mathrm{S}=1464 \mathrm{~m})$}

Unconformably overlies sandstone. A decimetre bedded, quite hard, blue, sandy, muddy, siltstone. Occasionally rhythmic in appearance, with alternating sandstone bands. occasional occurrences of Pelicaria sp. Top of unit is marked by a strongly bioturbated horizon.

$$
\begin{aligned}
& \text { W030 P, S (1302 m) } \\
& \text { W031 P, S (1427 m) }
\end{aligned}
$$

$23(\mathrm{U}=61 \mathrm{~m} ; \mathrm{S}=\mathbf{1 5 2 5} \mathrm{m})$

Unconformably overlies siltstone of unit 22 . Very similar to unit 21 , a decimetre 
bedded, moderately hard, blue, sandy, muddy siltstone. This unit is also rhythmic in appearance in places from occasional alternating sandy horizons on a cm scale. Top of unit is a sharp contact with overlying siltstone.

\section{$24(\mathrm{U}=148 \mathrm{~m} ; \mathrm{S}=1673 \mathrm{~m})$}

Conformably overlies siltstone. A muddy, slightly sandy, massive, Siltstone. Grainsize coarsens throughout entire unit and grades into overlying sandstone

W032 P, S (1565)

\section{5 (U = 116 m; $S=1789 \mathrm{~m})$}

Gradational contact with underlying siltstone. A hard, decimetre bedded, blue, muddy medium grained sandstone. Top of unit is a scoured surface with a few centimetres of topography.

$$
\begin{aligned}
& \text { W033 S (1700 m) } \\
& \text { W034 P (1700 m) } \\
& \text { W035 S (1775 m) } \\
& \text { W036 P (1775 m) } \\
& \text { W037 P, S (1778 m) }
\end{aligned}
$$

$$
26(\mathrm{U}=43 \mathrm{~m} ; \mathrm{S}=1832 \mathrm{~m})
$$

Unconformably overlies sandstone unit. A muddy, massive siltstone, with very little fine content. Unit coarsens upwards into fine sandstone. Occasional Crassostrea, Maorimactra and Pelicaria species. Unit grades into overlying sandstone.

$$
\text { W038 P, S (1801 m) }
$$

$$
27 \text { ( } U \text { = } 152 \mathrm{~m} ; \mathrm{S}=1984 \mathrm{~m} \text { ) }
$$

Gradational contact with underlying unit. A fine, grey, muddy sandstone. Some parts are massive, others metre to decimetre bedded. Unit coarsens upwards into overlying sandstone. Occasional Crassostrea, Maorimactra and Pelicaria species. Unit grades into overlying sandstone.

$$
\begin{aligned}
& \text { W039 P, S (1891 m) } \\
& \text { W040 P, S (1938 m) } \\
& \text { W041 P, S (1973 m) }
\end{aligned}
$$

$$
28(\mathrm{U}=163 \mathrm{~m} ; \mathrm{S}=2147 \mathrm{~m})
$$

Gradational contact with underlying unit. A Massive, concretionary, light grey, well sorted, homogeneous, mediumgrained, Quartzofeldspathic sandstone. Unit weathers brown and is poorly consolidated. Occasional muddy and lensoid shell horizons, containing, amongst others, species of Maorimactra, Phialopecten, Sectipecten, Crassostrea and Sectipecten. Top of unit is a scoured surface with $50 \mathrm{~cm}$ of topography.

$$
\begin{aligned}
& \text { W042 S (2005 m) } \\
& \text { W043 S (2124 m) } \\
& \text { W044 S (2126 m) } \\
& \text { W045 S (2129 m) } \\
& \text { W046 S (2146 m) } \\
& \text { W047 P (2146 m) }
\end{aligned}
$$

$29(\mathrm{U}=\mathbf{4} \mathrm{m} ; \mathrm{S}=\mathbf{2 1 5 1} \mathrm{m})$

Unconformably overlies sandstone. Hard fossiliferous medium-coarse well cemented sandstone. Unit is more than $30 \%$ calcite cement, with both reworked and in-situ Crassostrea shells. Reef forming unit. Top surface is scoured and has a topography of $20 \mathrm{~cm}$.

$$
\text { W048 (2149 m) }
$$

$30(\mathrm{U}=26 \mathrm{~m} ; \mathrm{S}=2177 \mathrm{~m})$ 
Unconformably overlies unit 29. A massive grey slightly muddy, well sorted Siltstone. Unit contains little or no fine fraction. Top contact is gradational over $10 \mathrm{~cm}$.

$$
\text { W049 S (2154 m) }
$$

$$
31 \text { (U = } 20 \mathrm{~m} ; \mathrm{S}=2197 \mathrm{~m})
$$

Gradational contact with underlying siltstone. A massive, well sorted, blue, very slightly silty Sandstone. Top of unit grades into overlying siltstone over 20 $\mathrm{cm}$.

$$
\begin{aligned}
& \text { W050 P, S (2178 m) } \\
& \text { W051 P, S (2189 m) }
\end{aligned}
$$

$$
32(\mathrm{U}=51 \mathrm{~m} ; \mathrm{S}=\mathbf{2 2 4 8} \mathrm{m})
$$

Gradational contact with underlying sandstone. Very similar to unit 30 , a massive grey slightly muddy, well sorted Siltstone. Unit contains little or no fine fraction. Top contact is sharp.

$$
33(\mathrm{U}=33 \mathrm{~m} ; \mathrm{S}=2281 \mathrm{~m})
$$

Conformably overlies Siltstone unit. A medium sorted, muddy medium grained sandstone, faintly decimetre bedded in places. Unit contains the Occasional Crassostrea valve in muddier horizons. Top contact is sharp.

$$
\begin{aligned}
& \text { W054 P, S (2250 m) } \\
& \text { W055 P, S (2266 m) } \\
& \text { W056 S (2271 m) } \\
& \text { W057 S (2281 m) }
\end{aligned}
$$

$$
34 \text { (U = } 18 \mathrm{~m} ; \mathrm{S}=2301 \mathrm{~m})
$$

Conformable contact with underlying unit. Slightly sandy silty mudstone. Occasional Crassostrea valve in sandier horizons. Top contact is sharp.
W058 P, S (2288 m)

$$
35 \text { (U = } 11 \mathrm{~m} ; \mathrm{S}=2312 \mathrm{~m})
$$

Conformably overlies mudstone. This unit is the same as unit 33. A medium sorted, muddy medium grained sandstone, faintly decimetre bedded in places. Unit contains the Occasional Crassostrea valve in muddier horizons. Top contact is sharp.

$$
36 \text { (U = } 17 \mathrm{~m} ; \mathrm{S}=\mathbf{2 3 2 9} \mathrm{m} \text { ) }
$$

Conformably overlies Sandstone. This unit is the same as unit 34. A slightly sandy, silty Mudstone. Occasional Crassostrea valve in sandier horizons. Top of unit is intensely bioturbated and burrowed.

$$
\text { W059 P, S (2316 m) }
$$

\section{$37(\mathrm{U}=433 \mathrm{~m} ; \mathrm{S}=2762 \mathrm{~m})$}

Unconformably overlies unit 36. A massive, silty very slightly sandy, mudstone. Highly fractured in places with some muddy bands containing no sand fraction. Scattered occurrences of Pelicaria sp. in sandier horizons, perhaps washed in from shallower environments. Top of unit is sharp contact.

$$
\begin{aligned}
& \text { W060 P, S (2337 m) } \\
& \text { W061 P, S (2377 m) } \\
& \text { W062 S (2387 m) } \\
& \text { W063 P, S (2440 m) } \\
& \text { W064 P, S (2445 m) } \\
& \text { W065 P, S (2507 m) } \\
& \text { W066 P, S (2547 m) } \\
& \text { W067 P, S (2638 m) } \\
& \text { W068 P, S (2693 m) } \\
& \text { W069 S (2721 m) } \\
& \text { W070 P, S (2756 m) }
\end{aligned}
$$


$38(\mathrm{U}=21 \mathrm{~m} ; \mathrm{S}=\mathbf{2 7 8 3} \mathrm{m})$

Conformably overlies mudstone. A massive, light grey, well sorted, homogenous, medium grained, quartzofeldspathic sandstone. Top of unit is a sharp contact.

W071 S (2776 m)

39 (U = $118 \mathrm{~m} ; \mathrm{S}=2901 \mathrm{~m})$

Conformably overlies sandstone of unit 38. A muddy, decimetre bedded, slightly fractured siltstone. Unlike most previous units this one fines upwards into a mudstone. Grades into overlying unit.

$$
\begin{aligned}
& \text { W072 P, S (2841 m) } \\
& \text { W073 P, S (2894 m) }
\end{aligned}
$$

$40(\mathrm{U}=101 \mathrm{~m} ; \mathrm{S}=3007 \mathrm{~m})$

Gradational contact with underlying unit. A massive Siltstone. Base of unit is sandy and poorly sorted and grades into a well sorted siltstone at the top, with little or no fine content. Top of unit is a sharp contact.

$$
\begin{aligned}
& \text { W074 S (3007 m) } \\
& \text { W075 P (3007 m) }
\end{aligned}
$$

41 (U = $12 \mathrm{~m} ; \mathrm{S}=3019 \mathrm{~m})$

Conformably overlies siltstone unit. A massive, well sorted micaceous, brown weathered sandstone. Unit contains a 1 $\mathrm{m}$ thick, fine grained laminated, lignitic, siltstone $2 \mathrm{~m}$ above its base. Top of unit is a sharp contact.

$$
\begin{aligned}
& \text { W076 S (3009 m) } \\
& \text { W077 S (3010 m) }
\end{aligned}
$$

$42(\mathrm{U}=11 \mathrm{~m} ; \mathrm{S}=3030 \mathrm{~m})$
Conformably overlies Sandstone of Unit 41. A fine grained, laminated, weathered Siltstone. Top of unit is sharp contact.

\section{$43(\mathrm{U}=\mathbf{5 0} \mathrm{m} ; \mathrm{S}=\mathbf{3 0 8 0} \mathrm{m})$}

Conformably overlies unit 42 . A massive well sorted micaceous, brown weathered sandstone. Unit contains various mudstone horizons, all are less than $1 \mathrm{~m}$ thick. Occasional valves of Crassostrea are found in sandier horizons. Top of unit is a sharp contact.

$44(\mathrm{U}=111 \mathrm{~m} ; \mathrm{S}=3191 \mathrm{~m})$

Conformably overlies sandstone. Massive, slightly silty, fractured, Mudstone, grades over entire unit into massive well sorted, weathered brown, medium grained, very poorly consolidated sandstone. Base of unit contains abundant foraminifera. Top of unit is a sharp contact.

$$
\begin{aligned}
& \text { W078 S (3090 m) } \\
& \text { W079 P (3090 m) } \\
& \text { W080 P, S (3119 m) } \\
& \text { W081 P, S (3119 m) } \\
& \text { W082 S (3157 m) }
\end{aligned}
$$

$45(\mathrm{U}=30 \mathrm{~m} ; \mathrm{S}=3221 \mathrm{~m})$

Conformably overlies sandstone of unit 44. A variable unit of interbedded sandstones and silty mudstones. Sandstone bands contain thin muddy horizons and are 4 to $5 \mathrm{~m}$ thick, well sorted yellow brown weathered micaceous sands. Mudstones are less than $1 \mathrm{~m}$ thick and 30 to $40 \mathrm{~cm}$ bedded with abundant foraminifera. Contacts between sandy and muddy horizons are gradational, generally over 5 to $30 \mathrm{~cm}$. 
Towards the top of the unit mudstone horizons become more dominant over sandstone horizons. Unit on average fines upwards. Muddier horizons contain occasional Pelicaria sp. and Tawera sp. Top of unit is a distinct contact with overlying sandstone.

W083 S (3194 m)

W084 P (3194 m)

W085 S (3204 m)

$46(\mathrm{U}=130 \mathrm{~m} ; \mathrm{S}=3351 \mathrm{~m})$

Conformably overlies siltstone of unit 45. A massive, well sorted, brown micaceous sandstone, with faint muddy horizons. Unit coarsens upwards slightly throughout entire thickness. Upper part of unit contains a $5 \mathrm{~m}$ thick mudstone band, $7 \mathrm{~m}$ below the top. Top of unit is a sharp contact.

$$
\begin{aligned}
& \text { W086 P, S (3222 m) } \\
& \text { W087 S (3322 m) } \\
& \text { W088 S (3345 m) } \\
& \text { W088 P (3345 m) } \\
& \text { W089 S (3345 m) } \\
& \text { W090 S (3349 m) }
\end{aligned}
$$

$$
47(\mathrm{U}=\mathbf{1 3 6} \mathrm{m} ; \mathrm{S}=\mathbf{3 4 8 7} \mathrm{m})
$$

Conformably overlies sandstone of unit 46. Muddy, jointed and fractured Siltstone. Unit coarsens throughout thickness and the top of unit contains thin interbeds of muddy sandstone. Sandstone horizons have Crassostrea ingens in growth position. Top of unit is a sharp contact with overlying mudstone.

$$
\begin{aligned}
& \text { W091 P, S (3373 m) } \\
& \text { W092 S (3440 m) } \\
& \text { W093 P, S (3440 m) } \\
& \text { W094 S (3463 m) }
\end{aligned}
$$

W095 P (3463 m)

W096 S (3482 m)

48 (U = $5 \mathrm{~m}$; $\mathrm{S}=3492 \mathrm{~m})$

Conformably overlies muddy sandstone horizon of unit 47. A very muddy fine sandstone. Top of unit is a sharp contact with overlying sandstone.

\section{9 (U = $64 \mathrm{~m} ; \mathrm{S}=3556 \mathrm{~m})$}

Conformably overlies unit 48. A massive, muddy, medium fossiliferous sandstone, silty and blue grey at its base, coarsening upwards into yellow weathered moderately concretionary sandstone, with a few thin finer grained horizons. Sandstones are concretionary with concretions in bands and up to $1 \mathrm{~m}$ in diameter. Unit contains Crassostrea, Pelicaria, Phialopecten and Chlamys species. Top of unit grades into overlying sandstone.

$$
\begin{aligned}
& \text { W097 P, S (3493 m) } \\
& \text { W098 S (3495 m) } \\
& \text { W099 S (3523 m) } \\
& \text { W100 P, S (3523 m) } \\
& \text { W101 P, S (3526 m) } \\
& \text { W102 S (3541 m) } \\
& \text { W103 S (3546 m) } \\
& \text { W104 P, S (3550 m) }
\end{aligned}
$$

$50(\mathrm{U}=46 \mathrm{~m} ; \mathrm{S}=3602 \mathrm{~m})$

Gradational contact with underlying sandstone. A massive, well sorted, concretionary, medium coarse sandstone. Sand is cross bedded in places and contains occasional blue silty horizons. Sands towards the base of the unit are yellow and preferentially concretionary. Fossiliferous sandy 
horizons are common. The top 10 metres of unit fines upwards into a muddy fine grained sandstone, the very top of which is strongly bioturbated.

\section{$51(\mathrm{U}=12 \mathrm{~m} ; \mathrm{S}=3614 \mathrm{~m})$}

Unconformably overlies bioturbated muddy sandstone of unit 50 . A blue grey predominantly fine grained sandy mudstone unit. General nature is alternating siltstones and fine sandstones. Sandstones are generally concretionary. Top of unit is strongly bioturbated and burrowed.

$52(\mathrm{U}=38 \mathrm{~m} ; \mathrm{S}=3652 \mathrm{~m})$

Unconformably overlies burrowed mudstone of unit 51. A prominent brown, micaceous medium coarse grained, massive, well sorted, muddy, sandstone. Unit has loaded base and is general highly concretionary. Top of unit fines and grades into overlying sandstone.

\section{3 ( $\mathrm{U}=6 \mathrm{~m} ; \mathrm{S}=3658 \mathrm{~m})$}

Gradational contact with underlying sandstone. A very muddy, fine grained, massive, blue sandstone. Unit fines upwards into a mudstone. Top of unit is a bored and scoured surface.

$$
\begin{aligned}
& \text { W105 S (3653 m) } \\
& \text { W106 P, S (3653 m) }
\end{aligned}
$$

\section{4 ( $\mathrm{U}=143 \mathrm{~m} ; \mathrm{S}=3801 \mathrm{~m})$}

Unconformably overlies unit 53. A massive, muddy, blue grey, yellow weathering, moderately concretionary, medium grained sandstone, with fine grained horizons. Top of unit is a sharp contact.
W107 P, S (3695 m)

$$
55(\mathrm{U}=\mathbf{2 4 9} \mathrm{m} ; \mathrm{S}=4050 \mathrm{~m})
$$

Conformably overlies sandstone of unit 54. A muddy, blue siltstone. Unit is occasionally faintly bedded and grades from no sand at base, to quite sandy at its top. Within siltstone sandy and less sandy layers alternate in a cyclic fashion. Unit is generally fossiliferous including amongst others Chlamys and Pelicaria species. Top of unit is a sharp contact.

$$
\begin{aligned}
& \text { W108 P, S (3841 m) } \\
& \text { W109 S (3941 m) } \\
& \text { W110 P, S (3941 m) } \\
& \text { W111 P, S (3989 m) }
\end{aligned}
$$

$$
56(\mathrm{U}=24 \mathrm{~m} ; \mathrm{S}=4074 \mathrm{~m})
$$

Conformably overlies sandy siltstone of unit 55. A restricted soft, yellow, well sorted, coarse to medium grained micaceous quartz sandstone. Unit contains occasional muddy horizons. It is occasionally trough cross bedded within gritty horizons and bioturbated in finer horizons. Top of unit is bioturbated and scoured with 30 to $40 \mathrm{~cm}$ of topography.

\section{$57(\mathrm{U}=\mathbf{2 2} \mathrm{m} ; \mathrm{S}=\mathbf{4 0 9 6} \mathrm{m})$}

Unconformably overlies sandstone of unit 56. Base of unit is a medium coarse grained, calcareous sandstone. It is reef forming with abundant crassostrea both reworked and in growth position. Unit grades into muddy, fine grained sandstone with abundant Stiracolpus.. Top of unit is gradational over $1 \mathrm{~m}$.

$$
\begin{aligned}
& \text { W112 S (4088 m) } \\
& \text { W113 P, S (1093 m) }
\end{aligned}
$$


$58(\mathrm{U}=\mathbf{2 8} \mathrm{m} ; \mathrm{S}=\mathbf{4 1 2 4} \mathrm{m})$

Gradational contact with underlying sandstone. Unit is a slightly sandy, fossiliferous mudstone. contains Chlamys gemulata, Phialopecten triphooki, Venericardia purpurata, Maoricardium spatiosum. Top of unit grades into Crassostrea shell bed of overlying unit over $40 \mathrm{~cm}$.

$$
\begin{aligned}
& \text { W114 S (4116 m) } \\
& \text { W115 S (4116 m) } \\
& \text { W116 P, S (4118 m) } \\
& \text { W117 P, S (4123 m) }
\end{aligned}
$$

\section{$59(\mathrm{U}=42 \mathrm{~m} ; \mathrm{S}=4166 \mathrm{~m})$}

Gradational contact with underlying mudstone. A variable, sandy, muddy, fossiliferous siltstone. Base of unit (4124 - $4134 \mathrm{~m}$ ) is a $10 \mathrm{~m}$ thick shell bed. Concretions of Crassostrea are common, and in many places a variety of mollusc shells are densely packed in a muddy, sandy matrix. Molluscs include Baryspira novaezelandiae, Crassostrea ingens, Chlamys Gemulata and Venericadia purpurata. Top of unit grades into overlying siltstone.

$60(\mathrm{U}=82 \mathrm{~m} ; \mathrm{S}=\mathbf{4 2 4 8} \mathrm{m})$

Gradational contact with underlying shell bed. A slightly sandy, muddy siltstone. Unit fines upwards into a light blue-grey, intensely bioturbated, fossiliferous siltstone. Common fossils include Crassostrea ingens and Tawera subsulcata. Top of unit is a bioturbated and scoured surface, with about $10 \mathrm{~cm}$ of topography.

$$
\text { W118 P, S (4167 m) }
$$

W119 S (4212 m)
W120 S (4219 m)

$$
61(\mathrm{U}=3 \mathrm{~m} ; \mathrm{S}=4251 \mathrm{~m})
$$

Unconformably overlying siltstone of unit 60. A coarse grained, fossiliferous rudstone. Unit contains abundant worn valves and broken shell fragments. It is greater than $30 \%$ calcite cement and a weathered grey brown colour. A reef forming unit. Top of unit grades into sandstone over $50 \mathrm{~cm}$.

$$
\begin{aligned}
& \text { W121 S (4249 m) } \\
& \text { W122 S (4250 m) }
\end{aligned}
$$

\section{$62(\mathrm{U}=29 \mathrm{~m} ; \mathrm{S}=4280 \mathrm{~m})$}

Gradational contact with underlying shell bed. A coarse grained, bioturbated, yellow-brownish, rusty coloured well sorted sandstone. Cross bedded in part, with abundant scattered worn fossils. Unit grades through silty fine sandstone into a siltstone. most of the unit contains occasional shell lags. Top of unit is scoured with about $20 \mathrm{~cm}$ of topography.

$$
\text { W123 P, S (4278 m) }
$$$$
\text { W124 S (4280 m) }
$$

$$
63(\mathrm{U}=3 \mathrm{~m} ; \mathrm{S}=4283 \mathrm{~m})
$$

Unconformably overlies siltstone of unit 62. A muddy hard, calcareous sandstone. A reef forming unit of a closely packed accumulation of broken and whole shells, including some in situ occurrences. Commonly occurring species include; Barbatia novaezelandiae, Chlamys Gemulata, Chlamys Delicatula, Venericardia purpurata, Dosinia greyi, Tawera subsulcata, Dosinula zelandica, Pullastra sp. Top of unit is scoured with 
$10 \mathrm{~cm}$ of topography and is also rarely bored.

$64(\mathrm{U}=>36 \mathrm{~m} ; \mathrm{S}=>4316 \mathrm{~m})$

Unconformably overlies shell bed of unit 63. A fine, non-fossiliferous, dark grey, sandy siltstone. Base of unit is alternating centimetre to 10 centimetre streaky and bioturbated siltstone. Top of unit is not seen.

\section{A3.2 Hautawa Road Section;}

The main purpose of this section was to clarify the stratigraphic succession at the top of the Wanganui River sequence. Much of this sequence is very weathered in the Wanganui River and is exposed in slips and farm tracks, because of the flatter farm land around Parakino. It was also very important to achieve better palaeomagnetic control than the very weathered material of the Wanganui section provided towards its top.

$\mathbf{1}(\mathrm{U}=\mathbf{3} \mathrm{m} ; \mathrm{S}=\mathbf{0} \mathrm{m})$

Base of unit not seen. Top $5 \mathrm{~m}$ of unit is a sandy, muddy, siltstone. Unit is gradational, there is certainly coarser sand material beneath here. Unit becomes much more silty towards top. Top of unit is a scoured surface with burrowing preserved in places. laminated. Mudstone horizons $1-5 \mathrm{~m}$ in thickness are common. Base of unit is loaded and contains rip up siltstone clasts. Unit becomes finer grained over top $15 \mathrm{~m}$ and grades into overlying shell bed.

$$
\text { H126 P, S (28 m) }
$$

\section{$3(\mathrm{U}=6 \mathrm{~m} ; \mathrm{S}=66 \mathrm{~m})$}

Gradational contact with underlying fine sandstone. A shell bed consisting of scattered worn and reworked shells in a fine sandy, silty matrix. Matrix fines upwards into a sandy siltstone, which is laminated in places. Species include, amongst others; Chlamys Crassostrea, Dosinula, Alcithoe, and Baryspira. Top of unit grades into overlying siltstone.

\section{$4(\mathrm{U}=58 \mathrm{~m} ; \mathrm{S}=124 \mathrm{~m})$}

Gradational contact with underlying shell bed. A blue grey, slightly muddy, sandy, siltstone. Baryspira sp. Top of unit coarsens rapidly over a $10 \mathrm{~m}$ into a slightly muddy, medium-fine grained, weathered, fine sandstone. Top of unit is a sharp contact with $10 \mathrm{~cm}$ of topography.

$$
\begin{aligned}
& \text { H127 P, S (94 m) } \\
& \text { H128 P, S (103 m) } \\
& \text { H129 P, S (118 m) } \\
& \text { H130 P, S (123 m) }
\end{aligned}
$$


and Dentalium marwicki. Unit has a sharp top contact.

$6(\mathrm{U}=31 \mathrm{~m} ; \mathrm{S}=>157 \mathrm{~m})$

Conformably overlies shell bed of unit 5 . A browney grey, slightly sandy, muddy siltstone, massive to decimetre bedded with few fossils. Top contact not seen.

$$
\text { H131 P, S (130 m) }
$$$$
\text { H132 P, S (137 m) }
$$$$
\text { H133 P, S (157 m) }
$$

\section{A3.3 Rangitikei River Section;}

This was not described in any more detail than is given in chapter 11 (Stratigraphy of the South Wanganui Basin sequences).

Palaeomagnetic and sediment sample heights (as metres above the base of the section) are listed below:

North Rangitikei River Section (North of the Rauoterangi Fault);

$\begin{array}{ll}\text { R134 } & 0 \\ \text { R135 } & 18 \\ \text { R136 } & 97 \\ \text { R137 } & 100 \\ \text { R138 } & 103 \\ \text { R139 } & 114 \\ \text { R140 } & 133 \\ \text { R141 } & 154 \\ \text { R142 } & 171 \\ \text { R143 } & 201 \\ \text { R144 } & 284 \\ \text { R145 } & 348 \\ \text { R146 } & 401 \\ \text { R147 } & 411 \\ \text { R148 } & 458 \\ \text { R149 } & 486\end{array}$

$\begin{array}{ll}\text { R150 } & 577 \\ \text { R150a } & 605 \\ \text { R150b } & 618\end{array}$

South Rangitikei River Section (South of the Rauoterangi fault);

$\begin{array}{ll}\text { R151 } & 0 \\ \text { R152 } & 67 \\ \text { R153 } & 108 \\ \text { R154 } & 144 \\ \text { R155 } & 153 \\ \text { R156 } & 166 \\ \text { R157 } & 170 \\ \text { R158 } & 179 \\ \text { R159 } & 194 \\ \text { R160 } & 221 \\ \text { R161 } & 249 \\ \text { R162 } & 323 \\ \text { R163 } & 421 \\ \text { R164 } & 455 \\ \text { R165 } & 489 \\ \text { R166 } & 538 \\ \text { R167 } & 653 \\ \text { R168 } & 729 \\ \text { R169 } & 780 \\ \text { R170 } & 792 \\ \text { R171 } & 897 \\ \text { R172 } & 963 \\ \text { R173 } & 1024 \\ \text { R174 } & 1048 \\ \text { R175 } & 1087 \\ \text { R176 } & 1100 \\ \text { R177 } & 1168 \\ \text { R178 } & 1211 \\ \text { R179 } & 1262 \\ \text { R180 } & 1303 \\ \text { R181 } & 1305 \\ \text { R182 } & 1327 \\ \text { R183 } & 1331\end{array}$




$\begin{array}{ll}\text { R184 } & 1331 \\ \text { R185 } & 1342 \\ \text { R186 } & 1350 \\ \text { R187 } & 1358 \\ \text { R188 } & 1359 \\ \text { R189 } & 1362 \\ \text { R190 } & 1377 \\ \text { R191 } & 1381 \\ \text { R192 } & 1397 \\ \text { R193 } & 1406 \\ \text { R194 } & 1407 \\ \text { R195 } & 1415 \\ \text { R196 } & 1417 \\ \text { R197 } & 1419 \\ \text { R198 } & 1434\end{array}$


390 


\section{Appendix - 4 Grain-size analyses}

All analyses were carried out in the Sedimentology Laboratory, Research School of Earth Sciences, Victoria University of Wellington. Three data sets are presented here: 1) analyses from the CIROS-2 drill-core, 2) analyses from the south Wanganui Basin strata, and 3) analyses from the present sea floor of the Wanganui Bight. Each data set is followed by a summary table of standard sedimentological statistical analyses. The procedure for analysis is given in detail in Barrett and Brooker (1989) and is summarised here, as relevant to the present study:

Several steps of preparation and analysis were necessary for the samples, but not all samples required all stages of preparation or analysis. The separate steps are described here as they were carried out in the laboratory. Every sample was dried and weighed before any preparation or analysis was undertaken.

\section{Step-1; Removal of Salts}

Samples were generally unconsolidated to begin with, but some samples were slightly cemented with carbonate cement. Samples containing an appreciable amount of carbonate were subjected directly to step- 2 or step- 3 of the analysis procedure. All samples were dried and weighed, then for those samples necessary salt was removed by heating the sample in deionised water on a water bath at $90^{\circ} \mathrm{C}$, standing the sample overnight and then discarding the saline solution. The sample was then dried and reweighed.

\section{Step-2; Removal of organic matter}

Very few samples contained organic matter. For samples that did contain organic matter, this was removed by adding a small amount of hydrogen peroxide to the samples and then heating them, to near boiling point, in deionised water on a water-bath. The sample was then left to digest until frothing ceased, then washed, dried and reweighed.

\section{Step-3; Removal of carbonate}

Carbonates were removed from samples simply by adding diluted hydrochloric acid, until any reaction incurred ceased. Then the sample was washed in deionised water, dried and reweighed. 


\section{Step-4; Wet sieving}

Each sample was wet sieved by passing through a 60 micron nylon mesh, the coarse fraction was dried, weighed and retained for dry sieve analysis. The suspended fine fraction was centrifuged, dried, weighed and retained for sedigraph analysis.

\section{Step-5; Dry sieving}

Each sample was sieved on a Fritsch shaker using a half phi sieve stack, from -4 to 4 phi, for 18 minutes using both intermittent and micro shaking modes. Each sieve fraction was then weighed and the weight recorded on a standard VUW grain-size data sheet. The pan fraction was retained to add to the fine fraction from the wet sieving.

\section{Step-6; Sedigraph analysis}

A 2 gram split of the fine fraction was disaggregated in $40 \mathrm{ml}$ of 1 gram per litre calgon solution for 5-10 minutes in the ultrasonic tank and then analysed using a Sedigraph 5100. The procedure of analysis is outlined in Barrett and Brooker (1989). Settling velocity results are automatically converted to phi size data by the sedigraph 5100 and printed out in tabular and graphic forms. This information was converted to percentage of total fine fraction data and entered on the VUW grain-size data sheet.

\section{Step-7; Statistical analysis of grain-size data}

This was done using the SIZE program for IBM PC. Mass precent data was entered into half phi size classes as required by each sample analysis. A file was then created using specified class limits, specified class midpoints, the number of classes, and specific midpoints for the two endmember class ranges. The SIZE program produced an analysis of weight percent data for each sample and a summary table including percentiles $(1,5,16$, $25,50,75,84,95)$ and folk and moment measures (mean, standard deviation, skewness and kurtosis). Both raw data and statistical summary tables are presented in this appendix. 
VUW PROGRAM FOR GRAIN SIZE ANALYSIS WRITTEN BY P BARRETT AND J ADAMS. FOR DETAILS OF DATA ENTRY, FOR EXAMPLES OF DATA INPUT STYLE OR FOR ANY OTHER ASPECTS OF RINNIMG THE PROGRAM READ THE FILE "SIZE LIST".

OCLASS MIDPTS-1.75-1.25 $-.75 \quad-.25 \quad .25 \quad .75 \quad 1.25 \quad 1.75 \quad 2.25 \quad 2.75 \quad 3.25 \quad 3.75 \quad 4.25 \quad 4.75 \quad 5,25 \quad 5.75 \quad 6.25 \quad 6.75 \quad 7.25 \quad 7.75 \quad 8.25 \quad 8.75 \quad 9.25 \quad 9.75$ OCLASS MIDPTS15.00

CLASS LIMITS-1.50-1.00 -.50 $.00 \quad .50 \quad 1.00 \quad 1.50 \quad 2.00 \quad 2.50 \quad 3.00 \quad 3.50 \quad 4.00 .4 .50 \quad 5.00 \quad 5.50 \quad 6.00 \quad 6.50 \quad 7.00 \quad 7.50 \quad 8.00 \quad 8,50 \quad 9.00 \quad 8.5010 .00$ OSAMPLES COLLECTED 13-14 JULY FROM CIROS-2 CORE

GW 32.02

$\begin{array}{llllllllllllllllllllllllllll}\text { DATA } & .25 & .15 & .04 & .09 & .08 & .16 & .22 & .41 & .44 & .95 & 1.55 & 2.16 & 2.00 & 1.23 & .54 & .85 & .67 & .63 & .60 & .57 & .56 & .35 & .57 & .43\end{array}$

$\begin{array}{lllllllllllllllllllllllllllll}\text { FREQUENCY } & 1 & 1.3 & .8 & .2 & .5 & .4 & .9 & 1.2 & 2.2 & 2.4 & 5.1 & 8.3 & 11.6 & 10.7 & 6.6 & 2.9 & 4.6 & 3.6 & 3.4 & 3.2 & 3.1 & 3.0 & 1.9 & 3.1 & 2.3\end{array}$ FREQUENCY ₹ 16.8

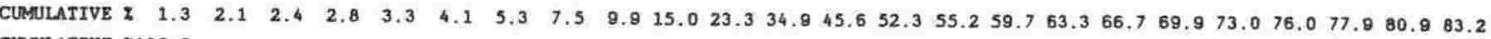
CUMULATIVE z100.0

GRAVEL $=2.15$ SAND $=32.76$ SILT $=38.08$ CLAY $=27.01$

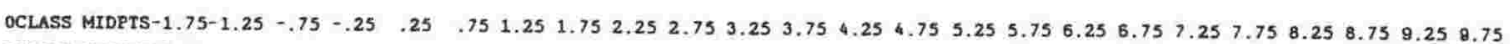
OCLASS MIDPTS15.00

CLASS LIMITS-1.50-1.00-.50 $.00 \quad .501 .001 .50 \quad 2.00 \quad 2.50 \quad 3.00 \quad 3.50 \quad 4.00 \quad 4.50 \quad 5.00 \quad 5.50 \quad 6.00 \quad 6.50 \quad 7.00 \quad 7.50 \quad 8.00 \quad 8.50 \quad 8.00 \quad 8.5010 .00$ GW 50.46

$\begin{array}{llllllllllllllllllllllllllllll}\text { DATA } & .00 & .00 & .00 & .00 & .00 & .00 & .01 & .01 & .01 & .02 & .06 & .44 & 1.65 & .86 & .47 & .77 & 1.01 & 1.05 & 1.06 & 1.02 & .82 & .64 & .51 & .53\end{array}$

$\begin{array}{llllllllllllllllllllllllllllllll}\text { FREQUENCY \& } & .0 & .0 & .0 & .0 & .0 & .0 & .1 & .1 & .1 & .1 & .4 & 3.0 & 11.3 & 5.9 & 3.2 & 5.3 & 6.9 & 7.2 & 7.2 & 7.0 & 5.6 & 4.4 & 3.5 & 3.6\end{array}$

FREQUENCY $\approx 25.3$

$\begin{array}{lllllllllllllllllllllllll}\text { CUMULATIVE } 2 & .0 & .0 & .0 & .0 & .0 & .0 & .1 & .1 & .2 & .3 & .8 & 3.8 & 15.0 & 20.9 & 24.1 & 29.4 & 36.3 & 43.4 & 50.7 & 57.7 & 53.3 & 67.6 & 71.1 & 74.7\end{array}$ CUMULATIVE 2100.0

GRAVEL $=.00$ SAND $=3.76$ SILT $=53.89$ CLAY $=42.35$

GW 57.05

$\begin{array}{lllllllllllllllllllllllllll}\text { DATA } & .12 & .01 & .03 & .05 & .12 & .21 & .31 & .72 & .81 & 1.28 & 1.07 & .73 & 1.20 & .56 & .02 & .10 & .34 & .20 & .58 & .76 & .97 & .92 & 1.01 & .50\end{array}$ $\begin{array}{lllllllllllllllllllllllllllll}\text { EREQUENCY } X & .4 & .0 & .1 & .2 & .4 & .8 & 1.1 & 2.7 & 3.0 & 4.7 & 4.0 & 2.7 & 4.4 & 2.1 & .1 & .4 & 1.3 & .7 & 2.1 & 2.8 & 3.6 & 3.4 & 3.7 & 1.8\end{array}$ FREQUENCY \& 53.3

$\begin{array}{lllllllllllllllllllllllllllll}\text { CUMULATIVE } 2 & .4 & .5 & .6 & .8 & 1.2 & 2.0 & 3.1 & 5.8 & 8.8 & 13.5 & 17.5 & 20.2 & 24.5 & 26.7 & 26.8 & 27.1 & 28.4 & 29.1 & 31.3 & 34.1 & 37.7 & 41.1 & 46.8 & 46.7\end{array}$ CUMULATIVE 2100.0

GRAVEL $=.48$ SAND $=19.70 \mathrm{SILI}=13.90 \mathrm{CLAY}=65.81$

GW 80.81

$\begin{array}{lllllllllllllllllllllllll}\text { DATA } & .00 & .00 & .09 & .04 & .06 & .09 & .10 & .17 & .14 & .18 & .22 & .25 & .36 & .18 & .10 & .14 & .18 & .19 & .50 & .43 & .36 & .36 & .44 & .40\end{array}$

$\begin{array}{lllllllllllllllllllllllllllll}\text { FREQUENCY } 2 & .0 & .0 & .9 & .4 & .6 & .8 & 1.0 & 1.7 & 1.4 & 1.8 & 2.2 & 2.5 & 3.6 & 1.8 & 1.0 & 1.4 & 1.8 & 1.9 & 4.9 & 4.2 & 3.6 & 3.6 & 4.3 & 4.0\end{array}$ FRBQUENCY \& 50.8

$\begin{array}{llllllllllllllllllllllllllllll}\text { CUMULATIVE Z } & .0 & .0 & .9 & 1.3 & 1.9 & 2.8 & 3.8 & 5.4 & 6.8 & 8.6 & 10.8 & 13.2 & 16.8 & 18.5 & 19.6 & 20.9 & 22.7 & 24.6 & 29.3 & 33.8 & 37.4 & 40.9 & 45.3 & 49.2\end{array}$ CUMULATIVE ₹100.0

GRAVEL $=.00$ SAND $=13.24$ SILT $=20.55$ CLAY $=66.21$

GW 98.83

$\begin{array}{llllllllllllllllllllllllll}\text { DATA } & .00 & .00 & .00 & 00 & .00 & .00 & .00 & .01 & .01 & .02 & .02 & .02 & .02 & .03 & .08 & .08 & .06 & .16 & .30 & .43 & .58 & .57 & .67 & .71\end{array}$

$\begin{array}{llllllllllllllllllllllllllllll}\text { FREQUENCY I } & .0 & .0 & .0 & .0 & .0 & .0 & .0 & .1 & .1 & .2 & .2 & .2 & .2 & .3 & .8 & .8 & .6 & 1.6 & 3.0 & 4.3 & 5.7 & 5.6 & 6.6 & 7.0\end{array}$

FREQUENCY \& 62.7

$\begin{array}{lllllllllllllllllllllllllll}\text { CUMULATIVE } \mathrm{z} & .0 & .0 & .0 & .0 & .0 & .0 & .0 & .1 & .2 & .4 & .6 & .8 & 1.0 & 1.3 & 2.1 & 2.8 & 3.5 & 5.0 & 8.0 & 12.3 & 18.0 & 23.7 & 30.3 & 37.3\end{array}$ CUMULATIVE $: 100,0$

GRAVEL $=.00$ SAND $=.79$ SILT $=11.49$ CLAY $=87.72$

GW 139.10

$\begin{array}{llllllllllllllllllllllllllll}\text { DATA } & .00 & .00 & .00 & .00 & .00 & .01 & .01 & .02 & .01 & .04 & .06 & .10 & .19 & .10 & .06 & .38 & .43 & .45 & .47 & 1.00 & .90 & .85 & 1.15 & 1.45\end{array}$

$\begin{array}{llllllllllllllllllllllllllllll}\text { FREQUENCY } 2 & .0 & .0 & .0 & .0 & .0 & .0 & .0 & .1 & 0 & .2 & .3 & .5 & .9 & .5 & .3 & 1.7 & 2.0 & 2.1 & 2.1 & 4.6 & 4.1 & 3.9 & 5.2 & 6.6\end{array}$

FREQUENCY $₹ 64.9$

$\begin{array}{lllllllllllllllllllllllllll}\text { CUIULATIVE } 2 & .0 & .0 & .0 & .0 & .0 & .0 & .1 & .2 & .2 & .4 & .7 & 1.1 & 2.0 & 2.5 & 2.7 & 4.5 & 6.4 & 8.5 & 10.6 & 15.2 & 19.3 & 23.2 & 28.4 & 35.1\end{array}$ CUMULATIVE $\$ 100.0$

GRAVEL $=.00$ SAND $=1.14$ SILT -14.06 CLAY -84.80 


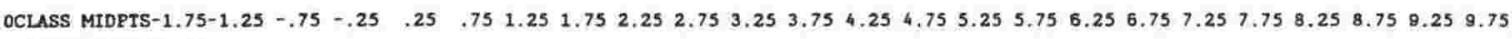
OCLASS MIDPTS 15.00

CLASS LIMITS-1.50-1.00 - $.50 \quad .00 \quad .501 .00 \quad 1.50 \quad 2.00 \quad 2.50 \quad 3.00 \quad 3.50 \quad 4.00 \quad 4.50 \quad 5.00 \quad 5.50 \quad 6.00 \quad 6.50 \quad 7.00 \quad 7.50 \quad 8.00 \quad 8.50 \quad 9.00 \quad 9.5010 .00$

GW 151.79

$\begin{array}{lllllllllllllllllllllllll}\text { DATA } & .00 & .00 & .00 & .00 & .00 & .00 & .01 & .02 & .01 & .01 & .02 & .11 & .07 & .11 & .08 & .18 & .25 & .25 & .27 & .32 & .19 & .23 & .25 & .22\end{array}$

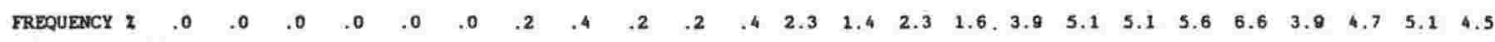

FREQUENCY ₹ 46,3

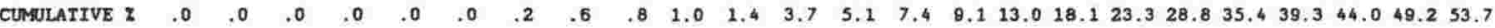
CUMULATIVE 2100.0

GRAVEL $=.00$ SAND $=3.70$ SILT $=31.69$ CLAY $=64.61$

GW 155.63

$\begin{array}{lllllllllllllllllllllllll}\text { DATA } & .00 & .00 & .00 & .00 & .01 & .01 & .02 & .06 & .10 & .27 & .48 & .64 & .69 & .52 & .14 & .35 & .33 & .52 & .52 & .70 & .81 & .48 & .55 & .56\end{array}$

$\begin{array}{llllllllllllllllllllllllllll}\text { EREQUEHCY } 2 & .0 & .0 & .0 & .0 & .1 & .1 & .2 & .5 & .9 & 2.5 & 4.4 & 5.9 & 6.3 & 4.8 & 1.3 & 3.2 & 3.0 & 4.8 & 4.8 & 6.4 & 7.4 & 4.5 & 5.0 & 5.1\end{array}$

FREQUENCY $\ 28.8$

CUMULATIVE \& .0

CUMLATIVE 2100,0

$\begin{array}{lllllllllllllllllllllllllllllllll}0 & 0 & 0 & 0 & .1 & .2 & .4 & 9 & 1.8 & 4.3 & 8.7 & 14.6 & 20.9 & 25.7 & 26.9 & 30.2 & 33.2 & 37.9 & 42.7 & 49.1 & 56.6 & 61.0 & 66.1 & 71.2\end{array}$

GRAVEL $=.00$ SAND $=14.57$ SILT $=34.56$ CLAY $=50.87$

GW 32.02

GW 50.46

GW 57.95

GW 80.81

CW 98.83

GW 139.10

GW 251.78

GW 165.63

\section{FOLK MEASURES MOMENT MEASURES}

$\begin{array}{llllllllll}1 & 5 & 16 & 25 & 50 & 75 & 84 & 95 & \text { MEAN SDEV SKEW KURT MEAN SDEV SKEW KURT GRVL SAND SILI CLAY }\end{array}$

$\begin{array}{lllllllllllllllllll}-1.8 & 1.4 & 3.1 & 3.6 & 4.8 & 8.310 .213 .9 & 6.02 & 3.67 & .48 & 1.08 & 6.47 & 4.42 & .87 & 2.80 & 2.1 & 32.8 & 38.1 & 27.0\end{array}$

$\begin{array}{lllllllllllllllll}3.6 & 4.1 & 4.6 & 5.6 & 7.510 .011 .514 .5 & 7.85 & 3.30 & .26 & .86 & 8.65 & 4.00 & .66 & 1.98 & .0 & 3.8 & 53.8 & 42.3\end{array}$

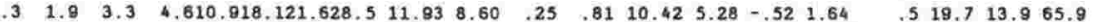

$\begin{array}{lllllllllllllllll}-.3 & 1.9 & 4.4 & 7.010 .113 .515 .118 .4 & 0.87 & 5.18 & -.03 & 1.05 & 10.59 & 4.91 & -.54 & 1.87 & .0 & 13.2 & 20.6 & 66.2\end{array}$

$\begin{array}{lllllllllllllllll}4.5 & 7.0 & 8.3 & 9.110 .812 .613 .415 .1 & 10.87 & 2.50 & .03 & .96 & 12.49 & 3.37 & -.77 & 2.04 & .0 & .8 & 11.5 & 87.7\end{array}$

$\begin{array}{llllllllllllllllll}3.8 & 6.1 & 8.1 & 9.211 .012 .813 .715 .5 & 10.95 & 2.81 & -.05 & 1.04 & 12.53 & 3.51 & -.91 & 2.31 & .0 & 1.1 & 14.1 & 84.8\end{array}$

$\begin{array}{lllllllllllllllll}2.9 & 4.5 & 6.3 & 7.2 & 8.612 .614 .016 .8 & 9.96 & 3.79 & .16 & .94 & 10.78 & 4.14 & -.17 & 1.46 & .0 & 3.7 & 31.7 & 64.6\end{array}$

$\begin{array}{llllllllllllllllll}2.1 & 3.1 & 4.1 & 4.9 & 8.110 .411 .513 .7 & 7.89 & 3.46 & .00 & .80 & 8.85 & 4.35 & .33 & 1.74 & .0 & 14.6 & 34.6 & 50.9\end{array}$ 
WUW PROGRAM FOR GRAIN SIZE ANALYSIS WRITTEN BY P BARRETT AND J ADAMS. FOR DETAILS OF DATA ENTRY, FOR EXAMPLES OF DATA INPUT STYLE OR FOR ANY OTHER ASPECTS OF RUNWING THE PROGRAM READ THE FILE "SIZE LIST".

OCLASS MIDPTS-3.25-2.75-2.25-1.75-1.25 - .75 -.25 $.25 \quad 75 \quad 1.25 \quad 1.75 \quad 2.25 \quad 2.75 \quad 3.25 \quad 3.75 \quad 4.25 \quad 4.75 \quad 5.25 \quad 5.75 \quad 6.25 \quad 6.75 \quad 7.25 \quad 7.75 \quad 8.25$ OCLASS MIDPTS 8.75 9.25 8.7515 .00

CLASS LIMITS-3.00-2.50-2.00-1.50-1.00 -.50 $.00 \quad .50 \quad 1.00 \quad 1.50 \quad 2.00 \quad 2.50 \quad 3.00 \quad 3.50 \quad 4.00 \quad 4.50 \quad 5.00 \quad 5.50 \quad 6.00 \quad 6.50 \quad 7.00 \quad 7.50 \quad 8.00 \quad 8.50$ CLASS LIMITS 9.009 .5010 .00 OW1-SAMPLES

พ001

$\begin{array}{llllllllllllllllllllllllllllll}\text { DATA } & .00 & .00 & .00 & .00 & .00 & .00 & .00 & .00 & .00 & .00 & .00 & .03 & 1.59 & 4.53 & 6.70 & .98 & 3.17 & 4.12 & 3.85 & 2.64 & 2.04 & 1.71 & 1.69 & .83\end{array}$ DATA .60 1.36

$\begin{array}{lllllllllllllllllllllllllllllllll}\text { FRPOUENCY } 2 & .0 & .0 & .0 & .0 & .0 & .0 & .0 & .0 & .0 & .0 & .0 & .1 & 4.2 & 12.0 & 17.8 & 2.6 & 8.4 & 11.0 & 10.2 & 7.0 & 5.4 & 4.5 & 4.5 & 2.2\end{array}$

FREQUESCY \& $1.92 .8 \quad 2.8 \quad 1.6 \quad 3.6$

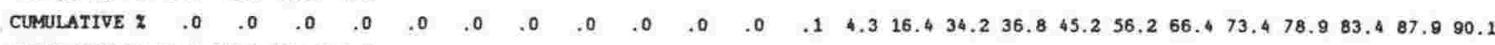
CUMULATIVE 292.094 .896 .4100 .0

GRAVEL $=.00$ SAND $=34.18$ SILT $=53.72$ CLAY $=12.10$

OCLASS MIDPTS-3.25-2.75-2.25-1.75-1.25 - $-75 \quad-.25 \quad .25 \quad .75 \quad 1.25 \quad 1.75 \quad 2.25 \quad 2.75 \quad 3.25 \quad 3.75 \quad 4.25 \quad 4.75 \quad 5.25 \quad 5.75 \quad 6.25 \quad 8.75 \quad 7.25 \quad 7.75 \quad 8.25$ OCLASS MIDPTS $8.75 \quad 9.25 \quad 9.7515 .00$

CLASS LIMITS-3.00-2.50-2.00-1.50-1.00 -.50 $.00 \quad .50 \quad 1.00 \quad 1.50 \quad 2.00 \quad 2.50 \quad 3.00 \quad 3.50 \quad 4.00 \quad 4.50 \quad 5.00 \quad 5.50 \quad 6.00 \quad 6.50 \quad 7.00 \quad 7.50 \quad 8.00 \quad 8.50$ CLASS LIMITS $9.00 \quad 0.5010 .00$

พ003

$\begin{array}{lllllllllllllllllllllllll}\text { DATA } & .00 & .00 & .00 & .00 & .00 & .00 & .00 & .01 & .01 & .03 & .29 & 2.4528 .0419 .25 & 5.85 & .09 & .33 & .67 & .93 & .97 & 1.31 & 1.50 & 1.58 & 1.20\end{array}$ DATA .791 .59

$\begin{array}{lllllllllllllllllllllllllll}\text { FREQUENCY } 2 & .0 & .0 & .0 & .0 & .0 & .0 & .0 & .0 & .0 & .0 & .4 & 3.6 & 40.8 & 28.0 & 8.5 & .1 & .5 & 1.0 & 1.4 & 1.4 & 1.9 & 2.2 & 2.3 & 1.7\end{array}$ FREQUENCY \& $1.4 \quad 1.1 \quad 1.2 \quad .0$

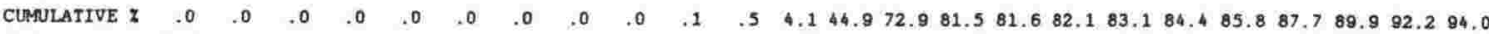
CUMULATIVE \& 95.496 .597 .7100 .0

GRAVEL $=.00$ SAND $=81.47$ SILT $=10.75$ CLAY $=7.78$

พ013

$\begin{array}{llllllllllllllllllllllllllllllllllllll}\text { DAIA } & .00 & .00 & .00 & .00 & .00 & .00 & .00 & .00 & .00 & .00 & .01 & .02 & .89 & 9.6117 .43 & 1.91 & 3.12 & 3.95 & 3.62 & 2.70 & 3.04 & 3.48 & 2.83 & 2.37\end{array}$ DATA 1.838 .24

$\begin{array}{llllllllllllllllllllllllllllll}\text { FREQUENCY } 2 & .0 & .0 & .0 & .0 & .0 & .0 & .0 & .0 & 0 & .0 & .0 & .0 & 1.3 & 13.8 & 25.1 & 2.7 & 4.5 & 5.7 & 5.2 & 3.9 & 4.4 & 5.0 & 4.1 & 3.4\end{array}$

FREQUEACY ₹ $\quad 3.4 \quad 3.0 \quad 2.6 \quad 11.9$

CUMULATIVE $z \quad .0 \quad .0 \quad .0 \quad .0$

CUMULATIVE ₹ 82.585 .588 .1100 .0

GRAVEL $=.00$ SAND $=40.22 \operatorname{SILT}=35.48 \mathrm{CLAY}=24.30$

พ016

$\begin{array}{llllllllllllllllllllllllllll}\text { DATA } & .00 & .00 & .00 & .00 & .00 & .02 & .06 & .07 & .03 & .01 & .02 & .4019 .4117 .45 & 7.70 & .27 & .81 & 1.44 & 1.50 & 1.70 & 1.56 & 1.48 & 1.41 & 1.01\end{array}$

DATA .813 .06

$\begin{array}{llllllllllllllllllllllllllllllll}\text { FREQUENCY } ~ & .0 & .0 & .0 & .0 & .0 & .0 & .1 & .1 & .0 & .0 & .0 & .6 & 31.4 & 28.2 & 12.5 & .4 & 1.3 & 2.3 & 2.4 & 2.7 & 2.5 & 2.4 & 2.3 & 1.6\end{array}$

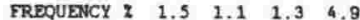

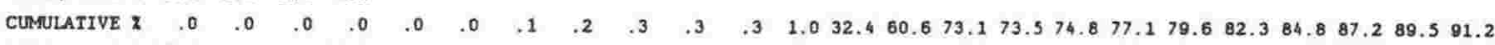
CUMULATIVE 292.793 .795 .1100 .0

GRAVEL $=.00$ SAND $=73.07$ SILT $=16.45$ CLAY $=10.48$

พ017

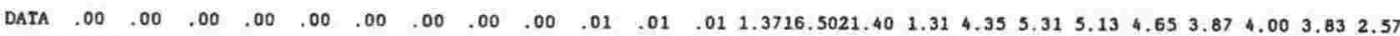
DATA $1.91 \quad 2.31$

$\begin{array}{llllllllllllllllllllllllllllll}\text { EREQUENCY } 2 & .0 & .0 & .0 & .0 & .0 & .0 & .0 & .0 & .0 & .0 & .0 & .0 & 1.7 & 19.9 & 25.9 & 1.6 & 5.3 & 6.4 & 6.2 & 5.6 & 4.7 & 4.8 & 4.6 & 3.1\end{array}$

$\begin{array}{llllll}\text { FREOUENCY } 2 & 2.6 & 2.5 & 2.3 & 2.8\end{array}$

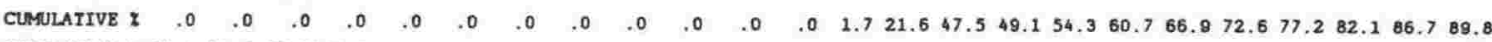
CUMULATIVE $\times 92.494 .897 .2100 .0$

GRAVEL $=.00$ SAND $=47.40$ SILI $=39.21$ CLAY $=13.30$

W018

$\begin{array}{lllllllllllllllllllllllllll}\text { DATA } & .00 & .00 & .00 & .00 & .00 & .00 & .00 & .00 & .00 & .00 & .01 & .01 & 1.18 & 5.48 & 5.79 & .91 & 2.63 & 2.94 & 2.94 & 2.78 & 2.29 & 2.34 & 2.16 & 1.64\end{array}$ DATA $1.01 \quad 1.87$

$\begin{array}{lllllllllllllllllllllllllllllll}\text { PREQUENCY \& } & .0 & .0 & .0 & .0 & .0 & .0 & .0 & 0 & .0 & .0 & .0 & .0 & 3.1 & 14.3 & 15.1 & 2.4 & 6.8 & 7.6 & 7.6 & 7.2 & 6.0 & 6.1 & 5.6 & 4.3\end{array}$ $\begin{array}{llllll}\text { FREQUENCY } ₹ & 3.8 & 2.6 & 2.6 & 4.9\end{array}$

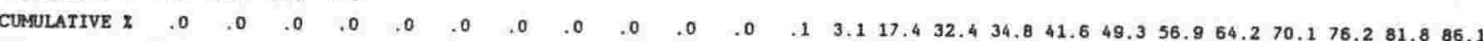
CUMULATIVE $\times 89.992 .595 .1100 .0$

GRAVEL $=.00$ SAND $=32.43$ SILT $=49.39 \mathrm{CLAY}=18.18$ 
OCLASS MIDPTS-3.25-2.75-2.25-1.75-1.25 - $-.75-.25 \quad 25 \quad .75 \quad 1.25 \quad 1.75 \quad 2.25 \quad 2.75 \quad 3.25 \quad 3.75 \quad 4.25 \quad 4.75 \quad 5.25 \quad 5.75 \quad 6.25 \quad 6.75 \quad 7.25 \quad 7.75 \quad 8.25$ OCLASS MIDPTS $8.759 .25 \quad 9.7515 .00$

CLASS LIMITS-3.00-2.50-2.00-1.50-1.00 -.50 .00 .50 1.00 1.50 2.00 2.50 3.00 3.50 4.00 4.50 5.00 $5.50 \quad 6.00 \quad 6.50 \quad 7.007 .50 \quad 8.00 \quad 8.50$ CLASS LIMITS 9.009 .5010 .00

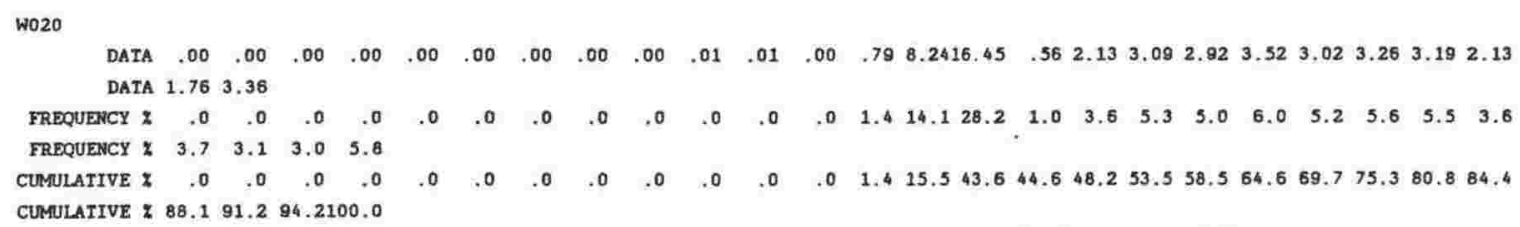

W024

$\begin{array}{lllllllllllllllllllllllllllll}\text { DATA } & .00 & .00 & .00 & .00 & .00 & .01 & .02 & .07 & .17 & .19 & .27 & 1.1617 .1211 .63 & 3.70 & .13 & 1.42 & 1.92 & 1.61 & 1.31 & 1.42 & 1.74 & 1.92 & 1.59\end{array}$ DATA $1.13 \quad 4.05$

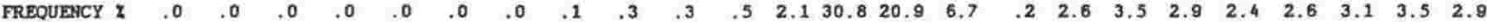
$\begin{array}{lllll}\text { FREQUENCY } ₹ \quad 3.0 & 2.5 & 2.0 & 7.3\end{array}$ CUMULATIVE $x$. CUMULATIVE 288.290 .792 .7100 .0

$\begin{array}{lllllllllllllllllllll}.0 & .0 & .1 & .2 & .5 & .8 & 1.3 & 3.4 & 34.2 & 55.1 & 61.7 & 62.0 & 64.5 & 68.0 & 70.9 & 73.2 & 75.8 & 78.9 & 82.3 & 85.2\end{array}$ GRAVEL $=.00$ SAND $=61.73$ SILT $=20.62$ CLAY $=17.65$

พ025

$\begin{array}{llllllllllllllllllllllllll}\text { DATA } & .00 & .00 & .00 & .00 & .00 & .00 & .00 & .00 & .00 & .00 & .01 & .01 & .24 & 3.46 & 3.19 & .04 & 1.50 & 1.79 & 1.94 & 2.03 & 2.07 & 2.13 & 1.89 & 1.26\end{array}$ DATA $.63 \quad 3.88$ $\begin{array}{lllllllllllllllllllllllllllll}\text { FREQUENCY \& } & .0 & .0 & .0 & .0 & .0 & .0 & .0 & .0 & .0 & .0 & .0 & .0 & .8 & 12.2 & 11.2 & .1 & 5.3 & 6.3 & 6.8 & 7.2 & 7.3 & 7.5 & 6.7 & 4.4\end{array}$ $\begin{array}{llllll}\text { EREQUENCY } 2 & 4.2 & 4.0 & 2.2 & 13.7\end{array}$

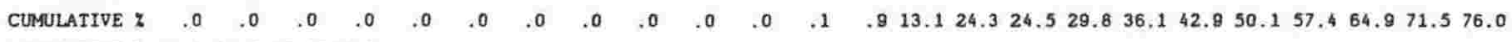
CUMULATIVE ₹ 80.184 .186 .3100 .0

GRAVEL $=.00$ SAND $=24.35$ SILT $=47.18$ CLAY $=28.47$

W026

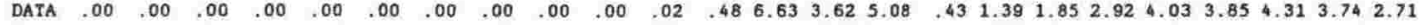
DATA $1.57 \quad 4.39$

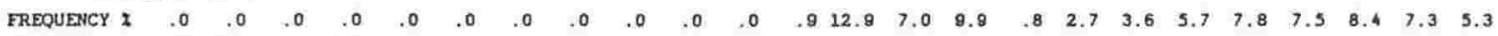
FREQUENCY $₹ \quad 4.7 \quad 3.8 \quad 3,1 \quad 8.5$

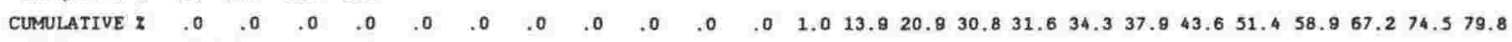
CUMULATIVE 284.588 .491 .5100 .0

GRAVEL $=.00$ SAND $=30.76$ SILT $=43.75$ CLAY $=25.49$

พ032

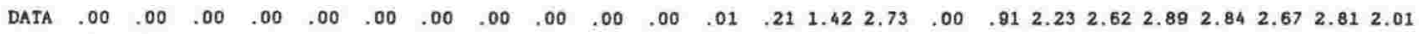
DATA $1.52 \quad 3.72$

$\begin{array}{lllllllllllllllllllllllll}\text { FREQUENCY } 2 & .0 & .0 & .0 & .0 & .0 & .0 & .0 & .0 & .0 & .0 & .0 & .0 & .7 & 4.5 & 8.6 & .0 & 2.9 & 7.0 & 8.3 & 9.1 & 8.0 & 8.4 & 8.8 & 6.3\end{array}$

FREQUENCY $Z$ Z $5.2 \quad 4.5 \quad 4.8 \quad 11.7$

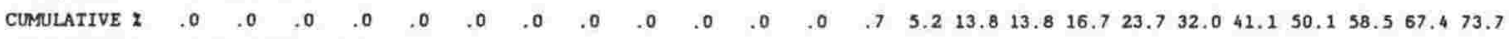
CUMULATIVE : 78.983 .588 .3100 .0

GRAVEL $=.00$ SAND $=13.80$ SILT $=53.58$ CLAY $=32.62$

OCLASS MIDPTS-3.25-2.75-2.25-1.75-1.25 - $-.75 \quad-.25 \quad .25 \quad .75 \quad 1.25 \quad 1.75 \quad 2.25 \quad 2.75 \quad 3.25 \quad 3.75 \quad 4.25 \quad 4.75 \quad 5.25 \quad 5.75 \quad 6.25 \quad 6.75 \quad 7.25 \quad 7.75 \quad 6.25$ OCLASS MIDPTS $8.75 \quad 9.259 .7515,00$

CLASS LIMITS-3.00-2.50-2.00-1.50-1.00 - $.50 .00 \quad .50 \quad 1.00 \quad 1.50 \quad 2.00 \quad 2.50 \quad 3.00 \quad 3.50 \quad 4.00 \quad 4.50 \quad 5.00 \quad 5.50 \quad 6.00 \quad 6.50 \quad 7.00 \quad 7.50 \quad 8.00 \quad 8.50$ CLASS LIMITS 9.009 .5010 .00

W033

$\begin{array}{llllllllllllllllllllllllllllllllll}\text { DATA } & .00 & .00 & .00 & .00 & .00 & .00 & .00 & .00 & .00 & .00 & .01 & .02 & .01 & 4.2915 .66 & 8.74 & 5.86 & 4.13 & 3.85 & 2.22 & 2.05 & 1.84 & 1.91 & 1.18\end{array}$ DATA $2.07 \quad 4.96$

$\begin{array}{llllllllllllllllllllllllllllllllll}\text { EREQUENCY } 2 & .0 & .0 & .0 & .0 & .0 & .0 & .0 & .0 & 0 & .0 & .0 & .0 & .0 & 7.0 & 25.5 & 14.2 & 9.5 & 6.7 & 6.3 & 3.6 & 3.3 & 3.0 & 3.1 & 1.9\end{array}$

FREQUENCY ₹ $\quad 1.7 \quad 2.5 \quad 3.4 \quad 8.1$

CUMULATIVE I

CUMULATIVE \& 86.088 .691 .9100 .0

GRAVEL $=.00$ SAND $=32.54$ SILT $=49.81$ CLAY $=17.65$

W035

$\begin{array}{llllllllllllllllllllllllllllll}\text { DATA } & .00 & .00 & .00 & .00 & .00 & .00 & .00 & .00 & .00 & .01 & .00 & .00 & .01 & 7.9720 .9510 .14 & 5.46 & 3.70 & 2.43 & 2.02 & 1.71 & 1.98 & 1.52 & 1.28\end{array}$ DATA $1.03 \quad 6.79$

$\begin{array}{lllllllllllllllllllllllllllllll}\text { FREQUENCY } 8 & .0 & .0 & .0 & .0 & .0 & .0 & .0 & .0 & .0 & .0 & .0 & .0 & .0 & 11.5 & 30.1 & 14.6 & 7.9 & 5.3 & 3.5 & 2.8 & 2.5 & 2.8 & 2.2 & 1.8\end{array}$ FREQUENCY \& $1.9 \quad 1.8 \quad 1.5 \quad 9.8$

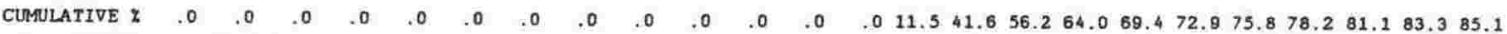
CUMULATIVE 287.088 .890 .2100 .0

GRAVEL $=, 00$ SAND $=41.62$ SILT $=41.65$ CLAY $=16.74$ 
พ039

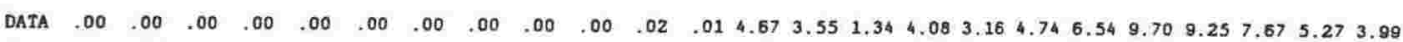
DATA 3.0114 .39

$\begin{array}{llllllllllllllllllllllllllll}\text { FREQUENCY } 2 & .0 & .0 & .0 & .0 & .0 & .0 & .0 & .0 & .0 & .0 & .0 & .0 & 5.3 & 4.1 & 1.5 & 4.7 & 3.6 & 5.4 & 7.5 & 11.1 & 10.6 & 8.8 & 6.0 & 4.6\end{array}$

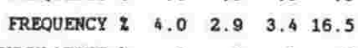

$\begin{array}{lllllllllllllllllllllllll}\text { CUMULATIVE } 1 & .0 & .0 & .0 & .0 & .0 & .0 & .0 & .0 & .0 & .0 & .0 & .0 & 5.4 & 9.4 & 11.0 & 15.6 & 19.3 & 24.7 & 32.2 & 43.3 & 53.8 & 62.6 & 68.6 & 73.2\end{array}$ CUMULATIVE \& $77.280 .183,5100.0$

GRAVEL $=, 00$ SAND $=10.97$ SILI $=57.67$ CLAY $=31.36$

W042

$\begin{array}{lllllllllllllllllllllllllllllllllll}\text { DATA } & .00 & .00 & .00 & .00 & .00 & .00 & .00 & .00 & .01 & .00 & .02 & .0519 .2824 .12 & 7.32 & 3.29 & 2.08 & 1.42 & 1.39 & 1.22 & 1.10 & 1.14 & .03 & .53\end{array}$ DATA .542 .03

$\begin{array}{lllllllllllllllllllllllllllll}\text { FREQUENCY } Z & .0 & .0 & .0 & .0 & .0 & .0 & .0 & .0 & 0 & .0 & .0 & .1 & 28.6 & 35.8 & 10.9 & 4.9 & 3.1 & 2.1 & 2.1 & 1.8 & 1.6 & 1.7 & 1.2 & .8\end{array}$ $\begin{array}{llllll}\text { EREQUENCY } 2 & .9 & .6 & .8 & .0\end{array}$

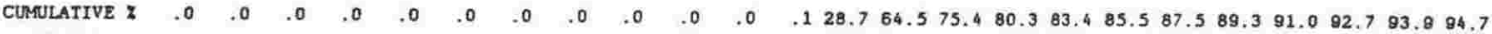
CUMULATIVE 2 95.6 96.297 .0100 .0

GRAVEL $=.00$ SAND $=75.39$ SILT $=18.51$ CLAY $=6.10$

W043

$\begin{array}{lllllllllllllllllllllllllll}\text { DATA } & .00 & .00 & .00 & .00 & .00 & .00 & .00 & .00 & .07 & .07 & .57 & 8.7629 .15 & 4.08 & 2.02 & .88 & .68 & .48 & .51 & .48 & .48 & .48 & .47 & .32\end{array}$ DATA $.27 \quad 1.31$

$\begin{array}{llllllllllllllllllllllllllllll}\text { FREQUENCY } 2 & .0 & .0 & .0 & .0 & .0 & .0 & .0 & .0 & .1 & .1 & 1.1 & 17.0 & 56.4 & 7.9 & 3.9 & 1.7 & 1.3 & .9 & 1.0 & .9 & .9 & .9 & 9 & 6\end{array}$ $\begin{array}{llllll}\text { FREQUENCY } 2 & .5 & .6 & .5 & .0\end{array}$

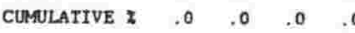
CIMULATIVE 296.496 .997 .5100 .0

$\begin{array}{llllllllllllllllllllllll}.0 & .0 & .0 & .0 & .1 & .3 & 1.4 & 18.3 & 74.8 & 82.7 & 86.6 & 88.3 & 89.6 & 90.5 & 91.5 & 92.4 & 93.4 & 94.3 & 95.2 & 95.8\end{array}$ GRAVEL $=.00$ SAND $=86.58$ SILT $=8.64$ CLAY $=4.78$

OCLASS MIDPTS-3.25-2.75-2.25-1.75-1.25 $-.75 \quad-.25 \quad .25 \quad .75 \quad 1.25 \quad 1.75 \quad 2.25 \quad 2.75 \quad 3.25 \quad 3.75 \quad 4.25 \quad 4.75 \quad 5.25 \quad 5.75 \quad 6.25 \quad 6.75 \quad 7.25 \quad 7.75 \quad 8.25$ OCLASS MIDPTS $8.75 \quad 9.259 .7315 .00$

CLASS LIMITS-3.00-2.50-2.00-1.50-1.00-.50 .00 .50 1.00 1.50 2.00 2.50 3.00 3.50 4.00 $4.50 \quad 5.00 \quad 5.50 \quad 6.00 \quad 6.50 \quad 7.00 \quad 7.50 \quad 8.00 \quad 8.50$ CLASS LIMITS 9.009 .5010 .00

พ044

$\begin{array}{llllllllllllllllllllllllllll}\text { DATA } & .00 & .00 & .00 & .00 & .00 & .00 & .00 & .01 & .01 & .01 & .01 & .2311 .76 & 4.64 & 3.73 & 5.01 & 6.35 & 7.6710 .6511 .37 & 9.84 & 8.30 & 6.86 & 4.34\end{array}$ DATA 3.5212 .55

$\begin{array}{llllllllllllllllllllllllllllllll}\text { FREQUENCY } 2 & .0 & .0 & .0 & .0 & .0 & .0 & .0 & .0 & .0 & .0 & .0 & .2 & 10.3 & 4.1 & 3.3 & 4.4 & 5.6 & 6.7 & 9.3 & 10.0 & 8.6 & 7.3 & 6.0 & 3.8\end{array}$

FREQUENCY : $3.1 \quad 3.2 \quad 3.1 \quad 11.0$

$\begin{array}{llllllllllllllllllllllllll}\text { CUMULATIVE } 2 & .0 & .0 & .0 & .0 & .0 & .0 & .0 & 0 & 0 & .0 & .0 & .2 & 10.6 & 14.6 & 17.9 & 22.3 & 27.9 & 34.6 & 43.9 & 53.9 & 62.5 & 69.8 & 75.8 & 79.6\end{array}$

CUMULATIVE : 82.785 .989 .0100 .0

GRAVEL $=, 00$ SAND $=17.90$ SILT $=57.94$ CLAY $=24.16$

W045

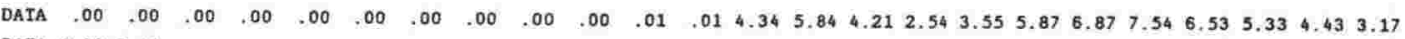
DATA 2.527 .41

$\begin{array}{llllllllllllllllllllllllllllllllll}\text { FREQUENCY } 2 & 0 & .0 & .0 & .0 & .0 & .0 & .0 & .0 & .0 & 0 & 0 & 0 & 5.8 & 7.8 & 5.6 & 3.4 & 4.7 & 7.8 & 9.2 & 10.1 & 8.7 & 7.1 & 5.9 & 4.2\end{array}$ FREQUENCY $₹ \quad 3.3 \quad 2.9 \quad 3.4 \quad 8.9$

$\begin{array}{lllllllllllllllllllllllll}\text { CUMULATIVE } 2 & .0 & .0 & .0 & .0 & .0 & .0 & .0 & .0 & .0 & .0 & .0 & .0 & 5.8 & 13.6 & 19.3 & 22.7 & 27.4 & 35.3 & 44.5 & 54.5 & 63.3 & 70.4 & 76.3 & 80.6\end{array}$ CUMULATIVE $283.8 \quad 86.790 .1100 .0$

GRAVEL $=.00$ SAND $=19.27$ SILT $=57.05$ CLAY $=23.68$

H046

$\begin{array}{llllllllllllllllllllllllllll}\text { DAIA } & .00 & .00 & .00 & .00 & .00 & .02 & .00 & .01 & .02 & .09 & 1.05 & 8.5269 .9128 .2211 .19 & 5.11 & 2.78 & 2.12 & 1.85 & 1.64 & 1.59 & 1.31 & 1.39 & 1.13\end{array}$ DATA $96 \quad 6.61$

$\begin{array}{lllllllllllllllllllllllllllllll}\text { FREQUENCY } 2 & .0 & .0 & .0 & .0 & .0 & .0 & .0 & .0 & .0 & .1 & .7 & 5.8 & 47.4 & 19.1 & 7.6 & 3.5 & 1.9 & 1.4 & 1.3 & 1.1 & 1.1 & .9 & 0 & 0\end{array}$ $\begin{array}{llllll}\text { FREQUENCY } & 8 & .7 & .7 & .7 & 4.5\end{array}$

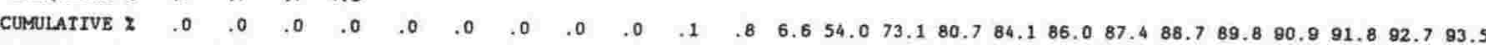
CUMULATIVE $\approx 94.294 .995 .5100 .0$

GRAVEL $=.00$ SAND $=80.65$ SILT $=12.05$ CLAY $=7.29$

พ048

$\begin{array}{lllllllllllllllllllllllll}\text { DATA } & .00 & .00 & .00 & .00 & .00 & .00 & .00 & .00 & .01 & .02 & .15 & 1.2420 .9510 .45 & 2.39 & .88 & .56 & .38 & .34 & .36 & .36 & .35 & .38 & .31\end{array}$

DATA $.28 \quad 1.18$

$\begin{array}{lllllllllllllllllllllllllllll}\text { FREQUENCY } 8 & .0 & .0 & .0 & .0 & .0 & .0 & .0 & .0 & .0 & .0 & .4 & 3.0 & 51.0 & 25.4 & 5.8 & 2.1 & 1.4 & .9 & .8 & .9 & .9 & .9 & .9 & .8\end{array}$

$\begin{array}{llllll}\text { FREDUENCY } \% & .6 & .6 & .7 & .0\end{array}$

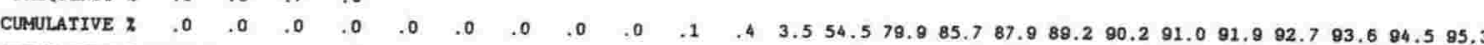
CUMULATIVE \& 95.996 .497 .1100 .0

GRAVEL $=.00$ SAND $=85.73$ SILT $=8.79$ CLAY $=5.48$ 
พ049

$\begin{array}{llllllllllllllllllllllll}\text { DATA } & .00 & .00 & .00 & .00 & .00 & .00 & .00 & .00 & .00 & .01 & .01 & .02 & .5719 .2123 .4811 .81 & 6.25 & 3.56 & 2.80 & 2.13 & 2.22 & 2.01 & 1.63 & 1.55\end{array}$ DATA $1.43 \quad 4.55$

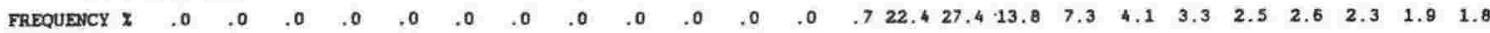
$\begin{array}{llllll}\text { EREQUENCY } ₹ & 1.7 & 1.3 & 1.7 & 5.3\end{array}$

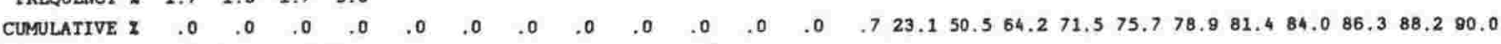
CUMULATIVE $291.793 .094 .7100,0$

GRAVEL $=.00$ SAND $=50.46$ SILT $=37.77$ CLAY $=11.77$

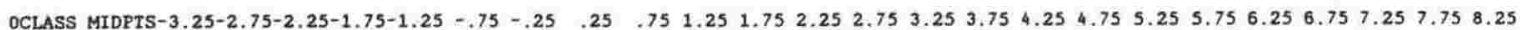
OCLASS MIDPTS $8.75 \quad 9.25 \quad 9.7515 .00$

CLASS LIMITS-3.00-2.50-2.00-1.50-1.00 -.50 .00 .50 1.00 1.50 2.00 2.50 3.00 3.50 4.00 4.50 $5.00 \quad 5.50 \quad 6.00 \quad 6.50 \quad 7.00 \quad 7.50 \quad 8.00 \quad 8.50$ CLASS LIMITS 9.009 .5010 .00

W062

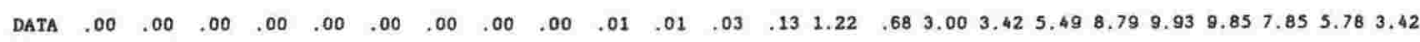
DATA 4.4814 .16

FREQUENCY \& $\quad .0 \quad .0 \quad .0 \quad 0$

$\begin{array}{llllll}\text { FREQUENCY } \& & 4.6 & 3.0 & 5.3 & 16.7\end{array}$

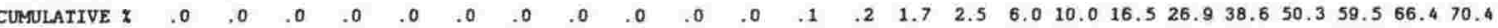
CUMULATIVE 275.078 .083 .3100 .0

GRAVEL $=.00$ SAND $=2.46 \mathrm{SILT}=63.90 \mathrm{CLAY}=33.64$

W069

$\begin{array}{llllllllllllllllllllllllllll}\text { DATA } & .00 & .00 & .00 & .00 & .00 & .00 & .00 & .00 & .00 & .00 & .01 & .01 & .01 & .18 & .19 & 1.55 & 3.26 & 3.46 & 6.9210 .17 & 9.88 & 8.58 & 6.63 & 3.58\end{array}$ DATA $2.96 \quad 9.59$

$\begin{array}{lllllllllllllllllllllllll}\text { EREQUENCY } Z & .0 & .0 & .0 & .0 & .0 & .0 & .0 & .0 & .0 & .0 & .0 & .0 & .0 & .2 & .3 & 2.1 & 4.4 & 4.7 & 9.4 & 13.8 & 13.5 & 11.7 & 9.0 & 5.0\end{array}$ FREQUEMCY ₹ $\quad$\begin{tabular}{lllll}
\hline .3 & 4.2 & 4.0 & 13.1
\end{tabular}

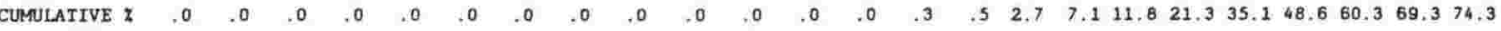
CUMULATIVE \& 78.782 .986 .9100 .0

GRAVEL $=.00$ SAND $=.55$ SILT $=68.78$ CLAY $=30.67$

W072

$\begin{array}{lllllllllllllllllllllllllllllllllllllllll}\text { DATA } & .00 & .00 & .00 & .00 & .00 & .00 & .00 & .00 & .00 & .00 & .01 & .01 & .03 & .09 & .11 & 2.21 & 1.37 & 2.21 & 1.97 & 3.24 & 4.96 & 6.69 & 6.57 & 5.55\end{array}$ DATA 4.9610 .39

$\begin{array}{lllllllllllllllllllllllllll}\text { FREOUENCY } Z & .0 & .0 & .0 & .0 & 0 & 0 & 0 & .0 & 0 & 0 & .0 & .0 & .0 & 1 & .2 & 3.6 & 2.2 & 3.6 & 3.2 & 5.3 & 8.1 & 10.9 & 10.7 & 9.1\end{array}$ $\begin{array}{llllll}\text { FREQUENCY } 2 & 9.6 & 8.0 & 8.1 & 17.0\end{array}$

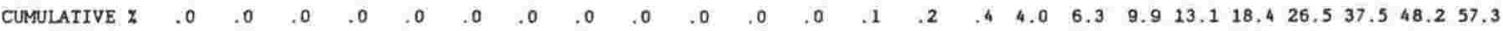
CUMULATIVE $\approx 66.974 .983 .0100 .0$

GRAVEL $=.00$ SAND $=.41$ SILT $=47.81$ CLAY $=51.78$

W074

$\begin{array}{lllllllllllllllllllllllllllllllllll}\text { DATA } & .00 & .00 & .00 & .00 & .00 & .01 & .00 & .00 & .00 & .00 & .01 & .37 & 5.08 & 6.30 & 3.01 & 2.72 & 4.94 & 6.35 & 7.40 & 7.73 & 7.48 & 5.53 & 5.45 & 2.69\end{array}$ DATA 4.3120 .59

$\begin{array}{lllllllllllllllllllllllll}\text { FREQUENCY } 2 & .0 & .0 & .0 & .0 & 0 & .0 & 0 & 0 & 0 & 0 & 0 & 4 & 5.2 & 6.5 & 3.1 & 2.8 & 5.1 & 6.5 & 7.6 & 8.0 & 7.7 & 5.7 & 5.6 & 2.8\end{array}$ FREQUENCY : $3.2 \quad 4.0 \quad 4.4 \quad 21.2$ $\begin{array}{lllll}\text { CURULATIVE }: & .0 & .0 & .0 & .0\end{array}$ CUMULATIVE 270.374 .378 .8100 .0

GRAVEL $=.00$ SAND $=15.24$ SILT $=49.09$ CLAY $=35.67$

พ076

$\begin{array}{lllllllllllllllllllllllllllll}\text { DATA } & .00 & .00 & .00 & .00 & .00 & .00 & .00 & .00 & .00 & .00 & .00 & .0617 .3228 .18 & 9.02 & 2.21 & 1.96 & 1.13 & 1.16 & 1.22 & 1.21 & 1.24 & 1.00 & .76\end{array}$ DATA .494 .09

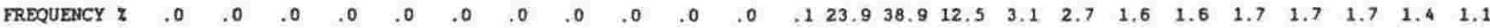
$\begin{array}{lllll}\text { FREQUENCY } 2 & .8 & 1.0 & .7 & 5.7\end{array}$

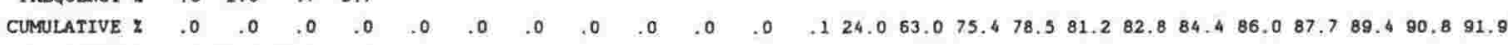
CUMULATIVE ₹ $92.6 \quad 93,794,3100,0$

GRAVEL $=.00$ SAND $=75.43 \mathrm{SILT}=15.38$ CLAY $=9.19$ 


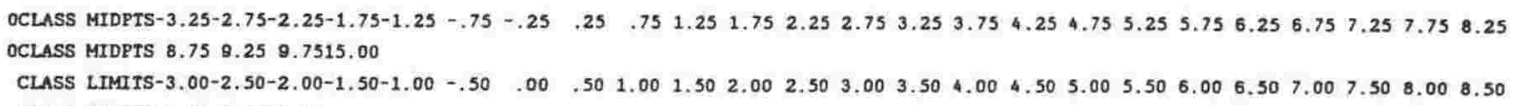
CLASS LIMITS 9.009 .5010 .00

พ077

$\begin{array}{lllllllllllllllllllllllllllll}\text { DATA } & .00 & .00 & .00 & .00 & .00 & .00 & .00 & .00 & .00 & .00 & .00 & .04 & 9.2714 .53 & 6.93 & 3.01 & 2.45 & 4.18 & 6.37 & 5.82 & 8.64 & 9.37 & 7.92 & 6.10\end{array}$ DATA 5.3722 .84

$\begin{array}{lllllllllllllllllllllllllllllll}\text { FREQUENCY } ₹ & .0 & .0 & .0 & .0 & .0 & .0 & .0 & .0 & .0 & .0 & .0 & .0 & 7.5 & 11.8 & 5.6 & 2.4 & 2.0 & 3.4 & 5.2 & 4.7 & 7.0 & 7.6 & 6.4 & 5.0\end{array}$ $\begin{array}{lllll}\text { FREQUENCY } 2 & 4.7 & 3.8 & 4.4 & 18.5\end{array}$

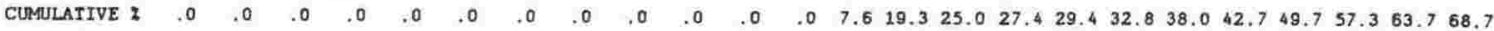
CURULATIVE \& 73.377 .181 .5100 .0

GRAVEL $=.00$ SAND $=24.97$ SILT $=38.76$ CLAY $=36.26$

W078

$\begin{array}{lllllllllllllllllllllll}\text { DATA } & .00 & .00 & .00 & .00 & .00 & .00 & .00 & .00 & .00 & .00 & .00 & .00 & .00 & .00 & .44 & 1.94 & 2.69 & 2.37 & 6.13 & 7.9610 .2212 .1613 .13 & 9.36\end{array}$ DATA 6.0319 .69

$\begin{array}{lllllllllllllllllllllllllllllll}\text { FREQUENCY } & 7 & .0 & .0 & .0 & .0 & .0 & .0 & .0 & .0 & .0 & .0 & .0 & .0 & .0 & .0 & .4 & 1.8 & 2.5 & 2.2 & 5.7 & 7.4 & 9.5 & 11.3 & 12.2 & 8.7\end{array}$ FREQUENCY $2 \quad 8.5 \quad 6.3 \quad 5.6 \quad 18.2$

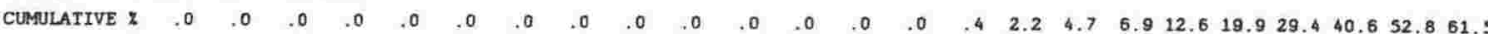
CUMULATIVE \& 69.976 .281 .8100 .0

GRAVEL $=.00$ SAND $=.41$ SILI $=52.38$ CLAY $=47.21$

W081

$\begin{array}{llllllllllllllllllllllllllllll}\text { DATA } & .00 & .00 & .00 & .00 & .00 & .00 & .00 & .00 & .00 & .00 & .00 & .00 & .00 & .94 & .87 & .69 & 5.38 & 6.85 & 7.38 & 8.24 & 8.16 & 8.59 & 6.94 & 4.17\end{array}$ DATA 3.1218 .40

$\begin{array}{llllllllllllllllllllllllllllllll}\text { FREQUENCY } 2 & .0 & .0 & .0 & .0 & .0 & .0 & .0 & .0 & .0 & .0 & .0 & .0 & .0 & 1.1 & 1.0 & .8 & 6.1 & 7.8 & 8.4 & 9.4 & 9.3 & 9.8 & 7.8 & 4.8\end{array}$

FREQUENCY \& $\quad 4.7 \quad 4.5 \quad 3.6 \quad 21.0$

CUMULATIVE $2 \quad .0 \quad .0 \quad .0 \quad .0$

CUMULATIVE : 71.075 .579 .0100 .0

GRAVEL $=.00$ SAND $=2.06$ SILI $=59.54$ CLAY $=38.39$

พ082

$\begin{array}{llllllllllllllllllllllllllllll}\text { DATA } & .00 & .00 & .00 & .00 & .00 & .00 & .00 & .00 & .05 & .11 & .75 & 6.9446 .2019 .88 & 9.38 & 3.31 & 1.88 & 1.10 & 1.19 & 1.28 & 1.36 & 1.45 & 1.19 & .80\end{array}$

DATA .692 .94

$\begin{array}{lllllllllllllllllllllllllllllll}\text { FREPUENCY Z } & .0 & .0 & .0 & .0 & .0 & .0 & .0 & .0 & .0 & .1 & .7 & 6.8 & 45.3 & 19.5 & 9.2 & 3.2 & 1.8 & 1.1 & 1.2 & 1.3 & 1.3 & 1.4 & 1.2 & .8\end{array}$

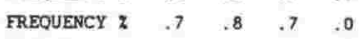

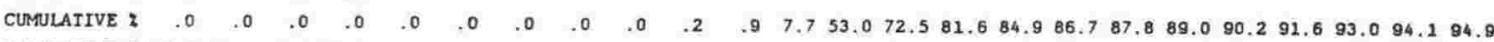
CUMULATIVE 295.696 .497 .1100 .0

GRAVEL $=.00$ SAND $=81.64$ SILI $=12.50$ CLAY $=5.85$

W085

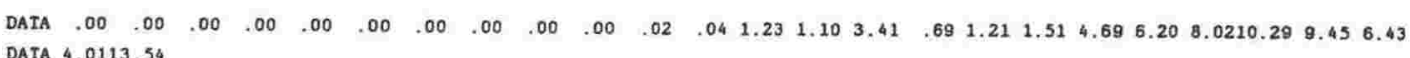

$\begin{array}{lllllllllllllllllllllllllllll}\text { FREQUENCY } 2 & .0 & .0 & .0 & .0 & .0 & .0 & .0 & .0 & .0 & 0 & .0 & .1 & 1.5 & 1.4 & 4.3 & .9 & 1.5 & 1.9 & 5.9 & 7.8 & 10.0 & 12.8 & 11.8 & 8.0\end{array}$ $\begin{array}{llllll}\text { EREQUENCY } 2 & 5.5 & 4.6 & 5.0 & 16.9\end{array}$

$\begin{array}{llllllllllllllllllllllllllll}\text { CUMULATIVE I } & .0 & .0 & .0 & .0 & .0 & .0 & .0 & .0 & .0 & .0 & .0 & .1 & 1.6 & 3.0 & 7.3 & 8.1 & 9.6 & 11.5 & 17.4 & 25.1 & 35.2 & 48.1 & 59.9 & 67.9\end{array}$ CUMULATIVE $273.4 \quad 78,0 \quad 83,1100.0$

GRAVEL $=.00$ SAND $=7.26$ SILT $=52.62$ CLAY $=40.12$

OCLASS MIDPTS-3.25-2.75-2.25-1.75-1.25 - -75 - $-25 \quad .25 \quad .75 \quad 1.25 \quad 1.75 \quad 2.25 \quad 2.75 \quad 3.25 \quad 3.75 \quad 4.25 \quad 4.75 \quad 5.25 \quad 5.75 \quad 6.25 \quad 6.75 \quad 7.25 \quad 7.75 \quad 8.25$ OCLASS MIDPTS 8.759 .259 .7515 .00

CLASS LIMITS-3.00-2.50-2.00-1.50-1.00 -.50 .00 $50 \quad 1.00 \quad 1.50 \quad 2.00 \quad 2.50 \quad 3.00 \quad 3.50 \quad 4.00 \quad 4.50 \quad 5.00 \quad 5.50 \quad 6.00 \quad 6.50 \quad 7.00 \quad 7.50 \quad 8.00 \quad 8.50$ CLASS LIMITS 9.009 .5010 .00

พ087

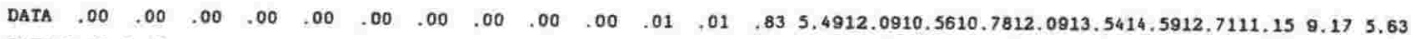
DATA 2.501 .46

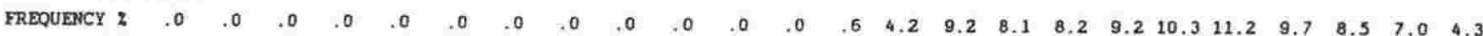

$\begin{array}{llllll}\text { FREQUENCY } ₹ & 3.3 & 2.9 & 1.9 & .0\end{array}$

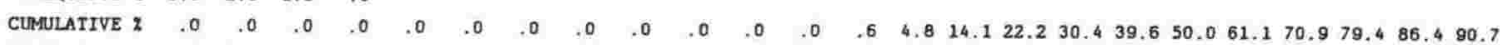
CUMULATIVE \& 94.097 .098 .9100 .0

GRAVEL $=.00$ SARD $=14.09$ SILT $=72.30$ CLAY $=13.61$ 
พ०88

$\begin{array}{llllllllllllllllllllllllllll}\text { DATA } & .00 & .00 & .00 & .00 & .00 & .00 & .01 & .01 & .05 & .10 & .43 & 6.9046 .8425 .70 & 8.80 & 3.94 & 2.43 & 1.17 & 1.46 & 1.12 & 1.11 & .88 & .74 & .38\end{array}$

DATA . 411.81

$\begin{array}{lllllllllllllllllllllllllllll}\text { FREQUENCY } ~ & . & .0 & .0 & .0 & .0 & .0 & .0 & .0 & .0 & .0 & .1 & .4 & 6.6 & 44.6 & 24.4 & 8.4 & 3.7 & 2.3 & 1.1 & 1.4 & 1.1 & 1.1 & .8 & .7 & .4\end{array}$

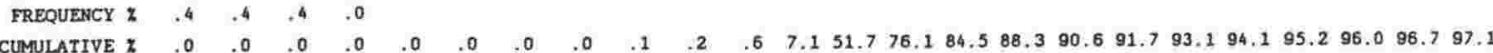
CUMULATIVE Z $97.5 \quad 97.998 .3100 .0$

GRAVEL $=.00$ SAND $=84.51$ SILT $=12.22$ CLAY $=3.26$

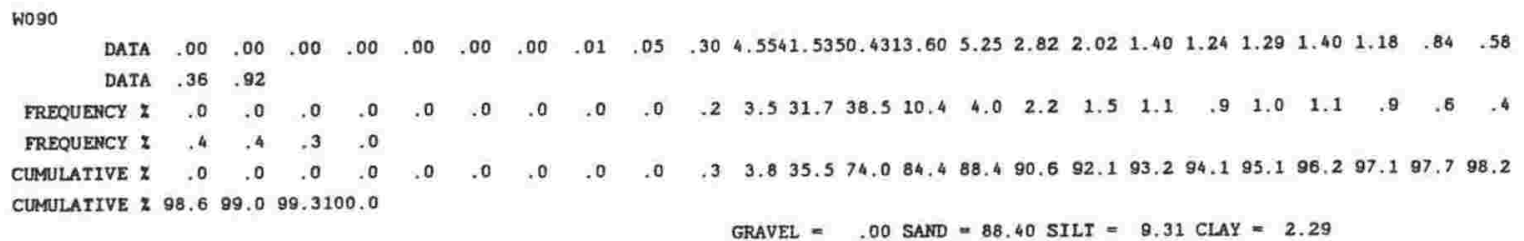

W091

$\begin{array}{lllllllllllllllllllllllllllllll}\text { DATA } & .00 & .00 & .00 & .00 & .00 & .00 & .00 & .00 & .00 & .00 & .00 & .00 & .00 & .28 & .00 & 1.27 & 3.05 & 4.83 & 7.18 & 7.31 & 8.51 & 8.01 & 6.16 & 3.69\end{array}$ DATA 2.616 .16

$\begin{array}{lllllllllllllllllllllllll}\text { FREQUENCY } 2 & .0 & .0 & .0 & .0 & .0 & .0 & .0 & .0 & .0 & .0 & .0 & .0 & .0 & .4 & .0 & 2.0 & 4.7 & 7.5 & 11.1 & 11.3 & 13.2 & 12.4 & 8.5 & 5.7\end{array}$ $\begin{array}{lllll}\text { FREQUENCY } & 7.5 & 4.1 & 4.0 & 9.5\end{array}$

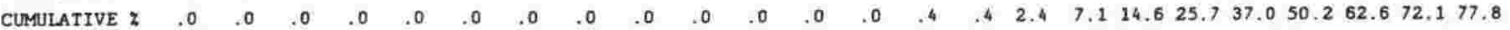
CUMULATIVE 282.386 .490 .5100 .0

GRAVEL $=.00$ SAND $=.43$ SILT $=71.65$ CLAY $=27.92$

w094

$\begin{array}{lllllllllllllllllllllllllllllllllll}\text { DATA } & .00 & .00 & .00 & .00 & .00 & .00 & .00 & .01 & .01 & .03 & .09 & .08 & .6911 .2315 .7513 .6310 .29 & 8.34 & 8.77 & 7.41 & 6.55 & 5.82 & 4.02 & 2.53\end{array}$ DATA $1.61 \quad 4.39$

$\begin{array}{llllllllllllllllllllllllllllll}\text { FREQUENCX } ₹ & .0 & .0 & .0 & .0 & .0 & .0 & .0 & .0 & .0 & .0 & .1 & .1 & .7 & 10.7 & 15.0 & 13.0 & 9.8 & 7.9 & 8.3 & 7.0 & 6.2 & 5.5 & 3.8 & 2.4\end{array}$

FREQUENCY 2 $1.7 \quad 2.1 \quad 1.5 \quad 4.2$

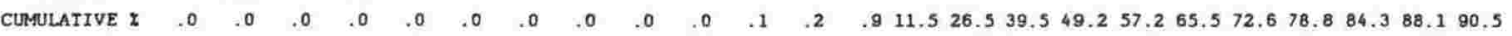
CUMULATIVE \& 92.294 .395 .8100 .0

GRAVEL $=.00$ SAND $=26.51$ SILT $=61.63$ CLAY $=11.86$

OCLASS MIDPTS-3.25-2.75-2.25-1.75-1.25 -.75 - $-.25 \quad .25 \quad .75 \quad 1.25 \quad 1.75 \quad 2.25 \quad 2.75 \quad 3.25 \quad 3.75 \quad 4.25 \quad 4.75 \quad 5.25 \quad 5.75 \quad 6.25 \quad 6.75 \quad 7.25 \quad 7.75 \quad 8.25$ OCLASS MIDPTS $8.75 \quad 9.25 \quad 9.7515 .00$

CLASS LIMITS-3.00-2.50-2.00-1.50-1.00 -.50 .00 .50 1.00 $1.50 \quad 2.00 \quad 2.50 \quad 3.00 \quad 3.50 \quad 4.00 \quad 4.50 \quad 5.00 \quad 5.50 \quad 6.00 \quad 6.50 \quad 7.00 \quad 7.50 \quad 8.00 \quad 8.50$ CLASS LIMITS 9.00

พ098

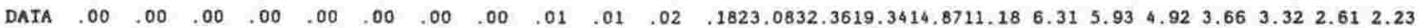
DATA 1.812 .44

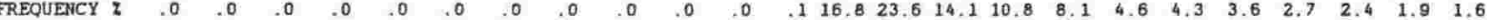

FREQUENCY : $\quad .9 \quad 1.2 \quad 1.3 \quad .0$

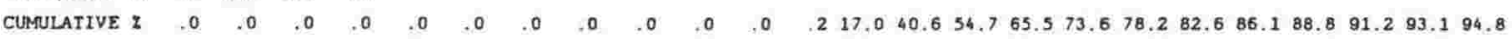
CUMULATIVE \& 95.796 .998 .2100 .0

GRAVEL $=.00$ SAND $=54.66 \mathrm{SILT}=38.48 \mathrm{CLAY}=6.86$

wo9g

$\begin{array}{lllllllllllllllllllllllllllllllllll}\text { DATA } & .00 & .00 & .00 & .00 & .00 & .00 & .00 & .00 & .00 & .00 & .01 & .1615 .9238 .9016 .61 & 9.33 & 7.56 & 4.67 & 4.56 & 4.23 & 3.71 & 3.16 & 2.90 & 1.68\end{array}$ DATA 1.542 .50

$\begin{array}{llllllllllllllllllllllllllllll}\text { FREOUENCY } ~ & .0 & .0 & .0 & .0 & .0 & .0 & .0 & .0 & .0 & .0 & 0 & .1 & 13.2 & 32.3 & 13.8 & 7.7 & 6.3 & 3.9 & 3.8 & 3.5 & 3.1 & 2.6 & 2.4 & 1.4\end{array}$ $\begin{array}{llllll}\text { FREQUENCY } & 2 & 1.2 & 1.4 & 1.3 & .0\end{array}$

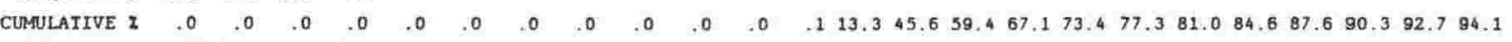
CUMULATIVE 295.296 .697 .9100 .0

GRAVEL $=.00$ SAND $=59.38$ SILI $=33.28$ CLAY $=7.34$ 
พ109

$\begin{array}{llllllllllllllllllllllllllllllllll}\text { DAIA } & .00 & .00 & .00 & .00 & .00 & .00 & .00 & .00 & .00 & .00 & .01 & .00 & .02 & .17 & 1.99 & 1.85 & 2.86 & 4.81 & 5.58 & 6.29 & 7.49 & 7.33 & 5.85 & 3.01\end{array}$ DATA 2.951 .32

$\begin{array}{lllllllllllllllllllllllllll}\text { FREQUENCY } 2 & .0 & .0 & .0 & .0 & .0 & .0 & .0 & .0 & .0 & .0 & .0 & .0 & .0 & .3 & 3.4 & 3.2 & 5.0 & 8.3 & 9.7 & 10.9 & 13.0 & 12.7 & 10.1 & 5.2\end{array}$

$\begin{array}{llllll}\text { FRDQUENCY } ₹ & 5.6 & 5.1 & 5.1 & 2.3\end{array}$

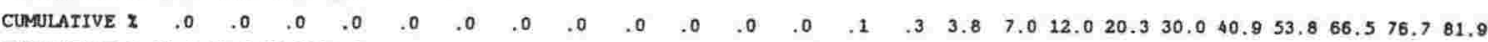
CUMULATIVE \& 87.592 .697 .7100 .0

GRAVEL $=.00$ SAND $=3.79$ SILT $=72.88$ CLAY $=23.32$

W111

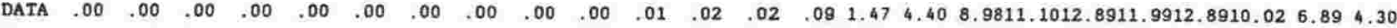
DATA $2.77 \quad .27$

$\begin{array}{llllllllllllllllllllllllllllllllll}\text { FREQUENCY Z } & .0 & .0 & .0 & .0 & .0 & .0 & .0 & .0 & .0 & .0 & .0 & .0 & .0 & .1 & 1.6 & 4.7 & 9.6 & 11.9 & 13.8 & 12.8 & 13.8 & 10.7 & 7.4 & 4.6\end{array}$ FREQUERCY $2 \quad 2.8 \quad 3.0 \quad 3.0 \quad 0$

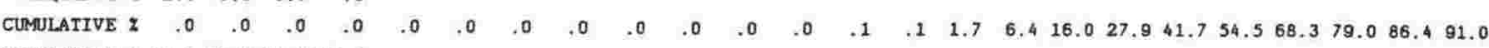
CUMULATIVE \& 93.896 .799 .7100 .0

GRAVEI $=.00$ SAND $=1.72$ SILT $=84.69$ CLAY $=13.59$

W114

$\begin{array}{llllllllllllllllllllllllllllllllll}\text { DATA } & .00 & .00 & .00 & .00 & .00 & .00 & .00 & .00 & .00 & .01 & .03 & .43 & 5.98 & 2.55 & 1.75 & .66 & 2.62 & 4.01 & 5.20 & 7.62 & 8.15 & 8.38 & 7.08 & 5.43\end{array}$

$\begin{array}{lllllllllllllllllllllllllllllll}\text { FREQUENCY } 2 & .0 & .0 & .0 & .0 & .0 & .0 & .0 & .0 & .0 & .0 & .0 & .6 & 8.6 & 3.6 & 2.5 & .9 & 3.7 & 5.7 & 7.4 & 10.9 & 11.7 & 12.0 & 10.1 & 7.8\end{array}$ ERDQUERCY 2 2 $4.1 \quad 4.7 \quad 1.4 \quad 4.1$

$\begin{array}{lllllllllllllllllllllllllllll}\text { CLMULATIVE } Z & 0 & 0 & 0 & .0 & 0 & .0 & .0 & .0 & .0 & .0 & .0 & .1 & .7 & 9.2 & 12.9 & 15.4 & 16.3 & 20.1 & 25.8 & 33.3 & 44.2 & 55.8 & 67.8 & 77.9 & 85.7\end{array}$ CUMULATIVE $z 89.994 .595 .9100 .0$

GRAVEL $=.00$ SAND $=15.38$ SILT $=62.56$ CLAY $=22.05$

wo01

พ003

พ013

Wo16

W017

พ019

พ020

W024

W025

พ026

พ032

พ033

W035

พ039

พ०42

พ043

W044

W045

W046

W048

พ049

พ062

พ069

พ072

พ074

W076

พ077

พ078

พ08 1

พ082

W085

W087

พ088

W090

พ091

พ094

พ098

พ099

W109

พ111

W114
P E R E E I I ES TOLK MEASURES MOMENT MEASURES

$\begin{array}{llllllllll}1 & 5 & 16 & 25 & 50 & 75 & 84 & 95 & \text { MEAN SDEV SKEW KURT MEAN SDEV SKEW KURT GRVL SAND SILT CLAY }\end{array}$ $\begin{array}{lllllllllllllllllllll}2.8 & 3.0 & 3.5 & 3.8 & 5.2 & 6.6 & 7.6 & 9.6 & 5.42 & 2.00 & 24 & 93 & 5.64 & 2.52 & 1.85 & 7.41 & 0 & 34.2 & 53.7 & 12 & 1\end{array}$ $\begin{array}{llllllllllllllllllll}2.2 & 2.5 & 2.7 & 2.8 & 3.1 & 3.6 & 5.8 & 8.8 & 3.89 & 1.74 & .80 & 3.32 & 3.99 & 2.43 & 2.7311 .06 & .0 & 81.5 & 10.8 & 7.8\end{array}$ $\begin{array}{lllllllllllllllllll}3.0 & 3.2 & 3.5 & 3.7 & 5.2 & 7.9 & 9.211 .9 & 6.00 & 2.74 & .47 & .85 & 6.46 & 3.66 & 1.33 & 3.73 & .0 & 40.2 & 35.5 & 24.3\end{array}$ $\begin{array}{lllllllllllllllllllll}2.5 & 2.7 & 2.9 & 2.9 & 3.3 & 5.0 & 6.810 .0 & 4.33 & 2.10 & .80 & 1.43 & 4.54 & 2.97 & 2.31 & 8.06 & 0 & 73.1 & 16.5 & 10.5\end{array}$ $\begin{array}{llllllllllllllllllll}2.9 & 3.2 & 3.4 & 3.6 & 4.6 & 6.8 & 7.7 & 9.5 & 5.24 & 2.03 & .50 & .82 & 5.41 & 2.50 & 1.73 & 6.73 & .0 & 47.5 & 39.2 & 13.3\end{array}$

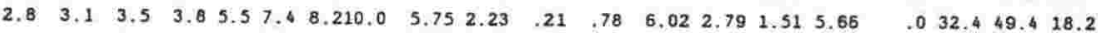
$\begin{array}{lllllllllllllllllll}2.9 & 3.2 & 3.5 & 3.7 & 5.2 & 7.5 & 8.410 .2 & 5.71 & 2.28 & .39 & .75 & 5.95 & 2.99 & 1.53 & 5.21 & .0 & 43.6 & 37.1 & 19.2\end{array}$ $\begin{array}{lllllllllllllllllll}1.7 & 2.6 & 2.8 & 2.9 & 3.4 & 6.8 & 8.310 .7 & 4.82 & 2.61 & .79 & .85 & 5.15 & 3.48 & 1.65 & 4.99 & .0 & 61.7 & 20.6 & 17.7\end{array}$ $\begin{array}{llllllllllllllllllllll}3.0 & 3.3 & 3.6 & 4.6 & 6.5 & 8.4 & 9.512 .9 & 6.54 & 2.91 & .18 & 1.02 & 7.19 & 3.61 & 1.10 & 3.32 & .0 & 24.3 & 47.2 & 28.5\end{array}$ $\begin{array}{llllllllllllllllllll}2.5 & 2.8 & 3.2 & 3.7 & 6.4 & 8.0 & 8.910 .8 & 6.17 & 2.66 & -.02 & .76 & 6.61 & 3.32 & 1.08 & 3.93 & .0 & 30.8 & 43.8 & 25.5\end{array}$ $\begin{array}{llllllllllllllllllll}3.1 & 3.5 & 4.9 & 5.6 & 7.0 & 8.6 & 9.611 .1 & 7.15 & 2.31 & .09 & 1.02 & 7.57 & 3.21 & 1.13 & 3.78 & .0 & 13.8 & 53.6 & 32.6\end{array}$ $\begin{array}{llllllllllllllll}3.3 & 3.5 & 3.7 & 3.9 & 4.7 & 6.8 & 8.410 .6 & 5.61 & 2.26 & .63 & 1.01 & 5.95 & 3.18 & 1.81 & 5.51\end{array}$ $\begin{array}{llllllllllllllll}3.2 & 3.4 & 3.6 & 3.8 & 4.3 & 6.4 & 8.212 .1 & 5.36 & 2.47 & .75 & 1.38 & 5.79 & 3.41 & 1.87 & 5.35\end{array}$ $\begin{array}{lllllllllllllll}2.8 & 3.0 & 4.6 & 5.5 & 6.8 & 8.710 .112 .6 & 7.15 & 2.83 & .19 & 1.23 & 7.73 & 3.64 & .99 & 3.01\end{array}$ $\begin{array}{lllllllllllllll}2.6 & 2.8 & 2.9 & 3.0 & 3.3 & 4.0 & 5.1 & 8.7 & 3.79 & 1.45 & .74 & 2.40 & 4.11 & 2.40 & 3.1413 .55\end{array}$ $\begin{array}{llllllllllllllll}1.9 & 2.2 & 2.5 & 2.6 & 2.8 & 3.0 & 3.7 & 7.9 & 2.97 & 1.16 & .63 & 5.27 & 3.44 & 2.29 & 3.7117 .57\end{array}$ $\begin{array}{llllllllllllllll}2.7 & 2.9 & 3.7 & 4.8 & 6.3 & 7.8 & 8.211 .4 & 5.40 & 2.66 & .13 & 1.10 & 6.92 & 3.39 & 1.20 & 3.94\end{array}$

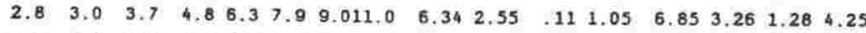
$\begin{array}{lllllllllllllllll}2.0 & 2.4 & 2.7 & 2.8 & 3.0 & 3.6 & 4.5 & 9.6 & 3.37 & 1.54 & .75 & 3.42 & 3.94 & 2.76 & 3.0611 .95\end{array}$ $\begin{array}{lllllllllllllllll}2.2 & 2.5 & 2.7 & 2.8 & 3.0 & 3.4 & 3.8 & 8.3 & 3.17 & 1.16 & .70 & 4.00 & 3.69 & 2.34 & 3.6316 .60\end{array}$ $\begin{array}{lllllllllllllllll}3.0 & 3.2 & 3.4 & 3.5 & 4.0 & 5.4 & 7.010 .1 & 4.81 & 1.94 & .73 & 1.50 & 5.13 & 2.82 & 2.37 & 8.28\end{array}$ $\begin{array}{llllllllllllll}3.4 & 4.4 & 5.5 & 5.9 & 7.0 & 9.010 .111 .8 & 7.51 & 2.27 & .32 & .98 & 8.12 & 3.39 & 1.14 & 3.12\end{array}$ $\begin{array}{lllllllllllllllll}4.2 & 4.8 & 5.7 & 6.1 & 7.1 & 8.6 & 9.611 .5 & 7.48 & 1.99 & .33 & 1.13 & 7.97 & 3.01 & 1.46 & 4.12\end{array}$ $\begin{array}{llllllllllllll}4.2 & 4.7 & 6.3 & 6.9 & 8.1 & 9.510 .111 .2 & 8.15 & 1.93 & .00 & 1.02 & 8.82 & 3.12 & .98 & 3.04\end{array}$ $\begin{array}{llllllllllllll}2.7 & 3.0 & 4.1 & 5.1 & 6.8 & 9.610 .712 .9 & 7.21 & 3.14 & .21 & .92 & 7.99 & 4.06 & .75 & 2.28\end{array}$

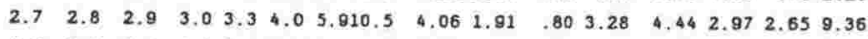
$\begin{array}{llllllllllllll}2.8 & 2.9 & 3.4 & 4.0 & 7.0 & 9.210 .312 .5 & 6.91 & 3.18 & .05 & .75 & 7.56 & 4.04 & .74 & 2.43\end{array}$ $\begin{array}{llllllllllllll}4.3 & 5.1 & 6.3 & 6.8 & 7.9 & 9.410 .211 .8 & 8.12 & 2.03 & .18 & 1.07 & 8.82 & 3.17 & 1.06 & 2.94\end{array}$ $\begin{array}{llllllllllllll}3.4 & 4.7 & 5.5 & 6.0 & 7.3 & 9.410 .813 .5 & 7.85 & 2.67 & .36 & 1.05 & 8.53 & 3.59 & .94 & 2.49\end{array}$ $\begin{array}{lllllllllllllll}2.0 & 2.4 & 2.6 & 2.8 & 3.0 & 3.6 & 4.4 & 8.5 & 3.33 & 1.36 & .71 & 2.88 & 3.80 & 2.41 & 3.2614 .30\end{array}$ $\begin{array}{llllllllllllll}2.9 & 3.8 & 5.9 & 6.5 & 7.6 & 0.210 .111 .9 & 7.86 & 2.28 & .13 & 1.24 & 8.41 & 3.34 & .94 & 3.07\end{array}$ $\begin{array}{llllllllllllllllll}3.1 & 3.5 & 4.1 & 4.7 & 6.0 & 7.2 & 7.8 & 9.1 & 5.98 & 1.77 & .05 & .90 & 6.10 & 1.91 & 1.15 & 6.57\end{array}$ $\begin{array}{llllllllllllllll}2.1 & 2.4 & 2.7 & 2.8 & 3.0 & 3.5 & 4.0 & 6.9 & 3.20 & 1.01 & .62 & 2.59 & 3.55 & 1.94 & 4.1122 .62\end{array}$ $\begin{array}{lllllllllllllll}1.7 & 2.0 & 2.3 & 2.4 & 2.7 & 3.0 & 3.5 & 6.4 & 2.81 & .97 & .52 & 2.78 & 3.10 & 1.62 & 4.0524 .62\end{array}$ $\begin{array}{lllllllllllllll}4.2 & 4.8 & 5.6 & 6.0 & 7.0 & 8.2 & 9.210 .8 & 7.25 & 1.81 & .25 & 1.08 & 7.66 & 2.72 & 1.68 & 5.31\end{array}$

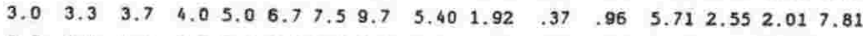
$\begin{array}{llllllllllllllll}2.7 & 2.8 & 3.0 & 3.2 & 3.8 & 5.1 & 6.2 & 8.6 & 4.34 & 1.68 & .56 & 1.22 & 4.55 & 2.17 & 2.4510 .90\end{array}$ $\begin{array}{lllllllllllllll}2.7 & 2.9 & 3.1 & 3.2 & 3.7 & 5.2 & 6.4 & 8.9 & 4.38 & 1.75 & .69 & 1.25 & 4.57 & 2.27 & 2.4410 .34\end{array}$ $\begin{array}{llllllllllllllll}3.7 & 4.2 & 5.3 & 5.8 & 6.9 & 7.8 & 8.7 & 8.7 & 6.93 & 1.68 & .05 & 1.04 & 7.00 & 1.95 & 1.40 & 7.38\end{array}$ $\begin{array}{llllllllllllllll}3.9 & 4.4 & 5.0 & 5.4 & 6.3 & 7.3 & 7.8 & 9.2 & 6.38 & 1.43 & .13 & 1.03 & 6.45 & 1.47 & .88 & 5.54\end{array}$ $\begin{array}{llllllllllllllll}2.6 & 2.9 & 4.3 & 5.4 & 6.8 & 7.8 & 8.4 & 9.7 & 6.49 & 2.04 & -.17 & 1.16 & 6.72 & 2.31 & 1.04 & 5.79\end{array}$
032.549 .817 .6 $\begin{array}{llll}.0 & 41.6 & 41.6 & 16.7\end{array}$ .011 .057 .731 .4 $\begin{array}{llll}.0 & 75.4 & 18.5 & 6.1\end{array}$ $\begin{array}{llll}.0 & 86.6 & 8.6 & 4.8\end{array}$ 017.957 .924 .2 $\begin{array}{llll}0 & 19.3 & 57.0 & 23.7\end{array}$ $\begin{array}{llll}.0 & 80.7 & 12.1 & 7.3\end{array}$ $\begin{array}{llll}.0 & 85.7 & 8.8 & 5.5\end{array}$ .050 .537 .811 .8 $.0 \quad 2.5 \quad 63.933 .6$ $0.4 \quad 47.851 .8$ 015.249 .135 .7 $\begin{array}{llll}.0 & 75.4 & 15.4 & 9.2\end{array}$ $.025 .0 \quad 38.8 \quad 36.3$ .0 .452 .447 .2 $\begin{array}{llll}.0 & 2.1 & 59.5 & 38.4\end{array}$ $\begin{array}{llll}.0 & 81.6 & 12.5 & 5.9\end{array}$ $\begin{array}{llllll}0 & 7.3 & 52.6 & 40.1\end{array}$ $\begin{array}{llll}.0 & 14.1 & 72.3 & 13.6\end{array}$ $\begin{array}{llll}0 & 84.5 \quad 22.2 \quad 3.3\end{array}$ $\begin{array}{llll}.0 & 88.4 & 9.3 & 2.3\end{array}$ $.0 \quad 471.627 .9$ .026 .561 .611 .9 $\begin{array}{llll}.0 & 54.7 \quad 38.5 & 6.9\end{array}$ $\begin{array}{lllll}.0 & 59.4 & 33.3 & 7.3\end{array}$ $\begin{array}{llll}.0 & 3.8 & 72.9 & 23.3\end{array}$ $\begin{array}{llll}0 & 1.7 & 84.7 & 13.6\end{array}$ .015 .462 .622 .1 $\begin{array}{llll}.0 & .568 .8 & 30.7\end{array}$ 
402 
vUN FROGRAM FOR GRAIN SIZE AHALYSIS WRITTEN BY P BARRETT AND $J$ ADAMS. FOR DETAILS OF DATA ENTRY. FOR EXAMPLES OF DATA INPUT STYLE OR FOR AHY OTHER ASPECTS OF RUNHING THE FROGRAM READ THE FILE "3IZE LIST".

OCLASS MIDPTS-3.25-2.75-2.25-1.75-1.25 $\quad-.75 \quad-.25 \quad .25 \quad .75 \quad 1.25 \quad 1.75 \quad 2.25 \quad 2.75 \quad 3.25 \quad 3.75 \quad 4.25 \quad 4.75 \quad 5.25 \quad 5.75 \quad 6.25 \quad 6.75 \quad 7.25 \quad 7.75 \quad 8.25$ OCLASS MIDPTS 8.759 .259 .7515 .00

CLASS LIMITS-3.00-2.50-2.00-1.50-1.00 -.50 .00 .50 $1.00 \quad 1.50 \quad 2.00 \quad 2.50 \quad 3.00 \quad 3.50 \quad 4.00 \quad 4.50 \quad 5.00 \quad 5.50 \quad 6.00 \quad 6.50 \quad 7.00 \quad 7.50 \quad 8.00 \quad 8.50$ CLASS LIMITS 9.009 .5010 .00

OWANGANUI BIGBT SEDIMENTS WBO1-WTH10

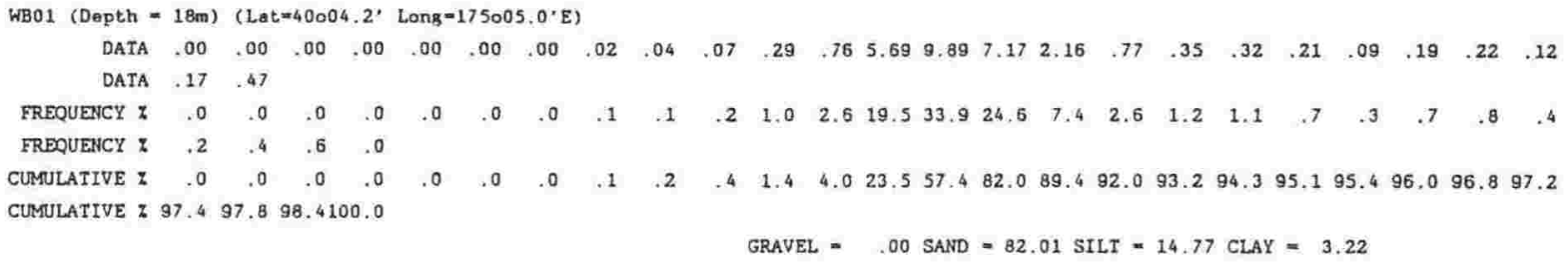

GRAVEL $=.00$ SAND $=82.01$ SILT $=14.77$ CLAY $=3.22$

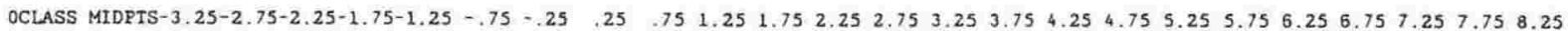
OCLASS MIDPTS 8.759 .259 .7515 .00

CLASS LIMITS-3.00-2.50-2.00-1.50-1.00 - .50 .00 .50 1.00 1.50 2.00 2.50 3.00 3.50 4.00 4.50 5.00 $5.50 \quad 6.00 \quad 6.50 \quad 7.007 .50 \quad 8.00 \quad 8.50$ CLASS LIMITS 9.009 .5010 .00

WB02 (Depth $=25 \mathrm{~m})\left(\right.$ Lat $=40004,3^{\circ}$ Long $\left.=175002.0^{\circ} \mathrm{E}\right)$

$\begin{array}{lllllllllllllllllllllllllllllllll}\text { DATA } & .80 & .00 & 2.25 & .00 & 2.46 & 1.39 & 1.73 & 1.64 & 1.98 & 2.09 & 2.00 & 1.07 & 3.69 & 2.14 & .41 & .05 & .08 & .05 & .05 & .05 & .08 & .10 & .11 & .12\end{array}$ DATA $\quad .10 \quad 43$

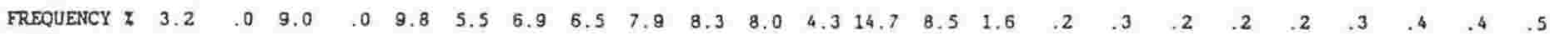
$\begin{array}{lllllll}\text { FREQUENCY } ₹ & .4 & .4 & .4 & .0\end{array}$

CUMULATIVE Z $\quad 3.2 \quad 3.2 \quad 12.2 \quad 12.2 \quad 22.0 \quad 27.5 \quad 34.5 \quad 41.0 \quad 48.9 \quad 57.2 \quad 65.2 \quad 69.5 \quad 84.2 \quad 92.8 \quad 94.4 \quad 94.6 \quad 94.995 .195 .3 \quad 95.5 \quad 95.8 \quad 96.2 \quad 96.7 \quad 97.2$ CUMULATIVE $\approx 97.597 .998 .3100 .0$

GRAVEL $=22.00$ SAND $=72.42 \mathrm{SILT}=2.28$ CLAY $=3.31$

WB03 (Depth $=43.9 \mathrm{~m})\left(\right.$ Lat $=40004.0^{\prime}$ Long $\left.=174055.9^{\prime} \mathrm{E}\right)$

$\begin{array}{lllllllllllllllllllllllllllllllll}\text { DATA } & .00 & .00 & .00 & .00 & .17 & .10 & .03 & .13 & .61 & 1.18 & 1.74 & 2.51 & 4.59 & 1.02 & .13 & .02 & .01 & .02 & .02 & .02 & .03 & .04 & .06 & .05\end{array}$ DATA $.05 \quad .28$

$\begin{array}{lllllllllllllllllllllllllllll}\text { FREQUENCY }: & .0 & .0 & .0 & .0 & 1.3 & .8 & .2 & 1.0 & 4.7 & 9.1 & 13.5 & 19.4 & 35.6 & 7.9 & 1.0 & .2 & .1 & .2 & .2 & .2 & .2 & .3 & .5 & .4\end{array}$ FREQUENCY $2 \quad .4 \quad 4 \quad 4 \quad .4 \quad, 0$

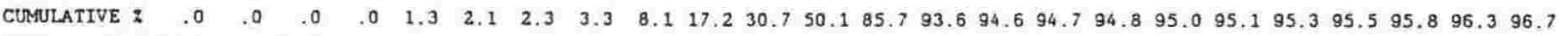
CUMULATIVE $=97.197,497.8100 .0$

GRAVEL $=1.32$ SAND $=93.26$ SILT $=1.70$ CLAY $=3.72$

WBO4 (Depth $=46 \mathrm{~m})\left(\right.$ Lat $=40005.2^{\prime}$ Long $\left.=174052.2^{\prime} \mathrm{E}\right)$

$\begin{array}{llllllllllllllllllllllllllll}\text { DATA } & .00 & .00 & .00 & .00 & .08 & .13 & .15 & .33 & .88 & 1.88 & 4.52 & 2.06 & 1.08 & .17 & .07 & .03 & .03 & .04 & .04 & .03 & .03 & .06 & .05 & .05\end{array}$ DATA $05 \quad 11$

$\begin{array}{llllllllllllllllllllllllllllll}\text { EREQUENCY } 2 & .0 & .0 & .0 & .0 & .7 & 1.1 & 1.3 & 2.8 & 7.4 & 15.7 & 37.8 & 17.2 & 9.0 & 1.4 & .6 & .3 & .3 & .3 & .3 & .3 & .3 & .5 & .4 & .4\end{array}$

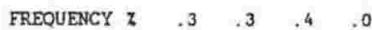

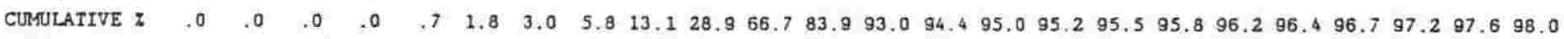
CUMULATIVE $z 98.398 .799 .1100 .0$

GRAVEL $=.67$ SAND $=94.31$ SILI $=2.59$ CLAY $=2.43$

WB07 (Depth $=60 \mathrm{~m})\left(\right.$ Lat $=40012,0^{\prime}$ Long $\left.=174039,0^{\prime} \mathrm{E}\right)$

$\begin{array}{llllllllllllllllllllllllll}\text { DATA } & .00 & .00 & .00 & .00 & .00 & .00 & .00 & .00 & .01 & .04 & .10 & .24 & .51 & .13 & .10 & .16 & .06 & .09 & .13 & .11 & .14 & .20 & .24 & .23\end{array}$ DATA $\quad .17 \quad .30$

$\begin{array}{llllllllllllllllllllllllllllll}\text { FREQUENCY } \% & .0 & .0 & .0 & .0 & .0 & .0 & .0 & .0 & .3 & 1.2 & 3.0 & 7.3 & 15.5 & 3.9 & 3.0 & 4.8 & 1.8 & 2.7 & 3.9 & 3.3 & 4.2 & 6.1 & 7.3 & 7.0\end{array}$

$\begin{array}{llllll}\text { FREQUENCY } ₹ \quad 5.2 & 5.2 & 5.2 & 9.1\end{array}$

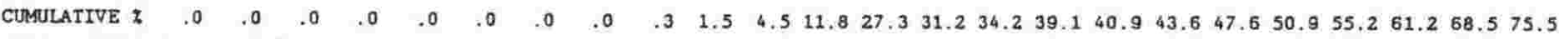
CUMULATIVE $₹ 80.6 \quad 65.890 .9100 .0$

GRAVEL $=.00$ SAND $=34.24$ SILT $=34.24$ CLAY $=31.52$

WB05 (Depth $=65.7 \mathrm{~m})\left(\right.$ Lat $=40006.8^{\prime}$ Long $\left.=174045.5^{\prime} \mathrm{E}\right)$

$\begin{array}{llllllllllllllllllllllllll}\text { DATA } & .00 & .00 & .00 & .00 & .00 & .00 & .01 & .01 & .02 & .03 & .16 & .40 & .53 & .10 & .14 & .00 & .01 & .06 & .11 & .11 & .13 & .17 & .21 & .20\end{array}$ $\begin{array}{lll}\text { DATA } & .18 & .37\end{array}$

$\begin{array}{llllllllllllllllllllllllllllllllll}\text { FREQUENCY } 2 & .0 & .0 & .0 & .0 & .0 & .0 & .3 & .3 & .6 & .9 & 4.9 & 12.2 & 16.1 & 3.0 & 4.3 & .0 & .3 & 1.8 & 3.3 & 3.3 & 4.0 & 5.2 & 6.4 & 6.1\end{array}$

FREQUENCY * $5.5 \quad 4.9 \quad 5.5 \quad 11.2$

$\begin{array}{llllllllllllllllllllllllllllllll}\text { CUMULATIVE } z & .0 & .0 & .0 & .0 & .0 & .0 & .3 & .6 & 1.2 & 2.1 & 7.0 & 19.1 & 35.3 & 38.3 & 42.6 & 42.6 & 42.9 & 44.7 & 48.0 & 51.4 & 55.3 & 60.5 & 56.9 & 72.9\end{array}$ CUMULATIVE 278.483 .388 .8100 .0

GRAVEL $=.00$ SARD $=42.55$ SILT $=24.32$ CLAY $=33.13$ 
OCLASS MIDPTS-3.25-2.75-2.25-1.75-1.25 $-.75 \quad-.25 \quad .25 \quad .75 \quad 1.25 \quad 1.75 \quad 2.25 \quad 2.75 \quad 3.25 \quad 3.75 \quad 4.25 \quad 4.75 \quad 5.25 \quad 5.75 \quad 6.25 \quad 6.75 \quad 7.25 \quad 7.75 \quad 8.25$ OCLASS MIDPTS 8.759 .259 .7515 .00

CLASS LIMITS-3.00-2.50-2.00-1.50-1.00 -.50 .00 .50 1.00 1.50 2.00 $2.50 \quad 3.00 \quad 3.50 \quad 4.00 \quad 4.50 \quad 5.00 \quad 5.50 \quad 6.00 \quad 6.50 \quad 7.00 \quad 7.50 \quad 8.00 \quad 8.50$ CLASS LIMITS 9.009 .5010 .00

WBOS (Depth $=80.4 \mathrm{~m}) \quad($ Lat $=40009.5$ Long $=174043.9$ ' $\mathrm{E})$

$\begin{array}{llllllllllllllllllllllllll}\text { DATA } & .00 & .00 & .00 & .00 & .00 & .00 & .01 & .01 & .07 & .18 & .54 & 1.15 & 5.07 & .71 & .71 & .32 & .29 & .21 & .36 & .40 & .36 & .67 & .74 & .72\end{array}$ DATA $.55 \quad 1.84$

$\begin{array}{lllllllllllllllllllllllllll}\text { FREQUENCX : } & .0 & .0 & .0 & .0 & .0 & .0 & .1 & .1 & .4 & 1.1 & 3.3 & 7.1 & 31.2 & 4.4 & 4.4 & 2.0 & 1.8 & 1.3 & 2.2 & 2.5 & 2.2 & 4.1 & 4.5 & 4.4\end{array}$

FREQUENCY $: \quad \begin{array}{llllll}4.0 & 4.4 & 3.4 & 11.3\end{array}$

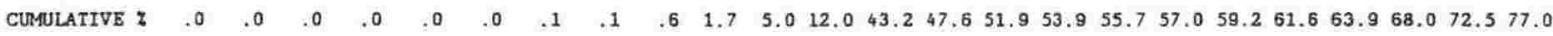
CUMULATIVE 780.985 .388 .7100 .0

GRAVEL $=.00$ SAND $=51.94$ SIL.T $=20.59$ CLAY $=27.47$

WB08 (Depth $=98$ ro $) \quad\left(\right.$ Lat $=40014.9$ ' Long $=174035.2^{\prime}$ E)

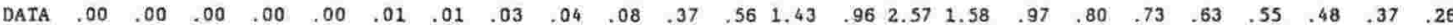
DATA $.20 \quad .83$

$\begin{array}{lllllllllllllllllllllllllllllll}\text { FREQUENCY } 2 & .0 & .0 & .0 & .0 & .0 & .1 & .1 & .2 & .3 & .6 & 2.7 & 4.0 & 10.2 & 6.9 & 18.4 & 11.3 & 6.9 & 5.7 & 5.2 & 4.5 & 3.9 & 3.4 & 2.7 & 1.9\end{array}$

FREQUENCY \& $\quad 1.6 \quad 2.0 \quad 1.4 \quad 5.9$

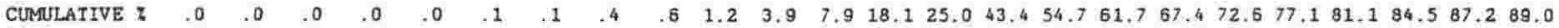
CUMULATIVE $\geq 90.692 .694 .1100 .0$

GRAVEL $=.00$ SAND $=43.41$ SILT $=43.77$ CLAY $=12.82$

WB09 $($ Depth $=105 \mathrm{~m})\left(\right.$ Lat $=40019.7^{\prime}$ Long $\left.=174039.0^{\prime} \mathrm{E}\right)$

$\begin{array}{lllllllllllllllllllllllllll}\text { DATA } & .00 & .00 & .00 & .00 & .03 & .04 & .03 & .13 & .38 & .42 & .90 & .36 & .45 & 2.53 & 6.03 & 2.39 & 1.46 & 1.23 & 1.35 & 1.40 & 1.85 & 2.58 & 2.40 & 2.18\end{array}$ DATA $1.94 \quad 3.93$

$\begin{array}{lllllllllllllllllllllllll}\text { FREQUENCY } 2 & .0 & .0 & .0 & .0 & .1 & .1 & .1 & .3 & 1.0 & 1.1 & 2.4 & 1.0 & 1.2 & 6.8 & 16.2 & 6.4 & 3.9 & 3.3 & 3.6 & 3.8 & 5.0 & 6.9 & 6.4 & 5.8\end{array}$

FREQUENCY I $\quad 4.6 \quad 4.3 \quad 5.2 \quad 10.5$

$\begin{array}{llllllllllllllllllllllllllllll}\text { CUMULAIIVE } z & .0 & 0 & .0 & .0 & .1 & .2 & .3 & .6 & 1.6 & 2.8 & 5.2 & 6.1 & 7.3 & 14.1 & 30.3 & 36.7 & 40.6 & 43.9 & 47.5 & 51.3 & 56.2 & 63.1 & 69.6 & 75.4\end{array}$ CUMULATIVE : 80.084 .389 .5100 .0

GRAVEL $=.08$ SAND $=30.21$ SILT $=39.29$ CLAY $=30.42$

WB10 $($ Depth $=114 \mathrm{~m})($ Lat $=40024,8$, Long $=174024.8, \mathrm{E})$

$\begin{array}{llllllllllllllllllllllllllllllllllll}\text { DATA } & 00 & .00 & .00 & .00 & .00 & .01 & .02 & .13 & .26 & 23 & .30 & 16 & 47 & 2.74 & 6.89 & 1.80 & 2.32 & 2.56 & 2.23 & 3.22 & 3.70 & 4.17 & 3.99 & 3.66\end{array}$ DATA $1.94 \quad 3.00$

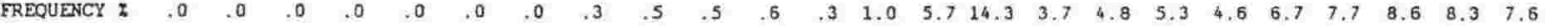
FREQUENCY \& $\quad 5.1 \quad 4.3 \quad 4.0 \quad 6.2$

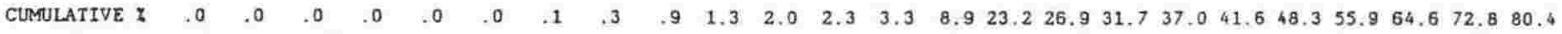
CUMULATIVE $₹$ 85. 5 89.8 93.8100 .0

GRAVEL $=.00$ SAND $=23.19$ SILT $=49.62$ CLAY $=27.20$

WBO1 (18m)

WBO2 $(25 \mathrm{~m})$

WBO3 $(43.9 \mathrm{~m})$

WBO $4(46 \mathrm{~m})$

WB07 (50m)

WBOS $(65,7 \mathrm{~m})$

WBOG $(80.4 \mathrm{~m})$

WBO8 (98m)

WB०9 $(105 \mathrm{~m})$

WB10(114m)

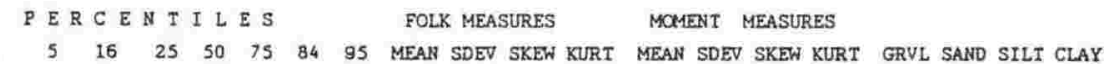

$\begin{array}{lllllllllllllllllllll}1.8 & 2.5 & 2.9 & 3.0 & 3.4 & 3.8 & 4.1 & 6.5 & 3.46 & .90 & .36 & 1.98 & 3.77 & 1.82 & 4.3125 .10 & .0 & 82.0 & 14.8 & 3.2\end{array}$

$\begin{array}{lllllllllllllllllllll}-2.5 & -2.3 & -1.3 & -.7 & 1.1 & 2.7 & 3.0 & 5.2 & .92 & 2.21 & .00 & .91 & 1.22 & 2.91 & 1.9810 .22 & 22.0 & 72.4 & 2.3 & 3.3\end{array}$

$\begin{array}{llllllllllllllllllll}-1.3 & .7 & 1.4 & 1.8 & 2.5 & 2.8 & 3.0 & 5.6 & 2.30 & 1.12 & -.05 & 1.99 & 2.65 & 2.26 & 3.8220 .70 & 1.3 & 93.3 & 1.7 & 3.7\end{array}$

$\begin{array}{llllllllllllllllllll}-.8 & .4 & 1.1 & 1.4 & 1.8 & 2.2 & 2.5 & 4.0 & 1.80 & .90 & .14 & 1.83 & 2.04 & 1.85 & 4.2026 .53 & .7 & 94.3 & 2.6 & 2.4\end{array}$

$\begin{array}{llllllllllllllllllllll}1.4 & 2.0 & 2.7 & 2.9 & 6.4 & 8.5 & 9.310 .6 & 6.12 & 2.96 & -.06 & .63 & 6.43 & 3.71 & .80 & 3.11 & .0 & 34.2 & 34.2 & 31.5\end{array}$

$\begin{array}{llllllllllllllllllll}.9 & 1.8 & 2.4 & 2.7 & 6.3 & 8.7 & 9.610 .9 & 6.08 & 3.16 & -.04 & .62 & 6.37 & 4.08 & .74 & 2.71 & .0 & 42.6 & 24.3 & 33.1\end{array}$

$\begin{array}{lllllllllllllllllllll}1.3 & 2.0 & 2.6 & 2.7 & 3.8 & 8.3 & 9.311 .4 & 5.24 & 3.10 & .63 & .69 & 5.86 & 4.09 & 1.08 & 3.10 & .0 & 51.9 & 20.6 & 27.5\end{array}$

$\begin{array}{llllllllllllllllllllll}1.3 & 2.2 & 2.9 & 3.5 & 4.3 & 6.3 & 7.410 .4 & 4.88 & 2.37 & .44 & 1.22 & 5.27 & 3.08 & 1.82 & 6.35 & .0 & 43.4 & 43.8 & 12.8\end{array}$

$\begin{array}{lllllllllllllllllll}7 & 2.0 & 3.6 & 3.9 & 6.3 & 8.5 & 9.510 .8 & 6.46 & 2.81 & .04 & .79 & 6.72 & 3.64 & .90 & 3.34 & .1 & 30.2 & 39.3 & 30.4\end{array}$

$\begin{array}{llllllllllllllllllll}1.2 & 3.2 & 3.8 & 4.2 & 6.6 & 3.1 & 8.810 .2 & 6.42 & 2.33 & -.05 & .74 & 6.69 & 2.96 & 1.03 & 4.52 & .0 & 23.2 & 49.6 & 27.2\end{array}$ 


\section{Appendix - 5}

\section{Magnetic measurements, site by site}

Measurement results are recorded for every specimen that underwent regular thermal demagnetisation. All measurements were made using cryogenic magnetometers. Three different magnetometers were used to measure samples: A two axis ScT cryogenic magnetometer (V) at the institute of geophysics, Victoria University of Wellington; A two axis semi-automated Cryogenic Consultants magnetometer (O) at the Geology Department, Oxford University; and a 2G Enterprises horizontal, 3 axis, cryogenic magnetometer $(\mathrm{G})$ in a magnetically shielded room at the Centre des Faibles Radioactivites, Gif-Sur-Yvette. Machine type, stratigraphic height, strike and dip are recorded for each site; and for each specimen, treatment level, total intensity $\left(\mathrm{mAm}^{-1}\right)$, corrected declination and inclination, azimuth and plunge are given.

Only thermal demagnetisation was carried out in this study. The treatment levels are labelled accordingly: $\mathrm{N} 00=\mathrm{NRM}$ measurement, $\mathrm{T} 05=$ demagnetisation at $50^{\circ} \mathrm{C}, \mathrm{T} 08=$ demagnetisation at $80^{\circ} \mathrm{C}, \mathrm{T} 10=$ demagnetisation at $100^{\circ} \mathrm{C}, \mathrm{T} 12=$ demagnetisation at $120^{\circ} \mathrm{C}$, etc. 
WANGANUI RIVER SITE 0010

HEIGHT $=0 \mathrm{~m}$ (base of section) 5 TRIKE $=043.0 \mathrm{DIP}=4.5$

SAMPLE FIELD NO. TREAT. INTENSITY CDEC CINC Y-AZ PLUNGE

W001001.1 W1-0101.1 N00 W001001.1 W1-0101.1 T05 W001001.1 W1-0101.1 T10 W001001.1 W1-0101.1 T15 W001001.1 W1-0101.1 T20 W001001.1 W1-0101.1 T25 W001001.1 W1-0101.1 T30 W001001.1 W1-0101.1 T35 W001002.1 W1-0102.1 N00 W001002.1 W1-01021 T05 W001002.1 W1-0102.1 T10 W001002.1 W1-0102.1 T15 W001002.1 W1-0102.1 T20 W001002.1 W1-0102.1 T25 W001002.1 W1-0102.1 T30 W001003.1 W1-0103.1 N00 W001003.1 W1-0103.1 T05 W001003.1 W1-0103.1 T10 W001003.1 W1-0103.1 T15 W001003.1 W1-0103.1 T20 W001003.1 W1-0103.1 T25 W001003.1 W1-0103.1 T30 W001004.1 W1-0104.1 N00 W001004.1 W1-0104.1 T05 W001004.1 W1-0104.1 T10 W001004.1 W1-0104.1 T15 W001004.1 W1-0104.1 T20 W001004.1 W1-0104.1 T25 W001004.1 W1-0104.1 T30 $\begin{array}{llll}0.709 \mathrm{E}-03 & 089.3 & -24.2 & 249.0\end{array}$ 74.0 74.0 $\begin{array}{llllll}0.739 \mathrm{E}-03 & 078.5 & 32.2 & 249.0 & 74.0 \\ 0.852 \mathrm{E}-03 & 083.2 & 32.5 & 249.0 & 74.0\end{array}$

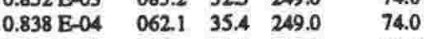
$\begin{array}{lllll}0.623 \mathrm{E}-04 & 050.1 & 50.9 & 249.0 & 74.0\end{array}$ $\begin{array}{llllll}0.417 \mathrm{E}-04 & 132.1 & 57.7 & 249.0 & 74.0\end{array}$ $\begin{array}{lllll}0.109 \mathrm{E}-03 & 162.8 & -60.5 & 244.0 & 74.0\end{array}$ $\begin{array}{lllll}0.721 \text { E- } 04 \quad 176.0 & -60.4 & 244.0 & 74.0\end{array}$ $\begin{array}{lllll}0.586 \mathrm{E}-04 & 177.3 & -38.7 & 244.0 & 74.0\end{array}$ $\begin{array}{lllll}0.490 \mathrm{E}-04 & 178.3 & -26.9 & 244.0 & 74.0\end{array}$ $\begin{array}{lllll}0.423 \mathrm{E}-04 & 186.2 & -44.0 & 244.0 & 74.0\end{array}$ $0.473 \mathrm{E}-04 \quad 147.9-18.7 \quad 244.0074 .0$ $\begin{array}{lllll}0.470 \mathrm{E}-04 & 146.4 & -18.7 & 244.0 & 74.0 \\ 0.115 \mathrm{E}-03 & 126.5 & -53.2 & 237.0 & 74.0\end{array}$ $\begin{array}{lllll}0.115 \mathrm{E}-03 & 126.5 & -53.2 & 237.0 & 74.0 \\ 0.916 \mathrm{E}-04 & 131.8 & -51.5 & 237.0 & 74.0\end{array}$ $\begin{array}{lllll}0.916 \mathrm{E}-04 & 131.8 & -51.5 & 237.0 & 74.0 \\ 0.728 \mathrm{E}-04 & 107.4 & -55.1 & 237.0 & 74.0\end{array}$ $\begin{array}{lllll}0.481 \mathrm{E}-04 & 108.4 & -42.5 & 237.0 & \mathbf{7 4 . 0}\end{array}$ $\begin{array}{lllll}0.431 \mathrm{E}-04 & 121.7 & -25.6 & 237.0 & 74.0\end{array}$ $\begin{array}{lllll}0.453 \mathrm{E}-04 & 128.3 & -33.9 & 237.0 & 74.0\end{array}$

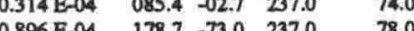
$\begin{array}{lllll}0.896 \mathrm{E}-04 & 178.7 & -73.0 & 237.0 & 78.0 \\ 0.636 \mathrm{E}-04 & 174.5 & -62.4 & 237.0 & 78.0\end{array}$ $\begin{array}{lllll}0.636 \mathrm{E}-04 & 174.5 & -62.4 & 237.0 & 78.0 \\ 0.496 \mathrm{E}-04 & 198.2 & -56.0 & 237.0 & 78.0\end{array}$

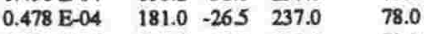
$\begin{array}{lllll}0.294 \mathrm{E}-04 & 174.9 & -39.3 & 237.0 & 78.0\end{array}$ $\begin{array}{lllll}0.163 \mathrm{E}-03 & 226.1 & -17.0 & 237.0 & 78.0\end{array}$ W001004.1 W1-0104.1 T35

WANGANUI RIVER SITE $002 \mathrm{~V}$

HEIGHT $=2 \mathrm{~m}$ (above base of section) STRIKE $=043.0 \mathrm{DIP}=4.5$

SAMPLE FIELD NO. TREAT. INTENSITY CDEC CINC Y-AZ PLUNGE

W002005.1 W5-4001.1 N00 W002005.1 W5-4001.1 T05 W002005.1 W5-4001.1 T10 W002005.1 W5-4001.1 T15 W002005.1 W5-4001.1 T20 W002005.1 W5-4001.1 T25 W002005.1 W5-4001.1 T30 W002005.1 W5-4001.1 T35 W002005.2 W5-4001.2 N00 W002006.1 W5-4002.1 N00 W002006.1 W5-4002.1 T05 W002006.1 W5 -4002.1 T10 W002006.1 W5-4002.1 T15 W002006.1 W5-4002.1 T20 W002006.1 W5-4002.1 T25 W002006.1 W5-4002.1 T30 W002006.1 W5-4002.1 T35 W002006.2 W5-4002.2 N00 W002007.1 W5-4003.1 N00 W002007.1 W5-4003.1 T05 W002007.1 W5-4003.1 T10 W002007.1 W5-4003.1 T15 W002007.1 W5-4003.1 T20 W002007.1 W5-4003.1 T25 W002007.1 W5-4003.1 T30 W002007.1 W5-4003.1 T35 W002007.2 W5-4003.2 N00

$\begin{array}{lrrrr}0.142 \text { E-03 } & 011.5 & -47.8 & 019.0 & 41.5 \\ 0.108 \text { E-03 } & 007.5 & -36.7 & 019.0 & 41.5 \\ 0.638 \text { E-04 } & 010.1 & -11.1 & 019.0 & 41.5 \\ 0.542 \text { E-04 } & 359.6 & 36.3 & 019.0 & 41.5 \\ 0.661 \text { E-04 } & 341.6 & 47.4 & 019.0 & 41.5 \\ 0.569 \text { E-04 } & 344.9 & 53.0 & 019.0 & 41.5 \\ 0.697 \text { E-04 } & 332.8 & 59.5 & 019.0 & 41.5 \\ 0.467 \text { E-04 } & 350.1 & 75.1 & 019.0 & 41.5 \\ 0.140 \text { E-03 } & 075.6 & -80.2 & 019.0 & 41.5 \\ 0.174 \text { E-03 } & 001.4 & -52.1 & 025.0 & 45.0 \\ 0.129 \text { E-03 } & 358.5 & -45.6 & 025.0 & 45.0 \\ 0.920 \text { E-04 } & 359.2 & -29.8 & 025.0 & 45.0 \\ 0.532 \text { E-04 } & 348.4 & -03.6 & 025.0 & 45.0 \\ 0.518 \text { E-04 } & 339.6 & 20.7 & 025.0 & 45.0 \\ 0.676 \text { E-04 } & 317.8 & 26.7 & 025.0 & 45.0 \\ 0.338 \text { E-04 } & 303.3 & 30.3 & 025.0 & 45.0 \\ 0.320 \text { E-04 } & 089.2 & -58.5 & 025.0 & 45.0 \\ 0.170 \text { E-03 } & 032.3 & -60.7 & 025.0 & 45.0 \\ 0.139 \text { E-03 } & 070.3 & -50.4 & 030.0 & 45.0 \\ 0.107 \text { E-03 } & 081.0 & -43.8 & 030.0 & 45.0 \\ 0.689 \text { E-04 } & 094.2 & -23.0 & 030.0 & 45.0 \\ 0.599 \text { E-04 } & 112.9 & 24.4 & 030.0 & 45.0 \\ 0.529 \text { E-04 } & 114.8 & 33.2 & 030.0 & 45.0 \\ 0.729 \text { E-04 } & 138.5 & 31.1 & 030.0 & 45.0 \\ 0.621 \text { E-04 } & 127.2 & 16.5 & 030.0 & 45.0 \\ 0.275 \text { E-04 } & 147.1 & -46.7 & 030.0 & 45.0 \\ 0.171 \text { E-03 } & 027.4 & -68.7 & 030.0 & 45.0\end{array}$

WANGANUI RIVER SITE 004P

HEIGHT $=166 \mathrm{~m}$ (above base of section) STRIKE $=043.0 \mathrm{DIP}=4.5$

SAMPLE FIELDNO. TREAT. INTENSITY CDEC CINC Y-AZ PLUNGE

W004008.1 W5-4104.1 N00 W004008.1 W5-4104.1 T05 W004008.1 W5-4104.1 T10 W004008.1 W5-4104.1 T10 W004008.1 W5-4104.1 T15
W004008.1 W5-4104.1 T20 W004008.1 W5-4104.1 T20 W004008.1 W5-4104.1 T25 W004008.1 W5-4104.1 T30 W004008.1 W5-4104.1 T35 W004009.1 W5-4105.1 N00 W004009.1 W5-4105.1 T05 W004009.1 W5-4105.1 T10 W004009.1 W5-4105.1 T15 W004009.1 W5-4105.1 T20 W004009.1 W5-4105.1 T25 W004009.1 W5-4105.1 T30 W004009.1 W5-4105.1 T35 W004009.1 W5-4105.1 T35 W004009.2 W5-4105.2 N00
W004010.1 W5-4106.1 N00 W004010.1 W5-4106.1 N00 W004010.1 W5 4106.1 TOS W004010.1 W5 4106.1 T10 W004010.1 W5-4106.1 T15 W004010.1 W5-4106.1 T20 W004010.1 W5-4106.1 T25 W004010.1 W5-4106.1 T30 W004010.1 W5-4106.1 T35 W004010.2 W5 4106.2 NOO

WANGANUI RIVER SITE $005 \mathrm{~V}$

HEIGHT $=211 \mathrm{~m}$ (above base of section) STRIKE $=043.0 \mathrm{DIP}=45$ SAMPLE FIELDNO. TREAT. INTENSITY CDEC CINC Y-AZ PLUNGE

W005011.1 W5-4207.1 N00 W005011.1 W5-4207.1 T05 W005011.1 W5-4207.1 T10 W005011.1 W5-4207.1 T15 W005011.1 W5-4207.1 T20 W005011.1 W5-4207.1 T25 W005011.1 W5-4207.1 T30 W005011.1 W5- 4207.1 T35 W005011.2 W5-4207.2 N00 W005012.1 W5-4208.1 N00 W005012.1 W5-4208.1 T05 W005012.1 W5-4208.1 T10 W005012.1 W5-4208.1 T15 W005012.1 W5-4208.1 T20 W005012.1 W5-4208.1 T25 W005012.1 W5-4208.1 T30 W005012.1 W5-4208.1 T35 W005012. WS-4208.2 N00 W005013.1 WS-4209.1 N00 W005013.1 W5-4209.1 T05 W005013.1 W5-4209.1 T10 w005013.1 W5-4209.1 T15 W005013.1 W5-4209.1 T20 w005013.1 W5-4209.1 T25 W005013.1 W5-4209.1 T30 W005013.1 W5-4209.1 T35 $\begin{array}{llll}0.122 \text { E-03 } & 031.7 & -70.6 & 220.0\end{array}$ $\begin{array}{lllll}0.553 & \mathrm{E}-0.4 & 078.8 & -66.4 & 220.0\end{array}$ $\begin{array}{llll}0.282 \text { E- } 04 & 144.9 & -29.0 & 220.0\end{array}$ $\begin{array}{llll}0.644 \mathrm{E}-04 & 158.2 & 28.3 & 220.0\end{array}$ $\begin{array}{llll}0.599 \mathrm{E}-0.4 & 162.8 & 39.3 & 220.0\end{array}$ $\begin{array}{llll}0.854 \mathrm{E}-04 & 165.3 & 49.6 & 220.0\end{array}$ $\begin{array}{llll}0.752 \text { E- } 04 & 161.4 & 39.8 & 220.0\end{array}$ $\begin{array}{lllll}0.500 \text { E-04 } & 160.2 & 67.9 & 220.0\end{array}$ $\begin{array}{llll}0.210 \mathrm{E}-03 & 010.1 & -63.6 & 220.0\end{array}$ $\begin{array}{lllll}0.161 \mathrm{E}-03 & 345.1 & -50.9 & 219.0\end{array}$ $\begin{array}{llll}0.122 \mathrm{E}-03 & 337.8 & 40.9 & 219.0\end{array}$ $\begin{array}{llll}0.798 \mathrm{E}-04 & 331.8 & -28.3 & 219.0\end{array}$ $\begin{array}{lllll}0.341 & \mathrm{E}-04 & 309.4 & 30.5 & 219.0\end{array}$ $\begin{array}{llll}0.417 \text { E- } 04 & 275.4 & 36.6 & 219.0\end{array}$ $\begin{array}{llll}0.430 \mathrm{E}-04 & 228.7 & 51.9 & 219.0\end{array}$ $\begin{array}{lllll}0.494 \mathrm{E}-0.4 & 218.4 & 53.4 & 219.0\end{array}$ $\begin{array}{lllll}0.324 \mathrm{E}-04 & 190.4 & 47.6 & 219.0\end{array}$ $\begin{array}{llll}0.395 \mathrm{E}-03 & 334.3 & -25.0 & 219.0\end{array}$ $\begin{array}{llll}0.201 \mathrm{E}-03 & 005.1 & -56.1 & 219.0\end{array}$ $\begin{array}{llll}0.160 \mathrm{E}-03 & 008.8 & -53.7 & 219.0\end{array}$ $\begin{array}{llll}0.985 \text { E-04 } & 012.2 & -54.0 & 219.0\end{array}$

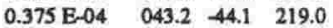
$\begin{array}{lllll}0.247 \mathrm{E}-04 & 033.8 & -50.1 & 219.0\end{array}$ 0.301 E-0 $4 \quad 029.7-11.0219 .0$ $\begin{array}{llll}0.129 \mathrm{E}-04 & 046.7 & 78.8 & 219.0\end{array}$ $\begin{array}{llll}0.274 \mathrm{E}-04 & 148.6 & 39.5 & 219.0\end{array}$ $\begin{array}{llll}0.125 \mathrm{E}-03 & 032.7 & -595 & 219.0\end{array}$

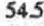

545 545 54.5 54.5 54.5 545 505 505 505 505

WANGANUI RIVER SITE 007V

HEIGHT $=309 \mathrm{~m}$ (above base of section) STRIKE $=043.0 \mathrm{DIP}=4.5$

SAMPLE FIELD NO. TREAT. INTENSITY CDEC CINC Y-AZ PLUNGE

W007014.1 W5-4410.1 N00 W007014.1 W5-4410.1 T05 W007014.1 W5-4410.1 T10 W007014.1 W5-4410.1 T15 w007014.1 W5-4410.1 T20 W007014.1 W5-4410.1 T25 W007014.1 W5-4410.1 T30 W007014.1 W5-4410.1 T30 W007014.2 W5-4410.2 N0O W007015.1 W5-4411.1 N00 W007015.1 W5-4411.1 T05 W007015.1 W5-4411.1 T10 W007015.1 W5- 4411.1 T15 W007015.1 W5- 4411.1 T15 W007015.1 W5-4411.1 T25 W007015.1 W5-4411.1 T30 W007015.1 W5-4411.1 T35 w007015.2 w5-4411.2 N00 w007016.1 W5-4412.1 N00 W007016.1 W5-4412.1 T05 $\begin{array}{lll}\text { W007016.1 W5- } 4412.1 & \text { T05 } \\ \text { W007016.1 W5-4412.1 T10 }\end{array}$ W007016.1 W5-4412.1 T15 W007016.1 W5-4412.1 T20 W007016.1 W5-4412.1 T25 W007016.1 W5-4412.1 T30

$\begin{array}{llll}0.496 \mathrm{E}-03 & 331.9 & -61.3 & 173.0\end{array}$ $\begin{array}{lllll}0.428 \mathrm{E}-03 & 325.4 & -60.3 & 173.0\end{array}$ $\begin{array}{llll}0.133 \mathrm{E}-03 & 318.0 & -57.8 & 173.0\end{array}$ $\begin{array}{llll}0.133 & 292.4 & -52.3 & 173.0\end{array}$ $\begin{array}{llll}0.697 \mathrm{E}-04 & 291.4 & -31.8 & 173.0 \\ 0.285 \mathrm{E}-04 & 261.0 & -06.6 & 173.0\end{array}$ $\begin{array}{llll}0.134 \mathrm{E}-04 & 188.5 & 64.4 & 173.0\end{array}$ $\begin{array}{llll}0.465 \mathrm{~B}-04 & 087.2 & 39.6 & 173.0\end{array}$ $\begin{array}{lllll}0.687 \mathrm{E}-03 & 333.6 & -61.9 & 173.0\end{array}$ $\begin{array}{llll}0.636 \mathrm{E}-03 & 332.1 & -43.6 & 175.0\end{array}$ $\begin{array}{lllll}0.568 \mathrm{E}-03 & 332.2 & -38.6 & 175.0\end{array}$ $\begin{array}{llllll}0.398 & \mathrm{E}-03 & 325.0 & -33.7 & 175.0\end{array}$ $\begin{array}{lllll}0.198 & \text { E- } 03 & 313.5 & -20.9 & 175.0\end{array}$ $\begin{array}{lllll}0.115 \mathrm{E}-03 & 305.7 & -10.6 & 175.0\end{array}$ $\begin{array}{lllll}0.112 \mathrm{E}-03 & 322.9 & 26.8 & 175.0\end{array}$

$\begin{array}{lllll}0.746 & \mathrm{E}-04 & 321.9 & 47.4 & 175.0\end{array}$

$\begin{array}{lllll}0.906 \mathrm{E}-04 & 059.3 & 47.1 & 175.0\end{array}$

$\begin{array}{lllll}0.709 \mathrm{E}-03 & 332.0 & -58.0 & 175.0\end{array}$

$\begin{array}{lllll}0.609 \mathrm{E}-03 & 344.0 & -55.0 & 175.0\end{array}$

$\begin{array}{lllll}0.427 \mathrm{E}-03 & 337.4 & -53.8 & 175.0\end{array}$

$\begin{array}{lllll}0.338 & \mathrm{E}-03 & 331.1 & -53.4 & 175.0\end{array}$

$\begin{array}{lllll}0.170 \mathrm{E}-03 & 324.5 & -50.9 & 175.0\end{array}$

$\begin{array}{lllll}0.731 & \text { E-04 } & 297.8 & -58.2 & 175.0\end{array}$

$\begin{array}{lllll}0.565 \text { E- } 04 & 289.9 & -50.2 & 175.0\end{array}$

0.404 E-04 $216.6 \quad-51.5 \quad 175.0$ $\begin{array}{lllll}0.650 \mathrm{E}-04 & 203.8 & -37.0 & 175.0\end{array}$

WANGANUI RIVER SITE $009 \mathrm{~V}$

HEIGHT $=395 \mathrm{~m}$ (above base of section) STRIKE $=043.0 \mathrm{DIP}=4.5$

SAMPLE FELD NO. TREAT. INTENSITY CDEC CINC Y-AZ PLUNGE

W009017.1 W5-4513.1 N00 W009017.1 W5-4513.1 T05 W009017.1 W5-4513.1 T10 W009017.1 W5-4513.1 T15 W009017.1 W5-4513.1 T20 W009017.1 W5-4513.1 T25 W009017.1 W5-4513.1 T30 w009017.1 W5-4513.1 T35 W009017.2 W5-4513.2 N00 W009018.1 WS-4514.1 N0O W009018.1 W5-4514.1 T05 W009018.1 W5-4514.1 T10 W009018.1 W5-4514.1 T15 W009018.1 W5-4514.1 T20 W009018.1 W5-4514.1 T25 W009018.1 W5-4514.1 T30 W009018.1 W5-4514.1 T35 W009019.1 W5-4515.1 N00 W009019.1 W5-4515.1 T05 W009019.1 W5-4515.1 T10 w009019.1 W5-4515.1 T15 W009019.1 W5-4515.1 T20 W009019.1 W5-4515.1 T25 W009019.1 W5-4515.1 T30 W009019.1 W5-4515.1 T35 W009019.2 W5-4515.2 N0O W009020.1 W5-4516.1 NOO W009020.1 W5-4516.1 T05 W009020.1 W5-4516.1 T10 W009020.1 W5-4516.1 T15 W009020.1 W5-4516.1 T20 W009020.1 W5-4516.1 T2S W009020.1 W5-4516.1 T30 W009020.1 W5-4516.1 T35 
W009021.1 W5-4517.1 N00 W009021.1 W5-4517.1 T0S W009021.1 W5-4517.1 T10 W009021.1 W5-4517.1 T15 W009021.1 W5-4517.1 T20 W009021.1 W5-4517.1 T25 W009021.1 W5-4517.1 T30 W009021.1 W5-4517.1 T35 W009021.2 W5-4517.2 N00

0.771 E-03 $\quad 356.1-57.5 \quad 205.0$ $0.700 \mathrm{E}-03 \quad 359.3-570 \quad 2050$ $\begin{array}{llll}0.700 \mathrm{E}-03 & 359.3 & -57.0 & 205.0 \\ 0.539 \mathrm{E}-03 & 358.1 & -55.8 & 205.0\end{array}$ $\begin{array}{lllll}0.258 \mathrm{E} & 358.1 & -55.8 & 205.0\end{array}$ $0.833 \mathrm{E}-04 \quad 007.0-493 \quad 205.0$ $\begin{array}{llll}0.590 \mathrm{E}-04 & 021.7 & -26.7 & 205\end{array}$ $\begin{array}{llll}0.467 \mathrm{E}-04 & 021.7 & -26.7 & 205.0 \\ 0.190 .1 & 09.0 & 205.0\end{array}$ $\begin{array}{rrrrr}0.467 \text { E-04 } & 079.1 & 09.0 & 205.0 \\ 0.190 \text { E- } 03 & 309.2 & -43.4 & 205.0\end{array}$ $\begin{array}{llllll}0.781 \mathrm{E}-03 & 342.3 & -54.0 & 205.0\end{array}$
35.

35.5

35.5

35.5

35.5

35.5

35.5
WANGANUI RIVER SITE 010V

W

SAMPLE FIELD NO. TREAT. INTENSITY CDEC CINC Y-AZ PLUNGE

W010022.1 W5-4618.1 NOO W010022.1 W5- 4618.1 T05 W010022.1 W5-4618.1 T10 W010022.1 W5-4618.1 T15 W010022.1 W5-4618.1 T20 W010022.1 W5-4618.1 T25 W010022.1 W5-4618.1 T30 W010022.1 W5-4618.1 T35 W010022.2 W5-4618.2 N0O W010023.1 W5-4619.1 N0O W010023.1 W5-4619.1 T05 W010023.1 W5-4619.1 T10 W010023.1 W5-4619.1 T15 W010023.1 W5-4619.1 T20 W010023.1 W5-4619.1 T25 W010023.1 W5-4619.1 T30 W010023.1 W5-4619.1 T35 W010023.2 W5-4619.2 N00 W010024.1 W5-4620.1 N00 W010024.1 W5-4620.1 T05 W010024.1 W5 $4620.1 \mathrm{~T} 10$ W010024.1 W5-4620.1 T15 W010024.1 W5-4620.1 T20 W010024.1 W5-4620.1 T25 W010024.1 W5-4620.1 T30 W010024.1 W5-4620.1 T35 W010025.1 W5-4621.1 N00 W010025.1 W5-4621.1 T05 W010025.1 W5-4621.1 T10 W010025.1 W5-4621.1 T15 W010025.1 W5-4621.1 T20 W010025.1 W5-4621.1 T25 W010025.1 W5-4621.1 T30 W010025.1 W5-4621.1 T35 W010025.2 W5-4621.2 N00 W010026.1 W5-4622.1 N00 W010026.1 W5-4622.1 T05 W010026.1 W5-4622.1 T10 W010026.1 W5-4622.1 T15 W010026.1 W5-4622.1 T20 W010026.1 W5-4622.1 T25 W010026.1 W5-4622.1 T30 W010026.1 W5-4622.1 T35

$\begin{array}{lllll}0.842 \mathrm{E}-03 & 005.2 & -573 & 220.0 & 26.5 \\ 0.736 \mathrm{E}-03 & 013.0 & -57.7 & 220.0 & 26.5 \\ 0.521 \mathrm{E}-03 & 013.4 & -59.8 & 220.0 & 26.5 \\ 0.258 \mathrm{E}-03 & 025.0 & -59.2 & 220.0 & 26.5 \\ 0.168 \mathrm{E}-03 & 051.5 & -70.6 & 220.0 & 26.5 \\ 0.153 \mathrm{E}-03 & 041.4 & -61.4 & 220.0 & 26.5 \\ 0.113 \mathrm{E}-03 & 053.2 & -53.7 & 220.0 & 26.5 \\ 0.128 \mathrm{E}-03 & 008.0 & -64.4 & 220.0 & 26.5 \\ 0.103 \mathrm{E}-02 & 355.7 & -56.6 & 220.0 & 26.5 \\ 0.823 \mathrm{E}-03 & 323.4 & -56.5 & 216.0 & 25.5 \\ 0.700 \mathrm{E}-03 & 321.0 & -56.3 & 216.0 & 25.5 \\ 0.496 \mathrm{E}-03 & 305.7 & -52.0 & 216.0 & 25.5 \\ 0.291 \mathrm{E}-03 & 282.3 & -36.9 & 216.0 & 25.5 \\ 0.204 \mathrm{E}-03 & 280.0 & -52.3 & 216.0 & 25.5 \\ 0.178 \mathrm{E}-03 & 271.1 & -41.8 & 216.0 & 25.5 \\ 0.149 \mathrm{E}-03 & 263.2 & -46.7 & 216.0 & 25.5 \\ 0.130 \mathrm{E}-03 & 245.9 & -33.2 & 216.0 & 25.5 \\ 0.987 \mathrm{E}-03 & 352.3 & -54.2 & 216.0 & 25.5 \\ 0.726 \mathrm{E}-03 & 358.2 & -55.7 & 218.0 & 26.5 \\ 0.604 \mathrm{E}-03 & 002.8 & -56.3 & 218.0 & 26.5 \\ 0.440 \mathrm{E}-03 & 009.7 & -56.0 & 218.0 & 26.5 \\ 0.181 \mathrm{E}-03 & 015.2 & -57.6 & 218.0 & 26.5 \\ 0.821 \mathrm{E}-04 & 046.2 & -53.1 & 218.0 & 26.5 \\ 0.651 \mathrm{E}-04 & 044.2 & -48.1 & 218.0 & 26.5 \\ 0.151 \mathrm{E}-03 & 124.7 & 10.5 & 218.0 & 26.5 \\ 0.816 \mathrm{E}-04 & 008.2 & 00.2 & 218.0 & 26.5 \\ 0.824 \mathrm{E}-03 & 355.2 & -55.0 & 217.0 & 30.0 \\ 0.688 \mathrm{E}-03 & 001.4 & -55.0 & 217.0 & 30.0 \\ 0.499 \mathrm{E}-03 & 003.7 & -53.4 & 217.0 & 30.0 \\ 0.221 \mathrm{E}-03 & 004.4 & -50.1 & 217.0 & 30.0 \\ 0.163 \mathrm{E}-03 & 000.4 & -39.8 & 217.0 & 30.0 \\ 0.152 \mathrm{E}-03 & 005.1 & -39.8 & 217.0 & 30.0 \\ 0.108 \mathrm{E}-03 & 007.2 & -595 & 217.0 & 30.0 \\ 0.187 \mathrm{E}-03 & 001.6 & -44.5 & 217.0 & 30.0 \\ 0.764 \mathrm{E}-03 & 355.2 & -58.2 & 217.0 & 30.0 \\ 0.667 \mathrm{E}-03 & 008.1 & -60.8 & 219.0 & 25.5 \\ 0.576 \mathrm{E}-03 & 022.5 & -59.0 & 219.0 & 25.5 \\ 0.363 \mathrm{E}-03 & 025.3 & -62.1 & 219.0 & 25.5 \\ 0.193 \mathrm{E}-03 & 079.2 & -55.0 & 219.0 & 25.5 \\ 0.114 \mathrm{E}-03 & 111.8 & -30.6 & 219.0 & 25.5 \\ 0.158 \mathrm{E}-03 & 109.6 & -15.7 & 219.0 & 25.5 \\ 0.150 \mathrm{E}-03 & 098.3 & -00.7 & 219.0 & 25.5 \\ 0.145 \mathrm{E}-03 & 092.2 & -39.8 & 219.0 & 25.5 \\ & & & & \end{array}$

WANGANUI RIVER SITE $014 \mathrm{~V}$

HEIGHT $=458 \mathrm{~m}$ (above base of section) STRIKE $=043.0 \mathrm{DIP}=4.5$

SAMPLE FIELD NO. TREAT. INTENSTTY CDEC CINC Y-AZ PLUNGE

$\begin{array}{llllllll}\text { W014027.1 W4-6516.1 N00 } & 0.499 \mathrm{E}-03 & 117.6 & -43.3 & 356.0 & 42.0 \\ \text { W014027.1 W4-6516.1 T05 } & 0.389 \mathrm{E}-03 & 114.3 & -50.3 & 356.0 & 42.0 \\ \text { W014027.1 W4-6516.1 T10 } & 0.324 \mathrm{E}-03 & 118.6 & -45.6 & 356.0 & 42.0 \\ \text { W014027.1 W4-6516.1 T15 } & 0.288 \mathrm{E}-03 & 121.1 & -44.6 & 356.0 & 42.0 \\ \text { W014027.1 W4-6516.1 T20 } & 0.217 \mathrm{E}-03 & 116.1 & -45.9 & 356.0 & 42.0 \\ \text { W014027.1 W4-6516.1 T25 } & 0.129 \mathrm{E}-03 & 128.9 & -40.7 & 356.0 & 42.0 \\ \text { W014027.1 W4-6516.1 T30 } & 0.535 \mathrm{E}-04 & 108.1 & -41.3 & 356.0 & 42.0 \\ \text { W014027.2 W4-6516.2 N00 } & 0.473 \mathrm{E}-03 & 040.3 & -57.9 & 356.0 & 42.0 \\ \text { W014028.1 W4-6517.1 N00 } & 0.135 \mathrm{E}-03 & 005.2 & -49.8 & 000.0 & 44.0 \\ \text { W014028.1 W4-6517.1 T05 } & 0.119 \mathrm{E}-03 & 302.5 & -60.9 & 000.0 & 44.0 \\ \text { W014028.1 W4-6517.1 T10 } & 0.578 \mathrm{E}-04 & 276.0 & -47.9 & 000.0 & 44.0 \\ \text { W014028.1 W4-6517.1 T15 } & 0.439 \mathrm{E}-04 & 263.6 & 03.9 & 000.0 & 44.0 \\ \text { W014028.1 W4-6517.1 T20 } & 0.475 \mathrm{E}-04 & 257.7 & 27.5 & 000.0 & 44.0 \\ \text { W014028.1 W4-6517.1 T25 } & 0.493 \mathrm{E}-04 & 287.9 & 19.4 & 000.0 & 44.0 \\ \text { W014028.1 W4-6517.1 T30 } & 0.499 \mathrm{E}-04 & 283.9 & 16.0 & 000.0 & 44.0 \\ \text { W014028.2 W4-6517.2 N00 } & 0.123 \mathrm{E}-03 & 344.8 & -73.8 & 000.0 & 44.0 \\ \text { W014029.1 W4-6518.1 N00 } & 0.138 \mathrm{E}-03 & 357.6 & -11.4 & 002.0 & 41.0 \\ \text { W014029.1 W4-6518.1 T05 } & 0.110 \mathrm{E}-03 & 325.4 & -14.2 & 002.0 & 41.0 \\ \text { W014029.1 W4-6518.1 T10 } & 0.715 \mathrm{E}-04 & 312.8 & 23.5 & 002.0 & 41.0 \\ \text { W014029.1 W4-6518.1 T15 } & 0.702 \mathrm{E}-04 & 307.3 & 37.9 & 002.0 & 41.0 \\ \text { W014029.1 W4-6518.1 T20 } & 0.829 \mathrm{E}-04 & 304.8 & 55.2 & 002.0 & 41.0 \\ \text { W014029.1 W4-6518.1 T25 } & 0.707 \mathrm{E}-04 & 304.1 & 53.0 & 002.0 & 41.0 \\ \text { W014029.1 W4-6518.1 T30 } & 0.719 \mathrm{E}-04 & 288.8 & 58.1 & 002.0 & 41.0 \\ \text { W014029.2 W4-6518.2 N00 } & 0.180 \mathrm{E}-03 & 002.3 & -39.1 & 002.0 & 41.0\end{array}$

WANGANUI RIVER SITE $015 \mathrm{~V}$

HEIGHT $=599 \mathrm{~m}$ (above base of section) STRIKE $=043.0 \mathrm{DIP}=45$

SAMPLE FIELDNO. TREAT. INTENSITY CDEC CINC Y-AZ PLUNGE

W015030.1 W4-6619.1 N00 W015030.1 W4-6619.1 T05 W015030.1 W4-6619.1 T10 W015030.1 W4-6619.1 T15 W015030.1 W4-6619.1 T20 W015030.1 W4-6619.1 T25 W015030.1 W4-6619.1 T30 W015030.2 W4-6619.2 N00 W015031.1 W4-6620.1 N00 W015031.1 W4-6620.1 T05 W015031.1 W4-6620.1 T10

$\begin{array}{lllll}0.141 \text { E-03 } & 007.8 & -55.3 & 246.0 & 53.0 \\ 0.127 \text { E-03 } & 018.5 & -65.7 & 246.0 & 53.0 \\ 0.531 \text { E-04 } & 009.8 & -61.0 & 246.0 & 53.0 \\ 0.118 \text { E-04 } & 166.3 & 17.7 & 246.0 & 53.0 \\ 0.435 \text { E-04 } & 173.5 & 49.1 & 246.0 & 53.0 \\ 0.407 \text { E-04 } & 187.2 & 53.8 & 246.0 & 53.0 \\ 0.292 \text { E-04 } & 180.2 & 50.6 & 246.0 & 53.0 \\ 0.138 \text { E-03 } & 006.1 & -433 & 246.0 & 53.0 \\ 0.153 \text { E-03 } & 012.1 & -45.6 & 253.0 & 47.0 \\ 0.126 \text { E-03 } & 003.9 & -62.6 & 253.0 & 47.0 \\ 0.544 \text { E-04 } & 356.4 & -65.6 & 253.0 & 47.0\end{array}$

W015031.1 W4-6620.1 T15 W015031.1 W4-6620.1 T20 W015031.1 W4-6620.1 T25 W015031.1 W4-6620.1 T30 W015031.2 W4-6620.2 NOO W0150321 W4-6621.1 N00 WO150321 W46621.1 NOD WO15032.1 W46021.1 TOS W015032.1 W46621.1 T10 W015032.1 W4-6621.1 T15 W015032.1 WA-6621.1 T20 W015032.1 W4-6621.1 T2S W015032.1 W4-6621.1 T30 W015032.2 W4-6621.2 N00 $\begin{array}{llll}0.349 \mathrm{E}-04 & 198.6 & 66.2 & 253.0\end{array}$

$\begin{array}{lllll}0.562 \text { E- } 04 & 203.7 & 48.8 & 253.0\end{array}$

$\begin{array}{lllll}0.568 \text { E- } 04 & 204.8 & 53.0 & 253.0\end{array}$

$\begin{array}{llll}0.572 \text { E- } 04 \quad 192.6 & 46.0 & 253.0\end{array}$

$\begin{array}{llll}0.127 \mathrm{E}-03 & 010.0 & -43.8 & 253.0\end{array}$

$\begin{array}{lllll}0.132 \mathrm{E}-03 & 022.2 & -34.9 & 257.0\end{array}$

$\begin{array}{lllll}0.116 \mathrm{E}-03 & 019.0 & -50.7 & 257.0\end{array}$

$\begin{array}{llll}0.464 \mathrm{E}-04 & 031.7 & -27.6 & 257.0\end{array}$

$\begin{array}{llll}0.298 \text { E-04 } & 093.4 & 64.2 & 257.0\end{array}$

0.433 E-04 $114.3 \quad 66.1 \quad 257.0$

$\begin{array}{llll}0.530 \mathrm{E}-04 & 193.5 & 72.5 & 257.0\end{array}$

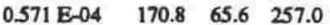

$\begin{array}{lllll}0.152 & \mathrm{E}-03 & 023.4 & -343 & 257.0\end{array}$
47.0

47.0

WANGANUI RIVER SITE $018 \mathrm{~V}$

HEKGHT $=701 \mathrm{~m}$ (above base of section) STRIKE=043.0 DIP=4.5

SAMPLE FELD NO. TREAT. INTENSITY CDEC CINC Y-AZ PLUNGE

W018033.1 W4-6722.1 NOO W018033.1 W4-6722.1 T05 W018033.1 W4-6722. T10 W018033.1 W4-6722.1 T15 W018033.1 W4-6722.1 T15 W018033.1 W4-6722.1 T20 W018033.1 W4-6722.1 T2S W018033.1 W4-6722.1 T30 W018033.2 W4-6722.2 NOO W018034.1 W4-6723.1 NOO W018034. W -6723.1 TOS W018034.1 W4-6723.1 T10 W018034.1 W4-6723.1 T15 W018034.1 W4-6723.1 T20 W018034.1 W4-6723.1 T25 W018034.1 W4-6723.1 T30 W0180342 W4-67232 NOO W018035.1 W4-6724.1 N0O w018035.1 W4-6724.1 T05 W018035.1 W4-6724.1 T05 W018035.1 W4-6724.1 T10 W018035.1 W4-6724.1 T15 W018035.1 W4-6724.1 T20 W018035.1 W4-6724.1 T25 W018035.1 W4-6724.1 T30 W018035.2 W4-6724.2 N00 W018035.2 W4-6724.2 N00 W018036.1 W4-6725.1 N00 W018036.1 W4-6725.1 T05 W018036.1 W4-6725.1 T10 W018036.1 W4-6725.1 T15 W018036.1 W4-6725.1 T20 W018036.1 W4-6725.1 T2S W018036.1 W4-6725.1 T30 W018036.2 W4-6725.2 NOO

$\begin{array}{lllll}0.302 \mathrm{E}-03 & 351.2 & -55.2 & 299.0 & 53.5 \\ 0.251 \mathrm{E}-03 & 333.2 & -64.7 & 299.0 & 53.5 \\ 0.148 \mathrm{E}-03 & 322.4 & -55.0 & 299.0 & 53.5 \\ 0.917 \mathrm{E}-04 & 290.4 & -53.5 & 299.0 & 53.5 \\ 0.725 \mathrm{E}-04 & 277.4 & -39.7 & 299.0 & 53.5 \\ 0.906 \mathrm{E}-04 & 265.7 & -11.4 & 299.0 & 53.5 \\ 0.938 \mathrm{E}-04 & 258.6 & -02.5 & 299.0 & 53.5 \\ 0.426 \mathrm{E}-03 & 013.3 & -50.6 & 299.0 & 53.5 \\ 0.367 \mathrm{E}-03 & 033.5 & -49.3 & 301.0 & 52.0 \\ 0.289 \mathrm{E}-03 & 041.4 & -55.8 & 301.0 & 52.0 \\ 0.170 \mathrm{E}-03 & 061.6 & -52.0 & 301.0 & 52.0 \\ 0.101 \mathrm{E}-03 & 073.3 & -42.3 & 301.0 & 52.0 \\ 0.670 \mathrm{E}-04 & 084.4 & -38.0 & 301.0 & 52.0 \\ 0.565 \mathrm{E}-04 & 082.4 & -24.7 & 301.0 & 52.0 \\ 0.504 \mathrm{E}-04 & 108.1 & -23.3 & 301.0 & 52.0 \\ 0.445 \mathrm{E}-03 & 013.8 & -61.9 & 301.0 & 52.0 \\ 0.481 \mathrm{E}-03 & 012.8 & -51.2 & 302.0 & 50.5 \\ 0.385 \mathrm{E}-03 & 003.5 & -50.4 & 302.0 & 50.5 \\ 0.276 \mathrm{E}-03 & 355.5 & -49.7 & 302.0 & 50.5 \\ 0.184 \mathrm{E}-03 & 352.4 & -40.5 & 302.0 & 50.5 \\ 0.139 \mathrm{E}-03 & 347.1 & -36.5 & 302.0 & 50.5 \\ 0.114 \mathrm{E}-03 & 348.1 & -39.5 & 302.0 & 50.5 \\ 0.914 \mathrm{E}-04 & 327.4 & -44.5 & 302.0 & 50.5 \\ 0.437 \mathrm{E}-03 & 013.2 & -48.6 & 302.0 & 50.5 \\ 0.306 \mathrm{E}-03 & 010.9 & -34.8 & 301.0 & 50.5 \\ 0.251 \mathrm{E}-03 & 010.3 & -36.0 & 301.0 & 50.5 \\ 0.160 \mathrm{E}-03 & 005.7 & -18.9 & 301.0 & 50.5 \\ 0.106 \mathrm{E}-03 & 004.6 & 07.1 & 301.0 & 50.5 \\ 0.863 \mathrm{E}-04 & 358.7 & 16.7 & 301.0 & 50.5 \\ 0.954 \mathrm{E}-04 & 001.3 & 15.9 & 301.0 & 50.5 \\ 0.664 \mathrm{E}-04 & 349.5 & -00.7 & 301.0 & 50.5 \\ 0.423 \mathrm{E}-03 & 019.6 & -51.7 & 301.0 & 50.5 \\ & & & & \end{array}$

WANGANUI RIVER STTE 0190

HEIGHT $=852 \mathrm{~m}$ (above base of section) STRIKE $=043.0 \mathrm{DIP}=4.5$

SAMPLE FIELDNO. TREAT. INTENSITY CDEC CINC Y-AZ PLUNGE

W019037.1 W1-0705.1 N00 W019037.1 W1-0705.1 T05 W019037.1 W1-0705.1 T10 W019037.1 W1-0705.1 T15 W019037.1 W1-0705.1 T20 W019037.1 W1-0705.1 T25 W019037.1 W1-0705.1 T30 W019037.1 W1-0705.1 T35 W019037.2 W1-0705.2 N00 W019037.2 W1-0705.2 T05 W019037.2 W1-0705.2 T10 W019037.2 W1-0705.2 T15 W019037.2 W1-0705.2 T20 W019037.2 W1-0705.2 T25 W019037.2 W1-0705.2 T25 W019037.2 W1-0705.2 T30 W019038.1 W1-0706.1 N00 W019038.1 W1-0706.1 TOS W019038.1 W1-0706.1 T15 W019038.1 W1-0706.1 T20 W019038.1 W1-0706.1 T25 W019038.1 W1-0706.1 T2S $\begin{array}{lll}\text { W019038.1 W1-0706.1 T30 } & \text { W } \\ \text { W019039.1 W1-0707.1 N00 }\end{array}$ W019039.1 W1-0707.1 T05 W019039.1 W1-0707.1 T10 w019039.1 W1-0707.1 T15 W019039.1 W1-0707.1 T20 W019039.1 W1-0707.1 T25 W019039.1 W1-0707.1 T25
W019039.1 W1-0707.1 T30 W019040.1 W1-0708.1 N00 W019040.1 W1-0708.1 T05 W019040.1 W1-0708.1 T10 W019040.1 W1-0708.1 T15 W019040.1 W1-0708.1 T20 W019040.1 W1-0708.1 T2S W019040.1 W1-0708.1 T30

$\begin{array}{lllll}0.380 \mathrm{E}-03 & 017.1 & -54.9 & 011.0 & 31.0 \\ 0.307 \mathrm{E}-03 & 014.3 & -57.1 & 011.0 & 31.0 \\ 0.199 \mathrm{E}-03 & 028.6 & -46.2 & 011.0 & 31.0 \\ 0.154 \mathrm{E}-03 & 023.5 & -43.1 & 011.0 & 31.0 \\ 0.111 \mathrm{E}-03 & 031.8 & -40.0 & 011.0 & 31.0 \\ 0.829 \mathrm{E}-04 & 068.3 & -44.3 & 011.0 & 31.0 \\ 0.724 \mathrm{E}-04 & 039.5 & -28.5 & 011.0 & 31.0 \\ 0.166 \mathrm{E}-03 & 032.8 & 20.8 & 011.0 & 31.0 \\ 0.320 \mathrm{E}-03 & 331.5 & -79.5 & 011.0 & 31.0 \\ 0.273 \mathrm{E}-03 & 328.8 & -78.2 & 011.0 & 31.0 \\ 0.177 \mathrm{E}-03 & 242.1 & -87.6 & 011.0 & 31.0 \\ 0.162 \mathrm{E}-03 & 152.6 & -87.2 & 011.0 & 31.0 \\ 0.138 \mathrm{E}-03 & 084.8 & -72.0 & 011.0 & 31.0 \\ 0.104 \mathrm{E}-03 & 094.6 & -66.9 & 011.0 & 31.0 \\ 0.248 \mathrm{E}-04 & 160.3 & -63.8 & 011.0 & 31.0 \\ 0.193 \mathrm{E}-03 & 095.3 & -75.6 & 015.0 & 25.0 \\ 0.166 \mathrm{E}-03 & 113.3 & -69.6 & 015.0 & 25.0 \\ 0.114 \mathrm{E}-03 & 124.4 & -63.9 & 015.0 & 25.0 \\ 0.814 \mathrm{E}-04 & 144.4 & -45.2 & 015.0 & 25.0 \\ 0.768 \mathrm{E}-04 & 145.3 & -28.9 & 015.0 & 25.0 \\ 0.111 \mathrm{E}-03 & 164.2 & -02.8 & 015.0 & 25.0 \\ 0.110 \mathrm{E}-03 & 176.4 & 06.7 & 015.0 & 25.0 \\ 0.261 \mathrm{E}-03 & 020.7 & -83.2 & 013.0 & 24.0 \\ 0.214 \mathrm{E}-03 & 047.2 & -77.8 & 013.0 & 24.0 \\ 0.156 \mathrm{E}-03 & 125.9 & -84.2 & 013.0 & 24.0 \\ 0.132 \mathrm{E}-03 & 088.6 & -74.0 & 013.0 & 24.0 \\ 0.132 \mathrm{E}-03 & 070.6 & -61.3 & 013.0 & 24.0 \\ 0.975 \mathrm{E}-04 & 124.1 & -75.4 & 013.0 & 24.0 \\ 0.947 \mathrm{E}-04 & 140.3 & -40.2 & 013.0 & 24.0 \\ 0.320 \mathrm{E}-03 & 013.6 & -58.9 & 008.0 & 19.0 \\ 0.251 \mathrm{E}-03 & 022.2 & -58.2 & 008.0 & 19.0 \\ 0.135 \mathrm{E}-03 & 057.5 & -58.5 & 008.0 & 19.0 \\ 0.937 \mathrm{E}-04 & 051.3 & -54.1 & 008.0 & 19.0 \\ 0.545 \mathrm{E}-04 & 051.3 & -37.7 & 008.0 & 19.0 \\ 0.233 \mathrm{E}-04 & 104.0 & 41.8 & 008.0 & 19.0 \\ 0.414 \mathrm{E}-04 & 043.3 & 67.8 & 008.0 & 19.0 \\ & & & & \\ & & & \end{array}$

WANGANUI RIVER SITE 0200

HEIGHT $=858 \mathrm{~m}$ (above base of section) STRIKE $=043.0 \quad \mathrm{DIP}=45$

SAMPLE FIELD NO. TREAT. INTENSITY CDEC CINC Y-AZ PLUNGE

W020041.1 W1-0809.1 N00 W020041.1 W1-0809.1 T05 W020041.1 W1-0809.1 T10 W020041.1 W1-0809.1 T15 W020041.1 W1-0809.1 T20

$\begin{array}{llll}0.118 \mathrm{E}-03 & 213.7 & -63.9 & 021.0\end{array}$ $\begin{array}{lllll}0.920 \mathrm{E}-04 & 192.2 & -82.1 & 021.0\end{array}$ $\begin{array}{lllll}0.809 \mathrm{E}-04 & 347.3 & -74.3 & 021.0\end{array}$ $\begin{array}{lllll}0.650 & \mathrm{E}-04 & 039.3 & -80.0 & 021.0\end{array}$ $0.531 \mathrm{E}-04 \quad 039.5-733-0210 \quad 73.0$ $\begin{array}{llllllll}\text { W020041.1 W1-0809.1 T25 } & 0.434 \mathrm{E}-04 & 075.7 & \mathbf{5} 5.6 & 021.0 & 73.0\end{array}$

3.5
3.5
3.5
3.5
3.5
2.0
2.0
2.0
2.0
2.0
2.0
0.5
0.5
0.5
0.5
0.5
0.5
0.5
0.5
0.5
0.5
50.5
50.5
50.5
50.5


W020041.1 W1-0809.1 T30 W020042.1 W1-0810.1 N00 W020042.1 W1-0810.1 T05 W020042.1 W1-0810.1 T10 W020042.1 W1-0810.1 T15 W020042.1 W1-0810.1 T20 W020042.1 W1-0810.1 T25 W020042.1 W1-0810.1 T30 W020043.1 W1-0811.1 N00 W020043.1 W1-0811.1 T05 W020043.1 W1-0811.1 T10 W020043.1 W1-0811.1 T15 W020043.1 W1-0811.1 T20 W020043.1 W1-0811.1 T25 W020043.1 W1-0811.1 T30 W020043.1 W1-0811.1 T35

$\begin{array}{llll}0.581 \mathrm{E}-04 \quad 231.4 & -07.8 \quad 020.0\end{array}$

$\begin{array}{lllll}0.494 \mathrm{~B}-04 & 260.4 & -00.6 \quad 020.0\end{array}$

$\begin{array}{lllll}0.351 & \mathrm{E}-04 & 263.7 & 02.3 & 020.0\end{array}$

$\begin{array}{llll}0.286 \mathrm{E}-04 & 268.4 & 22.9 & 020\end{array}$

$\begin{array}{llll}0.326 \mathrm{E}-04 & 281.5 & 58.5 & 020.0\end{array}$

$\begin{array}{llll}0.272 \text { E-04 } 019.4 \quad 73.1 \quad 020 & 0.0\end{array}$

$\begin{array}{lllllllll}0.839 & \mathrm{E}-04 & 173.0 & -28.4 & 020.0\end{array}$

$0.380 \mathrm{E}-04 \quad 158.7-45.1 \quad 020.0$

$\begin{array}{lllll}0.167 \mathrm{E}-04 & 175.1 & -57.5 & 020.0\end{array}$

$\begin{array}{lllll}0.300 & \text { E- } 05 & 279.5 & -67.3 & 020.0\end{array}$

$\begin{array}{lllll}0.190 \mathrm{E}-04 & 330.4 & 42.9 & 020.0\end{array}$

$\begin{array}{lllll}0.306 \mathrm{E}-04 & 353.5 & 27.1 & 0200\end{array}$

$\begin{array}{lllll}0.109 \mathrm{E}-04 & 119.9 & 72.8 & 020.0\end{array}$

$\begin{array}{lllll}0.307 \mathrm{E}-04 & 176.8 & 61.0 & 020.0\end{array}$

73.0

64.0

WANGANUI RIVER SITE 021V

HEIGHT $=890 \mathrm{~m}$ (above base of section) STRIKE=043.0 DIP=45

SAMPLE FIELDNO. TREAT. INTENSITY CDEC CINC Y-AZ PLUNGE

W021044.1 W4-6826.1 N00 W021044.1 W4-6826.1 T05 W021044.1 W4-6826.1 T10 W021044.1 W4-6826.1 T15 W021044.1 W4-6826.1 T20 W021044.1 W4-6826.1 T25 W021044.1 W4-6826.1 T30 W021044.2 W4-6826.2 N00 W021045.1 W4-6827.1 N00 W021045.1 W4-6827.1 T05 W021045.1 W4-6827.1 T10 W021045.1 W4-6827.1 T15 W021045.1 W4-6827.1 T20 W021045.1 W4-6827.1 T25 W021045.1 W4-6827.1 T30 W021045.2 W4-6827.2 N00 W021046.1 W4-6828.1 N0O W021046.1 W4-6828.1 T05 W021046.1 W4-6828.1 T10 W021046.1 W4-6828.1 T15 W021046.1 W4-6828.1 T20 W021046.1 W4-6828.1 T25 W021046.1 W4-6828.1 T30 $\begin{array}{lllll}0.186 \mathrm{E}-03 & 345.2 & -70.6 & 108.0 & 46.0\end{array}$ $\begin{array}{lllll}0.182 \mathrm{E}-03 & 334.7 & -53.3 & 108.0 & 46.0\end{array}$ $\begin{array}{lllll}0.115 \mathrm{E}-03 & 338.3 & -42.2 & 108.0 & 46.0\end{array}$

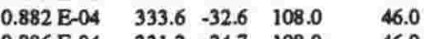
$\begin{array}{lllll}0.886 \mathrm{E}-04 & 331.2 & -24.7 & 108.0 & 46.0\end{array}$ $\begin{array}{lllll}0.682 \mathrm{E}-04 & 330.3 & -203 & 108.0 & 46.0\end{array}$ $\begin{array}{lllll}0.539 \mathrm{E}-04 & 326.0 & -26.6 & 108.0 & 46.0\end{array}$ $\begin{array}{lllll}0.146 \mathrm{E}-03 & 233.3 & -51.8 & 108.0 & 46.0\end{array}$ $\begin{array}{lllll}0.200 \mathrm{E}-03 & 049.5 & -79.5 & 106.0 & 49.0\end{array}$ $\begin{array}{lllll}0.153 \mathrm{E}-03 & 065.8 & -74.0 & 106.0 & 49.0\end{array}$ $\begin{array}{lllll}0.934 \text { E-04 } & 107.7 & -62.9 & 106.0 & 49.0\end{array}$ $\begin{array}{lllll}0.678 \mathrm{E}-04 & 122.3 & -39.3 & 106.0 & 49.0\end{array}$ $\begin{array}{lllll}0.573 \mathrm{E}-04 & 114.6 & -29.7 & 106.0 & 49.0 \\ 0.403 \mathrm{E}-04 & 145.5 & -28.9 & 106.0 & 49.0\end{array}$ $\begin{array}{rrrrr}0.403 \mathrm{E}-04 & 145.5 & -28.9 & 106.0 & 49.0 \\ 0.207 \mathrm{E}-04 & 168.9 & 12.7 & 106.0 & 49.0\end{array}$ $\begin{array}{lllll}0.204 \mathrm{E}-04 & 339.8 & -67.8 & 106.0 & 49.0\end{array}$

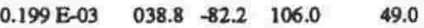

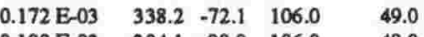
$\begin{array}{lllll}0.100 \mathrm{E}-03 & 304.1 & -80.0 & 106.0 & 49.0\end{array}$ $\begin{array}{lllll}0.679 \mathrm{E}-04 & 239.2 & -75.6 & 106.0 & 49.0\end{array}$

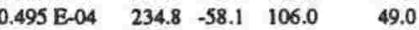
$\begin{array}{lllll}0.507 \mathrm{E}-04 & 229.7 & -36.2 & 106.0 & 49.0\end{array}$ $\begin{array}{lllll}0.370 \mathrm{E}-04 & 201.8 & -23.2 & 106.0 & 49.0\end{array}$

WANGANUI RIVER SITE 022V

HEIGHT $=1039 \mathrm{~m}$ (above base of section) STRIKE $=043.0 \quad \mathrm{DIP}=4.5$

SAMPLE FIELD NO. TREAT. DNTENSITY CDEC CINC Y-AZ PLUNGE

W022047.1 W4-6413.1 N00 W022047.1 W4-6413.1 T05 W022047.1 W4-6413.1 T10 W022047.1 W4-6413.1 T15 W022047.1 W4-6413.1 T20 W022047.1 W4-6413.1 T25 W022047.1 W4-6413.1 T30 W022047.2 W4-6413.2 N00 W022048.1 W4-6414.1 N00 W022048.1 W4-6414.1 T05 W022048.1 W4-6414.1 T10 W022048.1 W4-6414.1 T15 W022048.1 W4-6414.1 T20 W022048.1 W4-6414.1 T25 W022048.1 W4-6414.1 T30 W022048.2 W4-6414.2 N00 W022049.1 W4-6415.1 N00 W022049.1 W4-6415.1 T05 W022049.1 W4-6415.1 T10 W022049.1 W4-6415.1 T15 W022049.1 W4-6415.1 T20 W022049.1 W4-6415.1 T25 W022049.1 W4-6415.1 T30 $\begin{array}{llll}0.292 \mathrm{E}-03 & 010.2 & -56.9 & 070.0\end{array}$ $\begin{array}{lllll}0.244 \mathrm{E}-03 & 017.8 & -57.6 & 070.0\end{array}$ $\begin{array}{lllll}0.155 \mathrm{E}-03 & 037.0 & -53.5 & 070.0\end{array}$ $\begin{array}{lllll}0.110 \mathrm{E}-03 & 039.5 & -54.7 & 070.0\end{array}$ $\begin{array}{lllll}0.875 & E-04 & 0.44 .4 & -54.3 & 070.0\end{array}$ $\begin{array}{lllll}0.812 & \mathrm{E}-04 & 041.2 & -44.7 & 070.0\end{array}$ $\begin{array}{llll}0.770 \mathrm{E}-04 & 036.9 & -29.2 & 070.0\end{array}$ $\begin{array}{lllll}0.281 & \mathrm{E}-03 & 357.4 & -53.3 & 070.0\end{array}$ $\begin{array}{lllll}0.248 & \mathrm{E}-03 & 332.4 & -563 & 075\end{array}$ $\begin{array}{lllll}0.224 \mathrm{E}-03 & 343.9 & -65.0 & 075.0\end{array}$ $\begin{array}{lllll}0.154 & \mathrm{E}-03 & 331.0 & -63.7 & 075.0\end{array}$ $\begin{array}{lllll}0.111 & \mathrm{E}-03 & 316.5 & -73.2 & 075.0\end{array}$ $\begin{array}{lllll}0.762 \mathrm{E}-04 & 287.8 & -70.4 & 075.0\end{array}$ $\begin{array}{llll}0.586 \mathrm{E}-04 & 264.1 & -72.5 & 075.0\end{array}$ 0.640 E-04 $237.1 \quad-715 \quad 075.0$ $\begin{array}{lllll}0.302 & \mathrm{E}-03 & 354.7 & -55.3 & 075.0\end{array}$ $\begin{array}{lllll}0.371 \mathrm{E}-03 & 055.3 & -71.1 & 071.0\end{array}$ $\begin{array}{lllll}0.289 & \mathrm{E}-03 & 041.0 & -76.6 & 071.0\end{array}$ $\begin{array}{llll}0.219 \mathrm{E}-03 & 033.6 & -75.1 & 071.0\end{array}$ $\begin{array}{lllll}0.156 \mathrm{E}-03 & 033.0 & -82.0 & 071.0\end{array}$ $\begin{array}{lllll}0.122 \mathrm{E}-03 & 355.7 & -813 & 071.0\end{array}$ $0.108 \mathrm{E}-03 \quad 330.9 \quad 84.4 \quad 071.0$ $\begin{array}{lllll}0.769 \mathrm{E}-04 & 355.0 & -89.0 & 071.0\end{array}$ $\begin{array}{lllll}0.316 \mathrm{E}-03 & 016.5 & -60.7 & 071.0\end{array}$
W023052.2 W4-6312.2 N00 WANGANUI RIVER STTE 0260

HEIGKT $=1152 \mathrm{~m}$ (above base of section) STRIKE $=043.0 \mathrm{DIP}=4.5$ SAMPLE FIELDNO. TREAT. INTENSITY CDEC CINC Y-AZ PLUNGE

W026053.1 W1-1012.1 NOO W026053.1 W1-1012.1 T05 W026053.1 W1-1012.1 T10 W026053.1 W1-1012.1 T15 W026053.1 W1-1012.1 T20 W026053.1 W1-1012.1 T25 W026053.1 W1-1012.1 T30 W026053. W1-1012.3 N00 W0260533 W1-1012.3 T05 W026053.3 W1-1012.3 T10 W0260533 W1-10123 T15 W0260533 W1-1012.3 T20 W0260533 W1-1012.3 T25 W0260533 W1-1012.3 T30 W0260533 W1-1012.3 T35 W026054.1 W1-1013.1 N00 W026054.1 W1-1013.1 T05 W026054.1 W1-1013.1 T10 W026054.1 W1-1013.1 T15 W026054.1 W1-1013.1 T20 W026054.1 W1-1013. I T2S W026054.1 W1-1013.1 T30 W026054.1 W1-1013.1 T35 W026055.1 W1-1014.1 NOO W026055.1 W1-1014.1 T05 W026055.1 W1-1014.1 T10 W026055.1 W1-1014: T15 w026055.1 w1-1014.1 T20 w026055.1 W1-1014.1 T25 W026055.1 W1-1014.1 T30 W026055.1 W1-1014.1 T35 $\begin{array}{lllll}0.390 & \text { E-04 } & 285.4 & 23.7 & 163.0\end{array}$ $\begin{array}{lllll}0.650 \mathrm{E}-04 & 303.4 & 50.1 & 163.0\end{array}$

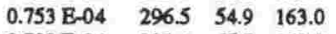

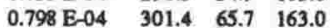
$\begin{array}{lllll}0.743 & \text { E- } 04 & 308.4 & 62.9 & 163.0\end{array}$ $0.562 \mathrm{E}-04 \quad 1420-71.8163 .0$ $\begin{array}{lllll}0.269 \text { E- } 04 & 116.4 & -58.3 & 163.0\end{array}$ $\begin{array}{llll}0.252 \mathrm{E}-04 & 074.7 & 23.1 & 163.0\end{array}$ $\begin{array}{lllll}0.286 \mathrm{E}-04 & 067.1 & 47.5 & 163.0\end{array}$ $\begin{array}{llll}0.306 \mathrm{E}-04 & 071.6 & 56.9 & 163.0\end{array}$ $\begin{array}{llll}0.340 \text { E- } 04 & 068.5 & 57.5 & 163.0\end{array}$ $\begin{array}{lllll}0.370 \mathrm{E}-04 & 049.0 & 66.9 & 163.0\end{array}$ $0.331 \mathrm{E}-04 \quad 056.6 \quad 54.2 \quad 163.0$ $\begin{array}{llll}0.330 \mathrm{E}-04 & 181.2 & 06.3 & 159.0\end{array}$ $\begin{array}{lllll}0.221 & \text { E-04 } & 179.9 & 41.7 & 159.0\end{array}$ $\begin{array}{lllll}0.475 & \mathrm{E}-04 & 165.2 & 84.6 & 159.0\end{array}$ $\begin{array}{llll}0.680 \mathrm{E}-04 & 121.0 & 76.5 & 159.0\end{array}$ $\begin{array}{llll}0.714 \mathrm{E}-04 & 137.1 & 73.4 & 159.0\end{array}$

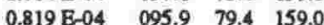
$0.694 \mathrm{E}-04 \quad 155.8 \quad 78.5 \quad 159.0$ $\begin{array}{lllll}0.542 \mathrm{E}-04 & 107.8 & 69.2 & 159.0\end{array}$ $\begin{array}{llll}0.980 \mathrm{E}-04 & 024.0 & 45.5 & 162.0\end{array}$ $\begin{array}{llll}0.124 \mathrm{E}-03 & 035.8 & 52.6 & 162.0\end{array}$

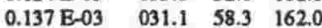

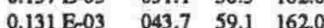
$\begin{array}{lllll}0.131 & \mathrm{E}-03 & 043.7 & 59.1 & 162.0 \\ 0.125 \mathrm{E}-03 & 041.8 & 56.1 & 162.0\end{array}$ $\begin{array}{lllll}0.125 \mathrm{E}-03 & 041.8 & 56.1 & 162.0 \\ 0.106 \mathrm{E}-03 & 041.6 & 56.4 & 162.0\end{array}$ $\begin{array}{lllll}0.754 \mathrm{E}-04 & 059.2 & 72.5 & 162.0\end{array}$

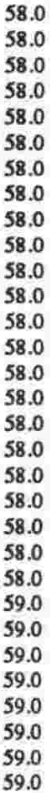
$\begin{array}{lllll}0.645 \mathrm{E}-04 & 301.2 & 38.6 & 163.0\end{array}$ $\begin{array}{llll}0.830 \mathrm{E}-04 & 033.4 & 47.1 & 162.0\end{array}$

WANGANUI RIVER SITE $027 \mathrm{~V}$

HEIGHT $=1187 \mathrm{~m}$ (above base of section) STRIKE $=043.0 \quad \mathrm{DIP}=4.5$

SAMPLE FELDNO. TREAT. INTENSITY CDEC CINC Y-AZ PLUNGE

W027056.1 W4-6207.1 NOO W027056.1 W4-6207.1 T05 W027056.1 W4-6207.1 T10 W027056.1 W46207.1 T15 W027056.1 W4-6207.1 T20 W027056.1 W4-6207.1 T25 W027056.1 W4-6207.1 T30 W027056.2 W4-6207.2 N0O W027057.1 W4-6208.1 N0O W027057.1 W4-6208.1 T05 W027057.1 W4-6208.1 T10 W027057.1 W4-6208.1 T15 W027057.1 W4-6208.1 T20 W027057.1 W4-6208.1 T20 $\begin{array}{lll}\text { W027057.1 W4-6208.1 T25 } & \text { T2 } \\ \text { W027057.1 W4-6208.1 T30 }\end{array}$ W027057.2 W4-6208.2 N00 W027058.1 W4-6209.1 N0O W027058.1 W4-6209.1 T05 W027058.1 W4-6209.1 T10 W027058.1 W4-6209.1 T15 W027058.1 W4-6209.1 T20 W027058.1 W4-6209.1 T25 W027058.1 W4-6209.1 T30 $\begin{array}{lllll}0.450 \mathrm{E}-03 & 027.0 & -64.8 & 229.0 & 59.0 \\ 0.463 \mathrm{E}-03 & 023.4 & -58.6 & 229.0 & 59.0 \\ 0.309 \mathrm{E}-03 & 028.9 & -60.1 & 229.0 & 59.0 \\ 0.150 \mathrm{E}-03 & 034.3 & -51.6 & 229.0 & 59.0 \\ 0.785 \mathrm{E}-04 & 057.0 & -39.0 & 229.0 & 59.0 \\ 0.412 \mathrm{E}-0.4 & 079.3 & -15.4 & 229.0 & 59.0 \\ 0.370 \mathrm{E}-04 & 103.0 & -163 & 229.0 & 59.0 \\ 0.482 \mathrm{E}-03 & 004.0 & -54.8 & 229.0 & 59.0 \\ 0.426 \mathrm{E}-03 & 001.5 & -66.4 & 227.0 & 60.0 \\ 0.436 \mathrm{E}-03 & 010.3 & -60.6 & 227.0 & 60.0 \\ 0.291 \mathrm{E}-03 & 006.5 & -61.1 & 227.0 & 60.0 \\ 0.123 \mathrm{E}-03 & 002.0 & -63.5 & 227.0 & 60.0 \\ 0.379 \mathrm{E}-0.4 & 006.4 & -41.3 & 227.0 & 60.0 \\ 0.215 \mathrm{E}-04 & 338.0 & 34.0 & 227.0 & 60.0 \\ 0.347 \mathrm{E}-04 & 294.2 & 29.2 & 227.0 & 60.0 \\ 0.360 \mathrm{E}-03 & 002.8 & -55.7 & 227.0 & 60.0 \\ 0.500 \mathrm{E}-03 & 033.4 & -69.4 & 230.0 & 59.5 \\ 0.521 \mathrm{E}-03 & 035.5 & -68.1 & 230.0 & 59.5 \\ 0.359 \mathrm{E}-03 & 044.4 & -71.5 & 230.0 & 59.5 \\ 0.181 \mathrm{E}-03 & 077.0 & -75.4 & 230.0 & 59.5 \\ 0.109 \mathrm{E}-03 & 137.3 & -68.6 & 230.0 & 59.5 \\ 0.755 \mathrm{E}-04 & 150.6 & -45.1 & 230.0 & 59.5 \\ 0.649 \mathrm{E}-04 & 177.4 & -31.8 & 230.0 & 59.5 \\ 0.436 \mathrm{E}-03 & 005.1 & -56.2 & 230.0 & 59.5\end{array}$ WANGANUI RIVER STTB $030 \mathrm{~V}$

HEIGHT $=1302 \mathrm{~m}$ (above base of section) $S T$ RIKE $=043.0 \mathrm{DIP}=4.5$

SAMPLE FIELD NO. TREAT. INTENSITY CDEC CINC Y-AZ PLUNGE

W030059.1 W4-6104.1 N00 W030059.1 W4-6104.1 T05

$\begin{array}{lllll}0.299 \mathrm{E}-03 & 356.3 & -54.7 & 309.0 \quad 71.5\end{array}$ $\begin{array}{lllllll}\text { W030059.1 W4-6104.1 T10 } & 0.200 \mathrm{E}-03 & 013.0 & -60.9 & 309.0 & 715\end{array}$ $\begin{array}{lllllll}\text { W030059.1 W4-6104.1 T15 } & 0.920 \mathrm{E}-04 & 013.0 & -66.0 & 309.0 & 715\end{array}$ $\begin{array}{llllllll}\text { W030059.1 W4-6104.1 T20 } & 0.488 \text { E-04 } & 325.2 & -59.4 & 309.0 & 715\end{array}$ $\begin{array}{lllllll}\text { W030059.1 W4-6104.1 T25 } & 0.324 \mathrm{E}-04 & 326.6 & -33.9 & 309.0 & 715 \\ \text { W030059.1 W }-6104.1 & \mathrm{~T} 30 & 0.226 \mathrm{E}-04 & 3129 & -24.5 & 309.0 & 715\end{array}$

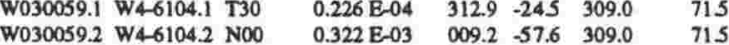
$\begin{array}{lllllll}\text { W030060.1 W4-6105.1 N00 } & 0.527 \mathrm{E}-03 & 342.2 & -65.3 & 302.0 & 73.5\end{array}$ $\begin{array}{lllllll}\text { W030060.1 W4-6105.1 T05 } & 0.439 \mathrm{E}-03 & 358.1 & -66.7 & 302.0 & 73.5\end{array}$ $\begin{array}{lllllll}\text { W030060.1 W4-6105.1 T10 } & 0.439 \mathrm{E}-03 & 358.1 & -66.7 & 302.0 & 73.5 \\ \text { W } & 0.299 & 354.1 & -66.8 & 302.0 & 73.5\end{array}$ $\begin{array}{llllllll}\text { W030060.1 W4-6105.1 T10 } & 0.299 \mathrm{E}-03 & 354.1 & -66.8 & 302.0 & 73.5 \\ \text { W030060.1 W4-6105.1 T15 } & 0.175 \mathrm{E}-03 & 343.2 & -68.9 & 302.0 & 73.5\end{array}$ $\begin{array}{llllllll}\text { W030060.1 W4-6105.1 T20 } & 0.113 \mathrm{E}-03 & 332.1 & -71.4 & 302.0 & 735\end{array}$ $\begin{array}{lllllll}\text { W030060.1 W4-6105.1 T25 } & 0.814 \mathrm{E}-04 & 330.3 & -77.8 & 302.0 & 735\end{array}$ $\begin{array}{llllllll}\text { W030060.1 W4-6105.1 T30 } & 0.297 \mathrm{E}-04 & 147.3 & -45.5 & 302.0 & 73.5\end{array}$ $\begin{array}{lllllll}\text { W030060.2 W4-6105.1 N00 } & 0.332 \mathrm{E}-03 & 346.3 & -62.1 & 302.0 & 73.5\end{array}$ \begin{tabular}{lllllll} 
W030061.1 W4-6106.1 NOO & $0.313 \mathrm{E}-03$ & 346.3 & -62.1 & 302.0 & 73.5 \\
\hline
\end{tabular} $\begin{array}{lllllll}\text { W030061.1 W4-6106.1 N00 } & 0.313 \mathrm{E}-03 & 354.0 & -59.6 & 307.0 & 74.5 \\ \text { W030061.1 W4-6106.1 T05 } & 0.304 \mathrm{E}-03 & 005.8 & -59.6 & 307.0 & 74.5\end{array}$ $\begin{array}{llllllll}\text { W030061.1 W4-6106.1 T10 } & 0.202 \mathrm{E}-03 & 005.1 & -53.3 & 307.0 & 74.5\end{array}$ $\begin{array}{llllllll}\text { W030061.1 W4-6106.1 T15 } & 0.879 \mathrm{E}-04 & 355.7 & -50.3 & 307.0 & 74.5\end{array}$ $\begin{array}{llllllll}\text { W030061.1 W4-6106.1 T20 } & 0.475 & \text { E-04 } & 347.4 & -25.3 & 307.0 & 74.5\end{array}$ $\begin{array}{llllllll}\text { W030061.1 W4-6106.1 T25 } & 0.417 \mathrm{E}-04 & 350.2 & 09.7 & 307.0 & 74.5\end{array}$ $\begin{array}{llllllll}\text { W030061.1 W4-6106.1 T30 } & 0.252 \mathrm{E}-04 & 338.4 & -05.1 & 307.0 & 74.5 \\ \text { W030061.2 W4-6106.2 N00 } & 0.356 \mathrm{E}-03 & 041.8 & -65.3 & 307.0 & 74.5\end{array}$

WANGANUI RIVER SITE $031 \mathrm{~V}$

HEIGHT $=1427 \mathrm{~m}$ (above base of section) STRIKE $=043.0 \quad \mathrm{DIP}=4.5$

SAMPLE FIELD NO. TREAT. INTENSITY CDEC CINC Y-AZ PLUNGE

$\begin{array}{lllllll}\text { W031062.1 W4-6001.1 NO0 } & 0.270 \mathrm{E}-03 & 290.3 & -63.2 & 300.0 & 56.0\end{array}$ $\begin{array}{lllllll}\text { W031062.1 W4-6001.1 TO5 } & 0.208 \text { E-03 } & 317.0 & -70.4 & 300.0 & 56.0\end{array}$ 
W031062.1 W4-6001.1 T10 W031062.1 W4-6001.1 T15 W031062.1 W4-6001.1 T20 W031062.1 W4-6001.1 T25 W031062.1 W4-6001.1 T30 W031062.2 W4-6001.2 N0O W031063.1 W4-6002.1 N00 W031063.1 W4-6002.1 T05 W031063.1 W4-6002.1 T10 W031063.1 W4-6002.1 T15 W031063.1 W4-6002.1 T20 W031063.1 W4-6002.1 T25 W031063.1 W4-6002.1 T30 W031063 2 W4-6002 2 N00 W031064.1 W4-6003.1 N00 W031064.1 W4-6003.1 T05 W031064.1 W4-6003.1 T10 W031064.1 W4-6003.1 T15 W031064.1 W4-6003.1 T20 W031064.1 W4-6003.1 T25 W031064.1 W4-6003.1 T30 W031064.2 W4-6003.2 NOO $\begin{array}{llll}0.169 \mathrm{E}-03 & 308.7 & -693 & 300.0\end{array}$ $\begin{array}{lllll}0.228 \mathrm{E}-03 & 341.8 & -75.0 & 302 & 0\end{array}$ $\begin{array}{lllll}0.228 \mathrm{E}-03 & 341.8 & -75.0 & 302.0 \\ 0.202 \mathrm{E}-03 & 033.7 & -69.1 & 302.0\end{array}$ $\begin{array}{llll}0.202 \mathrm{E}-03 & 033.7 & -69.1 & 302.0 \\ 0.166 \mathrm{E}-03 & 041.0 & -67.3 & 302.0\end{array}$ $\begin{array}{lllll}0.166 \mathrm{E}-03 & 041.0 & -67.3 & 302.0 \\ 0.121 & -03 & 047.0 & -66.8 & 302.0\end{array}$ $\begin{array}{lllll}0.121 \mathrm{E}-03 & 047.0 & -66.8 & 302.0\end{array}$ $0.774 \mathrm{E}-04 \quad 046.2-62.9 \quad 302.0$ $\begin{array}{lllll}0.729 \mathrm{E}-04 & 029.7 & -61.4 & 302.0\end{array}$ 0.181 E-03 $323.5-64.93020$ $\begin{array}{llll}0.163 \mathrm{E}-03 & 338.6 & -66.6 & 304.0\end{array}$ $\begin{array}{llll}0.163 \mathrm{E}-03 & 338.6 & -66.6 & 304.0 \\ 0.148 \mathrm{E}-03 & 025.1 & -65.3 & 304.0\end{array}$ $\begin{array}{lllll}0.108 \mathrm{E}-03 & 028.9 & -64.6 & 304.0\end{array}$ $0.607 \mathrm{E}-04 \quad 042.4-64.4 \quad 304.0$ $0.481 \mathrm{E}-04 \quad 046.2-64.2 \quad 304.0$ $\begin{array}{llll}0.430 \mathrm{E}-0.4 & 0.46 .3 & -67.7 & 304.0\end{array}$ $\begin{array}{llll}0.450 \mathrm{E}-04 & 051.1 & -74.0 & 304.0\end{array}$ $\begin{array}{lllll}0.243 \mathrm{E}-03 & 344.8 & -50.2 & 304.0\end{array}$ $0.121 \mathrm{~B}-03 \quad 278.0-60.5 \quad 300.0$ $\begin{array}{llll}0.101 \mathrm{E}-03 & 278.0 & -605 & 300.0\end{array}$ $\begin{array}{llll}0.101 & 265.9 & -57.0 & 300.0\end{array}$ $0.869 \mathrm{E}-04 \quad 240.7+4.1300 .0$ $0.227 \mathrm{E}-03 \quad 335.4-78.0 \quad 300.0$

WANGANUI RIVER SITE 0320

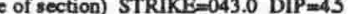
SAMPLE FIELD NO. TREAT. INTENSITY CDEC CINC Y-AZ PLUNGE

$\begin{array}{llll}\text { W032065.1 } & \text { W1-1315.1 } & \text { N00 } \\ \text { W032065.1 } & \text { W1-1315.1 } & \text { T05 } \\ \text { W032065.1 } & \text { W1-1315.1 } & \text { T10 } \\ \text { W032065.1 } & \text { W1-1315.1 } & \text { T15 } \\ \text { W032065.1 } & \text { W1-1315.1 } & \text { T20 } \\ \text { W032065.1 } & \text { W1-1315.1 } & \text { T25 } \\ \text { W032065.1 } & \text { W1-1315.1 } & \text { T30 } \\ \text { W032065.1 } & \text { W1-1315.1 } & \text { T35 } \\ \text { W032066.1 } & \text { W1-1316.1 } & \text { N00 } \\ \text { W032066.1 } & \text { W1-1316.1 } & \text { T05 } \\ \text { W032066.1 } & \text { W1-1316.1 } & \text { T10 } \\ \text { W032066.1 } & \text { W1-1316.1 } & \text { T15 } \\ \text { W032066.1 } & \text { W1-1316.1 } & \text { T20 } \\ \text { W032066.1 } & \text { W1-1316.1 } & \text { T25 } \\ \text { W032066.1 } & \text { W1-1316.1 } & \text { T30 } \\ \text { W032066.1 } & \text { W1-1316.1 } & \text { T35 } \\ \text { W032067.1 } & \text { W1-1317.1 } & \text { N00 } \\ \text { W032067.1 } & \text { W1-1317.1 } & \text { T05 } \\ \text { W032067.1 } & \text { W1-1317.1 } & \text { T10 } \\ \text { W032067.1 } & \text { W1-1317.1 } & \text { T15 } \\ \text { W032067.1 } & \text { W1-1317.1 } & \text { T20 } \\ \text { W032067.1 } & \text { W1-1317.1 } & \text { T25 } \\ \text { W032067.1 } & \text { W1-1317.1 } & \text { T30 } \\ \text { W032067.1 } & \text { W1-1317.1 } & \text { T35 } \\ \text { W032068.1 } & \text { W1-1318.1 } & \text { N00 } \\ \text { W032068.1 } & \text { W1-1318.1 } & \text { T05 } \\ \text { W032068.1 } & \text { W1-1318.1 } & \text { T10 } \\ \text { W032068.1 } & \text { W1-1318.1 } & \text { T15 } \\ \text { W032068.1 } & \text { W1-1318.1 } & \text { T20 } \\ \text { W032068.1 } & \text { W1-1318.1 } & \text { T25 } \\ \text { W032068.1 } & \text { W1-1318.1 } & \text { T30 }\end{array}$

$\begin{array}{llll}0.156 \mathrm{E}-03 & 176.9 & 05.9 & 348.0\end{array}$ $\begin{array}{lllll}0.112 \mathrm{E}-03 & 174.3 & 00.1 & 348.0\end{array}$ $\begin{array}{lllll}0.682 \mathrm{E}-04 & 176.8 & -01.4 & 348.0\end{array}$ $\begin{array}{llll}0.534 \mathrm{E}-04 & 175.6 & 05.9 & 348.0\end{array}$ $\begin{array}{llll}0.600 \mathrm{E}-04 & 177.4 \quad 05.4 \quad 348.0\end{array}$ $0.499 \mathrm{E}-04 \quad 169.7 \quad-01.6 \quad 348.0$ $\begin{array}{llll}0.587 \mathrm{~B}-04 & 168.6 & 01.2 & 348.0\end{array}$ $\begin{array}{llll}0.587 \mathrm{E}-04 & 168.6 & 01.2 & 348.0 \\ 0.241 \mathrm{E}-04 & 134.6 & 17.5 & 348.0\end{array}$ $\begin{array}{llll}0.241 \mathrm{E}-04 & 134.6 & 175 & 348.0 \\ 0.137 \mathrm{E}-03 & 174.8 & 04.0 & 345.0\end{array}$ $\begin{array}{lllll}0.137 \mathrm{E}-03 & 174.8 & 04.0 & 345.0 \\ 0.114 \mathrm{E}-03 & 170.5 & 045 & 345.0\end{array}$ $\begin{array}{llll}0.114 \mathrm{E}-03 & 170.5 & 045 & 345.0\end{array}$ $\begin{array}{lllll}0.680 \mathrm{E}-04 & 178.1 & -02.6 & 345.0\end{array}$ $0.574 \mathrm{E}-04 \quad 171.0 \quad-03.4 \quad 345.0$ $\begin{array}{llll}0.578 \mathrm{E}-04 & 173.1 & 04.1 & 345.0\end{array}$ $\begin{array}{llll}0.457 \mathrm{E}-04 & 158.1 & 12.7 & 345.0\end{array}$ $\begin{array}{llll}0.457 \mathrm{E}-04 & 158.1 & 12.7 & 345.0 \\ 0.276 \mathrm{E}-04 & 140.9 & 115 & 345.0\end{array}$ $\begin{array}{lllll}0.276 \text { E-04 } & 140.9 & 115 & 345.0 \\ 0.339 \text { E-04 } & 151.6 & 08.4 & 345.0\end{array}$ $\begin{array}{lllll}0.154 \mathrm{E}-03 & 169.7 & 03.9 & 345.0\end{array}$ $\begin{array}{llll}0.117 \mathrm{E}-03 \quad 163.2 & -05.5 & 345.0\end{array}$ $\begin{array}{llll}0.826 \mathrm{E}-04 & 159.7 & -03.7 & 345.0\end{array}$ $\begin{array}{llll}0.827 \mathrm{E}-04 \quad 157.0 & -00.8 \quad 345.0\end{array}$ $\begin{array}{llll}0.656 \mathrm{E}-04 & 165.8 & -04.6 & 345.0\end{array}$ $\begin{array}{llll}0.656 \mathrm{E}-04 & 165.8 & -04.6 & 345.0 \\ 0.527 \mathrm{E}-04 & 128.9 & 03.0 & 345.0\end{array}$ $\begin{array}{rrrr}0.527 \text { E-04 } & 128.9 & 03.0 & 345.0 \\ 0.597 \text { E- }-4 & 149.0 & -06.0 & 345.0 \\ 0.431 \text { E-04 } & 160.3 & -03.7 & 345.0\end{array}$ $\begin{array}{llll}0.431 \mathrm{E}-04 & 160.3 & -03.7 & 345.0\end{array}$ $\begin{array}{lllll}0.145 \mathrm{E}-03 & 167.1 & -02.1 & 346.0\end{array}$ $\begin{array}{lllll}0.108 \text { E-03 } & 164.8 & -115 & 346.0 \\ 0.758 \text { E-04 } & 161.1 & -13.7 & 346.0\end{array}$ $\begin{array}{llll}0.758 \text { E-04 } & 161.1 & -13.7 & 346.0 \\ 0.773 \text { E-04 } & 161.0 & -08.8 & 346.0\end{array}$ $\begin{array}{lllll}0.773 \text { E-04 } & 161.0 & -08.8 & 346.0 \\ 0.576 \text { E-04 } & 153.9 & -16.4 & 346.0\end{array}$ $\begin{array}{llll}0.576 \mathrm{E}-04 & 153.9 & -16.4 & 346.0 \\ 0.546 \mathrm{E}-04 & 159.5 & -09.1 & 346.0\end{array}$ $\begin{array}{llll}0.546 \mathrm{E}-04 & 159.5 & -09.1 & 346.0 \\ 0.498 \mathrm{E}-0.4 & 158.8 & -25.2 & 346.0\end{array}$

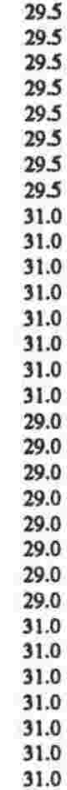

WANGANUI RIVER SITE $034 G$

HEIGHT $=1700 \mathrm{~m}$ (above base of section) $S T R I K E=043.0 \quad \mathrm{DIP}=45$

SAMPLE FIELDNO. TREAT. INTENSITY CDEC CINC Y-AZ PLUNGE W034069.1 W3-6365.1 T32 W034071.1 W3-6367.1 T16
W034069.1 W3-6365.1 N00 W034069.1 W3-6365.1 T08 W034069.1 W/3-6365.1 T12 W034069.1 W3-6365.1 T16 W034069.1 W3-6365.1 T18 W034069.1 W3-6365.1 T21 W034069.1 W3-6365.1 T24 W034069.1 W3-6365.1 T27 W034069.1 W3-6365.1 T30 W034069.1 W3-6365.1 T34 W034070.1 W3-6366.1 N00 W034070.1 W3-6366.1 T08 W034070.1 W3-6366.1 T12 W034070.1 W3-6366.1 T16 W034070.1 W3-6366.1 T18 W034070.1 W3-6366.1 T21 W034070.1 W3-6366.1 T24 W034070.1 W/6366.1 T27 W034070.1 W3-6366.1 T30 W034070.1 W3-6366.1 T32 W034070.1 W3-6366.1 T34 W034070.1 W3-6367.1 NOO W034071.1 W3-6367.1 T08 W034071.1 W3-6367.1 T12 W034071.1 W3-6367.1 T18 W034071.1 W3-6367.1 T21 W034071.1 W3-6367.1 T24 W034071.1 W3-6367.1 T27 W034071.1 W3-6367.1 T30 W034071.1 W3-6367.1 T32

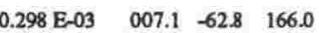
$\begin{array}{lllll}0.218 \mathrm{E}-03 & 006.9 & -62.7 & 166.0\end{array}$ $\begin{array}{lllll}0.138 \mathrm{E}-03 & 003.6 & -565 & 166.0\end{array}$ $\begin{array}{lllll}0.905 \mathrm{E}-04 & 358.0 & -48.1 & 166.0\end{array}$ $\begin{array}{llll}0.782 \text { E-04 } & 000.8 & -523 & 166.0\end{array}$ $\begin{array}{lllll}0.638 \mathrm{E}-04 & 355.3 & -51.9 & 166.0\end{array}$ $\begin{array}{llll}0.607 \text { E- } 04 & 003.1 & -45.9 & 166.0\end{array}$ $\begin{array}{llll}0.674 \mathrm{E}-04 & 004.4 & -43.9 & 166.0\end{array}$ $\begin{array}{lllll}0.552 \mathrm{E}-04 & 007.7 & -20.3 & 166.0\end{array}$ $\begin{array}{llll}0.641 \mathrm{E}-04 & 007.4 & -23.7 & 166.0\end{array}$ $\begin{array}{lllll}0.120 \mathrm{E}-04 & 358.9 & -63.0 & 166.0\end{array}$ $\begin{array}{lllll}0.392 & \mathrm{E}-03 & 023.6 & -592 & 160.0\end{array}$ $\begin{array}{lllll}0.392 \mathrm{E}-03 & 023.6 & -59.2 & 160.0 \\ 0.285 \mathrm{E}-03 & 026.4 & -53.8 & 160.0\end{array}$ $\begin{array}{lllll}0.285 \mathrm{E}-03 & 026.4 & -53.8 & 160.0 \\ 0.179 \mathrm{E}-03 & 031.3 & -51.4 & 160.0\end{array}$ $\begin{array}{lllll}0.179 \mathrm{E}-03 & 031.3 & -51.4 & 160.0 \\ 0.119 \mathrm{E}-03 & 026.7 & -43.3 & 160.0\end{array}$ $\begin{array}{lllll}0.108 & \mathrm{E}-03 & 034.4 & -36.6 & 160.0\end{array}$ $\begin{array}{lllll}0.953 & \mathrm{E}-04 & 030.4 & -33.6 & 160.0\end{array}$ $\begin{array}{lllll}0.947 \mathrm{E}-04 & 024.8 & -38.1 & 160.0\end{array}$ $\begin{array}{llllll}0.971 \text { E-04 } & 024.0 & -38.8 & 160.0\end{array}$ $\begin{array}{lllll}0.672 \text { E- } 04 & 045.5 & -29.0 & 160.0\end{array}$ $\begin{array}{lllll}0.729 \mathrm{E}-04 & 039.0 & -21.0 & 160.0\end{array}$ $\begin{array}{lllll}0.493 & \text { E-04 } & 037.9 & -29.2 & 160.0\end{array}$ $\begin{array}{lllll}0.314 \mathrm{E}-03 & 012.5 & -61.8 & 167.0\end{array}$ $\begin{array}{lllll}0.222 \mathrm{E}-03 & 010.7 & -61.9 & 167.0\end{array}$ $\begin{array}{lllll}0.142 E-03 & 010.7 & -61.3 & 167.0\end{array}$ $0.915 \mathrm{E}-04 \quad 013.4-66.1 \quad 167.0$ $\begin{array}{lllll}0.809 & \mathrm{E}-04 & 0.06 .8 & -66.4 & 167.0\end{array}$ $\begin{array}{lllll}0.745 \mathrm{E}-04 & 156.4 & -72.1 & 167.0\end{array}$ $\begin{array}{lllll}0.805 & \text { E- } 04 & 008.5 & -73.6 & 167.0\end{array}$ $\begin{array}{lllll}0.774 \mathrm{E}-04 & 350.8 & -79.7 & 167.0\end{array}$ $\begin{array}{lllll}0.661 \mathrm{E}-04 & 259.5 & -78.5 & 167.0\end{array}$ $\begin{array}{lllll}0.493 \text { E-04 } & 186.0 & -74.7 & 167.0\end{array}$ $\begin{array}{lllll}0.343 \mathrm{E}-04 & 056.1 & -47.0 & 167.0\end{array}$

34.0 34.0 34.0 34.0 34.0 34.0 34.0 34.0 34.0 39.0 39.0 39.0 39.0 39.0 39.0 39.0 39.0 39.0 39.0 36.0 36.0 36.0 36.0 36.0 36.0 36.0 36.0 36.0 36.0
36.0

\section{WANGANUI RIVER SITE 036G}

EEIGHT $=1775 \mathrm{~m}$ (above base of section) STRIKE $=043.0 \mathrm{DIP}=4.5$

SAMPLE FIELD NO. TREAT. INTENSITY CDEC CINC Y-AZ PLUNGE

W036072.1 W/3-6468.1 N00 $\quad 0.172 \mathrm{E}-03 \quad 0018-546 \quad 0610-36.0$

W0360721 W3-6468.1 T08 W036072.1 W3-6468.1 T12 W036072.1 W3-6468.1 T16 W036072.1 W3-6468.1 T18 W036072.1 W3-6468.1 T21 W036072.1 W3-6468.1 T24 W036072.1 W3-6468.1 T27 W036072.1 W3-6468.1 T30 W036072.1 W3-6468.1 T32 W036072.1 W3-6468.1 T34 W036072.1 W3-6468.1 T36 W036073.1 W3-6469.1 N0O W036073.1 W/3-6469.1 T08 W036073.1 W3-6469.1 T12 W036073.1 W3-6469.1 T16 W036073.1 W3-6469.1 T18 W036073.1 W3-6469.1 T21 W036073.1 W3-6469.1 T24 W036073.1 W3-6469.1 T27 W036073.1 W3-6469.1 T30 W036073.1 W3-6469.1 T32 W036073.1 W3-6469.1 T34 W036074.1 W3-6470.1 N00 W036074.1 W3-6470.1 T08 W036074.1 W3-6470.1 T12 W036074.1 W3-6470.1 T16 W036074.1 W3-6470.1 T18 W036074.1 W3-6470.1 T21 W036074.1 W3-6470.1 T24 W036074.1 W3-6470.1 T27 W036074.1 W3-6470.1 T30

$\begin{array}{llll}0.124 \mathrm{E}-03 & 353.5 & -46.5 & 061.0\end{array}$ $\begin{array}{llll}0.897 \text { E- } 04 \quad 352.7 & -39.3 & 061.0\end{array}$

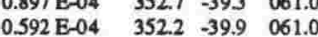
$\begin{array}{lllll}0.618 \text { E-04 } & 354.6 & -36.7 & 061.0\end{array}$ $0.473 \mathrm{E}-04 \quad 353.5 \quad-37.0 \quad 061.0$ $\begin{array}{llll}0.343 \mathrm{E}-04 & 0.42 .3 & -32.4 & 061.0\end{array}$ $0.347 \mathrm{E}-04 \quad 034.2 \quad-22.9 \quad 061.0$ $0.301 \mathrm{E}-04 \quad 0622 \quad-50.6 \quad 061.0$ $\begin{array}{llllll}0.193 & \mathrm{E}-04 & 346.8 & -06.9 & 061.0\end{array}$ $\begin{array}{lllll}0.279 \mathrm{E}-04 & 334.7 & 11.4 & 061.0\end{array}$ $\begin{array}{llll}0.476 \mathrm{E}-04 & 353.2 & -08.7 & 061.0\end{array}$ $\begin{array}{lllll}0.180 \mathrm{E}-03 & 020.6 & -65.7 & 065.0\end{array}$ $\begin{array}{llllll}0.140 \mathrm{E}-03 & 005.4 & 80.6 & 065.0\end{array}$ $\begin{array}{llllll}0.106 \mathrm{E}-03 & 340.4 & 83.2 & 065.0\end{array}$ $\begin{array}{llll}0.761 \mathrm{E}-04 & 214.2 & 83.9 & 065.0\end{array}$ $\begin{array}{lllll}0.663 \mathrm{E}-04 & 283.8 & -78.0 & 065.0\end{array}$ $\begin{array}{lllll}0.542 \mathrm{E}-04 & 281.9 & -78.7 & 065.0\end{array}$ $\begin{array}{lllll}0.447 & \mathrm{E}-04 & 172.1 & 88.1 & 065.0\end{array}$ $\begin{array}{lllll}0.384 \text { E- } 04 \quad 263.7 & -69.4 & 065.0\end{array}$ $\begin{array}{lllll}0.281 \mathrm{E}-04 & 233.7 & -56.6 & 065.0\end{array}$ $\begin{array}{lllllll}0.398 & \mathrm{E}-04 & 229.4 & -58.1 & 065.0\end{array}$ $\begin{array}{llllllll}0.313 \mathrm{E}-04 & 181.1 & -19.6 & 065.0\end{array}$ $0.119 \mathrm{E}-03 \quad 045.2 \quad-37.1 \quad 058.0$ $\begin{array}{llll}0.927 \mathrm{E}-04 & 040.1 & -22.1 & 058.0\end{array}$ $\begin{array}{lllll}0.496 \mathrm{E}-04 & 029.3 & -16.1 & 058.0\end{array}$ $\begin{array}{llll}0.389 \mathrm{E}-04 & 034.1 & 12.7 & 058.0\end{array}$ $\begin{array}{lllll}0.333 \mathrm{E}-04 & 024.1 & 02.0 & 058.0\end{array}$ $\begin{array}{lllllll}0.376 \mathrm{E}-04 & 049.6 & 31.1 & 058.0\end{array}$ $\begin{array}{llll}0.502 \mathrm{E}-04 & 069.2 & 35.5 & 058.0\end{array}$ $\begin{array}{llll}0.384 \mathrm{E}-04 & 033.0 & 28.9 & 058.0\end{array}$ $\begin{array}{lllll}0.504 \mathrm{E}-04 & 034.6 & 36.6 & 058.0\end{array}$ $\begin{array}{llll}0.559 \mathrm{E}-04 & 050.0 & 51.2 & 058.0\end{array}$

WANGANUI RIVER SITE $037 \mathrm{C}$

HEIGHT $=1778 \mathrm{~m}$ (above base of section) STRIKE $=043.0 \mathrm{DIP}=4.5$

SAMPLE FELD NO. TREAT. INTENSITY CDEC CINC Y-AZ PLUNGE

W037075.1 W3-6571.1 N00 
W0380802 W3-6676.2 T24 W038080.2 W3-6676.2 T30 W038080.2 W3-6676.2 T32 $0.359 \mathrm{~B}-03$ $0.351 \mathrm{E}-03$ $0.265 \mathrm{E}-03$

$\begin{array}{lll}125.9 & 78.1 & 131.0\end{array}$ $\begin{array}{lll}141.6 & 83.7 & 131.0 \\ 190.8 & 86.9 & 131.0\end{array}$ 42.0 w0380802 W3-6676.2 T34 W038080.2 W3-6676.2 T27

WANGANUI RIVER SITE $039 \mathrm{G}$

HEIGHT $=1891 \mathrm{~m}$ (above base of section) STRIKE $=043.0 \quad \mathrm{DIP}=45$

SAMPLE FIELD NO. TREAT. INTENSITY CDEC CINC Y-AZ PLUNGE

W039081.1 W2-1619.1 N00 W039081.1 W2-1619.1 T05 W039081.1 W2-1619.1 T10 W039081.1 W2-1619.1 T15 W039081.1 W2-1619.1 T20 W039081.1 W2-1619.1 T25 W039081.1 W2-1619.1 T30 W039081.1 W2-1619.1 T35 W039082.1 W2-1620.1 N00 W039082.1 W2-1620.1 T05 W039082.1 W/2-1620.1 T10 W039082.1 W2-1620.1 T15 W039082.1 W2-1620.1 T20 W039082.1 W2-1620.1 T25 W039082.1 W2-1620.1 T30 W039083.1 W/2-1621.1 N00 W039083.1 W2-1621.1 T05 W039083.1 W2-1621.1 T10 W039083.1 W2-1621.1 T15 W039083.1 W2-1621.1 T20 W039083.1 W2-1621.1 T25 W039083.1 W2-1621.1 T30 W039084.1 W2-1622.1 N00 W039084.1 W2-1622.1 T05 W039084.1 W2-1622.1 T10 W039084.1 W2-1622.1 T15 W039084.1 W2-1622.1 T20 W039084.1 W2-1622.1 T25

$\begin{array}{lllll}0.148 \mathrm{E}-03 & 297.1 & -47.7 & 020.0 & 33.0 \\ 0.169 \mathrm{E}-03 & 317.5 & -45.6 & 020.0 & 33.0 \\ 0.163 \mathrm{E}-03 & 322.9 & -41.1 & 020.0 & 33.0 \\ 0.173 \mathrm{E}-03 & 330.4 & -36.4 & 020.0 & 33.0 \\ 0.153 \mathrm{E}-03 & 334.8 & -29.5 & 020.0 & 33.0 \\ 0.855 \mathrm{E}-04 & 324.0 & -37.6 & 020.0 & 33.0 \\ 0.457 \mathrm{E}-04 & 338.6 & 15.5 & 020.0 & 33.0 \\ 0.697 \mathrm{E}-04 & 002.1 & -12.8 & 020.0 & 33.0 \\ 0.114 \mathrm{E}-03 & 204.6 & -23.4 & 022.0 & 37.0 \\ 0.760 \mathrm{E}-04 & 225.6 & -38.7 & 022.0 & 37.0 \\ 0.446 \mathrm{E}-04 & 282.7 & -35.8 & 022.0 & 37.0 \\ 0.621 \mathrm{E}-04 & 318.0 & -22.1 & 022.0 & 37.0 \\ 0.723 \mathrm{E}-04 & 334.0 & -16.5 & 022.0 & 37.0 \\ 0.600 \mathrm{E}-04 & 359.5 & -02.4 & 022.0 & 37.0 \\ 0.681 \mathrm{E}-04 & 007.4 & -07.7 & 022.0 & 37.0 \\ 0.186 \mathrm{E}-03 & 029.6 & -66.1 & 024.0 & 36.0 \\ 0.192 \mathrm{E}-03 & 031.3 & -62.6 & 024.0 & 36.0 \\ 0.206 \mathrm{E}-03 & 017.5 & -48.0 & 024.0 & 36.0 \\ 0.184 \mathrm{E}-03 & 018.8 & -51.5 & 024.0 & 36.0 \\ 0.142 \mathrm{E}-03 & 007.1 & -53.8 & 024.0 & 36.0 \\ 0.630 \mathrm{E}-04 & 222.8 & -23.4 & 024.0 & 36.0 \\ 0.118 \mathrm{E}-03 & 282.9 & -03.9 & 024.0 & 36.0 \\ 0.703 \mathrm{E}-04 & 098.1 & -49.0 & 025.0 & 27.0 \\ 0.857 \mathrm{E}-04 & 071.5 & -42.5 & 025.0 & 27.0 \\ 0.114 \mathrm{E}-03 & 050.1 & -34.7 & 025.0 & 27.0 \\ 0.122 \mathrm{E}-03 & 038.4 & -25.6 & 025.0 & 27.0 \\ 0.106 \mathrm{E}-03 & 029.0 & -15.1 & 025.0 & 27.0 \\ 0.950 \mathrm{E}-04 & 037.9 & -04.3 & 025.0 & 27.0 \\ 0.787 \mathrm{E}-04 & 037.6 & 05.7 & 025.0 & 27.0\end{array}$

WANGANUI RIVER SITE 040V

HEIGHT $=1938 \mathrm{~m}$ (above base of section) STRIKE $=043.0 \mathrm{DIP}=4.5$

SAMPLE FIELD NO. TREAT. INTENSITY CDEC CDNC Y-AZ PLUNGE

W040085.1 W4-0129.1 N00 W040085.1 W4-0129.1 T05 W040085.1 W4-0129.1 T10 W040085.1 W4-0129.1 T15 W040085.1 W4-0129.1 T20 W040085.1 W4-0129.1 T25 W040085.1 W4-0129.1 T30 W040085.2 W4-0129.2 NOO W040086.1 W4-0130.1 N00 W040086.1 W4-0130.1 T05 W040086.1 W4-0130.1 T10 W040086.1 W4-0130.1 T15 W040086.1 W4-0130.1 T20 W040086.1 W4-0130.1 T25 W040086.1 W4-0130.1 T30 W040086.2 W4-0130.2 N00 W040087.1 W4-0131.1 N00 W040087.1 W4-0131.1 T05 W040087.1 W4-0131.1 T10 W040087.1 W4-0131.1 T15 W040087.1 W4-0131.1 T20 W040087.1 W4-0131.1 T25 W040087.1 W4-0131.1 T30

$\begin{array}{lllll}0.218 \mathrm{E}-03 & 259.4 & -33.3 & 129.0 & 38.0 \\ 0.220 \mathrm{E}-03 & 281.1 & -24.8 & 129.0 & 38.0 \\ 0.205 \mathrm{E}-03 & 272.3 & -02.0 & 129.0 & 38.0 \\ 0.176 \mathrm{E}-03 & 247.7 & 05.1 & 129.0 & 38.0 \\ 0.177 \mathrm{E}-03 & 246.3 & 163 & 129.0 & 38.0 \\ 0.173 \mathrm{E}-03 & 243.9 & 22.2 & 129.0 & 38.0 \\ 0.154 \mathrm{E}-03 & 236.7 & 35.6 & 129.0 & 38.0 \\ 0.109 \mathrm{E}-03 & 230.8 & -74.2 & 129.0 & 38.0 \\ 0.759 \mathrm{E}-03 & 237.1 & -07.6 & 134.0 & 38.0 \\ 0.711 \mathrm{E}-03 & 232.4 & -06.2 & 134.0 & 38.0 \\ 0.723 \mathrm{E}-03 & 233.1 & 01.2 & 134.0 & 38.0 \\ 0.711 \mathrm{E}-03 & 230.7 & 04.9 & 134.0 & 38.0 \\ 0.659 \mathrm{E}-03 & 230.1 & 07.4 & 134.0 & 38.0 \\ 0.426 \mathrm{E}-03 & 226.1 & 11.1 & 134.0 & 38.0 \\ 0.351 \mathrm{E}-03 & 218.3 & 13.3 & 134.0 & 38.0 \\ 0.143 \mathrm{E}-03 & 297.2 & -63.0 & 134.0 & 38.0 \\ 0.383 \mathrm{E}-03 & 214.9 & -16.6 & 138.0 & 37.5 \\ 0.365 \mathrm{E}-03 & 211.7 & -15.8 & 138.0 & 37.5 \\ 0.379 \mathrm{E}-03 & 210.0 & -08.0 & 138.0 & 37.5 \\ 0.399 \mathrm{E}-03 & 208.8 & 00.7 & 138.0 & 37.5 \\ 0.378 \mathrm{E}-03 & 210.7 & 04.2 & 138.0 & 37.5 \\ 0.263 \mathrm{E}-03 & 209.6 & 02.4 & 138.0 & 37.5 \\ 0.207 \mathrm{E}-03 & 214.4 & 01.9 & 138.0 & 37.5 \\ 0.204 \mathrm{E}-03 & 117.7 & -75.0 & 138.0 & 37.5\end{array}$

WANGANUI RIVER SITE 041G

HEIGHT $=1973 \mathrm{~m}$ (above base of section) STRIKE $=043.0 \quad \mathrm{DIP}=45$

SAMPLE FIELD NO. TREAT. INTENSITY CDEC CINC Y-AZ PLUNGE

W041088.1 W3-6777.1 N00 W041088. W $\mathrm{W}-6777.1 \mathrm{~T} 08$ W041088.1 W3-6777.1 T12 W041088.1 W3-6777.1 T16 W041088.1 W3-6777.1 T18 W041088.1 W3-6777.1 T21 W041088.1 W3-6777.1 T24 W041088.1 W3-6777.1 T27 W041088.1 W3-6777.1 T30 W041088.1 W3-6777.1 T32 W041088.1 W3-6777.1 T34 W04 1088.1 W3-6777.1 T36 W041089.2 W3-6778.2 N00 W041089.2 W3-6778.2 T08 W041089.2 W3-6778.2 T12 W041089.2 W3-6778.2 T16 W041089.2 W3-6778.2 T18 W041089.2 W3-6778.2 T21 W041089.2 W3-6778.2 T24 W041089.2 W3-6778.2 T27 W041089.2 W3-6778.2 T30 W041089.2 W3-6778.2 T32 W041089.2 W3-6778.2 T34 W041089.2 W3-6778.2 T36 W04 1090.2 W3-6779.2 N00 W041090.2 W3-6779.2 T08 W04 1090.2 W3-6779.2 T12 W041090.2 W3-6779.2 T16 W041090.2 W3-6779.2 T18

$\begin{array}{lllll}0.111 \mathrm{E}-03 & 073.9 & -69.2 & 125.0 & 45.0 \\ 0.876 \mathrm{E}-04 & 087.6 & -64.4 & 125.0 & 45.0 \\ 0.637 \mathrm{E}-04 & 108.9 & -55.3 & 125.0 & 45.0 \\ 0.505 \mathrm{E}-04 & 104.9 & -51.2 & 125.0 & 45.0 \\ 0.476 \mathrm{E}-04 & 093.3 & -40.0 & 125.0 & 45.0 \\ 0.475 \mathrm{E}-04 & 080.9 & -31.6 & 125.0 & 45.0 \\ 0.325 \mathrm{E}-04 & 080.6 & -06.6 & 125.0 & 45.0 \\ 0.420 \mathrm{E}-04 & 105.0 & 06.2 & 125.0 & 45.0 \\ 0.491 \mathrm{E}-04 & 125.3 & 31.5 & 125.0 & 45.0 \\ 0.501 \mathrm{E}-04 & 126.5 & 37.7 & 125.0 & 45.0 \\ 0.414 \mathrm{E}-04 & 110.3 & 42.8 & 125.0 & 45.0 \\ 0.272 \mathrm{E}-04 & 132.4 & 49.6 & 125.0 & 45.0 \\ 0.753 \mathrm{E}-04 & 054.5 & -52.1 & 128.0 & 46.0 \\ 0.569 \mathrm{E}-04 & 075.6 & -16.5 & 128.0 & 46.0 \\ 0.465 \mathrm{E}-04 & 079.2 & 08.0 & 128.0 & 46.0 \\ 0.454 \mathrm{E}-04 & 085.4 & 21.1 & 128.0 & 46.0 \\ 0.504 \mathrm{E}-04 & 084.1 & 31.7 & 128.0 & 46.0 \\ 0.493 \mathrm{E}-04 & 090.1 & 31.1 & 128.0 & 46.0 \\ 0.321 \mathrm{E}-04 & 113.7 & 37.1 & 128.0 & 46.0 \\ 0.422 \mathrm{E}-04 & 100.0 & 44.4 & 128.0 & 46.0 \\ 0.474 \mathrm{E}-04 & 094.6 & 42.5 & 128.0 & 46.0 \\ 0.503 \mathrm{E}-04 & 100.3 & 44.5 & 128.0 & 46.0 \\ 0.277 \mathrm{E}-04 & 082.0 & 37.9 & 128.0 & 46.0 \\ 0.507 \mathrm{E}-04 & 087.3 & 33.7 & 128.0 & 46.0 \\ 0.673 \mathrm{E}-04 & 017.8 & -78.0 & 125.0 & 45.0 \\ 0.456 \mathrm{E}-04 & 025.9 & -725 & 125.0 & 45.0 \\ 0.235 \mathrm{E}-04 & 077.4 & -79.7 & 125.0 & 45.0 \\ 0.129 \mathrm{E}-04 & 227.2 & -74.8 & 125.0 & 45.0 \\ 0.198 \mathrm{E}-04 & 242.8 & -73.1 & 125.0 & 45.0\end{array}$

45.0

45.0

5.0

5.0

45.0

5.0

45.0

45.0

46.0

46.0

46.0

46.0

46.0

46.0

46.0

46.0

45.0

45.0 45.0

W041090.2 W3-6779.2 T21 W041090.2 W3-6779.2 T2 W041090.2 W3-6779.2 T27 W0410902 W/3-67792 T30 W041090.2 W3-6779.2 T32 W041090.2 W3-6779.2 T34

0.183 E-04 $230.9 \quad-51.8 \quad 125.0$ $\begin{array}{llll}0.216 \mathrm{E}-0.4 & 219.7 & -60.2 & 125.0\end{array}$ $\begin{array}{llll}0.189 \mathrm{E}-0.4 & 197.8 & -47.6 & 125.0\end{array}$ $\begin{array}{llll}0.183 \mathrm{E}-04 & 205.8 & -253 & 125.0\end{array}$ $\begin{array}{llll}0.120 \mathrm{E}-0.4 & 203.8 & 19.2 & 125.0\end{array}$ $\begin{array}{llll}0.132 \mathrm{E}-04 & 179.2 & 54.2 & 125.0\end{array}$ $\begin{array}{llll}0.227 \mathrm{E}-04 & 159.3 & 19.4 & 125.0\end{array}$

45.0 45.0 45.0

WANGANUI RIVER SITE 047C

HEIGHT $=2146 \mathrm{~m}$ (above base of section) STRIKE $=043.0 \mathrm{DIP}=4.5$

SAMPLE FIELDNO. TREAT. INTENSITY CDEC CINC Y-AZ PLUNGE

W047091.1 W3-6880.1 NOO W047091. W3-6880.1 T08 W047091.1 W3-6880.1 T12 W047091.1 W3-6880.1 T16 W047091.1 W3-6880.1 T18 W047091.1 W3-6880.1 T21 W047091.1 W3-6880.1 T24 W047091.1 W3-6880.1 T27 W047091.1 W3-6880.1 T30 W047091.1 W3-6880.1 T32 W047091.1 W3-6880.1 T34 W047091.1 W3-6880.1 T36 W047092.1 W3-6881.1 N0O W047092.1 W3-6881.1 TOS W047092.1 W3-6881.1 T12 W047092.1 W3-6881.1 T16 W047092.1 W3-6881.1 T18 W047092.1 W3-6881.1 T2 W047092.1 W3-6881.1 T2 W047092.1 W3-6881.1 T27 W047092.1 W3-6881.1 T30 W047092.1 W3-6881.1 T32 W047092.1 W3-6881.1 T34 W047093.1 W3-6882.1 NOO W047093.1 W3-6882.1 T08 W047093.1 W3-6882.1 T12 W047093.1 W3-6882.1 T16 W047093.1 W3-6882.1 T18 W047093.1 W3-6882.1 T21 W047093.1 W3-6882.1 T24 W047093.1 W3-6882.1 T27 W047093.1 W3-6882.1 T30 W047093.1 W3-6882.1 T32 W047093.1 W3-6882.1 T34 $\begin{array}{lllll}0.301 & \mathrm{E}-03 & 022.0 & -65.4 & 112.0\end{array}$ $0.268 \mathrm{E}-03 \quad 0140-628 \quad 1120$ $\begin{array}{lllll}0.205 \mathrm{E}-03 & 020.6 & -62.9 & 112.0\end{array}$ $\begin{array}{lllll}0.170 \mathrm{E}-03 & 017.2 & -62.8 & 112.0\end{array}$ $\begin{array}{lllll}0.163 \mathrm{E}-03 & 017.0 & -62.5 & 112.0\end{array}$ $\begin{array}{lllll}0.149 \mathrm{E}-03 & 011.5 & -62.3 & 112.0\end{array}$ $\begin{array}{lllll}0.129 \mathrm{E}-03 & 000.8 & -61.3 & 112.0\end{array}$ $0.120 \mathrm{E}-03 \quad 001.6-10.1 \quad 112.0$ $\begin{array}{lllll}0.101 \mathrm{E}-03 \quad 008.3 & -632 & 1120\end{array}$ $\begin{array}{lllll}0.101 \mathrm{E}-03 & 023.0 & -60.1 & 112.0\end{array}$ $\begin{array}{lllll}0.842 \text { E- } 04 & 034.7 & -55.5 & 112.0\end{array}$ $\begin{array}{lllll}0.786 & \mathrm{E}-04 & 018.2 & -50.5 & 112.0\end{array}$ $\begin{array}{llll}0.307 \text { E }-03 & 009.9 & -60.3 & 110.0\end{array}$ $\begin{array}{lllll}0.268 \mathrm{E}-03 & 009.2 & -58.3 & 110.0\end{array}$ $\begin{array}{lllll}0.214 \mathrm{E}-03 & 005.3 & -56.2 & 110.0\end{array}$ $\begin{array}{lllll}0.187 & \text { E- } 03 & 010.8 & -56.4 & 110.0\end{array}$ $\begin{array}{lllll}0.181 \text { E-03 } 013.6 & -55.8 & 110.0\end{array}$ $\begin{array}{lllll}0.169 \mathrm{E}-03 & 009.5 & -54.4 & 110.0\end{array}$ $\begin{array}{lllll}0.164 \mathrm{~B}-03 & 022.5 & -50.8 & 110.0\end{array}$ $\begin{array}{lllll}0.140 & \mathrm{E}-03 & 026.8 & -54.0 & 110.0\end{array}$ $\begin{array}{lllll}0.115 & \mathrm{E}-03 & 023.7 & -59.2 & 110.0\end{array}$ $\begin{array}{lllll}0.101 & \mathrm{E}-03 & 002.8 & -55.7 & 110.0\end{array}$ $\begin{array}{llll}0.868 \text { E-04 } & 015.5 & -44.5 & 110.0\end{array}$ $\begin{array}{lllll}0.287 \mathrm{E}-03 & 0195 & -54.9 & 107.0\end{array}$ $\begin{array}{lllll}0.256 \mathrm{E}-03 & 014.1 & -48.7 & 107.0\end{array}$ $\begin{array}{lllll}0.198 & \mathrm{E}-03 & 019.3 & -49.6 & 107.0\end{array}$ $\begin{array}{lllll}0.163 & \text { E-03 } & 022.8 & -45.6 & 107.0\end{array}$ $\begin{array}{lllll}0.157 \mathrm{E}-03 & 021.4 & -44.7 & 107.0\end{array}$ $\begin{array}{llll}0.180 \mathrm{E}-03 \quad 021.8 & 44.6 \quad 107.0\end{array}$ $\begin{array}{lllll}0.171 & \mathrm{E}-03 & 018.6 & -45.3 & 107.0\end{array}$ $\begin{array}{lllll}0.154 \mathrm{E}-03 & 024.1 & -48.7 & 107.0\end{array}$ $\begin{array}{lllll}0.120 \mathrm{E}-03 & 010.7 & -48.6 & 107.0\end{array}$ $\begin{array}{lllll}0.119 \mathrm{E}-03 & 000.8 & -42.6 & 107.0\end{array}$ $\begin{array}{lllll}0.110 \mathrm{E}-03 & 005.6 & -46.2 & 107.0\end{array}$ $\begin{array}{llll}0.866 \mathrm{E}-04 & 019.0 & -52.9 & 107.0\end{array}$

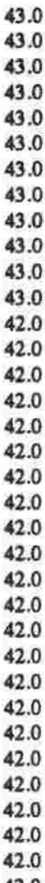

WANGANUI RIVER SITE 0490

HEIGHT $=2154 \mathrm{~m}$ (above base of section) STRIKE $=043.0 \mathrm{DIP}=4.5$

SAMPLE FELDNO. TREAT. DNTENSITY CDEC CDNC Y-AZ PLUNGE

W049094.1 W2-2323.1 N00 W049094.1 W2-2323.1 T05 W049094.1 W2-2323.1 T10 W049094.1 W2-2323.1 T15 W049094.1 W2-2323.1 T15
W049094.1 W2-2323.1 T20 W049094.1 W2-2323.1 T20 W049094.1 W2-2323.1 T30 W0490942 W2-2323.2 NOO W049094.2 W2-2323.2 T05 W049094.2 W2-2323.2 T10 W049094.2 W2-2323.2 T10 W049094.2 W2-2323.2 T15
W049094.2 W2-2323.2 T20 W0490942 W2-2323.2 T25 W0490942 W2-2323.2 T30 W049095.1 W2-2324.1 N0O W049095.1 W2-2324.1 T05 W049095.1 W2-2324.1 T10 W049095.1 W2-2324.1 T15 W049095.1 W2-2324.1 T20 W049095.1 W2-2324.1 T25 W049095.1 W2-2324.1 T30 W0490953 W2-2324.3 N00 W0490953 W2-23243 T05 W049095.3 W2-2324.3 T10 W0490953 W2-2324.3 T15 W049095.3 W2-2324.3 T20 W0490953 W2-2324.3 T25 W049095.3 W2-2324.3 T30 W049096.1 W2-2325.1 N00 W049096.1 W2-2325.1 T05 W049096.1 W2-2325.1 T10 W049096.1 W2-2325.1 T15 W049096.1 W2-2325.1 T20 W049096.1 W2-2325.1 T25 $0.141 \mathrm{E}-03$ $\begin{array}{lllll}0.102 \mathrm{E}-03 & 198.4 & -33.8 & 0140\end{array}$ $\begin{array}{lllll}0.837 \mathrm{E}-04 & 187.8 & -25.6 & 0140\end{array}$ $\begin{array}{llll}0.526 \mathrm{E}-04 & 193.3 & -19.3 & 014.0\end{array}$ $\begin{array}{llll}0.354 \mathrm{E}-04 & 214.0 & -29.7 & 014\end{array}$ $\begin{array}{lllll}0.306 \mathrm{E}-0.4 & 195.9 & -09.3 & 014.0\end{array}$ $0.247 \mathrm{E}-04 \quad 170.0 \quad 04.0 \quad 014.0$ $\begin{array}{lllll}0.115 \mathrm{E}-03 & 176.8 & -113 & 014.0\end{array}$ $\begin{array}{lllll}0.639 & \mathrm{E}-04 & 165.9 & -19.6 & 014.0\end{array}$ $\begin{array}{llll}0.551 \text { E-04 } 1503 & -065 & 014\end{array}$ $\begin{array}{llll}0.291 \mathrm{E}-0 . & 136.5 & 00.0 & 014 .\end{array}$ $\begin{array}{llll}0.340 \mathrm{E}-04 & 156.6 & 15.2 & 014 .\end{array}$ $\begin{array}{llll}0.289 \mathrm{E}-04 & 143.3 & 17.8 & 014.0\end{array}$ 0.432 E- $04 \quad 139.1 \quad 24.1 \quad 014.0$ $\begin{array}{lllll}0.153 \mathrm{E}-03 & 184.2 & -24.0 & 019.0\end{array}$ $\begin{array}{llllllllll}0.106 \mathrm{E}-03 & 178.4 & -27.0 & 019.0\end{array}$ $\begin{array}{llll}0.639 \mathrm{E}-04 & 225.5 & -42.1 & 019.0\end{array}$ $\begin{array}{lllll}0.479 \mathrm{E}-04 & 189.1 & -39.4 & 019.0\end{array}$ $\begin{array}{lllll}0.407 \mathrm{E}-04 & 189.1 & -13.0 & 019.0\end{array}$ $\begin{array}{lllll}0.408 \mathrm{E}-04 & 182.5 & -05.4 & 019.0\end{array}$

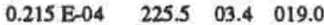

$\begin{array}{lllll}0.142 \mathrm{E}-03 & 200.9 & -26.7 & 019.0\end{array}$

$\begin{array}{lllll}0.116 \mathrm{E}-03 & 188.1 & -23.9 & 019.0\end{array}$ $\begin{array}{lllll}0.729 & \text { E- } 04 & 200.4 & -26.8 & 019.0\end{array}$ $\begin{array}{llll}0.520 \text { E- } 04 & 211.5 & -325 & 019.0\end{array}$ $0.438 \mathrm{E}-04 \quad 223.3 \quad-42.3 \quad 019.0$ $\begin{array}{lllll}0.411 & \mathrm{E}-04 \quad 207.8 \quad 46.6 & 019.0\end{array}$ $\begin{array}{lllll}0.289 & \text { E- } 04 & 175.6 & -50.6 & 019.0\end{array}$ $\begin{array}{lllll}0.111 & E-03 & 202.3 & -08.9 & 027.0\end{array}$ $\begin{array}{lllll}0.658 \text { E- } 04 & 194.6 & -145 & 027.0\end{array}$ $\begin{array}{lllll}0.299 & \text { E- } 04 & 206.3 & -17.3 & 027.0\end{array}$ 
W050097.1 W3-7186.1 T34 W050098.2 W3-7187.2 N00 W050098.2 W3-7187.2 TO W050098.2 W/3-7187.2 T12 W050098.2 W3-7187.2 T16 W050098.2 W3-7187.2 T18 W050098. 2 W3-7187.2 T21 W050098.2 W3-7187.2 T2 W050098.2 W3-7187.2 T2 W050098.2 W3-7187.2 T30 W050098.2 W3-7187.2 T32 W050098.2 W3-7187.2 T34 W050098.2 W3-7187.2 T36 W050099.1 W3-7188.1 N00 W050099.1 W3-7188.1 T0 W050099.1 W3-7188.1 T12 W050099.1 W3-7188.1 T16 W050099.1 W3-7188.1 T18 W050099.1 W3-7188.1 T21 W050099.1 W3-7188.1 T2 W050099.1 W3-7188.1 T27 W050099. 1 W/3-7188. 1 T30 W050099.1 W3-7188.1 T32

$\begin{array}{lrrll}0.224 \mathrm{E}-04 & 132.4 & 47.4 & 117.0 & 42.0 \\ 0.459 \mathrm{E}-03 & 256.2 & -03.5 & 115.0 & 43.0 \\ 0.470 \mathrm{E}-03 & 253.7 & -02.8 & 115.0 & 43.0 \\ 0.451 \mathrm{E}-03 & 253.8 & 00.8 & 115.0 & 43.0 \\ 0.423 \mathrm{E}-03 & 253.7 & 01.4 & 115.0 & 43.0 \\ 0.410 \mathrm{E}-03 & 252.7 & 01.8 & 115.0 & 43.0 \\ 0.393 \mathrm{E}-03 & 251.8 & 02.1 & 115.0 & 43.0 \\ 0.369 \mathrm{E}-03 & 249.8 & 03.4 & 115.0 & 43.0 \\ 0.356 \mathrm{E}-03 & 254.1 & 02.6 & 115.0 & 43.0 \\ 0.310 \mathrm{E}-03 & 255.9 & 04.1 & 115.0 & 43.0 \\ 0.298 \mathrm{E}-03 & 255.0 & 05.1 & 115.0 & 43.0 \\ 0.282 \mathrm{E}-03 & 253.5 & 02.8 & 115.0 & 43.0 \\ 0.271 \mathrm{E}-03 & 251.8 & 02.9 & 115.0 & 43.0 \\ 0.542 \mathrm{E}-04 & 004.3 & -48.0 & 118.0 & 35.0 \\ 0.361 \mathrm{E}-04 & 032.6 & -45.5 & 118.0 & 35.0 \\ 0.227 \mathrm{E}-04 & 040.6 & -17.5 & 118.0 & 35.0 \\ 0.162 \mathrm{E}-04 & 051.8 & 16.1 & 118.0 & 35.0 \\ 0.138 \mathrm{E}-04 & 051.2 & 21.2 & 118.0 & 35.0 \\ 0.151 \mathrm{E}-04 & 052.5 & 59.1 & 118.0 & 35.0 \\ 0.121 \mathrm{E}-04 & 086.2 & 50.8 & 118.0 & 35.0 \\ 0.105 \mathrm{E}-04 & 034.9 & 32.6 & 118.0 & 35.0 \\ 0.168 \mathrm{E}-04 & 065.0 & 33.0 & 118.0 & 35.0 \\ 0.129 \mathrm{E}-04 & 081.6 & 34.0 & 118.0 & 35.0\end{array}$

WANGANUI RIVER SITE 051G

HEIGHT $=2189 \mathrm{~m}$ (above bese of section) STRIKE $=043.0 \mathrm{DIP}=4 \mathrm{~S}$

SAMPLE FIELD NO. TREAT. INTENSITY CDEC CINC Y-AZ PLUNGE

W051100.1 W3-6983.1 N00 W051100.1 W3-6983.1 T08 W051100.1 W3-6983.1 T12 W051100.1 W3-6983.1 T16 W051100.1 W3-6983.1 T18 W051100.1 W3-6983.1 T21 w051100.1 W/3-6983.1 T2 W051100.1 W3-6983.1 T2 W051100.1 W3-6983.1 T30 W051100.1 W3-6983.1 T32 W051100.1 W3-6983.1 T34 W051101.1 W3-6984.1 NOO W051101.1 W3-6984.1 T08 W051101 1 W3-69841 T12 W051101.1 W3-6984.1 T16 W051101.1 W3-6984.1 T18 W051101.1 W3-6984.1 T2 W051101.1 W3-6984.1 T2 W051101.1 W3-6984.1 T27 W051101.1 W3-6984.1 T30 W051101.1 W3-6984.1 T32 W051101.1 W3-6984.1 T3 W051101.1 W3-6984.1 T36 W051102.1 W3-6985.1 N00 W051102.1 W3-6985.1 T08 W051102.1 W3-6985.1 T12 W051102.1 W3-6985.1 T16 W051102.1 W3-6985.1 T1 W051102.1 W3-6985.1 T2 W051102.1 W3-6985.1 T2 W051102.1 W3-6985.1 T27 W051102.1 W3-6985.1 T30 W051102.1 W3-6985.1 T32 W051102.1 W3-6985.1 T34

$\begin{array}{lllll}0.369 \mathrm{E}-03 & 027.2 & -64.7 & 167.0 & 48.0 \\ 0.335 \mathrm{E}-03 & 028.9 & -61.8 & 167.0 & 48.0 \\ 0.280 \mathrm{E}-03 & 037.2 & -62.5 & 167.0 & 48.0 \\ 0.241 \mathrm{E}-03 & 045.8 & -62.2 & 167.0 & 48.0 \\ 0.222 \mathrm{E}-03 & 047.8 & -61.8 & 167.0 & 48.0 \\ 0.201 \mathrm{E}-03 & 052.3 & -56.4 & 167.0 & 48.0 \\ 0.174 \mathrm{E}-03 & 058.6 & -53.8 & 167.0 & 48.0 \\ 0.163 \mathrm{E}-03 & 059.6 & -57.1 & 167.0 & 48.0 \\ 0.148 \mathrm{E}-03 & 043.8 & -59.7 & 167.0 & 48.0 \\ 0.169 \mathrm{E}-03 & 028.9 & -67.8 & 167.0 & 48.0 \\ 0.141 \mathrm{E}-03 & 045.4 & -63.9 & 167.0 & 48.0 \\ 0.382 \mathrm{E}-03 & 012.7 & -63.1 & 164.0 & 49.0 \\ 0.343 \mathrm{E}-03 & 010.8 & -58.3 & 164.0 & 49.0 \\ 0.288 \mathrm{E}-03 & 012.9 & -59.4 & 164.0 & 49.0 \\ 0.254 \mathrm{E}-03 & 015.5 & -56.9 & 164.0 & 49.0 \\ 0.245 \mathrm{E}-03 & 019.5 & -57.5 & 164.0 & 49.0 \\ 0.232 \mathrm{E}-03 & 019.2 & -51.7 & 164.0 & 49.0 \\ 0.220 \mathrm{E}-03 & 020.6 & -53.7 & 164.0 & 49.0 \\ 0.199 \mathrm{E}-03 & 024.8 & -51.9 & 164.0 & 49.0 \\ 0.172 \mathrm{E}-03 & 024.1 & -56.6 & 164.0 & 49.0 \\ 0.183 \mathrm{E}-03 & 031.6 & -48.2 & 164.0 & 49.0 \\ 0.186 \mathrm{E}-03 & 021.5 & -60.4 & 164.0 & 49.0 \\ 0.166 \mathrm{E}-03 & 030.1 & -63.3 & 164.0 & 49.0 \\ 0.316 \mathrm{E}-03 & 012.7 & -57.4 & 155.0 & 49.0 \\ 0.277 \mathrm{E}-03 & 016.3 & -56.6 & 155.0 & 49.0 \\ 0.223 \mathrm{E}-03 & 017.2 & -56.4 & 155.0 & 49.0 \\ 0.196 \mathrm{E}-03 & 020.7 & -55.9 & 155.0 & 49.0 \\ 0.185 \mathrm{E}-03 & 016.5 & -55.9 & 155.0 & 49.0 \\ 0.177 \mathrm{E}-03 & 014.2 & -54.9 & 155.0 & 49.0 \\ 0.174 \mathrm{E}-03 & 017.0 & -53.5 & 155.0 & 49.0 \\ 0.164 \mathrm{E}-03 & 026.8 & -53.3 & 155.0 & 49.0 \\ 0.143 \mathrm{E}-03 & 040.1 & -52.0 & 155.0 & 49.0 \\ 0.119 \mathrm{E}-03 & 026.8 & -54.0 & 155.0 & 49.0 \\ 0.902 \mathrm{E}-04 & 029.0 & -52.9 & 155.0 & 49.0 \\ 0.730 \mathrm{E}-04 & 027.1 & -53.0 & 155.0 & 49.0 \\ & & & & \end{array}$

WANGANUI RIVER SITE $058 C$

HEIGHT $=2288 \mathrm{~m}$ (above base of section) STRIKE $=043.0 \mathrm{DIP}=4.5$

SAMPLE FIELD NO. TREAT. INTENSTTY CDEC CINC Y-AZ PLUNGE

W058103.1 W3-7795.1 N00 W058103.1 W3-7795.1 T12 W058103.1 W3-7795.1 T16 W058103.1 W3-7795.1 T2 W058103.1 W3-7795.1 T24 W058103.1 W3-7795.1 T27 W058103.1 W3-7795.1 T30 W058104.1 W3-7796.1 NOD W058104.1 W3-7796.1 T12 W058104.1 W3-7796.1 T16 W058104.1 W3-7796.1 T2 W058104.1 W3-7796.1 T24 W058104.1 W3-7796.1 T27 W058104.1 W3-7796.1 T30 w058104.2 W3-7796. 2 NOD W058104.2 W3-7796.2 T12 W058104.2 W3-7796.2 T16 W058104.2 W3-7796.2 T2 W058104.2 W3-7796.2 T24 W058104.2 W/3-7796.2 T27 W058104.2 W3-7796.2 T30 w0591062 W3-78992 T05 w0591062 W/3-78992 T10 W059106. W/3-7899.2 T1 W059106.2 W/3-7899.2 T20 W059106.2 W3-7899.2 T2 W059106.2 W3-7899.2 T30 W059107. W W059107.1 W3-7800.1 T05 W059107.1 W3-7800.1 T10 W059107.1 W3-7800.1 T15 W059107.1 W3-7800.1 T20 W059107.1 W3-7800.1 T25 W059107.1 W3-7800.1 T30 $\begin{array}{llll}0.425 \mathrm{E}-0.04 & 349.1 & -30.0 & 168.0\end{array}$

$\begin{array}{lllll}0.333 \mathrm{E}-04 & 348.1 & -083 & 168.0\end{array}$

$\begin{array}{lllll}0.321 \mathrm{E}-0.4 & 346.0 & 18.7 & 168.0\end{array}$

$\begin{array}{lllll}0.369 & \text { E- } 04 & 346.1 & 28.8 & 168.0\end{array}$

$\begin{array}{lllll}0.388 & \mathrm{E}-04 & 331.5 & 20.1 & 168.0\end{array}$

$\begin{array}{lllll}0.337 \mathrm{E}-04 & 324.9 & 10.1 & 168.0\end{array}$

$\begin{array}{lllll}0.847 & \mathrm{E}-04 & 034.8 & -413 & 173.0\end{array}$

$\begin{array}{lllll}0.837 & \text { E- } 04 & 041.0 & 02.0 & 173.0\end{array}$

$\begin{array}{lllll}0.744 \mathrm{E}-04 & 037.1 & 11.9 & 173.0\end{array}$

$\begin{array}{llll}0.685 \mathrm{E}-04 & 008.5 & 23.4 & 173.0\end{array}$

$\begin{array}{lllll}0.650 \mathrm{E}-04 & 290.3 & 27.3 & 173.0\end{array}$

$\begin{array}{lllll}0.663 & \mathrm{E}-04 & 284.0 & 24.3 & 173.0\end{array}$

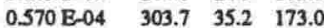

55.0

55.0

55.0

55.0

59.0

59.0

59.0
WANGANUI RIVER SITE $060 \mathrm{C}$

HEIGHT $=2337 \mathrm{~m}$ (above bese of section) STRIKE $=043.0 \quad \mathrm{DIP}=4.5$

SAMPLE FIELDNO. TREAT. INTENSITY CDEC CINC Y-AZ PLUNGE

W060108.2 W3-7901.2 N00

W060108.2 W3-7901.2 T0S

W060108.2 W3-7901 2 T10

W060108.2 W3-7901.2 T15

W060108.2 W3-7901.2 T20

W060108.2 W3-7901.2 T2

W060108.2 W3-7901.2 T30

W060109.1 W/-7902.1 N0O

W060109.1 W3-7902.1 T05

W060109.1 W3-7902.1 T10

W060109.1 W/3-7902.1 T15

W060109.1 W3-7902.1 T20

W060109.1 W3-7902.1 T2

W060109.1 W3-7902.1 T30

W060110.1 W/3-7903.1 N0O

W060110.1 W3-7903.1 T05

W060110.1 W3-7903.1 T10

W060110.1 W3-7903.1 T15

W060110.1 W3-7903.1 T2

W060110.1 W3-7903.1 T2

W060110.1 W3-7903.1 T30

$\begin{array}{lrrrr}0.934 \text { E-04 } & 346.8 & -50.5 & 201.0 & 41.0 \\ 0.512 \text { E-04 } & 344.5 & -42.5 & 201.0 & 41.0 \\ 0.298 \text { E-04 } & 334.8 & -24.7 & 201.0 & 41.0 \\ 0.227 \text { E-04 } & 330.9 & -00.8 & 201.0 & 41.0 \\ 0.237 \text { E-04 } & 331.4 & 01.1 & 201.0 & 41.0 \\ 0.188 \text { E-04 } & 338.7 & 22.3 & 201.0 & 41.0 \\ 0.115 \text { E-04 } & 339.9 & 00.8 & 201.0 & 41.0 \\ 0.543 \text { E-04 } & 058.6 & -62.6 & 192.0 & 53.0 \\ 0.229 \text { E-04 } & 109.1 & -30.4 & 192.0 & 53.0 \\ 0.208 \text { E-04 } & 132.5 & 15.4 & 192.0 & 53.0 \\ 0.365 \text { E-04 } & 132.9 & 36.3 & 192.0 & 53.0 \\ 0.335 \text { E-04 } & 132.4 & 44.0 & 192.0 & 53.0 \\ 0.272 \text { E-04 } & 111.8 & 26.3 & 192.0 & 53.0 \\ 0.236 \text { E-04 } & 145.1 & 22.9 & 192.0 & 53.0 \\ 0.868 \text { E-04 } & 117.2 & -25.4 & 200.0 & 45.0 \\ 0.955 \text { E-04 } & 128.0 & -01.2 & 200.0 & 45.0 \\ 0.937 \text { E-04 } & 135.0 & 10.8 & 200.0 & 45.0 \\ 0.760 \text { E-04 } & 143.5 & 10.7 & 200.0 & 45.0 \\ 0.664 \text { E-04 } & 144.8 & 14.8 & 200.0 & 45.0 \\ 0.658 \text { E-04 } & 153.6 & 25.2 & 200.0 & 45.0 \\ 0.516 \text { E-04 } & 140.3 & 27.6 & 200.0 & 45.0\end{array}$

WANGANUI RIVER SITE 0610

HEIGHT $=2377 \mathrm{~m}$ (above base of section) $5 T$ RIKE $=043.0 \mathrm{DIP}=4.5$

SAMPLE FIELDNO. TREAT, INTENSITY CDEC CINC Y-AZ PLUNGE

W061111.2 W3-8004.2 N00

W061111.2 W3-8004.2 T08

W061111.2 W3-8004.2 T12

W061111.2 W3-8004.2 T16

W061111.2 W3-8004.2 T18

W061111.2 W3-8004.2 T2

W061111.2 W3-8004.2 T2

W061111.2 W3-8004.2 T27

W061111.2 W3-8004.2 T30

W061111.2 W3-8004.2 T32

W061111.2 W3-8004.2 T34

W061111.2 W3-8004.2 T36

W061112.1 W3-8005.1 NOO

W061112.1 W3-8005.1 T08

W061112.1 W3-8005.1 T12

W061112.1 W3-8005.1 T16

W061112.1 W3-8005.1 T18

W061112.1 W3-8005.1 T21

W061112.1 W3-8005.1 T24

W061112.1 W3-8005.1 T27

W061112.1 W3-8005.1 T30

W061112.1 W3-8005.1 T32

W061112.1 W3-8005.1 T34

W061112.1 W3-8005.1 T36

W061113.1 W3-8006.1 N00

W061113.1 W3-8006.1 T08

W061113.1 W3-8006.1 T12

W061113.1 W/3-8006.1 T16

W061113.1 W3-8006.1 T18

W061113.1 W3-8006.1 T21

W061113.1 W3-8006.1 T24

W061113.1 W3-8006.1 T27

W061113.1 W3-8006.1 T30

W061113.1 W3-8006.1 T32

W061113.1 W3-8006.1 T34

$\begin{array}{lllll}0.592 \mathrm{E}-03 & 356.1 & -68.4 & 097.0 & 39.0\end{array}$

$\begin{array}{lllll}0.452 \mathrm{E}-03 & 351.9 & -67.6 & 097.0 & 39.0\end{array}$

$\begin{array}{lllll}0.324 \mathrm{E}-03 & 347.3 & -66.8 & 097.0 & 39.0\end{array}$

$\begin{array}{lllll}0.189 \mathrm{E}-03 & 336.0 & -633 & 097.0 & 39.0\end{array}$

$\begin{array}{llllll}0.141 & \mathrm{E}-03 & 324.8 & -61.8 & 097.0 & 39.0\end{array}$

$\begin{array}{lllll}0.897 \mathrm{E}-04 & 322.1 & -56.6 & 097.0 & 39.0\end{array}$

$\begin{array}{lllll}0.640 \text { E- } 04 & 341.7 & -65.0 & 097.0 & 39.0\end{array}$

$\begin{array}{lllll}0.697 \text { E- } 04 & 029.7 & -76.1 & 097.0 & 39.0\end{array}$

$\begin{array}{lllll}0.614 \mathrm{E}-04 & 000.8 & -69.9 & 097.0 & 39.0\end{array}$

$\begin{array}{lllll}0.419 \mathrm{E}-04 & 006.5 & -49.3 & 097.0 & 39.0\end{array}$

$\begin{array}{lllll}0.347 \mathrm{E}-04 & 358.6 & -57.8 & 097.0 & 39.0\end{array}$

$\begin{array}{lllll}0.365 \mathrm{E}-04 & 345.8 & -615 & 097.0 & 39.0\end{array}$

$\begin{array}{lllll}0.474 \mathrm{E}-03 & 004.2 & -59.9 & 096.0 & 34.0\end{array}$

$\begin{array}{lllll}0.343 \mathrm{E}-03 & 002.8 & -57.9 & 096.0 & 34.0\end{array}$

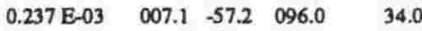

$\begin{array}{lllll}0.116 \mathrm{E}-03 & 008.9 & -51.1 & 096.0 & 34.0\end{array}$

$\begin{array}{lllll}0.775 \mathrm{E}-04 & 011.3 & -42.2 & 096.0 & 34.0\end{array}$

$\begin{array}{lllll}0.419 \mathrm{E}-04 & 014.3 & -22.0 & 096.0 & 34.0\end{array}$

$\begin{array}{lllll}0.344 \mathrm{E}-04 & 040.9 & -00.8 & 096.0 & 34.0\end{array}$

$\begin{array}{llllll}0.250 \mathrm{E}-04 & 078.6 & -04.9 & 096.0 & 34.0\end{array}$

$\begin{array}{llllll}0.139 \mathrm{E}-04 & 069.5 & -08.6 & 096.0 & 34.0\end{array}$

$\begin{array}{lllll}0.212 \mathrm{E}-04 & 058.5 & 11.4 & 096.0 & 34.0\end{array}$

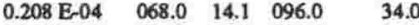

$\begin{array}{llllll}0.322 \mathrm{E}-04 & 003.5 & -06.2 & 096.0 & 34.0\end{array}$

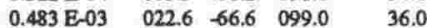

$\begin{array}{llllll}0.364 \mathrm{E}-03 & 016.5 & -65.4 & 099.0 & 36.0\end{array}$

$\begin{array}{llllll}0.253 \mathrm{E}-03 & 028.7 & -65.8 & 099.0 & 36.0\end{array}$

$\begin{array}{lllll}0.125 \mathrm{E}-03 & 048.8 & -615 & 099.0 & 36.0\end{array}$

$\begin{array}{lllll}0.823 \mathrm{E}-04 & 067.5 & -61.1 & 099.0 & 36.0\end{array}$

$\begin{array}{lllll}0.557 \text { E- } 04 & 086.4 & -41.9 & 099.0 & 36.0\end{array}$

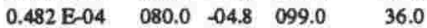

$\begin{array}{lllll}0.287 \mathrm{E}-04 & 105.8 & 00.8 & 099.0 & 36.0\end{array}$

$\begin{array}{lllll}0.216 \mathrm{E}-04 & 099.7 & 13.7 & 099.0 & 36.0\end{array}$

$\begin{array}{lllll}0.369 \mathrm{E}-04 & 087.9 & 15.8 & 099.0 & 36.0\end{array}$

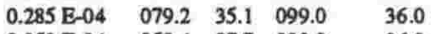

$\begin{array}{lllllll}\text { W061113.1 W3-8006.1 T36 } & 0.353 \text { E-04 } & 052.4 & 27.7 & 099.0 & 36.0\end{array}$

WANGANUI RIVER SITE $063 \mathrm{G}$

HEIGHT $=2440 \mathrm{~m}$ (above base of section) STRIKE $=043.0 \mathrm{DIP}=4.5$

SAMPLE FIELDNO. TREAT. DNTENSITY CDEC CINC Y-AZ PLUNGE

W063114.1 W3-8107.1 N0O

W063114.1 W3-8107.1 T10

W063114.1 W3-8107.1 T15

W063114.1 W3-8107.1 T20

W063114.1 W3-8107.1 T25

W063114.1 W3-8107.1 T30

W063114.1 W3-8107.1 T32

W063115.1 W3-8108.1 N00

W063115.1 W3-8108.1 T10

W063115.1 W3-8108.1 T15

W063115.1 W/3-8108.1 T20

W063115.1 W3-8108.1 T2

W063115.1 W3-8108.1 T30

W063115.1 W3-8108.1 T32

W063116.2 W3-8109.2 N0O

W063116.2 W3-8109.2 T10

$\begin{array}{lllll}0.529 & \mathrm{E}-04 & 208.0 & -66.9 & 112.0\end{array}$

34.0

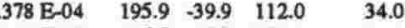

$\begin{array}{lllll}0.364 \mathrm{E}-04 & 195.7 & -16.7 & 112.0 & 34.0\end{array}$

$\begin{array}{lllll}0.337 \mathrm{E}-04 & 188.1 & -13.1 & 112.0 & 34.0\end{array}$

$\begin{array}{lllll}0.307 \mathrm{E}-04 & 183.7 & -43.2 & 112.0 & 34.0\end{array}$

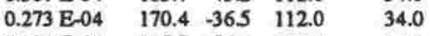

$\begin{array}{lll}125.7 & -54.6 & 112.0\end{array}$

$\begin{array}{lllll}0.103 \mathrm{E}-03 & 278.8 & -48.0 & 114.0\end{array}$

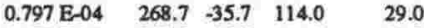

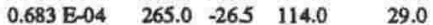

$\begin{array}{lllll}0.755 \mathrm{E}-04 & 263.6 & -24.8 & 114.0 & 29.0\end{array}$

$\begin{array}{lllll}0.788 \text { E- } 04 & 257.0 & -26.1 & 114.0 & 29.0\end{array}$

$\begin{array}{lllll}0.754 \mathrm{E}-04 & 253.8 & -21.2 & 114.0 & 29.0\end{array}$

$\begin{array}{lllll}0.722 \mathrm{E}-0.4 & 076.3 & -29.4 & 114.0 & 29.0\end{array}$

$\begin{array}{lllll}0.908 \mathrm{E}-04 & 069.6 & 14.0 & 115.0 & 30.0\end{array}$

$\begin{array}{llll}0.912 \mathrm{E}-04 & 078.8 & 27.3 & 115.0\end{array}$

$\begin{array}{lllll}0.966 \mathrm{E}-04 & 079.6 & 33.0 & 115.0 & 30.0\end{array}$

W063116.2 W3-8109.2 T15
W059105.2 W3-7898.2 T30

$\begin{array}{lllll}0.258 \mathrm{E}-04 & 303.7 & -50.2 & 172.0 & 55.0\end{array}$ 

$\begin{array}{llllllll}\text { W063116.2 W3-8109.2 T20 } & 0.993 \text { B-04 } & 068.5 & 31.0 & 115.0 & 30.0 \\ \text { W063116.2 W3-8109.2 T25 } & 0.108 \text { E-03 } & 069.6 & 30.6 & 115.0 & 30.0 \\ \text { W063116.2 W3-8109.2 T30 } & 0.960 \text { E-04 } & 072.9 & 30.0 & 115.0 & 30.0\end{array}$ $\begin{array}{lllllll}\text { W063116.2 W3-8109.2 T32 } & 0.177 \text { E-04 } & 189.2 & -34.0 & 115.0 & 30.0\end{array}$

WANGANUI RIVER STTE 064G

HEIGHT $=2445 \mathrm{~m}$ (above bese of section) STRIKE $=043.0 \mathrm{DIP}=45$

SAMPLE FIELDNO. TREAT. INTENSITY CDEC CINC Y-AZ PLUNGE

W064117.1 W2-2526.1 N00

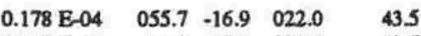
W064117.1 W2-2526.1 T05

$\begin{array}{llll}0.187 \mathrm{E}-04 & 142.3 & 27.2 & 022.0\end{array}$

W064117.1 W2-2526.1 T10

W064117.1 W2-2526.1 T15

W064117.1 W2-2526.1 T20

$\begin{array}{llll}0.266 \mathrm{E}-04 & 133.9 & 275 & 022\end{array}$

$\begin{array}{llll}0.376 \mathrm{E}-04 & 136.8 & 64.7 & 022.0\end{array}$

$\begin{array}{llll}0.329 \mathrm{E}-04 & 126.9 & 513 & 022.0\end{array}$

$\begin{array}{lllll}0.296 \text { E- } 04 \quad 099.0 & 18.4 \quad 0220\end{array}$

$\begin{array}{llll}0.107 \mathrm{E}-04 & 051.8 & -13.0 & 022.0\end{array}$

$\begin{array}{lllll}0.218 \mathrm{E}-04 & 324.3 & -34.1 & 020.0\end{array}$

$\begin{array}{llll}0.115 \text { B- } 04 & 113.1 & -64.8 & 020.0\end{array}$

$\begin{array}{llll}0.231 \mathrm{E}-04 & 179.0 & 59.9 & 020.0\end{array}$

$0.146 \mathrm{E}-04$

W064118.1 W2-2527.1

W064118.1 W2-2527.1 T15

W064118.1 W2-2527.1 T25

W064118.1 W2-2527.1 T30

W064119.1 W2-2528.1 N00

W064119.1 W2-2528.1 T05

$0.130 \mathrm{E}-04$

$\begin{array}{rrr}155.5 & 63.0 & 020.0 \\ 131.1 & -04.7 & 020.0\end{array}$

$\begin{array}{llll}262 \mathrm{E}-04 & 140.5 & 35.1 & 020.0\end{array}$

$0.258 \mathrm{E}-04 \quad 044.2-653 \quad 025.0$

$0.152 \mathrm{E}-04 \quad 154.4 \quad-313 \quad 025.0$

$0.171 \mathrm{E}-04 \quad 148.9 \quad-18.0 \quad 025.0$

$\begin{array}{llll}0.104 \mathrm{E}-04 & 142.2 & 36.2 & 025.0\end{array}$

$\begin{array}{llll}0.910 \mathrm{E}-05 & 101.6 & 54.7 & 025\end{array}$

$\begin{array}{llll}0.119 \mathrm{E}-04 & 086.8 & 005 & 025.0\end{array}$

$\begin{array}{lllll}0.130 \mathrm{E}-04 & 134.6 & 32.2 & 025.0\end{array}$
43.5

43.5

43.5

43.5

43.0

43.0

43.0

43.0
43.0

43.5

43.5

43.5

43.5

43.5
W064119.1 W2-2528.1 T30

WANGANUI RIVER STTE 065G

HEIGHT $=2507 \mathrm{~m}$ (above base of section) $\mathrm{STRIKE}=043.0 \mathrm{DIP}=4.5$

SAMPLE FIELDNO. TREAT. INTENSITY CDEC CDNC Y-AZ PLUNGE

W065120.1 W3-8210.1 N00

W065120.1 W3-8210.1 T10

W065120.1 W3-8210.1 T15

W065120.1 W3-8210.1 T20

W065120.1 W3-8210.1 T25

W065120.1 W3-8210.1 T30

W065120.1 W3-8210.1 T32

W065120.1 W3-8210.1 T34

W065120.1 W3-8210.1 T36

W065120.1 W3-8210.1 T38

W065121.1 W3-8211.1 N00

W065121.1 W3-8211.1 T10

W065121.1 W3-8211.1 T15

W065121.1 W3-8211.1 T20

W065121.1 W3-8211.1 T25

W065121.1 W3-8211.1 T30

W065121.1 W3-8211.1 T32

W065121.1 W3-8211.1 T34

W065121.1 W3-8211.1 T36

W065121.1 W3-8211.1 T38

W065122.1 W3-8212.1 N00

W065122.1 W3-8212.1 T10

W065122.1 W3-8212.1 T15

W065122.1 W3-8212.1 T20

W065122.1 W3-8212.1 T25

W065122.1 W3-8212.1 T30

W065122.1 W3-8212.1 T32

W065122.1 W3-8212.1 T34

W065122.1 W3-8212.1 T36

W065122.1 W3-8212.1 T38

$\begin{array}{llll}0.566 \text { E- } 04 & 012.5 & -49.7 & 065\end{array}$

34.0

$\begin{array}{llllll}0.339 \mathrm{E}-04 & 034.9 & -34.0 & 065.0 & 34.0\end{array}$

$\begin{array}{lllll}0.164 \mathrm{E}-04 & 020.6 & -29.6 & 065.0 & 34.0\end{array}$

$\begin{array}{lllll}0.140 \mathrm{E}-04 & 008.9 & 12.1 & 065.0 & 34.0\end{array}$

$\begin{array}{lllll}0.214 \mathrm{E}-04 & 016.0 & 38.7 & 065.0 & 34.0\end{array}$

$\begin{array}{lllll}0.206 \mathrm{E}-04 & 008.1 & 48.1 & 065.0 & 34.0\end{array}$

$\begin{array}{lllll}0.219 \mathrm{E}-04 & 030.9 & 40.5 & 065.0 & 34.0 \\ 0.136 \mathrm{E}-04 & 054.9 & 42.2 & 065.0 & 34.0\end{array}$

$\begin{array}{lllll}0.136 \mathrm{E}-04 & 054.9 & 42.2 & 065.0 & 34.0 \\ 0.251 \mathrm{E}-0.4 & 025.3 & 58.2 & 065.0 & 34.0\end{array}$

$\begin{array}{lllll}0.166 \mathrm{E}-04 & 127.5 & 84.1 & 065.0 & 34.0\end{array}$

$\begin{array}{lllll}0.575 \mathrm{E}-04 & 001.6 & -50.7 & 064.0 & 34.0\end{array}$

$\begin{array}{lllll}0.306 \mathrm{E}-04 & 008.5 & -44.9 & 064.0 & 34.0\end{array}$

$\begin{array}{lllll}0.184 \mathrm{E}-04 & 358.2 & -22.1 & 064.0 & 34.0\end{array}$

$\begin{array}{lllll}0.140 \mathrm{E}-04 & 350.5 & 01.8 & 064.0 & 34.0\end{array}$

$\begin{array}{lllll}0.170 \mathrm{E}-04 & 002.8 & 19.0 & 064.0 & 34.0 \\ 0.165 \mathrm{E}-04 & 000.8 & 36.0 & 064.0 & 34.0\end{array}$

$\begin{array}{lllll}0.165 \mathrm{E}-04 & 000.8 & 36.0 & 064.0 & 34.0 \\ 0.113 \mathrm{E}-04 & 035.8 & 53.1 & 064.0 & 34.0\end{array}$

$\begin{array}{lllll}0.210 \mathrm{E}-04 & 029.6 & 27.5 & 064.0 & 34.0\end{array}$

$\begin{array}{lllll}0.278 \mathrm{E}-04 & 050.2 & 25.6 & 064.0 & 34.0\end{array}$

$\begin{array}{lllll}0.201 \mathrm{E}-04 & 022.5 & 31.5 & 064.0 & 34.0\end{array}$

$\begin{array}{lllll}0.423 \mathrm{E}-04 & 027.0 & 33.5 & 062.0 & 31.0\end{array}$

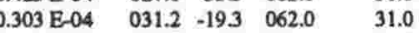

$\begin{array}{lllll}0.181 \mathrm{E}-04 & 030.7 & 03.1 & 062.0 & 31.0\end{array}$

$\begin{array}{lllll}0.216 \mathrm{E}-04 & 028.5 & 46.0 & 062.0 & 31.0\end{array}$

$\begin{array}{lllll}0.273 \mathrm{E}-04 & 031.1 & 64.0 & 062.0 & 31.0\end{array}$

$\begin{array}{llllll}0.229 \mathrm{E}-04 & 015.8 & 57.6 & 062.0 & 31.0\end{array}$

$\begin{array}{llllll}0.229 \mathrm{E}-04 & 015.8 & 57.6 & 062.0 & 31.0 \\ 0.195 \mathrm{E}-04 & 048.0 & 34.1 & 062.0 & 31.0\end{array}$

$\begin{array}{lllll}0.138 \mathrm{E}-04 & 033.8 & 21.9 & 062.0 & 31.0 \\ 0.203 \mathrm{E}-04 & 043.9 & 22.5 & 062.0 & 31.0\end{array}$

WANGANUI RIVER SITE 066G

HEIGHT $=2547 \mathrm{~m}$ (above base of section) STRIKE $=043.0 \mathrm{DIP}=4.5$

SAMPLE FIELD NO. TREAT. INTENSITY CDEC CINC Y-AZ PLUNGE

W066123.1 W3-8313.1 N00

W066123.1 W3-8313.1 T10

W066123.1 W3-8313.1 T15

W066123.1 W3-8313.1 T20

W066123.1 W3-8313.1 T25

W066123.1 W3-8313.1 T30

W066123.1 W3-8313.1 T32

W066123.1 W3-8313.1 T34

W066123.1 W3-8313.1 T36

W066123.1 W3-8313.1 T38

W066124.1 W3-8314.1 N00

W066124.1 W3-8314.1 T10

W066124.1 W3-8314.1 T15

W066124.1 W3-8314.1 T20

W066124.1 W3-8314.1 T25

W066124.1 W3-8314.1 T30

W066124.1 W3 8314.1 T34

W066124.1 W3-8314.1 T36

W066124.1 W3-8314.1 T38

W066124.1 W3-8314.1 T40

W066125.1 W3-8315.1 N00

W066125.1 W3-8315.1 T10

W066125.1 W3-8315.1 T15

W066125.1 W3-8315.1 T20

W066125.1 W3-8315.1 T25

W066125.1 W3-8315.1 T30

W066125.1 W3-8315.1 T32

W066125.1 W3-8315.1 T34

W066125.1 W3-8315.1 T36

W066125.1 W3-8315.1 T38

WANGANUI RTVER STIB 0670

HEIGHT $=2638 \mathrm{~m}$ (above base of section) STRIKE $=043.0 \quad \mathrm{DIP}=4.5$

SAMPLE FIELDNO. TREAT. INTENSITY CDEC CINC Y-AZ PLUNGE

W067126.2 W3-8416.2 N0O W067126.2 W3-8416.2 T10 W067126.2 W3-8416.2 T15 W067126.2 W3-8416.2 T20 W067126.2 W3-8416.2 T25 W067126.2 W/3-8416.2 T30 W067126.2 W3-8416.2 T32 W067126.2 W3-8416.2 T34 W067126.2 W3-8416.2 T36 W067126.2 W3-8416.2 T38 W067126.2 W3-8416.2 T40 W067127.2 W3-8417.2 N00 W067127.2 W3-8417.2 T10 W067127.2 W3-8417.2 T15 W067127.2 W3-8417.2 T20 W067127.2 W3-8417.2 T25 W067127.2 W3-8417.2 T30 W067127.2 W3-8417.2 T32 W067127.2 W3-8417.2 T34 W067127.2 W3-8417.2 T36 W067127.2 W3-8417.2 T38 W067127.2 W3-8417.2 T40 W067128.1 W3-8418.1 NOO W067128.1 W3-8418.1 T10 W067128.1 W3-8418.1 T15 W067128.1 W3-8418.1 T20 W067128.1 W3-8418.1 T25 W067128.1 W3-8418.1 T30 W067128.1 W3-8418.1 T32 W067128.1 W3-8418.1 T34 W067128.1 W3-8418.1 T36

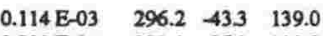
41.0 $\begin{array}{lllll}0.932 \text { E-04 } & 281.1 & -253 & 139.0 & 41.0\end{array}$

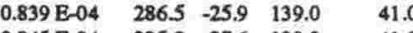
$\begin{array}{lllll}0.845 \mathrm{E}-04 & 285.2 & -27.6 & 139.0 & 41.0\end{array}$ $\begin{array}{lllll}0.874 \mathrm{E}-04 & 280.3 & -21.7 & 139.0 & 41.0\end{array}$ $\begin{array}{lllll}0.324 \mathrm{E}-04 & 267.2 & -14.9 & 139.0 & 41.0\end{array}$ $\begin{array}{lllll}0.900 \mathrm{E}-0.5 & 239.5 & 65.9 & 139.0 & 41.0\end{array}$ $\begin{array}{lllll}0.132 \mathrm{E}-04 & 065.1 & 34.5 & 139.0 & 41.0\end{array}$ $\begin{array}{lllll}0.230 \mathrm{E}-04 & 080.7 & 44.4 & 139.0 & 41.0\end{array}$ $\begin{array}{lllll}0.420 \mathrm{E}-04 & 135.6 & 21.6 & 139.0 & 41.0 \\ 0.462 \mathrm{E}-04 & 082.3 & 08.9 & 139.0 & 41.0\end{array}$ $\begin{array}{rrrrr}0.462 \mathrm{E}-04 & 082.3 & 08.9 & 139.0 & 41.0 \\ 0.942 \mathrm{E}-04 & 204.3 & -725 & 140.0 & 38.0\end{array}$

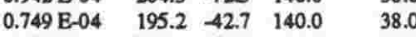
$\begin{array}{lllll}0.803 \mathrm{E}-04 & 210.0 & -55.7 & 140.0 & 38.0\end{array}$

$\begin{array}{lllll}0.721 \mathrm{E}-04 & 192.1 & -43.9 & 140.0 & 38.0\end{array}$

$\begin{array}{lllll}0.711 \text { E-04 } & 218.3 & -49.2 & 140.0 & 38.0\end{array}$

$\begin{array}{rrrrr}0.492 \mathrm{E}-04 & 213.9 & -29.0 & 140.0 & 38.0 \\ 0.217 \mathrm{E}-04 & 017.0 & 04.3 & 140.0 & 38.0\end{array}$

$\begin{array}{llllll}0.217 \mathrm{E}-04 & 017.0 & 04.3 & 140.0 & 38.0 \\ 0.279 \mathrm{E}-04 & 063.5 & 48.3 & 140.0 & 38.0\end{array}$

$\begin{array}{lllll}0.140 \mathrm{E}-04 & 086.5 & 30.6 & 140.0 & 38.0\end{array}$

$\begin{array}{lllll}0.136 \mathrm{E}-04 & 121.1 & 13.4 & 140.0 & 38.0\end{array}$

$\begin{array}{lllll}0.503 \mathrm{E}-04 & 154.0 & 55.8 & 140.0 & 38.0\end{array}$

$0.758 \mathrm{E}-04 \quad 1123-020 \quad 140.0-360$

$\begin{array}{lllll}0.950 \mathrm{E}-04 & 126.4 & 15.1 & 140.0 & 36.0\end{array}$

$\begin{array}{lllll}0.847 \text { E }-04 & 123.8 & 22.3 & 140.0 & 36.0\end{array}$

$\begin{array}{lllll}0.857 \mathrm{E}-04 & 128.6 & 29.8 & 140.0 & 36.0\end{array}$

$\begin{array}{lllll}0.609 \mathrm{E}-04 & 120.8 & 44.2 & 140.0 & 36.0\end{array}$

$\begin{array}{llllll}0.488 \mathrm{E}-04 & 114.8 & 56.4 & 140.0 & 36.0\end{array}$

$\begin{array}{lllll}0.394 \mathrm{E}-04 & 088.4 & -28.8 & 140.0 & 36.0\end{array}$

$\begin{array}{lllll}0.289 \mathrm{E}-04 & 087.5 & 13.8 & 140.0 & 36.0\end{array}$

$\begin{array}{rrrrr}0.115 \mathrm{E}-04 & 103.0 & 18.6 & 140.0 & 36.0 \\ 0.260 \mathrm{E}-04 & 073.2 & -01.2 & 140.0 & 36.0\end{array}$

\section{WANGANUI RIVER SITE $068 \mathrm{G}$}

HEIGHT $=2693 \mathrm{~m}$ (above base of section) STRIKE $=043.0 \mathrm{DIP}=4.5$

SAMPLE FIELD NO. TREAT. INTENSITY CDEC CDNC Y-AZ PLUNGE

W068129.1 W3-8519.1 N00

W068129.1 W3-8519.1 T10

W068129.1 W3-8519.1 T15

W068129.1 W3-8519.1 T20

W068129.1 W3-8519.1 T25

W068129.1 W3-8519.1 T30

W068129.1 W3-8519.1 T32

W068129.1 W3-8519.1 T34

W068129.1 W3-8519.1 T36

W068129.1 W3-8519.1 T38

W068129.1 W3-8519.1 T40

W068130.1 W3-8520.1 NOO

W068130.1 W3-8520.1 T10

W068130.1 W3-8520.1 T15

W068130.1 W/3-8520.1 T20

W068130.1 W3-8520.1 T25

W068130.1 W3-8520.1 T30

W068130.1 W3-8520.1 T32

W068130.1 W3-8520.1 T34

W068130.1 W3-8520.1 T36

W068130.1 W3-8520.1 T38

W068130.1 W3-8520.1 T40

W068131.1 W3-8521.1 N00

W068131.1 W3-8521.1 T10

W068131.1 W3-8521.1 T15

W068131.1 W3-8521.1 T20

W068131.1 W3-8521.1 T25

W068131.1 W3-8521.1 T30

W068131.1 W3-8521.1 T32

W068131.1 W3-8521.1 T34

W068131.1 W3-8521.1 T36

W068131.1 W3-8521.1 T38

W068131.1 W3-8521.1 T40

$0.168 \mathrm{E}-02 \quad 314.6-63.6 \quad 099.0$

40.0

$\begin{array}{lllll}0.860 \mathrm{E}-03 & 314.3 & -62.6 & 099.0\end{array}$

$\begin{array}{lllll}0.431 & \mathrm{E}-03 & 312.8 & -61.2 & 099.0\end{array}$

$\begin{array}{lllll}0.226 \mathrm{E}-03 & 315.0 & -61.6 & 099.0\end{array}$

$\begin{array}{lllll}0.768 & \mathrm{E}-04 & 328.4 & -55.0 & 099.0\end{array}$

$\begin{array}{lllll}0.369 \mathrm{E}-04 & 344.7 & -58.4 & 099.0\end{array}$

$\begin{array}{llll}0.335 \mathrm{E}-04 & 039.0 & -68.2 & 099.0\end{array}$

$0.268 \mathrm{E}-04 \quad 038.5 \quad-15.2 \quad 099.0$

$\begin{array}{lllll}0.264 \mathrm{E}-04 & 348.6 & -17.4 & 099.0\end{array}$

$\begin{array}{llll}0.334 \mathrm{E}-04 & 055.9 & -30.5 & 099.0\end{array}$

$\begin{array}{lllll}0.681 & \mathrm{E}-04 & 066.6 & -11.1 & 099.0\end{array}$

$\begin{array}{lllll}0.167 \text { E- }-02 & 313.0 & -62.1 & 103.0\end{array}$

$\begin{array}{lllll}0.751 \mathrm{E}-03 & 314.8 & -60.8 & 103.0\end{array}$

$\begin{array}{lllll}0.391 \mathrm{E}-03 \quad 317.1 & -58.6 \quad 103.0\end{array}$

$\begin{array}{lllll}0.226 \mathrm{E}-03 & 322.8 & -60.0 & 103.0\end{array}$

$\begin{array}{lllll}0.776 \text { E- }-04 & 000.8 & -495 & 103.0\end{array}$

$\begin{array}{llll}0.425 \mathrm{E}-04 & 016.1 & -77.3 & 103 .\end{array}$

$\begin{array}{llll}0.292 \mathrm{E}-04 & 074.4 & -68.0 & 103.0\end{array}$

$\begin{array}{lllll}0.198 \mathrm{E}-04 & 072.2 & -79.7 & 103.0\end{array}$

$\begin{array}{llll}0.284 \mathrm{E}-04 & 037.0 & -415 & 103.0\end{array}$

$\begin{array}{lllll}0.249 \mathrm{E}-04 & 058.5 & -29.2 & 103.0\end{array}$

$\begin{array}{llll}0.512 \mathrm{~B}-04 & 039.1 & -30.9 & 103.0\end{array}$

$\begin{array}{llll}0.217 \mathrm{E}-02 & 314.3 & -60.6 & 102.0\end{array}$

$\begin{array}{lllll}0.128 \mathrm{E}-02 & 312.1 & -57.9 & 102.0\end{array}$

$\begin{array}{lllll}0.789 \mathrm{E}-03 & 313.3 & -58.0 & 102.0\end{array}$

$\begin{array}{lllll}0.529 \mathrm{E}-03 & 313.9 & -57.7 & 102.0\end{array}$

$\begin{array}{lllll}0.138 \mathrm{E}-03 & 345.8 & -59.5 & 1020\end{array}$

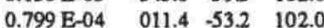

$\begin{array}{llll}0.332 \mathrm{E}-0.4 & 009.8 & -51.4 & 102.0\end{array}$

$\begin{array}{llll}0.173 \mathrm{E}-04 & 005.5 & -24.0 & 102.0\end{array}$

$\begin{array}{llll}0.251 & \mathrm{E}-04 & 038.3 & -19.8 \quad 102.0\end{array}$

$\begin{array}{lllll}0.256 \mathrm{E}-04 & 061.0 & -00.8 & 102.0\end{array}$

$\begin{array}{lllll}0.965 \mathrm{E}-04 & 056.9 & -32.7 & 102.0\end{array}$

40.0

40.0 
W070134.1 W/3-8624.1 T10 W070134.1 W/3624.1 T15 W070134.1 W3-8624.1 T20 W070134.1 W3-8624.1 T25 W070134.1 W3-8624.1 T30 W070134.1 W3-8624.1 T32 W070134.1 W3-8624.1 T34 W070134.1 W3-8624.1 T36 W070134.1 W3-8624.1 T38 $\begin{array}{lllll}0.388 & \text { E-O4 } & 0026 & -213 & 0960\end{array}$

0.305 E-04 $356.4 \quad 068096.0$ $\begin{array}{lllll}0.333 \mathrm{E}-0.4 & 343.5 & 40.1 & 096.0\end{array}$ $\begin{array}{lllll}0.268 \mathrm{E}-04 & 352.9 & 39.7 & 096.0\end{array}$ $\begin{array}{lllll}0.288 & \mathrm{E}-04 & 010.5 & 47.1 & 096.0\end{array}$ $\begin{array}{llllll}0.157 \mathrm{E}-04 & 359.2 & 392 & 096.0\end{array}$ 0.215 E04 $356.7 \quad 255 \quad 096.0$ $0.215 \mathrm{E}-04 \quad 356.7255$ $\begin{array}{llll}0.129 \mathrm{E}-04 & 016.0 & 28.5 & 096.0 \\ 0.133 \mathrm{E}-04 & 064.9 & 23.4 & 096.0\end{array}$

WANGANUI RIVER SITE 0720

F

SAMPLE FIELD NO. TREAT. INTENSTTY CDEC CINC Y-AZ PLUNGE

W072135.1 W2-2729.1 N00 W072135.1 W2-2729.1 T05 W072135.1 W2-2729.1 T10 W072135.1 W2-2729.1 T15 W072135.1 W2-2729.1 T20 W072135.1 W2-2729.1 T25 W072135.1 W2-2729.1 T30 W072136.1 W2-2730.1 N00 W072136.1 W2-2730.1 T05 W072136.1 W2-2730.1 T10 W072136.1 W2-2730.1 T15 W072136.1 W2-2730.1 T20 W072136.1 W2-2730.1 T25 W072136.1 W2-2730.1 T30 W072137.1 W2-2731.1 N00 W072137.1 W2-2731.1 T05 W072137.1 W2-2731.1 T10 W072137.1 W2-2731.1 T15 W072137.1 W2-2731.1 T20 W072137.1 W2-2731.1 T25 $\begin{array}{llll}0.962 \mathrm{E}-04 & 183.0 & 07.9 & 003.0\end{array}$ $\begin{array}{llll}0.630 \mathrm{E}-04 & 179.5 & 05.2 & 003.0\end{array}$ $\begin{array}{llll}0.346 \mathrm{E}-04 & 168.1 & 05.1 & 003.0\end{array}$ $\begin{array}{llll}0.338 \mathrm{E}-04 & 158.0 & 18.7 & 003.0\end{array}$ $\begin{array}{lllll}0.259 \mathrm{E}-04 & 144.6 & 25.6 & 003.0\end{array}$ $\begin{array}{lllll}0.239 \mathrm{E}-04 & 136.0 & 23.6 & 003.0\end{array}$ $\begin{array}{lllll}0.239 \mathrm{E}-04 & 136.0 & 23.6 & 003.0 \\ 0.142 \mathrm{E}-04 & 035.8 & 43.6 & 003.0\end{array}$ $\begin{array}{lllll}0.142 \mathrm{E}-04 & 035.8 & 43.6 & 003.0 \\ 0.113 \mathrm{E}-03 & 186.4 & 01.4 & 012.0\end{array}$ $\begin{array}{rrrrr}0.113 \mathrm{E}-03 & 186.4 & 01.4 & 012.0 \\ 0.886 \mathrm{E}-04 & 175.5 & -05.1 & 012.0\end{array}$ $\begin{array}{llll}0.886 \mathrm{E}-04 & 175.5 & -05.1 & 012.0 \\ 0.500 \mathrm{E}-04 & 173.9 & -10.8 & 012.0\end{array}$ $0.500 \mathrm{E}-04 \quad 173.9-10.8 \quad 012.0$ $0.330 \mathrm{E}-04 \quad 170.2-16.6 \quad 012.0$ $\begin{array}{lllll}0.269 \mathrm{E}-04 & 166.6 & -03.2 & 012.0\end{array}$

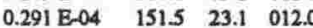
$0.382 \mathrm{E}-04 \quad 141.4 \quad 122 \quad 012.0$ $\begin{array}{lllll}0.382 \mathrm{E}-04 & 141.4 & 12.2 & 012.0 \\ 0.116 \mathrm{E}-03 & 182.7 & 02.6 & 006.0\end{array}$ $\begin{array}{rrrr}0.116 \mathrm{E}-03 & 182.7 & 02.6 & 006.0 \\ 0.776 \mathrm{E}-04 & 185.0 & -05.5 & 006.0\end{array}$ $\begin{array}{llll}0.776 \mathrm{E}-04 & 185.0 & -05.5 & 006.0\end{array}$ $\begin{array}{llllll}0.677 \text { E- } 04 & 178.8 & -06.9 & 006.0\end{array}$ $\begin{array}{lllll}0.343 \text { E- } 04 & 168.2 & -11.7 & 006.0\end{array}$ $\begin{array}{lllll}0.327 & \mathrm{E}-04 & 166.2 & -20.0 & 006.0\end{array}$ $\begin{array}{lllll}0.324 \mathrm{E}-0.4 & 169.3 & -22.4 & 006.0\end{array}$ $\begin{array}{lllll}0.237 \mathrm{E}-04 & 148.4 & -28.6 & 006.0\end{array}$

W075143.1 W/3-8931.1 T30 W075143.1 W3-8931.1 T32 W075143.1 W3-8931.1 T34 W075143.1 W3-8931.1 T36 W075143.1 W3-8931.1 T38

$\begin{array}{lllll}0.365 \mathrm{E}-04 & 083.8 & 50.6 & 099.0\end{array}$ $\begin{array}{lllll}0.256 \text { E-04 } & 119.1 & 56.2 & 099.0\end{array}$ $\begin{array}{lllll}0.245 \mathrm{E}-04 & 125.8 & 43.2 & 099.0\end{array}$ $\begin{array}{lllll}0.356 \mathrm{E}-0.4 & 092.1 & 39.9 & 099.0\end{array}$ $\begin{array}{lllll}0.294 \text { E- } 04 & 102.0 & 41.4 & 099.0\end{array}$ 66.0
66.0 66.0 W075143.1 W3-8931.1 T40

WANGANUI RIVER SITE $079 \mathrm{C}$

HEIGHT $=3090 \mathrm{~m}$ (above base of section) STRIKE=043.0 DIP=4.5 SAMPLE FIELD NO. TREAT. INTENSITY CDEC CINC Y-AZ PLUNGE

W079144.1 W3-9032.1 N00 W079144.1 W3-9032.1 T10 W079144.1 W3-9032.1 T15 W079144.1 W3-9032.1 T20 W079144.1 W3-9032.1 T25 W079144.1 W3-9032.1 T30 W079144.1 W3-9032.1 T32 W079144.1 W/3-9032.1 T34 w079144.1 W/3-9032. T36 W07914.1 W3-9032.1 T38 W079145.1 W3-9033.1 N00 W079145.1 W3-9033.1 T10 W079145.1 W3-9033.1 T10
W079145.1 W3-9033.1 T15 W079145.1 W3-9033.1 T15 W079145.1 W3-9033.1 T25 W079145.1 W3-9033.1 T30 W079145.1 W3-9033.1 T32 W079145.1 W3-9033.1 132 $\begin{array}{llll}\text { W079145.1 W3-9033.1 } & \text { T34 } \\ \text { W079145.1 W3-9033.1 } & \text { T36 }\end{array}$ $\begin{array}{llll}\text { W079145.1 W3-9033.1 T36 } & \text { T3 } \\ \text { W079145.1 W3-9033.1 T38 }\end{array}$ W079146.1 W3-9034.1 NoO W079146.1 W3-9034.1 T10 W079146.1 W3-9034.1 T15 W079146.1 W3-9034.1 T20 W079146.1 W3-9034.1 T25 W079146.1 W3-9034.1 T30 W079146.1 W3-9034.1 T32 W079146.1 W3-9034.1 T34

$\begin{array}{lrrrr}0.156 \text { E-03 } & 004.1 & -51.7 & 078.0 & 60.0 \\ 0.994 \text { E-03 } & 008.9 & -48.7 & 078.0 & 60.0 \\ 0.632 \text { E-04 } & 355.4 & -40.0 & 078.0 & 60.0 \\ 0.275 \text { E-04 } & 343.1 & -08.7 & 078.0 & 60.0 \\ 0.103 \text { E-04 } & 355.5 & 25.0 & 078.0 & 60.0 \\ 0.162 \text { E-04 } & 036.5 & 48.1 & 078.0 & 60.0 \\ 0.216 \text { E-04 } & 009.3 & 52.7 & 078.0 & 60.0 \\ 0.189 \text { E-04 } & 021.8 & 42.4 & 078.0 & 60.0 \\ 0.198 \text { E-04 } & 036.0 & 52.8 & 078.0 & 60.0 \\ 0.178 \text { E-04 } & 010.3 & 35.6 & 078.0 & 60.0 \\ 0.148 \text { E-03 } & 359.2 & -55.2 & 083.0 & 62.0 \\ 0.855 \text { E-04 } & 012.4 & -47.4 & 083.0 & 62.0 \\ 0.502 \text { E-04 } & 015.6 & -37.6 & 083.0 & 62.0 \\ 0.215 \text { E-04 } & 041.1 & -01.4 & 083.0 & 62.0 \\ 0.213 \text { E-04 } & 044.6 & 13.0 & 083.0 & 62.0 \\ 0.152 \text { E-04 } & 044.5 & 47.4 & 083.0 & 62.0 \\ 0.212 \text { E-04 } & 051.2 & 42.1 & 083.0 & 62.0 \\ 0.158 \text { E-04 } & 125.4 & 52.1 & 083.0 & 62.0 \\ 0.217 \text { E-04 } & 111.8 & 69.2 & 083.0 & 62.0 \\ 0.253 \text { E-04 } & 109.1 & 73.4 & 083.0 & 62.0 \\ 0.153 \text { E-03 } & 004.9 & -51.8 & 077.0 & 63.0 \\ 0.856 \text { E-04 } & 007.0 & -41.9 & 077.0 & 63.0 \\ 0.363 \text { E-04 } & 011.9 & -19.4 & 077.0 & 63.0 \\ 0.242 \text { E-04 } & 029.5 & 24.0 & 077.0 & 63.0 \\ 0.212 \text { E-04 } & 025.6 & 52.0 & 077.0 & 63.0 \\ 0.850 \text { E-05 } & 027.3 & 44.2 & 077.0 & 63.0 \\ 0.129 \text { E-04 } & 350.8 & 25.4 & 077.0 & 63.0 \\ 0.108 \text { E-04 } & 141.4 & 44.7 & 077.0 & 63.0 \\ 0.110 \text { E-04 } & 026.4 & 05.1 & 077.0 & 63.0 \\ 0.158 \text { E-04 } & 136.8 & 70.9 & 077.0 & 63.0\end{array}$
HEIGHT $=2894 \mathrm{~m}$ (above base of section) STRIKE=043.0 DIP=4 SAMPLE FIELD NO. TREAT. INTENSITY CDEC CINC Y-AZ PLUNGE

W073138.1 W3-8825.1 NOO W073138.1 W3 $8825.1 \mathrm{~T} 10$ W073138.1 W3-8825.1 T15 W073138.1 W3-8825.1 T20 W073138.1 W3-8825.1 T25 W073138.1 W3-8825.1 T30 W073138.1 W3-8825.1 T32 W073138.1 W3-8825.1 T34 W073138.1 W3-8825.1 T36 W073138.1 W3-8825.1 T38 W073139.1 W3-8826.1 N00 W073139.1 W3-8826.1 T10 W073139.1 W3-8826.1 T15 W073139.1 W3-8826.1 T20 W073139.1 W3-8826.1 T25 W073139.I W3-8826.1 T30 W073139.1 W3-8826.1 T32 W073139.1 W3-8826.1 T34 W073139.1 W3-8826.1 T36 W073139.1 W3-8826.1 T38 W073140.1 W3-8827.1 N00 W073140.1 W3-8827.1 T10 W073140.1 W3-8827.1 T15 W073140.1 W3-8827.1 T20 W073140.1 W3-8827.1 T25 W073140.1 W3-8827.1 T30 W073140.1 W3-8827.1 T32 W073140.1 W3-8827.1 T34 W073140.1 W3-8827.1 T36

$\begin{array}{llll}0.116 \mathrm{E}-03 & 346.9 & -59.1 & 003.0\end{array}$ 0.822 E-04 $350.8 \quad-58.1 \quad 003.0$ $\begin{array}{lllll}0.636 \mathrm{E}-04 & 330.8 & -59.0 & 003.0\end{array}$ $\begin{array}{llll}0.368 \mathrm{E}-04 & 301.9 & -51.2 & 003.0\end{array}$ $\begin{array}{lllll}0.298 \mathrm{E}-04 & 294.8 & -38.0 & 003.0\end{array}$ 0.233 E- $04 \quad 287.9 \quad-35.7 \quad 003.0$ $\begin{array}{lllll}0.231 \mathrm{E}-04 & 292.5 & -13.5 & 003.0\end{array}$ $\begin{array}{lllll}0.217 \mathrm{E}-04 & 326.5 & -29.6 & 003.0\end{array}$ $\begin{array}{lllll}0.217 \text { E-04 } & 326.5 & -29.6 & 003.0 \\ 0.257 \text { E-0.4 } & 3420 & -20.4 & 003.0\end{array}$ $\begin{array}{rrrr}0.257 \text { E-0.4 } & 342.0 & -20.4 & 003.0 \\ 0.260 \text { E- } 04 & 318.0 & 05.3 & 003.0\end{array}$ $\begin{array}{rrrr}0.260 \mathrm{E}-04 & 318.0 & 05.3 & 003.0 \\ 0.122 \mathrm{E}-03 & 357.9 & -72.0 & 001.0\end{array}$

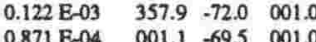
$\begin{array}{llll}0.871 \mathrm{E}-04 & 001.1 & -69.5 & 001.0\end{array}$ $\begin{array}{lllll}0.652 \mathrm{E}-04 & 000.8 & -72.1 & 001.0\end{array}$ $0.343 \mathrm{E}-04 \quad 026.2 \quad-76.6 \quad 001.0$ $\begin{array}{llll}0.204 \mathrm{E}-04 & 011.1 & -69.9 & 001.0\end{array}$ $\begin{array}{llll}0.139 \mathrm{E}-04 & 318.1 & -60.0 & 001.0\end{array}$

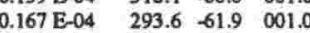
$0.210 \mathrm{E}-04 \quad 354.2-15.6 \quad 001.0$ $0.218 \mathrm{E}-04 \quad 311.2-01.4 \quad 001.0$ $0.207 \mathrm{E}-04 \quad 306.9 \quad 09.2 \quad 001.0$ $\begin{array}{lllll}0.997 & \mathrm{E}-04 & 354.3 & -50.9 & 357.0\end{array}$ $0.631 \mathrm{E}-04 \quad 357.0 \quad 44.8 \quad 357.0$ $\begin{array}{lllll}0.446 \mathrm{E}-04 & 347.4 & -42.9 & 357.0\end{array}$ $\begin{array}{lllll}0.252 \mathrm{E}-04 & 340.2 & -23.1 & 357.0\end{array}$ $\begin{array}{llll}0.159 \mathrm{E}-04 & 324.5 & 09.8 & 357.0\end{array}$ $\begin{array}{lllll}0.166 \mathrm{E}-04 & 326.8 & 25.8 & 357.0\end{array}$ $\begin{array}{lllll}0.155 \mathrm{E}-04 & 307.3 & 25.6 & 357.0\end{array}$ $\begin{array}{lllll}0.117 & \mathrm{E}-04 & 329.0 & 26.8 & 357.0\end{array}$ $\begin{array}{lllll}0.182 \mathrm{E}-04 & 320.3 & 07.9 & 357.0\end{array}$ $\begin{array}{llll}0.101 \mathrm{E}-03 & 007.4 & 03.8 & 357.0\end{array}$
28.0

28.0

28.0

28.0

28.0

28.0

28.0

28.0
28.0
25.0

25.0

25.0

25.0

5.0

25.0

25.0

25.0

29.0

9.0

29.0

29.0

29.0

29.0

29.0

29.0

29.0

WANGANUI RIVER SITE 075G

HEIGHT $=3007 \mathrm{~m}$ (above base of section) STRIKE $=043.0 \mathrm{DIP}=4.5$

SAMPLE FIELD NO. TREAT. INTENSITY CDEC CINC Y-AZ PLUNGE

W075141.1 W3-8928.1 N00 W075141.1 W3 $8928.1 \mathrm{~T} 10$ W075141.1 W3-8928.1 T15 W075141.1 W3-8928.1 T20 W075141.1 W3-8928.1 T25 W075141.1 W3-8928.1 T30 W075141.1 W3-8928.1 T32 W075141.1 W3 8928.1 T34 W075141.1 W3-8928.1 T36 W075141.1 W3-8928.1 T38 W075141.1 W3-8928.1 T40 W075142.1 W3-8929.1 N00 W075142.1 W3-8929.1 T10 W075142.1 W3-8929.1 T15 W075142.1 W3-8929.1 T20 W075142.1 W3-8929.1 T25 W075142.1 W3-8929.1 T30 W075142.1 W3-8929.1 T32 W075142.1 W3-8929.1 T34 W075142.1 W3-8929.1 T36 W075142.1 W3 8929.1 T38 W075142.1 W3-8929.1 T40 W075143.1 W3-8931.1 NOO W075143.1 W3-8931.1 T10 W075143.1 W3-8931.1 T15 W075143.1 W3-8931.1 T20 $\begin{array}{llll}0.249 \mathrm{E}-03 & 005.7 & -49.8 & 103.0\end{array}$ $0.144 \mathrm{E}-03 \quad 017.6-47.4 \quad 103.0$ $\begin{array}{lllll}0.614 \mathrm{E}-04 & 013.4 & -31.4 & 103.0\end{array}$ $\begin{array}{lllll}0.289 \mathrm{E}-04 & 049.0 & 18.4 & 103.0\end{array}$ $\begin{array}{lllll}0.337 & \mathrm{E}-04 & 0421 & 43.3 & 103.0\end{array}$ $\begin{array}{lllll}0.289 \mathrm{E}-0.4 & 055.5 & 56.2 & 103.0\end{array}$ $\begin{array}{lllll}0.348 \mathrm{E}-04 & 062.5 & 64.4 & 103.0\end{array}$ $\begin{array}{llll}0.348 \mathrm{E}-04 & 062.5 & 64.4 & 103.0 \\ 0.298 \mathrm{E}-0.4 & 107.9 & 55.6 & 103.0\end{array}$ $\begin{array}{llll}0.298 \mathrm{E}-04 & 107.9 & 55.6 & 103.0 \\ 0.320 \mathrm{E}-04 & 115.5 & 41.7 & 103.0\end{array}$ $\begin{array}{lllll}0.320 \mathrm{E}-04 & 115.5 & 41.7 & 103.0 \\ 0.413 \mathrm{E}-04 & 119.4 & 47.7 & 103.0\end{array}$ $\begin{array}{lllll}0.928 \mathrm{E}-04 & 051.6 & -07.6 & 103.0\end{array}$ $\begin{array}{lllll}0.209 \mathrm{E}-03 & 000.8 & -56.0 & 099.0\end{array}$ $\begin{array}{lllll}0.114 \mathrm{E}-03 & 008.9 & -55.4 & 099.0\end{array}$ $\begin{array}{lllll}0.548 \text { E. } 04 & 003.1 & -46.3 & 099.0\end{array}$ $\begin{array}{llll}0.203 \mathrm{E}-04 & 044.2 & 02.6 & 099.0\end{array}$ $\begin{array}{llll}0.241 \mathrm{E}-04 & 075.2 & 52.7 & 099.0\end{array}$ $\begin{array}{lllll}0.263 \mathrm{E}-04 & 065.4 & 62.7 & 099.0\end{array}$ $0.225 \mathrm{E}-04 \quad 046.1 \quad 56.1 \quad 099.0$ $\begin{array}{llll}0.208 \mathrm{E}-04 & 090.1 & 44.6 & 099.0\end{array}$ 0.235 E-04 $067.4 \quad 475 \quad 099.0$ $\begin{array}{lllll}0.2340 \mathrm{E}-04 & 084.5 & 46.8 & 099.0\end{array}$ $\begin{array}{llll}0.3406 \mathrm{E}-03 & 057.0 & -11.8 & 099.0\end{array}$ $\begin{array}{llll}0.906 \mathrm{E}-03 & 057.0 & -11.8 & 099.0 \\ 0.259 \mathrm{E}-03 & 003.9 & -51.7 & 099.0\end{array}$ $\begin{array}{llll}0.259 \mathrm{~B}-03 & 003.9 & -51.7 & 099.0\end{array}$ $\begin{array}{llll}0.140 \mathrm{E}-03 & 014.8 & -46.7 & 099.0\end{array}$ $\begin{array}{lllll}0.538 \mathrm{E}-04 & 025.6 & -36.7 & 099.0\end{array}$ $\begin{array}{llll}0.221 \mathrm{E}-04 & 085.6 & 25.1 & 099.0\end{array}$ W075143.1 W3-8931.1 T25

W079146.1 W3-9034.1 T36

$\begin{array}{lllll}0.158 & \text { E-0 } & 136.8 & 70.9 & 077.0\end{array}$

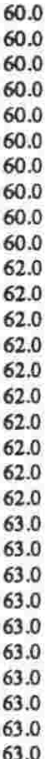

WANGANUI RIVER SITE $080 \mathrm{C}$

HEIGHT $=3119 \mathrm{~m}$ (above base of section) STRIKE $=043.0 \mathrm{DIP}=4.5$

SAMPLE FIELDNO. TREAT. INTENSITY CDEC CINC Y-AZ PLUNGE W080147.1 W3-9135.1 T10 W080147.1 W3-9135. T15 W080147.1 W3-9135.1 T20 W080147.1 W3-9135.1 T25 W080147.1 W3-9135.1 T30 W080147.1 W3-9135.1 T32 W080147.1 W3-9135.1 T34 W080147.1 W3-9135.1 T36 w080147. W W3-9135. T38 W080147.1 W3-9135.1 T40 W080148.1 W3-9136.1 NOO W080148.1 W3-9136.1 T10 W080148.1 W3-9136.1 T15 W080148.1 W3-9136.1 T20 
W081152.1 W2-3234.1 T30 W081152.3 W2-3234.3 NOO W081152.3 W2-3234.3 TOS W081152.3 W2-3234.3 T10 W081152.3 W2-3234.3 T15 W081152.3 W2-3234.3 T20 W0811523 W2-32343 T25 W081152.3 W2-3234.3 T30

$\begin{array}{llll}0.225 \mathrm{E}-04 \quad 149.7 & -552 \quad 107.0\end{array}$ $0.220 \mathrm{E}-03 \quad 210.5-41.1 \quad 107.0$ $\begin{array}{llll}0.220 \mathrm{E}-03 & 210.5 & -41.1 & 107.0 \\ 0.180 \mathrm{E}-03 & 201.9 & -45.2 & 107.0\end{array}$ $\begin{array}{llll}0.128 \mathrm{E}-03 & 202.6 & -4.6 & 107\end{array}$ $\begin{array}{llll}0.587 \mathrm{E}-04 & 193.0 & -60.7 & 107.0\end{array}$ $\begin{array}{llll}0.301 \text { E- } 04 \quad 184.5 & -69.2 & 107.0\end{array}$ $\begin{array}{llll}0.229 \mathrm{E}-04 & 010.5 & -71.1 & 107.0\end{array}$ $\begin{array}{rrrr}0.229 \mathrm{E}-04 & 010.5 & -71.1 & 107.0 \\ 0.263 \mathrm{E}-0.4 & 134.9 & 38.2 & 107.0\end{array}$

WANGANUI RTVER SITE 084G

HEIGHT $=3194 \mathrm{~m}$ (above base of section) STRIKE $=043.0 \mathrm{DIP}=4.5$ SAMPLE FIELD NO. TREAT. INTENSITY CDEC CINC Y-AZ PLUNGE

$\begin{array}{lll}\text { W084153.1 } & \text { W3-9238.1 } & \text { N00 } \\ \text { W084153.1 } & \text { W3-9238.1 } & \text { T10 } \\ \text { W084153.1 } & \text { W3-9238.1 } & \text { T15 } \\ \text { W084153.1 } & \text { W3-9238.1 } & \text { T20 } \\ \text { W084153.1 } & \text { W3-9238.1 } & \text { T25 } \\ \text { W084153.1 } & \text { W3-9238.1 } & \text { T30 } \\ \text { W084153.1 } & \text { W3-9238.1 } & \text { T32 } \\ \text { W084153.1 } & \text { W3-9238.1 } & \text { T34 } \\ \text { W084153.1 } & \text { W3-9238.1 } & \text { T36 } \\ \text { W084153.1 } & \text { W3-9238.1 } & \text { T38 } \\ \text { W084153.1 } & \text { W3-9238.1 } & \text { T40 } \\ \text { W084154.1 } & \text { W3-9239.1 } & \text { N00 } \\ \text { W084154.1 } & \text { W3-9239.1 } & \text { T10 } \\ \text { W084154.1 } & \text { W3-9239.1 } & \text { T15 } \\ \text { W084154.1 } & \text { W3-9239.1 } & \text { T20 } \\ \text { W084154.1 } & \text { W3-9239.1 } & \text { T25 } \\ \text { W084154.1 } & \text { W3-9239.1 } & \text { T30 } \\ \text { W084154.1 } & \text { W3-9239.1 } & \text { T32 } \\ \text { W084154.1 } & \text { W3-9239.1 } & \text { T34 } \\ \text { W084154.1 } & \text { W3-9239.1 } & \text { T36 } \\ \text { W084154.1 } & \text { W3-9239.1 } & \text { T38 } \\ \text { W084155.1 } & \text { W3-9240.1 } & \text { N00 } \\ \text { W084155.1 } & \text { W3-9240.1 } & \text { T10 } \\ \text { W084155.1 } & \text { W3-9240.1 } & \text { T15 } \\ \text { W084155.1 } & \text { W3-9240.1 } & \text { T20 } \\ \text { W084155.1 } & \text { W3-9240.1 } & \text { T25 } \\ \text { W084155.1 } & \text { W3-9240.1 } & \text { T30 } \\ \text { W084155.1 } & \text { W3-9240.1 } & \text { T32 } \\ \text { W084155.1 } & \text { W3-9240.1 } & \text { T34 } \\ \text { W084155.1 } & \text { W3-9240.1 } & \text { T36 } \\ \text { W084155.1 } & \text { W3-9240.1 } & \text { T38 } \\ \text { W084155.1 } & \text { W3-9240.1 } & \text { T40 }\end{array}$

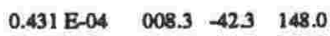

0.217 E-04 $044.4-29.2148 .0$

$\begin{array}{llll}0.132 \mathrm{E}-04 & 074.8 & 37.9 & 148.0\end{array}$

$\begin{array}{llll}0.212 \mathrm{E}-04 & 068.4 & 59.9 & 148.0\end{array}$

$\begin{array}{lllll}0.265 \mathrm{E}-04 & 098.1 & 49.4 & 148.0\end{array}$

$\begin{array}{lllll}0.330 \mathrm{E}-04 & 123.8 & 49.0 & 148.0\end{array}$

$\begin{array}{lllll}0.317 & \mathrm{E}-04 & 100.7 & 47.5 & 148.0\end{array}$

$\begin{array}{llll}0.317 \mathrm{E}-04 & 100.7 & 47.5 & 148.0 \\ 0.199 \mathrm{E}-04 & 104.0 & 54.2 & 148.0\end{array}$

$\begin{array}{lllll}0.199 \mathrm{E}-04 & 104.0 & 54.2 & 148.0 \\ 0.229 \mathrm{E}-04 & 101.6 & 48.8 & 148.0\end{array}$

$\begin{array}{lllll}0.229 & \text { E-04 } & 101.6 & 48.8 & 148.0 \\ 0.234 \text { E-04 } & 127.1 & 47.4 & 148.0\end{array}$

$\begin{array}{llll}0.234 \mathrm{E}-04 & 127.1 & 47.4 & 148.0\end{array}$

$\begin{array}{lllll}0.787 & \mathrm{E}-04 & 132.0 & -02.0 & 148.0\end{array}$

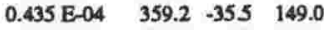

$\begin{array}{llll}0.154 \text { E. }-04 \quad 011.0 & -19.3 \quad 149.0\end{array}$

$\begin{array}{lllll}0.189 & \text { E-04 } & 010.4 & 61.6 & 149.0\end{array}$

$\begin{array}{lllll}0.181 \text { E-04 } & 0.42 .0 & 83.2 & 149.0\end{array}$

$\begin{array}{lllll}0.117 \text { E- } 04 & 126.0 & 36.1 & 149.0\end{array}$

$\begin{array}{llll}0.220 \mathrm{E}-04 & 140.9 & 48.7 & 149.0\end{array}$

$\begin{array}{lllll}0.171 & \mathrm{E}-04 & 096.3 & 28.5 & 149.0\end{array}$

$\begin{array}{lllll}0.167 \mathrm{E}-04 & 113.8 & 26.3 & 149.0\end{array}$

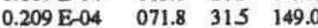

$\begin{array}{lllll}0.132 \mathrm{E}-04 & 109.2 & 19.9 & 149.0\end{array}$

$\begin{array}{lllll}0.446 \mathrm{E}-04 & 031.9 & -51.0 & 147.0\end{array}$

$\begin{array}{llll}0.196 \mathrm{E}-04 & 075.6 & -32.8 & 147.0\end{array}$

$\begin{array}{llll}0.142 \mathrm{E}-04 & 091.9 & 16.6 & 147.0\end{array}$

$\begin{array}{lllll}0.196 \mathrm{E}-04 & 105.3 & 40.7 & 147.0\end{array}$

$\begin{array}{llll}0.217 \mathrm{E}-04 \quad 127.5 \quad 41.6 & 147.0\end{array}$

$\begin{array}{lllll}0.206 \mathrm{E}-04 & 139.0 & 43.8 & 147.0\end{array}$

$\begin{array}{llll}0.206 \mathrm{E}-04 & 139.0 & 43.8 & 147.0 \\ 0.213 \mathrm{E}-04 & 101.0 & 58.5 & 147.0\end{array}$

$\begin{array}{llll}0.213 \mathrm{E}-04 & 101.0 & 585 & 147.0 \\ 0.225 \mathrm{E}-04 & 127.7 & 40.4 & 147.0\end{array}$

$\begin{array}{lllll}0.225 & \mathrm{E}-04 & 127.7 & 40.4 & 147.0 \\ 0.198 \mathrm{E}-04 & 124.4 & 71.9 & 147.0\end{array}$

$\begin{array}{llll}0.176 \mathrm{E}-04 & 136.1 & 56.3 & 147.0\end{array}$

$\begin{array}{llll}0.565 \mathrm{E}-04 & 127.8 & 065 & 147.0\end{array}$

45.0

45.0

45.0

45.0

45.0

45.0

45.0
45.0

45.0
47.0

47.0

47.0

47.0

47.0
47.0

47.0

47.0

47.0

47.0
41.0

41.0

41.0
41.0

41.0

41.0

41.0

41.0
41.0

41.0
41.0

WANGANUI RIVER SITE 086G

HEIGHT $=3222 \mathrm{~m}$ (above base of section) STRIKE $=043.0 \mathrm{DIP}=4.5$

SAMPLE FIELD NO. TREAT. INTENSITY CDEC CDNC Y-AZ PLUNGE

W086156.1 W2-3635.1 N00 W086156.1 W2-3635.1 T05 W086156.1 W2-3635.1 T10 W086156.1 W2-3635.1 T15 W086156.1 W2-3635.1 T20 W086156.1 W2-3635.1 T25 W086156.1 W2-3635.1 T30 W086157.1 W2-3636.1 N00 W086157.1 W2-3636.1 T05 W086157.1 W2-3636.1 T10 W086157.1 W2-3636.1 T15 W086157.1 W2-3636.1 T20 W086157.1 W2-3636.1 T25 W086157.1 W2-3636.1 T30 W086158.1 W2-3637.1 N00 W086158.1 W2-3637.1 T05 W086158.1 W2-3637.1 T10 W086158.1 W2-3637.1 T15 W086158.1 W2-3637.1 T20 W086158.1 W2-3637.1 T25 W086158.1 W2-3637.1 T30

$0.824 \mathrm{E}-04 \quad 220.7 \quad-38.6 \quad 099.0$ 37.0 $\begin{array}{lllll}0.639 \mathrm{E}-04 & 217.4 & -463 & 099.0 & 37.0\end{array}$ $\begin{array}{lllll}0.400 \mathrm{E}-04 & 213.4 & -50.2 & 099.0 & 37.0 \\ 0.197 \mathrm{E}-04 & 266.1 & -62.6 & 099.0 & 37.0\end{array}$ $\begin{array}{lllll}0.197 \text { E-04 } & 266.1 & -62.6 & 099.0 & 37.0 \\ 0.162 \text { E-04 } & 305.4 & -62.9 & 099.0 & 37.0\end{array}$

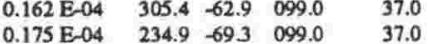
$\begin{array}{lllll}0.143 \mathrm{E}-04 & 289.5 & -50.1 & 099.0 & 37.0\end{array}$ $\begin{array}{lllll}0.881 \mathrm{E}-04 & 220.3 & -08.6 & 100.0 & 35.5\end{array}$ $\begin{array}{lllll}0.565 \text { E- } 04 & 217.1 & 10.0 & 100.0 & 35.5\end{array}$

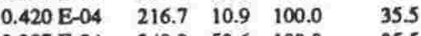

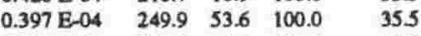
$\begin{array}{lllll}0.443 \mathrm{E}-04 & 297.5 & 70.1 & 100.0 & 35.5\end{array}$ $\begin{array}{lllll}0.251 \mathrm{E}-04 & 012.3 & 68.6 & 100.0 & 35.5\end{array}$ $\begin{array}{lllll}0.221 \mathrm{E}-0.04 & 334.9 & 49.3 & 100.0 & 35.5\end{array}$ $\begin{array}{lllll}0.717 \text { E-04 } & 211.6 & -30.1 & 101.0 & 35.5\end{array}$

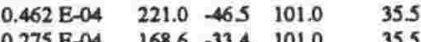
$\begin{array}{lllll}0.275 \mathrm{E}-04 & 168.6 & -33.4 & 101.0 & 35.5\end{array}$ $\begin{array}{rrrrr}0.139 \mathrm{E}-04 & 160.1 & -17.0 & 101.0 & 35.5 \\ 0.143 \mathrm{E}-04 & 157.7 & 605 & 101.0 & 35.5\end{array}$ $\begin{array}{rrrrr}0.143 \mathrm{E}-04 & 157.7 & 605 & 101.0 & 35.5 \\ 0.208 \mathrm{E}-04 & 088.0 & -08.3 & 101.0 & 35.5\end{array}$ $\begin{array}{lllll}0.251 \mathrm{E}-0.4 & 129.2 & 42.6 & 101.0 & 35.5\end{array}$

WANGANUI RIVER SITE 089G

HEIGHT $=3345 \mathrm{~m}$ (above base of section) STRIKE $=043.0 \quad \mathrm{DIP}=45$

SAMPLE FIELD NO. TREAT. INTENSITY CDEC CINC Y-AZ PLUNGE

W089159.1 W3-9341.1 N00 W089159.1 W3-9341.1 T10 W089159.1 W3-9341.1 T15 W089159.1 W3-9341.1 T20 W089159.1 W3-9341.1 T25 W089159.1 W3-9341.1 T30 W089159.1 W3-9341.1 T32 W089159.1 W3-9341.1 T34 W089159.1 W3-9341.1 T36 W089159.1 W3-9341.1 T38 W089159.1 W3-9341.1 T40 W089160.1 W3-9342.1 N00 W089160.1 W3-9342.1 T10 W089160.1 W3-9342.1 T15 W089160.1 W3-9342.1 T20 W089160.1 W3-9342.1 T25 W089160.1 W3-9342.1 T30 W089160.1 W3-9342.1 T32 W089160.1 W3-9342.1 T34 W089160.1 W3-9342.1 T36 W089160.1 W3-9342.1 T38 W089161.1 W3-9343.1 N00 W089161.1 W3-9343.1 T10 W089161.1 W3-9343.1 T15 W089161.1 W3-9343.1 T20 W089161.1 W3-9343.1 T25 $\begin{array}{lllll}0.103 \mathrm{E}-03 & 007.7 & -51.7 & 187.0 & 34.0\end{array}$ $\begin{array}{lllll}0.527 \mathrm{E}-04 & 012.6 & -52.8 & 187.0 & 34.0\end{array}$

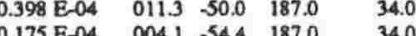
$\begin{array}{llllll}0.131 \text { E-04 } & 332.8 & -82.7 & 187.0 & 34.0\end{array}$ $\begin{array}{llllll}0.131 \mathrm{E}-04 & 332.8 & -82.7 & 187.0 & 34.0 \\ 0.790 \mathrm{E}-05 & 187.8 & -15.4 & 187.0 & 34.0\end{array}$ $\begin{array}{llllll}0.790 \mathrm{E}-05 & 187.8 & -15.4 & 187.0 & 34.0 \\ 0.119 \mathrm{E}-04 & 111.8 & -40.4 & 187.0 & 34.0\end{array}$ $\begin{array}{llllll}0.119 \mathrm{E}-04 & 111.8 & -40.4 & 187.0 & 34.0 \\ 0.108 \mathrm{E}-04 & 088.0 & -02.8 & 187.0 & 34.0\end{array}$

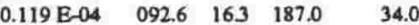
$\begin{array}{llllll}0.143 \mathrm{E}-04 & 143.0 & 24.2 & 187.0 & 34.0\end{array}$

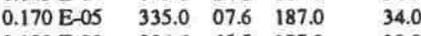
$\begin{array}{lllll}0.102 \mathrm{E}-03 & 004.6 & -655 & 187.0 & 39.0\end{array}$ $\begin{array}{lllll}0.536 \text { E- } 04 & 017.1 & -64.0 & 187.0 & 39.0\end{array}$ $\begin{array}{lllll}0.323 \mathrm{E}-04 & 037.3 & -60.6 & 187.0 & 39.0\end{array}$ $\begin{array}{lllll}0.100 \text { E-04 } & 112.5 & -25.9 & 187.0 & 39.0\end{array}$

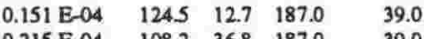
$\begin{array}{lllll}0.215 \mathrm{E}-04 & 108.2 & 36.8 & 187.0 & 39.0\end{array}$

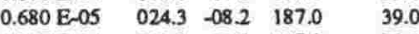
$\begin{array}{lllll}0.147 \mathrm{E}-04 & 123.1 & -31.2 & 187.0 & 39.0\end{array}$ $\begin{array}{lllll}0.124 \text { E- } 04 & 108.8 & -56.2 & 187.0 & 39.0\end{array}$ $\begin{array}{lllll}0.909 \mathrm{E}-04 & 344.3 & -55.1 & 187.0 & 33.0\end{array}$ $\begin{array}{llllll}0.502 & \mathrm{E}-04 & 342.2 & -44.8 & 187.0 & 33.0\end{array}$ $\begin{array}{lllll}0.170 \mathrm{E}-04 & 104.8 & 17.6 & 187.0 & 39.0\end{array}$

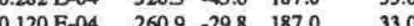
$\begin{array}{lrrrrr}0.120 \text { E- } 04 & 260.9 & -29.8 & 187.0 & 33.0 \\ 0.157 \text { E-0. } & 259.2 & 18.4 & 187.0 & 33.0\end{array}$

W089161.1 W3-9343.1 T30 W089161.1 W3-9343.1 T32 W089161.1 W3-9343.1 T34 W089161.1 W3-9343.1 T36

$\begin{array}{lllll}0.214 \mathrm{E}-0.4 & 220.7 & 57.2 & 187.0\end{array}$ $\begin{array}{llll}0.171 \mathrm{E}-04 & 196.9 & 43.4 & 187.0\end{array}$ $\begin{array}{llll}0.171 \mathrm{E}-04 & 196.9 & 43.4 & 187.0 \\ 0.168 \mathrm{E}-04 & 222.3 & 22.7 & 187.0\end{array}$ 33.0 W089161.1 W3-9343.1 T38

$\begin{array}{llll}0.119 \mathrm{E}-0.4 & 180.8 & 52.0 & 187.0\end{array}$

WANGANUI RIVER SITE 091C

HEIGHT $=3373 \mathrm{~m}$ (above base of section) STRIKE $=043.0 \mathrm{DIP}=4.5$

SAMPLE FIEID NO. TREAT. INTENSITY CDEC CINC Y-AZ PLUNGE

W091162.1 W2-4038.1 N00 W091162.1 W2-4038.1 T05 W091162.1 W2-4038.1 T10 W091162.1 W2-4038.1 T15 W091162.1 W2-4038.1 T20 W091162.1 W2-4038.1 T20 W091162.1 W2-4038.1 T30 W091163.1 W2-4039.1 NOO W091163.1 W2-4039.1 T05 W091163.1 W2-4039.1 T10 w091163.1 W2-4039.1 T15 W091163.1 W2-4039.1 T20 W091163.1 W2-4039.1 T25 W091163.1 W2-4039.1 T30 W091164.1 W2-4040.1 N00 W091164.1 W2-4040.1 T05 W0911641 W/2-4040.1 T10 w091164.1 W2-4040.1 T15 W091164.1 W2-4040.1 T20 W091164.1 W2-4040.1 T25 W091164.1 W/2-4040.1 T30

$\begin{array}{lllll}0.230 \mathrm{E}-03 & 189.9 & -73.4 & 153.0 & 53.0 \\ 0.207 \mathrm{E}-03 & 170.9 & -74.6 & 153.0 & 53.0 \\ 0.156 \mathrm{E}-03 & 184.6 & -82.8 & 153.0 & 53.0 \\ 0.907 \mathrm{E}-04 & 150.4 & -77.7 & 153.0 & 53.0 \\ 0.717 \mathrm{E}-04 & 163.1 & -69.1 & 153.0 & 53.0 \\ 0.544 \mathrm{E}-04 & 156.6 & -69.3 & 153.0 & 53.0 \\ 0.418 \mathrm{E}-04 & 147.9 & -78.1 & 153.0 & 53.0 \\ 0.215 \mathrm{E}-03 & 180.9 & -73.6 & 164.0 & 52.0 \\ 0.180 \mathrm{E}-03 & 185.3 & -77.3 & 164.0 & 52.0 \\ 0.143 \mathrm{E}-03 & 172.3 & -70.1 & 164.0 & 52.0 \\ 0.760 \mathrm{E}-04 & 168.7 & -70.2 & 164.0 & 52.0 \\ 0.573 \mathrm{E}-04 & 114.4 & -78.5 & 164.0 & 52.0 \\ 0.472 \mathrm{E}-04 & 086.2 & -69.5 & 164.0 & 52.0 \\ 0.348 \mathrm{E}-04 & 135.9 & -665 & 164.0 & 52.0 \\ 0.225 \mathrm{E}-03 & 200.3 & -77.9 & 167.0 & 53.3 \\ 0.192 \mathrm{E}-03 & 196.1 & -81.2 & 167.0 & 53.3 \\ 0.148 \mathrm{E}-03 & 175.8 & -73.7 & 167.0 & 53.3 \\ 0.836 \mathrm{E}-04 & 167.1 & -82.3 & 167.0 & 53.3 \\ 0.678 \mathrm{E}-04 & 157.7 & -80.7 & 167.0 & 53.3 \\ 0.538 \mathrm{E}-04 & 167.3 & -69.9 & 167.0 & 53.3 \\ 0.488 \mathrm{E}-04 & 147.8 & -60.1 & 167.0 & 53.3\end{array}$

WANGANUI RIVER SITE $093 \mathrm{G}$

HEIGHT $=3440 \mathrm{~m}$ (above base of section) STRIKE $=043.0 \mathrm{DIP}=4.5$

SAMPLE FIELD NO. TREAT. INTENSITY CDEC CINC Y-AZ PLUNGE

W093165.1 W3-9444.1 NOO W093165.1 W3-9444.1 T10 W093165.1 W3-9444.1 T15 W093165.1 W/3-9444.1 T20 W093165.1 W3-9444.1 T25 W093165.1 W3-9444.1 T30 W093165.1 W3-9444.1 T32 W093165.1 W3-9444.1 T34 W093165.1 W3-9444.1 T36 W093165.1 W3-9444.1 T38 W093165.1 W3-9444.1 T40 W093166.1 W3-9445.1 NOO W093166.1 W3-9445.1 T10 W093166.1 W3-9445.1 T15 W093166.1 W3-9445.1 T20 W093166.1 W3-9445.1 T25 W093166.1 W3-9445.1 T30 W093166.1 W3-9445.1 T32 W093166.1 W3-9445.1 T34 W093166.1 W3-9445.1 T36 W093166.1 W3-9445.1 T38 W093167.2 W3-9446.2 NO W093167.2 W3-9446.2 T10 W093167.2 W3-9446.2 T15 W093167.2 W3-9446.2 T20 W0931672 W3-946.2 T20 W093167.2 W3-9446.2 T30 W093167.2 W3-9446.2 T30
W093167.2 W3-9446.2 T32 W093167.2 W3-9446.2 T32
W093167.2 W3-9446.2 T34 W093167.2 W3-9446.2 T36 W093167.2 W3-9446.2 T38

$\begin{array}{llrll}0.387 \text { E-04 } & 068.3 & -44.7 & 158.0 & 47.0 \\ 0.291 \mathrm{E}-04 & 087.0 & -36.0 & 158.0 & 47.0 \\ 0.190 \mathrm{E}-04 & 106.8 & -08.2 & 158.0 & 47.0 \\ 0.241 \mathrm{E}-04 & 113.7 & 22.2 & 158.0 & 47.0 \\ 0.409 \mathrm{E}-04 & 137.1 & 32.4 & 158.0 & 47.0 \\ 0.359 \mathrm{E}-04 & 136.2 & 24.5 & 158.0 & 47.0 \\ 0.272 \mathrm{E}-04 & 132.8 & -04.1 & 158.0 & 47.0 \\ 0.300 \mathrm{E}-05 & 088.3 & 47.8 & 158.0 & 47.0 \\ 0.232 \mathrm{E}-04 & 177.6 & 29.9 & 158.0 & 47.0 \\ 0.224 \mathrm{E}-04 & 208.5 & 58.9 & 158.0 & 47.0 \\ 0.374 \mathrm{E}-04 & 054.5 & 06.5 & 158.0 & 47.0 \\ 0.118 \mathrm{E}-03 & 024.7 & -48.0 & 159.0 & 41.0 \\ 0.980 \mathrm{E}-04 & 024.7 & -44.3 & 159.0 & 41.0 \\ 0.855 \mathrm{E}-04 & 030.5 & -44.6 & 159.0 & 41.0 \\ 0.752 \mathrm{E}-04 & 041.0 & -44.4 & 159.0 & 41.0 \\ 0.535 \mathrm{E}-04 & 045.4 & -43.9 & 159.0 & 41.0 \\ 0.444 \mathrm{E}-04 & 056.3 & -12.0 & 159.0 & 41.0 \\ 0.561 \mathrm{E}-04 & 059.9 & -21.2 & 159.0 & 41.0 \\ 0.422 \mathrm{E}-04 & 132.5 & -00.8 & 159.0 & 41.0 \\ 0.415 \mathrm{E}-04 & 072.7 & 13.2 & 159.0 & 41.0 \\ 0.280 \mathrm{E}-04 & 088.1 & 06.4 & 159.0 & 41.0 \\ 0.327 \mathrm{E}-04 & 303.7 & -64.0 & 156.0 & 49.0 \\ 0.174 \mathrm{E}-04 & 324.5 & -28.1 & 156.0 & 49.0 \\ 0.880 \mathrm{E}-05 & 290.0 & -31.6 & 156.0 & 49.0 \\ 0.620 \mathrm{E}-05 & 209.9 & -10.3 & 156.0 & 49.0 \\ 0.142 \mathrm{E}-03 & 198.6 & 42.8 & 156.0 & 49.0 \\ 0.240 \mathrm{E}-04 & 210.5 & 30.6 & 156.0 & 49.0 \\ 0.187 \mathrm{E}-04 & 191.1 & 06.8 & 156.0 & 49.0 \\ 0.245 \mathrm{E}-04 & 180.8 & 32.8 & 156.0 & 49.0 \\ 0.260 \mathrm{E}-04 & 201.9 & 59.3 & 156.0 & 49.0 \\ 0.182 \mathrm{E}-04 & 180.8 & 39.5 & 156.0 & 49.0\end{array}$

47.0 47.0 47.0 47.0 47.0 47.0 47.0 47.0 41.0 41.0 41.0 41.0 41.0 41.0 41.0 49.0 49.0 49.0 49.0 49.0 49.0 49.0

WANGANUI RIVER SITE 095G

HEIGHT $=3463 \mathrm{~m}$ (above base of section) STRIKE $=043,0$ DIP $=4.5$

SAMPLE FIELDNO. TREAT. INTENSITY CDEC CINC Y-AZ PLUNGE

W095168.1 W3-9547.1 N00 W095168.1 W3-9547.1 T12 W095168.1 W3-9547.1 T16 W095168.1 W3-9547.1 T20 W095168.1 W3-9547.1 T2A W095168.1 W3-9547.1 T27 W095168.1 W3-9547.1 T30 W095169.1 W3-9548.1 N00 W095169.1 W3-9548.1 T12 W095169.1 W3-9548.1 T16 W095169.1 W3-9548.1 T20 W095169.1 W3-9548.1 T2 W095169.1 W3-9548.1 T27 
W097171.1 W3-5550.1 T18 W097171.1 W3-5550.1 T21 W097171.1 W3-5550.1 T24 W097171.1 W/3-5550.1 T27 W097171.1 W3-5550.1 T30 W097171.1 W3-5550.1 T32 W097171.1 W3-5550.1 T34 W097172.1 W3-5551.1 N00 W097172.1 W3-5551.1 T08 W097172.1 W3-5551.1 T12 W097172.1 W3-5551.1 T18 W097172.1 W3-5551.1 T21 W097172.1 W3-5551.1 T24 W097172.1 W3-5551.1 T27 W097172.1 W3-5551.1 T30 W097173.1 W3-5552.1 T08 W097173.1 W3-5552.1 T12 W097173.1 W3-5552.1 T16 W097173.1 W3-5552.1 T18 W097173.1 W3-5552.1 T21 W097173.1 W3-5552.1 T24 W097173.1 W3-5552.1 T27 W097173.1 W3-5552.1 T30 W097173.1 W3-5552.1 T32 W097172.1 W3-5551.1 T16 W097173.1 W3-5552.1 N00

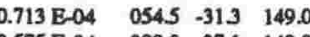
$\begin{array}{lllll}0.575 & \mathrm{E}-04 & 089.0 & -37.1 & 149.0\end{array}$ $\begin{array}{llll}0.575 \mathrm{E}-04 & 077.4 & -29.0 & 149.0\end{array}$ $\begin{array}{llll}0.521 \mathrm{E}-04 & 058.4 & -09.9 & 149.0\end{array}$ $\begin{array}{lllll}0.339 & \mathrm{E}-04 & 067.6 & 03.9 & 149.0\end{array}$ $\begin{array}{lllll}0.455 \mathrm{E}-04 & 058.0 & -053 & 149.0\end{array}$ $\begin{array}{lllll}0.377 \mathrm{E}-04 & 085.4 & 17.2 & 149.0\end{array}$ $\begin{array}{llll}0.833 \text { E-04 } & 343.2 & -72.8 & 146.0\end{array}$ $\begin{array}{lllll}0.702 & \mathrm{E}-04 & 316.5 & -62.9 & 146.0\end{array}$ $\begin{array}{lllll}0.147 \mathrm{E}-04 & 058.8 & -51.0 & 146.0\end{array}$ $\begin{array}{lllll}0.430 & \mathrm{E}-05 & 351.6 & 40.6 & 146.0\end{array}$ $\begin{array}{lllll}0.500 \mathrm{E}-05 & 264.6 & -28.6 & 146.0\end{array}$ $\begin{array}{llllll}0.173 & \mathrm{E}-0.4 & 293.6 & 02.4 & 146.0\end{array}$ $\begin{array}{lllll}0.173 & \mathrm{E}-0 . & 293.6 & 02.4 & 146.0 \\ 0.201 \mathrm{E}-0.4 & 289.3 & 30.9 & 146.0\end{array}$ $\begin{array}{llll}0.272 \mathrm{E}-04 & 118.9 & 703 & 146.0\end{array}$ $\begin{array}{llll}0.453 \mathrm{E}-04 & 329.3 & 25.1 & 146.0\end{array}$ $0.698 \mathrm{E}-04 \quad 354.0 \quad-43.0 \quad 151.0$ 0.551 E-04 $353.4 \quad-42.8 \quad 151.0$ 0.374 E-04 $345.1-41.3 \quad 151.0$ $0.206 \mathrm{E}-04 \quad 331.7 \quad-29.0 \quad 151.0$ $0.222 \mathrm{E}-04 \quad 325.6-06.5 \quad 151.0$ $\begin{array}{llll}0.285 \mathrm{E}-04 & 316.1 & 20.4 & 151.0\end{array}$ $\begin{array}{lllll}0.230 \mathrm{E}-04 & 333.4 & 48.8 & 151.0\end{array}$ $\begin{array}{llll}0.118 \mathrm{E}-04 & 196.8 & 78.4 & 151.0\end{array}$ $0.283 \mathrm{E}-04 \quad 282.2 \quad 46.1 \quad 151.0$ $\begin{array}{llll}0.182 \mathrm{E}-04 & 349.8 & 51.3 & 151.0\end{array}$
WANGANUI RIVER SITE $100 \mathrm{G}$

HEIGHT $=3523 \mathrm{~m}$ (above base of section) STRIKE $=043.0 \quad \mathrm{DIP}=4.5$

SAMPLE FIELD NO. TREAT. INTENSITY CDEC CINC Y-AZ PLUNGF

W100174.1 W3-9650.1 N00 W100174.1 W3-9650.1 T12 W100174.1 W3-9650.1 T16 W100174.1 W3-9650.1 T20 W100174.1 W3-9650.1 T24 W100174.1 W3-9650.1 T27 W100174.1 W3-9650.1 T30 W100175.1 W3-9651.1 N00 W100175.1 W3-9651.1 T12 W100175.1 W3-9651.1 T16 W100175.1 W3-9651.1 T20 W100175.1 W3-9651.1 T24 W100175.1 W3-9651.1 T27 W100175.1 W3 -9651.1 T30 W100176.1 W3-9652.1 NOO W100176.1 W3-9652.1 T12 W100176.1 W3-9652.1 T16 W100176.1 W3-9652.1 T20 W100176.1 W3-9652.1 T2 W100176.1 W3-9652.1 T27 W100176.1 W3-9652.1 T30 $\begin{array}{llll}0.485 \mathrm{E}-04 & 023.6 & 22.9 & 179.0\end{array}$

$\begin{array}{lllll}0.515 \mathrm{E}-04 & 022.6 & 35.1 & 179.0\end{array}$

$\begin{array}{llll}0.560 \mathrm{E}-04 & 031.2 & 50.7 & 179.0\end{array}$

$\begin{array}{llll}0.584 \mathrm{E}-04 & 015.1 & 40.5 & 179.0\end{array}$

$\begin{array}{llll}009.0 & 26.3 & 179.0\end{array}$

$\begin{array}{lllll}0.157 \mathrm{E}-03 & 022.3 & -53.2 & 179.0\end{array}$

$\begin{array}{lllll}0.107 & \mathrm{E}-03 & 025.1 & -50.0 & 179.0\end{array}$

$\begin{array}{llll}0.529 \mathrm{E}-04 & 048.0 & -352 & 179.0\end{array}$

$\begin{array}{lllll}0.310 \mathrm{E}-04 & 019.1 & -52.7 & 179.0\end{array}$

$\begin{array}{llll}0.320 \text { E- } 04 & 020.3 & -59.6 & 179.0\end{array}$

$0.283 \mathrm{E}-04 \quad 049.3 \quad-79.6 \quad 179.0$

$\begin{array}{llll}0.341 \mathrm{E}-04 & 128.0 & -83.1 & 179.0\end{array}$

$\begin{array}{llll}0.170 \mathrm{~B}-03 & 021.8 & -52.7 & 181.0\end{array}$

$\begin{array}{lllll}0.735 \mathrm{E}-04 & 0.47 .2 & -523 & 1810\end{array}$

$\begin{array}{lllll}0.593 \mathrm{E}-04 & 036.3 & -49.8 & 181.0\end{array}$

$\begin{array}{llll}0.476 \mathrm{E}-04 & 026.7 & -55.2 & 181.0\end{array}$

$\begin{array}{lllll}0.526 \mathrm{E}-04 & 0.49 .7 & -645 & 181.0\end{array}$

$\begin{array}{llll}0.483 \mathrm{E}-04 & 063.7 & -72.8 & 181.0\end{array}$
WANGANUI RIVER STIE 101G

HEIGHT $=3526 \mathrm{~m}$ (above base of section) STRIKE $=043.0 \mathrm{DIP}=45$

SAMPLE FIELD NO. TREAT. INTENSITY CDEC CINC Y-AZ PLUNGE
W101177.1 W3-5144.1 N00 W101177.1 W3-5144.1 T12 W101177.1 W3-5144.1 T16 W101177.1 W3-5144.1 T20 W101177.1 W3-5144.1 T2 W101177.1 W3-5144.1 T27 W101177.1 W3-5144.1 T30 W101178.2 W3-5145.2 N00 W101178.2 W3-5145.2 T16 W101178.2 W3-5145.2 T20 W101178.2 W3-5145.2 T24 W101178.2 W3-5145.2 T27 W101178 2 W3-5145.2 T30 W101179.2 W3-5146.2 NO0 W101179.2 W3-5146.2 T12 W101179.2 W3-5146.2 T16 W101179.2 W3-5146.2 T20 W101179.2 W3-5146.2 T2 W101179.2 W3-5146.2 T27 W101179.2 W3-5146.2 T30

$\begin{array}{lllll}0.888 \mathrm{E}-04 & 321.9 & -65.7 & 243.0 & 38.0 \\ 0.383 \mathrm{E}-04 & 241.8 & -77.1 & 243.0 & 38.0 \\ 0.273 \mathrm{E}-04 & 206.2 & -55.8 & 243.0 & 38.0 \\ 0.240 \mathrm{E}-04 & 191.7 & -38.2 & 243.0 & 38.0 \\ 0.261 \mathrm{E}-04 & 200.2 & -37.3 & 243.0 & 38.0 \\ 0.339 \mathrm{E}-04 & 189.3 & -32.1 & 243.0 & 38.0 \\ 0.296 \mathrm{E}-04 & 187.4 & -49.6 & 243.0 & 38.0 \\ 0.935 \mathrm{E}-04 & 296.9 & -51.2 & 247.0 & 31.0 \\ 0.449 \mathrm{E}-04 & 262.8 & -29.1 & 247.0 & 31.0 \\ 0.332 \mathrm{E}-04 & 232.8 & -27.0 & 247.0 & 31.0 \\ 0.370 \mathrm{E}-04 & 223.2 & -16.6 & 247.0 & 31.0 \\ 0.397 \mathrm{E}-04 & 206.5 & -25.1 & 247.0 & 31.0 \\ 0.298 \mathrm{E}-04 & 218.9 & -28.8 & 247.0 & 31.0 \\ 0.703 \mathrm{E}-04 & 029.6 & -34.0 & 244.0 & 32.5 \\ 0.586 \mathrm{E}-04 & 033.7 & -12.2 & 244.0 & 32.5 \\ 0.463 \mathrm{E}-04 & 046.7 & 05.9 & 244.0 & 32.5 \\ 0.477 \mathrm{E}-04 & 047.3 & 21.7 & 244.0 & 32.5 \\ 0.506 \mathrm{E}-04 & 046.6 & 37.4 & 244.0 & 32.5 \\ 0.470 \mathrm{E}-04 & 051.0 & 35.9 & 244.0 & 32.5 \\ 0.402 \mathrm{E}-04 & 048.9 & 52.7 & 244.0 & 32.5\end{array}$

WANGANUI RIVER SITE 104G

W

SAMPLE FIELDNO. TREAT. INTENSITY CDEC CINC Y-AZ PLUNGE

W104180.2 W3-5347.2 N0O W1041802 W3-5347.2 T12 W104180.2 W3-5347.2 T16 W104180.2 W3-5347.2 T2 W104180.2 W3-5347.2 T24 W104180.2 W3-5347.2 T27 W104180.2 W3-5347.2 T30 W104180.2 W3-5347.2 T34 W104181.2 W3-5348.2 NOD W104181.2 W3-5348.2 T12 W104181.2 W3-5348.2 T16 W104181.2 W3-5348.2 T21 W104181.2 W3-5348.2 T2 W104181.2 W3-5348.2 T27 W104181.2 W3.5348.2 T30 W104182.2 W3-5349.2 NOO W 104182.2 W3-5349.2 T12 W104182.2 W3-5349.2 T16 W104182.2 W3-5349.2 T2 W104182.2 W3-5349.2 T24

$\begin{array}{lrrrr}0.884 \mathrm{E}-04 & 165.3 & -37.1 & 233.0 & 46.5 \\ 0.815 \mathrm{E}-04 & 169.2 & -153 & 233.0 & 46.5 \\ 0.847 \mathrm{E}-04 & 167.9 & 01.8 & 233.0 & 46.5 \\ 0.909 \mathrm{E}-04 & 166.3 & 14.6 & 233.0 & 46.5 \\ 0.818 \mathrm{E}-04 & 169.1 & 15.7 & 233.0 & 46.5 \\ 0.770 \mathrm{E}-04 & 171.4 & 07.3 & 233.0 & 46.5 \\ 0.447 \mathrm{E}-04 & 144.4 & -05.6 & 233.0 & 46.5 \\ 0.362 \mathrm{E}-04 & 166.7 & 18.2 & 233.0 & 46.5 \\ 0.716 \mathrm{E}-04 & 247.8 & -80.1 & 229.0 & 48.0 \\ 0.466 \mathrm{E}-04 & 224.5 & -63.0 & 229.0 & 48.0 \\ 0.422 \mathrm{E}-04 & 201.9 & -32.7 & 229.0 & 48.0 \\ 0.653 \mathrm{E}-04 & 161.5 & 03.2 & 229.0 & 48.0 \\ 0.714 \mathrm{E}-04 & 156.6 & 10.2 & 229.0 & 48.0 \\ 0.714 \mathrm{E}-04 & 155.3 & 12.3 & 229.0 & 48.0 \\ 0.668 \mathrm{E}-04 & 154.5 & -12.3 & 229.0 & 48.0 \\ 0.369 \mathrm{E}-04 & 274.9 & -24.2 & 231.0 & 46.5 \\ 0.384 \mathrm{E}-04 & 253.2 & 20.4 & 231.0 & 46.5 \\ 0.515 \mathrm{E}-04 & 242.9 & 35.3 & 231.0 & 46.5 \\ 0.700 \mathrm{E}-04 & 239.1 & 29.7 & 231.0 & 46.5 \\ 0.676 \mathrm{E}-04 & 194.1 & 31.4 & 231.0 & 46.5\end{array}$

$\begin{array}{lllllll}\text { W104182.2 W3-5349.2 T27 } & 0.726 \mathrm{E}-04 & 197.5 & 28.1 & 231.0 & 465\end{array}$

WANGANUI RIVER SITE 106G

HEIGHT $=3653 \mathrm{~m}$ (above base of section) STRIKE $=043.0 \mathrm{DIP}=4.5$

SAMFLE FELD NO. TREAT. INTENSITY CDEC CINC Y-AZ PLUNGE W1061832 W3-5753. W106183.2 W3-5753.2 T16 W106183.2 W3-5753.2 T21 W106183.2 W3-5753.2 T24 W1061832 W3-5753.2 T27 W106183.2 W3-5753 2 T30 W106184.1 W3-5754.1 N00 W106184.1 W3-5754.1 T12 W106184.1 W3-5754.1 T16 W106184.1 W3-5754.1 T21 W106184.1 W3-5754.1 T24 W106184.1 W3-5754.1 T27 W106184.1 W3-5754.1 T30 W1061852 W3-5755.2 N00 V1061852 W3-5755.2 T12 W106185.2 W3-5755.2 T16 W106185.2 W3-5755.2 T21 W106185.2 W3-5755.2 T24 106185.2 W3-5755.2 T27 $0.599 \mathrm{E}-04 \quad 2827-54.6 \quad 090.0$ 35.0 $\begin{array}{lllll}0.317 \text { E- } 04 & 262.5 & -28.2 & 090.0 & 35.0\end{array}$

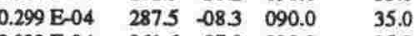
$\begin{array}{lllll}0.389 \mathrm{E}-04 & 261.6 & 07.9 & 090.0 & 35.0\end{array}$

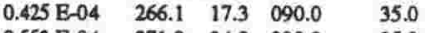
$\begin{array}{lllll}0.553 \mathrm{E}-04 & 271.9 & 34.9 & 090.0 & 35.0\end{array}$ $\begin{array}{lllll}0.498 \mathrm{E}-04 & 104.4 & -26.1 & 090.0 & 35.0\end{array}$ $\begin{array}{lllll}0.611 \mathrm{E}-0.4 & 166.2 & -48.2 & 088.0 & 33.5\end{array}$ $\begin{array}{lllll}0.568 \mathrm{E}-04 & 167.3 & -19.1 & 088.0 & 335\end{array}$ $\begin{array}{lllll}0.669 \mathrm{E}-04 & 175.8 & 02.9 & 088.0 & 33.5\end{array}$ $\begin{array}{lllll}0.490 \mathrm{E}-04 & 180.8 & 22.8 & 088.0 & 33.5 \\ 0.528 \mathrm{E}-0.4 & 181.4 & 15.1 & 088.0 & 33.5\end{array}$ $0.337 \mathrm{E}-04 \quad 154.3 \quad 38.0 \quad 088.0 \quad 335$ $\begin{array}{lllll}0.316 \mathrm{E}-0.4 & 132.1 & 54.9 & 088.0 & 33.5\end{array}$ $\begin{array}{lllll}0.688 \mathrm{E}-04 & 139.9 & -34.9 & 090.0 & 34.0\end{array}$ $\begin{array}{lllll}0.612 \mathrm{E}-04 & 157.5 & -22.8 & 090.0 & 34.0\end{array}$

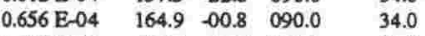
$\begin{array}{lllll}0.585 \mathrm{E}-04 & 156.5 & 07.9 & 090.0 & 34.0\end{array}$ $\begin{array}{lllll}0.616 \mathrm{E}-04 & 169.3 & 03.7 & 090.0 & 34.0\end{array}$ $\begin{array}{lllll}0.254 \mathrm{E}-04 & 163.4 & 58.3 & 090.0 & 34.0\end{array}$ $\begin{array}{lllll}0.378 \text { E- } 04 & 194.8 & 03.7 & 090.0 & 34.0\end{array}$

WANGANUI RTVER STIE $107 \mathrm{G}$

HEIGHT $=3695 \mathrm{~m}$ (above base of section) STRIKE $=043.0 \quad \mathrm{DIP}=4.5$

SAMPLE FELD NO. TREAT, INTENSITY CDEC CINC Y-AZ PLUNGE

W107186.1 W3-5856.1 N0O W107186.1 W3-5856.1 T12 W107186.1 W3-5856.1 T16 W107186.1 W3-5856.1 T21 W107186.1 W3-5856.1 T24 W107186.1 W3-5856.1 T27 W107186.1 W3-5856.1 T30 W107187.1 W3-5857.1 N00 W107187.1 W3-5857.1 T12 W107187.1 W3-5857.1 T16 W107187.1 W3-5857.1 T2 W107187.1 W3-5857.1 T24 W107187.1 W3-5857.1 T27 W107187.1 W3-5857.1 T30 W107188.1 W/3-5858.1 N00 W107188.1 W3-5858.1 T12 W107188.1 W3-5858.1 T16 W107188.1 W3-5858.1 T2 W107188.1 W3-5858.1 T24 W107188.1 W3-5858.1 T27

$\begin{array}{lllll}0.138 \mathrm{E}-03 & 010.4 & -35.6 & 358.0 & 28.0 \\ 0.101 \mathrm{E}-03 & 008.0 & -26.2 & 358.0 & 28.0 \\ 0.732 \mathrm{E}-04 & 010.0 & -18.5 & 358.0 & 28.0 \\ 0.774 \mathrm{E}-04 & 008.9 & -15.9 & 358.0 & 28.0 \\ 0.743 \mathrm{E}-04 & 012.9 & -13.0 & 358.0 & 28.0 \\ 0.743 \mathrm{E}-04 & 004.9 & 07.4 & 358.0 & 28.0 \\ 0.593 \mathrm{E}-04 & 012.0 & 16.8 & 358.0 & 28.0 \\ 0.155 \mathrm{E}-03 & 321.6 & -54.8 & 006.0 & 23.0 \\ 0.111 \mathrm{E}-03 & 305.1 & -47.2 & 006.0 & 23.0 \\ 0.944 \mathrm{E}-04 & 290.0 & -36.2 & 006.0 & 23.0 \\ 0.851 \mathrm{E}-04 & 290.7 & -28.2 & 006.0 & 23.0 \\ 0.944 \mathrm{E}-04 & 288.5 & -29.2 & 006.0 & 23.0 \\ 0.899 \mathrm{E}-04 & 294.5 & -34.8 & 006.0 & 23.0 \\ 0.659 \mathrm{E}-04 & 313.9 & -50.4 & 006.0 & 23.0 \\ 0.160 \mathrm{E}-03 & 021.2 & -46.2 & 359.0 & 33.0 \\ 0.111 \mathrm{E}-03 & 020.2 & -45.6 & 359.0 & 33.0 \\ 0.856 \mathrm{E}-04 & 022.4 & -44.3 & 359.0 & 33.0 \\ 0.764 \mathrm{E}-04 & 026.2 & -34.7 & 359.0 & 33.0 \\ 0.793 \mathrm{E}-04 & 029.0 & -39.5 & 359.0 & 33.0 \\ 0.750 \mathrm{E}-04 & 029.8 & -34.0 & 359.0 & 33.0 \\ 0.612 \mathrm{E}-04 & 033.4 & -44.4 & 359.0 & 33.0\end{array}$

WANGANUI RIVER SITE $108 \mathrm{C}$

HEIGHT $=3841 \mathrm{~m}$ (above base of section) STRIKE $=043.0 \mathrm{DIP}=4.5$ SAMPLE FIELDNO. TREAT. INTENSITY CDEC CINC Y-AZ PLUNGE

W108189.1 W3-5959.1 N00 W108189.1 W3-5959.1 T12 W108189.1 W3-5959.1 T16 W108189.1 W3-5959.1 T21 W108189.1 W3-5959.1 T24 W108189.1 W3-5959.1 T27 W108189.1 W3-5959.1 T30 W108190.1 W3-5960.1 N00 W108190.1 W3-5960.1 T12 W108190.1 W3-5960.1 T16 W108190.1 W3-5960.1 T21 W108190.1 W3-5960.1 T24 W108190.1 W3-5960.1 T27 W108191.1 W3-5961.1 N00 W108191.1 W3-5961.1 T12 W108191.1 W3-5961.1 T16 W108191.1 W3-5961.1 T21 W108191.1 W3-5961.1 T24 W108191.1 W3-5961.1 T27

$\begin{array}{lrrrr}0.872 \mathrm{E}-04 & 321.8 & -44.0 & 159.0 & 48.0 \\ 0.559 \mathrm{E}-04 & 314.8 & -50.4 & 159.0 & 48.0 \\ 0.404 \mathrm{E}-04 & 274.1 & -62.3 & 159.0 & 48.0 \\ 0.405 \mathrm{E}-04 & 282.7 & -42.7 & 159.0 & 48.0 \\ 0.351 \mathrm{E}-04 & 290.0 & -46.2 & 159.0 & 48.0 \\ 0.485 \mathrm{E}-04 & 285.8 & -31.9 & 159.0 & 48.0 \\ 0.289 \mathrm{E}-04 & 195.5 & -83.8 & 159.0 & 48.0 \\ 0.112 \mathrm{E}-03 & 326.2 & -19.2 & 157.0 & 45.0 \\ 0.972 \mathrm{E}-04 & 322.0 & -05.5 & 157.0 & 45.0 \\ 0.803 \mathrm{E}-04 & 320.8 & 07.0 & 157.0 & 45.0 \\ 0.669 \mathrm{E}-04 & 326.5 & 19.4 & 157.0 & 45.0 \\ 0.643 \mathrm{E}-04 & 326.4 & 20.2 & 157.0 & 45.0 \\ 0.584 \mathrm{E}-04 & 333.2 & 36.2 & 157.0 & 45.0 \\ 0.400 \mathrm{E}-04 & 219.0 & -04.2 & 164.0 & 48.0 \\ 0.580 \mathrm{E}-04 & 212.4 & 36.2 & 164.0 & 48.0 \\ 0.743 \mathrm{E}-04 & 204.8 & 36.1 & 164.0 & 48.0 \\ 0.842 \mathrm{E}-04 & 196.8 & 35.1 & 164.0 & 48.0 \\ 0.857 \mathrm{E}-04 & 204.1 & 37.2 & 164.0 & 48.0 \\ 0.757 \mathrm{E}-04 & 215.2 & 21.3 & 164.0 & 48.0\end{array}$

WANGANUI RTVER STTE $110 \mathrm{C}$

HEIGHT $=3941 \mathrm{~m}$ (above base of section) STRIKE $=043.0 \quad \mathrm{DIP}=4.5$

SAMPLE FIELD NO. TREAT. INTENSITY CDEC CDNC Y-AZ PLUNGE

W110192.1 W3-6062.1 NoO W110192.1 W3-6062.1 T12 W110192.1 W3-6062.1 T16 W110192.1 W3-6062.1 T2 W110192.1 W3-6062.1 T24 W110192.1 W3-6062.1 T27 W110193.1 W3-6063.1 NOO W110193.1 W3-6063.1 T12 W110193.1 W3-6063.1 T16 W110193.1 W3-6063.1 T2 W110193.1 W3-6063.1 T2 W110193.1 W3-6063.1 T27 W110194.1 W3-6064.2 NOO W110194.1 W3-6064.2 T12 W110194.1 W3-6064.2 T16 W110194.1 W3-6064.2 T16
W110194.1 W3-6064.2 T2 W110194.1 W3-6064.2 T2 W110194.1 W3-6064.2 T27

\section{0 \\ 28.0 \\ 28.0 8.0 28.0 23.0} 23.0 
WANGANUI RIVER STIB 1110

HEIGHT $=3989 \mathrm{~m}$ (above base of section) STRIKE=043.0 DIP=4

SAMPLE FIELDNO.TREAT. INTENSITY CDEC CINC Y-AZ PLUNGE

W111195.1 W2-4941.1 N00 W111195.1 W2-4941.1 T05 W111195.1 W2-4941.1 T10 W111195.1 W2-4941.1 T15 W111195.1 W2-4941.1 T20 W111195.1 W2-4941.1 T25 W111195.1 W2-4941.1 T30 W111196.1 W2-4942.1 N00 W111196.1 W2-49421 TOS W111196.1 W2-49421 T10 W111196.1 W2-4942.1 T15 W111196.1 W2-4942.1 T20 W111196.1 W2-4942.1 T25 W111196.1 W2-4942.1 T30 W111197.1 W2-4943.1 N0O W111197.1 W2-4943.1 T05 W111197.1 W2-4943.1 T10 W111197.1 W2-4943.1 T15 W111197.1 W2-4943.1 T20 W111197.1 W2-4943.1 T25

$\begin{array}{lllll}0.745 \mathrm{E}-04 & 178.7 & -27.9 & 051.0 & 31.5 \\ 0.297 \mathrm{E}-04 & 113.9 & -58.5 & 051.0 & 31.5 \\ 0.292 \mathrm{E}-04 & 357.6 & -83.1 & 051.0 & 31.5 \\ 0.220 \mathrm{E}-04 & 045.7 & -63.9 & 051.0 & 31.5 \\ 0.227 \mathrm{E}-04 & 125.3 & -40.0 & 051.0 & 31.5 \\ 0.118 \mathrm{E}-0.4 & 066.8 & -17.9 & 051.0 & 31.5 \\ 0.156 \mathrm{E}-04 & 078.6 & -39.9 & 051.0 & 31.5 \\ 0.506 \mathrm{E}-03 & 257.2 & -42.3 & 056.0 & 31.5 \\ 0.533 \mathrm{E}-03 & 261.5 & -45.2 & 056.0 & 31.5 \\ 0.488 \mathrm{E}-03 & 268.5 & -46.0 & 056.0 & 31.5 \\ 0.481 \mathrm{E}-03 & 272.1 & -46.5 & 056.0 & 31.5 \\ 0.136 \mathrm{E}-03 & 298.9 & -10.9 & 056.0 & 31.5 \\ 0.118 \mathrm{E}-03 & 299.1 & -11.4 & 056.0 & 31.5 \\ 0.998 \mathrm{E}-04 & 306.7 & 14.9 & 056.0 & 31.5 \\ 0.792 \mathrm{E}-0.4 & 208.1 & 08.1 & 057.0 & 29.5 \\ 0.542 \mathrm{E}-0.4 & 213.5 & 07.8 & 057.0 & 29.5 \\ 0.427 \mathrm{E}-0.4 & 184.3 & -22.2 & 057.0 & 29.5 \\ 0.375 \mathrm{E}-0.4 & 196.8 & -28.4 & 057.0 & 29.5 \\ 0.295 \mathrm{E}-0.4 & 194.2 & -43.2 & 057.0 & 29.5 \\ 0.190 \mathrm{E}-0.4 & 199.8 & -11.1 & 057.0 & 29.5 \\ 0.254 \mathrm{E}-0.4 & 167.3 & -12.3 & 057.0 & 29.5\end{array}$

WANGANUI RIVER SITE 113G

HEIGHT $=4093 \mathrm{~m}$ (above base of section) STRIKE $=043.0 \mathrm{DIP}=4.5$

SAMPLE FIELD NO. TREAT. INTENSITY CDEC CDNC Y-AZ PLUNGE

W113198.1 W3-7389.1 N00 W113198.1 W3-7389.1 T08 W113198.1 W3-7389.1 T12 W113198.1 W3-7389.1 T16 W113198.1 W3-7389.1 T18 W113198.1 W3-7389.1 T21 W113198.1 W3-7389.1 T24 W113198.1 W3-7389.1 T27 W113198.1 W3-7389.1 T30 W113198.1 W3-7389.1 T32 W113198.1 W3-7389.1 T34 W113199.1 W3-7390.1 N00 W113199.1 W3-7390.1 T08 W113199.1 W3-7390.1 T12 W113199.1 W3-7390.1 T16 W113199.1 W3-7390.1 T18 W113199.1 W3-7390.1 T21 W113199.1 W3-7390.1 T24 W113199.1 W/3-7390.1 T27 W113199.1 W3-7390.1 T30 W113199.1 W3-7390.1 T32 W113199.1 W3-7390.1 T34 W113200.1 W3-7391.1 N00 W113200.1 W3-7391.1 T08 W113200.1 W3-7391.1 T12 W113200.1 W3-7391.1 T16 W113200.1 W3-7391.1 T18 W113200.1 W3-7391.1 T21 W113200.1 W3-7391.1 T24 W113200.1 W3-7391.1 T27 W113200.1 W3-7391.1 T30 W113200.1 W3-7391.1 T32 W113200.1 W3-7391.1 T34

$\begin{array}{lllll}0.258 \mathrm{E}-03 & 214.0 & 33.9 & 013.0 & 42.0 \\ 0.268 \mathrm{E}-03 & 209.4 & 39.8 & 013.0 & 42.0 \\ 0.285 \mathrm{E}-03 & 210.7 & 40.9 & 013.0 & 42.0 \\ 0.292 \mathrm{E}-03 & 211.9 & 42.9 & 013.0 & 42.0 \\ 0.294 \mathrm{E}-03 & 211.8 & 44.3 & 013.0 & 42.0 \\ 0.329 \mathrm{E}-03 & 214.7 & 47.3 & 013.0 & 42.0 \\ 0.335 \mathrm{E}-03 & 219.4 & 46.5 & 013.0 & 42.0 \\ 0.292 \mathrm{E}-03 & 229.3 & 53.0 & 013.0 & 42.0 \\ 0.161 \mathrm{E}-03 & 232.4 & 47.4 & 013.0 & 42.0 \\ 0.277 \mathrm{E}-03 & 348.4 & -61.2 & 013.0 & 42.0 \\ 0.254 \mathrm{E}-04 & 194.6 & -53.9 & 013.0 & 42.0 \\ 0.104 \mathrm{E}-03 & 214.4 & 67.8 & 014.0 & 43.0 \\ 0.120 \mathrm{E}-03 & 188.7 & 71.3 & 014.0 & 43.0 \\ 0.133 \mathrm{E}-03 & 185.4 & 68.8 & 014.0 & 43.0 \\ 0.148 \mathrm{E}-03 & 178.6 & 66.0 & 014.0 & 43.0 \\ 0.164 \mathrm{E}-03 & 179.2 & 65.8 & 014.0 & 43.0 \\ 0.168 \mathrm{E}-03 & 179.2 & 62.1 & 014.0 & 43.0 \\ 0.154 \mathrm{E}-03 & 180.8 & 60.8 & 014.0 & 43.0 \\ 0.122 \mathrm{E}-03 & 153.9 & 62.9 & 014.0 & 43.0 \\ 0.489 \mathrm{E}-04 & 088.2 & 44.1 & 014.0 & 43.0 \\ 0.297 \mathrm{E}-04 & 334.1 & -02.4 & 014.0 & 43.0 \\ 0.719 \mathrm{E}-04 & 229.3 & 10.2 & 014.0 & 43.0 \\ 0.339 \mathrm{E}-03 & 225.8 & 06.8 & 019.0 & 43.0 \\ 0.337 \mathrm{E}-03 & 223.6 & 10.4 & 019.0 & 43.0 \\ 0.338 \mathrm{E}-03 & 223.5 & 12.0 & 019.0 & 43.0 \\ 0.348 \mathrm{E}-03 & 221.0 & 16.7 & 019.0 & 43.0 \\ 0.360 \mathrm{E}-03 & 219.5 & 17.2 & 019.0 & 43.0 \\ 0.388 \mathrm{E}-03 & 219.5 & 22.6 & 019.0 & 43.0 \\ 0.381 \mathrm{E}-03 & 221.6 & 24.1 & 019.0 & 43.0 \\ 0.354 \mathrm{E}-03 & 235.7 & 19.9 & 019.0 & 43.0 \\ 0.179 \mathrm{E}-03 & 277.4 & 09.2 & 019.0 & 43.0 \\ 0.103 \mathrm{E}-03 & 352.3 & 57.4 & 019.0 & 43.0 \\ 0.937 \mathrm{E}-04 & 282.6 & 02.8 & 019.0 & 43.0\end{array}$

WANGANUI RIVER SITE $116 \mathrm{G}$

HEIGHT $=4118 \mathrm{~m}$ (above base of section) STRIKE $=043.0 \mathrm{DIP}=4.5$

SAMPLE FIELD NO. TREAT. INTENSITY CDEC CINC Y-AZ PLUNGE

W116201.1 W3-7492.1 NOO W116201.1 W3-7492.1 T08 W116201.1 W3-7492.1 T12 W116201.1 W3-7492.1 T16 W116201.1 W3-7492.1 T18 W116201.1 W3-7492.1 T21 W116201.1 W3-74921 T24 W116201.1 W3-7492.1 T27 W116201.1 W3-7492.1 T30 W116201.1 W3-7492.1 T32 W116202.1 W3-7493.1 N00 W116202.1 W3-7493.1 T08 W116202.1 W3-7493.1 T12 W116202.1 W3-7493.1 T16 W116202.1 W3-7493.1 T18 W116202.1 W3-7493.1 T21 W116202.1 W3-7493.1 T24 W116202.1 W3-7493.1 T27 W116202.1 W3-7493.1 T30 W116202.1 W3-7493.1 T32 W116203.1 W3-7494.1 N00 W116203.1 W3-7494.1 T08 W116203.1 W3-7494.1 T12 W116203.1 W3-7494.1 T16 W116203.1 W3-7494.1 T18 W116203.1 W3-7494.1 T21 W116203.1 W3-7494.1 T24 W116203.1 W3-7494.1 T27 W116203.1 W3-7494.1 T30 W116203.1 W3-7494.1 T32

$\begin{array}{lllll}0.722 \text { E-04 } & 053.6 & 06.2 & 236.0 & 24.0 \\ 0.688 \text { E-04 } & 054.6 & 23.3 & 236.0 & 24.0 \\ 0.726 \text { E-04 } & 061.9 & 34.3 & 236.0 & 24.0 \\ 0.793 \text { E-04 } & 064.3 & 49.5 & 236.0 & 24.0 \\ 0.852 \text { E-04 } & 070.0 & 46.1 & 236.0 & 24.0 \\ 0.929 \text { E-04 } & 071.7 & 54.2 & 236.0 & 24.0 \\ 0.919 \text { E-04 } & 067.7 & 62.0 & 236.0 & 24.0 \\ 0.858 \text { E-04 } & 069.2 & 46.7 & 236.0 & 24.0 \\ 0.552 \text { E-04 } & 121.5 & 55.2 & 236.0 & 24.0 \\ 0.403 \text { E-04 } & 225.7 & 22.1 & 236.0 & 24.0 \\ 0.391 \text { E-04 } & 107.1 & 09.9 & 239.0 & 29.0 \\ 0.487 \text { E-04 } & 117.5 & 27.8 & 239.0 & 29.0 \\ 0.575 \text { E-04 } & 121.7 & 38.2 & 239.0 & 29.0 \\ 0.710 \text { E-04 } & 125.2 & 48.1 & 239.0 & 29.0 \\ 0.739 \text { E-04 } & 128.0 & 47.7 & 239.0 & 29.0 \\ 0.737 \text { E-04 } & 131.8 & 46.4 & 239.0 & 29.0 \\ 0.671 \text { E-04 } & 120.3 & 49.8 & 239.0 & 29.0 \\ 0.571 \text { E-04 } & 119.4 & 29.3 & 239.0 & 29.0 \\ 0.495 \text { E-04 } & 246.3 & 34.0 & 239.0 & 29.0 \\ 0.286 \text { E-04 } & 281.2 & 30.7 & 239.0 & 29.0 \\ 0.627 \text { E-04 } & 222.1 & -21.1 & 241.0 & 32.0 \\ 0.677 \text { E-04 } & 217.7 & -10.2 & 241.0 & 32.0 \\ 0.726 \text { E-04 } & 214.7 & 01.1 & 241.0 & 32.0 \\ 0.759 \text { E-04 } & 213.0 & 11.6 & 241.0 & 32.0 \\ 0.762 \text { E-04 } & 211.2 & 15.3 & 241.0 & 32.0 \\ 0.711 \text { E-04 } & 217.0 & 21.1 & 241.0 & 32.0 \\ 0.809 \text { E-04 } & 235.6 & 31.1 & 241.0 & 32.0 \\ 0.733 \text { E-04 } & 235.1 & 36.4 & 241.0 & 32.0 \\ 0.638 \text { E-04 } & 211.6 & 38.4 & 241.0 & 32.0 \\ 0.413 \text { E-04 } & 164.4 & 39.0 & 241.0 & 32.0 \\ 0.273 \text { E-04 } & 173.7 & 11.1 & 241.0 & 32.0\end{array}$

WANGANUI RIVER SITE $117 \mathrm{G}$

HEIGHT $=4123 \mathrm{~m}$ (ebove bese of section) STRIKE $=043.0 \mathrm{DIP}=4.5$

SAMPLB FIELDNO. TREAT. INTENSITY CDEC CINC Y-AZ PLUNGE

$\begin{array}{llllllll}\text { W117204.1 W3-9753.1 N00 } & 0.672 \text { E-04 } & 167.8 & 57.0 & 255.0 & 37.0 \\ \text { W117204.1 W3-9753.1 T10 } & 0.977 \text { E-04 } & 178.9 & 57.2 & 255.0 & 37.0 \\ \text { W117204.1 W3-9753.1 T15 } & 0.119 \text { E-03 } & 173.6 & 59.1 & 255.0 & 37.0 \\ \text { W117204.1 W3-9753.1 T20 } & 0.134 \text { E-03 } & 169.9 & 64.8 & 255.0 & 37.0 \\ \text { W117204.1 W3-9753.1 T25 } & 0.685 \text { E-04 } & 183.7 & 63.5 & 255.0 & 37.0 \\ \text { W117204.1 W3-9753.1 T27 } & 0.283 \text { E-04 } & 156.8 & 41.1 & 255.0 & 37.0 \\ \text { W117204.1 W3-9753.1 T30 } & 0.261 \text { E-04 } & 127.4 & -27.0 & 255.0 & 37.0 \\ \text { W117205.2 W3-9754.2 } \text { N00 } & 0.859 \text { E-04 } & 217.1 & -25.3 & 252.0 & 40.0 \\ \text { W117205.2 W3-9754.2 T10 } & 0.852 \text { E-04 } & 209.2 & -05.6 & 252.0 & 40.0 \\ \text { W117205.2 W3-9754.2 T15 } & 0.101 \text { E-03 } & 201.3 & 00.8 & 252.0 & 40.0 \\ \text { W117205.2 W3-9754.2 T20 } & 0.109 \text { E-03 } & 196.1 & 12.1 & 252.0 & 40.0 \\ \text { W117205.2 W3-9754.2 T25 } & 0.110 \text { E-03 } & 186.5 & 08.3 & 252.0 & 40.0 \\ \text { W117205.2 W3-9754.2 T27 } & 0.985 \text { E-04 } & 186.8 & -00.8 & 252.0 & 40.0 \\ \text { W117205.2 W3-9754.2 T30 } & 0.957 \text { E-04 } & 164.8 & -11.0 & 252.0 & 40.0 \\ \text { W117206.1 W3-9755.1 N00 } & 0.102 \text { E-03 } & 166.4 & 69.2 & 255.0 & 40.0 \\ \text { W117206.1 W3-9755.1 T10 } & 0.133 \text { E-03 } & 178.6 & 69.2 & 255.0 & 40.0 \\ \text { W117206.1 W3-9755.1 T15 } & 0.157 \text { E-03 } & 180.8 & 69.2 & 255.0 & 40.0 \\ \text { W117206.1 W3-9755.1 T20 } & 0.200 \text { E-03 } & 181.4 & 69.2 & 255.0 & 40.0 \\ \text { W117206.1 W3-9755.1 T25 } & 0.207 \text { E-03 } & 211.9 & 72.3 & 255.0 & 40.0 \\ \text { W117206.1 W3-9755.1 T27 } & 0.170 \text { E-03 } & 190.6 & 69.5 & 255.0 & 40.0 \\ \text { W117206.1 W3-9755.1 T30 } & 0.248 \text { E-04 } & 220.9 & 29.9 & 255.0 & 40.0\end{array}$

WANGANUI RIVER SITE $118 \mathrm{G}$

HEIGHT $=4167 \mathrm{~m}$ (above base of section) STRIKE $=043.0 \mathrm{DIP}=4.5$

SAMPLE FIELDNO. TREAT. INTENSITY CDEC CINC Y-AZ PLUNGE

W118207.1 W3-9856.1 T10

0.103 E- $03 \quad 356.5 \quad-69.6 \quad 221.0$

62.0

$\begin{array}{llll}0.516 \mathrm{E}-04 & 348.9 & -86.6 \quad 221.0\end{array}$

$\begin{array}{llll}0.314 \mathrm{E}-04 & 180.8 & -70.0 & 221.0\end{array}$

62.0

W118207.1 W3-9856.1 T20

W118207.1 W3-9856.1 T25

W118207.1 W3-9856.1 T27

W118207.1 W3-9856.1 T30

W118208.1 W3-9857.1 NOO

$\begin{array}{llll}0.325 \mathrm{E}-04 & 179.2 & -47.4 & 221.0\end{array}$

0.215 E-04 $175.3-273-221.0-62.0$

$\begin{array}{lllll}0.150 \mathrm{E}-04 & 178.6 & -23.8 & 221.0 & 62.0\end{array}$

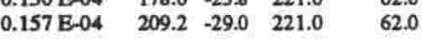

$\begin{array}{lllll}0.967 \mathrm{E}-04 & 001.6 & -62.6 & 219.0 & 57.0\end{array}$

$\begin{array}{lllll}0.460 \mathrm{E}-04 & 008.8 & -68.2 & 219.0 & 57.0\end{array}$

$\begin{array}{lllllll}\text { W118208.1 W3-9857.1 T15 } & 0.222 \text { E-04 } & 010.5 & -68.2 & 219.0 & 57.0\end{array}$

$\begin{array}{lllllll}\text { W118208.1 W3-9857.1 T20 } & 0.560 \mathrm{E}-05 & 181.6 & -56.1 & 219.0 & 57.0\end{array}$

$\begin{array}{lllllll}\text { W118208.1 W3-9857.1 T25 } & 0.770 \mathrm{E}-05 & 184.1 & 15.0 & 219.0 & 57.0\end{array}$

$\begin{array}{lllllll}\text { W118208.1 W3-9857.1 T27 } & 0.950 \text { E-05 } & 195.0 & 33.5 & 219.0 & 57.0\end{array}$

$\begin{array}{lllllll}\text { W118208.1 W3-9857.1 T30 } & 0.111 \mathrm{E}-04 & 148.1 & 49.0 & 219.0 & 57.0\end{array}$

$\begin{array}{lllllll}\text { W118209.1 W3-9858.1 N00 } & 0.868 \text { E-04 } & 011.3 & -58.6 & 215.0 & 54.0\end{array}$

$\begin{array}{lllllll}\text { W118209.1 W3-9858.1 T10 } & 0.351 \mathrm{E}-04 & 022.0 & -55.7 & 215.0 & 54.0\end{array}$

$\begin{array}{llllllll}\text { W118209.1 W3-9858.1 T15 } & 0.160 \mathrm{E}-04 & 042.8 & -52.0 & 215.0 & 54.0\end{array}$

$\begin{array}{llllllll}\text { W118209.1 W3-9858.1 T20 } & 0.770 \mathrm{E}-05 & 117.9 & 01.8 & 215.0 & 54.0\end{array}$

$\begin{array}{llllllll}\text { W118209.1 W3-9858.1 T25 } & 0.170 \text { E-04 } & 095.4 & 27.1 & 215.0 & 54.0\end{array}$

$\begin{array}{llllllll}\text { W118209.1 W3-9858.1 } & \text { T27 } & 0.123 \mathrm{E}-04 & 112.5 & 10.8 & 215.0 & 54.0 \\ \text { W118209.1 W3-9858.1 } & \text { T30 } & 0.800 \text { E-05 } & 141.7 & 17.0 & 215.0 & 54.0\end{array}$

WANGANUI RIVER SITE $123 \mathrm{~V}$

HEIGHT $=4278 \mathrm{~m}$ (above base of section) STRIKE $=043.0 \mathrm{DIP}=4.5$

SAMPLE FELDNO. TREAT. INTENSITY CDEC CINC Y-AZ PLUNGE

W123210.1 W4-0232.1 N00

W123210.1 W4-0232.1 T05

W123210.1 W4-0232.1 T10

W123210.1 W4-0232.1 T15

W123210.1 W4-0232.1 T20

W123210.1 W4-0232.1 T25

W123210.1 W4-0232.1 T30

W123210.2 W4-0232.2 N00

W123211.1 W4-0233.1 N00

W123211.1 W4-0233.1 T05

W123211.1 W4-0233.1 T10

W123211.1 W4-0233.1 T15

W123211.1 W4-0233.1 T20

W123211.1 W4-0233.1 T25

W123211.1 W4-0233.1 T30

W123211.2 W4-0233.2 NOO

W123212.1 W4-0234.1 N0O

W123212.1 W4-0234.1 T05

W123212.1 W4-0234.1 T10

W1232121 W4-0234.1 T15

W123212.1 W4-0234.1 T20

W123212.1 W4-0234.1 T25

W123212.1 W4-0234.1 T30

W123213.1 W4-0235.1 NOO

W123213.1 W4-0235.1 T05

W123213.1 W4-0235.1 T10

W123213.1 W4-0235.1 T15

W123213.1 W4-0235.1 T20

W123213.1 W4-0235.1 T25

W123213.1 W4-0235.1 T30

$0.338 \mathrm{E}-03$

$\begin{array}{rrrr}0.338 \mathrm{E}-03 & 356.1 & -44.4 & 225.0 \\ 0.298 \mathrm{E}-03 & 354.6 & -48.8 & 225.0\end{array}$

$\begin{array}{lll}354.6 & -48.8 & 225.0 \\ 002.3 & -47.5 & 225.0\end{array}$

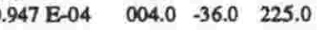

$\begin{array}{llll}0.546 \mathrm{E}-04 & 005.9 & -26.4 & 225.0\end{array}$

0.564 E-04 $009.6 \quad-30.6 \quad 225.0$

$\begin{array}{lllll}0.349 \mathrm{E}-04 & 006.5 & -27.8 & 225.0\end{array}$

$\begin{array}{lllll}0.263 \text { E-03 } & 359.7 & -42.0 & 228.0\end{array}$

$\begin{array}{lllll}0.290 & \mathrm{E}-03 & 358.9 & -47.4 & 228.0\end{array}$

$\begin{array}{lllll}0.260 \mathrm{E}-03 & 353.4 & 48.0 & 228.0\end{array}$

$\begin{array}{lllll}0.153 & \text { E- } 03 \quad 356.9 & -41.1 & 228.0\end{array}$

$\begin{array}{llll}0.584 \mathrm{E}-04 & 359.1 & -26.0 & 228.0\end{array}$

$\begin{array}{lllll}0.273 & \mathrm{E}-04 & 001.7 & 0.7 & 228.0\end{array}$

$\begin{array}{lllll}0.106 \mathrm{E}-04 & 029.5 & 24.0 & 228.0\end{array}$

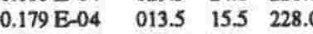

$\begin{array}{lllll}0.228 \mathrm{E}-03 & 353.6 & -50.0 & 229.0\end{array}$

$\begin{array}{lllll}0.251 & \mathrm{E}-03 \quad 003.0 & -51.3 & 229.0\end{array}$

$\begin{array}{llll}0.230 \mathrm{E}-03 & 000.8 & 50.3 & 229.0\end{array}$

$\begin{array}{lllll}0.152 \mathrm{E}-03 & 008.2 & -48.9 & 229.0\end{array}$

$\begin{array}{lllll}0.526 \mathrm{E}-0.4 & 017.0 & -39.4 & 229.0\end{array}$

$\begin{array}{llll}0.232 \mathrm{E}-04 & 047.0 & -40.6 & 229.0\end{array}$

$\begin{array}{lllll}0.177 \mathrm{E}-04 & 085.6 & -20.1 & 229.0\end{array}$

$\begin{array}{lllll}0.129 \mathrm{E}-04 & 081.7 & -255 & 229.0\end{array}$

$\begin{array}{lllll}0.294 \mathrm{E}-03 & 341.2 & -51.3 & 226.0\end{array}$

$\begin{array}{lllll}0.258 & \mathrm{E}-03 & 342.4 & -525 & 226.0\end{array}$

$\begin{array}{lllll}0.168 \mathrm{E}-03 & 334.8 & -55.0 & 226.0\end{array}$

$\begin{array}{llll}0.515 \mathrm{E}-04 & 308.8 & -44.3 & 226.0\end{array}$

$\begin{array}{llll}0.324 \mathrm{E}-0.4 & 247.0 & -22.2 & 226.0\end{array}$

$\begin{array}{lllll}0.343 & \mathrm{E}-04 & 239.7 & -07.7 & 226.0\end{array}$

$\begin{array}{llll}0.242 \mathrm{E}-04 & 198.6 & -22.1 & 226.0\end{array}$

34.5
34.5
34.5
34.5
34.5
34.5
34.5
32.5
32.5
32.5
325
32.5
32.5
32.5
32.5
355
35.5
35.5
35.5
35.5
355
35.5
35.5
445
445
445
445
445
445
445
445

HAUTAWA ROAD SITE $125 \mathrm{~V}$

HEIGHT $=0 \mathrm{~m}$ (base of section) STRIKE $=030.7 \mathrm{DIP}=4.8$

SAMPLE FIELDNO. TREAT. INTENSITY CDEC CINC Y-AZ PLUNGE

H125214.1 H1-0205.1 NOO H125214.1 H1-0205.1 TOS H125214.1 H1-0205.1 T10 H125214.1 H1-0205.1 T15 H125214.1 H1-0205.1 T2O H125214.1 H1-0205.1 T25 H125215.1 H1-0206.1 NOO H125215.1 H1-0206.1 T05 H125215.1 H1-0206.1 T10

$\begin{array}{lllll}0.833 \mathrm{E}-04 & 013.4 & -59.5 & 350.0 & 49.0 \\ 0.650 \mathrm{E}-04 & 018.8 & -57.4 & 350.0 & 49.0 \\ 0.509 \mathrm{E}-04 & 033.4 & -61.2 & 350.0 & 49.0 \\ 0.325 \mathrm{E}-04 & 123.4 & -47.1 & 350.0 & 49.0 \\ 0.241 \mathrm{E}-04 & 077.5 & -39.5 & 350.0 & 49.0 \\ 0.431 \mathrm{E}-04 & 322.1 & -68.2 & 350.0 & 49.0 \\ 0.861 \mathrm{E}-04 & 050.7 & -73.4 & 347.0 & 51.0 \\ 0.662 \mathrm{E}-04 & 058.5 & -82.0 & 347.0 & 51.0 \\ 0.544 \mathrm{E}-04 & 000.9 & -72.3 & 347.0 & 51.0 \\ 0.375 \mathrm{E}-04 & 104.0 & -40.9 & 347.0 & 51.0\end{array}$




\begin{tabular}{|c|c|c|c|c|c|c|c|}
\hline 5.1 & 6.1 & $T 20$ & $0.409 \mathrm{~B}$ & 145.4 & -55.9 & 347.0 & 51.0 \\
\hline H125215.1 & Н1-0206.1 & T2S & 0.677 E- 04 & 256.3 & -56.2 & 347.0 & 51.0 \\
\hline H 125216.2 & H1-0206.2 & NOO & $0.950 \mathrm{E}-04$ & 001.6 & -71.2 & 347.0 & 51.0 \\
\hline H125216.2 & H1-0206.2 & T05 & $0.846 \mathrm{E}-04$ & 001.0 & -74.0 & 347.0 & 51.0 \\
\hline H125216.2 & H1-02062 & T10 & 0.667 E- 04 & 004.9 & -76.1 & 347.0 & 51.0 \\
\hline H125216.2 & H1-0206.2 & T15 & $0.424 \mathrm{E}-0.4$ & 305.7 & -73.5 & 347.0 & 51.0 \\
\hline H125216.2 & H1-0206.2 & T20 & $0.398 \mathrm{E}-04$ & 215.6 & .783 & 347.0 & 51.0 \\
\hline H125216.2 & H1-0206.2 & T25 & 0.481 B- 04 & 096.7 & -61.0 & 347.0 & 51.0 \\
\hline H125217.1 & H1-0207.1 & NOO & $0.549 \mathrm{E}-04$ & 226.2 & -61.0 & 355.0 & 53.0 \\
\hline $\mathrm{H} 125217.1$ & H1-0207.1 & T05 & $0.477 \mathrm{E}-0.4$ & 210.2 & -503 & 355.0 & 53.0 \\
\hline H125217.1 & Н1-0207.1 & T10 & $0.481 \mathrm{E}-04$ & 220.9 & -333 & 355.0 & 53.0 \\
\hline H125217.1 & Н1-0207.1 & $\mathrm{T} 15$ & $0.623 \mathrm{E}-0.4$ & 196.4 & 14.0 & 355.0 & 53.0 \\
\hline H125217.1 & H1-0207.1 & T20 & 0.601 E-04 & 218.3 & -01.0 & 355.0 & 53.0 \\
\hline H125217.1 & H1-0207.1 & T25 & 0.990 E-04 & 246.6 & -16.0 & 355.0 & 53.0 \\
\hline H125218.2 & Н1-0207.2 & NOO & 0.692 E-04 & 008.3 & -55.1 & 355.0 & 53.0 \\
\hline H125218.2 & Н1-0207.2 & T05 & 0.612 E-04 & 009.8 & -50.6 & 355.0 & 53.0 \\
\hline H125218.2 & Н1-0207.2 & T10 & $0.466 \mathrm{E}-04$ & 324.8 & -61.9 & 355.0 & 53.0 \\
\hline H125218.2 & H1-0207.2 & $\mathrm{T} 15$ & 0.412 E-04 & 280.4 & -38.8 & 355.0 & 53.0 \\
\hline H125218.2 & H1-0207.2 & T20 & $0.182 \mathrm{E}-04$ & 289.9 & -18.3 & 355.0 & 53.0 \\
\hline H125218.2 & H1-0207.2 & T25 & $0.240 \mathrm{E}-04$ & 261.1 & -21.9 & 355.0 & 53.0 \\
\hline H125219.1 & H1-0208.1 & NOO & 0.398 E-04 & 357.9 & -45.8 & 355.0 & 54.0 \\
\hline H125219.1 & Н1-0208.1 & T0S & $0.240 \mathrm{E}-04$ & 350.1 & -47.9 & 355.0 & 54.0 \\
\hline H12S219.1 & H1-0208.1 & $\mathrm{T} 10$ & 0.579 E-05 & 015.6 & -035 & 355.0 & 54.0 \\
\hline H125219.1 & H1-0208.1 & T15 & 0.337 E-04 & 128.0 & 275 & 355.0 & 54.0 \\
\hline H125219.1 & H1-0208.1 & $\mathrm{T} 20$ & $0.168 \mathrm{E}-04$ & 117.0 & 47.0 & 355.0 & 54.0 \\
\hline H125219.1 & H1-0208.1 & T25 & $0.332 \mathrm{E}-04$ & 301.0 & -343 & 355.0 & 54.0 \\
\hline H125220.2 & H1-0208.2 & NoO & $0.692 \mathrm{E}-04$ & 318.8 & -50.9 & 355.0 & 54.0 \\
\hline H125220.2 & H1-0208.2 & T05 & $0.523 \mathrm{E}-04$ & 323.0 & -56.7 & 355.0 & 54.0 \\
\hline H125220.2 & Н1-0208.2 & T10 & $0.515 \mathrm{E}-04$ & 323.2 & -53.1 & 355.0 & 54.0 \\
\hline H125220.2 & H1-0208.2 & T15 & $0.346 \mathrm{E}-04$ & 311.1 & -56.8 & 355.0 & 54.0 \\
\hline H125220.2 & H $1-0208.2$ & $\mathrm{~T} 20$ & $0.282 \mathrm{E}-04$ & 298.2 & -41.1 & 355.0 & 54.0 \\
\hline H125220.2 & H $1-0208.2$ & {$[25$} & $0.340 \mathrm{E}-05$ & 347.7 & -18.1 & 355.0 & 54.0 \\
\hline
\end{tabular}

HAUTAWA ROAD STIE $126 \mathrm{~V}$

HEIGHT $=28$ (a)

SAMPLE FIELD NO. TREAT. INTENSITY CDEC CINC Y-AZ PLUNGE

H126221.1 H1-0309.1 N0O H126221.1 H1-0309.1 T05 H126221.1 H1-0309.1 T10 H126221.1 H1-0309.1 T15 $1126221 .+11-0309.1$ T20 H126222.2 H1-0309.2 NOO H126222.2 H1-0309.2 T05 H126222.2 H1-0309.2 T10 H126222.2 H1-0309.2 T15 H126222.2 H1-0309.2 T20 H126222.2 H1-0309.2 T2S H126223.1 H1-0310.1 N0O H126223.1 H1-0310.1 T05 H126223.1 H1-0310.1 T10 H126223.1 H1-0310.1 T15 H126223.1 H1-0310.1 T20 H126224.2 H1-0310.2 NOO H126224.2 H1-0310.2 T05 H126224.2 H1-0310.2 T10 H126224.2 H1-0310.2 T15 H126224.2 H1-0310.2 T20 H126224.2 H1-03102 T25 H126225.1 H1-0311.1 NOO H126225.1 H1-0311.1 T05 H126225.1 H1-0311.1 T10 H126225.1 H1-0311.1 T15 H126225.1 H1-0311.1 T20 H126226.2 H1-0311.2 NOO H126226.2 H1-0311.2 T05 H126226.2 H1-0311.2 T10 H1262262 H1-03112 T15 H1262262 H1-03112 T2O H126226.2 H1-0311.2 T2S H126227.1 H1-0312.1 NOO H126227.1 H1-0312.1 TOS H126227.1 H1-0312.1 T10 H126227.1 H1-0312.1 T15 H126227.1 H1-0312.1 T2O H1262282 H1-03122 NOO H126228.2 H1-0312.2 TOS H126228.2 H1-0312.2 T10 H126228.2 H1-0312.2 T15 H126228.2 H1-0312.2 T2O

$\begin{array}{lllll}0.871 & \mathrm{E}-04 & 099.7 & -68.3 & 014.0\end{array}$ $\begin{array}{llll}0.722 \mathrm{E}-04 & 101.3-646 & 014.0\end{array}$ $\begin{array}{llll}110.7 & -63.6 & 014.0\end{array}$ $\begin{array}{lllll}0.519 \mathrm{E}-04 & 1225 & -54.9 & 0140\end{array}$ $\begin{array}{lllll}0.425 \mathrm{E}-04 & 129.1 & -36.9 & 014.0\end{array}$ $\begin{array}{llll}0.469 \mathrm{E}-04 & 019.2 & -49.5 & 014.0\end{array}$ $\begin{array}{lllll}0.359 \mathrm{E}-04 & 021.7 & -36.8 & 014 .\end{array}$ $\begin{array}{lllll}0.238 \mathrm{E}-04 & 352.6 & -38.1 & 014.0\end{array}$ $\begin{array}{lllll}0.170 & \mathrm{E}-04 & 327.1 & 26.2 & 014.0\end{array}$ $\begin{array}{lllll}0.155 \mathrm{E}-04 & 348.7 & 212 & 014.0\end{array}$ $\begin{array}{lllll}0.196 \mathrm{E}-04 & 0963 & 68.5 & 0140\end{array}$ $\begin{array}{llll}0.878 \mathrm{E}-04 & 343.1 & -46.9 & 013.0\end{array}$ $\begin{array}{lllll}0.857 \text { E-04 } & 334.8 & -41.2 & 013.0\end{array}$ $\begin{array}{llll}0.758 \mathrm{E}-04 & 335.1 & -38.6 & 013.0\end{array}$ $\begin{array}{llll}0.568 \mathrm{E}-04 & 345.2 & -33.6 & 013.0\end{array}$ $\begin{array}{lllll}0.443 & \mathrm{E}-04 & 337.3 & -32.4 & 013.0\end{array}$ $\begin{array}{llll}0.504 \mathrm{E}-04 & 347.2 & -143 & 013.0\end{array}$ $\begin{array}{lllll}0.489 \text { E- } 04 \quad 341.9 & -13.9 & 013.0\end{array}$ $\begin{array}{lllll}0.443 \mathrm{E}-04 & 335.5 & -073 & 013.0\end{array}$ $\begin{array}{lllll}0.331 \mathrm{E}-04 & 318.1 & 18.0 & 013.0\end{array}$

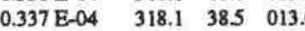
$\begin{array}{lllll}0.590 \mathrm{E}-04 & 307.7 & 33.2 & 013.0\end{array}$ $\begin{array}{lllll}0.575 \mathrm{E}-04 & 3415 & -72.1 & 012.0\end{array}$ $\begin{array}{lllll}0.484 \mathrm{E}-04 & 313.3 & -72.3 & 012.0\end{array}$ $\begin{array}{llll}0.365 \mathrm{E}-04 & 295.3 & -735 & 012.0\end{array}$ $\begin{array}{lllll}0.234 \mathrm{E}-04 & 257.4 & -45.9 & 012.0\end{array}$ $\begin{array}{lllll}0.198 \text { E-04 } & 268.1 & -37.4 & 012.0\end{array}$ $\begin{array}{lllll}0.698 \mathrm{~B}-0.4 & 332.7 & -30.8 & 012.0\end{array}$ $\begin{array}{lllll}0.632 \mathrm{E}-04 & 334.4 & -28.6 & 012.0\end{array}$ $\begin{array}{lllll}0.502 \mathrm{E}-04 & 318.6 & -21.2 & 012.0\end{array}$ $\begin{array}{lllll}0.469 \mathrm{E}-04 & 310.7 & -15.3 & 012.0\end{array}$ $\begin{array}{lllll}0.415 \mathrm{E}-04 & 307.4 & 03.1 & 012.0\end{array}$ $\begin{array}{llll}0.350 \mathrm{E}-04 & 304.1 & 20.6 & 012.0\end{array}$ $\begin{array}{llll}0.559 \mathrm{~B}-0.4 & 077.4 & -59.4 & 012.0\end{array}$ $\begin{array}{lllll}0.410 \mathrm{E}-04 & 090.8 & -59.5 & 012.0\end{array}$ $\begin{array}{lllll}0.316 \mathrm{E}-04 & 099.0 & -65.0 & 012.0\end{array}$ $\begin{array}{lllll}0.199 & \mathrm{E}-04 & 127.8 & -20.1 & 012.0\end{array}$ $\begin{array}{llll}0.222 \mathrm{E}-04 & 121.6 & -25.4 & 0120\end{array}$ $0.222 \mathrm{E}-04 \quad 121.6-25.4012 .0$ $\begin{array}{cccc}0.126 \mathrm{E}-03 & 020.1 & -36.0 & 012.0 \\ 0.109 \mathrm{E}-03 & 013.4 & -34.9 & 012.0\end{array}$ $\begin{array}{llll}0.109 \mathrm{E}-03 & 013.4 & -34.9 & 012.0 \\ 0.780 \mathrm{E}-04 & 024.4 & -27.4 & 012.0\end{array}$ $\begin{array}{lllll}0.780 \mathrm{E}-04 & 024.4 & -27.4 & 012.0\end{array}$ $\begin{array}{lllll}0.769 & \mathrm{E}-04 & 025.3 & -16.9 & 012.0\end{array}$ $\begin{array}{lllll}0.883 & \mathrm{E}-04 & 020.0 & -16.7 & 012.0\end{array}$ $\begin{array}{lllll}0.828 \mathrm{E}-04 & 020.8 & -09.7 & 012.0\end{array}$
H127232.1 H1-0416.1 T05 H127232.1 H1-0416.1 T10 H127232.1 H1-0416.1 T15 H127232.1 H1-0416.1 T2O H1272322 H1-0416.2 NOO H127232.2 H1-0416.2 TOS H1272322 H1-04162 T10 H127232.2 H1-0416.2 T15 H127232.2 H1-0416.2 T2O H127232.2 H1-0416.2 T2S H127233.1 H1-0417.1 NOO H127233.1 H1-0417.1 TOS H127233.1 H1-0417.1 T1O H127233.1 H1-0417.1 T15 H127233.1 H1-0417.1 T2O H127234.1 H1-0418.1 NOO H127234.1 H1-0418.1 TOS H127234.1 H1-0418.1 T10 H127234.1 H1-0418.1 T15 H127234.1 H1-0418.1 T2O H127235.1 H1-0419.1 NOO H127235. H1-0419.1 TOS H127235.1 H1-0419.1 T10 H127235.1 H1-0419.1 T15 H127235.1 H1-0419.1 T2O H127236.2 H1-0419.2 NOO H127236.2 H1-0419.2 TO5 H127236.2 H1-04192 T10 H127236.2 H1-0419.2 T15 H127236.2 H1-0419.2 T2O H127236.2 H1-0419.2 T25 $\begin{array}{llll}0.143 & 013.0 & 015 & 0820\end{array}$ $0.177 \mathrm{E}-04 \quad 001.0 \quad 68.7 \quad 0820$ $0.228 \mathrm{E}-04 \quad 341.6 \quad 85.9 \quad 082$ 0.246 E-04 $098.4 \quad-10.0 \quad 082$.

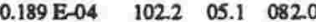
0.214 E-04 126.133 .20820 $0.214 \mathrm{E}-04126.1$ 33. 0.281 E $04 \quad 100.0 \quad 81.0$ $\begin{array}{lllll}0.356 \mathrm{E}-04 & 084.7 & 72.8 & 082.0\end{array}$ 0.259 E-04 $015.1 \quad-14.7 \quad 081.0$ $\begin{array}{lllll}0.220 & \text { E- } 04 & 010.6 & 07.0 & 081.0\end{array}$ $\begin{array}{lllll}0.251 & \text { E-0 } & 010.9 & 57.6 & 081.0\end{array}$

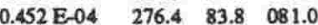
$\begin{array}{lllll}0.314 \text { E-04 } & 1395 & 84.9 & 081.0\end{array}$ $\begin{array}{llll}0.377 \mathrm{E}-04 & 204.2 & -37.6 & 080.0\end{array}$ $0.343 \mathrm{E}-04 \quad 204.2 \quad-24.2080 .0$ $\begin{array}{cccc}204.2 & -24.2 & 080.0\end{array}$ $\begin{array}{llll}0.566 \mathrm{E}-04 & 202.7 & 29.4 & 080.0\end{array}$

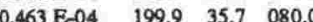
$\begin{array}{lllll}0.136 \mathrm{E}-0.4 & 040.9 & -34.6 & 089.0\end{array}$ $\begin{array}{lllll}0.953 \mathrm{E}-05 & 049.2 & 00.6 & 089.0\end{array}$ $\begin{array}{llll}0.186 \mathrm{E}-04 & 062.9 & 85.2 & 089.0\end{array}$ $\begin{array}{llll}0.460 \mathrm{E}-04 & 213.0 & 75.0 & 089.0\end{array}$ $\begin{array}{llll}0.363 \mathrm{E}-04 & 185.0 & 72.7 & 089.0\end{array}$ $0.667 \mathrm{E}-0.4 \quad 045.8 \quad-33.1 \quad 089.0$ $0.615 \mathrm{E}-04 \quad 043.3 \quad-28.2 \quad 089.0$ $\begin{array}{lllll}0.473 \mathrm{E}-0.4 & 0.42 .2 & -15.4 & 089.0\end{array}$ $\begin{array}{lllll}0.402 \mathrm{E}-0.4 & 059.8 & 11.7 & 0899.0\end{array}$ $\begin{array}{lllll}0.314 \mathrm{E}-0.4 & 060.7 & 27.4 & 089\end{array}$ $\begin{array}{lllll}0.287 \text { E-04 } & 041.7 & 43.7 & 089.0\end{array}$

HAUTAWA ROAD SITE $128 \mathrm{~V}$

IEIGHT $=103 \mathrm{~m}$ (above base of section) STRIKE $=030.7 \mathrm{DIP}=4.8$

SAMPLE FIELDNO. TREAT. INTENSITY CDEC CINC Y-AZ PLUNGE

H128237.1 H1-0520.1 N0O H128237.1 H1-0520.1 T05 H128237.1 H1-0520.1 T10 H128237.1 H1-0520.1 T15 H128237.1 H1-0520.1 T20 H128238.2 H1-0520.2 N0O H128238.2 H1-0520.2 T05 H128238.2 H1-0520.2 T10 H128238.2 H1-0520.2 T15 H128238.2 H1-0520.2 T20 H128238.2 H1-0520.2 T2S H128239.1 H1-0521.1 NOO H128239.1 H1-0521.1 TO5 H128239.1 H1-0521.1 T10 H128239.1 H1-0521.1 T15 H128239.1 H1-0521.1 T2O H128240.2 H1-0521.2 NOO H128240.2 H1-0521.2 T05 H128240.2 H1-05212 T10 H128240.2 H1-0521.2 T15 H128240.2 H1-0521.2 T2O H128240.2 H1-0521.2 T25 H128241.1 H1-0522.1 NOO H128241.1 H1-0522.1 TOS H128241.1 H1-0522.1 T10 H128241.1 H1-0522. T15 H128241.1 H1-0522.1 T2O H128242.2 H1-0522.2 NOO H128242.2 H1-0522.2 TOS H128242.2 H1-0522.2 T10 H128242.2 H1-0522.2 T15 H128242.2 H1-0522.2 T2O H128242.2 H1-05222 T25 H128243.1 HI-0523.1 NOO H128243.1 H1-0523.1 TOS H128243.1 H1-0523.1 T10 H128243.1 H1-0523.1 T15 H128243.1 H1-0523.1 T20 H128244.2 H1-0523.2 N0O H128244.2 HI-0523.2 TOS H128244. H1-0523.2 T10 H128244.2 H1-0523.2 T15 H128244.2 H1-0523.2 T2O H128244.2 H1-0523.2 T2S
HAUTAWA ROAD STIE 129V

HEIGHT $=118 \mathrm{~m}$ (above base of section) STRIKE $=030.7 \mathrm{DIP}=48$

SAMPLE FIELDNO. TREAT. INTENSITY CDEC CINC Y-AZ PLUNGE

H129245.1 H1-0101.1 N00 H129245.1 H1-0101.1 TOS H129245.1 H1-0101.1 T10 H129245.1 H1-0101.1 T15 H129245.1 H1-0101.1 T2O H129245.1 H1-0101.1 T25 H129246.2 H1-0101.2 N0O H129246.2 H1-0101.2 TOS H129246.2 H1-0101.2 T10 H129246.2 H1-01012 T15 H129246.2 H1-01012 T2O H129246.2 H1-0101.2 T2S

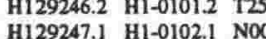
$\begin{array}{lll}\text { H129247.1 } & \text { H1-0102.1 NOO } \\ \text { H129247.1 } & \text { H1-0102.1 TO5 }\end{array}$ H129247.1 H1-0102.1 T10 H129247.1 H1-01021 T15 H129247.1 H1-0102.1 T2O

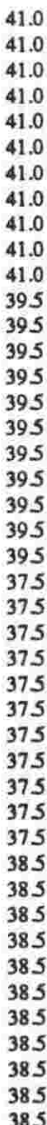

$\begin{array}{lrrll}0.433 \mathrm{E}-04 & 012.4 & -32.0 & 257.0 & 41.0 \\ 0.284 \mathrm{E}-04 & 020.7 & -26.9 & 257.0 & 41.0 \\ 0.196 \mathrm{E}-04 & 034.3 & 13.0 & 257.0 & 41.0 \\ 0.204 \mathrm{E}-04 & 036.4 & 50.8 & 257.0 & 41.0 \\ 0.682 \mathrm{E}-05 & 005.5 & 45.4 & 257.0 & 41.0 \\ 0.556 \mathrm{E}-04 & 016.0 & -40.9 & 257.0 & 41.0 \\ 0.420 \mathrm{E}-04 & 018.3 & -43.4 & 257.0 & 41.0 \\ 0.245 \mathrm{E}-04 & 018.7 & -35.4 & 257.0 & 41.0 \\ 0.804 \mathrm{E}-05 & 041.0 & 24.0 & 257.0 & 41.0 \\ 0.156 \mathrm{E}-04 & 024.2 & 52.0 & 257.0 & 41.0 \\ 0.125 \mathrm{E}-04 & 056.0 & 80.3 & 257.0 & 41.0 \\ 0.127 \mathrm{E}-04 & 339.7 & -45.9 & 262.0 & 39.5 \\ 0.746 \mathrm{E}-05 & 266.3 & -42.3 & 262.0 & 395 \\ 0.918 \mathrm{E}-05 & 208.6 & 43.5 & 262.0 & 39.5 \\ 0.189 \mathrm{E}-04 & 226.3 & 45.4 & 262.0 & 39.5 \\ 0.136 \mathrm{E}-04 & 259.7 & 17.7 & 262.0 & 39.5 \\ 0.227 \mathrm{E}-04 & 113.9 & -45.2 & 262.0 & 39.5 \\ 0.238 \mathrm{E}-04 & 133.3 & -21.0 & 262.0 & 39.5 \\ 0.261 \mathrm{E}-04 & 151.0 & -01.3 & 262.0 & 39.5 \\ 0.267 \mathrm{E}-0.4 & 165.0 & 16.6 & 262.0 & 39.5 \\ 0.275 \mathrm{E}-04 & 162.6 & 14.5 & 262.0 & 39.5 \\ 0.362 \mathrm{E}-04 & 198.2 & 00.7 & 262.0 & 39.5 \\ 0.338 \mathrm{E}-04 & 013.4 & -65.3 & 265.0 & 37.5 \\ 0.183 \mathrm{E}-04 & 027.5 & -71.1 & 265.0 & 37.5 \\ 0.646 \mathrm{E}-05 & 164.7 & 14.4 & 265.0 & 37.5 \\ 0.104 \mathrm{E}-04 & 176.9 & 52.1 & 265.0 & 37.5 \\ 0.112 \mathrm{E}-04 & 167.0 & 51.5 & 265.0 & 37.5 \\ 0.344 \mathrm{E}-04 & 219.1 & -09.3 & 265.0 & 37.5 \\ 0.409 \mathrm{E}-04 & 212.3 & 05.9 & 265.0 & 37.5 \\ 0.567 \mathrm{E}-04 & 207.5 & 23.4 & 265.0 & 37.5 \\ 0.667 \mathrm{E}-04 & 201.6 & 33.0 & 265.0 & 37.5 \\ 0.728 \mathrm{E}-04 & 201.8 & 32.7 & 265.0 & 37.5 \\ 0.716 \mathrm{E}-04 & 206.3 & 29.8 & 265.0 & 37.5 \\ 0.639 \mathrm{E}-04 & 032.3 & -66.2 & 260.0 & 38.5 \\ 0.561 \mathrm{E}-04 & 035.3 & -69.6 & 260.0 & 38.5 \\ 0.323 \mathrm{E}-04 & 071.4 & -71.5 & 260.0 & 38.5 \\ 0.169 \mathrm{E}-04 & 096.0 & -64.3 & 260.0 & 38.5 \\ 0.190 \mathrm{E}-04 & 146.2 & -71.1 & 260.0 & 38.5 \\ 0.416 \mathrm{E}-04 & 016.1 & -46.1 & 260.0 & 38.5 \\ 0.240 \mathrm{E}-04 & 011.9 & -42.7 & 260.0 & 38.5 \\ 0.159 \mathrm{E}-05 & 002.5 & -05.8 & 260.0 & 38.5 \\ 0.111 \mathrm{E}-04 & 197.0 & 75.8 & 260.0 & 38.5 \\ 0.171 \mathrm{E}-04 & 192.0 & 35.8 & 260.0 & 38.5 \\ 0.124 \mathrm{E}-04 & 180.2 & 48.1 & 260.0 & 38.5 \\ & & & & \end{array}$

41.0

41.0

41.0

41.0

41.0

41.5

415

415

415 
H129247.1 H1-0102.1 T25 H129248.1 H1-0103.1 NOO H129248.1 H1-0103.1 TOS H129248.1 H1-0103.1 T10 H129248.1 H1-0103.1 T15 H129248.1 H1-0103.1 T2O H129248.1 H1-0103.1 T25 H129249.1 H1-0104.1 NOO H129249.1 H1-0104.1 T05 H129249.1 H1-0104.1 T10 H129249.1 H1-0104.1 T15 H129249.1 H1-0104.1 T20 H129249.1 H1-0104.1 T25 H129250.2 H1-0104.2 N0O H129250.2 H1-0104.2 TOS H129250.2 H1-0104.2 T10 H129250.2 H1-0104.2 T15 H129250.2 H1-0104.2 T20 $\begin{array}{llll}0.344 \mathrm{E}-04 & 086.3 & -568 & 123.0\end{array}$ $\begin{array}{lllll}0.403 \mathrm{E}-04 & 158.2 & -37.0 \quad 119.0\end{array}$ $0.579 \mathrm{~B}-04 \quad 069.2 \quad-02.9 \quad 119.0$ $\begin{array}{llll}0.298 \mathrm{E}-04 & 171.9 & -46.2 & 119.0\end{array}$ $\begin{array}{llll}0.347 \text { E- } 04 \quad 124.2 & -05.6 & 119.0\end{array}$ $\begin{array}{llll}0.695 \mathrm{E}-04 & 087.0 & -26.9 & 119.0\end{array}$ $\begin{array}{llll}0.188 \mathrm{E}-04 & 143.0 & -205 & 125.0\end{array}$ $\begin{array}{lllll}0.115 \text { E-O4 } & 198.2 & -27.9 & 125.0\end{array}$ $\begin{array}{llll}0.201 \mathrm{E}-04 & 210.3 & 15.2 & 125.0\end{array}$ $\begin{array}{llll}0.324 \mathrm{E}-04 & 204.6 & 26.9 & 125.0\end{array}$ $\begin{array}{lllll}0.322 \mathrm{E}-0.4 & 212.2 & 20.1 & 125.0\end{array}$ $\begin{array}{lllllllll}0.272 \mathrm{E}-04 & 1025 & -53.4 & 125.0\end{array}$ $\begin{array}{llll}0.272 \mathrm{E}-04 & 102.5 & -53.4 & 125.0 \\ 0.353 \mathrm{E}-04 & 068.4 & 21.3 & 125.0\end{array}$ $\begin{array}{llll}0.353 \mathrm{E}-04 & 068.4 & 21.3 & 125.0 \\ 0.331 \mathrm{E}-0.4 & 058.7 & 53.9 & 125.0\end{array}$ $\begin{array}{lllll}0.331 \mathrm{E}-04 & 058.7 & 53.9 & 125.0 \\ 0.279 \mathrm{E}-0.4 & 039.4 & 73.2 & 125.0\end{array}$ $\begin{array}{llll}0.383 \mathrm{E}-04 & 016.6 & 83.5 & 125.0\end{array}$ $\begin{array}{lllll}0.310 \text { E- } 04 & 227.2 & 80.4 & 125.0\end{array}$ $\begin{array}{llll}0.281 \mathrm{E}-04 & 320.7 & 71.3 & 125.0\end{array}$ $0.412 \mathrm{E}-04 \quad 112.5-16.5 \quad 119.0$

HAUTAWA ROAD SITE $130 \mathrm{~V}$

HEIGHT $=123 \mathrm{~m}$ (above base of section) STRIKE $=030.7 \mathrm{DIP}=4.8$

SAMPLE FIELDNO.TREAT. INTENSITY CDEC CINC Y-AZ PLUNGE

H130251.1 H1-0728.1 N00 H130251.1 H1-0728.1 T05 H130251.1 H1-0728.1 T10 H130251.1 H1-0728.1 T15 H130251.1 H1-0728.1 T20 H130252.2 H1-0728.2 NOO H130252.2 H1-0728.2 T05 H130252.2 H1-0728.2 T10 H130252.2 H1-0728.2 T15 H130252.2 H1-0728.2 T2O H130252.2 H1-0728.2 T2S H130253.1 H1-0729.1 NOO H130253.1 H1-0729.1 T05 H130253.1 H1-0729.1 T10 H130253.1 H1-0729.1 T15 H130253.1 H1-0729.1 T20 H130254. H1-0729.2 NOO H130254.2 H1-0729.2 TOS H130254.2 H1-0729.2 T10 H130254.2 H1-0729.2 T15 H130254.2 H1-0729.2 T20 H130254.2 H1-0729.2 T25 H130255.1 H1-0730.1 NOO H130255.1 H1-0730.1 TO5 H130255.1 HI- 0730.1 T1O H130255.1 H1-0730.1 T15 H130255.1 H1-0730.1 T2O H130256.2 H1-0730.2 NOO H130256.2 H1-0730.2 T05 H1302562 H1-0730.2 T10 H1302562 H1-07302 T15 H130256.2 H1-0730.2 T2O H130256.2 H1-0730.2 T2 H130257.1 H1-0731.1 NOO H130257.1 H1-0731.1 TOS H130257.1 H1-0731.1 T10 H130257.1 H1-0731.1 T15 H130257.1 H1-0731.1 T2O H130258.2 H1-0731.2 NOO H130258.2 H1-0731.2 TOS H130258.2 H1-0731.2 T10 H130258.2 H1-0731.2 T15 H130258.2 H1-0731.2 T2

$\begin{array}{llrll}0.608 \text { E-04 } & 005.5 & -47.0 & 254.0 & 56.0 \\ 0.531 \text { E-04 } & 005.9 & -45.7 & 254.0 & 56.0 \\ 0.264 \text { E-04 } & 014.1 & -32.6 & 254.0 & 56.0 \\ 0.139 \text { E-04 } & 020.3 & -09.0 & 254.0 & 56.0 \\ 0.178 \text { E-04 } & 123.3 & 26.8 & 254.0 & 56.0 \\ 0.768 \text { E-04 } & 329.1 & -42.2 & 254.0 & 56.0 \\ 0.568 \text { E-04 } & 316.5 & -32.2 & 254.0 & 56.0 \\ 0.461 \text { E-04 } & 298.0 & -22.3 & 254.0 & 56.0 \\ 0.344 \text { E-04 } & 289.5 & 11.8 & 254.0 & 56.0 \\ 0.249 \text { E-04 } & 284.2 & 08.7 & 254.0 & 56.0 \\ 0.138 \text { E-04 } & 314.1 & 11.2 & 254.0 & 56.0 \\ 0.386 \text { E-04 } & 006.8 & -19.2 & 259.0 & 56.0 \\ 0.293 \text { E-04 } & 003.7 & -05.8 & 259.0 & 56.0 \\ 0.243 \text { E-04 } & 354.5 & 56.1 & 259.0 & 56.0 \\ 0.318 \text { E-04 } & 333.1 & 69.3 & 259.0 & 56.0 \\ 0.427 \text { E-04 } & 301.8 & 40.7 & 259.0 & 56.0 \\ 0.397 \text { E-04 } & 013.9 & 20.9 & 259.0 & 56.0 \\ 0.400 \text { E-04 } & 015.9 & 39.2 & 259.0 & 56.0 \\ 0.439 \text { E-04 } & 022.2 & 65.2 & 259.0 & 56.0 \\ 0.577 \text { E-04 } & 020.0 & 84.3 & 259.0 & 56.0 \\ 0.439 \text { E-04 } & 032.3 & 46.8 & 259.0 & 56.0 \\ 0.687 \text { E-04 } & 318.8 & 82.5 & 259.0 & 56.0 \\ 0.292 \text { E-04 } & 253.9 & -77.6 & 259.0 & 52.0 \\ 0.189 \text { E-04 } & 202.0 & -43.9 & 259.0 & 52.0 \\ 0.351 \text { E-04 } & 188.3 & 18.3 & 259.0 & 52.0 \\ 0.422 \text { E-04 } & 188.0 & 32.8 & 259.0 & 52.0 \\ 0.488 \text { E-04 } & 193.2 & 16.2 & 259.0 & 52.0 \\ 0.755 \text { E-04 } & 007.4 & -40.4 & 259.0 & 52.0 \\ 0.533 \text { E-04 } & 005.7 & -38.3 & 259.0 & 52.0 \\ 0.342 \text { E-04 } & 002.8 & -28.5 & 259.0 & 52.0 \\ 0.336 \text { E-04 } & 005.1 & 28.7 & 259.0 & 52.0 \\ 0.281 \text { E-04 } & 014.3 & 23.6 & 259.0 & 52.0 \\ 0.260 \text { E-04 } & 359.1 & 47.4 & 259.0 & 52.0 \\ 0.114 \text { E-03 } & 019.4 & -50.6 & 268.0 & 52.0 \\ 0.932 \text { E-04 } & 026.7 & -52.8 & 268.0 & 52.0 \\ 0.559 \text { E-04 } & 041.3 & -49.7 & 268.0 & 52.0 \\ 0.458 \text { E-04 } & 039.4 & -47.0 & 268.0 & 52.0 \\ 0.423 \text { E-04 } & 065.5 & -42.8 & 268.0 & 52.0 \\ 0.933 \text { E-04 } & 011.4 & -43.4 & 268.0 & 52.0 \\ 0.740 \text { E-04 } & 014.5 & -43.3 & 268.0 & 52.0 \\ 0.466 \text { E-04 } & 012.2 & -41.3 & 268.0 & 52.0 \\ 0.193 \text { E-04 } & 010.6 & 08.9 & 268.0 & 52.0 \\ 0.159 \text { E-04 } & 013.4 & -16.0 & 268.0 & 52.0 \\ 0.168 \text { E-04 } & 029.4 & 21.2 & 268.0 & 52.0 \\ & & & & \end{array}$

HAUTAWA ROAD SITE $131 \mathrm{~V}$

HEIGHT $=130 \mathrm{~m}$ (above base of section) $S T R I K E=030.7 \mathrm{DIP}=4.8$

SAMPLE FIELDNO. TREAT. INTENSTTY CDEC CINC Y-AZ PLUNGE

H131259.1 H1-0624.1 NOO H131259.1 H1-0624.1 T05 H131259.1 H1-0624.1 T10 H131259.1 H1-0624.1 T15 H131259.1 H1-0624.1 T20 $\mathrm{H} 131260.2 \mathrm{H} 1-0624.2$ NOO H131260.2 H1-0624.2 T05 H131260.2 H1-0624.2 T10 H131260.2 H1-0624.2 T15 H131260.2 H1-0624.2 T2O H131260.2 H1-0624.2 T2 H131261.1 H1-0625.1 N0O H131261.1 H1-0625.1 T0S H131261.1 H1-0625.1 T10 H131261.1 H1-0625.1 T15 H131261.1 H1-0625.1 T20 H131262.2 H1-0625.2 NOO H131262.2 H1-0625.2 T0S H131262.2 H1-0625.2 T10 H131262.2 H1-0625.2 T15 H131262 H1-0625.2 T20 H131262.2 H1-0625.2 T25 H131263.1 H1-0626.1 NOO H131263.1 H1-0626.1 TOS H131263.1 H1-0626.1 T10 H131263.1 H1-0626.1 T15 H131263.1 H1-0626.1 T2O H131264.2 H1-0626.2 NOO H131264.2 H1-0626.2 TOS

$\begin{array}{lrrrr}0.206 \mathrm{E}-04 & 025.0 & -81.0 & 212.0 & 55.0 \\ 0.292 \mathrm{E}-05 & 087.9 & -57.9 & 212.0 & 55.0 \\ 0.244 \mathrm{E}-04 & 177.6 & 46.5 & 212.0 & 55.0 \\ 0.358 \mathrm{E}-04 & 172.0 & 61.7 & 212.0 & 55.0 \\ 0.359 \mathrm{E}-04 & 169.6 & 61.9 & 212.0 & 55.0 \\ 0.486 \mathrm{E}-04 & 358.2 & -50.6 & 212.0 & 55.0 \\ 0.244 \mathrm{E}-04 & 354.1 & -44.3 & 212.0 & 55.0 \\ 0.432 \mathrm{E}-05 & 352.2 & -50.4 & 212.0 & 55.0 \\ 0.150 \mathrm{E}-04 & 223.5 & 79.4 & 212.0 & 55.0 \\ 0.131 \mathrm{E}-04 & 175.9 & 53.0 & 212.0 & 55.0 \\ 0.192 \mathrm{E}-04 & 230.6 & 60.3 & 212.0 & 55.0 \\ 0.393 \mathrm{E}-04 & 333.1 & -47.3 & 192.0 & 55.0 \\ 0.270 \mathrm{E}-04 & 323.5 & -39.2 & 192.0 & 55.0 \\ 0.125 \mathrm{E}-04 & 302.1 & 40.0 & 192.0 & 55.0 \\ 0.282 \mathrm{E}-04 & 253.4 & 63.4 & 192.0 & 55.0 \\ 0.232 \mathrm{E}-04 & 183.5 & 80.9 & 192.0 & 55.0 \\ 0.779 \mathrm{E}-04 & 147.3 & -74.5 & 192.0 & 55.0 \\ 0.550 \mathrm{E}-04 & 147.8 & -61.4 & 192.0 & 55.0 \\ 0.452 \mathrm{E}-04 & 161.8 & -23.8 & 192.0 & 55.0 \\ 0.511 \mathrm{E}-04 & 156.9 & 16.2 & 192.0 & 55.0 \\ 0.457 \mathrm{E}-04 & 146.3 & 18.9 & 192.0 & 55.0 \\ 0.453 \mathrm{E}-04 & 135.6 & 01.2 & 192.0 & 55.0 \\ 0.261 \mathrm{E}-05 & 142.8 & -83.6 & 195.0 & 55.0 \\ 0.984 \mathrm{E}-04 & 172.4 & -41.3 & 195.0 & 55.0 \\ 0.267 \mathrm{E}-04 & 193.1 & 30.5 & 195.0 & 55.0 \\ 0.441 \mathrm{E}-04 & 188.3 & 52.0 & 195.0 & 55.0 \\ 0.320 \mathrm{E}-04 & 207.1 & 36.2 & 195.0 & 55.0 \\ 0.502 \mathrm{E}-04 & 312.2 & -67.4 & 195.0 & 55.0 \\ 0.309 \mathrm{E}-04 & 299.8 & -58.8 & 195.0 & 55.0\end{array}$

55.0

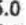

5.0

5.0

55.0

5.0

55.0

55.0

55.0

55.0

55.0

55.0

$(5.0$

55.0

55.0

5.0

$(25.0$

55.0
55.0
H1312642 H1-06262 T10 12642 H1-05262 T15 H131264.2 H1-0626.2 T2O H131264.2 H1-0626.2 T25 H131265.1 H1-0627.1 NOO H131265.1 H1-0627.1 TOS H131265.1 H1-0627.1 T10 H131265.1 H1-0627.1 T15 H131265.1 H1-0627.1 T2O H131266.2 H1-0627.2 NOO H131266.2 H1-0627.2 TOS H131266.2 H1-06272 T10 H131266.2 H1-06272 T15 11312662 H1-06272 T20 H131266.2 H1-0627.2 T2S

$0.166 \mathrm{E}-04$ $0.221 \mathrm{E}-04$ 0.356 E-04 $0.358 \mathrm{E}-04$ 0.412 E-04 $0.277 \mathrm{E}-04$ $0.483 \mathrm{E}-05$ $0.163 \mathrm{E}-04$ $0.184 \mathrm{E}-04$ $0.149 \mathrm{E}-03$ $0.130 \mathrm{E}-03$

$0.449 \mathrm{E}-0$ $0.449 \mathrm{E}-04$ $0.350 \mathrm{E}-04$

$220.3-13.0 \quad 195.0$ $\begin{array}{lll}221.5 & 06.9 & 195.0\end{array}$ $\begin{array}{lll}190.6 & 28.0 \quad 195.0\end{array}$ $\begin{array}{lll}200.2 & 18.6 \quad 195.0\end{array}$ $\begin{array}{lll}9.9 & -65.3 & 205.0\end{array}$ $\begin{array}{llll}048.1 & -61.7 & 205.0\end{array}$ $\begin{array}{lll}136.8 & -12.0 & 205.0\end{array}$ $\begin{array}{lll}158.3 & 55.6 & 205.0\end{array}$ $\begin{array}{lll}201.2 & 29.1 & 205.0\end{array}$ $\begin{array}{lll}353.3 & 695 & 205.0\end{array}$ $\begin{array}{llll}353.2 & -68.9 & 205.0\end{array}$ $\begin{array}{llll}353.8 & -70.8 & 205.0\end{array}$ $\begin{array}{llll}037.5 & -70.2 & 205.0\end{array}$ $298.9-81.205 .0$ HAUTAWA ROAD SITE $132 \mathrm{~V}$ tion) STRIKE $=030.7 \mathrm{DIP}=4.8$ SAMPLE FELDNO. TREAT. INTENSITY CDEC CINC Y-AZ PLUNGE

H132267.1 H1-9001.1 H132267.1 H1-9001.1 TOS H132267.1 H1-9001.1 T10 H132267.1 H1-9001.1 T15 H132267.1 H1-9001.1 T20 H132268.2 H1-9001.2 NOO H132268.2 H1-9001.2 TOS H132268.2 H1-9001.2 T10 H132268.2 H1-9001.2 T15 H132268.2 H1-9001.2 T2O H132268.2 H1-9001.2 T2S H132269.1 H1-9002.1 NOO H132269.1 H1-9002.1 T0S H132269.1 H1-9002.1 T10 H132269.1 H1-9002.1 T15 H132269.1 H1-9002.1 T2O H132270.2 H1-9002.2 NOO H132270.2 H1-9002.2 T05 H132270.2 H1-9002.2 T10 H132270.2 H1-90022 T15 H132270.2 H1-9002. T20 H132270.2 H1-9002.2 T25 H132271.1 H1-9003.1 NOO H132271.1 H1-9003.1 T05 H132271.1 H1-9003.1 T10 H132271.1 H1-9003.1 T15 H132271.1 H1-9003.1 T20 H1322722 H1-9003. NOO H132272 2 H1-90032 T05 H132272.2 H1-9003.2 T10 H132272.2 H1-9003.2 T15 $\begin{array}{lll}H 132272.2 & H 1-9003.2 & \text { T2O } \\ \text { H132272.2 } & \text { H1-9003.2 T25 }\end{array}$ $\begin{array}{lllll}0.592 & \text { E- } 04 & 267.0 & -41.9 & 138.0\end{array}$ $\begin{array}{lllll}0.497 \mathrm{E}-04 & 252.0 & -035 & 138.0\end{array}$ $\begin{array}{lllll}0.530 \mathrm{E}-04 & 243.3 & 10.9 & 138.0\end{array}$ $\begin{array}{llll}0.440 \text { E- } 04 \quad 267.6 & -00.3 & 138.0\end{array}$ $\begin{array}{lllll}0.983 \mathrm{E}-04 & 029.1 & -61.6 & 138.0\end{array}$ $\begin{array}{lllll}0.762 \mathrm{E}-04 & 028.0 & -66.0 & 138.0\end{array}$ $\begin{array}{lllll}0.529 \mathrm{E}-04 & 051.7 & -65.9 & 138.0\end{array}$ $\begin{array}{lllll}0.404 \mathrm{E}-04 & 076.6 & -54.0 & 138.0\end{array}$ $\begin{array}{lllll}0.513 & \mathrm{E}-04 & 078.9 & -36.8 & 138.0\end{array}$ $\begin{array}{lllll}0.545 \mathrm{E}-04 & 083.5 & -36.0 & 138.0\end{array}$ $\begin{array}{lllll}0.783 \mathrm{E}-04 & 308.2 & -4.5 & 140.0\end{array}$ $\begin{array}{lllll}0.663 \mathrm{E}-04 & 302.3 & -45.8 & 140.0\end{array}$ $\begin{array}{lllll}0.384 \text { E- } 04 \quad 275.7 & -47.2 & 140.0\end{array}$ $0.319 \mathrm{E}-04 \quad 264.1 \quad-40.1 \quad 140.0$ $\begin{array}{lllll}0.407 \mathrm{E}-04 & 268.2 & -57.1 & 140.0\end{array}$ $\begin{array}{lllll}0.101 \mathrm{E}-03 & 326.6 & -38.6 & 140.0\end{array}$ $\begin{array}{lllll}0.781 & \mathrm{E}-04 & 324.6 & -34.9 & 140.0\end{array}$ $\begin{array}{lllll}0.521 & \mathrm{~B}-04 & 325.8 & -30.7 & 140.0\end{array}$ $\begin{array}{llll}0.301 \mathrm{E}-0.4 & 311.5 & -17.4 \quad 140.0\end{array}$ $\begin{array}{llll}0.468 \mathrm{E}-04 & 299.0 & -06.6 & 140.0\end{array}$ $\begin{array}{lllll}0.390 \mathrm{E}-04 & 286.5 & -36.1 & 140.0\end{array}$ $\begin{array}{lllll}0.106 \mathrm{E}-03 & 125.4 & -70.6 & 142.0\end{array}$ $0.929 \mathrm{E}-04 \quad 144.3 \quad-66.6 \quad 142.0$ $\begin{array}{lllll}0.672 \mathrm{~B}-04 & 153.6 & -49.9 & 142.0\end{array}$ $\begin{array}{llll}0.585 \mathrm{E}-04 & 150.1 & -41.4 & 142.0\end{array}$ $\begin{array}{lllll}0.751 \mathrm{~B}-04 & 148.8 & -36.0 & 1420\end{array}$ $\begin{array}{lllll}0.489 \mathrm{E}-04 & 359.2 & -76.3 & 142.0\end{array}$ $\begin{array}{llll}0.255 \mathrm{E}-04 & 359.2 & -78.5 & 142.0\end{array}$ $\begin{array}{lllll}0.694 \mathrm{E}-05 & 138.4 & -57.8 & 142.0\end{array}$ $\begin{array}{lllll}0.192 \mathrm{E}-04 & 137.6 & 57.0 & 142.0\end{array}$ $\begin{array}{lllll}0.965 \mathrm{E}-0 . & 283.2 & 00.6 \quad 142.0\end{array}$ $\begin{array}{lllll}0.950 \mathrm{E}-04 & 295.4 & -60.8 & 142.0\end{array}$

HAUTAWA ROAD STE 133V

HEIGHT $=157 \mathrm{~m}$ (above base of section) STRIKE $=030.7 \mathrm{DIP}=4.8$

SAMPLE FIELDNO. TREAT. INTENSITY CDEC CINC Y-AZ PLUNGE

H133273.1 H1-9104.1 NOO

$\begin{array}{llll}0.285 & \mathrm{E}-03 \quad 007.9 & -643 & 184.0\end{array}$ 58.0 H133273.1 H1-9104.1 TOS H133273.1 H1-9104.1 T10 H133273.1 H1-9104.1 T15 H133273.1 H1-9104.1 T2O H133274.1 H1-9105.1 N0O H133274.1 H1-9105.1 TOS H133274.1 H1-9105.1 T10 H133274.1 H1-9105.1 T15 H133274.1 H1-9105.1 T20 H133275.1 H1-9106.1 NOO H133275.1 H1-9106.1 T05 H133275.1 H1-9106.1 T10 H133275.1 H1-9106.1 T15 133275.1 H1-9106.1 T20 133276.1 H1-9107.1 N0O 1133276.1 H1-9107.1 TOS 1133276.1 H!-9107.1 T10 H133276.1 H1-9107.1 T15 H133276.1 H1-9107.1 T20 H133277.2 H1-9107.2 NOO 


$\begin{array}{llllllll}\text { R135279.1 } & \text { R1-6136.1 } & \text { T20 } & 0.443 \text { E-04 } & 151.5 & 32.9 & 288.0 & 36.0 \\ \text { R135279.1 } & \text { R1-6136.1 } & \text { T25 } & 0.524 \text { E-04 } & 167.3 & 34.2 & 288.0 & 36.0 \\ \text { R135279.1 } & \text { R1-6136.1 } & \text { T30 } & 0.428 \text { E-04 } & 193.0 & 62.7 & 288.0 & 36.0 \\ \text { R135279.1 } & \text { R1-6136.1 } & \text { T35 } & 0.566 \text { E-04 } & 200.6 & 59.9 & 288.0 & 36.0 \\ \text { R135280.1 } & \text { R1-6137.1 } & \text { N00 } & 0.368 \text { E-03 } & 020.4 & -59.9 & 294.0 & 34.5 \\ \text { R135280.1 } & \text { R1-6137.1 } & \text { T05 } & 0.307 \text { E-03 } & 017.5 & -54.9 & 294.0 & 34.5 \\ \text { R135280.1 } & \text { R1-6137.1 } & \text { T10 } & 0.206 \text { E-03 } & 035.5 & -57.0 & 294.0 & 34.5 \\ \text { R135280.1 } & \text { R1-6137.1 } & \text { T15 } & 0.608 \text { E-04 } & 113.7 & -50.3 & 294.0 & 34.5 \\ \text { R135280.1 } & \text { R1-6137.1 } & \text { T20 } & 0.536 \mathrm{E}-04 & 166.2 & -20.3 & 294.0 & 34.5 \\ \text { R135280.1 } & \text { R1-6137.1 } & \text { T25 } & 0.580 \text { E-04 } & 170.5 & 02.9 & 294.0 & 34.5 \\ \text { R135280.1 } & \text { R1-6137.1 } & \text { T30 } & 0.507 \text { E-04 } & 179.0 & 04.3 & 294.0 & 34.5 \\ \text { R135280.1 } & \text { R1-6137.1 } & \text { T35 } & 0.664 \text { E-04 } & 178.6 & 49.6 & 294.0 & 34.5 \\ \text { R135280.2 } & \text { R1-6137.2 } & \text { N00 } & 0.370 \text { E-03 } & 014.0 & -61.9 & 294.0 & 34.5\end{array}$

RANGITIKEI RIVER STIE $136 \mathrm{~V}$

HEIGHT $=97 \mathrm{~m}$ (above base of section) STRIKE $=351 \quad \mathrm{DIP}=12$

SAMPLE FIEIDNO. TREAT. INTENSITY CDEC CINC Y-AZ PLUNGE

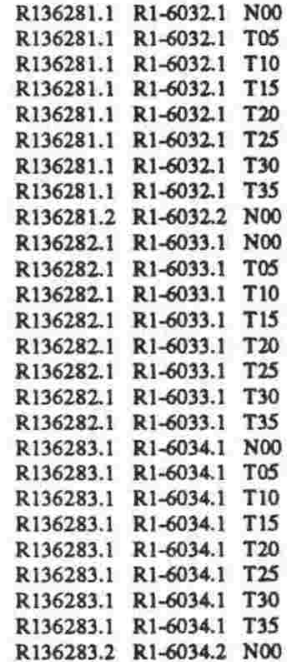

$0.427 \mathrm{E}-03 \quad 041.1 \quad-49.4 \quad 000.0$

$\begin{array}{llll}0.312 \mathrm{E}-03 & 0.46 .8 & -49.3 & 000.0\end{array}$

$\begin{array}{llll}0.212 \mathrm{E}-03 & 060.5 & -45.2 & 000.0\end{array}$

$\begin{array}{llll}0.140 \mathrm{E}-03 & 062.5 & -35.4 & 000.0\end{array}$

$\begin{array}{lllll}0.952 \mathrm{E}-0.4 & 057.9 & -39.2 & 000.0\end{array}$

$\begin{array}{llll}0.599 \mathrm{E}-0.4 & 0.5 .4 & -08.1 & 000.0\end{array}$

$\begin{array}{llll}0.378 \mathrm{E}-0.4 & 022.2 & 36.0 & 000.0\end{array}$

$\begin{array}{llll}0.273 \mathrm{E}-04 & 028.8 & 53.6 & 000.0\end{array}$

$\begin{array}{llll}0.488 \mathrm{E}-03 & 0.45 .9 & -56.4 & 000.0\end{array}$

$0.444 \mathrm{E}-03 \quad 034.2-55.0 \quad 003.0$

$\begin{array}{lllll}0.345 \mathrm{~B}-03 & 0 \$ 0.8 & -52.0 & 003.0\end{array}$

$\begin{array}{llll}0.243 \mathrm{E}-03 & 042.9 & -45.3 & 003.0\end{array}$

$\begin{array}{llll}0.165 \mathrm{E}-03 & 036.7 & -32.7 & 003.0\end{array}$

$\begin{array}{llll}0.118 \mathrm{E}-03 & 017.9 & -35.8 & 003.0\end{array}$

$\begin{array}{llll}0.107 \mathrm{E}-03 & 358.4 & -13.7 & 003.0\end{array}$

$\begin{array}{llll}0.728 \mathrm{E}-04 & 3345 & -08.7 & 003.0\end{array}$

$\begin{array}{lllll}0.508 \mathrm{E}-04 & 010.1 & -06.2 & 003.0\end{array}$

$\begin{array}{lllll}0.477 & \mathrm{E}-03 & 048.0 & -46.6 & 003.0\end{array}$

$\begin{array}{llll}0.416 \mathrm{E}-03 & 051.4 & -43.1 & 003.0\end{array}$

$0.297 \mathrm{E}-03 \quad 059.7 \quad-46.6 \quad 003.0$

$\begin{array}{llll}0.174 \mathrm{E}-03 & 050.8 & -48.3 & 003.0\end{array}$

$\begin{array}{llll}0.116 \mathrm{E}-03 & 062.4 & -50.5 & 003.0\end{array}$

$\begin{array}{llll}0.103 \mathrm{E}-03 & 048.3 & -56.2 & 0.03 .0\end{array}$

$\begin{array}{llll}0.118 \mathrm{E}-03 & 037.2 & -55.8 & 003.0\end{array}$

$\begin{array}{lllll}0.574 \mathrm{E}-04 & 039.9 & -62.3 & 003.0\end{array}$

$\begin{array}{lllll}0.464 \mathrm{E}-03 & 039.1 & -445 & 003.0\end{array}$

50.5

50.5

50.5

50.5

50.5

50.5

50.5

51.5

51.5
51.5

51.5

51.5

51.5

51.5

49.5

49.5

49.5

49.5

49.5

49.5

49.5

RANGITIKEI RIVER STIE $138 \mathrm{~V}$

HEIGHT $=103 \mathrm{~m}$ (above base of section) STRIKE $=101 \quad \mathrm{DIP}=04$

SAMPLE FIELD NO. TREAT. INTENSITY CDEC CINC Y-AZ PLUNGE

R138284.1 R1-5525.1 N00 R138284.1 R1-5525.1 T05 R138284.1 R1-5525.1 T10 R138284.1 R1-5525.1 T15 R138284.1 R1-5525.1 T20 R138284.1 R1-5525.1 T25 R138284.1 R1-5525.1 T30 R138284.1 R1-5525.1 T35 R138284.2 R1-5525.2 N00 R138285.1 R1-5526.1 NOO R138285.1 R1-5526.1 T05 R138285.1 R1-5526.1 T10 R138285.1 R1-5526.1 T15 R138285.1 R1-5526.1 T20 $\begin{array}{lll}\text { R138285.1 } & \text { R1-5526.1 } & \text { T25 } \\ \text { R138285.1 } & \text { R1-5526.1 } & \text { T30 }\end{array}$ R138285.1 R1-5526.1 T30 $\begin{array}{lll}R 138285.1 & R 1-5526.1 & T 35 \\ R 138285 & R 1-5526.2 & N 00\end{array}$ R138286.1 R1-5527.1 NOO R138286.1 R1-5527.1 TOS R138286.1 R1-5527.1 T10 R138286.1 R1-5527.1 T15 R138286.1 R1-5527.1 T20 R138286.1 R1-5527.1 T25 R138286.1 R1-5527.1 T30 R138286.1 R1-5527.1 T35 R138286.2 R1-5527.2 NO0 R138287.1 R1-5528.1 NOO R138287.1 R1-5528.1 TOS R138287.1 R1-5528.1 T10 R138287.1 R1-5528.1 T15 R138287.1 R1-5528.1 T20 R138287.1 R1-5528.1 T25 R138287.1 R1-5528.1 T30 R138287.1 R1-5528.1 T35 R138287.2 R1-5528.2 NOO

$\begin{array}{lllll}0.507 \mathrm{E}-03 & 014.8 & -47.7 & 350.0\end{array}$ $\begin{array}{lllll}0.425 \mathrm{E}-03 & 015.8 & -42.8 & 350.0\end{array}$ $\begin{array}{lllll}0.342 \mathrm{E}-03 & 021.3 & -42.4 & 350.0\end{array}$

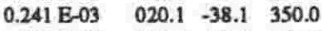
$\begin{array}{lllll}0.181 \mathrm{E}-03 & 017.7 & -33.9 & 350.0\end{array}$ $\begin{array}{llll}0.131 \mathrm{E}-03 & 015.3 & -28.6 & 350.0\end{array}$ $\begin{array}{llll}0.131 \mathrm{E}-03 & 015.3 & -28.6 & 350.0 \\ 0.110 \mathrm{E}-03 & 001.8 & -24.9 & 350.0\end{array}$ $\begin{array}{llll}0.110 \mathrm{E}-03 & 001.8 & -24.9 & 350.0 \\ 0.105 \mathrm{E}-03 & 009.5 & -21.7 & 350.0\end{array}$ $\begin{array}{lllll}0.105 \mathrm{E}-03 & 009.5 & -21.7 & 350.0 \\ 0.575 \mathrm{E}-03 & 044.0 & -48.0 & 350.0\end{array}$ $\begin{array}{lllll}0.575 \mathrm{E}-03 & 044.0 & -48.0 & 350.0 \\ 0.492 & 0.03 & 016.1 & -56.5 & 350.0\end{array}$ $\begin{array}{lllll}0.451 \mathrm{E}-03 & 011.1 & -55.4 & 350.0\end{array}$ $\begin{array}{llll}0.358 \mathrm{E}-03 & 010.2 & -52.4 & 350.0\end{array}$ $\begin{array}{llll}0.228 \mathrm{E}-03 & 005.6 & -51.8 & 350.0\end{array}$ $\begin{array}{llll}0.228 \mathrm{E}-03 & 005.6 & -51.8 & 350.0 \\ 0.168 \mathrm{E}-03 & 006.4 & -45.4 & 350.0\end{array}$ $\begin{array}{lllll}0.168 \text { E- } 03 & 006.4 & -45.4 & 350.0 \\ 0.129 \text { E- } 03 & 001.1 & -38.8 & 350.0\end{array}$ $\begin{array}{lllll}0.129 \mathrm{E}-03 & 001.1 & -38.8 & 350.0 \\ 0.101 & \mathrm{E}-03 & 353.8 & -28.7 & 350.0\end{array}$ $\begin{array}{lllll}0.101 & \mathrm{E}-03 & 353.8 & -28.7 & 350.0\end{array}$ $\begin{array}{lllll}0.753 \mathrm{E}-04 & 354.3 & -29.1 & 350.0\end{array}$ $\begin{array}{lllll}0.504 \mathrm{E}-03 & 028.5 & -57.1 & 350.0\end{array}$ $\begin{array}{lllll}0.518 \mathrm{E}-03 & 018.3 & -57.7 & 355.0\end{array}$ $\begin{array}{lllll}0.416 \mathrm{E}-03 & 017.8 & -52.0 & 355.0\end{array}$ $\begin{array}{lllll}0.316 \mathrm{~B}-03 & 023.8 & -47.7 & 355.0\end{array}$ $\begin{array}{lllll}0.208 \mathrm{E}-03 & 019.8 & -43.9 & 355.0\end{array}$ $\begin{array}{lllll}0.148 \mathrm{E}-03 & 022.5 & -42.6 & 355.0\end{array}$ $\begin{array}{lllll}0.106 \mathrm{E}-03 & 013.6 & -33.3 & 355.0\end{array}$ $\begin{array}{lllll}0.925 \mathrm{E}-04 & 014.2 & -20.7 & 355.0\end{array}$ $\begin{array}{lllll}0.812 \mathrm{E}-04 & 019.2 & -31.6 & 355.0\end{array}$ $\begin{array}{llll}0.812 \mathrm{E}-04 & 019.2 & -31.6 & 355.0 \\ 0.486 \mathrm{E}-03 & 023.6 & -59.9 & 355.0\end{array}$ $\begin{array}{llll}0.486 \mathrm{E}-03 & 023.6 & -59.9 & 355.0 \\ 0.487 \mathrm{E}-03 & 019.1 & -69.8 & 356.0\end{array}$ $\begin{array}{llll}0.487 \mathrm{E}-03 & 019.1 & -69.8 & 356.0 \\ 0.417 \mathrm{E}-03 & 017.2 & -66.1 & 356.0\end{array}$ $\begin{array}{lllll}0.318 \mathrm{E}-03 & 021.9 & -69.2 & 356.0\end{array}$ $\begin{array}{lllll}0.209 \mathrm{E}-03 & 016.9 & -74.6 & 356.0\end{array}$ $\begin{array}{lllll}0.143 \mathrm{E}-03 & 358.0 & -63.8 & 356.0\end{array}$ $0.113 \mathrm{E}-03 \quad 338.2-562 \quad 356.0$ $\begin{array}{lllll}0.113 \mathrm{E}-03 & 338.2 & -56.2 & 356.0 \\ 0.763 \mathrm{E}-0.4 & 328.4 & -28.2 & 356.0\end{array}$ $\begin{array}{llll}0.763 \mathrm{E}-04 & 328.4 & -28.2 & 356.0 \\ 0.937 \mathrm{E}-04 & 325.9 & -45.6 & 356.0\end{array}$ $\begin{array}{llll}0.493 \mathrm{E}-03 & 038.8 & -61.9 & 356.0\end{array}$

42.5

425
425

42.5

42.5

42.5
42.5

42.5

42.5

43.0

43.0

43.0

43.0
43.0

43.0

43.0

43.0

41.0

41.0

41.0
41.0

41.0

41.0

41.0

41.0
40.5

40.5

40.5
40.5

40.5

40.5

40.5
40.5

40.5

RANGITIKEI RIVER SITE 141V

HEIGHT $=154 \mathrm{~m}$ (above base of section) STRIKE $=101 \mathrm{DIP}=04$

SAMPLE FIELD NO. TREAT. INTENSTTY CDEC CINC Y-AZ PLUNGE

R141288.1 R1-5422.1 N00 R141288.1 R1-5422.1 T05 R141288.1 R1-5422.1 T10 R141288.1 R1-5422.1 T15 R141288.1 R1-5422.1 T20 R141288.1 R1-5422.1 T25 R141288.1 R1-5422.1 T30 R141288.1 R1-5422.1 T35 R141288.2 R1-5422.2 NOO R141289.1 R1-5423.1 N0O R141289.1 R1-5423.1 T05 R141289.1 R1-5423.1 T10

$\begin{array}{lllll}0.189 \mathrm{E}-03 & 353.4 & -55.2 & 039.0 & 45.0 \\ 0.136 \mathrm{E}-03 & 349.8 & -49.4 & 039.0 & 45.0 \\ 0.491 \mathrm{E}-04 & 329.5 & -41.7 & 039.0 & 45.0 \\ 0.493 \mathrm{E}-04 & 319.6 & 35.8 & 039.0 & 45.0 \\ 0.875 \mathrm{E}-04 & 318.7 & 54.4 & 039.0 & 45.0 \\ 0.917 \mathrm{E}-04 & 004.5 & 50.7 & 039.0 & 45.0 \\ 0.641 \mathrm{E}-04 & 351.1 & 26.9 & 039.0 & 45.0 \\ 0.787 \mathrm{E}-04 & 319.4 & 05.3 & 039.0 & 45.0 \\ 0.234 \mathrm{E}-03 & 351.3 & -65.1 & 039.0 & 45.0 \\ 0.171 \mathrm{E}-03 & 340.1 & -53.9 & 040.0 & 55.5 \\ 0.122 \mathrm{E}-03 & 357.4 & -45.2 & 040.0 & 55.5 \\ 0.405 \mathrm{E}-04 & 353.5 & -32.9 & 040.0 & 55.5\end{array}$

R141289.1 R1-5423.1 T15 R141289.1 R1-5423.1 T20 R141289.1 R1-5423.1 T25 R141289.1 R1-5423.1 T30 R141289.1 R1-5423.1 T35 R141289.2 R1-5423.2 N00 R141290.1 R1-5424.1 NOO R141290.1 R1-5424.1 T05 R141290.1 R1-5424.1 T10 R141290.1 R1-5424.1 T15 R141290.1 R1-5424.1 T20 R141290.1 R1-5424.1 T25 R141290.1 R1-5424.1 T30 R141290.1 R1-5424.1 T35 R141290.2 R1-5424.2 NOO $\begin{array}{lllllll}0.487 & \text { E-0 } & 307.4 & 88.1 & 040.0\end{array}$ $\begin{array}{lllll}0.595 \mathrm{E}-04 & 190.6 & 54.2 & 040.0\end{array}$ $\begin{array}{lllll}0.719 \mathrm{E}-04 & 223.5 & 53.8 & 040.0\end{array}$ $\begin{array}{llll}0.948 \mathrm{E}-04 & 184.7 & 30.1 & 040.0\end{array}$ $\begin{array}{lllll}0.438 \mathrm{E}-04 & 200.1 & -28.8 & 040.0\end{array}$ $0.211 \mathrm{E}-03 \quad 317.0 \quad-66.8 \quad 040.0$ $\begin{array}{lllll}0.179 \mathrm{E}-03 & 041.5 & -69.8 & 037.0\end{array}$ $\begin{array}{llllll}0.178 \mathrm{E}-03 & 033.7 & -41.0 & 037.0\end{array}$ $0.101 \mathrm{E}-03 \quad 057.4 \quad-40.2 \quad 037.0$ $\begin{array}{llll}0.592 \mathrm{E}-04 & 078.6 & 10.3 & 037.0\end{array}$

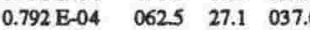
$\begin{array}{lllll}0.122 \mathrm{~B}-03 & 101.7 & 55.7 & 037.0\end{array}$ $\begin{array}{llll}0.148 \text { E- }-03 & 059.1 & 23.2 & 037.0\end{array}$ $\begin{array}{lllll}0.884 \text { E- } 04 & 106.3 & 44.6 & 037.0\end{array}$ $\begin{array}{llll}0.207 \mathrm{E}-03 & 047.0 & -54.6 & 037.0\end{array}$

RANGITIKEI RIVER SITE $142 \mathrm{~V}$

HEIGHT $=171 \mathrm{~m}$ (above base of section) STRIKE $=011 \quad \mathrm{DIP}=09$

SAMPLE FIELD NO. TREAT. INTENSITY CDEC CINC Y-AZ PLUNGE

\begin{tabular}{|c|c|c|c|c|c|c|}
\hline 2291.1 & R1-5829.1 & NOO & $0.302 \mathrm{E}-03$ & 101.8 & -70.4 & 105.0 \\
\hline R142291.1 & R1-5829.1 & T05 & $0.178 \mathrm{E}-03$ & 192.2 & -71.1 & 105.0 \\
\hline 142291.1 & R1-5829.1 & T10 & $0.139 \mathrm{E}-03$ & 191.3 & -45.0 & 105.0 \\
\hline 142291.1 & R1-5829.1 & T15 & $0.127 \mathrm{E}-03$ & 199.5 & -19.4 & 105.0 \\
\hline 2142291.1 & R1-5829.1 & T20 & $0.457 \mathrm{E}-0.4$ & 150.3 & 65.3 & 105.0 \\
\hline$R 142291.1$ & R1-5829.1 & T25 & 0.118 E-03 & 238.5 & 30.6 & 105.0 \\
\hline R142291.1 & R1-5829.1 & T30 & 0.977 E-04 & 185.6 & 38.3 & 105.0 \\
\hline R142291.1 & R1-5829.1 & T35 & $0.787 \mathrm{E}-04$ & 179.5 & 55.5 & 105.0 \\
\hline R142291.2 & R1-5829.2 & N00 & $0.397 \mathrm{E}-03$ & 052.1 & -60.8 & 105.0 \\
\hline R142292.1 & R1-5830.1 & NOO & $0.257 \mathrm{E}-0.3$ & 025.4 & -50.1 & 105.0 \\
\hline R142292.1 & R1-5830.1 & T05 & $0.156 \mathrm{E}-03$ & 357.0 & -44.0 & 105.0 \\
\hline 142292.1 & R1-5830.1 & T10 & $0.526 \mathrm{E}-0.4$ & 337.9 & -20.9 & 105.0 \\
\hline R142292.1 & R1-5830.1 & T15 & $0.633 \mathrm{E}-04$ & 292.7 & 37.4 & 105.0 \\
\hline R142292.1 & R1-5830.1 & $\mathrm{T} 20$ & 0.163 E-03 & 260.2 & 29.1 & 105.0 \\
\hline R142292.1 & R1-5 & T25 & E-04 & 348.2 & 74.2 & 105.0 \\
\hline 142292.1 & R1-5830.1 & T30 & $0.873 \mathrm{E}-0.4$ & 269.6 & 30.7 & 105.0 \\
\hline R142292.1 & R1-5830.1 & T35 & $0.113 \mathrm{E}-03$ & 132.5 & 33.1 & 105.0 \\
\hline R142292.2 & R1-5830.2 & NoO & $0.266 \mathrm{E}-03$ & 030.1 & -60.6 & 105.0 \\
\hline R142293.1 & R1-5 & NOO & $0.318 \mathrm{~B}-03$ & 076.9 & -84.0 & 101.0 \\
\hline R142293.1 & R1-5831.1 & T05 & $0.232 \mathrm{E}-03$ & 272.6 & -68.4 & 101.0 \\
\hline R142293.1 & R1-5831.1 & $\mathrm{T} 10$ & $0.167 \mathrm{E}-03$ & 234.0 & -493 & 101.0 \\
\hline R142293.1 & R1-5831.1 & T15 & 0.128 E- 03 & 242.4 & -27.9 & 101.0 \\
\hline R142293.1 & R1-5831.1 & $\mathrm{T} 20$ & $0.121 \mathrm{E}-03$ & 220.3 & 05.3 & 101.0 \\
\hline & R1-5831.1 & T25 & $0,917 \mathrm{E}-04$ & 222.5 & 48.1 & 101.0 \\
\hline R142293.1 & R1-5831.1 & $\mathrm{T} 30$ & $0.132 \mathrm{E}-03$ & 269.8 & 15.7 & 101.0 \\
\hline 142293.1 & R1-5831.1 & T35 & $0.603 \mathrm{E}-04$ & 351.3 & 40.0 & 101.0 \\
\hline & & & $0,430 \mathrm{E}-0$ & 352. & -85.2 & 101.0 \\
\hline
\end{tabular}

RANGITIKE] RIVER STTE $143 \mathrm{~V}$

HEIGHT $=201 \mathrm{~m}$ (above base of section) STRIKE $=101 \mathrm{DIP}=06$

SAMPLE FIED NO. TREAT. INTENSITY CDEC CINC Y-AZ PLUNGE

R143294.1 R1-5319.1 N00

R143294.1 R1-5319.1 T05

R143294.1 R1-5319.1 T10

R143294.1 R1-5319.1 T15

R143294.1 R1-5319.1 T20

R143294.1 R1-5319.1 T25

R143294.1 R1-5319.1 T30

R143294.1 R1-5319.1 T35

R143294.2 R1-5319.2 NOO

R143295.1 R1-5320.1 NOO

R143295.1 RI 5320.1 T05

R143295.1 R1-5320.1 T10

R143295.1 R1-5320.1 T15

R143295.1 R1-5320.1 T20

R143295.1 R1-5320.1 T25

R143295.1 R1-5320.1 T30

R143295.1 R1-5320.1 T35

R143295.2 R1-5320.2 NOO

R143296.1 R1-5321.1 NOO

R143296.1 R1-5321.1 T05

R143296.1 R1-5321.1 T10

R143296.1 R1-5321.1 TIS

R143296.1 R1-5321.1 T20

R143296.1 R1-5321.1 T25

R143296.1 R1-5321.1 T30

R143296.1 R1-5321.1 T35

$\begin{array}{llll}0.595 \mathrm{E}-03 \quad 009.5 & -65.6 \quad 228.0\end{array}$

545

$\begin{array}{lllll}0.467 & \mathrm{E}-03 & 005.9 & -62.7 & 228.0\end{array}$

$\begin{array}{llll}0.348 \mathrm{E}-03 & 004.4 & -62.5 & 228.0\end{array}$

$\begin{array}{lllll}0.147 & \mathrm{E}-03 & 347.7 & -645 & 228.0\end{array}$

$\begin{array}{lllll}0.110 \mathrm{E}-03 & 344.5 & -50.0 & 228.0\end{array}$

$\begin{array}{lllll}0.499 \mathrm{~B}-04 & 017.9 & -15.0 & 228.0\end{array}$

$\begin{array}{lllll}0.315 \mathrm{E}-04 & 033.9 & -74.7 & 228.0\end{array}$

$\begin{array}{lllll}0.406 & \mathrm{E}-04 & 324.3 & -32.8 & 228.0\end{array}$

$\begin{array}{lllll}0.611 \mathrm{E}-03 & 016.5 & -60.0 & 228.0\end{array}$

$\begin{array}{lllll}0.664 \mathrm{E}-03 & 359.4 & -66.6 & 226\end{array}$

$\begin{array}{lllll}0.514 \mathrm{E}-03 & 353.7 & -665 & 226.0\end{array}$

$\begin{array}{llll}0.407 \mathrm{E}-03 & 350.0 & -66.0 & 226.0\end{array}$

$\begin{array}{lllll}0.206 \mathrm{E}-03 & 330.6 & -73.5 & 226.0\end{array}$

$\begin{array}{llll}0.126 \mathrm{E}-03 & 327.8 & -67.4 & 226.0\end{array}$

$\begin{array}{lllll}0.132 \mathrm{E}-03 & 311.0 & -65.9 & 226.0\end{array}$

$\begin{array}{lllll}0.698 & \mathrm{E}-04 & 237.4 & -56.4 & 226.0\end{array}$

$\begin{array}{lllll}0.703 \mathrm{E}-04 & 026.2 & -313 & 226.0\end{array}$

$\begin{array}{lllll}0.588 & \mathrm{E}-03 & 0116 & -588 & 226.0\end{array}$

$\begin{array}{llll}0.597 \text { E }-03 & 014.8 & -61.4 & 229.0\end{array}$

$\begin{array}{lllll}0.429 \mathrm{E}-03 & 003.9 & -58.6 & 229.0\end{array}$

$\begin{array}{lllll}0.312 \mathrm{E}-03 & 005.3 & -58.1 & 229.0\end{array}$

$\begin{array}{lllll}0.147 & \mathrm{E}-03 & 354.7 & -66.0 & 229.0\end{array}$

$\begin{array}{llll}0.867 \text { E- } 04 & 019.5 & -49.9 & 229.0\end{array}$

$\begin{array}{lllll}0.125 \mathrm{E}-03 & 355.4 & -56.8 & 229.0\end{array}$

$\begin{array}{lllll}0.747 & \mathrm{E}-04 & 029.7 & -72.8 & 229.0\end{array}$

$\begin{array}{lllll}0.815 \mathrm{E}-04 & 345.3 & -39.7 & 229.0\end{array}$

$\begin{array}{llll}0.590 \mathrm{E}-03 & 011.3 & -57.1 & 229.0\end{array}$

545

54.5
54.5

54.5

54.5

54.5

54.5

505

50.5

50.5

50.5

505

505

50.5

51.0

51.0

51.0 
R145299.1 R1-5118.1 N00 R145299.1 R1-5118.1 T05 R145299.1 R1-5118.1 T10 R145299.1 R1-5118.1 T15 R145299.1 R1-5118.1 T20 R145299.1 R1-5118.1 T25 R145299.1 R1-5118.1 T30 R145299.1 R1-5118.1 T35 R145299.2 R1-5118.2 NOO $\begin{array}{lllll}0.232 \mathrm{E}-03 & 023.2 & -55.4 & 345.0\end{array}$

$\begin{array}{llll}0.197 \mathrm{E}-03 & 001.7 & -56.1 & 345.0\end{array}$

$0.105 \mathrm{E}-03 \quad 358.5 \quad-58.8 \quad 345.0$

$\begin{array}{lll}307.2 & -51.2 & 345.0\end{array}$

$\begin{array}{lllll}0.411 & \mathrm{E}-04 & 263.7 & -18.7 & 345.0\end{array}$

$0.119 \mathrm{E}-03 \quad 293.4 \quad 50.4 \quad 345.0$

$335.725 .8 \quad 345.0$

$\begin{array}{llll}0.617 \mathrm{E}-04 & 335.7 & 25.8 & 345.0 \\ 0.748 \mathrm{E}-04 & 295.4 & 10.1 & 345.0\end{array}$

$\begin{array}{lllll}0.224 \mathrm{E}-03 & 353.2 & -63.4 & 345.0\end{array}$

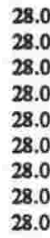

RANGITIKET RIVER SITE $146 \mathrm{~V}$

HEIGHT $=401 \mathrm{~m}$ (above base of section) STRIKE=101 DIP=06

SAMPLE FIELD NO. TREAT. INTENSITY CDEC CINC Y-AZ PLUNGE

R146300.1 R1-5013.1 N00 R146300.1 R1-5013.1 T05 R146300.1 R1-5013.1 T10 R146300.1 R1-5013.1 T1S R146300.1 R1-5013.1 T20 R146300.1 R1-5013.1 T25 R146300.1 R1-5013.1 T30 R146300.1 RI-5013.1 T3S R146300.2 R1-5013.2 N0O R146301.1 R1-5014.1 N00 R146301.1 R1-5014.1 TOS R146301.1 R1-5014.1 T10 R146301.1 R1-5014.1 T15 R146301.1 R1-5014.1 T20 R146301.1 R1-5014.1 T2S R146301.1 R1-5014.1 T30 R146301.1 R1-5014.1 T35 R146301.2 R1-5014.2 N00 R146302.1 R1-5015.1 N0O R146302.1 R1-5015.1 T05 R146302.1 R1-5015.1 T10 R146302.1 R1-5015.1 T15 R146302.1 R1-5015.1 T20 R146302.1 R1-5015.1 T25 R146302.1 R1-5015.1 T30 R146302.1 R1-5015.1 T35 \begin{tabular}{llrll}
$0.211 \mathrm{E}-03$ & 120.5 & -75.5 & 142.0 & 49.5 \\
$0.164 \mathrm{E}-03$ & 078.5 & -71.3 & 142.0 & 49.5 \\
$0.101 \mathrm{E}-03$ & 114.7 & -63.3 & 142.0 & 49.5 \\
$0.906 \mathrm{E}-04$ & 153.7 & -33.0 & 142.0 & 49.5 \\
$0.110 \mathrm{E}-03$ & 181.7 & -33.0 & 142.0 & 49.5 \\
$0.153 \mathrm{E}-03$ & 200.9 & -50.2 & 142.0 & 49.5 \\
$0.153 \mathrm{E}-03$ & 188.6 & -13.4 & 142.0 & 49.5 \\
$0.409 \mathrm{E}-04$ & 054.5 & 04.0 & 142.0 & 49.5 \\
$0.189 \mathrm{E}-03$ & 256.8 & 20.4 & 142.0 & 49.5 \\
$0.256 \mathrm{E}-03$ & 001.6 & -42.2 & 136.0 & 48.5 \\
$0.193 \mathrm{E}-03$ & 013.5 & -39.2 & 136.0 & 48.5 \\
$0.135 \mathrm{E}-03$ & 002.7 & -24.9 & 136.0 & 48.5 \\
$0.973 \mathrm{E}-04$ & 354.2 & -10.2 & 136.0 & 48.5 \\
$0.104 \mathrm{E}-03$ & 004.9 & -02.2 & 136.0 & 48.5 \\
$0.737 \mathrm{E}-04$ & 003.9 & 11.1 & 136.0 & 48.5 \\
$0.502 \mathrm{E}-04$ & 002.9 & -00.7 & 136.0 & 48.5 \\
$0.992 \mathrm{E}-04$ & 031.3 & -06.7 & 136.0 & 48.5 \\
$0.150 \mathrm{E}-03$ & 022.4 & -59.4 & 136.0 & 48.5 \\
$0.163 \mathrm{E}-03$ & 341.7 & -30.5 & 137.0 & 45.5 \\
$0.113 \mathrm{E}-03$ & 348.6 & -22.3 & 137.0 & 45.5 \\
$0.652 \mathrm{E}-04$ & 345.3 & 06.0 & 137.0 & 45.5 \\
$0.471 \mathrm{E}-04$ & 315.2 & 46.6 & 137.0 & 45.5 \\
$0.163 \mathrm{E}-04$ & 194.5 & -09.7 & 137.0 & 45.5 \\
$0.107 \mathrm{E}-03$ & 162.0 & 17.5 & 137.0 & 45.5 \\
$0.108 \mathrm{E}-03$ & 126.2 & 17.7 & 137.0 & 45.5 \\
$0.136 \mathrm{E}-03$ & 110.8 & -65.1 & 137.0 & 45.5 \\
$0.112 \mathrm{E}-03$ & 312.8 & -50.0 & 137.0 & 45.5 \\
\hline & & & &
\end{tabular}

RANGITIKEI RIVER SITE $147 \mathrm{~V}$

HEIGHT $=411 \mathrm{~m}$ (above base of section) STRIKE $=101 \mathrm{DIP}=06$

SAMPLE FIELD NO. TREAT. INTENSITY CDEC CINC Y-AZ PLUNGE

R147303.1 R1-4909.1 N00 R147303.1 R1-4909.1 T05 R147303.1 R1-4909.1 T10 R147303.1 R1-4909.1 T15 R147303.1 R1 4909.1 T20 R147303.1 R1- 4909.1 T25 R147303.1 R1-4909.1 T30 R147303.1 R1-4909.1 T35 R147303.2 R1-4909.2 N00 R147304.1 R1-4910.1 NOO R147304.1 R1-4910.1 T05 R147304.1 R1-4910.1 T10 R147304.1 R1-4910.1 T15 R147304.1 R1-4910.1 T20 R147304.1 R1-4910.1 T25 R147304.1 R1-4910.1 T30 R147304.1 RI-4910.1 T35 R147304.2 R1-4910.2 N00 R147305.1 R1-4911.1 N00 R147305.1 R1-4911.1 TOS R147305.1 R1-4911.1 T10 R147305.1 R1-4911.1 T15 R147305.1 R1-4911.1 T20 R147305.1 R1-4911.1 T25 R147305.1 R1-4911.1 T30 R147305.1 R1-4911.1 T35 R147305.2 R1-4911.2 NOO R147306.1 R1-4912.1 NOO R147306.1 R1-4912.1 TOS R147306.1 R1-4912.1 T10 R147306.1 R1-4912.1 T15 R147306.1 R1-4912.1 T20 R147306.1 RI-4912.1 T25 R147306.1 R1-4912.1 T30 R147306.1 R1-4912.1 T35

$\begin{array}{llll}0.474 \mathrm{E}-03 \quad 021.1 & -55.0 & 356.0\end{array}$ $\begin{array}{lllll}0.355 & E-03 & 010.1 & -60.8 & 356.0\end{array}$ $\begin{array}{llll}0.218 \mathrm{E}-03 & 009.5 & -61.2 & 356.0\end{array}$ $\begin{array}{lllll}0.658 & \mathrm{E}-04 & 012.0 & -61.3 & 356.0\end{array}$ $0.582 \mathrm{E}-04 \quad 285.1 \quad-48.2 \quad 356.0$ $\begin{array}{lllll}0.585 & \mathrm{E}-04 & 226.0 & -26.4 & 356.0\end{array}$

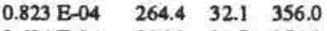
$\begin{array}{llll}0.624 \text { E- } 04 & 026.1 & 20.7 & 356.0\end{array}$ $\begin{array}{lllll}0.593 & \mathrm{E}-03 & 022.6 & -52.7 & 356.0\end{array}$ $\begin{array}{lllll}0.358 \mathrm{E}-03 & 305.0 & -67.5 & 355.0\end{array}$ 0.267 E $-03 \quad 295.5-612 \quad 355.0$ $\begin{array}{llll}0.140 \mathrm{E}-03 & 271.5 & -45.9 & 355.0\end{array}$

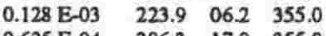
$\begin{array}{llll}0.625 \mathrm{E}-04 & 206.3 & 17.0 & 355.0\end{array}$

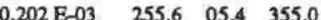
$\begin{array}{lllll}0.894 \mathrm{E}-0.4 & 183.2 & -38.9 & 355.0\end{array}$ $\begin{array}{lllll}0.698 \mathrm{E}-04 & 098.9 & -72.6 & 355.0\end{array}$ $\begin{array}{llll}0.727 \mathrm{E}-03 & 326.3 & -62.4 & 355.0\end{array}$ $\begin{array}{lllll}0.662 \mathrm{E}-03 & 011.9 & -62.2 & 355.0\end{array}$ $\begin{array}{lllll}0.500 \mathrm{E}-03 & 358.3 & -66.6 & 355.0\end{array}$ $\begin{array}{lllll}0.369 \mathrm{E}-03 \quad 354.0 & -64.2 \quad 355.0\end{array}$ $\begin{array}{lllll}0.213 \mathrm{E}-03 & 328.3 & -70.4 & 355.0\end{array}$ $\begin{array}{lllll}0.105 \mathrm{E}-03 & 348.0 & -40.6 & 355.0\end{array}$ $\begin{array}{lllll}0.190 & \mathrm{E}-03 & 355.8 & -13.2 & 355.0\end{array}$ $\begin{array}{lllll}0.116 \mathrm{E}-03 & 338.9 & -38.0 & 355.0\end{array}$ $\begin{array}{lllll}0.103 \mathrm{E}-03 & 321.2 & -32.6 & 355.0\end{array}$ $\begin{array}{lllll}0.704 \mathrm{E}-03 & 034.0 & -64.1 & 355.0\end{array}$ $\begin{array}{lllll}0.521 \mathrm{E}-03 & 031.9 & -713 & 006.0\end{array}$

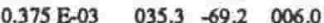
$\begin{array}{lllll}0.264 \mathrm{E}-03 & 033.7 & -69.8 & 006.0\end{array}$ $\begin{array}{lllll}0.136 \mathrm{E}-03 & 109.3 & -76.0 & 006.0\end{array}$ $\begin{array}{lllll}0.108 \mathrm{E}-03 & 133.9 & -52.5 & 006.0\end{array}$ $\begin{array}{llll}0.812 \text { E-04 } & 020.7 & 22.2 & 006.0\end{array}$

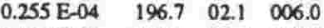
$\begin{array}{lllll}0.174 \mathrm{E}-03 & 022.1 & 23.7 & 006.0\end{array}$ $\begin{array}{lllll}0.588 \mathrm{E}-03 & 038.7 & -59.2 & 006.0\end{array}$
53.5

53.5

53.5

53.5

53.5

53.5

53.5

59.0

59.0

59.0

59.0

59.0

48.5

48.5

48.5

48.5

48.5

48.5

48.5

47.5

47.5

47.5

475

47.5

475 47.5

RANGITIKEI RIVER SITE $148 \mathrm{~V}$

HEIGHT $=458 \mathrm{~m}$ (above base of section) STRIKE $=056$ DIP $=06$

SAMPLE FIELDNO. TREAT. INTENSITY CDEC CINC Y-AZ PLUNGE

R148307.1 R1-4805.1 NOO R148307.1 R1-4805.1 T05 R148307.1 R1-4805.1 T10 R148307.1 R1-4805.1 T15 R148307.1 R1-4805.1 T20 R148307.1 R1-4805.1 T25 R148307.1 R1-4805.1 T30 R148307.1 R1-4805.1 T35 R148307.2 R1-4805.2 NOO R148308.1 R1-4806.1 N00 R148308.1 R1-4806.1 T05 R148308.1 R1-4806.1 T10 R148308.1 R1-4806.1 T15 R148308.1 R1-4806.1 T20 R148308.1 R1-4806.1 T25

\begin{tabular}{|c|c|c|c|c|c|c|}
\hline R148308.1 & R1 -4806.1 & 130 & $0.715 \mathrm{E}-04$ & 267.8 & 03.3 & 077.0 \\
\hline R148308.1 & R1-4806.1 & T35 & $0.597 \mathrm{E}-04$ & 311.4 & 09.0 & 077.0 \\
\hline R148308.2 & R1-4806.2 & NoO & $0.244 \mathrm{E}-03$ & 004.2 & -64.0 & 077.0 \\
\hline R148309.1 & R1-4807.1 & NOO & $0.151 \mathrm{E}-03$ & 306.9 & -78.1 & 079.0 \\
\hline R148309.1 & R1-4807.1 & T05 & $0.144 \mathrm{E}-03$ & 316.1 & -69.0 & 079.0 \\
\hline R148309.1 & R1-4807.1 & $\mathrm{T} 10$ & 0.673 E-04 & 179.3 & -71.3 & 079.0 \\
\hline R148309.1 & R1-4807.1 & T15 & $0.131 \mathrm{E}-04$ & 029.1 & -47.0 & 079.0 \\
\hline R148309.1 & R1 4807.1 & $\mathrm{~T} 20$ & $0.998 \mathrm{E}-05$ & 251.3 & -26.8 & 079.0 \\
\hline R148309.1 & R1-4807.1 & T25 & $0.267 \mathrm{E}-04$ & 308.2 & -54.8 & 079.0 \\
\hline R148309.1 & R1-4807.1 & T30 & 0.745 E- -04 & 243.0 & -37.4 & 079.0 \\
\hline R148309.1 & R1-4807.1 & T35 & 0.407 E- 04 & 125.7 & -72.6 & 079.0 \\
\hline R148309.2 & R1- -4807.2 & NoO & 0.206 E- 03 & 017.0 & -68.8 & 079.0 \\
\hline R148310.1 & R1-4808.1 & NOO & 0.335 E-03 & 046.0 & -71.1 & 077.0 \\
\hline R148310.1 & R1-4808.1 & T05 & $0.287 \mathrm{E}-03$ & 049.0 & -64.6 & 077.0 \\
\hline R148310.1 & R1-4808.1 & T10 & $0.207 \mathrm{E}-03$ & 0.53 .5 & -66.8 & 077.0 \\
\hline R148310.1 & R1-4808.1 & T15 & $0.124 \mathrm{E}-03$ & 076.9 & -65.8 & 077.0 \\
\hline R148310.1 & R1-4808.1 & T20 & 0.122 E-03 & 153.2 & -43.7 & 077.0 \\
\hline R148310.1 & R1-4808.1 & T25 & 0.275 E-04 & 010.0 & 30.1 & 077.0 \\
\hline R148310.1 & R1-4808.1 & T30 & $0.754 \mathrm{E}-04$ & 009.7 & 17.7 & 077.0 \\
\hline R148310.1 & R1 -4808.1 & T35 & $0.827 \mathrm{E}-04$ & 037.9 & 22.8 & 077.0 \\
\hline R148310.2 & R1- 4808.2 & NoO & $0.261 \mathrm{E}-03$ & 055.1 & -643 & 077.0 \\
\hline
\end{tabular}

RANGITIKEI RIVER SITE $149 \mathrm{~V}$

HEIGHT $=486 \mathrm{~m}$ (above base of section) STRIKE $=056 \mathrm{DIP}=06$

SAMPLE FELD NO. TREAT. INTENSITY CDEC CINC Y-AZ PLUNGE

R1493111 R1 47011 TOS

R149311.1 R1-4701.1 T10

R149311.1 R1-4701.1 T1S

R149311.1 R1-4701.1 T20

R149311.1 R1-4701.1 T25

R149311.1 R1-4701.1 T30

R149311.1 R1-4701.1 T35

R149311.2 R1-4701.2 N00

R149312.1 R1-4702.1 NOO

R149312.1 R1- 4702.1 T05

R149312.1 R1-4702.1 T10

R149312.1 R1-4702.1 T15

R149312.1 R1-4702.1 T20

R1493121 Rl-47021 T25

R149312.1 R1-4702.1 T30

R149312.1 R1 -4702.1 T35

R149312.2 R1-4702.2 NOO

R149313.1 R1-4703.1 NOO

R149313.1 R1 4703.1 T05

R149313.1 R1-4703.1 T10

R149313.1 R1-4703.1 T15

R149313.1 R1-4703.1 T20

R149313.1 R1-4703.1 T25

R149313.1 R1-4703.1 T30

R149313.1 R1-4703.1 T35

R149313.2 R1-4703.2 NOO

R149314.1 R1-4704.1 NOO

R149314.1 R1-4704.1 T05

R149314.1 R1-4704.1 T10

R149314.1 R1-4704,1 T15

R149314.1 R1 4704.1 T20

R149314.1 R1 4704.1 T2S

R149314.1 R1-4704.1 T30

0.318 E-03 $359.1-617 \quad 039.0$

$\begin{array}{lllll}0.242 & E-03 & 343.3 & -67.4 & 039.0\end{array}$

$\begin{array}{lllll}0.133 & \mathrm{E}-03 & 047.0 & -81.6 & 039.0\end{array}$

$\begin{array}{lllll}0.711 & \mathrm{E}-04 & 198.5 & -76.1 & 039.0\end{array}$

$\begin{array}{lllll}0.606 \mathrm{E}-04 & 194.4 & -54.8 & 039.0\end{array}$

$\begin{array}{llll}0.684 \mathrm{E}-04 & 202.9 & -41.0 & 039.0\end{array}$

$\begin{array}{llll}0.622 \mathrm{E}-04 & 140.5 & 46.1 & 039.0\end{array}$

$\begin{array}{llll}0.494 \mathrm{E}-04 & 1775 & 01.0 & 039.0\end{array}$

$\begin{array}{llll}0.423 \mathrm{E}-03 & 052.2 & -43.2 & 039.0\end{array}$

$\begin{array}{lllll}0.237 & \mathrm{E}-03 & 085.2 & -56.7 & 041.0\end{array}$

$\begin{array}{lllll}0.246 \mathrm{E}-03 & 073.9 & -52.1 & 041.0\end{array}$

$\begin{array}{lllll}0.210 \mathrm{E}-03 & 067.2 & -43.7 & 041.0\end{array}$

$\begin{array}{lllll}0.142 \mathrm{E}-03 & 071.5 & -28.8 & 041.0\end{array}$

$\begin{array}{lllll}0.117 & \mathrm{E}-03 & 063.4 & -26.4 & 0410\end{array}$

$\begin{array}{lllll}0.817 \text { E-0 } 4 & 026.6 & -35.7 & 041.0\end{array}$

$\begin{array}{llll}0.288 \mathrm{E}-04 & 242.4 & 63.2 & 041.0\end{array}$

$\begin{array}{lllll}0.577 \mathrm{E}-0.4 & 331.9 & -52.7 & 041.0\end{array}$

$\begin{array}{lllll}0.309 & \mathrm{E}-03 & 139.5 & -74.4 & 041.0\end{array}$

$\begin{array}{llll}117.2 & -765 & 047.0\end{array}$

$\begin{array}{lll}103.7 & 82.6 & 047.0\end{array}$

$\begin{array}{lllll}0.181 & \mathrm{E}-03 & 224.1 & 83.3 & 047.0\end{array}$

0.993 E-04 $116.1 \quad 07.9 \quad 047.0$

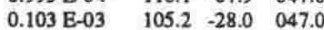

$\begin{array}{lllll}0.156 \mathrm{E}-03 & 207.8 & -45.5 & 047.0\end{array}$

$\begin{array}{llll}0.785 \mathrm{E}-0.4 & 145.7 & 22.5 & 047.0\end{array}$

$\begin{array}{llll}0.147 \mathrm{E}-04 & 178.4 & -69.1 & 047.0\end{array}$

$\begin{array}{lllll}0.354 \mathrm{E}-03 & 146.6 & -36.1 & 047.0\end{array}$

$\begin{array}{lllll}0.270 & \text { E-03 } & 084.0 & -627 & 047.0\end{array}$

$\begin{array}{lllll}0.217 & E-03 & 047.7 & -66.5 & 047.0\end{array}$

$\begin{array}{lllll}0.149 \mathrm{E}-03 & 069.3 & -55.1 & 047.0\end{array}$

$\begin{array}{llll}0.814 \text { E- }-0.4 & 110.2 & -27.4 & 047.0\end{array}$

$\begin{array}{lllll}0.342 \mathrm{E}-04 & 153.8 & -20.9 & 047.0\end{array}$

$\begin{array}{lllll}0.368 & \text { E-0 } 4 & 173.8 & 10.7 & 047.0\end{array}$

$\begin{array}{lllll}0.219 \mathrm{E}-04 & 226.7 & 29.3 & 047.0\end{array}$

$\begin{array}{lllll}0.380 & \mathrm{E}-04 & 165.9 & 33.8 & 047.0\end{array}$

$\begin{array}{llll}0.276 \mathrm{E}-03 & 028.5 & -65.6 & 047.0\end{array}$

32.0

32.0

32.0

32.0

32.0

32.0

32.0

32.0

30.5

30.5

30.5

305

30.

30.5

305

36.0

36.0

36.0

36.0

36.0

36.0

36.0

36.0

315

315

315

31.5

31.

31.

315

RANGITIKEI RIVER SITE ISIV

HEIGHT $=0 \mathrm{~m}$ (base of section) STRIKE=129 DIP=05

SAMPLE FIELDNO. TREAT. INTENSITY CDEC CINC Y-AZ PLUNGE

R151315.1 R1-4089.1 N00

R151315.1 R1-4089.1 T05

R151315.1 R1-4089.1 T10

R151315.1 R1-4089.1 T15

R151315.1 R1 4089.1 T20

R151315.1 R1-4089.1 T2S

R151315.1 R1-4089.1 T30

R151315.2 R1 -4089.2 NOO

R151315.2 R1-4089.2 T05

R151316.1 R1-4090.1 NOO

R151316.1 R1-4090.1 TOS

R151316.1 R1- $\$ 090.1$ T10 
R152318.1 R2-3986.1 T25 $\begin{array}{lll}R 152318.1 & R 2-3986.1 & \text { T30 } \\ \text { R152318.2 } & \text { R2-3986.2 } & \text { N00 }\end{array}$ R152319.1 R2-3987.1 N00 R152319.1 R2-3987.1 T05 R152319.1 R2-3987.1 T10 R152319.1 R2-3987.1 T15 R152319.1 R2-3987.1 T20 R152319.1 R2-3987.1 T2 R152319.1 R2-3987.1 T30 $\begin{array}{lll}R 152319.2 & R 2-3987.2 & \text { NOO }\end{array}$

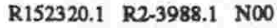
R152320.1 R2-3988.1 T05 R152320.1 R2-3988.1 T10 R152320.1 R2-3988.1 T15 $\begin{array}{llll}R & 152320.1 & R 2-3988.1 & T 20\end{array}$ $\begin{array}{lll}R 152320.1 & R 2-3988.1 & T 25\end{array}$ R152320.1 R2-3988.1 T30
0.101 E-04 $.687 \mathrm{E}-03$ $0.383 \mathrm{E}-0$. $0.417 \mathrm{E}-03$ $0.380 \mathrm{~B}-03$ $0.269 \mathrm{E}-0.3$ $0.150 \mathrm{E}-03$ $0.119 \mathrm{E}-03$ 0.129 E-03 $0.116 \mathrm{E}-03$ $0.337 \mathrm{E}-03$ $0.358 \mathrm{E}-03$ $0.366 \mathrm{~B}-03$ $0.190 \mathrm{E}-03$ $131 \mathrm{E}-03$ $0.908 \mathrm{E}-04$ $0.687 \mathrm{E}-04$

$0.103 \mathrm{E}-03$ $0.495 \mathrm{E}-03$ $\begin{array}{lll}277.0 & -50.1 & 217.0\end{array}$ $\begin{array}{lll}251.5 & -51.1 & 217.0\end{array}$ $\begin{array}{lll}228.9 & -61.1 & 217.0\end{array}$ $\begin{array}{lll}010.6 & -52.3 & 217.0\end{array}$ $010.2 \quad-51.6 \quad 217.0$ $006.5 \quad-50.6 \quad 217.0$ $\begin{array}{lll}005.5 & -45.7 & 217.0 \\ 013.9 & -49.9 & 217.0\end{array}$ $013.9-49.9217 .0$ $\begin{array}{lll}358.6 & -43.9 & 217.0\end{array}$ $\begin{array}{lll}358.4 & -32.3 & 217.0\end{array}$ $\begin{array}{lll}031.1 & -59.1 & 217.0\end{array}$ $\begin{array}{lll}005.0 & -61.1 & 209.0\end{array}$ $005.6-47.4 \quad 209.0$ $\begin{array}{lll}005.6 & -47.4 & 209.0 \\ 0.77 .9 & 209.0\end{array}$ $\begin{array}{llll}359.1 & -35.9 & 209.0\end{array}$ $\begin{array}{llll}352.5 & -20.4 & 209.0\end{array}$ $029.0-08.5 \quad 209.0$ $\begin{array}{lll}342.3 & -09.3 & 209.0\end{array}$

RANGITIKEI RIVER SITE $153 \mathrm{~V}$

HEIGHT $=108 \mathrm{~m}$ (above bese of section) STRIKE=129 DIP=05

SAMPLE FIELD NO. TREAT. INIENSITY CDEC CINC Y-AZ PLUNGE

R153321.1 R2-3883.1 N00 R153321.1 R2-3883.1 T05 R153321.1 R2-3883.1 T10 R153321.1 R2-3883.1 TIS R153321.1 R2-3883.1 T20 R153321.1 R2-3883.1 T2 R153321.1 R2-3883.1 T30 R153321.2 R2-3883.2 N00 $\begin{array}{lll}R & 153322.1 & R 2-3884.1 \\ N\end{array}$ R153322.1 R2-3884.1 T05 R153322.1 R2-3884.1 T10 R153322.1 R2-3884.1 T1S R153322.1 R2-3884.1 T20 R153322.1 R2-3884.1 T25 R153322.1 R2-3884.1 T30 R153322.2 R2-3884.2 NOO R153323.1 R2-3885.1 NOO R153323.1 R2-3885.1 T05 R153323.1 R2-3885.1 T10 R153323.1 R2-3885.1 T1 R153323.1 R2-3885.1 T20 R153323.1 R2-3885.1 T25 R153323.1 R2-3885.1 T30 $\begin{array}{lllll}0.540 \mathrm{E}-03 & 317.9 & -49.4 & 353.0 & 46.5 \\ 0.482 \mathrm{E}-03 & 322.2 & -48.2 & 353.0 & 46.5 \\ 0.356 \mathrm{E}-03 & 316.2 & -48.0 & 353.0 & 46.5 \\ 0.150 \mathrm{E}-03 & 292.7 & -57.8 & 353.0 & 46.5 \\ 0.108 \mathrm{E}-03 & 271.7 & -64.1 & 353.0 & 46.5 \\ 0.904 \mathrm{E}-04 & 291.5 & -18.0 & 353.0 & 46.5 \\ 0.109 \mathrm{E}-03 & 306.8 & -30.0 & 353.0 & 46.5 \\ 0.468 \mathrm{E}-03 & 318.9 & -41.6 & 353.0 & 46.5 \\ 0.343 \mathrm{E}-03 & 032.0 & -46.1 & 359.0 & 46.5 \\ 0.292 \mathrm{E}-03 & 040.3 & -51.3 & 359.0 & 46.5 \\ 0.112 \mathrm{E}-03 & 062.4 & -46.7 & 359.0 & 46.5 \\ 0.751 \mathrm{E}-04 & 066.6 & -41.7 & 359.0 & 46.5 \\ 0.706 \mathrm{E}-04 & 066.6 & -32.9 & 359.0 & 46.5 \\ 0.571 \mathrm{E}-04 & 085.2 & -36.0 & 359.0 & 46.5 \\ 0.533 \mathrm{E}-04 & 076.6 & -31.3 & 359.0 & 46.5 \\ 0.347 \mathrm{E}-03 & 027.6 & -62.6 & 359.0 & 46.5 \\ 0.405 \mathrm{E}-03 & 007.3 & -54.1 & 349.0 & 47.0 \\ 0.352 \mathrm{E}-03 & 012.1 & -58.7 & 349.0 & 47.0 \\ 0.256 \mathrm{E}-03 & 009.4 & -55.1 & 349.0 & 47.0 \\ 0.125 \mathrm{E}-03 & 009.7 & -56.4 & 349.0 & 47.0 \\ 0.796 \mathrm{E}-04 & 013.4 & -68.4 & 349.0 & 47.0 \\ 0.616 \mathrm{E}-04 & 343.3 & -51.4 & 349.0 & 47.0 \\ 0.346 \mathrm{E}-04 & 327.0 & -47.3 & 349.0 & 47.0 \\ 0.413 \mathrm{E}-03 & 358.8 & -63.0 & 349.0 & 47.0 \\ & & & & \end{array}$ RANGITIKEI RIVER STTE $154 \mathrm{~V}$ HEIGHT $=144 \mathrm{~m}$ (above bese of section) STRIKE $=136$ DIP $=04$ SAMPLE FIELD NO. TREAT. INTENSITY CDEC CINC Y-AZ PLUNGE

R154324.1 R2-3677.1 N00 R154324.1 R2-3677.1 T05 R154324.1 R2-3677.1 T10 R154324.1 R2-3677.1 Tis R154324.1 R2-3677.1 T20 R154324.1 R2-3677.1 T2 R154324.1 R2-3677.1 T30 R154324.2 R2-3677.2 N00 R154325.1 R2-3678.1 N00 R154325.1 R2-3678.1 TOS R154325.1 R2-3678.1 T10 R154325.1 R2-3678.1 T1S $\begin{array}{llll}R & 154325.1 & R 2-3678.1 & T 20\end{array}$ R154325.1 R2-3678.1 T25 $R 154325.1 \quad R 2-3678.1 \quad T 30$ R154325.2 R2-3678.2 N00 R154326.1 R2-3679.1 NOO R154326.1 R2-3679.1 TOS R154326.1 R2-3679.1 T10 R154326.1 R2-3679.1 T15 R154326.1 R2-3679.1 T20 R154326.1 R2-3679.1 T2 R154326.1 R2-3679.1 T30 R154326.2 R2-3679.2 N00

$\begin{array}{lllll}0.303 \mathrm{E}-03 & 009.0 & -43.0 & 025.0 & 59.5 \\ 0.231 \mathrm{E}-03 & 010.7 & -50.5 & 025.0 & 59.5 \\ 0.151 \mathrm{E}-03 & 012.7 & -47.0 & 025.0 & 59.5 \\ 0.797 \mathrm{E}-04 & 014.2 & -47.7 & 025.0 & 59.5 \\ 0.526 \mathrm{E}-04 & 001.1 & -28.3 & 025.0 & 59.5 \\ 0.272 \mathrm{E}-04 & 224.5 & -22.1 & 025.0 & 59.5 \\ 0.334 \mathrm{E}-04 & 038.8 & -25.3 & 025.0 & 59.5 \\ 0.244 \mathrm{E}-03 & 014.1 & -57.7 & 025.0 & 59.5 \\ 0.253 \mathrm{E}-03 & 030.5 & -44.6 & 023.0 & 59.5 \\ 0.204 \mathrm{E}-03 & 034.6 & -48.0 & 023.0 & 59.5 \\ 0.123 \mathrm{E}-03 & 040.6 & -42.9 & 023.0 & 59.5 \\ 0.611 \mathrm{E}-04 & 047.6 & -13.9 & 023.0 & 59.5 \\ 0.496 \mathrm{E}-04 & 066.4 & -00.6 & 023.0 & 59.5 \\ 0.428 \mathrm{E}-04 & 076.9 & 18.8 & 023.0 & 59.5 \\ 0.319 \mathrm{E}-04 & 107.0 & 26.6 & 023.0 & 59.5 \\ 0.230 \mathrm{E}-03 & 040.1 & -58.1 & 023.0 & 59.5 \\ 0.460 \mathrm{E}-03 & 004.7 & -62.3 & 023.0 & 59.5 \\ 0.406 \mathrm{E}-03 & 359.7 & -61.8 & 023.0 & 59.5 \\ 0.162 \mathrm{E}-03 & 357.7 & -69.7 & 023.0 & 59.5 \\ 0.125 \mathrm{E}-03 & 348.4 & -65.9 & 023.0 & 59.5 \\ 0.819 \mathrm{E}-04 & 052.1 & -56.5 & 023.0 & 59.5 \\ 0.141 \mathrm{E}-04 & 018.6 & -09.3 & 023.0 & 59.5 \\ 0.146 \mathrm{E}-04 & 091.9 & -55.6 & 023.0 & 59.5 \\ 0.503 \mathrm{E}-03 & 047.4 & -69.3 & 023.0 & 59.5\end{array}$

RANGITIKEI RIVER SITE $155 \mathrm{~V}$

HEIGHT $=153 \mathrm{~m}$ (above base of section) STRIKE=136 $\mathrm{DIP}=04$

SAMPLE FIELD NO. TREAT. INTENSITY CDEC CINC Y-AZ PLUNGE

R155327.1 R2-3271.1 N00 R155327.1 R2-3271.1 TOS R155327.1 R2-3271.1 T10 R155327.1 R2-3271.1 T15 R155327.1 R2-3271.1 T20 R155327.1 R2-3271.1 T25 $\begin{array}{llll}R & R 5327.1 & R 2-3271.1 & T 30\end{array}$ R155327.2 R2-3271.2 N00 R155328.1 R2-3272.1 N00 R155328.1 R2-3272.1 T05 R155328.1 R2-3272.1 T10 R155328.1 R2-3272.1 T15 $\begin{array}{llll}R & 155328.1 & R 2-3272.1 & T 20\end{array}$ R155328.1 R2-3272.1 T2 R155328.1 R2-3272.1 T30 R155328.2 R2-3272.2 N0O
9.5

9.5 59.5 29.5 9.5 59.5 9.5 .5 9.5 59.5
9.5
59.5

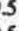
59.5
59.5 9.5 5.5
59.5 59.5 9.5

$\begin{array}{lllll}0.592 \mathrm{E}-03 & 001.8 & -63.5 & 038.0 & 62.5 \\ 0.409 \mathrm{E}-03 & 006.8 & -52.3 & 038.0 & 62.5 \\ 0.288 \mathrm{E}-03 & 360.0 & -51.6 & 038.0 & 62.5 \\ 0.174 \mathrm{E}-03 & 000.2 & -44.7 & 038.0 & 62.5 \\ 0.804 \mathrm{E}-04 & 339.8 & -33.2 & 038.0 & 62.5 \\ 0.743 \mathrm{E}-04 & 313.3 & -20.3 & 038.0 & 62.5 \\ 0.924 \mathrm{E}-04 & 172.0 & -54.6 & 038.0 & 62.5 \\ 0.596 \mathrm{E}-03 & 355.3 & -70.9 & 038.0 & 62.5 \\ 0.581 \mathrm{E}-03 & 015.6 & -61.5 & 047.0 & 61.0 \\ 0.384 \mathrm{E}-03 & 023.6 & -52.0 & 047.0 & 61.0 \\ 0.255 \mathrm{E}-03 & 026.8 & -51.6 & 047.0 & 61.0 \\ 0.148 \mathrm{E}-03 & 029.2 & -43.0 & 047.0 & 61.0 \\ 0.119 \mathrm{E}-03 & 014.9 & -47.4 & 047.0 & 61.0 \\ 0.116 \mathrm{E}-03 & 016.3 & -43.6 & 047.0 & 61.0 \\ 0.123 \mathrm{E}-03 & 006.6 & -26.0 & 047.0 & 61.0 \\ 0.650 \mathrm{E}-03 & 358.8 & -74.0 & 047.0 & 61.0\end{array}$

RANGITIKEI RIVER SITE $156 \mathrm{~V}$

HEIGHT $=166 \mathrm{~m}$ (above base of section) STRIKE=136 DIP=04

SAMPLE FELDNO. TREAT. INTENSITY CDEC CINC Y-AZ PLUNGE

R156329.1 R2-3780.1 T05

R156329.1 R2-3780.1 T10 0.808 E-04

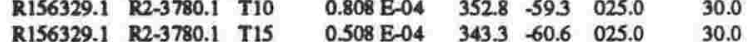

$\begin{array}{llllllll}\text { R156329.1 } & \text { R2-3780.1 } & \text { T15 } & 0.508 \text { E-04 } & 343.3 & -60.6 & 025.0 & 30.0 \\ \text { R156329.1 } & \text { R2-3780.1 } & \text { T20 } & 0.570 \text { E-04 } & 338.3 & -57.6 & 025.0 & 30.0\end{array}$

$\begin{array}{lllllllll}\text { R156329.1 } & \text { R2-3780.1 } & \text { T20 } & 0.570 \mathrm{E}-04 & 338.3 & -57.6 & 025.0 & 30.0 \\ \text { R156329.1 } & \text { R2-3780.1 } & \text { T25 } & 0.589 \mathrm{E}-04 & 321.3 & -21.3 & 025.0 & 30.0\end{array}$

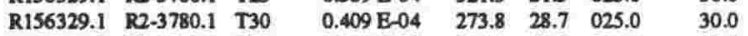

$\begin{array}{llllllll}R 156329.2 & R 2-3780.2 & \text { N00 } & 0.338 \text { E-03 } & 076.1 & -49.2 & 025.0 & 30.0\end{array}$

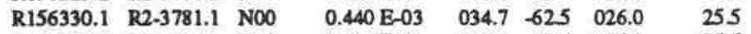

$\begin{array}{llllllll}R 156330.1 & R 2-3781.1 & \text { T05 } & 0.396 \mathrm{E}-03 & 036.8 & -62.6 & 026.0 & 25.5\end{array}$

$\begin{array}{lllllllll}\text { R156330.1 R2-3781.1 T10 } & 0.270 & \text { E-03 } & 037.0 & -63.7 & 026.0 & 25.5\end{array}$

$\begin{array}{llllllll}\text { R156330.1 R2-3781.1 T15 } & 0.147 \mathrm{E}-03 & 078.3 & -75.3 & 026.0 & 25.5\end{array}$

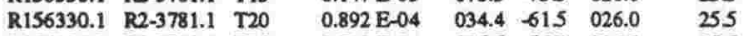

\begin{tabular}{llllllll}
$R 156330.1$ & $R 2-3781.1$ & T25 & $0.702 \mathrm{E}-04$ & 095.5 & -56.0 & 026.0 & 25.5 \\
\hline
\end{tabular}

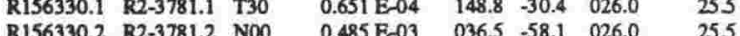

$\begin{array}{lllllllll}\text { R156330.2 } & \text { R2-3781.2 } & \text { N00 } & 0.485 \mathrm{E}-03 & 036.5 & -58.1 & 026.0 & 25.5 \\ \text { R156331.1 } & \text { R2-3782.1 } & \text { N00 } & 0.480 \mathrm{E}-03 & 026.1 & -52.7 & 027.0 & 27.5\end{array}$

$\begin{array}{llllllll}R 156331.1 & \text { R2-3782.1 } & \text { N00 } & 0.480 \text { E-03 } & 026.1 & -52.7 & 027.0 & 27.5 \\ \text { R156331.1 } & \text { R2-3782.1 } & \text { T05 } & 0.410 \text { E-03 } & 027.9 & -57.9 & 027.0 & 27.5\end{array}$

$\begin{array}{llllllll}R 156331.1 & \text { R2-3782.1 } & \text { T10 } & 0.212 \mathrm{E}-03 & 038.9 & -59.9 & 027.0 & 27.5\end{array}$

$\begin{array}{llllllll}R 156331.1 & R 2-3782.1 & \text { T15 } & 0.138 \mathrm{E}-03 & 034.4 & -56.8 & 027.0 & 27.5\end{array}$

$\begin{array}{llllllll}\text { R156331.1 } & \text { R2-3782.1 } & \text { T20 } & 0.119 \text { E-03 } & 075.9 & -62.0 & 027.0 & 275 \\ \text { R156331. } & \text { R2-3782 } & \text { T25 } & 0.118 \text { E-03 } & 082.0 & -54.9 & 027.0 & 27.5\end{array}$

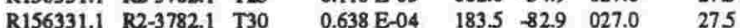

$\begin{array}{llllllll}\text { R156331.2 R2-3782.2 N00 } & 0.475 \text { E-03 } & 017.2 & -48.9 & 027.0 & 275\end{array}$

RANGITIKEI RIVER SITE $157 \mathrm{~V}$

HEIGHT $m 170 \mathrm{~m}$ (above base of section) STRIKE=136 DIP=05

SAMPLE FIRDDNO, TREAT. INTENSITY CDEC CINC Y-AZ PLUNGE

R157332.1 R2-3474.1 N00 R157332.1 R2-3474.1 TOS R157332.1 R2-3474.1 T10 R157332.1 R2-3474.1 T15 $\begin{array}{lll}\text { R157332.1 R2-3474.1 T20 } & \text { R }\end{array}$ R157332.1 R2-3474.1 T25 $\begin{array}{lll}R & 157332.1 & \text { R2-3474.1 T30 }\end{array}$ $\begin{array}{lll}R 157332.2 & \text { R2-3474.2 N00 }\end{array}$ $\begin{array}{llll}R & 157333.1 & R 2-3475.1 \quad N O 0\end{array}$ R157333.1 R2-3475.1 T05 R157333.1 R2-3475.1 T10 R157333.1 R2-3475.1 T15 R157333.1 R2-3475.1 T20 R157333.1 R2-3475.1 T2S $\begin{array}{llll}R & 157333.1 & R 2-3475.1 & T 30\end{array}$ R157333.2 R2-3475.2 N0O R157334.1 R2-3476.1 N00 R157334.1 R2-3476.1 TOS R157334.1 R2-3476.1 T10 R157334.1 R2-3476.1 T15 R157334.1 R2-3476.1 T20 R157334.1 R2-3476.1 T25 R1573341 R2-3476.1 T30

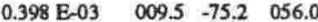
$0.276 \mathrm{E}-03$

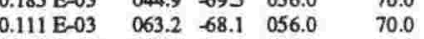

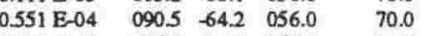

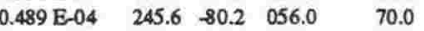
$\begin{array}{lllll}0.428 \text { E- } 04 & 238.1 & -71.4 & 056.0 & 70.0\end{array}$

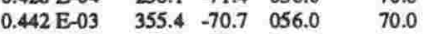
$\begin{array}{lllll}0.429 \mathrm{E}-03 & 007.0 & -61.4 & 068.0 & 72.5\end{array}$ $\begin{array}{lllll}0.319 \mathrm{E}-03 & 009.0 & -57.6 & 068.0 & 725\end{array}$ $\begin{array}{llllll}0.202 \mathrm{E}-03 & 014.0 & -57.2 & 068.0 & 725\end{array}$

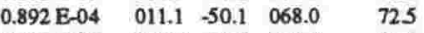

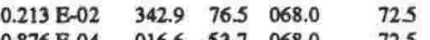
$\begin{array}{lllll}0.876 \mathrm{E}-04 & 016.6 & -53.7 & 068.0 & 72.5\end{array}$

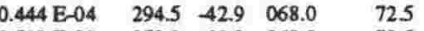
$\begin{array}{lllll}0.513 \mathrm{E}-03 & 359.3 & -69.2 & 068.0 & 72.5\end{array}$ $\begin{array}{lllll}0.452 \mathrm{E}-03 & 026.2 & -55.8 & 060.0 & 71.5\end{array}$

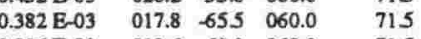
$\begin{array}{lllll}0.286 \mathrm{E}-03 & 019.6 & -63.0 & 060.0 & 71.5 \\ 0.173 \mathrm{E}-03 & 0228 & -61.9 & 060.0 & 715\end{array}$ $\begin{array}{lllll}0.132 \mathrm{E}-03 & 359.0 & -65.1 & 060.0 & 715\end{array}$ $\begin{array}{lllll}0.784 \mathrm{E}-04 & 052.1 & -44.8 & 060.0 & 715\end{array}$ $\begin{array}{lllll}0.784 \mathrm{E}-04 & 052.1 & -44.8 & 060.0 & 715 \\ 0.586 \mathrm{E}-04 & 289.7 & -56.6 & 060.0 & 715\end{array}$

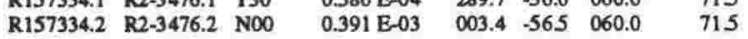

RANGITIKEI RIVER SITE $160 \mathrm{~V}$

HEIGHT $=221 \mathrm{~m}$ (above base of section) STRIKE=121 DIP=06

SAMPLE FIELDNO. TREAT. INTENSITY CDEC CINC Y-AZ PLUNGE

\begin{tabular}{|c|c|c|c|c|c|c|c|}
\hline R160335.1 & R2-4301.1 & NOO & 0.402 E- 03 & 034.7 & -52.9 & 121.0 & 56.5 \\
\hline R160335.1 & R2-4301.1 & T05 & 0.349 E- 03 & 024.3 & -55.0 & 121.0 & 56.5 \\
\hline R160335.1 & $R 2-4301.1$ & T10 & 0.253 E- 03 & 039.8 & -54.8 & 121.0 & 565 \\
\hline R160335.1 & R2-4301.1 & $\mathrm{T} 15$ & $0.135 \mathrm{E}-03$ & 044.1 & -36.6 & 121.0 & 56.5 \\
\hline R160335.1 & R2-4301.1 & $\mathrm{T} 20$ & $0.961 \mathrm{E}-04$ & 045.4 & -315 & 121.0 & 565 \\
\hline R 160335.1 & R2-4301.1 & T25 & $0.934 \mathrm{E}-04$ & 127.3 & -50.5 & 121.0 & 56.5 \\
\hline R160335.1 & R2-4301.1 & T30 & $0.117 \mathrm{E}-03$ & 083.6 & -08.7 & 121.0 & 565 \\
\hline R160335.2 & R2-4301.2 & NOO & 0.348 E-03 & 327.6 & -41.1 & 121.0 & 565 \\
\hline R160336.1 & R2-4302.1 & NOO & $0.512 \mathrm{E}-03$ & 012.6 & -59.6 & 118.0 & 545 \\
\hline R160336.1 & R2-4302.1 & T05 & 0.421 E- -03 & 016.9 & -53.6 & 118.0 & 54.5 \\
\hline R160336.1 & R2-4302.1 & T10 & $0.268 \mathrm{E}-03$ & 020.0 & -51.9 & 118.0 & 54.5 \\
\hline R160336.1 & R2-4302.1 & T15 & 0.175 E-03 & 047.8 & -47.7 & 118.0 & 545 \\
\hline R160336.1 & $R 2-4302.1$ & $\mathrm{~T} 20$ & 0.145 E-03 & 048.3 & -425 & 118.0 & 54.5 \\
\hline R160336.1 & $R 2-4302.1$ & T25 & 0.720 E-04 & 062.7 & -17.0 & 118.0 & 54.5 \\
\hline R160336.1 & R2-4302.1 & T30 & $0.424 \mathrm{E}-04$ & 040.1 & -40.2 & 118.0 & 545 \\
\hline R160336.2 & $R 2-4302.2$ & NoO & $0.565 \mathrm{E}-03$ & 000.7 & -64.7 & 118.0 & 545 \\
\hline R160337.1 & R2-4303.1 & NoO & $0.484 \mathrm{E}-03$ & 005.9 & -56.1 & 122.0 & 56.0 \\
\hline R160337.1 & R2 -4303.1 & T05 & 0.377 E- 03 & 014.2 & -49.7 & 122.0 & 56.0 \\
\hline R160337.1 & R2-4303.1 & $\mathrm{T} 10$ & 0.237 E -03 & 011.2 & -48.8 & 122.0 & 56.0 \\
\hline R160337.1 & R2-4303.1 & T15 & 0.137 B- -03 & 021.3 & -37.0 & 122.0 & 56.0 \\
\hline R160337.1 & R2-4303.1 & $\mathrm{T} 20$ & 0.919 E-04 & 039.8 & -00.6 & 122.0 & 56.0 \\
\hline R160337.1 & R2.-4303.1 & T25 & 0.131 E-03 & 001.7 & -00.9 & 122.0 & 56.0 \\
\hline R160337.1 & R2-4303.1 & T30 & 0.757 E- -04 & 327.1 & 21.2 & 122,0 & 56.0 \\
\hline & & & & & -71.6 & 122.0 & 56.0 \\
\hline
\end{tabular}

\section{RANGTTIKEI RIVER SITE $162 \mathrm{~V}$}

HEIGHT $=323 \mathrm{~m}$ (above base of section) STRIKE=121 DIP=09

SAMPLE FELDNO. TREAT. INTENSITY CDEC CINC Y-AZ PLUNGE

R162338.1 R2-3168.1 N00 R162338.1 R2-3168.1 T05

R162338.1 R2-3168.1 T10

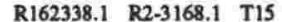

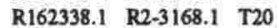
R162338.1 R2-3168.1 T25 $\begin{array}{lll}R 162338.1 & \text { R2-3168.1 T30 }\end{array}$ R162338.2 R2-3168.2 N00

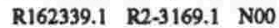
R162339.1 R2-3169.1 T05

$\begin{array}{lllll}0.844 \mathrm{E}-03 & 023.0 & -66.6 & 308.0 & 55.5 \\ 0.623 \mathrm{E}-03 & 005.7 & -53.8 & 308.0 & 55.5 \\ 0.416 \mathrm{E}-03 & 000.4 & -48.4 & 308.0 & 55.5 \\ 0.267 \mathrm{E}-03 & 359.5 & -42.2 & 308.0 & 55.5 \\ 0.213 \mathrm{E}-03 & 352.3 & -36.6 & 308.0 & 55.5 \\ 0.149 \mathrm{E}-03 & 008.0 & -44.1 & 308.0 & 55.5 \\ 0.120 \mathrm{E}-03 & 002.7 & -39.8 & 308.0 & 55.5 \\ 0.927 \mathrm{E}-03 & 006.1 & -55.7 & 308.0 & 55.5 \\ 0.791 \mathrm{E}-03 & 025.0 & -66.0 & 312.0 & 56.5 \\ 0.530 \mathrm{E}-03 & 014.2 & -57.2 & 312.0 & 56.5 \\ 0.284 \mathrm{E}-03 & 007.4 & -58.1 & 312.0 & 56.5\end{array}$ R162339.1 R2-3169.1 T10
56.5
56.5
565
56.5
56.5
56.5
565
565
545
54.5
54.5
54.5
54.5
545
54.5
545
56.0
56.0
56.0
56.0
56.0
56.0
56.0
56.0 

$R 162340.1 \quad R 2-3170.1 \quad T 10$

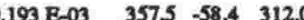
$\begin{array}{lllll}0.540 \mathrm{E}-04 & 120.7 & -37.9 & 312.0\end{array}$ $\begin{array}{lllll}0.746 \mathrm{E}-03 & 037.4 & -613 & 311.0\end{array}$ $\begin{array}{llllll}0.302 \mathrm{E}-03 & 035.5 & -50.9 & 311.0\end{array}$ $0.184 \mathrm{~B}-03 \quad 047.5-44.0 \quad 311.0$ $0.112 \mathrm{E}-03 \quad 057.7 \quad-37.6 \quad 311.0$ $\begin{array}{llll}0.140 \mathrm{E}-03 & 025.2 & -41.2 & 311.0\end{array}$ $\begin{array}{lllll}0.113 & \mathrm{E}-03 & 037.6 & -19.3 & 311.0\end{array}$

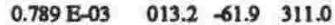
$\begin{array}{lllll}0.538 & \mathrm{E}-03 & 027.7 & -54.3 & 311.0\end{array}$
R162339.1 R2-3169.1 T15 R162339.1 R2-3169.1 T20 R162339.1 R2-3169.1 T2S $\begin{array}{lll}R 162339.1 & R 2-3169.1 & \text { T30 }\end{array}$ R162339.2 R2-3169.2 N00 R162340.1 R2-3170.1 N00 R162340.1 R2-3170.1 T05 R162340.1 R2-3170.1 T15 R162340.1 R2-3170.1 T20 R162340.1 R2-3170.1 T25 R162340.1 R2-3170.1 T30

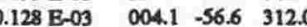
$\begin{array}{lllll}0.265 \text { E- } 04 \quad 262.6 & -38.0 & 312.0\end{array}$ $\begin{array}{lllll}0.751 \mathrm{E}-03 & 022.4 & -68.0 & 312.0\end{array}$

RANGITIKEI RIVER SIIE 163V

HEIGHT $=421 \mathrm{~m}$ (above base of section) STRIKE=121 DIP $=09$

SAMPLE FIELDNO. TREAT. INTENSITY CDEC CINC Y-AZ PLUNGE

R163341.1 R2-2962.1 N00 R163341.1 R2-2962.1 T05 R163341.1 R2-2962.1 T10 R163341.1 R2-2962.1 T15 R163341.1 R2-2962.1 T25 R163341.1 R2-2962.1 T30 R163341.2 R2-2962.2 N00 R163342.1 R2-2963.1 N00 R1633421 R2-2963.1 T05 R163342.1 R2-2963.1 T10 R163342.1 R2-2963.1 T1 R163342.1 R2-2963.1 T20 R163342.1 R2-2963.1 T25 R163342.1 R2-2963.1 T30 R163342.2 R2-2963.2 NOO R163343.1 R2-2964.1 NOO R163343.1 R2-2964.1 T0S R163343.1 R2-2964.1 T15 R163343.1 R2-2964.1 T20 R163343.1 R2-2964.1 T25 R163343.1 R2-2964.1 T30 R163343.2 R2-2964.2 NOD

$\begin{array}{lllll}0.114 \mathrm{E}-02 & 117.2 & -48.2 & 029.0 & 18.5 \\ 0.529 \mathrm{E}-03 & 358.9 & -52.8 & 029.0 & 18.5 \\ 0.377 \mathrm{E}-03 & 351.5 & -53.7 & 029.0 & 18.5 \\ 0.198 \mathrm{E}-03 & 345.9 & -41.9 & 029.0 & 18.5 \\ 0.138 \mathrm{E}-03 & 343.9 & -34.5 & 029.0 & 18.5 \\ 0.488 \mathrm{E}-04 & 056.8 & -48.1 & 029.0 & 18.5 \\ 0.715 \mathrm{E}-04 & 222.5 & 84.8 & 029.0 & 18.5 \\ 0.428 \mathrm{E}-03 & 346.7 & -59.1 & 029.0 & 18.5 \\ 0.442 \mathrm{E}-03 & 011.8 & -39.6 & 032.0 & 17.5 \\ 0.410 \mathrm{E}-03 & 018.1 & -36.4 & 032.0 & 17.5 \\ 0.284 \mathrm{E}-03 & 016.2 & -27.6 & 032.0 & 17.5 \\ 0.159 \mathrm{E}-03 & 014.3 & -16.4 & 032.0 & 17.5 \\ 0.181 \mathrm{E}-03 & 020.0 & 08.4 & 032.0 & 17.5 \\ 0.136 \mathrm{E}-03 & 053.1 & -25.4 & 032.0 & 17.5 \\ 0.208 \mathrm{E}-03 & 022.3 & 00.3 & 032.0 & 17.5 \\ 0.466 \mathrm{E}-03 & 019.5 & -51.9 & 032.0 & 17.5 \\ 0.471 \mathrm{E}-03 & 303.9 & -71.6 & 032.0 & 16.5 \\ 0.486 \mathrm{E}-03 & 333.5 & -73.9 & 032.0 & 16.5 \\ 0.361 \mathrm{E}-03 & 282.4 & -74.2 & 032.0 & 16.5 \\ 0.262 \mathrm{E}-03 & 248.1 & -65.5 & 032.0 & 16.5 \\ 0.188 \mathrm{E}-03 & 243.3 & -48.2 & 032.0 & 16.5 \\ 0.131 \mathrm{E}-03 & 184.5 & -07.9 & 032.0 & 16.5 \\ 0.172 \mathrm{E}-03 & 155.3 & -12.3 & 032.0 & 16.5 \\ 0.477 \mathrm{E}-03 & 042.3 & -64.3 & 032.0 & 16.5\end{array}$
R163341.1 R2-2962.1 T20 R163343.1 R2-2964.1 T10
RANGITIKEI RIVER SITE 164 V

HEIGHT $=455 \mathrm{~m}$ (above base of section) STRIKE $=121 \mathrm{DIP}=09$

SAMPLE FIELDNO. TREAT. INTENSITY CDEC CINC Y-AZ PLUNG

R164344.1 R2-3065.1 N00 R164344.1 R2-3065.1 T05 R164344.1 R2-3065.1 T10 R164344.1 R2-3065.1 T15 R164344.1 R2-3065.1 T20 R164344.1 R2-3065.1 T25 R164344.1 R2-3065.1 T30 R164344.2 R2-3065.2 N00 R164345.1 R2-3066.1 NOO R164345.1 R2-3066.1 TOS R164345.1 R2-3066.1 T10 R164345.1 R2-3066.1 T15 R164345.1 R2-3066.1 T20 R164345.1 R2-3066.1 T25 R164345.1 R2-3066.1 T30 R164345.2 R2-3066.2 NOO R164346.1 R2-3067.1 NOO R164346.1 R2-3067.1 T05 R164346.1 R2-3067.1 T10 R164346.1 R2-3067.1 T15 R164346.1 R2-3067.1 T20 R164346.1 R2-3067.1 T25 R164346.1 R2-3067.1 T30 R164346.2 R2-3067.2 NOO

$\begin{array}{lllll}0.823 \mathrm{E}-03 & 008.3 & -63.3 & 225.0 & 36.0 \\ 0.493 \mathrm{E}-03 & 016.3 & -62.5 & 225.0 & 36.0 \\ 0.339 \mathrm{E}-03 & 007.7 & -67.9 & 225.0 & 36.0 \\ 0.198 \mathrm{E}-03 & 324.6 & -78.4 & 225.0 & 36.0 \\ 0.167 \mathrm{E}-03 & 249.5 & -85.1 & 225.0 & 36.0 \\ 0.106 \mathrm{E}-03 & 014.5 & -53.2 & 225.0 & 36.0 \\ 0.347 \mathrm{E}-04 & 015.1 & -09.0 & 225.0 & 36.0 \\ 0.742 \mathrm{E}-03 & 010.4 & -50.3 & 225.0 & 36.0 \\ 0.774 \mathrm{E}-03 & 004.7 & -54.6 & 222.0 & 39.5 \\ 0.462 \mathrm{E}-03 & 008.0 & -52.3 & 222.0 & 39.5 \\ 0.241 \mathrm{E}-03 & 005.8 & -51.3 & 222.0 & 39.5 \\ 0.116 \mathrm{E}-03 & 012.2 & -44.6 & 222.0 & 39.5 \\ 0.844 \mathrm{E}-04 & 087.7 & -14.3 & 222.0 & 39.5 \\ 0.576 \mathrm{E}-04 & 134.8 & 40.0 & 222.0 & 39.5 \\ 0.934 \mathrm{E}-04 & 299.9 & -13.2 & 222.0 & 39.5 \\ 0.773 \mathrm{E}-03 & 016.2 & -40.6 & 222.0 & 39.5 \\ 0.682 \mathrm{E}-03 & 344.8 & -54.3 & 229.0 & 37.5 \\ 0.406 \mathrm{E}-03 & 002.2 & -55.4 & 229.0 & 37.5 \\ 0.257 \mathrm{E}-03 & 354.0 & -48.5 & 229.0 & 37.5 \\ 0.148 \mathrm{E}-03 & 349.5 & -38.4 & 229.0 & 37.5 \\ 0.438 \mathrm{E}-04 & 320.6 & -26.0 & 229.0 & 37.5 \\ 0.181 \mathrm{E}-03 & 314.1 & -01.6 & 229.0 & 37.5 \\ 0.597 \mathrm{E}-04 & 359.2 & 30.9 & 229.0 & 37.5 \\ 0.754 \mathrm{E}-03 & 354.7 & -59.0 & 229.0 & 37.5\end{array}$

RANGITIKEI RIVER SITE $165 \mathrm{~V}$

HEIGHT $=489 \mathrm{~m}$ (above base of section) STRIKE $=121$ DIP $=09$

SAMPLE FIELD NO. TREAT. INTENSITY CDEC CINC Y-AZ PLUNGE

R165347.1 R2-2859.1 NOO R165347.1 R2-2859.1 T05 R165347.1 R2-2859.1 T10 R165347.1 R2-2859.1 T15 R165347.1 R2-2859.1 T20 R165347.1 R2-2859.1 T25 R165347.1 R2-2859.1 T30 R165348.1 R2-2860.1 NOO R165348.1 R2-2860.1 T05 R165348.1 R2-2860.1 T10 R165348.1 R2-2860.1 T15 R165348.1 R2-2860.1 T20 R165348.1 R2-2860.1 T2 R165348.1 R2-2860.1 T30 R165348.2 R2-2860.2 NOO R165349.1 R2-2861.1 NOO R165349.1 R2-2861.1 T05 R165349.1 R2-2861.1 T10 R165349.1 R2-2861.1 T15 R165349.1 R2-2861.1 T20 R165349.1 R2-2861.1 T2 R165349.1 R2-2861.1 T30 R165349.2 R2-2861.2 N00 R165347.2 R2-2859.2 NOO

$\begin{array}{lllll}0.188 \mathrm{E}-02 & 187.1 & 59.2 & 350.0 & 39.5 \\ 0.176 \mathrm{E}-02 & 189.2 & 57.6 & 350.0 & 39.5 \\ 0.171 \mathrm{E}-02 & 187.4 & 59.3 & 350.0 & 39.5 \\ 0.142 \mathrm{E}-02 & 190.3 & 53.9 & 350.0 & 39.5 \\ 0.100 \mathrm{E}-02 & 192.1 & 51.1 & 350.0 & 39.5 \\ 0.371 \mathrm{E}-03 & 196.9 & 39.6 & 350.0 & 39.5 \\ 0.182 \mathrm{E}-03 & 170.2 & 32.7 & 350.0 & 39.5 \\ 0.177 \mathrm{E}-02 & 178.8 & 58.4 & 350.0 & 39.5 \\ 0.220 \mathrm{E}-02 & 193.4 & 55.2 & 354.0 & 47.5 \\ 0.195 \mathrm{E}-02 & 192.8 & 53.4 & 354.0 & 47.5 \\ 0.188 \mathrm{E}-02 & 195.3 & 52.5 & 354.0 & 47.5 \\ 0.155 \mathrm{E}-02 & 195.8 & 51.0 & 354.0 & 47.5 \\ 0.915 \mathrm{E}-03 & 199.1 & 47.0 & 354.0 & 47.5 \\ 0.213 \mathrm{E}-03 & 240.7 & -10.3 & 354.0 & 47.5 \\ 0.300 \mathrm{E}-03 & 271.8 & -57.8 & 354.0 & 47.5 \\ 0.195 \mathrm{E}-02 & 190.9 & 54.1 & 354.0 & 47.5 \\ 0.189 \mathrm{E}-02 & 186.6 & 57.2 & 353.0 & 48.0 \\ 0.172 \mathrm{E}-02 & 185.3 & 58.5 & 353.0 & 48.0 \\ 0.163 \mathrm{E}-02 & 184.7 & 58.2 & 353.0 & 48.0 \\ 0.137 \mathrm{E}-02 & 188.4 & 56.5 & 353.0 & 48.0 \\ 0.891 \mathrm{E}-03 & 191.1 & 54.6 & 353.0 & 48.0 \\ 0.292 \mathrm{E}-03 & 193.9 & 46.2 & 353.0 & 48.0 \\ 0.129 \mathrm{E}-03 & 232.4 & 13.9 & 353.0 & 48.0 \\ 0.171 \mathrm{E}-02 & 175.1 & 63.6 & 353.0 & 48.0\end{array}$

39.5
39.5
39.5
39.5
39.5
39.5
39.5
39.5
47.5
47.5
47.5
47.5
47.5
47.5
47.5
47.5
48.0
48.0
48.0
48.0
48.0
48.0
48.0
48.0
RANGITHKEI RIVER SITE $167 \mathrm{~V}$

RIGITT $=653 \mathrm{~m}$ (ebove base of section) STRIKE=121 DIP=09

R167350.1 R2-2656.1 N00 R167350.1 R2.2656.1 TOS 2167350.1 R2-2656.1 T10 R167350.1 R2-2656.1 T15 R167350.1 R2-2656.1 T20 R167350.1 R2-2656.1 T25 R167350.1 R2-2656.1 T30 R167350.2 R2-2656.2 N00 R167351.1 R2-2657.1 N00 R167351.1 R2-2657.1 T05 R167351.1 R2-2657.1 T10

$\begin{array}{llll}0.458 \mathrm{E}-03 & 020.1 & -52.4 & 309.0\end{array}$ 225 $\begin{array}{lllll}0.286 \mathrm{E}-03 & 019.1 & -50.4 & 309.0 & 22.5\end{array}$ $\begin{array}{lllll}0.176 \mathrm{E}-03 & 009.5 & -47.1 & 309.0 & 22.5\end{array}$ $\begin{array}{lllll}0.162 \mathrm{E}-03 & 353.1 & -42.7 & 309.0 & 22.5\end{array}$ $\begin{array}{lllll}0.138 \mathrm{E}-03 & 324.8 & -34.8 & 309.0 & 22.5\end{array}$ $\begin{array}{lllll}0.856 \mathrm{~B}-04 & 288.9 & 09.9 & 309.0 & 22.5\end{array}$ $\begin{array}{lllll}0.390 \mathrm{E}-03 & 033.0 & -43.1 & 309.0 & 22.5\end{array}$ $\begin{array}{lllll}0.305 \mathrm{E}-03 & 359.7 & -45.6 & 308.0 & 24.0\end{array}$ $\begin{array}{lllll}0.260 \mathrm{E}-03 & 357.7 & -37.0 & 308.0 & 24.0 \\ 0.148 \mathrm{E}-03 & 345.5 & -22.7 & 308.0 & 24.0\end{array}$ $\begin{array}{rrrrr}0.148 \mathrm{E}-03 & 345.5 & -22.7 & 308.0 & 24.0 \\ 0.860 \mathrm{E}-04 & 336.5 & 07.5 & 308.0 & 24.0\end{array}$ $\begin{array}{llllllll}\text { R167351.1 } & \text { R2-2657.1 } & \text { T20 } & 0.116 \mathrm{E}-03 & 332.1 & 38.2 & 308.0 & 24.0 \\ \text { R167351.1 } & \text { R2-2657.1 } & \text { T25 } & 0.143 \mathrm{E}-03 & 342.1 & 34.5 & 308.0 & 24.0 \\ \text { R167351.1 } & \text { R2-2657.1 } & \text { T30 } & 0.637 \text { E-04 } & 054.4 & 30.9 & 308.0 & 24.0\end{array}$ $\begin{array}{llllllll}\text { R167351.1 } & \text { R2-2657.1 } & \text { T20 } & 0.116 \mathrm{E}-03 & 332.1 & 38.2 & 308.0 & 24.0 \\ \text { R167351.1 } & \text { R2-2657.1 } & \text { T25 } & 0.143 \mathrm{E}-03 & 342.1 & 34.5 & 308.0 & 24.0 \\ \text { R167351.1 } & \text { R2-2657.1 } & \text { T30 } & 0.637 \text { E-04 } & 054.4 & 30.9 & 308.0 & 24.0\end{array}$ $\begin{array}{lllllllll}\text { R167351.1 } & \text { R2-2657.1 } & \text { T30 } & 0.637 \text { E-04 } & 054.4 & 30.9 & 308.0 & 24.0 \\ \text { R167351.2 } & \text { R2-2657.2 } & \text { N00 } & 0.420 \text { E-03 } & 037.8 & -59.8 & 308.0 & 24.0\end{array}$

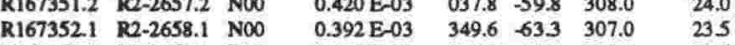
$\begin{array}{llllllll}R 167352.1 & R 2-2658.1 & N 00 & 0.392 \mathrm{E}-03 & 349.6 & -63.3 & 307.0 & 235 \\ \text { R167352.1 } & \text { R2-2658.1 } & \text { T05 } & 0.347 \mathrm{E}-03 & 348.0 & -61.3 & 307.0 & 23.5\end{array}$

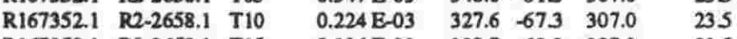
$\begin{array}{llllllll}R 167352.1 & \text { R2-2658.1 } & \text { T15 } & 0.126 \mathrm{E}-03 & 308.7 & -69.3 & 307.0 & 23.5 \\ \text { R1673521 } & \text { R2-2658.1 } & \text { T20 } & 0.914 \text { E-04 } & 233.9 & -72.8 & 307.0 & 23.5\end{array}$ $\begin{array}{lllllllll}\text { R167352.1 } & \text { R2-2658.1 } & \text { T20 } & 0.914 \mathrm{E}-04 & 233.9 & -72.8 & 307.0 & 23.5 \\ \text { R167352.1 } & \text { R2-2658.1 } & \text { T25 } & 0.127 \mathrm{E}-03 & 349.8 & -63.7 & 307.0 & 23.5\end{array}$

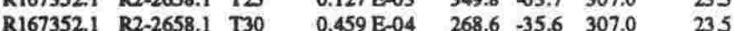
$\begin{array}{llllllll}\text { R167352.2 } & \text { R2-2658.2 NOO } & 0.374 \text { E-03 } & 022.4 & -63.5 & 307.0 & 23.5\end{array}$

RANGITIKEI RIVER SITE $169 \mathrm{~V}$

HEIGHT $=780 \mathrm{~m}$ (above base of section) STRIKE $=121 \mathrm{DIP}=09$

SAMPLE FIELD NO. TREAT. DNTENSITY CDEC CINC Y-AZ PLUNGE

$\begin{array}{llllllll}\text { R169353.1 } & \text { R2-2553.1 } & \text { N00 } & 0.443 \text { E-03 } & 004.8 & -52.1 & 240.0 & 20.0 \\ \text { R169353.1 } & \text { R2-2553.1 } & \text { T05 } & 0.399 \text { E-03 } & 003.6 & -51.4 & 240.0 & 20.0 \\ \text { R169353.1 } & \text { R2-2553.1 } & \text { T10 } & 0.219 \text { E-03 } & 341.2 & -15.9 & 240.0 & 20.0 \\ \text { R169353.1 } & \text { R2-2553.1 } & \text { T15 } & 0.155 \text { E-03 } & 355.0 & -49.6 & 240.0 & 20.0 \\ \text { R169353.1 } & \text { R2-2553.1 } & \text { T20 } & 0.103 \text { E-03 } & 348.2 & -51.4 & 240.0 & 20.0 \\ \text { R169353.1 } & \text { R2-2553.1 } & \text { T25 } & 0.711 \text { E-04 } & 045.9 & -61.7 & 240.0 & 20.0 \\ \text { R169353.1 } & \text { R2-2553.1 } & \text { T30 } & 0.135 \mathrm{E}-03 & 165.7 & -32.7 & 240.0 & 20.0 \\ \text { R169353.2 } & \text { R2-2553.2 } & \text { N00 } & 0.410 \mathrm{E}-03 & 350.4 & -53.1 & 240.0 & 20.0 \\ \text { R169354.1 } & \text { R2-2554.1 } & \text { N00 } & 0.657 \text { E-03 } & 022.1 & -46.6 & 243.0 & 21.0 \\ \text { R169354.1 } & \text { R2-2554.1 } & \text { T05 } & 0.561 \text { E-03 } & 021.8 & -49.4 & 243.0 & 21.0 \\ \text { R169354.1 } & \text { R2-2554.1 } & \text { T10 } & 0.417 \text { E-03 } & 027.4 & -48.1 & 243.0 & 21.0 \\ \text { R169354.1 } & \text { R2-2554.1 } & \text { T15 } & 0.277 \text { E-03 } & 037.2 & -48.7 & 243.0 & 21.0 \\ \text { R169354.1 } & \text { R2-2554.1 } & \text { T20 } & 0.290 \text { E-03 } & 047.6 & -46.6 & 243.0 & 21.0 \\ \text { R169354.1 } & \text { R2-2554.1 } & \text { T25 } & 0.937 \text { E-04 } & 357.5 & -45.4 & 243.0 & 21.0 \\ \text { R169354.1 } & \text { R2-2554.1 } & \text { T30 } & 0.939 \text { E-04 } & 047.4 & -35.9 & 243.0 & 21.0 \\ \text { R169354.2 } & \text { R2-2554.2 } & \text { N00 } & 0.414 \text { E-03 } & 355.9 & -42.5 & 243.0 & 21.0 \\ \text { R169355.1 } & \text { R2-2555.1 } & \text { N00 } & 0.315 \text { E-03 } & 034.7 & -46.3 & 244.0 & 18.5 \\ \text { R169355.1 } & \text { R2-2555.1 } & \text { T05 } & 0.271 \text { E-03 } & 034.0 & -47.6 & 244.0 & 18.5 \\ \text { R169355.1 } & \text { R2-2555.1 } & \text { T10 } & 0.115 \text { E-03 } & 056.1 & -42.4 & 244.0 & 18.5 \\ \text { R169355.1 } & \text { R2-2555.1 } & \text { T15 } & 0.655 \text { E-04 } & 083.8 & -28.8 & 244.0 & 18.5 \\ \text { R169355.1 } & \text { R2-2555.1 } & \text { T20 } & 0.126 \text { E-03 } & 050.1 & -03.8 & 244.0 & 18.5 \\ \text { R169355.1 } & \text { R2-2555.1 } & \text { T25 } & 0.163 \text { E-03 } & 146.3 & -16.5 & 244.0 & 18.5 \\ \text { R169355.1 } & \text { R2-2555.1 } & \text { T30 } & 0.310 \text { E-04 } & 306.6 & -13.8 & 244.0 & 18.5 \\ \text { R169355.2 } & \text { R2-2555.2 } & \text { N00 } & 0.396 \text { E-03 } & 030.0 & -45.9 & 244.0 & 18.5\end{array}$

RANGITIKEI RIVER SITE $171 \mathrm{~V}$

HEIGHT $=897 \mathrm{~m}$ (above base of section) STRIKE $=120 \mathrm{DIP}=08$

SAMPLE FIELDNO. TREAT. INTENSITY CDEC CINC Y-AZ PLUNGE

R171356.1 R2-2350.1 N00

$0.460 \mathrm{E}-03 \quad 026.7-63.7 \quad 320.0$

705

R171356.1 R2-2350.1 TO5

R171356.1 R2-2350.1 T10

$\begin{array}{llll}0.109 \mathrm{E}-03 & 005.0 & -74.2 & 320.0\end{array}$

0.595 E-04 $246.5 \quad 62.2 \quad 320.0$

$\begin{array}{llll}0.748 \mathrm{E}-0.04 & 265.5 & -54.9 & 320.0\end{array}$

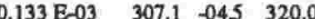

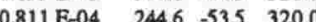

$\begin{array}{lllll}0.532 \mathrm{E}-03 & 037.2 & -68.1 & 320.0\end{array}$

$\begin{array}{lllll}0.396 & \mathrm{E}-03 & 042.1 & -63.0 & 316.0\end{array}$

$\begin{array}{lllll}0.115 \text { E-03 } & 070.6 & -61.7 & 316.0\end{array}$

$\begin{array}{lllll}0.961 & \text { E-04 } & 100.1 & -61.7 & 316.0\end{array}$

$\begin{array}{lllll}0.374 \mathrm{E}-04 & 117.5 & 44.6 & 316.0\end{array}$

$\begin{array}{lllll}0.594 \mathrm{E}-04 & 282.9 & -51.4 & 316.0\end{array}$

$0.407 \mathrm{E}-04 \quad 080.1 \quad-43.5 \quad 316.0$

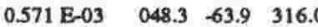

$\begin{array}{lllll}0.473 & \text { E- } 03 & 019.0 & -54.9 & 325.0\end{array}$

$\begin{array}{lllll}0.394 \mathrm{E}-03 & 019.9 & -51.0 & 325.0\end{array}$

$\begin{array}{lllll}0.154 \mathrm{E}-03 & 008.9 & -21.4 & 325.0\end{array}$

$\begin{array}{lllll}0.117 & \mathrm{E}-03 & 005.2 & -16.9 & 325.0\end{array}$

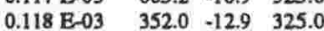

$\begin{array}{llllllll}\text { R171358.1 } & \text { R2-2352.1 } & \text { T25 } & 0.967 \text { E-04 } & 331.9 & -39.4 & 325.0 & 70.0 \\ \text { R171358.1 } & \text { R2-2352.1 } & \text { T30 } & 0.999 \text { E-04 } & 359.0 & -33.7 & 325.0 & 70.0\end{array}$

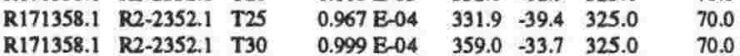

$\begin{array}{llll}0.506 \mathrm{E}-03 & 014.0 & -55.2 & 325.0\end{array}$

705

705

705

70.5

705
705
685

68.5

685

68.5

68.5

68.5

70.0

70.0

70.0

70.0

R171358.2 R2-2352.1 NOO

70.0

RANGITIKE RIVER SITE $172 \mathrm{~V}$

IEIGHT $=963$ (above base of section) STRIKE=120 DIP $=08$

SAMPLE FIELD NO. TREAT. INTENSITY CDEC CINC Y-AZ PLUNGE

R172359.1 R2-2247.1 N00

$\begin{array}{llll}0.946 \mathrm{E}-03 & 031.3 & -53.0 & 303.0\end{array}$

67.0

R172359.1 R2-2247.1 T05

R172359.1 R2-2247.1 T10

R172359.1 R2-2247.1 T15

R172359.1 R2-2247.1 T20

R172359.1 R2-2247.1 T25

R172359.1 R2-2247.1 T30

R172359.2 R2-2247.2 NOO

$172360.1 \quad R 2-2248.1 \quad$ NOO

$\begin{array}{lllll}0.737 & \mathrm{E}-03 & 028.2 & -523 & 303.0\end{array}$

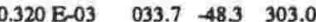

$\begin{array}{lllll}0.242 & E-03 & 034.6 & -445 & 303.0\end{array}$

$\begin{array}{llll}0.191 \mathrm{E}-03 & 044.9 & -40.1 & 303.0\end{array}$

$0.155 \mathrm{E}-03 \quad 068.6-67.4 \quad 303.0$

$\begin{array}{llll}0.167 & \mathrm{E}-03 & 330.5 & -49.8 \quad 303.0\end{array}$

$\begin{array}{lllll}0.988 & \mathrm{E}-03 & 026.7 & -52.3 & 303.0\end{array}$

$\begin{array}{lllll}0.774 \mathrm{E}-03 & 009.7 & -60.6 \quad 304.0\end{array}$

$\begin{array}{lllll}0.641 \text { E-03 } 001.6 & -56.0 & 304.0\end{array}$

$\begin{array}{rrrr}0.414 \mathrm{E}-03 & 350.2 & -57.7 & 304.0\end{array}$
SAMPLE FELDNO. TREAT. NNTENSITY CDEC CINC Y-AZ PLUNGE $\begin{array}{lllll}0.417 \mathrm{E}-03 & 013.1 & -50.1 & 309.0 & 22.5\end{array}$ $\begin{array}{lllll}0.260 \mathrm{E}-03 & 357.7 & -37.0 & 308.0 & 24.0\end{array}$

$\begin{array}{llll}0.385 \text { E-03 } & 016.0 & -64.2 & 320.0\end{array}$

$\begin{array}{lllll}0.500 \mathrm{E}-03 & 046.1 & -65.0 & 316.0\end{array}$
67.0

67.0

67.0
67.0

67.0

67,0

70.5

705

.0
.0
.0
.0
.0
.0
.0
.0
.0
.0
.0
.0
.0
.0
5
5
5
5
5
5
85
85


R172360.1 R2-2248.1 T15 R172360.1 R2-2248.1 T20 R172360.1 R2-2248.1 T25 $\begin{array}{lll}R 172360.1 & \text { R2-2248.1 T30 }\end{array}$ R172360.2 R2-2248.2 NOO

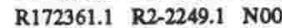
R172361.1 R2-2249.1 T05 R172361.1 R2-2249.1 T10 R172361.1 R2-2249.1 T15 R172361.1 R2-2249.1 T20 R172361.1 R2-2249.1 T25 $\begin{array}{lll}R 172361.1 & R 2-2249.1 & \text { T30 }\end{array}$
$0.203 \mathrm{E}-03 \quad 323.7-472 \quad 3040$ $\begin{array}{lllll}0.114 & \mathrm{E}-03 & 318.1 & -49.4 & 304.0\end{array}$ $\begin{array}{llll}0.805 \mathrm{E}-04 & 265.7 & -38.2 & 304\end{array}$ $\begin{array}{lllll}0.101 \mathrm{~B}-02 & 021.9 & -54.2 & 304.0\end{array}$ $\begin{array}{lllll}0.879 \mathrm{E}-03 & 020.1 & -57.0 & 300.0\end{array}$

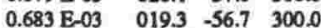
$\begin{array}{lllll}0.449 \mathrm{E}-03 & 019.5 & -56.1 & 300.0\end{array}$ $\begin{array}{llll}0.226 \mathrm{E}-03 & 018.1 & -44.8 & 300.0\end{array}$ $\begin{array}{llll}0.177 \mathrm{E}-03 & 039.5 & -38.0 & 300.0\end{array}$ $0.148 \mathrm{E}-03 \quad 006.6 \quad-23.5 \quad 300.0$ $\begin{array}{llllllllll}0.619 & \mathrm{E}-04 & 350.0 & -54.9 & 300.0\end{array}$ $\begin{array}{lllllllll}0.103 & \mathrm{E}-02 & 012.1 & -56.0 & 300.0\end{array}$ $0.120 \mathrm{E}-03 \quad 317.3 \quad-41.8 \quad 304.0$

\section{RANGITIKEI RIVER SITE 174V}

HEIGHT $=1048 \mathrm{~m}$ (above base of section) STRIKE $=129 \mathrm{DIP}=08$

SAMPLE FIELD NO. TREAT. INTENSITY CDEC CINC Y-AZ PLUNGE

R174362.1 R2-2044.1 N00 R1743621 R2-2044.1 T05 R174362.1 R2-2044.1 T10 $\begin{array}{lll}R 174362.1 & \text { R2-2044.1 T15 }\end{array}$ $\begin{array}{lll}R 174362.1 & R 2-2044.1 & \text { T20 }\end{array}$

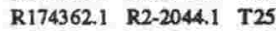
R174362.1 R2-2044.1 T30 R174362.2 R2-2044.2 NOO R174363.1 R2-2045.1 N00 R174363.1 R2-2045.1 T05 $\begin{array}{lll}R 174363.1 & R 2-2045.1 & T 10\end{array}$ R174363.1 R2-2045.1 T15 $\begin{array}{lll}R 174363.1 & R 2-2045.1 & T 20\end{array}$ R174363.1 R2-2045.1 T25 $\begin{array}{lll}R 174363.1 & \text { R2-2045.1 T30 }\end{array}$ $R 174363.2$ R2-2045.2 N00 R174364.1 R2-2046.1 N00 $\begin{array}{lll}\text { R174364.1 R2-2046.1 T05 } & \text { T }\end{array}$ R174364.1 R2-2046.1 T10 $\begin{array}{lll}R 174364.1 & R 2-2046.1 & \text { T15 }\end{array}$ R174364.1 R2-2046.1 T20 $\begin{array}{llll}R 174364.1 & R 2-2046.1 & T 25\end{array}$ R174364.1 R2-2046.1 T30

$0.344 \mathrm{E}-03 \quad 009.5-54.0 \quad 009.0$ $\begin{array}{lllll}0.349 \mathrm{E}-03 & 009.6 & -54.4 & 009.0\end{array}$ $\begin{array}{lllll}0.290 \text { E-03 } & 010.2 & -52.7 & 009.0\end{array}$ $\begin{array}{lllll}0.195 \mathrm{E}-03 & 008.5 & -48.0 & 009.0\end{array}$ $0.137 \mathrm{E}-03 \quad 011.4-41.8 \quad 009.0$ $\begin{array}{llll}0.116 \mathrm{E}-03 & 006.7 & -42.7 & 009.0\end{array}$ $\begin{array}{lllll}0.854 \mathrm{E}-04 & 009.8 & -36.6 & 009.0\end{array}$ $\begin{array}{lllll}0.332 & \mathrm{E}-03 & 017.9 & -463 & 009.0\end{array}$ $\begin{array}{llllll}0.272 \mathrm{E}-03 & 354.8 & -552 & 000.0\end{array}$ $\begin{array}{lllllll}0.247 \text { E- } 03 \quad 349.8 & -55.3 & 000 & 0\end{array}$ $\begin{array}{lllll}0.181 & \mathrm{E}-03 & 343.0 & -51.2 & 000.0\end{array}$ $\begin{array}{lllll}0.931 & \text { E- }-04 & 323.5 & -34.9 & 000.0\end{array}$ $\begin{array}{lllll}0.626 \mathrm{E}-04 & 311.1 & 04.3 & 000.0\end{array}$ $\begin{array}{lllll}0.745 & \mathrm{E}-04 & 288.0 & 41.6 & 000.0\end{array}$ 0.773 E- $04 \quad 289.3 \quad 46.3 \quad 000.0$ $0.260 \mathrm{E}-03 \quad 018.3-60.0 \quad 000.0$ $\begin{array}{lllll}0.350 \mathrm{E}-03 & 015.3 & -62.3 & 005.0\end{array}$ $\begin{array}{lllll}0.341 \mathrm{E}-03 & 012.5 & -62.6 & 005.0\end{array}$ $\begin{array}{lllll}0.190 \mathrm{E}-03 & 013.9 & -69.0 & 005.0\end{array}$ $\begin{array}{llll}0.166 \mathrm{E}-03 & 008.3 & -69.3 & 005.0\end{array}$ $\begin{array}{lllll}0.125 & \text { E-03 } & 355.2 & -70.6 & 005.0\end{array}$ $\begin{array}{lllll}0.102 \mathrm{E}-03 & 009.9 & -69.1 & 005.0\end{array}$ $\begin{array}{lllll}0.111 \mathrm{E}-03 & 009.7 & -71.6 & 005.0\end{array}$ $\begin{array}{lllll}0.321 \mathrm{E}-03 & 359.1 & -64.9 & 005.0\end{array}$
49.5

49.5

49.5

49.5

49.5

RANGITIKEI RIVER SITE $176 \mathrm{~V}$

HEIGHT $=1100 \mathrm{~m}$ (above base of section) STRIKE=129 DIP=08

SAMPLE FIELD NO. TREAT. INTENSTTY CDEC CINC Y-AZ PLUNGE

R176365.1 R2-1841.1 N00 R176365.1 R2-1841.1 TO5 R176365.1 R2-1841.1 T10 R176365.1 R2-1841.1 T15 $\begin{array}{lll}R 176365.1 & R 2-1841.1 & T 20\end{array}$ R176365.1 R2-1841.1 T25 $\begin{array}{lll}R 176365.1 & R 2-1841.1 & T 30\end{array}$ R176365.2 R2-1841.2 N00 R176366.1 R2-1842.1 N00 R176366.1 R2-1842.1 TOS R176366.1 R2-1842.1 T10 R176366.1 R2-1842.1 T15 $\begin{array}{llll}R & 176366.1 & R 2-1842.1 & T 20\end{array}$ R176366.1 R2-1842.1 T25 $\begin{array}{lll}R 176366.1 & \text { R2-1842.1 T30 }\end{array}$ R176366.2 R2-1842.2 N00 R176367.1 R2-1843.1 N00 R176367.1 R2-1843.1 T05 R176367.1 R2-1843.1 T10 R176367.1 R2-1843.1 T15 R176367.1 R2-1843.1 T20 $\begin{array}{lll}R 176367.1 & R 2-1843.1 & \text { T25 }\end{array}$ R176367.1 R2-1843.1 T30 R176367.2 R2-1843.2 N00 $0.331 \mathrm{E}-03 \quad 007.4-57.10040$ $\begin{array}{lllll}0.160 \mathrm{E}-03 & 001.8 & -57.8 & 004.0\end{array}$ $\begin{array}{lllll}0.145 \mathrm{E}-03 & 001.8 & -57.8 & 004.0\end{array}$ $\begin{array}{llll}0.132 & 343.6 & -61.9 & 004.0\end{array}$ $0.671 \mathrm{E}-04 \quad 301.5-193 \quad 004.0$ 0.787 E-0. $211.4 \quad-80.0 \quad 004.0$ $\begin{array}{lllll}0.265 \mathrm{E}-03 & 023.1 & -573 & 004.0\end{array}$ $\begin{array}{lllll}0.265 \mathrm{E}-03 & 023.1 & -57.3 & 004.0 \\ 0.213 \mathrm{E}-03 & 009.8 & -63.0 & 008.0\end{array}$ $\begin{array}{lllll}0.213 \mathrm{E}-03 & 009.8 & -63.0 & 008.0 \\ 0.223 \mathrm{E}-03 & 015.7 & -60.0 & 008.0\end{array}$ $\begin{array}{lllll}0.223 \mathrm{E}-03 & 015.7 & -60.0 & 008.0\end{array}$ $\begin{array}{lllll}0.145 \mathrm{E}-03 & 018.7 & -61.6 & 008.0\end{array}$ $\begin{array}{lllll}0.533 \mathrm{E}-04 & 004.4 & -68.8 & 008.0\end{array}$ $\begin{array}{lllll}0.454 \mathrm{E}-04 & 281.7 & -41.2 & 008.0\end{array}$ $\begin{array}{llll}0.414 \mathrm{E}-04 & 131.9 & -05.8 & 008.0\end{array}$ $\begin{array}{llll}0.326 \mathrm{E}-04 & 112.2 & 425 & 008.0\end{array}$ $\begin{array}{lllll}0.225 \mathrm{E}-03 & 038.8 & -57.8 & 008.0\end{array}$ $\begin{array}{lllll}0.224 \mathrm{E}-03 & 019.9 & -59.4 & 010.0\end{array}$ $\begin{array}{lllll}0.219 & \mathrm{E}-03 & 020.9 & -59.5 & 010.0\end{array}$ $\begin{array}{lllll}0.160 \mathrm{E}-03 & 017.6 & -61.7 & 010.0\end{array}$ $\begin{array}{lllll}0.642 \mathrm{E}-04 & 020.9 & -613 & 010.0\end{array}$ $\begin{array}{llll}0.486 \mathrm{E}-04 & 030.3 & -62.2 & 010.0\end{array}$ $\begin{array}{lllll}0.492 \mathrm{E}-04 & 080.6 & -58.7 & 010.0\end{array}$ $\begin{array}{lllll}0.396 \text { E-04 } & 019.0 & -18.6 & 010.0\end{array}$ $\begin{array}{llll}0.289 \mathrm{E}-03 & 019.2 & -51.4 & 010.0\end{array}$
39.0

39.0

39.0

39.0

39.0

39.0

39.0

39.0

37.0

37.0

37.0

37.0

37.0

37.0

38.5

38.5

38.5

38.5

38.5

38.5

38.5
RANGITIKEI RIVER SITE 177V

HEIGHT $=1168 \mathrm{~m}$ (above base of section) STRIKE $=129 \mathrm{DIP}=08$

SAMPLE FIELD NO. TREAT. INTENSTTY CDEC CINC Y-AZ PLUNGE

$\begin{array}{lll}R & 177368.1 & R 2-1738.1 \quad N 00\end{array}$ R177368.1 R2-1738.1 T05 R177368.1 R2-1738.1 T10 R177368.1 R2-1738.1 T15

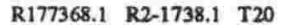
$\begin{array}{llll}R & 177368.1 & R 2-1738.1 & T 25\end{array}$ $\begin{array}{lll}R 177368.1 & R 2-1738.1 & \text { T } 30\end{array}$ R177368.2 R2-1738.2 N00 R177369.1 R2-1739.1 N00 R177369.1 R2-1739.1 T05 R177369.1 R2-1739.1 T10 R177369.1 R2-1739.1 T15 $\begin{array}{lll}R 177369.1 & R 2-1739.1 & T 20\end{array}$ $\begin{array}{llll}R & \text { R } 777369.1 & R 2-1739.1 & T 25\end{array}$ R177369.1 R2-1739.1 T30 R177369.2 R2-1739.2 N00 R177370.1 R2-1740.1 N00 R177370.1 R2-1740.1 T05 R177370.1 R2-1740.1 T10 R177370.1 R2-1740.1 T15 $\begin{array}{lll}R 177370.1 & R 2-1740.1 & T 20\end{array}$ $\begin{array}{lll}R 177370.1 & R 2-1740.1 & T 25\end{array}$ $\begin{array}{lll}R 177370.1 & R 2-1740.1 & T 30\end{array}$ R177370.2 R2-1740.2 N00

$\begin{array}{lllll}0.330 \mathrm{E}-03 & 030.9 & -58.5 & 359.0 & 63.5 \\ 0.209 \mathrm{E}-03 & 024.3 & -595 & 359.0 & 63.5 \\ 0.131 \mathrm{E}-03 & 021.6 & -57.4 & 359.0 & 63.5 \\ 0.636 \mathrm{E}-04 & 348.7 & -59.7 & 359.0 & 63.5 \\ 0.152 \mathrm{E}-04 & 326.3 & -33.4 & 359.0 & 63.5 \\ 0.835 \mathrm{E}-05 & 050.1 & -54.2 & 359.0 & 63.5 \\ 0.538 \mathrm{E}-05 & 180.5 & 15.8 & 359.0 & 63.5 \\ 0.375 \mathrm{E}-03 & 037.3 & -59.0 & 359.0 & 63.5 \\ 0.266 \mathrm{E}-03 & 358.4 & -50.0 & 355.0 & 64.5 \\ 0.229 \mathrm{E}-03 & 019.3 & -46.5 & 355.0 & 64.5 \\ 0.156 \mathrm{E}-03 & 029.3 & -53.7 & 355.0 & 64.5 \\ 0.640 \mathrm{E}-04 & 036.8 & -56.3 & 355.0 & 64.5 \\ 0.414 \mathrm{E}-04 & 049.0 & -67.9 & 355.0 & 64.5 \\ 0.327 \mathrm{E}-04 & 066.9 & -793 & 355.0 & 64.5 \\ 0.418 \mathrm{E}-04 & 103.0 & -64.9 & 355.0 & 64.5 \\ 0.298 \mathrm{E}-03 & 012.3 & -47.1 & 355.0 & 64.5 \\ 0.253 \mathrm{E}-03 & 014.1 & -563 & 350.0 & 66.0 \\ 0.224 \mathrm{E}-03 & 020.3 & -60.7 & 350.0 & 66.0 \\ 0.149 \mathrm{E}-03 & 013.4 & -65.9 & 350.0 & 66.0 \\ 0.642 \mathrm{E}-04 & 316.5 & -703 & 350.0 & 66.0 \\ 0.316 \mathrm{E}-04 & 236.1 & -71.0 & 350.0 & 66.0 \\ 0.305 \mathrm{E}-04 & 282.7 & -33.2 & 350.0 & 66.0 \\ 0.405 \mathrm{E}-05 & 149.6 & -38.9 & 350.0 & 66.0 \\ 0.296 \mathrm{E}-03 & 014.0 & -53.4 & 350.0 & 66.0\end{array}$

63.5

03.5

(3.5

63.5

63.5

RANGITIKEI RIVER STTE $178 \mathrm{~V}$

HEIGHT $=1211 \mathrm{~m}$ (above base of section) STRIKE $=089 \mathrm{DIP}=04$

SAMPLE FIELD NO. TREAT. INTENSITY CDEC CINC Y-AZ PLUNGE

$\begin{array}{llllllll}R 178371.1 & \text { R2-1634.1 N00 } & 0.237 \text { E-03 } & 016.9 & -86.1 & 127.0 & 35.5\end{array}$ $\begin{array}{llllllll}R 178371.1 & R 2-1634.1 & \text { TOS } & 0.166 \mathrm{E}-03 & 018.1 & -62.5 & 127.0 & 35.5\end{array}$ $\begin{array}{llllllll}R 178371.1 & \text { R2-1634.1 T10 } & 0.106 & \mathrm{E}-03 & 011.2 & -62.0 & 127.0 & 35.5\end{array}$ $\begin{array}{lllllllll}R 178371.1 & R 2-1634.1 & T 15 & 0.471 & E-04 & 353.2 & -67.0 & 127.0 & 35.5\end{array}$

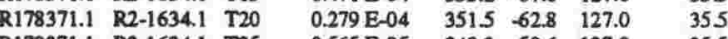
$\begin{array}{llllllll}R 178371.1 & R 2-1634.1 & \text { T25 } & 0.565 \mathrm{E}-05 & 240.3 & -59.6 & 127.0 & 35.5 \\ R 178371.1 & \text { R2-1634.1 } & \text { T30 } & 0.236 \mathrm{E}-05 & 113.0 & -00.1 & 127.0 & 35.5\end{array}$ $\begin{array}{lllllllll}\text { R178371.1 } & \text { R2-1634.1 } & \text { T30 } & 0.236 \mathrm{E}-05 & 113.0 & -00.1 & 127.0 & 35.5 \\ \text { R178371.2 } & \text { R2-1634.2 } & \text { N00 } & 0.266 \mathrm{E}-03 & 003.6 & -71.8 & 127.0 & 35.5\end{array}$ $\begin{array}{llllllll}R 178372.1 & R 2-1636.1 & N 00 & 0.340 \mathrm{E}-03 & 329.9 & -65.5 & 131.0 & 37.0\end{array}$ $\begin{array}{lllllllll}R & 178372.1 & R 2-1636.1 & \text { T05 } & 0.221 \mathrm{E}-03 & 004.8 & -50.6 & 131.0 & 37.0\end{array}$ $\begin{array}{llllllll}R 178372.1 & \text { R2-1636.1 } & \text { TOS } & 0.221 \mathrm{E}-03 & 004.8 & -50.6 & 131.0 & 37.0 \\ \text { R178372.1 } & \text { R2-1636.1 } & \text { T10 } & 0.158 \text { E-03 } & 353.8 & -44.8 & 131.0 & 37.0\end{array}$ $\begin{array}{llllllll}R 178372.1 & \text { R2-1636.1 T15 } & 0.966 \mathrm{E}-04 & 357.2 & -40.8 & 131.0 & 37.0\end{array}$ $\begin{array}{llllllll}R 178372.1 & \text { R2-1636.1 } & \text { T20 } & 0.265 \mathrm{E}-04 & 019.0 & -50.4 & 131.0 & 37.0 \\ \text { R178372 } & \text { R2-1636.1 } & \text { T25 } & 0.319 \mathrm{E}-04 & 341.7 & -18.9 & 131.0 & 37.0\end{array}$

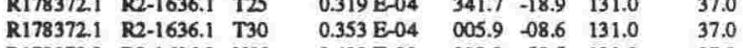
$\begin{array}{llllllll}\text { R178372.2 } & \text { R2-1636.2 N00 } & 0.438 \text { E-03 } & 298.8 & -58.5 & 131.0 & 37.0\end{array}$ $\begin{array}{lllllllll}R & 178373.1 & R 2-1637.1 & N 00 & 0.289 \mathrm{E}-03 & 346.7 & -68.8 & 136.0 & 39.0\end{array}$ $\begin{array}{lllllllll}R 178373.1 & R 2-1637.1 & \text { TOS } & 0.183 & \mathrm{E}-03 & 004.4 & -56.3 & 136.0 & 39.0\end{array}$ $\begin{array}{llllllll}\text { R178373.1 } & \text { R2-1637.1 } & \text { T10 } & 0.129 \mathrm{E}-03 & 008.9 & -63.0 & 136.0 & 39.0 \\ \text { R178373.1 } & \text { R2-1637.1 } & \text { T15 } & 0.654 \text { E-04 } & 006.4 & -59.4 & 136.0 & 39.0\end{array}$

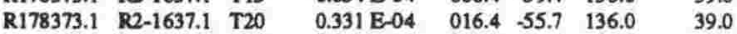

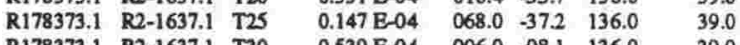

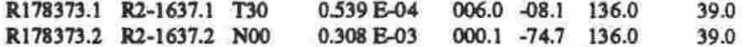

RANGITIKE] RIVER SITE $179 \mathrm{~V}$

HEIGHT $=1262 \mathrm{~m}$ (above base of section) STRIKE $=089 \mathrm{DIP}=04$

SAMPLE FELD NO. TREAT, INTENSITY CDEC CINC Y-AZ PLUNGE R179374.1 R2-15311 T05 R179374.1 R2-1531.1 T10 R179374.1 R2-1531.1 T15 $\begin{array}{lll}R 179374.1 & \text { R2-1531.1 T20 }\end{array}$ R179374.1 R2-1531.1 T25 R179374.1 R2-1531.1 T30 R179374.2 R2-1531.2 NOO R179375.1 R2-1532. N00 R179375.1 R2-1532.1 T05 R179375.1 R2-1532.1 T10 R179375.1 R2-1532.1 T15 R179375.1 R2-1532.1 T20 R179375.1 R2-1532.1 T25 $\begin{array}{lll}R 179375.1 & \text { R2-1532.1 T30 }\end{array}$ R179375.2 R2-15322 NOO R179376.1 R2-1533.1 N00 R179376.1 R2-1533.1 T05 R179376.1 R2-1533.1 T10 R179376.1 R2-1533.1 T15 $\begin{array}{lll}R 179376.1 & \text { R2-1533.1 T20 }\end{array}$ $\begin{array}{llll}R 179376.1 & \text { R2-1533.1 T25 }\end{array}$ R179376.1 P2-1533.1 T30

$0.495 \mathrm{E}-03 \quad 007.9-67.0-184.0$ $\begin{array}{lllll}0.335 \mathrm{E}-03 & 352.3 & -64.0 & 184.0\end{array}$ $\begin{array}{lllll}0.239 \mathrm{E}-03 & 343.2 & -65.9 & 184.0\end{array}$ $\begin{array}{lllll}0.147 \mathrm{~B}-03 & 335.1 & -69.4 & 184.0\end{array}$ $\begin{array}{llll}0.128 \mathrm{E}-03 & 319.4 & -60.6 & 184.0\end{array}$ $\begin{array}{lllll}0.708 \mathrm{E}-04 & 340.1 & -53.2 & 184.0\end{array}$ $\begin{array}{llll}0.524 \mathrm{E}-04 & 296.2 & -59.4 & 184.0\end{array}$ $\begin{array}{lllll}0.467 \mathrm{E}-03 & 009.9 & -57.7 & 184.0\end{array}$ $\begin{array}{llll}0.458 \mathrm{E}-03 & 022.2 & -71.1 & 182.0\end{array}$ $\begin{array}{lllll}0.310 \mathrm{E}-03 & 013.7 & -65.1 & 182.0\end{array}$ $\begin{array}{llll}0.221 \mathrm{E}-03 & 004.1 & -71.4 & 182.0\end{array}$ $\begin{array}{lllll}0.160 \mathrm{~B}-03 & 015.6 & -74.0 & 182.0\end{array}$ $\begin{array}{lllll}0.101 \mathrm{E}-03 & 344.5 & -87.5 & 182.0\end{array}$ $\begin{array}{lllll}0.809 \mathrm{E}-0.4 & 273.8 & 84.9 & 182.0\end{array}$ $\begin{array}{lllll}0.416 \mathrm{E}-04 & 093.3 & 85.5 & 182.0\end{array}$ $\begin{array}{llll}0.521 \mathrm{E}-03 & 006.2 & -72.2 & 182.0\end{array}$ 

$\begin{array}{lll}R 181382.1 & R 2-0712.1 & T 10\end{array}$
R181381.1 R2-0711.1 T15 R181381.1 R2-0711.1 T20 R181381.1 R2-0711.1 T25 R181381.1 R2-0711.1 T30 R181381.2 R2-0711.2 N00 R181382.1 R2-0712.1 N00 R181382.1 R2-0712.1 T0S R181382.1 R2-0712.1 T1S R181382.1 R2-0712.1 T20 R181382.1 R2-0712.1 T25 R181382.1 R2-0712.1 T30 $\begin{array}{llll}0.182 \mathrm{E}-04 & 223.4 & 14.1 & 331.0\end{array}$ $0.220 \mathrm{E}-04 \quad 244.2 \quad 415 \quad 331.0$ $\begin{array}{llll}0.434 \mathrm{E}-04 & 222.2 & 11.1 & 331.0\end{array}$ $\begin{array}{lllll}0.133 \mathrm{E}-03 & 358.0 & -32.0 & 331.0\end{array}$ $\begin{array}{lllll}0.128 \mathrm{E}-03 & 024.7 & -518 & 332.0\end{array}$ $\begin{array}{lllll}0.109 \mathrm{E}-03 & 034.2 & -65.2 & 332.0\end{array}$ 0.614 E-04 $0521-60.2 \quad 3320$ $\begin{array}{llll}0.614 \mathrm{E}-04 & 052.1 & -60.2 & 332.0 \\ 0.372 \mathrm{E}-04 & 085.0 & -69.9 & 332.0\end{array}$ $\begin{array}{lllll}0.372 \mathrm{E}-04 & 085.0 & -69.9 & 332.0 \\ 0.388 \mathrm{E}-04 & 148.2 & -752 & 332.0\end{array}$ $\begin{array}{llll}0.388 \mathrm{E}-04 & 148.2 & -75.2 & 332.0\end{array}$ $\begin{array}{lllll}0.285 \mathrm{E}-04 & 197.2 & -72.4 & 332.0\end{array}$ $\begin{array}{lllll}0.394 \mathrm{E}-04 & 150.6 & -30.7 & 332.0\end{array}$ $\begin{array}{lllll}0.117 \mathrm{E}-03 & 0.44 .9 & -36.2 & 332.0\end{array}$ $\begin{array}{llll}0.444 \mathrm{E}-04 & 251.6 & 33.7 & 331.0\end{array}$

\section{RANGITIKEI RIVER SITE $182 \mathrm{~V}$}

HEIGHT $=1327 \mathrm{~m}$ (above base of section) STRIKE=075 DIP $=05$

SAMPLE FIELD NO. TREAT. INTENSITY CDEC CINC Y-AZ PLUNGE

R182383.1 R2-0507.1 N00 R182383.1 R2-0507.1 T05 R182383.1 R2-0507.1 T10 R182383.1 R2-0507.1 T15 R182383.1 R2-0507.1 T20 R182383.1 R2-0507.1 T25 R182383.1 R2-0507.1 T30 R182383.2 R2-0507.2 N00 R182384.1 R2-0508.1 N00 R182384.1 R2-0508.1 T05 R182384.1 R2-0508.1 T10 R182384.1 R2-0508.1 T15 R182384.1 R2-0508.1 T20 R182384.1 R2-0508.1 T25 $\begin{array}{lll}R 182384.1 & R 2-0508.1 & T 30\end{array}$ R182384.2 R2-0508.2 N00 R182385.1 R2-0509.1 N00 R182385.1 R2-0509.1 T05 R182385.1 R2-0509.1 T10 R182385.1 R2-0509.1 T15

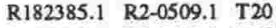
R182385.1 R2-0509.1 T25 R182385.1 R2-0509.1 T30 R182385.2 R2-0509.2 N00
RANGITIKDI RIVER STTE 188V

HIIGHT $=1359 \mathrm{~m}$ (above base of section) STRIKE $=075 \mathrm{DIP}=05$

SAMPLE FIELD NO. TREAT. INTENSITY CDEC CINC Y-AZ PLUNGE

R188392.1 R2-0913.1 N00 R188392.1 R2-0913.1 T05 R1883921 20.0913.1 T10 13.1 T15 R18 $120913.1 \mathrm{~T} 20$ R188392.1 R2-0913.1 T25 R188392.1 R2-0913.1 T30 R188392.2 R2-0913.2 NOO R188393.1 R2-0914.1 NOO R188393.1 R2-0914.1 T05 R188393.1 R2-0914.1 T10 $\begin{array}{lll}\text { R188393.1 R2-0914.1 T15 } & \text { R } \\ \text { R188393.1 } & \text { R2-0914.1 } & \text { T20 }\end{array}$ $\begin{array}{lll}\text { R188393.1 } & \text { R2-0914.1 T15 } \\ \text { R188393.1 } & \text { R2-0914.1 T20 }\end{array}$ R188393.1 R2-0914.1 T25 R188393.1 R2-0914.1 T30 R188393.2 R2-0914.2 N00 R188394: R2-0915. NOO R188394.1 R2-0915.1 N0O R168394.1 R2-0915.1 TOS R188394.1 R2-0915.1 T10 R188394.1 R2-0915.1 T15 R188394.1 R2-0915.1 T20 R188394.1 R2-0915.1 T25 R188394.1 R2-0915.1 T30 $\begin{array}{lrrll}0.342 \mathrm{E}-03 & 067.3 & -72.7 & 282.0 & 30.0 \\ 0.249 \mathrm{E}-03 & 222.2 & -82.8 & 282.0 & 30.0 \\ 0.175 \mathrm{E}-03 & 191.8 & -60.3 & 282.0 & 30.0 \\ 0.176 \mathrm{E}-03 & 194.1 & -27.8 & 282.0 & 30.0 \\ 0.259 \mathrm{E}-03 & 196.9 & 03.7 & 282.0 & 30.0 \\ 0.304 \mathrm{E}-03 & 195.5 & 08.5 & 282.0 & 30.0 \\ 0.258 \mathrm{E}-03 & 183.9 & 14.6 & 282.0 & 30.0 \\ 0.310 \mathrm{E}-03 & 201.9 & -74.3 & 282.0 & 30.0 \\ 0.921 \mathrm{E}-03 & 335.4 & -53.2 & 281.0 & 31.5 \\ 0.665 \mathrm{E}-03 & 324.7 & -50.5 & 281.0 & 31.5 \\ 0.505 \mathrm{E}-03 & 312.4 & -44.5 & 281.0 & 31.5 \\ 0.389 \mathrm{E}-03 & 299.3 & -37.2 & 281.0 & 31.5 \\ 0.323 \mathrm{E}-03 & 264.4 & -18.5 & 281.0 & 31.5 \\ 0.372 \mathrm{E}-03 & 237.6 & 05.7 & 281.0 & 31.5 \\ 0.330 \mathrm{E}-03 & 240.2 & 01.7 & 281.0 & 31.5 \\ 0.517 \mathrm{E}-03 & 034.7 & -54.6 & 281.0 & 31.5 \\ 0.970 \mathrm{E}-03 & 355.0 & -52.8 & 280.0 & 33.5 \\ 0.723 \mathrm{E}-03 & 344.1 & -50.5 & 280.0 & 33.5 \\ 0.542 \mathrm{E}-03 & 336.6 & -48.1 & 280.0 & 33.5 \\ 0.381 \mathrm{E}-03 & 322.1 & -43.6 & 280.0 & 33.5 \\ 0.246 \mathrm{E}-03 & 291.0 & -18.9 & 280.0 & 33.5 \\ 0.244 \mathrm{E}-03 & 270.4 & 03.0 & 280.0 & 33.5 \\ 0.233 \mathrm{E}-03 & 253.1 & 17.8 & 280.0 & 33.5 \\ 0.634 \mathrm{E}-03 & 352.7 & -56.3 & 280.0 & 33.5\end{array}$ R188394.2 R2-0915.2 NOO

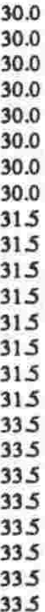

RANGITIKEI RIVER SITE $189 \mathrm{~V}$

HEIGHT $=1362 \mathrm{~m}$ (above base of section) STRIKE $=075 \mathrm{DIP}=05$ SAMPLE FIELDNO. TREAT. INTENSITY CDEC CINC Y-AZ PLUNGE

R189395.1 R2-1222.1 N00 R189395.1 R2-1222.1 T05 R189395.1 R2-1222.1 T10 R189395.1 R2-1222.1 T15 R189395.1 R2-1222.1 T20 R189395.1 R2-1222.1 T25 R189395.1 R2-1222.1 T30 R189395.2 R2-1222.2 NOO R189396.1 R2-1223.1 N00 R189396.1 R2-1223.1 TOS R189396.1 R2-1223.1 T10 R189396.1 R2-1223.1 T15 R189396.1 R2-1223.1 T20 R189396.1 R2-1223.1 T25 R189396.1 R2-1223.1 T30 R189396.2 R2-1223.2 NOO R189397.1 R2-1224.1 NOO $\begin{array}{lll}\text { R189397.1 } & \text { R2-1224.1 } & \text { N00 } \\ \text { R189397.1 } & \text { R2-1224.1 } & \text { T05 }\end{array}$ $\begin{array}{lll}R 189397.1 & R 2-1224.1 & \text { TOS } \\ \text { R189397.1 } & \text { R2-1224.1 } & \text { T1 }\end{array}$ R189397.1 R2-1224.1 T15 R189397.1 R2-1224.1 T20 R189397.1 R2-1224.1 T25 R189397.1 R2-1224.1 T25 $\begin{array}{lll}R 189397.1 & R 2-1224.1 & T 30 \\ \text { R189397.2 } & \text { R2-1224.2 NO0 }\end{array}$

$\begin{array}{lllll}0.489 \mathrm{E}-03 & 006.2 & -56.3 & 022.0 & 77.0 \\ 0.299 \mathrm{E}-03 & 008.0 & -52.5 & 022.0 & 77.0 \\ 0.219 \mathrm{E}-03 & 009.3 & -50.7 & 022.0 & 77.0 \\ 0.144 \mathrm{E}-03 & 012.7 & -445 & 022.0 & 77.0 \\ 0.909 \mathrm{E}-04 & 005.1 & -32.3 & 022.0 & 77.0 \\ 0.773 \mathrm{E}-04 & 020.0 & -14.9 & 022.0 & 77.0 \\ 0.652 \mathrm{E}-04 & 000.7 & -27.5 & 022.0 & 77.0 \\ 0.438 \mathrm{E}-03 & 351.0 & -69.0 & 022.0 & 77.0 \\ 0.746 \mathrm{E}-03 & 347.0 & -67.0 & 022.0 & 79.5 \\ 0.441 \mathrm{E}-03 & 354.7 & -60.2 & 022.0 & 79.5 \\ 0.341 \mathrm{E}-03 & 351.2 & -60.0 & 022.0 & 79.5 \\ 0.216 \mathrm{E}-03 & 338.4 & -59.5 & 022.0 & 79.5 \\ 0.115 \mathrm{E}-03 & 308.9 & -46.0 & 022.0 & 79.5 \\ 0.703 \mathrm{E}-04 & 282.5 & -23.6 & 022.0 & 79.5 \\ 0.739 \mathrm{E}-04 & 259.6 & -10.4 & 022.0 & 79.5 \\ 0.618 \mathrm{E}-03 & 354.9 & -66.5 & 022.0 & 79.5 \\ 0.826 \mathrm{E}-03 & 010.2 & -64.9 & 022.0 & 73.0 \\ 0.558 \mathrm{E}-03 & 017.0 & -54.8 & 022.0 & 73.0 \\ 0.470 \mathrm{E}-03 & 014.0 & -53.9 & 022.0 & 73.0 \\ 0.354 \mathrm{E}-03 & 026.1 & -51.5 & 022.0 & 73.0 \\ 0.234 \mathrm{E}-03 & 036.3 & -43.9 & 022.0 & 73.0 \\ 0.154 \mathrm{E}-03 & 045.2 & -33.7 & 022.0 & 73.0 \\ 0.110 \mathrm{E}-03 & 057.7 & -20.4 & 022.0 & 73.0 \\ 0.739 \mathrm{E}-03 & 005.8 & -63.4 & 022.0 & 73.0\end{array}$

\section{RANGITIKEI RIVER SITE $190 \mathrm{~V}$}

HEIGHT $=1377 \mathrm{~m}$ (above base of section) STRIKE $=075$ DIP $=05$

SAMPLE FIELD NO. TREAT. INTENSITY CDEC CLNC Y-AZ PLUNGE

R185387.1 R2-1326.1 T15

R185387.1 R2-1326.1 T25

R185387.1 R2-1326.1 T30

R185387.2 R2-1326.2 N00

R185388.1 R2-1327.1 NOO

R185388.1 R2-1327.1 T05

R185388.1 R2-1327.1 T10

R185388.1 R2-1327.1 T15

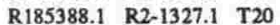

$\begin{array}{lll}R 185388.1 & R 2-1327.1 & T 25\end{array}$

R185388.1 R2-1327.1 T30

R185388.2 R2-1327.2 NOO

$\begin{array}{lllll}0.383 \mathrm{E}-04 & 356.2 & -64.8 & 035.0 & 52.0\end{array}$

$\begin{array}{lllll}0.334 \mathrm{E}-04 & 342.7 & -63.0 & 035.0 & 52.0\end{array}$

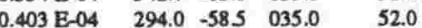

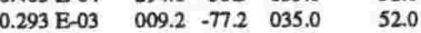

$\begin{array}{llllll}0.298 \mathrm{E}-03 & 004.9 & -67.5 & 039.0 & 53.5\end{array}$

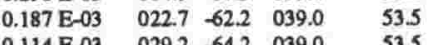

$\begin{array}{lllll}0.114 \mathrm{E}-03 & 029.2 & -64.2 & 039.0 & 53.5\end{array}$

$\begin{array}{lllll}0.594 \mathrm{E}-04 & 034.6 & -69.4 & 039.0 & 53.5\end{array}$

$\begin{array}{lllll}0.396 \mathrm{E}-04 & 017.2 & -80.6 & 039.0 & 53.5 \\ 0.188 \mathrm{E}-04 & 066.0 & -46.6 & 039.0 & 53.5\end{array}$

$\begin{array}{lllll}0.188 \text { E-04 } & 066.0 & -46.6 & 039.0 & 53.5 \\ 0.968 \text { E-05 } & 322.7 & -41.7 & 039.0 & 53.5\end{array}$

$\begin{array}{lllll}0.375 \mathrm{E}-03 & 015.0 & -63.9 & 039.0 & 53.5\end{array}$

RANGITIKE] RIVER SITE $186 \mathrm{~V}$

HEIGHT $=1350 \mathrm{~m}$ (above base of section) STRIKE $=075 \mathrm{DIP}=05$

SAMPLE FIELD NO. TREAT. INTENSITY CDEC CINC Y-AZ PLUNGE

R186389.1 R2-0304.1 N00 R186389.1 R2-0304.1 T05 R186389.1 R2-0304.1 T10 R186389.1 R2-0304.1 T15 R186389.1 R2-0304.1 T20 R186389.1 R2-0304.1 T25 R186389.1 R2-0304.1 T30 R186389.2 R2-0304.2 N00 R186390.1 R2-0305.1 N00 R186390.1 R2-0305.1 T05 R186390.1 R2-0305.1 T10 R186390.1 R2-0305.1 T15 R186390.1 R2-0305.1 T20 R186390.1 R2-0305.1 T25 $\begin{array}{lll}R 186390.1 & R 2-0305.1 & T 30\end{array}$ R186390.2 R2-0305.2 NOO R186391.1 R2-0306.1 N00 R186391.1 R2-0306.1 T05 R186391.1 R2-0306.1 T10 R186391.1 R2-0306.1 T15 R186391.1 R2-0306.1 T20 R186391.1 R2-0306.1 T25 R186391.1 R2-0306.1 T30

$0.604 \mathrm{E}-04-073.8-65.9-173.0$ $\begin{array}{lllll}0.604 \mathrm{E}-04 & 073.8 & -65.9 & 173.0 & 39.0 \\ 0.554 \mathrm{E}-04 & 085.2 & -57.7 & 173.0 & 39.0\end{array}$ $\begin{array}{lllll}0.301 \mathrm{E}-04 & 119.3 & -47.4 & 173.0 & 39.0\end{array}$ $\begin{array}{lllll}0.242 \mathrm{E}-04 & 136.3 & -213 & 173.0 & 39.0\end{array}$ $\begin{array}{lllll}0.234 \mathrm{E}-04 & 142.7 & -20.1 & 173.0 & 39.0\end{array}$ $\begin{array}{lllll}0.182 \mathrm{E}-04 & 133.8 & -263 & 173.0 & 39.0\end{array}$ $\begin{array}{lllll}0.146 \mathrm{E}-04 & 095.9 & -36.8 & 173.0 & 39.0\end{array}$ $\begin{array}{lllll}0.583 \mathrm{E}-04 & 039.3 & -78.8 & 173.0 & 39.0\end{array}$ $\begin{array}{lllll}0.315 \mathrm{E}-0.4 & 057.9 & -73.4 & 175.0 & 40.5\end{array}$ $\begin{array}{lllll}0.260 \mathrm{E}-04 & 055.9 & -43.7 & 175.0 & 40.5\end{array}$ $\begin{array}{lllll}0.107 \mathrm{E}-04 & 094.0 & -05.9 & 175.0 & 40.5\end{array}$ $\begin{array}{llllll}0.177 \mathrm{E}-04 & 128.7 & 465 & 175.0 & 40.5\end{array}$ $\begin{array}{lllll}0.181 \mathrm{E}-04 & 127.2 & 58.9 & 175.0 & 40.5\end{array}$ $\begin{array}{lllll}0.247 \mathrm{E}-04 & 104.0 & 67.1 & 175.0 & 40.5\end{array}$ $\begin{array}{lllll}0.213 \mathrm{E}-04 & 113.7 & 73.1 & 175.0 & 40.5\end{array}$

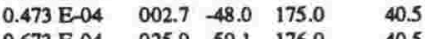
$\begin{array}{llllll}0.673 \mathrm{E}-04 & 025.9 & -59.1 & 176.0 & 40.5\end{array}$ $\begin{array}{lllll}0.544 \mathrm{E}-04 & 036.0 & -53.9 & 176.0 & 40.5\end{array}$ $\begin{array}{lllll}0.376 \mathrm{E}-04 & 0.46 .7 & -53.7 & 176.0 & 40.5\end{array}$ $\begin{array}{lllll}0.196 \mathrm{E}-04 & 106.0 & -29.1 & 176.0 & 40.5\end{array}$

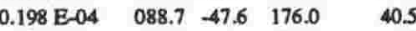
$\begin{array}{lllll}0.108 \mathrm{E}-04 & 052.7 & -49.2 & 176.0 & 40.5\end{array}$ $\begin{array}{lllll}0.416 \mathrm{E}-05 & 330.2 & -80.6 & 176.0 & 40.5\end{array}$ R186391.2 R2-0306.2 N00
R190398.1 R2-0201.1 N00 R190398.1 R2-0201.1 T05 R190398.1 R2-0201.1 T10 R190398.1 R2-0201.1 T15 R190398.1 R2-0201.1 T20 R190398.1 R2-0201.1 T25 R190398.1 R2-02011 T30 R190398.2 R2-0201.2 N00 R190399.1 R2-0202.1 NOO R190399.1 R2-0202.1 T05 R190399.1 R2-0202.1 T10 R190399.1 R2-0202.1 T15 $R 190399.1 \quad R 2-0202.1 \quad T 20$ R190399.1 R2-0202.1 T25 R190399.2 R2-0202.2 NOO R190400.1 R2-0203.1 NOO R190400.1 R2-0203.1 T05 R190400.1 R2-0203.1 T10 $R 190400.1 \quad R 2-0203.1$ T15 $R 190400.1 \quad R 2-0203.1 \quad T 20$ R190400.1 R2-0203.1 T25 R190400.1 R2-0203.1 T30 R190400.2 R2-0203.2 N00 R190399.1 R2-0202.1 T30

43.0 43.0 43.0 43.0 43.0 43.0 43.0 43.0 43.5 43.5 43.5 435 435 435 435 435 435 455 45.5 455 45. 45.5 45.5 45.5 45.5

RANGITIKEI RIVER SITE $191 \mathrm{~V}$

HEIGHT $=1381 \mathrm{~m}$ (above base of section) STRIKE $=075 \mathrm{DIP}=05$

SAMPLE FELD NO. TREAT. INTENSITY CDEC CINC Y-AZ PLUNGE

R191401.1 R2-1119.1 N00 R191401.1 R2-1119.1 T05 R191401.1 R2-1119.1 T10 R191401.1 R2-1119.1 T15 R191401.1 R2-1119.1 T20 R191401.1 R2-1119.1 T25 R191401.1 R2-1119.1 T30 R191401.2 R2-1119.2 NOO R191402.1 R2-1120.1 NOO R191402.1 R2-1120.1 T05 R191402.1 R2-1120.1 T10

$\begin{array}{lllll}0.202 \mathrm{E}-03 & 278.9 & -87.6 & 074.0 & 35.0 \\ 0.136 \mathrm{E}-03 & 035.8 & -72.4 & 074.0 & 35.0 \\ 0.902 \mathrm{E}-04 & 052.1 & -81.4 & 074.0 & 35.0 \\ 0.573 \mathrm{E}-04 & 114.8 & -78.8 & 074.0 & 35.0 \\ 0.373 \mathrm{E}-04 & 145.8 & -58.1 & 074.0 & 35.0 \\ 0.104 \mathrm{E}-04 & 151.2 & -27.1 & 074.0 & 35.0 \\ 0.131 \mathrm{E}-04 & 155.9 & -36.3 & 074.0 & 35.0 \\ 0.211 \mathrm{E}-03 & 059.2 & -83.5 & 074.0 & 35.0 \\ 0.178 \mathrm{E}-03 & 027.3 & -77.6 & 081.0 & 34.0 \\ 0.125 \mathrm{E}-03 & 006.5 & -63.5 & 081.0 & 34.0 \\ 0.863 \mathrm{E}-04 & 357.4 & -67.0 & 081.0 & 34.0\end{array}$


R191402.1 R2-1120.1 T15 R1914021 R2-11201 T20 R191402.1 R2-1120.1 T25 R191402.1 R2-1120.1 T30 R191402.2 R2-1120.2 N0O R191403.1 R2-1121.1 N00 R191403.1 R2-1121.1 T05 R191403.1 R2-1121.1 T10 R191403.1 R2-1121.1 T15 R191403.1 R2-1121.1 T20 R191403.1 R2-1121.1 T25 R191403.1 R2-1121.1 T30 $0.216 \mathrm{E}-04 \quad 358.5-548 \quad 0810$ $\begin{array}{lllll}0.140 \mathrm{E}-04 & 356.3 & -283 & 0810\end{array}$ $0.134 \mathrm{E}-04 \quad 357.8-533 \quad 081.0$ $\begin{array}{llll}0.134 \mathrm{E}-04 & 357.8 & -533 & 081.0\end{array}$ $0.228 \mathrm{E}-03 \quad 348.7-74.0 \quad 081.0$ 0.122 E-03 $031.9-62.7083 .0$ $\begin{array}{llllll}0.872 \mathrm{E}-04 & 038.1 & -75.7 & 083.0\end{array}$ $\begin{array}{lllll}0.872 & \mathrm{E}-04 & 038.1 & -75.7 & 083.0 \\ 0.499 & \mathrm{E}-04 & 085.5 & -80.1 & 0833.0\end{array}$ $\begin{array}{lllll}0.499 & \mathrm{E}-04 & 085.5 & -80.1 & 083.0 \\ 0.256 \mathrm{E}-04 & 074.3 & -763 & 083.0\end{array}$ $\begin{array}{lllll}0.256 \mathrm{E}-04 & 074.3 & -76.3 & 083.0\end{array}$ 0.163 E-04 $082.0 \quad-50.8 \quad 083.0$ $\begin{array}{lllll}0.998 \mathrm{E}-05 & 071.0 & -43.6 & 083.0\end{array}$ $\begin{array}{llllll}0.181 & \mathrm{E}-03 & 358.7 & -81.7 & 083.0\end{array}$ $\begin{array}{lllll}0.418 \mathrm{E}-04 & 354.8 & -673 & 081\end{array}$

\section{RANGITIKEI RIVER SITE $192 \mathrm{~V}$}

HEIGHT $=1397 \mathrm{~m}$ (above base of section) STRIKE=075 DIP=05

SAMPLE FIELD NO, TREAT. INTENSITY CDEC CINC Y-AZ PLUNGE

R192404.1 R2-1016.1 N00 R192404.1 R2-1016.1 T05 $\begin{array}{lll}R 192404.1 & R 2-1016.1 & T 10\end{array}$ R192404.1 R2-1016.1 T15 R192404.1 R2-1016.1 T20 R192404.1 R2-1016.1 T25 R192404.1 R2-1016.1 T30 R192404.2 R2-1016.2 N00 R192405.1 R2-1017.1 N00 R192405.1 R2-1017.1 T05 R192405.1 R2-1017.1 T10 R192405.1 R2-1017.1 T15 R192405.1 R2-1017.1 T20 R192405.1 R2-1017.1 T25 R192405.1 R2-1017.1 T30 R192405.2 R2-1017.2 NOO R192406.1 R2-1018.1 N00 R192406.1 R2-1018.1 T05 R192406.1 R2-1018.1 T10 R192406.1 R2-1018.1 T15

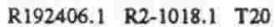
$\begin{array}{lll}R 192406.1 & R 2-1018.1 & T 25\end{array}$ R192406.1 R2-1018.1 T30

$\begin{array}{llll}0.454 \mathrm{E}-03 & 021.5 & -663 & 330.0\end{array}$ 42.0 $0.375 \mathrm{E}-03$ $\begin{array}{lllll}0.330 \mathrm{E}-03 & 006.7 & -61.5 & 330.0\end{array}$ $\begin{array}{lllll}0.276 \mathrm{E}-03 & 003.5 & -64.4 & 330.0\end{array}$ $\begin{array}{lllllllllllll}0.201 \mathrm{E}-03 & 010.8 & -67.1 & 330.0\end{array}$ $\begin{array}{lllll}0.123 \mathrm{E}-03 & 348.5 & -70.8 & 330.0\end{array}$ $\begin{array}{lllll}0.120 \mathrm{E}-03 & 343.8 & -70.4 & 330.0\end{array}$ $\begin{array}{lllll}0.434 \mathrm{E}-03 & 359.3 & -57.5 & 330.0\end{array}$ $\begin{array}{lllll}0.437 \mathrm{E}-03 & 055.3 & -60.3 & 334.0\end{array}$ $\begin{array}{lllll}0.341 \mathrm{E}-03 & 053.5 & -54.2 & 3340\end{array}$ $\begin{array}{llll}0.304 \mathrm{E}-03 & 051.8 & -49.9 & 334.0\end{array}$ $\begin{array}{llll}0.231 \mathrm{E}-03 & 057.8 & -44.6 & 334.0\end{array}$ $\begin{array}{llll}0.216 \mathrm{E}-03 & 060.7 & -43.3 & 334.0\end{array}$ $0.170 \mathrm{E}-03 \quad 061.7 \quad-42.6 \quad 334.0$ $\begin{array}{llll}0.166 \mathrm{E}-03 & 061.9 & -52.1 & 334.0\end{array}$ $\begin{array}{llll}0.553 \mathrm{E}-03 & 015.4 & -63.0 & 334.0\end{array}$ $\begin{array}{lllll}0.335 \mathrm{E}-03 & 058.8 & -72.8 & 333.0\end{array}$ $\begin{array}{llll}0.238 \mathrm{E}-03 & 022.4 & -72.7 & 333.0\end{array}$ $\begin{array}{llll}0.206 \mathrm{E}-03 & 021.1 & -71.8 & 333.0\end{array}$ $\begin{array}{lllll}0.138 & \mathrm{E}-03 \quad 037.1 & -79.7 & 333.0\end{array}$ $\begin{array}{llll}0.101 \mathrm{E}-03 & 085.8 & -79.6 & 333.0\end{array}$ $\begin{array}{lllll}0.885 \mathrm{E}-04 & 097.9 & -69.9 & 333.0\end{array}$ $\begin{array}{lllll}0.120 \mathrm{E}-03 & 077.1 & -65.9 & 333.0\end{array}$ R192406.2 R2-1018.2 N00

RANGITIKEI RIVER SITE $193 \mathrm{~V}$

HEIGHT $=1406 \mathrm{~m}$ (above base of section) STRIKE $=075 \mathrm{DIP}=05$

SAMPLE FIELDNO. TREAT, NNTENSITY CDEC CINC Y-AZ PLUNGE

R193407.1 R2-0198.1 N00

$0.806 \mathrm{E}-04 \quad 018.9-303 \quad 215.0$

37.5 R193407.1 R2-0198.1 T05 R193407.1 R2-0198.1 T10 R193407.1 R2-0198.1 T15 R193407.1 R2-0198.1 T20 R193407.1 R2-0198.1 T25 R193407.1 R2-0198.1 T30 R193407.2 R2-0198.2 N00 R193408.1 R2-0199.1 N00 R193408.1 R2-0199.1 T05 R193408.1 R2-0199.1 T10 R193408.1 R2-0199.1 T15 R193408.1 R2-0199.1 T20 R193408.1 R2-0199.1 T25 R193408.1 R2-0199.1 T30 R193408.2 R2-0199.2 N00 R193409.1 R2-0100.1 N00 R193409.1 R2-0100.1 T05 R193409.1 R2-0100.1 T10 R193409.1 R2-0100.1 T15 R193409.1 R2-0100.1 T20 R193409.1 R2-0100.1 T2 R193409.1 R2-0100.1 T30 R193409.2 R2-0100.1 NOO $0.317=04 \quad 3503-08.1215 .0$ $\begin{array}{llll}0.156 \mathrm{~B}-04 & 286.7 & 48.2 & 215.0\end{array}$ $\begin{array}{llll}0.266 \mathrm{E}-04 & 286.7 & 48.2 & 215.0\end{array}$ $\begin{array}{lll}261.0 & 55.5 & 215.0\end{array}$ $0.430 \mathrm{E}-04 \quad 285.7 \quad 64.4 \quad 215.0$ $\begin{array}{llll}0.123 \mathrm{E}-03 & 027.5 & -715 & 215.0\end{array}$ $0.858 \mathrm{E}-04 \quad 135.9-63.9 \quad 215.0$ $\begin{array}{llll}0.858 \mathrm{E}-04 & 135.9 & -63.9 & 215.0 \\ 0.678 \mathrm{E}-04 & 091.8 & -60.4 & 215.0\end{array}$ $\begin{array}{llll}0.515 \mathrm{E}-04 & 127.0 & -44.3 & 215.0\end{array}$ $\begin{array}{llll}0.318 \mathrm{E}-04 & 169.9 & 06.0 & 215.0\end{array}$ $\begin{array}{lllll}0.249 & \mathrm{E}-04 & 180.9 & 16.7 & 215.0\end{array}$ $\begin{array}{llll}0.270 \text { E-04 } & 193.6 & 27.5 & 215.0\end{array}$ $\begin{array}{llll}0.837 \text { E-05 } & 216.1 & 29.1 & 2150\end{array}$ $\begin{array}{llll}0.154 \mathrm{E}-03 & 018.2 & -615 & 215.0\end{array}$ $\begin{array}{llll}0.861 \mathrm{E}-04 & 001.2 & -84.3 & 216.0\end{array}$ $\begin{array}{llll}0.743 \mathrm{E}-04 & 359.2 & -63.9 & 216.0\end{array}$ $\begin{array}{lllll}0.217 \text { E- } 04 \quad 300.8 & -48.4 & 216.0\end{array}$ $\begin{array}{llll}0.275 \text { E-04 } & 261.4 & 49.7 & 216.0\end{array}$ $\begin{array}{llll}0.379 \mathrm{E}-04 & 249.4 & 60.8 & 216.0\end{array}$ $\begin{array}{llll}0.258 \mathrm{E}-04 & 352.0 & 81.0 & 216.0\end{array}$ $\begin{array}{llll}0.432 \mathrm{E}-04 & 023.0 & 83.0 & 216.0\end{array}$ $\begin{array}{llll}0.117 \mathrm{E}-03 & 044.6 & -76.6 & 216.0\end{array}$

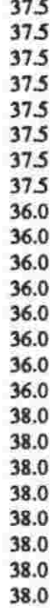

RANGITIKEI RIVER SITE $194 \mathrm{~V}$

(a) $=1407 \mathrm{~m}$ (above base of section) STRIKE $=075$ DIP $=05$

SAMPLE FIELDNO.TREAT. INTENSITY CDEC CINC Y-AZ PLUNGE

R194410.1 R2-4295.1 N00 R194410.1 R2-4295.1 T05 R194410.1 R2-4295.1 T10 R194410.1 R2-4295.1 T15 R194410.1 R2-4295.1 T20 R194410.1 R2-4295.1 T25 R194410.1 R2-4295.1 T30 R194410.2 R2-4295.2 N00 R194411.1 R2-4296.1 NOO R194411.1 R2-4296.1 TOS R194411.1 R2-4296.1 T10 R194411.1 R2-4296.1 T15 R194411.1 R2-4296.1 T20 R194411.1 R2-4296.1 T25 R194411.1 R2-4296,1 T30 R194411.2 R2-4296.2 NOO R194412.1 R2-4297.1 NOO R194412.1 R2-4297.1 T05 R194412.1 R2-4297.1 T10 $R 194412.1 \quad R 2-4297.1 \quad T 15$ R194412.1 R2-4297.1 T20 R194412.1 R2-4297.1 T2 R194412.1 R2-4297.1 T30 R194412.2 R2-4297.2 NOO

$\begin{array}{rrrrr}0.548 \text { E-05 } & 202.6 & -40.8 & 249.0 & 42.0 \\ 0.160 \text { E-04 } & 282.8 & -41.1 & 249.0 & 42.0 \\ 0.180 \text { E-04 } & 230.5 & 51.9 & 249.0 & 42.0 \\ 0.440 \text { E-04 } & 208.2 & 54.2 & 249.0 & 42.0 \\ 0.533 \text { E-04 } & 204.7 & 54.6 & 249.0 & 42.0 \\ 0.563 \text { E-04 } & 216.1 & 50.4 & 249.0 & 42.0 \\ 0.460 \text { E-04 } & 203.9 & 53.3 & 249.0 & 42.0 \\ 0.217 \text { E-04 } & 220.1 & 30.5 & 249.0 & 42.0 \\ 0.545 \text { E-04 } & 017.2 & -19.0 & 256.0 & 47.5 \\ 0.600 \text { E-04 } & 031.0 & -26.2 & 256.0 & 47.5 \\ 0.520 \text { E-04 } & 028.4 & 19.1 & 256.0 & 47.5 \\ 0.495 \text { E-04 } & 037.0 & 50.4 & 256.0 & 47.5 \\ 0.462 \text { E-04 } & 037.3 & 55.3 & 256.0 & 47.5 \\ 0.385 \text { E-04 } & 039.9 & 72.7 & 256.0 & 47.5 \\ 0.339 \text { E-04 } & 039.9 & 69.5 & 256.0 & 47.5 \\ 0.258 \text { E-04 } & 053.2 & 01.0 & 256.0 & 47.5 \\ 0.581 \text { E-03 } & 195.9 & 40.5 & 263.0 & 48.5 \\ 0.227 \text { E-04 } & 269.7 & -39.0 & 263.0 & 48.5 \\ 0.232 \text { E-04 } & 237.4 & 19.9 & 263.0 & 48.5 \\ 0.414 \text { E-04 } & 211.1 & 40.7 & 263.0 & 48.5 \\ 0.526 \text { E-04 } & 216.2 & 46.5 & 263.0 & 48.5 \\ 0.576 \text { E-04 } & 204.2 & 47.6 & 263.0 & 48.5 \\ 0.466 \text { E-04 } & 214.4 & 52.2 & 263.0 & 48.5 \\ 0.359 \text { E-04 } & 186.5 & 41.0 & 263.0 & 48.5\end{array}$

RANGITIKEI RIVER SITE $195 \mathrm{~V}$

HEIGHT $=1415 \mathrm{~m}$ (above base of section) STRIKE $=075 \mathrm{DIP}=05$

SAMPLE FIELDNO. TREAT, INTENSITY CDEC CINC Y-AZ PLUNGE

$\begin{array}{llllllll}\text { R195413.1 } & \text { R2-4192.1 } & \text { N00 } & 0.251 \text { E-04 } & 321.9 & -59.4 & 176.0 & 67.0 \\ \text { R195413.1 } & \text { R2-4192.1 } & \text { T05 } & 0.181 \text { E-04 } & 017.8 & -505 & 176.0 & 67.0 \\ \text { R195413.1 } & \text { R2-4192.1 } & \text { T10 } & 0.237 \text { E-04 } & 255.0 & 19.7 & 176.0 & 67.0 \\ \text { R195413.1 } & \text { R2-4192.1 } & \text { T15 } & 0.554 \text { E-04 } & 217.0 & 56.8 & 176.0 & 67.0 \\ \text { R195413.1 } & \text { R2-4192.1 } & \text { T20 } & 0.519 \text { E-04 } & 201.1 & 48.5 & 176.0 & 67.0 \\ \text { R195413.1 } & \text { R2-4192.1 } & \text { T25 } & 0.411 \text { E-04 } & 199.9 & 49.3 & 176.0 & 67.0 \\ \text { R195413.1 } & \text { R2-4192.1 } & \text { T30 } & 0.484 \text { E-04 } & 188.3 & 33.8 & 176.0 & 67.0 \\ \text { R195413.2 } & \text { R2-4192.2 } & \text { N00 } & 0.427 \text { E-04 } & 025.6 & -59.8 & 176.0 & 67.0 \\ \text { R195414.1 } & \text { R2-4193.1 } & \text { N00 } & 0.520 \text { E-04 } & 330.8 & -54.8 & 184.0 & 67.0 \\ \text { R195414.1 } & \text { R2-4193.1 } & \text { T05 } & 0.501 \text { E-04 } & 342.4 & -56.7 & 184.0 & 67.0 \\ \text { R195414.1 } & \text { R2-4193.1 } & \text { T10 } & 0.177 \text { E-04 } & 292.2 & -565 & 184.0 & 67.0 \\ \text { R195414.1 } & \text { R2-4193.1 } & \text { T15 } & 0.292 \text { E-04 } & 245.9 & 19.4 & 184.0 & 67.0 \\ \text { R195414.1 } & \text { R2-4193.1 } & \text { T20 } & 0.275 \text { E-04 } & 226.6 & 33.0 & 184.0 & 67.0 \\ \text { R195414.1 } & \text { R2-4193.1 } & \text { T25 } & 0.325 \text { E-04 } & 231.4 & 45.2 & 184.0 & 67.0 \\ \text { R195414.1 } & \text { R2-4193.1 } & \text { T30 } & 0.299 \text { E-04 } & 248.1 & 28.8 & 184.0 & 67.0 \\ \text { R195414.2 } & \text { R2-4193.2 } & \text { N00 } & 0.732 \text { E-04 } & 047.8 & -74.4 & 184.0 & 67.0 \\ \text { R195415.1 } & \text { R2-4194.1 } & \text { N00 } & 0.432 \text { E-04 } & 026.5 & -54.7 & 180.0 & 72.0 \\ \text { R195415.1 } & \text { R2-4194.1 } & \text { T05 } & 0.482 \text { E-04 } & 017.7 & -40.0 & 180.0 & 72.0 \\ \text { R195415.1 } & \text { R2-4194.1 } & \text { T10 } & 0.203 \text { E-04 } & 018.9 & -20.6 & 180.0 & 72.0 \\ \text { R195415.1 } & \text { R2-4194.1 } & \text { T15 } & 0.202 \text { E-04 } & 035.6 & 66.8 & 180.0 & 72.0 \\ \text { R195415.1 } & \text { R2-4194.1 } & \text { T20 } & 0.280 \text { E-04 } & 341.4 & 81.1 & 180.0 & 72.0 \\ \text { R195415.1 } & \text { R2-4194.1 } & \text { T25 } & 0.295 \text { E-04 } & 282.2 & 84.7 & 180.0 & 72.0 \\ \text { R195415.1 } & \text { R2-4194.1 } & \text { T30 } & 0.244 \text { E-04 } & 129.0 & 74.5 & 180.0 & 72.0 \\ \text { R195415.2 } & \text { R2-4194.2 } & \text { N00 } & 0.574 \text { E-04 } & 035.6 & -32.2 & 180.0 & 72.0\end{array}$

RANGITIKEI RIVER SITE $196 \mathrm{~V}$

HEIGHT $=1417 \mathrm{~m}$ (above base of section) STRIKE $=075 \mathrm{DIP}=05$

SAMPLE FIELD NO. TREAT. INTENSITY CDEC CINC Y-AZ PLUNGE

$\begin{array}{llllllll}\text { R196416.1 } & \text { R2-6441.1 } & \text { N00 } & 0.589 \text { E-04 } & 165.6 & 64.9 & 151.0 & 57.0 \\ \text { R196416.1 } & \text { R2-6441.1 } & \text { T05 } & 0.926 \text { E-04 } & 178.8 & 44.5 & 151.0 & 57.0 \\ \text { R196416.1 } & \text { R2-6441.1 } & \text { T10 } & 0.147 \text { E-03 } & 193.6 & 49.1 & 151.0 & 57.0 \\ \text { R196416.1 } & \text { R2-6441.1 } & \text { T15 } & 0.183 \text { E-03 } & 190.9 & 51.8 & 151.0 & 57.0 \\ \text { R196416.1 } & \text { R2-6441.1 } & \text { T20 } & 0.190 \text { E-03 } & 195.2 & 55.0 & 151.0 & 57.0 \\ \text { R196416.1 } & \text { R2-6441.1 } & \text { T25 } & 0.174 \text { E-03 } & 197.6 & 57.0 & 151.0 & 57.0 \\ \text { R196416.1 } & \text { R2-6441.1 } & \text { T30 } & 0.143 \text { E-03 } & 178.7 & 54.0 & 151.0 & 57.0 \\ \text { R196416.1 } & \text { R2-6441.1 } & \text { T35 } & 0.941 \text { E-04 } & 194.0 & 44.6 & 151.0 & 57.0 \\ \text { R196416.2 } & \text { R2-6441.2 } & \text { N00 } & 0.116 \text { E-03 } & 329.5 & 52.0 & 151.0 & 57.0 \\ \text { R196417.1 } & \text { R2-6442.1 } & \text { N00 } & 0.765 \text { E-04 } & 048.4 & 40.6 & 152.0 & 575 \\ \text { R196417.1 } & \text { R2-6442.1 } & \text { T05 } & 0.111 \text { E-03 } & 227.3 & 75.0 & 152.0 & 575 \\ \text { R196417.1 } & \text { R2-6442.1 } & \text { T10 } & 0.163 \text { E-03 } & 201.8 & 69.9 & 152.0 & 575 \\ \text { R196417.1 } & \text { R2-6442.1 } & \text { T15 } & 0.217 \text { E-03 } & 197.3 & 69.1 & 152.0 & 575 \\ \text { R196417.1 } & \text { R2-6442.1 } & \text { T20 } & 0.211 \text { E-03 } & 190.0 & 70.1 & 152.0 & 57.5 \\ \text { R196417.1 } & \text { R2-6442.1 } & \text { T25 } & 0.237 \text { E-03 } & 193.6 & 64.9 & 152.0 & 575 \\ \text { R196417.1 } & \text { R2-6442.1 } & \text { T30 } & 0.208 \text { E-03 } & 191.7 & 63.7 & 152.0 & 57.5 \\ \text { R196417.1 } & \text { R2-6442.1 } & \text { T35 } & 0.146 \text { E-03 } & 184.3 & 67.8 & 152.0 & 57.5 \\ \text { R196418.1 } & \text { R2-6443.1 } & \text { N00 } & 0.167 \text { E-03 } & 145.9 & 74.7 & 154.0 & 56.5 \\ \text { R196418.1 } & \text { R2-6443.1 } & \text { T05 } & 0.190 \text { E-03 } & 181.5 & 73.6 & 154.0 & 56.5 \\ \text { R196418.1 } & \text { R2-6443.1 } & \text { T10 } & 0.278 \text { E-03 } & 200.6 & 68.8 & 154.0 & 565 \\ \text { R196418.1 } & \text { R2-6443.1 } & \text { T15 } & 0.303 \text { E-03 } & 196.9 & 72.1 & 154.0 & 56.5 \\ \text { R196418.1 } & \text { R2-6443.1 } & \text { T20 } & 0.308 \text { E-03 } & 192.4 & 71.1 & 154.0 & 56.5 \\ \text { R196418.1 } & \text { R2-6443.1 } & \text { T25 } & 0.269 \text { E-03 } & 158.3 & 75.4 & 154.0 & 56.5 \\ \text { R196418.1 } & \text { R2-6443.1 } & \text { T30 } & 0.230 \text { E-03 } & 149.6 & 75.1 & 154.0 & 56.5 \\ \text { R196418.1 } & \text { R2-6443.1 } & \text { T35 } & 0.181 \text { E-03 } & 177.4 & 72.5 & 154.0 & 56.5 \\ \text { R196418.2 } & \text { R2-6443.2 } & \text { N00 } & 0.821 \text { E-04 } & 133.9 & 50.3 & 154.0 & 56.5\end{array}$

RANGITIKEI RIVER SITE $197 \mathrm{~V}$

HEIGHT $=1419 \mathrm{~m}$ (above base of section) STRIKE $=075 \mathrm{DIP}=05$

SAMPLE FIELDNO. TREAT. INTENSITY CDEC CINC Y-AZ PLUNGE

R197419.1 R2-6338.1 N00 R197419.1 R2-6338.1 T05 R197419.1 R2-6338.1 T10 R197419.1 R2-6338.1 T15 R197419.1 R2-6338.1 T20 $R 197419.1 \quad R 2-6338.1 \quad T 25$ R197419.1 R2-6338.1 T30 $\begin{array}{lll}\text { R197419.1 R2-6338.1 T35 } & \text { R }\end{array}$ R197419.2 R2-6338.2 N00 R197420.1 R2-6339.1 N00 R197420.1 R2-6339.1 TO5 R197420.1 R2-6339.1 T10 R197420.1 R2-6339.1 T15 $\begin{array}{lll}R 197420.1 & R 2-6339.1 & T 20\end{array}$ R197420.1 R2-6339.1 T25 $\begin{array}{lllll}R & R & 97420.1 & R 2-6339.1 & \text { T30 }\end{array}$ R197420.1 R2-6339.1 T35 R197420.2 R2-6339.2 N00 R197421.1 R2-6340.1 NOO R197421.1 R2-6340.1 T05 R197421.1 R2-6340.1 T10 R197421.1 R2-6340.1 T15 R197421.1 R2-6340.1 T20 R197421.1 R2-6340.1 T25 R197421.1 R2-6340.1 T30 R197421.1 R2-6340.1 T35 R197421.2 R2-6340.2 N00

$\begin{array}{lrrrr}0.195 \text { E-03 } & 335.8 & -51.3 & 275.0 & 505 \\ 0.194 \text { E-03 } & 333.2 & -42.3 & 275.0 & 50.5 \\ 0.180 \text { E-03 } & 329.9 & -35.0 & 275.0 & 50.5 \\ 0.139 \text { E-03 } & 322.0 & -24.7 & 275.0 & 50.5 \\ 0.147 \text { E-03 } & 319.4 & -28.9 & 275.0 & 50.5 \\ 0.130 \text { E-03 } & 319.3 & -15.0 & 275.0 & 50.5 \\ 0.102 \text { E-03 } & 290.1 & 36.1 & 275.0 & 50.5 \\ 0.289 \text { E-04 } & 210.1 & -20.2 & 275.0 & 50.5 \\ 0.848 \text { E-04 } & 251.6 & -77.3 & 275.0 & 505 \\ 0.826 \text { E-04 } & 355.0 & -74.9 & 271.0 & 45.5 \\ 0.780 \text { E-04 } & 327.3 & -61.8 & 271.0 & 45.5 \\ 0.444 \text { E-04 } & 346.4 & -54.4 & 271.0 & 455 \\ 0.423 \text { E-05 } & 249.2 & 79.4 & 271.0 & 45.5 \\ 0.213 \text { E-04 } & 195.2 & 14.8 & 271.0 & 45.5 \\ 0.483 \text { E-04 } & 159.2 & -37.5 & 271.0 & 45.5 \\ 0.426 \text { E-04 } & 091.6 & -59.5 & 271.0 & 45.5 \\ 0.870 \text { E-04 } & 201.2 & 52.6 & 271.0 & 45.5 \\ 0.128 \text { E-03 } & 113.2 & -62.6 & 271.0 & 45.5 \\ 0.120 \text { E-03 } & 168.9 & -55.2 & 268.0 & 43.5 \\ 0.107 \text { E-03 } & 224.1 & -54.3 & 268.0 & 43.5 \\ 0.757 \text { E-04 } & 210.8 & -47.0 & 268.0 & 43.5 \\ 0.703 \text { E-04 } & 200.1 & -08.9 & 268.0 & 43.5 \\ 0.655 \text { E-04 } & 206.3 & -04.9 & 268.0 & 43.5 \\ 0.106 \text { E-03 } & 189.0 & -05.5 & 268.0 & 43.5 \\ 0.122 \text { E-03 } & 194.1 & 31.5 & 268.0 & 43.5 \\ 0.753 \text { E-04 } & 205.7 & 40.2 & 268.0 & 43.5 \\ 0.117 \text { E-03 } & 224.9 & -38.0 & 268.0 & 435\end{array}$


426 
Abbott, S.T. and Carter, R.M. (1990); The sequence architecture of midPleistocene (0.35-0.95 Ma.) cyclothems from New Zealand: facies development during a period of orbital control on sealevel cyclicity. In; S.T. Abbott and R.M Carter (eds), Seismic sequence analysis of Plio-Pleistocene cyclothems, Wanganui Basin; A field workshop held for the Basin Studies Group of the Geological Survey of New Zealand.

Abbott, S.T. and Carter, R.M. (eds) (1990); Seismic sequence analysis of PlioPleistocene cyclothems, Wanganui Basin; A field workshop held for the Basin Studies Group of the Geological Survey of New Zealand.

Adams, C.G.; Benson, R.H.; Kidd, R.B.; Ryan, W.B.F. and Wright, R.C. (1977); The Messinian salinity crisis and evidence of late Miocene eustatic changes in the world ocean. Nature, vol. $269,383-386$.

Adams, C.J. (1965); New Zealand potasium-argon age list - 2. New Zealand Journal of Geology and Geophysics, vol. 18, 443-467.

Allen, J.L. and Shive, P.N. (1974); Mossbauer Effect Obser vations of the "X-Phase" in the Ilmenite-Hematite Series. Journal of Geomagnetism and Geoelectricity, vol. 26, 329-333.

Allen, J.R.L. (1983); Studies in fluviatile sedimentation: bar complexes and sandstone sheets (low sinuosity braided streams) in the Brownstones (L. Devonian), Welsh Borders. Sedimentary Geology, vol. 33, 237-293.

Amin, B.S.; Lal, D and Somayajulu, B.L.K (1975); Chronology of marine sediments using the ${ }^{10} \mathrm{Be}$ method: Intercomparison with other nethods. Geochimica et Cosmochimica Acta, vol. 39, 1187-1192.
Anderson, J.B. (1992); The Antarctic continental shelf; results from marine geologic and geophysical investigations. In; R.J. Tingey (ed), Antarctic Geology. Oxford; Oxford University Press, 285-334.

Anderton, P.W. (1981); Structure and evolution of the South Wanganui Basin, New Zealand. New Zealand Journal of Geology and Geophysics, vol. 24, 3963.

Bardin, V.I. (1982); Lithology of East Antarctic Mor aines and some problems of Cenozoic history, In; C. Craddock (ed), Antarctic Geoscience, Madison: University of Wisconsin Press, 10691076.

Barrett, P.J. (1975); Textural characteristics of Cenozoic preglacial and glacial sediments at Site 270, Ross Sea, Antarctica. In; D.E. Hayes et al. (eds), Initial reports of the Deep Sea Drilling Project, vol. 28, Washington, D.C.: United States Government Printing Office, 157.

Barrett, P.J. (1982); Proposal for Cenozoic investigations in the western Ross Sea (CIROS), New Zealand Antarctic Record, vol. 4, no. 2, 32-39.

Barrett, P.J. (ed) (1989); Antarctic Cenozoic history from the CIROS-I drillhole, McMurdo Sound. DSIR Bulletin 245, 254 p.

Barrett, P.J. (1991); Antarctica and global climatic change: a geological perspective. In; C. Harris and B. Stonehouse (eds), Cambridge: Antarctica and Global Climate Change, Scott Polar Institute and Belhaven Press, 35-50. 
Barrett, P.J. and Brooker, M.R. (1989); Grain-size analysis at VUW. Unpublished laboratory manual, Research School of Earth Scienes, Victoria University of Wellington, 26p.

Barrett, P.J. and Elliot, D. (1973); Reconaissance geologic map of the Buckley Island Quadrangle, Transantarctic Mountains, Antarctica. Antartic Geologic map A-3, Washington, D.C.: United States Geological Survey.

Barrett, P.J. and Hambrey, M.J. (1992); Plio-Pleistocene sedimentation in Ferrar Fiord, Antarctica. Sedimentology, vol. $39,109-123$.

Barrett, P.J. and Powell, R.D. (1982); Middle Cenozoic glacial beds at Table Mountain, Southern Victoria Land. In; C. Craddock (ed), Antarctic Geoscience. Madison: University of Wisconsin Press, 1059-1067.

Barrett, P.J.; Adams, C.J.; McIntosh, W.C.; Swisher, C.C. III and Wilson, G.S. (1992); Geochronological evidence supporting Antarctic deglaciation three million years ago. Nature, vol. 359, 816-818.

Barrett, P.J.; Hambrey, M.J.; Harwood, D.M.; Pyne, A.R. and Webb, P.-N. (1989); Synthesis. In; P.J. Barrett (ed) Antarctic Cenozoic history from the CIROS-1 drillhole, McMurdo Sound. DSIR Bulletin 245, 241-251.

Barrett, P.J., and Scientific Staff (1985); Plio-Pleistocene glacial sequence cored at CIROS-2, Ferrar Fjord, western McMurdo Sound. New Zealand Antarctic Record, vol. 6, no.2, 8-19.

Beer, J.; Andree, M.; Oeschger, H.; Stauffer, B.; Balzer, R.; Bonani, G.; Stoller, C.; Suter, M.; Wolfli, W. (1983a); Temporal ${ }^{10} \mathrm{Be}$ variations in ice. Radiocarbon, vol. 25 , no. 2, 269 278.
Beer, J; Bonani, G.; Hofmann, H.J.; Suter, M.; Synal, A; Woolfli, W; Oeschger, H.; Siegenthaler, U. and Finkel, R.C. (1987); ${ }^{10} \mathrm{Be}$ measurements on polar ice: comparison of Arctic and Antarctic Records. Nuclear Instruments and Methods in Physics Research. vol B29, 203-206.

Beer, J.; Oeschger, H.; Andree, M.; Bonani, G.; Suter, M.; Wolfli, W.; and Langway, C.C. (1983b); Temporal variations in the $10 \mathrm{Be}$ concentration levels found in the Dye-3 ice core, Greenland: Proceedings of the Symposium on Ice and Climate modelling, Evanston, Illinois, U.S.A., Annals of Glaciology, vol. 5., 317.

Behrendt and Cooper (1991):Evidence of rapid Cenozoic uplift of the shoulder escarpment of the Cenozoic West Antarctic rift system and a speculation on possible climate forcing. Geology, vol. $19,315-319$.

Benson, R.A. (1975); The origin of the psychrosphere as recorded in changes of deep sea ostracod assemblages. Lethalia, vol. 8, 69-83.

Berger, W.H. and Roth, P.H. (1975). Oceanic Micropaleontology: Progress and Prospect. Reviews of Geophysics and Space Physics, vol. 13, 561-585.

Berggren, W.A. (1972a); Late PliocenePleistocene glaciation. In; A.S. Laughton; W.A. Berggren; et al. (eds), Initial reports of the Deep Sea Drilling Project, vol. 12. Washington, D.C.: United States Government Printing Office, 953-963.

Berggren, W.A. (1972b); A Cenozoic timescale - some implications for regional geology and palaeobiogeography, Lethaia, vol. 5, 195.

Berggren, W.A. (1973); The Pliocene time scale: calibration of planktonic foraminiferal and calcareous nannoplanktonic zones. Nature, vol. 243, 391-397. 
Berggren, W.A.; Kent, D.V. and Van Couvering, J.A. (1985); The Neogene: Part 2 Neogene geochronology and chronostratigraphy. In; N.J. Snelling (ed), Geochronology and the Geologic Time Scale. Geological Society of ondon Memoir 10, 211-260.

Berner, R.A. (1970); Sedimentary pyrite formation. American Journal of Science, vol. $268,1-23$.

Berner, R.A. (1972); Sulfate reduction, pyrite formation, and the oceanic sulfur budget. In; D. Dyrssden and D. Jagner (eds), The changing chemistry of the oceans: Nobel symposium 20. Almqvit and Wksell, 347-361.

Berner, R.A. (1980); Early Diagenesis. Princeton, New Jersey: Princeton University Press, 241p.

Berner, R.A. (1984); Sedimentary pyrite formation: An update. Geochimica et Cosmochimica Acta, vol. 48, 605-615.

Beu, A.G. (1969); Index macrofossils and New Zealand Pliocene and Lower Pleistocene time-stratigraphy. New Zealand Journal of Geology and Geophysics, vol. 12, 643-658.

Beu, A.G. (1970); The Hautawan Stage: a reply. New Zealand Journal of Geology and Geophysics, vol. 13, 877-878.

Beu, A.G. and Maxwell, P.A., drawings by Brazier, R.C. (1990); Cenozoic Mollusca of New Zealand. New Zealand Geological Survey Paleontological Bulletin 58, 518p.

Beu, A.G.; Edwards, A.R. and Pillans, B.J. (1987); A review of New Zealand Pleistocene stratigraphy, with emphasis on the marine rocks. In; M. Itihara and T. Kamei (eds.), Proceedings of the first international colloquium on Quaternary stratigraphy of Asia and Pacific Area, Osaka, 250-269.

Beus, A.A. (1966); Geochemistry of Beryllium. San Fransisco: Freeman, U.S.A.
Bloemendal , J.; Lamb, B. and King, J. (1988); Paleoenvironmental implications of rock magnetic properties of Late Quaternary sediments cores from the eastern equatorial Atlantic. Paleoceanography, vol. 3, 61-88.

Bourles, D; Raisbeck, G.M. and Yiou, F. (1989); ${ }^{10} \mathrm{Be}$ and ${ }^{9} \mathrm{Be}$ in marine sediments and their potential for dating. Geochimica et Cosmochimica Acta, vol. 53, 443-452.

Bourles, D.; Raisbeck, G.M.; Yiou ,F.; Loiseaux, J.M.; Lieuvin, M.; Klein, J. and Middleton, R. (1984); Investigation of the possible association of $10 \mathrm{Be}$ and $26 \mathrm{Al}$ with biogenic matter in the marine environment. Nucelar Instruments and Methods in Physics Research, vol. 233, no. B5, 367-370.

Brady, H.T. (1979); A diatom report on DVDP Cores $3,4 a, 12,14,15$ and other related surface successions, In; T. Nagata (ed), Proceedings of Seminar III on Dry Valley Drilling Project, 1978, National Institute of Polar Research Memoirs, Special Issue 13 Tokyo, 165175.

Brady, H.T. (1980); Palaeoenvironmental and Biostratigraphic studies in the McMurdo Sound and Ross Sea Regions, Antarctica. Unpublished PhD thesis, Macquarie University, Australia.

Brady, H.T. (1982); Late Cenozoic History of Taylor and Wright Valleys and McMurdo Sound Inferred from Diatoms in Dry Valley Drilling Project Cores, In; C. Craddock (ed), Antarctic Geoscience, Madison: University of Wisconsin Press, 1123-1131.

Brady, H.T and McKelvey, B.C. (1979); The interpretation of a Tertiary tillite at Mount Feather, southern Victoria Land, Antarctica. Journal of Glaciology, vol. 22, 189-193.

Brady, H.T. and McKelvey, B.C. (1983); Some aspects of the Cenozoic glaciation of southern Victoria Land. Journal of Glaciology, vol. 29, 343-349. 
Breza, J.R. (1992); High-resolution study of Neogene ice-rafted debris, site 751, Southern Kerguelan Plateau. In; Wise, S.W., Jr; Schlich, R., et al., (eds), Proceedings of the Ocean Drilling Program, Scientific Results, volume 120, part 1, College Station, Texas, 207221.

Broecker, W.S. (1961); Mixing phenomena within the atmosphere and oceans as determined from radiocarbon data. Unpublished report .

Brown, L. (1987); ${ }^{10} \mathrm{Be}$ : recent applications in Earth Sciences. Philosophical Transactions of the Royal Society of London, vol. A323, 75-86.

Brown, L.; Klein, J.; Middleton, R.; Selwyn Sacks, I. and Tera, F. (1982); ${ }^{10} \mathrm{Be}$ in island-arc volcanoes and implications for subduction. Nature, vol.. 299, 718-720.

Brown, L.; Sacks, I.S.; Tera, F.; Klein, J. and Middleton, R. (1981); Beryllium-10 in continental sediments. Earth and Planetary Science Letters, vol. 55, 370376.

Brown, L.F. and Fisher,W.L. (1977); Seismic stratigraphic interpretation of depositional systems: Examples from Brazilian rift and pull apart basins. In; C.E. Clayton (ed); Seismic Stratigraphy - Applications to Hydrocarbon Exploration, American Association of Petroleum Geologists, Memoir 26, 213 248.

Brown, T.A.; Nelson, D.E.; Southon, J.R. and Vogel, J.S. (1987); ${ }^{10} \mathrm{Be}$ production rate variations as recorded in a midlatitude lake sediment. Nuclear Instruments and Methods in Physics Research, Vol. B29, 232-237.

Buddington, A.F. and Lindsley, D.H. (1964); Iron-titanium oxide minerals and synthetic equivalents. Journal of Petrology, vol. 5, part 2, 310-357.
Burkle, L.H. and Abrams, N. (1986); Diatom species diachrony in late Neogene sediments of the Southern Ocean. South African Journal of Science, vol. 82, 505-506.

Burkle, L.H. and Pokras, E.M. (1991); Implications of a Pliocene stand of Nothofagus (southern beech) within 500 kilometers of the South Pole. Antarctic Science, vol. 3, no. 4, 389-403.

Burkle, L.H.; Gayley, R.I.; Ram, M. and Petit, J.-R. (1988); Diatoms in Antarctic ice cores: Some implications for the glacial history of Antarctica. Geology, vol. 16, 326-329.

Burkle, L.H; Prentice, M.L. and Denton, G.H. (1986); Neogene Antarctic Glacial History: new evidence for marine diatoms in continental deposits. EOS, Transactions of the American Geophysical Union, vol. 67, no. 16, 295.

Burton, B.P. (1985); Theoretical analysis of chemical and magnetic ordering in the system $\mathrm{Fe}_{2} \mathrm{O}_{3}-\mathrm{FeTiO}_{3}$. American Mineralogist, vol. 70, 1027-1035.

Buttler, R.F. (1992); Paleomagnetism. Boston: Blackwell Scientific Publications, 319 p.

Cande, S.C. and Kent, D.V. (1992); A new geomagnetic polarity time scale for the Late Cretaceous and Cenozoic. Journal of Geophysical Research, vol. 97, 13917-13951.

Carmichael, C.M. (1961); The magnetic properties of ilmenite-haematite crystals. Proceedings of the Royal Society, series A, vol. 263, 508-530.

Carter, R.M; Abbott, S.T.; Fulthorpe, C.S.; Haywick, D.W. and Henderson, R.A. (1991); Application of global sea-level and sequence stratigraphic models in Southern Hemisphere Neogene strata from New Zealand. In; D.I.M. Macdonald (ed), Sea level changes at active plate margins. International Association of Sedimentologists, Special Publication 12, 41-65. 
Carter, R.M.; Carter, L.; Williams, J. and Landis, C.A. (1985); Modern and relict sedimentation on the Otago continental shelf. New Zealand Oceanographic Institute, Memoir 93, 43p.

Chanell, J.E.T.; and Hawthorne, T. (1990); Progressive dissolution of titanomagnetites at ODP Site 653 (Tyrrhenian Sea). Earth and Planetary Science Letters, vol. 96, 469-480.

Chanell, J.E.T.; Hawthorne, T. and Torii, M. (1990); Contrasting magnetic properties in leg 107 sediments: preservation and alteration of titanomagnetite at adjacent sites. In; K.A. Kastens; J. Mascle et al. (eds) Proceedings of the Ocean Drilling Program, Scientific Results, vol. 107, 113-128.

Ciesielski, P.F. (1975); Biostratigraphy and palaeoecology of Neogene and Oligocene silicoflagellates from cores recovered during Antarctic Leg 28, Deep Sea Drilling Project. In; D.E. Hayes and L.A. Frakes et al. (eds), Initial Reports of the Deep Sea Drilling Project, vol. 28. Washington, D.C.: U.S. Government Printing Office, 625-692.

Ciesielski, P.F. (1983); The Neogene diatom stratigraphy of DSDP Leg 71. In; W.J. Ludwig; V. Krasheninnikov; et al., Initial reports of the Deep Sea Drilling Project, vol. 71, Washington, D.C.: U.S. Government Printing Office, 757-767.

Cifelli, R. (1969). Radiation of the Cenozoic Planktonic Foraminifera. Systematic Zoology, vol. 18, 154-168.

Cita, M.B. (1975); The Miocene/Pliocene boundary: History and definition, In; T. Saito and L.H.Burkle (eds), Late Neogene epoch boundaries, New York: Micropaleontology Press, 1-30.

Clapperton, C.M. and Sugden, D.E. (1990); Late Cenozoic glacial history of the Ross Embayment, Antarctic. Qua ternary Science Reviews, vol. 9, 253-272.
Claridge, G.G.C. and Campbell, I.B. (1968); Soils of the Shackleton Glacier region, Queen Maud Range, Antarctica. New Zealand Journal of Science, vol. 11, 11-15.

Claridge, G.G.C. and Campbell, I.B. (1989); Clay Mineralogy. In; P.J., Barrett, (ed), Antarctic Cenozoic history from the CIROS-1 drill-hole, McMurdo Sound, DSIR Bulletin 245, 185-193.

Cole, J.W. (1979); Structure, petrology and genesis of Cenozoic Volcanism, Taupo Volcanic Zone, New Zealand - a review. New Zealand Journal of Geology and Geophysics, vol. 22, 631-657.

Collen, J.D. (1972); Studies in the Wanganui Series: Pliocene Formainifera from Wanganui Basin. Unpublished $\mathrm{PhD}$ thesis lodged in the library, Victoria University of Wellington, 547 p.

Collinson, J.D. (1969); The sedimentology of the Grindslow Shales and the Kinderscout Grit: a deltaic complex in the Namurian of northern England. Journal of Sedimentary Petrology, vol. 39, 194-221.

Cranfield, D.E. and Berner, R.A. (1986); Dissolution and pyritisation of magnetite in anoxic marine sediments. Geochimica et Cosmochimica Acta, vol. 51, 645-659.

Cronin, T.M. (1991); Pliocene shallow water paleoceanography of the North Atlantic Ocean based on marine ostracodes. Quaternary Science Reviews, vol. 10, 175-188.

DeBoer, P.L.; Langereis, C.G.; Zijderveld, J.D.A; Romein, A.J.T.; Porter, C.; DeJong, A.F.M.; Alderliesten, C. and van der Borg, $\mathrm{K}$ (1987); Beryllium-10 data from redeposited Late Miocene pelagic sediments (East Java, Indonesia). Nuclear Instruments and Methods in Physics Research, Vol. B29, 322-326. 
Deer, W.A.; Howie, R.A. and Zussman, J. (1989); An Introduction to the Rock Forming Minerals. London: Longman Scientific and Technical, 528p.

Denton, G.H. (1985); Did the Antarctic ice sheet influence late Cainozoic climate and evolution in the Southern Hemisphere? South African Journal of Science, vol. 81, 224-229.

Denton, G.H. and Hughes, T.J. (ed) (1981); The last great ice sheets. New York: Wiley-Interscience.

Denton, G.H.; Prentice, M.L. and Burkle, L.M. (1992); Cainozoic history of the Antarctic ice sheet. In; R.J. Tingey (ed); The Geology of Antarctica, Oxford monographs on geology and geophysics, no. 17. Oxford: Clarendon Press, 365-433.

Denton, G.H.; Prentice, M.L.; Kellogg, D.E. and Kellog, T.B. (1984); Late Tertiary history of the Antarctic ice sheet: Evidence from the Dry Valleys. Geology, vol. 12, 263-267.

Domack, E.W.; Jull, A.J.T.; Anderson, J.B.; Linick, T.W. and Williams, C.R. (1989); Application of tandem accelerator mass-spectrometer dating to late Pleistocene-Holocene sediments of the East Antarctic continental shelf. Quaternary Research, vol. 31, 277-278.

Doumani, G.A. and Minshew, V.H. (1965); General Geology of the Mt. Weaver area, Queen Maud Mountains, Antarctica. In; J.B. Hadley (ed), Geology and paleontology of the Antarctic, Antarctic research Series, vol. 6, Washington, D.C.,: American Geophysical Union, 127-139.

Dowsett, H.J. and Cronin, T.M. (1990); High eustatic sea level during the middle Pliocene: Evidence from the southeastern U.S. Atlantic Coastal Plain. Geology, vol. 18, 435-438.
Dowsett, H.J. and Loubere, P. (1992); High resolution late Pliocene sea-surface temperature record from the Northeast Atlantic Ocean. Marine Micropalaeontology, vol. 20,91-105.

Dowsett, H.J.; Cronin, T.M.; Poore, R.Z.; Thompson, R.C.; Whatley, R.C. and Wood, A.M. (1992); Micropaleontological Evidence for Increased Meridional Heat Transport in the North Atlantic Ocean During the Pliocene. Science, vol. 258, 1133-1135.

Drewry, D.J. (1980); Pleistocene bimodal response of Antarctic ice. Nature, vol. 287, 214-216.

Drewry, D.J. (1983); Antarctica: Glaciological and geophysical folio, Cambridge: Cambridge University Press.

Dunbar, R.B.; Late Pliocene-Quaternary Biosiliceous Sedimentation at site 798, Japan Sea. In; J. Ingle; K. Suyehiro; M. von Breymann; et al. (eds) Proceedings of the Ocean Drilling Program, Scientific Results, vol. 128, College Station Texas.

Dunlop, D.J. (1979); On the use of Zijderveld vector diagrams in multicomponent paleomagnetic samples. Physics of the Earth and Planetary Interiors, vol. 20, 12-24.

Duplessy, J.C. (1978); Isotope Studies. In; J. Gribbin (ed), Climatic Change, Cambridge: Cambridge University Press.

Edwards, A.R. (1987); An Integrated Biostratigraphy, Magnetostratigraphy, and Oxygen Isotope Stratigraphy for the Late Neogene of New Zealand. New Zealand Geological Survey Record, no. 23, 80p.

Edwards, A.R.; Hornibrook, N. de B.; Raine, J.I.; Scott, G.H.; Stevens, G.R.; Strong, C.P. and Wilson, G.J. (1988); A New Zealand Cretaceous-Cenozoic Geological Time Scale. New Zealand Geological Survey, Record 35, 135-149. 
Eggers, A.J. (1979); Scallop Hill Formation, Brown Peninsula, McMurdo Sound, Antarctica. New Zealand Journal of Geology and Geophysics, vol. 22, no. 3, 353-361.

Eisenhauer, A.; Mangini, A; Segl, M.; Beer, J.; Bonani, G.; Suter, M. and Woolfli, W. (1987); High Resolution ${ }^{10} \mathrm{Be}$ and ${ }^{230} \mathrm{Th}$ profiles in DSDP site 580. Nuclear Instruments and Methods in Physics Research, vol. B29, 326-331.

Elliot, T. (1986); Siliciclastic shorelines. In; H.G. Reading (ed), Sedimentary environments and facies. Oxford: Blackwells, 155-188.

Elliott, D.; Barrett, P.J. and Mayewski, P.A. (1974); Reconnaissance geologic map of the Plunket Point Quadrangle, map of the Plunket Point Quadrangle,
Faure, G. and Harwood, D.M. (1990); Marine microfossils in till clasts of the Elephant Moraine on the east antarctic ice sheet. Antarctic Journal of the United States, vol. 25, no. 5, 23-25.

Faure, G. and Taylor, K.S. (1981); Provenance of some glacial deposits in the Transantarctic Mountains based on $\mathrm{Rb}-\mathrm{Sr}$ dating of feldspars. Chemical Geology, vol. 32, no. 3/4, 271-290.

Feldmeyer, A.E.; Jones, B.C.; Firth, C.W. and Knight, J. (1943); Geology of the Palmerston-Wanganui Basin, "west side", North Island, New Zealand. Superior Oil Company Report, Unpublished, held as open file petroleum report 171 by the New Zealand Geological Survey, Lower Hutt. 
Fleming, C.A. (1953); The Geology of the Wanganui Subdivision. New Zealand Geological Survey, Bulletin, no. 52, 362p.

Fleming, C.A. (1959) (ed); Lexique stratigraphique international, vol. 6, Oceanie, Fasc. 4, New Zealand, C.N.R.S., Paris.

Fleming, C.A. (1978); [Tertiary Stratigraphy] Wanganui - Manawatu, In; R.P. Suggate; G.R. Stevens and M.T. TePunga (eds), The Geology of New Zealand. Wellington: Government Printer, Wellington, New Zealand, vol. 2, 460-465.

Fulthorpe, C.S. (1991); Geological controls on seismic sequence resolution: Geology, vol. 19, 61-65,

Galloway, W.E. (1989); Genetic stratigraphic sequences in basin analysis I: architecture and genesis of floodingsurface bounded depositional units: American Association of Petroleum Geologists, Bulletin, vol. 73, 125-142.

Gardner, L.R. (1973); Chemical models for sulfate reduction in closed anaerobic marine environments. Geochimica et Cosmochimica Acta, vol. 37, 53-68.

Gladenkov, Yu. B.; Barinov, K.B. Basilian, A.E. and Cronin, T.M. (1991); Stratigraphy and paleoceanography of Pliocene deposits of Karaginsky Island, Eastern Kamchatka, U.S.S.R. Quaternary Science Reviews, vol. 10, 239-245.

Gleadow, A.J.W. and Fitsgerald, P.G. (1987); Uplift history and structure of the Transantarctic Mountains: new evidence from fission track dating of basement apatites in the Dry Valleys area, southern Victoria Land. Earth and Planetary Science Letters, vol. 82, 1-14.

Goel, P.S.; Jha, S.; Lal, D.; Radakrishna, P. and Rama (1956); Cosmic ray produced beryllium isotopes in rain water. Nuclear Physics, vol. 1, 196-201.

Goel, P.S.; Kharkar, D.P.; Lal, D.; Narasappaya, N.; Peters, B. and Yatirajam, V. (1957); Beryllium-10 concentrations in deep sea sediment. Deep-Sea Research, vol. 4, 202-210.
Gombos, A.M., Jr and Ciesielski, P.F. (1983); Late Eocene to early Miocene diatoms from the southwest Atlantic, In; W.J. Ludwig; V. Krasheninnikov; et al.., Initial reports of the Deep Sea Drilling Project, volume 71, Washington, D.C.: U.S. Government Printing Office, 583-634.

Guichard, F.; Reyss, J.-L. and Yokohama,.Y. (1978); Growth rate of a manganese nodule measured with ${ }^{10} \mathrm{Be}$ and ${ }^{26} \mathrm{Al}$. Nature, vol. 272, 155-156.

Gunn, B. M. and Warren, G. (1962); Geology of Victoria Land between the Mawson and Mulock Glaciers, Antarctica. New Zealand Geological Survey, bulletin 71, 157p.

Haag, M.; Heller, F.; Allenspach, R. and Roche, K. (1990); Self-reversal of natural remanent magnetisation in andesitic pumice. Physics of the Earth and Planetary Interiors, vol. 65, 104108.

Halbach, P., Segl, M., Puteanus, D. and Mangini, A. (1983); Co-fluxes and growth rates in ferromanganese deposits from central Pacific seamount areas. Nature; vol.304, no.25, 716-719.

Hambrey, M.J. and Barrett, P.J. (1993); Cenozoic Sedimentary and Climate Record, Ross Sea Region, Antarctica. In; J.P. Kennett and D.A. Warnke (eds); The Antarctic Palaeoenvironment: A Perspective on Global Change, Part 2. Antarctic Research Series, Washington, D.C.: American Geophysical Union.

Hambrey, M.J. and Harland, W.B. (eds) (1981); Earth's pre-Pleistocene glacial record. Cambridge: Cambridge University Press, 1004p.

Hambrey, M.J.; Barrett, P.J.; Ehrmann, W.U. and Larsen, B. (1992); Cenozoic sedimentary processes on the Antarctic continental margin and the record from deep drilling. Z. Geomorph. N.F., 7399. 
Hambrey, M.J.; Barrett, P.J. and Robinson, P.H. (1989); Stratigraphy. In; Barrett, P.J. (ed); Antarctic Cenozoic history from the CIROS-1 drillhole, McMurdo Sound, DSIR Bulletin 245, 23-48.

Hambrey, M.J.; Ehrmann, W.U. and Larsen, B. (1991); Cenozoic Glacial Record of the Prydz Bay Continental Shelf, East Antarctica. In; J. Barron, B. Larsen et al. Proceedings of the Ocean Drilling Program, Scientific Results, vol. 119, 77-132.

Haq, B.U. (1973). Transgressions, Climatic Change and Diversity of Calcareous Nannoplankton. Marine Geology, vol. $15,25-30$.

Haq, B.U. (1991); Sequence stratigraphy, sea-level change, and significance for the deep sea. In; D.I.M. Macdonald (ed); Sedimentation, Tectonics and Eustasy, Sea-level Changes at Active Margins. Special Publication 12 of the International Association of Sedimentologists, 3-39.

Haq, B.U.; Hardenbol, J. and Vail, P.R. (1987); Chronology of Fluctuating SeaLevels Since the Triassic. Science, vol. $235,1156-1167$.

Haq, B.U.; Hardenbol, J. and Vail, P.R. (1988); Mesozoic and Cenozoic Chronostratigraphy and Cycles of Sealevel Change. In; C.K. Wilgus et al. (eds), Sea-Level changes: an integrated approach, Society of Economic Paleontologists and Mineralogists, Special Publication 42, 71-108.

Harwood, D.M. (1985); Late Neogene climatic fluctuations in the southern high-latitudes: implications of a warm Pliocene and deglaciated Antarctic continent. South African Journal of Science, vol.81, 239-241.

Harwood, D.M. (1986); Diatom biostratigraphy and paleoecology with a Cenozoic history of ntarctic ice sheets, Unpublished $\mathrm{PhD}$ thesis lodged in the library, Ohio State University, Columbus Ohio, U.S.A., 592p.
Harwood, D.M.; Lazarus, D.B.; Ablemann, A.; Aubrey, M.-P.; Berggren, W.A.; Heider, F.; Inokuchi, H.; Maruyama, T.; McCartney, K.; Wei, W. and Wise, S.W., Jr. (1992); Neogene Integrated Magnetobiostratigraphy of the central Kerguelan Plateau, Leg 120. In; Wise, S.W., Jr; Schlich, R., et al., Proceedings of the Ocean Drilling Program, Scientific Results, volume 120, Texas: College Station, 1031-1052.

Harwood, D.M.; Scherer, R.P. and Webb, P.N. (1989); Multiple Miocene Marine Productivity Events in West Antarctica as Recorded in Upper Miocene Sediments Beneath the Ross Ice Shelf (Site J-9). Marine Micropalaeontology, vol. 15, 91-115.

Hay, R.F. (1967); Geological Map of New Zealand 1:250,000, Sheet 7 Taranaki, New Zealand Department of Scientific and Industrial Research, Wellington.

Hay, R.F. (1978); [Tertiary Stratigraphy] North Taranaki and east to National Park, In; R.P. Suggate; G.R. Stevens and M.T. TePunga (eds), The Geology of New Zealand. Wellington: Government Printer, Wellington, New Zealand, vol. 2, 456-460.

Hayes, D.E. and Davey, F.J. (1975); A geophysical study of the Ross Sea, Antarctica. In; D.E. Hayes; L.A. Frakes; and others (eds). Initial Reports of the Deep Sea Drilling Project, vol. 28. Washington, D.C.: U.S. Government Printing Office, 887-908.

Hayes, D.E.; Frakes, L.A. and others (1975). 'General Synthesis Deep Sea Drilling Project Leg 28'. In; D.E. Hayes; L.A. Frakes; and others (eds). Initial Reports of the Deep Sea Drilling Project, vol. 28. Washington, D.C.: U.S. Government Printing Office, 919 942. 
Hays, J.D; Saito, T.; Opdyke, N.D. and Burkle, L.H. (1969); PliocenePleistocene sediments of the equatorial Pacific. Their paleomagnetic, biostratigraphic and climate record. Geological Society of America, Bulletin vol. 80, 1481-1514.

Henken-Mellies, W.U.; Beer, J.; Heller, F.; Hsu, K.J.; Shen, C.; Bonani, G., Hofmann, H.J.; Suter, M. and Wolfli, W. (1990); ${ }^{10} \mathrm{Be}$ and ${ }^{9} \mathrm{Be}$ in South Atlantic DSDP Site 519: Relation to geomagnetic reversals and to sediment composition. Earth and Planetary Sciece Letters, vol. 98, 267-276.

Hilgen, F.J. and Langereis, C.G. (1988); The age of the Miocene-Pliocene boundary in the Capo Rossello area (Sicily). Earth and Planetary Science Letters, vol. 91, 214-222.

Hill, R.S.; Harwood, D.M. and Webb, P.N. (1991): Abstract in; proceedings of the 8th Gondwana Symposium, Hobart, Australia.

Hodell, D.A.; Muller, D.W.; Ciesielski, P.F. and Mead, G.A. (1991); Synthesis of oxygen and carbon isotopic results from site 704: Implications for major climatic-geochemical transitions during the Late Neogene. In; P.F Ciesielski; Y. Kristoffersen; et al. (eds), proceedings of the Ocean Drilling Program, Scientific Results, vol. 114, 475-480.

Hoffman, K.A. (1992); Self-Reversal of Thermoremanent Magnetisation in the Ilmenite-Hematite System: OrderDisorder, Symmetry, and Spin Alignment. Journal of Geophysical Research, vol. 97, no. 87, 10883-10895.

Hoffman, K.A. and Day, R. (1978); Separation of multicomponent NRM: A general method. Earth and Planetary Science Letters, vol. 40, 433-438.
Hofmann, H.J.; Beer, J.;Bonani, G.; Von Gunten, H.R.; Raman, S.; Suter, M.; Walker, R.L.; Woolfli, W. and Zimmermann, D. (1987); ${ }^{10}$ Be Half-life and AMS-standards. Nuclear Instruments and Methods in Physics Research, vol. B29, 32-36.

Hornibrook, N. deB.; Brazier, R.C. and Strong, C.P. (1989); Manual of New Zealand Permian to Pleistocene Foraminiferal Biostratigraphy. New Zealand Geological Survey Paleontological Bulletin, no. 56, 175p.

Hoskins, R. (ed) (1982); Stages of the New Zealand marine Cenozoic: a synopsis. New Zealand Geological Survey Report, no. $107,74 \mathrm{p}$.

Hunt, D. and Tucker, M.E. (1992); Stranded parasequences and the forced regressive wedge systems tract: deposition during base-level fall. Sedimentary Geology, vol. 81, 1-9.

Inn, K.G.W.; Raman, S.; Coursey, B.M.; Fassett, J.D. and Walker, R.L. (1987); Development of the ${ }^{10} \mathrm{Be}:{ }^{9} \mathrm{Be}$ isotopic standard reference material. Nuclear Instruments and Methods in Physics Research, vol. B29, 27-31.

Inoue, T. and Tanaka, S. (1976); ${ }^{10} \mathrm{Be}$ in marine sediments. Earth and Planetary Science Letters, vol. 29, 155-160.

Ishman, S.E. and Webb, P.N. (1988); Late Neogene benthic foraminifera from the Victoria Land Basin margin, Antarctica: application to glacio-eustatic and tectonic events. Revue de Paleobiologie, special volume 2, part 2, 523-551.

Ishman, S.E. and Reick, H.J. (1993); A Late Neogene Antarctic glacio-eustatic record, Victoria Land Basin margin, Antarctica. In; J.P. Kennett and D.A. Warnke (eds), The Antarctic Palaeoenvironment: A Perspective on Global Change, Part 2. Washington, D.C.: Antarctic Research Series, American Geophysical Union. 
Jansen, E; A.J.; van der Borg, K. and DeJong, A.F.M. (1987); Terriginous supply of $10_{\mathrm{Be}}$ and dating with ${ }^{14} \mathrm{C}$ and ${ }^{10} \mathrm{Be}$ in sediments of the Angola Basin (SE Atlantic). Nuclear Instruments and Methods in Physics Research. vol. B29, 311-316.

Jenkins, D.G. (1971); Stratigraphic position of the New Zealand PliocenePleistocene boundary: Comment. Tuatara, vol. 14, no. 2, 418-420.

Jervey, M.T. (1988); Quantitative geological modelling of siliciclastic rock sequences and their seismic expression. In; C.K. Wilgus et al. (eds), Sea-Level changes: and integrated approach, Society of Economic Paleontologists and Mineralogists, Special Publication 42, 47-69.

Jha, R. and Lal, D. (1982); On cosmic ray produced isotopes in surface rocks. In; K.G. Vohra; K.C. Pilai; U.C. Mishra and S. Sadadivan (eds): Natural Radiation Environment. Wiley Eastern, New Delhi, India. 629-635.

Karlin, R. and Levi, S. (1985); Geochemical and sedimentological control of the magnetic properties of hemipelagic sediments. Journal of Geophysical Research, vol. 90, 1037310392.

Keigwin, L. and Thunell, R. (1979); Middle Pliocene climatic change in the western Mediterranean from faunal and oxygen isotopic trends. Nature, vol. 282, 294-296.

Kellogg, T.B. and Kellogg, D.E. (1981); Pleistocene sediments below the Ross Ice Shelf. Nature, 293, 130-133.

Kellogg, T.B. and Kellogg, D.E. (1983); Interpretation from sediment cores from the Ross Ice Shelf Site J-9, Antarctica Reply, Nature, 303, 511-513.

Kellogg, T.B. and Kellogg, D.E. (1985); Evidence bearing on the former existence of grounded ice sheets in the Ross Sea, Antarctic, South African Journal of Science, vol.81, 237-238.
Kellogg, T.B. and Kellogg, D.E. (1986); Diatom Biostratigraphy of sediment cores beneath the Ross Ice Shelf. Micropalaeontology, 32, 74-79.

Kemp, E.M. and Barrett, P.J. (1975); Antarctic glaciation and Early Tertiary vegetation. Nature, vol. 258, 507-508.

Kennett, J. P. (1970); Pleistocene Paleoclimates and foraminiferal biostratigraphy in subantarctic DeepSea Cores. Deep Sea Research, vol. 17, 125-140.

Kennett, J.P. (1977). Cenozoic evolution of Antarctic Glaciation, the CircumAntarctic Ocean, and their Impact on Global Paleoceanography. Journal of Geophysical Research, vol. 82, 38433859.

Kennett, J.P. (1982). Marine Geology. Englewood Cliffs, New Jersey: Prentice Hall, Inc., 813p.

Kennett, J.P. and Shackleton, N.J. (1976); Oxygen Isotopic Evidence for the Development of the Psychrosphere 38 Myr. ago. Nature, vol. 260, 513-515.

Kennett, J.P. and Watkins, N.D. (1974); Late Miocene-Early Pliocene paleomagnetic stratigraphy, paleoclimatic and biostratigraphy in New Zealand. Geological Society of America, Bulletin , vol. 85, 1385-1398.

Kennett, J.P.; Houtz, R.E. and others (1975). Cenozoic paleoceanography in the Southwest Pacific Ocean, Antarctic Glaciation and the development of the Circum-Antarctic Current. In; J.P. Kennett and R.E. Houtz (ed). Initial Reports of the Deep Sea Drilling Project, Volume 29, Washington, D.C.: U.S. Governement Printing Office. 1155-1169.

Kennett, J.P.; Watkins, N.D. and Vella, P. (1971); Paleomagnetic Chronology of Pliocene-Early Pleistocene Climates and the Plio-Pleistocene Boundary in New Zealand. Science, vol. 171, 276-279. 
Kennett, J.P.; Watkins, N.D. and Vella, P. (1972); Geomagnetic dates on a New Zealand Upper Miocene-Pliocene section. Earth and Planetary Science Letters, vol. 16, 195-199.

Ker, D.S. (1973); Stratigraphy and Engineering Geology of the lower Wanganui Valley, Koriniti to Parakino. New Zealand Journal of Geology and Geophysics, vol. 16, no. 2, 189-208.

Kilius, I.R.; Beukens, R.P.; Chang, K.H.; Lee, H.W.; Litherland, A.E.; Elmore, D.; Ferraro, R. and Gove, H.E. (1980); Measurement of ${ }^{10} \mathrm{Be} /{ }^{9} \mathrm{Be}$ ratios using an Electrostatic Tandem Accelerator. Nuclear Instruments and Methods. in Physics research, vol. 171, 355-360.

Kirschvink, J.L. (1980); The least squares line and plane and the analysis of palaeomagnetic data. Geophysical Journal of the Royal Astronomical Society, vol. 62, 699-718.

Klein, J.; Middleton, R. and Tang, $\mathrm{H}$. (1982); Modifications of an FN Tandam for quatitative ${ }^{10} \mathrm{Be}$ measurement. Nuclear Instruments and Methods in Physics research, vol. 193, 601-616.

Kobayashi, K. and Nomura, M. (1972); Iron sulphides in the sediment cores from the sea of Japan and their geophysical implications. Earth and Planetary Science Letters, vol. 16, 200208.

Krantz, D.E. (1991); A chronology of Pliocene sea-level fluctuations: The U.S. Middle Atlantic Coastal Plain record. Quaternary Science Reviews, vol. 10, 163-174.

Ku, T.L., Kusakabe, M., Nelson, D.E., Southon, J.R., Korteling, R.G., Vogel, J. and Nowikow, I. (1982); Consistancy of oceanic deposition of ${ }^{10} \mathrm{Be}$ as recorded in manganese crusts. Nature, 299, p240.

Kumar, A. and Bhalla, M.S. (1984a); Source of stable remanence in chromite ores. Geophysical Research Letters, vol. 11, 177-180.
Kumar, A. and Bhalla, M.S. (1984b); Palaeomagnetism of sukinda chromites and their geological implications. Geophysical Journal of the Royal Astronomical Society, vol. 77, 863-874.

Kusakabe, M.; Ku, T.L.; Southon, J.R.; Vogel, J.S.; Nelson, D.E.; Measures, C.I. and Nozaki, Y. (1987); The distribution of ${ }^{10} \mathrm{Be}$ and ${ }^{9} \mathrm{Be}$ in ocean water. Nuclear Instruments and Methods in Physics Research, vol. B29, 306-310.

Kvale, T.J.; Alton, G.D.; Compton, D.J.; Pegg, D.J. and Thompson, J.S. (1985); Physics review Letters, vol. 55, 484.

Kyle, P.R. (1981); Glacial history of the McMurdo Sound area as indicated by the distribution and nature of McMurdo Volcanic Group rocks. In; L.D. McGinnis (ed) Dry Valley Drilling Project, Washington, D.C.: Antarctic Research Series, vol. 33, American Geophysical Union, 403-412.

Lal, D. (1962); Cosmic Ray Produced Radionuclides in the Sea. Journal of the Oceanographical Society of Japan, 20th Anniversary volume, 600-614.

Lal, D. and Peters, B. (1967); Cosmic-ray produced radioactivity on the Earth. In; K.Sitte (ed): Handbuch der Physik, Springer-Verlag, Berlin, Germany. vol. 46, 551-612.

LaPrade, K.E. (1984); Climate, geomorphology, and glaciology of the Shackleton Glacier Area, Queen Maud Mountains, Transantarctic Mountains, Antarctica. In; M.D. Turner and J.F. Splettstoesser (eds) Antarctic Research Series, vol. 36, Washington, D.C.: American Geophysical Union, 163-196.

Lawson, C.A. and Nord, G.L.Jr. (1984); Remanent magnetization of a "paramagnetic" composition in the Ilmenite-Hematite solid solution series. Geophysical Research Letters, vol. 11, no. 3, 197-200. 
Lawson, C.A.; Nord, G.L.Jr.; Dowty, E. and Hargraves, R.B. (1981); Antiphase Domains and Reverse Thermoremanent Magnetism in Ilmenite-Hematite Minerals. Science, vol. 213, 1372-1374.

Leckie, R.M. and Webb, P.-N. (1979); Scallop Hill Formation and associated Pliocene marine deposits of southern McMurdo Sound. Antarctic Journal of the United States, vol. 14, no. 5, 54-56.

Leg 119 Shipboard Scientific Party (1988); Early glaciation of Antarctica. Nature, vol. 333, 303-304.

Leg 120 Scientific Drilling Party (1988); ODP at Kerguelen Plateau: Leg 120 explores origins and history. Geotimes, vol. $33,12-16$.

Liddicoat, J.C.; Opdyke, N.D. and Smith, G.I. (1980); Paleomagnetic polarity in a $930 \mathrm{~m}$ core from Searles Valley, California. Nature, vol. 286, 22-25.

Lienert, B.R.; Christoffel, D.A. and Vella, P. (1972); Geomagnetic dates on a New Zealand Upper Miocene-Pliocene section. Earth and Planetary Science Letters, vol. 16, 195-199.

Litherland, A.E. (1984); Accelerator Mass Spectrometry. Nuclear Instruments and Methods in Physics Research, vol. B5, 100-108.

Loutit, T.S. and Kennett, J.P. (1979); Application of carbon isotope stratigraphy to Late Miocene shallow marine sediments, New Zealand. Science, vol. 204, 1196-1199.

Loutit, T.S.; Hardenbol, J; Vail, P.R. and Baum, G.R. (1988); Condensed sections: The key to Age Dating and Correlation of Continental Margin Sequences. In; C.K. Wilgus et al. (eds), Sea-Level changes: and integrated approach, Society of Economic Paleontologists and Mineralogists, Special Publication 42, 183-213.
Lowrie, W. (1990); Identification of Ferromagnetic minerals in a rock by Coercivity and Unblocking Temperature Properties. Geophysical Research Letters, vol. 17, no. 2, 159-162.

Macdonald, D.I.M. (ed) (1991); Sea level changes at active plate margins, International Association of Sedimentologists, Special Publication 12.

McCorkell, R.; Fireman, E.L. and Langway, C.C. Jr. (1967); Aluminium26 and Beryllium-10 in Greenland Ice. Science, vol. 158, 1690-1692.

McElhinny, M.W. (1973); Palaeomagnetism and Plate Tectonics. New York: Cambridge University Press, $386 \mathrm{p}$.

McFadden, P.L. and McElhinny (1988); The combined analysis of remagnetisation circles and direct observations in palaeomagnetism. Earth and Planetary Science Letters, vol. 87, 161-172.

McGregor, V.R. (1965); Notes on the geology of the area between the heads of the Beardmore and Shackleton Glaciers, Antarctica. New Zealand Journal of Geology and Geophysics, vol. 8, 278-291.

McGuire, D.M. (1989); Paleomagnetic Stratigraphy and Magnetic Properties of Plicoene Strata, Turakina River, North Island, New Zealand. Unpublished $\mathrm{PhD}$ thesis lodged in the Victoria University of Wellington Library, 236p.

$\mathrm{M}^{\mathrm{C}}$ Hargue, L.R. and Damon, P.E. (1991); The Global Beryllium-10 Cycle. Reviews of Geophysics, vol. 29, no. 2, 141-158.

McKelvey, B.C. (1975); Preliminary Site Reports - DVDP Sites 10 and 11, Taylor Valley. Dry Valley Drilling Project, Bulletin No. 5, 16-60. 
McKelvey, B.C. (1979); The MiocenePleistocene stratigraphy of Eastern Taylor Valley - An interpretation of DVDP cores 10 and 11 . In; T. Nagata (ed), Proceedings of the seminar III on Dry Valley Drilling Project, Memoirs of the National Institute of Polar Research, Special Issue, No. 13, 177-186

McKelvey, B.C. (1981); The lithologic logs of DVDP cores 10 and 11, Eastern Taylor Valley. In; L.D. McGinnis (ed); Dry Valley Drilling Project. Antarctic Research Series, vol. 33, Washington D.C.: American Geophysical Union, 6394.

McKelvey, B.C. (1988); Amery Oasis research testing ice sheet history hypothesis. Australian National Antarctic Research Expeditions Newsletter, no. 53, 8.

McKelvey, B.C. and Stephenson, N.C.N. (1990); A geological reconnaissance of the Radok Lake area, Amery Oasis, Prince Charles Mountains. Antarctic Science, vol. 2, no. 1, 53-66.

McKelvey, B.C.; Webb, P.N.; Harwood, D.M. and Mabin, M.C.G. (1991); The Dominion Range Sirius Group: a record of the late Pliocene - early Pleistocene Beardmore Glacier. In; M.R.A. Thomson; J.A. Crame and J.W. Thompson (eds), Geological Evolution of Antarctica, Cambridge: Cambridge University Press, 675-682.

MacPherson, A.J. (1987); The McKay Glacier / Granite Harbour System (Ross Dependency, Antarctica) - A Study in nearshore glacial marine sedimentation. Unpublished $\mathrm{PhD}$ thesis lodged in the Victoria University of Wellington library, $173 \mathrm{p}$.

Mackin, J.E. (1986); Control of dissolved $\mathrm{Al}$ distributions in marine sediments by clay reconstitution reactions: Experimental evidence leading to a unified theory. Geochimica et Cosmochimica Acta, vol. 50, 207-214.
Mangini, A. (1986); Application of ${ }^{230} \mathrm{Th}$, ${ }^{23}{ }^{1} \mathrm{~Pa}$ and ${ }^{10} \mathrm{Be}$ Radioisotopes in Sedimentary Geology. In A.J. Hurford; E.Jager and J.A.M.ten Cate (eds); Dating Young Sediments. Committee for Co-Ordination of joint Prospecting for mineral resources in Asian offshore areas Technical Publication, No. 16, 5972.

Mangini, A.; Segl, M.; Bonani, G.; Hofmann, H.J.; Morenzoni, E.; Nessi, M.; Suter, M.; Woolfli, W. and Turekian, K. (1984); Massspectrometric ${ }^{10} \mathrm{Be}$ dating of deep-sea sediments applying the Zurich Tandem Accelerator. Nuclear Instúments and Methods in Physics Research, vol. B5, 353-358.

Marchant, D.R.; Lux, D.R.; Swisher, C.C., III and Denton, G.H. (1989); Early Pliocene volcanic ash rests on a polar desert pavement. Antarctic Journal of the United States, vol. 24, no. 5, 58-60.

Marchant, D.R. (1992); A new approach for determining Pliocene palaeoclimates and ice sheet histroy of East Antarctica. (Abstract) In; Cenozoic Glaciations and Deglaciations, Geological Society of London Meeting.

Marchant, D.R.; Swisher, C.C. III; Lux, D.R., West, D.P. and Denton, G.H. (1993); Pliocene Palaeoclimate and East Antarctic Ice-Sheet History from Surficial Ash Deposits. Science, vol. 260, 667-669.

Martin, A.K. and Fleming, B.W. (1986); The Holocene shelf sediment wedge off the south and east coast of South Africa. In; R.J. Knight and J.R. McLean (eds), Shelf Sands and Sandstones. Canadian Society of Petroleum Geologists, Memoir 11, 27-44.

Matthews, R.K. and Poore, R.Z. (1980); Tertiary ${ }^{18} \mathrm{O}$ record and glacioeustatic sea-level fluctuations. Geology, vol. 8, 103-106. 
Mayewski, P.A. (1975); Glacial Geology and late Cenozoic history of the Transantarctic Mountains, Antarctica. Columbus: Institute of Polar Studies report no. 56. The Ohio State University.

Mayewski, P.A. and Goldthwait, R.P. (1985); Glacial events in the Transantarctic Mountains: A record of the East Antarctic Ice Sheet. In; M.D. Turner and J.F. Splettstoesser (eds) Geology of the Transantarctic Mountains, Washington, D.C.: Antarctic Research Series, volume 36, American Geophysical Union, 275-324.

Measures, C.I. and Edmond, J.M. (1982); Beryllium in the water column of the central North Pacific. Nature, vol. 297, 51-53.

Melhuish, A. (1990); Late Cenozoic deformation along the PacificAustralian plate margin, Dannevirke region, New Zealand, unpublished MSc. thesis lodged in the Victoria University Library, Wellington, New Zealand, $116 \mathrm{p}$.

Mercer, J.H. (1968); Glacial Geology of the ReedyGlacier area, Antarctica. Geological Society of America Bulletin, vol. 79, 217-225.

Mercer, J.H. (1972); Some obser vations on the glacial geology of the Beardmore Glacier area. In; R.J. Adie (Ed) Antarctic Geology and Geophysics, Oslo: Universitetsforlarget, 427-433.

Mercer, J.H. (1983); Cenozoic glaciations in the Southern Hemisphere. Annual Reviews of Earth and Planetary Science, vol. 11, 99-132.

Mercer, J.H. (1985); When did openmarine conditions last prevail in the Wilkes and Pensacola Basins, East Antarctica, and when was the Sirius Formation emplaced?. South African Journal of Science, vol.81; 243-244.
Merril, J.R.; Honda, M. and Arnold, J.R. (1960); Methods for Separation and Determination of Beryllium in Sediments and Natural Waters. Analytical Chemistry, vol. 32, no. 11, 1420-1426.

Merril, J.R.; Lyden, E.F.X.; Honda, M. and Arnold, J.R. (1960); Sedimentary Geochemistry of the beryllium isotopes. Geochimica et Cosmochimica Acta, vol. 18, 108-129.

Microstrat, Inc. (1990); Slide set on Sequence stratigraphy.

Middleton, G.V. (1973); Johannes Walther's Law of the Correlation of Facies. Geological Society of America Bulletin, vol. 84, 979-988.

Middleton, R. and Klein, J. (1987); 26Al: measurement and applications. Philosophical Transactions of the Royal Society of London, Series A, vol. 323, 121-143.

Miller, K.G. and Fairbanks, R.G. (1985); Cainozoic $\delta^{18} \mathrm{O}$ record of climate and sea level. South African Journal of Science, vol. 81, 248-249.

Miller, K.G.; Fairbanks, R.G. and Mountain, G.S. (1987); Tertiary oxygen isotope synthesis, sea level history, and continental margin erosion. Paleoceanography, vol. 2, 1-19.

Mitchum, R.M., Jr. (1977); Seismic Stratigraphy and Global Changes of Sea Level, Part 11: Glossary of Terms used in Seismic Stratigraphy. In; C.E. Payton (Ed) Seismic Stratigraphy - applications to hydrocarbon exploration, American Association of Petroleum Geologists, Memoir 26, 205-212.

Mitchum, R.M. Jr and Van Wagoner, J.C. (1991); High-frequency sequencesand their stacking patterns: sequencestratigraphic evidence of high-frequency eustatic cycles. Sedimentary Geology, vol. 70, 131-160. 
Mitchum, R.M., Jr.; Vail, P.R. and Thompson, S., III. (1977); Seismic stratigraphy and global changes of sea level, Part 2: The depositional sequence as a basic unit for stratigraphic analysis. In; C.E. Payton (ed), Seismic Stratigraphy - applications to hydrocarbon exploration, American Association of Petroleum Geologists, Memoir 26, 53-62.

Morgan, P.G. (1924); Classification of upper and middle Tertiary strata in New Zealand. In; T. H. Withers (ed); The fossil cirripedes of New Zealand. New Zealand Geological Survey paleontological bulletin, no. 10 .

Morgan, P.G. and Gibson, W. (1927); The Geology of Egmont Subdivision, New Zealand Geological Survey, Bulletin 27.

Morris, B.D. (in prep.); The geology of the Matemateaonga Formation, Central Taranaki, New Zealand ,Unpublished $\mathrm{PhD}$ thesis lodged in the Victoria University of Wellington library.

Morris, J.D. (1991); Applications of Cosmogenic ${ }^{10} \mathrm{Be}$ to problems in the Earth Sciences. Annual Reviews of Earth and Planetary Sciences, vol. 19, 313-350.

Morris, J.D.; Leeman, W.P. and Tera, F. (1990); The subducted component in island arc lavas: constraints from $\mathrm{Be}$ isotopes and B-Be systematics. Nature, vol. 344, 31-36.

Morse, J.W.; Millero, F.J.; Cornwell, J.C. and Rickard, D. (1987); The Chemistry of the Hydrogen Sulfide and Iron Sulfide Systems in Natural Waters. Earth-Science Reviews, vol. 24, 1-42.

Mougenot, D.; Boillot, G. and Rehault, J-P. (1983); Prograding shelf break types on passive continental margin: some European examples. Society of Economic Palaeontologists and Mineralogists, Special Publication 33, 61-77.
Muckherjee, S. (1962); Geology, mineralogy and Geochemistry of the chromite deposite of Nausahi, Keonjhar District. Journal of the Society of India, vol. 34, 29-45.

Muller, R. (1977); Science, vol. 196, 489.

Mumme, T.C.; Lamb, S.H. and Walcott, R.I. (1989); The Raukumara palaeomagnetic domain: constraints on the tectonic rotation of the east coast, North Island, New Zealand, from palaeomagnetic data. New Zealand Journal of Geology and Geophysics, vol. 32, 317-326.

Nagata, T. (1961); Rock Magnetism. Tokyo: Maruzin, 350 p.

Nelson, C.S. and Hume, T.M. (1977); Relative intensity of tectonic events revealed by the Tertiary sedimentary record in the North Wanganui Basin and adjacent areas, New Zealand. New Zealand Journal of Geology and Geophysics, vol. 20, no. 2, 369-392.

Nelson, D.E.; Southon, J.R.; Vogel, J.S., Korteling, R.G. and $\mathrm{Ku}$, T.L. (1984); Progress in ${ }^{14} \mathrm{C}$ and ${ }^{10} \mathrm{Be}$ dating at SFU. Nuclear Instruments and Methods in Physics Research, vol. B5, 139-143.

Ness, G.; Levi, S. and Couch, R. (1980); Marine magnetic anomaly timescales for the Cenozoic and Late Cretaceous: a precis, critique and synthesis. Reviews of Geophysics and Space Physics, vol. 18, 753-770.

Nio, S.D. and Yang, C.S. (1991); Sea-level fluctuations and the geometric variability of tide-dominated sandbodies. Sedimentary Geology, vol. 70, 161-193.

Nishiizumi, K.; Arnold, J.R.; Elmore, D.; Ma, X; Newman, D. and Grove, M.E. (1983); ${ }^{36} \mathrm{Cl}$ and ${ }^{53} \mathrm{Mn}$ in Antarctic meteorites and ${ }^{10} \mathrm{Be}-{ }^{36} \mathrm{Cl}$ dating of Antarctic ice. Earth and Planetary Science Letters, vol. 62, 407-417. 
Nishiizumi, K.; Elmore, D.; Ma, X. and. Arnold, J.R. (1984); ${ }^{10} \mathrm{Be}$ and ${ }^{36} \mathrm{Cl}$ depth profiles in an Apollo 15 drill core. Earth and Planetary Science Letters, vol. $70,157-163$.

Nishiizumi, K.D.; Kohl, C.P.; Arnold, J.R.; Klein, J.; Fink, D. and Middleton, R. (1991); Cosmic ray produced ${ }^{10} \mathrm{Be}$ and ${ }^{26} \mathrm{Al}$ in Antarctic rocks: exposure and erosion history. Earth and Planetary Science Letters, vol. 104, 440-454.

Nishiizumi, K.D.; Lal, D.; Klein, J.; Middleton, R. and Arnold, J.R. (1986); Production of ${ }^{10} \mathrm{Be}$ and ${ }^{26} \mathrm{Al}$ by cosmic rays in terrstrial quartz in situ and implications for erosional rates. Nature, vol. $319,134-136$.

Nord, G.L.Jr. and Lawson, C.A. (1989); Order-disorder transition-induced twin domains and magnetic properties in ilmenite-hematite. American Mineralogist, vol. 74, 160-176.

North American Commision on Stratigraphic Nomenclature (1983); North American Stratigraphic Code. American Association of Petroleum Geologists Bulletin, vol. 67, 841-875.

Oeschger, H. (1987); Accelerator Mass Spectrometry and ice core research. Nuclear Instruments and Methods in Physics Research, vol. B29, 196-202.

Ongley, M. (1946); Groundwater resources of the Palmerston-Wanganui Basin. New Zealand Journal of Science and Technology, vol. B26, 200-205.

Park, J. (1910); The Geology of New Zealand: and introduction to the historical, structural and economic geology, Christchurch, N.Z.: Whitcombe and Tombs, 488p.

Payton, C.E. (ed.) (1977); Seismic stratigraphy - applications to hydrocarbon exploration. American Association of Petroleum Geologists, Memoir 26, 516p.
Perrett, T.L. (1990); Variations in sediment texture and biota off $a$ wave dominated coast, Peka Peka Beach, New Zealand. Unpublished MSc thesis lodged in the Victoria University of Wellington library. $135 \mathrm{p}$.

Pickard, J.; Adamson, D.A.; Harwood, D.M.; Miller, G.H., Quilty, P.G. and Dell, R.K. (1986); Early Pliocene marine sediments in the Vestfold Hills, East Antarctica: implications for coastline, ice sheet and climate. South African Journal of Science, vol.82, 520521.

Pickard, J.; Adamson, D.A.; Harwood, D.M.; Miller, G.H., Quilty, P.G. and Dell, R.K. (1988); Early Pliocene marine sediments coastline and climate of East Antarctica. Geology, vol. 16, 158-161.

Pillans, B.J.; Roberts, A.P.; Wilson, G.S.; Abbott, S.T. and Alloway, B.V. (submitted); Magnetostratigraphic, lithostratigraphic and tephrostratigraphic constraints on lower/middle Pleistocene sea level changes, Wanganui Basin, New Zealand.

Poore (1982); Temporal and spatial distribution of ice-rafted mineral grains in Pliocene sediments of the North Atlantic: Implications for Late Cenozoic climatic history. In; J.E. Warme, R.G. Douglas and E.L. Winterer (eds), The Deep Sea Drilling Project: A decade of progress. SEPM Special Publication, no. $32,505-515$.

Posamentier, H.W.; Allen, G.P.; James, D.P. and Tesson, M. (1992); Forced Regression in a Sequence Stratigraphic Framework: Concepts, Examples, and Exploration Significance. American Associatoin of Petroleum Geologists Bulletin, vol. 76, no. 11, 1687-1709. 
Posamentier, H.W.; Jervey, M.T. and Vail, P.R. (1988); Eustatic controls on clastic deposition I - Conceptual framework. In; C.K. Wilgus et al. (eds), Sea-Level changes: and integrated approach. Society of Economic Paleontologists and Mineralogists, Special Publication 42, 109-124.

Posamentier, H.W. and Vail, P.R. (1988); Eustatic controls on clastic deposition II - Sequence and Systems Tract models. In; C.K. Wilgus et al. (eds), Sea-Level changes: and integrated approach. Society of Economic Paleontologists and Mineralogists, Special Publication $42,126-154$.

Prentice, M.L. (1982); Surficial geology and stratigraphy in central Wright Valley, Antarctica: implications for Antarctic Tertiary glacial history. Unpublished M.S. thesis lodged in the University of Maine Library, 248p.

Prentice, M.L. (1986); Peleus glaciation of Wright Valley, Antarctica. South African Journal of Science, vol. 81, 241-243.

Prentice, M.L. and Matthews, R.K. (1988); Cenozoic ice-volume history: Development of a composite oxygen isotope record. Geology, vol. 16, 963966.

Prentice, M.L.; Denton, G.H.; Burkle, L.H. and Hodell, D.A. (1987); Evidence from Wright Valley for the esponse of the antarctic ice sheet to climate warming. Antarctic Journal of the United States, vol. 22 , no. 5, 56-58.

Prentice, M.L.; Denton, G.H.; Lowell, T.V.; Conway, H. and Heusser, I.E. (1986); Pre-late Quaternary glaciation of the Beardmore Glacier region, Antarctica. Antarctic Journal of the United States, vol. 21, no. 5, 95-98.

Press, F. and Siever, R. (1982); Earth, 3rd edition. San Fransisco: W.H. Freidman, $613 \mathrm{p}$.
Prince, R.A.; Heath, G.R. and Kominz, M. (1980); Palaeomagnetic studies of central North Pacific sediment cores: stratigraphy, sedimentation rates, and the origin of magnetic instability. Geological Society of America, Bulletin, part 2, vol. 91, 1789-1835.

Prothero, D.R. (1990); Interpreting the Stratigraphic Record. New York: W.H. Freeman, 410p.

Purser, K.H. (1976); U.S. Patent 4037100 (filed March, 1976)

Purser, K.H. (1978); Accelerators - The solution to direct $14 \mathrm{C}$ detection. In; H.E. Gove (ed) Proceedings of the First Conference on Radiocarbon Dating with Accelerators, University of Rochester, 1-32.

Purucker, M.E.; Elston, D.P. and Bressler, S.L. (1981); Magnetic Stratigraphy of Late Cenozoic glaciogenic sediments from drill cores, Taylor Valley, Transantarctic Mountains, Antarctica. In; L.D. McGinnis (ed), Dry Valley Drilling Project. Washington, D.C.: Antarctic Research Series, vol. 33, American Geophysical Union, 109-129.

Pyne, A.R., Robinson, P.H., Barrett, P.J. (1985); Core log, description and photographs, CIROS-2, Ferrar Fjord, Antarctica. Antarctic Data Series, VUW, no. 11,80 p.

Raisbeck, G.M. and Yiou, F. (1984); Production of Long-Lived Cosmogenic Nuclei and their applications. Nuclear Instruments and Methods in Physics Research, vol. B5, 91-99.

Raisbeck, G.M.; Yiou, F.; Bourles, D.; Lestringuez, J. and Deboffle, D. (1984); Measurement of ${ }^{10} \mathrm{Be}$ with a Tandetron Accelerator operating at $2 \mathrm{MV}$. Nuclear Instruments and Methods in Physics Research, vol. B5, 175-178.

Raisbeck, G.M.; Yiou, F.; Fruneau, M.; Lieuvin, M. and Loiseaux, J.M. (1978a); Measurement of ${ }^{10} \mathrm{Be}$ in $1,000-$ and 5,000-year-old Antarctic ice. Nature, vol. 275, 731-732. 
Raisbeck, G.M.; Yiou, F.; Fruneau, M.; Lieuvin, M. and Loiseaux, J.M. (1978); Beryllium-10 Mass Spectrometry with a Cyclotron. Science, vol. 202, 215-217.

Raisbeck, G.M.; Yiou, F.; Fruneau, M.; Loiseaux, J.M. and Lieuvin, M. (1979); ${ }^{10} \mathrm{Be}$ concentration and residence time in the ocean surface layer. Earth and Planetary Science Letters, vol. 43, 237 240.

Raisbeck, G.M.; Yiou, F.; Fruneau, M.; Loiseaux, J.M.; Lieuvin, M.; Ravel, J.C. and Lorius, C. (1981); Cosmogenic ${ }^{10} \mathrm{Be}$ concentrations in Antarctic ice during the past 30,000 years. Nature, vol. 292, 825-826.

Raisbeck, G.M.; Yiou, F.; Fruneau, M.; Loiseaux, J.M.; Lieuvin, M.; Ravel, J.C.; Reyss, Y.M. and Guichard, G.(1980); ${ }^{10} \mathrm{Be}$ concentration and residence time in the deep ocean. Earth and Planetary Science Letters, vol. 51, 275-278.

Ramsbottom, W.H.C. (1979); Rates of Transgression and Regression in the Carboniferous of Northern Europe. Journal of the Geological Society of London, vol. 136, 147-153.

Refai, E.; Wassif, N.A. and Shoab, A. (1989); Stability of remanence and palaeomagnetic studies of some chromite ores from Barramiya and Allawi occurences, Eastern Desert Egypt. Earth and Planetary Science Letters, vol. 94, 151-159.

Reineck, H.E. and Singh, I.B. (1986); Depositional Sedimentary Environments, (2 nd edition). Tubingen: Springer-Verlag, $551 \mathrm{p}$.

Reyss, J.-L.; Yokohama, Y. and Guichard, G. (1981); Production cross sections of ${ }^{26} \mathrm{Al},{ }^{22} \mathrm{Na},{ }^{7} \mathrm{Be}$ from argon and ${ }^{10} \mathrm{Be}$, ${ }^{7} \mathrm{Be}$ from Nirtogen: Implications for production rates of ${ }^{26} \mathrm{Al}$ and ${ }^{10} \mathrm{Be}$ in the atmosphere. Earth and Planetary Science Letters, vol. 53, 203-210.
Roberts, A.P. (1990); Cainozoic Palaeomagnetism and Tectonics of the Marlborough Region, South Island, New Zealand. Unpublished $\mathrm{PhD}$ thesis lodged in the Victoria University of Wellington library. 204 p.

Roberts, A.P. and Pillans, B.J. (submitted); Rock Magnetism of Lower/Middle Pleistocene marine sediments from the Wanganui Basin, New Zealand.

Roberts, A.P. and Turner, G.M. (Submitted); Diagenetic formation of ferrimagnetic Iron Sulphide minerals in rapidly deposited marine sediments, South Island, New Zealand.

Robertson, W.A. (1963); Palaeomagnetism of Some Mesozoic Intrusives and Tuffs from Eastern Australia. Journal of Geophysical Research, vol. 68, no. 8, 2299-2312.

Ronai, A. (1981); Magnetostratigraphy of Pliocene-Quaternary sediments in the Great Hungarian Plain. Earth Evolution and Science, vol. 3, no. 4, 265-267.

Ryan et al (1976); Quantitative evaluation of the depth of the western Mediterranean before, during and after the Late Miocene salinity crisis. Sedimentology, vol. 23, 791-813.

Savin, S.M. (1977); The history of the Earth's surface temperature during the past 100 million years. Annual Reviews of Earth and Planetary Sciences, vol. 5, 319-355.

Scherer, R.P. (1991); Quaternary and Tertiary microfossils from beneath Ice Stream B: evidence for a dynamic West Antarctic Ice Sheet history. Global and Planetary Change, vol. 4, no. 4, 395412.

Schmidt, P.W. (1985); Bias in converging great circle methods. Earth and Planetary Science Letters, vol. 72, 427432. 
Scott, G.H. (1982); Review of Kapitean stratotype and boundary with Opoitian Stage (Upper Neogene, New Zealand). New Zealand Journal of Geology and Geophysics, vol. 25, 475-485.

Segl, M.; Mangini, A.; Beer, J.; Bonani, G.; Suter, M.; Woolfli, W. and C.Measures, C. $(1987) ;{ }^{10} \mathrm{Be}$ in the Atlantic Ocean, a transect at $25^{\circ} \mathrm{N}$. Nuclear Instruments and Methods in Physics Research. vol. B29, 332-334.

Segl, M.; Mangini, A.; Beer, J.; Hofmann, H.J.; Morenzoni, E.; Nessi, M.; Suter, M. and Woolfli, W. (1984a); ${ }^{10} \mathrm{~B} \mathrm{e}$ dating of the inner structure of $\mathrm{Mn}$ encrustations applying the Zurich Tandem Accelerator. Nuclear Instruments and Methods in Physics Research, vol. B5, 359-364.

Segl, M.; Mangini, A.; Bonani, G.; Hofmann, H.J.; Nessi, M.; Suter, M.; Woolfli, W.; Friedrich, G.; Pluger, W.L.; Wiechowski, A. and Beer, J. (1984b); ${ }^{10} \mathrm{Be}$ dating of a manganese crust from Central North Pacific and implications for oceanic palaeocirculation. Nature, vol. 309, 540543.

Seward, D (1974); Some aspects of Sedimentology of the Wanganui Basin, North Island, New Zealand. Unpublished $\mathrm{PhD}$ thesis lodged in the The Victoria University of Wellington Library, 314p.

Seward, D.; Christoffel, D.A. and Lienert, B. (1986); Magnetic polarity stratigraphy of a Plio-Pleistocene marine sequence of North Island, New Zealand. Earth and Planetary Science Letters, vol. 80, 353-360.

Shackleton, N.J. and Hall, M.A. (1985); Oxygen and carbon isotope stratigraphy of Deep Sea Drilling Project Hole 552A: Plio-pleistocene glacial history. In; Initial reports of the Deep Sea Drilling Project, vol. 81, Washington, D.C.: U.S. Government Printing Office, 599-609.
Shackleton, N.J. and Kennett, J.P. (1975); Paleotemperature history of the Cenozoic and the initiation of Antarctic Glaciation: Oxygen and carbon isotope analyses in DSDP sites 277, 279 and 281, In; J.P. Kennett; R.E. Houtz et al., (ed) Initial reports of the Deep Sea Drilling Project, vol. 29, Washington, D.C.: U.S. Government Printing Office, 743-755.

Shackleton, N.J. and Opdyke, N.D. (1973); Oxygen Isotope and Palaeomagnetic Stratigraphy of Equatorial Pacific Core V28-238: Oxygen IsotopeTemperatures and Ice Volumes on a 105 Year and 106 Year Scale. Quaternary Research, vol. 3, 39-55.

Shackleton, N.J. and Opdyke, N.D. (1977); Oxygen isotope and palaeomagnetic evidence for early Northern Hemisphere glaciation. Nature, vol. 270, 216-219.

Shackleton, N.J.; Berger, A. and Peltier, W.R. (1990); An alternative astronomical calibration of the lower Pleistocene timescale based on ODP Site 677. Transactions of the Royal Society of Edinburgh, vol. 81, 251-261.

Shackleton, N.J.; Hall, M.A.; Mayer, L.; Pisias and ODP Leg 138 Shipboard Scientific Party (1992); Oxygen Isotope Stratigraphy of the Pliocene in ODP site 846. Abstract in; Proceedings of the fourth international conference on palaeoceanography, Kiel, Germany, 260-261.

Sharma, P.; Klein, J.; Middleton, R. and Church, T.M. (1987); ${ }^{26} \mathrm{Al}$ and ${ }^{10} \mathrm{Be}$ in authigenic marine minerals. Nuclear Instruments and Methods in Physics Research, vol. B29, 335-340.

Shelly, D. (1980); Manual of Optical Mineralogy. New York: Elsevier, 239p.

Sloss, L.L. (1950); Paleozoic stratigraphy in the Montana area. American Association of Petroleum Geologists Bulletin, vol. 34, 423-451. 
Sloss, L.L.; Krumbein, W.C. and Dapples, E.C. (1949); Integrated facies analysis. In; C.R. Longwell (ed) Sedimentary facies and geologic history, Geological Society of America, Memoir 39, 91124.

Smith, P.M. (1981); The Role of the Dry Valley Drilling Project in Antarctic and International Science Policy. In; L.D. McGinnis (ed) The Dry Valley Drilling Project. . Antarctic Research Series, vol. 33. Washington, D.C.: American Geophysical Union.

Somayajulu, B.L.K. (1977); Analysis of causes for the beryllium-10 variations in deep sea sediments. Geochimica et Cosmochimica Acta, vol. 41, 909-913.

Somayajulu, B.L.K.; Sharma, P.; Klein, J.; Middleton, R.; Williams, D.F. and Moore, W.S. (1991); Changes in the depositional flux of ${ }^{10} \mathrm{Be}$ in the Orca Basin, Gulf of Mexico: Incerse correlation with $\partial^{18} \mathrm{O}$. Chemical Geology (Isotope Geoscience Section), vol. 86, 253-258.

Southon, J.R.; Caffee, M.W.; Davis, J.C.; Moore, T.L.; Proctor, I.D.; Schumacher, B. and Vogel, J.S. (1990); The new LLNL AMS spectrometer. Nuclear Instruments and Methods in Physics Research, 301-305.

Southon, J.R.; Ku, T.L.; Nelson, D.E.; Reyss, J.L.; Duplessy, J.C. and Vogel, J.S. (1987); ${ }^{10} \mathrm{Be}$ in a deep-sea core: implications regarding ${ }^{10} \mathrm{Be}$ production changes over the past $420 \mathrm{ka}$. Earth and Planetary Science Letters. vol. 85, 356364.

Southon, J.R.; Nelson, D.E.; Korteung, R.; Nowikow, I.; Hammaren, E.; McKay, J. and Burke, D. (1982); Techniques for the direct measurement of natural beryllium-10 and Carbon-14 with a tandem accelerator. In L.A.Currie (ed); Nuclear and Chemical Dating techniques, American Chemical Society Symposium Series, vol. 176, 516.
Southon, J.R.; Vogel, J.S.; Richards, G. and Nelson, D.E. (1984); The measurement of ${ }^{10} \mathrm{Be}$ with an Accelerator at $3 \mathrm{MV}$. Nuclear Instruments and Methods in Physics Research, vol. 219, 435-437.

Sparks, R.J.; Wallace, G.; Bartle, C.M.; Coote, G.E.; Ditchburn, R.G.; Lowe, D.C.; McCabe, W.J. and Pohl, K.P. (1984); Status of the New Zealand Tandem Accelerator Mass Spectrometry facility. Nuclear Instruments and Methods in Physics Research, vol. B5, 155-158.

Speden, I.G. (1962); Fossiliferous Quaternary marine deposits in the McMurdo Sound region, Antarctica. New Zealand Journal of Geology and Geophysics, vol. 5, 746-777.

Stacey, F. and Banerjee, S. (1974); The Physical Properties of Rock Magnetism. New York: Elsevier, 195 p.

Stern, T.A. and Davey, F.J. (1989); Crustal Structure and origins of basins behind the Hikurangi subduction zone, In; R.A. Price (ed), Origin and evolution of sedimentary basins and their energy and mineral source, American Geophysical Union geophysical monograph 48, 7385.

Stern, T.A.; Davey, F.J. and Smith, E.G.C. (1986); Crustal structure studies in New Zealand. In; M. Barazngi and L.Brown (eds), Reflection seismology: A global perspective. Geodynamics series, vol. 13, Washington, D.C.: American Geophysical Union, 121-132.

Stern, T.A.; Quinlan, G.M and Holt, W.E. (1992); Crustal shortening and basin formation behind an active subduction zone: Wanganui Basin, New Zealand, Basin Research, vol. 4, 197-214.

Stormer, J.C. (1983); The effects of recalculation on estimates of temperature and oxygen fugacity from analyses of multicomponent irontitanium oxides. American Mineralogist, vol. $68,586-594$. 
Sugden, D.E. (1992); Antarctic ice sheets at risk?. Nature, vol. 359, 775-776.

Suggate,R.P. ; Stevens, G.R. and TePunga, M.T. (eds) (1978); The Geology of New Zealand. Government Printer, Wellington, New Zealand, vol. 2, 460465.

Suter, M. (1990); Accelerator mass spectrometry: state of art in 1990. Nuclear Instruments and Methods in Physics Research, vol. B32, 211-223.

Sweeney, R.E. and Kaplan, I.R. (1973); Pyrite Framboid Formation: Laboratory Synthesis and Marine Sediments. Economic Geology, vol. 68, 618-634.

Swift, D.J.P. (1970); Quaternary Shelves and the Return to grade, Marine Geology, vol. 8, 5-30.

Swift, D.J.P.; Hudleson, P.M.; Brenner, R.L. and Thompson, P. (1987); Shelf construction in a foreland basin: storm beds, shelf sandbodies, and shelf-slope depositional sequences in the Upper Cretaceous Mesaverde Group, Cliffs, Utah. Sedimentology, vol. 34, 423-457.

Swisher, C.C. and Prothero, D.R. (1990);. Science, vol. 249, 760-762.

Tanaka, S.; Inque, T. and Imamura, M. (1977); The ${ }^{10} \mathrm{Be}$ method of dating sediments - comparison with the Paleomagnetic method. Earth and Planetary Science Letters, vol. 37, 5560.

Tarafa, M.E.; Whelan, R.S.; Oremland, R.S. and Smith, R.L. (1987); Evidence of microbiological activity in Leg 95 (New Jersey transect) sediments. In; C.W. Poag; A.B. Watts et al. (eds). Initial Reports of the Deep Sea Drilling Program, Leg 95, 635-640.

Tarling, D.H. (1983); Palaeomagnetism: London: Chapman and Hall, 379p.

TePunga, M.T. (1952); The Geology of the Rangitikei Valley, New Zealand. Geological Survey, Memoir 8, 46p.
Tera, F.; Brown, L.; Morris, J. and Selwyn Sacks, I. (1986); Sediment incorporation in island-arc magmas: Inferences from ${ }^{10} \mathrm{Be}$. Geochimica et Cosmochimica Acta, vol. 50, 535-550.

Thompson, R. and Oldfield, F. (1986); Environmental Magnetism. London: Allen and Unwin, 227p.

Torsvik, T.H. (1986); Interactive Analysis of Palaeomagnetic Data: IAPD User -Guide. Universitet I Bergen, 74p.

Tucker, M.E. (1988); Techniques in Sedimentology. Oxford: Blackwell Scientific Publications, 394p.

Tucker, M.E. (1991); Sedimentary Petrology (second edition).Oxford: Blackwell Scientific Publications, 260p.

Turekian, K.K.; Cochran, J.K.; Krishnaswani, S.; Lanford, W.A.; Barker, P.D. and Bauer, K.A. (1979); The measurement of ${ }^{10} \mathrm{Be}$ in manganese nodules using a tandem Van der Graff Accelerator. Geophysics Research Letters, vol. 6, 417-420.

Turner, G.M. and Kamp, P.J.J. (1990); Palaeomagnetic location of the Jaramillo Subchron and the MatuyamaBrunhes transition in the Castlecliffian stratotype section, Wanganui Basin, New Zealand. Earth and Planetary Science Letters, vol. 100, 42-50.

Turner, G.M.; Roberts, A.P.; Laj, C.; Kissel, C.; Mazaud, A.; Guitton, S. and Christofel, D.A. (1989); New Paleomagnetic results from Blind River: Revised magnetostratigraphy and tectonic rotation of the Marlborough region, South Island, New Zealand. New Zealand Journal of Geology and Geophysics, vol 32, 191-196.

Turner, R.E. (1944); Geology of Northern Wellington and Southern Hawkes Bay. Unpublished manuscript lodged in the Victoria University of Wellington Library. 
Vail, P.R.; Audemard, F.; Bowman, S.A.; Eisner, P.N. and Perez-Cruz, G. (1991); The stratigraphic signatures of tectonics, eustacy and sedimentation: an overview. In; A. Seilacher and G. Eisner (eds) Cycles and Events in Stratigraphy, II, Tubingen: Springer-Verlag.

Vail, P.R.; Hardenbol, J. and Todd, R.G. (1984); Jurassic unconformities, chronostratigraphy and sea level changes from seismic stratigraphy and biostratigraphy. American Association of Petroleum Geologists, Memoir 36, 129-144.

Vail, P.R.; Mitchum, R.M. and Thompson, S. (1977); Seismic stratigraphy and global changes of sea level, Part 3: Relative changes of sea level from coastal onlap. In; C.W., Payton (ed), Seismic Stratigraphy - Applications to Hydrocarbon Exploration. Ammerican Association of Petroleum Geologists, Memoir 26, 83-97.

Van der Wateren, F.M. and Verbers A.L.L.M. (1991); Glacial geology and mountain uplift in North Victoria Land. (Abstract). In; Proceedings; Sixth International Symposium on Antarctic Earth Sciences; Tokyo, Japan. 637.

Van Wagoner, J.C. (1985); Reservoir facies distibution as controlled by sealevel change. Abstracts with Programs, Society of Economic Paleontologists and Mineralogists Midyear Meeting, Golden Colorado, 91-92.

Van Wagoner, J.C.; Mitchum, R.M.; Campion, K.M. and Rahmanian, V.D. (1990); Siliciclastic sequence stratigraphy in well logs, cores, and outcrops. American Association of Petroleum Geologists, Methods in Exploration Series, No. 7, 55p.
Van Wagoner, J.C.; Posamentier, H.W.; Mitchum, R.M.; Vail, P.R.; Sarg, J.F.; Loutit, T.S. and Hardenbol, J. (1988); An overview of the fundamentals of sequence stratigraphy and key definitions. In; C.K. Wilgus et al. (eds) Sea-Level changes: and integrated approach, Society of Economic Paleontologists and Mineralogists, Special Publication 42, 39-45.

Vella, P. (1953); The Genus Pelicaria in the Tertiary of East Wairarapa. Transactions of the Royal Society of New Zealand, vol. 81, 35-48.

Vella, P. (1963a); Plio-Pleistocene Cyclothems, Wairarapa, New Zealand. Transactions of the Royal Society of New Zealand, vol. 2, no. 2.

Vella, P. (1963b); Upper Pleistocene Succession in the Inland Part of Wairarapa Valley, New Zealand. Transactions of the Royal Society of New Zealand, vol. 2, no. 4, 63-78.

Verbers, A.L.L.M. and Van der Wateren, F.M. (1991); A glacial geological reconnaissance of the Southern Prince Albert Mountains, Victoria Land, Antarctica. (Abstract) In; Proceedings; Sixth International Symposium on Antarctic Earth Sciences; Tokyo, Japan, 637.

Walcott, R.I. (1978); Present Tectonics and Late Cenozoic Evolution of New Zealand. Geophysical Journal of the Royal Astronomical Society, vol. 52, 137-164.

Walcott, R.I. (1984); The Kinematics of the plate boundary zone through New Zealand: a comparison of short and long term deformations. Geophysical Journal of the Royal Astronomical Society, vol. 79, 613-633.

Walcott, R.I. (1987); Geodetic strain and the deformation history of the North Island of New Zealand during the late Cainozoic. Philosophical Transactions of the Royal Society of London, Series $A$, vol. 321, 163-181. 
Walker, R.G. (1984); General Introduction: Facies, Facies Sequences and Facies Models. In; R.G. Walker, (ed) Facies Models (2nd edition), Geological Association of Canada, Geoscience Canada Reprint Series 1, 1-9.

Walker, R.G. (ed) (1984); Facies Models (2nd edition), Geological Association of Canada, Geoscience Canada Reprint Series 1, 317p.

Walker, R.G. (1990); Facies modelling and sequence stratigraphy. Journal of Sedimentary Petrology, vol. 60, no. 5, 777-786.

Walker, R.G. (1992); Facies, Facies Models and Modern Stratigraphic Concepts. In; R.G. Walker and N.P. James (eds) Facies Models: Response to Sea Level Change, Geological Association of Canada, 1-14.

Walker, R.G. and James, N.P. (eds) (1992); Facies Models: Response to Sea Level Change. Geological Association of Canada, Geoscience Canada Reprint Series 1, 409p.

Warren, G. (1970); Geology Sheet 14. In; V.C. Bushnell and C. Craddock (eds) Antarctic Map Folio Series, Folio 12, New York: American Geographical Society.

Webb, P.-N. (1972); Wright Fjord, Pliocene marine invasion of an Antarctic dry valley. Antarctic Journal of the United States, vol. 7, 222-232.

Webb, P.-N. (1974); Micropaleontology, paleoecology and correlation of the Pecten Gravels, Wright Valley, Antarctica and description of Trochoelphidiella onyxi n. sp., n. gen. Journal of Foraminiferal Research, vol. 4, no. 3, 154-199.

Webb, P.-N. (1990); The Cenozoic history of Antarctica and its global impact. Antarctic Science, vol.2, no.1, 3-21.
Webb, P.-N. (1991); A review of the Cenozoic stratigraphy and palaeontology of Antarctica, In; M.R.A. Thomson; J.A. Crame and J.W. Thompson (eds), Geological Evolution of Antarctica, Cambridge: Cambridge University Press, 599-608.

Webb, P.-N. and Andreasen, J.E. (1986); $\mathrm{K} / \mathrm{Ar}$ dating of volcanic material associated with the Pliocene Pecten Conglomerate (Cockburn Island) and Scallop Hill Formation (McMurdo Sound). Antarctic Journal of the United States, vol. 21, no. 5, 59.

Webb, P.-N. and Harwood, D.M. (1991); Late Cenozoic glacial history of the Ross Embayment, Antarctica. Quaternary Science Reviews, vol. 10, 215-223.

Webb, P.-N. and Harwood, D.M. (in press); Pliocene fossil nothofagus (Southern Beech) from Antarctica: phytogeography, dispersal strategies, and survival in high latitude glacialdeglacial environments.

Webb, P.-N. and Wrenn, J. (1982); Upper Cenozoic Micropaleontology and Biostratigraphy of Eastern Taylor Valley, Antarctica. In; C. Craddock (ed) Antarctic Geoscience. Madison: University of Wisconsin Press, 11171122.

Webb, P.-N.; Harwood, D.M.; McKelvey, B.C.; Mabin, M.C.G. and Mercer, J.H. (1986); Late Cenozoic tectonic and glacial history of the Transantarctic Mountains. Antarctic Journal of the United States, vol. 21, no. 5, 99-100.

Webb, P.-N.; Harwood, D.M.; McKelvey, B.C.; Mercer, J.H. and Stott, L.D. (1984); Cenozoic marine sedimentation and ice-volume variation on the East Antarctic craton. Geology, vol. 12, 287 291.

Westcott-Lewis, M.F. and Parry, L.G. (1971); Thermoremanence in synthetic rhombohedral Iron-Titanium Oxides. Australian Journal of Physics, vol. 24, 735-742. 
Wilgus, C.K.; Hastings, B.S.; Posamentier, H.W.; Ross, C.A. and Kendall, C.G. (eds) (1988); Sea level changes: an integrated approach. Society of Economic Paleontologists and Mineralogists, special publication 42 , $407 \mathrm{p}$.

Williams, D.F. (1988); Evidence for and against sea-level changes from the stable isotope record of the Cenozoic. In; C.K. Wilgus et al. (eds), Sea-Level changes: and integrated approach, Society of Economic Paleontologists and Mineralogists, Special Publication 42, 31-36.

Wilson, G.S. (1990); Beryllium-10; A method for tracing and dating Antarctic Ice Sheet fluctuation in the Pliocene Era (abstract). In; Proceedings of the seventh International cnference on Geochronology, Cosmochronology and Isotope Geology, 112.

Wilson, G.S. and Ditchburn, R.G. (1992); Beryllium Systematics in rock materials and its measurement and purification for measurement on an Accelerator Mass Spectrometer. DSIR Physical Sciences report 53, 32p.

Wilson, G.S. and Sparks, R.J. (1991); Dating of Pliocene Antarctic margin sediments; a new development of the ${ }^{10} \mathrm{Be}$ dating procedures. In; Proceedings of the sixth international symposium on Antarctic Earth Sciences, National Institute of Polar Research, Japan, 615.

Wise, S.W.; Breza, J.; Harwood, D.M. and Wei, W. (1991); Paleogene glacial history of Antarctica. In; D.W. Muller; J.A. McKenzie and H. Weissert (eds), Controversies in Modern Geology, London: Academic Press, 133-171.

Woolfli, W. (1987); Nuclear Intruments and Methods in Physics Research, vol. B29, 1-.

Worsley, T.R.; Nance, D. and Moody, J.B. (1984); Global Tectonics and Eustacy for the Past 2 Billion years. Marine Geology, vol. 58, 373-400.
Wright, I.C. (1986); Paleomagnetic Studies of the Late Miocene Mangapoike River Section, Northern Hawke's Bay, New Zealand. Unpublished $\mathrm{PhD}$ thesis lodged in the Victoria University of Wellington Library, 208 p.

Wright, I.C. and Walcott, R.I. (1986); Large tectonic rotation of part of New Zealand in the last $5 \mathrm{Ma}$. Earth and Planetary Science Letters, vol. 80, 348352.

Wright, I.C. and Vella, P.P. (1988); A New Zealand Late Miocene magnetostratigraphy: glacioeustatic and biostratigraphic correlations. Earth and Planetary Science Letters, vol. 87, 193204.

Yiou, F. and Raisbeck, G.M. (1972); Physics Review Letters; 29, p372.

Yiou, F. and Raisbeck, G.M. (1981); The age of sediments beneath the Ross Ice Shelf as implied by cosmogenic ${ }^{10} \mathrm{Be}$ concentrations. (Abstract) Transactions of the American Geophysical Union (EOS)' vol. 62, 297.

Yokohama, Y.F.; Guichard, Y.F.; Reyss, J.-L. and Van, N.H. (1978); Oceanic residence times of dissolved beryllium and aluminum deduced from cosmogenic tracers $10_{\mathrm{Be}}$ and $26 \mathrm{Al}$. Science, vol. 201, 1016-1017.

Zinsmeister, W.J. and Webb, P.-N. (1982); Cretac ous-Tertiary geology and paleontology of Cockburn Island. Antarctic Journal of the United States, vol. 17 , no. 5, 41-42.

Zijderveld, J.D.A. (1967); Demagnetisiation of rocks: Analysis of results; In; D.W. Collinson, K.M. Creer and S.K. Runcorn (eds), Developments in Solid Earth Geophysics, volume 3, 254-286.

Zijderveld, J.D.A. (1975); Palaeomagnetism of the Estrel Rocks, Unpublished $\mathrm{PhD}$ thesis, state university of Utrecht, 199 p. 
Zijderveld, J.D.A.; Zachariasse, J.W.; Verhallen, P.J.J.M. and Hilgen, F.J. (1986); The age of the MiocenePliocene boundary. Newsletters on Stratigraphy, vol. 16, no. 3, 169-181. 